UNIVERSIDADE DE SÃo PAULO

FACUldade DE Filosofia, LETRAS E CiÊnCIAS Humanas

DEPARTAMENTO DE HISTÓRIA

POGRAMA DE PÓS-GRADUAÇÃO EM HISTÓRIA SOCIAL

JANAínA DE Almeida TELES

\title{
Memórias dos cárceres da ditadura: os testemunhos e as lutas dos presos políticos no Brasil
}


UNIVERSIDADE DE SÃo PAULO

FACUldade DE Filosofia, LETRAs E CiÊnCIAS Humanas

DEPARTAMENTO DE HISTÓRIA

POGRAMA DE PÓS-GRADUAÇÃO EM HiSTÓRIA SOCIAL

\section{Memórias dos cárceres da ditadura: \\ os testemunhos e as lutas dos \\ presos políticos no Brasil}

Janaína de Almeida Teles

Tese do Doutorado apresentada ao Programa de História Social do Departamento de História da Faculdade de Filosofia, Letras e Ciências Humanas da Universidade de São Paulo, para a obtenção do título de doutora em História.

Orientadora: Profa. Dra. Zilda Márcia Grícoli Iokoi.

Versão corrigida

São Paulo

Abril de 2011 


\section{Resumo}

O processo de reconstituição factual e de reflexão crítica acerca da ditadura civilmilitar de 1964 e de seu legado permanece incompleto e permeado por zonas de silêncio e interdições. Decorridos pouco mais de trinta anos da Lei de Anistia, muitos acontecimentos permanecem desconhecidos ao tempo em que se observa a existência de importantes lacunas nas articulações entre o passado e o presente e, mais especificamente, entre o legado da ditadura e a memória daqueles que a ela se opuseram ativamente.

Visando contribuir para o entendimento desse passado, e de seu legado, esta pesquisa procurou caracterizar o protagonismo dos presos políticos na defesa de transformações sociais e na luta contra a ditadura e, ao mesmo tempo, oferecer um panorama reflexivo sobre a construção de suas memórias a respeito dessas lutas e da experiência-limite da tortura e da prisão.

Para alcançar esses objetivos, a pesquisa pautou-se por um amplo registro das memórias desses protagonistas por meio da metodologia da História Oral de Vida - um conjunto de 90 entrevistas com ex-presos políticos. O que permitiu a coleta de informações até aqui inéditas no que diz respeito à organização dos presos e à atuação dos órgãos repressivos. A execução e desenvolvimento dessa metodologia deram origem a reflexões teóricas que visaram interpretar o material coletado, contextualizando-o crítica e historicamente. Partiu-se, ainda, da premissa de que tais testemunhos, juntamente com os de advogados, familiares e militantes permitiriam aprofundar as pesquisas desenvolvidas sobre as lutas revolucionárias e de resistência; a clandestinidade; as formas institucionais da repressão política e as disputas políticas estabelecidas dentro e fora dos cárceres.

Os depoimentos dos ex-presos permitiram, ainda, a análise de suas estratégias de sobrevivência e memória. Tais estratégias foram aqui discutidas à luz dos esforços empreendidos para a compreensão da maneira como eles próprios reorganizaram identidades, constituíram grupos de ação política e definiram maneiras de se relacionar com o legado das experiências-limite. Reconstruir as tramas dessa história, com o suporte do material coletado, apresenta novas possibilidades de interpretação desse período recente da história brasileira cuja atualidade permanece.

Palavras-chave: Presos Políticos; Testemunhos; Ditadura militar; História Oral; Aparelho Repressivo de Estado; Luta armada. 


\begin{abstract}
The process of reconstituting the facts and of producing a critical analysis of the civilian-military dictatorship of 1964 and its legacy is incomplete and permeated by interdits and silence. After a little more than thirty years of the Amnesty Law, many events remain unknown, while important lacunae abide between the past and the present and, more specifically, between the legacy of the dictatorship and the memory of those who actively opposed it.

Aiming to contribute to the understanding of this past and of its legacy, this study sought to describe the protagonism of political prisoners in the defense of social transformation and in the struggle against the dictatorship. At the same time, it aimed to offer a reflective view on the ways former prisoners have constructed their memories of these struggles and of the limit-experience of torture and prison.

To achieve these objectives, the study made use of an extensive record of the memories of these protagonists. Using the methodology of Oral Life History, a set of 90 interviews with ex-political prisoners was conducted, allowing the collection of as yet unpublished information relating to the prisoners' organization and the actions of the repressive agencies. The execution and development of this methodology gave rise to theoretical reflections which sought to interpret the material collected by contextualizing it critically and historically. The underlying premise was that these testimonies, together with those of lawyers, family members, and militants of the opposition, would allow us to deepen research on revolutionary struggles and resistance, on life in clandestinity, on the institutional forms of political repression, and on the political debates carried on inside and outside the prisons.

The testimonies of the former prisoners also made possible an analysis of their strategies for survival and memory. These strategies were discussed here in an effort to understand the way that the ex-prisoners themselves reorganized identities, constructed political action groups, and defined ways of relating to the legacy of limit-experiences. The reconstruction of the frames of this history, based upon the material collected introduces new oportunities for interpretation of this recent period in Brazilian history, which has echoes in the present day.
\end{abstract}

Keywords: Political Prisoners; Testimonies; Military Dictatorship; Oral History; Repressive State Apparatus; Armed Struggle. 


\section{Agradecimentos}

Agradeço à Zilda Márcia Grícoli Iokoi pela orientação, incentivo e sensibilidade.

Ao Marcelo Ridenti pela generosidade e incentivo.

Ao Marcos Napolitano e ao Paulo Endo pelas aulas e sugestões.

Ao Júlio Ramos de Toledo pelo respeito com que gravou, ouviu e cuidou das entrevistas.

Agradeço a todos os que de maneira generosa me concederam entrevistas.

Agradeço à Fundação Ford do Brasil por tornar possível o projeto de história oral dos presos políticos.

Agradeço ao LEI-FFLCH (USP) e ao AEL (Unicamp), cuja parceria possibilitou a realização do projeto de história oral dos presos políticos.

Agradeço ao CNPq pela bolsa de estudos concedida na fase final do doutoramento.

Aos amigos e companheiros: Flamarion Maués, Gisela Maria Moreau, Guga Stroeter, Carlos Alberto Lobão Cunha, Cecília MacDowell Santos, James N. Green, André Sabóia Martins, Idibal Pivetta, Ana Maria de Almeida Camargo, Márcio Seligmann-Silva e Álvaro Machado Dias.

Em especial, agradeço o amor de Amelinha, César, Edson, Criméia e Joca. A vocês, o meu carinho. 
Quanto faças, supremamente faze.

Mais vale, se a memória é quanto temos,

Lembrar muito que pouco.

E se o muito no pouco te é possível,

Mais ampla liberdade de lembrança

Te tornará teu dono.

Ricardo Reis em "Odes" 


\section{Sumário}

Apresentação 011

\section{Capítulo I}

O ponto de vista da memória: a relevância do testemunho 017

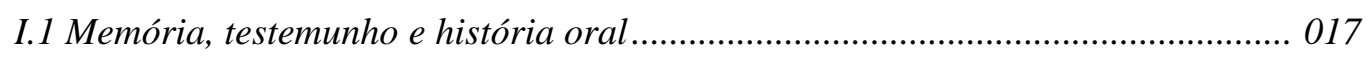

1.1 O projeto de história oral dos presos políticos ................................................ 026

I.2 Os usos e a crítica da cultura da memória .............................................................. 037

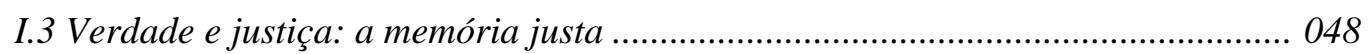

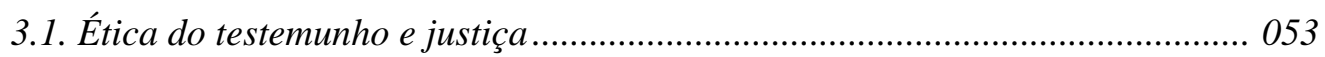

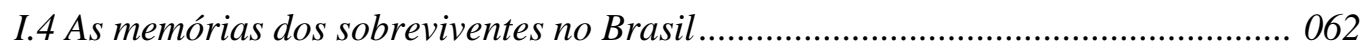

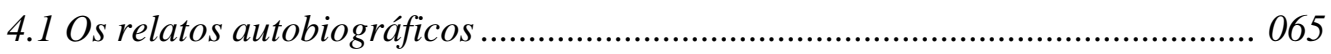

\section{Capítulo II}

O sistema repressivo: dos centros de tortura e extermínio aos presídios políticos ................................................................................. 075

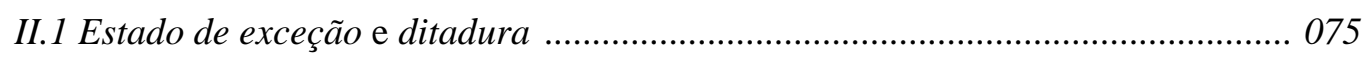

II.2 As faces secretas e clandestinas da repressão política ......................................... 081

2.1 Eliminar, "sem deixar vestígios" .......................................................................... 087

2.2 Conceituação e antecedentes dos campos de concentração no Brasil.............. 090

2.3 A destruição da Guerrilha do Araguaia: das operações de inteligência

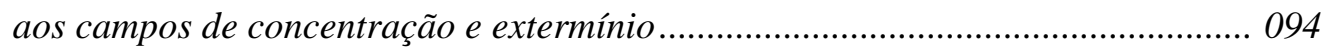

II.3 Os centros de tortura e extermínio: o sistema DOI-Codi....................................... 107

3.1 Os campos argentinos e os centros de tortura e extermínio no Brasil.............. 115

3.2 A “Casa da Morte” e os centros clandestinos de tortura e extermínio ............. 142

\section{Capítulo III}

O cotidiano nos presídios políticos: reconstruindo identidades. .............. 161

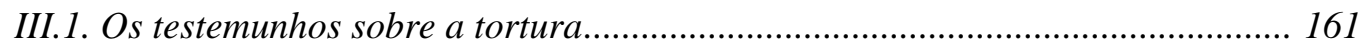

III.2. Os limites e as possibilidades do testemunho.................................................... 183

III.3. O cotidiano nos presídios políticos ................................................................... 208

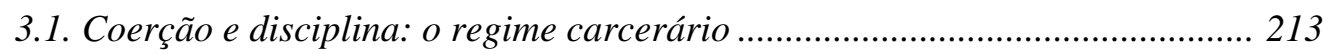

3.2. O controle da movimentação dos presos: a revista e o "banho de sol”.......... 220

3.3. A comunicação dentro e fora dos presídios: as visitas e a correspondência... 233

3.4. Os encontros e desencontros nas visitas .................................................... 237

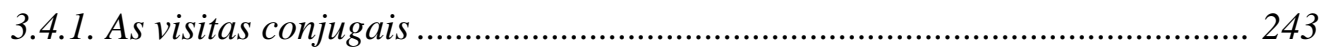


3.4.3. Restrições e controle da leitura e dos trabalhos manuais ............................ 248

3.4.4. Os trabalhos manuais e artísticos.................................................................. 255

III.4.1. Os coletivos de presos políticos: convergências e divergências .......................258

4.2. As mulheres e a reorganização do cotidiano na prisão ................................... 271

\section{Capítulo IV}

\section{As lutas por melhores condições carcerárias e as denúncias de abusos}

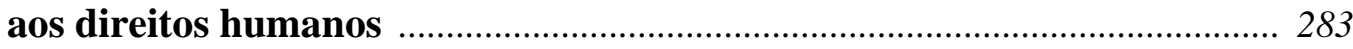

IV.1 As denúncias de tortura e de graves violações de direitos humanos ................... 283

IV.2 As greves de fome e as lutas por melhores condições carcerárias ..................... 285

2.1 A greve de fome do presídio Tiradentes em São Paulo ................................... 287

2.2 Novo período de adaptação: o convívio na Casa de Detenção ......................... 316

IV.3 Os julgamentos por motivos políticos na Justiça Militar..................................... 325

3.1 Informando as prisões e localizando os presos políticos................................... 331

3.2 Resistindo à ditadura, defendendo presos políticos......................................... 341

3.3 As estratégias de defesa na Justiça Militar..................................................... 353

3.4 Os recursos de julgamentos por crimes políticos nos tribunais superiores .... 371

\section{Capítulo V}

Rompendo o isolamento: as lutas pela redemocratização e a anistia......... 385

V.1. A greve de fome da Penitenciária do Estado de São Paulo ................................ 385

1.2. O presídio político de São Paulo ....................................................................... 399

V.2. Saindo da prisão: refazendo a vida e a política ................................................. 408

V.3 As greves de fome nacionais e as lutas pela anistia........................................... 419

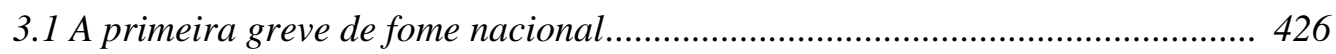

3.2 A greve de fome pela anistia ampla, geral e irrestrita ................................... 431

V.4 O balanço e a continuidade da luta................................................................... 442

\section{Considerações finais}

As lutas e disputas pelas memórias sobre a ditadura .............................. 463

1. O Projeto Brasil: Nunca Mais e a construção da memória

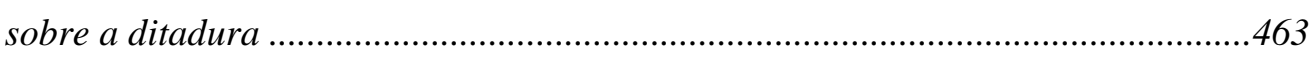

1.1. A conflituosa história das memórias sobre a ditadura ........................................ 463

1.2. O marco inaugural da memória sobre a ditadura: o Projeto "Brasil:

Nunca Mais”. .467

1.3. A conformação de uma história e memória oficiais .480 
Referências Bibliográficas ................................................................. 493

Documentos e periódicos ................................................................... 504

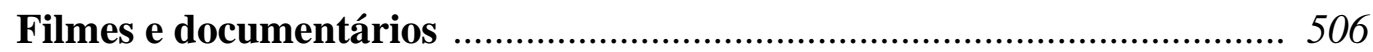

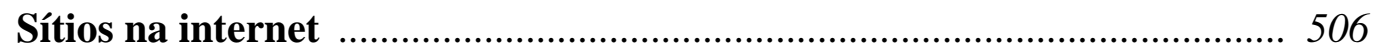

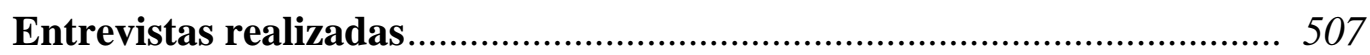

Acervo Audiovisual sobre ex-Presos Políticos/AEL-LEI .......................... 507

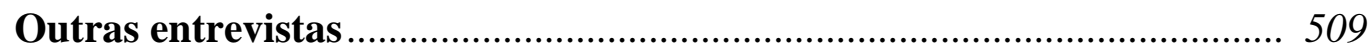

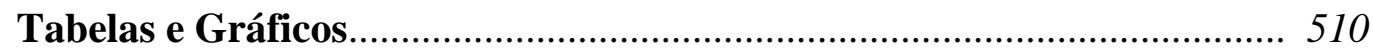

Tabela de porcentagens de presos processados por filiação partidária.... 510

Gráficos sobre a literatura de testemunho .......................................... 511

Bibliografia de literatura de testemunho …........................................... 513 


\section{Memórias dos cárceres da ditadura:}

\section{os testemunhos e as lutas dos presos políticos no Brasil}

\section{Apresentação}

No Brasil, a elaboração e o trabalho de memória sobre o passado recente, em especial aquele referente à ditadura civil-militar de 1964, permanecem inconclusos, como um "luto inacabado". Decorridos poucos mais de trinta anos da Lei de Anistia (1979) considerada "recíproca" e cuja interpretação equiparou a tortura praticada pelos agentes da repressão política às ações dos opositores da ditadura -, muitos acontecimentos e crimes desse período continuam desconhecidos ou não esclarecidos, numa inequívoca violação dos direitos estabelecidos pela institucionalidade republicana do período pósditadura.

As indenizações pagas às famílias e sobreviventes, a Lei dos Mortos e Desaparecidos Políticos (Lei 9.140/95) ou a reformulação da Comissão de Anistia (2001) não garantiram, na maior parte dos casos, a recuperação factual dos crimes ou dos restos mortais dos militantes assassinados, nem a punição dos responsáveis pelas torturas, assassinatos ou desaparecimentos forçados. A recuperação desses eventos avança com dificuldades, na medida em que o Estado se desobrigou a fornecer esclarecimentos ou investigá-los, deixando às vítimas a incumbência da comprovação da autoria e das circunstâncias desses crimes em procedimentos administrativos instaurados em instâncias do poder Executivo ${ }^{2}$. As ações civis solicitando informações e a restituição dos restos mortais de desaparecidos têm sua tramitação prolongada por décadas em função dos obstáculos burocráticos e recursos interpostos pelo Estado e não chegam a uma decisão final ou um desfecho ${ }^{3}$.

\footnotetext{
${ }^{1}$ V. AlmeidA, C. et al. (orgs.). Dossiê Ditadura: mortos e desaparecidos políticos no Brasil (1964-1985). São Paulo, IEVE/Imprensa Oficial, 2009.

${ }^{2}$ As famílias têm de encaminhar suas solicitações à Comissão Especial de Mortos e Desaparecidos Políticos (SEDH) provando ou fornecendo indícios de que seus parentes foram assassinados por motivos políticos. A Comissão de Anistia (Ministério da Justiça) exige dos requerentes a comprovação de que os danos trabalhistas sofridos foram decorrência de perseguição política para obterem a condição de anistiado e uma indenização vitalícia, na forma de uma pensão mensal.

${ }^{3}$ Chama a atenção o caso da ação dos familiares dos desaparecidos da Guerrilha do Araguaia, iniciada em 1982, sua sentença foi proferida em 2003. As possibilidades de recurso se esgotaram em 2007 e até o momento sua execução não ocorreu. V. Teles, Janaina de A. Os herdeiros da memória. A luta dos familiares de mortes e desaparecidos políticos por 'verdade e justiça' no Brasil. Mestrado/História-USP, 2005.
} 
Algumas das mais importantes fontes oficiais disponíveis sobre tais fatos sofreram processos de depuração e expurgos nos quais foram suprimidos documentos que constavam de seus acervos, antes de serem franqueados ao acesso público ${ }^{4}$. Estas práticas foram constatadas nos arquivos do DEOPS/SP (1924-1983), cujo acesso é irrestrito desde o final de 1994, e nos do extinto Serviço Nacional de Informações (SNI) (1964-1990), custodiados pelo Arquivo Nacional desde dezembro de 2005, em regime de acesso restrito. Nesse sentido, o caso da Guerrilha do Araguaia é emblemático: nas 21.319 páginas de documentos do SNI, entregues à justiça em 2008 com o objetivo de atender à sentença da ação movida pelos familiares dos guerrilheiros desaparecidos ${ }^{5}$, nenhuma informação foi encontrada sobre quando, como e onde foram presos ou morreram os guerrilheiros, onde foram enterrados ou para onde foram transferidos seus restos mortais após a 'operação limpeza' realizada na região pelas Forças Armadas ou quem chefiou e participou dessas operações.

Apesar dessas dificuldades e obstáculos, familiares, militantes, jornalistas, historiadores e pesquisadores em geral obtiveram dados novos e avanços na reconstituição e compreensão desse passado. A questão, porém, permanece, e as principais fontes sobre a repressão estatal do período, os arquivos das Forças Armadas, continuam inacessíveis.

No Brasil, a rememoração e o trabalho de luto sobre o passado recente não assumiram o caráter público e social como em outros países da América Latina, onde diversos processos e instrumentos de apuração dos fatos e responsabilidades estão em curso. Observa-se por parte do Estado a interdição do passado ao priorizar a compensação econômica por meio do pagamento de reparações, sem empenhar-se na busca pela recuperação da verdade ou em promover a investigação e punição dos crimes. A ausência de uma justiça retrospectiva e os insuficientes avanços obtidos na apuração dos fatos históricos levam à repetição dos reclamos de desrespeito aos direitos humanos do passado. Crimes e queixas que se arrastam até o presente sem respostas efetivas,

\footnotetext{
${ }^{4}$ Magalhães, Mário. "Papéis da ditadura somem dos arquivos”. Folha de S. Paulo, 04/02/2007. No acervo do DEOPS/SP, transferido para o Arquivo do Estado de S. Paulo em janeiro de 1992, havia arquivos referentes às FFAA vazios e dossiês com páginas arrancadas. Extinto em 1983 e mantido na sede da Política Federal/SP, as fichas de pessoas sob vigilância tinham dados atualizados até 1991. V. "Primeiras fotos das vítimas da ditadura militar no Brasil"; "Somem pastas do Araguaia"; "Material comprova mortes”. Diário Popular, 19/03/92; e “Arquivos violados?”, Metro News, 19/03/92.

${ }^{5}$ V. CORTE Interamericana de Direitos Humanos. Caso Gomes Lund e Outros ("Guerrilha do Araguaia") Vs. Brasil. Sentença de 24 de Novembro de 2010 (Exceções Preliminares, Mérito, Reparações e Custas), p. 73 e 106, item 292. Disponível em: <http://www.corteidh.or.cr/docs/casos/articulos/seriec_219_por.pdf>. Acesso em 10/05/2011.
} 
indicando a persistência de um passado "que não passa”. ${ }^{6}$ Soma-se a esta realidade, a proliferação das práticas de tortura na atualidade, que emerge como uma persistência e continuidade, estimuladas pela impunidade dos crimes do passado e do presente.

O reaparecimento do passado conflitivo e de questões pendentes na atualidade indicam a incapacidade da sociedade brasileira de articular as heranças e memórias da ditadura do ponto de vista político, institucional, cultural e simbólico. A retomada do debate público sobre como lidar com esse passado - a questão da punição aos torturadores e a formação de uma Comissão de Verdade - trazem novas perspectivas e possibilidades para a história contemporânea brasileira marcada por bloqueios, mecanismos de denegação e banalização dos conflitos. A continuidade do dano e a persistência da exigência por "justiça e verdade" motivam a interpelação sobre como se constituíram as memórias dos ex-presos políticos, buscando, a partir dessa perspectiva, pensar e analisar as presenças e sentidos desse passado.

No final da ditadura, o regime conseguiu impor seu projeto de Lei de Anistia, assim como a interpretação de que ela fora recíproca, contemplando vítimas e algozes, estabelecendo seus limites para o retorno do Estado de Direito: o silêncio sobre os crimes cometidos pelo terrorismo de Estado. Limitou-se a transição para a democracia nos seguintes termos: aconteceram “erros e excessos” de ambos os lados, como em toda “guerra”, mas estes deveriam ficar no passado. Deu-se por encerrada essa etapa, negando a existência de uma política de Estado criminosa ou a necessidade de apurá-la, deixando de lado os conflitos e legados contrapostos. A anistia garantiu o retorno de milhares de perseguidos políticos ao país, mas, ao impedir a investigação jurídica do passado, teve como consequência a obliteração da possibilidade das vítimas de narrar suas memórias e vivências traumáticas na esfera pública, dificultando a transmissão e a inscrição dessas experiências na memória coletiva. Negou-se a necessidade de se constituir no país um processo eficaz de lidar com seu passado recente, favorecendo a manipulação e instrumentalização dessa memória e, em especial, o esquecimento desses crimes para as futuras gerações ${ }^{7}$.

No Brasil, nenhum processo baseado em marcos judiciais ou extrajudiciais foi estabelecido para indagar a verdade e incutir alguma forma de justiça retrospectiva

\footnotetext{
${ }^{6}$ Rousso, Henry. “La trayectoria de un historiador del tiempo presente, 1975-2000”, em PÉROTIN-DUMON, Anne (dir.). Historizar el pasado vivo en América Latina, 2007, p.45, 66-7. V. http://etica.uahurtado.cl/historizarelpasadovivo/es_contenido.php. Acesso em 15/12/2010.

${ }^{7}$ Ricoeur, Paul. A memória, a história, o esquecimento. Campinas, Unicamp, 2007, p.93-104.
} 
adequada ao estabelecimento de um foro de escuta das vozes reprimidas (notoriamente incômodas) de vítimas, que deste modo falariam em público pela primeira vez. Nenhum mecanismo efetivo foi criado para obter informação histórica e iniciar uma ação ritual e política abrangendo toda a sociedade. Não se constituiu um ritual de luto coletivo capaz de reconhecer as perdas históricas e responsabilidades de quem se beneficiou com a opressão, mas antes impôs-se tacitamente a premissa de um balanço que iguala inaceitavelmente "violências" de ambos os lados. Nenhum pedido público de perdão foi pronunciado. Dir-se-ia que a inexistência de um processo amplo e aberto voltado à avaliação destes acontecimentos e ao acolhimento das indagações limitou as possibilidades de alívio das feridas abertas e a consequente reparação das perdas do passado $^{8}$.

A decisão do Supremo Tribunal Federal (abril de 2010) que considerou constitucional a Lei de Anistia de 1979, mantendo a interpretação de que ela também se aplicaria aos torturadores, reforça os dispositivos de denegação e esquecimento sobre a violência estatal daquele período ${ }^{9}$. O Estado não assumiu seu papel, erigindo obstáculos à construção de uma memória pública sobre a ditadura, na qual sobreviventes e as novas gerações pudessem revisitar esse período como passado e não como "eterno presente"10. A sentença da Corte Interamericana de Direitos Humanos da OEA sobre a repressão à Guerrilha do Araguaia, divulgada em dezembro de 2010, condenando o Estado brasileiro por não apurar os casos de desaparecimentos forçados, não revogar a lei de anistia e não submeter a processo legal os violadores de direitos humanos mantém em aberto a questão do enfrentamento do passado recente no Brasil.

Tendo em vista a escassez e debilidade de políticas públicas de memória e dos poucos instrumentos instituídos no país para compartilhar publicamente as experiências desse passado traumático, nesse trabalho nos propusemos a tarefa de registrar as memórias dos ex-presos políticos do período ditatorial, fazendo uso da História Oral, no âmbito do projeto Intolerância e Resistência: Memórias da repressão política no Brasil (1964-1985), realizado pelo Laboratório de Estudos sobre a Intolerância (LEI) da FFLCH/USP e o Arquivo Edgard Leuenroth (AEL) da Unicamp, entre 2008 e $2010^{11}$.

\footnotetext{
${ }^{8}$ LACAPRA, Dominick. Escribir la historia, escribir el trauma. Buenos Aires, Nueva Visión, 2005, p.65-7.

9 V. http://www.oab.org.br/arquivos/pdf/Geral/ADPF_anistia.pdf; e http://www.stf.jus.br. Acesso em: 10/12/2010.

${ }^{10}$ Carnovale, Vera; Lorenz, Federico e Pittaluga, Roberto (comps.). Historia, memoria y fuentes orales. Buenos Aires, CeDinCI, 2006, p.14.

${ }^{11}$ Este projeto foi realizado com o aporte da Fundação Ford do Brasil e coordenado pelos professores Zilda Márcia Grícoli Iokoi (LEI) e Marcelo Ridenti (AEL). O projeto registrou 80 entrevistas em vídeo entre
} 
Estes testemunhos permitem-nos aprofundar as pesquisas e análises sobre as experiências dos sobreviventes, as lutas revolucionárias e de resistência do período, o cotidiano da militância na clandestinidade, o debate e disputas políticas estabelecidos dentro e fora dos cárceres e as formas institucionais e clandestinas da repressão política.

Ao analisar o cotidiano da vida dos presos, buscamos avaliar a emergência desses sujeitos políticos que lutaram por propostas de transformação social e revolução, e resistiram à ditadura. Esta resistência articulada e vivenciada nos presídios políticos foi marcada pela denúncia da tortura e da atuação ilegítima e criminosa do Estado. Ao impor desgaste político ao regime, colaborou decisivamente com a campanha pela anistia, ampla, geral e irrestrita para os perseguidos políticos e a redemocratização do país.

Por meio do registro dos depoimentos dos ex-presos políticos, procuramos analisar suas estratégias de sobrevivência, como reorganizaram identidades e constituíram grupos de ação política, mas também suas estratégias de memória, como seu drama particular foi e é lembrado por eles próprios ${ }^{12}$. Reconstruir as tramas da história dessas memórias nos apresenta novas possibilidades de interpretação desse período recente da história brasileira, articulando as relações estabelecidas entre essas memórias, a política e a cultura brasileira.

A importância de registrar depoimentos orais justifica-se à luz da tímida sistematização das memórias e histórias dos ex-presos políticos e à dispersão da documentação sobre as lutas e experiências que protagonizaram. Neste trabalho, procuramos analisar suas memórias como tema central, de modo a recuperar as mudanças e continuidades de suas propostas diante da derrota dos projetos revolucionários, sua atuação na formação de redes de solidariedade, na rearticulação da política institucional e dos novos movimentos sociais que surgiram no período.

Ao delinear as relações entre as memórias, silêncios e esquecimentos sobre a tortura, a repressão estatal e a experiência nos cárceres da última ditadura no Brasil buscamos resgatar e analisar o legado desses sobreviventes, o significado de elaborar esse passado traumático, as mudanças de sentidos desse passado e as possibilidades e impossibilidades de inscrição dessas experiências e histórias na memória coletiva.

2008 e 2010, com vistas a formar um acervo audiovisual e um banco de dados disponível ao público, tendo como pesquisadora Janaina de Almeida Teles e o assistente de pesquisa Júlio Ramos de Toledo.

${ }^{12}$ V. Ollier, María Matilde. La creencia y la pasión. Privado, público y político en la izquierda revolucionária. Buenos Aires, Ariel, 1998. 


\section{Capítulo I}

\section{O ponto de vista da memória: a relevância do testemunho}

\section{I.1. Memória, testemunho e história oral}

A emergência da memória no espaço público, no decorrer do século $\mathrm{XX}$, colocou em evidência a história contemporânea e a chamada "história do tempo presente". As demandas por reparação das feridas abertas por guerras, genocídios e ditaduras durante o século XX fizeram com que os trabalhos de memória ganhassem grande espaço no presente. Essa valorização inédita do passado recente fez crescer o interesse pelo testemunho. A história passou a constituir e utilizar fontes orais e analisar testemunhos tanto quanto os documentos materiais e escritos. A memória se transformou em um dos principais temas de investigação da história. No último século, a relação da historiografia com a memória interferiu nas práticas tradicionais de investigação do passado gerando importantes controvérsias nos territórios do historiador ${ }^{13}$.

Os embates e debates travados em torno dos usos e abusos da "cultura da memória” e suas relações com a história revelaram-se bastante frutíferos, destacando a condição transitória da historiografia, colocando em perspectiva e explorando as tensões existentes no trabalho de interpretação do passado. Isso implicou no repensar constante do que conta como história, no sentido de processo histórico ou de intento de interpretação deste, assim como o repensar de objetivos, pressupostos e o significado das temporalidades na história e na memória. Nesse contexto, sublinhou-se “[...] o problema do status e a natureza do testemunho, que não só transmite informação sobre os feitos

\footnotetext{
${ }^{13}$ Traverso, Enzo. "História y memória. Notas sobre um debate". In: Franco, Marina y LeVin, F. (comps.). Historia reciente. Perspectivas y desafios de un campo en construcción. Buenos Aires, Paidós, 2007, p.72; e Traverso, Enzo. El pasado, instruciones de uso. Historia, memoria, política. Madrid, Marcial Pons, 2007a. Os estudos sobre memória são inúmeros em escala nacional e internacional. A força interdisciplinar do tema pode ser atestada em coletâneas e publicações editadas recentemente: [WEINRICH, 2001]; [JELIN, 2002]; [SELIGMANN-SILVA, 2003]; [BRESCIANI; NAXARA,2004]; [SELIGMANN-SILVA, 2005]; [SeligmanN-Silva,2006]; [OBerti; Pittaluga,2006]; [LaCAPra,2006]; [Friedlander, 2007] e [RICOEUR, 2007]. Cf. a bibliografia.
} 
senão que é testemunha da experiência, em particular nos difíceis casos de acontecimentos extremos e experiências traumáticas”14.

A história e a memória são esferas distintas que se entrecruzam constantemente, mas compartilham a mesma preocupação e objeto: a elaboração do passado. A memória, seja individual ou coletiva, assim como a história, é sempre uma visão do passado mediada pelo presente. Entendida como um conjunto dinâmico de representações coletivas do passado forjadas no presente, a memória estrutura identidades sociais, inscrevendo-as na história e dando-lhes sentido [TRAVERSO, 2007: 67]. A memória apóiase na experiência vivida pelas pessoas e em função deste caráter subjetivo não pode ser fixada. Assim como a historiografia, a memória é uma “[...] construção, está sempre 'filtrada' pelos conhecimentos posteriormente adquiridos, pela reflexão que se segue ao acontecimento, ou por outras experiências que se superpõem à primeira e modificam a recordação"15.

O sujeito é parte integrante do processo de conhecimento e influenciado pelo seu tempo, tanto a história como a verdade possuem sua marca ou núcleo temporal ${ }^{16}$. Para os historiadores que trabalham com fontes orais é sempre difícil encontrar o equilíbrio entre empatia e distância dos testemunhos, entre o reconhecimento das singularidades e a visão em perspectiva. O historiador sofre os condicionamentos do presente, mas cabe a ele explicitar sua busca pelo equilíbrio entre passado e presente, entre uma visão por vezes interior e exterior do passado construída simultaneamente pela adesão e pelo distanciamento crítico dos relatos, pela tensão existente entre a singularidade da memória e a universalização e, a compreensão que emerge de sua inscrição num contexto histórico mais geral [TRAVERSO, 2007: 75-6]. A construção das leituras e interpretações da realidade é feita a partir dessas tensões, sempre calcada na força de gravidade que emana do presente e na visão fragmentada, cheia de lacunas e descontinuidades dos testemunhos e da memória [ADORNO, 1986].

Ao longo das últimas décadas a noção de testemunha recebeu nova forma de validação. Na atualidade, a memória adquiriu a forma de um mandato ético: o testemunho é cada vez mais identificado com a figura da vítima. Sobreviventes vêm conquistando o direito de expressar a memória da dor e o testemunho tem sido considerado o que mais se

\footnotetext{
${ }^{14}$ LACAPRA, Dominick. Historia em tránsito. Experiencia, identidad, teoría crítica. Buenos Aires, Fondo de Cultura Econômica, 2006, p.18. Tradução livre da autora.

${ }^{15}$ Traverso, Enzo. Op.cit., p.73. Tradução livre da autora.

${ }^{16}$ ADORNo, Theodor. "Caracterização de Walter Benjamin”, em CoHN, Gabriel (org.). Theodor Adorno. São Paulo, Ática, 1986, p.190-3.
} 
aproxima da experiência vivida. Após a II Guerra Mundial, a ética ficou condenada a se rearticular e ser pensada a partir da expressão da dor e do sofrimento do corpo humano. A sobrevivência e o testemunho assumem o valor de crítica necessária, pois encerram a possibilidade de trazer à voz a barbárie que a sociedade quer esquecer ${ }^{17}$.

Desde o julgamento de nazistas como Eichmann em 1961 até os julgamentos de Barbie (1987), Touvier (1994) e Papon (1998), na França e em outros países, novos testemunhos surgiram, muitos sobreviventes se sentiram encorajados a falar. Memórias literárias tornaram-se atos de testemunho do sofrimento da guerra e da Shoah, como atesta o sucesso tardio dos escritos de Primo Levi. Nos anos 1940 e 1950, essas testemunhas eram vozes marginais no discurso público sobre a II Guerra Mundial. Os relatos heroicos da Resistência eram mais úteis para a política cultural de países humilhados pela ocupação e a colaboração [WINTER, 2006: 74].

Nos anos 1960, a sanção de leis de imprescritibilidade ${ }^{18}$ dos crimes contra a humanidade em vários lugares conduziu à realização de grandes processos contra nazistas, como o julgamento de Frankfurt (1963-1965), o de Dusseldorf (1975) e o de Colônia (1980), na Alemanha ${ }^{19}$. Nesse momento, a estabilidade política estava completa, as vítimas dos campos de concentração puderam entrar em cena, revelando outras narrativas que não cabiam no modelo heroico [WINTER, 2006: 74]. "Essa dissimetria da recordação - a glorificação de vítimas antes ignoradas e o esquecimento de heróis outrora idealizados - indica a ancoragem profunda da memória coletiva no presente” [TRAVERSO, 2007: 71]. Esta relação de influência mútua revela também a necessidade do debate constante em torno de suas implicações.

Desde então, a memória do genocídio judeu assumiu a hegemonia, fortalecendo a crescente “judicialização do passado”. No final dos anos 1980, no marco do julgamento de Klaus Barbie abriu-se um vasto espaço de reflexão em torno das contradições existentes entre memória, justiça e história [Rousso, 2007: 68-9]. Os testemunhos diretos ganharam evidência por meio da publicidade dos grandes processos criminais contra

\footnotetext{
${ }^{17}$ Adorno, Theodor. Dialética Negativa, citado em Seligmann-SiLva, Márcio. Adorno. PubliFolha, 2003, p.87-90; e WiNTER, Jay. "A geração da memória: as reflexões sobre 'boom da memória' nos estudos contemporâneos de história”, em Seligmann-Silva, Márcio (org.). Palavra e imagem: memória e escritura. Chapecó, Argos, 2006.

${ }^{18} \mathrm{Em} 1965$ ocorreria a prescrição dos crimes nazistas, para evitá-la essas leis foram editadas nos países que acolheram o direito internacional relacionado aos crimes contra a humanidade. V. Rousso, H. Op.cit., p.72; WINTER, Jay. Op.cit., p.74.

${ }^{19}$ Conhecidos como "processo de Auschwitz" e "processo de Majdanek", respectivamente. Em Colônia foram julgados Kurt Lichka e Herbert Hagen, graças à ação persistente do casal Klarsfeld. V. Rousso, H. Op.cit., p.71.
} 
nazistas e da historiografia, caminhando lentamente pela memória coletiva [RICOEUR, 2007: 187]. Essas modificações das representações do passado, das normas e práticas institucionais relacionadas à memória dos crimes de Estado colocaram em discussão questões como a da responsabilidade, a da “culpa coletiva” e individual, a do "dever de memória” e seus limites, inclusive na versão judicial, das manipulações da memória obrigada e das comemorações ${ }^{20}$.

Esse debate redimensionou a relação existente entre memória e história. Estas têm suas próprias temporalidades que não se identificam necessariamente. A memória possui uma temporalidade qualitativa que pode colocar em questão o continuum da história, assim como o tempo linear, mecânico e vazio da historiografia tradicional, conforme analisou Walter Benjamin [TRAVERSO, 2007: 75]. A recordação pode surgir como ato redentor da memória dos vencidos, como mostra uma foto de abril de 2000, na qual se podem ver indígenas disparando nos relógios das comemorações oficiais do V Centenário do chamado "Descobrimento do Brasil” ${ }^{21}$.

A demanda por memória que surgiu no Brasil no final dos anos 1970, impulsionada em grande medida pela campanha em defesa da anistia, ampla, geral $e$ irrestrita para os perseguidos políticos, tinha como objetivo valorizar a memória dos vencidos e redimir os sobreviventes num cenário de disputas e embates para pôr fim à ditadura, conjugando novas e velhas formas de fazer política. Essa demanda correspondia também ao "impulso imediato e violento" de contar "aos outros” sua história e fazer com que "os outros” participassem dela, uma exigência expressa antes e depois do final da ditadura $^{22}$.

Surgiram, desde o final daquele período, distintas narrativas sobre o passado recente produzidas por sobreviventes e protagonistas em romances e livros autobiográficos ou de entrevistas e reportagens biográficas. Esta demanda inicial por memória colocava em questão os laços que unem as gerações e os veículos de transmissão de histórias, memórias e crenças, que produzem identificações e criam identidades $^{23}$. Esses relatos já expunham uma série de problemas abertos em torno do passado recente: os limites e bloqueios existentes na relação que a sociedade, os grupos

\footnotetext{
${ }^{20}$ V. Rousso, H. Op.cit., p.71; e Ricoeur, Paul. Op.cit., p.93-104.

${ }^{21}$ LöwY, Michael. Walter Benjamin: aviso de incêndio. Uma leitura das teses "Sobre o conceito de história”. São Paulo, Boitempo, 2005.

${ }^{22}$ LeVI, Primo. É isto um homem? Rio de Janeiro, Rocco, 1988, p.7-8.

${ }^{23}$ V. OBeRTI, Alejandra. "El valor del testimonio: usos, accesos y saberes". Texto apresentado no Seminário Internacional 30 Anos de Anistia no Brasil: o direito à memória, à verdade e à justiça. Fadusp, São Paulo, 25 a 28/09/09.
} 
políticos e sociais constroem entre o passado e o presente no Brasil, em especial, quando se trata de experiências-limite e cruciais da vida do país.

Com o interesse pelos estudos sobre a memória e o trauma histórico [LACAPRA, 2006: 147] ganhou força o uso de conceitos psicanalíticos transportados do ambiente analítico para o dos processos de formação de memórias coletivas, visando compreender como as sociedades lidam com as situações-limite, as perdas e o luto. Conceitos e categorias freudianas revelaram-se pertinentes à reflexão relativa ao caráter social destes problemas $^{24}$, principalmente no que tange ao papel da compulsão à repetição traumática nas formações mnemônicas - quando o acontecimento passado irrompe em estado bruto, no lugar da recordação - um passado que surge como repetição e resistência a transformá-lo em lembrança [RICOEUR, 2007: 83-7]. Dir-se-ia que a compulsão à repetição impede a conscientização dos acontecimentos traumáticos e que "em seu lugar surgem fenômenos de substituição, sintomas, que mascaram o retorno do recalcado de modos diversos”. Muitos aspectos das experiências das vítimas da ditadura podem ser compreendidos à luz desta reflexão, à qual se complementa pela perspectiva de que, em circunstâncias particulares, "porções inteiras do passado reputadas esquecidas e perdidas podem voltar” [RICOEUR, 2007: 452-3].

Em situações pós-traumáticas distinções fundamentais são derrubadas, como a distinção entre o então e o agora, “[...] mediante a qual se pode recordar o que nos aconteceu no passado sem deixar de dar-se conta de que vivemos aqui e agora e temos possibilidade para o futuro" [LACAPRA, 2005: 68]. Situações que demandam o trabalho de luto, quando se alcança certo distanciamento do passado mediante a valorização e o reconhecimento dos que sobreviveram, relativa aceitação das perdas e uma recordação mais apaziguada e elaborada do passado. Obtém-se uma integração da perda à experiência da rememoração e a perlaboração ${ }^{25}$.

No Brasil, no final da ditadura, os primeiros relatos dos sobreviventes publicados - de exilados, militantes ou presos políticos -, punham em primeiro plano a denúncia dos crimes da ditadura e a militância, período em que ocorreu certa valorização da memória militante. Numa conjuntura em que a ditadura dava seus últimos suspiros, mas insistia em

\footnotetext{
${ }^{24}$ V. FREUd, S. Totem e Tabu (1913), O futuro de uma ilusão (1927), O mal estar na cultura (1929), Moisés e o Monoteísmo (1934), entre outras obras. Cf. RicoEuR, Paul. Op.cit., p.91-3.

${ }^{25}$ Freud, S. "Recordar, repetir e elaborar" (1914). Trad. Paulo César de L. Souza. Jornal de Psicanálise, São Paulo, 27 (51): 125-136, jul. 1994 e "Luto e melancolia" (1917). Artigos sobre Metapsicologia. Rio de Janeiro, Imago, 1999. V. tb. RICOEUR, Paul. Op.cit., p.91, 453-2; LACAPRA, D. Op.cit., 2005, p.105-110; Rousso, H. Op.cit; WeInRICH, Harald. LETE. Arte e crítica do esquecimento. Rio de Janeiro. Civilização Brasileira, 2001, p.190-1.
} 
se manter, sobreviventes e militantes necessitavam legitimar sua posição política. A memória se erigiu não somente contra o esquecimento, mas também, contra a ditadura que ocultava e negava seus crimes.

A campanha em defesa da “anistia, ampla geral e irrestrita” para os perseguidos políticos mobilizou amplos setores da sociedade civil e estabeleceu uma contra memória, rompendo com a invisibilidade e o silêncio impostos aos presos políticos, combatendo a imagem de "subversivos" e "terroristas" que lhes fora atribuída pela ditadura. ${ }^{26}$ Os movimentos de anistia foram fundamentais para a construção de uma identidade de militantes e ativistas políticos para os guerrilheiros. O horizonte desta memória, porém, era o das lutas políticas e institucionais mais do que o dos direitos. A reivindicação pelos caídos/mortos, pelo direito à verdade e à justiça ficou, desde os primeiros anos da democracia, reduzida a expressões minoritárias.

Os grupos e entidades de familiares, sobreviventes e militantes dos direitos humanos como a CJP/SP (1972), a Comissão de Familiares e Mortos e Desaparecidos Políticos (1974), o Centro Santo Dias de Direitos Humanos (1980) e o GTNM/RJ $(1985)^{27}$, entre outros, continuaram essa luta, reivindicando justiça e o esclarecimento dos crimes cometidos pelas forças de segurança, o desmantelamento do aparelho repressivo, a depuração do Estado, a revogação da LSN e do legado autoritário. Tornaram-se os agentes dessa memória, provocando o debate e a atenção, tentando gerar participação e tornar públicos e legítimos os relatos silenciados, criando e elaborando rituais, comemorações e marcas simbólicas de reconhecimento e pertencimento, como as missas celebradas na Praça da Sé (SP) desde os anos 1970 em homenagem aos mortos e desaparecidos políticos; o Prêmio Vladimir Herzog de Jornalismo, criado em 1979; e a entrega da Medalha Chico Mendes, do GTNM/RJ, iniciada em 1989.

Ainda que as demandas por justiça e verdade tenham permanecido presentes nos movimentos sociais e partidos políticos, deve-se ter em vista que isto se consolidou de maneira marginal, o que dificultou a construção de vínculos com o passado recente e as memórias dos mortos e desaparecidos políticos. Em função da recorrente divulgação de novas denúncias sobre a violência estatal do período ditatorial e a insistente exigência

\footnotetext{
${ }^{26}$ V. GReCO, Heloisa Amélia. Dimensões fundamentais da luta pela anistia. Doutorado, FAFICH/UFMG, 2003, p.75-9.

${ }^{27}$ Nos anos seguintes, Grupos Tortura Nunca Mais foram organizados em outros estados, em São Paulo (1987), Minas Gerais, Pernambuco, Paraná e Bahia, em geral, compostos por ex-presos políticos e familiares de mortos e desaparecidos políticos.
} 
desses direitos, essas vozes, embora marginais, aos poucos foram construindo um discurso e uma memória mais identificados com as vítimas.

Um aspecto digno de nota do período inicial da demanda por memória diz respeito à maneira como alguns relatos autobiográficos impuseram uma pesada carga crítica às organizações revolucionárias ligadas à luta armada. Livros como $O$ que é isso, Companheiro? (1979), de Fernando Gabeira, e Os carbonários (1980), de Alfredo Sirkis, faziam essa crítica pela via do humor e da ironia, procurando ressaltar o caráter aventureiro (no limite, irresponsável) das ações armadas. Algumas dessas obras foram escritas no exílio e estiveram muito mais preocupadas em discorrer sobre o debate político e o cotidiano da militância clandestina do que sobre a vida nos cárceres ou depois dela $^{28}$. Ainda assim, essas obras provocaram grande impacto, com repercussões em âmbito nacional e, por vezes, internacional, o que as levou a assumir um papel destacado na formação das representações sociais sobre a ditadura ${ }^{29}$.

Em um momento de grandes mudanças políticas e econômicas, em que a ditadura procurava controlar o processo de transição para a democracia, era necessário fazer uma avaliação daqueles acontecimentos históricos e das experiências extremas envolvendo as derrotas e conquistas para explicar, situar e direcionar a atuação política. A perspectiva de conquistar espaços políticos por meio da organização e participação nos novos movimentos sociais, no sindicalismo, partidos políticos e entidades era objeto de disputas e transformações de concepções e práticas políticas.

Os testemunhos e relatos autobiográficos cumpriram o papel de buscar explicações, organizar ideias e avaliações com coragem e lucidez. Alguns dos mais significativos relatos, porém, estavam marcados pela queixa e pela recriminação, pelo peso das perdas de companheiros, das perdas simbólicas e do sentimento de culpa. Compunham uma enumeração de erros e equívocos nos quais essas experiências e lutas eram desvalorizadas, deixando pouco espaço ao reconhecimento dos que sobrevieram e

\footnotetext{
${ }^{28}$ Livros como os de BETto, Frei. Cartas da prisão. Rio de Janeiro, Civilização Brasileira, 1977; BetTo, Frei. Das catacumbas: cartas da prisão (1969-1971). Rio de Janeiro, Civilização Brasileira, 1978, e VIANNA, Gilney Amorim. 131-D. Linhares: Memorial da prisão política. Contagem, Editora História/Comitê Brasileiro pela Anistia/ Movimento Feminino pela Anistia, 1979; LIMA, Haroldo. Itinerário. Salvador, Comitê Brasileiro pela Anistia - Núcleo Bahia, 1979; DiAs, Luzimar Nogueira (Org.). Esquerda armada: testemunhos dos presos políticos do Presídio Milton Dias Moreira no Rio de Janeiro. Vitória, Edições do Leitor, 1979, relataram a vida na prisão.

${ }^{29}$ Anos depois, esses livros influenciaram minisséries de TV, como “Anos Rebeldes” (1992) e ganharam versões no cinema, como os filmes O que é isso, Companheiro? (de Bruno Barreto, 1997) e Batismo de Sangue (de Helvécio Ratton, 2006).
} 
de seu legado ${ }^{30}$. Parte do luto tão necessário, a descrição das cenas da violência das torturas e das terríveis condições de sequestro e prisão ou da memória afetiva daqueles dias mostrava a força da sua presença. Esses relatos testemunham a enorme dificuldade de contar e de alcançar certa "reconciliação" consigo e com o passado e realizar o trabalho de luto. Tratam da dificuldade de operar a distinção entre aqueles que sobreviveram e os companheiros assassinados ou desaparecidos, a distinção entre o passado e o presente.

A memória dos crimes da repressão estatal expressa no espaço público pelos primeiros testemunhos tendia a contribuir para isolar e deslegitimar ditaduras [TRAVERSO, 2007: 81]; não obstante, no caso brasileiro, isto não significou a geração de rupturas radicais, acompanhadas de "fraturas simbólicas" com o passado. A ditadura brasileira não foi derrubada como o nazi-fascismo europeu em 1945 e nem ficou completamente desmoralizada como na Argentina, após a derrota na Guerra das Malvinas. Não houve no país uma depuração das instituições militares e de segurança, nem processos judiciais para apurar responsabilidades das violações aos direitos humanos. A fase da aflição e angústia inicial descrita nos relatos ficou em grande medida sufocada e o trabalho de luto foi perenizado.

A rememoração pública da ditadura foi impedida em diversos aspectos e momentos e, de certa maneira, ainda não pôde dar lugar ao distanciamento crítico. Houve um distanciamento cronológico, mas as condições para a rememoração ou a escritura da história, em especial sobre o funcionamento do aparato repressivo do Estado e seus crimes, continuam travadas em função da multiplicação de obstáculos políticos à investigação jurídica e até científica, como a manutenção do sigilo sobre os principais arquivos da repressão política.

Dois marcos inaugurais da memória sobre a ditadura, a publicação do livro Brasil Nunca Mais, em 1985, e a abertura da vala clandestina de Perus, em 1990, foram fundamentais para que a identidade das vítimas ganhasse relevância. Esses foram dois momentos emblemáticos de divulgação de denúncias dos crimes cometidos pela repressão estatal do período. Ambos estavam calcados em registros documentais que, no primeiro caso, foram representados pelos autos dos processos abertos contra os perseguidos políticos produzidos pela Justiça Militar e no segundo, por provas materiais e/ou indiciárias, pelos restos mortais de desaparecidos políticos parcialmente analisados e

\footnotetext{
${ }^{30}$ V., por exemplo, Polari, Alex. Em Busca do Tesouro Perdido. Rio de Janeiro: Codecri, 1982; e DANIEL, Herbert. Passagem para o próximo sonho. Rio de Janeiro, Codecri, 1982.
} 
identificados pela medicina forense, em face de indícios preservados por cerca de 25 anos.

Na década de 1990, os desdobramentos políticos e institucionais gerados por esses dois momentos inaugurais da memória da ditadura foram limitados e insuficientes. A admissão da responsabilidade do Estado pelos assassinatos e desaparecimentos forçados e a política de reparação de familiares e sobreviventes foi um importante momento de reconhecimento dos seus direitos e da identidade das vítimas do passado ditatorial. Estas memórias, porém, continuaram a ser objeto de disputas, conflitos e lutas, tendo em vista a ausência de políticas públicas que garantissem uma resposta efetiva para as demandas por “Verdade e Justiça”. Enquanto a memória dos desaparecidos argentinos ficou polarizada entre a identidade de combatente e a de vítima, o Brasil assistiu a uma dinâmica simbólica tanto mais tênue, tendo em vista as dificuldades para que a memória de mortos e desaparecidos políticos pudesse encontrar expressão na esfera pública ${ }^{31}$.

Nesses anos, começou a consolidar-se uma produção historiográfica que buscava um distanciamento do passado, empenhando-se por compreender o funcionamento da ditadura instaurada com o golpe de 1964 e fazer a crítica das esquerdas revolucionárias e da luta armada. Por outro lado, ocorreu um relativo declínio na produção de relatos sobre a memória da ditadura nas suas diversas manifestações e modalidades de testemunhos de sobreviventes, em comparação com a produção inicial do final dos anos 1970. Ao todo, contabilizamos 99 livros em forma de reportagem ou romance autobiográfico sobre o período ditatorial, os quais distribuem-se ao longo dos anos, de acordo com os gráficos em anexo ${ }^{32}$. Como se pode notar, a maior produção deste tipo deu-se no final da década de 1970 e início dos anos 80.

Iniciativas para constituir acervos orais em universidades buscaram desenvolver a pesquisa sobre a ditadura na perspectiva da memória. Em especial, chamou a atenção um projeto de história oral de militares organizado por pesquisadores do CPDOC da Fundação Getúlio Vargas que resultou na publicação de livros contendo parte das entrevistas realizadas, ganhando considerável repercussão ${ }^{33}$.

\footnotetext{
${ }^{31}$ V. VeZZETTI, Hugo. Sobre la violencia revolucionaria. Memórias y olvidos. Buenos Aires, Siglo XXI, 2009, p.40.

${ }^{32}$ V., em anexo, os gráficos e a bibliografia de testemunhos, p. 503 e p. 505.

${ }^{33}$ D'ARAÚJo, M.C., SOARES G. A. D. e CASTRO, C. (orgs.). Visões do Golpe: a memória militar sobre 1964. Rio de Janeiro, Relume-Dumará, 1994; Os anos de chumbo: a memória militar sobre a repressão. Rio de Janeiro, Relume-Dumará, 1994; A volta aos quartéis: a memória política sobre a abertura. Rio de Janeiro, Relume-Dumará, 1995.
} 
Desde 2008, as iniciativas governamentais no campo da memória e da reparação simbólica às vítimas ${ }^{34}$ mostram alguma mudança neste panorama, ainda que prevaleça a insuficiência de políticas de memória, de acervos orais que organizem e divulguem os testemunhos de sobreviventes, advogados, militantes e familiares de prisioneiros e de mortos e desaparecidos políticos. Assim, o registro desses testemunhos torna-se uma questão importante para a reflexão historiográfica e um ponto de partida para organizar estudos pautados pelo escopo da história oral, como se deu em relação aos ex-presos políticos, no projeto Intolerância e Resistência: Memória da Repressão política no Brasil (1964-1985).

\section{I.1.1. O projeto de história oral dos presos políticos}

O projeto de história oral dos presos políticos acima citado foi elaborado em 2001 com o objetivo de constituir um acervo audiovisual de testemunhos sobre a repressão estatal e a ditadura no Brasil. Pensado como um instrumento de preservação e transmissão da memória, seu enfoque dirigiu-se aos ex-presos políticos. O projeto tomou forma em um momento de inflexão da presença da memória sobre o passado ditatorial no espaço público, colocando os sobreviventes da violência estatal no centro das medidas de reparação. Durante os anos 1990, os familiares de mortos e desaparecidos políticos foram o foco do pagamento de indenizações simbólicas e os sujeitos das ações e demandas de busca de informações e da recuperação de restos mortais desses militantes. No início dos anos 2000, com a ampliação da Lei de Anistia, os sobreviventes dos cárceres políticos tornaram-se o ponto de convergência da adoção de políticas de reparação.

Em 1999, as comemorações dos 20 anos da Anistia levaram o governo de São Paulo a propor um projeto de lei que previa indenização a torturados em dependências do Estado e convênios para a proteção de testemunhas. Além disso, o governo paulista anunciou que planejava a transformação do antigo prédio da polícia política do estado, o DEOPS, em um espaço destinado à arte ${ }^{35}$. Em setembro daquele ano, no prédio do

\footnotetext{
${ }^{34}$ Algumas mudanças são sentidas tais como as Caravanas da Anistia e a construção do Memorial da Anistia (em andamento), iniciativas da Comissão de Anistia (Ministério da Justiça). V. http://portal.mj.gov.br/data/Pages/MJ20BF8FDBPTBRIE.htm. Acesso em 03/10/2011. A SEDH organizou 3 livros, seminários, exposições fotográficas sobre temas afins e 27 Memoriais das Pessoas Imprescindíveis, em diversas cidades do país. V. http://www1.direitoshumanos.gov.br/mortosedesap/id_livro. Acesso em 03/09/2011.

35 “Comemoração dos 20 anos da lei começa hoje com ato em SP”. Folha de S. Paulo, 23/08/99.
} 
DEOPS foi montada a peça Lembrar é Resistir, de Izaías Almada e Analy Alvarez, tendo como cenário as antigas celas, gerando comoção nos espectadores pelo realismo das cenas e a proximidade com os atores. A peça ficou em cartaz por quase um ano, sob a direção de Silnei Siqueira, e depois foi apresentada durante algumas semanas no prédio do DEOPS/RJ, dirigida por Nelson Xavier. Em julho de 2002, o prédio do DEOPS foi reaberto passando a sediar o Memorial da Liberdade ${ }^{36}$.

A criação de um "lugar de memória" naquele formato e local gerou debates e polêmicas sobre como deveria ser preservado e como reconstruir as memórias e histórias desse passado. Desde então, o memorial passou por inúmeros processos de transformação e descaracterização do prédio. Foram destruídas duas celas, localizadas no térreo, o chamado "Fundão", formado por celas que funcionavam como solitárias. O espaço recebeu novas pinturas, quando foram raspadas as inscrições deixadas nas paredes das celas por presos políticos de diversas gerações. Essa postura institucional gerou críticas. Em 2008, foi renomeado como Memorial da Resistência, num projeto coordenado pela Secretaria de Estado da Cultura de São Paulo e pela Secretaria Especial dos Direitos Humanos da Presidência da República (SEDH). A mudança de nome "era reivindicada por ex-presos e perseguidos políticos”. De acordo com o então secretário de Estado da Cultura, João Sayad, “chegava a ser uma ironia ser chamado de Memorial da Liberdade. O novo nome é mais adequado e presta homenagem aos que lutaram aqui” ${ }^{37}$.

Nesse período, organizaram-se grupos e entidades de ex-presos políticos mobilizados para debater as propostas de leis estaduais de reparação econômica para os perseguidos políticos e as demandas de ampliação da lei de anistia. Assim, em 2000, surgiu em São Paulo o Fórum Permanente dos Ex-Presos e Perseguidos Políticos, que organizou encontros e debates sobre essas questões ${ }^{38}$. Em janeiro de 2001, foi editada a lei de reparação do Estado de São Paulo (lei 10.726/01), que instaurou uma Comissão de Reparação para avaliar pedidos de indenização para os que foram presos e torturados por motivos políticos durante a ditadura ${ }^{39}$. Neste mesmo ano, a Medida Provisória 2.151 foi transformada na Lei 10.559 em 2002; assim, ampliaram-se os parâmetros e critérios para estabelecer a reparação aos perseguidos políticos, e criou-se a Comissão de Anistia, no

\footnotetext{
${ }^{36}$ A reforma custou R\$ 12,5 milhões. “Museu do Imaginário só fica pronto no fim do ano”. O Estado de S. Paulo, 03/07/2002.

37 “Memorial da Resistência rebatiza celas do antigo Dops”. Agência Estado, 02/05/2008.

${ }^{38}$ V. http://www.oamigoescolar.com.br/site/jornais/edi100_not_1.htm. Acesso em 02/05/2011.

${ }^{39}$ Nesse período, diversos estados editaram leis de reparação econômica: no Rio Grande do Sul e Paraná, em 1997; Santa Catarina, em 1998; Minas Gerais, em 1999; Pernambuco, em 2000; São Paulo e Ceará, em 2001; Rio Grande do Norte, em 2003, Rio de Janeiro e Bahia, em 2004.
} 
âmbito do Ministério da Justiça, destinada principalmente a examinar os pedidos de indenização daqueles que tiveram danos trabalhistas durante a ditadura ${ }^{40}$.

Nesse cenário de mobilizações em torno da memória da ditadura e das medidas de reparação econômica, foi elaborado o projeto de história oral dos presos políticos. Um projeto piloto foi desenvolvido em $2002^{41}$, mas somente em 2008 tornou-se possível o início da sua realização ${ }^{42}$. Das 80 entrevistas do projeto, 17 delas foram realizadas com mulheres. Do total, 11 entrevistas ocorreram no Rio de Janeiro e duas foram gravadas em Recife (PE), com o apoio da Fundação Joaquim Nabuco. As demais foram realizadas em São Paulo, sendo que dois entrevistados atuaram no Nordeste (no Ceará e na Bahia). Essas entrevistas somam 333 horas gravadas ${ }^{43}$.

Inspirado na experiência da ONG argentina Memoria Abierta, que organizou seu Arquivo de História Oral com mais de 640 entrevistas de sobreviventes, militantes e familiares de desaparecidos políticos registradas em vídeo ${ }^{44}$, o objetivo do projeto é trabalhar o depoimento enquanto processo de documentação, garantindo a transparência de seu método e procedimentos, o compromisso de retorno à comunidade, cujos testemunhos foram registrados, e seu caráter público ${ }^{45}$.

\footnotetext{
${ }^{40}$ Sobre a Comissão de Anistia, ver MEZAROBBA, Glenda. O preço do esquecimento: as reparações pagas às vítimas do regime militar (uma comparação entre Brasil, Argentina e Chile). Doutorado/Ciências Políticas, USP, 2007, p.135-53.

${ }^{41} \mathrm{Em}$ 2002, com financiamento da USP, foram realizadas cinco entrevistas, em colaboração com o cineasta Claudio Kahns. V. as entrevistas de Alberto Becker, César Augusto Teles, Raphael Martinelli, Murilo Melo e Sara Becker, feitas por Janaina de A. Teles, Zilda M. Grícoli Iokoi e Claudio Kahns.

${ }^{42}$ Desse total, 74 entrevistas foram realizadas pela pesquisadora Janaina de A. Teles. O assistente de pesquisa Júlio Ramos de Toledo fez as gravações das entrevistas em fitas mini-DV e colaborou na textualização e edição das transcrições das mesmas. Os depoimentos, as transcrições das entrevistas e o material audiovisual ficarão disponíveis na Biblioteca do LEI - FFLCH/USP e no AEL-Unicamp. Um banco de dados contendo informações sobre o perfil dos entrevistados, tais como partido, profissão, idade, presídio em que ficaram e quais foram seus advogados facilará o acesso às entrevistas. Das 80 entrevistas realizadas, 15 foram publicadas no livro TelEs, Janaina de A.; RIDENTI, M.; IOKOI, Zilda M. Grícoli (orgs.). Intolerância e Resistência: Testemunhos da repressão política no Brasil (1964-1985). São Paulo, FFLCH/USP, 2010. Doravante, o Acervo Audiovisual de ex-Presos Políticos, constituído pelo projeto, será citado como AAPP/AEL-LEI.

${ }^{43}$ V., em anexo, a lista dos entrevistados. O projeto realizou também o Seminário Internacional 30 anos de Anistia no Brasil: o direito à memória, à verdade e à justiça, de 25 a 28/08/2009, na Faculdade de Direito da USP, em parceria com a Fundação Heinrich Böll e o Instituto Goethe; uma Mostra de Cinema: Espectros em retrospectos: O Cinema como Memória de Regimes Autoritários, realizada entre 03 e 09/08/2009, no Cinusp e na Galeria Olido, em parceria com o NEV/USP e Instituto Goethe; e uma viagem à Argentina para conhecer o trabalho da ONG Memoria Abierta, entre outros.

${ }^{44}$ Memoria Abierta é uma ONG formada em 2000 por cinco organismos de direitos humanos: Madres de Plaza de Mayo, Abuelas de Plaza de Mayo, Servicio Paz y Justicia, Centro de Estudios Legales y Sociales y Asemblea Permanente por los Derechos Humanos. Seu arquivo oral é coordenado por Alejandra Oberti. As entrevistas somam aproximadamente 1.600 horas e estão organizadas em uma base de dados, abertas à consulta pública. V. o site www.memoriabierta.org.ar.

${ }^{45}$ V. Meiry, José Carlos Sebe Bom. Manual de História Oral. $3^{a}$ ed., São Paulo, Loyola, 2000; e Definindo história oral e memória. In: Cadernos CERU, n 5, série 2, São Paulo, 1994.
} 
O testemunho sobre o passado é sempre datado, um exercício de memória que traz a marca do momento em que é pronunciado. Impressões e avaliações narradas sobre uma mesma experiência podem ser recontadas de uma maneira bastante diferente anos depois do primeiro relato. $\mathrm{O}$ ato de lembrar sempre se produz quando já transcorreu algum tempo. Essa marca implica na distinção que ela estabelece entre o antes e o depois. A memória é a guardiã da profundeza do tempo e da distância temporal. "E é esse intervalo de tempo, entre a impressão original e seu retorno, que a recordação percorre” [RICOEUR, 2007: 35-7, 72].

A memória tem outra característica: tanto chega-nos espontaneamente quanto se faz objeto de busca sendo, neste sentido, “exercitada”. “Lembrar-se é ter uma lembrança ou ir em busca de uma lembrança” [RICOEUR, 2007: 24]. A lembrança é alternadamente encontrada e buscada. A memória é a conjunção da evocação simples e do esforço de recordação, da estimulação externa e da leitura interna de imagens, que busca semelhanças e realiza associações [RICOEUR, 2007: 37-8]. Os gregos antigos tinham dois termos para designar a lembrança e compreender o ato de lembrar. De um lado, a mnémé designava a lembrança ou imagem do passado que aparece, acolhe-se ou recebe-se passivamente, no limite. Ela foi caracterizada como afecção - pathos (paixão). De outro lado, a anamnésis indicava a lembrança considerada objeto de busca, geralmente, denominada recordação. A memória é associada à representação, imagem, imitação, sensação, mas também à busca, ao aprender, à disciplina, à ascese - o “exercício”, o que exige um penoso treinamento tendo como base a repetição, utilizado nas escolas, nas artes ou na vida cotidiana [RICOEUR, 2007: 36,71-4].

Esse duplo sentido da memória transporta-se para o domínio da história. A historiografia cada vez mais se fundamenta na busca dessa "memória exercitada” como fonte de investigação e interpretação. Neste sentido, o projeto de história oral com expresos políticos tem o sentido de busca pelo testemunho dos protagonistas da história, daqueles que viveram nos cárceres da ditadura, fornecendo um convite ao resgate de suas lembranças, desde a intermediação do historiador/entrevistador, o qual exerce o papel de quem busca e estimula a lembrança, que assim emerge na voz dos entrevistados.

Tal papel duplo deve ser concebido à luz de outra dicotomia, desta vez estabelecida pelas dimensões epistemológicas a serem conferidas ao discurso oral e por sua articulação com os diferentes níveis de interpretação do dito e, doravante, com a construção de consensos (senão verdades) históricos. 
Tornar-se-á claro pela leitura das entrevistas que o relato oral simultaneamente coloca-se no âmbito e distancia-se da facticidade (respeitados determinados limites naturais para tanto, entre os quais destaca-se o tempo transcorrido em relação aos conteúdos da experiência relatados) e que esta dinâmica articula ao menos dois planos relativamente independentes de desenvolvimento discursivo. Um destes planos poderia ser sumariamente denominado o plano da "memória episódica”, ao passo que o outro, sob a mesma inspiração, denominar-se-ia plano da "memória semântica"46.

O primeiro plano versa sobre uma forma de resgate memorialístico que urge pela recriação da experiência de realidade naquilo que ela possui de imparcial (sob a extensão e os limites em que isto se faz possível) e fidedigno à facticidade material dos acontecimentos (por exemplo, em que dia aconteceu algo, como estavam as pessoas, qual a ordem dos eventos, que consequências objetivas sucederam-se); o segundo plano inclui o resgate do sentido da experiência e, portanto, dos efeitos que esta atualiza no momento em que a pessoa é interpelada (por exemplo, como ela se sentiu ou se sente em relação a algo; qual era o "clima” em determinada situação).

O plano da "memória semântica” é mais afeito a variações interindividuais (dadas duas ou mais pessoas que tenham participado de um mesmo evento) do que o plano da “memória episódica”. Neste mesmo sentido, trata-se de um plano em relação ao qual o conteúdo relatado pode modificar-se mais substancialmente em função da história de vida subsequente aos eventos e da atmosfera política em determinada atualidade. Por exemplo, o relato acerca de como alguém viveu o "clima” de determinado acontecimento histórico é, obviamente, muito dependente de como a sociedade, no momento em que este se faz interpelado, considera e respalda aqueles que tomaram parte em tal acontecimento - não sendo de se desconsiderar que o descaso oficial e a falta de suporte e compensação por determinada atuação política em prol de objetivos comuns dirima a importância atribuída aos mesmos.

Desta referência decorre a proposição de que esta tese seja compreendida como articuladora de dois planos de memória: um cujo objetivo é contribuir à caracterização de um momento histórico fundamental e suscitar discussões; e outro que versa sobre os próprios sujeitos e sobre o "sentido" daquilo que dizem, o qual pode parecer enviesado (como quando uma experiência francamente negativa é caracterizada como neutra),

\footnotetext{
${ }^{46}$ ADES, César. "Múltipla Memória”, em: Revista Psicologia USP, Memória, vol. 4 (1/2/2). São Paulo, Psicologia USP, 1993, p.9-24.
} 
conforme revela a maneira como esta experiência constitui a atualidade deste sujeito, enquanto alguém que fala do ponto de vista do presente.

A memória, em seu caráter semântico e, portanto, enquanto intimamente dependente da articulação estabelecida com um determinado momento presente em que se faz resgatada, emerge do compartilhamento de um ethos. Neste sentido, a construção do testemunho de sobreviventes só é possível por seu caráter dialógico; sendo pois mediada pela capacidade de escuta ativa e pela vontade e experiência afetiva resultante do ato de contar.

O testemunho pode assumir diversas formas que combinam diferentes estratégias de enunciação e diversas modalidades de expressão da subjetividade. Conforme assinalou Michael Pollack, essas formas de solicitar e produzir o testemunho não são alheios ao resultado que se obtém:

“[...] os testemunhos judiciais e, em menor grau, os realizados frente a comissões de investigação histórica [tais como as Comissões de Verdade] estão claramente determinados pelo destinatário. A entrevista de história oral também implica que o testemunho é solicitado por alguém, mas se dá em torno de uma negociação e da relação pessoal entre entrevistador e entrevistado. Finalmente, a escritura autobiográfica reflete uma decisão pessoal de falar publicamente por parte de quem o faz. Cada uma destas ou outras modalidades de expressão indicam diferentes graus de espontaneidade, diferentes relações da pessoa com sua própria identidade e diferentes funções do 'tomar a palavra, ${ }^{47}$."

O testemunho produzido pela história oral estabelece uma relação com "um/a outro/a” que, através do diálogo com alguém que pergunta, edita, ordena e pede, constrói uma narrativa social com sentido. Esse testemunho exige necessariamente a presença de um outro que escute ativamente e torne-se um participante, ainda que diferenciado e com distintas reações. O que se espera nesse diálogo não é identidade, mas o reconhecimento da alteridade. Esse processo empático pode afirmar e ser veículo de reconhecimento do sobrevivente e suas histórias. Nesse contexto, o testemunho pode ir além da reatualização da situação traumática e contribuir para que o sobrevivente assuma suas perdas, nomeie e atribua sentido a essas experiências [JELIN, 2002: 84-5, 89, 92-5].

A proposta de registrar os testemunhos dos presos políticos no Brasil surgiu como uma forma de captar as mudanças e permanências existentes na percepção dos protagonistas diretos desses acontecimentos e experiências. O lapso de tempo de uma geração, pouco mais de 20 anos depois do surgimento dos primeiros testemunhos de

\footnotetext{
${ }^{47}$ V. POLLACK, Michael. L'expérience concentrationnaire. Essai sur le maintien de l’identité sociale. Paris, Métailié, 1990, apud JELIN, E. op.cit., p 85. Tradução livre da autora.
} 
sobreviventes, configurava-se um momento privilegiado para registrar suas memórias. Estes novos testemunhos compõem um instrumento fundamental para "historicizar as memórias” sobre a ditadura [JELIN, 2002: 69]. Esta multiplicação de narrativas testemunhais sobre o passado recente constitui um elemento indispensável na reconstrução crítica desses acontecimentos e experiências. O registro de diversas vozes torna-se um ponto de partida do qual podem surgir outras vozes - no âmbito analítico, crítico e artístico - que as tomam como interlocutoras e fazem mais rico o campo de memórias em conflito ${ }^{48}$.

Devido às características do grupo estudado, o tipo de testemunho que registramos está a meio caminho entre a História Oral de Vida e o que se costuma chamar de entrevista Temática. A história de vida cuida mais livremente de impressões, subjetividades, sem questionários ou perguntas diretamente indutivas. Respeitando o testemunho dos ex-presos como produtores e narradores de sua história, o roteiro de perguntas do projeto buscou deixar o entrevistado o mais livre possível para contar sua vida, marcada pela vivência política dos anos de ditadura, pela clandestinidade, prisão e tortura e as marcas decorrentes dessas experiências-limite. Por um lado, estávamos atentos para que cada testemunho refletisse a experiência pessoal e tomasse o ritmo e o tempo de cada um, e, por outro lado, o roteiro das entrevistas buscou direcionar as perguntas para as questões específicas dessa experiência singular, a da vivência nos cárceres políticos da ditadura ${ }^{49}$. A maioria das entrevistas tiveram duração média de 5 horas. Algumas delas, porém, duraram de 8 a 11 horas e requereram que se retornasse duas ou três vezes à casa ou local de trabalho do entrevistado(a). Procurou-se respeitar o tempo de cada um(a) na medida em que ele(a) não se repetisse. Nesses casos, a narrativa era interrompida, quando solicitava-se que o entrevistado respondesse às questões com mais objetividade ${ }^{50}$.

O questionário utilizado como guia nas entrevistas foi pensado de maneira abrangente, de forma que contextualizasse a vida dos ex-presos políticos. Convidamos os entrevistados a falar sobre a família, a presença da política e da religião nos diferentes momentos de suas vidas, a formação educacional, o trabalho, os afetos, a militância, os

\footnotetext{
${ }^{48}$ OBERTI, Alejandra. "Memorias y testigos, una discusión actual”, em DE LA PEZA, Maria Del Carmen (coord.). Memoria(s) y política. Experiencia, poéticas y construcciones de nación. Buenos Aires, Prometeo Libros, 2009 a, p.71; e VAldez, Patrícia. Tiempo óptimo para la memoria (2000). Disponível em: $<$ www.memoriaabierta.org.ar>. Acesso em 06/04/2011.

${ }^{49}$ V. OBERTI, Alejandra. "El valor del testimonio: usos, accesos y saberes". op. cit.

${ }^{50}$ Esse é o procedimento utilizado por Memoria Abierta. Cf. entrevista com Alejandra Oberti. Buenos Aires, fev./2009.
} 
diferentes posicionamentos políticos antes e depois da prisão, mas também sobre assuntos delicados como a tortura, suas sequelas e repercussões. O objetivo era registrar a avaliação de cada um sobre suas histórias e seu legado.

Esses testemunhos assinalam não somente fatos e subjetividades relacionados à ditadura, mas também ao processo sociopolítico das décadas anteriores e posteriores ao período do terrorismo de Estado. Voltada para a atualidade dessas histórias e memórias, as entrevistas registraram também os diversos enfoques e avaliações a respeito do debate político travado no presente em torno das reparações aos anistiados, da punição aos torturadores e de outras reivindicações e tipos de justiça retrospectiva. A abrangência e a duração das entrevistas permitem uma aproximação da gravitação que o passado recente teve na vida dessas pessoas e do país em seus diversos matizes e complexidades, produzindo narrativas que apresentam uma ampla diversidade [OBERTI, 2009].

A utilização do recurso visual, registrando as entrevistas em vídeo, pretendeu ser mais uma forma de captar e apresentar, com mais possibilidades técnicas, as emoções e singularidades de cada entrevistado, oferecendo assim um contexto mais amplo, o que dá lugar a uma resposta crítica mais informada sobre os temas abordados nas entrevistas e sobre as possibilidades e impossibilidades de realizar e arquivar testemunhos orais.

O procedimento utilizado na realização das entrevistas compreendeu três fases. Na pré-entrevista, feita pessoalmente ou por telefone, ficaram registrados os objetivos, o teor da entrevista e que a mesma seria transcrita. O entrevistado foi consultado e informado de que poderia corrigi-la antes que fosse disponibilizada para o público, na USP e Unicamp. Os depoimentos foram colhidos preferencialmente na residência dos depoentes ou em outra locação indicada por eles, onde fosse possível garantir condições favoráveis, privacidade e a não interferência de terceiros.

O processo de preparação das entrevistas para enviá-las ao entrevistado mostrou-se muito trabalhoso, tendo envolvido, entre outras vicissitudes, a migração das imagens das entrevistas do vídeo para os DVDs e a posterior realização da transcrição e edição de cada uma delas - momento no qual excluímos as repetições comuns à fala e corrigimos os principais erros sintáticos e morfológicos. Este processo tornou-se ainda mais demorado em função da espera da revisão das transcrições por parte dos entrevistados.

Inexiste atualmente um levantamento exaustivo sobre o número de pessoas punidas por razões políticas durante a ditadura civil-militar brasileira; de todo o modo, é de se considerar que tenha sido bastante expressivo. Desde o golpe de 1964, as perseguições incluíram, em maior quantidade, a suspensão dos direitos políticos, a perda 
de mandato político ou de cargo público, a demissão ou perda de mandato sindical, a perda de vaga em escola pública ou a expulsão de escola particular, mas também prisão e exílio - por banimento, asilo ou refúgio. A inclusão dos nomes de opositores do regime nos arquivos do aparato repressivo causou inúmeras dificuldades, especialmente, no mercado de trabalho. A publicação de sucessivos atos institucionais e as disseminadas perseguições levaram Roberto Ribeiro Martins a calcular em mais de 1 milhão o número de brasileiros que necessitaram diretamente de anistia ${ }^{51}$.

Diante das dimensões do universo a ser pesquisado e visando garantir maior representatividade e proporcionalidade à amostragem, partimos das categorias e dados percentuais compilados pelo Projeto Brasil: Nunca Mais (BNM) para estabelecer os critérios de seleção da amostragem de ex-presos políticos a serem entrevistados. Essa seleção foi organizada em conformidade com os dados relativos a sexo, idade, partido político a que pertencia, ocupação profissional, nível de instrução, origem e tipo de acusação que motivou o indiciamento e a condenação do prisioneiro ${ }^{52}$.

De acordo com os dados do BNM, os perseguidos políticos atingidos pela Justiça Militar durante a ditadura somam 17.420 pessoas, das quais 7.367 (42,3\%) foram acusadas judicialmente e 10.034 foram atingidas na fase de inquérito ${ }^{53}$. Os processos judiciais voltados à repressão dos crimes políticos concentraram-se em duas fases. Na primeira, que se estendeu até março de 1967, iniciaram-se ações penais contra 2.127 perseguidos políticos (28,8\%); enquanto na segunda fase, 4.460 pessoas (60,5\%) foram denunciadas entre novembro de 1969 e novembro de 1974 [WESCHLER, 1990: 23, 51] ${ }^{54}$. Em função de sua relevância numérica e qualitativa, a maioria dos entrevistados foi afetada na segunda fase. Os presos políticos desta fase foram condenados a penas maiores e permaneceram períodos mais longos nos cárceres. Não obstante, registramos também

\footnotetext{
${ }^{51}$ V. levantamento detalhado no Cap. II; MARTINS, Roberto Ribeiro. Liberdade para os brasileiros: anistia ontem e hoje. Rio de Janeiro, Civilização Brasileira, 1978, p. 152; e V. MEZAROBBA, Glenda. Op.cit.

${ }^{52}$ V., em anexo, a tabela contendo as quantidades e porcentagens de processos por partidos ou organizações políticas na Justiça Militar; e a tabela relacionando quantia de entrevistados com partido, sexo, idade, ocupação etc.

${ }^{53}$ Esses números foram obtidos de 707 processos da Justiça Militar transcorridos entre 1964 e 1979. Dos 7.367, aproximadamente $88 \%$ eram do sexo masculino e $12 \%$ do feminino. Note-se que nos processos judiciais há nomes repetidos, pois há pessoas que aparecem em mais de um processo. RIDENTI, Marcelo. $O$ fantasma da revolução brasileira. São Paulo, Ed. Unesp, 1993, p.122; ARQUIDIOCESE de São Paulo. Perfil dos atingidos. Petrópolis, Vozes, 1987, p.15-6.

${ }^{54}$ Entre os réus, 1.517 (20,5\%) moravam no Estado de São Paulo. ARquidiocesE de São Paulo (1987), p.914; RIDENTI (1993), p. 68-72, p.122-3; e WESCHLER, Lawrence. Um milagre, um universo. São Paulo, Companhia das Letras, 1990, p.23, 51-2 e 60-1.
} 
alguns testemunhos de presos políticos do primeiro ciclo repressivo, assim como daqueles que foram presos entre os anos de 1975 e 1979.

A maioria dos perseguidos políticos processados pela Justiça Militar foi acusada de participação em organizações partidárias clandestinas, somando 4.935 (66,9\%) pessoas, sendo que do total de denunciados, 5.104 (69,2\%) pessoas foram formalmente presas e 2.828 (38,3\%) condenadas, indicando a seletividade da repressão judicial. Esses números, contudo, não são exatos, pois muitos perseguidos, embora tenham sido presos e torturados, não foram alvo de qualquer espécie de registro ou indiciamento na justiça. Do total de réus, 1.843 (25\%) pessoas denunciaram as torturas sofridas ${ }^{55}$, mas testemunhos relatam que, em diversas ocasiões, as denúncias feitas em juízo não foram registradas. A maioria dos presos entrevistados foi processada e condenada, pois eles foram os que permaneceram mais tempo nas prisões. Não deixamos, porém, de registrar depoimentos emblemáticos como os de dois militantes do PCdoB que atuaram na Guerrilha do Araguaia e foram sequestrados e torturados por meses, sem serem submetidos a nenhum processo judicial. Registramos também o testemunho de uma militante da AP (Ação Popular) que permaneceu presa com os dois filhos pequenos por dois meses, mas não foi processada judicialmente ${ }^{56}$.

Durante o período de realização do projeto, como já indicamos acima, foram coletas e transcritas 80 entrevistas com ex-presos políticos nas cidades de São Paulo, Rio de Janeiro e Recife. A amostragem de entrevistas colhidas é bastante representativa da totalidade dos presos políticos da década de setenta; foram entrevistadas pessoas de diferentes ocupações e faixas etárias, as quais militaram em 14 organizações de esquerda existentes durante a ditadura, além de marinheiros e sargentos envolvidos nos conflitos do período do golpe de 1964. De acordo com o BNM, chega a 15 o número das organizações mais afetadas pela repressão estatal naquele período. Com esta abrangência conseguimos dar voz aos principais protagonistas dessa comunidade localizados, principalmente, em São Paulo. Entrevistamos 17 mulheres e 63 homens, obtendo também uma visão de gênero da experiência de prisão no Brasil naquele período. Esta diversidade acarretou maior dificuldade para encontrar as pessoas representativas dessas organizações, abrangendo dirigentes e militantes de base, além de pessoas que permaneceram na prisão durante grande parte do período.

\footnotetext{
${ }^{55}$ Desse universo de denúncias foram identificados 283 tipos de tortura, sendo que 1.461 homens e 382 mulheres foram torturados; e foram indicados 444 torturadores. WESCHLER (1990), p.23, 51-2 e 60-1.

${ }^{56}$ V. entrevistas concedidas por Criméia A. S. de Almeida, Danilo Carneiro e Maria Auxiliadora de A. Arantes à autora. V. listagem em anexo.
} 
Os entrevistados, em geral, colaboraram e se sentiram menos intimidados com a presença da câmera de vídeo do que inicialmente conjecturou-se. Esta peculiaridade ofereceu-nos a oportunidade de produzir entrevistas particularmente longas e abrangentes. Poucos convidados se recusaram a participar do projeto, sendo que aqueles que o fizeram, alegaram a intenção de evitar a exposição de experiências e temas de profunda delicadeza em público. Para uma parcela considerável das pessoas, essa experiência representou sua primeira entrevista de história de vida, o que favoreceu a produção de depoimentos notoriamente espontâneos e tensos. Cabe destacar que dois convidados a participar do projeto manifestaram seu desejo de que suas entrevistas não fossem gravadas em vídeo, o que inviabilizou sua colaboração.

O fato de o trabalho ter sido registrado em vídeo demandou conversas preliminares consideravelmente detalhadas e longas, permitindo ao entrevistado conhecer os detalhes do projeto, de modo a se sentir suficientemente seguro para conceder a entrevista. Os momentos de “negociação” com os entrevistados acerca dos conteúdos e períodos a serem narrados proliferaram. Vários entrevistados solicitaram pausas durante a entrevista para conversar a respeito da maneira como visavam abordar temas de particular dificuldade -relacionados à tortura; às tarefas exercidas na clandestinidade; às disputas e divergências políticas vividas nas prisões e nas organizações de esquerda.

Os testemunhos compilados neste projeto representam fontes documentais ricas e importantes para a recuperação da história das lutas de resistência e das instituições da repressão estatal, úteis também para complementar outras fontes e fazer inferências sobre acontecimentos históricos. Em especial, eles contribuem para a compreensão da experiência de prisão durante a ditadura, suas consequências e o papel da memória e dos esquecimentos em que esses sujeitos incorreram “a fim de acomodar-se ao passado, negálo ou reprimi-lo” [LACAPRA, 2005: 105].

Vários depoimentos surgiram com surpreendente intensidade e paixão. Durante a realização das entrevistas, impuseram-se, constantemente, questões a respeito das possibilidades de conciliar os afetos com os procedimentos da reconstrução objetiva do passado. Os testemunhos exigiram um significativo esforço de escuta ativa e interação empática, capaz de assegurar a dinâmica e a objetividade necessárias para o sucesso do projeto. O processo de entrevista demandou disposição e coragem dos entrevistados, que, de certa maneira, “voltaram a viver fatos” dolorosos e difíceis do passado.

Os testemunhos dos ex-presos políticos formam o conjunto documental principal da presente tese. Além disso, foram realizadas algumas entrevistas com advogados e 
militantes que formaram a rede de solidariedade aos prisioneiros políticos do período analisado. Tais entrevistas contribuíram para nos aproximar do debate político e jurídico de então e das relações estabelecidas entre o que era vivido nas prisões e fora delas. Além disso, utilizamos alguns documentos provenientes dos acervos pessoais dos entrevistados, documentos dos arquivos dos órgãos de segurança ou aqueles dirigidos pelos ex-presos às comissões de reparação estaduais ou à Comissão de Anistia, do Ministério da Justiça.

\section{I.2. Os usos e a crítica da cultura da memória}

A memória tem ocupado parte considerável do espaço público graças à proliferação de museus, comemorações, filmes, programas televisivos e outras manifestações culturais. Durante o século XX, presenciou-se uma grande valorização do passado e dos chamados "lugares de memória”. Esse fenômeno assemelha-se a práticas recorrentes na história, chamadas por Eric Hobsbawm de "invenção das tradições": passados sobre os quais se constroem práticas dirigidas a reforçar a coesão social de um grupo ou comunidade e legitimar certas instituições e valores ${ }^{57}$. O século $\mathrm{XX}$, contudo, foi marcado por um fenômeno característico da modernidade que estabeleceu um processo de reificação do passado, fazendo com que a memória fosse, em larga escala, institucionalizada, ordenada, transformada em espetáculo, ritualizada e se tornasse um objeto de consumo, estetizado, neutralizado e rentável [TRAVERSO, 2007: 68].

A I Guerra Mundial representou o ponto culminante do declínio da "experiência transmitida” (Erfahrung) típica das sociedades tradicionais e perpetuada de uma geração a outra, que forjava as identidades de grupos por meio da oralidade. O traço distintivo da modernidade e das sociedades de massas, com seu ritmo veloz e marcado pelo caos do universo mercantil, é o das “experiências vividas” (Erlebnis), vivências individuais, frágeis, voláteis e efêmeras ${ }^{58}$. Em contraposição ao tempo mecânico, produtivo e disciplinador da sociedade industrial ${ }^{59}$, a proliferação da “cultura da memória”60 tornou-

\footnotetext{
${ }^{57}$ Cf. HOBSBAWN, Eric; RANGER, Terence (orgs.). A invenção das tradições. Rio de Janeiro: Paz e Terra, 1984.

${ }^{58}$ Cf. BENJAmin, Walter. “O narrador: considerações sobre a obra de Nicolai Leskov” (1936). In: Obras escolhidas: Magia e técnica, arte e política. São Paulo, Brasiliense, 1985.

59 Thompson, E. P. “Time, work-discipline and industrial Capitalism”. Customs in Common, Londres, Merlin Press, 1991, citado em Traverso, Enzo. Op.cit., p.69.

${ }^{60}$ Cf. expressão de HuYsSEn, Andreas. "En busca del futuro perdido". In: En busca del futuro perdido. Cultura y memoria en tiempos de globalización. Buenos Aires, FCE/Goethe-Institut, 2002; e Seduzidos pela memória: arquitetura, monumentos, mídia. Rio de Janeiro, Aeroplano, 2000.
} 
se, em muitos casos, o resultado paradoxal do declínio da transmissão da experiência em um mundo sem referências [TRAVERSO, 2007: 69].

As tiranias do século XX, em especial o nazismo no contexto da II Guerra Mundial, revelaram formas e proporções inéditas de controle da memória social. O “boom da memória” figurou-se entre as principais implicações e repercussões culturais da Shoah. A história do III Reich foi "relida como uma guerra contra a memória, [...] falsificação [...] e negação da realidade, até o ponto de fuga definitiva da realidade" ${ }^{61}$. Inicialmente, os cadáveres dos campos de extermínio nazistas eram exumados para serem queimados e, assim, para que se desfizessem rapidamente das provas. Em seguida, foi adotada a "solução final” - eufemismo utilizado para mascarar a queima dos corpos das pessoas assassinadas nas câmaras de gás em crematórios. O crime seria perfeito, sem rastros, sem corpos, sem memória da injustiça. Neste sentido, o que se tentou exterminar "não foi somente [as] milhões de vidas humanas, mas também uma exigência de justiça, e também nomes: e, primeiramente, a possibilidade de dar, de inscrever, de chamar e de lembrar o nome" 62 .

Na América Latina, o desaparecimento forçado foi uma das principais estratégias utilizadas pelas ditaduras para empreender de maneira sistemática a repressão estatal e o controle da memória. Na Guatemala, pelo menos 60 mil desaparecidos políticos foram enterrados em valas comuns, dificultando e até impossibilitando a identificação de seus restos mortais. Na Argentina, centenas de pessoas, ainda vivas, foram atiradas de aviões ao mar nos chamados "voos da morte" ${ }^{63}$. No Brasil, as Forças Armadas também tentaram eliminar provas de seus crimes, como o fizeram ao exumarem e queimarem os restos mortais dos militantes do PCdoB assassinados durante a Guerrilha do Araguaia, transformando-os definitivamente em desaparecidos políticos ${ }^{64}$.

A era dos genocídios e da memória das ditaduras do século XX, ameaçada pela atuação estatal que busca apagar seus crimes e reescrever o passado, impôs "uma reconfiguração da problemática da memória e do recordar em comum»65. O regime de

\footnotetext{
${ }^{61}$ Levi, Primo. Os afogados e os sobreviventes (1986). Rio de Janeiro, Paz e Terra, 1990, p.14.

${ }^{62}$ DerRidA, Jacques. Força de lei. São Paulo: Martins Fontes, 2007, p.140.

${ }^{63}$ Verbitsky, Horacio. O Vôo. A história da operação militar de extermínio que abalou a Argentina. São Paulo, Globo, 1995.

${ }^{64}$ De acordo com Pedro Cabral, ele foi o piloto que trasladou para a Serra das Andorinhas parte dos restos mortais dos guerrilheiros desaparecidos na Guerrilha do Araguaia, onde supostamente teriam sido queimados. Desde 1993, ele se nega a fornecer a latitude e a longitude do local onde isso teria ocorrido ou os nomes dos militares que ordenaram e participaram dessa operação, sem sofrer nenhuma sanção judicial. V. CABRAL, Pedro C. Xambioá, Guerrilha do Araguaia. Rio de Janeiro, Record, 1993.

${ }^{65}$ VezzetTI, Hugo (2009), p.22-3. Tradução livre da autora.
} 
memória social mudou e o papel da vítima e do testemunho passou a ocupar um espaço relevante. Muitas das formas instituídas de memórias tomaram como preocupação central o registro e a evocação dos crimes, dos sobreviventes e das vítimas, não de batalhas, vitórias, combatentes e heróis [TRAVERSO, 2007]. Este tipo de registro de memória tende a separar-se da entonação exaltante da nação, assumindo um caráter reativo contra as ditaduras e suas ameaças de retorno, mas no qual muitas vezes pode prevalecer uma orientação retrospectiva mais do que prospectiva [VEZZETTI, 2009: 24, 40].

Nos anos 1990, por toda a Europa debateu-se de forma ampla e prolongada sobre como comemorar a Shoah, o que gerou controvérsias e disputas a respeito de enfoques nacionais e políticos, mas também reflexões sobre a noção de memória e os tipos de memórias que são desencadeadas pelas comemorações, ligadas ao Estado e a outras expressões sociais e culturais. Agentes de governos têm um interesse evidente por legitimar narrativas e, frequentemente, chamam essas comemorações e políticas de identidade nacionais de “memória coletiva”, mas este é um termo que não se esgota em um conjunto de histórias formadas pelo ou sobre o Estado [WINTER, 2006].

Nas disputas pelas memórias dos períodos pós-ditaduras, contudo, têm predominado a busca por reafirmar e reiterar uma suposta identidade nacional, que em geral não respeita a diferença e o “outro” e pouco questiona as nossas próprias percepções a respeito dessa identidade ${ }^{66}$. Na "guerra de identidades" instaurada pela nova "virada memorialista”, muitos dos “lugares de memória” ou dispositivos de memória continuam a cultuar espaços e símbolos como representantes de uma imaginada unidade da comunidade política, repetindo identificações de modo mecânico, avessos à tensão existente entre a memória institucional e as memórias ativas de sobreviventes e grupos de ação política. As novas práticas e modalidades de memória que trabalham com a história oral e as imagens são frequentemente canalizados "por discursos ainda mais rígidos e cegos à outridade, do que o patriotismo que sustentava a historiografia até há pouco” [SELIGMANN-SiLVA, 2008: 103] ${ }^{67}$.

Existem, no entanto, outras instâncias de comemoração que expressam a história trágica de minorias perseguidas, como a que sobreveio com a queda do muro de Berlim e

\footnotetext{
${ }^{66}$ SeLIGMANN-SILVA, Márcio. "Deletar arquivos, apagar o passado: ars oblivionalis, entre a necessidade e a resistência". In: Cadernos AEL, Anistia e direitos humanos. Campinas: Unicamp/IFCH/AEL, v. 13, n.24/25, 2008, p.103.

${ }^{67} \mathrm{~V}$. livros que debatem em profundidade essa questão na Argentina, como por exemplo: BuCHENHORST, Ralph e LoRenzano, Sandra (eds.). Políticas de la memoria. Tensiones en la palabra y la imagen. Buenos Aires: Gorla; Mexico, Universidad del Claustro de Sor Juana, 2007; e BrodSKY, Marcelo (Ed.). Memoria en construcción: el debate sobre la ESMA. Buenos Aires, La marca editorial, 2005.
} 
do socialismo. A criação e disseminação de narrativas sobre o passado surgem e expressam também outras "políticas de identidade”, redimindo grupos étnicos e minorias desprivilegiadas, exigindo seu direito à palavra, à ação, sua liberdade e autodeterminação. Nesses casos, as políticas de memória são "uma contra-história que desafia a generalização da História”68.

A denúncia da tortura, dos assassinatos e desaparecimentos políticos durante a ditadura civil-militar brasileira foi um importante instrumento da luta de resistência. Os presos políticos foram determinantes para estabelecer os fatos e as denúncias, testemunhas oculares de assassinatos e torturas. Eles, ao lado dos familiares, advogados e militantes compreenderam que a preservação da memória destes crimes e a reconstrução do passado eram fundamentais para por fim à ditadura. A importância desse trabalho de denúncia fez com que a repressão estatal tenha matado mães de militantes assassinados pelo regime porque elas denunciaram tais crimes, conforme aconteceu com Zuzu Angel ${ }^{69}$.

Ainda que as ditaduras (tal como no nazismo) não tenham logrado seu intento de apagar completamente a memória, muitos dos vestígios do passado foram eliminados com êxito. Não obstante esta não é a única ameaça à memória. De acordo com Tzvetan Todorov, a memória na contemporaneidade estaria ameaçada justamente pela abundância e pelo excesso de informação do passado ${ }^{70}$.

A despeito do fato de que esta perspectiva se faça válida em diversos contextos, é de se ter em vista que, no Brasil, faz-se inadequada a afirmação de que existiram efetivos abusos quanto ao uso da cultura da memória, assim como a afirmação de que houve grande difusão de informação sobre a ditadura. Embora o trabalho de memória sobre a ditadura tenha sido revestido de algum prestígio nos últimos anos, predominam as resistências e bloqueios. Há um déficit de práticas e instituições públicas capazes de cumprir a função de compartilhar as memórias deste período, no âmbito do público.

Em resposta à história monumental, a história social e cultural do século XX deslocou seus estudos para as margens das sociedades modernas. A história voltada para

\footnotetext{
${ }^{68}$ A citação é de Wernet Sollor, retiradas da introdução a Fabre e O’Meally (1994, p.7) feita por WiNTER, Jay. op.cit., p.73.

${ }^{69}$ A história de Zuzu Angel transformou-se em tema de um programa o Linha Direta Justiça, da TV Globo, exibido em 27/11/03, e de um longa-metragem de Sérgio Rezende, em 2006. V. ALMEIDA (2009), p. 246-48 e 649-51. Há outro caso de uma mãe que pode ter sido assassinada porque denunciava a morte da filha: Esmeraldina, mãe de Nilda Carvalho Cunha, foi encontrada enforcada em sua casa, em 20/10/72. Nilda havia sido presa durante a Operação Pajussara, que resultou na morte de Iara Iavelberg e Carlos Lamarca, e morreu em consequência das torturas sofridas, em 14/11/71, em Salvador (BA). Ver ALMEIDA (2009), p.291-92 e 382-83.

${ }_{70}$ ToDORov, Tzvetan. Los abusos de la memoria. Buenos Aires, Barcelona/Espanha, Paidós/Asterisco, 2000, p.11-4.
} 
o mercado adotou também um foco próximo dos seus atores ao reconstituir essas vidas. Tais mudanças foram possíveis devido a uma variação no uso das fontes de pesquisa acadêmica, com destaque para a história oral, que há décadas tem sido considerada legítima $^{71}$. O desenvolvimento da tecnologias de transmissão de informação também ajudou a impulsionar o "boom da memória” ao longo das últimas gerações. Desde os anos 1960 e 1970 surgiram bancos de dados audiovisuais que preservam a voz e a imagem das vítimas e testemunhas do Holocausto e de sobreviventes de outras ditaduras e traumas históricos [WINTER, 2006:74]. Histórias do passado recente, apoiadas em operações de memória, ultrapassam as fronteiras acadêmicas e atingem a esfera dos meios de comunicação, da política, recebendo, porventura, impulsos do Estado.

A valorização do passado, porém, não pode servir de argumento para que se evitem as demandas do presente. Esta perspectiva alinha-se à de Todorov, o qual, contrário ao frenesi contemporâneo por comemorações [RICOEUR, 2007: 98], realça as limitações das recordações minuciosas de sofrimentos passados para a adequada interpretação das ameaças da atualidade. A fixação no passado pode nos fazer parecer bravos combatentes pela memória e justiça, sem nos obrigar a assumir eventuais responsabilidades do presente [TODOROV, 2000: 52].

Voltado para a dinâmica da guerra do Kosovo nos anos 1990, Todorov buscou recuperar o processo de reconciliação polonês para criticar os abusos dos usos da memória e salientar a necessidade de um possível esquecimento para se conseguir viver em comunidade. Recorreu aos conceitos de luto e elaboração da psicanálise para tratar da necessidade de se conquistar certo distanciamento com respeito aos agravos passados, a necessidade da aceitação das perdas e de evitar a pulsão à repetição da memória traumática. Não se limitou a destacar a dimensão estatal e institucional de um programa orientado para a reconciliação, mas deixou de lado uma análise mais atenta e crítica sobre os abusos dos usos da reconciliação, em especial, na Polônia. Mesmo forçando "um pouco a significação dos mecanismos e alcances do trabalho subjetivo do luto”, Todorov destacou a questão das consequências éticas e políticas orientadas para o futuro que se pode conquistar por meio da valorização da exemplaridade da memória ao envolver a responsabilidade e o consentimento dos sujeitos e grupos envolvidos nos agravos sofridos [VEZZETTI, 2009: 24-7]. A memória exemplar não nega a singularidade do acontecido passado e pode servir como modelo para compreender situações novas, possibilitando

\footnotetext{
${ }^{71}$ SARLO, Beatriz. Tempo Passado. Cultura da memória e guinada subjetiva. São Paulo, Companhia das Letras/UFMG, 2007, p.11-2.
} 
analogias e distinções, inserindo-se e ocupando a esfera pública. Nesta perspectiva, o passado pode ser utilizado como princípio de ação no presente [TODOROV, 2000: 30-3].

A narração e a memória fundam uma temporalidade que a cada repetição e variante torna a se atualizar. Para Walter Benjamin, os homens voltaram da I Guerra Mundial emudecidos. O choque teria liquidado a experiência transmissível e a experiência em si mesma: o que se viveu como choque era forte demais para as dimensões do corpo humano, não havia mais a possibilidade de que os restos da experiência se incorporassem a algum futuro. Os homens que presenciaram essas situações-limite como novidade perderam a possibilidade de reconhecer sua própria experiência. Seu caráter inesperado foi vivido fisicamente nos mutilados, doentes, famintos e nos milhões de mortos, mas permaneceu incompreensível. O despejo de livros de guerra, dez anos depois, era muito diferente da experiência passada de boca em boca [SARLO, 2007].

De acordo com Beatriz Sarlo, por meio de Walter Benjamim aprendemos que a experiência é aquilo que se sofre, mas pode ser relatado e transmitido. Sua perspectiva, porém, é pessimista e melancólica, pois ele estava consciente de que as condições históricas da transmissão oral da experiência não existem mais. Com o advento do romance, antes mesmo da I Guerra Mundial, estava cindida a relação entre o vivido e sua compreensão. "No momento em que o risco da experiência se interioriza na subjetividade moderna, o relato da experiência se torna tão problemático como a própria possibilidade de construir um sentido.” [SARLO, 2007:27].

Para a autora, o verdadeiro testemunho teria de ser como os textos de Primo Levi, que escreveu relatos curtos - “a matéria-prima da indignação deve ser restringida”. Para ela, o caso de Levi não pode ser analisado como outros que se debruçaram sobre as críticas da centralidade do sujeito, pois aos que saíram dos campos de concentração é impossível não falar, razão extratextual, psicológica, ética e compartilhada por quase todos sobreviventes [SARLO, 2007: 34].

Por outro lado, sabemos que, no Brasil e em outras partes, muitos sobreviventes não escreveram ou testemunharam, mas certamente não esqueceram as experiências traumáticas da tortura e prisão. O que importa aqui está relacionado às possibilidades de realizar o testemunho na esfera pública e construir formas de compartilhar coletivamente essas experiências. De fato, muitos sobreviventes não conseguem deixar de relatar, mas em geral o fazem no âmbito privado ou em círculos fechados. Essas lembranças e memórias estão presentes, atuantes, guardadas, reprimidas ou não. A importância do 
testemunho reside nas suas implicações simbólicas e políticas, seja como documento e objeto de analistas, como expressão artística ou presença em processos judiciais. Há no Brasil uma enorme dificuldade de expressar e elaborar publicamente as memórias das experiências extremas da história recente nas suas diversas modalidades.

Beatriz Sarlo ressalta que a memória pode ser um impulso moral da história e também uma de suas fontes, mas a memória não deve sustentar uma epistemologia ingênua, pois não há equivalência entre o direito de lembrar e a afirmação de uma verdade da lembrança; tampouco o dever de memória obriga a aceitar essa equivalência. Ela insiste, com razão, que a memória está contida em outras operações produzidas pelo distanciamento, como a interpretação histórica ou a recuperação estética da dimensão biográfica [SARLO, 2007:44]. As narrações pessoais se multiplicaram e se tornaram mais numerosas do que outras formas narrativas, como a investigação e o ensaio. Para ela, o problema é que a historiografia tem julgado estas fontes "mais reveladoras" do que as demais [SARLO, 2007: 11-2].

A autora não critica o testemunho feito em juízo, pois sua importância política, ética e jurídica é incontestável. Sua preocupação está centrada nos testemunhos e relatos de ex-guerrilheiros que descrevem o ambiente político e subjetivo dos tempos da luta armada. Tal experiência seria tão importante que não caberia no relato banalizado do cotidiano. Esses relatos apresentariam uma visão fechada, heroica e pouco crítica das práticas de militantes e organizações. Sarlo insiste que há uma diferença entre os relatos sobre a militância política e os chamados "relatos do terror", os quais teriam uma prerrogativa especial [OBERTI, 2009a]. Além disso, os testemunhos em julgamentos e Comissões de Verdade são determinantes quando há a ausência de outra documentação que comprove os crimes cometidos em ditaduras ${ }^{72}$.

Sob este argumento, o valor dos depoimentos colhidos ao longo da presente pesquisa faz-se paradigmático em relação à questão da comprovação histórica ou jurídica dos fatos, a despeito da existência justificada de discussões metodológicas e políticas acerca da sua confiabilidade - a consistência e o caráter reiterável dos discursos provenientes de relatos pessoais em geral ou dos coletados por meio da história oral.

Não é de se excluir a possibilidade de que um determinado depoimento seja, ao longo do tempo, repensado pelo depoente e que este reformule sua posição pública acerca do tema, sem prejuízos ao seu empenho em ser maximamente verdadeiro em relação às

\footnotetext{
${ }^{72}$ Palestra de Beatriz Sarlo no Instituto Cervantes, em 31/05/2007, São Paulo, Brasil.
} 
suas convicções. Esta possibilidade, todavia, não dirime o caráter potencialmente estratégico de se tomar tais falas como substanciais para o melhor entendimento possível do período histórico em questão e, nele, do papel e da experiência de alguns dos principais envolvidos, posto que estes relatos representam aquilo que a sociedade brasileira poderia coletar de mais consistente e fidedigno em relação a temas de profundo interesse contemporâneo. Sobretudo, o resgate da experiência afetiva destes sujeitos, favorecida pela metodologia da história oral, produz condições oportunas para uma compreensão dos próprios fatos e daquele momento histórico (que, por meio de uma sucessão de eventos, atinge-nos na atualidade) de maneira mais enriquecedora.

A discussão atual sobre a relevância da cultura da memória e da legitimidade do uso de relatos pessoais para a análise de acontecimentos históricos pode encaminhar-se para além da polarização entre documento e testemunho. Um exemplo emblemático da opção pela exposição pública de testemunhos deu-se na Comissão de Verdade e Reconciliação sobre os crimes cometidos durante o apartheid na África do Sul. Naquele contexto, poder-se-ia atribuir a predileção pelo depoimento à ausência de documentos escritos, mas, ao contrário, a opção por dar voz às vítimas visava fortalecer e dar a máxima visibilidade ao testemunho na esfera pública. Aqueles fatos, pertinentes a toda a sociedade, deveriam inscrever-se na memória pública por meio da experiência transmitida pelo testemunho, incorporando-os à história do país ${ }^{73}$.

Outro argumento de Beatriz Sarlo é que o relato pormenorizado do cotidiano em nada contribuiria para uma contextualização histórica, para uma análise econômica e suas relações com a política do período ${ }^{74}$. Em sentido contrário, o caso brasileiro demonstra como o testemunho do cotidiano dos guerrilheiros ajuda a esclarecer aspectos importantes da história factual relacionada, inclusive, à política econômica. No documentário Cidadão Boilesen, lançado em $2009^{75}$, aparecem depoimentos inéditos de pessoas que articularam ou participaram da ação que matou o presidente da Ultragás, Henning Boilesen, em abril de 1971. Boilesen organizava e recolhia a contribuição de banqueiros e empresários para

\footnotetext{
${ }^{73}$ TeLES, Edson Luis de Almeida. Brasil e África do Sul: os paradoxos da democracia. Doutorado, São Paulo: USP, FFLCH, 2007.

${ }_{75}^{74}$ Palestra de Beatriz Sarlo. Idem, ibidem.

75 Cidadão Boilesen, Brasil, 2009, 92min., direção de Chaim Litewski. De acordo com depoimentos apresentados no filme, o levantamento feito pelas organizações MRT e ALN incluíam os nomes de Peri Igel, também do grupo Ultragás, e Sebastião Camargo, da Camargo Correa, como os principais articuladores da "caixinha" da OBAN. A colaboração de Boilesen era bastante conhecida, ele chegou a trazer um instrumento de tortura dos EUA, conhecido como "Pianola Boilesen", utilizado para dar choques elétricos nas vítimas. De acordo com o BNM, a Ford e a General Motors também contribuíam para a OBAN [BNM, 1989: 73].
} 
sustentar o centro de tortura conhecido como Operação Bandeirante (OBAN), localizado na cidade de São Paulo. Depoimentos apresentam dados novos e estarrecedores de vítimas e torturadores, que dão testemunho da participação de Boilesen em sessões de tortura e sobre o funcionamento do apoio dos empresários. Um depoimento, em especial, confirma que Boilesen teria levado Delfim Neto, então ministro de Fazenda, nas reuniões regulares, que ocorriam às quintas-feiras, para explicar detalhes da política econômica do governo e defender a necessidade das contribuições ${ }^{76}$.

Neste documentário, o ex-presidente Fernando Henrique Cardoso destaca a importância dessas contribuições para obter o compromisso dos dirigentes e das elites brasileiras com o projeto da ditadura, envolvendo-os de forma decisiva com o chamado “trabalho sujo” e suas consequências. Ele argumenta que a arrecadação não ocorreu por falta de recursos e condições materiais para reorganizar o aparelho repressivo, mas efetivamente para comprometê-los.

Outro depoimento que chama a atenção é o do ex-governador de São Paulo, Paulo Egydio Martins. Ele assumiu ter sido um dos articuladores do grupo de empresários, antes do golpe de 1964, declarando, inclusive, que seus membros andavam armados. Naquele ano, iniciou-se a formação do Grupo Permanente de Mobilização Industrial (GPMI) criado para adaptar o poderio bélico das Forças Armadas à doutrina de Segurança Nacional. Este grupo cresceu e voltou-se para a exportação, a ponto de transformar o Brasil no $5^{\circ}$ colocado do mundo na lista de vendedores de armamentos nos anos 1970 [BNM, 1989: 72]. Paulo Egydio definiu Boilesen como "um utópico, um idealista, de natureza extrovertida, aberta. Foi uma vítima de si mesmo”.

Diversos policiais e militares confirmaram a amizade de Boilensen com torturadores famosos como o delegado Sérgio Paranhos Fleury e o capitão Bernoni Arruda Albernaz. O filme apresenta também um documento do SNI, no qual consta que Boilesen “ajudou substancialmente a organização da OBAN” e que se expunha muito. De fato, Boilesen estivera muitas vezes na sede do centro de torturas, em decorrência disso acabou sendo visto por diversos presos.

Na Argentina, os discursos testemunhais foram amplamente divulgados na mídia, principalmente quando do julgamento da Junta Militar nos anos 1980. Mas, de acordo com Sarlo, a indispensável narração da vítima em primeira pessoa não foi submetida ao

\footnotetext{
${ }^{76}$ O jornalista Silvio Ferraz deu este depoimento, segundo o qual o “Dr. Gastão”, ao final das reuniões, passava o chapéu para recolher a contribuição para a OBAN. V. tb. AlENCASTRO, Luiz Felipe. "1964: por quem os sinos dobram?”, em TELES, Janaina (org.). Mortos e desaparecidos políticos: Reparação ou impunidade? 2a . ed. São Paulo, Humanitas/FFLCH-USP, 2001, p. 39-43.
} 
escrutínio metodológico. Transformou-se em “matéria-prima da indignação”, serviu de impulso para a transição democrática, que se deu sob o signo do Nunca Más. Lembrar foi uma atividade de restauração dos laços sociais e comunitários perdidos no exílio ou destruídos pela violência de Estado, quando acabaram as ditaduras do sul da América Latina. Os discursos foram indispensáveis para a restauração de uma esfera pública de direitos. As ditaduras representaram uma ruptura de épocas, mas as transições democráticas não emudeceram as vítimas apesar da enormidade e da novidade desse fenômeno [SARLO, 2007: 44-7] ${ }^{77}$.

De fato, não podemos afirmar que a ditadura no Brasil emudeceu as vítimas, mas tampouco seria o caso de se referir a uma abundância de testemunhos sobre esse período. O processo de transição política no Brasil, marcado pela “conciliação pelo alto”, foi responsável por uma política de silêncio e esquecimento sobre os crimes da ditadura, como ocorrera após a ditadura de Getúlio Vargas. Na atualidade, ainda são grandes as dificuldades para construir uma esfera pública onde essas experiências possam ser compartilhadas e sejam debatidos os direitos negados às vítimas do terrorismo de Estado do período. Essas características da história brasileira criaram um quadro de silêncio, inexistindo no país os problemas criados pelo fetiche da verdade testemunhal.

Parte dos testemunhos sobre os crimes da ditadura foi confrontada por outros documentos, muitos de origem policial, que comprovaram tais crimes, como os da Justiça Militar resguardados pelo Projeto Brasil: Nunca Mais. Os testemunhos tiveram um papel central nas campanhas de denúncias de violações de direitos humanos durante a ditadura, conseguindo impor certo desgaste ao regime. No período pós-ditadura, porém, passaram a ocupar um lugar marginal. As denúncias assumiram um papel simbólico, ocuparam $o$ lugar da justiça, mas não foram acompanhadas por iniciativas políticas e institucionais efetivas de apuração da verdade. A divulgação das denúncias teve um papel preponderante na elaboração e construção simbólica deste passado, mas não levou a uma ação política relevante e efetiva que propiciasse a livre narrativa do passado, conforme ocorreu na África do Sul [TELEs, 2007].

No Brasil, crescem em amplitude e rigor as investigações sobre as circunstâncias históricas nas quais ocorreu a repressão estatal daquele período. Mas ainda há muito a ser esclarecido sobre como se estabeleceu e se organizou o aparelho repressivo. Importantes

\footnotetext{
${ }^{77}$ Chama a atenção o fato de Beatriz Sarlo não analisar o caso brasileiro. Ela faz referências aos relatos testemunhais excessivamente detalhados sobre os casos de desaparecidos argentinos, chilenos e uruguaios, sem citar o Brasil. V. SARLO, B. Op.cit., p.52.
} 
investigações indicam o estabelecimento de um quadro bastante genérico, mas muitos de seus aspectos ainda não são de conhecimento público ${ }^{78}$. Desta maneira, o quadro diferencia-se daquele que se revela em relação ao extermínio dos judeus durante a II Guerra Mundial, cujo significado ético e político ainda espera por uma análise global em relação ao “[...] sentido e as razões do comportamento dos carrascos e das vítimas [...] reforçando a opinião de quem gostaria que Auschwitz ficasse incompreensível para sempre"

No Brasil, uma série de questionamentos, tanto do ponto de vista factual, quanto ético e político, ainda não foi estabelecida. Não sabemos, em grande medida, as circunstâncias dos assassinatos e desaparecimentos forçados e nem a localização dos restos mortais destes dissidentes políticos; não sabemos os nomes dos comandantes, dos componentes ou das operações de extermínio e desaparecimento; assim como não sabemos de que maneira se davam as decisões de assassinar ou desaparecer, tendo em vista que tais decisões, na maioria das vezes, davam-se nos centros de tortura, como os DOI-Codi, ou nos campos de concentração, como os de Bacaba ou Xambioá, no sudeste do Pará.

E não é somente sobre tortura e a repressão política que não sabemos como foram tomadas as decisões. A sociedade civil não conhece a maneira como as decisões que ditaram os rumos da política econômica e das relações internacionais foram tomadas, assim como pouco se conhece sobre as decisões relacionadas à construção das obras faraônicas do período. Não conhecemos o funcionamento de cada ministério ou universidade. Além dos arquivos militares, há muitas outras instâncias do Estado (poder judiciário incluído), que ainda não disponibilizaram publicamente seus arquivos.

O Brasil foi um dos países que mais eficientemente realizou em ato as palavras dos carrascos nazistas: a "profecia da violência sem trauma”, segundo a qual "Não haverá portadores do seu sofrimento, ninguém dele se lembrará. Nada aconteceu”80. Primo Levi relatou esta ameaça feita pelos nazistas aos prisioneiros dos campos de concentração:

\footnotetext{
${ }^{78}$ V. Brasil: Nunca Mais (1985), Dossiê dos Mortos e Desaparecidos Políticos a partir de 1964 (1995), Direito à Memória e à Verdade, da SEDH (2007); Dossiê Ditadura, op.cit. e Habeas Corpus, da SEDH (2010).

${ }^{79}$ Agamben, Giorgio. O que resta de Auschwitz. O arquivo e a testemunha. Homo Sacer III [1998]. São Paulo, Boitempo, 2008, p.20.

${ }^{80}$ SAFATLE, Vladimir. "Do direito ao uso da violência contra o estado ilegal”. In: SAFATLE, Vladimir e TElES, Edson (orgs.). O que resta da ditadura? A exceção brasileira. São Paulo, Boitempo, 2010, p. 23752.
} 
"Seja qual for o fim desta guerra, a guerra contra vocês nós ganhamos; ninguém restará para dar testemunho, mas, mesmo que alguém escape, o mundo não lhe dará crédito. Talvez haja suspeitas, discussões, investigações de historiadores, mas não haverá certezas, porque destruiremos as provas junto com vocês. E ainda que fiquem algumas provas e sobreviva alguém, as pessoas dirão que os fatos narrados são tão monstruosos que não merecem confiança: dirão que são exageros da propaganda aliada e acreditarão em nós, que negaremos tudo, e não em vocês. Nós é que ditaremos a história dos Lager [campos]” [LEVI, 1990:1].

Estas “[...] são as palavras que as ditaduras sul-americanas não cansaram de repetir àqueles que elas procuraram exterminar. A violência simbólica do desaparecimento do nome, da anulação completa dos traços, talvez, seja o sintoma mais brutal [...]” [SAFATLE, 2010: 238-9]. E é esta violência simbólica a que deixa marcas mais profundas.

Diante da ausência de justiça e da insuficiência das políticas públicas de memória no Brasil, predominam o sigilo, o silêncio e certo revisionismo histórico - ainda que o testemunho tenha tido um papel central para divulgar as denúncias dos crimes do terrorismo de Estado e fundamentado os próprios processos da Justiça Militar. Neste contexto, a importância do testemunho para a compreensão e a recuperação factual do passado recente é ainda maior. Não há como se referir a uma abundância do testemunho ou a uma fetichização da verdade testemunhal no Brasil.

\section{I.3. Verdade e Justiça: a memória justa}

As dificuldades em se estabelecer uma compreensão sobre a história recente estão relacionadas às singularidades do testemunho, principalmente do testemunho daqueles de que vivenciaram experiências traumáticas, como as dos campos de concentração nazistas, conforme ressaltou Agamben: “[...] o que aconteceu nos campos aparece aos sobreviventes como a única coisa verdadeira e, como tal, absolutamente inesquecível; por outro, tal verdade é, exatamente na mesma medida, inimaginável, ou seja, irredutível aos elementos reais que a constituem. Trata-se de fatos tão reais que, comparativamente, nada é mais verdadeiro; uma realidade que excede necessariamente os seus elementos factuais: é esta a aporia de Auschwitz. [...]” [AGAMBEN, 2008]. Ao contrário da situação vivida nos campos nazistas ou na Argentina, a maioria das vítimas da ditadura brasileira sobreviveu àquele tempo. Eles pouco falaram a respeito das experiências de tortura, sequestro, prisão 
e exílio e, como acontece a muitos sobreviventes de situações-limite, quando contam, "seu testemunho alcança apenas parte ínfima de tal situação"81.

Primo Levi viu na “figura máxima da despersonalização”, o muçulmano (o último passo antes da morte física), termo comum utilizado nos Lager, a verdade daquele “campo biopolítico”: “Toda testemunha do universo concentracionário seria apenas suplemento àquela testemunha que não pôde testemunhar e sucumbiu².” Muito já se disse sobre os limites e impossibilidades de testemunhar eventos tão traumáticos. Reside no centro do testemunho da Shoah “algo intestemunhável”. Mas poderíamos dizer que "a autoridade dos sobreviventes” foi destituída, pois as "verdadeiras testemunhas”, “as testemunhas integrais” seriam “os que tocaram o fundo”, os que não voltaram, os muçulmanos $^{83}$ ? Poderíamos definir o testemunho dos sobreviventes dos campos, dos centros de tortura ou dos presídios da ditadura brasileira como menos autêntico? Estes sobreviventes testemunham sobre "um outro que falta”? Eles falam em lugar dos que morreram? Eles assumem para si o ônus de testemunhar pelos mortos, as "autênticas" testemunhas? Sabem que devem testemunhar justamente pela impossibilidade de testemunhar dos que se foram e que este testemunho traz consigo essa lacuna?

A origem etimológica da palavra testemunha possibilita-nos aprofundar a compreensão sobre o estatuto do testemunho na atualidade. Ela nos remete a terstis como “o que vê”, a testemunha que se aproxima dos paradigmas da historiografia (ístor) e da cena do tribunal - o terceiro enquanto instância de decisão em um julgamento entre duas partes. Superstes, por outro lado, é aquele que sobreviveu a uma desgraça, à morte, aquele que passou por um acontecimento e subsistiu muito mais além desse acontecimento. Mas o sobrevivente é também aquele que habita a clausura de um acontecimento extremo que se aproximou da morte, que "se mantêm no fato", algo como o mártir moderno. O modelo de testemunho como terstis é visual e influenciado pelo modelo representacionista do positivismo, que acredita ser possível transitar entre o tempo da cena histórica e o tempo em que se escreve a história. O paradigma do superstes tem a audição e não a visão no seu centro e está mais aberto ao testemunho e ao ato de testemunhar, sem reduzi-lo a meio. Neste modelo, pressupõe-se uma falta de

\footnotetext{
${ }^{81}$ LyOTARD, Jean-François. La diferencia. Barcelona, Gedisa, 1988, p.15.

${ }^{82}$ Seligmann-Silva, Márcio (org.). “Introdução”, em Palavra e imagem: memória e escritura. Chapecó (SC), 2006, p.22.

83 SELIGMANN-Silva, (2006); e LeVI, (1990), p.47.
} 
correspondência entre as palavras e essa experiência da morte. Valorizar o paradigma do superstes, entretanto, não significa a negação do testemunho como terstis ${ }^{84}$.

Giorgio Agambem utilizou-se também de uma outra acepção da palavra testemunha para debater o valor e o sentido do testemunho. Ele destacou a palavra author, que significa "pôr em ser, dar existência”, aquilo que “dá ‘força de prova’ ao que em si falta, e vida ao que por si só não poderia viver”. A este respeito, Agamben afirma: “[...] é o ato imperfeito ou a incapacidade que o precedem e que ele vem a integrar que dá sentido ao ato ou à palavra do auctor-testemunha. [...] Um ato de autor que tivesse a pretensão de valer por si é um sem-sentido, assim como o testemunho do sobrevivente é verdadeiro e tem razão de ser unicamente se vier a integrar o de quem não pode dar testemunho. [...] o sobrevivente e o muçulmano são inseparáveis, e só a unidade-diferença entre eles constitui o testemunho" ${ }^{85}$. Desse modo, Agamben põe em relevo a ausência dos que morreram e que a testemunha fala por eles, em nome desta falta. Mas, ao fazê-lo, retira dos sobreviventes um tanto da sua centralidade e força, deixando sobre eles também um peso e uma responsabilidade excessivos.

Podemos concordar com Agamben que é “[...] o isolamento da sobrevivência em relação à vida [...]”, a separação entre o ser vivo e o ser que fala, entre a zoé e o bíos, a vida puramente biológica e a vida política, o não-homem e o homem, que o testemunho refuta [AGAMBEN, 2008: 157-6]. Em especial, com relação aos campos de concentração nazistas. Para ele o “[...] sujeito do testemunho é constitutivamente cindido, só tendo consistência na desconexão e na separação - não sendo, contudo, redutível às mesmas”. A testemunha é o sujeito ético que dá testemunho de uma dessubjetivação. Agamben, contudo, acaba por enfatizar que não é possível “atribuir o testemunho”, pois este é o "preço desta cisão, dessa inquebrantável intimidade do muçulmano e da testemunha, de uma impotência e de uma potência de dizer” [AGAMBEN, 2008: 151]. Enfraquecendo ou retirando do sobrevivente a capacidade, contraditoriamente assinalada por ele, de testemunhar e se considerar a si próprio um autor, de conferir e tomar para si a força e a coragem que o testemunho exige e representa.

Agamben realizou um admirável esforço de ressaltar a importância da figura do mulçumano, dos "restos" ou remanescentes de Auschwitz, construída em termos das

\footnotetext{
${ }^{84}$ Benveniste, E. O vocabulário das Instituições Indo-europeias. Vol.II: Poder, Direito, religião. Trad. D. Bottman, Campinas, Unicamp, 1995, citado em SELIGMANN-SILVA, Márcio. "Testemunho e a política da memória: o tempo depois das catástrofes”. Projeto História, São Paulo, 30, p.71-98, jun.2005, p.80-1.

85 Benveniste, E. Problemas de linguística geral. Vol. I e II. Campinas, Pontes, 2005 e 1989; citado em AgAmBEN, G., (2008), p.150-1. Destaque meu.
} 
possibilidades e dos limites de compreender esse fenômeno, em função da importância ética e política desse extermínio na atualidade [LACAPRA: 2006, 217]. O próprio Primo Levi expressou a contradição existente no testemunho delegativo reivindicado por ele: “um não está jamais no lugar de outros”86. Ao formular o "paradoxo do testemunho", além de chamar a atenção para a necessidade de buscar o sentido do silêncio e da ausência dos que morreram Levi, ao invés de querer invalidar o testemunho, buscou revelar "o seu chão aporético, ruinoso", algo impossível e necessário ao mesmo tempo, conforme escreveu Márcio Seligmann-Silva:

“Assim como o "muçulmano" no Lager é um vulto invisível (que os demais resistem a olhar e cujo olhar está embaçado), o próprio sobrevivente convive com a imagem de si como vulto. Ele está cindido entre o mundo de "dentro" e o "fora" do campo de concentração, e o que está "dentro", a realidade "entre parênteses" [...] engloba o fora ${ }^{87}$. O sobrevivente sofre o pânico de ser apenas um vulto: ele sente a necessidade de testemunhar, contar a sua história para religar os fragmentos de sua identidade; por outro lado, teme que ninguém queira ouvir a sua história "inverossímil", inimaginável, invivível” [SELIGMANN-SILVA, 2006: 23].

Para Agamben, a "autoridade do testemunho não está ligada a uma verdade factual, à conformidade entre ditos e feitos, entre memória e acontecimentos”. Sua autoridade estaria vinculada a algo que “é intrínseco à linguagem como tal”, "à relação imemorial entre o que se pode dizer e o que não, entre o externo e o interno da linguagem”. Por meio de uma característica intrínseca à linguagem - o testemunho - é que se poderia refutar os "argumentos" dos negacionistas da Shoah [AGAMBEN, 2008: 151]. Daí sua conclusão: “Ao definir o testemunho unicamente através do 'mulçumano', o paradoxo de Levi contém a única refutação possível de todo argumento negacionista”. [AGAMBEN, 2008: 151].

Carlo Guinzburg contesta Agamben: esta definição de testemunho permite aos negacionistas o domínio da "verdade factual”. “A linguagem pode expressar tanto a verdade como a mentira. Uma refutação tirada da natureza intrínseca da linguagem jamais poderá refutar a mentira do negacionismo”,88. Guinzburg lembra que Primo Levi não definiu "o testemunho unicamente através do 'muçulmano”, ao contrário, para ele são as

\footnotetext{
${ }^{86}$ LEVI, P. Os afogados e os sobreviventes, p.60 da edição inglesa, citado em LaCapra, (2006), p.249. Destaque meu.

${ }^{87}$ SELIGMANN-SILVA cita depoimento de Criméia A. S. de Almeida no documentário "Que bom de ver vivia” (1989), de Lúcia Murat; e DERridA, Jacques. "Fora. As palavras angulosas de Nicolas Abraham e Maria Torok”, em LANDA, Fábio. Ensario sobre a criação teórica em Psicanálise. De Ferenczi a Nicolas Abraham e Maria Torok. São Paulo, UNESP, 1999, p.269-319.

${ }^{88}$ GinZBURG, Carlo. "Prueba, memoria y olvido", Nuestra Memoria (Año XI · No 26 · Dic./2005), Buenos Aires, Fundación Memoria del Holocausto, p.16.
} 
exceções (os “sobreviventes”) quem testemunham pela norma (os “afogados”, os “muçulmanos”). Trata-se, pois, de um testemunho parcial, imperfeito. Era o próprio Levi quem dizia de si mesmo: "minha voz é débil, e ainda um pouco profana”, ", “[...] mas estava convencido de que entre a linguagem e aquilo que - a falta de algo melhor - deve chamar-se 'realidade' há uma analogia: a linguagem pode falar da realidade” [GuinZBURG, 2005: 17]. Agamben teria adotado o termo "testemunho absoluto" e não a expressão “testemunho integral” utilizada por Primo Levi. Esta tradução implicou na definição que considera “o testemunho unicamente através do 'mulçumano”, uma deformação considerável do pensamento de Levi ${ }^{90}$.

O esforço mobilizado em torno do debate a respeito do "negacionismo" do extermínio dos judeus, nos anos 1990, colocou em evidência tanto os indícios materiais desses fatos, como os traços de memória dos testemunhos dos sobreviventes ${ }^{91}$, que têm sido validados cada vez mais de forma igual nos processos judiciais. O negacionismo e o relativismo, apesar de suas controvérsias indecentes, recolocaram em questão a necessidade da reflexão histórica sobre os rastros e fragmentos materiais, os indícios, a verdade e o valor de prova na história e na justiça ${ }^{92}$. Involuntariamente, fizeram avançar a pesquisa histórica e sua reflexão metodológica e teórica. Chamaram a atenção para a questão de que a discussão sobre a existência da Shoah e demais eventos históricos não deveria ser proibida, porque a verdade histórica, ao contrário da verdade judicial, não deve se transformar em verdade oficial. “Toda contribuição científica - incluídas as assim chamadas 'definitivas' - é, por definição, inacabada e falsificável” [GuINZBURG, 2005:15].

Mudanças de interpretação de um mesmo testemunho ou da documentação disponível podem alterar ou influir na narrativa histórica. Qualquer documento, independentemente de seu suporte e origem, seja um testemunho, um papel escrito ou uma sala de banho num campo de extermínio nazista, “[...] a despeito de seu caráter mais ou menos direto, sempre guarda uma relação altamente problemática com a realidade. Mas a realidade ('a coisa em si') existe”,

\footnotetext{
${ }^{89}$ LEVI, Primo. Il sistema periodico. Torino, 1975, pág. 229; citado em GinZBURG, (2005), p.17.

${ }^{90}$ Guinzburg refere-se à edição italiana de Giorgio Agamben, citado em GinZBURG, (2005), p.17.

${ }^{91}$ V. FRIEDLANDER, Saul. (comp.). En torno a los limites de la representación. El nazismo y la solución final. Bernal: Univ. Nacional de Quilmes, 2007. Publicado originalmente em inglês, em 1992.

${ }^{92}$ GuinzBuRG, (2005), p.15; e VidAL-NAQUet, Pierre. Os assassinos da memória: "um eichmann de papel" e outros ensaios sobre o revisionismo. Campinas, Papirus, 1987; e Reflexiones sobre el genocidio. Los Judios, la memoria y el presente. Buenos Aires, Paidos, 2005.

${ }_{93}$ GuinzBuRg, Carlo. "Unus testis - o extermínio de judeus e o princípio de realidade”, em: $O$ fio e os rastros. São Paulo, Companhia das Letras, 2007, p.229.
} 
A memória e a destruição da memória são recorrentes na história, mas o que ocorreu nos campos de extermínio nazistas assinalou, de forma inédita, o questionamento sobre a realidade e sua destruição e os limites do conhecimento histórico, pondo em xeque sua competência analítica [GuinzBuRG, 2007: 230]. Como reafirmou VidalNaquet, as câmaras de gás (ou, poderíamos afirmar, os desaparecimentos forçados na América Latina) foram (e têm sido) demonstrados e quem afirma o contrário é que deveria comprovar tal afirmação [GUINZBURG, 2005:15].

\title{
I.3.1. Ética do testemunho e justiça
}

Giorgio Agamben tratou dos limites da demanda judicial e do testemunho em juízo sobre a Shoah. Ele assinalou que não se trata de não emitir um julgamento, mas que o decisivo é: “[...] que o direito não pretenda esgotar a questão. Há uma consistência não jurídica da verdade, na qual a quaestio facti nunca poderá ser reduzida à quaestio iuris. Cabe ao sobrevivente precisamente isso: tudo o que leva uma ação humana para além do direito, o que a subtrai radicalmente ao Processo”. Esta reflexão é sustentada pelo argumento de que o direito não tende ao estabelecimento da justiça, nem sequer da verdade, o direito

\begin{abstract}
"Busca unicamente o julgamento. Isso fica provado para além de toda dúvida pela força da coisa julgada, que diz respeito também a uma sentença injusta. A produção da res judicata - com a qual a sentença substitui o verdadeiro e o justo, vale como verdadeira a despeito da sua falsidade e injustiça - é o fim último do direito. Nessa criatura híbrida, a respeito da qual não é possível dizer se é fato ou norma, o direito encontra paz; além disso ele não consegue ir. [...] Ora, se a essência da lei - de toda lei - é o processo, se todo direito (e a moral que está contaminada por ele) é unicamente direito (e moral) processual, então execução e transgressão, inocência e culpabilidade, obediência e desobediência se confundem e perdem importância. [...] Uma das consequências que é possível tirar dessa natureza auto-referencial do julgamento [...] é que a pena não é consequência do julgamento, mas que ele mesmo é a pena [...]. 'Poder-se-ia dizer até que a pena completa está no julgamento; que a pena infligida - o cárcere, o carrasco interesse apenas enquanto for, por assim dizer, prolongamento do julgamento (pense-se no termo justiçar) ${ }^{\prime \prime 94}$.
\end{abstract}

Partindo deste ponto de vista, Agamben questionou os limites dos 12 processos de Nuremberg e de outros realizados dentro e fora da Alemanha. Embora eles tenham sido “necessários” foram insuficientes, pois envolveram apenas centenas de pessoas e

\footnotetext{
94 Agamben, (2008), p.28-9. Agamben utiliza-se da interpretação do jurista italiano S. Satta de que o direito busca unicamente o julgamento; em SATTA, S. Il mistério del processo. Milano, Adelphi, 1994, p.26.
} 
contribuíram "[...] para difundir a ideia de que o problema já estivesse superado" [AgAmBen, 2008: 29]. Foram necessários cerca de 50 anos para se entender que o problema colocado por Auschwitz era tão grande que o direito não o havia esgotado e, sim, que este problema o havia questionado a ponto de levá-lo à ruína. Ao apontar para a “zona cinzenta”, Levi teria descoberto uma "zona de irresponsabilidade”, na qual o oprimido se torna opressor e o carrasco aparece como vítima, que se situaria aquém do bem e do mal. Levi teria deslocado a ética para esta zona, onde se manifestou em plenitude a banalidade do mal ${ }^{95}$.

Para Dominick LaCapra a importância da descrição da "zona cinzenta” feita por Levi e sobre a colaboração das vítimas ao nazismo é inegável e apresenta os casos mais difíceis de analisar e compreender. Mas a hipérbole “Auschwitz-agora-em todas as partes”, construída por Agamben [LACAPRA, 2006: 250], produz uma generalização do que aconteceu na “zona cinzenta”, que destrói as diferenças históricas e envolve a todos as vítimas são igualmente consideradas cúmplices da lógica da Shoah, porque todos nós participaríamos da tendência de "reprimir ou negar os restos 'não dialetizáveis"” [LACAPRA, 2006: 201]. Levi, entretanto, não apagou por completo a distinção entre vítima e verdugo e restringiu sua análise aos Sonderkommando e ao Conselho Judeu, principalmente o do gueto de Lodz. A perspectiva de Agamben, entretanto, tende a enfatizar o apagamento radical das distinções. Ele dá muita ênfase à lacuna, à falta ou à perda, ao esquecimento, à evasivibilidade, à inacessibilidade ou ao que está além dos limites da representação da experiência-limite, da denominação e da normatividade. Esta orientação nos leva ao paroxismo extremo que pode dificultar ou impedir a reflexão e o conhecimento desse fenômeno [LACAPRA, 2006: 199-201].

Para Agamben, no contexto pós-Auschwitz, “[...] a única ‘ética’ verdadeira - em contraste com uma ridicularizada 'moral' da responsabilidade, culpa, arrependimento e talvez normatividade e limites normativos em geral - é a ética da pura potencialidade, abertura e exposição” [LACAPRA, 2006: 258]. LaCapra, por outro lado, busca ressaltar as condições específicas de possibilidade da ética, mesmo após Auschwitz: “[...] a abjeção absoluta é o ponto final da ética, tanto que as normas éticas são impossíveis de se aplicar ao comportamento do absolutamente abjeto e desempoderado [do Mulçumano], mas, paradoxalmente, continuam sendo importantes para ele” [LACAPRA, 2006: 256]. Agamben tende a subsumir “[...] Auschwitz, um fenômeno histórico complexo, em um

\footnotetext{
${ }^{95}$ Cf. Agamben, (2008), 30-1; e Levi, (1990), p.32.
} 
discurso teoricista ou elevado que tende a isolá-lo das condições de sua emergência histórica e a anular qualquer distinção ou especificidade. [...] Ele tem propensão a uma resposta [...] do tipo “tudo ou nada” e transhistórico” [LACAPRA, 2006: 214-5].

Esta perspectiva tende a excluir uma ideia de elaboração, considerada aqui não como redenção plena, recuperação total ou cesura não mitigada, senão como processo recorrente que jamais transcenderá completamente a reatuação ou a repetição compulsiva do trauma ou das situações-limite, “[...] mas permitirá certa distância crítica dos conflitos e uma possibilidade de transformação significativa, incluindo mudanças desejáveis com relação às responsabilidades e obrigações da vida cívica”. Esta visão mantém distância de qualquer concepção normativa da ética ou da política. [LACAPRA, 2006:195-7]. A interpretação de Agamben,

"[...] ao seguir de modo muito literal a divisão estabelecida por Levi entre os "afogados” e os "sobreviventes", entre o "muçulmano" e os demais presos, acabou por hipostasiar o que existiu apenas de modo dinâmico. Muitos "muçulmanos" sobreviveram e testemunharam, como o próprio Agamben - contraditoriamente - o reconhece. O maior problema desta divisão estanque que ele procura traçar é a eliminação e condenação de qualquer raciocínio jurídico: para Agamben o testemunho deve ser pensando apenas como superstes, sobrevivente, e não como testis, terceiro em uma cena jurídica, "testemunha ocular”. Na economia-política da memória, no entanto, o julgamento e o testemunho têm um valor inestimável. [...] Senão corre-se o risco de cair no 'esquecimento feliz', nietzscheano, do homem dionisíaco que sempre diz sim, que, [...] é antípoda da ética do testemunho” [SELIGMANN-SILVA, 2006: 23-4].

Uma ética do testemunho parte da "figura mínima” do corpo humano dilacerado, o homem "zerificado" em tudo o que o Humanismo havia lhe atribuído, mas ele próprio é um homem. “Se Primo Levi fala da polaridade entre os ‘salvos’ e os ‘afogados’ é para pôr em movimento as fronteiras: para mostrar a situação do 'salvo' como alguém condenado a viver 'na morte' de que escapou; e, por outro lado, para apresentar os 'afogados' como figuras fantasmáticas, visadas, mas nunca alcançadas pelo testemunho de 'terceiros'. Ele desmonta a visão tradicional, cristã, que separa os salvos dos condenados” [SELIGMANNSILVA, 2006: 21].

Como despojar o sobrevivente do desejo de acusar e de justiça, perguntam-se muitos sobreviventes? ${ }^{96}$ Essa falta, essa lacuna, o valor e o sentido do testemunho importam também para pensar a história das ditaduras latino-americanas e, em especial, a da Argentina, onde a maioria dos prisioneiros não sobreviveu aos campos de extermínio e

\footnotetext{
${ }^{96}$ AmÈRY, Jean. Más allá de la culpa y la expiación. Tentativas de superación de una víctima de la violencia. $2^{\mathrm{a}}$ ed., Valencia/Espanha, Pré-textos, 2004, p.47-9. Na introdução deste livro, de 1966, Amèry explica que o processo de Auschwitz, iniciado naquele ano, influenciou-o a escrever seu testemunho. $\mathrm{O}$ mesmo ocorreu com outras vítimas.
} 
tornaram-se desaparecidos. Na Argentina, onde, desde 2005, têm sido realizados diversos processos judiciais para estabelecer a culpa e a punição dos responsáveis pelo desaparecimento de milhares de pessoas, seria possível falar de ausência de legitimidade dos testemunhos? Lá, vários sobreviventes testemunharam pela primeira vez a partir de 2005, após o início dos julgamentos penais de crimes contra a humanidade.

Ao final da II Guerra Mundial, a ênfase das preocupações residia em descobrir e documentar os crimes ocorridos. Nos julgamentos de Nuremberg houve apenas o testemunho de um sobrevivente (apesar da tradição herdada do direito romano de não aceitar como prova o que é afirmado por um único testemunho [GINZBURG, 2007]). As provas produzidas então foram fundamentalmente documentais. A grande mudança em relação ao lugar do testemunho dos sobreviventes ocorreu no julgamento de Eichman em Jerusalém, em 1961. O testemunho dos sobreviventes assumiu papel fundamental como prova jurídica e para a estratégia da acusação: tratava-se de colocar no centro das atenções a memória do genocídio como parte importante da identidade judia. A partir de então, o testemunho assumiu um lugar central nos julgamentos, engrossando a chamada “era do testemunho"

Na Argentina, os “julgamentos pela verdade” e os processos para responsabilizar os “apropriadores” de bebês, os filhos dos desaparecidos políticos nascidos em cativeiro adotados por militares ou desconhecidos, que se iniciaram nos anos 1990, assim como os primeiros processos do Chile para punir crimes da ditadura, foram decisivos para que o direito internacional de direitos humanos criasse uma jurisprudência a respeito da comprovação de crime de desaparecimento forçado por meio de indícios, tendo em vista as dificuldades para se encontrar os restos mortais e as provas materiais desses crimes ${ }^{98}$. Nestes julgamentos, o testemunho dos sobreviventes tem sido fundamental.

Desde a formação da primeira experiência de Comissão de Verdade no mundo, a Conadep, e o julgamento das Juntas Militares, o sistema judiciário argentino tem

\footnotetext{
${ }^{97}$ WIEVIORKA, Annete. L'ère du témoin, Paris, Plon, 1998; e de "From survivor to witness: voices from de Shoah”. In: WINTER, Jay; SIVAN, Emmanuel. War and Remembrance in the Twentieth Century. Cambridge: Cambridge University Press, 1999; citados em JeLin, Elisabeth. Los trabalhos de la memoria. Madrid, Siglo XXI, 2002, p.83.

${ }^{98}$ V. os casos na OEA: Barrios Altos, Almonacid, entre outros. Por outro lado, o direito internacional tem produzido lentamente instrumentos de proteção às vítimas. A resolução 47/133 da ONU sobre desaparecimentos forçados foi aprovada em 18/12/92 e a Convenção Interamericana sobre Desaparecimento Forçado de Pessoas foi adotada pela OEA, em 09/06/94. Apenas em 29/06/06 foi aprovado o projeto de Convenção Internacional de Proteção às Pessoas Vítimas de Desaparecimento Forçado da ONU.
} 
registrado centenas de depoimentos para configurar a responsabilidade desses crimes ${ }^{99}$. Por outro lado, na atualidade, a maneira como foram organizadas as ações penais contra perpetradores na Argentina faz com que alguns acusados sejam réus em vários processos, o que obriga também a que muitos sobreviventes tenham que depor em juízo várias vezes, tendo de repetir o seu relato a cada julgamento. Isso tem provocado grande sofrimento e desgaste aos sobreviventes. As ações penais com o objetivo de imputar os responsáveis pelo desaparecimento forçado de milhares de pessoas apuram somente as responsabilidades caso a caso.

Em larga medida, o debate sobre o alcance e os limites dos processos judiciais está ocorrendo na Argentina, no Chile e no Uruguai. Na Argentina, muitos atores sociais defendem a palavra de ordem "Todos por todos" - a exigência de processar todos os mandantes e executores dos crimes contra a humanidade para fazer justiça a todos os desaparecidos políticos. Pelo menos 1.604 acusados, entre civis dos órgãos de segurança e membros das Forças Armadas, estão ou estiveram envolvidos em causas judiciais vinculadas ao terrorismo de Estado, mas apenas 182 imputados obtiveram sentença definitiva, sendo que 167 foram condenados e 15 absolvidos ${ }^{100}$.

A permanente mobilização política dos grupos de sobreviventes e familiares de desaparecidos políticos, principalmente na Argentina, busca evitar uma aceitação cômoda dessas condenações que possa gerar uma falsa sensação de superação. A possibilidade de forçar os limites da lei e do direito preside a motivação dessas demandas por "verdade e justiça”. Há um amplo e intenso debate visando a construção de uma consciência da necessidade de mudanças, para além do âmbito jurídico, na cultura, na educação, na política e nas instituições.

Desde a anulação das leis de anistia, na Argentina, a relação existente entre memória e a justiça retroativa, construída a partir da demanda das vítimas e em nome de seus direitos, enfatiza que a existência e repercussão dos julgamentos penais vão além do exercício e vigência do direito e transbordam as fronteiras dos procedimentos judiciais. Eles supõem que as vítimas, inclusive as que não tiveram acesso à justiça, possam ser

\footnotetext{
${ }^{99}$ Teve início em 1998, em La Plata, um “juízo pela Verdade” sobre o campo La Cacha, onde foram registrados 800 testemunhos. Em 2006, a primeira ação penal iniciada depois da anulação das Leis de Obediência Devida e de Punto Final (2005), condenou Miguel Etchecolatz, em La Plata, onde foram ouvidos 150 depoimentos. Na causa judicial referente ao Campo de Mayo, 300 testemunhas foram ouvidas.

${ }^{100}$ Desse total, 428 processados estão com prisão preventiva decretada. Dados de fevereiro de 2011. V. Terrorismo de Estado, a 34 años del golpe. Bs. As., CELS, 23/03/2010; e http://www.cels.org.ar/wpblogs/. Acesso em: 04/02/2011. V. tb. o Spot de difusão dos julgamentos, onde se pode conhecer uma série de programas de propaganda visando divulgá-los.
} 
reconhecidas e suas memórias sejam admitidas na esfera pública, possibilitando uma ampla deliberação e apropriação do passado recente, das normas do direito e dos valores de justiça [VezzetTI, 2009: 17-8]. Para Vezzetti, vivencia-se na Argentina a experiência aporética da justiça ao se "exigir calcular o incalculável”, conforme apontou Jacques Derrida $^{101}$.

De acordo com Vezzetti, contudo, contrariamente ao que se alega, “[...] não há e nem houve na Argentina uma política de Estado” no que se refere à justiça retrospectiva. Além disso, há “[...] uma contraposição entre uma justiça aplicada aos crimes do passado e uma justiça guardiã dos direitos básicos, relegados no presente” [VEZzETTI, 2009:40]. De acordo com o Centro de Estudos Legais e Sociais (CELS), existe na Argentina um quadro de deterioração dos direitos sociais e jurídicos. A atuação do governo faz uma gestão "mais focada em administrar a relação com os organismos de direitos humanos do que na execução de uma política eficiente para remover os sérios obstáculos no processo de justiça” ${ }^{\prime 102}$.

O balanço do CELS sobre os processos por delitos de lesa a humanidade de 2007 assinala uma "ausência de uma estratégia eficiente de persecução penal”, e uma ausência de políticas destinadas a transformar procedimentos, hábitos e valores nas Forças de Segurança, militares, e no aparato da justiça. O balanço aponta que organismos judiciais e do poder executivo têm responsabilidade pela fragmentação das causas, o que tem levado a uma “exposição desmesurada das testemunhas”. Há ainda deficiências no cumprimento de funções essenciais como a proteção das testemunhas, presentes também em relação à repercussão pública dos processos [VEZZETTI, 2009: 41].

O balanço é ruim quando se trata da justiça do ponto de vista da equidade social e da cidadania: "Fracassa, então, a construção efetiva de um Estado “de direito” que deve começar por garantir o básico”. Há na Argentina “uma implantação muito importante e firme do reclamo pelo esclarecimento e justiça sobre os crimes da ditadura. Mas essa focalização convive com a ausência de uma concepção integral dos direitos e da justiça que se evidencia tanto nas instituições e hábitos da sociedade civil como na fragilidade das políticas de Estado” [VEZZETTI, 2009: 41-2].

Mas para além do resultado dos processos judiciais em curso, da morosidade, da eficácia e do cumprimento das regras do direito, e do número de condenados, a matéria e

\footnotetext{
${ }^{101}$ DERRIDA, Jacques. “O direito à justiça”, em: Força de Lei. O fundamento místico da autoridade. São Paulo, Martins Fontes, 2007.

${ }^{102}$ Relatório Anual do CELS de 2007, citado em VezzeTti, (2009), p.40.
} 
os problemas que emergem dos julgamentos revelam uma questão essencial, “[...] o conhecimento e o reconhecimento das heranças e das responsabilidades da sociedade" com respeito tanto ao seu passado e quanto ao presente. De acordo com Vezzetti:

"Pensar e conhecer o que passou obriga a enfretar uma problemática complexa, densa, difícil de discernir e de estabelecer; impulsiona questões até o passado mais longínquo e até o presente: perguntas sobre o Estado, sobre o sistema político, as lideranças, as organizações e as instituições da sociedade. E tudo isso se situa mais além da investigação judicial na medida em que há um horizonte de verdade histórica que não fica somente sob a competência dos especialistas, sejam juízes ou historiadores” [VEZZETTI, 2009: 18].

No caso brasileiro, muito distinto do panorama da Argentina, as questões sobre a dificuldade de se encontrar uma "capacidade de escuta” e a de que os sobreviventes ficam “mudos” depois da guerra e de outras experiências-limite surgiram no debate sobre as memórias da ditadura, e são colocadas nos testemunhos dos entrevistados. A lógica repressiva reduziu as pessoas ao "jogo da sobrevivência", que presidiu o funcionamento dos centros de tortura e de extermínio da ditadura brasileira, ainda que as formas de organização, as proporções da estrutura repressiva e a extensão dos crimes cometidos no país guardem muitas diferenças com outras ditaduras. É muito difícil justificar a sobrevivência, seja no campo nazista ou na Argentina. Aqui como em outros lugares, o silêncio imposto aos sobreviventes tornou-os, muitas vezes, mudos, mas seus testemunhos surgem e ressurgem reafirmando impossibilidades, limites e singularidades.

Filósofos como Derrida e Paul Ricoeur trataram da impossibilidade de se controlar o tempo do luto ou de legislar sobre o imperdoável. Ricoeur sublinhou que o perdão não deve ser imposto através da usura do tempo, a prescrição, ou da usura da justiça, a ausência de julgamentos. É preciso buscar preservar os vestígios dos fatos para vivenciar uma “terapia da memória”, pois importa curar a capacidade destrutiva das recordações. Ricoeur ressaltou a necessidade de um trabalho da memória e do luto, que se realizaria por meio de processos judiciais ou extrajudiciais como as Comissões de Verdade, ou outros instrumentos que promovessem o esclarecimento dos fatos e o acolhimento dessas narrativas por parte das sociedades ${ }^{103}$. Não é possível conquistar uma “memória justa” sem a busca por edificar uma sociedade mais justa [VEZzETTI, 2009: 17].

Alguns autores enfatizam, porém, a função terapêutica do direito e da justiça para as vítimas e coletividades, e sua importância na elaboração simbólica de traumas sociais, mesmo que não conduzam às transformações políticas e jurídicas da realidade que gerou

\footnotetext{
${ }^{103}$ Ricoeur, Paul. "Dever de memória, dever de justiça”. In: A crítica da conviç̧ão. Lisboa/Portugal, Edições 70, 1997, p.161-73.
} 
esses traumas ${ }^{104}$. A transmissão de experiências em situações extremas tornou-se o centro da preocupação de autores como Diana Kordon e Lucila Edelman, que chamam a atenção para o fato de que a ausência de justiça sanciona o silêncio imposto ou induzido pelo Estado, o que gera consquências para todos, não apenas para as vítimas:

“A ausêcia de sanção do crime por parte do Estado durante tantos anos, que no âmbito psicossocial inabilitou as funções que deveria cumprir enquanto garante da ordem simbólica, lugar de terceiridade e como regulador dos intercâmbios, deixou aberta a possibilidade de reativação periódica das vivências de desamparo que operam como um fator desestruturante do psiquismo.

A elaboração dos lutos e da situação traumática está sempre sob a influência alienante dos diferentes discursos sociais acerca da mesma. Durante o período ditatorial esta força alienante tinha uma potência dada por uma situação de terror e a constituição de um campo paranoide. O silêncio social era a norma. [...] o secreto implica uma organização, uma interpretação do não-dito, quer dizer, que o não-dito, o oculto, o será respondendo a determinadas leis de funcionamento psicológico de um grupo familiar ou social.

O silêncio abarca diferentes aspectos: o silêncio social induzido pelo Estado, a identificação alienada com esse mandato de silêncio e a necesidade de manter silêncio posterior à situação traumática"105.

Os que foram perseguidos em períodos de exceção são, sem dúvida, vítimas da opressão e, por vezes, de violências extremas como a tortura. Torna-se essencial para esses grupos e para a sociedade reconhecer essa condição para que se possa sair da posição de vítima. O testemunho é um importante caminho para a constituição de novas identidades em situações pós-traumas sociais, seja ele realizado no âmbito da arte, da história ou da justiça. No caso brasileiro, o "bloqueio e o sequestro do testemunho" impedem que este se dê tanto em sua forma jurídica, como em outros modos. "O fantástico e escandaloso sequestro das provas e dos testemunhos mantém o Brasil como que congelado no tempo, quando se trata do enfrentamento político-jurídico e do trabalho de memória da nossa ditadura. As elites [...] estigmatizam as tentativas de se estabelecer a verdade e a justiça como sendo meros atos de revanchismo"106.

Diversos autores refletiram de forma crítica sobre o testemunho, tentando recuperá-lo do revisionismo e do negacionismo. Lyotard acentuou a importância das vítimas poderem tornar-se "acusadores” no ambiente judicial para superarem a condição de vítima. Sem um dano que se torne público e seja comprovado, sem destinatários para ouvir este reclamo não há testemunha, nem testemunho [SELIGMANN-SiLVA, 2009: 8].

\footnotetext{
${ }^{104}$ SAFATLE, Vladimir. "Encontro marcado". Reportagem, 65, fev./2005, p.31-4.

${ }^{105}$ V. KoRDON, D. e EDELMAN, L. Efectos psicológicos multigeneracionales de la represión de la dictadura, em: www.psi.uba.ar/biblioteca/bvs/aappg/revistas_digitalizadas. Tradução livre da autora. Agradeço a André Sabóia a indicação dessa leitura.

${ }^{106}$ V. Seligmann-Silva, Márcio. O caso brasileiro ou o não-lugar do testemunho. Mimeo, ago. 2009, p.2. Texto apresentado no Seminário Internacional 30 anos de anistia no Brasil: o direito à memória, à verdade e à justiça, Fadusp, 25 a 28/08/2009.
} 
Neste sentido, ele considera que se aquele que acusa se vê despojado dos meios de argumentar converte-se em vítima. “[...] Se o destinador, o destinatário e o sentido do testemunho ficam neutralizados, então é como se não houvesse existido o dano. [...] Aquele que apresenta uma demanda ante o tribunal é escutado, mas aquele que é vítima fica reduzido ao silêncio”"107. Esta vítima que não supera a condição de vítima torna-se um índice de uma "presença debilitada” [GUINZBURG, 2005, 17].

"É próprio da vítima não poder provar que ela sofreu um dano. Um sujeito que acusa é alguém que sofreu um prejuízo e que dispõe de meios para prová-lo. Se converte em vítima se perde esses meios. Os perde se, por exemplo, o autor do dano é direta ou indiretamente o seu juiz. O juiz tem a autoridade para rechaçar o testemunho do acusador como falso ou tem a capacidade de impedir sua publicação [...]. Em geral, aquele que acusa torna-se uma vítima quando não é possível nenhuma apresentação do dano que ele afirma ter sofrido. Reciprocamente, o "crime perfeito" consistiria, não em matar a vítima ou as testemunhas (ou seja, acrescentar novos crimes ao primeiro e assim agravar a dificuldade de apagar tudo), mas antes em obter o silêncio das testemunhas, a surdez dos juízes e a inconsistência (loucura) do testemunho.

Neutraliza-se o destinador, o destinatário, e o sentido do testemunho; tudo se passa então como se ele não tivesse um referente (como se ele não tivesse um dano).

Se ninguém administra a prova, se ninguém a admite, e se a argumentação que a sustenta é considerada absurda, a demanda daquele que acusa é indeferida, o dano do qual ele se queixa não pode ser atestado. Aquele que acusa se converte em vítima [novamente]. Se ele persiste em invocar este dano como se ele existisse, os demais (declarantes, destinatários, experts que comentam o testemunho) poderão facilmente fazê-lo se passar por louco” [LYOTARD, 1988: 20-2].

Rejeitar a imposição de silêncio e a repressão de traumas decorrentes de sequestros, tortura, prisão, assassinatos e desaparecimentos forçados denotam a importância de resgatar o testemunho dos sobreviventes, especialmente no Brasil. Registrar as marcas do sobrevivente cindido que busca religar os fragmentos da sua identidade e que ao mesmo tempo não consegue ou não quer falar dessas experiênciaslimites. A tensão existente entre a postura de querer contar, refazer identidades e a de silenciar assumiu uma singularidade no Brasil que merece análise detida. Desde o período final da ditadura, com uma "transição política” estabelecida sem rupturas significativas, foram engendrados processos políticos, instituições e normas que ainda hoje se interpõem para bloquear ou postergar a reflexão e elaboração social do passado recente. Entrelaçando o público e o privado, os relatos dos presos políticos nos oferecem pistas para interpretar a cultura e a política nacionais.

\footnotetext{
107 Lyotard, J-F. Op.cit., p.20-2. Tradução livre da autora. Chama a atenção que Brasil, Paraguai e Guatemala sejam os únicos países na América Latina nos quais o cidadão comum não pode ser autor ou coautor de ações penais, apenas o Ministério Público tem essa prerrogativa.
} 
Em diversos lugares, o reconhecimento da violência e a rememoração do passado têm ocorrido de maneira indissociável das lutas por justiça, seja por meio dos tribunais ou das Comissões de Verdade, e do reconhecimento da importância da retribuição simbólica. $\mathrm{Na}$ atualidade, os caminhos da memória de traumas sociais têm sido, em maior ou menor grau, mediados pela história e pela justiça. A interpretação histórica, porém, está sempre em trânsito, enquanto a justiça visa uma sentença definitiva; o processo dá visibilidade às questões que o dano implica, embora, a cena jurídica seja limitada. E, em especial, não são com os mesmos ouvidos que o historiador e o juiz ouvem o testemunho [RICOUER, 2007: 334-7]. Reconhecemos a necessidade de “[...] aceitar o testemunho com o seu sentido profundamente aporético de exemplaridade possível e impossível, de singularidade que nega o universal da linguagem e nos remete 'diante da lei', e ao mesmo tempo exige e cobra esta mesma lei. Sua negação determinada deixa sua marca desconstrutivista tanto na linguagem, na literatura, como na lei” [SELIGMANN-SILVA, 2006:24].

Reconhecemos a necessidade de uma ética do testemunho que transcenda “[...] os limites da normatividade que articula as relações entre as pessoas em grupos ou âmbitos institucionais” [LACAPRA, 2006: 202], sem diminuir ou excluir a importância da busca por mudanças desejáveis no reconhecimento de responsabilidades e obrigações da vida social visando um futuro palpável. "Uma ética que implique numa normatividade que não deve confundir-se com a lei positiva, sujeita à programação e codificação rígida, nem tampouco cair na normalização” [LACAPRA, 2006: 203]; uma ética relacionada a práticas articuladoras abertas ao questionamento e à transgressão radical e que estabeleça limites legítimos à afirmação grupal e pessoal.

\section{I.4 As memórias dos sobreviventes no Brasil}

A produção historiográfica sobre o período ditatorial tem tratado a história e as memórias dos presos políticos predominantemente por meio de estudos de caso. Complementando esta visada, esta tese prioriza o papel das memórias de militantes das esquerdas revolucionárias. Por meio do uso da memória oral buscamos recuperar os embates políticos, as mudanças e permanências nas suas propostas diante da derrota dos projetos, assim como a formação de redes de solidariedade e sua participação na rearticulação da política institucional e no surgimento dos novos movimentos sociais dos 
anos $1970^{108}$.

A produção memorialística sobre a ditadura alcançou grande repercussão no final dos anos 1970 e início da década de $1980^{109}$. Importantes análises e estudos sobre a relação entre o Estado e a oposição do período, abordando a dinâmica das lutas políticas institucionais e da sociedade civil foram produzidas [ALVES, 1984; SKIDMORE, 1995; GASPARI, 2002; 2004]. Trabalhos fundamentais sobre as esquerdas revolucionárias [GORENDER, 1987; AARÃO, 1991] e sua relação com a sociedade e a cultura [RIDENTI, 1993; 2000] trataram de maneira crítica a experiência da luta armada no Brasil. Contudo, diversos aspectos da resistência protagonizada pelos presos políticos nos centros de tortura, na vida cotidiana dos cárceres e do debate político travado por eles naquele período merecem uma análise mais atenta e sistemática. Neste trabalho nos propomos a investigar as memórias dos presos políticos dos anos 1970, tendo como objetivo recuperar e analisar o significado de suas lutas e memórias.

Pesquisas recentes avançaram nos estudos sobre a luta pela anistia [FERREIRA BAstos, 2007; Swensson JR., 2007; MEZAROBBA, 2008], a Justiça Militar e os órgãos de segurança [SWENSSON JR., 2006; JOFFILY, 2008] e a literatura de testemunho do período ditatorial [SILVA, 2008]. Nesse trabalho, o enfoque recai sobre a recuperação da memória, do cotidiano e das lutas dos presos políticos, seus desdobramentos e disputas pela memória sobre a ditadura.

Para compreender o funcionamento e a dinâmica das relações estabelecidas entre a repressão seletiva, as prisões, os processos judiciais, a mobilização jurídica transnacional e a política daqueles anos, entendemos ser necessário resgatar como os presos atuaram, buscando interferir na conjuntura do país. Recolhendo seus testemunhos sobre o cotidiano nos cárceres, podemos recuperar suas propostas e análises políticas e ideológicas, suas mudanças e permanências.

Durante a ditadura, as prisões ocorreram em duas fases mais significativas: a primeira se iniciou quando do golpe de 1964 e, a segunda, após a publicação do AI-5, em 1968. Ao lançar nosso olhar, especialmente, para as prisões da segunda fase, consideramos ser possível aprofundar a compreensão sobre as lutas revolucionárias e de

\footnotetext{
${ }^{108}$ Estudos de caso sobre presos políticos: FARIA, Cátia. Revolucionários, Bandidos e Marginais. Presos políticos e comuns sob a ditadura militar. Mestrado, História/UFF, 2005; RiBEIRO, Flávia Maria F. A subida do monte purgatório: estudo da experiência dos presos políticos da penitenciária regional de Linhares (1969-1972). Mestrado, História/UFJF, 2007; GASPAROTTO, Alessandra. “O Terror renegado." Uma reflexão sobre os episódios de retratação pública protagonizado por integrantes de organização de combate à ditadura civil-militar no Brasil (1964-1975). Mestrado, História/UFRGS, 2008.

${ }^{109} \mathrm{~V}$. as indicações na bibliografia, em anexo.
} 
resistência à ditadura; sobre as lutas dos presos políticos e como elas se transformaram, entre 1977 e 1979, em uma demanda de importantes setores sociais que visavam o fim da ditadura e influenciaram a política brasileira.

Apesar do crescente interesse pela memória e o testemunho, não é possível falarmos de um “boom de memória” no Brasil, embora haja uma quantia considerável de publicações sobre as memórias da ditadura ${ }^{110}$. Apenas recentemente a produção memorialista sobre a ditadura começou a ser estudada no âmbito da face da literatura que trata do testemunho [SELIGMANN-SILVA, 2005: 85; GiNZBURG, 2003, 2004, 2009] ${ }^{111}$.

Pode-se afirmar que há poucos registros de depoimentos de ex-presos políticos ou de exilados, e uma parte considerável dessa produção foi realizada ainda no período ditatorial. Vale destacar também que esses projetos não se utilizaram da metodologia da história oral e nem elaboraram uma análise especificamente sobre as experiências de prisão ou da própria produção dos depoimentos ${ }^{112}$. Após o fim da ditadura, as exceções são os depoimentos de sobreviventes compilados no livro sobre o Presídio Tiradentes, aqueles recolhidos por iniciativa da Fundação Perseu Abramo e alguns trabalhos sobre a participação da mulher na luta armada. Os quais, na maioria, são demasiado curtos e registrados sem o uso da metodologia da história oral ${ }^{113}$.

Em nossa pesquisa procuramos, por meio da realização de entrevistas que visaram abarcar a história de vida dos ex-presos políticos, compreender sua atuação e estabelecer uma análise crítica frente aos seus projetos e práticas políticas. Buscamos compreender como lidam com o passado, as dificuldades de estabelecer e distinguir estas experiências, e de explicitar as limitações e possibilidades de realizar o luto em relação aos mortos, desaparecidos e às derrotas de seus projetos.

\footnotetext{
${ }^{110}$ V., em anexo, gráficos referentes à bibliografia da literatura de testemunho.

${ }^{111}$ Desde 1985, algumas obras abordaram este tema na perspectiva da análise literária, mas sem privilegiar a questão da literatura de testemunho. V. SÜSSEKIND, F. Literatura e vida literária: Polêmicas, diários \& retratos. Rio de Janeiro : Jorge Zahar, 1985; DALCASTAGNÈ, R. O espaço da dor: O regime de 64 no romance brasileiro. Brasília, Editora UnB, 1996; PELLEGRINI, T. Gavetas vazias: ficção e política nos anos 70. São Carlos (SP), Eduscar/Mercado de Letras, 1996; FrANCO, R. Itinerário político do romance pós-64: A Festa. São Paulo, Editora Unesp, 1998; SILVERMAN, M. Protesto e o novo romance brasileiro. $2^{\mathrm{a}}$ ed. revista. Rio de Janeiro, Civilização Brasileira, 2000.

${ }^{112}$ CASO, A. (1976); CAVALCANTI, P. C. U.; RAMOS, J. (1978); COSTA, A. de O. (1980); BETTO, Frei (1978); DIAS, L. N. (1979). Os relatos biográficos publicados recentemente, ver, por exemplo, os livros de Flávio Tavares (1999), Maria do Carmo Brito (2003), Ottoni Fernandes Jr. (2004), Renato Martinelli (2006), Frei Betto (2009) e Maurice Politi (2009). Cf. bibliografia.

${ }^{113}$ Freire, A.; AlMADA, I. e PONCE, J. A. de G. (orgs.). (1997); CARVALHO, L. M. (1998); MAUÉs, F. e ABRAMO, Z. W. (2006); ARANTES, M. A. de A. C. (1994); FERREIRA, E. F. X. (1996); LIMA, R. R. de (1998); os documentários Que bom te ver viva (1989) e 15 Filhos (1996).
} 
Por um lado, estes sobreviventes foram os principais responsáveis pela existência de um debate público acerca de tais temáticas; por outro, uma série de premissas ideológicas, marcas e traumas infligidos favoreceram seu silêncio e esquecimentos deste passado - dimensão esta, que só pode vir à tona, analisada de maneira conjugada à enorme resistência de setores do Estado e da sociedade ${ }^{114}$.

Esta tese estabelece uma aproximação com a bibliografia de testemunhos, tomando como referência os projetos de coleta de depoimentos já publicados ${ }^{115}$, aos quais complementa com uma nova base de memórias de ex-presos políticos, aqui registradas em entrevistas de larga abrangência, em muitos sentidos, reveladoras, a partir das quais foi possível uma considerável reconstituição das memórias dos presos políticos entre 1969 e 1979.

\section{I.4.1. Os relatos autobiográficos}

O novo biografismo no Brasil teve origem no resgate da trajetória das esquerdas, duramente reprimidas pela ditadura, tendo transcendido esta temática em um segundo momento, o qual se ramificou em várias direções: literatura, romance, reportagem, trabalho histórico e audiovisual. Neste último âmbito, adquiriu expressão notável em conteúdos voltados à televisão. Com a obra monumental de Pedro Nava [GALVÃo, 2005], publicada ainda durante os anos 1970, o memorialismo e o romance-reportagem cresceram em importância, ao mesmo tempo em que amplificaram seu diálogo através de uma dissolução parcial das fronteiras entre história e literatura.

O memorialismo de jovens que vivenciaram a instalação do terror de Estado surgiu nesta época. Estes relatos priorizaram a experiência da guerrilha urbana e a vivência daqueles que se exilaram e, desta posição, caracterizaram a realidade da tortura, do cárcere e do próprio exílio. Embora o livro O que é isso, companheiro? (1979), de Fernando Gabeira, tenha sido o representante deste grupo a alcançar maior repercussão e vendas, poderíamos citar o romance de Renato Tapajós, Em câmara lenta (1977), como um dos primeiros relatos a tratar de maneira direta da experiência da tortura e morte no

\footnotetext{
${ }^{114}$ KeHL, M. R. “Tortura e sintoma social”, em: SAFAtLE, V.e TelEs, E. (orgs.). (2010).

${ }^{115}$ V. Memórias do exílio (1978); Memórias das mulheres no exílio (1978); Tiradentes, um presídio da ditadura (1997); e Pela Democracia, contra o arbítrio. A oposição democrática, do golpe de 1964 à campanha das Diretas Já. ABrAmo, Z. W.; MAuÉs, F. (orgs.). São Paulo, Ed. Fundação Perseu Abramo, 2006.
} 
cárcere. Cartas da prisão (1969-1971), de Frei Betto, publicado na Itália em 1971 e subsequentemente em outros países, sob o título Nos subterrâneos da história, foi censurado e só conseguiu sair no Brasil em $1977^{116}$. Este livro e Memórias, de Gregório Bezerra (1979), cuja segunda parte trata do período 1946-1969, estiveram nas listas dos livros mais vendidos do país, nos anos de seus respectivos lançamentos. Cabe destacar ainda a publicação de livros de testemunhos, tais como Memórias do exílio. Brasil 196419 ?? $(1978)^{117}$.

Na segunda metade da década de 1970, predominou o gênero do romancereportagem, influenciado pelo modelo norte-americano de ficcionalização de eventos de impacto midiático. Este modelo de abordagem temático-estilístico pauta-se pelo discurso jornalístico. No romance-reportagem, o destaque após a ditadura foi o livro 1968: o ano que não terminou (1998), de Zuenir Ventura. Este tipo de memorialismo, ligado ao primeiro ciclo de memórias - cujo percurso se iniciou no período final da ditadura - teve continuidade através de obras esparsas, ao longo dos anos, entre as quais cabe mencionar Iara (1992), de Judith Patarra, e Memórias do esquecimento (1999), de Flávio Tavares [GALVÃO, 2005: 97-110] ${ }^{118}$.

O aspecto central destas obras é a tessitura formada pelo relato da experiência da tortura e pela reflexão autocrítica sobre a luta armada, a militância e a clandestinidade. Há de se destacar o fato de que tal tendência não esgotou as abordagens possíveis sobre o tema, as quais permanecem em desenvolvimento, tal como se destaca pela recente publicação de livros e entrevistas que, ao invés de enfatizar a autocrítica e as reflexões sobre a militância e a clandestinidade, focam a experiência da prisão, como é o caso de Resistência atrás das grades e de Diário de Fernando (2009).

O primeiro ciclo de memória foi precedido por uma fase de desenvolvimento de perspectivas alternativas àquelas do período de maior repressão política. Algumas experiências nas artes plásticas, teatro e política, do início dos anos 1970 configuram um

\footnotetext{
${ }^{116}$ Foi editado por Ênio da Silveira, da Civilização Brasileira, graças ao empenho do escritor Hermilo Borba Filho, com prefácio de Tristão de Athayde. V. o prefácio da nova edição de BETTO, Frei. Cartas da Prisão. Rio de Janeiro, Agir, 2008, em www.ediouro.com.brcartasdaprisaoolivro.asp. No ano de 1977 foi publicado também BRITO, F.; LESBAUPIN, I.; CHRISTO, C. A. L. O canto da Fogueira: Cartas de três dominicanos quando em cárcere político. Rio de Janeiro, Vozes. Em 1978, outro livro de Frei Betto sobre as prisões foi publicado. V. BETTo. Frei Das catacumbas. Rio de Janeiro, Civilização Brasileira, 1978.

${ }^{117}$ A obra Memórias do exílio, foi publicada em Portugal, em 1976, e no Brasil, em 1978. Em junho de 1976, foi publicado A esquerda armada no Brasil (1967-1971), em Portugal, obra ganhadora do Prêmio Casa de Las Américas na categoria testemunho [CASO, 1976]. Foi amplamente copiada em xerox no Brasil e era citada pelas autoridades da ditadura como evidência dos crimes da esquerda [MARTINS FILHO, 2003]. Também em Portugal, no mesmo ano de 1976, foi lançado pelas Edições Maria da Fonte o livro Documentos dos presos políticos brasileiros: Acerca da repressão fascista no Brasil.

${ }^{118}$ Sobre a divisão em dois ciclos de memória ver MARTins FiLHO (2003).
} 
marco histórico entre os esforços de reação à ditadura e defesa da redemocratização; muitas destas criações foram realizadas por grupos marginalizados nas periferias das grandes cidades (como em São Paulo) [RIDENTI, 1999]. Surge também nesta época um tipo de romance desiludido com as propostas de transformação revolucionária da sociedade e com a própria condição do escritor, explicitando a "cultura da derrota" [FRANCO, 2003: 358-62].

Enquanto alguns romances dos anos 1960 recorreram a procedimentos literários pouco explorados ao longo da tradição literária brasileira (como a fragmentação e a montagem), os romances da “cultura da derrota” demonstram maior apego às formas consagradas. Estes trabalhos foram significativamente responsáveis pela manutenção do cenário cultural brasileiro, a despeito do fato de que muitas obras não obtiveram atenção do público e da crítica. O espaço privilegiado de muitos destes romances é o bar, um espaço de pouca ação [FrANCO, 2003]. Com o início do processo de abertura política e diminuição da censura, surgem o "romance-reportagem” e o “romance de denúncia”, os quais iniciaram uma nova maneira de tratar a denuncia da violência ditadorial ${ }^{119}$.

A oposição à ditadura por meio da literatura também foi contemplada através da literatura do testemunho, igualmente chamado de romance da "geração da repressão"120. Estes relatos testemunham, por via da estética e do depoimento direto, as experiências traumáticas vividas neste período, numa tentativa de as assimilar. Há uma dose de bravura embutida nestas obras, que configuraram uma maneira de enfrentamento do sofrimento e do risco da inverossimilhança, com vias à atuação política, para se evitar a continuidade da violência. Algumas destas obras buscaram reconstituir o rosto desfigurado dos mortos, redimindo-os, o que permitiu inscrever e atualizar suas vidas e anseios no presente. Um dos aspectos mais prementes destas obras é a clara inspiração dos relatos na necessidade de expiar e explicar a culpa, o porquê e a maneira como sobreviveram.

Em sua longa entrevista transformada em biografia, Maria do Carmo Brito tratou da morte de seu marido Juarez Guimarães Brito, a qual presenciou em 1970. Ele se suicidou para evitar a prisão, quando o casal foi apanhado em um cerco policial. Ela relatou as tentativas de esclarecimento das circunstâncias dos assassinatos de

\footnotetext{
${ }^{119}$ Exemplos do primeiro caso são Lúcio Flávio, o passageiro da agonia e Aracelli, meu amor, e do segundo, Os que bebem como cães (1975), expondo as práticas de tortura e o cotidiano dos presos políticos [FRANCO, 2003: 363].

${ }^{120}$ CANDIDO, A. “Os brasileiros e a literatura latino-americana”. Novos Estudos Cebrap. São Paulo, v. 1, 1, p. 58-68, dez. 1981.
} 
companheiros $^{121}$, depois de ser banida em troca da liberdade do embaixador alemão, em junho de 1970, juntamente com outros 39 militantes. Seu relato é emblemático do ponto apresentado acima, conforme tenta dar conta da ausência dos que foram mortos naquele período, dos conflitos e tensões gerados em função do comportamento na tortura, da dor de entregar companheiros e das tentativas de suicídio para pôr fim a tantos sofrimentos.

Outro assunto presente é o das infiltrações policiais e do modo como os militantes as enfrentaram. Em diversos trechos do livro, Maria do Carmo fala deste assunto e, em especial, do assassinato de seus companheiros da VPR, decorrente da delação de Cabo Anselmo, em especial, a que levou ao massacre de seis militantes na Chácara São Bento, próxima a Recife, em janeiro de 1973 [ViAnNA, 2003:120-3] ${ }^{122}$.

No início da abertura política, surgiu uma safra de romances esteticamente ousados, os quais ultrapassaram as linhas mestras do universo característico da "cultura da derrota”. Esta safra recorreu ao uso da montagem, fragmentação e multiplicação dos pontos de vista narrativos. Sua importância histórica esteve ligada ao fato de ter narrado a história política após 1968. Segundo proposta de Renato Franco, podemos chamá-los de “romances da resistência”, pois ofereceram uma resposta à modernização autoritária e conservadora do período ditatorial. Em maior ou menor grau, estes livros reconhecem as possibilidades críticas do ato narrativo e seu potencial para trazer à tona o fato de que algo fundamental foi silenciado e esquecido, de resistir à censura, à repressão política e de refletir a respeito destas situações-limite ${ }^{123}$.

Ao final dos anos 1970 e início da década de 80, surgiram diversas publicações sobre a memória das esquerdas, entre as quais algumas que se tornaram verdadeiros bestsellers. ${ }^{124}$ De acordo com Daniel Aarão Reis Filho, a razão para que a versão da história de Fernando Gabeira e outros tenha alcançado tamanha receptividade está ligada ao seu viés conciliador. Durante o período de transição política parecia mais “pertinente” uma

\footnotetext{
${ }^{121}$ Alguns deles também trocados quando do sequestro do embaixador alemão: Aderbal Alves Coqueiro do MRT, Jeová Assis Gomes e Carlos Eduardo Fleury, do Molipo, além de Ivan Mota Dias e José Raimundo da Costa, seus companheiros na VPR.

${ }^{122}$ V. tb. Linha Direita Justiça sobre Cabo Anselmo, exibido em 05/07/2007, na TV Globo; e ALMEIDA (2009). Localizsmod apenas 4 autobiografias escritas por mulheres: MourA, M. A Revolta das Vísceras. São Paulo, Codecri, 1982; LuCA, D. C. No corpo e na alma. Criciúma, Ed. do autor, 2002; FALCON, Y. Mergulho no passado. A ditadura que vivi. Maceió, Livro Rápido, 2007; Meloni, C. 1968 - O tempo das escolhas. São Paulo, Nova Alexandria, 2010.

${ }^{123}$ V. Confissões do Ralfo (1975), de S. Sant'Ana; Reflexos do Baile (1976), de Antônio Callado; Zero (1979), de Inácio Loyola Brandão, entre outros [FRANCO, 2003: 366-8]. Outra parte desse grupo pode ser chamada de "ficção radical", pois refletiu também sobre o romance em uma sociedade autoritária onde surgia uma poderosa indústria cultural: A Festa (1976), de Ivan Ângelo; Quatro-Olhos (1976), de R. Pompeu, e outros.

${ }^{124}$ Cf. já citado, o livro de Fernando Gabeira, $O$ que é isso companheiro? vendeu mais de 250 mil exemplares em 40 edições. V. site da Companhia das Letras.
} 
recuperação do passado que conjugasse pontos de vista [ROLLEMBERG, 2003: 76].

A conciliação e a ambiguidade características da transição política brasileira marcaram os testemunhos dos ex-presos políticos e sobreviventes, os quais tiveram que enfrentar os dilemas e dificuldades de refletir a respeito dessas experiências limite reflexão a qual se faz particularmente pungente em face do desafio para o estabelecimento de um discurso público em que se afirme a condição de vítima, sem que se resvale na vitimização. Neste mesmo sentido, o princípio norteador do delicado equilíbrio a se assumir na elaboração do discurso público acerca da experiência da repressão, implica uma caracterização dos companheiros mortos e desaparecidos como protagonistas de uma história de luta e sofrimento, cuja valorização evite os contornos esquemáticos da heroicização.

Muitas das disputas relativas às memórias dos sobreviventes e seu papel nas reflexões voltadas à compreensão da ditadura giram em torno das questões relativas à ênfase a ser atribuída ao papel voluntário e ativo dos militantes das esquerdas revolucionárias; ao prisma para que se efetue o resgate crítico de seus projetos; e, finalmente, do seu lugar na luta de resistência à ditadura. Os testemunhos recolhidos durante a elaboração desse trabalho retratam as divergências de avaliação sobre essas experiências, confrontando diversas visões e versões a respeito, conforme analisaremos a seguir.

Uma característica marcante dos livros do primeiro ciclo de memória aparece na introdução do livro Memórias do exílio (1976, 1978), onde os organizadores preocuparam-se em destacar uma visão contrária à postura de vitimização:

"Evitamos a martirologia. Salvo exceções, os exilados brasileiros não podem ser consistentemente caracterizados como 'vítimas inocentes de uma injustiça'. Via de regra, foram e são agentes políticos suficientemente maduros para reconhecer os riscos acarretados pela luta política. A ditadura brasileira é uma monstruosidade, não uma 'injustiça'” [CAVALCANTI; RAMOS, 1978: 17] ${ }^{125}$.

O terrorismo de Estado instaurado em 1964, contudo, gerou injustiças e sofrimentos ainda não elaborados pela sociedade brasileira. A importância desse reconhecimento e da necessidade de uma avaliação acabou por ser menosprezada, pois o respeito aos que morreram (percebido como tema prioritário ou questão pendente) e a preocupação em legitimar o discurso de exilados e militantes que tentavam se inserir no

\footnotetext{
${ }^{125}$ Este livro foi lançado em setembro de 1978, no Brasil, e contém um anexo sobre as torturas sofridas por Frei Tito e seu suicídio na França, e uma carta de Maria Auxiliadora Lara Barcellos, que se suicidou na Alemanha em 1976. V. AlMEIDA (2009), p.591 e 653.
} 
novo cenário político ocuparam maior espaço nos textos dos que escreveram suas autobiografias, romances ou reportagens sobre o período. Assim, predominaram os livros como os de Fernando Gabeira, que narram ações espetaculares, em tom de humor ácido e autocrítico.

O segundo ciclo de memória, iniciado nos anos 1990, foi marcado por um relativo distanciamento histórico, num quadro de construção democrática, o que fez do ato de rememorar algo desvinculado diretamente da luta imediata contra a ditadura. Um aspecto de destaque dos depoimentos é a avaliação sobre o período. Significativamente, as vozes militares foram mais prolixas do que no ciclo anterior. Entre estes discursos, predomina a negação da tortura como prática sistemática da ditadura. Outro aspecto da memória militar é que ela se dividiu entre os que reconhecem o predomínio da hierarquia durante a ditadura (porção minoritária e, geralmente, ligada aos ex-membros do DOI-Codi) e os que alegam “excessos” e desrespeito à hierarquia, quando da utilização da tortura [MARTINS FILHO, 2003].

Do lado das esquerdas, os autores continuaram a tratar dos assassinatos e desaparecimentos políticos tentando lidar com os sentimentos de culpa relacionados à tortura, mortes e exílio. Passaram a enfocar também os crimes e "justiçamentos" da esquerda, em alguns livros como os de Carlos Eugênio da Paz. Enquanto Carlos Eugênio (o “comandante Clemente” da ALN) busca explicar o "justiçamento” de Márcio Leite de Toledo, o livro de Renato Martinelli pretende homenagear o amigo assassinado criticando duramente a ação que levou a sua morte [MARTINELLI, 2006]. Estes temas delicados ainda não foram objeto de muitos testemunhos e de uma análise mais profunda.

Em Tiradentes, um presídio da ditadura (1997), os organizadores do livro retomaram a questão da vitimização, da auto-representação dos sobreviventes e da percepção da sociedade a respeito deles: salientando que o mais importante é o debate sobre seus projetos políticos. Na exposição feita na introdução do livro, eles apresentaram sua reflexão a respeito da preocupação em não serem identificados com as vítimas:

“[...] Nem bandidos, nem heróis, nem vítimas, como inadvertidamente se têm tratado muitos dos casos de mortos e desaparecidos, e dos que foram presos e torturados de um modo geral. Não somos vítimas inocentes. Ninguém entrou na luta dos anos 60 de maneira inocente. Todos os que lutaram tinham projetos para a sociedade brasileira. Os que lutaram sabiam por que estavam lutando e foram à guerra por seus ideais. Aqui não há vítimas, no sentido piedoso do termo. Ninguém foi obrigado a entrar em qualquer das organizações revolucionárias existentes. Quem entrou o fez por livre iniciativa, por resolução própria, por convicção. [...] Ninguém é vítima ao aderir a uma causa de livre e espontânea vontade, mesmo considerando a possibilidade de uma ou outra falha no 
recrutamento de um militante. É curioso notar, inclusive, que de todos os textos que recebemos, não há nenhum em que o autor faça qualquer alusão a uma eventual condição de vítima daquele processo de luta política. E só não comete erros quem não ousa.

[...] no quadro da opção pela luta armada, restaria dizer que mais valeria a pena discutir, dentro de uma perspectiva histórica, os projetos daqueles grupos para a sociedade e não os fatos de menor importância: se éramos heróis ou bandidos, vítimas ou comedores de criancinhas, sonhadores ingênuos ou perigosos terroristas ${ }^{126}$."

O tema da autocrítica à experiência de luta armada, embora controverso e delicado, tem recebido tratamentos diversos e também aparece no livro Tiradentes. Nos livros do guerrilheiro Carlos Eugênio, que não foi preso e conseguiu exilar-se, essa temática aparece de forma marginal. Em Tiradentes, junto à descrição do cotidiano no presídio, a questão da autocrítica aparece com mais destaque. Contudo, sente-se a ausência das variadas versões e visões sobre como o debate político e a questão da autocrítica foi tratada nos cárceres brasileiros. O depoimento de Renato Tapajós define de forma suscinta sua visão sobre as posições e posturas mais marcantes entre os presos políticos do presídio Tiradentes:

“[...] Havia os que achavam que a prisão era a continuidade, sem mudança, do mesmo confronto que havia lá fora e que, portanto, cabia aos presos gerar constantes fatos políticos para intensificar o atrito com as forças da repressão. Havia os que pensavam como nós - que a prisão mudava as condições da luta e que, por isso, devíamos evitar o confronto e aproveitar a situação para estudar, planejar, avaliar, refletir e fazer a autocrítica da política adotada e que levara a sérios reveses. E havia os que pensavam que ali era o fim da linha e que não havia mais nada a fazer, senão ficar quieto, esperando o momento de voltar à rua. Essas diferentes visões da situação geravam intermináveis discussões, ácidos confrontos, intensificando antipatias, gerando ódios pessoais e políticos. Em alguns momentos, todos se uniam contra a repressão, fosse ela representada pelas medidas emanadas das Auditorias de Guerra, fosse gerada pela banal estupidez dos nossos carcereiros. E, às vezes, chegávamos a envolver os presos comuns, que ocupavam o pavilhão II e que foram, com o tempo, transferidos para dar lugar à massa crescente de presos políticos” [FREIRE, 1997: 345] ${ }^{127}$.

Nesta passagem, Tapajós traça um panorama do debate político dos presos em São Paulo, vicissitudes com as quais a presente tese dialoga e, sob uma nova ótica, aprofunda. Neste sentido, a tese igualmente dialoga e complementa a abrangente pesquisa de Marcelo Ridenti, cuja análise crítica das esquerdas revolucionárias do período tornou-se paradigmática, sem que tenha se voltado especificamente para a experiência dos

\footnotetext{
${ }^{126}$ FrEIRE, 1997, p.36-7. Destaques meus.

${ }^{127}$ Para outras avalições ver: entrevista de Manoel Cyrillo de Oliveira Netto concedida à autora. SP, em 08/11/2008, 30/11/2008 e 27/01/2009; BETTO (2009); e POLITI, (2009).
} 
prisioneiros políticos e para a compreensão do debate político e suas lutas, a formação das redes de solidariedade e os desdobramentos relativos ao seu legado ${ }^{128}$.

O registro de Flávio Tavares (1999) marca o início de um novo período na produção de obras memorialistas, o qual toma como inspiração as demandas por memória da sociedade civil brasileira da década de 1990. Esta obra imprime tom alternativo à temática da vitimização, aproximando-se da complexidade dessas experiências-limite, conforme expressou ao final de seu livro:

"Fomos vítimas da ditadura sim, mas não só nós -, mas também eles, os construtores das vítimas. O batalhão triunfante nasceu com o medo. E, ao implantar o terror com ele aterrorizou-se também. A sala de torturas decidiu o triunfo e a derrota numa guerra que, praticamente, não chegou à guerra e que, assim, despojada de beligerância e inchada de violência e horror, selou nossa destruição, mas desfez, também, todos os valores e princípios de convivência.

Assim, a tortura destruiu os torturados e aniquilou, também, os torturadores ao transformá-los de combatentes militares em verdugos, tornando-lhes o mundo incompreensível ${ }^{129}$."

Assim como emerge da leitura do livro de memórias de Ottoni Fernandes Jr. militante da ALN, que permaneceu preso por 4 anos - a tônica da reconstrução das memórias do passado recente porventura adquire contornos idealizados, tal como na apresentação do livro, onde os guerrilheiros são chamados de “anjos rebeldes”:

"O fato concreto, que procurávamos desconhecer - confiantes na pureza e justiça de nossos ideais e cegos por um voluntarismo juvenil -, era que a economia brasileira crescia a taxas de $11 \%$ ao ano desde 1968 . A classe média, assustada com a repressão, deixava-se seduzir pelas delícias da sociedade de consumo e compunha um mercado consumidor de 10 milhões de pessoas que mantinha a economia funcionando a pleno vapor. Só vim a entender esse processo na cadeia.

A classe média, porém, pagava seu preço. Não existiam liberdade política, eleições livres, respeito aos direitos civis. Reclamava da censura à imprensa, mas no fundo aceitava esta anestesia que a poupava de conflitos morais.

[...] Tínhamos, na ponta de língua, uma boa justificativa para abandonar o trabalho político na universidade. O AI-5 fechou todas as portas para a ação política. Para que o movimento avançasse, era preciso derrubar a ditadura militar. Na prática, era uma racionalização. A história dos movimentos políticos mostrava que era possível manter a presença junto ao movimento popular, desde que com a linguagem correta, a forma de organização apropriada e propostas sensíveis aos ouvidos da maioria. Ainda havia espaço para manter hasteada a bandeira do ensino livre e gratuito, da melhoria da qualidade do ensino público, contra a perseguição aos alunos, professores e pelas liberdades democráticas.

Éramos anjos que queriam tomar o céu de assalto, descolados do mundo real, sem perceber o medo, o conflito da classe média, tentada pelas benesses do milagre

\footnotetext{
${ }^{128}$ O livro de memórias sobre o presídio Tiradentes [Freire, 1997], [BETtO; Politi, 2009] e [GoRENDER, 1998:230-31] abordam parte deste debate e histórias.

${ }^{129}$ V. TAVARES, 2009, p.264-5. Destaques meus.
} 
econômico, mas ainda aspirando a democracia.” [FERNANDES JÚNIOR, 2004: 31-2. Destaques meus.]

É de se considerar que a idealização da resistência e das esquerdas revolucionárias não é uma abordagem livre de ressalvas, dada a possibilidade de abolir algumas tintas relativas ao efetivo sentido do passado, da violência e, com ela, do terrorismo de Estado. As disputas políticas e as divergências mencionadas por Tapajós fornecem-nos um quadro das dificuldades para se tratar as memórias dos sobreviventes dos cárceres da ditadura. Estas aliam-se ainda às disputas pela memória no presente e aos desafios para a elaboração simbólica da experiência traumática vivida pelas milhares de pessoas que, durante este período, foram sequestradas, torturadas e aprisionadas.

Um número significativo de relatos, tais como emerge entre os que se encontram registrados nesta tese, centralizam suas narrativas no que aconteceu até a libertação da prisão ou até o retorno do exílio (logo após a anistia), em face do quê estabelecem paralelos entre a extensão e os limites da narrativa e da trajetória política delineada. Sob este mote, dir-se-ia que as continuidades ou mediações possíveis entre esse passado recente e o presente tornam-se frágeis, tênues ${ }^{130}$.

Essa fragilidade no que tange à continuidade nas narrativas e mediações entre passado e presente remete-nos à premissa de que a cultura da memória no Brasil desenvolveu-se predominantemente por meio do relato subjetivo em primeira pessoa, nos romances autobiográficos, livros de testemunho e filmes. Na medida em que esta observação faz-se válida, segue a existência de um número relativamente modesto de vias abertas à sistematização coletiva e social dessas memórias.

A construção democrática tem implicado uma série de ausências e silêncios nas narrativas históricas, os quais impõem-se sobre essas memórias - substrato fundamental para a compreensão das lutas contra a ditadura nos anos 1970 - de modo que se pode dizer que o silenciamento sobre a violência política e a elaboração simbólica a respeito desse período configuram processos ativos e não simples reflexos de um abandono.

\footnotetext{
${ }^{130}$ Para exemplos, ver: TAVARES, 1999; FERNANDES JR., 2004; VIANNA, 2003, entre outros.
} 


\section{Capítulo II}

\section{O sistema repressivo: dos centros de tortura e extermínio aos presídios políticos}

\section{Estado de exceção e ditadura}

O presente capítulo revisita reflexões acerca do sistema repressivo brasileiro durante a ditadura, desenvolvidas ao longo de algumas décadas de esforços voltados ao avanço do entendimento relativo à parte não visível da repressão e de suas relações com as estruturas institucionais. As sínteses e considerações alinhavadas visam compreender e inserir as narrativas dos testemunhos aqui compilados que, precisamente, lançam nova luz sobre o sistema repressivo.

Os ordenamentos jurídicos dos estados de exceção configuram zonas de indeterminação onde se destacam a suspensão dos direitos civis e políticos e o esvaziamento das prerrogativas institucionais - características estas cuja visada permite analisar e aprofundar os estudos sobre a extensão e os limites da legalidade constituída pela ditadura civil-militar brasileira.

$\mathrm{O}$ poder que instaurou a ditadura autoproclamou-se soberano. Invocando a Constituição de 1946, os ideólogos civis e militares do golpe de Estado de 1964 deitaram as bases de uma estrutura de poder que passou a dar um "significado jurídico a uma esfera de ação em si extrajurídica"131, típica de regimes de exceção, no sentido atribuído por Giorgio Agamben, o qual ressalta a suspensão da ordem jurídica como sua condição extrema. No limite, dir-se-ia que o estado de exceção não se constitui como um direito especial (por exemplo, o direito de guerra), mas como a própria suspensão do direito, que ocorre e transita na zona de indeterminação situada entre a lei e a situação de fato. Tal é o que se destaca do trecho inicial do Ato Institucional $\mathrm{n}^{\circ} 1$, editado pelo governo instaurado com o golpe de 1964:

“[...] A revolução se distingue de outros movimentos armados pelo fato de que nela se traduz, não o interesse e a vontade de um grupo, mas o interesse e a vontade da Nação.

A revolução vitoriosa se investe no exercício do Poder Constituinte. Este se manifesta pela eleição popular ou pela revolução. Esta é a forma mais expressiva e mais radical do Poder Constituinte. Assim, a revolução vitoriosa, como Poder Constituinte, se legitima por si mesma. Ela destitui o governo anterior e tem a capacidade de constituir o novo

${ }^{131}$ Agamben, Giorgio. Estado de exceção. São Paulo, Boitempo, 2004, p.24. 
governo. Nela se contém a força normativa, inerente ao Poder Constituinte. Ela edita normas jurídicas sem que nisto seja limitada pela normatividade anterior à sua vitória. Os Chefes da revolução vitoriosa, graças à ação das Forças Armadas e ao apoio inequívoco da Nação, representam o Povo e em seu nome exercem o Poder Constituinte, de que o Povo é o único titular.

[...] Os processos constitucionais não funcionaram para destituir o governo, que deliberadamente se dispunha a bolchevizar o País. Destituído pela revolução, só a esta cabe ditar as normas e os processos de constituição do novo governo e atribuir-lhe os poderes ou os instrumentos jurídicos que lhe assegurem o exercício do Poder no exclusivo interesse do País. Para demonstrar que não pretendemos radicalizar o processo revolucionário, decidimos manter a Constituição de 1946, limitando-nos a modificá-la, apenas, na parte relativa aos poderes do Presidente da República, a fim de que este possa cumprir a missão de restaurar no Brasil a ordem econômica e financeira e tomar as urgentes medidas destinadas a drenar o bolsão comunista, cuja purulência já se havia infiltrado não só na cúpula do governo como nas suas dependências administrativas. Para reduzir ainda mais os plenos poderes de que se acha investida a revolução vitoriosa, resolvemos, igualmente, manter o Congresso Nacional, com as reservas relativas aos seus poderes, constantes do presente Ato Institucional [...]"132.

Fazendo uso de um golpe de Estado e da força dos tanques nas ruas, os militares institucionalizaram a exceção, a tortura e o assassinato (mesmo que não constassem na norma explicitamente) com a extensão dos poderes do Executivo, partindo do próprio ordenamento, que contém em si a brecha do estado de sítio e de emergência. Esta extensão ocorreu, muitas vezes, no âmbito legislativo (bastante cerceado) por meio da promulgação de decretos, cassações de mandatos e disposições, mas principalmente como consequência da delegação contida nas normas ditas de “plenos poderes”, como os atos institucionais.

O corpo passou a ser o meio fundamental para a ação do regime e a câmara de tortura se configurou “como a exceção política originária na qual a vida exposta ao terrorismo de Estado foi incluída no ordenamento social e político” [TELES, 2007]. Este vínculo entre ditadura e exceção localiza o topos indecidível da exceção, a um tempo dentro e fora do ordenamento jurídico, tanto nas salas de tortura e campos de extermínio, quanto nas Auditorias da Justiça Militar e presídios, passando o desaparecimento forçado a caracterizar uma espécie de não-lugar absoluto.

Para melhor analisarmos esses aspectos recorremos ao breve histórico do estado de exceção feito por Giorgio Agamben. Desde a Primeira Guerra Mundial e mais enfaticamente a partir do desmoronamento das democracias europeias, entre 1934 e 1948, o nazismo foi “[...] entendido como a instauração, por meio do estado de exceção, de uma guerra civil legal que permite a eliminação física não só dos adversários políticos, mas

${ }^{132}$ V. Ato Institucional n ${ }^{\circ}$. 1, de 09/04/64, em <www.senado.gov.br/legislação>. Destaques meus. 
também de categorias inteiras de cidadãos que, por qualquer razão, pareçam não integráveis ao sistema político [...]” [AGAMBEN, 2008:17-8, 13].

Na República de Weimar, o artigo 48 da Constituição estabelecia plenos poderes (atribuição ao poder executivo de promulgar decretos com força de lei) ao presidente do Reich nas situações em que a "segurança pública e a ordem” estivessem ameaçadas. Logo que o poder foi entregue a Hitler, promulgou-se o Decreto para a proteção do povo e do Estado, no dia 28 de fevereiro de 1933, que suspendia os artigos da Constituição de Weimar relativos às liberdades individuais. $\mathrm{O}$ decreto não foi revogado durante todo $\mathrm{o}$ Terceiro Reich, de modo que pode ser considerado, de um ponto de vista jurídico, um estado de exceção que durou 12 anos [AGAMBEN, 2008:13].

O argumento utilizado para efetuar o golpe de Estado de 1964, supostamente deflagrado em defesa da democracia, nos remete ao conceito de “ditadura constitucional” de Carl Schmitt e nos lembra o acontecido na Alemanha de 1930. Sabe-se que, em julho daquele ano, o governo de Brüning não obteve maioria. Ao invés de apresentar seu pedido de demissão, este conseguiu do presidente Hindenburg o recurso ao artigo 48 e a dissolução do Reichstag (Parlamento). A partir desse momento, a Alemanha deixou de ser uma república parlamentar. Este estado de exceção foi justificado por Schmitt, no plano constitucional, a partir da ideia de que o presidente agia como "guardião da Constituição”. Como lembra Agamben, “[...] o fim da República de Weimar mostra, ao contrário e de modo claro, que uma “democracia protegida” não é uma democracia e que o paradigma da ditadura constitucional funciona como uma fase de transição que leva fatalmente à instauração de um regime totalitário” [AGAMBEN, 2008: 28-9]. Há uma tendência presente no Estado moderno de, progressivamente, substituir a declaração do estado de exceção por uma generalização do paradigma da segurança como técnica de governo [IDEM, IBIDEM].

Apesar de não termos vivenciado a implantação do totalitarismo, conhecemos outras formas de violência extrema, tais como aquelas perpetradas pela ação de grupos de extermínio (por exemplo, Esquadrões da Morte), que agiram pesadamente contra aqueles que foram considerados "não integráveis" ao status quo que se impunha, em consonância com o extermínio dos opositores da ditadura. 
Considerando a definição de alguns autores segundo a qual vivemos no Brasil um “autoritarismo crônico” ou "socialmente implantado"”33 é relevante avaliar a atuação da repressão política e judicial aos opositores da ditadura e seu significado à luz da teoria do estado de exceção. Nesse contexto, é possível constatar como as doutrinas militares contra-insurgentes assumiram grande importância no plano normativo, quando se tratou de defender a ordem interna, alegando supostos casos de crise. Essas doutrinas representaram figuras específicas da excepcionalidade, que adquiriram significado pela expressão jurídica poder de fato, em face da qual expressaram uma autonomização da autoridade militar, destacando o papel dos militares como intérpretes e reformadores das pautas jurídicas, que convencionaram a realidade normativa de exceção da violência do Estado $^{134}$.

Desde o fim do Estado Novo, uma série de intervenções militares indicava uma crescente influência militar na política do país, tal como no episódio do golpe "legalista" do General Lott, supostamente para proteger a Constituição e garantir a posse de Juscelino Kubitschek e seu vice, João Goulart, nos idos de $1955^{135}$. Proclamando-se intérpretes da Constituição e dos “limites da lei”, um dos momentos mais marcantes desse intervencionismo foi o veto militar à posse de Goulart e sua reversão com a Campanha da Legalidade, liderada por Leonel Brizola em 1961.

A ditadura civil-militar instaurada em 1964 representa um período de exceção cujos complexos desdobramentos ainda têm reflexos no presente, remetendo-nos ao questionamento das singularidades do enfrentamento entre Estado e oposição, do ponto

\footnotetext{
${ }^{133}$ De acordo com Juan Linz, os regimes autoritários burocrático-militares foram os mais difundidos no século XX e, também, no Brasil e Argentina. Neles reconhece a presença de uma fusão de oficiais e burocratas e o baixo grau de participação política da população; a ausência de uma ideologia e de um partido de massa; a tendência à existência de um partido único que restringiria a participação. Neles pode haver o pluralismo político, mas sem que se estabeleça uma disputa eleitoral livre. AQUINo, Maria Aparecida de. "Estado autoritário brasileiro pós-64: conceituação, abordagens historiográfica, ambiguidades, especificidades”. In: UFRJ, UFF, CPDOC, APERJ. 1964-2004. 40 anos do golpe. Ditadura militar e resistência no Brasil. Anais do Seminário. Rio de Janeiro, 7 Letras/Faperj, 2004, p.56 e 66.

${ }^{134}$ V. PÉRIÈs, Gabriel. "La doctrina militar contrainsurgente com fuente normativa de um poder de facto exterminador basado sobre la excepcionalidad”. In: FEIERSTEIn, Daniel (org.). Terrorismo de Estado y genocídio em América Latina. Bs. As./Argentina, Prometeu, 2009, p.221-22.

${ }_{135}$ Duas semanas depois da destituição de Carlos Luz foi decretado o Estado de Sítio, que durou dois meses, sendo este levantado apenas com a posse de Juscelino Kubitschek. Nesse período, o "poder moderador" de Lott se exerceu com base em medidas como a censura à chamada "imprensa comunista" etc. O artigo 176, da Constituição de 1946, dispunha que as Forças Armadas eram "constituídas essencialmente pelo Exército, Marinha e Aeronáutica, instituições nacionais permanentes, organizadas com base na hierarquia e na disciplina, sob a autoridade suprema do Presidente da República e dentro dos limites da lei." O dia 11/11/55 revelou serem os militares os principais intérpretes dos "limites da lei", o que foi se acentuando nos anos seguintes até o golpe de 1964. V. BENEVIDES, Maria Victoria. UDN e o Udenismo. Rio de Janeiro, Paz e Terra, 1981. Agradeço a André Sabóia a indicação desse aspecto anterior ao golpe de estado de 1964.
} 
de vista jurídico-normativo, e à influência dessa vicissitude no período da chamada “transição política”.

Para Agamben, a política nacional-socialista e, com ela, boa parte da política moderna, implica no desaparecimento da distinção entre os termos polícia e política: a polícia torna-se então política, e a tutela da vida coincide com a luta contra o inimigo. Seu objetivo era "[...] fortificar a saúde do conjunto do povo e eliminar as influências que prejudicam o desenvolvimento biológico da nação. [...] Somente nesta perspectiva adquire todo o seu sentido o extermínio dos hebreus, em que polícia e política, motivos eugenéticos e motivos ideológicos, tutela da saúde e luta contra o inimigo tornam-se absolutamente indiscerníveis.” [AGAMBEN, 2002: 154-55]. O que nos lembra os argumentos de defesa da "guerra suja” implementada pelos militares em 1964 como um ato cirúrgico para limpar a sociedade da ameaça comunista.

Esta posição coaduna-se com a de Hannah Arendt, que assinalou que o totalitarismo nazista configurou-se desde o domínio da burocracia administrativa e do despotismo, levando à necessidade de uma lei de exceção para que indivíduos de nacionalidades diferentes pudessem viver na Alemanha (em contraste com o domínio da lei que fundamentava os Estados-nações), de onde passaram a ser deportados e, subsequentemente, exterminados. Ao se referir ao totalitarismo, Arendt afirma:

\footnotetext{
"O terror, como o conhecemos hoje, ataca sem provocação preliminar, e suas vítimas são inocentes até mesmo do ponto de vista do perseguidor. Esse foi o caso da Alemanha nazista, quando a campanha de terror foi dirigida contra os judeus, isto é, contra pessoas cujas características comuns eram aleatórias e independentes da conduta individual específica [ARENDT, 2004: 308-9; 26].”
}

Hannah Arendt volta-se para o problema fundamental formulado a partir da análise de crimes como os praticados pela Alemanha nazista, crimes que se dirigem contra toda a humanidade e "[...] que são e só podem ser cometidos por uma lei criminosa e num Estado criminoso" [ARENDT, 2000: 284].

$\mathrm{Na}$ ditadura brasileira predominou a aplicação do terror aos grupos revolucionários, aos movimentos sociais e de oposição. O terrorismo de Estado foi utilizado principalmente para exterminar e reprimir oponentes, mas também como instrumento corriqueiro para intimidar e disciplinar as massas e torná-las obedientes, embora não tenha ocorrido a aplicação generalizada do terror a “vítimas inocentes”, principalmente, nos grandes centros urbanos. Tendo em vista esses objetivos, produziu-se 
no país uma legislação de exceção e uma grande estrutura administrativa e institucional, que possuía relativa eficiência.

Fortalecendo o diálogo que vem se alinhavando, Agambem destaca que: “À diversidade das tradições jurídicas corresponde, na doutrina, a divisão entre os que procuram inserir o estado de exceção no âmbito do ordenamento jurídico e aqueles que o consideram exterior a esse ordenamento, isto é, como um fenômeno essencialmente político ou, em todo caso, extrajurídico.” [AGAMBEN, 2004: 38]. Ele mesmo se pergunta: se é próprio do estado de exceção a suspensão (total ou parcial) do ordenamento jurídico, como poderá essa suspensão ser ainda compreendida na ordem legal? Como pode uma anomia ser inscrita na ordem jurídica? Permanece, assim, o problema da investigação a respeito da legalidade do estado de exceção em ditadura. [AGAMBEN, 2004: 38-40].

A questão da legalidade das ditaduras “[...] apresenta-se como a abertura de uma lacuna fictícia no ordenamento, com o objetivo de salvaguardar a existência da norma e sua aplicabilidade à situação normal. [...] É como se o direito contivesse uma fratura essencial entre o estabelecimento da norma e sua aplicação e que, em caso extremo, só pudesse ser preenchida pelo estado de exceção, ou seja, criando-se uma área onde essa aplicação é suspensa, mas onde a lei, enquanto tal, permanece em vigor.” [AGAMBEN, 2004: 48-9].

No caso brasileiro, essa lacuna fictícia incluída no ordenamento jurídico atinge a sua máxima expressão com a edição do AI-5, em dezembro de 1968. Esse decreto, sobrepondo-se à Constituição de 1967, dava poderes extraordinários ao presidente da República e suspendia várias garantias constitucionais. Essa lacuna fica evidente principalmente nos dois últimos artigos do decreto. Os artigos de $\mathrm{n}^{\text {os }} 10$ e 11 determinavam que todas as ações praticadas com base nesse ato institucional e seus agentes ficavam isentos de responsabilização civil ou penal. Conforme se pode ler no texto:

“[...] Art. 10 - Fica suspensa a garantia de habeas corpus, nos casos de crimes políticos, contra a segurança nacional, a ordem econômica e social e a economia popular.

Art. 11 - Excluem-se de qualquer apreciação judicial todos os atos praticados de acordo com este Ato institucional e seus Atos Complementares, bem como os respectivos efeitos. $[\ldots]^{\prime 36}$

\footnotetext{
${ }^{136} \mathrm{O}$ último artigo do AI-5, de $\mathrm{n}^{0}$. 12, determinava apenas que o ato entrava em vigor naquela data. V. Ato Institucional $n^{0}$. 5, de 13/12/68, em <www.senado.gov.br/legislação>.
} 
O ato repressivo autorizado pela legislação de exceção incluía em seu próprio texto a anistia e o "apagamento" dos efeitos das leis que regulam a punição a quaisquer crimes, desde que cometidos pelos agentes que atuassem em conformidade com o AI-5. O estado de exceção ficava autorizado a reprimir, de acordo com o seu ordenamento, cujo texto continha a sua própria suspensão [TELES, 2007: 49-50]. Com isso, legaliza-se a montagem de um aparato de repressão política, estruturado em torno dos DOI-Codis, Deops, da Justiça Militar e do sistema carcerário. Sua atuação foi combinada à da repressão clandestina exercida nos locais e campos de extermínio e desaparecimento forçado.

\section{As faces secretas e clandestinas da repressão política}

Durante a ditadura no Brasil, ao contrário do que ocorreu na Argentina (cujo "eixo da atividade repressiva deixou de girar ao redor dos cárceres para estruturar-se em torno do sistema de desaparição de pessoas”, levado a efeito nos campos de extermínio por instituições militares ${ }^{137}$ ), a utilização sistemática do desaparecimento forçado e dos assassinatos sob tortura conviveu com o sequestro e a prisão de milhares de pessoas em todo o país. A seletividade e a condução de diversas formas de repressão ao mesmo tempo mesclaram o uso da legalidade de exceção com atividades clandestinas, que funcionaram à margem da mesma, caracterizando a administração do poder e suas disputas no período. A cientista política Pilar Calveiro considera que a ditadura argentina se constituiu num "poder desaparecedor", 138 , ao passo que no Brasil, podemos dizer, predominou um “poder torturador” 139.

Na Argentina, a figura do desaparecido e sua contrapartida institucional, os campos de extermínio, representaram uma mudança fundamental - deixaram de ser uma das formas da repressão para se converter na modalidade repressiva do poder. Houve

\footnotetext{
${ }^{137}$ Calveiro estima que haja entre 15 mil e 20 mil desaparecidos políticos na Argentina, mas alerta para o risco de que, diante dessas cifras, a massificação deste fenômeno pode torná-lo uma questão de estatística e desumanizá-lo. V. CALVEIRO, Pilar. Poder y desaparición: los campos de concentración en Argentina, $1^{\text {a }}$. ed., $3^{a}$. reimp. Buenos Aires, Colihue, 2006, p.29-30. Tradução livre da autora.

${ }^{138}$ CALVEIRO, Pilar. Op.cit., p.13, 29-30. Calveiro é sobrevivente de campos de extermínio na Argentina Mansión Seré, Comisaría de Castelar, centro de Thames e ESMA (Escuela de Mecánica de la Armada) -, tendo permanecido mais tempo neste último, cerca de um ano.

${ }^{139}$ Expressão tomada emprestada de Jean Amèry, sobrevivente de campos de concentração nazistas, para quem "[...] a tortura não foi elemento acidental, senão a essência do III Reich", "[...] porque [...] se realizou precisamente nela em toda a sua plenitude”. V. AMÈRY, Jean. "La tortura”. In: Más allá de la culpa y la expiación. op.cit., p.85 e 93.
} 
uma reorganização de elementos já existentes e a incorporação de outros: os campos foram o quirófano onde empreenderam a operação cirúrgica, considerada necessária para salvar a sociedade da "subversão”, e o campo de prova de uma nova sociedade ordenada, controlada, aterrada [CALVEIRO, 2006: 27-8] ${ }^{140}$. "As Forças Armadas assumiram o disciplinamento da sociedade, para modelá-la à sua imagem e semelhança. Elas mesmas como corpo disciplinado, de maneira tão brutal como para internalizar, fazer carne, aquilo que imprimiriam sobre a sociedade" [CALVEIRO, 2006: 11]. No caso brasileiro, as referências à linguagem médica do AI-1, tais como as “[...] medidas destinadas a drenar o bolsão comunista, cuja purulência já se havia infiltrado não só na cúpula do governo como nas suas dependências administrativas”, nos remetem também a uma intervenção cirúrgica.

No Brasil, não houve uma simples continuação ou repetição aumentada de práticas antes vigentes, mas uma reorganização do Estado e do aparelho repressivo, que combinou o uso de diversas modalidades de repressão para estruturar-se. As Forças Armadas coordenaram e se envolveram efetivamente nesse aparato e assumiram o papel de polícia política. “[...] Pela primeira vez na história do Brasil as Forças Armadas envolviam-se profundamente na tortura a presos políticos e na execução de operações de repressão à população”, elas que tinham uma imagem “[...] até então associada ao seu papel institucional na defesa do país contra a agressão externa” [ALVES, 2005: 207]. Esse Estado ditatorial representou uma nova configuração, imprescindível para a institucionalização que se seguiu ${ }^{141}$.

Não foi mais do mesmo, nem um monstro engendrado na sociedade, como um corpo estranho a ela, mas um Estado estruturado para disseminar a disciplina e a obediência, eliminando o disfuncional, o incômodo e o conflitivo, que combinou velhas e novas formas de repressão política. Interessa-nos aqui tratar da relação entre as faces visível e invisível da repressão política, a qual foi adotando distintas características ao

\footnotetext{
${ }^{140} \mathrm{Na}$ Argentina, o uso do conceito de campo de concentração para definir os locais de extermínio dos desaparecidos políticos e as analogias com os campos nazistas circulavam desde a publicação da famosa carta-denúncia de Rodolfo Walsh, de 24/03/77, desaparecido desde então. A partir de 1983, a imprensa divulgou abertamente estas analogias antes mesmo das eleições presidenciais que marcaram o fim da ditadura. V. DuHALDE, Eduardo Luis. El Estado Terrorista Argentino. Barcelona: Editorial Argos Vergara, 1983. Nesse livro, Duhalde cita o Comisíon Argentina de Derechos Humanos: Informe del campo de concentración y Exterminio de "La Perla", Madrid, 1980. E ainda, KoutzII, Flávio. Pedaços de morte no coração. Um depoimento de um brasileiro que passou quatro anos no inferno das prisões políticas da Argentina. Porto Alegre, LPM, 1984, p.122-25; e GoRETTA, Nilda Actis e outros. Ese infierno. Buenos Aires, Altamira, 2006, p.283-96.

${ }^{141}$ Para uma análise das continuidades na administração do aparelho de Estado após a ditadura, ver BerCovici, Gilberto. "O Direito Constitucional Passa, o Direito Administrativo Permanece": Persistência da Estrutura Administrativa de 1967. In: SAFATLE, Vladimir e TeLES, Edson (orgs.). op.cit., p.77-90.
} 
longo da ditadura. E explorar suas características e modalidades específicas de controle e repressão para falar também da sociedade e do tempo histórico que o produziu.

O aparato repressivo brasileiro evoluiu para uma atuação centralizada e violenta optando pelo extermínio da liderança dos dissidentes políticos ou dos quadros da luta armada, impondo assim sucessivas derrotas às esquerdas revolucionárias. O número relativamente menor de vítimas fatais, se comparado ao dos demais países da América Latina, ocorreu sob um regime que utilizou a repressão clandestina e ilegal juntamente com aquela baseada na legalidade de exceção, com o objetivo de difundir o medo e legitimar a ditadura, oficializando a repressão por meio de processos na justiça militar ${ }^{142}$. Atuaram para a formação desse aparato a elaboração do projeto de estruturação de um sistema específico de repressão e informação anterior às grandes demonstrações de massa e às ações armadas de grande repercussão e também as motivações reativas a esse contexto [FICO, 2001: 63].

Até hoje não foi possível fazer um levantamento abrangente das vítimas da repressão política, mas sabe-se que somente nos primeiros meses após o golpe de 1964, cerca de 50 mil pessoas foram presas no país ${ }^{143}$. A maioria das vítimas da repressão estatal era sequestrada e torturada, mas uma parte muito menor foi processada pela justiça militar e uma menor ainda foi condenada e permaneceu nos cárceres ${ }^{144}$. Entre os condenados, recursos de presos políticos encaminhados ao STM (Superior Tribunal Militar) lograram obter a redução de penas daqueles enquadrados na Lei de Segurança Nacional $^{145}$.

Após a edição do AI-5, entre os anos de 1969 e 1971, o Estado constituiu uma rede de unidades secretas, institucionalizando a tortura e órgãos de segurança e informações "segundo parâmetros de extrema centralização e coerência"146. O SNI havia sido criado às claras, através de uma lei aprovada pelo Congresso Nacional em 13 de

\footnotetext{
${ }^{142}$ V. ALMEIDA (2009), no qual estão registrados 426 mortos e desaparecidos políticos.

${ }^{143}$ Alves, Maria Helena Moreira. op.cit., p.59. Segundo o Ministério da Justiça, 62 mil pedidos de anistia ou indenizações foram apresentados à Comissão de Anistia em função de perseguições políticas que prejudicaram a trajetória profissional de requerentes durante a ditadura. Desde sua criação, dos 38 mil casos julgados, 25 mil foram deferidos. Desses, 10 mil tiveram direito a reparação econômica. V. Comissão de Anistia em www.mj.gov.br. Acesso em: 05/12/2010.

${ }^{144}$ De acordo com a pesquisa do Projeto Brasil: Nunca Mais, os atingidos pela Justiça Militar somam 17.420 pessoas: 7.367 (42,3\%) denunciados, 6.395 (36,7\%) indiciados e $2.183(12,5 \%)$ testemunhas ou declarantes e 2.828 (38,3\%) foram condenados. Desses, 88\% são do sexo masculino e $12 \%$ mulheres. ARQUIDIOCESE de São Paulo. Perfil dos atingidos. op.cit., p.15-6 e RIDENTI, M. op.cit., 1993, p.122.

${ }^{145}$ Pereira, Anthony W. Sistemas judiciais e repressão política no Brasil, Chile e Argentina. In: SANTos, Cecília MacDowell; Teles, Edson; Teles, Janaina de A. (orgs.). Desarquivando a Ditadura: Memória e Justiça no Brasil. Vol. II, São Paulo, Hucitec, 2009, p.203-224.

${ }^{146}$ FICO, Carlos. Além do golpe: versões e controvérsias sobre 1964 e a ditadura militar. Rio de Janeiro, Record, 2004, p.76-91.
} 
junho de 1964, um parlamento, contudo, cerceado por cassações e pela legislação de exceção. A lei determinava que o SNI era "isento de quaisquer prescrições que determinem a publicação ou divulgação de sua organização, funcionamento e efetivos”"147. Antes, em 27 de abril, um decreto-lei havia instituído os Inquéritos Policiais Militares (IPM), que promoveram grande perseguição a diversos setores das oposições, em particular, militares, sindicalistas e estudantes ${ }^{148}$.

Em julho de 1970, porém, tendo em vista a segunda fase de institucionalização do regime promovida a partir do acirramento dos conflitos com as oposições, em 1968, e os enfrentamentos com a esquerda revolucionária por meio das ações armadas, o ministro do Exército, Orlando Geisel, definiu que o Exército assumiria o comando das atividades de segurança e, dois meses depois, criou os Destacamentos de Operações de InformaçõesCentros de Operações de Defesa Interna (DOI-Codi) [GASPARI, 2002: 176], de forma velada através de diretrizes administrativas. A eficácia comprovada da experiência piloto organizada em São Paulo, na Operação Bandeirante - criada em julho de 1969 -, onde atuaram em conjunto diversas forças policiais e serviços de informação militares coordenados pelo Exército, deu origem a esse formato da estrutura repressiva.

A aplicação seletiva do poder coercitivo sobre a sociedade civil visando a legitimidade e a institucionalização da ditadura fica evidente ao observarmos a quantidade relativamente menor de oposicionistas assassinados, se a compararmos com outros países latino-americanos ${ }^{149}$. Na condução da repressão política prevaleceu a centralização e a hierarquia militar, ainda que, no princípio, entre os anos 1964 e 1968, ela tenha sido conduzida de forma incipiente e assistemática. A diversidade de grupos militares existentes não sustentava a clássica divisão entre "linha dura” e “moderados”, mas implicava uma dinâmica de disputas acirradas na condução do poder ${ }^{150}$.

O projeto de repressão e controle, no Brasil, supôs uma complexa estrutura, que incluía a espionagem e a polícia política, mas também a censura e uma sofisticada

\footnotetext{
147 Cf. o $2^{\circ}$. par. do art. $4^{\circ}$, da lei no. 4.341. V. SouZA, Percival. Autópsia do medo. São Paulo, Globo, 2000, p.466-69.

148 CoUTO, Ronaldo Costa. História indiscreta da ditadura e da abertura. Brasil: 1964-1985. Rio de Janeiro, Record, 1998, p.67.

${ }^{149}$ V. AlmeIDA, 2009. Maria H. M. Alves sugere que a esquerda tinha cerca de 6.000 militantes. Pode-se pensar na hipótese de que o número de 426 mortos e desaparecidos políticos apurados até o momento represente cerca de $10 \%$ da esquerda revolucionária daquele período, mas há consenso de que é muito difícil estabelecer a quantidade de militantes que atuaram durante a ditadura.

${ }^{150}$ MARTINS FILHO, João Roberto. “A ditadura revisitada: unidade ou desunião?”, em UFRJ, UFF, CPDOC e APERJ. 1964-2004. 40 anos do golpe. Ditadura militar e resistência no Brasil. Rio de Janeiro, 7 letras, 2004, p.114.
} 
propaganda política ${ }^{151}$. Enquanto os órgãos de informação foram criados através de leis, decretos e outros diplomas ostensivos [FICO, 2004: 82], o sistema DOI-Codi, voltado somente para a repressão política, tinha origem em diretrizes secretas do Conselho de Segurança Nacional e de autoridades designadas pelo presidente da República.

Aliada a essa estrutura estava a face mais visível da repressão sustentada na legalidade de exceção, composta pelos DEOPS, existentes desde os anos 1920; pela Justiça Militar, com competência para processar e julgar os enquadrados na LSN desde 1965; os IMLs e cemitérios públicos e os presídios. O sistema carcerário já existente foi reutilizado para punir, separar e isolar os dissidentes. O uso sistemático de valas clandestinas em cemitérios públicos de São Paulo, Rio de Janeiro e Pernambuco desmentem as hipóteses de "autonomia" e de "excessos” dos setores ligados às práticas de tortura [TELES, 2005]. Não houve um processo de autonomização dos órgãos de segurança, pois a independência operacional com que trabalhavam não se confundia com a sua suposta autonomia em relação ao oficialato [FICO, 2004: 83]. Tal como a instituição do sistema dos DOI-Codis, a censura política à imprensa foi implantada através de diretrizes sigilosas, escritas ou não, ao contrário da censura moral e de costumes, que utilizava a legalidade de exceção mas era assumida abertamente [FICO, 2004: 89-91].

Esse panorama alinha-se à máxima de que o poder esconde-se e revela-se naquilo que exibe e oculta, como assinala Pilar Calveiro (2006). Exibe-se sempre uma parte, a que aparece como sistema penal, no exercício supostamente legítimo da violência, mas esconde outra parte, aquela considerada "vergonhosa”. Entre essas esferas se manifestam aspectos aparentemente incompatíveis e surgem diversas conexões. A necessidade da difusão da "cultura do medo" direcionou o estabelecimento de critérios para a ocultação ou divulgação das notícias sobre a tortura, os mortos e os desaparecidos políticos. Como apontou Maria Helena M. Alves, a tortura garantiu, em larga medida, a eficiência não somente como método de interrogatório, mas como forma de controle político. A censura e o domínio exercido sobre as instituições culturais como universidades, cinemas, teatro, TV e jornais impuseram o silêncio e estimularam a autocensura, difundiram a sensação de isolamento e descrença e foram fortes elementos dissuasivos da constestação [ALVES, 1985:169].

As mudanças no aparato repressivo ocorreram de maneira gradual durante os anos 1960, mas uma inflexão substancial de estratégia da repressão política se deu após a

${ }^{151}$ FICO, Carlos. Reinventando o otimismo. Rio de Janeiro, FGV, 1997. 
edição do AI-5, quando se iniciou a segunda fase de institucionalização da ditadura. A utilização sistemática do desaparecimento forçado, iniciada em 1971, representou uma importante modificação com o objetivo de encobrir seus crimes, auxiliada pelas operações de infiltração de agentes policiais, os chamados “cachorros”. As mortes, às claras, de alguns e o desaparecimento de outros eram parte de uma política global, cuja intenção era ocultar a realidade da tortura institucionalizada do regime e, ao mesmo tempo, forjar casos exemplares e uma permanente ameaça a todos [TELES, 2005].

As execuções sumárias de prisioneiros e criminosos comuns era uma prática usual no Brasil, principalmente, após o surgimento dos Esquadrões da Morte no final dos anos 1950, e eram realizadas abertamente. Os primeiros esquadrões da morte surgiram no Rio de Janeiro. Em 1958, o chefe de polícia general Amauri Kruel criou um grupo especial na polícia destinado a combater a “criminalidade”. O delegado do Serviço de Vigilância, Cecil Borer, criou o Serviço de Diligências Especiais com liberdade para empregar quaisquer métodos. Assim, surgiram os esquadrões. Não simulavam falsos tiroteios. Eles assinavam seus crimes deixando junto ao cadáver um cartaz com o seu símbolo, o desenho de uma caveira sobre duas tíbias. Sua origem vinha de uma estrutura legal, mas atuavam na zona de indistinção entre o legal e a "situação de fato" própria dos estados de exceção, formando grupos paramilitares. Para a opinião pública, o esquadrão era sinônimo de execução, “justiçamento” e punição exemplar. E parte dela apoiava sua atuação $^{152}$.

Um dos mais célebres esquadrões da morte foi o comandado pelo delegado do DEOPS/SP Sérgio Paranhos Fleury, que se destacou após o golpe de 1964. Em São Paulo, os presos políticos com frequência viam estampadas nos jornais fotos de presos correcionais (chamados de “corrós”) mortos pelo Esquadrão e que, no dia anterior, circulavam pelo Presídio Tiradentes, cuidando da faxina ou da entrega de alimentos. No início dos anos 1970, seus agentes enfrentaram dificuldades para agir devido à atuação de Hélio Bicudo, do Ministério Público Estadual de São Paulo. A ação impetrada na justiça civil contra o delegado Fleury chegou ao STF em março de 1971, um dos 4 processos movidos contra o esquadrão, encaminhados por procuradores do Ministério da Justiça ${ }^{153}$.

\footnotetext{
${ }^{152}$ SouZA, Percival de. Autópsia do medo. Vida e morte do delegado Sérgio Paranhos Fleury. São Paulo, Globo, 2000.

${ }^{153}$ BETTO, Frei. Diário de Fernando nos cárceres da ditadura militar. São Paulo, Rocco, 2009, p.47. V. PEREIRA, Anthony W. Ditadura e Repressão: O autoritarismo e o estado de direito no Brasil, no Chile e na Argentina. São Paulo, Paz e Terra, 2010, p.141.
} 
Em 1974, ano da posse do general-presidente Ernesto Geisel, 53 militantes políticos desapareceram e sabe-se do registro de apenas um "morto oficial”"154. Desse modo, garantia-se a representação de moderado a Geisel e ao seu governo, a forma encontrada para lidar com os problemas de legitimidade enfrentados pela ditadura relacionados com o declínio do "milagre econômico" e o aumento das denúncias sobre os abusos aos direitos humanos, dentro e fora do país. Geisel, porém, tinha como objetivo emitir sinais claros de que eliminaria qualquer ameaça à realização da transição política controlada. Assim, continuaram, em menor escala, as simulações de suicídios e mortes em tiroteio. A vitória do MDB nas eleições de 1974, no entanto, colocava em xeque as possibilidades dos militares de controlarem esse processo [TELES, 2005].

No período em que transcorreu a repressão à Guerrilha do Araguaia, especialmente a partir de 1973, intensificou-se a eliminação dos dissidentes, mas de modo velado, desaparecendo com os que faziam oposição aberta ao regime, eliminando-os, "sem deixar vestígios". Naquele momento, tanto quanto nas cidades, não interessava divulgar a existência de uma guerrilha patrocinada por comunistas no sudeste do Pará. Apenas em 1993 as Forças Armadas reconheceram oficialmente sua existência.

\subsection{Eliminar, "sem deixar vestígios"}

Em outro trabalho ${ }^{155}$ tratamos do documento encontrado entre os pertences do general Antônio Bandeira, que comandou as Forças Armadas até o fim da II Campanha contra a Guerrilha do Araguaia (1972-1974). Bandeira participou de uma reunião com os generais Ernesto e Orlando Geisel, Milton Tavares e o então presidente da República, general Emílio G. Médici, cujo conteúdo registrou em ata. A reunião ocorreu em maio de 1973, quando se discutiu as diretrizes da repressão política, descritas no documento, cujo objetivo principal era “[...] a utilização de todos os meios para eliminar, sem deixar vestígios, as guerrilhas rurais e urbanas, de qualquer jeito, a qualquer preço”156.

De acordo com reportagem da revista IstoÉ, foram constituídos dois grupos secretos - um no CIE (Centro de Informações do Exército) de Brasília e outro no DOI-CODI de

\footnotetext{
154 Seu nome era Afonso Henrique Martins Saldanha, militante do PCB que morreu em 08/12/74 em decorrência das torturas sofridas, depois de libertado. Frei Tito se suicidou em 07/08/74, no exílio, atormentado pelas torturas do delegado Sérgio P. Fleury. Cf. ALMEIDA, 2009, p. 591-92 e 600.

155 TELES, Janaina de A. Os familiares de mortos e desaparecidos políticos e a luta por "verdade e justiça" no Brasil. In: SAFatLe e Teles (2010). V. tb. em AlmeIDA, 2009.

${ }^{156}$ RiBeIRo JR., Amaury. “A ordem é matar”, IstoÉ, São Paulo, 24/03/2004.
} 
São Paulo. Eles estavam autorizados a assassinar e sumir com os corpos de dissidentes e teriam sido responsáveis pelo desaparecimento de cerca de oitenta presos políticos entre 1973 e 1975. Em depoimento cedido à IstoÉ, um general que não quis se identificar e atuou na área de informações, ligado ao ex-presidente Geisel, explicou: “em 1973 concluímos que ou a gente matava todo mundo ou essas guerrilhas nunca mais teriam fim”. De fato, em 1973, verificou-se um significativo aumento na quantidade de desaparecidos políticos no país ${ }^{157}$.

O ex-sargento do DOI-CODI/SP, Marival Dias Chaves do Canto, em entrevista publicada na reportagem “Os matadores”, na mesma edição de 24 de março de 2004 de Isto $E^{158}$, divulgou os nomes de alguns dos envolvidos no extermínio: os coronéis do Exército Paulo Malhães, José Brant Teixeira e Audir Santos Maciel, além dos ex-cabos Félix Freire Dias e José Bonifácio Carvalho.

De acordo com a revista, o CIE (Brasília) se encarregou do serviço de informação e repressão à Guerrilha do Araguaia e dos militantes perseguidos no Cone Sul da América Latina. Os responsáveis por estas ações do CIE foram os coronéis Paulo Malhães (“Dr. Pablo”) e José Brant Teixeira (“Dr. César”). O grupo do DOI-Codi/SP deveria exterminar os militantes do PCdoB e o Comitê Central do PCB, que permaneciam nos centros urbanos do país.

A importância do documento e dos testemunhos citados é inegável, pois confirmam a intenção deliberada da cúpula das Forças Armadas e da ditadura de eliminar aqueles considerados “irrecuperáveis” sem chamar a atenção da sociedade. A ata dessa reunião documenta um momento preciso em que os militares brasileiros - ao mesmo tempo em que se organizavam de forma centralizada e secreta, prendendo milhares de militantes e utilizando a Justiça Militar para condená-los por supostos crimes cometidos contra a segurança nacional - optam por uma política de desaparecimento seletivo dos dissidentes $^{159}$.

Com o fortalecimento do aparato repressivo empreendido após a edição do AI-5, a repressão implementou o controle político, desenvolvendo “programas de pacificação” e

\footnotetext{
157 Num total de 73 militantes assassinados, 38 deles se tornaram desaparecidos e 35 compuseram a estatística dos chamados "mortos oficiais". Em contrapartida, no ano anterior, num total de 68 dissidentes políticos assassinados, 44 foram mortos e 24 desapareceram. E no ano seguinte, conforme mencionado, há o registro de 53 desaparecidos políticos e apenas um morto [ALMEIDA, 2009].

${ }^{158}$ RiBeIRo JR., Amaury. “Os matadores”, IstoÉ, São Paulo, 24/03/2004.

${ }^{159}$ Caso venha a ser divulgada a cópia fac-símile desse documento na íntegra, ficaria patente a opção pela cúpula do regime militar por uma política de extermínio das dissidências, homóloga em certa medida à decisão pela "Solução Final", o extermínio dos judeus nas câmaras de gás, estabelecida na reunião de Wansee, em 1942, na Alemanha nazista.
} 
blitz [ALVES, 2005: 193-94] e implantando uma vasta rede secreta articulada a setores clandestinos, controlada por militares e os serviços de informação, que juntamente com as polícias civil, militar e federal desempenhavam funções de polícia política e de defesa interna.

Os “programas de pacificação” eram operações de ocupação de uma determinada área para realizar a busca e detenção em larga escala da população desarmada, na forma de blitz. Essas práticas persistiram principalmente entre 1969 e 1974, quando levantavam barricadas e procediam à busca de carros e casas. As pessoas sem documentação eram consideradas suspeitas e, frequentemente, essas operações resultavam em detenções em massa, espancamentos e intimidação generalizada. Apesar da censura, os jornais noticiaram, por exemplo, que em 16 de junho de 1969, no final de semana que antecedeu a visita de Nelson Rockefeller ao Brasil, cerca de 6 mil pessoas foram "preventivamente detidas” no Rio de Janeiro. Uma blitz nacional chamada “Operação Gaiola” foi realizada dias antes das eleições de 1970 para o Congresso, quando 10 mil pessoas foram detidas, muitas das quais eram candidatas pelo MDB [ALVES, 2005].

Operações em grandes proporções foram realizadas também em regiões rurais. Tal é o caso da repressão ao campo de treinamento de guerrilha da Vanguarda Popular Revolucionária (VPR), no Vale do Ribeira (SP), quando nove guerrilheiros foram cercados por cerca de 10 mil soldados. A maior operação de repressão em larga escala à população rural, porém, deu-se durante a Guerrilha do Araguaia (1972-1974) [ALVEs, 2005: 194].

A área onde ocorreu a guerrilha compreendia uma região de cerca de $30 \mathrm{mil} \mathrm{Km}^{2}$, localizada entre as cidades de Marabá e o vilarejo de São Geraldo, ao sul do Pará. Uma área equivalente ao território da Bélgica ${ }^{160}$. A preparação da guerrilha consistia em formar três destacamentos designados pelas letras A, B e C, subdivididos em três grupos cada um. Buscaram a aproximação com a população local exercendo um trabalho político discreto, em especial porque a maioria dos guerrilheiros deslocados para a região estava sendo perseguida nos grandes centros urbanos ${ }^{161}$.

\footnotetext{
${ }^{160}$ V. Relatório Parcial da Investigação sobre a Guerrilha do Araguaia, MPF, jan. /2002. Estima-se que cerca de 100 mil famílias indígenas e camponesas viviam nessa região. O governo tinha a intenção de removê-los da área, aplicando a técnica dos militares americanos usada no Vietnã - substituir a população de uma área para mantê-la sob controle, ver: ALVES, 2005, p.197, nota 34. O jornalista Elio Gaspari calcula que havia vinte mil habitantes na região e, possivelmente, cinco mil pessoas vivendo efetivamente na área onde se deu a guerrilha. Velho, Otávio Guilherme. Frentes de expansão e estrutura agrária. apud GASPARI, Elio. A ditadura escancarada. op.cit., p.437 e 407.

${ }^{161} \mathrm{O}$ destacamento A se organizou na região de São Domingos, próxima à cidade de Marabá (PA). O destacamento B se instalou entre Santa Isabel e Palestina, mais próximos de São Geraldo (PA). Mais ao sul
} 
Os primeiros guerrilheiros do Partido Comunista do Brasil (PC do B) chegaram ao sudeste do Pará e proximidades, entre 1966 e 1967, procurando locais para iniciar a fase de preparação do projeto de "guerra popular prolongada", inspirado na Revolução Chinesa. A maioria dos guerrilheiros, porém, chegou a partir de 1969, depois da edição do AI-5 e o início do recrudescimento da repressão política. O declínio da Guerrilha do Araguaia ocorreu a partir de outubro de 1973, quando se iniciou a ofensiva coordenada pelo CIE, depois do término do levantamento feito na região por diversas operações de informação ao longo de um ano.

\subsection{Conceituação e antecedentes dos campos de concentração no Brasil}

Uma questão importante e recorrente em relação à Guerrilha do Araguaia diz respeito à extensão e aos limites da possibilidade de se referir ao conceito de campo de concentração para o desenvolvimento de reflexão acerca da natureza da repressão na região. Desde o ano de 1980, quando se deu a primeira caravana de familiares à região da guerrilha, militantes dos direitos humanos e familiares associaram aquilo que observaram e os relatos coletados com características típicas de campos de concentração [TELES, 2005].

Neste sentido, a repressão política organizada durante a ditadura não introduziu por tal atividade, um fato novo, mas antes reproduziu uma prática recorrente ao longo da primeira metade do século XX. No Brasil, os campos foram utilizados no século passado em diversas formas e modalidades de confinamento de militares e civis.

Os campos foram utilizados contra os que participaram da Revolta da Vacina, em 1904, das greves da década de 1910 e das revoltas tenentistas dos anos 1920. Na Primeira República, desde 1922, o país esteve sob a vigência do estado de sítio em largos períodos e eram afastados da sociedade os considerados "indesejáveis" ou que promoviam “ameaça” à ordem estabelecida. Dessa forma, internaram dissidentes e revoltosos, mas também proletários, pobres e "vadios" que eram punidos com o desterro ou enviados a campos de concentração ${ }^{162}$.

organizou-se o destacamento C, próximo a Pau Preto (PA). Em 1972, os destacamentos contavam com 73 combatentes mal equipados e mal armados. V. AlmEIDA, (2009).

${ }^{162}$ Pinheiro, Paulo Sérgio. Estratégias da ilusão: a revolução mundial e o Brasil (1922-1935). São Paulo, Companhia das Letras, 1991, p.13-4. 
Durante a ditadura de Getúlio Vargas, o Estado Novo, dissidentes passaram a ser julgados pela justiça militar, e os internamentos e desterros “[...] atingiram em larga proporção cidadãos sem responsabilidade nas revoltas que motivaram o estado de sítio, e sem culpa formada”. A política de repressão à dissidência armada de 1935 tinha também como um dos seus objetivos principais atingir os pobres do Rio de Janeiro e São Paulo [Pinheiro, 1991: 104]. A partir de 1942, quando Getúlio Vargas passou a apoiar os “aliados” na II Guerra Mundial, os campos foram então utilizados para aprisionar alemães, italianos e japoneses, os chamados "súditos do eixo",163.

Pesquisas recentes indicam que o uso de campos de concentração ocorreu em outros lugares, durante a ditadura. Pelo menos foi o que aconteceu em Itaqui (RS) em 1964. Entre os dias 31 de março e 6 de agosto o hangar do aeroclube da cidade foi cercado por arame-farpado eletrificado, onde ficaram presos sob a vigilância de militares o prefeito e o vice-prefeito, vereadores e seus suplentes, líderes camponeses e estudantis, sindicalistas, médicos e advogados. O tenente-coronel Caetano Pinto Rocha, comandante da Guarnição do I Regimento de Cavalaria, ordenou a prisão de cerca de 40 pessoas, encarceradas por 111 dias, sob a acusação de cometerem "crimes contra o Estado e seu patrimônio, contra a ordem política e social, bem como efetuarem atos de guerra revolucionária”164.

Um interventor, o fazendeiro Júlio Santiago, assumiu o lugar do prefeito. A nova Câmara de Vereadores remeteu ofício ao comandante da guarnição e propôs a cassação dos mandatos dos prisioneiros. Em ofício de 17 de abril de 1964, dirigido ao presidente do IPM, a Câmara de Vereadores rotulou os prisioneiros de "verdadeiros filhos do diabo", determinados a levar a cabo um "plano diabólico", um "processo de comunização do país” [SILVA, 2011].

Houve desespero e tentativa de suicídio no campo e alguns permaneceram mais de 40 dias sem acusação formal. Por fim, as acusações que pesaram sobre eles foram: apoiar a reforma agrária na fazenda chamada de Mata-Fome; pertencer ao PTB; lançar um manifesto propondo uma "frente de mobilização popular" em apoio às "reformas de base" do presidente João Goulart [idem, ibidem].

\footnotetext{
163 Perazzo, Priscila Ferreira. Prisioneiros de guerra. Os "súditos do eixo" nos campos de concentração brasileiros (1942-1945). São Paulo, Humanitas-Imesp, 2009, p.33.

${ }^{164}$ SILVA, Juremir Machado da. "Campos de concentração em Itaqui (RS)”. Correio do Povo. Porto Alegre (RS), 209, 27/04/2011; e TeIXEIRA, Iberê Athaide. Nuvens de Chumbo sobre o Cambaí - a Queda de João Goulart, um Campo de Prisioneiros em Itaqui. Porto Alegre, Martins Livreiro, 2009.
} 
A definição de campo de concentração e seu histórico permitem uma melhor compreensão de como essa prática foi utilizada durante a Guerrilha do Araguaia, onde o conceito se aplica de maneira mais precisa e abrangente. $\mathrm{O}$ conceito de campo surgiu no final do século XIX. A proposta era a de internar civis considerados “indesejáveis” na Guerra dos Bôeres (1899-1902), quando os ingleses encarceraram os africaners, descendentes de europeus, em campos de concentração na África do Sul. Nesse momento, pela primeira vez foi adotada essa prática em moldes “industriais”, com a justificativa de manter sob "custódia protetora” suspeitos, cujas ofensas não podiam ser provadas e que não podiam ser condenados pelo processo legal comum. Presidiam esses confinamentos os motivos utilitários e os interesses dos governantes, conforme observou Hannah Arendt [ARENDT, 1989: 490-1].

Historiadores debatem se os primeiros campos de concentração surgiram na África do Sul ou em Cuba, quando em 1896 os espanhóis os criaram para reprimir a insurreição da colônia. Em ambos os casos, trata-se da instalação de um estado de exceção numa guerra colonial. A base jurídica desse internamento não vinha do direito comum, mas da Schutzhaft, uma medida policial preventiva, com origem no estado de sítio prussiano de 1871 [AGAMBEN, 2002: 173].

De acordo com Giorgio Agamben, os campos de concentração não nasceram do direito ordinário ou do desenvolvimento do direito carcerário, mas de uma combinação dos preceitos do estado de exceção e da lei marcial. O campo é “[...] o espaço que se abre quando o estado de exceção começa a tornar-se a regra” [AGAMBEN, 2002:173-6]. Os primeiros campos da Alemanha foram obra dos governos socialdemocratas em 1923 quando, após a proclamação do estado de exceção, internaram milhares de comunistas, e criaram também um campo para estrangeiros, em Cottbus-Sielow, para refugiados judeus orientais. De 1919 a 1923, os governos de Weimar proclamaram várias vezes o estado de exceção, mas quando os nazistas assumiram o poder, em fevereiro de 1933, os direitos fundamentais da Constituição foram suspensos por tempo indeterminado. Em seguida, em março de 1933, Himmler criou um campo de concentração para presos políticos fora das regras do direito, em Dachau [AGAMBEN, 2002:173-6].

O soberano ou o poder executivo decidem sobre a exceção, geralmente temporária e em nome de uma situação artificial de perigo como a alegação de risco à segurança nacional, e acabam por produzir uma situação de fato. O campo de concentração se constitui em um espaço de exceção, ao mesmo tempo fora e dentro do ordenamento 
jurídico, um híbrido situado entre o direito e a situação de fato, no qual os dois termos tornam-se "indiscerníveis" e "onde tudo é possível”"

A produção do direito e sua aplicação deixaram de ser momentos distinguíveis. O conceito nacional-socialista de raça, com sua peculiar imprecisão e inconsistência, tornou-se ao mesmo tempo normatização e execução. O estado de exceção, portanto, é a “[...] aposta na decisão política soberana, que opera na absoluta indiferenciação de fato e direito” [AgAmBEN, 2002: 178-9]. “A essência do campo consiste na materialização do estado de exceção e na criação de um espaço em que a vida nua [a vida puramente biológica] e a norma entram num limiar de indistinção [...]” [AGAMBEN, 2002: 180]. O habitante do campo "movia-se em uma zona de indistinção entre externo e interno, exceção e regra, lícito e ilícito, na qual os próprios conceitos de direito subjetivo e de proteção jurídica não faziam mais sentido [...]” [AGAMBEN, 2002: 177]. Ele era despojado de seu estatuto político, reduzido à vida biológica e privado de suas prerrogativas humanas.

Essa análise do estado de exceção nazista coloca em evidência certas semelhanças com a figura imprecisa do "inimigo interno" da Doutrina de Segurança Nacional. A indistinção existente entre a normatização feita por meio da edição dos Atos Institucionais, os decretos-lei e o fato, a institucionalização da violência da tortura. O uso generalizado da tortura confundindo-se com a edição do AI-5, por tempo indeterminado, e a suspensão do habeas corpus - a aplicação da norma se tornou "a sua própria produção”. O que gerou atrocidades como a repressão à Guerrilha do Araguaia, com o extermínio e desaparecimento dos guerrilheiros e a repressão generalizada à população local aprisionada nos campos de concentração, onde foram privados de seus direitos fundamentais, de seu estatuto político e desumanizados.

O campo de concentração, normalmente, é considerado como um espaço aberto, mas delimitado para vigiar, onde ficam reclusas pessoas que, por algum motivo, devem ser isoladas. A prática de internar pessoas, civis ou militares, que foi relativamente comum na primeira metade do século XX, e depois da II Guerra Mundial ficou associada aos campos nazistas, em especial, aos campos de extermínio como Auschwitz, que se constituíram em uma “desvairada fabricação em massa de cadáveres [...] precedida pela preparação, histórica e politicamente inteligível, de cadáveres vivos” [ARENDT, 1989: 498].

\footnotetext{
${ }^{165}$ Expressão que Arendt retirou da frase de David Rousset: “Os homens normais não sabem que tudo é possível” [ARENDT, 1989: 337, 491].
} 
Hannah Arendt classificou os campos em três categorias, correspondentes às “concepções ocidentais de uma vida após a morte”: Limbo, Purgatório e Inferno. “Ao Limbo correspondem aquelas formas relativamente benignas, que já foram populares mesmo em países não-totalitários, destinadas a afastar da sociedade todo tipo de elementos indesejáveis - os refugiados, os apátridas, os marginais e os desempregados -; os campos de pessoas deslocadas, por exemplo, que continuaram a existir mesmo depois da guerra, nada mais são do que os campos para os que se tornaram supérfluos e inoportunos. O Purgatório é representado pelos campos de trabalho da União Soviética, onde o abandono alia-se ao trabalho forçado e desordenado. O Inferno, no sentido mais literal, é representado por aquele tipo de campo que os nazistas aperfeiçoaram e onde toda a vida era organizada, completa e sistematicamente, de modo a causar o maior tormento possível” [ARENDT, 1989: 498; 496].

Importa, neste momento, a análise das características e especificidades de confinamento existente nos campos de concentração utilizados durante a repressão à Guerrilha do Araguaia, verificar as semelhanças e diferenças dessa experiência histórica em relação aos demais períodos repressivos em que se fez uso de campos no Brasil por meio da análise e classificação acima descritas.

\subsection{A destruição da guerrilha do Araguaia:}

\section{das operações de inteligência aos campos de concentração e extermínio}

Transportada a discussão acerca do caráter oportuno do uso do conceito de campo de concentração para se referir à repressão à Guerrilha do Araguaia, destaca-se o fato de que as operações de combate aos guerrilheiros assumiram grandes proporções, tanto em função da vastidão da área em que transcorreram, como pelo efetivo humano e material empregado. Nessa região, organizaram-se quatro principais bases militares que, entre outras funções, foram amplamente utilizadas como campos de concentração.

Essas bases militares apenas começaram a operar como campos em um segundo momento, sendo que até outubro de 1973 as mesmas deram lugar a operações de inteligência (coleta de informações), coordenadas pelo exército.

Desde o início, diversas operações de informação foram organizadas na região onde atuaram muitos agentes experientes, conforme revelaram alguns testemunhos de oficiais que as chefiaram e documentos militares anonimamente divulgados. Desde 1969, 
o exército fazia levantamento de informação na região ${ }^{166}$. Em novembro de 1970 , as Forças Armadas realizaram manobras conjuntas de contraguerrilha na região que compreendia o sudeste do Pará, o noroeste de Goiás (hoje, Tocantins) e o sudoeste do Maranhão, batizada de Operação Carajás. O objetivo era inibir a presença de militantes de agrupamentos de esquerda e buscar mais informações. Nessa operação utilizaram grande aparato militar, inclusive bombas napalm, helicópteros e paraquedistas, deixando a população bastante amedrontada [MoRAIS; SILVA, 2005: 23].

Em agosto de 1971, homens da $11^{\text {a }}$ Região Militar do Comando Militar do Planalto, comandado pelo general Antônio Bandeira de Melo, e do CIE realizaram a Operação Mesopotâmia em cidades próximas à região onde se iniciaria em 1972 o combate à Guerrilha do Araguaia. Dirigiram-se às cidades de Marabá (PA), Imperatriz, Tocantinópolis (MA) e Porto Franco (TO) onde prenderam 31 militantes e simpatizantes dos agrupamentos VAR-Palmares (Vanguarda Armada Revolucionária-Palmares) e PRT (Partido Revolucionário dos Trabalhadores), localizados próximos a Imperatriz, destinados a treinamentos de guerrilha e a servir como base de apoio da VAR-Palmares. Foram todos desarticulados. Antes, porém, em março teve início a Operação Macedônia que fez na região o levantamento de informações necessário para realizar essas prisões ${ }^{167}$.

As Forças Armadas brasileiras iniciaram a fase de enfrentamento e repressão à Guerrilha do Araguaia no vilarejo de São Domingos do Araguaia, próximo a Marabá (PA), área onde estava organizado o Destacamento A da guerrilha ${ }^{168}$. No dia 12 de abril de 1972, a Operação Peixe III, formada por um pelotão antiguerrilha, composto de 24 integrantes, fracassou ao não encontrar os guerrilheiros [MORAIS; SILVA, 2005: 55, 66-9,

\footnotetext{
${ }^{166}$ V. CARVALHO, Luiz Maklouf. O coronel rompe o silêncio. Rio de Janeiro, Objetiva, 2004. O cel. Lício A. Ribeiro Maciel afirmou em juízo, em 04/03/2010, que desde 1969 fazia esses levantamentos de informação. Ele participou também da operação que levou à morte de dois militantes do Molipo em Goiás: Jeová Assis Gomes, em 09/01/72, e Arno Preis, em 15/02/72. Cf. processo das famílias da Guerrilha do Araguaia iniciado em 1982, $\mathrm{n}^{\circ}$. 2003.01.00.041033-5/DF, de 1982.

${ }^{167}$ A operação foi subdivida em Operação Terra I e II. O relatório foi assinado pelo Gen. Div. Dióscoro Vale (Cmt do CMP/11 ${ }^{\text {a }}$ RM) e pelo Cel. Henrique Beckmann Filho, em agosto de 1971. V. Operação Mesopotâmia, Ordem de operações n ${ }^{\circ}$ 01-SPC/71.

${ }^{168}$ Em março de 1972, o general de brigada Darcy Jardim de Matos, comandante da $8^{\text {a }}$ Região Militar, organizou a Operação Peixe I, composta de uma equipe de investigação. Em abril, o Exército não conhecia o terreno, não sabia a quantidade e nem a localização exata dos guerrilheiros, assim, outra operação de informação foi organizada, a Operação Peixe II, por Jardim de Matos e o tenente-coronel Raul Augusto Borges. Dessa vez levantaram suspeitas e nenhum guerrilheiro foi preso. Paralelamente, o gabinete do ministro do Exército, Orlando Geisel, enviou homens para realizar atividades de informações na região. A Operação Cigana foi coordenada pelo chefe da seção de operações do CIE, o tenente-coronel Carlos Sérgio Torres. Outra operação, a Missão Xambioá, chegou à região do Destacamento C da guerrilha. Cf. MoRAIS; SILVA, 2005, p. 78, 91-2, 116, 133.
} 
77-84]. Eles passaram a se refugiar na floresta ${ }^{169}$. As operações de inteligência e repressão do exército tiveram êxito considerável, de modo que, entre o final de 1972 e início do ano seguinte, havia se rompido definitivamente o contato da guerrilha com o partido, após o assassinato sob tortura de quatro dirigentes do $\mathrm{PCdoB}^{170}$, acrescido a isso a prisão de diversos militantes em vários estados do país, inviabilizando o envio de novos quadros para a guerrilha ${ }^{171}$.

Entre 1972 e 1974, os militares realizaram três campanhas - termo utilizado pelos militantes do PCdoB - para eliminar a guerrilha. As operações envolveram mais de 7.200 homens das três forças ${ }^{172}$, profissionais especializados, agentes infiltrados e o que havia de mais moderno em termos de armamento e logística. Em nenhum momento os militares deixaram a área. Cada fase foi executada por meio de diversas operações.

A primeira campanha ocorreu entre abril e junho de 1972, ao passo que já em maio iniciou-se a Operação Peixe IV, com a participação das três Forças e da Polícia Militar. A nova missão tinha como objetivo infiltrar militares no meio da população para obter a localização e identificação dos guerrilheiros. O INCRA empregou agentes de informação e prepararam-se iniciativas de assistência social para mascarar sua presença na região. As atividades da Ação Cívico-Social (Aciso) eram organizadas pelo Exército, em colaboração com os governos e a Polícia Militar de vários estados (Goiás, Mato Grosso e Pará), a FAB e o Projeto Rondon - do Ministério do Interior. Juntos forneciam, quinzenalmente, assistência médica e educacional encaminhando médicos, dentistas, enfermeiros, remédios da Central de Medicamentos do governo, merenda escolar e livros didáticos para os moradores. Chegaram a desembarcar 2,5 toneladas de medicamentos. Forneciam também carteiras de identidade aos moradores. Desenvolveram ainda atividades voltadas para o lazer com a organização de gincanas, competições esportivas, banda de música e eventos. Os militares seguiram para Marabá, Araguatins (TO) e Xambioá $(\mathrm{TO})^{173}$.

\footnotetext{
${ }^{169}$ O Plano de Operação foi assinado pelo gen. Darcy Jardim de Matos e conferido pelo coronel Alair de Almeida Pitta, chefe da $3^{\text {a }}$ seção da $8^{\text {a }}$ RM. Cf. MoRAIS; SILVA, 2005, p. 78.

${ }^{170}$ Carlos Nicolau Danielli, Lincoln Cordeiro Oest e Luiz Guilardini eram membros da Comissão Executiva do Comitê Central do partido. Lincoln Bichalho Roque era do CC e buscava recursos para a guerrilha. V. ALMEIDA, 2009.

${ }^{171}$ POMAR, Wladimir. Araguaia, Op. cit., p.41.

${ }^{172}$ Cf. MoRAIS; Silva, 2005, p. 236. Studart fala da participação de 4.000 homens. STUDART, Hugo. A Lei da Selva. Estratégias, imaginário e discurso dos militares sobre a Guerrilha do Araguaia. São Paulo, Geração Editorial, 2006, p.16, nota 14.

${ }^{173}$ Cf. Morais, T. e Silva, E. op.cit, p.147, 330-33; Fico, Carlos. Como eles agiam, Op.cit., p.195. Para quantidade de medicamentos, V. GASPARI, 2002: 423
} 
O Exército centralizou o comando, planejamento e a execução das operações no CIE para conseguir identificar e localizar os guerrilheiros ${ }^{174}$. Manter segredo sobre a guerrilha tinha o propósito de não reconhecer sua existência, evitar a propagação das notícias e seus possíveis “efeitos multiplicadores”. Havia o medo de que a região se transformasse numa “zona liberada”. De acordo com o general Médici: "Era preciso esconder as operações para que elas tivessem sucesso” ${ }^{175}$. Conforme Sebastião Rodrigues de Moura, o major Curió, que coordenou as operações finais: “A ordem superior era não deixar rastros da guerrilha, para poupar o Brasil [...] de uma Farc, um movimento montonero (guerrilha argentina), um Sendero Luminoso”176.

Nesse período, outras regiões próximas também sofreram com operações de informação e repressão. Em março de 1973, com a finalidade de “neutralizar” e “apurar a profundidade” da atuação de D. Pedro Casáldaliga na região de Luciara, Santa Terezinha e São Félix (MT), ao sul de onde ocorria a Guerrilha do Araguaia, as Forças Armadas realizaram a Operação Luciara com o objetivo de “restabelecer a ordem interna” nessas regiões [FICO, 2001:194-95].

Militares e civis infiltraram-se por toda a região. O INCRA, a Campanha de Erradicação da Malária (CEM) e o Departamento Nacional de Estradas de Rodagem (DNER) ajudaram com instalações, pessoal e fornecendo falsos documentos de identidade. O Exército comprou terras para abrigar militares disfarçados de posseiros. Em cinco meses investigaram a rede de apoio da guerrilha e produziram arquivo com um fichário contendo mais de quatrocentos nomes. Descobriram que pelo menos 20 camponeses haviam aderido à guerrilha, 158 moradores da região apoiavam diretamente o movimento, cuja rede movimentava cerca de 258 pessoas. Os guerrilheiros haviam conseguido organizar treze núcleos da ULDP (União pela Liberdade e pelos Direitos do Povo), cada um composto de 3 a 5 integrantes ${ }^{177}$.

\footnotetext{
${ }^{174}$ De acordo com o cel. Lício Augusto Ribeiro Maciel, o CIE era composto pela 4 a seção (Brasília), que era o setor responsável pelas operações, chefiada pelo tenente-coronel Carlos SérgioTorres, que respondia pelo combate à guerrilha rural. CARVALHO, Luiz Maklouf. O coronel rompe o silêncio, op.cit., p.103. Sabese que Torres foi o comandante da Operação Sucuri, segundo o Relatório da Operação Sucuri/maio/74; e que seu nome consta no Tomo II, volume 3, “Os Funcionários” (Repressores) do Projeto BNM.

${ }^{175}$ SCARTEZINI, Antônio Carlos. Segredos de Médici, op.cit., p.36.

${ }^{176}$ NossA, Leonencio. Não se corta erva daninha pelo caule. OESP, 22/06/09, p.A6; e NossA, Leonencio. Curió abre arquivo e revela que Exército executou 41 no Araguaia, OESP, 21/06/09.

${ }^{177}$ V. GAMA, Rinaldo. Veja, 13/10/93, p.16-28 apud GASPARI, E. Op.cit, p.435, nota 170. Em junho de 2009, o major Curió, um dos principais responsáveis do CIE pela Operação Marajoara, forneceu parte dos seus arquivos pessoais para o jornal $O$ Estado de S. Paulo. NossA, Leonencio. Curió abre arquivo e revela que Exército executou 41 no Araguaia, OESP, 21/06/09; NosSA, Leonencio. Não se corta erva daninha pelo caule. OESP, 22/06/09, p.A6; NOSSA, Leonencio e MADUEÑO, Denise. Aumenta a pressão pela abertura de todos os arquivos sobre a Guerrilha do Araguaia. OESP, 22/06/09, p.A4. Essas informações
} 
Em setembro, guerrilheiros do Destacamento A tomaram o posto da Polícia Militar localizado no entroncamento da Transamazônica com a estrada de São Domingos. $\mathrm{O}$ ataque rendeu-lhes seis fuzis, um revólver, munição, fardas e calçados. Nesse período, guerrilheiros do Destacamento B prenderam, julgaram e executaram um camponês colaborador do Exército [MORAIS; SILVA, 2005: 423, 444].

Munidos das informações, em outubro de 1973, um efetivo de cerca de 250 soldados iniciou a Operação Marajoara com o apoio do $23^{\circ}$. Batalhão de Infantaria da Selva, de Marabá, que contava com cerca de 400 homens ${ }^{178}$. Contaram com apoio também de uma tropa de fuzileiros, aviões e helicópteros da FAB, todos descaracterizados e com nomes falsos, alguns a serviço da inexistente Mineração Aripuanã ou da Agropecuária Araguaia [GASPARI, 2002: 436]. A operação dividiu-se em duas fases: na primeira, prenderam grande parte da população local, neutralizando a rede de apoio da guerrilha; na segunda, vasculharam a área em busca de depósitos e guerrilheiros $^{179}$.

A maioria dos lavradores e pequenos comerciantes foi levada presa para as bases militares, que efetivamente se constituíram em verdadeiros campos de concentração. A base militar localizada na cidade de Marabá (PA) utilizava três imóveis de apoio, sendo que a sede do DNER - identificada como "Casa Azul” pelos camponeses, cujos depoimentos foram recolhidos pelo Ministério Público Federal $-{ }^{180}$ serviu de campo para onde foram levados e torturados guerrilheiros e moradores da região. A sede do INCRA e o presídio militar da PM (ou do antigo grupamento de Tiro de Guerra) também foram usados para realização de “interrogatórios” e como prisão de suspeitos de participar ou colaborar com os guerrilheiros, além de possuírem pista de pouso.

Outra base importante ficava na localidade de Bacaba, no Km 68 da Rodovia Transamazônica, próxima a São Domingos do Araguaia (PA), onde era o canteiro de obras da Mendes Júnior, contratada para a construção dessa rodovia. Nessa base havia

vieram a público logo após a Corte Interamericana de Direitos Humanos da OEA admitir o caso dos familiares dos desaparecidos da Guerrilha do Araguaia.

${ }^{178}$ Coronel Álvaro de Souza Pinheiro, "Guerrilha na Amazônia: uma experiência no passado, o presente e o futuro”, edição brasileira da Military Review, jan.-mar./95, p.58-79.

${ }^{179}$ Segundo outra fonte, a operação foi desencadeada com cerca de 300 militares em trajes civis (120 da $8^{\text {a }}$ RM, com comando e o Estado-maior; 100 da Brigada de Paraquedistas, também com comando e Estadomaior; do CMP, um destacamento de informação). O CIE participou com 30 agentes. A FAB atuou no transporte e mais 4 homens do CISA no setor de informação. As PMs do Pará e de Goiás atuaram nas barreiras de estradas, prisões e vigilância das vias de acesso. V. MorAIS; SILVA, 2005: 449.

${ }^{180}$ V. Relatório Parcial da Investigação sobre a Guerrilha do Araguaia, MPF, jan./02. O relatório é baseado em 55 depoimentos de moradores da região da guerrilha, recolhidos pelo MPF em julho de 2001 para os Inquéritos Civis Públicos no 1/2001 - PA; n 3/2001 - SP e n ${ }^{0}$ 5/2001 - DF. Participei dessa investigação na região da Guerrilha do Araguaia, em 2001, como consultora do MPF. 
pista de pouso e uma grande área para a detenção de camponeses suspeitos, além de alojamentos para os militares e prisões para “interrogatórios”.

Na cidade de Xambioá, então Estado de Goiás, hoje Tocantins, às margens do rio Araguaia, ficava outra base militar, que também tinha pista de pouso e funcionou como prisão e local de “interrogatórios”. Era a base das operações que ocorriam no rio Araguaia. Em Araguaína, cidade do Estado de Goiás, hoje Tocantins, constituiu-se outra base militar, entretanto menos citada nos relatos dos camponeses sobreviventes.

Havia também pequenas bases em outras localidades, como nos lugarejos de Oito Barracas (município de São Domingos do Araguaia) e São Raimundo (próximo à divisa dos municípios de São Domingos e de São Geraldo do Araguaia), e na cidade de Araguatins, além de algumas bases temporárias montadas em propriedades privadas no campo. As bases militares, ao menos em Bacaba e Xambioá, contavam com efetivos do Exército, Marinha e Aeronáutica, além da Polícia Militar local.

Os relatos registrados pelo MPF confirmam que as Forças Armadas, para sufocar o movimento guerrilheiro, sitiaram toda a região durante a terceira campanha. Nessa última fase da guerrilha houve prisões em larga escala. Bastava a notícia de que um comerciante vendera produtos aos guerrilheiros para justificar a sua prisão, ou que um lavrador tivesse alimentado ou deixado algum dos "terroristas" dormir em sua casa. Muitos moradores foram presos sem sequer compreender o motivo. Outros foram presos por terem deliberadamente aderido à guerrilha e ido morar na mata com os guerrilheiros $^{181}$.

Após os sequestros executados pelos militares, muitos camponeses e comerciantes foram submetidos a espancamentos e outras torturas. Embora seja difícil identificar nos depoimentos o critério utilizado para empregar a tortura, parte considerável dos presos sofreu violências físicas, morais e psicológicas. Alguns morreram ou ficaram mutilados, vítimas de armamentos militares deixados na floresta ${ }^{182}$. Outros moradores mais próximos aos guerrilheiros, ou que conheciam bem a floresta, sofreram duras torturas

\footnotetext{
${ }^{181}$ Ver depoimento de Emmanuel Wambergue concedido ao MPF, Marabá (PA), 02/07/01. Na região de São Domingos, Brejo Grande e Palestina 300 pessoas teriam sido presas. Os agentes do Exército eram conhecidos como "secretas" e moravam nas comunidades sem trabalhar, anotando nomes e informações sobre as pessoas que tinham contato com a guerrilha. Ver tb. depoimento de Antonio Rodrigues da Silva concedido ao MPF, São Domingos do Araguaia (PA), 04/07/01.

${ }^{182}$ É o caso de Sabino Alves da Silva, morto quando mexia numa granada. Lauro Rodrigues dos Santos perdeu o braço. Ver depoimento de Lauro Rodrigues dos Santos concedido ao MPF, São Domingos do Araguaia (PA), 04/07/01.
} 
para dar informações e aceitar trabalhar como guias do Exército nas buscas de guerrilheiros $^{183}$.

Houve um elevado número de pessoas sequestradas. Moradores declararam terem ficado presos junto com mais de 80 ou 90 pessoas detidas em Marabá. Um depoente registra ter contado, em Araguaína, 25 celas com mais de 50 pessoas presas em cada uma $^{184}$. Alguns afirmaram que todos os homens foram detidos e que só não foram presos os que fugiram ou aceitaram colaborar com o Exército ${ }^{185}$. As mulheres ficaram sozinhas para cuidar da família e da roça, sendo que muitas foram para as cidades, com medo de serem assediadas ou feridas. Outros relataram que casas, plantações e árvores frutíferas foram queimadas para que os guerrilheiros ficassem sem apoio ou comida ${ }^{186}$. Mulheres foram presas e torturadas, outras chegaram a ser levadas com as crianças para exercer trabalho escravo nos acampamentos militares ${ }^{187}$.

De acordo com vários depoimentos, os campos de concentração de Bacaba e Xambioá eram áreas abertas, com construções utilizadas como alojamento e depósitos pelos militares, além de escritórios usados pelo setor de informação para “interrogatórios”. Em Bacaba havia duas áreas destinadas aos presos. Na primeira, ficavam encarcerados os guerrilheiros ou aqueles que ainda estavam sendo submetidos a interrogatórios. Na outra ficavam os camponeses já interrogados ou que serviam de guias - essa área não era cercada, mas os camponeses não fugiam com medo de serem recapturados e sofrerem mais violências. No campo de Xambioá, os prisioneiros ficavam encerrados em lugares similares a currais limitados por arames farpados ${ }^{188}$.

Alguns lavradores relataram terem sido amarrados e levados para o campo de Bacaba, depois à sede do INCRA, em Marabá, e, em seguida, para Araguaína, onde ficaram detidos no Quartel da Polícia Militar. Outros ouviram relatos sobre pessoas amarradas e penduradas num buraco na sede do INCRA, tendo visto suas marcas de

\footnotetext{
${ }^{183}$ Este foi o caso de "Peixinho", Raimundo Nonato dos Santos. V. depoimento concedido ao MPF, São Domingos do Araguaia (PA), 14/07/01.

${ }^{184}$ Depoimento de José Rufino Pinheiro concedido ao MPF, idem, 05/07/01.

${ }^{185}$ Depoimento de José Francisco Dionísio concedido ao MPF, idem, 06/07/01.

${ }^{186}$ V. depoimento de Margarida Ferreira Felix concedido ao MPF, São Domingos do Araguaia (PA), 02/07/01; Depoimento de João Vitório da Silva, idem, 05/07/01.

${ }^{187}$ Alguns relatos dão conta que a mulheres dos camponeses que aderiram à guerrilha, Batista e Pedro Carretel, foram presas, torturadas e obrigadas a trabalhar nos campos.

${ }^{188}$ Depoimento de Sinézio Martins Ribeiro concedido ao MPF, idem, ididem.
} 
tortura. ${ }^{189}$ Vários depoimentos informaram a existência de um buraco, chamado de Vietnã, no campo de Xambioá (TO) usado para aprisionar ou torturar ${ }^{190}$.

Os depoimentos coincidem ao indicar o procedimento seguido pelas Forças Armadas nas prisões e interrogatórios, e a respeito dos tipos de torturas praticados. Normalmente, os camponeses eram presos em suas próprias residências, no campo, na mata ou no caminho para o trabalho. Eram abordados com gritos, pancadas de fuzis, socos e pontapés na cabeça. Por vezes os soldados pediam apenas aos "suspeitos" que os acompanhassem. Alguns moradores eram algemados e levados, em muitas ocasiões, a pé até os campos. Outros eram envolvidos em sacos de estopa, sem poder mover-se ou ver para onde eram levados ${ }^{191}$.

Os que residiam próximos a São Domingos do Araguaia foram sequestrados e levados primeiro para o campo de concentração de Bacaba. A maioria permanecia ali apenas por poucos dias e, depois, eram transferidos para Marabá, normalmente à noite, deitados na boleia de um caminhão e sob ameaça de serem agredidos caso levantassem. Os depoimentos identificam o campo de Bacaba como o lugar onde ocorriam as mais violentas torturas. De Marabá os presos eram transferidos para outros locais, mas há relatos de retorno ao campo de Bacaba, mesmo depois de terem sido soltos ${ }^{192}$. Alguns contaram terem sido levados para Belém, Araguaína e Brasília ${ }^{193}$.

A tortura dos presos ocorreu em todos os campos. Relatos mencionam casos eventuais de prisioneiros mantidos amarrados sobre formigueiros, transportados pendurados de helicóptero, mantidos em quartos com produtos químicos, obrigados a cavar sua suposta sepultura e mantidos por dias sem alimentação ${ }^{194}$.

Alguns testemunhos dão conta de que, após os espancamentos, os presos recebiam atendimento médico. O terror e o medo instalados na região marcaram a todos. Isto levou vários moradores a colaborarem com as Forças Armadas. Vários prisioneiros relataram que era comum ouvir gritos nos campos, especialmente, no de Marabá. Nesse local,

\footnotetext{
${ }^{189}$ V. depoimento de Adão Rodrigues Lima e Salviana Xavier Lima concedido ao MPF, idem, 03/07/01.

${ }^{190}$ Depoimento de Sebastião Gomes da Silva concedido ao MPF, em Xambioá (TO), 12/07/01. Na "Casa Azul" também havia um buraco utilizado para torturar. Ver tb. depoimento de Pedro Moraes da Silva concedido ao MPF, São Domingos do Araguaia (PA), 04/07/01.

${ }^{191}$ V. depoimento de Margarida Ferreira Felix, Op.cit.

${ }^{192}$ V. depoimento de Adão Rodrigues Lima e Salviana Xavier Lima concedido ao MPF, Op.cit.

${ }^{193}$ Depoimento de Sinvaldo de Souza Gomes concedido ao MPF, São Domingos do Araguaia (PA), 03/07/01.

${ }^{194}$ V., por exemplo, depoimentos de João Vitório da Silva e de Rocilda Sousa dos Santos concedidos ao MPF, São Domingos do Araguaia (PA), 05/07/01.
} 
devido sua proximidade com a cidade, motores eram acionados durante as sessões de tortura, a fim de abafar os gritos das vítimas.

Em razão das prisões e dos tormentos dispensados aos presos, vários moradores relataram sequelas nos sobreviventes. Alguns presos ficaram loucos ou com marcas físicas, como no caso de Frederico Barros da Silva. Simpatizante da guerrilha, forneceu comida aos guerrilheiros, foi preso e levado para o campo de Bacaba, onde passou fome e foi torturado com choques elétricos e espancamento. Permaneceu mais de seis meses preso, sendo levado para Marabá e Araguaína (PA). Sua casa foi incendiada. Nunca mais se recuperou e foi considerado louco, tendo sido internado pelo Exército no manicômio de Belém (PA) por dois anos ${ }^{195}$. Outros faleceram devido às sequelas das torturas ${ }^{196}$. Alguns camponeses foram assassinados na floresta, confundidos com guerrilheiros. Outros desapareceram depois de presos. O número de camponeses assassinados ainda é desconhecido $^{197}$.

Todas as prisões foram realizadas sem qualquer formalidade legal ou controle judicial, podendo ser caracterizadas como sequestros. Havia, contudo, o controle dos presos exercido, por exemplo, por meio da rotina de chamada dos prisioneiros e das fotografias feitas quando da chegada aos campos $^{198}$. O tempo de duração dos sequestros variava em períodos de alguns dias até mais de seis meses.

As Forças Armadas utilizaram tropas regulares para reprimir a guerrilha, mas sem sucesso. A terceira e última fase de repressão - entre outubro de 1973 e final de 1974 caracterizou-se pela generalização da violência, com a eliminação de todos os guerrilheiros, mesmo quando presos com vida; e grande repressão aos moradores, como

\footnotetext{
${ }^{195}$ Frederico foi torturado pelo Major Curió e foi pendurado pelos testículos. V. depoimento de José Moraes Silva concedido ao MPF, São Domingos do Araguaia (PA), 03/07/01 e de Pedro Moraes da Silva, op.cit. Maria Nazaré Ferrreira Brito e Adalgiza Moraes da Silva também relataram que seus maridos ficaram loucos após as torturas. Cf. depoimento de Maria Nazaré Ferrreira Brito, idem, ibidem; e de Adalgiza Moraes Silva concedido ao MPF, idem, 06/07/2001. Vários testemunhos relataram que os homens foram torturados dependurados pelos testículos.

${ }^{196}$ Antônio Araújo Veloso morreu em consequência das torturas sofridas. Ele e a esposa eram simpatizantes da guerrilha. V. Direito à memória e à verdade, op.cit., p. 264. Outros casos apresentados à CEMDP/SEDH foram indeferidos, como o de Simão Pereira da Silva. "Raimundo das Moças", Raimundo Gomes, João Pereira Carvalho e Antonio Nogueira seriam alguns dos que morreram em função das sequelas da tortura de acordo com os depoimentos registrados pelo MPF.

197 Sabe-se de 6 camponeses desaparecidos, sendo que se conhece os nomes completos apenas de 4: Antônio Alfredo de Lima, Luiz Vieira, Lourival de Moura Paulino e Juarez Rodrigues Coelho. Manoel Pereira Marinho foi citado. De outros, conhecem-se apenas os apelidos: Batista, Joaquinzão, Edite e Pedro Carretel. V. ALmeIDA, 2009; e NossA, L. Curió abre arquivo e revela que Exército executou 41 no Araguaia, OESP, 21/06/09. V. depoimento de Sinvaldo de Souza Gomes. Idem, ididem. Ele relatou que o guia Sinézio presenciou a morte de 3 camponeses na floresta. Afirmou que Curió esteve na região, em 2000, quando prometeu indenizar os camponeses.

${ }^{198}$ A realização de fotografias foi ressaltada em vários depoimentos de presos. De acordo com os registros, os guerrilheiros também eram fotografados.
} 
forma de obter informações e impedir a sobrevivência da guerrilha ${ }^{199}$. O alcance da violência com o uso generalizado da tortura e o aprisionamento da população em campos de concentração, a decapitação de guerrilheiros e o desaparecimento de seus restos mortais, não deixam dúvidas de que os governos militares decidiram destruir a guerrilha e extirpá-la da história. Disseminou-se o terror, o controle e o disciplinamento da população.

Nessa última fase de repressão à guerrilha permaneciam na região 53 guerrilheiros. Eles se concentraram na área onde originalmente os Destacamentos A e B haviam se organizado. Em dezembro de 1973, onze guerrilheiros já haviam sido presos ou mortos. A maior parte dos combatentes, então, juntou-se numa só coluna. No dia 25 de dezembro planejavam reunir-se para avaliar a situação num pequeno morro na região de Palestina, próximo à Transamazônica. Patrulhas militares encontraram o local da reunião, onde também estava acampada a Comissão Militar. Maurício Grabois, o principal dirigente, e mais três guerrilheiros morreram nesse confronto. Em seguida, outros três desapareceram [ALMEIDA, 2009].

De acordo com o major Curió, até a metade da terceira campanha chegaram a ocorrer combates, mas, a partir daí "houve uma perseguição atrás de rastros [...]. A terceira campanha é que teve o efeito que o regime desejava”. No final de março de 1974, a maioria dos guerrilheiros já havia sido presa e assassinada. Alguns foram decapitados. Curió confirmou que as Forças Armadas prenderam e executaram 41 guerrilheiros nessa fase $^{200}$. Entre abril e outubro, havia ainda 14 guerrilheiros remanescentes [ALMEIDA, 2009]. Vários moradores, especialmente os que trabalharam como guias das Forças

\footnotetext{
${ }^{199}$ Durante 1973, o general francês Paul Aussaresses, ex-combatente na Argélia, ensinou técnicas de tortura nos cursos do Comando de Operações na Selva e Ações Antiguerrilha (COSAG) do Exército, em Manaus (AM). Segundo ele e o general Manuel Contreras, chefe da DINA (Chile), os militares e oficiais dos países latino-americanos faziam esse curso. $\mathrm{O}$ envio de oficiais chilenos era realizado a cada dois meses, o treinamento ocorria na Escola Nacional de Informações (ESNI), em Brasília, e era complementado em Manaus. V. o documentário Escuadrones de la muerte, op.cit. De acordo com o tenente José Vargas Jiménez, autor do livro Bacaba: memórias de um guerreiro de selva da Guerrilha do Araguaia (Editora do Autor, Campo Grande (MS), 2007), ele treinou em Manaus nesse período e, em seguida, foi enviado para combater a guerrilha.

${ }^{200}$ Curió se disfarçou como Marco Antônio Luchini do INCRA. Foi adjunto do coordenador da Operação Sucuri. Ocupou o espaço deixado pelo major Gilberto A. Zenkner, instalado em Brasília. Antes, foi ajudante de ordens do comandante do CMP Olavo Vianna Moog. Atuou no setor de informação desde 1960. Pertenceu ao SNI e participou de operação contra organizações de esquerda no Paraná. Os 41 guerrilheiros correspondiam a $61 \%$ do total de baixas. Curió confirmou que pelo menos 4 guerrilheiros foram decapitados. NossA, L. Curió abre arquivo e revela que Exército executou 41 no Araguaia, OESP, 21/06/09; NosSA, L. Não se corta erva daninha pelo caule. OESP, 22/06/09, p.A6; NOSSA, L. e MADUEÑO, D. Aumenta a pressão pela abertura de todos os arquivos sobre a Guerrilha do Araguaia. OESP, 22/06/09, p.A4. Depoimentos de Pedro Ribeiro Alves e Sinézio afirmaram que Jaime Petit da Silva foi decapitado. Cf. dep. concedidos ao MPF, São Geraldo do Araguaia (PA), 19/07/01.
} 
Armadas, viram alguns guerrilheiros presos $^{201}$. O coronel Lício Maciel confirmou que nesta fase recebeu “ordem superior” para capturar os guerrilheiros “vivos ou mortos”202.

Não há informações sobre quanto tempo os guerrilheiros permaneceram presos, sendo torturados. Eles eram seviciados para fornecer a informação sobre os encontros (os pontos) marcados a cada 15 (ou 10) dias na floresta. Foram aterrorizados para aderirem ao Exército e colaborarem nas buscas de outros guerrilheiros. Ofereceram-lhes a promessa de poupar suas vidas em troca da colaboração, conforme aconteceu com Antonio de Pádua Costa (Piauí), executado após alguns meses ${ }^{203}$. As informações sobre quando e como foram executados continuam sob sigilo. Os campos de internamento da população tornaram-se campos de extermínio para os guerrilheiros.

Antônio de Pádua Costa, guerrilheiro conhecido como Piauí, foi visto conduzido por soldados na cidade de São Domingos do Araguaia ${ }^{204}$. Depois de preso foi forçado a trabalhar como guia das Forças Armadas e ficou no campo de Bacaba. Manoel Leal Lima, o ex-guia do Exército conhecido como Vanu, relatou que no final da guerrilha Piauí foi assassinado em Bacaba, assim como Luiz Renê Silveira e Silva e o camponês Pedro Carretel. Afirmou ter acompanhado a equipe que os executou. Ele e outros guias teriam atuado como infiltrados (secretas) e receberam assistência do Exército por sua colaboração pelo menos até 2001. De acordo com a documentação encontrada pelo MPF na sede de um órgão secreto do Exército, em Marabá, essa assistência era coordenada pela Operação Anjo da Guarda ${ }^{205}$.

José Genoino Neto, guerrilheiro preso em 18 de abril de 1972, foi espancado em público, na praça de Xambioá. A cabeça decapitada do cadáver de Rosalindo Souza ficou exposta por alguns dias no campo de concentração de Xambioá ${ }^{206}$. O corpo do guerrilheiro João Carlos Haas Sobrinho foi exposto à população de Porto Franco (MA),

\footnotetext{
${ }^{201}$ Eles indicaram 21 guerrilheiros que teriam sido presos com vida pelas Forças Armadas, sendo que 18 foram vistos em campos de concentração. Alguns guias afirmaram que havia rumores de que guerrilheiros foram enterrados no campo de Bacaba e de que alguns corpos foram deixados na mata. V. depoimento de José Rufino Pinheiro, Idem, ibidem. Como guia do Exército, afirmou ter visto os guerrilheiros Lúcia Maria de Souza e Osvaldo Orlando da Costa serem mortos. Depoimento do ex-guia Ângelo Lopes de Souza, concedido ao MPF, São Domingos do Araguaia (PA), 06/07/01. Há fotos do guerrilheiro Piauí, amarrado, com uma equipe militar. V. ALMEIDA, 2009.

${ }^{202}$ VALENTE, Rubens. "Ordens no Araguaia eram dadas por quatro generais". Folha de S. Paulo, 28/06/09.

${ }^{203}$ Antonio de Pádua Costa, Tobias Pereira Júnior e Lúcio Petit da Silva teriam ficado muito tempo presos, o que se verifica se compararmos as datas de morte dos relatórios militares entregues ao ministro da Justiça, em 1993, e os depoimentos do MPF. V. ALMEIDA, 2009.

${ }^{204}$ Ver depoimentos de Adão Rodrigues Lima e Salviana Xavier Lima concedido ao MPF. Idem, ibidem; e de Raimundo Nonato dos Santos. Idem, ibidem.

${ }^{205}$ Depoimento de Manoel Leal Lima, ex-guia conhecido como Vanu, concedido ao MPF, São Domingos do Araguaia (PA), 12/07/01.

${ }^{206}$ Entrevista concedida por Sinézio Martins Ribeiro à autora. Xambioá (TO), 18/07/2001.
} 
onde havia morado inicialmente. O corpo de Osvaldo Orlando da Costa foi pendurado em um helicóptero e exibido em toda região [ALMEIDA, 2009] ${ }^{207}$.

Os guerrilheiros Glênio Sá e Genoíno foram mantidos incomunicáveis, sem visitas de familiares e advogados durante 13 meses. Genoino permaneceu 5 anos na prisão, mas foi condenado em função de sua militância em partido clandestino. O processo da Justiça Militar não considerou sua participação na Guerrilha do Araguaia. Criméia de Almeida, sequestrada grávida, teve seu filho no cárcere, o PIC de Brasília, onde permaneceu 5 meses. Não teve acesso a advogados e nem chegou a ser processada - o que ocorreu à maioria dos sobreviventes, tal como ex-guerrilheiro Danilo Carneiro, preso por mais de um ano $^{208}$. Perante a Justiça Militar, a Guerrilha do Araguaia não existiu ${ }^{209}$.

Na região da guerrilha, o toque de recolher foi imposto aos moradores e alguns foram obrigados a se apresentar periodicamente nos campos, especialmente o de Bacaba. Esse controle era exercido em intervalos de cinco a seis dias, depois os prazos iam se estendendo a apresentações mensais ou bimestrais.

A população sofreu vários tipos de danos materiais decorrentes da repressão das Forças Armadas. Após o sequestro dos homens, os militares determinavam à família dos presos que se afastassem de suas casas, roças, colheitas e animais de criação, que eram destruídas ou incendiadas. Alguns camponeses foram expulsos de suas próprias terras que passaram a ser ocupadas por pessoas que haviam colaborado com os militares. Houve casos de camponeses obrigados a hospedar grupos de militares e a trabalhar como informantes.

Esses danos se agravavam pela permanência dos arrimos de família presos ou obrigados a trabalhar para o Exército. Vários lavradores - alguns espontaneamente e outros obrigados após sofrerem tortura ou ameaças - trabalharam como guias das tropas, serviços para os quais eram remunerados. Únicos conhecedores da floresta onde se encontravam os guerrilheiros, alguns moradores permaneceram meses a serviço das Forças Armadas. Em quase todas as famílias ouvidas pelo MPF havia alguém que tinha

\footnotetext{
${ }^{207}$ Numa das fichas encontradas nos arquivos de Curió consta que Osvaldo Orlando Costa foi morto por Arlindo Vieira, em 07/02/74, e sepultado em Xambioá. Teria sido "exumado em 19/01/75 e levado para a Serra das Andorinhas", mas não informa o local onde ele e os outros guerrilheiros foram enterrados e nem os nomes dos comandantes e membros das operações. V. NossA, Leonencio. "Curió abre arquivo e revela que Exército executou 41 no Araguaia”, OESP, 21/06/09.

${ }^{208}$ Entrevista concedida por Danilo Carneiro à autora. SP, 24 e 25/06/2010. AAPP/LEI-USP.

${ }^{209}$ Para os envolvidos em ações armadas e guerrilha, os processos resultavam em penas superiores a 5 anos de prisão. De um total de 2.828 condenados, 880 receberam penas superiores a 5 anos. V. Projeto Brasil: Nunca Mais, tomo III: Perfil dos atingidos, p.12-3. V. Entrevista de Criméia A. S. de Almeida concedida à autora. Idem, ibidem. V. tb. Coelho, Maria Francisca P. José Genoino. Escolhas políticas. São Paulo, Centauro, 2007, p.193-4; 199-237.
} 
trabalhado como guia, em uma incursão apenas ou por vários meses. De acordo com a população, sem os serviços dos guias locais o Exército sequer teria conseguido se mover na selva.

Em 2009, o major Curió afirmou que obedecia ordens e não se sentia derrotado. “As Forças Armadas cumpriram uma missão constitucional, preservaram as instituições, a independência e a soberania da pátria e não permitiram um Estado independente no Brasil, o que no bojo da guerra de guerrilhas extirpou momentaneamente uma ideologia adversa, o comunismo ${ }^{210}$." Como tantos outros algozes, exime-se de responsabilidades e justifica os diversos crimes cometidos consciente de que os campos, a tortura e a execução sumária não constavam do ordenamento jurídico da própria ditadura.

O terror e a intimidação instalados contra os guerrilheiros e a população ocorreu sob a justificativa de se evitar "os efeitos multiplicadores” sobre o inimigo potencial - os camponeses e indígenas da região e até a população urbana. Possibilitou também a ocupação militar de uma região estratégica para os planos de desenvolvimento econômico do Estado. Os conflitos envolvendo posse de terras foram, em grande medida, controlados, forçando a evasão da população. As manobras realizadas pelas Forças Armadas no Vale do Ribeira e na região da Guerrilha do Araguaia assemelharam-se “[...] às manobras norte-americanas no Vietnã, sob o nome de 'programas de pacificação’[...]”211.

O Estado de Segurança Nacional, juntamente com o combate à esquerda armada e revolucionária, estabeleceu um vasto plano de controle político e social, principalmente em áreas de interesse econômico, buscando manter a população sob vigilância e controle ${ }^{212}$.

\footnotetext{
${ }^{210}$ NossA, L. "Não se corta erva daninha pelo caule”. OESP, 22/06/09, p.A6.

${ }^{211}$ ALVES, M. H. M. op.cit., 2005, p.201. Durante o conflito no Vietnã, a doutrina contra-insurrecional do general Creighton Abrams defendia a estratégia de "Limpar e Manter". Uma campanha de guerra química atingiu milhares de hectares com o uso de "agente laranja" para "limpar" o terreno de batalha. O Plano Fênix provocou o assassinato de 25 mil líderes camponeses para "limpar" a população insurrecta. Abrams implementou ainda o programa de "aldeias estratégicas", a instalação forçada de milhões de camponeses vietnamitas em campos de concentração (V. PETRAS, J. Carta aberta ao general Petraeus. In: http://resistir.info/petras/petras_09mar07_p.html).

${ }^{212}$ A impunidade é uma realidade muito presente no Pará. De acordo com a Comissão Pastoral da Terra, entre 1982 e 2008 foram assassinados 687 lideranças e trabalhadores rurais no estado. Do total de mortos, apenas em 259 casos houve processo criminal ou inquérito policial. Muitos já prescreveram pelo decurso do tempo. Assim, 62\% dos assassinatos do período sequer foram investigados. Dos 144 processos criminais localizados, apenas 18 chegaram a julgamento de algum acusado, representando apenas 12,5\%. Apenas 9 mandantes e 18 pistoleiros e intermediários foram condenados. Dos 9 mandantes condenados, nenhum deles cumpriu ou está cumprindo a pena estipulada pelo tribunal do júri. Encontram-se foragidos ou estão aguardando julgamento de recurso em liberdade. V. "CNJ e a impunidade dos crimes no campo no Pará" no site < www.cptnac.com.br $>$. Acesso em: 04/02/2011.
} 


\section{Os centros de tortura e extermínio: o sistema DOI-Codi}

O golpe de estado de 1964 deu origem aos primeiros inquéritos policiais-militares do período. A subsequente reestruturação dos orgãos de informação e de segurança levou, inicialmente, à criação do SNI (orgão de informação do sistema executivo federal) e, a seguir, à reconfiguração dos orgãos de informação das forças armadas. Desde os anos 1920, a repressão política era, predominantemente, conduzida pelos DEOPS, as polícias civis que uniam as atividades de informação e de repressão, mas que não possuíam a articulação nacional desejada. Com a percepção da ebulição dos movimentos sociais dos primeiros anos de ditadura e da luta armada urbana, inicia-se um processo ainda mais amplo de estruturação de alicerces e funções do aparato repressivo do estado.

A partir de 1967, inicia-se um período de reorganização dos órgãos de informação das forças armadas. Ao contrário do SNI (Serviço Nacional de Informações), que era mais voltado para a coleta, análise e difusão de dados, o CIE, o CISA e o Cenimar se constituíram em “órgãos mistos”, combinando operações de informação e de repressão voltadas à segurança interna ${ }^{213}$.

Em São Paulo, a partir de junho de 1968, intensificaram-se as prisões de militantes das organizações de luta armada, em especial da ALN e VPR, efetuadas principalmente pelo DEOPS/SP e o DEIC (Departamento Estadual de Investigações Criminais) ${ }^{214}$. Em 8 de novembro de 1968, um casal de militantes da ALN de São Paulo, Catarina Helena e João Antônio Abi-Eçab, morreu em circunstâncias misteriosas no interior de São Paulo. No mesmo dia, João Antônio havia participado da ação de “expropriação” do IPEG (Instituto de Previdência do Estado da Guanabara), na cidade do Rio de Janeiro, organizada pela $\mathrm{ALN}^{215}$.

A versão oficial divulgada na imprensa foi a de que o casal havia sido vítima de um acidente de carro próximo a Vassouras (SP). Desde o início, suspeitas recaíram sobre o acidente, pois a versão policial atribuiu a morte do casal à explosão do veículo em que viajavam, em consequência da detonação dos explosivos que transportavam. Reportagens

\footnotetext{
${ }^{213}$ O CIE (Centro de Informações do Exército) foi criado em 1967, unindo a 2a . Seção do Estado Maior do Exército com a Divisão de Informações do ministro do exército. Em 1968 foi cirado N-SISA (Núcleo de Serviço de Informações e Segurança transformado em CISA (Centro de Informações e Segurança da Aeronáutica), em 20/05/70. O Cenimar (Centro de Informações da Marinha) existia desde 1955 e foi reestruturado em 1971, voltado também para as operações especiais (FICO, 2001, p.91-92).

${ }^{214}$ V. “Quedograma da ALN" (Levantamento das prisões e mortes dos militantes da ALN feita pela própria organização nos anos 1970). Arquivo pessoal de Suzana K. Lisbôa.

${ }^{215}$ Agradeço ao jornalista Mário Magalhães e biógrafo de Carlos Marighella, segundo o qual entrevistas com militantes da ALN confirmaram a participação de João Antônio nessa ação.
} 
do jornal Última Hora lançaram dúvidas sobre esta versão, pois um motorista teria visto “que o carro dos estudantes era perseguido por uma viatura policial e que os agentes da lei disparavam sem cessar contra o Volks”216. O investigador de polícia da delegacia de Vassouras questinou a possibilidade de um acidente numa reta de quatro quilômetros; e o responsável pelo trabalho fotográfico da polícia foi proibido de documentar o material das sacolas encontradas no carro.

Em 2001, foi possível realizar a exumação dos restos mortais de Catarina. O laudo concluiu que sua morte foi consequência de um tiro que a atingiu pelas costas e que não havia sinais de autópsia feita anteriormente ${ }^{217}$. No final de 1968, tomava corpo a rearticulação do aparelho repressivo que levaria à organização do sistema DOI-Codi.

No início de 1969, os dirigentes da ALN Rolando Frati e Argonauta Pacheco foram presos ${ }^{218}$. Um novo ciclo de prisões resultantes da descoberta de um sítio em Itapecerica da Serra (SP) emprestado para a VPR levou à descoberta da residência de membros do GTA (Grupo Tático Armado) da ALN em São Paulo. Em 28 de janeiro de 1969, Marco Antônio Braz de Carvalho foi assassinado com vários tiros desfechados pelas costas por policiais do DEOPS chefiados pelo delegado Raul Nogueira de Lima, conhecido como "Raul Careca", o policial que matou a tiros o estudante do colégio Marina Cintra, José Guimarães em 3 de outubro de 1968. “Marquito” tinha realizado treinamento de guerrilha em Cuba e dirigia o GTA e, também, era acusado de ter participado da execução do agente da CIA Charles Rodney Chandler. Ele se encaminhou para o apartamento de João Leonardo da Silva, que havia sido preso e faltara a diversos "pontos", quando foi surpreendido pelos policiais do DEOPS sem chance de defesa [ALMEIDA, 2009: 129-30].

Durante o primeiro semestre de 1969, muitos presos políticos de São Paulo eram levados para o Pelotão de Investigações Criminais (PIC) do $2^{\circ}$. Batalhão de Polícia do Exército (PE) e ao $2^{\circ}$. Esquadrão de Reconhecimento Mecanizado, conhecido como o

\footnotetext{
${ }^{216}$ V. "Marighella: polícia procura outro estudante”, Última Hora, de 20/11/68. V. tb. “Esta confusa história da metralhadora”. Última Hora, 22/11/68;

${ }^{217}$ Em abril de 2001 reportagens feitas pelo jornalista Caco Barcellos para o Jornal Nacional (TV Globo) apresentaram outra versão. Ele entrevistou um ex-soldado do Exército Valdemar Martins de Oliveira que relatou a operação na qual um casal de estudantes foi torturado e executado na mesma data, suspeito de participar da execução do capitão do Exército norte-americano Charles Rodney Chandler, agente da CIA, em 12/10/68, organizada pela VPR e ALN. O militar reconheceu a foto de Catarina como uma das pessoas executadas em um sítio localizado em São João do Meriti (RJ) e confirmou que o acidente foi forjado [ALMEIDA, 2009: 122-4]. Não se sabe ao certo quais órgãos de segurança e informação teriam participado dessa operação, mas esse testemunho confirmaria o envolvimento do Exército e o uso clandestino de um sítio, prática que viria a ser muito utilizada nos anos 1970.

${ }^{218}$ V. "Quedograma da ALN". Idem, ibidem.
} 
“Rec Mec”, situados próximo a sede do II Exército ao lado do parque Ibirapuera. Ali eram torturados e mantidos incomunicáveis, de acordo com o testemunho de Dulce Maia de Souza entre outros ${ }^{219}$. Os presos eram transferidos constantemente de uma dependência a outra e torturados na "Escolinha da PE”, conforme Carlos Roberto Pittoli, $3^{\circ}$. sargento daquela unidade e militante da VPR, preso no dia 5 de fevereiro de 1969.

No Rio de janeiro, os militares também estavam envolvidos em operações características de polícia política, os militantes presos eram torturados no DEOPS, no quartel da PE, localizado na rua Barão de Mesquita, ou na $1^{\text {a }}$. Companhia da PE, situada na Vila Militar ${ }^{220}$.

No primeiro semestre de 1969 também ocorreram prisões de militantes de outras organizações de luta armada em São Paulo, pessoas ligadas ao MRT (Movimento Revolucionário Tiradentes) e à Ala-Vermelha, uma dissidência do PCdoB. Derly José de Carvalho, dirigente da Ala que havia treinado guerrilha na China em 1966, foi preso no dia 28 de maio de 1969. Uma série de prisões de militantes do MRT, alguns eram seus irmãos, e de sua família levaram a casa onde Carvalho morava. Ele foi preso por Sérgio Paranhos Fleury, então, um policial do DEIC, órgão que assumira, naquele momento, parte das atividades de repressão à luta armada. No DEIC, Carvalho foi torturado pessoalmente por Fleury e Romeu Tuma, entre outros:

“Tive sorte, [...] porque o Sérgio Fleury era um doente mental, traficante e viciado. Era
um ótimo estrategista nessa coisa de fazer campana e tudo, mas era absolutamente
estúpido para fazer interrogatório. [...] A minha prisão, a dos meus irmãos e de mais
alguns companheiros [do Sindicato] dos Metalúrgicos de São Bernardo foram um
trampolim para ele entrar no DEOPS e ser delegado lá, que era o que ele queria. Ele era
da divisão de assalto a banco do DEIC. Eu fui para o DEIC, mas ele armou metralhadora
naquele prédio inteiro, porque os caras do DEOPS, do Exército e da Marinha queriam me
buscar de qualquer jeito. Ele não deixou. Saiu pau lá [...].
[...] Eu comecei a ser torturado no DEIC, uma questão de uns 10, 15 dias, mais ou menos.
Fiquei noventa dias incomunicável [...]. No DEOPS, fiquei numa cela do fundão. A maior
parte da tortura que eu sofri foi no DEIC. E quem batia era a equipe do Fleury [...]. Lá
tinha choque elétrico... As perguntas que eles faziam estavam relacionadas com as [...]
ações que foram abertas, [...] queriam saber onde é que estava o dinheiro. E também sobre
os aparelhos e os contatos. [...] Nesse período em que fiquei no DEIC fui torturado
pessoalmente pelo Fleury, pelo Brasileiro, [...] pelo Rubão, [...] pelo Fininho. Desses
caras eu me lembro o nome, dos outros...
[...] quando fui levado para o DEOPS [...] já havia muitos companheiros presos e aí a
gente conseguiu, inclusive, mandar informação para fora, através dos presos comuns a

${ }^{219}$ Entrevista concedida por Dulce Maia de Souza à autora. SP, 24/10/2008. AAPP/AEL-LEI; entrevista concedida por Alípio V. Freire à autora. SP, 19/12/2008, 15/03 e 13/04/2010. AAPP/AEL-LEI. V. tb. PITTOLI, Carlos Roberto. “A fortaleza e o queijo”, em Tiradentes, op.cit., p.109-10. Pittoli ficou incomunicável na PE durante 6 meses.

${ }^{220}$ Entrevista concedida por Antonio Roberto Espinosa à autora. SP, 25/05, 06 e 18/08/2009. AAPP/AELLEI. 
gente começou a montar um esquema. A tortura diminuiu, de vez em quando tinha uma sessão, porque aí a discussão já era sobre a questão do movimento sindical [...], a minha militância no Partido Comunista Brasileiro e no Partido Comunista do Brasil, que eles achavam partidos de bunda mole, que não eram perigosos. Eles só vieram a me interrogar sobre a viagem para a China no encerramento do inquérito, quando já estavam para mandá-lo para a auditoria.

[...] Eu acho que [...] fui o primeiro, praticamente, que foi preso pelo Fleury. Até então ele estava acostumado a mexer com a bandidagem! [...] quem estava preparado para esse tipo de coisa eram o Magnotti, o Romeu Tuma. Eu fui torturado no pau-de-arara com o Romeu Tuma sentado na frente. [...] a mim ele nunca torturou [fisicamente], mas eu estava no pau-de-arara aqui e, do lado, [ele dizia]: '- Eu sou bonzinho, eu entendo, sou da Ordem Política e Social'. O Magnotti também era assim, eles eram os bonzinhos e quem torturava era o Fleury e os meganhas dele, os investigadores.

[...] [eles estavam interessados] numa ação que a Ala Vermelha tinha feito e tinha sido 'aberta'. [...] muitas vezes, o Tuma e o Magnotti falaram: '- Mas tá na cara que você participou, todo mundo sabe! Abre o jogo logo, acaba com isso e ninguém mais vai pro pau. Nós vamos pegar esses companheiros seus e desmanchar eles no pau-de-arara!' Eu falava: “- Isso aí é com eles' ${ }^{221}$.”

Novas prisões foram efetuadas pelo DEOPS/SP, órgão responsável também pelas mortes dos militantes da VPR Hamilton Fernando da Cunha, assassinado em 11 de fevereiro, e Carlos Roberto Zanirato, em 29 de junho de 1969. No segundo semestre de 1969, o DEIC/SP foi responsável pela morte de dois militantes da Var-Palmares. Em 29 de julho agentes do DEIC assassinaram o líder estudantil Fernando Borges de Paula Ferreira atingido e preso numa emboscada no Largo da Banana, em São Paulo. Nesse local o metalurgico João Domingues da Silva também foi ferido e conseguiu fugir, mas acabou preso no mesmo dia em Osasco (SP). Alguns meses depois, no dia 23 de setembro, morreu no Hospital das Clínicas.

No mês de julho de 1969 foi criada a Operação Bandeirante (OBAN), resultado de um processo dirigido pelo comandante do II Exército, o general José Canavarro Pereira. Empresários e banqueiros foram recrutados pelo professor Antonio Delfim Neto, então ministro da Fazenda, e aderiram ao projeto contribuindo com grandes somas em dinheiro para a formação da Oban [GASPARI, 2002b: 60]. O órgão reuniu pessoal proveniente das três Forças Armadas, do Departamento de Ordem Política e Social (DEOPS), do Departamento da Polícia Federal (DPF) e da Secretaria de Segurança Pública (Polícia Militar e Polícia Civil). A OBAN não foi legalmente oficializada, mas se tornou o meio pelo qual as Forças Armadas passaram a atuar em grande escala nas operações de ordem policial, especializadas em repressão política ${ }^{222}$.

\footnotetext{
${ }^{221}$ Entrevista concedida por Derly José de Carvalho à autora. SP, 29/06 e 06/07/2010. AAPP/AEL-LEI.

${ }^{222}$ Em outubro de 1970, foi expedida uma diretriz e o documento "Planejamento de Segurança Interna" instituindo o SISSEGIN, "Sistema de Segurança Interna", por meio de diretrizes sigilosas do CSN aprovadas pelo presidente e não por diplomas legais regulares ou excepcionais como atos institucionais,
} 
Fundada sob o signo da ambiguidade, a OBAN não foi institucionalizada formal e juridicamente, mas por meio de um conjunto de medidas administrativas internas. Seu ato de fundação, no entanto, contou com a presença de importantes autoridades civis e militares. Seu objetivo consistia em "identificar, localizar e capturar os elementos integrantes dos grupos subversivos que atuam na área do II Exército, particularmente em São Paulo, com a finalidade de destruir ou pelo menos neutralizar as organizações a que pertençam” 223 .

Inicialmente, a OBAN funcionou nas dependências do $2^{\circ}$. Esquadrão de Reconhecimento Mecanizado (Rec-Mec) e, em seguida, a partir de 7 de setembro de 1969, passou a ocupar a 36 ${ }^{\mathrm{a}}$. Delegacia de Polícia, na rua Tutóia, próxima àquele quartel no bairro do Paraíso. No mesmo mês, o professor assistente da cadeira de Direito Constitucional da Faculdade de Direito de Guarulhos, Benedito Nunes Dias, assumiu a direção geral do DEOPS/SP e convidou Fleury para trabalhar com ele $\mathrm{e}^{224}$. As prisões efetuadas pelo DEOPS/SP continuaram a se suceder durante o ano de 1969. Em 3 de setembro, José Wilson Lessa Sabbag foi preso por policiais do DEOPS/SP e, possivelmente, assassinado por agentes da OBAN. Em 4 de novembro, a ALN recebeu um duro golpe, seu principal dirigente, Carlos Marighella, foi vítima de execução sumária em uma operação organizada por Fleury e sua equipe do DEOPS/SP [ALMEIDA, 2009: 160-163].

Não obstante, após um ano de funcionamento, a Oban conseguiu resultados considerados satisfatórios, e o comando das Forças Armadas decidiu disseminar o modelo em todo o país, criando os Centros de Operações de Defesa Interna - Destacamentos de Operações de Informações, chamados de DOI-CODI. As diretrizes administrativas que os

atos complementares ou decretos-leis. Fico considera possível que o SISSEGIN tenha sido chancelado por um dos decretos-secretos instituídos a partir de 1971. O documento foi produzido pela comissão composta pelos ministros da Justiça, do Exército, da Marinha, da Aeronáutica, do chefe do SNI e do secretário-geral do CSN. V. FICO, C., op.cit., p.119-20.

${ }^{223} \mathrm{O}$ comando coube ao coronel Antônio Lepiane, chefe do Estado-Maior da $2^{\text {a }}$ Divisão de Infantaria. O ministro da Justiça, Luís Antônio da Gama e Silva, e o general Carlos de Meira Mattos, chefe da Inspetoria Geral das Polícias Militares, também desempenharam um papel importante nesse processo. Ver JofFILY, Mariana. "Quando o ataque é a melhor defesa: interrogatórios políticos da Oban e do DOI-CODI”. In: Antíteses, Ahead of Print do v.2, $\mathrm{n}^{\circ} .4$, jul./dez. de 2009. Disponível em: $<$ http://www.uel.br/revistas/uel/index.php/antiteses>. Destaques meus.

${ }^{224}$ Fleury e Romeu Tuma tiveram as ascenções de carreira mais rápidas na polícia civil que se tem notícia. Tuma, em especial, destacou-se no Serviço Secreto do DEOPS e, por fim, tornou-se seu diretor. Fleury relacionava-se tão bem com Tuma que, quando da sua morte em 1979, sua amante, Leonora Rodrigues de Oliveira, amedrontada, entregou todos os documentos de Fleury a Tuma. Segundo Percival de Souza, Tuma indicou o delegado Alcides Cintra Bueno Filho para ser o responsável do DEOPS e do DOI-Codi/SP pelo esquema de ocultação de cadáveres efetuado no cemitério D. Bosco, em Perus, São Paulo. V. SouzA, P., op.cit., p. 27, 35, 45, 61 e 63, 180-81. 
implantaram eram secretas e formuladas pelo Conselho de Segurança Nacional, mas aprovadas pelos presidentes-generais Costa e Silva e Médici (e pela Junta Militar) e executadas pelos ministros militares e comandantes das forças locais [FICO, 2001:122].

Logo após o sequestro do embaixador norte-americano, a junta militar baixou os Atos Institucionais 13 e 14 no dia 5 de setembro de 1969, destinados a reforçar a estrutura legal do aparato repressivo. O AI-13 dava ao Executivo o poder de banir do país "o brasileiro que, comprovadamente, se tornar inconveniente, nocivo ou perigoso à Segurança Nacional”. O AI-14, uma emenda à Constituição de 1967, tornava a pena de morte, a prisão perpétua e o banimento aplicáveis em casos de "guerra psicológica, guerra adversa revolucionária ou subversiva” e de guerra externa. A definição desses tipos de guerra era vaga, assim como a ideia de que qualquer cidadão era potencialmente um “inimigo interno".

Em setembro de 1969 foi decretada nova Lei de Segurança Nacional e, em outubro, outorgada outra Constituição sob a forma da Emenda $\mathrm{n}^{0} .1$, durante o período em que o Congresso Nacional foi fechado por determinação dos militares [ALVES, 2005:18990].

Nesse contexto, similares à OBAN, os CODI tinham representantes das três Forças Armadas e das Polícias Civil e Militar, comandados pelo chefe do Estado-Maior do Exército. Estavam incumbidos de planejar, coordenar e assessorar as medidas de defesa interna, tanto de informações quanto de segurança. Os DOIs eram as unidades móveis e dinâmicas, controlados operacionalmente pela $2^{\text {a }}$ Seção do Estado-Maior do Exército e subordinados aos CODI ${ }^{225}$. Para combater o "inimigo interno", o DOI-CODI inspirou-se na teoria francesa sobre a "guerra revolucionária". Os franceses foram pioneiros em identificar e refletir sobre os conflitos, cujas características residiam na “indistinção entre política, ideologia e operações militares”. Eles localizavam no controle das informações e na unificação dos comandos político e militar o eixo do combate à “guerra revolucionária”, assentada na ação psicológica e na doutrinação ideológica, de caráter “insidioso" e "subliminar" 226.

\footnotetext{
${ }^{225}$ Todas as chefias de seções e subseções, à exceção da administrativa, cabiam aos oficiais das Forças Armadas. V. GASPARI, Elio. A ditadura escancarada. op.cit., p.181. Em 1970 foram criados os DOI-Codi do I Exército (Rio de Janeiro), do II Exército (São Paulo), do IV Exército (Recife) e do Comando Militar do Planalto (Brasília); em 1971 os da $5^{\text {a }}$ Região Militar (Curitiba), da 4 ${ }^{a}$ Divisão de Exército (Belo Horizonte), da $6^{\text {a }}$ Região Militar (Salvador), da $8^{\mathrm{a}}$ Região Militar (Belém) e da 10 ${ }^{\mathrm{a}}$ Região Militar (Fortaleza); em 1974, o do III Exército (Porto Alegre), substituindo a Divisão Central de Informações. FICO, 2001, p.124.

${ }^{226}$ V. MARTINS FILHO, João Roberto. "Tortura e ideologia: os militares brasileiros e a doutrina da guerre révolutionnaire (1954-1979)”. In: SANTOS, Cecília MacDowell; Teles, Edson; Teles, Janaina de A.
} 
O sistema DOI-Codi se constituiu na face secreta, mas também clandestina da repressão política. Esses centros de tortura funcionavam geralmente em lugares públicos como delegacias de polícia ou quartéis. O sistema foi utilizado para atuar e reprimir conjuntamente, e contou com o apoio de outros organismos além do CIE, tais como o Cenimar e o Cisa - os órgãos de informação e segurança das Forças Armadas envolvidos na ação de repressão direta por meio de sua atuação nos DOI-Codis ou em separado. Representantes da agência local do SNI também compunham os Codi.

Aliados a esse sistema, outros centros de tortura, de caráter totalmente clandestino, foram utilizados, e dos quais pouco se sabe. Alguns depoimentos de presos políticos registrados na Justiça Militar dão conta da existência de centros clandestinos de tortura em diversos estados do país: a "Casa dos horrores”, próxima a Fortaleza, no Ceará; a “Casa de São Conrado”, no Rio de Janeiro; a "Casa da Morte”, em Petrópolis (RJ); uma casa e o Colégio Militar, em Belo Horizonte (MG); a "Fazenda 31 de março", em Parelheiros, São Paulo [BNM, 1989: 239-46]; e a casa do Alto da Boa Vista, no Rio de Janeiro.

A casa do Alto da Boa Vista é, possivelmente, outro segredo bem guardado do Exército, conforme testemunho de Frederico Pessoa da Silva, um dos jornalistas e militantes do PCB presos pelo DOI-Codi/SP em outubro de 1975. Passado o período de torturas, Frederico Pessoa foi transferido para o Deops/SP e, em seguida, para o Presídio do Hipódromo. Estava confinado cerca de três ou quatro meses, quando foi retirado do presídio durante a madrugada e levado para o Rio de Janeiro. Desesperada, sua família entrou em contato com um antigo conhecido e amigo do general Reinaldo Mello de Almeida, comandante do I Exército, na tentativa de evitar novas torturas. Seus familiares receberam a notícia de que ele não seria torturado, contudo, Frederico experimentou no DOI-Codi/RJ outro tipo de tortura, que não deixava marcas físicas. No quarto dia de torturas foi levado para uma casa, que ele supõe localizada no Alto da Boa Vista. A transferência dele pode ter sido uma forma de fugir às pressões do comandante do I Exército e uma tentativa de conseguir uma possível retratação. De acordo com seu relato, esse foi um dos momentos mais difíceis entre as experiências-limite que vivenciou:

“[...] Para mim, tirando o negócio da tortura da minha mulher, do ponto de vista do sofrimento pessoal a tortura sem pancada foi pior do que a do DOI-CODI/SP, com choque e pancada. A tortura lá foi assim: me deixaram cinco dias sem dormir. Eles

(orgs.), 2009, Vol. I. De acordo com Carlos Fico, a criação do sistema teve forte influência norteamericana. V. FICO, 2001, p.115. 
pegavam, te levavam para uma sala de interrogatório completamente gelada, parecia um frigorífico e você ficava algemado numa cadeira de dentista [...]. O cara interrogava, você não falava, aí ele te levava pra uma cela pequena que a entrada, [...] parecia a de uma porta de frigorífico. [...] Era uma cela que você não podia ficar em pé, não podia deitar... sem nenhum tipo de janela nem coisa nenhuma. A cela era um forno, não sei se era proposital ou por causa do calor do Rio de Janeiro, sei lá 40 graus e [...] eu estava encapuzado... e não podia tirar, porque estava algemado com as mãos para trás. Aí daqui a pouco, passado algum tempo, [...] o cara te pega e leva de novo pra geladeira. E aí interroga, você volta pra uma segunda cela, com um sistema de som com um barulho ensurdecedor parecia turbina de avião, para você não dormir. [...] Numa terceira cela, você entrava e sentia um cheiro de vômito, sangue, de urina, de fezes e o chão todo melecado, sinal de que as pessoas que entraram ali estavam bastante machucadas [...] nessa cela o som era de pessoas torturadas, inclusive crianças, então eram gritos, gritos de mulher, grito de homem, grito de criança, e vários gritos, você tinha a sensação de que era muita gente que estava sendo supliciada naquele momento. E, aí, voltava pra geladeira. [...] Então, eles ficaram fazendo isso durante a segunda, a terça, a quarta e a quinta-feira, quando de noite eles me tiraram de madrugada do DOI-CODI e me levaram para uma casa no Alto da Boa Vista. Eu sei que é lá, porque eu conheço aquela área e posso calcular mais ou menos quanto tempo você gasta na Avenida Conde de Bonfim desde o Quartel do Exército até começar a subir a serra, e depois você sai do outro lado.

[...] Os caras me levaram deitado, entre o banco da frente e o banco de trás e o cara veio com uma bota ou um sapato em cima pressionando para eu não levantar a cabeça, certamente pra ninguém na rua ver. Chegou no lugar ele buzinou três ou quatro vezes, abriu uma garagem, o carro entrou e aí lá dentro o cara disse: 'Pode tirar o capuz' e eu não tirei. Ele arrancou o capuz da minha cabeça e disse: 'Olha, não faz a menor diferença você olhar na nossa cara'. A única coisa que eu não conseguia ver foram os nomes, porque o pessoal do Exército pelo, menos um deles, parecia que era o chefe tava com uma farda e tinha esparadrapo cobrindo o lugar onde fica o nome. Aí me levaram pra um quarto sem janela que era o 'paraíso': cama limpa, lençol limpo, toalha limpa, tinha um banheiro anexo, porque eu estava podre nesses cinco dias. Tomei banho, o cara trouxe comida, pela primeira vez eu comi com alguma vontade e dormi, cai no sono, não sei quanto tempo. [...] Aí o cara me acorda e faz uma piada do tipo: '- Você vai ter muito tempo pra dormir', ou se 'Você vai dormir pra sempre!' [...] Ele me dá um papel e uma caneta para eu fazer minha autocrítica. Aí eu escrevo uma carta pra minha família, me despedindo da minha família, dizendo que eu não me arrependia de nada e se tinha alguma coisa que eu me arrependia era de ver que em São Paulo não tinha um círculo eficientemente forte pra resistir aquilo, que era a única coisa que eu me arrependida porque o resto eu repetiria tudo de novo. Aí o cara pegou e rasgou o papel e diz: ' - Não tem jeito, só matando!' O fato é que ele me deu um soco, mas na mesma hora chamaram ele [...]. Não sei quanto tempo depois, era quase noite, ele vem e bota o capuz em mim de novo, algema e me põe num carro e sai de lá, descendo. [...] Quando chegou embaixo, [...] me tiraram do carro e me meteram num camburão. Depois eu vi que era um camburão do Exército e cheguei no DOI-CODI. [...] Lá, me botaram num outro camburão [...] da polícia do Exército e me levaram para o DOPS. E já era sexta-feira à noite. [...] Depois, voltei para São Paulo ${ }^{227}$.”

No mesmo período em que algumas dessas casas clandestinas, utilizadas como centros de extermínio, começaram a ser operadas pelos órgãos de informação, foram criados os campos de concentração na região da Guerrilha do Araguaia, analisados no item anterior.

${ }^{227}$ Cf. entrevista de Frederico Pessoa da Silva concedida à autora. SP, 26, 27 e 28/08/2008. AAPP/AELLEI. 


\subsection{Os campos argentinos e os centros de tortura e extermínio no Brasil}

Retomarei aqui as definições de campo de concentração analisadas no item anterior, conforme os estudos de Hannah Arendt e Giorgio Agamben. Utilizo como referência principalmente a definição de Arendt de campos de extermínio, onde a vida era organizada de forma sistemática para causar o maior tormento possível. E o conceito de campo compreendido como o espaço onde se localiza a indistinção entre lei e sua aplicação, entre lei e situação de fato, como materialização do estado de exceção e espaço em que a "vida nua”, a vida exposta, meramente biológica e “matável”, e a norma entram em um limiar de indistinção.

Para Agamben, porém, encontram-se virtualmente num campo todos os que estejam num local com essas características, independentemente da natureza ou da denominação dos crimes ali cometidos ou de sua topografia [AGAMBEN, 2002: 181]. Essa formulação muito abrangente representa, contudo, um esforço de teorizar sobre o estado de exceção na atualidade que pode nos auxiliar a compreender a enorme estrutura burocrática e administrativa criada pela legalidade de exceção e a diversidade de modalidades repressivas usadas durante a ditadura brasileira.

Levando-se em conta que Arendt e Agamben centralizaram suas análises principalmente nos campos nazistas, buscarei aqui estabelecer algumas comparações com os campos e centros clandestinos de tortura da Argentina, em função da sua proximidade temporal e das semelhanças existentes entre as duas ditaduras, orientadas pela Doutrina de Segurança Nacional. Essa referência nos possibilita situar e analisar melhor o aparato repressivo brasileiro e o sistema DOI-Codi.

A maioria dos campos de extermínio argentinos localizava-se em dependências de órgãos de segurança, em lugares fechados, controlados e operados pelo pessoal das polícias ou das Forças Armadas, submetidos à cadeia de comando militar. Nesses locais, os presos políticos não eram identificados pelos nomes, mas apenas por um número, permaneciam sempre encapuzados e acorrentados pelos pés, obrigados a ficar deitados ou agachados, sem poder falar ou se mexer, geralmente, mantidos em compartimentos sem teto, separados, individualmente, por divisórias de madeira de 80 centímetros de altura. Esses locais chamavam-se “cuchetas” e permitiam aos guardas verem os prisioneiros simultaneamente, como num panóptico. Os prisioneiros eram submetidos a toda sorte de torturas, disciplina e crueldade. O objetivo era desumanizá-los por dias ou meses. E ainda que tivessem diferenças, todos os campos coincidiam no principal - manter e alimentar o 
aparato do "poder desaparecedor" - o destino final era a morte, salvo em casos muito excepcionais $^{228}$.

Os chamados “subversivos” eram considerados menos que seres humanos, conforme as palavras do general Ramón Camps, chefe da Polícia da Província de Buenos Aires: “não desapareceram pessoas, mas subversivos” [CALVEIRO, 2006: 37]. A institucionalização dos campos formou uma "máquina de torturar, extrair informação, aterrorizar e matar”. Nos campos argentinos era suportada a morte lenta, dolorosa e sinistra conjugada com a tortura e o tormento indiscriminados e ilimitados, onde era utilizado também o trabalho escravo. Era uma maquinaria, que levou a uma dinâmica baseada na rotina, na burocratização e naturalização da morte, o que dava a ela aparência de um dado em planilha. “A sentença de morte de um homem era só uma inscrição 'QTH fixo', sobre o dossiê de um desconhecido" 229 .

A "guerra subversiva” era especial, era uma "guerra suja” que necessitava de métodos excepcionais, sem ética. Era preciso erradicar, exterminar a ameaça subversiva o que explica a ferocidade retratada nos testemunhos dos poucos sobreviventes. Um dia, chegava a ordem de "traslado" com uma lista, às vezes esta já vinha pronta de fora do campo, como em La Perla, e o guarda organizava a fila e entregava os "pacotes”, o nome pelo qual eram tratados os presos destinados ao desaparecimento forçado [CALVEIRO, 2006: 38].

“Traslado” era o termo que indicava os procedimentos de matar e desaparecer com o prisioneiro. Sabe-se muito pouco sobre eles, mas eram rodeados de tensão e violência. Em certos casos, os prisioneiros eram transportados para longe do campo e fuzilados, atados e amordaçados. Enterravam ou queimavam os cadáveres, por vezes, jogavam-nos na rua e simulavam tiroteios. O método adotado de maneira massiva foi o de jogar ao mar os prisioneiros adormecidos por soníferos, para onde eram transportados de caminhão ou de avião, os chamados "voos da morte”. “A aplicação do sonífero arrebatava do prisioneiro sua última possibilidade de resistência, mas também seus traços mais elementares de humanidade: a consciência, o movimento” [CALVEIRO, 2006: 38]. Amordaçados, adormecidos, manietados, encapuzados, os “pacotes” eram jogados ao mar ainda vivos.

\footnotetext{
${ }^{228}$ Alguns poucos conseguiram fugir de campos de extermínio, ver CALVEIRo, Pilar. op.cit., p.30-1. Outros, em pequeno número, foram libertados; destes, vários realizaram trabalho escravo. Fala-se em 4.800 desaparecidos na ESMA, sendo que cerca de 200 prisioneiros políticos desse campo sobreviveram.

${ }^{229} I d$., Ib., p.32 e 34. De acordo Calveiro, funcionaram 340 campos de extermínio na Argentina presentes em 11 das 23 províncias do país. A organização Memoria Abierta fez um levantamento com mais de 600 campos. <www.memoriaabierta.org.ar>. Acesso em 10/01/2011. Livre tradução da autora.
} 
A determinação em anular as marcas da existência dos "subversivos” fez com que fossem organizadas maternidades improvisadas nos campos para que as prisioneiras grávidas tivessem seus filhos, antes de serem assassinadas. Estes foram criados pelos militares e algozes de seus pais, para que crescessem educados pela ideologia contrária, para que as marcas da presença e as heranças dos pais não sobrevivessem nem nos filhos. Estima-se que haja 500 bebês "apropriados”, dos quais em 103 casos se conseguiu reconstituir suas identidades ${ }^{230}$.

O dispositivo dos campos se encarregava de fragmentar seu funcionamento, utilizando grande quantidade de pessoal especializado em distintas tarefas para, assim, "suspender" responsabilidades morais. Havia os "Grupos de Tarefa”, divididos entre as “patotas” que sequestravam e os que faziam o "trabalho sujo”, os grupos de inteligência para manejar as informações e a tortura, conduzida sempre por um oficial; outros eram guardas que faziam a segurança e controle dos prisioneiros; e havia ainda os que os “trasladavam” [CALVEIRO, 2006: 38-9].

Os mecanismos para despojar as vítimas de seus atributos humanos facilitavam a execução mecânica e rotineira das ordens. Um “dispositivo montado para aquietar consciências, previamente treinadas para o silêncio, a obediência e a morte”. Era parte do mecanismo a autorização dos superiores para reforçar a "aparência” de procedimento burocrático. “A autorização dos superiores legalizava esses dispositivos, onde se é apenas uma peça da engrenagem, gerando impotência e sensação de falta de responsabilidade entre os torturadores e funcionários subalternos.” Havia uma relação de superioridade vaga, na qual não estavam declarados o nome ou sobrenome deles próprios e dos superiores [CALVEIRO, 2006: 39].

No Brasil, os DOI-Codis foram os principais locais onde se dava a decisão sobre a vida e a morte dos dissidentes e perseguidos políticos e onde muitos deles foram assassinados. No DOI-Codi do II Exército, por exemplo, pelo menos 64 pessoas foram vítimas de homicídio ou desaparecimento forçado, no período transcorrido entre setembro de 1970 e janeiro de $1976^{231}$. As descrições e relatos dos sobreviventes nos indicam que

\footnotetext{
${ }^{230}$ V. o site www.abuelasplazademayo.org.ar; e Pai acha filho 'roubado' na ditadura argentina. OESP, 24/02/10; HARDMAN, Francisco Foot. Vozes que não se deixam morrer. OESP, 28/02/10, p.J5.

${ }^{231}$ Dos 426 mortos e desaparecidos políticos que se tem notícia no Brasil, 105 foram assassinados em São Paulo. Desse total, 64 morreram ou desapareceram no DOI-Codi/SP e 5 no Deops/SP; 22 foram assassinados entre 1968 e setembro de 1970, 4 antes da formação da Oban e o restante, assassinados neste local, sendo que dois tornaram-se desaparecidos políticos: Virgílio Gomes da Silva, em 29/09/69, e Antônio dos Três Reis de Oliveira, em 17/05/70. Entre 1970 e 1976, 24 militantes desapareceram. V. [ALMEIDA, 2009].
} 
nesses lugares ocorria a suspensão de direitos, a suspensão do sujeito jurídico e da identidade do sujeito, mas não em dimensões massivas, conforme registram os testemunhos a respeito dos campos argentinos [CALVEIRO, 2006].

Destacam-se as diferenças fundamentais existentes entre a repressão política argentina e a brasileira: a extensão e profundidade do trabalho de despersonalização dos prisioneiros, que os transformava em mortos-vivos antes de matá-los, e o desaparecimento massivo dos mesmos. A repressão política na Argentina atingiu essencialmente os militantes, mas alcançou uma periferia muito ampla de pessoas direta ou indiretamente vinculadas a eles. A arbitrariedade na escolha de quem sequestrar proporcionava a capacidade de disseminar terror na sociedade, gerando uma ameaça constante e generalizada [CALVEIRO, 2006: 45-6]. Os campos concebidos como depósitos de corpos dóceis que esperavam a morte, aceitando em filas a injeção de sonífero (pensando ser vacina), foram possíveis pela disseminação generalizada do terror, por meio da tortura e despersonalização do prisioneiro. Eram “mortos que caminham”, de acordo com a expressão do suboficial Raúl David Vilariño. O campo foi efeito e foco da disseminação do terror [CALVEIRO, 2006: 52-3, 61].

Não se conhece testemunhos no Brasil que descrevam lugares onde os prisioneiros eram sistematicamente mantidos encapuzados em tempo integral, acorrentados sentados ou deitados, identificados apenas por números. Descrições, feitas na Justiça Militar, de sobreviventes sequestrados e levados para a "Fazenda 31 de março" relataram, porém, que ali foram mantidos acorrentados, nos intervalos da tortura, pelos tornozelos e pulsos em argolas de ferro fixadas na cama ou em blocos de cimento num quarto com janelas lacradas. Outro sobrevivente narrou que além de ser torturado no pau-de-arara, foi pendurado pelos pés, permanecendo suspenso por longos períodos, e que sofreu sessões de “afogamento" num rio próximo desse local ${ }^{232}$.

Há, contudo, procedimentos da repressão política argentina bastante similares aos da brasileira. Nos centros de tortura, tais como os DOI-Codis, era patente a fragmentação das tarefas de repressão, também era comum a ocultação dos nomes verdadeiros daqueles que torturavam e trabalhavam em contato direto com os presos. Os torturadores eram chamados por apelidos ou "nomes de guerra” como "Dr. Pepe” ou “Dr. Tibiriçáa", sempre fazendo alusão a patentes e cargos mais altos do que aqueles que efetivamente exerciam. Adotar a aparência de procedimento burocrático também fazia parte das práticas da

${ }^{232}$ Cf. depoimentos de 3 sobreviventes sequestrados em 1975, citados em BNM, 1985, p.243-6. 
repressão brasileira: havia a informação recebida e processada; formulários, dossiês e relatórios regulares que registravam nomes e números, ordens recebidas e cumpridas; turnos de guarda etc. Tudo muito impessoal, cada homem como uma peça de um mecanismo maior, que disseminava o terror.

Nos DOI-Codi havia uma clara divisão de tarefas e setores compartimentados com distintas atribuições. No DOI-Codi do II Exército, por exemplo, três equipes de “interrogatório” se revezavam em turnos de 24-48 hrs. Elas não eram compostas pelos mesmos agentes das equipes de "busca e apreensão". O trabalho de sistematizar as informações extorquidas nos “interrogatórios" era feito pelo setor de "informação e análise”, cuja sala ficava no mesmo corredor das salas de torturas ${ }^{233}$. Divisão de tarefas que aumentava a eficiência e compartilhava responsabilidades. A confiança na impunidade dos torturadores era enorme, tanto que a maioria dos ex-presos políticos entrevistados não menciona o uso de capuzes durante as sessões de tortura no DOI-Codi do II Exército ${ }^{234}$.

Pilar Calveiro identificou dois mecanismos de tortura na ditadura argentina: o tormento como tecnologia eficaz, fria, asséptica e eficiente de “chupar” e o tormento inquisitorial $^{235}$. "Os dois pretendem produzir a verdade, produzir um culpado e arrasar o sujeito, mas o fazem de maneiras diferentes. Ambas as formas implicam o processamento dos corpos, a extração do que serve e o desprezo do homem. Entretanto, a modalidade inquisitorial destrói mais os corpos, é mais brutal, leva mais sofrimento direto sobre suas vítimas, mas é menos eficiente para extrair, está menos preparada para aproveitar até a última gota útil de um homem. Também é provável que a modalidade “asséptica” produza uma menor deterioração pessoal nos homens que a aplicam e lhes permita conceber-se a si mesmos como simples pessoal técnico” [CALVEIRO, 2006: 70].

O tormento como tecnologia eficaz correspondia à busca por informação operativamente valiosa, para lograr sequestrar mais gente e, em geral, durava poucos dias. A tortura era usada de maneira irrestrita e ilimitada, não importando se deixava marcas, sequelas, lesões ou até se matava a vítima. Representava também uma iniciação ao universo concentracionário, assinalava uma ruptura entre o mundo de fora e o de dentro,

\footnotetext{
${ }^{233}$ Entrevista concedida por Marival do Canto Chaves, ex-agente do DOI-Codi/SP e do CIE, à Comissão de Familiares de Mortos e Desaparecidos Políticos. São Paulo, CJP-SP, 20/06/92. V. tb. [FICO, 2001, p.125].

${ }^{234}$ Presos pelo DOI-Codi/SP em 1975 mencionaram o uso de capuz; prisioneiros do Rio de Janeiro também, mas não foi possível determinar os períodos ou locais onde essa prática era mais utilizada.

${ }^{235}$ A "patota” era o grupo operativo encarregado "chupar”, ou seja, a operação de sequestrar os prisioneiros, na rua, em casa ou no local de trabalho. "Chupar" pode significar também sugar todo conhecimento útil do prisioneiro e fazê-lo "transparente” [CALVEIRO, 2006, p.34 e 61].
} 
um antes e um depois. A nudez, o capuz, as mordaças, os grilhões, a dor e perda de pertença assinalavam que as normas, as lógicas do mundo exterior e a própria humanidade estavam canceladas. O torturador não via o rosto da vítima, castigava um corpo sem rosto, castigava um subversivo não um homem. Ocorria "uma negação da humanidade da vítima em dobro: frente a si mesma e frente a quem a atormenta”, que facilitava e naturalizava o tormento para quem praticava a tortura. O tempo e a vida eram controlados pelos torturadores, pois a tortura para ser eficaz deveria ser ilimitada [CALVEIRO, 2006: 62-3].

No ritual purificador, mais que centrar-se na informação buscavam o castigo das vítimas, seu desmembramento físico, como uma espécie de vingança que era concretizada em signos visíveis sobre os corpos. Nesses casos usavam o castigo com paus e chicotadas, que deixavam marcas. Esse tratamento era acompanhado de tortura sexual, visando à humilhação, e foram frequentes as violações de homens [CALVEIRO, 2006: 66]. Os torturadores e mandantes consideravam que estavam consumando um "ato de purificação”, castigando o mal como "cruzados do bem e da moralidade” [CALVEIRO, 2006: 68].

A tortura no Brasil visava alcançar a despersonalização do indivíduo tanto para obter informação quanto para castigar, reprimir e normatizar. A tortura, embora amplamente utilizada e de maneira muitas vezes ilimitada, tinha como objetivo central quebrar as resistências dos prisioneiros para obter informações sobre os "pontos” encontros e contatos com outros militantes, geralmente, realizados na rua - e "aparelhos", os lugares usados como esconderijos, para realizar reuniões, guardar material etc. Buscavam informações sobre a composição e estrutura das organizações clandestinas e suas atividades para neutralizá-las ou destruí-las. Uma das principais diferenças era que no Brasil torturavam também para obter informações que auxiliassem a formar a acusação dos processos na Justiça Militar ${ }^{236}$.

Os repressores brasileiros utilizaram as mais cruéis e diversificadas técnicas de tortura, passando a exportar "tecnologia” de tortura por meio de cursos no exterior e no país. Embora buscassem produzir o máximo de tormento ao prisioneiro, na maior parte

\footnotetext{
${ }^{236}$ Na Argentina, havia prisioneiros políticos “legais”, aqueles cuja prisão foi reconhecida formalmente. Uma parte deles foi submetida ao poder judicial e, outra, ficou à disposição do poder executivo, sem ser processada judicialmente. Esse dispositivo foi criado pelo Estado de sítio decretado por Isabel Peron no final de 1974 e mantido até as eleições de 30/10/83, quando teve fim a ditadura. Antes do golpe de 26/03/76, calcula-se que havia 1.500 presos políticos no país. A maior parte dos presos políticos considerados "legais" foi presa no período anterior a este golpe. KoutziI, Flávio. Pedaços de morte no coração. Porto Alegre, LPM, 1984, p.26-9.
} 
das vezes o objetivo final não era a morte ou o desaparecimento. No Brasil, a busca pela despersonalização do preso não chegou ao nível e grau de sistematização utilizado na Argentina, porque o objetivo da repressão política era eliminar os dissidentes de forma bastante seletiva. Na Argentina, a meta de erradicar a subversão com armas excepcionais foi levada ao extremo: o desaparecimento forçado de milhares de pessoas por meio dos campos de extermínio.

De acordo com os testemunhos, a tortura no DOI-Codi do II Exército poderia durar um período de uma semana a um mês, aproximadamente. Gradualmente, a tortura era intensa nos primeiros dias e ia diminuindo nas semanas seguintes. Contudo, houve casos em que sua duração foi maior. Depois de um ou dois meses, em geral, o prisioneiro era levado para o Deops, onde poderia voltar a ser torturado pelo brutal delegado Sérgio Paranhos Fleury, o que gerava grande tensão entre os presos, ou, por vezes, voltar para o DOI. No DEOPS, o preso poderia permanecer cerca de um a três meses, até ser formalizado seu inquérito, quando era libertado ou enviado para algum presídio.

De acordo com a Lei de Segurança Nacional (decreto-lei 898/69), os presos políticos podiam ficar incomunicáveis por 10 dias, sendo autorizado que permanecessem 40 dias presos na fase de inquérito ${ }^{237}$, uma das lacunas na zona de indistinção entre o que estava “fora e dentro do ordenamento jurídico" da ditadura brasileira. Nesse período, o preso poderia ser torturado sem que as autoridades constituídas fossem obrigadas a dar qualquer satisfação a respeito. Diversos relatos testemunharam que os prisioneiros permaneciam sem poder avistar-se com seus familiares ou defensores por meses e, somente após longo período de reclusão, iniciava a formalização dos processos na Justiça Militar.

No DOI-Codi/SP, os presos não conseguiam fazer contato com familiares e advogados, na maioria das vezes isso ocorria somente no Dops, depois de alguma espera. $\mathrm{O}$ isolamento era quase total. A espera para saber qual seria o destino do prisioneiro era outra forma de tortura e representava uma ameaça permanente, pois várias pessoas voltaram a ser torturadas depois da fase inicial. Parentes e advogados frequentemente se dirigiam ao DOI-Codi na tentativa de encontrar seus familiares e clientes ou, pelo menos, obter o reconhecimento da prisão deles. Idibal Pivetta, advogado de presos políticos, que

\footnotetext{
${ }^{237}$ Cf. FICO, 2001, p.113, que cita 45 dias, mas em BNM, 1985, consta 40 dias, p.175. De acordo com o Código Penal Policial Militar da época, a prisão preventiva só podia ser decretada quando houvesse prova do fato delituoso ou indícios suficientes de autoria, fundada na garantia da ordem pública.
} 
chegou a ficar preso por mais de dois meses em 1973 (entre outras prisões), relatou como era a busca por informações sobre as pessoas sequestradas:

\begin{abstract}
"Se alguém tivesse sido preso, eu sabia que eles não iriam reconhecer, mas eu ia lá [no DOI-Codi], batia na porta e falava: '- Queria falar com o oficial do dia'. Aí vinha um cara, um tenentinho, e eu falava: '- Queria falar com o fulano de tal que está detido aí, sou advogado dele'. [...] Nem mandavam entrar, você ficava na porta, voltava alguém cinco minutos depois falando: '- Não tem nenhum preso com esse nome'. Assim eles ficavam sabendo que o advogado já sabia e que estava mexendo os pauzinhos e, isso, acredito, evitou até mortes. Eu andava com uma máquina Lettera 22 e papel timbrado no carro [...]. Já estavam escritos todos os dados das pessoas, pois tinha gente que me deixava procuração para me constituir como advogado. [...] me traziam procurações de pessoas, que ficavam guardadas comigo. Se a pessoa 'caísse', eu já tinha como fazer o habeas corpus e levar na Auditoria, mesmo sabendo que não ia funcionar, mas assim o juiz auditor ficava sabendo. Comunicava para eles e ia para o DOI-Codi, onde fui umas 50 vezes. Era uma verdadeira loucura chegar lá, bater na porta, às vezes, de madrugada e ver surgir o sentinela. E eu insistia. [...] O engraçado é que chamavam, sempre chamaram. [...] Voltava alguém e dizia: '- Não tem cliente seu aqui', puto da vida! De qualquer forma, ficavam sabendo que sabíamos. Acho que isso foi muito importante. Isso e a comunicação para gente como o Gerald Thomas [que era da Anistia Internacional] ou para alguma outra pessoa, de Cuba ou outro lugar. Como faziam esse trâmite, não sei, mas funcionava e acho que funcionou muito. Muitas mortes aconteceram, mas algumas, acredito, foram evitadas. Quais, não sei $^{238}$.”
\end{abstract}

Como na Argentina, após a fase de inquérito a possibilidade de reiniciar a fase de torturas estava sempre presente, mas era relativamente excepcional [CALVEIRO, 2006: 70]. Desde o momento em que cessava essa fase, restavam a debilidade física, as dores, a culpa, o sofrimento e a angústia. Enquanto o militante sequestrado permanecesse nos centros de tortura, continuava a tortura surda, a incerteza sobre a vida, o isolamento, a desconfiança de todos, a má alimentação, o maltrato e a humilhação. O medo gerado pelo terror da tortura, da insegurança e incerteza sobre a vida era permanente, conforme relatou Maria Amélia de A. Teles, militante do PCdoB presa em 28 de dezembro de 1972, com o marido e um dirigente do partido, Carlos Nicolau Danielli, assassinado sob tortura no dia 30 de dezembro, no DOI-Codi/SP:

“Quando estávamos na OBAN [DOI-Codi], [os torturadores] faziam uma classificação
separando os 'terroristas' e os 'subversivos'. Os terroristas eram os ligados à luta armada
e eram considerados os inimigos prioritários deles. Eu nunca soube se me classificavam
de terrorista ou subversiva, mas a gente tinha medo de que sendo classificada como
terrorista era maior a probabilidade de ser morta. Havia horas que eles me torturavam
muito e eu achava que morreria. Eles sempre me chamavam de terrorista na hora da
tortura, mas eu ficava tempos sem ser nomeada. O Danielli era considerado terrorista e foi
assassinado sob tortura dias depois da nossa prisão, mas ele era dirigente, procurado, tinha
foto dele no álbum de 'terroristas' e havia um x naqueles que já haviam sido mortos. E
havia a questão da Criméia [minha irmã] ser guerrilheira e eles punham na minha conta as

${ }^{238}$ Entrevista concedida por Idibal Almeida Pivetta à autora. SP, 12/11 e 04/12/2008. AAPP/AEL-LEI. 
atividades dela. Eles falavam que nós três éramos responsáveis pelos 8 militares mortos no Araguaia.

Eles diziam que eu ia morrer. Eu iria a um ponto com o 'Gustavo' [Luiz Ghilardini] na rua Domingos de Moraes e haveria um tiroteio e eu seria morta neste tiroteio. Depois que o Danielli morreu, o delegado Calandra, conhecido como 'capitão Ubirajara', apareceu com a manchete do jornal 'Terrorista morto em tiroteio', com a foto do Danielli torturado ao lado, no jornal, e disse: 'Leia essa manchete, porque você pode ganhar uma manchete igual'. Eu respondi que ele não havia morrido daquele jeito. E ele retrucou: 'Aqui nós damos a versão que nós queremos'.

Somente em 22 de junho de 1973, quando acabou minha incomunicabilidade e tive contato com advogados, no DOPS, é que fiquei achando que era considerada 'subversiva'. Quando saí da OBAN, no final de fevereiro, continuei na dúvida. Levaramme para o DOPS e achei que não queriam me matar, mas fiquei na dúvida até junho ${ }^{239}$."

No Brasil, como em outros lugares, diversos relatos descrevem que durante ou logo após as primeiras sessões de tortura o prisioneiro, muitas vezes, “[...] preferia literalmente morrer do que regressar a essa situação [...]. A morte podia aparecer como uma libertação/liberação [...]. E, sem embargo, decidir a própria morte era uma das coisas que estava vetada [...]”. Descobria-se, então, “não a dificuldade de viver senão a de morrer”. Muitos sobreviventes relatam intentos, às vezes absurdos e desesperados, para encontrar a morte: “[...] tomar água podre, deixar de respirar, tentar suspender voluntariamente qualquer função vital. Mas não era tão simples. A máquina inexorável havia se apropriado zelosamente da vida e da morte de cada um” [CALVEIRO, 2006: 66]. Similar ao que acontecia na Argentina, mesmo julgando-se deuses, os torturadores associavam comumente o DOI-Codi ao inferno e deixavam claro que eram donos da vida e da morte e do tempo naquele lugar.

Anivaldo Padilha, um metodista militante da Ação Popular (AP), foi preso em 28 de fevereiro de 1970, em função de uma denúncia feita ao DEOPS/SP pelo pai de um militante. Agentes do delegado Sérgio P. Fleury fizeram campana na casa a noite toda, mas pela manhã, quando Anivaldo e os companheiros foram presos, ele havia passado a responsabilidade da operação para o DOI-Codi ${ }^{240}$. Anivaldo, depois de ser muito torturado, foi enviado ao Dops, mas teve de retornar ao DOI-Codi três vezes, um procedimento incomum, que levou-o a pensar seriamente em se suicidar. Anivaldo foi vítima da resistência do Dops em formalizar seu processo na Justiça Militar. A polícia civil alegava falta de elementos para processá-lo. Foi torturado nas três ocasiões para

\footnotetext{
${ }^{239}$ Entrevista concedida por Maria Amélia de A. Teles à autora. SP, 20/08/2001. V. a classificação citada acima, em "Terroristas e subversivos". Informações, Álbum nº.1-A, DEOPS/SP, 30-Z-160-14.894 e ss. Danielli e Ghilardini foram assassinados sob tortura, respectivamente, em 30/12/72 e 04/01/73. V. AlmeIDA, 2009, p. 398-400 e p. 409-410.

${ }^{240}$ V. mais sobre a trajetória de Padilha em GREEN, James N. Apesar de Vocês. Oposição à ditadura brasileira nos Estados Unidos, 1964-1985. São Paulo, Companhia das Letras, 2009, p.308-15 e ss.
} 
confessar algo que servisse para fundamentar o inquérito policial. Anivaldo relatou-nos sua experiência de terror diante da tortura:

"Fui preso como membro da APML, se bem que na prisão eles não conseguiram identificar isso de forma muito clara. Eu tinha criado nesse período vários grupos com os quais me relacionava, como desdobramento do trabalho da AP. Alguns tinham metodistas e pessoas de outras igrejas também, em São Paulo principalmente. A rede que eu mencionei era em grande parte ecumênica, a rede de rota de fuga também era de pessoas ligadas às igrejas. [...] Eu tinha acabado de voltar de três acampamentos de trabalhos que eu havia organizado, um deles ficava na região de Tenente Portela, no Rio Grande do Sul, divisa com Argentina, numa das áreas que eu estava organizando como rota de fuga. Era um grande acampamento em duas cidades em Ijuí e em Tenente Portela. Havia um programa de alfabetização também, outro na região de Uberlândia (MG) e um outro, em Feira de Santana (BA). A minha prisão se deu numa circunstância muito esquisita, mas que mostrou alguns furos de segurança.

[...] foi na primeira acareação que as torturas começaram com a palmatória e com choques elétricos na mão, amarraram os eletrodos na mão. Depois eles nos levaram para a cela, naquela noite logo depois me chamaram novamente para nova acareação com a Eliana e esse processo de tortura durou o tempo que a gente esteve lá. A primeira vez nós ficamos 21 ou 20 dias na Operação Bandeirante [DOI-Codi] e as torturas eram diárias nesse período. Foram muito intensas no começo e depois é que diminuíram um pouco.

[...] primeiro [queriam] que a gente confessasse e assumisse que era da AP. [...] me lembro que, quando cheguei, a primeira coisa que o capitão Albernaz falou foi: '- Olha, a guerra acabou para você, então é melhor contar tudo’. Ele já foi dizendo: ‘- Porque aqui ninguém sai vivo sem contar a história'.

[...] depois que abriram o pacote, viram o material, constataram que tinha coisa da AP, aí eles queriam a confirmação da participação na AP. O outro objetivo era destruir a pessoa, fazer você se sentir totalmente destruído do ponto de vista moral, psicológico, físico. E isso é uma coisa muito terrível. Eu confesso que, naquele momento, entrei numa crise profunda de medo, sabia que ia continuar sendo torturado, tinha medo de não resistir. Não no sentido de morrer, isso nem tanto, mas tinha medo de não resistir e dizer tudo que sabia. Eu sabia bastante coisa, tinha condições de entregar muita gente do comitê central. [...] Eu tinha ponto naquela semana com pessoas do Comitê Regional. [...]sabia onde algumas pessoas moravam, que faziam parte dos grupos que eu havia criado, grupos de apoio. Sabia onde muitas dessas pessoas trabalhavam, residiam, ou seja, eu tinha condições de encher a OBAN com muita gente. Além de pessoas da igreja, jovens que eu sabia que eram militantes de outras organizações também. Eu tinha duas colegas da ALN, ou seja, podia fazer um estrago enorme. Então, foi um processo de crise muito grande. Principalmente, na primeira noite e na segunda também, mas essa [primeira] noite foi terrível. Eu cheguei realmente a considerar, a contemplar a possibilidade de um suicídio, porque eu tinha certeza, naquele momento, que não ia sair vivo de lá. Pelo nível de violência que eu tinha visto, e pelo tipo de informação que eles queriam e que eu não ia dar". ${ }^{241}$

Ainda que o tempo de permanência usual no DOI-Codi de São Paulo fosse de um a dois meses, alguns militantes estiveram nesse centro de tortura por um longo período, como nos relatou Artur Scavone, guerrilheiro do Molipo (Movimento de Libertação Popular). Scavone ficou nove meses no DOI-Codi/SP, entre fevereiro e outubro de 1972. Outros presos também permaneram sequestrados ali por muito tempo, tais como Pedro

${ }^{241}$ Entrevista concedida por Anivaldo Padilha à autora. SP, 09 e 21/12/2009, AAPP/AEL-LEI. 
Rocha e André Ota, militantes do Molipo, e Eliana Potiguara, Darci Miyaki, Linda Tayah, militantes da ALN (Ação Libertadora Nacional), entre outros ${ }^{242}$.

No período acima mencionado aconteceu uma série de prisões de militantes da ALN e do Molipo, algumas seguidas de assassinatos e desaparecimentos, decorrentes da ação de agentes infiltrados. Possivelmente, a longa permanência desses militantes no DOI-Codi deveu-se à necessidade dos órgãos de segurança de manter em sigilo a ação desses agentes infiltrados, evitando a comunicação das prisões e das suspeitas de determinados militantes às organizações guerrilheiras.

Em geral, a situação de domínio do preso nos DOI-Codis era quase total, o que gerava enorme desespero, conforme nos foi relatado por Rosalina Santa Cruz, militante da VAR-Palmares, presa no Rio de Janeiro em 3 de dezembro de 1971, com o marido, Geraldo Leite:

"Eu tive um diálogo com o torturador que mostra a nossa impotência diante de todo o poder e da impunidade deles. Eu estava no DOPS do Estado do Rio de Janeiro, em Niterói, quando a gente foi interrogado pelos agentes do DOI-CODI. Você chega ao limite e, então, disse para o torturador: '- Me matem.' E ele respondeu: '- Eu não lhe mato, mato se eu quiser, quando eu quiser e vou te fazer em pedacinhos por quanto tempo eu quiser'. Acho que isso é uma coisa expressiva da tortura, você está sozinho na mão de um torturador que diz que tem o tempo que quiser e é senhor da minha vida e da minha morte. Ele pode, ele tem todo o tempo para lhe torturar. E a tortura é uma questão de limite, todos os seres humanos têm um limite, um limite de dor, o limite da sua desestruturação. Essa frase me colocou isso muito claramente. Lembro de ter tido essa sensação só uma vez, não várias vezes, essa de querer morrer e não conseguir morrer. E de não ter ali nenhuma condição de morrer, de bater a cabeça na parede e sair daquela situação.

[...] A prisão da gente foi consequência da prisão dos camponeses [...] de Cachoeira de Macacu. Eles foram para Imperatriz do Maranhão e [acabaram] presos. Em 1971, [a repressão] descobriu aquela área e prenderam [...] os camponeses, que foram torturados e obrigados a dizer de onde vinham e quem os levou para a luta armada. Isso aí era uma coisa que eles não poderiam negar que sabiam, qualquer tortura tira essa informação. Eles faziam de uma forma que você não morre enquanto não falar, você tem toda a segurança de que não vão matá-lo, mas torturá-lo até a última instância da sua resistência física e mental.

[...] Eles seguiram a gente, [prenderam] e levaram para o DOPS e a gente até ganhou tempo com isso. [...] Eles me botaram no pau-de-arara e me deram choques, mas as perguntas não eram inteiramente direcionadas.

[...] no fim da noite eles botaram a gente no salão do DOPS e encontrei uma menina, a Gilcione, que era da AP e me conhecia. Depois eles sumiram com a gente, ficamos 52 dias incomunicáveis, mas tinha essa menina de testemunha.

[...] No outro dia, eles haviam lido os documentos que estavam na minha casa, 70 horas depois é que eles vieram [...] e disseram: '- Vocês são da VAR [Palmares], vocês sabem do congresso de Recife!' Enquanto isso, a gente ficou no DOPS durante 48 horas dando

\footnotetext{
${ }^{242}$ Entrevista concedida por Artur M. Scavone à autora. SP, 12/09/2008, AAPP/AEL-LEI. Cf. tb. as entrevistas concedidas por Maria Amélia de A. Teles, Pedro Rocha Filho e André Ota à autora. Idem, ibidem.
} 
ponto frio, contando história. Sem um interrogatório direcionado [...]. A tortura pode ser muito cruel, mas você tem como inventar uma história, inventar um ponto. [...] Apanha-se mais quando volta, mas ganha-se tempo. [...] Nos levaram para o DOPS da Guanabara e foi uma loucura também. [...] Antes, veio o Cenimar e o DOI-CODI. [...] Aí levaram a gente para o DOI-CODI. Fomos para a 'geladeira' e começou outro tipo de interrogatório, dirigido para a questão da VAR. Só que eles já tinham perdido tempo com a gente! ${ }^{243,}$

Em agosto de 1971, a Operação Mesopotâmia percorreu diversas cidades da região do "Bico do Papagaio”, assim como de cidades próximas à área onde se iniciaria o combate à Guerrilha do Araguaia em 1972. A operação resultou na prisão de 31 pessoas, militantes e simpatizantes do PRT e da VAR-Palmares. Três sítios destinados a servir de área de treinamento de guerrilha e base de apoio da VAR-Palmares foram desarticulados próximos a Imperatriz (MA) ${ }^{244}$. Um IPM foi instaurado para apurar o envolvimento dessas pessoas com aquela organização clandestina. Na ocasião foram presos Eliezer Vaz Coelho, Pedro Gomes dos Santos e Joair da Silva, militantes deslocados de São Paulo e Cachoeira de Macacu (RJ) para a região. E, por fim, a organização sofreu várias baixas no então Estado da Guanabara, como a prisão do padre Gerson da Conceição e do casal Rosalina e Geraldo. A operação resultou também na morte de Epaminondas Gomes de Oliveira, uma liderança local do PCB. Preso no dia 9 de agosto de 1971, morreu no dia 20, em um acampamento militar próximo a Imperatriz (MA) [ALMEIDA, 2009: 268-69] ${ }^{245}$.

Em meados de 1971, diversos militantes do Molipo retornaram clandestinamente de Cuba ao Brasil. Documentos oriundos dos arquivos do DEOPS/SP indicam que havia um agente policial infiltrado no Molipo. As prisões e as mortes dos militantes da organização em circunstâncias não esclarecidas, iniciadas em novembro de 1971, indicam isso. De acordo com o livro Direito à Memória e à Verdade, os órgãos de segurança tinham informação de que alguns desses militantes teriam chegado ao norte de Goiás, após tentarem se fixar na Bahia, próximos ao rio São Francisco. Esconder ou não chamar

\footnotetext{
${ }^{243}$ Entrevista de Rosalina Santa Cruz de Oliveira concedida à autora. SP, 08/05 e 06/10/2009, AAPP/AELLEI.

${ }^{244}$ V. Operação Mesopotâmia, Ordem de operações no 01-SPC/71, p.67. De acordo com o documento, procurava-se também por José Porfírio, líder camponês e ex-deputado estadual por Goiás, que pertencia ao PRT. Desaparaceu no caminho entre Brasília e Goiânia (GO) com o filho, em 07/06/73. V. AlMEIDA, 2009, p. 444-45.

${ }^{245}$ Cf. RiBeIRo JR., Amaury. "Mesopotâmia: uma operação militar desconhecida”, O Globo, 05/04/1998. Sobre a morte de Epaminondas, cf. RI-Reservado no . 10, de 16/09/71, do BPEB. V. tb. MoRAIS, T. e SILVA, E., 2004, p.23-5. O cel. Lício Maciel afirmou em juízo, em 04/03/2010, ter participado da operação que levou à morte de Epaminondas. V. processo das famílias da Guerrilha do Araguaia iniciado em 1982, $\mathrm{n}^{\circ}$. 2003.01.00.041033-5/DF.
} 
a atenção para a atuação desses agentes infiltrados pode ter sido um dos motivos que ocasionaram a longa permanência de alguns presos no DOI-Codi/SP ${ }^{246}$.

Preso no dia 24 de fevereiro de 1972, dia do incêndio do edifício Andraus, Artur Scavone se dirigia a um "ponto" com uma companheira. Levou uma rajada de metralhadora, foi levado ao DOI-Codi/SP e, em seguida, para o Hospital das Clínicas:

“[...] fizeram um curativo, porque era só ferimento, e disseram que não precisava operar [...] mas nisso começam a chegar todos os caras queimados do Andraus. O hospital vira um pandemônio [...], e eu ali amarrado na maca, querendo saber o que aconteceu. Não passava ninguém, tinha um cara do DOI-CODI na frente, um mendigo dormindo de um lado, outro do outro. [...] eles me levaram para o corredor [...] e todo mundo que passava, eu dizia: '- Sou o Betão da ALN. Meu nome é Arthur Scavone, avisa a minha família'. Não deu outra, o meu pai foi avisado no mesmo dia [...]. E o meu velho [...] tinha trabalhado na Folha de S. Paulo [...] e conseguiu, dois dias depois, publicar um retrato meu dizendo que eu estava desaparecido. O que aliviou a minha cara, porque [...] os companheiros não iam aparecer em ponto algum [...].

[...] Fiquei no DOI-CODI nove meses. Voltei a ser interrogado seis meses depois. [...] Antes, fui para o Hospital do Cambuci, fiquei lá mais ou menos uma semana. Voltei para o DOI-CODI, e fiquei uns cinco dias sendo interrogado.

[...] quando cheguei lá, o Ustra me recebeu. [...] Ele me deu um tapa no ouvido direito que achei que tinha sido um tiro. Eu estava semi-coberto, eles me puseram um pulouver na cara e eu via por baixo. Isso perfurou o tímpano. [...] E aí [...] vieram as ameaças [...]. Fui interrogado pelo Mangabeira, que era o delegado Gaeta, se eu não estou enganado, e pelo Jesus Cristo, o JC. Me botaram na cadeira do dragão, mas sem usar toda a estrutura dela. O que eles usaram mesmo para valer foi o choque elétrico na orelha. [...] eles sabiam como eu estava, imagino eu, provavelmente, muita morte para eles não era a melhor coisa. [...] já haviam passado uns companheiros lá e haviam sido assassinados. Eu não tinha tanto valor, eles ficaram nesse esquema leve, vamos dizer assim. Passaram um dia me interrogando pesado e eu [...] sem dar uma de herói, falava: '- O que vocês querem saber, eu conto. A gente não sabe onde é que estão os outros, ninguém sabe [...]'. [...] Inventei um monte de histórias. [...] Contei práticas que a gente tinha e que não levavam a entregar ninguém.

[...] Voltei para o hospital de novo, porque o negócio estava complicado. Fiquei lá mais uma semana e meia para me recuperar [...]. Voltei para o DOI-Codi [...]. Minha prisão estava divulgada, o meu pai ia lá me procurar, então, eles já estavam fazendo um interrogatório mais pro forma. [...] São nove meses em que não houve tortura diretamente, mas eu ficava na cela com os caras que estavam sendo torturados. Quando saí do DOICODI, não podia ouvir choro de criança, não podia ouvir barulho de cano, porque é o que era usado para fazer o pau-de-arara. Convivi com a tortura, além de ter sido torturado no início.

[...] tenho uma forma de me preservar, não tenho memória de coisa ruim, muito forte [...] e não faço muita questão de lembrar.

\footnotetext{
${ }^{246}$ V. os casos de Ruy Carlos Vieira Berbert (02/01/72), Jeová Assis Gomes (09/01/72) e Arno Preis (15/02/72), mortos ou desaparecidos em Natividade, Guaraí e Paraíso do Norte (atual Paraíso do Tocantins) (TO), antigo estado de Goiás. V. AlmEIDA, 2009, p. 301-303, 305-307, 319-323. Nesse período, foram assassinados mais 14 militantes do Molipo: Aylton Adalberto Mortati e José Roberto Arantes de Almeida (04/11/71); Francisco José de Oliveira (05/11/71); Flávio Carvalho Molina (07/11/71); Carlos Eduardo Pires Fleury (10/12/71); Hiroaki Torigoe (05/01/72); Frederico Eduardo Mayr (24/02/72); Lauriberto José Reyes e Alexander José Ibsen Voerões (27/02/72); Boanerges de Souza Massa (21/06/72); Antônio Benetazzo e João Carlos Cavalcanti Reis (30/10/72). V. ALMEIDA, 2009.
} 
[...] A gente estava lá porque eles não queriam, segundo as histórias que contavam, que a gente fosse para o DOPS, para que o Fleury não nos interrogasse. Era a concorrência entre eles, então, nós estávamos sendo guardados ali na fase final para evitar isso. E quem me fichou no DOPS foi o Romeu Tuma, amigo do Fleury. Nós fomos para o DOPS para fazer a ficha e só. Voltamos para o DOI- Codi. Eles não deixaram a gente ficar lá2 ${ }^{247}$.”

Darci Miyaki, por exemplo, permaneceu no DOI-Codi/SP entre janeiro e agosto de 1972. Ela havia iniciado sua militância política no movimento estudantil de São Paulo, onde ingressou na ALN. Em 1969 saiu do país e realizou treinamentos de guerrilha em Cuba e, depois, na Coreia do Norte. No final de 1971 regressou ao Brasil clandestinamente para realizar tarefas relacionadas ao setor de informações e estratégia da organização. Pouco depois, foi presa no Rio de Janeiro no dia 25 de janeiro de 1972, pelo DOI-Codi/RJ. Torturada desde o primeiro momento, no dia 27 foi transferida para o DOICodi/SP juntamente com o dirigente nacional da ALN Hélcio Pereira Fortes, assassinado sob tortura no dia seguinte, naquele centro de tortura ${ }^{248}$. Miyaki nos relatou sobre a angústia vivida em decorrência da intensa tortura, de testemunhar a morte do companheiro e do fato de permancer um longo período naquele local:

\begin{abstract}
"Eu não tinha roupa, não tinha toalha de banho e não recebia visitas no DOI-Codi. Eu tive muita hemorragia por causa da tortura e não conseguia entender aquele sangue, via oral e vaginal, porque antes de eu 'cair' tinha acabado a minha menstruação. Como era difícil! Eu não tinha família que me visitasse, nem adiantava ter família, nós não tínhamos nada. Era papel higiênico, eu enrolava, enrolava, enrolava aquilo, mas sujava tudo, a calcinha, tudo. E eu só tinha aquela... Demorou até começar a ter outras presas lá, as meninas, a Jô, a Linda Tayah. [...] Eu não falava com ninguém. Até elas começarem a receber visitas no DOI-Codi... demorou. Depois de tanto tempo ali chegou um momento em que alguns passaram a ter visitas esporádicas. Algumas pessoas, acho que todos, não sei, passaram a receber visitas. O Artur Scavone, a Cida Costa...

A visita era... depois do pátio, antes de você chegar nas celas tinha um banco no corredor, na frente tinha o lugar onde ficava um corintiano, um juiz, ele ficava lá datilografando. Não lembro o nome dele, mas a visita era ali.

[...] me sentia muito mal, não falava com ninguém, mesmo depois de sair da solitária, ou de ir para o Tiradentes, não queria falar com ninguém ${ }^{249}$."
\end{abstract}

Algumas visitas de parentes de foram autorizadas no DOI-Codi/SP, não obstante, os testemunhos nos indicam que a manutenção de determinados presos neste centro de tortura tinha por objetivo manter em sigilo a atuação de ex-militantes infiltrados, conforme o relato de Hamilton Pereira. Ele foi um dos militantes da ALN mantidos confinados no DOI-Codi/SP por um longo período. Preso em Anápolis (GO), no dia 10 de

\footnotetext{
${ }^{247}$ Entrevista concedida por Artur M. Scavone à autora. Idem, ibidem.

${ }^{248}$ Preso no dia 22/01/72, no Rio de Janeiro, Hélcio foi transferido para o DOI-Codi/SP. A versão oficial publicada nos jornais informou que ele havia sido morto em tiroteio numa tentativa de fuga, mas vários presos testemunharam as torturas a que ele foi submetido no DOI-Codi/SP. V. ALMEIDA, 2009, p.312-13.

${ }^{249}$ Entrevista concedida por Darci T. Miyaki à autora. SP, 10/03/2011.
} 
junho de 1972, Pereira foi submetido a torturas e permaneceu incomunicável cerca de 3 meses em quartéis do Exército em Goiânia e Brasília. Após ficar detido no PIC de Brasília, foi transferido para o DOI-Codi/SP, onde permaneceu de março a outubro de $1973^{250}$. De acordo com seu testemunho:

“[...] não entendia muito bem como é que tinham conseguido [me prender]. Só muitos anos mais tarde é que eu fui desvendar isso. [...] o João Henrique [...] um médico [...] conhecido por uma capa da revista Isto É, com a manchete 'Jota: O cachorro da repressão ${ }^{251}$. Era o termo usado pelo SNI [...] para agente infiltrado. Esse cara saiu do nosso aparelho, passou por Curitiba, na casa do meu irmão, Nilo, que o conhecia, pediu ajuda financeira e foi para a Argentina. Em seguida, fez contato com a família - ele estava pensando em ir para o Chile, inicialmente; mas o irmão dele fez um acordo com a repressão. Aí trouxeram-no de volta. E [ele] fez o acordo. Esse cara fez um estrago monumental na ALN. Entregou meio mundo. Eu só vim a saber disso algum tempo depois. Tinha alguns indícios...

[...] Eu passei pela cela onde eles armaram a farsa do suicídio do Vladimir Herzog. [...] Dali eu os vi chegarem com o corpo do companheiro Luís José da Cunha, o Crioulo. Foi um ritual macabro: eles dançavam em torno do corpo, no pátio, urravam como animais. Dava para ver por uma frestazinha assim. Mataram Luís José da Cunha, mataram Antonio Carlos Bicalho Lana, o Bruno. [...] foi um ano de ondas repressivas sucessivas. Um ano de terror.

[...] A Oban não era lugar para preso ficar, era lugar de interrogatório. A primeira vez que eu fui, em 1972, fiquei uma semana de interrogatório. Não passei pelo DOPS, fui levado para o [Presídio] Tiradentes. Fiquei sem entender por quê. Depois do Tiradentes imediatamente me puxaram para um novo interrogatório lá na Oban. Aí eu fiquei mais uns dias. Depois, fui devolvido a Brasília para prestar o depoimento, no dia 14 de novembro. Muitos anos depois, conclui que permaneci tanto tempo porque eles imaginavam que eu sabia o percurso feito pelo João Henrique, que, naquele momento, estava entregando a ALN. Ele é responsável por dez ou 12 mortes naquele período...

Eu tinha indícios, mas não podia afirmar nada... Eu era interrogado sobre coisas que só ele sabia... ${ }^{252}$.”

Há poucas informações sobre as circunstâncias das mortes e desaparecimentos dos

militantes. Não se sabe ao certo quanto tempo e quais suplícios tiveram que suportar aqueles que foram assassinados pelo sistema DOI-Codi. É difícil estabelecer um padrão, uma lógica para a própria maneira de operar, mas conforme mencionado anteriormente no

\footnotetext{
${ }^{250}$ MAUÉs, Flamarion. “'Ter simplesmente este livro nas mãos é já um desafio’: livros de oposição no regime militar, um estudo de caso.” Em Questão, Porto Alegre, v. 11, n. 2, p. 259-279, jul./dez. 2005, p. 261.

${ }^{251}$ A reportagem que divulgou a atuação de "J", entre outros, como agente infiltrado foi a seguinte: FiLHO, Expedito. "Anatomia da sombra. Os informantes do porão militar tinham contrato de trabalho e salários para delatar”. Veja, 20/05/92, p. 40-5.

${ }^{252}$ Entrevista com Hamilton Pereira. SP, 10/01/2007 e Brasília, 23/03/2007, em FoRTES, Alexandre e FerReIRA, Marieta de Moraes (orgs.). Muitos Caminhos, Uma Estrela: Memórias de Militantes do PT. São Paulo, Perseu Abramo, 2008. Segundo Marival Chaves do Canto, ex-agente do DOI-Codi/SP, as delações do médico João Henrique Ferreira de Carvalho, o “Jota”, permitiu a eliminação de pelo menos 10 pessoas. A partir de 1973, ele delatou todos os líderes da ALN: Antônio Carlos Bicalho Lana, Sônia Maria de Moraes Angel Jones, Issami Nakamura Okama, Ronaldo Mouth Queiroz, Luiz José da Cunha, Wilson Silva, Ana Rosa Kucinscki, Arnaldo Cardoso Rocha, Francisco Seiko Okano e Francisco Emanuel Penteado. Cf. Veja, op.cit., 18/11/92; e ALMEIDA, 2009.
} 
caso de Antônio de Pádua Costa, ceder à tortura e fornecer informações durante a Guerrilha do Araguaia não era garantia de que seriam poupados. O mesmo ocorreu a outros prisioneiros vítimas da repressão política. Contudo, poucos presos tornaram-se desaparecidos ou foram assassinados depois de passarem longos períodos presos como ocorreu com Edgard Aquino Duarte ou Eduardo Collen Leite, o "Bacuri”.

Bacuri, integrante da ALN, certamente foi um caso especial, uma vez que estava jurado de morte pelo delegado Fleury, assumindo a sua morte o caráter de vingança. $\mathrm{O}$ longo calvário de Bacuri, no entanto, demonstra a variedade de arbitrariedades e modalidades repressivas a que poderiam ser submetidos os prisioneiros políticos. Preso no dia 21 de agosto de 1970, na cidade do Rio de Janeiro, por Fleury e sua equipe, foi levado para uma residência particular utilizada como centro clandestino de tortura, em São Conrado. Nesse local, encontrava-se preso Ottoni Guimarães Fernandes Júnior, que denunciou a prisão e as torturas sofridas por ele e Bacuri em depoimento prestado à época na Justiça Militar. Bacuri foi levado ao Cenimar/RJ e ao DOI-Codi/RJ, onde foi visto pela ex-presa política Cecília Coimbra. Levado a uma residência particular, em São Paulo, seus gritos chamaram a atenção dos vizinhos, que avisaram a polícia. Assim, foi transferido para o $41^{\circ}$. Distrito Policial, no bairro de Vila Rica em São Paulo, cujo delegado titular era Fleury. Nesse período, o poderoso delegado havia sido transferido para essa delegacia por ter se indisposto com o major Valdir Coelho, chefe da Operação Bandeirante, em uma disputa para decidir quem ficava com um preso capturado por Fleury. De acordo com Percival de Souza, a partir desse episódio o Cenimar (Centro de Informações da Marinha) se aproximou definitivamente do delegado ${ }^{253}$.

Depois de algum tempo na $41^{\text {a }}$. delegacia, Bacuri foi novamente transferido para o Cenimar/RJ, onde permaneceu sendo torturado até meados de setembro, quando foi levado para a sede do DOI-CODI/SP. Em outubro foi removido para o Dops paulista, sendo encarcerado na cela 4 de um lugar conhecido como "fundão", composto por um conjunto de celas individuais isoladas das demais.

No dia 25 de outubro, todos os jornais do país divulgaram a nota oficial do DEOPS/SP relatando a morte de Joaquim Câmara Ferreira, dirigente da ALN, ocorrida no dia 23 daquele mês. Embora estivesse preso no DEOPS, nessa nota constava a informação de que Eduardo Leite havia conseguido fugir. O testemunho de cerca de 50 presos políticos do DEOPS paulista comprova que Eduardo jamais saíra de sua cela

${ }^{253}$ SouZA, Percival de. Autópsia do Medo. Rio de Janeiro, Globo, 2000, p.26. 
naqueles dias. Eduardo não tinha condições de caminhar ou fugir, após mais de três meses de torturas diárias. Essas denúncias, porém, não foram registradas pelo juiz auditor Nelson Machado Guimarães. No dia 8 de dezembro, 109 dias após sua prisão e 42 dias após seu sequestro do DEOPS, os jornais do país publicavam nota oficial informando a morte de Eduardo em um tiroteio nas imediações da cidade de São Sebastião, no litoral paulista. Não há testemunhos sobre em qual local ele teria ficado até o momento de sua morte.

A notícia oficial da morte em tiroteio de Eduardo teve como objetivo evitar a inclusão de seu nome na lista dos prisioneiros a serem soltos em troca da libertação do embaixador da Suíça no Brasil, Giovanni Enrico Bucher, sequestrado no dia 7 de dezembro por militantes da VPR e do MR-8. Seu nome encabeçava a lista e seria constrangedor soltá-lo, pois, oficialmente, estava foragido e, na realidade, completamente desfigurado e mutilado pela tortura [ALMEIDA, 2009: 212-14].

Outro caso que não coincide com o ocorido com a maioria é o de Edgar Aquino Duarte. Preso em junho de 1971, Edgar permaneceu detido na cela 4 do "fundão" no DEOPS/SP durante três meses. Em agosto de 1971 esteve no DOI-Codi/RJ, quando conversou com alguns presos. Em outubro e novembro de 1971 esteve no DOI-Codi/SP, conforme testemunhos. Em julho de 1972, foi para o Regimento de Cavalaria localizado no Setor Militar Urbano de Brasília, onde provavelmente permaneceu por oito ou nove meses. Enviado novamente ao DEOPS/SP, foi visto entre 19 de março e junho de 1973. Edgar dizia ter tido uma entrevista com um oficial do Exército que lhe dissera que seu caso estava à disposição do CIE. Alguns presos chegaram a ouvir os carcereiros dizerem que ele morreria porque sabia "um segredo de Estado”. Poucos dias antes de desaparecer, tiraram-lhe o capuz que sempre era obrigado a usar, que não era usual entre os presos de São Paulo, nesse período. Contou aos companheiros que a retirada do capuz e a permissão para o banho de sol eram sinais de que seria morto. Ele acreditava que seus companheiros seriam responsabilizados pelo seu assassinato, que ocorreria porque sabia que Cabo Anselmo era um agente infiltrado ${ }^{254}$.

Artur Scavone relatou sobre o cotidiano e a tensão vivida pelos prisioneiros no DOI-Codi/SP:

\footnotetext{
${ }^{254}$ Entre as testemunhas de sua prisão que denunciaram o seu desaparecimento na justiça militar estão José Genoino Neto, Ivan Akselrud Seixas, Paulo Vannuchi, Manuel Henrique Ferreira, Carlos Vítor Alves Delamônica, Maria Amélia de Almeida Teles e César Augusto Teles. V. ALMEIDA, 2009, p. 441-43.
} 
“[...] a gente ficava acompanhando todo mundo que chegava, todos os que eram torturados, mas a gente via de esguelha, ou sabia de outros, ouvia a gritaria. [...] O que a gente fazia muito era jogar xadrez [...] com tabuleiro virtual. Era uma forma de ocupar o tempo. Eu me lembro do marinheiro, o Edgar Aquino [Duarte], que estava na nossa cela e que depois sumiu. O Edgar era uma figura fantástica como pessoa [...] procurava manter as coisas organizadas. [...] às vezes chegava coisa embrulhada em folha de jornal. [...] nós estávamos já há mais tempo lá, a família começava a ter quase certeza de que a gente estava lá e começava a mandar entregar coisas. Eu me lembro que chegava folha de jornal, o Edgar ficava lendo jornal e, cada meia folha, ele demorava uma tarde para ler. Lia metade de uma folha de jornal, depois lia a outra metade, os anúncios, tudo, porque aquilo ali era um resto de contato com o mundo. Não tinha caneta e nem papel [...] O Edgar viveu bastante tempo com a gente naquela cela e o que me lembro é que ele era um cara muito metódico [...]. Tinha uma vontade muito grande de viver, de pensar nas coisas que estavam acontecendo.

[...] Eu aprendi músicas espanholas, uma música chamando greve em espanhol. [...] A gente cantava muito. O número de pessoas na cela variou muito: dez, cinco, seis. Em nove meses passou muita gente por lá. Havia algumas companheiras presas, a Linda Tayah, que estava grávida; a outra que também [...] levou um tiro de raspão e ficou com a perna imobilizada.

[...] Depois que eu fui fichado no DOPS, voltamos e fiquei pouco tempo no DOI-Codi. Acho que foi coisa de um mês. Aí fui mandado para o Tiradentes, foi uma sensação de liberdade! Ir para o Tiradentes foi como voltar para o mundo ${ }^{255}$."

No Brasil, eram mais nítidas as diferenças entre o momento da tortura em que há necessidade de "aniquilar” e “despersonalizar” para obter informações rapidamente e o que se segue depois dos primeiros dias, em que já foram obtidas, ou não, as informações mais valiosas para desbaratar a organização política a que pertence o militante. A atuação dos torturadores era estabelecida de acordo com as necessidades e prioridades que surgiam do ponto de vista operacional, conforme a informação obtida, mas também de acordo com o órgão que comandava a operação. Embora a prioridade fosse a informação, desejavam “quebrar” o militante a ponto de transformá-lo num outro, anulando-o ou afastando-o definitivamente de seus projetos políticos e existenciais. Isso ocorreu, de certo modo, nos casos de “arrependimentos públicos” de militantes apresentados na televisão, entre 1970 e 1975.

Nos DOI-Codi, a sensação de incerteza e terror vivida pelo preso permeava todo o ambiente. Diversos depoimentos relatam o temor de todos ao ouvirem o barulho das chaves abrindo a porta do setor onde ficavam as celas, indicando que alguém seria retirado para nova sessão de torturas. Mesmo tendo passado o período mais dramático, por alguns meses o destino era incerto. Essa realidade foi vivida por Criméia A. S. de Almeida, militante do PCdoB que havia participado da Guerrilha do Araguaia, cujo

${ }^{255}$ Entrevista concedida por Artur M. Scavone à autora. Idem, ibidem. 
sequestro efetuado pelo DOI-Codi do II Exército ocorreu quando estava grávida de 7 meses. Torturada grávida em São Paulo e em Brasília, sua prisão nunca foi oficializada:

"Quando fui presa pela Oban [DOI-Codi], eles diziam que eu ia morrer. Eu achava que ia morrer. Durante todo o período em que permaneci sequestrada, minha prisão se deu totalmente alheia a qualquer legalidade, fiquei submetida a todo tipo de ameaças. Depois que descobriram minha identidade, eles me chamavam de 'terrorista' todo o tempo. Fizeram várias simulações de execução, colocavam-me encapuzada no carro do César, meu cunhado que também estava preso lá, e diziam que ele iria capotar na Serra das Araras e pegar fogo. Fizeram 'roleta russa' com a arma deles e diziam que eu estava com sorte, porque não saía tiro. Mas a arma era automática e se tivesse uma bala ali estaria na agulha, portanto, eu percebi que aquilo era encenação. Ao me levarem para Brasília, eles fizeram ameaças por duas vezes. Na primeira me levaram a um aeroporto, que imagino ser na base aérea de Cumbica, eu estava com venda nos olhos, mas consegui ver uma placa de sinalização da estrada indicando 'Cumbica', na segunda vez. Na primeira vez, eles me levaram até lá e ficaram um tempo num local bastante deserto. Depois disseram que não poderia ser naquele dia e me levaram de volta para a Oban. Na segunda vez, fomos eu, o José Duarte e um tal de Paulo. Os torturadores estavam em uns 20. Eu não achei que ia morrer na viagem, porque eles estavam juntos no carro. Eu achava que eles iam me matar naquele lugar esquisito, que era Cumbica.

Em Brasília eles diziam que não torturavam. O gal. Bandeira disse que eu poderia trabalhar no Ministério da Saúde etc. Depois dizia que eu era terrorista, culpada pela morte de 8 militares no Araguaia e que a minha pena seria de 20 anos ou até pena de morte. Então, ele ficava falando que o meu filho, o Joca, seria meu carcereiro. Depois que o Joca saiu da prisão, eu, às vezes, pensava que não seria morta porque eles tinham quebrado a minha incomunicabilidade, minha família materna sabia da minha prisão. Outras vezes, achava que não, que tiraram o Joca de mim para ficar mais livre para me matar. O gal. Bandeira quando se irritava punha uma pistola 45 em cima da mesa. Quando fui libertada, saí num carro com três militares, o que para mim era a morte certa, embora o general tivesse dito que me soltaria para me presentear pelo meu aniversário. Era dia 20 de abril e eu faço aniversário no dia 17.

Quando eles me levaram para Belo Horizonte, achei que fossem me matar, porque o gal. Bandeira [...] dizia também que eu poderia ser morta pelos companheiros, num assalto ou por estupro. Eele dizia que eu poderia me suicidar, porque os companheiros do partido desconfiariam de mim e, então, sentindo-me muito isolada, me mataria, atirando-me no metrô ou de algum prédio. [...] Fui seguida por agentes policiais por muitos anos, acho que pelo menos até 1982, embora no meu habeas data haja informações até 1989 e, num documento do Infocrim há dados até $2001^{256}$.”

Era comum, no momento da libertação, os prisioneiros serem ameaçados de morte caso viessem a reincidir e voltassem a militar. Diversos testemunhos e vários entrevistados deixaram registrados relatos similares ao de Criméia, as ameaças eram feitas no Dops ou mesmo na Auditoria Militar.

No Brasil, mediante o tormento buscava-se arrancar do militante informação, mas, também, a sua humanidade, até deixá-lo vazio. Era um processo que visava o controle e a submissão do preso, mas que certamente não contou com o mesmo grau de controle e

\footnotetext{
${ }^{256}$ Cf. entrevista concedida por Criméia Alice Schmidt de Almeida à autora. São Paulo, 27/07/2000, 28 e $30 / 11 / 2001$ e 20/10/2004.
} 
imposição do sofrimento observados na Argentina, nem a mesma quantidade de vítimas. Naquele país, o sistema repressivo caracterizado pelo dispositivo concentracionário levou a extremos o objetivo de produzir sujeitos completamente submissos aos desígnios dos campos. Apesar das diferenças entre os diversos campos, predominou a "lógica perversa" que insistia em manter assistência médica aos presos mesmo que seu destino final fosse o "traslado", o desaparecimento forçado. Era necessário manter certa aparência de normalidade, incutir expectativa de sobrevivência para obter passividade.

Durante a ditadura brasileira, a assistência médica cumpria essas funções, embora essencialmente garantisse eficiência à tortura. De acordo com o testemunho de Rosalina Santa Cruz,

\begin{abstract}
"A tortura não era usada só para tirar informações, ela vem para te desestruturar [...] a tortura também é isso, tortura-se pela informação e pela humilhação, pela submissão, pela desestruturação do outro. Eu acho que eles tinham toda uma técnica para te levar a isso, era quase que uma vingança, um desmontar a sua capacidade de lutar, algo assim: 'Quando você sair daqui, nunca mais vai enfrentar essa luta’. Era deixar você destruído como indivíduo, como pessoa. É o que fizeram com muitos companheiros que foram para a televisão, companheiros que renegaram tudo sob extrema pressão. É a forma mais cruel da tortura, é a que destrói e leva a pessoa a renegar, na condição de tortura, os seus próprios ideais, seus próprios princípios e dignidade ${ }^{257}$."
\end{abstract}

O medo era constante, pois mesmo depois de cumprir pouco mais de um ano de prisão, tendo passado por vários locais de reclusão como a Vila Militar e o presídio Talavera Bruce, em Bangu, no Rio de Janeiro, Rosalina foi sequestrada pelo DOI-Codi em fevereiro de 1974, em São Paulo, quando seu filho tinha 5 meses de idade. Seu processo na Justiça Militar ainda tramitava e seu irmão, Fernando Santa Cruz, militante da AP, foi preso e desapareceu no dia 23 de fevereiro. Ela narrou o drama e as diferenças entre os tormentos sofridos nos distintos momentos em que foi presa:

"Na tortura física eles faziam os interrogatórios, por exemplo, em mim foi assim: ficava um cara na minha frente com uma luz forte e outro cara ficava atrás [olhando]. Um perguntava na frente e o outro dizia '- É mentira'. E te dava telefone, batia, mas de um jeito para não deixar marca, mas você 'via estrela'. Tinha outro jeito, mais sofisticado, que era o do bonzinho e o mauzinho. Desde o DOPS/RJ eles usavam esse método, penso que mais grosseiramente. Acho que no DOI-Codi/RJ a tortura era empregada de forma mais organizada. Tinha aquele cara que chegava depois de você ter apanhado e dizia: 'Olha, sei que você é uma pessoa de classe média, uma estudante ou uma profissional. Vamos ver em que você pode colaborar. Fala porque esses caras são uns brutamontes, vão te matar'. Se fazia meio de parceiro e teu protetor e outros chegavam, batiam na porta, como um teatro enorme, dizendo: '- Como é? Vou bater, vou pegar essa mulher!' E o [bonzinho] dizia: '- Não, espera aí, estou terminando de conversar'.

${ }^{257}$ Entrevista concedida por Rosalina Santa Cruz à autora. Idem, ibidem. 
No DOI-Codi/RJ tinha também a geladeira. Você ia para uma sala muito escura, ficava sem beber água, abria e fechava o olho e não via nada, era mesmo uma escuridão. Você ia perdendo a noção de tempo e eles usavam isso. Tiravam você dali e levavam para uma sala super branca com luz intensa, uma coisa muito sofisticada que não se teve em outros lugares do Brasil, que eu saiba. Em São Paulo, fui presa em 1974 [pelo DOI-Codi] e não tinha isso, não existiam as geladeiras. No Rio de Janeiro, eram seis celas pretas e elas eram usadas de forma a desestruturar fisicamente a pessoa, porque você ficava sem beber água, começava a sentir muita sede até despelar o rosto. Os caras abriam a cela e jogavam água em cima de você. Aí você ficava querendo tomar aquela água [...]. E tinha muito frio e se começava a tremer muito de frio [...]. Não se podia sentar, porque as celas eram muito estreitas, tinha-se que ficar de cócoras ou em pé. Não dava para deitar. E, ao mesmo tempo, eles ficavam no olho mágico te vigiando e dizendo: '- Levanta, não senta'. Ficava-se nua naquela cela e a sensação era de que você estava emparedada. Se a pessoa tivesse claustrofobia, enlouquecia ali dentro. E mais, havia uma música muito alta, depois um som estridente que parecia serra, depois gritos de pessoas sendo torturadas, que você não sabia se vinha dali ou não. Esse tipo de sofisticação na tortura aconteceu no Rio. Os caras ficavam encapuzados ao seu lado, quando se chegava na sala de interrogatório, que era branca. O interrogador ia recebendo informações para atualizar as perguntas. Fui torturada durante quase todo esse período, fiquei com 36 quilos, a ponto das outras presas me apelidarem de Biafra, Bia. Senti desespero o tempo todo, nos 52 dias de tortura da primeira vez, e na segunda também $[. . .]^{258}$.”

Os DOI-Codi se constituíram na materialização do estado de exceção durante a ditadura, neles a suspensão de direitos, a desumanização e a despersonalização dos prisioneiros buscaram transformá-los em corpos destituídos de autonomia, vidas torturáveis e matáveis, expostas aos limites da violência, da crueldade e do extermínio. Como vimos anteriormente, nesses centros de tortura, agentes do Estado operaram no limiar das leis de exceção e sua própria execução, concretizando o que ficava indefinido durante os 10 dias de incomunicabilidade do prisioneiro, conforme o prazo autorizado pela LSN, e os 40 dias de prisão preventiva, que poderia ser decretada. Essas brechas legais, exterioridades jurídicas não passíveis de criminalização, abriram a possibilidade para todo tipo de práticas clandestinas dos órgãos repressivos, em especial, a utilização da tortura - não legalizada pela legislação de exceção, mas permitida em função da generalizalção dessa zona de indistinção e da enorme ampliação do poder do Executivo.

No Brasil, não chegaram ao nível da extensão e sistematização das práticas de supressão de direitos e desubjetivação dos prisioneiros dos campos argentinos. E apesar da diversidade de características, os DOI-Codis certamente eram lugares destinados a manter isolados da sociedade aqueles considerados “indesejáveis”, tais como nos campos de concentração e confinamento da primeira metade do século XX. As diferenças existentes entre os campos argentinos e os da Guerrilha do Araguaia são consideráveis, levando-se em conta a massividade do extermínio empregado na Argentina.

\footnotetext{
${ }^{258}$ Entrevista concedida por Rosalina Santa Cruz de Oliveira à autora. Idem, ibidem.
} 
Os DOI-Codis, a partir de 1970, não foram utilizados de forma tão massiva, apesar da existência dos "programas de pacificação" que detiveram milhares de pessoas em blitz e em momentos críticos, para disseminar o medo, a vigilância e o controle sobre a sociedade. O confinamento e isolamento impostos nos DOI-Codis ocorreram por períodos menores para a maioria dos perseguidos políticos; desse modo, a extensão dos tormentos aplicados foi menor do que na Argentina. Nestes locais, as vítimas vivenciaram uma situação correspondente a dos campos de concentração. Os DOI-Codis funcioanaram, em geral, em locais públicos, combinando atividades clandestinas com aquelas conferidas pela legalidade de exceção. Embora possam ser considerados campos, segundo a definição abrangente do conceito em Agamben, possivelmente a terminologia que mais leve em consideração as especificidades do sistema repressivo brasileiro organizado a partir de 1967, e que estabelece uma distinção com o caso argentino, seja a de “centros de tortura e de extermínio”. Excetuando-se, como já dissemos anteriormente, o que aconteceu na região da Guerrilha do Araguaia.

Os militares estabeleceram uma considerável legislação de exceção que alcançou diversos ramos da atividade administrativa do Estado. Lugares como o DEOPS, constituídos legalmente com função de polícia política muito antes do golpe, foram importantes meios para reprimir e realizar operações de informação e segurança interna. Cumpriram papel destacado tanto no polo mais visível da repressão política quanto no invisível, seus agentes transitaram com desenvoltura nessa zona de indistinção do estado de exceção, operando clandestinamente em conjunto com o sistema DOI-Codi e também com órgãos como o CIE e Cenimar no manejo dos centros clandestinos de tortura e extermínio, realizando investigações, interrogatórios, torturas e transporte de prisioneiros para esses centros.

Em geral, o DEOPS não representou o lugar de decisão sobre a vida e a morte dos “indesejáveis” ou aqueles considerados “irrecuperáveis”, embora 5 militantes tenham sido assassinados ou tenham se tornado desaparecidos no DEOPS/SP ${ }^{259}$. A exceção como um fenômeno inscrito e interno à aplicação da norma possibilitou a coexistência de órgãos como os campos de concentração e extermínio, os DEOPS, DOI-Codis, a rede de centros clandestinos de extermínio e os presídios, uma das chaves do êxito da ditadura por um

\footnotetext{
${ }^{259}$ A partir de 1970 foram assassinados ou desapareceram os seguintes militantes presos no DEOPS/SP: Olavo Hansen (Port), em 09/05/70; Eduardo Collen Leite (ALN), em 08/12/70; Luiz Hirata (AP), em 20/12/71; Dênis Casemiro (VPR), desaparecido em 18/05/71; e Edgar Aquino Duarte, desaparecido em junho de 1973.
} 
período relativamente longo, combinando assim diversas modalidades repressivas do Estado.

Um aspecto acerca da estrutura do aparelho repressivo, que se faz digno de nota, auxiliando o entendimento da maneira como as prisões, torturas e mortes supramencionadas vieram a cabo, refere-se às potenciais associações entre as diversas instâncias repressivas. Neste sentido, alguns estudos sobre o aparelho repressivo estabelecido durante a ditadura têm chamado a atenção para a formação de uma 'rede paralela' à cadeia institucional de comando e ao Sistema Nacional de Segurança Interna (Sissegin), criado pelo presidente Médici em 1970 [FICO, 2001: 111-20].

De acordo com Priscila C. B. Antunes, ao destinar ao Exército a coordenação do combate às diversas formas de contestação ao regime, seu funcionamento passou a depender do bom relacionamento dos comandantes militares das três forças; nesse sentido, os DOIs teriam mantido um alto grau de autonomia em relação aos Codis e não teriam contado com muita colaboração dos centros de informações das Forças Armadas, em especial, do Cenimar e CISA. Apesar de funcionarem em conjunto com os estadosmaiores, os serviços de informações teriam ficado subordinados diretamente aos seus respectivos ministros, o que os colocava acima do sistema DOI-Codi, pois os DOIs eram agências locais. Apenas o CIE, um órgão de informação e operações subordinado diretamente ao ministro do Exército, colaborava de forma efetiva com o sistema ${ }^{260}$. O jornalista Elio Gaspari, por seu turno, refere-se muitas vezes ao CIE como um poder paralelo à hierarquia militar (designada como “a tigrada” do CIE) ${ }^{261}$.

Embora as relações entre os diversos níveis e estruturas descritos acima não fossem consensuais e as disputas pela primazia das ações repressivas fossem intensas, novos estudos, documentos e testemunhos têm apontado para o predomínio da centralização e da hierarquia militar e a existência de uma complexa rede de colaboração envolvendo o CIE, militares de alta patente e agentes civis do setor de informação e segurança.

Em abril de 1971, dois militantes da VPR, Dênis Casemiro e Bartolomeu Toledo, foram presos pelo delegado Fleury. Eles haviam adquirido um sítio às margens da rodovia Belém-Brasília, localizado próximo a Imperatriz (MA), onde foram descobertos. Denis

\footnotetext{
${ }^{260}$ V. ANTUNES, Priscilla C. B. SNI \& ABIN. Uma leitura dos serviços secretos brasileiros ao longo do século XX. Rio de Janeiro, FGV, 2002, p.72; e AnTunes, Priscilla C. B. Argentina, Brasil e Chile e o desafio da reconstrução das agências nacionais civis de inteligência no contexto de democratização. Doutorado, IFCH/Unicamp, 2005, p.164-7

${ }^{261}$ V. GASPARi, E. A ditadura envergonhada. op.cit., p.41; A ditadura encurralada. op.cit., p.15, 39, 106.
} 
foi trazido para o DEOPS/SP, onde foi torturado por quase um mês, sendo fuzilado no dia 18 de maio. As autoridades não fizeram nenhuma comunicação oficial da sua morte ${ }^{262}$.

Durante esse período, era transportado pelos corredores com um capuz cobrindo seu rosto para impossibilitar sua identificação. Um dos presos que o conhecia, Waldemar Andreu, chegou a conversar com ele por alguns minutos. Ele estava confiante de que a retirada do capuz significava que as torturas acabariam e que o perigo de ser assassinado havia passado. Não obstante, foi fuzilado, conforme conclusão da análise feita pela Unicamp quando da identificação de seus restos mortais encontrados na Vala de Perus, em 1991 [ALMEIDA, 2009: 249-51].

Em seguida, no mês de agosto de 1971, homens da $11^{\text {a }}$ Região Militar do Comando Militar do Planalto, comandado pelo general Bandeira, e do CIE (Centro de Informações do Exército) realizaram a Operação Mesopotâmia em cidades próximas à região onde se iniciaria o combate contra a Guerrilha do Araguaia. Conforme já mencionado, militantes e simpatizantes da VAR-Palmares e do PRT foram presos, o que resultou na desarticulação de sítios destinados a treinamentos de guerrilha. Antes, em março do mesmo ano, a Operação Macedônia havia feito o levantamento de informações na região necessário para realizar essas prisões ${ }^{263}$.

Diversas operações de informação e repressão pouco conhecidas podem ter sido alavancadas pela ação do delegado Fleury, que participou de outras intervenções de segurança interna em conjunto com o DOI-Codi e o CIE, como no caso da infiltração de “Cabo Anselmo” na VPR, a partir de outubro de 1970, e a investigação que resultou no assassinato do capitão Carlos Lamarca, na Bahia, entre agosto e setembro de 1971, durante a Operação Pajussara ${ }^{264}$.

Parte significativa das vítimas da atuação de Anselmo foi levada para a "Casa da Morte”, em Petrópolis, coordenada pelo CIE, onde desapareceram. Por outro lado, as operações que levaram à morte de Lamarca, Iara Iavelberg e Zequinha, entre outros, apesar das divergências, demonstra a prevalência da hierarquia e da interação existente entre o delegado Fleury e os DOI-Codis. A perseguição aos militantes do MR-8

\footnotetext{
${ }^{262}$ Cf. RIBEIRO JR., Amaury. "Mesopotâmia: uma operação militar desconhecida”, O Globo, 05/04/98. Apenas em 1991, os restos mortais de Denis foram identificados pela equipe coordenada pelo legista Badan Palhares, na Unicamp. V. ALMEIDA, 2009, p. 249-51.

${ }^{263}$ A operação foi subdivida em Operação Terra I e II. O relatório foi assinado pelo Gen. Div. Dióscoro Vale (Cmt do CMP $/ 11^{a}$ RM) e pelo Cel. Henrique Beckmann Filho, em agosto de 1971. V. "Operação Mesopotâmia”, idem, ibidem.

${ }^{264}$ V. "Relatório Operação Pajussara”, Ministério do Exército/VI Exército/6 ${ }^{\mathrm{a}}$ Região Militar/Quartel General-2 ${ }^{\mathrm{a}}$ seção, 1971. Protocolado no SD/SAF em 06/03/75, sob nº 249.
} 
(Movimento Revolucionário 8 de outubro), assumida ao final pelo então major Nilton de Albuquerque Cerqueira (chefe da $2^{\mathrm{a}}$. Seção do Exército na Bahia e comandante do DOICodi baiano), contou com a ativa colaboração de Fleury e de diversos órgãos de segurança e informação ${ }^{265}$. O major Cerqueira, por seu turno, participou também de diversas outras operações, inclusive, de combate à Guerrilha do Araguaia em $1974^{266}$.

Outro exemplo de operação que demonstra a colaboração entre o delegado Fleury e o general Bandeira deu-se na prisão do então militante do PC do B, Danilo Carneiro.

A história de Danilo na militância intensificou-se a partir do momento em que foi viver no sudeste do Pará, em 1970, a fim de participar de treinamentos para o movimento que viria a ser chamado de Guerrilha do Araguaia. No início, Danilo sentiu-se despreparado para fazer parte do projeto e pediu para se afastar, era sua opinião que a estrutura daquela proposta de "guerra popular" se encontrava muito precária, não havia armamento, material e nem pessoal suficiente.

Nesse sentido, a direção do partido combinou com Danilo Carneiro que ele seria liberado quando do início da guerrilha. No dia 12 de abril de 1972, quando ocorreu o primeiro ataque do Exército ao destacamento guerrilheiro localizado próximo a Marabá (PA), onde Danilo morava, ele recebeu dinheiro para sair da região. No dia seguinte, foi preso na Transamazônica e viveu, possivelmente, uma das piores experiências de tortura entre os entrevistados. Danilo foi torturado durante aproximadamente sete meses, em várias cidades, em Marabá, Belém, São Paulo, Rio de Janeiro, mas, principalmente, em Brasília (DF). No PIC de Brasília, as torturas a que foi submetido foram coordenadas pelo general Bandeira e contaram com a participação ativa do delegado Fleury:

“[...] enfiaram-me um capuz, algemaram e me levaram. Eu entrei num avião, [...] cheio de oficiais. [...] e encapuzados [eu e o Eduardo] e chegamos num presídio [...]. Dentro de uma cela, ouço baterem na parede, bato também e uma voz diz: '- Você está no Centro Militar de Brasília, no Batalhão de Polícia do Exército, no PIC, Polícia de Investigação Criminal. [...] - A barra está muito pesada, mataram alguns companheiros dias atrás'. Eu fiquei receoso. [...]

Logo depois, encapuzaram-me e me tiraram da cela. Desceram comigo todo arrebentado e me jogaram numa sala, [...]; o capuz saiu, [...] e eu reconheci, era o Fleury. Aí ele diz assim: '- Você até agora conversou com as pessoas que não sabem dialogar, mas aqui você vai falar com pessoas que sabem' [...] Aí começa uma tortura violentíssima, [...] todas aquelas perguntas [sobre] organização, onde, quando, quem [...]. E foi um troço muito feroz [...]. Tiravam-me da cela, torturavam, passavam dois, três dias sem torturar e dois, três dias torturando. [...] O Fleury me torturou pessoalmente. O tempo todo ele me

\footnotetext{
${ }^{265}$ V. JosÉ, E.; MiRAndA, O. Lamarca, o capitão da guerrilha. 16a. ed., São Paulo, Global, p. 150-152, 160-164; e ALMEIDA, 2009: p.273-281.

${ }^{266}$ O major Lício Augusto Ribeiro divulgou a participação de Nilton de A. Cerqueira no combate à Guerrilha do Araguaia, confirmada pelo próprio Cerqueira. V. CARVALHO, 2004, p. 191 e ss.
} 
interrogava. Eu me lembro como se fosse hoje, ele começou assim: '- Nós temos um minuto, dois, dez, uma hora...'. À medida que ia avançando o tempo, ele ia gritando: 'Temos um ano, dez anos...' E gritava histericamente: '- Agora você está conversando com quem sabe dialogar!’ Ele usava exatamente essa expressão.

Ele sabia das coisas [da Guerrilha] do Araguaia, pelas perguntas dele dava para ver [...], quando cheguei em Brasília já tinha quase um mês, acho, que [estava preso].

[...] O Fleury voltou a me torturar várias vezes, durante vários dias, fazendo as mesmas perguntas. Chegou um momento [...] que eles queriam saber sobre o aparelho em São Paulo, [...] o aparelho do Rio, sobre o pessoal da direção. [...] Sofri um traumatismo craniano, mas foi [resultado] de ponta pé e espancamento.

[...] Várias vezes, fui torturado pelo Fleury sem capuz, quando era torturado por outros, eles botavam capuz. [...] cheguei a pesar 37 quilos em Brasília. [...] Um dia, comecei a sentir que não ia resistir. [...] Acordo e estou no pé de um cara, quando olho, estava sem capuz [...], vejo um cara cheio de estrelas com uma bengala dizendo assim: '- Quero informação nem que você tenha que trucidar esse cara!' [...] O Fleury estava do lado. Depois, fiquei sabendo que era o general Bandeira. A partir desse momento a barra pesou terrivelmente, porque eles me tiraram fora do presídio, levaram-me para um lugar que não sei onde fica, fizeram corredor polonês [...]. E o Fleury estava lá participando dessas torturas $[\ldots]^{267}$."

Este depoimento de Danilo Carneiro, assim como as operações de informação que precederam a Guerrilha do Araguaia e as prisões de militantes-chave de grupos armados que tentavam se organizar na região do Bico do Papagaio e proximidades sugerem uma articulação mais afinada entre o CIE e outros órgãos de informação e repressão, como o DEOPS/SP e o delegado Fleury (tradicionalmente ligado ao Cenimar) do que a historiografia existente faz supor, que, geralmente, ressalta os aspectos relativos às disputas internas entre os serviços de informação das três forças.

Com a implantação da ditadura e, especialmente, após a edição do AI-5, as Forças Armadas, sob a tutela do Exército, assumiram o papel de polícia política e estrapolando suas prerrogativas constitucionais de garantir a segurança das fronteiras e dos interesses geopolíticos do país. De fato, a alavancagem de poder do Exército e as divergências que surgiram em decorrência de tal supremacia (muitas vezes sugerida por membros das Forças Armadas e de órgãos de informação ${ }^{268}$ ) não dirimiu a existência de uma esfera de colaborações.

Sem desconsiderar a real importância das disputas regionais e daquelas que opuseram militares e civis no âmbito do controle das forças de segurança, é de se ter em vista que as operações descritas acima revelam que o núcleo do sistema repressivo era numericamente restrito e bem articulado, o que ajuda a entender a lealdade entre os

\footnotetext{
${ }^{267}$ Entrevista concedida por Danilo Carneiro à autora. SP, 24 e 25/06/2010. AAPP/AEL-LEI.

${ }^{268}$ V., por exemplo, os livros de entrevistas com militares da FGV, especialmente, o livro D’ARAúJo, M. C.; SOARES, G.; CASTRO, C. Os anos de chumbo: a memória militar sobre a repressão. Rio de Janeiro, Relume-Dumará, 1994.
} 
envolvidos. Essa lealdade chega até os dias de hoje pelo acobertamento mútuo e a manutenção dos segredos envolvendo os crimes cometidos.

Nesse mesmo sentido, no dia 4 de julho de 1975 teve início a Operação Acarajé, que articulou o CIE, o DOI-Codi da $6^{\text {a }}$ Região Militar e que teve a participação do delegado Fleury. No relatório de agosto de 1975 sobre da referida operação, o SNI justificou-a da seguinte maneira: “A subversão no Brasil apenas mudou de roupagem. Ao invés de atos de terrorismo que caracterizaram a hegemonia das chamadas linhas foquista e militarista, passou a atuar dentro da linha pacifista, apregoada pelo PCB”269.

A citada operação resultou na prisão de 42 militantes e simpatizantes do PCB de Salvador (BA), entre os quais incluido Sérgio Santana, vereador do MDB. Na operação, os presos foram encapuzados e levados para um local conhecido como Fazendinha, em Alagoinhas, onde atualmente funciona um quartel da Polícia Militar do Estado da Bahia. As diligências ficaram a cargo do DOI-Codi de Salvador, comandado naquele período por Adyr Fiúza de Castro. Note-se que ex-presos políticos testemunharam que o coronel Carlos Alberto Brilhante Ustra chefiou a operação, utilizando o codinome “doutor Luiz Antônio”, e comandou diretamente os interrogatórios e as sessões de tortura ${ }^{270}$. Nesse período, o próprio coronel Ustra chefiava a Seção de Operações do CIE, cargo que exerceu de dezembro de 1974 a 1977.

Dos presos na operação, quatorze foram condenados em março de 1976 por reorganizarem partido proscrito, sendo que alguns passaram quase dois anos no cárcere. O engenheiro Luiz Fernando Contreras de Almeida declarou em 2000, que além de Ustra, o delegado Fleury dirigiu uma das sessões de tortura a que foi submetido [JosÉ, 2000: 135], mais um indício de que as divisões e disputas existentes entre os diversos grupos diretamente envolvidos na repressão às esquerdas não se sobrepunham ao encaminhamento centralizado das operações de segurança e informação.

\footnotetext{
${ }^{269}$ MAGALHãES, Mário. “Ex-presos dizem que Ustra chefiou ação com tortura na BA”, Folha de S. Paulo, 10/02/2009.

${ }^{270}$ José, E. As asas invisíveis do Padre Renzo. São Paulo, Casa Amarela, 2000, p.134-8. Ustra comandou o DOI-Codi/SP de setembro de 1970 a janeiro de 1974. V. MAGALHÃES, M. Idem, ibidem.
} 


\subsection{A “Casa da Morte” e os centros clandestinos de tortura e extermínio}

No Brasil, apesar dos avanços das investigações sobre as circunstâncias históricas nas quais se desenvolveu a ditadura, ainda não está suficientemente esclarecido como se estabeleceu, organizou e operou a repressão política. Uma série de questionamentos, tanto do ponto de vista factual quanto ético e político, ainda não foram estabelecidos e investigados: principalmente aqueles relacionados às circunstâncias dos assassinatos por razões políticas, aos desaparecimentos forçados, à localização de seus restos mortais e aos responsáveis pelo aparato repressivo e essas operações. Tendo em vista que a maioria das decisões a respeito do assassinato de militantes se dava no âmbito do sistema DOI-Codi, ou nos centros de extermínio, é necessário sistematizar o que se sabe sobre a utilização das casas clandestinas de tortura para exterminar e desaparecer com os prisioneiros.

Parte constitutiva do sistema DOI-Codi, esses locais clandestinos representavam o aspecto mais invisível, obscuro e desconhecido do funcionamento dos órgãos de informação e segurança interna daquele período. Esta sistematização nos auxilia na compreensão da lógica da repressão sobre os critérios adotados para estabelecer o destino dos prisioneiros políticos, a conhecer o percurso e os sofrimentos a que estavam submetidos antes de se tornarem objeto do sistema carcerário e da justiça militar, ou serem assassinados.

Em alguns casos, a decisão final sobre a sorte de um determinado preso diferia em relação a outro. Em certas ocasiões, o sequestrado tornava-se um desaparecido político, levado para os centros clandestinos de tortura e extermínio como a "Casa da Morte", que o CIE coordenou em Petrópolis (RJ). Tais centros não eram utilizados apenas para o extermínio, mas eram efetivamente importantes para a tortura de militantes que, porventura, não estavam marcados para morrer, mas antes eram vistos pelo sistema como potenciais colaboradores, os infiltrados (denominados “cachorros”).

Essa rede de casas e lugares clandestinos existiu em várias partes do país. Pretendiam aplicar o máximo de sofrimento, sem testemunhas, para tirar a vitalidade e algo mais dos prisioneiros e obter algum resultado operacional, como manter segredo sobre infiltrações. Ou conseguir algum tipo de colaboração voluntária (ou não), operacional, técnica, política, que visava precisamente a “transformação” dos prisioneiros em infiltrados (denominados “cachorros”).

É possível estabelecer alguns paralelos entre esses centros de tortura e extermínio e campos de extermínio argentinos (i.e., a ESMA). Não obstante, é de se considerar que, 
na maioria dos casos, a engenharia de produção do sofrimento e despersonalização dos militantes nesses centros de tortura brasileiros não chegou ao nível de sistematização dos campos argentinos, bem como a escala de vítimas delineou-se em ordem diversa de grandeza. Por exemplo, os registros proporcionados pelos poucos sobreviventes brasileiros revelam que as pessoas não foram supliciadas e subjugadas por períodos tão longos quanto se fez comum na Argentina - o que, sem dúvida alguma, não dirime o impacto das torturas e do horror vividos, bem como das marcas indeléveis deixadas nas vítimas.

O caso das torturas levadas a cabo na casa de Petrópolis é emblemático, tal como é revelado pelos relatos da ex-prisioneira Inês Etienne Romeu que, por 96 dias, resistiu de maneira singular às enormes pressões e sofrimentos inomináveis voltados à sua desestruturação psíquica e emocional no intuito de conseguir a sua adesão ou retratação pública. Quase dez anos depois desses eventos, ela revelou o que se passou consigo e com diversos militantes com quem manteve contato naquela ocasião, todos eles desaparecidos.

Inês Etienne foi presa em 5 de maio de 1971, por agentes do delegado Fleury, num “ponto" marcado, desde abril, com um camponês da região de Imperatriz (MA) ${ }^{271}$. Naquele momento, Inês era dirigente da Vanguarda Popular Revolucionária (VPR) e se preparava para sair do país. Levada para o DEOPS/SP, foi severamente torturada. Desesperada, inventou um encontro no Rio de Janeiro que se realizaria no dia seguinte. Transferida, assim que chegou ao local (no bairro de Cascadura), jogou-se sob as rodas de um ônibus. Ficou bastante ferida e, após passar por três hospitais, foi finalmente levada para Petrópolis (RJ), onde começou a ser torturada, numa cama de campanha com lençóis estampados com as iniciais do CIE.

Foi torturada e interrogada por um dos agentes de São Paulo, que ela reconheceu como um dos torturadores que a havia seviciado no momento de sua prisão. De acordo com seu depoimento, depois de três dias presa “os agentes já sabiam que as informações que eu lhes pudesse fornecer seriam inúteis: as pessoas que eu poderia eventualmente comprometer já conheciam minha prisão $[\ldots]^{272 » \text {. }}$

Depois que o agente de São Paulo parou de interrogá-la, Inês foi espancada pelos agentes que trabalhavam na casa. Eles queriam saber coisas como: onde estava o dinheiro

\footnotetext{
${ }^{271}$ Cf. já mencionado, uma operação comandada pelo delegado Fleury em Imperatriz (MA) resultou, em abril de 1971, na prisão de Dênis Casemiro e Bartolomeu Toledo, militantes da VPR. V. RIBEIRO JR., op.cit., 05/04/98.

${ }^{272}$ RoMeU, Inês Etinnne. "Relatório Inês. Dossiê da tortura.” Pasquim, no . 607, RJ, 12 a 18/01/81, p.4-5, 26. Este relatório foi escrito por Inês em 1971, logo após ser libertada da "Casa da Morte”, quando estava hospitalizada.
} 
da organização; o “esquema médico” da VPR e o nome da pessoa que buscaria o médico, quando do sequestro do embaixador suíço; ou onde Lamarca estivera escondido. “Quando não me submetiam a torturas físicas, destroçavam-me mentalmente”, fazendo isso quase que ininterruptamente. “Dr. Roberto”, quem depois soube ser o capitão Freddie Perdigão Pereira, era um dos mais brutais torturadores, ele a espancou diversas vezes, tentou estrangulá-la, durante a noite colocava-a nua e molhada exposta ao inverno de Petrópolis. Foi torturada com choques elétricos e espancamentos. Um mês depois, aproximadamente, "Dr. Roberto" chegou a dizer-lhe que

“[...] eles não queriam mais informação alguma; estavam praticando o mais puro sadismo, pois eu já fora condenada à morte e que ele decidira que ela seria a mais lenta e cruel possível, tal o ódio que sentia pelos 'terroristas'. Fui então obrigada a escrever três documentos: uma análise sobre as esquerdas, os motivos de minha saída da organização e uma crítica sobre os órgãos de repressão do governo. Evidentemente as condições em que foram escritos estes documentos não refletem verdadeiramente o que penso sobre os assuntos neles abordados.

[...] Alguns dias após submetida a verdadeiro horror, apareceu o Dr. Teixeira, oferecendome uma saída 'humana': o suicídio. Disse-me que eu tinha sido condenada à morte, mas ao invés de uma morte lenta nas mãos do Dr. Roberto, eu poderia dar cabo da minha vida. Aceitei e pedi um revólver, pois já não suportava mais. Entretanto, Dr. Teixeira queria que o meu suicídio fosse público. Propôs-me então que eu me atirasse debaixo de um ônibus, como já fizera. Concordei e no dia seguinte (7 de julho) fui levada para o local. No momento em que deveria atirar-me sob as rodas de um ônibus, agachei-me e segurei as pernas de um deles, chorando e gritando. Minha atitude começou a despertar a atenção de populares e imediatamente fui reconduzida para a casa. Por não ter me matado, fui violentamente castigada [...]. Durante esse período fui estuprada duas vezes por Camarão [...].

Em 19 ou 20 de julho terminou essa fase de torturas. Dr. Pepe comunicou-me que haviam chegado a uma decisão a meu respeito: eu deveria tornar-me agente da repressão e infiltrar-me em minha organização. Fingi aceitar pois eu precisava quebrar a minha incomunicabilidade. Estava literalmente reduzida a um verme. O tratamento que me foi dispensando foi o mais cruel e mais desumano.

Apesar de concordar, aparentemente, com a solução do Dr. Pepe, pedi-lhe novamente que me entregasse à Justiça. Dr. Pepe reiterou-me que eu sabia demais e que, se chegasse aos tribunais, poderia denunciar tudo [...].

Nesta época fui forçada a assinar papéis em branco e escrever declarações ditadas por eles sobre a minha situação, desde o momento de minha prisão. Forçaram-me ainda a assinar um contrato de trabalho em que me comprometia a colaborar com os órgãos de segurança em troca de minha liberdade e de dinheiro. Neste contrato constava uma cláusula segundo a qual se eu não cumprisse o combinado, minha irmã [...] seria presa [...] eu estava arrasada, doente, reduzida a um verme e obedecia como um autômato.

[...] Obrigaram-me também a gravar um 'tape' em que me declaro agente remunerada do governo, e filmaram-me contando notas de dez cruzeiros, quando li o meu 'contrato de trabalho'.

Declarei nesse 'tape' que fui muito bem tratada por meus carcereiros. [...] Não me recordo de tudo o que disse, mas afirmo que era tudo falso e mentiroso. [...]

O vídeotape foi gravado no dia 4 de agosto.

[...] Entretanto, por conversas ouvidas de madrugada, entre Pardal e Laurindo, pressenti que se tramava uma cilada que culminaria com a minha morte. [...] para não colaborar com a farsa de uma 'morte acidental', cortei os pulsos [...] Perdi muito sangue [mas ...] 
ocorreu-me a certeza de que deveria lutar pela minha vida, porque tinha esperanças de denunciar tudo o que ocorrera e ainda todas as coisas que presenciei no inferno em que estava. Assim, gritei por Pardal que [...] providenciou os primeiros socorros.

[...] Durante o meu tempo de cativeiro tentei suicídio quatro vezes [...] mas não sou e nunca fui uma suicida em potencial.

[...] trouxeram-me numa perua veraneio [...] e deixaram-me na porta da casa da minha irmã [no dia 12 de agosto...] em Belo Horizonte.

[...] Ameaçaram-me de morte ou de condenação para o resto da vida, nas prisões. Como se o que eu passei não representasse a pena mais cruel que qualquer crime pudesse jamais acarretar [ROMEU, 1981: 4-5]."

Inês deveria inventar uma fuga do hospital para onde foi levada após a primeira tentativa de suicídio. Ela havia perdido 20 quilos, foi internada para tratamento e a família fez contato com o advogado Iberê Bandeira de Melo e um militar, para tentar regularizar sua situação legal. Pouco mais de um mês depois, Dr. Pepe foi até a clínica onde estava e propôs que ela fosse para um convento no Rio “[...] a fim de ser 'recuperada' [...]. Teria a obrigação de entregar os remanescentes da VPR [...] e se [...] tentasse fugir [...] o videotape e o contrato seriam exibidos nas prisões, para que os presos políticos fossem convencidos de que [...] realmente era uma agente do governo [ROMEU, 1981: 26].”

Em novembro de 1971, a fim de evitar que Inês fosse assassinada numa simulação de acidente ou suicídio, o advogado Augusto Sussekind de Moraes Rego conseguiu que Inês fosse presa legalmente. Em agosto de 1972, ela foi condenada a prisão perpétua. Em maio de 1977, sua pena foi reduzida pelo STM a 30 anos de reclusão; ela permaneceu na penitenciária Talavera Bruce, em Bangu, no Rio de Janeiro, até 29 de agosto de 1979. Dois anos depois, em 1981, com o apoio de familiares de desaparecidos políticos e da $\mathrm{OAB}$ e ABI, localizou e denunciou o centro de extermínio onde esteve sequestrada, em Petrópolis [TELES, 2005]. Em seguida, denunciou o auxílio à tortura prestado pelo médico Amílcar Lobo, cujo registro profissional foi cassado pelo Conselho Regional de Medicina do Rio de Janeiro.

Nesse relatório divulgado por ocasião da denúncia sobre a casa, Inês relacionou as pessoas que lá estiveram presas e que, desde então, constam como desaparecidas políticas. Ela citou dez nomes de dirigentes e militantes de organizações adeptas da luta armada, as quais viu, ouviu os gritos ou que foram citadas pelos torturadores ${ }^{273}$. Inês relatou também que no mês de maio de 1971, soube por “Camarão” que o Cabo Anselmo

\footnotetext{
${ }^{273}$ Mariano Joaquim da Silva, dirigente da VAR-Palmares; Carlos Alberto Soares de Freitas, dirigente da VAR-Palmares; Marilena Villas Boas Pinto, militante do MR-8; Rubens Beirodt Paiva, deputado federal cassado; Aluísio Palhano Pedreira Ferreira, da VPR; Ivan Mota Dias, dirigente da VPR; Walter Ribeiro Novaes, da VPR; Paulo de Tarso Celestino da Silva, dirigente da ALN; Heleny Telles Ferreira Guariba, da VPR; e José Raimundo da Costa, dirigente da VPR [ALMEIDA, 2009].
} 
havia sido preso. Em fins de junho, "Dr. Teixeira” disse-lhe que Anselmo estava trabalhando para os órgãos de segurança como infiltrado. Apesar das dificuldades para estabelecer um padrão na condução e funcionamento do centro de extermínio de Petrópolis, alguns aspectos e características chamam a atenção.

Inês conversou com Mariano, líder camponês e dirigente da VAR-Palmares, por três vezes. Este contou-lhe ter sido preso e torturado em Recife e, finalmente, chegado na “Casa da Morte” no dia 2 de maio, onde continuou sendo torturado ininterruptamente por quatro dias. Até o dia 31 de maio, ele permaneceu no centro clandestino fazendo o serviço doméstico. "Dr. Teixeira” disse a Inês, em princípio de julho, que Mariano fora executado, pois era considerado “irrecuperável”. Dr. Pepe informou a Inês que Carlos Alberto Soares de Freitas, também dirigente da VAR-Palmares, foi preso em fevereiro e executado por seu grupo, pois “[...] todos os ‘cabeças’ seriam sumariamente mortos, após interrogatório”. Ele contou também que a morte do deputado cassado Rubens Beirodt Paiva ocorreu em decorrência das torturas e foi “uma mancada” [ROMEU, 1981: 26].

Antônio Joaquim de Souza Machado e Carlos Alberto Soares de Freitas foram presos pelo DOI-Codi/RJ, na Rua Farme de Amoedo, no dia 15 de fevereiro de 1971 e, desde então, tornaram-se desaparecidos. Na mesma data e local foi preso Sérgio Emanuel Dias Campos, que confirma ter sido torturado nas dependências do DOI-Codi. De acordo com Rosalina Santa Cruz, as prisões da VAR-Palmares desse período foram decorrentes da ação de um agente infiltrado de codinome Grego:

"Uma história que a gente acompanhou muito de perto foi a do Grego, que era um cara que veio [de Cuba] com o [Aderval Alves] Coqueiro. [...] quando ele chegou, eu fui a primeira pessoa procurada por ele.

[...] O Coqueiro era um dirigente que voltou de Cuba sem nenhuma estrutura. Não havia estrutura para receber as pessoas que foram fazer treinamento em Cuba e haviam saído no sequestro [do embaixador alemão]. O Coqueiro voltou junto com esse cara, um exmarinheiro chamado Grego. Ele não tinha contato e procurou uma pessoa conhecida, o Joaquim, a quem eu dava assistência. Através do Joaquim, passei o meu contato que era o Breno [Carlos Alberto Soares de Freitas]. [...] Depois, o Coqueiro foi seguido e morto, em função do trabalho do Grego. [...] Não sei como a gente não 'caiu' nessa hora, porque entramos num 'ponto' com esse ex-marinheiro. [...] Esse cara, o Grego, também foi para Recife $^{274}, ”$

\footnotetext{
${ }^{274}$ Entrevista concedida por Rosalina Santa Cruz à autora. Idem, ibidem. Aderval Alves Coqueiro era militante do MRT (Movimento Revolucionário Tiradentes), chegou de Cuba em 31/01/71 e foi assassinado em 06/02/71 [AlmEIDA, 2009, p.227-29]. Diversos relatos de ex-presos políticos descrevem a promessa feita por Coqueiro de que voltaria rapidamente para ajudar na luta e para soltá-los. V., por exemplo, CunHA, Carlos Alberto Lobão. "Desesperar jamais. Aprendemos muito nesses anos", em Tiradentes, op.cit., p.239.
} 
Dirigentes da VPR e da Var-Palmares, como James Alen Luz (conhecido como Ciro), não acreditaram que Grego fosse o agente infiltrado, mas havia desconfianças em São Paulo e Pernambuco. Conforme o relato de Rosalina, Raimundo Gonçalves Figueiredo, de Recife (PE), desconfiava de Grego, pois as pessoas estavam sendo seguidas após cobrirem ponto com ele. Os testemunhos recolhidos nesta pesquisa indicam que a maioria das prisões dos militantes que foram mortos na casa de Petrópolis foram resultado da atuação de Cabo Anselmo e Grego, cada um atuando em separado - um na VPR outro na Var-Palmares. Alen Luz chegou a discutir a respeito das suspeitas que recaíam sobre Grego com outros militantes, inclusive com Rosalina e Geraldo, mas se recusava a aceitar essa hipótese:

\begin{abstract}
“O Ciro dizia: '- Ele não é a infiltração, eu ponho a mão no fogo!' Ele mandou um amigo e o Grego para casa da família dele em Goiás, enquanto resolvia o problema de Recife, onde o Raimundo dizia que tinha sido seguido por esse cara. [Um dia] estou no cine Paissandu [no Rio de Janeiro] e vejo o Grego passar, e disse: '- O cara voltou e sem falar com o Ciro'. [...] Eu sei que ele recebeu o Grego de volta. Abriu um ponto em Recife para ele e morreu um monte de gente. É quando morre o Raimundo. E a gente foi descobrindo que o cara era infiltração e que estava dentro da organização, porque veio de Cuba seguido. [...] a gente não tinha controle sobre as mortes, as prisões.

[...] Nós tínhamos um ponto com o Sérgio Emanuel Dias Campos, que era na época do comando regional, e a gente era parte do comando. O Sérgio Emanuel encontrou com a gente e disse: '- O Breno furou dois pontos.' E disse: '- Ele pode estar preso'. [...] fomos com nosso carro até a praça perto da Farme de Amoedo. [...] o Sérgio entrou, porque ele morava na casa. Na hora que ele entrou, o Geraldo [...] viu [...] gente saindo de tudo quanto era carro, eles estavam de tocaia. [...] O Sérgio foi levado para o DOI-Codi/RJ e teve um processo normal. O Antonio Joaquim, muito menos importante na organização do que o Sérgio, não. Mas ele sabia da infiltração, porque foi quem recebeu o Coqueiro. Pode ser por isso que ele foi levado para a 'Casa da Morte' junto com o Breno ${ }^{275}$."
\end{abstract}

Muitos anos depois, em abril de 1987, Rosalina soube que Grego se chamava Vitor Luiz Papandreu, quando a revista IstoÉ estampou sua foto na capa com a seguinte manchete: "Vítima de Fuzilamento". Amilcar Lobo se reuniu com familiares de desaparecidos políticos no dia 17 de abril para relatar as informações sobre os que desapareceram na "Casa da Morte” ou no DOI-Codi (RJ), onde, como médico, prestou auxílio aos torturadores. De acordo com a matéria, Papandreu foi reconhecido por Lobo quando procurado por um familiar dele após a reunião. De acordo com Lobo, Papandreu teria sido fuzilado em Petrópolis pelo então major Rubens Sampaio.

Grego foi reconhecido também pelo coronel Jefferson Cardim Osório, que em 1968 estava preso no quartel do Boqueirão, em Curitiba (PR). Segundo ele, Papandreu

\footnotetext{
${ }^{275}$ Entrevista concedida por Rosalina Santa Cruz à autora. Idem, ibidem. Raimundo foi morto em 28/04/71, em Recife (PE) [ALMEIDA, 2009, p.244-45].
} 
servia como soldado no quartel e se interessou por ajudá-lo a fugir. Fugiu com o auxílio de outros dois soldados e do major Joaquim Pires Cerveira, que respondia a processo em liberdade. Cerveira está desaparecido desde dezembro de 1973 [ALMEIDA, 2009: 507512). Os dois se refugiaram na embaixada do México. Papandreu viajou para Cuba e depois, Chile. De lá, voltou para o Brasil. De acordo com Lobo, em fins de 1971 ou começo de 1972, Papandreu estava na "Casa da Morte” e sofria um processo agudo de esquizofrenia, mas o major Sampaio ainda queria que ele os levasse a um lugar em Goiás. Sem condições de viajar, Lobo assistiu a execução de Papandreu com um "tiro na testa"276.

De acordo com as investigações de Sergio Ferreira, primo de Carlos Alberto Soares de Freitas (o Breno), e militante atuante da Comissão de Familiares de Mortos e Desaparecidos Políticos e do Comitê Brasileiro pela Anistia, nos anos 1970 e 1980, a história das prisões de Breno e seus companheiros apresenta indícios de que Grego seria um agente infiltrado:

"Em Cuba, o Grego se integra à comunidade de exilados e conheceu o James Alen Luz. [...] Em janeiro de 1970, o Coqueiro, que saiu no sequestro do [embaixador] alemão, volta para o Brasil com o Grego, com um esquema da VAR-Palmares, [...] embora fosse de outra organização. Quem se responsabiliza pela volta do Coqueiro é o meu primo, o Breno.

[...] Eles vêm pelo Chile, a Flávia Cavalcante, uma militante da VAR, esteve com o Coqueiro lá. [...] Mas ela e o Galeno não têm certeza de que quem estava com o Coqueiro era o tal Grego. Mostramos a foto da Isto É e eles ficaram na dúvida [...]. O Coqueiro dormiu na casa dela no Chile antes de entrar no Brasil, ela achou que era o Grego na foto, mas não deu certeza. Claro que, naquela foto, ele está muito jovem!

O Coqueiro chegou ao Rio de Janeiro no dia $1^{\circ}$. de fevereiro ou no final de janeiro e o Breno destacou duas pessoas para cuidarem dele, uma era a Lurdinha, a mulher do James Alen, e a outra pessoa era o 'Bigode', o Antonio Joaquim Machado [...].

[...] Conversei com a Lurdinha. Ela alugou um apartamento com o nome da mãe e elas moravam lá. [...] Entre os dias 1 e 3 de fevereiro (acho que a queda do Breno começa aí), o Bigode disse para a Lurdinha: '- O Grego quer se encontrar com o Coqueiro. Eles são muito amigos e ele quer se reencontrar com o companheiro de Cuba'. A Lurdinha respondeu: '- A ordem do comando é que ninguém vai ao aparelho em que ele está. Em hipótese alguma. Não se pode levar ninguém ao aparelho!'

[...] Nessa época, o comando da VAR Palmares, [...] era composto pelo meu primo e o Mariano, porque os outros já tinham 'caído'. [...] Tinha o James Alen também [...], mas do comando original restavam apenas o Breno e o Mariano.

[...] Enfim, a Lurdinha tinha vida legal, como a Rosalina e o Geraldo Leite. Em 3 de fevereiro, ela foi para Recife a trabalho e encontrou-se com o James Alen, acho que no dia 6 de fevereiro. Simultaneamente, neste dia a Lurdinha foi presa no Recife e o

\footnotetext{
276 "Vítima de Fuzilamento", IstoÉ, 29/04/87, p.22-5. Amilcar Lobo relata que atendeu a um rapaz com as características físicas de Papandreu, que estava com alucinações e agressivo, um quadro de esquizofrenia. Major Sampaio o chamava de "Papaleo”. Na segunda vez que visitou o "paciente”, viu o major matá-lo, sem precisar a data. Segundo o major, 10 pessoas já haviam sido mortas na casa, denominada por ele de “aparelho”. V. LoBO, Amilcar. A hora do lobo, a hora do carneiro. Petrópolis, Vozes, 1989, p.35-7.
} 
Coqueiro foi morto no Rio de Janeiro. Ela foi presa e torturada, quando saiu da cadeia e reencontrou a mãe, [...] ela lhe contou que depois que viajou, o Bigode levou um rapaz lá, que seria o Grego. Isso foi no dia 6 de fevereiro, a morte do Coqueiro saiu nos jornais, acho que no dia seguinte, assim: 'Primeiro banido morto'.

O Joaquim Machado viu aquilo numa banca de jornal, [...] e rapidamente se desfez do aparelho dele no Catete. [...] Ele se sentiu ameaçado, porque comprava passaportes para a organização com dois policiais, que ele subornava. Esses policiais foram presos, essa é outra pista [...] registrada nos arquivos do DEOPS/RJ. Bem, entre 7 de fevereiro até o dia 15, o Joaquim começou a pular de galho em galho. Ele dormiu em casa de gente da AP etc. No dia 15, o Sergio Campos foi se encontrar com o Breno na pensão [onde eles moravam] e saíram juntos. O Breno virou para ele e falou: '- O Bigode dormiu aqui ontem a noite, pois não tinha lugar para ficar. Eu o deixei dormir aqui!' O Sérgio está vivo e nos contou isso [...], possivelmente, o Bigode pode ter sido seguido pelo Grego ou pelos militares para quem ele trabalhava. Neste dia, todos eles foram presos... ${ }^{277,}$

O testemunho de Inês sobre a "Casa da Morte”, assim como os depoimentos registrados na justiça militar e nesta pesquisa, suscita questões sobre os critérios utilizados pela repressão política para eliminar os “indesejáveis”. Eles nos permitem conhecer parte dos percursos e suplícios a que estavam submetidos os presos políticos antes de terem suas prisões legalizadas. E também um pouco do funcionamento da rede clandestina de centros de tortura e extermínio do sistema DOI-Codi. “Terroristas” e “irrecuperáveis” eram torturados antes de morrerem, mas somente alguns se tornavam desaparecidos. Os relatos dos sobreviventes e dos poucos militares que falaram indicam que a "Casa da Morte” foi organizada no início do funcionamento do sistema DOI-Codi, sendo parte de sua estrutura clandestina.

Essas casas foram criadas para que os diversos órgãos de segurança e informação tivessem maior liberdade para torturar e decidir a maneira como alguns militantes destinados a morrer deveriam ser executados, ao passo que em 1973, a cúpula militar decidiu pelo extermínio das lideranças de todos os partidos das esquerdas revolucionárias, ampliando seu papel no sistema DOI-Codi.

Presos sequestrados pelos DOI-Codis e os DEOPS foram levados para a "Casa da Morte”278. Agentes de outros organismos torturaram e interrogaram no local, o que teria representado um rompimento na orientação dos manuais militares de manter a compartimentação das funções e na execução das operações. A “Casa da Morte” era dirigida pelo CIE, mas as operações de segurança eram coordenadas pelos Centros de

\footnotetext{
${ }^{277}$ Entrevista concedida por Sérgio Ferreira à autora. RJ, 25/03/2011.

${ }^{278} \mathrm{O}$ caso de Aluísio Palhano Pedreira Ferreira ilustra isso, embora algumas datas não coincidam. Ele foi visto com marcas de tortura no DOI-Codi/SP por Altino Dantas, de onde teria sido retirado em 20/05/71. Palhano contou-lhe que havia sido sequestrado na rua, em São Paulo, em 09/05/71 e que, no dia seguinte, foi levado ao Cenimar/RJ. O ex-preso político Nelson Rodrigues Filho o viu no DOI-Codi/RJ. Inês Etienne contou que Palhano teria sido levado para Petrópolis em 13/05/71 [ALMEIDA, 2009, p.251-52].
} 
Operações de Defesa Interna (Codi), que contavam com pessoal de diversos setores. Os órgãos de segurança e informação militares de informação, por sua vez, eram subordinados aos respectivos ministros de cada força, mas deveriam agir de acordo com o Codi e o general comandante do Exército [FICO, 2001: 92]. Essa sobreposição de hierarquias era parte da lógica repressiva, criando uma gama enorme de órgãos e funções para dar lugar a todos aliados e lidar com as disputas, mas que centralizava a decisão sobre a vida e a morte dos "terroristas", banidos, “cubanos", enfim, os considerados “irrecuperáveis”.

De acordo com o testemunho de Inês Etienne, a maioria dos militantes assassinados na casa era de dirigentes da VPR e foram vítimas da ação do agente infiltrado “Cabo Anselmo”. Vários depoimentos coincidem quanto à perspectiva de que o delegado Fleury coordenava a atuação de Anselmo como infiltrado, possivelmente em parceria com o Cenimar, a partir de outubro de 1970 ou mesmo anteriormente, desde sua chegada de Cuba ao Brasil ${ }^{279}$.

A despeito da afirmação de que havia começado a trabalhar para a repressão política em 1970, quando teria sido preso, há relatos que sugerem que a entrada de Anselmo nos órgãos de informação pode ter se dado bem antes dessa data. Em 2001, o antigo diretor do DEOPS/RJ, Cecil Borer (1913-2003), concedeu entrevista ao jornalista Mário Magalhães, publicada em 31 de agosto de 2009 no jornal Folha de S. Paulo, na qual Borer afirma que Anselmo já era informante do Cenimar, do DEOPS/RJ e da Agência Central de Inteligência (CIA), antes do golpe de 1964. Esta informação aponta para a possibilidade de que Anselmo tenha atuado como infiltrado no Brasil desde sua chegada de Cuba em $1970^{280}$.

Inês Etienne enumerou vinte pessoas trabalhando na casa, entre eles um médico, Amilcar Lobo, e pelo menos sete oficiais. Sabem-se os nomes completos de apenas quatro - o capitão Freddie Perdigão Pereira (“Dr. Roberto”), o tenente coronel Orlando Rangel (“Dr. Pepe”), e o do policial militar Jarbas Fontes (“Pardal”). De acordo com o

\footnotetext{
${ }^{279}$ V. declarações de José Anselmo dos Santos, o Cabo Anselmo, em: "Relatório da Paquera”, DEOPS/SP, 04/06/71. Recém chegado de Cuba, José Maria Ferreira Araújo (Araribóia) pode ter sido o primeiro a ser delatado por Anselmo, em 23/09/70. Em seguida, Edson Neves Quaresma e Yoshitane Fujimore, em 05/12/70; e os já mencionados militantes que estiveram na "Casa da Morte". Além disso, Eudaldo Gomes da Silva, Evaldo Luiz Ferreira de Souza, Jarbas Pereira Marques, José Manoel da Silva, Pauline Reichstul, Soledad Barret Viedma, foram executados em 08/01/73, na Chácara São Bento, nas proximidades de Recife.

${ }^{280}$ Magalhães, Mário. “Ação de Anselmo é pré-64, diz policial”. Folha de S. Paulo, 31/08/09. Cf. mencionado, Borer foi um dos criadores do Esquadrão da Morte no RJ, nos anos 1950, e Fleury um dos principais homens do Esquadrão em SP, nos anos 1960 e 1970. Ambos teriam trabalhado com o agente infiltrado Cabo Anselmo e mantiveram contatos regulares com a Marinha e o Cenimar.
} 
jornalista Percival de Souza, “Dr. Teixeira” é o major Rubens Sampaio, também citado por Amilcar Lobo [SOUZA, 2000: 278].

Os prisioneiros considerados “irrecuperáveis” foram levados para diversos órgãos de segurança e casas clandestinas. Segundo Percival de Souza, Perdigão, agente do DOICodi/SP que atuava na "Casa da Morte”, dava-se muito bem com Sampaio e Fleury, eram agentes duros nos interrogatórios e especialistas em torturas. Atuaram juntos, por exemplo, na captura de Carlos Lamarca, na Bahia. Perdigão serviu nos DOI-Codis do Rio de Janeiro e São Paulo, no CIE e chegou a coronel quando trabalhava no SNI. Em 1970, era conhecido como "Dr. Nagib”, no DOI-Codi/RJ. Ele foi denunciado como torturador quando atuava nesse centro de tortura e extermínio e aparece em duas listas do $\mathrm{BNM}^{281}$. Participou, juntamente com “Dr. Pepe", da Operação Kimble, a que matou os remanescentes da VPR em Pernambuco, em janeiro de 1973. Ficou conhecido em 1981, quando do atentado do Riocentro. Na reabertura do caso, o IPM indiciou o coronel Perdigão como um dos artífices do atentado que explodiu a bomba no carro onde estavam um sargento, morto na hora, e um capitão, que ficou gravemente ferido [SoUZA, 2000: 278-9, 408, 448].

Outro aspecto que chama a atenção é o fato de um dos dirigentes da VPR, Ivan Mota Dias, (suspeito de ter participado das ações que levaram aos sequestros dos embaixadores da Alemanha e da Suíça em 1970), tenha sido preso em 15 de maio de 1971 pelo CISA e desaparecido na "Casa da Morte”. O preso político Alex Polari de Alverga testemunhou ter ouvido pelo serviço de alto-falantes da Base Aérea do Aeroporto do Galeão, o anúncio da “queda do Comandante Cabanas, da VPR”. Inês Etienne relatou que dias antes, um dos torturadores da casa conhecido como "Dr. Guilherme” lhe disse que iriam prender Ivan no dia 15. Logo depois, contou-lhe que ele havia sido executado [ALMEIDA, 2009: 248-49]. Esses relatos indicam uma relação próxima e de colaboração entre os diversos órgãos de segurança e informação.

A mesma engrenagem foi utilizada pelo DOI-Codi/SP para montar um sistema semelhante num sítio, idealizada para cumprir as mesmas funções da casa de Petrópolis, local onde eram levados os prisioneiros considerados "especialíssimos”. O sítio era denominado "Fazenda 31 de março" e controlado pelo delegado Fleury. Lá morreu Joaquim Câmara Ferreira, antigo comunista e comandante da ALN, falecido em

\footnotetext{
${ }^{281}$ V. "Elementos Envolvidos Diretamente em Torturas", em "Os Funcionários”, Tomo II, Vol. 3, p. 39; e “A Pesquisa BNM", Tomo II, Vol. 1, p. 209; “As Torturas”, Tomo V, vol. 3, p.769. V. tb. "Membros dos órgãos da Repressão", Tomo II, Vol. 3, "Os Funcionários”, p.233. V. http://www.torturanuncamaisrj.org.br/denuncias. Acesso em 05/03/2011.
} 
consequência das torturas sofridas em 23 de outubro de 1970. De acordo com o testemunho de um dos sobreviventes, Maurício K. Segall:

\begin{abstract}
"No sítio, bem primitivo, ao qual chegamos de olhos vendados, a iluminação era de velas, pois não havia luz elétrica. O sítio aparentemente tinha dois quartos, uma sala/cozinha e um banheiro. Os choques elétricos aplicados no pau-de-arara eram gerados num aparelho, acionado por manivela manual. Já estava lá sendo torturado Viriato, recém chegado de Cuba... Tudo que se passava num dos cômodos, mesmo com porta fechada, se ouvia nos demais [...]. Quando fui pendurado, o interrogador era o próprio Fleury [...]. Em meio da minha tortura no pau de arara, já de noite, que vinha durando algum tempo, houve uma agitação coletiva, colocaram uma espécie de apoio nos meus quadris, de forma que fiquei só parcialmente pendurado e a maioria dos policiais deixou às pressas o sítio, deixando apenas dois ou três para trás. Não sei quanto tempo isto durou (no mínimo 2 horas) mas, a um certo momento fui tirado com as pernas totalmente inermes do pau de arara só podendo andar amparado e fiquei sentado na sala com uma venda nos olhos, mas que deixava uma fresta na parte de baixo. Logo depois ouvi uma pessoa chegando, arfando desesperadamente, com falta de ar, com sintomas muito parecidos com ataque cardíaco (que eu conhecia pois eram semelhantes aqueles do meu pai, por ocasião de sua morte). Esta pessoa foi levada para o quarto que tinha a cama e não o pau de arara. Fiquei sabendo que era Toledo pelos comentários que vinham sendo feitos pelos policiais. Havia muita agitação entre eles e Toledo não parava de arfar. A um certo momento, vi pela fresta inferior da venda dos olhos, passarem duas pernas vestidas de branco calçadas com sapatos brancos. Não havia dúvida que era um médico. Logo depois, Toledo parava de arfar. Muito rapidamente o acampamento foi levantado e fomos levados de olhos vendados para o DOPS e a seguir para a OBAN [...]. Ouvi diversas manifestações de irritação do pessoal da OBAN com o pessoal do Fleury devido à morte de Toledo sem que eles pudessem tê-lo interrogado também [...]. Soube depois também que o fato de Maria, Viriato e eu termos sobrevivido ao sítio se deveu, em boa parte, à morte prematura de Toledo." 282
\end{abstract}

Apesar das disputas e divergências existentes entre os diversos órgãos de segurança e informação, alguns grupos de agentes desses mesmos órgãos atuaram conjuntamente em várias operações. Este foi o caso do então capitão Ênio Pimentel Silveira, chefe da Divisão de Investigações da Operação Bandeirante, do DOI-Codi/SP e do CIE, entre 1969 e 1986 e amigo pessoal do delegado Fleury. De acordo com reportagem da revista Época, capitão Pimentel, também conhecido como "Dr. Ney”, frequentava a "Fazenda 31 de março"283.

\footnotetext{
${ }^{282}$ V. depoimento de Maurício K. Segall, em Almeida, 2009, p.207. Em setembro de 1970, Câmara Ferreira enviou José da Silva Tavares, que voltava do treinamento de guerrilha em Cuba, para região norte. João Alberto Capiberibe, Carlos Augusto Sampaio e Tavares foram presos em 10/09/70, quando Tavares se tornou um infiltrado e delatou Câmara Ferreira, em 23/10/1970. Cf. RIBEIRO JR., Amaury. "Mesopotâmia: uma operação militar desconhecida”, O Globo, 05/04/1998.

${ }^{283}$ V. LOYOLA, L. "O filho do caçador”, Época, 10/11/03. Segundo a matéria, o sítio estava localizado em Parelheiros e era alugado de um amigo de Enio e Fleury. O casal Sônia Maria Angel Jones e Antônio Carlos Bicalho Lana, militantes da ALN, foram assassinados no sítio, em 1973. Neste ano, "Dr. Ney" teria interrogado brasileiros no Estádio Nacional, no Chile, após o golpe de Pinochet. Também teria interrogado prisioneiros da Guerrilha do Araguaia. Em 1991, a CPI da Vala de Perus fez diligências, mas não conseguiu localizar o sítio. Cf. CALIGIURI FILHo, Júlio César e outros. Onde estão? (Relatório da CPI da Vala de Perus) São Paulo, Câmara Municipal, 1992.
} 
“Dr. Ney” teria levado para os meios militares os métodos aprendidos com Fleury para implementar infiltrações e criar redes de centros clandestinos de tortura e extermínio; juntos, mantiveram esses lugares onde prisioneiros importantes eram levados sem que ninguém soubesse e eram convertidos em “cachorros” (infiltrados). Em 1979, ele foi promovido e passou a atuar no CIE de Brasília, onde tinha a função de controlar as infiltrações mantidas pelo Exército ${ }^{284}$.

Em 1992, matérias publicadas na revista Veja (20 de maio e 18 de novembro) divulgaram informações sobre as infiltrações e as redes de centros clandestinos de extermínio, baseadas em depoimento do ex-agente do DOI-CODI/SP, Marival Dias Chaves do Canto, nas quais revelava em parte como atuavam os infiltrados. Nesse momento, disse que alguns desaparecidos em São Paulo eram mortos com aplicação de injeção usada para matar cavalos e, em seguida, eram esquartejados. De acordo com ele, na "Casa da Morte” os militantes também eram esquartejados para dificultar a descoberta e a identificação do morto.

Marival Chaves confirmou que havia diversas casas clandestinas utilizadas pelo CIE, a de São Conrado (RJ), a de Petrópolis e o sítio de São Paulo. No final de 1973, o DOI-Codi usou uma casa no bairro do Ipiranga, em São Paulo, e montou outro centro clandestino na estrada de Itapevi. Em 1975, por questões de segurança, a casa de Itapevi foi substituída por uma fazenda, na beira da Rodovia Castello Branco, a 30 quilômetros de São Paulo, de um amigo do major André Leite Pereira Filho, chefe das equipes de interrogatório do DOI-Codi/SP. Disse ainda que nas casas do Ipiranga e da estrada de Itapevi havia grilhões para acorrentar os pés e as mãos dos presos às camas e a blocos de cimento. Nas casas de São Paulo, havia uma equipe especializada em ocultar cadáveres. Explicou os procedimentos para jogar os corpos em rios e afirmou que numa ponte na estrada que liga a cidade de Avaré à Rodovia Castello Branco haveria corpos. De acordo com o ex-agente, pelo menos oito dirigentes do PCB teriam sido jogados nesse local ${ }^{285}$; não obstante, escavações realizadas em 1992 não detectaram vestígios comprobatórios.

\footnotetext{
${ }^{284}$ Em 23/05/86, Ênio foi encontrado morto na casa onde morava no Forte Itaipu, em Santos, com 4 tiros no peito, 3 disparados à queima-roupa. O IPM considerou que sua morte foi decorrente de suicídio. Seu amigo Fleury foi assassinato em 1979, mas a versão oficial concluiu por morte acidental.

${ }^{285}$ Hiram de Lima Pereira, Luís Inácio Maranhão Filho, João Massena Melo, Orlando Bonfim Júnior, Elson Costa, Itair José Veloso, Jayme Amorim de Miranda e José Montenegro de Lima teriam sido torturados na casa de Itapevi e, depois, jogados ao rio. Segundo Marival Chaves, presos em São Paulo também eram transferidos para Petrópolis como Issami Okano, Ana Rosa Kucinski e seu marido, Wilson Silva, da ALN; e Walter de Souza Ribeiro, José Roman e David Capistrano, do PCB. A prática de ocultação dos corpos era feita por meio do esquartejamento. Eduardo Leite, da ALN, foi preso pela equipe do Fleury e ficou na casa de São Conrado.
} 
Em 2010, a Secretaria Especial de Direitos Humanos (SEDH) empreendeu buscas por restos mortais de desaparecidos políticos. As buscas foram feitas em quatro estados por uma equipe formada por funcionários da SEDH, agentes da Polícia Federal, procuradores da República e um consultor externo, o ex-preso político Ivan A. Seixas. As pesquisas preliminares feitas em Petrópolis consistiram em buscar registros de pessoas que foram vítimas de mortes violentas ou de indigentes enterrados no cemitério municipal, cujos nomes coincidissem com as datas, causa mortis e descrições de 19 militantes desaparecidos no Rio de Janeiro [SEDH, 2010:168-69]. Os dados apresentados pela SEDH, contudo, não indicam a ocorrência do mesmo padrão utilizado pelos órgãos de segurança no cemintério Dom Bosco, em Perus (SP), ou no cemitério Ricardo de Albuquerque, no Rio de Janeiro, onde os nomes encontrados nos livros de registro coincidiam com os "nomes de guerra" usados pelos militantes na clandestinidade; e as respectivas requisições de exames necroscópico continham marcas distintivas como o “T”, de terrorista, ou “sub”, de subversivo ${ }^{286}$.

As investigações da SEDH em busca dos restos mortais dos militantes da VPR desaparecidos em julho de 1974, no Parque Nacional do Iguaçu, próximo a Medianeira $(\mathrm{PR})$ não conseguiram localizá-los, mas obtiveram novos dados que se somam às informações encontradas nos arquivos do DEOPS/SP e às investigações de jornalistas. A prisão e morte de Onofre Pinto, Joel e Daniel José de Carvalho, José Lavecchia, Victor Carlos Ramos e o argentino Enrique Ernesto Ruggia se deu em decorrência da ação de um ex-militante infiltrado, Alberi Vieira dos Santos ${ }^{287}$.

Os documentos comprovam que Onofre Pinto era monitorado no exterior pelo menos desde 1970. Em 1974, o grupo entrou clandestinamente no Brasil, numa emboscada para prendê-los, chamada Operação Juriti, comandada pelos coronéis do CIE Paulo Malhães e José Brandt Teixeira. Alberi contou com o auxílio de um agente policial infiltrado. De acordo com esse agente (que não declarou seu nome), o major Sebastião Rodrigues de Moura, o Curió, militar que comandou as operações finais de extermínio

\footnotetext{
${ }^{286}$ As escavações não foram iniciadas, pois algumas das sepulturas estão sob as calçadas da avenida que corta o cemitério ao meio e nas encostas dos morros ao redor. De acordo com a administração do cemitério, os mortos investigados foram enterrados em covas rasas na década de 1970, podem ter sido exumados cinco anos depois e jogados em valas comuns. LoYolA, Leandro. "Na pista dos desaparecidos", em http://revistaepoca.globo.com/Revista/Epoca/0,EMI223049-15223,00.html. Acesso em 11/04/2011.

${ }^{287}$ V. PALMAR, Aluizio. Onde foi que vocês enterraram nossos mortos? Foz de Iguaçu, Travessia dos Editores, 2005, p. 213-32. Não foi possível comprovar o desaparecimento de outro militante que estaria no grupo de Onofre, Gilberto Faria Lima (Zorro) [ALMEIDA, 2009, p.584-89].
} 
dos guerrilheiros do PCdoB, no sudeste do Pará, participou dessa operação ${ }^{288}$. Outros dois ex-militantes da VPR também atuaram como agentes infiltrados nesta operação: Maria Madalena de Azevedo e Gilberto Giovaneti [AlmEIDA, 2009, p.587-88].

Outro ex-agente do CIE informou anonimamente à SEDH os nomes de outros militares e policiais que teriam participado da operação: o capitão e chefe da Divisão de Investigações do DOI-Codi/SP Enio Pimentel da Silveira, o "Dr. Ney”, e os agentes de codinome "Camarão", "Laicato" (mencionados no relato de Inês Etienne Romeu) e "Presuntinho". As informações sobre a localização dos restos mortais fornecidas pelo militar, contudo, foram bastante imprecisas, assim, não foi possível encontrar nenhum vestígio dos militantes desaparecidos ${ }^{289}$. Não obstante, tais informações reforçam os indícios, compilados neste capítulo, indicativos da colaboração existente entre os diversos órgãos do aparato repressivo, naquele período.

Em janeiro de 1979, Alberi Vieira dos Santos foi assassinado, seu corpo apareceu crivado de balas e mutilado: outro caso de um colaborador dos órgãos repressivos que foi eliminado. Alberi era sargento da Brigada Militar do Rio Grande do Sul, de onde foi expulso pelo AI-1. Participou de uma tentativa de deflagrar um movimento guerrilheiro na cidade de Três Passos (RS), em março de 1965. Preso no mês de abril daquele ano, foi condenado a oito anos de prisão e libertado em 1973. Ele teria começado a colaborar com o CIE em junho do mesmo ano 290 .

Em 2008, veio a público o diário de um militar do CIE, que apresentou informações (bastante imprecisas) sobre sua participação em diversas operações de segurança $^{291}$. Carioca participou da Operação Juriti, enviado pelo major Gilberto Ayrton Zenkner, o “Dr. Nunes”, comandante da Operação Sucuri (operação de informação que antecedeu a terceira campanha de repressão à Guerrilha do Araguaia iniciada em maio de 1973), sob as ordens do coronel Paulo Malhães. De acordo com sua versão, entretanto, o

\footnotetext{
${ }^{288}$ V. PALMAR, 2005, p.230. Segundo Percival de Souza, o delegado Fleury teria participado da operação e matado Onofre Pinto [SouZA, 2000, p.251-57].

${ }^{289}$ Outras duas escavações foram organizadas na região com a participação da EAAF em 2001 e 2005. V. ALMEIDA, 2009, p.589; e SEDH, 2010, p.167-68.

${ }^{290}$ Dois irmãos de Santos também foram assassinados: José Soares dos Santos apareceu morto com marcas de tortura, na região de Foz de Iguaçu (PR), em janeiro de 1977. E Silvano Soares dos Santos foi vítima de morte violenta em 25/06/70 [Almeida, 2009, p.683]. V. tb. PALMAR, 2005; e Dossie dos Mortos e Desaparecidos Políticos a partir de 1964. São Paulo, IMESP, 1996, p.225.

${ }^{291}$ Tais Moraes é filha de um militar que combateu a Guerrilha do Araguaia. Ela teve acesso ao diário de Carioca e realizou seu livro baseando-se em depoimentos anônimos de militares. V. MorAEs, T. Sem vestígios. Revelações de um agente secreto da ditadura militar brasileira. São Paulo, Geração Editorial, 2008, p.212, 219-222. Segundo o jornalista Vasconcelo Quadros, o agente do CIE José Reis seria o pai de Moraes. V. Jornal do Brasil, 13/12/2008.
} 
grupo de militantes da VPR teria sido assassinado após reagir a tiros à ordem de prisão [MORAES, 2008: 163-165].

Antes, em janeiro de 1972, Carioca teria participado da perseguição aos militantes do Molipo no norte de Goiás, que resultou na morte de Jeová Assis Gomes e o desaparecimento de Rui Carlos Vieira Berbert ${ }^{292}$. Posteriormente, integrou a Operação Sucuri e atuou na Operação Marajoara, destinada a exterminar os guerrilheiros do PCdoB, entre 1973 e 1974 [MorAEs, 2008: 105-155]. Neste período, teria participado também da execução de um grupo de militantes que chegou à Casa Azul, em Marabá, vindo de Brasília. Um dos integrantes do grupo seria Honestino Guimarães, presidente da UNE e militante da AP, preso no Rio de Janeiro em outubro de 1973. O grupo era composto ainda por outro brasileiro, um francês e um argentino [MORAES, 2008: 134137].

No início de 1974, Carioca teria participado da operação de extermínio de David Capistrano da Costa, membro do Comitê Central do PCB, que entrou clandestinamente no Brasil, vindo da Argentina. Carioca transportou o dirigente comunista do Rio Grande do Sul ao DOI-Codi/SP e, em seguida, para a “Casa da Morte”, em Petrópolis, onde ele teria sido esquartejado [MORAES, 2008: 172-176]. Carioca relatou ainda sua participação na “Chacina da Lapa”, quando dirigentes do PCdoB foram presos e assassinados na capital paulista, em dezembro de 1976 [MORAEs, 2008: 155-159] ${ }^{293}$.

No dia 30 de março de 2011, uma reportagem especial de Roberto Cabrini exibiu no programa Conexão Repórter, do canal de TV SBT, uma entrevista com o policial

\footnotetext{
${ }^{292}$ Segundo o então major Lício Augusto Maciel, Boanerges de Souza Massa não era o informante do Molipo. Carioca afirmou que, depois de preso, Massa foi eliminado. Lício informou também que 2 dirigentes do Molipo foram presos pelo delegado Fleury próximo à estrada PA-70, sem precisar local e data; e que participou da ação que matou o militante do Molipo Arno Preis, em Goiás. V. MoRAEs, 2008, p. 99-102 e 229.

${ }^{293}$ A identidade de Carioca não foi revelada por Taís Moraes. De acordo com o jornalista Hugo Studart, Carioca seria o sargento do Exército, Joaquim Artur Lopes de Souza. Ele teria sido assassinado em 1987, mas contraditoriamente acompanhou a internação no Hospital das Forças Armadas do então presidente Collor em 1990. V. BELÉm, Euler de França. “O agente secreto que enganou o líder goiano do PSOL”, em Jornal Opção. O coronel Paulo Malhães teria levado Carioca para atuar no jogo do bicho, no Rio de Janeiro, por intermédio de seu amigo, o ex-capitão Airton Guimarães Jorge, que virou bicheiro. V. MORAES, 2008, p. 212-213. Guimarães foi denunciado como torturador nos anos 1960. Em 2007, foi preso pela Operação Furacão, da PF, por envolvimento no jogo do bicho e em grupos de extermínio no Espírito Santo. V. AlmeIDA, 2009, p. 164. O nome de Joaquim Artur Lopes de Souza consta no BNM, Tomo II, vol. 3 do livro "Os Funcionários”, em “Repressores”, p. 100. Participou em setembro de 1971 de diligências e investigações como $3^{\circ}$ Sargento do Exército, no DF. Informações do Processo n. ${ }^{\circ}$ 179/72 da $11^{\mathrm{a}} \mathrm{RM} / \mathrm{CJM}$. Nos documentos da "Operação Sucuri" aparece como sargento, codinome Zezinho, disfarçado de dono de boteco. V. http://www.torturanuncamais-rj.org.br/noticias.asp?Codnoticia=21\&ecg=. Chama a atenção, que em 01/07/74, a Agência de Campo Grande do SNI recebeu comunicação telegráfica da POLINTER/MT informando que David Capistrano, José Roman e outros estavam presos na Delegacia Regional da Polícia de Aquidauana (MT). Cinco dias depois, a informação foi desmentida. Info. No.342/15/ACG/74, 05/07/74. Arquivo pessoal de Maria Augusta de Oliveira.
} 
federal João Lucena Leal, denunciado por diversos presos políticos como torturador, tendo atuado no Ceará em 1970, conforme registrado no BNM. Na entrevista, Leal declarou ter participado da repressão à Guerrilha do Araguaia pelo menos entre abril de 1972 a outubro de 1973. Ele afirma ter testemunhado a execução de 15 guerrilheiros. Ele relatou também que participou da Operação Condor, numa tentativa de sequestrar Leonel Brizola no Uruguai, sem, contudo, determinar data ou qualquer outra informação. Em Rondônia, Lucena enriqueceu atuando como advogado de traficantes e assassinos, tais como o fazendeiro Darli Alves, que matou o líder seringueiro Chico Mendes no Acre, em $1987^{294}$.

Em seguida, no dia 11 de maio, uma revelação feita pelo advogado Paulo Fonteles Filho (membro do Grupo de Trabalho Tocantins que busca os restos mortais dos desaparecidos da Guerrilha do Araguaia do Ministério da Defesa), na Radio Brasil Atual, apresentou novos indícios de que houve uma extensa rede de colaboração entre diversos órgãos de segurança e informação, em especial, durante a Guerrilha do Araguaia, que compunha o sistema DOI-Codi. De acordo com Fonteles Filho, o ex-delegado do DEOPS/SP Romeu Tuma foi visto na região da guerrilha a partir de setembro de 1972. Tuma foi reconhecido por ex-militares, ex-mateiros e camponeses e identificado como sendo o delegado Silva ou “Dr. Silva”, um dos mais violentos da repressão que se abateu contra os guerrilheiros e moradores da região naquele período. O advogado afirmou que outros membros da equipe de Tuma que atuaram na Guerrilha do Araguaia estão vivos, sendo que João Lucena Leal seria um deles ${ }^{295}$.

Reportagens da jornalista Tatiana Merlino, nas quais entrevistou um ex-mateiro, três ex-soldados e um ex-funcionário do INCRA, indicam que Tuma esteve na região da Guerrilha do Araguaia entre 1972 e 1976. O ex-senador teria sido visto nas bases militares de Bacaba e Xambioá e na sede do DNER, locais onde guerrilheiros e camponeses eram torturados e mortos ${ }^{296}$. De acordo com Abel Honorato de Jesus, que trabalhou como guia do Exército e morou na base de Bacaba, próxima a Marabá (PA),

\footnotetext{
294 Sobre sua atuação como torturador no Ceará, ver: BNM, Tomo V, vol. 1, “As Torturas”. V. http://www.torturanuncamais-rj.org.br.

${ }_{295}$ V. http://outroladodanoticia.com.br/inicial/14393-guerrilha-do-araguaia-entrevista-de-paulo-fontelesfilho.html. Nessa entrevista, Fonteles Filho afirmou que a empresa Camargo Correa foi uma das principais colaboradoras da repressão à Guerrilha do Araguaia, mas não apresentou indícios que sustentasse tal afirmação.

296 MERLino, Tatiana. Ex-soldados afirmam que Romeu Tuma integrou combate à guerrilha, em http://apublica.org/2011/06/ex-soldados-dizem-que-romeu-tuma-participou-do-combate-a-guerrilha/. Acesso em 23/08/2011.
} 
Tuma era o "Dr. Silva”. A partir do segundo semestre de 1972, Tuma foi visto muitas vezes na base e atuava nas “operações das mortes” [MERLINO, 2011].

O ex-soldado Manoel Messias Guido Ribeiro serviu na base de Xambioá e afirma ter visto Tuma, conhecido como “Dr. Silva”, pela primeira vez em maio de 1974. Ele o viu também na sede do DNER e no Quartel 52 Bis. Segundo Ribeiro, Tuma seria responsável por “despachar os mortos”. Outro ex-soldado, Antonio Adalberto Fonseca, corroborou esta afirmação. Tuma esteve na base de Xambioá, quando o guerrilheiro Daniel Ribeiro Callado, o Doca, foi preso em maio de 1974 [MerLino, 2011].

Para outros, como João Mendes Vilarins, que trabalhou como pedreiro e carpinteiro do INCRA, em 1975, Tuma era conhecido como “Dr. Carlos”. O ex-soldado Valdim Pereira de Souza também identificou Tuma como “Dr. Carlos”, presença constante nas operações “de limpeza”, que teriam ocorrido em 1976, quando foram eliminados restos mortais de guerrilheiros do PCdoB. O soldado trabalhou como motorista do tenente-coronel da reserva Sebastião Rodrigues de Moura, o Curió, entre 1976 e $1983^{297}$.

Estes apontamentos fazem-se particularmente relevantes para o delineamento da hipótese de que membros do DEOPS/SP participaram institucional e regularmente da repressão à Guerrilha do Araguaia, perspectiva a qual deve ser considerada à luz do testemunho que confirma a participação do delegado Fleury na brutal e sistemática tortura do guerrilheiro Danilo Carneiro, que aconteceu ao longo do ano de 1972, tal como descrito no item “Os campos argentinos e os centros de tortura e extermínio no Brasil” do presente capítulo.

A eficácia da ditadura brasileira adveio de sua capacidade de conservar dispositivos democráticos, tais como a manutenção do Congresso Nacional (bastante cerceado) e o bipartidarismo, associado à organização dessa ampla rede que combinava diversas modalidades repressivas. Seu efeito foi o de disseminar o medo e a naturalização das leis e práticas de exceção.

Em relação a essas práticas, vários testemunhos confirmam a existência de uma rede clandestina de casas e centros de tortura e extermínio utilizada como parte constitutiva do sistema DOI-Codi. Esses lugares, em conjunto com o sistema, constituíram-se no topos da indistinção entre o legal e a situação de fato -, e

\footnotetext{
${ }^{297}$ Vilarins reivindica uma indenização na Comissão de Anistia do Ministério da Justiça por maus tratos enquanto serviu o Exército. V. Merlino, Tatiana. Apagando o rastro, em http://apublica.org/2011/06/apagando-o-rastro/. Acesso em 23/08/2011.
} 
materializaram a exceção durante a ditadura, processando e desaparecendo com os corpos, desumanizando os presos em busca da anulação e passividade. Submetidos a todos os horrores, alguns poucos sobreviventes espalharam a notícia do terror vivido nesses lugares de extermínio, quando levados aos cárceres, entre os companheiros ou denunciando-os na justiça militar. Essas notícias ajudaram a difundir o terror e também a indignação.

As razões da sobrevivência foram múltiplas, mas em geral seguiram as determinações impostas pela dinâmica do "poder torturador" e da repressão seletiva instaurados pela ditadura e justificados pela Doutrina de Segurança Nacional. Trata-se aqui de buscar na memória e nos testemunhos dos sobreviventes o modo como lidaram com essas experiências-limite de terror e dor desde os primeiros dias de prisão, durante o cumprimento de longas penas, até a atualidade.

Como pudemos considerar neste capítulo, o aparelho repressivo pautou-se por uma complexa rede de centros clandestinos de tortura e extermínio, onde militantes-chave e outros menos conhecidos sofreram as agruras e arbitrariedades do sistema repressivo extrajudicial. Poucos foram os relatos que pudemos coletar para lançar luz sobre esses meandros. Revela-se nesta insuficiência a importância de testemunhos como o de Inês Etienne e Danilo Carneiro que, tendo sobrevivido a tamanho horror, disponibilizaram uma série de informações cujo resgate não se deu sem enorme dor.

Os testemunhos relativos à tortura devem se escorar em reflexões teóricas que nos permitam um entedimento das diversas dimensões simbólicas dessas experiencias-limite foco primordial do capítulo subsequente. Vencida esta etapa, avançaremos em sentido ao entedimento da experiência do encarceramento na ditadura através dos relatos da parte mais visível do sistema repressivo que inclui, entre outras vicissitudes, testemunhos decisivos sobre o sistema carcerário. 


\section{Capítulo III \\ O cotidiano nos presídios políticos: \\ reconstruindo identidades}

Os efeitos da repressão política promovida pelo terrorismo de estado sobre a militância no Brasil possuem ao menos duas facetas: uma se manifesta através da alteração das disposições exteriores e, a outra, pode ser definida desde os efeitos psíquicos que alinhava. A ditadura civil-militar brasileira caracterizou-se por um "poder torturador", cujas contrapartidas institucionais desmembraram-se entre os centros de tortura e extermínio (sua esfera menos visível) e os presídios e a justiça militar (sua face mais visível).

Nestes moldes, a repressão fez das técnicas de indução do sofrimento sua marca, em face do que se faz válido considerar que produziu efeitos menos evidentes e outros mais evidentes. Entre os primeiros, destacaram-se os notáveis efeitos sobre a subjetivização das vítimas, enquanto os segundos versam sobre as novas formas de organização cotidiana na prisão. Neste capítulo consideraremos ambos, na ordem delineada acima.

\section{Os testemunhos sobre a tortura}

A tortura, empregada de modo sistemático durante a ditadura brasileira, era essencial na engrenagem repressiva criada desde o golpe de 1964 e foi parte vital dos procedimentos da justiça militar instituídos pela legislação de exceção do período. Diversos testemunhos e textos associam o ato de ser torturado com a imagem da "descida ao inferno" [BNM, 1989: 239], o que significa sentir a mais terrível solidão e impotência.

Em geral os depoimentos sobre a tortura no Brasil são relatos que enfocam mais os aspectos factuais da experiência de tortura do que sua face subjetiva e interior. Houve muitas maneiras de resistir, mas a brutalidade inaudita da tortura impôs sequelas, dificuldades e impossibilidades de falar desse trauma histórico e de integrá-lo a uma narrativa. Não obstante, os sobreviventes têm se defrontado com a tarefa de rememorar o trauma da tortura e de enlutar os mortos. Tarefa árdua e ambígua que envolve um confronto permanente com a ferida aberta, envolvendo a resistência e a negação desses 
traumas. Tentativas de superação que cobram um consolo, nunca totalmente alcançável [JELIN, 2002: 68].

Evocar a dor novamente por meio da recordação do trauma é de certa forma renová-la. O passado pesa e, por isso, quem foi ferido tende a evitar a recordação. Alguns sentiram o imperativo de contar como uma necessidade para sobreviver ou sobreviveram para poder contar. Outros sobreviventes tentam “defender-se da invasão de memórias difíceis" impedindo ou reprimindo "seu ingresso" na consciência ou na esfera pública. "Levantam âncora, afastam-se momentaneamente ou para sempre, das recordações genuínas” [Levi, 1990: 11,14]. Por outro lado, o exercício da memória, a evocação frequente, mantém a recordação viva, mas evocá-la com excessiva frequência pode gerar uma narrativa que tende a fixar-se em estereótipos, cristalizada, enrijecida numa fórmula, ataviada, que instala-se "no lugar da recordação não trabalhada e cresce à sua custa" [LEVI, 1990: 9,13].

A narrativa militante pode contrastar com muitos testemunhos. Para as mães, por exemplo, o desaparecimento forçado surgiu como algo totalmente inesperado e inexplicável, mas entre os militantes é possível encontrar quem tenha vivenciado experiências limite e a tortura não como algo inesperado, uma ruptura ou um vazio [JELIN, 2002: 94]. Além disso, a apresentação de um mesmo relato é complexa, na medida em que pode abarcar vários "processos entrelaçados no âmbito existencial [...] como o 'acting out', o retorno do recalcado, a perlaboração, que têm intermediações sutis e se apresentam sob formas híbridas ou combinadas” [LACAPRA, 2005: 107].

Apesar da enorme dificuldade, alguns dos entrevistados falaram de temas delicados como a luta travada internamente, dos medos e dilemas no processo de tortura. Expuseram-se, com intensidade e emoção e, em determinados momentos, pareciam viver novamente a angustia da experiência demolidora do passado como se esta estivesse acontecendo no presente. Em certas passagens, os testemunhos assumiram uma intensidade tal que era perceptível que a pessoa estava se colocando "ali com todo o seu ser”. ${ }^{298}$ E, em alguns casos, o relato sobre o desmoronamento, assim como o retorno da lembrança que aparecia com a mesma força do passado, era acompanhado de alguma elaboração. O testemunho, em geral, implica em voltar para o passado e, simultaneamente, estar aqui no presente e ser capaz de distinguir esses dois tempos sem prendê-los na polaridade passado/presente. Esta dupla inscrição está presente nos relatos

\footnotetext{
${ }^{298}$ Felman, Shoshana e Dori LAUB, M. D., Testimony: Crises of Witnessing in Literature, Psychoanalysis, and History. Nova York, Routledge, 1992, p.59 apud LACAPRA, 2005, p.107 apud LACAPRA, 2005, p.107.
} 
registrado pelas entrevistas dessa pesquisa, as pessoas recordam o que aconteceu sem perder a noção do presente, mesmo que haja momentos nos quais elas voltem a viver compulsivamente o passado [LACAPRA, 2005:107-9].

A tortura tem por objetivo produzir a perda da percepção e do sentido do tempo e do espaço. Ela obriga o torturado a lutar contra si mesmo, cindindo a pessoa ao meio; ela coloca a mente contra o corpo, que sente profunda dor. "A mente quer ser fiel à causa e aos companheiros; não quer, de forma alguma, entregá-los. O corpo, submetido a toda sorte de intimidação e aviltamento, para ver-se livre da tortura, tende a falar e assim fazer a vontade do torturador ${ }^{299}$."

O torturador busca abrir uma brecha na alma do torturado e penetrar sua intimidade para “[...] possuir o outro e fazê-lo um outro sujeito que confessa e reconhece ser de fato subversivo, inimigo da humanidade, traidor da pátria, e se for religioso, ser pecador, amaldiçoado de Deus e um excomungado da Igreja. Esta cisão da mente e do corpo, opondo os dois eus, deixa sequelas profundas e em alguns casos, trágicas, como foi com Frei Tito” [BofF, 1987: 13], que não conseguiu deixar de imaginar o torturador a persegui-lo no exílio, na França, e suicidou-se alguns anos depois.

De acordo com Maren e Marcelo Viñar, o objetivo da tortura “[...] é provocar a explosão das estruturas arcaicas constitutivas do sujeito, isto é, destruir a articulação primária entre o corpo e a linguagem. Sabemos que a tortura conduz, pelo isolamento, punições, sede e esgotamento, a profundas perturbações orgânicas e psíquicas (estados alucinatórios, de confusão e oníricos). Mas raramente insistimos sobre a natureza da produção psíquica que daí resulta, ou sobre os caminhos pelos quais ela conduz tanto à coerência consigo mesmo, quanto à capitulação diante do adversário", 300 .

Durante a ditadura no Brasil, a tortura foi utilizada de forma científica, os torturadores eram auxiliados por médicos e psicólogos. Especialistas eram formados no exterior, especialmente na Escola das Américas, mas os próprios brasileiros também ensinavam suas técnicas aos estrangeiros, ministrando cursos no Brasil ou em outros países $^{301}$. A tortura era uma prática institucional que buscava informação por meio da violência extrema, mas de forma controlada, estudada, e que visava

\footnotetext{
${ }^{299}$ Boff, Leonardo. "Prefácio”, em: EloysA, Branca (org.). Io. Seminário do Grupo Tortura Nunca Mais. Petrópolis, VOZES, 1987, p.13.

${ }^{300}$ VIÑAR, Maren e Marcelo. Exílio e tortura. São Paulo, Escuta, 1992, p.73.

301 V. o documentário "Escuela Francesa - Escuadrones de la muerte", op.cit., que trata da troca de experiências e know-how de tortura entre franceses, brasileiros e latino-americanos, especialmente, nos cursos ministrados em Manaus (AM), ainda pouco conhecidos. No filme Batalha de Argel (1965) há uma
} 
“[...] instaurar entre dois humanos uma relação não-humana, na medida em que o torturador se coloca na posição de um deus e o torturado na de criatura indefesa, culpada e não-humana. [...] a marca fundamental da situação de tortura é a desumanização dos participantes: o torturador se coloca acima da condição humana e força o torturado a se colocar na situação abaixo da condição humana. O suplício não é apenas a dor, é a humilhação cuja função primordial é a desumanização"302.

A tortura, comumente referida como a "travessia do inferno”303 , é o suplício físico e psíquico extremo, o desamparo, a solidão, o medo-pânico, o sentimento de abandono, a perda da percepção e da memória, a destituição do humano e a infantilização. Por meio da violência, o torturador reduz o sujeito à condição de coisa:

"Violência paradoxal, pois o que o torturador deseja da 'coisa' é que ela atue como 'gente': uma coisa é inerte, passiva e silenciosa, mas o que o torturador deseja da 'coisa' é que ela sofra, grite, confesse, fale. A loucura da situação de tortura é esta: deseja-se que, através da dor e da degradação, um ser humano vire 'coisa' e ao mesmo tempo permaneça gente para que reconheça no torturador um outro ser humano, pois se tal reconhecimento não existir, não pode haver confissão, não pode haver capitulação e, sobretudo, não pode haver admissão do poder do torturador. Assim, o que a tortura cria é a situação-limite e impossível na qual se destrói a humanidade de alguém para que esse mesmo alguém atue como humano, isto é, estabeleça com o algoz uma relação intersubjetiva, sem a qual o torturador perde a função e perde o sentido.” [CHAUI, 1987: 33-4].

Muitos relatos de sobreviventes apontam que as pessoas torturadas tinham consciência dessa situação contraditória: "Eu fazia força para não parar de pensar.”; "Eu fazia de tudo para não dormir”; "Eu fazia um esforço imenso para não me deixar seduzir”; "Eu fazia de tudo para discriminar”; "Eu procurava jeitos para ter certeza de que não estava enlouquecendo”. A resistência à tortura é um enorme esforço para não perder a lucidez e “[...] não permitir que o torturador penetre na alma, no espírito, na inteligência do torturado”, que se aposse da subjetividade e a humanidade do torturado [CHAUI, 1987: 34].

A sedução da morte durante a tortura foi sentida por jovens e velhos militantes, para os que participavam de grupos de luta armada e para os que atuavam no tradicional PCB [BNM, 1989: 218-21]. Este foi o caso do coronel da PM Vicente Silvestre, preso em 9 de julho de 1975 juntamente com cerca de 80 policiais militares entre militantes e simpatizantes do partido. Silvestre era militante do partido desde os anos 1950 e um ativista das lutas sindicais da categoria. Apesar de ressaltar sua tranquilidade durante os

cena em que se vê o uso do pau-de-arara. Esta modalidade de tortura da Europa medieval teria sido atualizada pela ditadura brasileira.

${ }^{302}$ CHAUí, Marilena. A tortura como impossibilidade da política. In: ElOYSA, B., 1987, p.32-3.

${ }^{303}$ Os torturadores, perversamente, denominavam o DOI-Codi/RJ de "Paraíso". V. POLARI, A. op.cit. 
meses de tortura a que foi submetido, Silvestre descreveu que sentiu-se desesperado e que experimentou o desejo de morrer, recurso extremo para escapar ao sofrimento:

"E aí foi pau de arara, aquela cadeira do dragão, afogamento [...] e isso se repetia, não passava um dia que eu não ia para tortura. Quando fui para lá eu estava com uma formação física muito boa, eu praticava esportes, pesava 90 quilos, três ou quatro meses depois [...] eu pesava 70 quilos.

[...] Nos momentos em que eles queriam informações que eu não tinha, eles continuavam torturando, porque achavam que eu estava resistindo e, na verdade, eu não tinha a informação, não existia o que eles imaginavam. Não fiquei desesperado com isso, sempre fiz uma análise histórica, mesmo lá dentro, de que não era o primeiro e nem o último. A história está cheia de embates e eu sou mais um. Preocupava-me com a família, com os filhos, mas desespero mesmo nunca me deu e eles achavam que a minha tranquilidade era uma forma de resistir.

[...] Mesmo quando morreram o José Ferreira de Almeida e o Herzog, sentia que a tortura era uma coisa calculada. Tanto que, enquanto eu estava pendurado no pau de arara, mesmo com capuz, via que havia uma barra de calça branca e um sujeito me examinava com o estetoscópio [e dizia:] '- Tá tudo bem, tudo bem.’ E eles continuavam. [...] Em uma ocasião apresentaram-me ao José Ferreira de Almeida, achei que ele não ia resistir mais de tão debilitado que ele estava por causa da tortura. Ele queria falar comigo, mas não tinha nem forças para falar. Logo depois o mataram. Eu não vi o José Ferreira morto, mas sabemos que pelo fato de ele ter sido empalado houve uma decisão de matá-lo. O José Ferreira de Almeida despertou muito ódio dentro do DOI-CODI [...].

A certa altura das torturas a coisa agravou-se tanto, a tortura era tão implacável, que não tinha limites, a ponto de eu sentir que naquele momento o melhor que poderia me acontecer era a morte, porque não tinha como me livrar daquela gente e da tortura, passou-me isso pela cabeça. Com a morte do Herzog, aquelas idas e vindas que eu fazia da prisão do QG para o DOI-CODI e as torturas diminuíram e, depois, acabaram ${ }^{304}$.”

Esta posição encontra uma contrapartida e, simultaneamente, um espelhamento na máxima de que diante da tortura “era preciso sobreviver a qualquer custo”. Isto é, usufruir do direito de cuidar de si mesmo, urgentemente e sem concessões, quando a vida estava cotidianamente ameaçada, sob o jugo permanente da violência extrema da tortura. Abdicar de cuidar da própria vida, dos seus filhos e familiares marcaria uma "adesão concreta e radical a um regime de morte". Por outro lado, "recusar-se a agir de modo solidário, regendo-se por um princípio que não o da preocupação com a própria sobrevivência, pode, em certas circunstâncias, definir uma longa convivência acusatória e superegoica, como uma outra versão do traumático [...]”. A sobrevivência pode implicar na convivência com um ego degradado e enfraquecido: "Sobreviver não é suficiente, uma vez que permanece sob suspeita o preço que se pagou por isso ${ }^{305}$.”. Nas palavras de Helio Pellegrino,

\footnotetext{
${ }^{304}$ Entrevista concedida por Vicente Silvestre à autora. SP, 16/09/2009. AAPP/AEL-USP.

${ }^{305}$ V. ENDO, Paulo César. A violência no coração da cidade. Um estudo psicanalítico. São Paulo, Escuta, 2005, p. 238-42.
} 
"ao quebrar-se frente à tortura, o torturado consuma - e assume - uma cisão que lhe rouba o uso e o gozo pacíficos do seu corpo. A ausência de sofrimento corporal, ao preço da confissão que lhe foi extorquida, lhe custa a amargura de sentir-se traidor, traído pelo próprio corpo. Sua carne apaziguada testemunha e denuncia a negação de si mesmo, enquanto pessoa. A tortura, quando vitoriosa, opera no sentido de transformar sua vítima em desgraçada - e degradada - espectadora de sua própria ruína.

Por isto, o torturado não pode falar, embora esta seja uma exigência quase sobre-humana. Sua não-fala, ou a fala do despistamento, constituem, na tortura, o discurso do herói. Um tal silêncio, no entanto, vai provocar o recrudescimento da violência e o risco da morte física. Se o torturado não fala, pode morrer fisicamente. Se fala, e confessa, sucumbe a uma discórdia fundamental e morre como pessoa. Ao torturado, na tortura, só resta a saída - inimaginavelmente difícil - do silêncio. Através dela, garante e afirma, em grau heroico, a sua integridade de pessoa, pela realização de um valor supremo 306 .”

Diante desse dilema, a instrumentalização da resistência possível à tortura e à violência extrema foi vária, a despeito da existência de uma orientação mais ou menos comum entre as organizações de esquerda. Em seu livro Em busca do tesouro (1982), Alex Polari descreveu a orientação que recebeu da VPR sobre como resistir à tortura, que sintetiza a de outros relatos. Havia basicamente dois métodos, cujos nomes não coincidem, mas tratam basicamente das mesmas situações descritas por vários entrevistados nessa pesquisa:

“[...] o método 'turco', que consistia em negar sempre e dizer o menos possível, inclusive informações falsas, e o 'francês', que se baseava em muitas estórias, contra-informações, pontos frios, disfarces, simulações de colaboração etc. O método turco é mais simples, quem consegue levá-lo adiante se enrola menos. Contudo, enraivece mais os torturadores. E se tem chances de ser morto ainda no período crítico do interrogatório. O método francês propicia muitas pausas, saídas em falso, tempo para se recuperar. Os caras ficam realmente putos quando constatam nossas mentiras mas eles têm que se guiar sempre pelo princípio de que toda confissão pode ser verdadeira. Dessa credulidade compulsória depende seu emprego ${ }^{307}$."

Muitos tentaram enfrentar a tortura fornecendo o máximo de informações falsas aos torturadores, conforme o método “francês” citado acima. Foi uma prática comum entre os prisioneiros que sofreram torturas inventar 'pontos' falsos e, por vezes, até usálos para tentar o suicídio, uma maneira de fazer parar o suplício e evitar a delação de outros companheiros. Lúcia Murat, líder estudantil e dirigente do MR-8 (DI-GB), foi presa no Rio de Janeiro no dia 31 de março de 1971, num quarto alugado onde estava escondida com uma companheira, Pupi. Em geral, o sofrimento físico começava no

\footnotetext{
${ }^{306}$ V. Pellegrino, Helio. “O tesouro encontrado”. In: POLARI, A., op.cit., p.14. Grifos no original.

${ }^{307}$ PolARI, A. op.cit., p.127. O livro A tortura, de Henri Alleg, é seu depoimento-denúncia sobre a tortura na Argélia. Transformou-se num modelo de comportamento - ele não falou nada sob tortura - para militantes de esquerda dos anos 1960 e 1970. ALLEG, Henri. La question. Paris, Editions de Minuit, 1958. Edição brasileira: ALLEG, Henri. A tortura. São Paulo, Zumbi, 1959.
} 
trajeto percorrido até chegar-se ao centro de tortura:

“Aí começou o horror, a gente já saiu de lá apanhando dentro do carro. Botaram um capuz e foi no pau, no pau... Eu imagino que chegamos de madrugada no DOI-CODI. Rapidamente fiquei nua, não me lembro como, a roupa foi tirada e, de capuz o tempo todo, desde que saí de lá. [...] Na hora, olhei e falei: '- Cara, quero morrer, não vou aguentar essa porra. Vou abrir um esquema para me suicidar e sair fora dessa brincadeira’. Eu realmente não demorei pra dizer. Na mesma hora, um filho da puta de um torturador... descobriu que aquilo era mentira. Na hora ele falou: '- Eu nunca vi uma pessoa de comando falar tão rápido'. Eu pensei: '- Eu abro um esquema inventado [...]'. Objetivamente, não sabia o que tinha sido entregue, não sabia de nada. Foi um susto, quando entrei lá e eles sabiam de tudo da Bahia. Então, a questão era me segurar sobre o imediato. Falei para eles que tinha voltado para o Rio pra sair do Brasil, não queria mais continuar, estava aguardando o passaporte e não estava fazendo nada. Acho que foi essa a história, acho que o principal que contei foi que no próximo ponto, eu tinha de ficar na sacada de um prédio e esperar quando iria passar um certo carro embaixo. Com isso, imaginei: eles me põem na sacada de um prédio, eu me jogo e acabou a brincadeira. Assim, logo depois de tomar as primeiras porradas, bolei essa porra e pensei '- Foda-se, até lá eu aguento’. Aí o pau comeu, fiquei no pau-de-arara bastante tempo, quando saí a minha perna tinha dançado. Eu tive uma flebite na perna direita, ela estava desse tamanho. Aí, me levaram até lá e comecei a ficar desesperada, porque não quiseram subir, eu estava em traste. Eu tenho impressão que foi por isso que não subiram comigo até o apartamento. Deixaram-me na rua dentro de um carro e comecei a ficar 'histérica'. Falei: '- Bom, agora quando eu voltar acabou, os caras não vão pegar ninguém, estou fodida e mal paga'. Aí foi a pior sensação da minha vida, a sensação de não poder morrer. Foi a pior sensação que tive na vida, que eu me lembre. Realmente, a sensação de não poder morrer, naquele momento, foi horrível. Foi horrível. Fiquei histérica, chorava, chorava, chorava igual a uma louca.

[...] Aí comecei a inventar outra história: '- A culpa é de vocês, os caras não vão passar aqui, porque vão ver que não sou eu’. Eles puseram um homem com uma peruca loira lá em cima. [...] E mantive essa história. Voltei e foi um pau, piorou, houve muito pau. Foi um horror, começou barata, tudo. Tenho horror de barata, mas punham baratas passeando em cima da gente. Tinha um maluco lá que fazia coleção de barata. Acho que eram amarradas por barbantes, pode ser fantasia minha, porque sou meio míope e eu estava sem óculos, mas a ideia que tenho é que elas eram amarradas por barbantes. [...] Eles as punham na vagina, era horrível. [...] Fui muito torturada. Estava um lixo total, quando me levaram lá [no 'ponto' falso] tinham se passado 12 horas, eu acho.

[...] foi um caos, queria morrer e não conseguia morrer. [...] Nessa confusão toda, praticamente, tinha liberado os 'pontos' com a organização, [...] as 48 horas [...] ${ }^{308}$.,

Reinaldo Morano Filho, estudante de medicina da USP e militante da ALN, passou à clandestinidade no dia 5 de novembro de 1969, um dia depois do assassinato de

Carlos Marighella. Para ele, a primeira experiência de estranhamento e choque ocorreu neste momento. Abandonar tudo e passar a viver isolado foi muito difícil. Acabou engajando-se no Grupo Tático Armado, o GTA da ALN. Em 15 de agosto de 1970, Reinaldo foi preso pela equipe do delegado Fleury que, desde março daquele ano, estava lotado no 41 ${ }^{\text {a }}$ Distrito de Polícia, em Vila Rica, bairro da Zona Leste de São Paulo,

${ }^{308}$ Entrevista concedida por Lúcia Murat à autora. RJ, 25/03/2010. AAPP/AEL-LEI. 
afastado da coordenação de operações do DEOPS/SP em função de disputas com o DOICodi/SP e denúncias de corrupção [GASPARI, 2002b: 179]. Reinaldo contou-nos sobre a orientação da ALN para enfrentar a tortura e os recursos que utilizou para esquivar-se do desespero e do medo de delatar:

“[...] a gente tinha uma combinação, uma coisa que a gente chamava de 'ponto de polícia'. Era um ponto que era para abrir, mas não no primeiro dia. O meu era na Av. Santo Amaro, nas imediações do número 1.000. A ideia era que algum companheiro passasse de ônibus e me visse no ponto. Eu, postado no ponto, numa avenida super movimentada, era uma comprovação de que eu estava preso. E abri isso, acho que na segunda feira, eu tinha sido preso no sábado.

[...] Fiquei na $41^{\mathrm{a}}$ até setembro, [...] uns 20 dias. [...] E aí fui para o DOI-CODI/SP. [Antes,] fui ameaçado pelo Fleury, ele me chamou na sala dele e falou que eu ia para o DOI-CODI, que se eu 'abrisse' alguma coisa lá que não tinha falado para ele, na volta ele ia me dar o troco. Quer estímulo maior do que esse para não 'abrir' as coisas no DOICODI?

[...] acho que ninguém está realmente preparado para aquilo [a tortura]. Eu fazia parte de um micro grupo, composto pelo Mariano, o Idésio Brianezi, que tinha sido morto; o Antonio dos Três Reis de Oliveira, que tinha sido morto; aquele operário de Osasco, que foi morto; cada um numa circunstância. Vou dizer para você que em agosto de 1970 não era uma política da repressão assassinar, obrigatoriamente, todos os integrantes de GTA. Tenho a impressão que não. Falava-se muito da tortura, eu tinha lido alguns depoimentos, aquele do Júlio Fuchik, "Testamento sob a Forca"; o Henry Alleg, da Argélia. Era um tema, esse tipo de coisa circulava entre a gente, mas quando achei que fosse ser assassinado, quando eles começaram a insistir muito sobre o 'aparelho'... Eu não podia abrir o 'aparelho', o lugar onde eu morava. É uma das situações onde não se tem muito o que escolher, não podia. Em não podendo isso resultava em muita raiva por parte deles. Nunca fui um cara corajoso, destemido, nunca fui. Na verdade, eu tinha medo, tive medo quando fui preso, pendurado, torturado. O medo faz parte, foi um, digamos, companheiro de viagem. Tenho impressão de que ele faz parte do kit básico dos seres humanos, mas acho que ele também está sujeito a determinadas intempéries e circunstâncias.

Quando terminava uma rodada de 'pau', fazia na minha cabeça um balanço de que eles não tinham avançado, que, na verdade, o que eu havia dito já tinha ouvido de um outro [torturador]... Eles tinham algumas coisas a meu respeito, algumas pessoas que eu conhecia, e comecei falando desses: o Mariano, os que estavam mortos. Depois, eles falaram de algumas outras coisas que ficaram sabendo por alguma razão, era uma informação que não acrescentaria, mas que em algum momento daria uma certa credibilidade para o que eu estava falando. Depois de apanhar, apanhar, valorizando a informação, eu podia contar alguma coisa, mas teve coisas que nunca falei. Tipo uma ação grande lá do Banco do Brasil, no Jabaquara, uma outra num cartório, enfim, algumas coisas que não era o caso de falar. [... Outras] eu admiti, depois de um pouco de salamaleque, mas admiti. $O$ que fui percebendo é que, talvez, estivesse mais ideologicamente instigado a resistir para passar por aquele período, e menos [preparado] do ponto de vista de estratagemas. A minha história foi ficando um pouco sem pé, mas fui aprendendo. Por exemplo, eles queriam saber quem era o cara com quem eu morava, escolhi um cara da faculdade, que era bem de direita, [...] e descrevia esse cara. [...] Eu comecei a não apresentar contradição com coisas desse tipo, o que, de certa forma, valorizava o meu depoimento ${ }^{309}$.”

${ }^{309}$ Entrevista concedida por Reinado Morano Filho à autora. SP, 17/10/2008 e 16/04/2010, AAPP/AELLEI. 
A tortura ultrapassa as fronteiras do centro de tortura ou de extermínio, ela “[...] cria no espaço social algo como um referente de punição, cujos efeitos trágicos visam não somente à vítima, mas, através dela, o grupo social no qual provoca medo e paralisia” [VIÑAR, M.; M., 1992: 73]. Os efeitos aterrorizantes da tortura e a difusão do medo foram retratados por Hebert Daniel, dirigente da VPR que não foi preso e conseguiu se exilar em 1973:

"E o medo. Medo? Não: pavor. A maior parte dos simpatizantes e aliados desertava; as ameaças eram absolutamente apavorantes. As notícias pavorosas de torturas chegavam a todos. Não há ninguém - nas camadas da população onde a esquerda tinha contatos - que não soubesse perfeitamente dos horrores. Só não eram publicados, o que parecia tornar o terror relativamente secreto e menor. Curiosamente, só depois que as notícias de torturas começaram a ser divulgadas é que elas começaram a afetar realmente os que já sabiam delas. Publicados, os fatos escabrosos (que se sabiam) começaram a ter mais realidade. Muita gente, que conhecia - e não só por ouvir dizer - os casos de tortura, ao ler as denúncias tomou consciência da extensão do fenômeno. É fantástico como a imprensa faz a realidade!

As torturas - e suas narrativas - eram uma espécie de segredo da gente de esquerda, cochichado como se fosse indecente falar desta imoralidade em alta voz. Eram também motivo de desistência. Tantas vezes, conversando com simpatizantes tive a impressão de que a opção que se apresentava não era pela militância e por uma tentativa de fazer a revolução. Optar pela luta armada parecia uma opção pela morte ou pela tortura! A derrota já estava clara e inevitável para todos que viam os grupos armados do exterior. E, no entanto, havia esperanças. Oh, sim: muitos se entusiasmavam quando uma ação vitoriosa tinha uma repercussão enorme. Aí, esperavam que a guerrilha viesse a crescer e produzir mais vitórias contra a ditadura.

Por mais esperança que inspirasse, nem por isso a esquerda armada inspirava ações reais: apenas e tão só expectativa. Ninguém, naquele estado de coisas, queria correr o risco absurdo. Donde a guerrilha tiraria seus quadros? Mistério... ${ }^{310,}$

Durante a ditadura, o corpo do dissidente ou do "indesejável” passou a ser fundamental para a ação do regime, a câmara de tortura se configurou na materialização do estado de exceção e do terrorismo de Estado. Para o indivíduo, porém, o corpo se constitui na

“[...] superfície de expressão de todos os níveis da vida relacional, desde o mais íntimo até a do sujeito social. É uma sombra e uma presença que não têm necessidade de ser pensada. É o lugar de articulação do ser e do parecer, o que oferecemos a nós mesmos e aos outros. É uma permanência, formal e funcional, em movimento contínuo. É este corpo implícito que serve de suporte ao pensar, ao dizer, ao fazer, que está presente em cada gesto, em cada olhar, na mímica, na música do discurso. Lugar de ancoragem onde se inscreve o símbolo e a especularidade, onde se modela o sujeito. Lugar de ancoragem onde se sustenta, se encobre, se transgride uma ética. A experiência de si encontra seu elemento central na maneira de habitar o corpo numa continuidade harmônica" [VIÑAR, M.; M., 1992: 75].

\footnotetext{
${ }^{310}$ DANIEL, Hebert. Passagem para o próximo sonho. Rio de Janeiro, Codecri, 1982, p.59.
} 
A tortura possui um caráter indelével, deixa um estigma, mesmo quando não é possível reconhecer nenhum traço objetivo. Quem foi torturado, permanece como tal e não esquece. Para muitos que a sofreram, já no primeiro golpe o prisioneiro torna-se consciente de seu desamparo. Este golpe contém o germe da brutalidade e de tudo o que sofrerá depois. No primeiro golpe começa-se a perder o que Jean Amèry denominou de “confiança no mundo”. ${ }^{311}$ Perde-se muito da expectativa de ajuda, elemento constitutivo da psique humana como a luta pela existência. Esse ritual de ingresso violento visa romper a capacidade de resistência do prisioneiro, seu colapso moral ou qualquer possibilidade dele se tornar um exemplo [LEVI, 1990: 18-9].

Prisioneiros políticos como Amèry esperam eventualmente ser presos e torturados; em geral, estão familiarizados com a literatura sobre a tortura. Por isso, acreditam ser possível prever o que vai lhes acontecer. Amèry percebeu, porém, que não sabia, "não porque aquele horror superasse toda imaginação, mas porque se tornara realidade.” Foi tomado de surpresa: “sabia e não sabia” o que significava ingressar no cárcere do campo de Breendonk, para onde o ameaçaram levar caso não confessasse. E, segundo ele, “como era previsível”, falou. Felizmente, não sabia nada além de nomes falsos e de esconderijos onde estivera à noite, cuja localização desconhecia. Mas havia falado.

Resistir representa um enorme esforço do torturado para se distinguir do torturador e não fazer seu “jogo” [CHAUí, 1987: 36]. Outra característica da experiência de tortura perceptível em muitos relatos de pessoas que sobreviveram a ela refere-se ao sentimento de "estar num palco", porque de imediato sua roupa era arrancada, seu corpo exibido, havia a presença de uma plateia de torturadores, militares, presos e até empresários, mas também havia o sentimento de "irrealidade criado pelo aparato técnicocientífico da tortura que só poderia intimidar quando exibido (seja pela descrição prévia feita ao torturado, seja pela visão de companheiros torturados)”. Essa situação absurda acontece fora do alcance dos olhos da população e consiste em exibir escondendo e esconder exibindo, na qual se

“[...] opera sob o sigilo de nomes e funções, donde o sentimento dos torturados de estar na situação de protagonistas de um espetáculo insano, onde ninguém é o que é, e onde tudo é o que nada é. Esta dimensão do espetáculo clandestino, no qual o poder se apresenta como absoluto porque sem nome, sem lugar e sem rosto, revela um dos aspectos mais impressionantes da tortura [...]” [CHAUí, 1987: 34].

\footnotetext{
311 J. Améry, preso pela Gestapo como membro de um grupo da resistência belga, em julho de 1943, considera que a tortura moderna desconhece a cumplicidade teológica existente na Inquisição, que vinculava torturador e torturados, quando existia uma profunda e perversa comunhão. Na atualidade, para a vítima, o torturador não é senão o “outro”, o mal radical. V. AMÉRY, J. Op.cit, p.18, 99.
} 
Em A verdade da repressão (artigo publicado no jornal Opinião, em 1973) ${ }^{312}$, Antonio Candido trata da violência policial e de seu objetivo de fabricar uma outra personalidade. Este é o paradoxo fundamental da tortura, ela é utilizada para destituir a subjetividade de alguém e produzir, forjar uma outra, para que este outro eu, que é também a "coisa” na qual foi transformada, possa reconhecer o torturador como "sujeito" e, assim, confessar:

“A polícia aparece então como agente que viola a personalidade, roubando ao homem os precários recursos de equilíbrio de que usualmente dispõe: pudor, controle emocional, lealdade, discrição, dissolvidos com perícia ou brutalidade profissionais... De fato, a polícia tem necessidade de construir a verdade do outro para poder manipular o eu do seu paciente. A sua força consiste em opor o outro ao eu, até que este seja absorvido por aquele e, deste modo, esteja pronto para o que se espera dele: colaboração, submissão, omissão, silêncio" [CÂNDIDO, 1980: 115-6].

Vários dos ex-prisioneiros políticos entrevistados relataram que foram tomados pelo espanto diante da brutalidade da violência da tortura, mesmo tendo lido e conversado muito sobre o assunto antes da prisão. Dir-se-ia: o ingresso nos centros de tortura, onde se empregava a violência extrema, implicava uma experiência de surpresa e choque, que tendia a produzir grande desorganização das fronteiras entre razão e loucura, borrando os limites da experiência do sofrimento. Esse estranhamento, por vezes, dava-se pela percepção de que quem quer desumanizá-lo com tamanha violência é outro ser humano, enfim, o que lhe é familiar ${ }^{313}$, conforme o testemunho de César Augusto Teles, militante do PCdoB, preso em São Paulo no dia 28 de dezembro de 1972:

"Lá no DOI-CODI/SP, apesar de eu conhecer todas essas histórias de tortura, é quando você toma um choque grande devido à falta de experiência, vamos chamar assim, porque é uma coisa totalmente fora do alcance dos sentimentos, da sensibilidade, é absurdo! Você fica desnorteado, a selvageria e os propósitos que os caras têm ali, então, talvez por isso eu tenha esquecido muita coisa, depois não conseguia lembrar detalhes. A Amelinha, minha mulher, que foi presa junto comigo, dizia para eles: '- Vocês não podem ter nascido de uma mulher, vocês são monstros!' E, realmente, você ficava completamente perdido, nós fomos bastante torturados, quase uns doze dias [...] [ininterruptamente] e, depois, pelo menos durante 45 dias $^{314}$."

\footnotetext{
312 “A verdade da repressão”, Opinião, nº 12, 22-29, jan., 1973, e republicado em Candido, A. Teresina etc. Rio de Janeiro: Paz e Terra, 1980.

${ }^{313}$ FREUD, S. "O estranho”. In: Edição Standard Brasileira das obras psicológicas completas de S. Freud, Vol. XVII. Rio de Janeiro, Imago, 1976.

${ }^{314}$ V. entrevista cedida por César Augusto Teles a Claudio Kahns, Janaina de A. Teles e Zilda M. Grícoli Iokoi. SP, 17/07/2002, AAPP/AEL-USP. V. tb. entrevista concedida por Alberto Becker, militante do MRT, a Claudio Kahns, Janaina de A. Teles e Zilda M. Grícoli Iokoi. SP, 26/07/2002, AAPP/AEL-USP.
} 
Tradicionalmente, argumentou-se que “a tortura era o meio de forçar as pessoas a falarem a verdade” [BNM, 1989: 17], mas sabe-se que sofisticadas práticas e instrumentos de tortura podem levar as pessoas a admitir tudo o que lhes for sugerido. $\mathrm{Na}$ tortura, a confissão não é necessariamente a verdade dos fatos ou a contrapartida da mentira. O caso do ex-preso político pernambucano e dirigente nacional do PCBR, Marcelo Mário de Melo, preso no dia 9 de abril de 1971, ilustra essa afirmação: ele confessou ter participado de um assalto a banco, do qual realmente não tomou parte. Posteriormente, seus torturadores disseram-lhe que sabiam disso, mas queriam testá-lo. Marcelo foi condenado a 12 anos de reclusão como partícipe deste assalto num dos dez processos da Justiça Militar nos quais foi indiciado.

“O fato de eu ter sido preso sozinho me favoreceu muito, numa época que já estava tudo acabado [...]. Tinha havido o assassinato do Odijas Carvalho, uma coisa considerada primarismo da parte deles. Ele foi morto sob tortura e Dom Hélder entrou [no caso], eles ficaram na defensiva. Fui preso nesse clima, isso também me favoreceu, [...] o PCBR estava acabado e fui o solitário preso por último. A minha estratégia de [defesa no] interrogatório foi de jogar a minha militância para frente, eu entrei no PCB em 1961, mas disse que entrei depois de 1965. Argumentei muito [...], sei que deu para segurar muita coisa [...]. Eu era um cara muito visado, muito conhecido. [...] Agora, a situação mais desesperadora para mim foi a seguinte: fui enquadrado num processo como sendo autor de um tiroteio onde morreu o tenente Matheus Levine Ferreira. Nesse processo, pessoas torturadas no desespero inventaram uma história e botaram o nome daqueles caras que já estavam na clandestinidade, era o meu caso. [...] Quando chego lá no esquadrão da polícia da aeronáutica os caras querem saber disso. Fiquei num desespero tão grande, não sabia de absolutamente nada dos detalhes dessa operação, fui me situando pelo que eu ouvia dos caras. Aí assinei o depoimento dizendo que participei, confirmei aquele depoimento todinho que tinha lido antes. Confirmei, assinei e disse que quem tinha dado o tiro que matou o tenente fui eu.

[...] os caras estavam com aquela sede tão grande de saber quem era o cara, para sair dali, eu satisfiz a vontade deles, pronto. [...] Aí, pensei, depois vou para a justiça tentar me livrar.

[...] Só que os caras já estavam sabendo que eu não estava nisso e estavam só fazendo um jogo comigo. Depois eles chegaram, me chamaram de novo e disseram: '- Você não participou disso, a gente sabe, por que você disse que foi você?’. Foi uma coisa de doido, um desbaratino mental terrível!

[...] quando cheguei na Casa de Detenção no Recife [...] quis me suicidar mesmo, desespero. Escrevi uma carta, [...] mas terminei desistindo [...].

Eu senti a minha fragilidade, era dirigente político e pelos critérios do PCBR, veja bem, confirmar é a mesma coisa que abrir, abrir alguma informação nova ou confirmar algo para os critérios do PCBR era a mesma coisa. [...] eu achava que [aquela postura] era incompatível com as minhas funções.

[...] Discutia-se sobre a tortura, mas só na base da motivação ideológica, do compromisso político etc. O fato de você ter posição de não falar nada, fica no tudo ou nada e você não estabelece estratégias intermediárias.

[...] acabei aceitando a realidade, foi uma coisa muito lenta, de encarar a realidade, que eu não era um super-herói e aceitar os meus limites, encarar as coisas. [...] eu tinha de 
assumir o meu real, discutir e assumir a realidade, botar os pés na terra. Então, isso para mim teve um significado muito grande, [...] foi um momento marcante na minha vida ${ }^{315,}$.

Márcia Mafra, militante da ALN presa no dia 21 de fevereiro de 1971, também fez referência à questão da confissão e da mentira na tortura em seu depoimento, contextualizando os dilemas impostos pela violência, relatando como mentir ou silenciar era uma necessidade vital para o torturado:

“[...] Antes de a gente ser preso, pensava-se muito na prisão, em tortura etc. Tinha até um livrinho, já não me lembro mais de quem, de um francês, chamado A Tortura. E tinha uma discussão, na qual muita gente dizia o seguinte: 'Não pode falar nada'. E penso que sempre achei: '- Não, isso não existe'. Acho isso hoje também, pensando sobre como me comportei. Você tem que criar uma situação em que eles acreditem no que você está falando, mas você está mentido! [...] Você tinha ponto, às vezes, uma semana depois, no caso da nossa organização. De início, na tortura, era essa coisa intensa, maluca. Era você e eles, e porrada pra cacete, pau-de-arara, choque! Os primeiros dias eram aqueles que você tinha um ponto, se não aparecesse algo em um, dois dias, começavam a desconfiar. Você tinha ponto, mas não era necessariamente no dia seguinte. Havia ponto que você ia só para conversar... Tinha ponto uma vez por mês para falar de outras coisas, outras atividades. Era assim: havia pontos em primeira instância e, depois, contatos. E essa era a lógica da intensidade dos primeiros dias de tortura. Contra a força, o que se faz? Ou você entregava ou criava uma circunstância para mentir e eles acreditavam, porque se não, você continuava apanhando do mesmo jeito. Eu acho que eu consegui fazê-los acreditar no que eu estava falando.

[...] Eu fui presa às sete da noite... Eu me lembro de estar amanhecendo quando [...] dei um ponto falso. [...] Eu estava no pau-de-arara e um cara, não lembro quem, me botou um revólver na cabeça e mandei o cara atirar. A partir daí acharam que eu ia me matar... Durou essa estória. No dia seguinte, quando fui para o ponto falso, eu sacaneei. Fiquei o tempo inteiro na beira da calçada de modo que eles tivessem de ficar perto de mim, porque eles estavam apavorados, achando que eu ia me jogar debaixo de um ônibus.

[...] Claro que isso não foi racional. Naquele momento, foi como eu achei que tinha de me virar. [...] Pode ser que eu estivesse mesmo querendo morrer, que estivesse testando o blefe do cara. Honestamente, não sei.

[...] Consta de um papel meu, um documento da repressão, uma frase que é a seguinte: 'Cuidado com a presa, porque ela tem um forte sentimento de traição'. [...] Porque eu teria entregue um ponto falso! [...] Eu alimentei essa situação, porque você tem que dar verossimilhança para a situação.

[...] E quando fui presa, muita gente já tinha sido presa e sabíamos um pouco como aquilo funcionava, pessoas haviam contado. [...] Falando sobre não confiar nos papéis da polícia, se um cara ler isso, pensará: ‘- Ela entregou tudo’. A minha sorte foi que ninguém caiu ${ }^{316, ”}$

Manoel Cyrillo de Oliveria Netto, militante da ALN e vice-comandante da ação que realizou o sequestro do embaixador norte-americano, Charles Elbrick, em 4 de setembro de 1969, foi preso no dia 30 daquele mês. Em seu depoimento, falou também

\footnotetext{
${ }^{315}$ Entrevista concedida por Marcelo Mário de Melo à autora. SP, 27/11/2009; e Recife (PE), 22/04/2010, AAPP/AEL-LEI.

${ }^{316}$ Entrevista de Márcia Mafra concedida à autora. SP, 08/02/2009, AAPP/AEL-LEI.
} 
sobre como lidou com a necessidade de mentir na tortura:

“Eu morava na Aclimação [...] fiz química industrial no Científico e [depois] fui preso. Em todos os meus depoimentos de cadeia, nos interrogatórios, inventei que estudava arquitetura, de modo que não precisava falar muito sobre a origem da minha militância. [...] Nunca fiz movimento estudantil, nem como universitário e muito menos como secundarista. Essa foi a forma que encontrei para não precisar explicar muito como cheguei à ALN, em 1969. [...] Os caras acreditavam tanto na tortura, que não se dignaram a ir à Universidade de São Paulo, que ficava pertinho e [...] checar o arquivo. Se eu disse que era estudante de arquitetura, sou estudante de arquitetura. O que você falava no 'pau' era o correto. Virei estudante de arquitetura!

Mas como a gente termina entrando na ALN? Era um Brasil diferente do atual, muito diferente. Existia no bairro uma turma de amigos que se reunia na padaria. Dois desses companheiros nossos eram um pouco mais velhos, eles estavam fazendo o serviço militar quando aconteceu mais uma daquelas tentativas de golpe: não deixar o Jango tomar posse. E o Brizola resistiu a isso. [...] Aqueles dois companheiros que já tinham preocupações políticas, resolveram se engajar nesse movimento. [...] Começaram a organizar algumas atividades de turmas de bairro como a leitura coletiva de jornal comentada, e isso com o tempo evoluiu para leitura de livros e, depois, para leituras de documentos de organizações. [...] O grupo começou com muita gente e foi minguando, mas quatro companheiros entraram na ALN. [...] Lemos 'Porque resisti à prisão' e optamos pela organização de Marighella. [...] Um desses caras era meu tio, João Carlos Cavalcanti Reis, mas ele não era muito mais velho do que eu. Essa era minha preocupação na tortura, não falar nada sobre ele ${ }^{317}$."

Os testemunhos citados dão conta do espanto e estranhamento diante da tortura e todo esforço realizado pelos militantes para manter-se em silêncio ou conseguirem mentir. Outros relatos, porém, contrastam com respeito à surpresa diante da violência, conforme o depoimento de Beatriz Bargieri, dirigente regional da Ação Popular (Marxista-Leninista), presa no dia 5 de setembro de 1973, momento em que diversos militantes e dirigentes da organização foram presos e desapareceram. Beatriz preparavase para abandonar a clandestinidade e retomar sua vida legal, pois havia sido absolvida pelo Superior Tribunal Militar (STM) em um processo no Rio de Janeiro. Presa na casa de uma amiga, ela conta que foi sequestrada por engano,

“[...] a gente estava numa fase de desmontar alguns esquemas e não deu tempo. Eu fui presa [...] num carro com capuz, agachada e falando que tinha havido algum engano.

\footnotetext{
${ }^{317}$ Entrevista de Manoel Cyrillo de O. Netto. Idem, ibidem. Esses depoimentos redimensionam o debate incorporado ao ofício do historiador sobre o papel que os arquivos de regimes repressivos desempenham na sociedade contemporânea. Os documentos destes arquivos, tendo sobrevivido às instituições que lhes deram origem, produzem um efeito-bumerangue, quando são utilizados como prova dos abusos então cometidos, para fins de reparação, ferramentas para o exercício da democracia e dos direitos civis. Seu valor de prova, contudo, reside no fato de que refletem a estrutura, funções e atividades dos organismos nos quais se originaram, não em função de portarem uma suposta verdade expressa a partir de sessões de tortura ou em outros tipos de documentos como relatórios do setor de análise e informação. A verdade que o historiador pretende encontrar nesses documentos, assim como nos testemunhos, supõe uma rigorosa verificação do contexto de produção e do conteúdo dos mesmos. V. CAMARGo, Ana Maria de A. "Os arquivos e o acesso à verdade”. In: SANTOS, C. M.; TELES, E.; Teles, J. de A. (orgs.). op.cit., p. 426, 431 e 436.
} 
Quando cheguei lá, eles me levaram para ver quem era, saíram gritando, felizes da vida, porque tinham identificado quem eu era. Eu fiquei cento e cinco dias no DOI-CODI. Eu particularmente estava muito motivada e muito preparada para uma série de circunstâncias e foi um momento em que houve um enfrentamento, mas eu estava muito preparada e deu para segurar bastante a situação. [...] E nisso, acho que o Paulo Wright me ajudou muito, porque ele me criticava dizendo que eu tinha uma posição muito dogmática. Eu defendia que só se podia dizer o nome e pronto, aquelas coisas que a gente lê lá atrás... E ele dizia que o mais importante não era você, era o que você estava preservando e que, às vezes, para se preservar as coisas maiores, você tem de abrir mão de algumas coisas, que até seria ótimo dizer: '- Eu sou fulano, eu não tenho nada a declarar'. Mas, depois, o resto todo desmonta, e não adianta nada. Ele vinha conversando isso comigo. Tive de me defrontar com esta situação lá e acho que foi importante, foi muito difícil aceitar que há outras formas, que você tem algo a preservar, mais do que a você mesmo. Na verdade, você nunca está preparado, você vai se defrontando com situações novas, porque preparado você nunca vai estar."’18

O torturado poderá escapar à imediatidade do torturador em direção ao trabalho de diferenciação de si e do outro e tentar restabelecer-se frente à brutalidade incomensurável que lhe aplaca e ao paradoxo da desumanização mencionado ${ }^{319}$, mas “na tortura, trata-se sempre de passar por uma morte quer seja a do corpo ou a do ideal. Este, por sua vez, não é estranho às suas raízes corporais [...].” As ditaduras e a violência da tortura "são capazes de quebrar este amálgama constitutivo do ser” [VIÑAR, M.; M., 1992: 77-8].

Os depoimentos dos sobreviventes entrevistados, contudo, trazem narrativas em que essas dualidades são matizadas, histórias de pequenas e grandes resistências diante da dor e sofrimento extremos que relativizam a imposição da morte do corpo ou do espírito. Conforme ressaltou Rosalina Santa Cruz em sua entrevista: “A tortura pode ser muito cruel, mas você tem como inventar uma história, inventar que tem um ponto. Eles querem saber uma coisa e você conta, inventa [...]. Você apanha mais quando volta, mas [...] consegue ganhar tempo.»320 Por vezes, durante a tortura o preso descobria forças antes desconhecidas, conforme relato de Anivaldo Padilha:

“Eles [...] achavam que eu era uma pessoa muito importante na AP, porque o material apreendido era um material da direção nacional, eles pensavam que eu tinha contato direto, que eu era, talvez, membro do comitê central. [...] Havia essa suspeita e eu duvidava que eles fossem aceitar totalmente o fato da gente não ter as informações [...]. Então, tive quase certeza de que eu ia morrer, mas ao mesmo tempo [havia] um medo muito grande de não aguentar e sucumbir à pressão e dedar as pessoas. Foi um drama de consciência muito grande. Foi aí que eu comecei a pensar em suicídio. Sentei num colchão no chão que tinha na cela e fiquei pensando, refletindo sobre a vida. Fiz toda uma

\footnotetext{
318 Entrevista concedida por Beatriz Bargieri à autora e Marcelo Ridenti. São Paulo, 18/10/2008, AAPP/AEL-LEI.

${ }^{319}$ Para Jean Améry, o torturador é a expansão de um poder sádico e heterogêneo, que, analisado a partir da experiência da vítima, encarna o mal radical. A ausência de defesa e a fragilidade do torturado é tal que se diria vencido por um poder quase divino e transcendente. V. AMÈRY, J. Op.cit, p.18, nota 8.

${ }^{320}$ V. entrevista concedida por Rosalina Santa Cruz à autora. Idem, ibidem.
} 
retrospectiva da minha vida, pensando na minha família, nos meus amigos, companheiros. Eu pensava: não posso de jeito nenhum querer salvar a minha vida e dedar essas pessoas, porque mesmo que eu consiga sair daqui vivo, não vou conseguir viver mais com a minha consciência. [...] isso estava muito claro para mim. Eu não tinha escolha ou aceitava essa situação e teria que encontrar uma maneira de sair dela ou o suicídio era o caminho. Acontece que não tinha como se suicidar, porque no momento em que fui preso eles tiraram o meu cinto. Eu não tinha nenhum objeto cortante, nada, nada. Por isso, quando vejo aquela foto do Herzog enforcado, quem passou pela OBAN sabe que aquilo era uma cena impossível. Você não tinha meios de cometer suicídio lá.

[...] Pensei: - bom, não estou aqui gratuitamente. Era um risco calculado. Era um risco que eu sabia que existia e era parte e resultado de um compromisso que assumi lá na minha juventude, de lutar por mudanças no Brasil. Você sabe que o ser humano em geral quando está numa situação-limite e não vê saída, busca as forças onde você consegue encontrá-las [...] e essas forças estão dentro de você. Eu, objetivamente, estava numa situação totalmente a mercê deles e [...] eu pensei: a minha vida deixou de me pertencer, pertence a Deus desde o início. [...] se eu tiver que morrer aqui, eles que assumam a responsabilidade pela minha morte. [...] - Talvez até a minha morte possa servir de fator para abalar a ilusão que muitas pessoas têm da ditadura. Eu era muito conhecido no meio ecumênico no Brasil e internacionalmente.

[...] Eu pensei: - eu era simplesmente magérrimo [...] e de repente eu me via numa sala com cinco ou seis brutamontes. [...] Por que eles precisam de quatro, cinco, seis para me torturar? [...] Eu pensei: - Eu sou mais forte do que eles, do ponto de vista moral [...] eu sou mais forte. [...] Se eles com todo esse poder ainda precisam me torturar é porque eu sou mais forte e tenho condições de resistir, de não colaborar. E, talvez, morrer, mas seria uma forma de resistência. Percebi naquele momento, nessa reflexão, ali eu me dei conta exatamente de que a prisão é uma frente de luta. Eu falei: - A guerra não terminou para mim. A partir daqui é uma outra batalha e vou tentar resistir. [...] Claro, que com muita insegurança e muito medo.

Sentei, tentei relaxar e comecei a entrar num momento de grande serenidade e tranquilidade. [...] E fui ficando tranquilo e dormi numa tranquilidade muito grande. E foi incrível, quando eu acordei de manhã, eu senti algo que eu realmente não consegui me explicar ainda. Eu passei por um processo de amnésia, não conseguia lembrar nem o nome do meu pai e nem o nome da minha mãe. [...] O fato é que a partir dali eles me torturaram a vontade e eu não conseguia dar o nome de ninguém, mesmo que eu quisesse. Eu falava: '- Não sei, não sei, não sei.' Eu estava tão convicto de que eu não conhecia ninguém, que realmente me convenci de [...] uma mentira. [...] Foi um mecanismo que me ajudou muito. Muitos falam que foi um milagre, uma experiência mística. Pode ter sido!” 321

Alguns prisioneiros reagiam à violência física na "mesma moeda” como forma de manter intacta sua dignidade e esta era uma transgressão intolerável para os torturadores. Em resposta, a tortura era aplicada com raiva e método, mas de forma ainda mais intensa, pois era necessário domar o infrator e transformá-lo em um “exemplo”. Este foi o caso de Lenira Machado, dirigente do PRT presa no dia 13 de maio de 1971, pela equipe do delegado Fleury, ocasião em que foram presos também seu companheiro Altino Dantas, uma companheira e o filho, ainda criança, Aritanã. Lenira foi torturada durante 45 dias no DOI-Codi (SP):

${ }^{321}$ Entrevista de Anivaldo Padilha concedida à autora. Idem, ibidem. Destaques meus. 
“No DOPS, me levaram para uma cela normal, até que [...] o Fleury disse: '- Não, ela tem que ir para o calabouço', aquelas celas isoladas [...] no 'fundão’. [...] Passei três dias lá. [...] só saí, quando o DOI-CODI venceu a briga com o DOPS e fui transferida para a Rua Tutóia. Aí se [...] iniciou o processo de tortura, [...] nos três plantões. O Ustra encaminhava as perguntas, dizendo que não gostaria de me ver sofrer muito, que eu evitaria o meu sofrimento falando. [...] eu fiquei na cela isolada acima da antiga garagem da casa. [...] não tive contato com ninguém no DOI-CODI também.

[...] eu fazia o controle dos dias com os palitos de fósforos que o 'Zé Porrada' me dava, eu tinha um calendário próprio [...]. Mas eu também perdi a noção de horas de sono, quer dizer, qualquer movimento de entrada e saída de carro no pátio do DOI-CODI, eu subia para enxergar [pelo basculante] o que é que estava acontecendo.

[...] A primeira pergunta foi o meu nome e eu não reconhecia que era a Lenira, [...] apanhei durante dez dias para dizer o meu nome, isso me deu muito tempo. Duas coisas [me ajudaram]: ter levado o Aritanã, [...] oficializando a nossa prisão pelo DOPS, e a segunda, foi ganhar dez dias [...] para reconhecer que eu era Lenira, isso foi uma vantagem muito grande.

[...] Na hora que chegaram com a minha carteira de identidade [...] não dava para continuar naquela encenação, apanhando por causa do nome. [...] no outro dia de manhã é que realmente começou o pau violento. [...] me colocaram no pau de arara e o JC sentou num dos cavaletes, com uma vasilha, um copo de água na mão e um punhado de sal na outra, toda a vez que me davam choque, eu abria a boca e ele jogava o sal na boca e a água pelo nariz, isso aumenta a potência do choque. Eu sei que consegui soltar a minha mão do ferro e fiquei presa pelos pés e com as mãos soltas e quieta. Numa hora em que ele se distraiu e mexeram a máquina, eu peguei ele pela cintura e puxei. Soltei a mão de tudo e puxei ele. O JC caiu por cima de mim e bateu o rosto na quina do outro cavalete de madeira, o que fez um corte grande e começou a sangrar. Fiquei toda cheia de sangue dele. Pararam a sessão, me tiraram do pau-de-arara com o ferro e me jogaram no chão e suspenderam tudo. Ele foi fazer curativo e demorou muito. A minha impressão jogada no chão é que ele demorou muito. Quando ele voltou, me disse que tinha sido obrigado a ir ao hospital militar e que tinha levado sete pontos. Ele se abaixou, me amarrou no mesmo no cano, chamou um outro policial e falou para ele: '- Segura na outra ponta do cano', e ele segurou na outra, eles me levantaram esticando os braços e fiquei pendurada lá em cima. Ele virou para o outro policial e disse: ‘- Quando eu contar até cinco, solta'. Ele contou e soltaram o cano. Eu caí, cerca de um metro e oitenta. Fui jogada no chão, eu estava naquela posição de pau-de-arara e a coluna foi direto no chão. Afetou a coluna e perdi o controle da cabeça. A denúncia que havia em relação a mim é que eu tinha um esquema de socorro, de saúde, um hospital clandestino montado e eles queriam os nomes dos médicos que participavam desse esquema. E eu falava: '- Não tem nada disso, não tem nome nenhum, vocês estão sonhando'.

[...] E prenderam o Décio Noronha, meu ginecologista, e o pediatra do Aritanã [e outros] médicos. [...] O Décio disse: '- Olha, ela está com problema de coluna e ela não tinha esse problema, porque é minha paciente há muito tempo. Quando eu sair daqui, vou denunciar.' Isso durou vários dias. Eu era arrastada para a sala de tortura e o Décio estava saindo da sala. Até que um dia, [...] o Décio foi solto. Numa das sessões de torturas, [...] um enfermeiro [...] foi chamado, porque eu estava muito mal, e ele disse: '- Ela perdeu o controle da [coluna na altura da] cabeça, qualquer coisa que vocês fizerem agora ela morre!' [...] e fui levada para o hospital militar [...] Eu tinha dores horrorosas, naquele momento a tortura não doía tanto, o que doía era a minha coluna. Eu tinha paralisia de um lado inteiro e muita dor, constante. O médico que veio me atender estava bêbado e [...] me deu uma injeção de morfina. E me levaram de volta.

[...] Foi assim por 45 dias, da cadeira do dragão para o choque na boca e no ouvido, do choque na boca e no ouvido para o pau-de-arara e, no outro dia, começava tudo de novo. 
[...] continuei dizendo que não sabia de nada, dizia que só fazia tradução e era uma pessoa frágil. [...] Eu não sei se, naquele momento, torturavam para conseguir informação ou para me quebrar. Fisicamente quebrada eu já estava, mas não psicologicamente.”322

Uma experiência de resistência à brutalidade extrema foi vivida por Jesus Paredes Sotto preso em 1974, quando iniciava-se o governo do general Ernesto Geisel. Pela primeira vez Jesus falou numa entrevista sobre sua militância e a experiência de prisão. Após tantos anos, ficou emocionado ao falar da violência da tortura, do desespero, da impotência que sentiu e do sofrimento para manter sua capacidade de resistência. Ele pareceu reviver os dias de tortura. Militante da VPR, participou do GT [Grupo Tático] da organização e de suas principais ações armadas. Em 1971 decidiu militar no MR-8, juntamente com Carlos Lamarca, em função da avaliação de que faltavam condições operacionais à VPR para manter as ações e do perigo que o isolamento impunha a eles.

A morte de Lamarca no sertão baiano, em setembro de 1971, no entanto, representou um momento de inflexão para ele e o MR-8. Sua morte e as diversas prisões de dirigentes e militantes debilitaram decisivamente a organização. $\mathrm{O}$ partido avaliou, em dezembro de 1972, no Chile, que era necessário mudar e interromper as ações armadas, decidindo-se por retornar ao trabalho político nas fábricas, junto às bases do movimento sindical e manter os principais dirigentes fora do país ${ }^{323}$. O deslocamento de militantes do MR-8 para realizar esse trabalho havia se iniciado em 1970, o que deu certo fôlego à organização $^{324}$. O partido persistiu na proposta de continuar organizando a luta armada no campo também e foi seriamente atingido pela repressão. "A morte do Lamarca foi o ponto culminante, um divisor de águas [... avaliamos] não dá por aqui, não agora. O poder é a ponta do fuzil, não tem outra história. Então, a gente foi para São Bernardo. [...] Consegui legalizar um 'nome frio', mas com respaldo. Eu casei com a minha companheira, comecei a trabalhar em metalúrgicas e consegui chegar à fábrica, na Chrysler. „325 Com o tempo, Jesus começou uma atuação discreta no sindicato. Mas uma prisão desencadeou a última “queda” do MR-8 e Jesus foi preso pelo DOI-CODI/SP na madrugada do dia 22 de abril de 1974:

\footnotetext{
${ }^{322}$ Entrevista concedida por Lenira Machado à autora. São Paulo, 09 e 15/04/2009, AAPP/AEL-LEI.

${ }^{323}$ Entrevista concedida por Jesus Paredes Sotto à autora. Rio de Janeiro, 21/03/2010, AAPP/AEL-LEI. Perfil dos atingidos, op.cit.; e SADER, Eder. Quando novos personagens entraram em cena. Esperiências e lutas dos trabalhadores da grande São Paulo (1970-1980). 2a . Ed., São Paulo, Paz e Terra, 1986, p.170-1, entre outros. Parte dos militantes da antiga DI-GB saiu do MR-8.

${ }^{324}$ Depoimentos de militantes do MR-8 (DI-GB) relataram o início desse trabalho nas fábricas. V. RIDENTI, M. op.cit., p.171-72.

${ }^{325}$ Entrevista concedida por Jesus Paredes Sotto à autora. Idem, ibidem.
} 
"Eu tive muito azar, porque entreguei a minha arma e as minhas bombas dois meses antes, senão eles não tinham me pego vivo. Eu não ia me entregar vivo de maneira nenhuma, eu sabia o que eles iam fazer. Eu comecei a fazer discursos, os caras me dando coronhadas, porrada... Eu chamei eles de vagabundos, que o socialismo ia vencer, imagina! Era um desespero danado. Quando vi o companheiro [no camburão], desmontei, não consegui falar mais nada. Ele tava em carne viva, só tinha olhos. Não consegui falar mais nada, porque mais nada tinha sentido, eu sabia que ia para lá para morrer. Eu tava sabendo que iam me matar, porque eles matavam todo mundo do grupo tático. Eu cheguei no DOI-CODI com os olhos vendados, mas me pareceu que era o estacionamento. Eles me tiraram do carro, me encheram de porrada e me arrastaram para uma sala. Tiraram o capuz e veio um senhor e começou a falar, falar e eu quieto. [...] O cara veio me oferecer para mudar de lado, eu ia ganhar bem, não sei o que, um montão de conversas. E eu quieto. No final, eu me lembro que ele olhou pra mim e disse: '- Você não está vendo que tudo isso é ilusão?’ Na hora, eu até achei engraçado, mesmo naquela circunstância, aí eu falei bem baixinho para ele: '- Então, por que é que nós estamos aqui?' Acabou a conversa, acabou a conversa. Então, comecei a ser torturado, 45 dias depois, fui para o DOPS.

Eles querem carne para moer e eu não ia dar, a minha, eu não podia negar, mas a dos outros eu não dou. Eles queriam pontos, aparelhos. Eu os convenci que não tinha ponto, que eu era legal e os companheiros sabiam da fábrica que eu trabalhava e só. Eu não me lembro quantos dias, eu contei muito bem até o $21^{\circ}$. dia. Teve um dia que eu acordei na sala e comecei a me perder [na contagem] e me tiraram da sala. Não sei se tava amanhecendo ou escurecendo, eu me perdi. Tinha uma sequência de três equipes, eles trocaram alguma e acho que o fizeram para me confundir. Eu não sei, aí já não sabia mais quantos dias eram. Eu conseguia acompanhar pelas equipes, cada equipe ficava 24 horas, mas depois desse dia eu já estava muito fraco. Às vezes, um cara jogava um prato lá dentro, a gente não conseguia nem se mexer, era muito choque e você vai ficando paralisado. Eu tinha pontos, mas eu não ia abrir companheiro, porque eu estava convencido de que eles iam me matar. Quanto mais eu falasse mais eu manteria aquele suplício. Eu preferi calar a boca. No final, começou uma coisa assim: '- Ação tal?', 'Participei’, '- Onde?’, eles tinham tudo: ‘- Em tal lugar’. E só ficava nisso. Eles sabiam quem eu era, por isso eles estraçalharam o companheiro e a companheira dele, que estava grávida e abortou lá dentro. Eles sabiam que eu era o Jesus, o coitado do companheiro que me entregou não sabia, nem conseguia entender... Para ele, eu era um operário. A minha sorte é que o Franklin Martins estava viajando, então mandaram ele para me dar assistência até ele voltar.

Eu aprendi muito do bicho homem naquela desgraça lá. As pessoas mais limitadas gostam de torturar, as pessoas mais inteligentes não. Digo, torturar gratuitamente. Eles querem isso, quando conseguem isso, acabou. Tem cara que é sádico, é sádico. Ele chegava as 7 hs da manhã e começava a dar choques, o dia todo. O cara não levantava para fazer xixi! Você é quem tinha que pedir para ele ir fazer xixi, tinha pessoas assim. E tinha pessoas que não, eram os que eu mais temia. [...] Então, imagina, as últimas ações foram em 71, quanta gente caiu, quanta gente eles mataram na tortura, eles tinham tudo. [...] Eu fiz resistência em entregar companheiros e não entreguei ninguém [...].

[...] Eu não me lembro bem, já estava muito confuso, não me lembro das coisas, às vezes, eu misturo... É um lugar apavorante, é preferível mil vezes a morte, não tenho a menor dúvida. Esse negócio do eletrochoque não mata. No tempo do nazismo, o cara apanhava, apanhava e numa semana estava morto. Agora, o choque com acompanhamento médico, você não morre. Parece que vai queimando por dentro os nervos e fica muito doloroso, fica lancinante. O choque elétrico vai queimando e vai formando um caminho. Foi uma coisa... Os companheiros cedem porque é uma coisa..., as palavras são pequenas, as palavras são pequenas, para falar da tortura, não é nada... [...] naquela altura do campeonato, não pedia para morrer porque não abria a boca. Acho que foi no quarto ou quinto dia, o cara veio com um revólver e aí eu fiquei valente para caramba. Eu não conseguia quase andar, mas eu abri a camisa e disse: '- Atira covarde, atira'. E o cara não 
atirou, ele disse: '- É isso que você quer? Tá quase pronto'. Ele achou que eu estava no meu limite, achou que eu ia me assustar com o revólver. Se eu tivesse forças eu tinha pegado o revólver dele. Deixa para lá, passou e eu sobrevivi.”

Outro depoimento bastante emocionado foi o de Celso Brambilla, que, em alguns momentos, parecia voltar a viver o passado como se ele estivesse acontecendo no presente. Celso não era um militante típico, trabalhava como metalúrgico da Mercedez de São Bernardo do Campo (SP), estudava Engenharia e era diretor do DCE da UFSCar. Foi preso com seus companheiros da Liga Operária durante a madrugada do dia 27 de abril de 1977, em plena vigência do "Pacote de Abril". Faziam pichações e distribuição de panfletos sobre o $1^{\mathrm{o}}$. de maio. Levado para o DOPS, foi muito torturado juntamente com sua companheira de partido, Márcia Bassetto, seu tímpano do lado esquerdo estourou, ele ficou surdo e com diversas complicações físicas:

“[...] Nós fomos presos pela PM [...]. Na hora em que eu entro no DOPS [...] os caras me arrebentam de pancada [...]. Falavam: '- Comunista. Comunista tem que apanhar!' Não perguntavam nada. Aquilo ali você pode entender que era uma maneira de quebrar o moral. Tapa, empurrão, numa roda com oito, nove caras. Me puseram sentado e quando eu começo a falar o cara me dá uma porrada na boca e mordo a língua. [...] Eu fico me lembrando agora, mas hoje não é nada. Eu volto a falar e pá, tomo outro tapa. Comecei a falar novamente, o cara vêm por trás e ... me deu 'um telefone', espirrou sangue no cara que estava datilografando. Ele falou '- Filha da puta'. Estourou tudo, sangrou olho, nariz... [...] O apelido do cara era 'Sanhaço', ele era fortão.

É um trauma tremendo. Eu só não caí no chão, porque fiz uma força tremenda. Eu fiquei pelo menos uns dez anos, antes era toda semana, depois uma vez por mês, aqueles ossinhos se moviam e eu tinha que me segurar, porque perdia o equilíbrio. Na hora [...] você não sabe do que é capaz, porque eu tinha um medo de choque, quando o cara veio com o choque para cima de mim, eu falei '- Putz, agora vou entregar todo mundo, dizer que enforquei Tiradentes!' Mas passado um tempo o choque era refresco.

[...] naquela roda com oito, nove caras me batendo, eu tentei simular um desmaio. [...] só que percebi [...] que não era só fingimento, eu estava entrando na deles e me desestabilizando emocionalmente. Eu parei e falei: '- Vou ter que me aguentar'. A partir daí a coisa foi acontecendo, pancada, pancada, pancada e putz, pau de arara. [...] Choques, mas a coisa mais dolorida foi a palmatória. Eu fiquei anos com parte da mão e dos pés insensíveis. Palmatória nas mãos e nos pés, chegava a arrepiar de tanta dor.

[...] Nessa pancadaria toda eu não tinha conseguido 'soltar' nada ainda. [...] e aí eles engrossaram com a Márcia. Claro, porque eles não queriam perder tempo, e aí foi, talvez, o meu erro, eu deveria ter chamado para mim a 'confusão'. Mas a Márcia era até mais antiga do que eu, eu era um cara de base. [...] E começaram a torturar a mim e a Márcia juntos. [...] tem um momento em que [...] eles mandam que eu dê um choque nela. Eu pego nas mãos dela e tomo o choque junto com ela. [...] eles estavam barbarizando a Márcia. Se eu não faço aquilo, não sei o que eles seriam capazes de fazer. A Márcia passou por uma tortura muito pior do que a minha. Você conhece a Márcia, ela é uma mocinha, eu era atleta, era forte, tinha estrutura, se bem que o que mais vale na tortura é a cabeça e, por isso, ela suportou tudo incrivelmente. Mas eu a abracei e tomamos o choque juntos.

[...] naquele momento, eu acreditava que se não fizesse isso ela ia sofrer mais ainda. Era para eles me fazerem recuar diante do sofrimento dela. Muita gente pode achar que eu falhei nessa hora, mas, naquele momento, foi a única saída que vislumbrei. 
[...] Quando eles conseguem o ponto de encontro, o torturador diz '- Ah, está vendo, eu atrasei o relógio’. Mas nós estávamos com a consciência tranquila, porque [...] tínhamos resistido quarenta e oito horas. Tanto é que todo o mundo, além de nós, fugiu.

[...] Eu entrei no DOPS com 78 quilos e, depois, [...] eu pesava 65.”326

Os testemunhos daqueles que sofreram a tortura concordam sobre um ponto: "é na alucinação e no estado onírico que cada um preserva ou trai seus valores éticos” ${ }^{\text {„27 }}$. A confusão, a alucinação e a loucura foram experimentadas pelos prisioneiros políticos. Este foi o caso de Danilo Carneiro, um dos que viveu uma das piores experiências de tortura entre os entrevistados. Danilo foi torturado durante aproximadamente sete meses, em várias cidades, mas, principalmente, em Brasília (DF). Diante de tanta violência as fronteiras entre realidade e alucinação foram, algumas vezes, destruídas:

“[...] Eu comecei a entrar em desespero. [Colocaram] um cachorro policial, que agarra os meus testículos, começa a puxar [...] Era um troço pavoroso. Você está, vamos dizer assim, debilitado, meio zonzo, dor para todo lado [...] Aí vem o interrogatório e eu conto uma história que tinha sentido pela primeira vez, aí eu falei: tenho que dar informação senão estou liquidado.

O Fleury estava lá, participando dessas torturas [...]. Nesse dia, eles me levam para a beira do lago: “- Você vai ser fuzilado”, no Lago Paranoá. [...] Eles me botam num tamborete, botam uma venda nos meus olhos bem fininha, que dava para ver a luz, e vem uns caras com metralhadora e pápápápápápá!!!! Eu desmaio [...] Aí eu comecei a falar lá de trás [do início da militância] [...], porque você tem que dizer alguma verdade para eles. E contando uma história bem devagar, porque eu sabia que tinha que ganhar tempo para me recuperar, senão eu morria. Eu tinha certeza que estava morrendo nesse momento. Depois dessa simulação na beira do lago, me levaram e começaram o interrogatório, que durou até a noite.

[...] Quando eu entro na cela, começo a enlouquecer, perder o sentido. E me dá um troço tão estranho na cabeça que eu não consigo pensar mais, os pensamentos se desconectam como se tudo se misturasse na sua cabeça e me dá uma ansiedade, eu bato com muita violência na porta e começo a dar cabeçada no chão, cabeçada na parede, cabeçada na grade. Aí eu digo para o cara que estava [na cela] do meu lado que estou enlouquecendo, estou morrendo. Ele manda um comunicado para o presídio todo. Essa parte é meio barra pesada, me deixa tomar uma água senão não vai não... Nesse momento em que eu comecei a perceber que estava realmente enlouquecendo e que perdi todo o controle, gritava e batia para o companheiro ao lado, aquele que ficou um tempão do lado da minha cela quando eu cheguei... E nesse período também estava lá o Paulo Fonteles, que era militante de AP, tinha sido preso. A esposa dele também estava lá, a Ecilda. O Paulo nesse momento manda uma mensagem para o presídio sobre a minha situação, o pessoal então se mobiliza e começa a cantar. E ele diz assim: “- Companheiro...”, tentando conversar comigo, mas eu não sei dizer para você o que era [que ele falava], mas ele tentava dizer para mim que procurasse falar com ele. Com isso, ouvir o canto dos companheiros e falar com ele, aquela coisa que estava na minha cabeça e que era terrível... Até hoje, aqui, nesse momento, comentando com você, se eu ficar pensando muito parece que vai dar um nó na minha cabeça. A barra era pesadíssima, eu sentia que estava enlouquecendo. Eu queria morrer e batia na parede e batia... Eu sei que fui me acalmando, o pessoal cantando, mais de 300 presos cantando no presídio... Cantaram

\footnotetext{
${ }^{326}$ Entrevista concedida por Celso Brambilla à autora. SP, 18/12/2009, AAPP/AEL-LEI.

${ }^{327}$ VIÑAR, Maren e Marcelo. Exílio e tortura. São Paulo, Escuta, 1992, p.73.
} 
canções, vários tipos de canções. Coisas de sensibilidade e eu fui me refazendo. Eu sei que agarrei na grade, subi um pouco [...] e comecei a fazer um discurso violento, não sei o que eu disse, e agradeci a solidariedade dos companheiros. [...] todo mundo ficou em silêncio. A Ecilda cantava muito bem, então, eles pediram para a Ersilda cantar. É um momento que você sabe que esgotou todas as suas energias, que não tem mais como resistir e que está ficando louco. É um processo muito complexo para você segurar essa barra, mas diante dessa situação eu consegui me controlar em função da cantoria e de fazer esse discurso, aquilo foi como um desabafo. [...] Eu fui melhorando aos poucos, daquele estado desesperador. [...] Os guardas tinham invadido o presídio para obrigar o pessoal a se calar, eles não calavam e chega mais soldados e dá porrada nas celas. Em nenhum momento o pessoal, apesar das ameaças, parou de cantar. [...] Eu não comia, não tinha como mastigar, estava com o maxilar fraturado, perdi 9 dentes na hora que eles deram coronhadas. [...] No outro dia quando eles me tiraram para ser torturado novamente eu já estava mais refeito. Sistematizei as histórias para passar aquilo como se fosse tudo verdadeiro, dei as informações que não comprometiam, que eu sabia que eram informações que muitos já conheciam. [...] Chegou um momento que qualquer cabo ou soldado podia entrar na cela e me dar porrada [...] me torturavam sem estar um comandante ali, eles mesmos resolviam e torturavam, qualquer sargento. [...] Depois daquele dia eu voltei a ser torturado várias vezes. [...] Me levaram para São Paulo e fui para a OBAN, onde sofri torturas: pau-de-arara, choque [...] no Rio de Janeiro também [...].".328

Muitos estudos fazem referência à experiência de alucinação ou algo semelhante ao estado onírico que ocorre durante a tortura. A alucinação abre alternativa "[...] ao universo mais primitivo: a prioridade do corpo em detrimento da realidade exterior, ou sujeição desse corpo à verdade da realidade vivida como catástrofe e como morte” [ViÑAR, M.; M., 1992: 76]. Para alguns se apresenta a possibilidade de "abandonar o corpo para salvar o espírito” em direção à alucinação, quando ocorre o desaparecimento das urgências do corpo dolorido na substituição simbólica e onde reencontrará sua pertinência. Busca-se “[...] imagens de outros corpos, de palavras, de gestos que são a carne do grupo com o qual aquele que foi torturado partilhava ideais. Esta substituição é um trabalho que permite passar pela morte real, onde o desaparecimento do corpo no símbolo permite salvar identificações anteriores e escapar à dualidade como única alternativa aparente. Reapropriação de um outro próprio, alteridade irredutível ao outro que se oferece na imediatidade do torturador. Um outro próprio, que duplica a clivagem espírito/corpo e estabelece a clivagem ideal/morte” [VIÑAR, M.; M., 1992: 77]. No intervalo das sessões de tortura, porém,

“[...] os carrascos deixam à vítima um tempo aparentemente vazio que deve lhe permitir recuperar-se fisicamente e 'refletir' sobre as vantagens da capitulação. As marcas das sessões precedentes (afogamento, choque elétrico, enforcamento, golpes...) funcionam como lembrança antecipada do horror destinado a se renovar. É neste tempo vazio que o sujeito marcado pelas experiências da tortura pode continuar a se deixar tomar pelo

${ }^{328}$ Entrevista concedida por Danilo Carneiro à autora. Idem, ibidem. 
horror, ou, bem, encontrando-se já ausente, transformar-se em mãe nutridora de seu próprio corpo atormentado, reencontrar suas partes, seus contornos, tratar suas feridas, acalmar sua dor, e através destes cuidados preservar-se do ódio do inimigo. Recuperar, no corpo destruído pela tortura, um outro espaço próprio que contém uma corporalidade alucinada e a possibilidade de ser uma mãe nutridora de si mesmo é, pois, o único meio: ele restitui o espaço de intimidade, de segredo, disto que lhe é bem próprio” [VIÑAR, M.; M., 1992: 77].

A alucinação pode libertar temporária ou definitivamente o torturado da sensação de tempo interminável, imposta pelo sofrimento físico, e da angústia gerada pela impotência para por fim aos tormentos. A espera e a incerteza sobre o que virá, talvez, sejam ainda piores do que sofrer a própria violência física. Na suspensão do tempo e do discernimento constroem-se as tramas da "fraqueza ou da coerência” do torturado. Alguns dos entrevistados, como Danilo, conseguiram falar algo sobre a experiência de ter ultrapassado as fronteiras existentes entre os acontecimentos reais e o fantástico, a mistura do delírio com o tormento físico. Eles relataram um pouco como conseguiram, em certa medida, "ultrapassar o imediatismo desta experiência invasora” e perceber a tortura como agressão física vinda do exterior, mantendo alguma coisa da integridade do sujeito torturado preservada ao reencontrarem em si e nos companheiros a solidariedade e formas de simbolizar suas perdas, mantendo partes de si ilesas e reforçadas [VIÑAR: 1992: 32, 46, 51-2].

\section{Os limites e possibilidades do testemunho}

A violência, muitas vezes, emudece as vítimas e os que estão ao seu redor. Uma das condições de sua eclosão é a elisão da linguagem, que coloca de lado o lugar e o reconhecimento da diferença e da singularidade do sujeito. O silenciamento da linguagem pode ser um dos efeitos da violência, frente a qual o psiquismo não pode "representar uma força que o atinge de forma excessiva e inesperada"329. O sobrevivente, tanto o que vivenciou quanto o que assistiu a experiências-limite, tem de lidar com o trauma, aquilo que surpreende a consciência tumultuando-a e que foge à sua compreensão. Ele tem de lidar com a própria “[...] resistência à transposição (tradução) do inimaginável para o

\footnotetext{
${ }^{329}$ V. FREUD, S. "Além do princípio do prazer”. In: Escritos sobre a psicologia do inconsciente. Vol.II, (1915-1920)/Sigmund Freud. Rio de janeiro, Imago, 2006.; e SCARRY, E. op.cit. citada em ENDO, Paulo César. A violência no coração da cidade. Um estudo psicanalítico. São Paulo, Escuta, 2005, p.89.
} 
registro das palavras; [...] a culpa devido à cisão entre a imagem (da cena traumática) e a

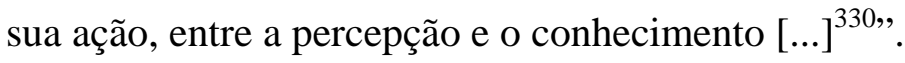

O silêncio do sobrevivente pode ser deliberado, uma forma de gestão de uma identidade que busca uma reinserção na vida "normal” ou resultado da dificuldade de expressar e se impor diante "da ausência de condições sociais favoráveis que autorizam, solicitam ou abrem à possibilidade de escuta”. Esse silêncio é indicador também do limite do que é possível e do limite do que é dizível. E, ainda, pode ser um índice do limite sobre o que o sobrevivente consegue dizer [JELIN, 2002: 80]. Alguns não falaram por muitos anos por não contar com os veículos ou os recursos simbólicos para localizar e dar sentido aos acontecimentos e romper com o vazio de diálogo produzido entre grupos sociais, gerações etc [JELIN, 2002: 83]. De acordo com Freud, “a recordação traumática pode implicar uma temporalidade demorada ou tardia e um período de latência entre um acontecimento anterior, real ou fantasiado, e outro posterior que de algum modo o evoca e dispara de novo a repressão [...] e se faz presente no comportamento" [LACAPRA, 2005: $108]$.

De acordo com Paulo Endo, a “desmoralização da experiência e com ela a desmoralização da fala nos desastres provocados pela guerra, executou-se antes no corpo, atravessando-o e ultrapassando-o como um instrumento ou um obstáculo desimportante, privado de linguagem e inerme. [...] O ataque ao corpo é uma maneira de interromper a linguagem em seu princípio originário: o da mediação e da distância que se quer impor, que se pode impor. Violentar o corpo só atinge pleno êxito quando se alcança a dessubjetivação do sujeito, privando-o dos lugares onde ele se constitui”331. "A dor física não tem voz”, daí a dificuldade de falar sobre a tortura. Conforme Elaine Scarry, “a dor física não apenas resiste à linguagem, mas a destrói ativamente, conduzindo a uma imediata reversão a um estado anterior à linguagem, aos sons e gritos que um ser humano emite antes que a linguagem tenha sido aprendida ${ }^{332}$.”

O emudecimento se constitui num dos principais efeitos da violência da tortura. O que implica na enorme dificuldade de falar sobre a experiência da tortura, sobre o sentimento de culpa ou a culpa objetiva, sobre as responsabilidades da delação, da colaboração e suas consequências. Para os prisioneiros, essa realidade foi vivenciada de

\footnotetext{
${ }^{330}$ V. SeligmanN-Silva, M. “Apresentação da questão”. In: História, Memória, Literatura. O testemunho na Era das Catástrofes. op.cit., p.50-1.

${ }^{331}$ ENDO, Paulo César. A violência no coração da cidade. Um estudo psicanalítico. São Paulo, Escuta, 2005, p.92.

${ }^{332}$ SCARRY, Elaine. The body in pain. The making and unmaking of the world. NY, Oxford, 1985, p.3-4, citado em ENDO, Paulo. Op.cit, p.94.
} 
maneira complexa, incluindo diferentes aspectos. Eles eram obrigados a suportar os efeitos e implicações da tortura num meio onde a convivência com pessoas desconhecidas era forçada, vivendo confinados em espaços exíguos e péssimas condições carcerárias. Para sobreviver era essencial lidar com a resistência à despersonalização impostas pela repressão política, num cotidiano repleto de limitações e imposições. Márcia Mafra identificou essa especificidade do testemunho dos ex-prisioneiros políticos em seu depoimento:

“Talvez, por isso que a memória sobre esse período seja muitas vezes recontada pelos exilados. [...] Eles não têm tantas questões delicadas para dar conta. [...] Não estou dizendo que é fácil, mas para os presos, com todas essas paixões que perduram até hoje, é mais difícil. O cara que foi exilado teve dificuldades, com certeza. Não estou querendo dizer que é fácil, psicologicamente deve ter sido muito difícil, porque não foi uma escolha. Agora, as implicações do que eles podem dizer são muito menores, neste sentido falo de facilidade.”

As dificuldades de relatar ficam evidentes em relação à tortura sexual, situações em que a tarefa de testemunhar, distinguir temporalidades e dar sentido a esta experiência profundamente traumática impõe uma difícil exposição. Poucas mulheres no universo das ex-prisioneiras entrevistadas falaram a respeito. De acordo com Leane Ferreira de Almeida, militante do POC (Partido Operário Comunista) presa em 1971:

“[...] não é à toa que é difícil, é que havia as taras dos torturadores. Tinha um torturador, que eu não sei o nome verdadeiro, chamado Jacó, era loiro, acho que de olho claro. Ele adorava tirar as roupas das mulheres, de ver as mulheres nuas. E eu acho que foi, talvez, a pior experiência, pior do que o pau de arara, porque era pura perversidade, não tinha objetivo nenhum. Ele não queria informação nenhuma. Ele me chamava muitas vezes, acho que tinha predileção especial por mim, ligava os fiozinhos de choque no mamilo do seio e se divertia com uma manivelinha. Nunca tocou em mim, mas era uma coisa aterrorizante quando nos chamavam, sempre de madrugada. Eu tinha a impressão, [...] que aquilo era necessário para ele se excitar de alguma maneira. Era uma perversidade de caráter sexual, porque em nenhum momento ele me pedia informação. Ele me chamava várias vezes e me contou que era casado com uma mulher mais velha. Isso é uma coisa bem marcante, aquela sensação de ser completamente impotente e de não ter nenhum propósito aquela situação e de que você não tem poder de fazer parar aquilo. Isto era um circo de horrores [...] a única coisa que me lembro, era de que ele falava e eu chorava sem parar. Ele fazia as coisas e eu chorava de dor e de desamparo, não tinha mais nada o que fazer $^{333}$."

As mulheres enfrentaram a dor física e as humilhações impostas aos prisioneiros homens, mas também tiveram que suportar a tortura sexual. Os relatos de prisioneiras políticas trazem outros aspectos da tortura sexual e suas formas de resistir a ela, como nos

\footnotetext{
${ }^{333}$ Entrevista concedida por Leane Ferreira de Almeida à autora. SP, 20/03/2009, AAPP/AEL-LEI.
} 
contou Lucia Murat. Após ter sido levada para Salvador (BA), onde foi torturada por uma semana, ela foi trazida de volta ao DOI-Codi/RJ, quando começaram as torturas sexuais:

\begin{abstract}
"Aí começa a tortura sexual, com um torturador diferente, aí o troço era o que ele disse para mim: '- Hoje, eu não preciso dar um choque grande em você, eu posso dar um choquinho que ele vai ter o mesmo efeito do grande, você já virou a minha cachorrinha de Pavlov'. Era verdade, a gente estava totalmente desestruturada. Aí começou a tortura sexual, que é um outro tipo de tortura, não é um pau para você abrir um ponto.

Você ficava nua com um capuz, com uma corda que prendia o capuz e prendia aqui atrás [no pescoço e nas mãos amarrada nas costas], então você não tinha poder. Por exemplo, o cara vinha de sacanagem em cima dos seus peitos e você não podia fazer assim, ou na tua vagina e você não podia se mexer, porque qualquer movimento teu, você se enforcava. $\mathrm{O}$ que era muito perverso, porque na prática eles faziam você ser conivente com o ato, para não se enforcar você deixava e isso foi barra-pesada. E no fundo, naquele momento, sinceramente, eu preferia a tortura sexual do que apanhar, isso também é uma coisa muito terrível de você conviver no resto da vida, mas eu preferia, com certeza, era menos dolorido.

[...] depois eu tive muitos papos com esse torturador, a última cena do "Que bom te ver viva” foi um diálogo que eu tive com ele... Ele se considerava muito inteligente, queria provar que também era inteligente. [...] como a gente dizia que eram todos burros e idiotas, monstros, ele gostava de mostrar que era uma pessoa com um pensamento sofisticado. Eu bati muitos papos com ele, obviamente que eu gostava também de bater papo, óbvio, você também quer ter poder em algum momento, nem que seja através do teu raciocínio. Não sei, ele dizia que [a tortura sexual] era uma técnica de interrogatório [...], era para me desestruturar e tal. [...] eles sempre utilizam a palavra interrogatório, técnica de interrogatório e nunca tortura. [...] você sempre ficava naquele pavor, agora vou eu, agora vai não sei quem, a insegurança é um horror, a insegurança é um horror. Esse período foi aquele em que eu mais me fodi, mais do que com o pau pesado, eu acho $^{334}$."
\end{abstract}

As mulheres viveram de maneiras diferentes a tortura e, em especial, a tortura sexual, conforme nos contou Maria Luiza Garcia Rosa, a Pupi, militante do MR-8 (DIGB). Presa quatro vezes durante a ditadura, a segunda prisão foi a mais longa e a tortura mais violenta:

“Eles usaram pau-de-arara, muita barata, tortura sexual. Não cópula, mas essa coisa de ficar com aquele peru horrível, aquelas coisas. Abriam a braguilha e tiravam. Eu nem lembro o que eles falavam, porque [...] aquilo para mim era uma hora de descanso, podiam fazer o que quisessem, eu não tinha esse problema moral com sexo. Não tinha. Mesmo na primeira prisão que eles fizeram alguma coisa... Mas isso para mim não tinha a menor importância, moralmente nunca me atingiu. Nego beijar, ficar se raspando, eu ficava lá, assim, tipo ausente. Eu me ausentava simplesmente. Era um momento até bom, que pelo menos eu estava descansando de coisas que realmente me afetavam. Moralmente isso nunca me afetou. Eles faziam para humilhar, entre aspas, para abaixar o moral. Eu

\footnotetext{
${ }^{334}$ Entrevista concedida por Lúcia Murat à autora. Idem, ibidem. Depois de libertada, Lúcia tornou-se cineasta e dirigiu dois longa-metragens sobre o período da prisão. O primeiro, denominado Que bom te ver viva (1989), é um documentário que apresenta trechos de entrevistas com ex-prisioneiras políticas encadeados pelas falas de uma personagem que havia sido presa política, interpretada pela atriz Irene Ravache. O segundo, chama-se Quase dois irmãos (2004), a respeito do cotidiano dos presos políticos na Ilha Grande no período em que dividiam as mesmas dependências que os presos comuns.
} 
nunca vi sadismo. Eu pessoalmente nunca senti sadismo. Só senti técnica o tempo todo. [...] Usaram barata, muita barata, mas eu também não tinha o menor medo de barata. Você ficava lá no pau-de-arara e aí elas passam na vagina e tal. Isso tudo era para te fazer entrar em desespero. A única coisa que me desesperava era dor mesmo, mas o resto... ${ }^{335,}$

A tortura para as mulheres assumiu outras formas, dimensões e significados. Algumas prisioneiras relataram que foram torturadas com especial violência justamente por serem mulheres, pois feria o orgulho dos torturadores ter de enfrentá-las, conforme contou-nos Dulce Maia de Souza, militante da VPR, presa em 26 de janeiro de 1969. Dulce foi a primeira mulher envolvida diretamente em ações armadas a ser presa em São Paulo. Sequestrada, levaram-na presa para a Polícia do Exército, localizada próximo ao Quartel-General do II Exército, em São Paulo. Poucas horas antes ela havia entrado secretamente no local com a ajuda de um sargento, Carlos Roberto Pittoli, de guarda naquele dia. Ela tinha a intenção de conhecer o local e avistar-se com os presos da VPR que estavam lá, para planejar uma fuga:

“[...] não me penduraram no pau de arara, simplesmente, colocaram-me num banco como se fosse essa mesa com a cabeça solta, com pingos d água na narina, choque elétrico, vela acesa, enfim... Já tinham me posto no corredor polonês, tinham me quebrado muito de porradas. Deixaram-me ali com os pingos d'água e o Pitoli veio me ver. Eu me lembro bem que para mim foi terrível vê-lo, porque percebi que ele queria ver a minha reação. Pensei, provavelmente, a intenção dele era essa, sair dali seguro de que eu não havia falado. E ele ficou muito emocionado e eu apavorada com medo que o vissem. Ele foi preso tempos depois, não me lembro quantos meses depois, mas foram meses. Essa é uma imagem muito forte. Tenho várias imagens fortes da minha tortura, inclusive, porque houve militares que foram muito simpáticos, como tinha o Pitoli lá dentro, devia haver outros, não organizados, mas simpáticos ao nosso movimento. Eles me deram uma atenção nesse momento, não digo entre os torturadores, claro, costumo dizer que havia mesmo entre aqueles militares subalternos, havia uma atitude, talvez, até de simpatia por nós.

[...] Acho que me trataram com muito mais ódio, eles me destrataram muito, muito, muito por ser mulher. Destrataram-me muito por ser amiga de Chico Buarque, de Vandré... aí eles já sabiam quem eu era [...] Justo por ser mulher, eu dizia que eles não tinham o direito de me tratar daquela maneira. Eu fui muito arrogante, eu penso, também exagerei a dose, talvez. E daí eles me torturaram muito mais, mas isso era também uma forma de... eu tinha que resistir bravamente, porque não queria abrir de maneira alguma, não queria entregar os meus amigos. [...] Eu fui muito torturada, porque os enfrentava e era mulher. Como uma mulher enfrenta um grupo de torturadores?! Eles diziam que eu era macho, dentro de todo aquele preconceito deles. Não estavam me atacando ao dizer que eu era macho, para mim até era um elogio, porque eu estava enfrentando a eles. Eles achavam que eu resistia como um macho. Eu, nesse momento, não achava que fosse preconceito, discriminação.

[...] Eles queriam mesmo era me subjugar. Muito, muito, muito. Logicamente, perguntavam muita coisa, mas havia o ódio, não só por eu ser mulher como pela minha condição. Eles sabiam da família a que eu pertencia, tinham conhecimento da militância

335 Entrevista concedida por Maria Luiza Garcia Rosa (Pupi) à autora. Rio de Janeiro, 25/03/2010, AAPP/AEL-LEI. 
de meus irmãos. Eles também tiveram sempre uma atitude... O Vanderico, que era o diretor do DOPS na época, foi um dos que me interrogou muito. O próprio Fleury, mais ainda. O Vanderico conhecia meu pai e o Fleury conheceu muito meu pai também. Papai foi muito amigo do pai dele, que era médico e são da mesma cidade, de Tietê, interior de São Paulo ${ }^{336, "}$

Alguns testemunhos contrastam com essa avaliação sobre a tortura em mulheres. Beatriz Bargieri relatou que, em certas ocasiões, sentiu-se discriminada, desvalorizada, em especial, quando foi poupada de constrangimentos pelos torturadores, justamente por ser mulher, o que ocorreu na fase das torturas e também na judicial.

“[...] eu, geralmente, digo que as coisas na minha vida são todas de cabeça para baixo, quando fiquei no DOI-CODI fui para a cela forte que era em frente, era fechada, blindada, sem nada, era escuro. Mas os homens que ficavam na cela forte ficavam lá e não comiam, não bebiam, mas eu, como mulher, podia ir ao banheiro. A única cela que tinha banheiro era a das mulheres, e eu podia ir uma ou duas vezes por dia ao banheiro. Isso eu achava um absurdo, entendeu, porque achava assim, só porque sou mulher eu posso ir e os outros não podem. E foi por aí mesmo que comecei a perceber o lado inverso, que era a maneira deles tratarem as mulheres. Era como se as mulheres fossem as pobrezinhas que precisavam dessas coisas, desses mimos. Isso me deixou assim extremamente irritada.

[...] Havia, é lógico, a questão sexual. Mas, naquela época, existia uma situação que era diferente das anteriores, [...] não houve, que eu saiba, a sevícia sexual, coisa que tinha havido em 1971 e 1972 [...]. Tinha havido uma mudança, mas isso [a tortura sexual] não implicava em você ser absolutamente destruída por esse lado, isso realmente é uma questão da decomposição da pessoa.

[...] Havia a exposição [do corpo nu], mesmo que não tenha a sevícia propriamente dita, mas o envolvimento era todo neste sentido [sexual].

[...] Não havia ameaças de estupro, mas [...] todas as falas levavam a entender isso, bastava você 'querer' ouvir e se envolver de alguma forma, esse é o problema da decomposição da pessoa como ser humano. Eles pegavam a pessoa e iam analisando as características de cada um. Havia pessoas especializadas ali para analisar as supostas fraquezas e fortalezas de cada um. [E a questão sexual poderia ser uma delas].

[...] Eu não sei se sei explicar, [...] só na hora mesmo é que a gente vê [...]. Eu tinha muita consciência do que dependia de mim. [...] Eu estava muito consciente e acreditava muito no que eu estava fazendo, na minha militância e na minha opção. E tive que decidir lá, porque eu poderia ter uma saída individual ou uma saída coletiva, e esse processo de decisão não foi fácil. Uma saída individual no seguinte sentido [...] acho que passa pela cabeça de todo mundo, você pode ficar louca, fingir isso ou aquilo. Ou uma saída coletiva que era de segurar as coisas e reverter o que eles estavam fazendo. Eu vi que estava preparada, é isso, foi um momento de muita criatividade, fui muito criativa. Eu sabia absolutamente tudo o que estava se passando, eu tive controle o tempo inteiro das coisas. Foi naquele momento, se fosse um pouquinho antes ou pouquinho depois, talvez, eu não tivesse... E eu percebi isso e foi muito importante, porque isso me fortaleceu mais ainda e me deu mais energia”337.

\footnotetext{
${ }^{336}$ Entrevista concedida por Dulce Maia de Souza à autora. São Paulo, 24/10/2008, AAPP/AEL-LEI. V. sobre o planejamento da fuga da PE, em Tiradentes, um presídio da ditadura, op.cit., p.96-117.

${ }_{337}$ Entrevista concedida por Beatriz Bargieri à autora e Marcelo Ridenti. São Paulo, 18/10/2008, AAPP/AEL-LEI.
} 
Havia entre as organizações de esquerda, naquele período, a tendência a considerar a resistência à tortura de um ponto de vista heroico, conforme o relato de Jorge Eduardo Saavedra Durão, dirigente da VAR-Palmares preso pelo DEOPS, na cidade de Porto Alegre (RS), em dezembro de 1971:

“[...] A maioria tinha uma reação muito pouco racional. Eu, por exemplo, fazia o seguinte, andava e dormia com um vidrinho com uma cápsula de cianureto, na mesinha de cabeceira, no bolso... Não se discutia isso, a orientação era essa, se alguma pessoa do comando da VAR-Palmares fosse presa deveria tomar aquela cápsula de cianureto e eu tomei, só que não funcionou.

[...] A discussão sobre o comportamento na tortura não existia, havia uma doutrinação e a leitura de coisas como o livro do Dimitrov, o dirigente do Partido Comunista Búlgaro, aquele sobre o processo [do incêndio] no Reichstag, que era mais ou menos o seguinte: você deve ser um homem de ferro, um super-homem, sei lá, e seguir o padrão Dimitrov. Era o máximo que se falava sobre o assunto. Havia uns textos que diziam que tinha o bom e o mau policial, para você não se iludir quando fosse preso. Acho que havia um certo escapismo. Havia uma espécie de um manual que circulava na VAR dizendo coisas assim: quando você for preso é preciso resistir nas primeiras horas, quer dizer, quanto mais você resistir no início as pessoas vão saber que foi preso e menor será o impacto da sua prisão. Enfim, a prática se revelou muito diferente, para mim pelo menos, de toda a teoria preexistente ${ }^{338}$."

Essa tendência intransigente produziu o efeito de bloquear a discussão entre os militantes e criou obstáculos para enfrentar as consequências da tortura durante o período de confinamento nos presídios, bem como também após o fim da ditadura. Prevaleceu entre os próprios sobreviventes, em grande medida, a resistência em reconhecer a permanência do trauma e o próprio silenciamento sobre a tortura e a vida na prisão. Há ainda um grande silêncio em torno deste assunto, conforme salientou Rosalina Santa Cruz de Oliveira:

"Acho que é uma coisa muito difícil de fazer. [...] Acho que isso a gente teria que ver, olhar a questão da tortura como limite humano, que naquela época a gente não fazia muito. A gente era muito rigoroso com quem abria, com quem falava.

$\mathrm{Eu}$ acho que no filme 'Que bom te ver viva' tem um depoimento da Pupi que é muito bonito, quando ela diz: '- Eu acho que eu não abri, não caiu ninguém a partir da minha prisão. Não abri coisas que levassem as pessoas a caírem, mas abri informação, abri comportamento'. Eu acho que existe um monte de coisas, no momento em que eu entrei no teatro deles, que conversei... a gente precisa ver essa questão da relação tortura/ torturador com a visão de que o ser humano tem um limite e numa situação-limite como a tortura a gente tem que julgar o torturador e não o torturado. E, muitas vezes, a gente julgou muito os companheiros. Quando você era considerado que tinha um comportamento bom, se sente muito no poder de julgar. Mas, geralmente, porque você teve circunstâncias na tortura que te permitiram manter uma dignidade ou não abrir. Acho que foi muito doloroso para as companheiras que abriram, eu acho que se desestruturaram muito. Elas são vítimas do sistema e da tortura e devem ser respeitadas. A tortura não é

${ }^{338}$ Entrevista concedida por Jorge Eduardo Saavedra Durão à autora. RJ, 26/03/2010, AAPP/AEL-LEI. 
uma coisa épica, eu sempre falo da tortura com essa parte humana, porque quando você conta da tortura só como ou uma situação de vítima ou uma situação de que você dominou a situação, que você respondeu aos torturadores, tem um certo tom de heroísmo que não é muito real. Eu acho que na tortura éramos seres humanos, não éramos nem heróis, nem super-homens e nem super mulheres. E nem só vítimas. Eu também acho que quando a tortura vem com um sentimento muito desumano, rebaixa o indivíduo que é torturado 339 ."

Para além dos aspectos apontados acima, algumas entrevistas registram uma tendência à intransigência no trato das responsabilidades e consequências frente à tortura, o que reforçou o silenciamento sobre esta experiência. Embora a solidariedade entre os presos tenha sido uma marca constante, uma necessidade de humanização e de distinção em relação aos torturadores, após os piores momentos da tortura, esse acolhimento solidário nem sempre foi compartilhado, dirimindo a vontade de falar sobre o tema.

Tal como relatou Ariston de Oliveira Lucena, havia diferenciações no tratamento entre os presos a respeito da avaliação do comportamento na tortura. Lucena era militante da VPR e escapou ao cerco militar de 41 dias no Vale do Ribeira juntamente com o capitão Carlos Lamarca, em 31 de maio de 1970. Preso no início de agosto do mesmo ano, permaneceu cerca de dois meses no DOI-Codi/SP e no Deops/SP, locais onde foi severamente torturado. Ele foi um dos quatro guerrilheiros condenados a pena de morte no Brasil durante a ditadura:

“[...] Houve um processo de discussão de autocrítica [do comportamento na tortura] no [presídio] Romão Gomes. O coletivo da ALN chamava-se 'Eixo', que na verdade era uma tentativa de reestruturar a ALN com o Molipo. Tinha gente da VPR que fazia parte disso, o Laerte e eu, só que estávamos em outro escalão. E havia essas conversas. Eu participei de grupos de autocrítica na cadeia, balanço de comportamento no pau. É uma coisa que, posteriormente, encheu meu saco sobremaneira, exatamente porque isso foi usado contra mim para definir critérios de militância e de hierarquia. Posteriormente, eu vim a descobrir que tinha gente envolvida com coisas muito mais graves do que eu e que estavam num outro patamar de participação. E [...] eu me recolhi. Comecei a ver a cadeia com outro tipo de preocupação, já não tinha mais essa, voltada para a política orgânica. Comecei a [...] ler sobre cinema [...] e me dedicar a outras coisas ${ }^{340}$.”

Esses aspectos da vivência da tortura e do trauma fizeram com que muitos dos entrevistados tenham silenciado sobre estas experiências. Muitos afirmaram que estavam testemunhando pela primeira vez um registro público sobre a tortura e a prisão. As dificuldades de enfrentar a tortura, suas implicações e sequelas marcaram os testemunhos

\footnotetext{
${ }^{339}$ Entrevista concedida por Rosalina Santa Cruz de Oliveira à autora. Idem, ibidem.

${ }^{340} \mathrm{Na}$ fuga ao cerco militar, o tenente da PM Alberto Mendes Junior foi aprisionado e, posteriormente, morto pelos guerrilheiros para possibilitar sua fuga. Entrevista concedida por Ariston Lucena à autora. SP, 13/12/2008. AAPP/AEL-LEI. Os condenados a pena de morte no Brasil foram Theodomiro Romero dos Santos, na Bahia, e Ariston e Diógenes Sobrosa, em São Paulo. V. tb. GASPARI, E. A ditadura escancarada, op.cit., p.196-201.
} 
dos sobreviventes que falaram sobre a questão, mas muitos foram evasivos sobre o assunto. Fizeram poucas referências e descrições sobre a angústia, os sonhos e pesadelos relacionados a essas experiências, mesmo quando estimulados por perguntas. Alguns declararam que não se consideram traumatizados pela experiência de tortura e de longos períodos de prisão, conforme relataram Ariston Lucena e Jorge Eduardo Saavedra Durão. De acordo com Lucena ter permanecido mais de nove anos preso não foi uma experiência traumática:

"O meu medo era de voltar para tortura. Agora, de ficar em cana eu não tinha medo, nunca tive problema com isso. Tanto é que fiquei nove anos na cadeia numa boa, não fiquei traumatizado ${ }^{341}$.”

Jorge Eduardo Saavedra Durão é outro entrevistado que ao avaliar sua experiência de prisão, não a considerou marcada pelo trauma:

“[...] Eu fiz análise durante dez anos e não sei se isso me ajudou. Eu não tenho uma mentalidade muito marcada pela coisa da culpa e também espero não cair numa postura de autocomplacência. Mas quem vive nos séculos 20 e 21 precisa ter um certo senso de proporção com relação aos seus próprios traumas, desgraças e sofrimentos. Eu adoro ler coisas de história, acabei de ler dois livros muito interessantes, um foi o '1989' e o outro 'Alemanha 1945'. É o seguinte, o holocausto, não sei quantos milhões de russos, de alemães, poloneses mortos, foi tanta gente massacrada, o khmer rouge, enfim, basta ter um pouco de senso de história para no fim você achar que pelo menos, individualmente, até que eu tive uma certa sorte. Aliás, tive pessoas tão próximas e tão queridas como o Breno, que foi barbaramente assassinado e não gosto nem de pensar em meio a quantos sofrimentos, que realmente eu não me considero uma pessoa traumatizada.

Eu não me lembro muito dos sonhos. A minha mulher ficou oito meses numa solitária e ela estudou num colégio de freiras, até hoje ela tem pesadelos em que associa a prisão a aquele ambiente repressivo do colégio. Em algum lugar fica alguma coisa, mas acho que os meus fantasmas, talvez, estejam bem guardados, enfim, não os vejo me atormentando no dia-a-dia ${ }^{342, "}$

Embora diversos sobreviventes tenham sentido a necessidade imperiosa de relatar o que viveram, muitos necessitaram de décadas para fazê-lo. A maioria não testemunhou publicamente. Tratar do testemunho sobre a tortura significa tocar mais profundamente na questão das possibilidades e impossibilidades de dizer e de narrar a respeito, dos ecos simbólicos do trauma e da reinserção dos sobreviventes na vida coletiva e social. Quem testemunha se debate entre dois extremos: pode-se contar, com a possibilidade de perder a audiência que não quer ou não pode escutar tudo o que os sobreviventes têm para dizer; ou este se cala para conservar vínculos sociais, com o custo de reproduzir um vazio de

\footnotetext{
${ }^{341}$ Entrevista concedida por Ariston Lucena à autora. Idem, ibidem.

${ }^{342}$ Entrevista concedida por Jorge Eduardo Saavedra Durão à autora. Idem, ibidem.
} 
comunicação. Muitas vezes, são necessárias uma ou mais gerações para se conseguir dar sentido a acontecimentos envolvendo situações-limite e traumas sociais ${ }^{343}$.

O relato repetitivo do sobrevivente pode representar uma tentativa de postergar a tomada de consciência de que se perdeu definitivamente alguém muito querido ou um ideal político, mas também pode enfatizar a morte e ser parte de um processo de elaboração dessas perdas. Esta ritualização de contar faz com que o sobrevivente "lembre" constantemente a necessidade de responder a essas perdas, como no caso de Rosalina, irmã de Fernando Santa Cruz, desaparecido em 23 de fevereiro de 1974.

A família Santa Cruz denunciou e lutou pelo esclarecimento do desaparecimento de Fernando desde o início. Rosalina é um exemplo de como o relato e a repetição da cena traumática revelam este dilema ético, o da consciência da responsabilidade de contar essa história. Muitas vezes, mais do que tentar compreender, relatar é um ato de transmitir aos outros o que aconteceu ${ }^{344}$. Esses sobreviventes falam do que viveram (num discurso em primeira pessoa) e observaram (como terceiros) nos centros de tortura, mas também daquilo que vivenciam no presente, (re)atualizando histórias e traumas vividos na ditadura:

"Eu tenho culpa de ter sobrevivido, é uma das coisas que eu conto muito. Na minha relação com a morte de Fernando, eu me sentia muito culpada, porque eu dizia: '- Olha, eu optei pela luta armada e o Fernando não. Eu optei por participar da VAR e o Fernando, da AP. O Fernando sempre acreditou na luta de massas, era mais moço do que eu, porque eu sobrevivi?' Eu me sentia com uma certa culpa por ter sobrevivido e me perguntava porque eu sobrevivi e ele não. Eu acho que era o que nos perguntávamos sobre a nossa sobrevivência, o que é exigido da gente por ter sobrevivido? O que a gente está devendo à sociedade, à luta, à resistência por ter sobrevivido, porque era mero acaso. Sobreviver era mero acaso, não se tinha nenhuma garantia de sobreviver. Não havia explicações para a sobrevivência de cada um ali, porque a gente está vendo hoje nos documentos como era morrer ou sobreviver numa relação dessas de prisão e tortura.

[...] Naquele momento, não conversávamos muito sobre a questão dos que estavam morrendo. Eu acho que a gente conversava muito das nossas ações, da nossa vivência, da nossa vida. Havia muito essa relação feminina, que eu acho característica das mulheres, de falar mais da subjetividade: '- Sabe aquele dia em que eu fiquei muito triste, o dia em que eu tive uma decepção afetiva, amorosa ou com a minha família, com a minha tia, ou sobre como é o meu pai'. Eu acho que a gente tinha uma coisa muito subjetiva nas nossas conversas, nas reflexões, nas relações. Acho que devia ser muito diferente o coletivo masculino do nosso. A gente tinha muita florzinha, coisinhas que a gente pintava,

\footnotetext{
343 PollaK, M. L'expérience concentrationnaire. op.cit.; e POLLAK, M. e HeINICH, Nathalie. "Le témoignage”, em Actes de la recherche em Sciences Sociales, n.62-63, jun., 1986, citados em JELIN, E., op.cit., p.80-83.

${ }^{344}$ CARUTH, Cathy. Modalidades do despertar traumático. (Freud, Lacan e a Ética da memória). In: Nestrovski, Arthur e SEligmann-Silva, Márcio (orgs.). Catástrofe e representação. São Paulo, Escuta, 2000, p.111-2, 120-1, 125, 127-9.
} 
papelzinho com pensamentos colados na parede. [...] mas não conversávamos muito sobre os que estavam morrendo ${ }^{345}$."

A questão do sentimento de culpa por ter sobrevivido e do testemunho por delegação ${ }^{346}$, aquele feito no lugar dos que morreram, está mais presente nos relatos de ex-prisioneiros que são familiares de militantes mortos ou desaparecidos, mas este sentimento aparece também nos testemunhos dos demais. Alguns ex-presos políticos fizeram relatos emocionados sobre os amigos e companheiros assassinados pela repressão estatal, como Manoel Cyrillo Netto, entre outros. ${ }^{347}$ Eles manifestaram suas tentativas de compreender e preparar-se para o momento que não foi possível evitar: a morte inesperada do parente que morreu cedo demais, subitamente, de forma violenta, sem o seu testemunho. Esta perspectiva dialoga com a de Marcelo Ridenti, que em O fantasma da Revolução Brasileira (1993) assinala que o sentimento de culpa com relação aos companheiros mortos era um importante elemento na dinâmica da clandestinidade, que condicionava e regia os agrupamentos armados, principalmente, no período final de sua atuação [RIDENTI, 1993: 270]. Tal como é de se notar, a diferença entre as duas posições reside na relativa importância atribuída ao sentimento de culpa em relação aos companheiros mortos na dinâmica da luta política daquele período.

Em convergência à posição que destacamos, o relato de José Olavo Ribeiro, militante da Var-Palmares e companheiro de Heleny Telles Ferreira Guariba, militante da VPR que desapareceu em 12 de julho de 1971 na Casa da Morte de Petrópolis, é atravessado pela dificuldade de assimilar e simbolizar esse choque ${ }^{348}$. Sua narrativa é profundamente marcada por essa perda, assim como pelos sentimentos de culpa e impotência por não ter podido evitá-la, apesar de suas tentativas:

“[...] Heleny chegou a mandar algum recado via outros presos que tinham visita. Eu sabia que ela estava militando e que tinha contato [...] com o Moisés, que era ex-marinheiro. [...] O José Raimundo [da Costa]. Ela gostava muito dele [...] e saiu da prisão decidida a reorganizar a VPR [...] em março [abril] de 1971. [...] Tinha havido quedas enormes. [...] Eu me lembro que ela falou: ' - Fica tranquilo que eu aprendi muito nessa prisão, não vou fazer nenhuma besteira. Eu vou por o pé-no-chão, vou reorganizar a minha vida pessoal primeiro'. Ela tinha dois filhos, estava um rolo, porque a família tinha se apossado deles. [...] Ela tentou realmente reorganizar a vida, não conseguiu e logo partiu quase para uma clandestinidade. [...] O fato é que todo dia vinha notícia dela, gente avisando: ‘- Olha, a Heleny está se expondo muito.’ [...] E as quedas continuavam acontecendo, mas toda vez que eu mandava recado ela me tranquilizava. [...] ela mandava recado, quando era mais

\footnotetext{
${ }^{345}$ Entrevista concedida por Rosalina Santa Cruz de Oliveira à autora. Idem, ibidem. Grifos meus.

346 Termo utilizado por Primo Levi. V. LEVI, P. op.cit., p.48.

${ }^{347}$ V. as entrevistas concedidas por Leane de Almeida, idem, ibidem; Lúcia Murat, idem, ibidem; e Rômulo Noronha de Albuquerque à autora. RJ, 22/03/2010, entre outros.

${ }^{348}$ Entrevista de José Olavo Ribeiro concedida à autora. SP, 28/10 e 09/11/2009. AAPP/AEL-LEI.
} 
pessoal, pelo José Carlos Dias, [...] mais político, pela [...] Dulce Muniz. [...] A ALN tinha uma desconfiança de que [...] alguém da VPR, que tinha estado em Cuba era agente infiltrado. [...] O pessoal da VPR não acreditava, achava que era uma posição política da ALN contra a VPR, que estavam inventando essa história. [...] Nas vésperas da Heleny desaparecer, um preso da ALN veio da OBAN, Manoel Porfírio Filho, que estava no Pavilhão 2. [...] Ele era um cara de confiança total e mandou um recado para mim [...]: tem uma infiltração no comando da VPR, mas ele não sabia que era o cabo Anselmo. O Aluísio Palhano foi preso num ponto e [... Manoel] ouviu isso do Palhano [...] da sala de torturas, numa hora em que ficaram sozinhos.

[...] Eu fiquei apavorado com a situação da Heleny, porque eu sabia que ela era próxima do Moisés [José Raimundo, do comando]. Mandei um recado, que tinha uma infiltração na VPR. Para que ela tomasse muito cuidado. [...] Isso foi num sábado de visita. No sábado seguinte, a Dulce voltou e falou: '- Tive com a Heleny e ela falou que você está sonhando [...]. Fiquei irritado e falei: ‘- [...] volta e fala que [...] é sério’. [...] No meio da semana o José Carlos Dias foi me visitar. E [disse] '- Decretaram a prisão preventiva da Heleny’. Eu abri o jogo. [...] Era um esquema armado para pegá-la, eles decretaram a preventiva sem nenhuma razão processual. [...] Eu falei: '- Vai atrás dela!' [...] Ele conseguiu falar com ela mais uma vez. Ela de novo desconversou e falou que era tudo exagero, que eu estava doido. Foi para o Rio e caiu. [...] Quase um mês depois, a mulher de um preso, Fernando Casadei, [...] me passou a informação de que a Heleny caiu num ponto com Paulo de Tarso Celestino [da Silva, da ALN]. Era um ponto do comando. [...] Foi assim que eu recebi o recado. Eu fiquei gelado na hora. [...] e passei o recado. [...] Subi da visita, que acabava mais ou menos às 7 horas. [...] Estou vendo o Jornal Nacional e aparece a manchete: 'Terrorista é morto a tiros'. A Globo sempre dava assim [essas notícias...] E quem era o 'terrorista'? O José Raimundo! [...] Um outro preso que foi para a OBAN falou que viu o José Raimundo lá, muito machucado. [...] Eu tinha certeza que o contato, a pessoa que a Heleny mais confiava era ele. [...] nunca mais tivemos notícias da Heleny.

O meu pai chegou a ir para o Rio algumas vezes, tentou mexer alguma coisa [...]. O exsogro dela era general reformado do Exército, o general Guariba. Ele foi conversar com o Golbery [...] que deixou muito claro: 'Ela está morta, não tem mais o que fazer.' Eu não consegui mais notícias. Só tivemos alguma notícia dela depois, através da Inês Etienne [Romeu]. [...] Ela não chegou a ver a Heleny, mas ouviu tudo, sabia de tudo. Ficou claro que ela morreu lá, junto com o Paulo Celestino, e que o esquema era do cabo Anselmo. Este esquema eu descobri ainda na prisão [...] Houve um contato de mais um preso que estava no Tiradentes, que foi para a OBAN e descobriu um cabo da Marinha [preso], que acabou desaparecendo, chamava-se Edgar [Aquino Duarte ...]. Ele falou que era o cabo Anselmo quem estava derrubando todo mundo. [...] O mais terrível disso é que ele continuou derrubando gente até 1973. É uma coisa terrível, que eu não consigo entender. Ninguém acreditava que ele era agente da repressão.

[...] A prisão deles no 'ponto' tinha uma testemunha [...] Alguém da ALN que estava cobrindo o ponto à distância por causa da segurança, para saber se estava tudo bem. [...] A última pessoa com quem falei sobre isso foi o Diógenes Arruda, o Arrudão. [...] Eu nunca me esqueço disso, ele foi se despedir de mim e falou: '- Eu vou sair daqui, fico uns dois meses no Brasil e vou para o Chile. Já estou com um esquema arrumado e vou denunciar esse bandido no Chile'. E foi exatamente o que ele fez. [...] e teve uma briga pesada com o Onofre, que não acreditou nele, achou que era intriga. [...] Por isso o Anselmo continuou derrubando gente até [...], praticamente, dois anos depois da morte da Heleny ${ }^{349}$."

\footnotetext{
${ }^{349}$ Em entrevista de Flávio A. Leão Salles (Rogério), do GTA da ALN/RJ, ele confirmou ter comparecido a um ponto de José Raimundo da Costa, a seu pedido, para checar se o mesmo estava vigiado pela polícia. A informação foi confirmada, mas a VPR não afastou ou expulsou Cabo Anselmo da organização. Entrevista concedida por Flávio A. Leão Salles à autora. RJ, 15/02/2002.
} 
Sobreviver significava usufruir o direito de cuidar de si mesmo quando a vida estava ameaçada e religar-se com os outros e com o mundo de fora. Nestes casos, a perda do ente querido faz com que os ganhos e qualidades daquele que sobreviveu fiquem desvalorizados. É como se essa mimetização da culpa “pudesse arrancar qualquer orgulho (amor) narcísico extraído da proeza de ter sobrevivido em condições ostensivamente adversas. Sobreviver supõe, neste caso, abdicar das condições que possibilitam o viver. Literalmente: paga-se com a renúncia ao prazer o fato de ter sobrevivido” [ENDO, 2005: $238-9]^{350}$.

O evento traumático é, muitas vezes, reprimido ou negado e registrado depois de passado algum tempo. Em distintos lugares onde se viveu guerras, conflitos políticos violentos e repressão, os processos para manifestar e elaborar traumas sociais e tornar públicas as interpretações e sentidos desses passados são dinâmicos. Estão ligados a processos individuais, mas também às estratégias políticas de diversos atores sociais. Por vezes, essas lembranças irrompem como experiências sem sentido e sem um "antes” e um “depois” claramente marcados. Para muitos sobreviventes as repetições de sintomas, os retornos do recalcado surgem por meio de sentimentos de angústia, pesadelos ou reiterações ritualizadas que servem de reforço à ancoragem de identidades. Para alguns, a elaboração do passado assume também o significado de uma traição à memória do que ocorreu e dos que morreram [JELIN, 2002: 68-9, 94].

Alguns dos ex-prisioneiros políticos entrevistados falaram sobre a dificuldade de contar e dizer como se sentiam, apresentaram histórias e sentimentos matizados e entremeados com a alucinação da experiência de tortura. Alguns foram presos em uma situação de esgotamento e cansaço, tentando um afastamento da organização, temporário ou definitivo, o que também dificultou uma atitude de resistência diante da tortura. $\mathrm{O}$ sentimento de culpa pela morte de um companheiro ou a falta de preparo não favoreciam que se estabelecesse uma "estratégia” alternativa para resistir à tortura. Muitos prisioneiros tentaram e conseguiram, em certa medida, inventar estórias, "pontos”, ou dar informações mais ou menos importantes que o ajudaram a se livrar do sofrimento imediato. Algumas dessas estratégias, porém, geraram vergonha, pois pesava sobre todos a referência de seguir o modelo ideal daquele que não fala nada sob tortura, nem mesmo o

\footnotetext{
${ }^{350}$ A história de Manoel Henrique Ferreira é emblemática. Militante da VPR, foi preso e torturado, retratouse na TV, mas permaneceu preso cerca de sete anos, no Rio de Janeiro. Após dois anos de isolamento, pediu para retornar ao "coletivo" dos presos. Depois de longo debate, passou a conviver com os demais. Em liberdade continuou próximo aos amigos de cativeiro. V. Carta de Manoel Henrique dirigida à D. Paulo E. Arns. Presídio Político, Rio de Janeiro, 1976. Arquivo pessoal de Marcelo Mário de Melo.
} 
nome. O que era diferente do sentimento de culpa pela morte de algum companheiro ou da culpa e responsabilidade direta pela delação de alguém, que ao fim era assassinado. $\mathrm{O}$ relato de Manoel Cyrillo apresentou-nos alguns dos limites e possibilidades de resistência na tortura e seu sentimento de culpa:

“Eu não atribuo à ação do embaixador norte-americano absolutamente nada do que termina acontecendo em São Paulo no mesmo mês de setembro, dia 30, quando aconteceu a minha prisão. [...] Sou preso em função das quedas que aconteceram no dia 24 de setembro. Nós estávamos preparando uma daquelas grandes ações de propaganda, de expropriação e recolhimento de armamento [...] nas vésperas [...] expropriamos o carro que nós usaríamos na ação. [...] A gente foi [...] tirar o carro do lugar e trocar a placa [...]. Vou eu e um companheiro, o Luiz Fogaça Balboni. [...] Começa um tiroteio infernal [...] e começamos a correr [...] e nisso ouço o Fogaça me chamando pelo 'nome de guerra': 'Benê, Benê.' Quando eu olho para trás, o peito dele estava totalmente ensanguentado, tinha levado um tiro pelas costas. [...] seguro ele pelo braço e tento fazer com que caminhasse [...] ele vai ficando pesado, mais pesado, até que ele desfalece. [...] Na minha cabeça eu pensei que ele estivesse morto, posteriormente, [...] a gente veio descobrir que tudo aquilo aconteceu às 3,4 horas da tarde. Ele deu entrada no hospital quase meia noite e veio a falecer no dia seguinte: zero hora e quarenta e cinco minutos, [...] Vou embora, mas eu fico muito abalado com toda aquela situação, esse problema do Fogaça. Eu fiquei muito abalado [...] e a organização decidiu me retirar do Brasil, me encaminhar para Cuba para fazer treinamento de guerrilha.

No dia seguinte, de manhã, eu fui levado para São Sebastião para aguardar, descansar, me refazer e aguardar a elaboração dos documentos falsos para eu viajar. [...] Um dos outros grupos do GTA [...] resolve parar na mesma Alameda Campinas [...] e poucas horas depois do nosso tiroteio, o grupo vai lá para retirar o carro e dois companheiros terminam sendo presos. Essas prisões iniciam um processo de queda do GTA. Alguém falou da casa que nós estávamos, [...] em São Sebastião. [...] a repressão levou uns 10 ou 12 carros da Operação Bandeirante e mais uma tropa [...] do Exército. [...] Eu estava dormindo [...] e quando eu vi, estava preso.

[...] Foi muito complicado para mim, porque tinha uns cinco dias que eu estava totalmente desligado da organização, em São Sebastião (SP). [...] E quando eu chego na Operação Bandeirante, eu começo a ver uma série de companheiros [...] Foi um choque muito grande. No pau, na sala de tortura, no pau de arara, aquela balburdia toda da técnica de tortura. Os torturadores falavam muito que na véspera tinha morrido ali o Virgílio Gomes da Silva, 'o Jonas'. E eu não entendia como o Virgílio tinha caído! Sabe, muito complicado! A sala toda suja de sangue, toda melecada e eles diziam: '- É o sangue do Virgílio’. É muito complicado esse negócio de tortura, de prisão, relatar, por mais que a gente relate é meio difícil.

[...] Acho que eles não tinham a informação de que eu estaria naquela casa e que estava desligado da organização. Eles pensavam que eu tinha contatos, porque queriam um ponto. Eu inventei um ponto só para parar a tortura. Eles montaram todo aquele esquema e me levaram ao ponto numa rua embaixo da Florêncio de Abreu [...] não aconteceu nada e ficou por isso mesmo.

[...] Eles já sabiam que eu havia participado da ação do embaixador. Mas na minha cabeça eu tinha que preservar a trajetória política até chegar à organização [...] Eram os únicos nomes que eu sabia [...]. Eu podia falar tudo menos aquilo. E [...] termino entrando num caminho de falar das ações que eu fiz, o que não foi muito legal [...] porque ajudou a eles a montar o quebra-cabeças, mas foi o que na hora eu consegui e assumo as consequências. É isso, e no dia 16 de outubro [de 1969], fui para o DOPS.

[...] Se discutia esse tipo de coisa, mas eu não tinha a menor noção do que pudesse ser um pau de arara. Você perder obturação de dente por causa de choque elétrico, eu nunca 
imaginei que isso fosse possível [...], que você defeque e urine, simultaneamente. Você não tem o menor controle do organismo. Eu nunca imaginei, não sabia, não fazia ideia do que pudesse ser a tortura mesmo. É totalmente louco aquela balburdia mental que eles provocam para destruir a sua estrutura de raciocínio, de pensamento. Falam simultaneamente, e você tem que responder uma coisa, e eles interrompem, perguntando uma quarta, quinta, sexta vez. E pancadas simultâneas, enfim, toda aquela balburdia. Não dá para você ter noção, eu não tinha noção de que pudesse ser aquilo ${ }^{351}$.”

Outra faceta do sentimento de culpa presente nas entrevistas associa-se às implicações impostas pela tortura. Muitas vezes este tema aparece de maneira velada, fazendo emergir a percepção de que existem significativas e duradouras marcas de paralisia e silenciamento na memória individual e coletiva dos ex-presos políticos entrevistados. A enorme dificuldade de narrar ou falar a respeito da experiência de tortura, das responsabilidades e sequelas decorrentes da violência extrema tem sido um obstáculo para as investigações a respeito das memórias e histórias dos prisioneiros políticos e o sentido da sua luta.

Leane Ferreira de Almeida, militante do POC, vivia na clandestinidade e cuidava de tarefas do setor de organização e infraestrutura do partido. Ela relatou-nos sobre seu sofrimento diante da ferocidade da tortura e da desestruturação de uma companheira, bastante abalada por causa das sevícias. Leane testemunhou a enorme dificuldade de manter a capacidade de resistência e as nuances dos limites de cada um diante dessa situação extrema de dilaceramento e tormento. Falou-nos ainda sobre a dor de presenciar a morte sob tortura de um companheiro.

Alguns meses antes da prisão de Leane, em 15 de julho de 1971, o POC havia discutido em uma conferência a proposta de organizarem um recuo e mudanças táticas na sua forma de atuação. O clima de 1970 era de certo derrotismo, corria a avaliação de que a luta não teria desdobramentos. Tentando contrapor-se a este clima, alguns militantes procuraram contatos internacionais que lhes ampliassem o horizonte asfixiante do Brasil. Havia divergências sobre a continuidade do pequeno grupo armado do POC, ativo entre os anos de 1969 e 1971, que atuava em conjunto com outros grupos como a VPR, Rede, MR-8 e MRT ${ }^{352}$. Dois de seus dirigentes, Ângela Mendes de Almeida e Luiz Eduardo da Rocha Merlino, foram à França em dezembro de 1970, estabelecer os primeiros contatos

\footnotetext{
${ }^{351}$ Luiz Fogaça Balboni levou os tiros por volta das 15hs, foi levado pela polícia ao hospital apenas às 18:30hs e morreu à 1 h30 da madrugada do dia 25/09/69. V. Dossiê Ditadura, op.cit., p.150-1.

${ }^{352}$ V. entrevista concedida por Maurício Frejman à autora. San José, Costa Rica, 27/05/2010; e entrevista concedida por Laurindo Junqueira Filho à autora. SP, 22/04 e 06/05/2010. AAPP/AEL-LEI. De acordo com um documento de 1972, encontrado nos arquivos do DOPS/SP, um membro do POC fez treinamento de guerrilha em Cuba entre setembro de 1967 e julho de 1968. V. Inf.674/72-II, Grupo da Ilha, Pasta 104, folha 400 .
} 
que acarretaram na adesão à IV Internacional Comunista. Desses contatos surgiram as cinco teses publicadas em Combate $\mathrm{n}^{\circ}$ 1, em $1971^{353}$. Este processo de mudanças foi interrompido em decorrência de uma sequência de prisões, que resultou no assassinato sob tortura de Merlino, no dia 19 de julho. Preso em Santos (SP) no dia 15, ele havia chegado ao país cinco dias antes. As prisões e torturas buscavam desbaratar a organização, mas tinham como objetivo também descobrir os contatos do POC com outros grupos implicados na luta armada ${ }^{354}$.

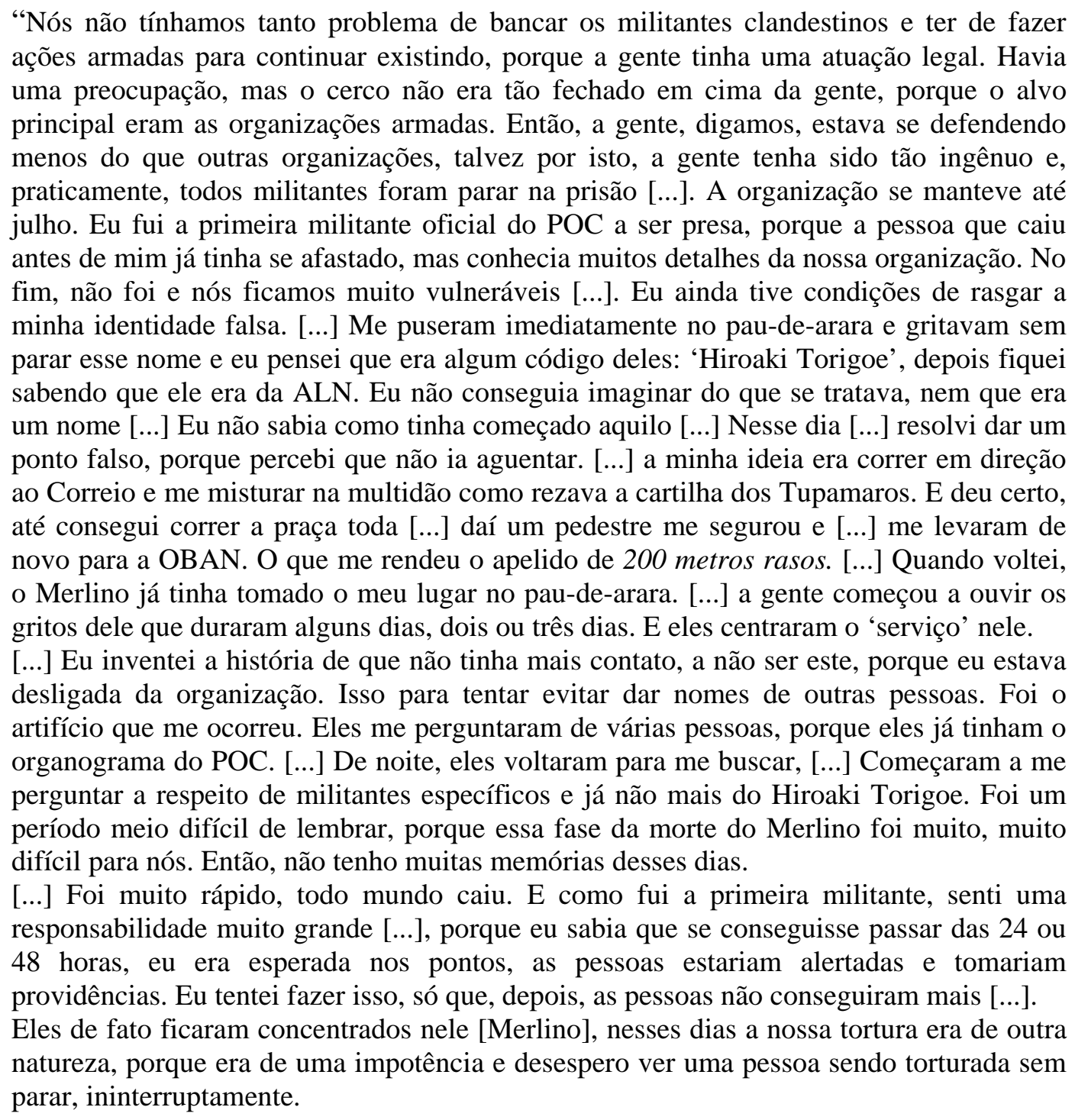

${ }^{353}$ V. "Por uma revisão da estratégia de guerra revolucionária”, “Questões de organização e programa para o movimento operário", "Sobre a construção do partido leninista de combate", "O que é o PCB" e "Teses sobre o ABC" no site www.ovp-sp.org/hist_poc.htm; e entrevista de Ângela Mendes de Almeida concedida à autora. SP, 20/03/04.

${ }^{354}$ Entrevista de Leane Ferreira de Almeida concedida à autora. SP, 20/03/09, AAPP/AEL-LEI. A primeira versão oficial para a morte de Merlino foi de suicídio; a segunda, afirmava que ele teria morrido de "autoatropelamento"! Militantes do POC denunciaram sua morte sob tortura na Justiça Militar: Eleonora Menecucci, Ricardo Prata Soares, Laurindo Junqueira Filho, Guido Rocha e Zilá Prestes Pra Baldi. V. Dossiê Ditadura, op.cit., p.259-62. 
[...] cheguei [na cela] num estado lastimável, eu nem tinha noção. [...] a gente ficava numa condição sub-humana [...] e de impotência. Essa sensação de ver uma pessoa sendo torturada por um bando de homens, com todas as armas na mão, uma pessoa completamente indefesa e que a gente amava. A gente amava o Merlino, ele era uma figura toda luz, toda positiva, sempre bem-humorado. Quem o conhecia gostava muito dele. [...] Ele estava sempre brincando, lembro que ele se preocupava comigo [...], com os outros. [...] Ele era um dirigente capaz [...] promissor.”

Em muitos relatos registrados nas entrevistas há referências rápidas ao fato de que suas prisões tinham sido decorrência da delação de um companheiro que havia sido muito torturado. Poucos falaram detidamente sobre as consequências e marcas deixadas. Alguns relataram informalmente, sem deixar gravar suas falas, que o terror provocado pela tortura podia fazer com que um prisioneiro se antecipasse ao torturador, fornecendo informações como a localização de casas, 'aparelhos', lugares mais comuns de 'pontos' da organização, mesmo quando não era interrogado a respeito. Houve várias formas e graus de responsabilidade e de sentimentos de culpa.

Ariston Lucena contou-nos como enfrentou a violência da tortura, o ódio dos militares por ter participado da fuga espetacular do Vale do Ribeira com Lamarca, suas estratégias para tentar evitar falar as principais informações e tratou também, de forma velada, dos seus sentimentos de culpa:

"A minha prisão aconteceu da seguinte forma: eu estava fazendo um levantamento de bancos. Estávamos andando numa rua ali nas proximidades da Afonso Celso, na Vila Mariana, quando eu me dei conta, os caras chegaram. Acho que eram três policiais numa viatura e o Laerte, um amigo que estava comigo, saiu correndo e entrei em luta com os caras. [...] fui preso e levado para uma delegacia. Eles não sabiam quem eu era direito. Isso foi em uma quinta-feira. [...] Os caras demoraram quatro dias para descobrir quem eu era. Só aí me levaram para o DOPS. Chegando lá, eu falei quem eu era, [...] porque naquela época tinha o Esquadrão da Morte, eles [...] tinham matado alguns presos políticos [...] Aí eu falei: '- Esses caras podem querer me matar achando que eu sou bandido'. [...] Já fui para o pau-de-arara, fui pendurado e desse primeiro pau que eu tomei, fiquei 15 dias sem andar. [...] Na quinta, a OBAN veio e me levou. Ali começou o processo de tortura, de violência, de choque elétrico, porrada!

Eu digo que esses quatro dias foram preciosos, porque na verdade o que é que eles queriam? [...] o "ponto", "aparelho" e "nome” e eu não tinha mais nenhum ponto para dar e nenhum aparelho, porque [...] a minha prisão era notória. [...] não derrubei ninguém, nenhum militante. Eu derrubei aliados, gente que eu tinha contato, mas militante não derrubei ninguém, não derrubei ninguém. Isso muito me alivia, porque se porventura alguém que eu abrisse fosse preso com certeza seria morto, porque já estava começando a história de matar os prisioneiros.

Eu fiquei vários dias na tortura, vários dias, mas eram alternados, dia sim dia não.

[...] Tenho um trauma, porque toda vez que eu ia subir para o 'pau', o cara chegava para abrir a cela balançando a chave e, então, subia e 'pau'. [...] Eu fiquei muitos anos sem poder ouvir esse barulho de chave balançando, ficava em pânico! Lá na Detenção o cara vinha balançando a chave e eu ficava transtornado. Levei muitos anos para me recuperar disso. 
[...] Nesse tempo em que eu fiquei sendo torturado, [...] eles achavam que eu poderia estar escondendo [informações], então apanhei muito. Uma coisa pela qual apanhei muito também foi a história da morte do tenente no Vale do Ribeira. Eu apanhei muito por conta disso, porque eles queriam que eu confirmasse que eu executei o tenente [...].

Um dia, [...] a OBAN me chamou de volta, porque tinham sido presos dois caras, que estiveram no Vale do Ribeira. [...] Aí eu cheguei e caguetei os caras [...] Eles apanharam muito por conta disso, porque não tinham contado que estiveram lá. [...] Nesse mesmo período o Erasmo Dias [...] me levou [...] para o Vale do Ribeira para fazer a reconstituição da fuga. [...] Eles me algemaram numa árvore e me lembro [...] porque era 6 de outubro, [...] completei o meu aniversário de 19 anos algemado numa árvore. Ele simulou um fuzilamento, porque eu tinha 'aberto' o negócio da morte do tenente [...] a localização da cova [...]. Ele me mandou entrar na cova do tenente e falou: 'Agora você vai morrer que nem ele, seu filho da puta', e simulou o fuzilamento.

[...]Depois eu voltei para o DOPS junto com uma penca de gente [...] fiz o 'Cartório' e acho que em dez ou quinze dias, fui transferido para o presídio Tiradentes. Eu fiquei uma semana lá e me mandaram para a Casa de Detenção ${ }^{355}$.”

Sobre as diversas formas de colaboração com os opressores, Primo Levi escreveu que esta disponibilidade de colaborar é matizada por muitas nuanças, nasce de múltiplas raízes e está diretamente ligada à ferocidade da opressão. Os nazistas, por exemplo, tinham em mente que não bastava relegar os colaboradores às tarefas marginas nos campos, “[...] o modo melhor de comprometê-los é carregá-los de crimes, manchá-los de sangue, expô-los tanto quanto possível: assim contraem com os mandantes o vínculo da cumplicidade e não mais podem voltar atrás” [LEVI, 1990:21]. Para Levi, nestes casos, a máxima culpa sempre recai sobre o sistema. Para ele, é sempre imprudente emitir um juízo moral, pois é muito difícil avaliar essas situações: “A condição de vítima não exclui a culpa, e esta com frequência é objetivamente grave, mas não conheço tribunal humano ao qual atribuir sua avaliação” [LEVI, 1990:22].

A delação é citada de forma recorrente nos testemunhos, marcou o ambiente de terror vivido nos cárceres, mas é um tema espinhoso e muitos não trataram do assunto. Muitos tentaram não punir novamente o companheiro que delatou, isolando-o e recriminando-o. Muitas vezes, era possível estabelecer distinções entre os que falaram sob tortura; os chamados "arrependidos” que se retrataram e negaram sua luta na TV; e os que se tornaram “cachorros”, infiltrando-se nos grupos revolucionários, entregando excompanheiros à repressão política e à morte. Mas era sempre difícil lidar com as fronteiras movediças existentes entre a delação e a colaboração.

Maria Luiza Garcia Lopes, conhecida como Pupi, militante do MR-8 (DI-GB), presa em 31 de março de 1971 e levada para o DOI-CODI/RJ, contou-nos como sofreu com a autorrecriminação, a ausência de autoestima e as discriminações dos companheiros

${ }^{355}$ Entrevista concedida por Ariston Lucena à autora, idem, ibidem. 
em decorrência de seu comportamento considerado ruim na tortura, tanto no período de prisão como na vida fora da cadeia. Para ela, sobreviver teve um custo alto:

“[...] A [minha] aparência não era de destruição, era uma aparência normal. [...] Mas eu estava muito destruída, a minha autoestima inexistia, eu estava muito anulada. Quando você fica num nível de depressão muito alto, o pessoal diz que você desenvolve uma anadonia, não tem grandes vontades, não tem grandes prazeres [...] eu inexistia enquanto ser, afetivamente.

No coletivo não conversamos sobre isso. Era assim: -"Você não fez legal. Mas é a vida, nem todo mundo precisa ser legal..." É o que eu sinto, pode ser que não seja isso.

Poucas pessoas assumem que abriram. [...] Eu lembro que eu era uma chata. E elas diziam -"Para com isso, já tá bom." Eu queria expiar a minha culpa falando, falando, falando. Não me lembro de ninguém falar que abriu. Eu não me lembro. Não sei se eu não tinha condição mental na minha cabeça de ouvir alguém...

[...] Quando eu saí, elas me desprezavam. Depois esquecem. [...] Depois nego esquece, nem lembra. Cinco anos depois, seis anos depois nego nem sabe, nem lembra o que fez. Nem lembra. Depois eu encontrei um outro, [...] eu o chamei pra conversar, ele ouviu e falou: '- Mas por que você está me falando isso tudo? Eu não estou entendendo.' Quer dizer, é uma coisa que passa. Não é importante. [...]”356.

Na tortura, a intensidade da dor física, a privação sensorial provocada pela fome, a ausência de sono, a manutenção em salas escuras ou o uso de capuz, a ruptura dos laços afetivos e com o mundo pessoal conduzem à solitária presença do corpo dolorido, o que muitas vezes faz desaparecer todo o resto da existência. Este momento da tortura pode levar a uma experiência de desorganização da relação do sujeito consigo mesmo e com o mundo, chamado por Maren Viñar de demolição ${ }^{357}$. Dependendo da pessoa, pode ter lugar ao fim de algumas horas, dias ou meses. "A demolição é a experiência do desmoronamento e da loucura - metódica e cientificamente induzida - que desloca o indivíduo de seu mundo amado e investido para o colocar diante de um buraco sinistro, repleto de vergonha, de humilhação, de urina, de horror, de dor, de excrementos, de corpos e de órgãos mutilados. [...] Tudo isto se inscreve num espaço vivido como incomensurável e num tempo eterno, que tem as características do pesadelo e do espaço onírico” [VIÑAR, M.; M., 1992: 45-7].

Alguns entrevistados conseguiram contar, ao menos em parte, como sofreram a experiência de demolição na tortura. Maria Luiza Garcia Lopes viveu um processo de desmoronamento diante da tortura que teve repercussões permanentes na sua vida:

“[...] Já sabiam quem eu era e tudo. Eu consegui segurar, porque não queria matar, nem ativa nem passivamente. [...] consegui segurar e mentir. [...] Inventei um ponto qualquer

\footnotetext{
${ }^{356}$ Entrevista concedida por Maria Luiza Garcia Lopes (Pupi) à autora, idem, ibidem.

${ }^{357}$ Primo Levi usou o termo demolição para se referir aos que "submergiram” nos campos nazistas e não voltaram para contar. V. LEVI, P. op.cit., p.48.
} 
na minha cabeça [...] me levaram para o ponto e não tinha ninguém. Voltei e aí sim comecei a ser torturada mesmo. [...] Eles queriam pessoas que estavam na legalidade, sabiam que eu tinha sido uma pessoa importante no movimento vestibulando [...] Quando eles viram que já tinham passado 24 horas, pararam de me perturbar [sobre pontos]. [...] Eu resisti mais um dia, não sei, e aí comecei a falar. Foi a maior tragédia da minha vida, porque estava todo mundo em casa. Eu era tão firme, para que eles iam sair de casa? Como eles eram da Faculdade de Medicina, eles iam largar a faculdade? Era complicado, era uma estrutura de movimento que não se sustentava. [...] Eu falei o primeiro, falei o segundo, falei o terceiro e o quarto. Falei quatro pessoas e essas falaram o resto e fiquei marcada para sempre como delatora.

[...] Eles tinham uma estratégia com as pessoas, que era a história de levar para televisão, o que era terminar completamente com a crença de você em você mesmo. Era te aniquilar completamente, quase como uma lavagem cerebral, mas não para você deixar de ser comunista, eles tentavam, mas isso creio que eles não achavam que era possível. [O objetivo] era terminar com todo o seu amor-próprio [...]. Comigo eles foram jogando assim: -'Não vale a pena, todo mundo já abriu. A gente já sabe tudo, a gente só quer saber se você realmente está colaborando, porque você precisa'. Mas eu resolvi abrir quando vi que a dor estava forte, na verdade, tive que fazer o seguinte [raciocínio]: eu já sofri, já paguei a minha parte, essa revolução não vai dar em nada. Tive que fazer isso, pensei, vamos dividir os ônus. [...] Eu tive que fazer esse comércio comigo mesma para conseguir falar. Quer dizer, eu não estava aguentando a dor. [...] Era muita dor, muita dor.

[...] nunca perdi a consciência, minha consciência estava cada vez mais aguçada. Daí a depressão. A auto-estima lá no pé. [...] Eu sabia que eles iam estar em casa, sabia que ia ser uma merda enorme, mas enfim, já não tinha mais muita crença de que aquela revolução ia dar certo e, enfim, fiz esse comércio comigo mesma, e fiquei péssima! ${ }^{358,}$

Diante da destruição provocada pela tortura e a necessidade de reparação, o torturado busca uma restituição e, muitas vezes, o único ser disponível é o torturador. Neste contexto, o terror e o desamparo podem gerar a submissão e a aliança com o inimigo, “[...] dos quais a confissão e a delação são os produtos visíveis exteriormente, são o resultado de uma relação de cumplicidade perversa entre o prisioneiro e seus torturadores. [...] a relação de submissão perversa e masoquista é o produto da degradação que substitui o abandono da demolição.” [VIÑAR, M.; M., 1992: 49].

Primo Levi relatou que a vergonha e o sentimento de culpa recorrentes dos sobreviventes dos campos nazistas estavam relacionadas ao fato de terem "falhado no aspecto da solidariedade humana”, terem sido omissos no socorro aos demais presos, pois a regra principal dos campos era “cada qual cuidar antes de tudo de si mesmo”. De acordo com ele, poucos "sobreviventes se sentem culpados de ter deliberadamente lesado, subtraído, golpeado um companheiro: quem o fez (os Kapos, mas não só eles) trata de recalcar a lembrança [...]” [LEVI, 1990: 44]. Às vezes, não passava de um sentimento de culpa e não uma responsabilidade concreta, de "uma sombra de uma suspeita”. Era uma suposição, mas corrói. A suposição de que sobreviveram os “piores, os egoístas, os

${ }^{358}$ Entrevista concedida por Maria Luiza Garcia Lopes (Pupi), idem, ibidem. 
violentos, os insensíveis, os colaboradores da 'zona cinzenta', os delatores [...] os mais adaptados [...]” [LEVI, 1990: 46-7].

É interessante notar que algumas causas recorrentes de sentimento de culpa entre ex-prisioneiros, tais como a percepção de ausência de solidariedade para com os companheiros e outras formas de perda de contato afetivo, não se fizeram presentes nos relatos coletados neste trabalho, ao contrário do que relatou Levi em relação aos campos nazistas. Tanto pelo contrário, muitos ressaltaram a ajuda inestimável recebida dos companheiros, assinalando que o sentimento de culpa emergiu da maneira como enfrentaram os próprios limites na tortura e da relativa capacidade em se manter íntegro em relação aos compromissos éticos e políticos assumidos - sentimento relacionado às responsabilidades e implicações das delações sob tortura, sobretudo, aquelas que ocasionaram prisões, tortura e assassinatos de militantes por parte da repressão.

Um aspecto que diferencia o panorama em foco neste trabalho daquele discutido por Levi e que pode ajudar a compreensão desta diferença refere-se ao fato de que, segundo o autor, os campos nazistas eram constituídos por uma "zona cinzenta”, onde havia prisioneiros simples e os considerados “privilegiados”, vítimas que colaboraram de muitas maneiras com os nazistas [LEVI, 1990: 17-38], coisa que não encontramos por aqui, ao menos não de maneira tão evidente. No caso brasileiro, dir-se-ia que as fronteiras entre o "nós", os combatentes e resistentes, e “eles", os torturadores e ditadores, mantiveram-se tanto mais íntegras, tal que os limites do mundo de "dentro”, dos aliados, e o de "fora", o dos algozes dos centros de tortura e extermínio, permaneceram mais nítidos e sua lógica mais facilmente decifrável.

A “vergonha” e o sentimento de culpa relacionados com tudo que se viu e viveu nos campos pesaram sobre os diversos sobreviventes que, logo após a libertação, suicidaram-se. Esse foi um momento crítico de depressão em que revisava-se o que passou e media-se a "diminuição" a que chegaram. "Os casos de suicídio durante o cativeiro” foram raros. De acordo com Levi, porque “o suicídio é próprio do homem e não do animal” e nos Lager vivia-se como animal subjugado; o dia era ocupado pela sobrevivência, "justamente pela iminência constante da morte, faltava tempo para concentrar-se na ideia de morte"; e a dureza do cativeiro era compreendida como uma punição, “não era preciso punir-se com o suicídio por uma culpa (verdadeira ou suposta) que já se expiava com o sofrimento de todos os dias”. O sentimento de vergonha ressurgiu após a libertação [LEVI, 1990: 42-3]. 
Aqui também se revela outro ponto de distinção entre a experiência vivida nos campos nazistas e a experiência dos presos políticos brasileiros. No Brasil, foram raros os casos de sobreviventes que suicidaram-se após serem libertados. O suicídio foi praticado no exílio, quando já estavam a salvo, por algumas pessoas cuja experiência de tortura tornou-se insuportável, conforme aconteceu com Maria Auxiliadora Lara Barcellos e Frei Tito. Outros suicidaram-se em função de não conseguirem conviver com o fato de terem delatado companheiros, por não terem conseguido recuperar-se do desmoronamento decorrente da tortura, conforme ocorreu com Solange Lourenço Gomes, ou por terem colaborado com a repressão concordando em fazer retratações públicas na TV, como no caso de Massafumi Yoshinaga [ALMEIDA, 2009] ${ }^{359}$.

Por outro lado, há autores e atores políticos que argumentam que, durante a ditadura, os militantes aceitavam a possibilidade da morte ou do "suicídio altruísta”, sacrifício justificado pela sobrevivência do grupo e do projeto revolucionário. Segundo Ridenti, “o sacrifício pessoal e, no limite, a morte, iam perdendo o sentido revolucionário, de conquista da vida, para ganhar contornos de obrigação moral com os companheiros caídos e com a sobrevivência do próprio grupo guerrilheiro” [RIDENTI, 1993: 267].

Muitas das vicissitudes levantadas neste capítulo e, nele, nas entrevistas alinhavadas, podem ser compreendidas desde a perspectiva do "suicídio revolucionário”, tal como apontado por Ridenti, que afirma que houve "inúmeros suicídios de militantes revolucionários confrontados com uma situação repressiva aparentemente sem saída: alguns mataram-se ao serem cercados pela polícia [...]; outros preferiram colocar-se numa situação em que, necessariamente, seriam mortos pelos policiais que os cercavam [...]; vários mataram-se ou tentaram o suicídio na cadeia, diante da brutalidade das torturas [...]” [RIDENTI, 1993: 270] ${ }^{360}$.

Visando aprofundar o entendimento desse fenômeno, acreditamos ser necessário considerar-se a existência de diferenças entre as tentativas de suicídio em situações de tortura e a postura desafiadora daqueles que decidiram por uma ação potencialmente fatal. Durante um processo desumanizador como a tortura, faz-se imperiosa a intenção de evitar mais sofrimento e a degradação física, a qual não poderia encontrar outra via de realização senão a morte. Esta dinâmica ganha especial força pela iminência do

\footnotetext{
${ }^{359}$ V. os casos de Solange Lourenço Gomes, Massafumi Yoshinaga, Maria Auxiliadora Lara Barcellos, Frei Tito Alencar, Gustavo Buarque Schiller [Dossiê Ditadura, 2009] e de Bartolomeu José Gomes. V. Tiradentes, op.cit., p.385.

${ }^{360}$ Vale lembrar que diversas versões oficiais de morte por suicídio ou em tiroteio já foram desmentidas, cf. Pelo direito à memória e à verdade, op.cit.; Dossiê Ditadura, op.cit., e as observações de Ridenti no posfácio à 2a . ed. do livro Fantasmas da Revolução Brasileira (2010).
} 
desmoronamento psicológico e, sobretudo, do pânico frente à possibilidade de não conseguir aguentar em silêncio, o que tanto pode levar à loucura, quanto à intenção de se suicidar. A tortura "nos impõe a alienação total de nosso próprio corpo, tornado estrangeiro a nós, e nosso inimigo de morte” [PeLlegrino, 1982: 13]. O suicídio, nestes casos, pode tornar-se uma forma de negar a negação do outro imposta pelo torturador e ser um ato extremo de soberania [Idem, ibidem].

O desejo de se suicidar por causa da tortura faz-se assim diverso da intenção regente do suicídio em sentido e condições mais amplas, quando a intenção subjacente ao ato se dá em potencial liberdade. Neste último caso, a decisão transcorre com um grau maior de vontade e autonomia, a qual se faz ausente nas condições de extrema violência e desumanização levada a cabo pela tortura. Enfim, acreditamos na importância da distinção entre a intenção daquele que direciona-se ao suicídio porque se vê ameaçado e daquele que o visa enquanto sofre a tortura, dadas as diferenças psicológicas subjacentes.

A tortura e o aniquilamento do corpo se constituem no "estado extremo" da ruptura da harmonia entre corpo e mente, o corpo passa a ser um elemento capital na produção de sofrimento, descontrole e alucinação. Por meio da tortura, tenta-se estabelecer “[...] um mundo binário de horror paranóico onde não existe senão a vítima e o torturador. Este último se apresenta como o agente de um código onde poder e lei não funcionam mais como um terceiro, mas como garantidor de sua impunidade. A colusão entre o ato sádico e a lei coloca o torturador na posição de um outro, cuja onipotência é função de falta de defesa e do sofrimento do corpo torturado” [VIÑAR, M.; M., 1992: 76].

Nas entrevistas aqui analisadas, sonhos relacionados aos traumas de quem sofreu tortura e prisão foram algumas vezes mencionados, sobretudo por entrevistados que foram estimulados a discorrer sobre o assunto. Na maioria dos casos, os sonhos citados referem-se mais ao período posterior à prisão. Pedro Rocha, por exemplo, quando perguntado sobre a questão, afirmou que sonhava muito com fugas no período de nove meses em que permaneceu sequestrado no DOI-Codi (SP). Durante o seu longo período de confinamento em presídios de São Paulo, os sonhos desapareceram. ${ }^{361}$ Criméia de Almeida, por outro lado, registrou brevemente que depois do período em que permaneceu sequestrada, no DOI-Codi (SP) e no PIC (Brasília), seus sonhos mais recorrentes continuaram relacionados às perseguições sofridas por ela e sua família:

${ }^{361}$ Entrevista de Pedro Rocha Filho concedida à autora. SP, 05/03/2010. AAPP/AEL-LEI. 
"Depois que fui presa não tive mais sonhos agradáveis, meus sonhos são sempre pesadelos nos quais estou sendo perseguida por ladrões, bandidos, polícia ou animais. Ou nos quais estou perdida. Já tive alguns sonhos em que naufraguei em alto mar. Também há pesadelos com perseguições ao meu filho, aos meus sobrinhos e eu não consigo gritar nem correr em direção ao local onde eles estão sendo perseguidos. Esses sonhos parecem muito reais, acordo assustada e não consigo dormir depois com medo da 'continuação' do pesadelo. Antes de ser presa eu tinha sonhos agradáveis e pesadelos, mas depois da prisão só me lembro dos pesadelos ${ }^{362}$."

O retorno do passado surge como suspensão da temporalidade na repetição da experiência traumática do sonho, mesmo para pessoas que testemunharam diversas vezes como Criméia, ativa militante da Comissão de Familiares de Mortos e Desaparecidos Políticos. Estes pesadelos citados exprimem um pouco das dificuldades e limites que a permanente 'tarefa' de reconstruir subjetivamente essas experiências-limite e alcançar o distanciamento entre presente e passado requerem.

Paralelamente - e de maneira ainda mais recorrente -, a presença de traços do passado traumático foi revelada por meio do choro; ao passo que alguns entrevistados manifestaram ambos, tal como foi o caso para Anivaldo Padilha ${ }^{363}$, para quem os sonhos foram um importante veículo de elaboração dos traumas e reconstrução de seu universo simbólico.

Anivaldo tornou-se um destacado militante defensor dos direitos humanos e articulador das denúncias dos crimes da ditadura no exílio vivido nos Estados Unidos. Fez parte de um programa das igrejas Metodista e Presbiteriana de informação e educação pública, direcionado para a realização de lobbies visando à mudança da política externa norte-americana na América Latina. Seu trabalho consistia em divulgar as denúncias sobre a repressão estatal e as torturas no Brasil. As informações tratavam da natureza do golpe de Estado e o papel desempenhado pelos Estados Unidos; seu apoio à ditadura e aos treinamentos de interrogatório e tortura de policiais e militares brasileiros. A realização de palestras nas quais relatava sua experiência pessoal na tortura foi muito importante para sua elaboração subjetiva:

“[...] tive [...] uma experiência [marcante...] em Dakota do Sul. Depois de uma palestra sobre a ditadura no Brasil, contei da minha experiência de prisão e torturas. Quando abri para discussão, a primeira pergunta foi [...] '- O senhor falou de ditadura no seu país, torturas, o que é um absurdo, mas o senhor não disse quando os comunistas assumiram o poder no Brasil'. Essa foi outra situação que me deu um [...] estalo, porque para a

${ }^{362}$ Entrevista de Criméia A. S. de Almeida concedida à autora. SP, 27/07/2000, 28 e 30/11/2001, 20/10/2004

363 Outros militantes emocionaram-se e choraram durante as entrevistas tais como Rômulo Noronha de Albuquerque, Lúcia Murat, Jesus Paredes Sotto, Celso Bambrilla, Márcia Basseto, Manoel Cyrillo e José Olavo Ribeiro. 
ideologia americana quem praticava aquelas atrocidades [...] eram os russos, os países comunistas, conforme a propaganda do governo e da mídia. A gente tinha que desconstruir esse discurso. Então, eu mudei minha metodologia, começava minhas palestras com análises [...] mas [mudei] e comecei a falar um pouco da minha experiência pessoal, porque percebi [...] que usar o verbo na primeira pessoa acabava sendo bastante importante na comunicação de ideias [...]. Eu comecei a contar minha experiência, quando terminava [...] entrava no campo da análise. E conseguia prender a atenção das pessoas, elas queriam saber por que isso acontecia. Percebi que com essa mudança metodológica a gente, realmente, conseguiu mobilizar muitas pessoas. [...] A gente levava folhetos com sugestões para deputados, senadores, escreverem para editores de jornais exigindo melhor cobertura sobre o Brasil, cartas ao Departamento de Estado, ao Ministério da Justiça e também aos amigos. A gente produzia esse material e o boletim periódico, que se chamava Brazil Information Boletin.

[...] eu tinha pesadelos, praticamente toda noite, eram pesadelos que eu acordava gritando. Eu estava sempre sendo torturado. [...] Isso foi um processo que demorou mais de um ano, bem mais, [...] quase três anos e, depois, foi diminuindo. Esse processo começava sempre com os pesadelos em que eu estava sendo torturado e ameaçado de ser executado. $\mathrm{Eu}$ era preso e levado para a tortura, mas esse pesadelo foi diminuindo. No momento em que começaram, eu era preso, levavam-me para a prisão e para a tortura. Depois, [com o tempo] eu comecei a reagir à prisão, mas ia preso de qualquer jeito. Passei, também a reagir na tortura, gritava, pulava, esperneava contra os torturadores. Foi diminuindo [e parando] no momento em que eu era preso e conseguia fugir. Eu resistia bastante à prisão e acordava antes do término do pesadelo e não sabia se tinha sido preso ou não, mas reagia de maneira bem forte à prisão. Por duas vezes eu reagi de forma violenta à prisão. Eu estava numa manifestação carregando um tipo de sarrafo com uma faixa e, quando os policiais vieram para me pegar, eu reagi com aquele sarrafo e fugi. Na segunda vez [que sonhei], eu acertei o policial, porque ele veio, segurei o sarrafo no meio, ele veio com o cassetete para me bater [...]. Fui com o cassetete direto na cara dele, com muita violência [...]. Eu vi o sangue sair na hora, ele caiu e eu fugi. Foi o último pesadelo que eu tive. Mais ou menos em 1976, a Anistia Internacional dos Estados Unidos organizou um grupo de psicólogos, psiquiatras, psicanalistas, antropólogos, sociólogos. Um grupo multidisciplinar para estudar o impacto da tortura nas pessoas que tinham passado por essa experiência. Reuniram um grupo de pessoas e me convidaram. Tinha um chileno, militante do MIR, um vietnamita, um da África do Sul, um coreano da Coreia do Sul e um das Filipinas. Fizemos um grupo de terapia, cada um falou da sua experiência e eles analisaram. Teve quatro sessões e eu percebi que de todos nós, quem sentia menos o trauma da tortura era eu. Claro, esse é um trauma que você não elimina as sequelas, elas estão aí sempre. A conclusão deles é que o fato de eu ter feito todo aquele trabalho de educação e mobilização contra a ditadura, de pressão ao Congresso americano, na mídia e no executivo, e todas as palestras em que falava da minha experiência na tortura durante cinco anos, fui trabalhando e colocando isso para fora. Eles falaram que a forma como os pesadelos terminaram foi como geralmente se trabalha num processo terapêutico. Eu fiz isso de forma, digamos, espontânea. $O$ fato é que no momento em que dei a última porrada no policial, praticamente, simbolicamente matei a polícia e com isso, parei de ter os pesadelos. E realmente eu nunca mais tive pesadelos. [...] $\mathrm{O}$ fato de não ter segurado essa questão dentro de mim e ter falado... Eu falei mesmo, falava para grupos pequenos ou plateias enormes de 300, 400 pessoas, 1000 pessoas, dependendo da natureza do encontro e das conferências das quais era convidado a participar!

[...] Não sei o que ficou da tortura. Penso muito nisso, sempre perguntei sobre isso. Eu fiz um processo terapêutico, mas não motivado pela prisão ou a tortura [...]. Foi motivado por um certo período de conflito conjugal, uma terapia mais voltada para a questão familiar do que propriamente para esse aspecto. A gente tocou nisso, mas essa terapia não aprofundou nada. Eu me pergunto muitas vezes, o que ficou, quais são as sequelas? Há momentos em que acho que superei muito, há outros em que penso: talvez não, que fico em dúvida. Por exemplo: não me importo de falar sobre esse período, não me importo 
mesmo, toda vez que sou convidado para falar ou me pedem para falar, falo sem problema. Não é prazeroso, e quando falo daqueles momentos mais cruciais da tortura não consigo conter as lágrimas, não consigo mesmo! Porque não faço questão de contêlas, elas vêm e eu deixo, choro a vontade! Quando penso nos companheiros que morreram... Quer dizer, tudo isso são aspectos importantes que estão aí e me emocionam ${ }^{364}$."

A repetição onírica está a favor da sobrevivência, os sonhos traumáticos e a compulsão à repetição buscam refazer os caminhos desconhecidos do trauma e do reprimido, buscando a prontidão e o domínio da realidade excessiva do trauma e dos efeitos insidiosos e degradantes da convivência com o traumático [ENDO, 2005: 144-6, 243]. Anivaldo e outros encontraram nos sonhos, nas narrativas de sua experiência e na ação solidária ao organizar as denúncias de torturas, no exterior ou no país, seu modo de poder ver-se e reconhecer-se novamente, aspecto determinante para a reconstrução da identidade.

Como é de se notar, estas experiências no limite entre realidade e fantasia representaram a solução possível para o enorme desafio de se manter vivo. A sobrevivência, na tortura, adquiria sentido limítrofe e este sentido, dir-se-ia, desvela-se plenamente à luz de seu correlato mais “visível”, imposto pela necessidade de sobreviver às agruras da prisão. Os presídios políticos representaram a parte mais notável da faceta legalista do sistema repressivo; enquanto na tortura o desafio primário era resistir à perda de si-mesmo, no presídio impunha-se a necessidade de se reinventar, através de novas formas de socialização e provimento simbólico, para não sucumbir frente às condições impostas por esta forma “crônica” de aniquilamento.

\section{O cotidiano nos presídios políticos}

A legalização da prisão representava para os sobreviventes dos centros de tortura e extermínio um grande alívio e, como iremos argumentar ao longo da próxima seção, delineavam espaços para a introspecção e discussão acerca das experiências da tortura e para o debate sobre os rumos da luta política.

A obscura situação de encarceramento dos presos políticos ganhava contornos legalistas quando, após dias ou meses de torturas e incertezas, o prisioneiro era transferido oficialmente para um presídio. Nessas circunstâncias, os presídios chegaram a

${ }^{364}$ Entrevista de Anivaldo Padilha concedida à autora. SP, 09 e 21/12/2009. AAPP/AEL-LEI. 
ser associados à representação do "purgatório", o limbo situado entre o inferno e o paraíso $^{365}$. Ser transferido a um presídio podia significar chegar a um ambiente com melhores condições para aguardar o transcorrer do processo na Justiça Militar e tentar recuperar o debilitado estado físico, o que frequentemente fazia-se acompanhar por intensa movimentação psicológica. Era o desafogo depois de tantos sofrimentos, reveses e derrotas; o momento de reconstruir identidades.

Apesar do conforto proporcionado pelo reencontro solidário com os companheiros, os presídios representavam um alívio relativo, pois várias pessoas foram retiradas desses locais e levadas para serem novamente torturadas. O caso de Frei Tito talvez seja o mais conhecido, quando já estava preso no Tiradentes foi levado para o DOICodi, em fevereiro de 1970, e novamente voltou a ser torturado. Tentou o suicídio. Anos depois, em 7 de agosto de 1974, na França, finalmente consumou a tentativa ${ }^{366}$. Isso ocorreu a outros presos também, conforme nos contou Lúcia Murat, levada novamente ao DOI-Codi/RJ depois de ter sua prisão legalizada:

"Fui para um quartel que não me lembro o nome e acabei ficando com a Biga [Abigail Paranhos] no Becondias. Aí fiquei muito deprimida, eu não conhecia a Biga, ela era do PCBR. Era uma menina que fazia Direito e ficou muito amiga minha depois. [...] Ela estava sozinha havia um ano, de castigo, quando ela me viu foi uma festa. Mas a cela era uma bosta, vou filmar isso qualquer dia desses, acho que a cela ainda está lá. A cela era um buraco, não tinha luz, nem nada [...] havia um beliche e uma daquelas privadas turcas. [...] Eu comecei a ter visitas, mas nesse período de pós-tortura fiquei inteiramente assexuada, totalmente deprimida. [...] Eu fiquei um tempão lá, [...] uns seis meses, sei lá. Lembro-me de que em agosto [de 1971], quando [a localização do] Lamarca 'caiu', eles foram me buscar de novo para voltar para o DOI-CODI. Foi outro horror! Eu estava com a Biga, que me salvou, porque eu tentei suicídio. Quando o soldadinho chegou para mim, eu disse: “- Para onde vão me levar? Não tinha auditoria prevista, nem nada”. Um cara do S2, que era gente fina, disse: “- Na verdade, você vai ser levada para o DOI-CODI”. Aí, entrei no banheiro, encontrei uma gilete e tentei me cortar. A Biga entrou, me deu dois tabefes e tirou a gilete. Os soldados vieram e deram uma injeção de calmante. [...] Cheguei no DOI-CODI e [...] estava histérica, inteiramente histérica. O tal de Cineli, que tinha me interrogado na Bahia, veio com as informações sobre o Lamarca, o Zequinha.

Eles não sabiam da área rural até esse momento. Dessa vez, porém, foi só interrogatório. Eu fiquei sem saber o que estava acontecendo, não sabia que [a localização do] Lamarca tinha 'caído', não sabia sequer que o Lamarca estava na Bahia. Fiquei numa cela sozinha, não sei se era a da geladeira. Fui levada para a Bahia para ser interrogada. Não tenho certeza, não me lembro direito, mas [...] fiquei na Aeronáutica, quando cheguei, logo depois já estava todo mundo morto. A Iara [Iavelberg] já tinha morrido e eles estavam perseguindo justamente o Zequinha e o Lamarca ${ }^{367}$."

\footnotetext{
${ }^{365}$ V. CANDIDO, Antonio. “O purgatório”, em Tiradentes: um presídio da ditadura, op.cit., p.15; e BETTO, Frei. Diário de Fernando, op.cit., p.45, entre outros.

${ }^{366}$ V. Dossiê Ditadura, op.cit., p.591-92.

${ }^{367}$ Entrevista de Lúcia Murat concedida à autora. Idem, ibidem.
} 
Militantes foram levados repetidas vezes aos centros de tortura e extermínio depois de já terem sido conduzidos aos presídios. O caso de Reinaldo Morano Filho é emblemático neste sentido. Tendo sido preso em 15 de agosto de 1970, foi torturado em diversos centros de tortura até ser transferido para o presídio Tiradentes, em novembro de 1970. Não obstante, já em dezembro do mesmo ano retornou ao DEOPS/SP para “prestar esclarecimentos”, sob a justificativa “de que tinham sobrado coisas a esclarecer...”. Fato que repetiu-se algumas vezes. Morano foi levado novamente para o Deops/SP em março de 1972; e retornou ao DOI-Codi/SP entre 14 e 23 de novembro do mesmo ano e, novamente, em outubro de 1974, quando já estava preso por mais de quatro anos ${ }^{368}$.

A despeito da possibilidade de retorno aos centros de tortura, nos presídios era possível aos presos avistarem-se com advogados, receber visitas, tomar banhos de sol e, de maneira mais ampla, estabelecer alguma rotina. Isto não significa que a vida no presídio desenvolvesse-se em condições razoáveis. Na realidade, as condições carcerárias eram péssimas e vários presos sabiam que teriam de suportar muitos anos de confinamento. Em geral, os cárceres eram locais sujos e opressivos. O atendimento às necessidades mais elementares era dificultado ou negado e quaisquer conquistas, mínimas que fossem, tornavam-se muito importantes.

Para sobreviver nos presídios, e superar a ameaça de dissolução física e psicológica que ronda todo prisioneiro, era essencial o estabelecimento de rotinas. A experiência dos antigos comunistas e dos prisioneiros “de consciência” apontava no sentido da criação dos “coletivos”, como eram conhecidas as maneiras de organização dos prisioneiros à luz da necessidade de organizar as rotinas e a própria sobrevivência. Em geral, o "coletivo" incluía toda a população da cela e tinah na solidariedade seufator de aglutinação.

Todos (ou quase todos) organizaram-se para limpar as celas, arrumar seus “mocós”, inventar modos de tornar menos intragável a comida, ler e esconder livros contrabandeados, fazer artesanato em couro, miçangas, tricô ou crochê e demais tipos de trabalhos artísticos - além do desenvolvimento de práticas lúdicas, como o carteado, xadrez, dama, ping-pong, futebol e vôlei. Estas atividades eram fundamentais para a preservação da sanidade física e psíquica destes prisioneiros.

\footnotetext{
${ }^{368}$ Note-se que o "Atestado de Permanência e Conduta" de Reinaldo Morano Filho fornecido pela Casa de Detenção possui informações falsas com o objetivo de ocultar que algumas transferências registradas se tratavam de retornos à Oban/DOI-Codi e não à auditoria da justiça militar. Requerimento de Reinaldo Morano Filho dirigido à Comissão Especial criada pela lei 10.726/2001, da Secretaria da Justiça e da Defesa da Cidadania do Estado de São Paulo. SP, 05/07/2002. Arquivo pessoal de Reinaldo Morano Filho.
} 
O tempo de confinamento nos presídios foi retratado como "exílio interno", conforme o testemunho de Renato Tapajós, militante da Ala Vermelha preso em 30 de agosto de 1969. Um período de suspensão da realidade de fora dos presídios, no qual os presos confrontavam-se cotidianamente com a violência extrema da vida dentro dos cárceres. As "rotinas protetoras" tomavam quase todo o tempo dos presos e tinham a função de evitar que ficassem remoendo a difícil realidade da cadeia. E também de evitar a dura realidade de fora, na qual companheiros estavam sendo presos ou mortos e as organizações de esquerda desmanteladas. De acordo com Tapajós, o "noticiário era um dos poucos canais por onde o real se filtrava. Mas o Jornal Nacional da TV Globo era também uma peça de ficção, não muito diferente do seriado Jornada nas Estrelas que passava nas madrugadas”. O cotidiano do presídio foi a expressão, segundo ele, da “fantasia construída” pelos presos, repleta de suas histórias e desejos, “como se criássemos uma bolha de ficção no meio daquela realidade inóspita” [FREIRE E OUTROS, 1997: 350-1].

No presídio Tiradentes a rotina foi retratada como sendo “agitada"; nela,

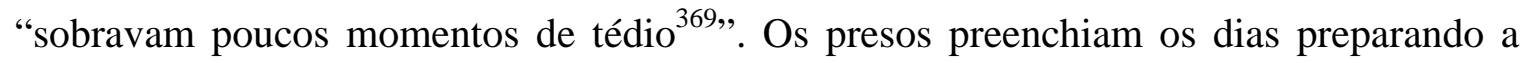
comida nos fogareiros elétricos de duas bocas, limpando as celas, descendo para o pátio quando era autorizado o "banho de sol" ou as visitas, fazendo artesanato, discutindo notícias ou qualquer atividade organizada pelos diversos grupos de estudos. Estudavam de tudo, desde marxismo, história, economia, idiomas até matemática, português ou geografia. Cada um aportava seus conhecimentos nos cursos, enriquecendo e aprofundando também os debates coletivos. Apesar da perda da liberdade e das muitas limitações impostas, podiam trocar experiências e continuar a evoluir intelectualmente, embora as direções dos presídios tentassem proibir a leitura, interditando livros, revistas e jornais que abordassem temas considerados proibidos, como política, filosofia, marxismo etc. Havia um conflito permanente entre os presos e os censores dos presídios.

Os “coletivos" foram definidos como "uma espécie de socialismo dentro da cadeia”370 e constituíram-se na estratégia fundamental de sobrevivência. Estabelecer critérios de convivência foi determinante para se manterem bem durante os longos anos de reclusão. Os “coletivos” foram organizados de diversas maneiras, mas neles todos tinham tarefas e deveres, e dividiam tudo. Desse modo elegiam representantes para

\footnotetext{
369 TAPAJÓs, Renato. “A floresta de panos”, em Tiradentes, op.cit., p.345.

${ }^{370}$ Benedito, Mouzar e REZEnde, José Roberto. Ousar lutar. Memórias da guerrilha que vivi. São Paulo, Viramundo, 2000, p.136.
} 
estabelecer relações com outros coletivos e estruturar deliberações. As atividades dos “coletivos” abrangiam desde a recepção dos novos presos, procurando tranquilizá-los dando apoio emocional e medicamentos aos debilitados pela tortura, até a renovação desse apoio aos que ficavam abalados pelos anos de prisão. Por meio dos "coletivos” os presos organizaram as maneiras de dar apoio material e emocional aos familiares mais necessitados, assim como sistematizavam o debate político, preparavam e divulgavam as denúncias de torturas, assassinatos e desaparecimentos, e discutiam como enfrentar as péssimas condições carcerárias em que viviam.

Outra função da organização levada à cabo era o combate da sensação de vazio. Vários prisioneiros ressentiram-se da derrota que representava estar ali e da derrota sofrida por seu agrupamento político. Muitas vezes, predominava a sensação de isolamento até em relação aos outros presos, o que os fazia sentirem-se como "náufragos num barco à deriva ${ }^{371 ”}$. Nestes momentos, o prisioneiro voltava-se para dentro de si, para suas angústias e medos, abrindo caminho à tristeza e à depressão.

Destaca-se nas várias entrevistas registradas nesta pesquisa a preocupação dos expresos políticos em reafirmar que estavam conscientes dos riscos que assumiram, os quais poderiam levá-los à tortura, à prisão, ao exílio ou à morte. Esse aspecto foi destacado no livro Tiradentes, um presídio da ditadura: “Todos nós tivemos a opção da escolha e sabíamos porque estávamos lutando. E qual era o inimigo”372. Entretanto, conforme ressaltou Antonio Candido no prefácio ao livro supramencionado, diversos militantes testemunharam que "não sabiam exatamente o que enfrentavam" e atestaram sua falta de preparo: "Éramos, na maioria, pessoas cheias de boas intenções diante da vida, mas que não tivemos quase nenhum preparo para enfrentar as condições de prisioneiro. No entanto, enfrentamos e acho que com muita dignidade” [CANDIDO, 1997: 13].

De acordo com José Roberto Rezende, militante da VPR que permaneceu preso por nove anos no Rio de Janeiro: "O militante não pensa que vai ser preso um dia. Eu mesmo acreditava que não cairia jamais. É um esquema de defesa fortíssimo [...]” [BenEdito e REzende, 2000:91]. De acordo com Vicente Roig, dirigente da AlaVermelha preso em 31 de agosto de 1969 e um dos militantes que fez parte das primeiras levas de presos políticos enviados para o Tiradentes:

\footnotetext{
${ }^{371}$ TAPAJÓs, Renato. “Uma floresta de panos”, op.cit., p.350-1.

372 CANDIDO, Antonio. "O purgatório", op.cit., p.13, citando trecho da introdução escrita pelos organizadores do livro.
} 
“[...] por ocasião da queda [...] não tínhamos a menor ideia do que era a prisão e nem de suas várias fases e principalmente daquilo que viria a ser o cotidiano de longos anos. As primeiras vagas informações de que a cadeia não era uma sucessão infindável de dias de tortura e que após uma primeira fase, às vezes não muito breve, no DOI-Codi, à época Oban, e no DEOPS, sobrevinha um longo período de longos dias de espera pela liberdade, nos foi dada por um preso comum que puseram na nossa cela, no quartel da rua Tutóia. Era uma figura, como tantas outras que viríamos a conhecer nos anos seguintes, simpática, falante, 'cadeeiro velho', inúmeras passagens pela cadeia e muitas histórias [...]. De qualquer maneira, sem o saber, prestou-nos um grande serviço. Restabeleceu em nós, naquele dificílimo momento, a dimensão de tempo, que havíamos perdido, a noção de etapas, de fases, de que ao término da tempestade viria uma relativa bonança. Essa coisa elementar de entender que [...] a tortura é uma fase limitada no tempo, nos deu alento que quem o colocou ali jamais poderia $\operatorname{supor}^{373}$."

Vários ex-presos entrevistados nessa pesquisa destacaram que, apesar de serem jovens e inexperientes (parte considerável não tinha muito tempo de militância, mesmo aqueles que assumiram posições de direção), enfrentaram com dignidade as adversidades dos cárceres da ditadura. O “coletivo" foi o instrumento com o qual aprenderam a enfrentar essa nova e dura realidade.

\subsection{Coerção e disciplina: o regime carcerário}

A primeira metade da década de 1970 caracterizou-se pela dispersão dos presos políticos por diversos presídios, em face da premissa do raciocínio assumido pelos órgãos de segurança interna, que os classificava entre aqueles considerados “irrecuperáveis” e os demais, supostamente menos perigosos ou combativos. Essa classificação foi adotada com variações de acordo com o estado da federação e o período, tendo como objetivo dividir, desestabilizar e dificultar ao máximo a vida cotidiana nos presídios políticos. Os órgãos responsáveis pela repressão política, seguindo a orientação do sistema prisional e sua separação tradicional entre presos indiciados e condenados, contraventores e criminosos, procuraram dividir os presos políticos classificando-os nessas duas grandes categorias.

Essas divisões, desde o século XIX, serviam ao propósito de imprimir um mecanismo disciplinar diferenciado de "transformação" do preso, visando sua “recuperação" ou "regeneração"374. As "técnicas corretivas” buscavam transformar o preso num indivíduo “dócil” e, por meio do trabalho forçado, transformar o ladrão num

\footnotetext{
${ }^{373}$ RoIG, Vicente. "Encontro e reencontro com o amor e a vida”, em Tiradentes, op.cit., p.126.

374 Foucault, Michel. Vigiar e Punir. Vigiar e punir. História da violência nas prisões. $10^{\mathrm{a}}$. ed., Petrópolis, Vozes, 1993, p. 209.
} 
“indivíduo mecanizado”, num operário "útil” [FouCAULT, 1993: 216]. Não obstante, essas técnicas não foram aplicadas inteiramente nos presídios políticos brasileiros. Nos cárceres da ditadura, as autoridades recorreram, principalmente, ao esquema políticomoral do sistema prisional (misturado ao "modelo técnico-médico da cura e da normalização”), visando, por meio da vigilância e da coerção disciplinar, o isolamento e a solidão, a imobilidade do corpo e do espírito do preso [FOUCAULT, 1993: 212, 220-1] com o objetivo de gerar desânimo, desesperança e submissão. Desse modo, buscavam afastar o preso da atividade política e minar seu ímpeto e sua perspectiva de continuar na luta política.

No Rio de Janeiro, em especial, os prisioneiros políticos enfrentaram a imposição de uma verdadeira “via-sacra”, a rotatividade incluía o confinamento em diversos quartéis na Vila Militar ${ }^{375}$, no presídio Hélio $G_{0 m e s}^{376}$ e em masmorras como a prisão da Fortaleza de Santa Cruz ${ }^{377}$ [BenEdito; Rezende, 2000]. Em São Paulo, a partir de 1968, a maioria dos presos era encaminhada para o Presídio Tiradentes. Em setembro de 1970, contudo, 30 presos foram transferidos para a Casa de Detenção do Estado São Paulo (o Carandiru - designação do bairro onde ficava localizado), por ordem do juiz-auditor da II Auditoria Militar, Nelson Machado Guimarães. Na Casa de Detenção foram mantidos com os presos comuns no pavilhão 8, no mesmo andar em que ficavam os assaltantes de banco processados pela Lei de Segurança Nacional. Tal situação, que durou 13 meses, facilitava a criação de conflitos violentos entre presos comuns e políticos [POLITI, 2009: 20]. Entre setembro e outubro de 1970, 6 frades dominicanos foram transferidos do Tiradentes para vários quartéis de São Paulo ${ }^{378}$. No início de 1971, outro grupo de presos políticos foi punido com a transferência para a Casa de Detenção ${ }^{379}$.

Em 1971, iniciou-se uma fase de maior vigilância e repressão no presídio Tiradentes. Os presos se mobilizaram para denunciar as transferências arbitrárias anunciadas para presídios de presos comuns e as péssimas condições carcerárias. Para um conjunto de presos foi se delineando a possibilidade da execução dos assassinatos que não haviam sido concretizados na transferência anterior ao Carandiru. O resultado da movimentação realizada ao longo do ano foi uma pequena reforma no Pavilhão I, a

\footnotetext{
${ }^{375}$ V., por exemplo, entrevistas concedidas por Jorge Eduardo Saavedra Durão, Maria Luiza Garcia Rosa e Lucia Murat à autora. RJ, 26/03/2010, 25/03/2010. AAPP/AEL-USP.

${ }^{376}$ Entrevista concedida por Paulo Henrique Lins à autora. RJ, 23/11/2008. AAPP/AEL-USP.

${ }^{377}$ Entrevista concedida por Rômulo Noronha de Albuquerque à autora. RJ, 22/03/2010. AAPP/AEL-USP.

378 BetTo, Frei. Das Catacumbas. 3a. ed., Rio de Janeiro, Civilização Brasileira, 1985, p.93-5. Foram levados para a prisão do Regimento de Cavalaria da PM e para o quartel-general do II Exército.

${ }^{379}$ Entrevista concedida por Aytan Miranda Sipahi à autora. Idem, ibidem.
} 
retirada gradual dos presos comuns e a determinação da reunificação dos presos políticos no Tiradentes [POLITI, 2009: 20]. O não cumprimento dessas reivindicações motivou uma greve de fome organizada por um conjunto minoritário dos presos do Tiradentes, com 32 dias de duração. Durante a greve, levas de presos foram transferidas para a Casa de Detenção, a Penitenciária do Estado de São Paulo e a Penitenciária de Presidente Venceslau, no interior de São Paulo. Ao longo de mais de 3 anos, a maioria dos presos políticos permaneceu no Tiradentes. A partir de maio de 1973 com sua desativação, eles foram transferidos e espalhados nos estabelecimentos existentes na época: o Presídio do Hipódromo, a Penitenciária do Estado São Paulo e a Casa de Detenção.

Em março de 1975, após a realização de uma greve de fome na Penitenciária do Estado de São Paulo, os presos (a maioria ligada à luta armada) foram transferidos para o presídio da Polícia Militar Romão Gomes, transformado então num estabelecimento para presos políticos ${ }^{380}$. Uma parcela de presos políticos, militantes do PCB e de outros partidos não vinculados à luta armada, permaneceu no presídio do Hipódromo até 1977. Com a redução da população carcerária deste presídio, os presos remanescentes foram reunidos no presídio Romão Gomes.

A perspectiva dos militares e autoridades carcerárias era a de anular, controlar e domesticar os presos e suas potencialidades reduzindo ou excluindo os estímulos e tudo que pudesse ajudar na organização de ideias e no exercício da inteligência e do corpo. No Tiradentes, em São Paulo, e em vários presídios brasileiros, porém, não foi instituído o uso da cela individual. A presença de outros prisioneiros em uma mesma cela diminuía a solidão e certa rotina vazia, monótona, repetitiva, opressiva, mecanizada e controlada [KoutZII, 1984: 33]. Em geral, os presos políticos ficaram alojados em celas compartilhadas, o que criou dificuldades nos momentos de superlotação, mas modificou positivamente sua utilização do tempo e facilitou a ajuda mútua. No presídio Tiradentes, contudo, manteve-se o regime de cela fechada, os prisioneiros podiam sair apenas na hora das visitas e do banho de sol. Isso tornava a convivência bastante difícil. A ala feminina, por outro lado, mantinha as celas abertas e as presas políticas podiam transitar livremente de uma cela a outra.

As autoridades pretendiam subordinar e disciplinar os presos e, de acordo com as entrevistas aqui analisadas, predominou no presídio Tiradentes o uso de um "regulamento implícito”, não escrito, cuja aplicação dependia da direção e dos carcereiros, o que

\footnotetext{
${ }^{380}$ Entrevista concedida por Artur M. Scavone à autora. Idem, ibidem; e CoELHO, Marco Antônio Tavares. Herança de um sonho. As memórias de um comunista. Rio de Janeiro, Record, 2000, p.465.
} 
ajudava a manter certo clima de tensão. A falta de regras precisas de funcionamento e do uso de um regulamento interno escrito favorecia o "jogo arbitrário" e as "oscilações no comportamento dos carcereiros” [KoUTZII, 1984: 32]. No Tiradentes, porém, era possível corromper os carcereiros para conseguir pequenos "favores” como cigarros, informação e transferências ou visitas a outras celas.

O quadro coercitivo do sistema carcerário ditatorial brasileiro apresentou peculiaridades locais que impedem generalizações. Em muitos casos, o sistema carcerário apresentou grande rigidez, assemelhando-se ao modelo implementado na Argentina e no Uruguai (países com os sistemas mais rígidos); em outros casos, foi nitidamente mais brando.

Na Argentina, após o golpe de 1976, generalizaram-se regras extremamente rigorosas: proibiu-se a leitura, era permitida apenas a entrada da bíblia nos presídios ${ }^{381}$; e proibiu-se a ginástica ou qualquer treinamento físico ou esportivo. Era proibido cantar ou assoviar, assim como comunicar-se com outros prisioneiros fora do horário do "recreo" (o banho de sol). Tornou-se obrigatório o uso de uniforme e foi proibido todo tipo de trabalho manual. Além disso, havia regras rígidas relativas à movimentação do preso no interior da cela individual, no banho, na revista e na hora de acordar. As chamadas eram diárias e havia revistas periódicas nas celas. As regras impostas com respeito à organização do “recreo", à alimentação, às cartas e os cuidados médicos eram bastante rigorosas. O desrespeito a essas regras implicava em sanções disciplinares e castigos físicos, embora sua aplicação tenha apresentado variações dependendo do presídio e do período [KouTZII, 1984: 33-4].

Na Penitenciária de Linhares, localizada em Juiz de Fora (MG), os prisioneiros políticos experimentaram um regime carcerário bastante rígido ${ }^{382}$. Em São Paulo, os presos políticos transferidos para a Casa de Detenção, em 1970, e para Penitenciária do Estado a partir de 1974, foram também submetidos a um regime carcerário muito rígido. A Penitenciária do Estado ("Penita” no jargão da cadeia) era uma fortaleza construída em 1922, com vários pavilhões de cinco andares e 480 celas individuais cada um. Nas laterais do terreno havia oficinas e escolas profissionalizantes, ao fundo, hortas e um campo de futebol. Na entrada ficava estampada a advertência: "Aqui o trabalho, a disciplina e a

\footnotetext{
${ }^{381}$ Note-se que em alguns presídios como o de Coronda, na Argentina, era autorizada apenas a leitura do Novo Testamento. V. KouTZII, F. op.cit., p.32. A Bíblia era a única leitura permitida no DOI-Codi/SP, conforme as entrevistas realizadas para esta pesquisa. Flávio Koutzii, um militante trotskista brasileiro, ficou preso na Argentina de 1975 a 1980.

${ }^{382}$ Entrevista concedida por Gilney Vianna à autora. SP, 05/03/2011.
} 
bondade resgatam a sua falta”. A organização interna da Penitenciária primava pela eficiência e era regida por uma burocracia que reduzia o prisioneiro a um número dentro de uma cela [ВЕTTO, 2009: 182-3]. O modelo disciplinar seguido era similar ao das prisões inglesas ${ }^{383}$

Os presos políticos, conforme já referido, começaram a ser levados para o presídio Tiradentes a partir de 1968, e o controle exercido ainda não era muito rígido. Havia mais brechas e possibilidades de resistência a serem exploradas pelos detentos. O prédio era antigo, estava em péssimas condições e tinha um aspecto de masmorra. O embrião do futuro presídio Tiradentes foi inaugurado em 1852 como a Casa de Correção e, em 1938, tornou-se a Casa de Detenção. A partir de 1962, quando terminaram as obras da nova Casa de Detenção, o “Carandiru”, a velha cadeia da Estação da Luz passou a chamar-se Recolhimento de Presos Tiradentes ${ }^{384}$. Os guardas eram corruptos, assim como eram rotineiros os maus-tratos, castigos corporais, tráfico de comida, bebidas alcoólicas e entorpecentes. O Tiradentes foi desativado em maio de 1973 [Idem, ibidem] e os últimos presos políticos remanescentes foram transferidos para a Casa de Detenção ou para o presídio do Hipódromo. Em julho de 1974, os presos políticos foram transferidos do Carandiru para a Penitenciária, por ordem do Secretario de Segurança Pública, Erasmo Dias.

Ao visitar o presídio Tiradentes em 1971, o então procurador do Estado Hélio Bicudo descreveu a terrível situação em que viviam os presos: "Nesse presídio de feição medieval, são abrigados os chamados 'presos correcionais' (os “corrós”). Homens reduzidos à condição de animais, que se amontoam em celas infectas, sempre acrescidas de mais alguns após as famosas batidas policiais. Eles aí dão ingresso, muitas vezes com qualificações inverídicas, e passam a vegetar naquilo que a gíria policial convencionou chamar de 'mofo'." Bicudo realizou a visita com o objetivo de apurar as execuções sumárias feitas pelo Esquadrão da Morte e as práticas de tortura em presos comuns. Desde 1969, sucessivas denúncias de presos políticos contribuíram para tornar pública tal situação. Em julho de 1970, pelo menos oito detidos, conhecidos dos presos políticos porque cuidavam da faxina da prisão, foram assassinados em represália pela morte de um investigador de polícia. Em função dessa denúncia, Bicudo iniciou um processo contra o

\footnotetext{
${ }^{383}$ Entrevista concedida por Artur M. Scavone à autora. Idem, ibidem.

${ }^{384}$ CAMARGOS, Márcia M. de R.; e SACCHETTA, Vladimir. "A história do presídio Tiradentes: um mergulho na iniquidade” em Tiradentes, op.cit., p.486-91.
} 
delegado Sérgio Paranhos Fleury, no qual determinava a apuração das atividades do Esquadrão da Morte [Idem, ibidem $]^{385}$.

Durante o Estado Novo havia sido criada uma ala especial para presos políticos no Tiradentes, uma vocação retomada em 1968, quando os opositores da ditadura começaram a ser levados para lá, em especial após a prisão dos metalúrgicos da greve de Osasco e, em seguida, da prisão de centenas de estudantes no XXX Congresso da UNE, em Ibiúna. A ala especial ficava no Pavilhão I, mas com a chegada de um grande número de presos, foi estendida ao Pavilhão II. Apesar das terríveis descrições registradas sobre o presídio, comparado ao sofrimento vivido nos centros de torturas e extermínio, o presídio representava o início de uma fase de relativa estabilidade, tendo sido nomeado de "Hotel Tiradentes” por alguns presos, conforme Luiz Raul Machado, militante da AP preso no dia 15 junho de 1969, em Belo Horizonte ${ }^{386}$.

Inicialmente, o Pavilhão I tinha seis celas, quatro delas eram bem grandes e as outras duas comportavam quatro presos cada. Havia muita rotatividade na população carcerária do Tiradentes. Ao final de 1969, uma grande leva de presos chegou e esgotou a lotação do presídio. Desse modo, foi necessário desativar uma antiga lavanderia do andar superior do prédio e transformá-la na cela 7, onde chegaram a ficar cerca de 50 presos, a maioria deles ligada à ALN [Idem, ibidem]. Aos domingos, em meio a tantos militantes ateus, havia missas organizadas pelos frades dominicanos na cela 7, que contavam com os emblemáticos sermões de Frei Betto ${ }^{387}$.

As celas 1 e 4 eram as menores, sendo que a cela 1 era designada Monteiro Lobato, em homenagem ao seu ilustre "hóspede" dos tempos do Estado Novo ${ }^{388}$. A cela 3 recebeu o nome de Mário Alves, em homenagem ao dirigente do PCBR assassinado sob tortura em 1970, no DOI-Codi do Rio de Janeiro. A cela 4 era chamada de "aristocracia" ou “cela dos lordes”, onde ficaram presos naquele período o historiador Caio Prado Junior, o deputado cassado Hélio Navarro, um padre, entre outros.

No auge da repressão política, o presídio Tiradentes chegou a abrigar cerca de 250 presos políticos ${ }^{389}$. Com o aumento da população carcerária, os presos políticos

\footnotetext{
${ }^{385}$ Idem, ibidem, p.491.

${ }^{386}$ MACHADO, Luiz Raul. "Recordação da casa dos vivos”, em: Tiradentes, op.cit., p.67.

${ }^{387}$ PRADO JunIOR, Antonio de Pádua. “A massa quer sangue, então terá...”, em Tiradentes, op.cit., p. 132; e MACHADO, Luiz Raul. "Recordação da casa dos vivos”, em Tiradentes, op.cit., p.72.

${ }^{388}$ Monteiro Lobato foi preso em janeiro de 1941 e ficou 3 meses preso no Tiradentes. CAMARGOS, Márcia M. de R.; e SACCHETTA, Vladimir. op.cit., p.495; e MACHADO, Luiz Raul. Idem, p.72.

389 Entrevista concedida por Carlos Alberto Lobão Cunha à autora. SP, 23/04/2010. Maurice Politi afirma que esse número pode ter variado entre 300 a 400 presos. PoLITI, M. Resistência atrás das grades. op.cit., p.20.
} 
começaram a ser levados para o Pavilhão II, habitado pelos presos comuns. Desde o início de 1970, os presos políticos começaram a ocupação de celas desse pavilhão. Esse pavilhão era o mais antigo, datado da fundação do prédio, e tinha onze celas, todas elas coletivas e de variados tamanhos. As janelas das celas eram amplas e gradeadas, por onde o frio ou o calor entravam sem barreiras. No térreo ficavam cerca de duzentos presos comuns; no andar de cima, estavam uma centena de presos comuns, quase todos enquadrados na LSN, por envolvimento em assaltos a banco. Inicialmente, os presos políticos ficavam isolados no final do corredor ${ }^{390}$. Em março de 1972, esse pavilhão já era ocupado inteiramente por presos políticos ${ }^{391}$.

Ali a sensação de isolamento era maior, quer fosse em função da distância física em relação ao conjunto dos demais presos políticos, quer da aproximação forçada com os presos comuns. Em geral, no Pavilhão II ficavam os presos mais pobres, conforme o relato de Cloves de Castro, um operário militante da ALN preso em 1970:

“No Tiradentes, [...] na entrada tinha o Pavilhão I, onde ficavam os presos ..., assim, os presos de classe média. [...] Nós fomos para o Pavilhão II... Você atravessava o Tiradentes e em frente à carceragem, [...] passava-se pela triagem e, em cima, tinham as celas com os presos comuns que foram esvaziadas para nos abrigar. As condições eram terríveis, nós chegamos a ficar num espaço, mais ou menos de três por dois metros [...] como esse aqui, com 14 pessoas [...]. Tinha dois beliches, você tinha um corredorzinho de 50 centímetros, onde ficava o banheiro, que o pessoal chamava o boi [...]. No começo, nós comíamos a comida do presídio, depois nos organizamos e fazíamos a nossa refeição, ajudados pelas famílias que traziam mantimentos. Normalmente, a gente pegava as comida do presídio e aproveitávamos a carne, feijão, que a gente refazia e aproveitava. Era raro a gente tomar sol. Caso fôssemos para 'o sol', ficávamos uns 40 minutos. Era terrível, muito terrível!

[...] Nós chegamos e botávamos companheiros no chão para dormir, para evitar que fossem colocados em celas com os presos comuns ${ }^{392}$."

A ameaça de alojar presos políticos em celas de presos comuns era constante. Em fevereiro de 1970, segundo Adilson Odair Citelli, militante do PCBR preso em 17 de janeiro daquele ano, ao protestar por ser obrigado a ficar numa dessas celas conjuntas alegando direitos e convenções internacionais de proteção aos prisioneiros políticos, recebeu a seguinte resposta de um carcereiro: “Aqui vocês só têm direito de respirar, e isso enquanto não forem colocados numa câmara de gás ${ }^{393}$,.

\footnotetext{
${ }^{390}$ BetTo, Frei. Das catacumbas, op.cit., p.97 e 106.

391 Abaixo-assinado dos presos políticos do presídio Recolhimento de Presos Tiradentes, assinado por 130 presos e enviado ao STM e às I e II Auditorias de Guerra da II Região Militar. SP, 28/03/72. Publicado em Politi, M. Resistência atrás das grades. op.cit., p.134.

${ }^{392}$ Entrevista concedida por Cloves de Castro à autora. SP, 28/04/2009. AAPP/AEL-LEI. V. tb. SISTER, Sérgio. “Cadeia só funciona para inocentes que nem eu”, em Tiradentes, op.cit., p.205.

${ }^{393}$ CITELLI, Adilson Odair. “O pequeno concerto que não virou canção”, em Tiradentes, op.cit., p.193.
} 
As presas políticas habitavam a ala feminina, que tinha oito celas no andar superior do lado sul do presídio, imediatamente atrás e colada ao Pavilhão II. O acesso era possível por meio de uma escadaria íngreme localizada depois do corredor onde estavam as celas das presas comuns. O local era uma velha torre circular construída de paredes maciças e rodeada por guaritas. Isolada do resto do presídio pelo pátio feminino, tinha uma porta de ferro como única entrada. Duas celas menores ficavam no térreo e o acesso às celas do piso superior se fazia por meio das duas escadas dispostas cada uma nas laterais do hall da entrada. Na parte superior havia uma espécie de mezanino que permitia a visão do que acontecia na parte de baixo do prédio. Devido a essas características, a ala feminina das presas políticas ficou conhecida como a "Torre das donzelas”394. Apesar dessa denominação “romântica”, frequentemente era possível flagrar ratazanas circulando por todo o presídio. Eventualmente, conseguiam matá-las ${ }^{395}$.

A seguir, examinaremos as regras e proibições que compunham o regulamento implícito vigente no presídio Tiradentes, estabelecendo um quadro comparativo com o conjunto do sistema carcerário que englobava os presos políticos de São Paulo e, eventualmente, com outros presídios de outros estados do país.

\subsection{O controle da movimentação dos presos: a revista e o "banho de sol”}

No presídio Tiradentes as celas compartilhadas em regime fechado exigiram dos prisioneiros políticos a organização pautada pela formação dos “coletivos”, com vias ao estabelecimento de uma rotina capaz de mitigar a repetição e a monotonia. A manutenção das celas fechadas em tempo integral possibilitava um grande controle sobre a movimentação dos presos. A regra que autorizava ao preso sair apenas na hora do banho de sol e para receber as visitas tinha por objetivo debilitar o corpo e propiciar a perda de energia física e psíquica. Ao preso eram dificultadas condições para que adquirisse condicionamento físico e reforçasse o cuidado consigo e sua individualidade.

Essa prática visava diminuir as possibilidades de realização de maior variedade de atividades, assim como uma melhor interação entre os presos. Nessas condições, o “corpo

\footnotetext{
${ }^{394}$ PoliTI, M., op.cit., p.18; e SIPAHI, Rita. "Em nome da rosa”, em Tiradentes, op.cit., p.183; MAFRA, Márcia. "O mundinho, o mundão e seus (des)encontros”, em Tiradentes, op.cit., p.321-34.

${ }^{395}$ Entrevista concedida por Darci Miyaki à autora. SP, 10/03/2011; CITELLI, Adilson Odair. "O pequeno concerto que não virou canção", em Tiradentes, op.cit., p.198-201; e "Abaixo-assinado dos presos políticos do Recolhimento de Presos Tiradentes (presídio Tiradentes)" dirigido ao STM, às I e II Auditorias de Guerra da IIa. Região Militar, 28/03/72; em POLITI, M. op.cit., p.130.
} 
humano entra numa maquinaria de poder que o esquadrinha, o desarticula e o recompõe” [FOUCAULT, 1993: 127] para aprofundar sua sujeição. A coerção disciplinar utilizada contra os presos políticos, porém, não foi direcionada ao esforço físico do corpo ou ao trabalho forçado. Ao contrário, o sistema prisional seguiu o esquema político-moral que, influenciado pelo modelo monástico, exercia a coerção e a imposição da hierarquia com o objetivo de imobilizar e isolá-los [FOUCAULT, 1993: 220-1]. A solidão e a imobilização eram os mecanismos e os instrumentos pelos quais se produzia sofrimento e que deveriam suscitar a reflexão, o arrependimento e “uma espécie de auto-regulação da pena”, uma “individualização espontânea do castigo” e, por fim, a submissão do preso [FOUCAULT, 1993: 212].

Imobilizar o preso levava-o a ter mais horas de sono, o que poderia exacerbar a sensação de opressão e o fechamento sobre si mesmo, criando espaço para que cedesse a pensamentos sombrios e depressivos. Esse era o principal objetivo de manter os presos fechados nas celas. Procuravam retirar-lhes a autonomia, impondo-lhes os horários para despertar ou dormir, para fazer refeições e ter momentos de lazer. O objetivo final era conseguir a perda de controle do próprio corpo e a supressão da vontade do preso.

Apesar da aplicação dos recursos coercitivos descritos acima, os presos políticos do Tiradentes tinham alguma flexibilidade para controlar o tempo dentro das celas, os horários para dormir, acordar e até o fazer das refeições - já que "reciclavam”, em suas cozinhas improvisadas, a comida oriunda do presídio. A ajuda dos familiares, que forneciam boa parte dos alimentos, possibilitava melhorias na comida. A carceragem não exercia um controle tão rígido quanto a esses aspectos e horários. Os prisioneiros cuidavam para que o cotidiano fosse repleto de atividades para usufruir melhor de seu tempo e combater a imposição de isolamento e imobilidade do sistema carcerário:

"Na cadeia, a rigor, as pessoas deprimidas eram poucas porque a atividade era tão grande e tão frenética! [...] Com essa coisa da privação da liberdade, ainda bem que a gente tem capacidade de abstração, porque era difícil. Ás vezes, no final da tarde eu ficava muito tempo sentado na janela vendo o outro lado da Avenida Tiradentes. Isso é uma coisa que gravei na minha retina, todas aquelas lojas, desde o Museu de Arte Sacra até o quartel em frente da polícia militar. E tinha várias lojas que faziam uniforme militares do lado de lá, essa coisa fica. Reli algumas coisas do Thomas Mann na prisão e lembro da questão do tempo, que ele trabalhou em A montanha mágica. Quando é que o tempo passa? Quando há mais atividade, o tempo passa mais rápido, mas quando tem menos atividade e repetição, temos a impressão de que nada acontece. Eu fiquei com aquela visão das pessoas que estavam libertas lá fora, passando... Muita coisa aconteceu, quando entrei na 
cadeia não tinha metrô, mas quando sai podia-se andar de metrô. Esse olhar no horizonte da avenida fazia você soltar o pensamento, era uma coisa interessante.”396

Inicialmente, os presos políticos mantidos no Tiradentes tinham o direito ao "banho de sol” no espaço reservado ao pátio interno por apenas duas horas, uma vez por semana. O local era chamado de “chiqueirinho”, entre os Pavilhões I e II, onde uma grade o separava da parte maior do pátio. O usufruto desse direito foi variável, de acordo com a época ou o pavilhão, conforme o testemunho de alguns ex-presos que afirmam que, em determinados períodos, havia banho de sol diariamente ${ }^{397}$. Era possível também burlar o regime de cela fechada por meio de corrupção ou de um carcereiro mais acessível.

Os testemunhos dos ex-presos e advogados de defesa colhidos nesta pesquisa desenvolvem a noção de que a administração dos presídios mantinha uma íntima relação com as Auditorias Militares e os DOI-Codis e eram, na prática, responsáveis pela modulação das penas, ainda que certo poder permanecesse outorgado aos diretores de presídios e carcereiros, tal como em outros sistemas prisionais [FOUCAULT, 1993: 21721]. Proibir o banho de sol, a leitura e as visitas, abrir as celas ou não, comprar cigarros, entregar livros à cela ao lado faziam muita diferença no cotidiano dos presos. A direção do presídio alertava os carcereiros a respeito dos riscos que a presença dos presos políticos trazia; eram "terroristas perigosos e traiçoeiros”. No início, muitos carcereiros eram bastante rígidos, mas, com o tempo, tornavam-se mais flexíveis, alguns tinham consciência de que com os "políticos" a situação era diferente, pois no futuro poderiam estar "por cima”:

“[...] logo era despertada a curiosidade de ver ali no 'cadeião' aqueles jovens de classe média, tão diferentes de todos com quem eles usualmente lidavam. Alguns se aproximavam mais e começavam a conversar. Queriam saber por que estávamos ali. Entre eles, o Ditinho era uma 'mãe'. Logo que chegava, ia abrindo as portas das celas para que pudéssemos circular livremente entre uma e outra, o que, evidentemente, era proibido. E lá se ia, deixando-nos 'à vontade’. Só voltava em geral no final do plantão para passar a chave. Plantão do Ditinho era moleza!

Havia o Napolitano. Com cerca de 40 anos, ele era truculento ao extremo e não cansava de se vangloriar de que, com ele 'preso era na porrada'.

[...] era um dos que ficavam mais intrigados com a nossa presença. Para ele, preso era marginal, bandido, e nós éramos ‘tudo doutor’! Aquilo não entrava na sua cabeça. De qualquer maneira, gostava de conversar com a gente e nos tratava razoavelmente, porque ‘com político nunca se sabe! Vai que esses caras amanhã estão por cima... ${ }^{398, \text { ” }}$

\footnotetext{
${ }^{396}$ Entrevista concedida por Aytan M. Sipahi à autora. SP, 29/04 e 20/05/2009. AAPP/AEL-LEI.

${ }^{397}$ PoLiTI, M. op.cit., p.23; Cloves de Castro relatou que o banho de sol não era regular e durava cerca de 40 minutos. Entrevista concedida por Cloves de Castro à autora. Idem, ibidem. Carlos Alberto Lobão afirmou que em determinado período o banho de sol ocorria duas vezes por semana. V. CunHA, Carlos Alberto Lobão, "Desesperar jamais. Aprendemos muito nesses anos”, em Tiradentes, op.cit., p.224.

${ }^{398}$ AzEVEDO, Ricardo. “O plantão do Napolitano”, em Tiradentes, op.cit., p.86.
} 
As celas tinham vários beliches que ficavam encostados à parede. A quantidade variava conforme o tamanho de cada cela, mas, em geral, faltava espaço. Na cela 7, que chegou a comportar cerca de 40 presos, no final da tarde, os presos desmonestavam os beliches para poder caminhar ${ }^{399}$. O “mocó” era o nome dado ao exíguo espaço reservado a cada um em sua própria cama. Muitos usavam, como divisórias, lençóis e roupas trazidos pela família. Com o tempo, adquiriram TV, mesas e estantes improvisadas. A permissão para a entrada de aparelhos de televisão se deu quando da Copa do Mundo de Futebol de $1970^{400}$. As celas tinham uma composição heterogênea que impunha um constante exercício de tolerância, mas, muitas vezes, os integrantes das organizações e tendências políticas se reagrupavam, pedindo transferência para determinada cela e se uniam usando de artimanhas junto à carceragem.

Os domingos eram reservados à faxina e ao "futebol de cela”. Dois jogadores, um de cada lado, tentavam jogar bolas feitas de meias velhas enroladas nos gols feitos de caixotes. Na cela 7, devido ao seu tamanho, jogavam três contra três ${ }^{401}$. Os beliches transformavam-se em arquibancadas e os jogos geravam disputas acirradas e bem humoradas $^{402}$.

Apesar do predomínio da solidariedade e do bom humor na convivência e no trato do dia a dia entre os presos, no presídio Tiradentes desenvolvia-se um ambiente de muita disputa política. Carlos Alberto Lobão Cunha, militante da ALN preso em 23 de outubro de 1969, ilustra a atmosfera da ala masculina, que em determinados momentos (neste caso, entre julho e agosto de 1970) chegou a impedir a difícil circulação de alguns presos entre as celas:

"No DOPS, raramente você saía da cela para tomar sol, [...] mas algumas das conversas entre as celas se davam no banho de sol. Eventualmente alguém saía para distribuir mantimento que chegava a mais e trocava informações. Aquela missa de Natal com os dominicanos, no DOPS [...] a gente aproveitou para sair da cela e fazer contatos.

[...] era muito difícil conviver com os outros grupos. No Tiradentes, [...] eu lembro particularmente do Diógenes de Arruda Câmara, que estava preso na cela 1 e o Paulo de Tarso Venceslau também. O Diógenes, velho comunista, circulava, porque você ficava preso na cela, mas sempre conseguia, subornando algum carcereiro, passar duas horas numa outra, fora do horário do banho de sol. O Diógenes circulava muito. Eu me lembro de uma situação em que circulou um documento atribuído a ele ou ele próprio fez circular um texto escrito a mão sobre o Partido Comunista, o papel do partido, como organizar, como fundamentar e o que era importante. A gente achou ótimo: nossa, que texto legal,

\footnotetext{
${ }^{399}$ Entrevista concedida por Aytan M. Sipahi à autora. Idem, ibidem.

${ }^{400}$ Entrevista concedida por Carlos Alberto Lobão Cunha à autora. SP, 10/10/2010.

${ }^{401}$ CunHA, Carlos Alberto Lobão. "Desesperar jamais. Aprendemos muito nesses anos”, em Tiradentes, op.cit., p.239.

${ }^{402}$ PRADO JunIOR, Antonio de Pádua. “A massa quer sangue, então terá...”, em Tiradentes, op.cit.
} 
bem escrito, sólido e tal, o cara deve ser bom. Mais tarde a gente descobriu que não era dele, era um texto do Stalin, publicado fazia muito tempo. O Diógenes circulava muito, conversava aqui e ali, mas a gente detectou o seguinte, acredito que não deliberadamente, as pessoas [por meio dele] começaram a ser jogadas umas contra as outras, gente da própria ALN.

As pessoas da cela 7 e boa parte da ALN, enfim, a sua coordenação proibiu o Diógenes de entrar na cela. Eu fui eleito para a coordenação da cela com mais dois, um era o Casadei e o outro, não lembro. [...] A coordenação pediu para ele, pessoalmente, que não fosse mais lá; estava proibido de entrar lá. Ele ficou indignado, mas, enfim, teve de aceitar ${ }^{403 ”}$.

Especialmente a partir de 1971, as revistas nas celas tornaram-se mais frequentes no presídio Tiradentes e, em geral, ocorriam em dias e horários indefinidos para surpreender os presos. Estes eram retirados das celas e revistados sob a alegação de realizarem buscas por documentos "subversivos". Isso acontecia, principalmente, depois do banho de sol ou das visitas. Nessas "batidas”, beliches, colchões e objetos pessoais dos presos eram quebrados ou jogados para fora das celas. Livros eram revirados e, alguns, apreendidos. Eventualmente, o resultado dessas buscas traduzia-se na abertura de novos inquéritos, em castigos ou represálias. Os presos poderiam ser reconduzidos ao DOI-Codi ou ao DEOPS para novos "interrogatórios" e até sofrerem com a suspensão do banho de sol ou das visitas [POLITI, 2009:23].

As revistas às celas envolviam grande aparato; os soldados da PM entravam no presídio no meio da noite visando criar um clima de instabilidade e intimidação, a pretexto de encontrar facas e baralhos. Era um momento de especial hostilidade e provocações; uma ocasião para lembrar aos presos que não tinham direito a um lugar para si e para coisas que fossem suas. Às vezes, um “olheiro" que trabalhava na administração do presídio avisava com antecedência e alguns presos tinham tempo de esconder objetos e documentos mais importantes ${ }^{404}$.

Além do futebol durante o banho de sol, a ginástica era indispensável para homens e mulheres presos no Tiradentes, que a praticavam diariamente dentro da cela, pela manhã. Na época, estavam em voga os exercícios utilizados pela Real Força Aérea Canadense e divulgados em um pequeno livro ${ }^{405}$. Outros presos praticavam ioga para

\footnotetext{
${ }^{403}$ Entrevista concedida por Carlos Alberto Lobão Cunha à autora. SP, 05/05 e 17/09/2009. AAPP/AELLEI.

${ }^{404}$ MACHADO, Luiz Raul. “Recordação da casa dos vivos”, em: Tiradentes, op.cit., p.69-70.

405 Entrevista concedida por Darci Myiaki à autora. Idem, ibidem. Darci ensinava os exercícios canadenses na ala feminina; MACHADO, Luiz Raul. Idem, p.69.
} 
aprender a lidar com a ansiedade gerada pelo confinamento nas celas e o sentimento de impotência ${ }^{406}$.

As presas políticas mantidas no presídio Tiradentes viveram sob um regime carcerário um pouco mais flexível, pois as celas ficavam abertas e elas podiam movimentar-se com mais desenvoltura em seu espaço. O horário reservado ao banho de sol era diário; no pátio feminino as presas praticavam vôlei com frequência ${ }^{407}$.

Os presos políticos transferidos para a Casa de Detenção de São Paulo, em 1970, viveram sob um regime carcerário mais rígido, típico de instituições disciplinares. Levados para o Pavilhão 8, foram obrigados a compartilhar e conviver no mesmo espaço dos assaltantes de banco processados pela LSN e no pavilhão de presos comuns reincidentes. Eram mantidos em celas individuais e fechados durante todo o dia, saindo apenas durante o banho de sol ou a visita - semanal. Ao chegar, receberam um prato, caneca e colher de alumínio e uma calça de brim azul claro, como uniforme ${ }^{408}$.

Autofalantes (chamados pelos presos de "Boca de ferro") veiculavam a programação musical de uma rádio, ou aparelho de som, a critério dos presos comuns. Carlos Alberto Lobão Cunha reteve na memória, particularmente, a exaustiva repetição da “Ave Maria”, de Gounod, às 18 horas, e o encerramento das transmissões, com o “Tico-tico no fubá”, de Zequinha de Abreu, às 21 horas. A alimentação, já pronta, era fornecida pela instituição e de péssima qualidade; os presos não tinham permissão para cozinhar. O banho de sol ocorria uma vez por semana durante o período da manhã ${ }^{409}$. No início de 1971, os presos políticos conquistaram o direito a uma hora diária de banho de $\operatorname{sol}^{410}$. De acordo com o relato de Lobão, mesmo com um regime carcerário rígido era possível driblar as proibições e adversidades:

“A gente ficou numa situação ruim, o banho de sol era num período só por semana e
tinhamos que receber a comida de lá que era muito ruim. A gente fazia o que
chamávamos de 'recortado'. Pedíamos para as visitas trazerem sal e azeite. Pegava-se um
pouco de comida, lavava toda a carne em cima daquela fossa turca, tinha um cano e mais
nada, e tirava a gordura. Depois, pegava-se um prato de alumínio, desfiava a carne,
colocava um pouco de feijão, um pouco de arroz, azeite e sal e esquentava num pirulito.
O pirulito é um artefato em que se pega uma folha de jornal inteira, dobra e a transforma

\footnotetext{
${ }^{406}$ SISTER, Sérgio. “Cadeia só funciona para inocentes que nem eu”, em Tiradentes, op.cit., p.207; e CunHA, Carlos Alberto Lobão. "Desesperar jamais. Aprendemos muito nesses anos", em Tiradentes, op.cit., p.242.

${ }_{407}$ Entrevista concedida por Lenira Machado à autora. Idem, ibidem.

${ }^{408}$ SIPAHI, Aytan M. op.cit., p.235; e BETTO, Frei. Cartas da prisão. Rio de Janeiro, Civilização Brasileira, 1977.

${ }^{409}$ Entrevista concedida por Carlos Alberto Lobão Cunha à autora. SP, 10/10/2010.

${ }^{410}$ SIPAHI, Aytan M, op.cit., p.235.
} 
num cilindro oco, e ao colocar fogo não sai fumaça, porque era proibido ter fósforo dentro da cela. Com aquele pirulito, tinhamos dois pirulitos, esquentava-se o prato e a gente comia $^{411}$."

No presídio Tiradentes, nova leva de presos sofreu punição disciplinar e foi transferida para a Casa de Detenção do Carandiru. Durante o período de negociações que se seguiram ao sequestro do embaixador da Suíça Giovanni Enrico Bucher, em dezembro de 1970, um preso da cela 6, o jornalista Nelson Gato, negou-se a aceitar sua inclusão na lista de prisioneiros a serem trocados pelo diplomata. Na ocasição, ele foi encaminhado ao DEOPS e fez declarações à imprensa criticando a esquerda, quando retornou, representantes de várias celas se dirigiram ao diretor do presídio para manifestar a impossibilidade de conviverem com ele, por quebra de confiança ${ }^{412}$. Essa reação gerou a punição; os presos da cela 6 que protestaram, incluindo alguns outros, considerados lideranças, foram levados para o Carandiru. De acordo com o testemunho de Aytan M. Sipahi, dirigente regional do PCBR preso em 16 de janeiro de 1970 pelo DEOPS/SP:

"Eu estava na cela seis quando houve o sequestro do embaixador da Suíça e lá estava também o jornalista Nelson Gato, que resolveu não sair no sequestro. Ele não chegou a aderir à repressão, mas fez um jogo duplo. Então, nós dissemos que ele não podia mais ficar conosco. Duas horas depois chegou o DOI-CODI com um carrão [...] e levou todo mundo que tinha feito pressão contra o Nelson Gato para o Carandiru. Ficamos no pavilhão 8 de castigo. Passamos três meses lá e, depois, voltamos ${ }^{413}$.”

No final de 1971, os presos políticos levados para o Carandiru em setembro de 1970 foram transferidos de volta ao Tiradentes. No início da greve de fome de maio de 1972, contudo, os grevistas e mais alguns presos foram levados novamente para o Carandiru. Ao final de 32 dias, mesmo derrotados, pois não conseguiram a reunificação de todos os presos políticos, foram alojados no Pavilhão 5, o pavilhão reservado aos considerados loucos e aos ameaçados de morte (os presos "no seguro", conforme o jargão), onde receberam melhor tratamento.

Nesse pavilhão havia celas individuais (aquelas que tinham janelas voltadas para o pátio interno) e duplas (aquelas com janelas voltadas para o pátio externo) abertas durante o dia, o que permitia o trânsito livre na galeria de presos políticos, cujo corredor tinha formato de “L”. As celas eram abertas de manhã cedo, às 7 hs, e fechadas às $18 \mathrm{hs}$. A qualidade da comida servida melhorou e era permitido ter mantimentos nas celas

\footnotetext{
${ }^{411}$ Entrevista concedida por Carlos Alberto Lobão Cunha à autora. SP, 05/05 e 17/09/2009. AAPP/AELLEI.

${ }^{412}$ SIPAHI, Aytan M., em Tiradentes, op.cit., p.234-5.

${ }^{413}$ Entrevista concedida por Aytan M. Sipahi à autora. Idem, ibidem.
} 
(alimentos frios/secos, temperos etc.), o que se pode atribuir à repercussão da greve de fome e à pretensão do diretor da Casa de Detenção, o coronel aposentado da Força Pública de São Paulo Fernão Guedes, de se candidatar a deputado. Os presos políticos e familiares passaram a receber um tratamento melhor, inclusive, durante a revista obrigatória antes e depois da visitas. Aumentaram as horas e dias do banho de sol e os presos políticos foram autorizados a utilizar uma cela como oficina de artesanato ${ }^{414}$.

Em maio de 1973, com a desativação do Tiradentes que daria lugar às obras do metrô $^{415}$, a maioria dos presos políticos foi transferida para o presídio do Hipódromo. Tempos depois, as presas foram levadas para a Casa do Egresso, localizada junto ao complexo da Casa de Detenção. Lá eram consideradas “reeducandas” e submetidas a um regime carcerário rígido. Elas eram mantidas em celas coletivas, mas obrigadas a usar um uniforme cáqui, grande e desajeitado. Havia mais conforto material do que no Hipódromo, mas eram mantidas isoladas, inclusive, das presas comuns. As refeições eram servidas pela instituição e de péssima qualidade; elas não podiam incrementar a comida pois não tinham permissão para cozinhar. As visitas ocorriam aos sábados, à tarde; e no pátio interno podiam se reunir com as famílias e demais visitantes. O período de reclusão na Casa do Egresso foi muito difícil para o coletivo de presas políticas ${ }^{416}$.

Em 1974, algumas presas foram levadas para a Penitenciária Feminina, dirigida por freiras, onde eram mantidas em celas individuais. A militante do POC, Ângela Rocha, permaneceu mais tempo presa e ficou na penitenciária até $1976^{417}$. No ano seguinte, Elza Monnerat, dirigente do PCdoB presa durante a “Queda da Lapa” em dezembro de 1976, passou a ocupar o estabelecimento onde permaneceu até $1979^{418}$. Assim que chegavam, as presas eram submetidas ao isolamento em solitárias por alguns dias. O castigo mais usual às presas comuns era o confinamento nas solitárias, mas também a transferência para o Juqueri. De acordo com Beatriz Bargieri, na penitenciária havia

“[...] uma série de regras, tinha horário para tudo, tinha horário para jogar bola, para a ginástica, para fazer trabalhos manuais, para ver televisão [...]. A gente ficava lá com as presas comuns, até começamos a participar de um teatro. [...] a gente não quis intervir em nada do assunto que elas iriam tratar. Elas escreveram a peça, só que quando a

\footnotetext{
${ }^{414}$ Entrevista concedida por Carlos Alberto Lobão Cunha à autora. SP, 10/10/2010.

${ }^{415}$ CAMARgOS, Márcia M. de R.; SACCHETTA, Vladimir. op.cit., p.485.

${ }^{416}$ Entrevista concedida por Maria Amélia de A. Teles à autora, idem, ibidem; e TELES, Maria Amélia de A. "Lembranças de um tempo sem sol...", em PEDro, Joana Maria; WolfF, Cristina Scheibe (orgs). Gênero, Feminismo e Ditaduras no Cone Sul. Ilha de Santa Catarina, Editora Mulheres, 2010, p.290.

${ }^{417}$ FreIRE, Alípio Viana. "Um acervo de imagens dos presídios políticos: o cotidiano através das artes plásticas”. In: Projeto História, São Paulo, no.21, p.183-203, nov. 2000.

${ }^{418}$ SiMAS, Mário. Gritos de Justiça: Brasil (1963-1979). São Paulo, FTD, 1986, p.249.
} 
encenaram, era uma peça forte de questionamento da instituição prisão etc. Não havia meio das freiras entenderem que a gente não tinha feito nada, que aquilo era criação delas. Tinha uma riqueza enorme aquilo, foi o maior sucesso quando elas apresentaram o teatro para as famílias. A partir daí as freiras passaram a aceitar a nossa reivindicação de ter uma sala para poder ler os livros e discos deixados por outras presas políticas, de juntar todos os documentos, mas tiraram a gente do convívio com as presas comuns"419.

Em julho de 1974, os presos políticos confinados no Carandiru foram transferidos para a Penitenciária do Estado de São Paulo, onde passaram a viver sob um regime carcerário ainda mais rígido do que aquele a que as presas foram submetidas. Na Penitenciária, os mecanismos de controle e coerção - característicos das instituições disciplinares - eram exercidos com maior intensidade do que em outros estabelecimentos prisionais de São Paulo. Em maio de 1972, quando foi iniciada a greve de fome, uma leva de presos políticos do Tiradentes havia sido levada para a Penitenciária, onde ficaram poucos dias ${ }^{420}$. As celas eram individuais, mas, em 1974, os presos políticos foram alojados numa ala separada ${ }^{421}$.

Aos presos da Penitenciária não era permitido manter objetos pessoais dentro das celas. Era obrigatório o uso do uniforme, calça, calção e blusão de brim caqui, o mesmo tecido da toalha de banho. Este era controlado, os presos se dirigiam em fila até o espaço coletivo reservado para tomar banho e eram vigiados pelos guardas. Era obrigatório locomover-se em fila e havia uma grande presença de funcionários e guardas. Com o tempo, os presos políticos se recusaram a tomar banho nesse local, pois faltavam condições higiênicas mínimas e passaram a se lavar na torneira que ficava acima da privada turca. O direito ao "banho de sol” era exercido apenas uma vez por dia no pátio durante uma hora e em separado dos presos comuns. O pátio era um pequeno espaço limitado pelo muro que separava os pavilhões, cujo tamanho não permitia a prática do futebol, mas onde os presos faziam ginástica e caminhadas. O sinal de silêncio tocava às 21:30 hs, quando as luzes eram apagadas. As atividades do presídio começavam às 6 horas da manhã. Regularmente, um autofalante transmitia música, a homilia do pastor e jogos de futebol. Durante a noite, quando da ronda carcerária as luzes eram acesas

\footnotetext{
${ }^{419}$ Entrevista concedida por Beatriz Bargieri à autora. Idem, ibidem.

${ }^{420}$ Neste período, 18 presos políticos ficaram na penitenciária, no $3^{\circ}$. andar do pavilhão 2, durante 7 dias, em BetTo, Frei. Cartas da prisão. op.cit., p.45 e 52, 56. Poucos dias depois foram levados ao Carandiru, mas Manoel Cyrillo, Francisco Gomes da Silva e Celso Antunes Horta permaneceram mais tempo na penitenciária. Entrevista concedida por Manoel Cyrillo de Oliveira Netto à autora. Idem, ibidem.

${ }^{421}$ Entrevista concedida por Artur M. Scavone à autora. Idem, ibidem.
} 
atrapalhando o sono dos $\operatorname{presos}^{422}$. Nas palavras de Scavone, o regime carcerário na Penitenciária era tão rigoroso, que estabelecia outro padrão de cadeia:

“[...] era como o padrão inglês, aliás, ela foi construída pelos ingleses. Você tem os andares em ferradura, vazados no centro e você enxerga todos os andares. As portas eram de madeira, mas de uns 15 centímetros de espessura. Celas individuais, [...] com aquela cama pendurada na parede com um banheirinho turco; a latrina de agachar e uma torneira. [...] eram celas individuais e relativamente grandes até, se você considerar que era um cara sozinho lá dentro. Na Detenção, elas eram menores.

[...] A porta tinha um furo cônico, com a abertura para dentro, que era para o sujeito chegar lá e olhar se você está lá dentro, se está vivo. Havia uma portinha que a gente chamava de guichê, que era uma portinha que abria para passar comida e as coisas.

[...] A janela era grande, você podia subir na janela para ficar olhando lá fora, tinha gente que criava pombo, passarinho ali, tinha de tudo no vão da janela. [...] Você era sozinho na cela, não tinha com quem falar.

[...] comíamos a comida que eles serviam lá e não podíamos ter nada de fora. A comida era assim: no café da manhã, passava o carrinho com o café, depois passava o carrinho com leite, depois passava o carrinho com pão, quer dizer, você nunca conseguia tomar o café da manhã. Depois, vinha uma laranja no almoço, alguma coisa assim e mais nada, você não tinha comida, mas tinha sobremesa. O cigarro, o açúcar eram moedas de troca na cadeia. Então, o que é que acontecia? A gente soube que tínhamos direito de receber o bolo quando se fazia aniversário, era a única coisa que tínhamos direito de receber de fora. Assim, todo mundo começou a fazer aniversário, então vinham bolos enormes de casa e a gente dividia o bolo entre os presos. A gente pegava o bolo e falava: '- $\mathrm{O}$ Maninho!', chamando o cara de cima e ele respondia: - 'Fala terrorista!' Era assim que eles falavam com a gente (risos). '- Baixa a teresa aí', e ele abaixava a cordinha e você dava um pedaço de bolo para o cara, e isso era uma festa! $\mathrm{O}$ cara debaixo pedia: ' $\mathrm{E}$ ai, maninho!' Você batia no chão, que passava o barulho, e mandava o bolo ${ }^{423}$."

Em meados de 1973, durante o período inicial de permanência dos presos políticos no presídio do Hipódromo, havia uma relação difícil com a administração da instituição e eles tiveram de enfrentar intervalos de tempo sem ter direito ao banho de sol. Chegram a ficar mais de 15 dias sem poder sair. Ao questionarem o diretor do Hipódromo sobre o assunto, receberam a seguinte resposta: “Terrorista não precisa de banho de sol”. Demorou algum tempo para que pudessem usufruir desse direito com regularidade.

Os presos políticos ficavam em celas coletivas, cujas portas permaneciam abertas durante o dia. O tamanho das celas variava. As duas celas do fundo eram grandes, com 6 ou 7 beliches onde cabiam 15 pessoas; e duas celas intermediárias tinham capacidade para 6 pessoas e, nas menores, cabiam 3 pessoas. Nesse período, havia 40 presos que tinham uma cozinha improvisada, onde podiam "melhorar" a comida trazida da Casa de

\footnotetext{
${ }^{422}$ Frei Betto relata que, em maio de 1972, o banho de sol era usufruído duas vezes por semana na Penitenciária de S. Paulo. V. BetTO, Frei. Cartas da prisão. op.cit., p.42.

${ }^{423}$ Entrevista concedida por Artur M. Scavone à autora. Idem, ibidem.
} 
Detenção. Desfrutavam do banho de sol três vezes por semana no terraço do prédio ${ }^{424}$, onde também jogavam futebol ${ }^{425}$.

Na ala feminina, cerca de 30 presas políticas [SANTOS, 2000:11] ficavam em celas coletivas, mantidas abertas para livre circulação no corredor central, que eram fechadas cedo, o que limitava o acesso à televisão, pois somente em uma cela havia o aparelho ${ }^{426}$. Elas tinham autorização para "refazer" a comida do presídio acrescentando os mantimentos trazidos pelas famílias e mantinham algum contato com as presas comuns no horário do banho de sol, que a elas se referiam como “as do terror”427. Faziam também trabalhos manuais como bordado, tricô, crochê e colares.

Apesar dos esforços dos presos políticos para melhorarem suas condições de vida, o Hipódromo era um presídio infecto, como a maioria deles, conhecido como Cadeião da Mooca, onde as condições sanitárias eram terríveis. Foi palco de várias revoltas de presos comuns, que chegaram a incendiá-lo [CoElho, 2000: 433-4]. Por esse motivo, o Hipódromo foi desativado pelo governo do Estado de São Paulo em 1994.

Os presos da Penitenciária de Linhares, em Juiz de Fora (MG), viveram sob um regime carcerário bastante rígido. Eram mantidos em celas individuais e encontravam-se apenas quando tinham acesso ao pátio durante duas horas diárias pela manhã e mais duas, à tarde. De acordo com o relato de Gilney Amorim Viana (militante da ALN), preso no Rio de Janeiro:

“[...] Podíamos transitar entre as celas apenas no horário reservado ao uso do pátio... Ficávamos 19 horas trancados, fechados dentro das celas. No horário do pátio podíamos fazer esportes, geralmente, o pessoal jogava um pouco de futebol, mas o pessoal era muito tímido lá, eram muito acanhados. ${ }^{48,}$

O cotidiano era bastante controlado em Linhares, sirenes indicavam a hora da higiene pessoal e do banho (que eram especialmente controlados e vigiados); da alimentação; de despertar; de sair das celas (os “cubículos”), sempre sob a vigilância dos carcereiros. À noite, a hora de dormir era estabelecida por meio do momento em que apagasse a iluminação das celas. Os presos não podiam manter fósforos, isqueiros, periódicos, revistas ou rádios dentro das celas. Não podiam receber livros, apenas aqueles

\footnotetext{
${ }^{424}$ Entrevista concedida por Frederico Pessoa da Silva à autora. Idem, ibidem.

425 SANTOS, Joel Rufino dos. Quando eu voltei, tive uma surpresa. Rio de Janeiro, Rocco, 2000, p.11.

${ }^{426}$ Entrevista concedida por Maria Amélia de A. Teles à autora. Idem, ibidem.

427 Teles, Maria Amélia de A. "Lembranças de um tempo sem sol...”, em Pedro, Joana Maria; WoLfF, Cristina Scheibe (orgs). op.cit., p.290.

${ }^{428}$ Entrevista concedida por Gilney Amorim Viana à autora. Idem, ibidem.
} 
de caráter didático ${ }^{429}$. As visitas ocorriam nos parlatórios vigiados por policiais e as revistas nas celas eram frequentes e violentas ${ }^{430}$.

Os presos políticos foram severamente punidos quando adotaram posturas de enfrentamento como medida de pressão para conquistarem algum direito. Em Linhares, alguns presos sofreram punição exemplar com o isolamento imposto por anos em função de um ato de desobediência que ocorreu em setembro de 1971, envolvendo reivindicação de melhorias na qualidade da alimentação. O protesto foi considerado uma tentativa de motim e os policiais militares entraram no presídio, quebraram os objetos pessoais dos presos e transferiram as presas políticas para Belo Horizonte.

Visando romper a unidade do grupo foram isolados, na galeria da ala feminina das presas políticas, aqueles considerados as lideranças do movimento. Como punição, catorze presos foram transferidos para a ala "C" e permaneceram separados do convívio com os demais presos. Proibidos de sair das celas, ficaram sem banho de sol por dois meses e suas visitas permaneceram suspensas nesse período ${ }^{431}$. Gilney Amorim Viana ficou isolado nesta galeria durante seis anos e meio, onde tinha acesso apenas ao pátio lateral. Na avaliação de Viana:

“[...] aquilo foi um ato de desobediência e não um motim. Nós não aceitamos entrar na cela sem que se esclarecessem os problemas com a comida, a ausência da carne etc. A comida não estava adequada. Aí eles cercaram o presídio, chamaram as tropas e deram um ultimato para a gente: '- Se até tal hora vocês não entrarem nas celas, nós vamos entrar em ação, com cão, bomba e armamento.' Nós esticamos a corda até o limite. E, depois, recuamos e nos recolhemos às celas. Nós rejeitamos o primeiro ultimato, eles viram que tinha resistência, porque depois de almoçar você tinha que se recolher às celas e nós não fomos, não aceitamos. [...] Aí, depois disso, fiquei na 'tranca dura’! ${ }^{432,}$

De acordo com a descrição de Fernando Sanna Pinto, a penitenciária de Linhares era um “inferno”, pois mantinha um sistema de 'recompensas e punições’ que dividia os presos em três blocos. No Bloco A estariam os considerados "recuperáveis" e os que acabavam de chegar. No B, aqueles tidos como "menos perigosos" e, no Bloco C, os “irrecuperáveis”. Na Penitenciária de Linhares era comum presenciar policiais militares espancando presos políticos, sem razão aparente ou explicação ${ }^{433}$.

\footnotetext{
${ }^{429}$ V. Comissão Interamericana de Direitos Humanos - Informe anual 1973 - $1^{\text {a }}$ seção, parte III Brasil; citado em RiBEIRO, Flávia Maria F. op.cit., p.135-6.

430 SAnNA PinTo, Fernando. Depoimento apresentado à Comissão de Anistia. Montpellier (França), 26/05/2005. Arquivo pessoal de Fernando Sanna Pinto.

${ }^{431}$ RiBEIRO, Flávia Maria F. op.cit., p.149-50.

${ }^{432}$ Entrevista concedida por Gilney Amorim Viana à autora. Idem, ibidem.

433 SANNA PINTO, Fernando. Idem, ibidem.
} 
Uma das punições mais severas a presos políticos que se tem notícia foi imposta aos prisioneiros do Rio de Janeiro transferidos dos presídios da Ilha Grande e do continente para a Fortaleza de Santa Cruz. Ali ficaram confinados cerca de 9 meses numa cela que era um buraco cavado na rocha, o qual chamavam de "túnel velho”. Os militares tinham como objetivo estabelecer uma experiência com um sistema de premiações relacionado ao comportamento dos presos [REZENDE; BENEDITO, 2000: 126].

Na Fortaleza, o castigo reservado aos que adotavam posturas de enfrentamento era muito severo, o mesmo utilizado no período da escravidão: o confinamento nas “celas do passado”. Os escravos mais rebeldes condenados à morte ficavam nestas celas, buracos escavados na pedra que variavam de 1,80 a 0,70 centimentros. Da cela eram obrigados a ver o enforcamento dos outros, antes de serem executados. José Roberto Rezende esteve preso durante 7 dias nessas celas, como castigo contra um protesto dos presos [REZENDE; Benedito, 2000: 127-30]. Depois de um período de conflitos com Celso Lungaretti, um dos presos políticos e militante da VPR que “arrependeu-se” na televisão, os presos protestaram contra a permanência dele na cela, os policiais reprimiram com bombas de gás lacrimogêneo e cacetadas. Nessa atmosfera, os presos trazidos da Ilha Grande (há mais tempo na Fortaleza) prepararam uma greve de fome com o objetivo de conseguirem transferência para o continente:

\begin{abstract}
"Na Fortaleza de Santa Cruz, [...] soubemos depois que eles queriam criar três níveis de graduação de presídios: os dos recuperáveis, os irrecuperáveis e dos passíveis de recuperação.

[...] Quando nós fomos para lá, em março de 1974, [...] não sabíamos para onde estávamos sendo levados. Chegando lá é que a gente viu onde estávamos. [...] saímos da mão da PM e ficamos nove meses sob a custódia do Exército brasileiro.

[...] nós estávamos num lugar como se fosse uma adega, um depósito encravado na rocha, no fundo da rocha tinha uma água que escorria e ia direto para o mar; do alto da cela, com cinco ou seis metros de altura caía um pó como se fosse um bolor que batia no nosso rosto e criava micose de barba, porque eram coisas centenárias, seculares.

Ali foi o lugar onde estiveram presos escravos, onde esteve Andresito Artigas, um herói do Paraguai, e Garibaldi. Um lugar que foi usado no período colonial como masmorra, como centro de tortura. Tanto que na Fortaleza de Santa Cruz tinha um lugar que chamavam de 'cova da onça', por causa dos gritos dos torturados que pareciam com o urro da onça, onde eles faziam o serviço completo. Ali, esquartejavam e o cara caía num buraco e ia direto para o mar, no período colonial. [...] Mas foi nesta prisão histórica, com essa história macabra de tortura, de assassinatos políticos, que nós [...] fizemos uma greve de fome [em novembro] que obrigou a uma intervenção do I Exército no comando da Fortaleza. Naquele momento, o major Magno deixou de ser o comandante por intervenção do I Exército. Eles queriam acabar com a nossa greve de fome, porque a pressão internacional foi grande. [...] acho que foram uns 9 dias de greve de fome ${ }^{434}$.,
\end{abstract}

${ }^{434}$ Entrevista concedida por Rômulo Noronha de Albuquerque à autora. Idem, ibidem. V. REZENDE; BENEDITO, op.cit., p. 127-30. 
Esta situação extrema foi superada, pois a greve de forme foi vitoriosa. Por meio da negociação intermediada pelo major Miranda, do QG do I Exército, os presos políticos foram enviados de volta para o continente classificados como “irrecuperáveis”, mas conquistaram todas as suas reivindicações. Nas vésperas das eleições de 1974, retornaram ao Presídio Provisório Hélio Gomes, o "PP”, e, em seguida, para o presídio da Ilha Grande $^{435}$.

Tal como demonstram estas descrições, o panorama do sistema carcerário com o qual tiveram que lidar os presos políticos brasileiros possuía peculiaridades e variações locais, que o tornavam particularmente multifacetário, não sendo entretanto de se desconsiderar a genérica presença de péssimas condições de existência e os constantes maus-tratos inflingidos, que exigiram recorrentes apelos para lutas variadas, frequentemente moldadas sob a tônica das greves de fome.

\subsection{A comunicação dentro e fora dos presídios: as visitas e a correspondência}

Os primeiros presos políticos a chegarem ao presídio Tiradentes em 1969 aprenderam com os presos comuns o alfabeto dos surdos-mudos ${ }^{436}$ (instituído com modificações ${ }^{437}$ ) para facilitar o contato com os demais companheiros. Com os presos comuns aprenderam também a usar a "teresa" - um fio com um peso numa das extremidades que servia para transportar bilhetes chamados "papagaios” e outros objetos de uma cela a outra. Um preso girava o barbante e o arremessava até alcançar o braço estendido de outro preso na janela ou porta de uma cela adiante ${ }^{438}$. Em São Paulo, a “teresa” era muito utilizada, particularmente, na Penitenciária, onde a imposição do isolamento foi mais intensa ${ }^{439}$.

A comunicação nos presídios exigia uma iniciação com a população carcerária para aprender as gírias, os sinais, os gestos e ritos. O domínio da sinalização, da técnica do telégrafo e do código Morse foi indispensável para o convívio nos presídios políticos. Usavam também a comunicação do reflexo do espelho na contraluz do sol para sinalizar a

\footnotetext{
${ }^{435}$ Entrevista concedida por Rômulo Noronha de Albuquerque à autora. Idem, ibidem.

${ }^{436}$ MAIA, Dulce de Souza. “A morte, as donzelas e a Canção dos pescadores”, em Tiradentes, op.cit., p.103.

${ }^{437}$ Entrevista concedida por Carlos Alberto Lobão Cunha à autora. SP, 10/10/2010.

${ }^{438}$ MAIA, Dulce de Souza. “A morte, as donzelas e a Canção dos pescadores”. Idem, ibidem; PITTOLI, Carlos Roberto. “A fortaleza e o queijo”, em Tiradentes, op.cit., p.116.

${ }^{439}$ Entrevista concedida por Artur M. Scavone à autora. Idem, ibidem.
} 
aproximação de guardas e impedir que a mensagem pudesse ser interceptada ${ }^{440}$. No Carandiru, faziam uso de pedaços de espelho para observar o corredor e garantir a segurança das trocas entre as celas e conversas ${ }^{441}$. Na ala feminina, a troca de mensagens e informações era chamada de "Rádio Sueca" para evitar que as autoridades e funcionários do presídio descobrissem a origem das fontes e canais dessas "notícias"442.

No período em que os presos políticos passaram a ocupar parte do Pavilhão II do Tiradentes, eles se comunicavam com os companheiros do Pavilhão I por meio da linguagem de sinais, principalmente, no horário do banho de sol, que ocorria em horários distintos. Da janela de algumas celas os presos conversavam com os que estavam no pátio $^{443}$.

Os militantes da ALN, em especial, estabeleceram modificações no alfabeto dos surdos-mudos para não serem compreendidos pelos demais e assim manter uma comunicação exclusiva entre seus membros, conforme relato de Carlos Alberto Lobão Cunha:

\begin{abstract}
“A gente 'escrevia' com as mãos. Fizemos uma coisa que as outras organizações ficaram irritadas, porque inventamos sinais diferentes para todas as vogais, então, só nós sabíamos o que estava sendo comunicado; e fizemos também um sinal diferente para as consoantes mais usadas: P, R, C. Nós da ALN tinhamos um alfabeto próprio e que ninguém podia ler a não ser a gente. E assim o Pavilhão I se comunicava com o II etc ${ }^{444}$.”
\end{abstract}

A ala feminina comunicava-se como os presos políticos de diversas maneiras, inclusive através de um pequeno buraco feito na parede da cela de fundo do Pavilhão II:

“[...] A gente tinha contato com as meninas, era um contato direto, porque da cela 21, acho que era a de número 21, a gente furou um buraco de uma espessura de mais de 30 centímetros, um buraco superfino que a gente chamava... de algum nome feminino. Por ali se trocava papéis diretamente. Enrolava-se o papel no canudinho e tinha um horário marcado para passar. Marcávamos por meio do código morse. Você batia na parede e tinha a cela feminina do outro lado. A gente teve a pachorra de fazer isso... Chamava-se ‘julieta'?!? Não sei, não lembro como se chamava. O buraco era tapado com gesso. Aliás, boa parte da cela 21 tinha aqueles ladrilhos de gesso branco, atrás deles sempre havia um buraco no qual era guardado um texto. A gente guardava, fechava o ladrilho, passava o gesso e, assim, guardava as coisas ${ }^{445}$."

\footnotetext{
${ }^{440}$ LOBO, Elza F.“Os sinais, os gestos e os ritos”, em Tiradentes, op.cit., p.219.

${ }^{441}$ PitToli, Carlos Roberto. “A fortaleza e o queijo”, em Tiradentes, op.cit., p.116.

442 LoBo, Elza F, op.cit., p.219.

${ }^{443}$ Entrevista concedida por Carlos Alberto Lobão Cunha à autora. SP, 05/05 e 17/09/2009. AAPP/AELLEI.

${ }^{444}$ Idem, ibidem.

${ }^{445}$ Idem, ibidem.
} 
A comunicação foi facilitada, quando alguns presos políticos, como o médico Aytan M. Sipahi e os dentistas Marlene Soccas e Carlos Botazzo, começaram a tratar da saúde dos demais presos ${ }^{446}$, o que lhes permitia veicular informações e bilhetes entre os presos políticos.

No Tiradentes e demais presídios políticos era comum ouvir presos e presas cantarem para comemorar alguma data especial, para espantar a monotonia e a chatice da rotina de arbítrio. Cantar era uma maneira de transmitir mensagens, emoções, mas, principalmente, esperança. Para muitos presos do Tiradentes e da Casa de Detenção, os sábados ou domingos eram marcados pelo hino “A Internacional”, cantado em homenagem aos companheiros mortos ou desaparecidos. Na despedida dos companheiros que saíam, todos cantavam para aquele que partia a "Suíte do Pescador” e, muitas vezes, “A Internacional” também ${ }^{447}$. Em determinado período, “Apesar de Você” de Chico Buarque virou hino dos presos, cantada aos berros com batuque de latas e mesas. Às vezes, a cantoria era seguida de represálias tais como as vistorias violentas nas celas ${ }^{448}$.

Os rádios eram artefatos importantes, pois sintonizavam o noticiário nacional e internacional e estabeleciam alguma relação dos presos com o "mundo exterior”. Em determinado período era autorizado somente a entrada de rádios AM/FM no presídio Tiradentes. Em outros momentos, foi possível adquir rádios Transglobe e assim, regularmente, os presos sintonivam as transmissões da BBC, de Londres, e da Rádio Pequim $^{449}$. De acordo com o relato de Carlos Alberto Lobão:

"Eu lembro que nós passamos um ano no Carandiru, quando voltamos para o Tiradentes só se podia ter radinho de pilha AM/FM, mas a gente tinha um Transglobe Philco que sintonizava rádios de Moscou, Havana, Pequim. Era um Transglobe enorme de uns trinta, quarenta centímetros, que guardávamos e nunca 'caiu'. Ele foi levado lá para dentro com corrupção de funcionário; com suborno, se consegue tudo em qualquer prisão, ainda mais numa prisão brasileira ${ }^{450}$."

Na Penitenciária do Estado de São Paulo era permitido adquirir apenas rádios AM/FM, mas a comunicação entre os presos era mantida com muita dificuldade devido ao rigoroso isolamento imposto aos presos. A criatividade foi acionada para lidar com a

\footnotetext{
${ }^{446}$ V. Tiradentes, op.cit.; e "Abaixo-assinado dos presos políticos do Recolhimento de Presos Tiradentes (presídio Tiradentes)” dirigido ao STM, às I e II Auditorias de Guerra da IIa. Região Militar, 28/03/72; em POLITI, M. op.cit., p.133.

${ }^{447}$ SouZA, Dulce Maia de, op.cit.; CunHA, Carlos Alberto Lobão da Cunha, em Tiradentes, op.cit., p.245.

${ }^{448}$ FERRO, Sérgio. “Auto-retrato a chicotadas”, em Tiradentes, op.cit., p.217; SÁ, Ayberê Ferreira de. Das ligas camponesas à anistia. Memórias de um militante trotskista. Recife, Fundação de Cultura Cidade de Recife, 2007, p.201.

${ }^{449}$ SISTER, Sérgio. “Cadeia só funciona para inocentes que nem eu”, em Tiradentes, op.cit., p.207.

${ }^{450}$ Entrevista concedida por Carlos Alberto Lobão Cunha à autora. Idem, AAPP/AEL-LEI.
} 
situação, os presos utilizavam um tipo de comunicação feita por meio do esgoto do presídio chamado "telefone»" ${ }^{451}$. Nas palavras de Scavone:

“[...] Na Penitenciária era uma gritaria, porque [...] eram três ou quatro pavilhões construídos um depois do outro e havia uma distância grande entre eles. E como você conversava? Você ficava sozinho na cela, não tinha com quem falar, então, você conseguia falar com alguém que estivesse no outro pavilhão, a uns 100 metros de distância, berrando. Era um berreiro para você falar com os caras ou falar com alguém do seu lado, que você não via, o cara de cima, o debaixo ou o do lado de cá.

[...] para gente se comunicar com os outros, inclusive com o cara preso na cela forte, a gente tirava água do sifão da privada turca (antes jogava água para limpar), porque o encanamento era um só e, embaixo, também tirava-se o sifão. Aquele cano de esgoto virava um meio de comunicação e o cara gritava: “- Eu quero ouvir o jogo do Corinthians hoje!” Você ligava o radinho e deixava em cima da privada para o cara ouvir o jogo, inclusive, aquele que estava na cela forte lá embaixo, pelado, molhado. Isso era bom para ele se distrair. A comunicação entre nós era difícil, porque não tinha como a gente se falar e ficar berrando [na janela], porque eles [os policiais] poderiam acompanhar. Então, a gente usava o código morse na parede, ponto era uma batida e traço eram dois pontos e, assim, a gente conseguia se comunicar. De uma cela para outra a gente se comunicava pelo buraquinho da cela com o código Morse também. Então, eu assoviava para o Genoino, que estava na cela da frente, pois eu queria passar a informação para ele, por exemplo, que hoje tinha cinema na Penitenciária, que era a única coisa interessante lá. Descia todo mundo para um lugar assistir um filme, era uma coisa fantástica para a gente. Creio que isso acontecia a cada 15 dias. Se você queria falar alguma coisa como: "Vai ter um abaixo-assinado no cinema, hoje”, então, eu chamava o Genoino. Ponto, era uma passada de dedo assim, dois pontos você fazia assim, era traço. [...] E, assim, você conseguia se comunicar, ficava com o olho doendo, mas conseguia se comunicar. E usávamos também um pedaço de espelho pelo lado de fora da janela, [...] você punha o espelho e falava em linguagem dos surdos-mudos, que na cadeia se usava direto ${ }^{452}$."

A comunicação entre os presos se dava de diversas maneiras, as brechas e soluções encontradas para sua limitação exigiam muita criatividade. Em determinados períodos, essa criatividade direcionou-se para a criação de textos e a montagem de peças teatrais, favorecida também pela concentração de diversos presioneiros ligados às artes cênicas. No presídio Tiradentes, principalmente, havia muitas presas políticas ligadas ao teatro, tais como Heleny Telles Guariba, Elza Ferreira Lobo, Nilda Maria, Isa Freazza, Dulce Maia de Souza, Maria Barreto Leite e Dudu Barreto Leite ${ }^{453}$.

\footnotetext{
${ }^{451}$ Entrevista concedida por Manoel Cyrillo de Oliveira Netto à autora. Idem, ibidem.

${ }^{452}$ Entrevista concedida por Artur M. Scavone à autora. Idem, ibidem.

${ }^{453}$ V. LOBO, 1997: 221-24; e entrevistas concedidas por Dulce de Souza Maia e Elza F. Lobo à autora. Idem, ibidem.
} 


\subsection{Os encontros e desencontros nas visitas}

As visitas eram essenciais para amenizar o isolamento imposto aos presos e estabelecer contato com o mundo exterior (o “mundão” no jargão da cadeia ${ }^{454}$ ), com parentes e amigos. Eram os dias mais esperados. Para muitos presos a vida cotidiana na cadeia girava em torno das visitas, conforme o relato de Carlos Alberto Soares, um dirigente do PCBR preso em Recife, em 1971:

“Os 'meninos' costumavam dizer o seguinte, que o nosso dia durava uma semana, porque nós marcávamos e organizávamos tudo para a próxima visita, vivíamos a ansiedade da espera da visita. Nós vivíamos de semana em semana e não de dia a dia, porque nos organizávamos em função das visitas, recebíamos notícias, recebíamos ajuda para o problema de alimentação, conversávamos com a nossa família e havia os encontros conjugais. Então, o nosso dia-a-dia era semanal! $!^{455,}$

As presas políticas confinadas no Tiradentes destacaram a importância das visitas, um momento de renovação e estreitamento dos laços afetivos e familiares, para o qual dispendiam tempo preparando-se. Lenira Machado contou-nos sobre a atmosfera predominante na véspera dos dias de visitas na ala feminina:

“À noite fazia-se limpeza de pele, máscaras de água fria nos olhos, algodãozinho nos olhos, principalmente, à véspera da visita. Colocávamos bobes no cabelo, a roupa mais bonita que tínhamos, queríamos aparecer bem para os familiares. Passar a roupa até as tantas da noite para, no sábado, ir bem até o pátio do presídio. Isso para a gente era uma festa, era um preparativo como se você estivesse aqui fora se preparando para um baile ou alguma coisa desse tipo. Sexta-feira à noite, na nossa cela, era uma movimentação: '- Me empresta isso, me empresta aquilo', '- Com que sapato você vai?', '- Eu vou com tal', ‘Ah, então empresta tal’. A gente fazia um troca-troca de coisas lá dentro ${ }^{456}$ !”

Na ala masculina, o dia de visita era motivo de ansiedade e de preocupação com a vaidade também. Antes e após a visita, era liberado o jogo de baralho; a maneira encontrada pelos presos para relaxar da tensão que esses encontros geravam ${ }^{457}$. Esses eram dias cheios de emoções, associados à imagem de festa e da movimentação típica de praça pública, onde as pessoas se abraçavam, brincavam com as crianças, riam, choravam e formavam grupos. Os dias de visita eram emblemáticos em função da atmosfera de solidariedade predominante, conforme relato de Aytan M. Sipahi:

\footnotetext{
${ }^{454}$ MAFrA, Márcia. “O mundinho, o mundão e seus (des)encontros”, em Tiradentes, op.cit., p.321-34.

${ }^{455}$ Entrevista concedida por Carlos Alberto Soares à autora. Recife (PE), 23/04/2010. AAPP/AEL-LEI.

${ }^{456}$ Entrevista concedida por Lenira Machado à autora. Idem, ibidem; e MAFRA, Márcia, op.cit., p.321-34.

${ }^{457}$ CunHA, Carlos Alberto Lobão, em Tiradentes, op.cit.
} 
"O dia de visita era uma festa, todo mundo se arrumava da melhor maneira possível e, depois, havia as comidas que as famílias traziam, que eram muito solidárias. [...] Eu recebia visita da Elenita e dos meus filhos, e do meu irmão. Ele morava no Rio, era alto funcionário da Eletrobrás e ficou com os dois filhos da Rita (minha irmã, presa no Tiradentes também). Ele vinha para a visita deles, ficava aqui e voltava. Teve um dia que ele falou brincando: '- Eu vou ficar preso também', porque ele ficou tomando conta de tudo. Ele dizia assim: '- Eu acho que é melhor ficar preso, porque estou trabalhando demais!'

[...] A coisa mais linda era chegar à visita e ver um daqueles presos trazer uma bolsa bonita e entregar para o seu familiar! Tanto, que eu tive de fazer uma para a minha mulher, mas não sei se o design surtiu o efeito que as outras surtiram. [...] Nunca fui bom em trabalhos manuais! A solidariedade era uma coisa bonita... ${ }^{45 \%}$.

No presídio Tiradentes, os presos políticos recebiam visitas inicialmente às quartas-feiras, mas, depois, elas foram transferidas para os sábados à tarde. As alas masculina e feminina recebiam visitas em pátios distintos, mas no mesmo horário ${ }^{459}$. Em determinado período, as visitas do Pavilhão I ocorriam em dias diferentes das do Pavilhão $\mathrm{II}^{460}$. Durante a semana, os visitantes começavam a chegar ao pátio por volta das $13 \mathrm{hs}$, juntamente com as presas políticas que tinham maridos ou parentes presos na ala masculina. Em geral, nesse dia as famílias que residiam em São Paulo eram mais presentes. Às 16hs, o encarregado do plantão iniciava a chamada dos presos para retornarem às celas e, então, começavam as despedidas, carregadas de pesar e lágrimas. Nas tardes de sábado formavam-se filas do lado de fora, à espera do término das rigorosas e demoradas revistas e da permissão para entrar no pátio. Era o dia em que havia maior presença de familiares de outras cidades e estados. Algumas famílias faziam o trajeto RioSão Paulo de ônibus todos os finais de semana.

O encontro dos casais ocorria às $3^{\mathrm{a}}$. feiras, era uma das poucas ocasiões para estabelecerem contatos e trocas de informações entre as duas alas de presídio. Ponchos de tricô ajudavam a despistar a atenção dos guardas dos carinhos mútuos. Durante uma hora conversavam sobre tudo, inclusive, sobre suas crises conjungais. Nos dias de visitias podia-se ver o pátio da ala feminina por um pequeno orifício do portão de ferro que separava o pátio da ala masculina. Os casais presos e formalmente casados recebiam as visitas em conjunto, sobretudo, quando tinham filhos, que eram trazidos pelos avós ou outros parentes. Alguns casais se formaram da troca de bilhetes durante as visitas de uma ala para outra ${ }^{461}$.

\footnotetext{
${ }^{458}$ Entrevista concedida por Aytan M. Sipahi à autora. Idem, ibidem.

${ }^{459}$ SIPAHI, Rita. "Em nome da rosa”, em Tiradentes, op.cit., p. 186.

${ }^{460}$ Entrevista concedida por Carlos Alberto Lobão Cunha à autora. SP, 10/10/2010.

${ }^{461}$ RoIG, Vicente. "Encontro e reencontro com o amor e a vida”, em Tiradentes, op.cit., p.129; OLIVEIRA, Eleonora Menicucci de. "Reconstruindo práticas de liberdade”, em Tiradentes, op.cit., p. 296-7.
} 
As visitas eram momentos muito valiosos para os pais e mães presos (em geral, uma minoria na população carcerária composta de presos muito jovens), porque podiam avistar-se com seus filhos, conforme ressaltou Eleonora Menecucci de Oliveira:

“Aos sábados, descíamos para as visitas dos familiares. Eu recebia muito poucas visitas, uma vez que minha família morava em Belo Horizonte. [...] As visitas da [minha filha] Maria [...] eram esperadas com grande ansiedade. Sua chegada me transformava em um ninho de alegria, com um coração materno do tamanho da saudade que sentia dela, enorme. Quando ela apontava no portão com uma de minhas irmãs, sempre de mãos dadas, era como se estivesse me falando de que seu 'porto seguro' estava em Duca, Beth ou minha mãe. Seus olhos grandes e negros sempre me perguntavam alguma coisa, curiosa desde pequena. Conversava com todos e reclamava das revistas da carceragem.

Maria recusava-se sempre a ficar comigo, na Torre, por mais algumas horas após as visitas. O dia que a carceragem autorizou sua permanência, conseguir que ela aceitasse foi muito doloroso e doído para nós duas. Embora todas as meninas da Torre procurassem agradá-la, ela chorava. Insegura, pedia pela tia Do Carmo. Imediatamente, eu a devolvi à minha irmã, e fiquei com minha dor de mãe ao sentir as marcas cravadas em sua tão pequenina vida ${ }^{462}$."

As visitas que contavam com a presença dos filhos geravam vivências de grande alegria e carinho, mas de muita tristeza também, pois os presos se confrontavam com o sentimento de separação iminente e a constatação do sofrimento dos filhos, o que os deixava particularmente preocupados, conforme o testemunho de Rita Sipahi a respeito de sua filha:

"Ela chegava para as visitas com uma carinha triste, mas logo estava conversando com os adultos - presos ou visitantes -, rindo, fazendo tudo com muita graça.

Desde a primeira vez que me encontrou presa, ainda no DEOPS, insistia em me levar de volta para casa. Sua tática era a de tentar convencer as autoridades carcerárias delegados, tiras, guardas, carcereiros, etc. - de que eu não podia ficar ali naquele lugar, pois precisava tomar conta dela e do irmão. E discursava, discursava. Eram literalmente discursos e que hoje eu não saberia reproduzir.

Começava por fazer perguntas e, com seu jeito especial de cativar, passava aos argumentos:

- Sabe... minha mãe precisa ir embora. É ela que leva a gente pra escola, põe a gente pra dormir, conta histórias..., etc. etc.

Quando, junto ao portão do presídio, eu os acompanhava me despedindo, era terrível ouvi-la proferir para a carcereira todas as suas falas, sem parar, e resistindo a sair, cheia de argumentos absolutamente procedentes ${ }^{463}$."

Ao final do dia, restavam os pratos de comida trazidos pelas famílias e a chamada “síndrome pós-visita”. Os jantares após a visita faziam a alegria da turma responsável pela cozinha, que ficava dispensada de ter de preparar a refeição. Instalava-se, então, um “momento mágico” no presídio, potencializado pela “energia emocional” trazida pelos

\footnotetext{
462 OliveIRA, Eleonora Menicucci de, em Tiradentes, op.cit., p. 298-9.

463 SIPAHI, Rita. "Em nome da rosa”, em Tiradentes, op.cit., p.187.
} 
familiares e visitantes; momento em que, conectados às notícias e às recentes lembranças deixadas pelos visitantes, sentia-se com força a saudade dos parentes, filhos e amigos e sonhava-se com o "mundo de fora"464. A visita foi retratada como uma "festa triste” por Aytan M. Sipahi, pois gerava sentimentos ambíguos e era seguida da "síndrome pósvisita”:

\begin{abstract}
"Eu era casado e tinha dois filhos, a Elenita se desdobrava para cuidar deles e me visitar... Depois que eu casei, ela comprou um carrinho e nas visitas ela trazia um bocado de coisas, porque as celas organizavam uma lista de pedidos e davam para as mulheres e os familiares. Como minha mulher tinha mais facilidade do que as outras, ela já tinha uma vida profissional, eles sempre pediam muita coisa para ela...

[...] Você ia para a visita feliz, tinha aquelas duas, três horas, nunca tinha visita íntima, mas era uma felicidade total com os filhos. Depois aquilo acabava e você ficava muito impotente, as coisas estavam acontecendo lá fora: o filho ficava doente ou a mulher tinha uma dificuldade e você não tinha possibilidade de intervir. Isso dava uma tristeza, era uma solidão pós-encontro amoroso, pós-encontro com a família. Era aquela solidão e você sente a sensação de que você de fato é preso. Um dia eu estava numa discussão com um carcereiro e dizendo a ele que ele também era prisioneiro das circunstâncias, da vida terrível que ele levava e tudo isso, que ele era tão preso quanto a gente, em função das limitações políticas dele. Fiz todo um raciocínio lógico e o pessoal estava ouvindo a conversa. O carcereiro acabou com todos meus argumentos: '- É doutor Aytan, mas eu acabo meu horário e vou embora para casa. E o senhor fica aqui!’ (risos). [...] Isso foi algo lapidar, ele mostrou o que é a liberdade ${ }^{465}$."
\end{abstract}

Na Casa de Detenção, durante o período em que os presos políticos permaneceram no Pavilhão 8, os horários reservados às visitas e ao banho de sol eram sistematicamente suspensos, de acordo com o relato de Antonio Roberto Espinosa, dirigente da VarPalmares preso no Rio de Janeiro em 21 de novembro 1969, juntamente com sua companheira Maria Auxiliardora Lara Barcelos e Chael Charles Schreier, assassinado sob tortura no dia seguinte, na $1^{\mathrm{a}}$. Companhia da PE, na Vila Militar:

“[...] O Pavilhão 8 tinha 700 presos e nós éramos uns 32 presos políticos. [...] Normalmente, o quinto andar era um andar de castigo, celas individuais, então, nós ficávamos sem contato. [...] Foi um período [...] em celas individuais, praticamente sem visitas, porque vira e mexe havia algum problema. Durante uma determinada época, por exemplo, deu uma peste, então a cadeia ficou em isolamento, não tinha visita, vira e mexe caía alguém, preso comum, no corredor. Das celas que davam para frente do pátio, lá embaixo, ficava uma enfermaria que não tinha médico, outros presos atendiam, era muito precária. Você olhava e tinham colocado camas até do lado de fora, no pátio, porque não cabiam dentro da enfermaria. Você preso, a peste te cercando e se aproximando. Não acabou pegando nenhum preso político, mas isso durou um mês e meio ou dois, e morreu gente. Nós ali, vendo a peste chegar, sem visita, o pessoal de fora não sabia o que acontecia. Demorou um tempo para que os advogados fossem informados, mesmo eles tiveram restrição para fazer contato com os presos. Foi um período extremamente complicado, você não sabia quando tinha banho de sol, chegamos a ficar acho que uns

\footnotetext{
${ }^{464}$ Alessi FILHO, Vicente. “O pau do loirão e os ovos que ‘teresa’ traz”, em Tiradentes, op.cit., p.166-7.

${ }^{465}$ Entrevista concedida por Aytan M. Sipahi à autora. Idem, ibidem.
} 
três ou quatro meses sem banho de sol, sem nada, sem sair da cela. Quando saíamos era aquele negócio, não ver ser humano é... Tinha alguns companheiros que falavam como loucos, quando saíamos [...]. Depois de três meses sem ver um ser humano, sem falar com um ser humano, louco por um ouvido [...] e, quando você via, de repente, acabava o banho de sol $[\ldots]^{466}$.”

Na Penitenciária do Estado de São Paulo, as visitas se davam em condições bastante restritivas, pois ocorriam uma vez por semana no parlatório e tinham duração de cerca de 40 minutos $^{467}$. As visitas acabavam sendo experiências difíceis e dolorosas, principalmente, para os filhos dos presos, conforme relato de Lenira Machado:

“[...] o Altino e alguns outros companheiros estavam na Penitenciária numa situação de castigo. [...] era um horror, primeiro porque eu e o Altino estávamos separados, mas eu não podia, mesmo estando solta, pensar em me separar legalmente, porque eu só podia entrar lá com a certidão de casamento. Se eu não tivesse a certidão ele não recebia visita. Então, você tinha essa restrição e tinha o parlatório.

O parlatório sempre existiu na Penitenciária. Você tinha um lado da mesa e não podia passar, não podia esticar as mãos. A polícia toda em volta de você escutando o que conversávamos e não podíamos nem pegar na ponta da mão da pessoa! Eu tinha um problema seríssimo com o Aritanã, porque ele queria me abraçar e ao pai, mas havia a reação dos policiais ${ }^{468}$."

No presídio do Hipódromo, os presos recebiam regularmente visitas de familiares e amigos nas tardes de sábado, durante cerca de três horas. Os presos casados legalmente também podiam receber visitas em conjunto, no pátio da ala masculina ${ }^{469}$.

Nos estados do Rio de Janeiro e de Pernambuco, as famílias tinham outros obstáculos a enfrentar para conseguir visitar os presos políticos, pois, em determinados períodos, eles ficaram confinados em presídios distantes dos centros urbanos, como o Presídio de Ilha Grande (RJ) (o que ocorreu até 1975) e a Penitenciária da Ilha de Itamaracá (PE) (até 1979). Segundo Rômulo Noronha, militante da ALN preso no dia 11 de março de 1970 no Rio de Janeiro, o isolamento imposto pela distância do presídio da Ilha Grande dificultava enormemente as visitas dos parentes. Do Rio de Janeiro, as famílias tinham que se dirigir a Mangaratiba e de lá pegavam um barco para a ilha. O tempo de permanência permitido na ilha era curto, apenas 3 horas, pois, do contrário, perdiam o barco de volta. Quando havia uma tempestade, era necessário esperar o mar se acalmar para pegar outra embarcação, mas, naquela época, as pousadas não eram comuns

\footnotetext{
${ }^{466}$ Entrevista concedida por Antonio Roberto Espinosa à autora. SP, 25/05, 06 e 18/08/2009. AAPP/AELLEI. V. tb. Dossiê Ditadura, op.cit., p.164-6.

${ }^{467}$ Entrevista concedida por Artur M. Scavone à autora. Idem, ibidem; e BETTO, Frei. Cartas da prisão, op.cit., p.53.

${ }_{468}$ Entrevista concedida por Lenira Machado à autora. Idem, ibidem.

${ }^{469}$ Entrevista concedida por Maria Amélia de Almeida Teles à autora. Idem, ibidem.
} 
na ilha, o que criava mais obstáculos aos visitantes, quando havia problemas desse tipo [REZENDE; BENEDITO, 2000:132]:

"No início, eu tinha visita só da minha mãe, porque a minha companheira ainda estava sendo procurada, clandestina. As visitas ocorriam a cada 21 dias e eram somente de familiares diretos. [...] A Ilha Grande era isolada de tudo. [...] Depois conquistamos que as visitas fossem a cada 15 dias, mas foi preciso fazer 3 greves de fome lá para conquistar nossos direitos. ${ }^{470}$."

De acordo com o testemunho de Lúcia Murat, além da localização do presídio, havia outras dificuldades a serem enfrentadas, como as perseguições políticas que continuaram depois de solta, em 1974. Havia também vicissitudes no âmbito afetivo que dificultavam enormemente as relações amorosas com os presos e as visitas na Ilha Grande:

\begin{abstract}
"Quando eu saí da prisão, fui visitar o Cláudio [Torres da Silva] ${ }^{471}$, que estava preso na Ilha Grande. A gente reatou o namoro, mas não se casou, eu podia visitá-lo sendo 'oficialmente' concubina. Eles deixavam, se você comprovasse que tinha vivido junto mais de cinco anos. A gente pegou umas testemunhas que comprovaram e pronto. Antes, quando estávamos presos, a gente se correspondia, mas isso eu podia fazer com qualquer pessoa, acho que era possível se corresponder com outros presos.

[...] Eu tinha sido expulsa da faculdade, mas a mamãe conseguiu uma transferência [...] para a UFF. Comecei a trabalhar no JB, mas fui demitida, porque o SNI mandou. Depois disso, comecei a ser perseguida pelo CCC. Eu trabalhava no jornal Opinião e eles mandavam carta para lá, foi um caos. Mandaram carta para minha família... Depois, eu passei a namorar outro cara, o Cláudio estava preso e tinha esses conflitos todos. Eu não aguentava mais cadeia, mas tinha que ir visitá-lo na Ilha Grande. Eu ia para lá muito mal, não aguentava mais aquilo. Aí resolvi ir para o Rio Grande do Sul com esse cara, a título de fugir do CCC. Fiquei seis meses no Rio Grande do Sul e, quando voltei, tudo se acalmou. [...] O Cláudio foi solto antes da anistia, depois que ele foi solto, eu não fui mais à cadeia ${ }^{472}$.”
\end{abstract}

Nas visitas, apesar das vicissitudes, predominaram os encontros e trocas de todos os tipos e delas surgiram casamentos, filhos e muitas conversas com advogados, padres, artistas, cantores, políticos, que, aos poucos, foram ampliando e fortalecendo os vínculos com o "mundo exterior” e a rede de solidariedade e apoio aos presos políticos no Brasil.

\footnotetext{
${ }^{470}$ Entrevista concedida por Rômulo Noronha de Albuquerque à autora. RJ, 22/03/2010. AAPP/AEL-LEI.

${ }^{471}$ Cláudio foi um dos dirigentes do MR-8 (DI-GB) que participou do sequestro do embaixador norteamericano em 1969.

${ }^{472}$ Entrevista concedida por Lúcia Murat à autora. Idem, ibidem.
} 


\title{
3.4.1. As visitas conjugais
}

Os presos políticos de São Paulo foram os que menos usufruíram das visitas conjugais ou "visitas íntimas”, como eram chamadas. Nos demais estados, embora em períodos distintos, os presos políticos desfrutaram desse direito. Eventualmente, a direção dos presídios proibia as visitas conjugais para impor uma punição disciplinar. Em função da suspensão das visitas conjugais, algumas vezes, organizaram-se protestos, tais como o das famílias, esposas e companheiras dos presos políticos de Pernambuco, feita na Assembleia Legislativa, para assegurar esse direito. O relato de Carlos Alberto Soares, preso na Casa de Detenção de Recife, ilustra a atmosfera dessas visitas:

\begin{abstract}
"Quando eu cheguei ao presídio, não havia o que nós chamamos de encontros conjugais. Então, nós fizemos a reivindicação para ter direito, já que os presos comuns tinham. Mas não havia a menor estrutura para isso e nós também não tínhamos como montar essa estrutura. Havia lá uma coisa que ainda hoje me arrependo de não ter tirado foto. Para receber as suas companheiras, os presos comuns faziam o que a gente chamava de 'barraquinha'. Você imagine, eles colocavam na parede do presídio um plástico na diagonal, o que formava uma espécie de triângulo com ângulo reto e dentro botavam uma cama. O tamanho máximo da barraca era o de uma cama. Você cobria aquilo ali, forrava com papel. Era um negócio terrível. Tinha uma comissão de encontros conjugais, um pessoal que encaminhava as coisas, porque era necessário dar um dinheirinho para a guarda do presídio e ajudar os presos comuns a melhorar a capa que eles usavam no sábado. Nossas visitas eram no sábado e as deles, no domingo. Nós usávamos essas barraquinhas para os encontros conjugais. Havia uma comissão para organizar os horários, porque nós tínhamos, por exemplo, 4 ou 5 barracas dessas e 10 casais e a visita durava no máximo três horas. Então, havia um horário para a entrada e outro para a saída, havia duas horas no máximo para você dividir em 2 ou 3 casais. Tudo isso era organizado. Nós conseguimos botar um plástico por cima, tentamos melhorar algumas coisa junto aos presos comuns. Isso funcionou e foi assim que surgiram os meus dois filhos, nessas barraquinhas!

[...] No começo, alguns presos políticos não quiseram usar as barracas. Na época, a minha esposa, a Rosa, estava presa no Bom Pastor. Nós conversamos e ela ia me visitar lá, tinhamos visitas conjugais uma vez por semana. [...] Nós começamos a ter esses encontros e algumas pessoas que tinham um pouco mais de resistência foram se acostumando etc. Ao final, um certo número de companheiros que tinham companheira dividiu os horários e organizaram esses encontros conjugais. E foi assim até sairmos da Casa de Detenção [...] e irmos para Itamaracá ${ }^{43}$ ”.
\end{abstract}

No início, essas vistas conjungais não eram institucionalizadas em Recife, o que não representou um obstáculo para os presos comuns e políticos, que as organizaram com eficiência. Em outros períodos, porém, essas visitas foram instrumentos de maior controle coercitivo, conforme Marcelo Mário de Melo:

\footnotetext{
${ }^{473}$ Entrevista concedida por Carlos Alberto Soares à autora. Idem, ibidem.
} 
"Havia visita íntima desde o começo. Na Casa de Detenção do Recife, a vida sexual dos presos não era legalizada. Então, os presos comuns tinham as 'barraquinhas', [...] eles corrompiam os guardas e era permitido que eles tivessem seu encontro sexual. [...] A gente também dava 'bola' aos guardas e alugava as barraquinhas dos presos comuns. $\mathrm{O}$ nosso ministro de relações sexuais, que cuidava disso com muito zelo, era o José Arlindo Soares, um cientista social daqui. [...] Em julho de 1973, fomos transferidos para a penitenciaria Barreto Campelo e lá os encontros conjugais eram legalizados. Havia uma área de celas separadas para os encontros sexuais. Você tinha que fazer um requerimento, dar o nome da companheira e mandar um retratinho dela.

Eu tive uma dificuldade, porque no primeiro namoro, mandei o retratinho; aí acabou o namoro, então, mandei o segundo. [...] No terceiro namoro, me chamaram e disseram que isso era atentado à moral e aos bons costumes, que era um absurdo! Então, baixaram uma norma que entre o segundo relacionamento e o terceiro tinha que esperar um ano. Aí eu fiquei meio em pânico, tinha que esperar um ano... Mas essa norma terminou não vigorando ${ }^{474}$.”

Desde o início dos anos 1970, os presos políticos ficaram em uma ala separada na penitenciária de Salvador, na chamada galeria F. Depois de um período de luta para conquistar melhores condições carcerárias, as visitas íntimas foram autorizadas, conforme Theodomiro Romeiro dos Santos:

“Na Bahia, nós reivindicamos o direito a visita íntima. [...] Mas, no início, a gente não tinha nada, as nossas aspirações eram as elementares, que todos pudessem descer quando a primeira visita chegasse. Caso chegasse uma visita só, que todos pudessem descer para usufruir daquele momento de lazer, de distração. Eram essas coisas mais elementares que a gente queria, como poder circular na galeria. As outras coisas vieram depois que a gente conseguiu essas.

Acho que as visitas íntimas começaram, provavelmente, em janeiro de 73. Eu não me lembro, mas... Bruno, meu filho, nasceu em dezembro de 73, o que significa que deve ter começado nessa época.

[...] eu me separei na prisão e fiquei um bom tempo sem ser casado e tinha mais tempo, mais disponibilidade, aí, naturalmente, eu era a pessoa que [...] cuidava da creche, no dia das visitas. Acho que isso aconteceu de 74 a 79, quatro anos. Eu me dou muito bem com crianças, elas gostam de mim. E, assim, passei a manjar tudo, trocar fralda etc ${ }^{475}$."

Em março de 1975, alguns meses depois da greve de fome dos presos políticos da penitenciária do Estado de São Paulo, eles foram transferidos para o presídio político do Barro Branco. As celas eram coletivas e não ofereciam condições adequadas para receber visitas conjugais, mas os presos da cela 4 decidiram estabelecer escalas de horários para receber suas companheiras e esposas nos mocós da cela, aos sábados no dia regular das visitas $^{476}$.

Desde 1971, através de muita luta e greves de fome, os presos políticos da Ilha Grande conquistaram, inclusive, o direito a visita conjugal. Em maio de 1975, depois de

\footnotetext{
${ }^{474}$ Entrevista concedida por Marcelo Mário de Melo à autora. Idem, ibidem.

${ }^{475}$ Entrevista concedida por Theodomiro Romeiro dos Santos à autora. Idem, ibidem.

${ }^{476}$ Entrevista concedida por André Ota à autora. Idem, ibidem.
} 
realizarem uma greve de fome de 17 dias, os presos da Ilha Grande conseguiram ser transferidos para o presídio da rua Frei Caneca, onde ocuparam uma ala exclusiva para presos políticos, mantendo todas suas conquistas, inclusive, o direito a visita íntima. As celas eram coletivas, assim, estabeleceram escalas de horários e muitos começaram relacionamentos duradouros na cadeia, onde foram geradas algumas crianças ${ }^{477}$.

\subsubsection{A correspondência}

A troca de correspondência era muito valorizada entre os presos políticos, pois receber notícias e comunicar-se com o mundo exterior representava uma ruptura da lenta rotina e do isolamento dos presídios. Muitas vezes, as cartas serviram de estímulo para continuar a luta pela sobrevivência nos cárceres. Apesar de todas as limitações e censura impostas pela administração dos presídios, as cartas circularam em grande número. A autocensura tornou-se um hábito adquirido e necessário aos presos. Para muitos, as cartas eram um meio de escapar da dura realidade do presídio, o meio pelo qual desenvolviam sua imaginação e criatividade, conforme nos contou Beatriz Bargieri:

\footnotetext{
“Os dias de prisão na penitenciária também foram muito criativos, lá surgiu uma criatividade diferente. Eu escrevia dezenas de cartas ao mesmo tempo e tinha assuntos diferentes para cada um com quem me correspondia. Lá, aconteceu exatamente aquilo que diz a imagem que a gente ouve falar: '- O meu corpo está preso, mas a minha alma não'. Foi isso o que aconteceu, porque nunca escrevi tanto na minha vida, nunca imaginei tanto. Aconteceu algo extremamente rico, muito rico. No começo éramos duas presas. Havia uma sala na qual a gente podia ficar juntas, uma sala que herdamos das ex-presas políticas que foram juntando uma biblioteca, discos etc. Depois de um certo tempo, uns 6 meses depois, conquistamos esse espaço, porque antes ficávamos juntas com as presas comuns. Neste local, comecei a fazer bordado com lã etc. [...] e conversávamos sobre a vida de cada uma. Foi incrível essa convivência.

A gente se arrepende, mas eu joguei fora minhas cartas. [...] eu escrevia cartas coloridas, com aquelas coisas bem frescas [...]. Ainda estou pensando sobre o que vou fazer, porque soube que tem outras pessoas que guardaram [minhas cartas]. Certa vez, recebi uma carta de uma italiana que, em solidariedade, não sei, mandou-me uma carta. Eu mandei de volta outra carta, supercolorida, e ela respondeu dizendo que eles tinham chorado muito, porque eles estavam esperando me dar uma força, mas fui eu quem deu força a eles... ${ }^{478,}$
}

\footnotetext{
${ }^{477}$ V. ReZende; Benedito, op.cit., p.134; e Cipriano, Perly; VianA, Gilney A. Fome de Liberdade. A luta dos presos políticos pela anistia. Vitória, s.n., 1992, p.38.

${ }^{478}$ Entrevista concedida por Beatriz Bargieri à autora e Marcelo Ridenti. Idem, ibidem.
} 
Muitos presos políticos, conscientes de que enfrentariam longos anos nos cárceres, tentaram reorganizar suas vidas e relações afetivas por meio das visitas conjugais e da correspondência, conforme nos contou o jornalista e poeta Marcelo Mário de Melo:

\begin{abstract}
“Com relação à subjetividade, passado aquele momento de tortura, a gente sabia que tinha penas longas - eu imaginava que fosse sair depois de uns dez anos de prisão - então, eu estava preparado para uma cadeia longa. A minha perspectiva foi a de organizar uma rotina carcerária, com atividade física, [...] lia e escrevia muito na prisão. E batalhei pela reorganização da minha vida afetiva. Eu tinha uma companheira de uma relação de três anos, quando fui preso. Na clandestinidade, eu a via com dificuldade, porque eu estava fora do estado. Ela não foi mais me visitar, inclusive por questões de pressão política e familiar. Eu, então, comecei um namoro com uma menina que era presa política, havia uma atração entre nós antes da prisão, a Lilia Guedes, mas na época não houve nada. Havia uma atração e ela estava presa na colônia penal de Bom Pastor, aí a gente começou a se corresponder e nós começamos a namorar nas audiências de julgamento. Depois, com um ano e pouco de prisão ela foi solta e nós mantivemos essa relação por três anos. Ela morava no Rio de Janeiro, vinha passar as férias de meio e de fim de ano, [...].

Depois, comecei outro romance. [...] Eu escrevi muito, cartas, muita poesia, manifestos [e os diários das greve de fome]! Isso, do ponto de vista afetivo, teve muita importância, pois tive vários romances na prisão. Depois, tinha a 'queda', quando o namoro acabava e, as 'ressurreições', quando começava outro namoro ${ }^{479}$."
\end{abstract}

Muitas vezes, os presos coletivizavam as notícias lendo as cartas que chegavam para todo o grupo. As presas que eram mães tinham o hábito de ler as cartas de seus filhos para as companheiras de cela e este gesto tinha enorme significação, por sua grande carga afetiva, gerando maior integração entre elas ${ }^{480}$. Os pais também compartilhavam as notícias enviadas nas cartas de seus filhos [SANTOS, 2000: 11]. Não obstante a permanência das diferenças políticas entre os presos, a preocupação coletiva com as famílias de cada preso foi emblemática durante os anos de convívio nos presídios políticos.

O historiador Joel Rufino dos Santos, por exemplo, escreveu cartas coloridas e ilustradas para seu filho Nelson, à época com 8 anos, nas quais contava sobre o cotidiano da cadeia, mas também episódios da história do Brasil como o do Quilombo de Palmares, a do Candomblé e de Iemanjá, a do bonde no Rio de Janeiro etc ${ }^{481}$. Preocupados com a formação dos filhos, os presos explicavam nas cartas a teoria da evolução das espécies; ilustravam e resumiam livros que conheciam e inventavam estórias, até mesmo estórias em quadrinhos ${ }^{482}$. As cartas das quais se tem conhecimento traziam desde notícias sobre as famílias, cotidiano do presídio e disposições psicológicas dos presos, até análises sobre

\footnotetext{
${ }^{479}$ Entrevista concedida por Marcelo de Mário Melo à autora. Idem, ibidem.

${ }^{480}$ MENICUCCI, Eleonora. "Reconsturindo práticas de liberdade”, em Tiradentes, op.cit., p.298-9.

${ }^{481}$ SANTOS, Joel R. op.cit., p.35, 37, 41, 45, 49, 55, 61.

${ }^{482}$ LoBo, Elza F., em Tiradentes, op.cit., p.220.
} 
a conjuntura política e a estrutura do sistema prisional ${ }^{483}$. Alguns presos optaram por não escrever cartas, pois consideravam que elas poderiam acabar fornecendo informações para os órgãos repressivos ${ }^{484}$.

Em 1971, Frei Betto conseguiu que parte de suas cartas da prisão fossem publicadas no exterior [BETTO, 2009: 183]; como decorrência, a enfermeira Maria, do Presídio Tiradentes, teve de responder a uma sindicância. Apesar de proibido no Brasil, um exemplar do livro entrou clandestinamente no presídio. Após a publicação do livro estabeleceu-se uma censura especial à correspondência dos frades dominicanos presos. Frei Betto, então, criou um sistema de códigos que impedia os censores de compreenderem o conteúdo das cartas. Os frades passaram a usar um sistema de chave numérica que selecionava as palavras chaves do texto por meio de combinações, tais como 5-8-4 ou 4-7-8. O leitor deveria contar o número de palavras do texto criado pelo missivista, segundo um código baseado na combinação 5-8-4, conforme o exemplo relatado por Frei Fernando: “Deus bíblico é chamado Jeová, que pune o assassino e salva o assassinado, pois é assim pela mão divina, live de repressão, que os profetas, se vivos hoje, fariam de sua missão em Brasília a nova Babilônia infiel em verdade hoje ameaçada pelo uivo faminto do guaraí.” Assim chegaria à seguinte mensagem: “Jeová assassinado pela repressão de Brasília em Guaraí ${ }^{485}$.”

Ao longo de quase quatro anos, Frei Fernando dedicou-se também a registrar o cotidiano dos cárceres políticos por onde passou. Anotava em letra miúda no papel de seda e, em seguida, desmontava uma caneta Bic opaca, cortava ao meio o canudo da carga, enrolava ali as anotações e remontava-a. No dia de visita, trocava a caneta por outra idêntica levada por um dos frades que chegava para vê-lo. Os riscos eram permanentes, pois os presos eram revistados antes e depois das visitas e sempre ocorriam revistas violentas nas celas. Muitas vezes, Frei Fernando e outros foram obrigados a destruir suas anotações ou deixar de fazê-las. Frei Fernando também escondeu suas anotações em papel de seda dentro dos cigarros, protegido por fumo nas beiradas [BETTO, 2009: 55-6]. Sua caneta despertou as suspeitas dos carcereiros, mas seu diário não foi descoberto; assim como diversos documentos, manifestos e denúncias que chegaram ao exterior dos presídios durante todo o período ditatorial [BETTO, 2009: 12-3].

\footnotetext{
${ }^{483}$ MAFRA, Márcia, em Tiradentes, op.cit., p.320-34.

${ }^{484}$ Entrevista concedida por Alberto Henrique Becker à autora. SP, 11/03/2011.

485 BETTO, Frei. O diário de Fernando, op.cit., p.167. Jeová Assis Gomes, militante do Molipo, foi assassinado num campo de futebol na cidade de Guaraí (TO), em 09/01/72. V. Dossiê Ditadura, op.cit., p.305-6.
} 
Os presos recebiam muitas cartas de pessoas que participavam de campanhas de solidariedade organizadas pela Anistia Internacional e outras entidades de defesa dos direitos humanos. Essas cartas chegavam de diversas partes do mundo e tinham o objetivo de transmitir mensagens de esperança aos presos. Eventualmente, este tipo de correspondência se prolongava; outras vezes, porém, os presos não recebiam respostas às suas missivas, conforme nos contou André Ota, militante do Molipo preso em São Paulo no dia 20 de novembro de 1971:

"Eu tinha uns amigos que, depois fiquei sabendo que eram da Anistia Internacional, como o Victor e outras pessoas. E tinha outros conhecidos de outros grupos. Na verdade, o pessoal da Anistia Internacional apenas denunciava a prisão e a tortura. Eu sei que na cadeia recebi, por exemplo, cartas de senhoras, sei lá de onde, da Itália, da Áustria, dizendo que ficaram sabendo da minha prisão, aquelas coisas, e que sentiam muito. Eu respondi, mas depois não veio resposta e não sei aonde ficou essa correspondência ${ }^{486}$."

As cartas enviadas pelas pessoas articuladas à rede de solidariedade aos presos circularam em maior quantidade a partir da segunda metade da década de 1970. As cartas cumpriram um importante papel como suporte psicológico e político aos presos e meio de divulgação do que ocorria no Brasil, e de ampliação da rede de solidariedade. Vários ex-presos políticos entrevistados guardam com carinho dezenas de cartas da família, amigos e dessas pessoas que nunca conheceram, mas que foram solidárias naquele período difícil em que experimentaram situações extremas ${ }^{487}$.

\subsubsection{Restrições e controle da leitura e dos trabalhos manuais}

No presídio Tiradentes, assim como na maioria dos presídios políticos da primeira metade da década de 1970, a entrada de livros e material de leitura não era proibida, mas a restrição e o controle sobre seu conteúdo foram constantes. Os livros, jornais e revistas eram objeto de censura de acordo com seu conteúdo. Não obstante, em diversas ocasiões os presos criaram condições para organizar bibliotecas.

\footnotetext{
${ }^{486}$ Entrevista concedida por André Ota à autora. Idem, ibidem.

${ }^{487}$ José, Emiliano. As asas invisíveis do padre Renzo. op.cit.; V. entrevistas concedidas por Rosalina Santa Cruz de Oliveira, Reinaldo Morano Filho e Manoel Cyrillo de Oliveira Netto à autora. Idem, ibidem, entre outros.
} 
Os jornais no presídio Tiradentes eram mutilados pelos censores, o noticiário de interesse dos presos referente à política, prisões, sequestros e assaltos a banco ou à conjuntura internacional era recortado. Os presos direcionavam sua atenção, então, para as informações sobre as lutas internas da ditadura ${ }^{488}$. Livros teóricos ou marxistas entravam clandestinamente nos presídios por meio, principalmente, de familiares que trocavam as capas e as primeiras páginas dos livros. Em determinado período, de acordo com o relato de Alípio V. Freire, militante da Ala Vermelha preso em agosto de 1969:

"Tinhamos assinatura de jornais no Tiradentes, isso não era um problema, mas alguns livros não entravam, porque a auditoria não autorizava. A gente criava, então, outros mecanismos, vamos supor: a gente precisava do livro do Lênin 'O que fazer?'. Supondo que essa edição tivesse 300 páginas, é claro que a auditoria não ia liberar esse livro no Tiradentes, porque lá só entrava livro liberado pela auditoria. Você pegava um outro livro do mesmo tamanho, com a mesma quantidade de páginas, por causa lombada, e ia na auditoria. Eles carimbavam 'autorizando'. O livro era desmontado e colado o outro que nos interessava naquela capa, deixando a parte de índice, do título, do carimbo e a autorização da auditoria tal qual estava e ele entrava ${ }^{489}$."

Partes das bibliotecas montadas dessa maneira e os documentos produzidos pelos próprios presos ou considerados mais importantes ficavam escondidos sob o antigo assoalho das celas e/ou outros esconderijos improvisados. Lobão recorda-se que numa cela do Pavilhão II onde ficou, os livros mais importantes ficavam sob o assoalho, e eram identificados e puxados por um barbante que continha na extremidade próxima ao chão um pequeno pedaço de papel com o respectivo título:

“[...] Acho que as celas maiores eram a cela 21 e a 3, de onde fui transferido quando a gente começou a greve de fome. [...] Na cela 3, a gente fez uma biblioteca da seguinte forma: o chão da cela era de madeira, aquelas madeiras macheadas, a gente serrou em algum lugar dos dois lados, levantou a tábua e jogava os livros lá para dentro. Você levantava aquela tábua e só via os barbantes com os nomes dos livros. Puxava-se e lá estava o livro no final do barbante. A gente lia à noite. De dia colocávamos algum movelzinho em cima desse lugar. A gente sempre teve uma boa biblioteca em qualquer situação, quer dizer, boa dentro das condições possíveis de se conseguir na cadeia”490.

As luzes eram apagadas à noite e para ler os presos acendiam suas luminárias em seu "mocó", fechado com cortinas ou cobertores para não atrapalharem o sono dos demais. Havia uma biblioteca em cada cela, onde alguns presos mais hábeis

\footnotetext{
488 SISTER, Sérgio. “Cadeia só funciona para inocentes que nem eu”, em Tiradentes, op.cit., p.208.

${ }^{489}$ Entrevista concedida por Alípio Viana Freire à autora. SP, 19/12/2009, 15/03 e 13/04/2010. AAPP/AELLEI.

${ }^{490}$ Entrevista concedida por Carlos Alberto Lobão Cunha à autora. Idem, AAPP/AEL-LEI.
} 
improvisavam estantes. Outros chegavam ao requinte de fazer estantes com gavetas secretas, como os presos da cela 2, do Pavilhão I ${ }^{491}$.

Os ex-presos políticos entrevistados para esta pesquisa mostraram-se mais voltados à leitura e à luta diária para obter livros, jornais e informações. Alguns manifestaram certo aborrecimento com a disciplina e a prática de atividades físicas e de confecção do artesanato a que os presos se impunham para manter a organização e a limpeza das celas. De acordo com Aytan Sipahi:

“[...] Chegavam os jornais, todo mundo lia, comentava, quando havia algum assalto a banco alguns vibravam bastante, porque aquilo, naquele tempo, era considerado uma forma correta de fazer política, ainda hoje alguns consideram assim. Isso tudo era para nós uma atividade grande. Depois da comida, cada um lavava o seu prato e ia conversar, lia os jornais, ouvia rádio, ia ler os livros preferidos, ler Marx.

[...] Nós éramos bastante racionalistas. [...] Mas, em geral, não havia conflito entre fazer trabalho manual e ter uma atividade mais intelectual. [...] A ALN na cadeia tinha um sistema de solidariedade muito grande, o Lobão era um dos organizadores disso. Ele tinha quase como tarefa fazer alguma coisa para vender, para fazer solidariedade. Era muito bonita essa solidariedade, porque eram os jovens que vinham da classe média ou alta, da universidade e, hoje, a gente vê que nessa faixa de idade as pessoas estão classificando a solidariedade do cotidiano de coisa piegas. Uma coisa favorável aos presos políticos é que eles eram muito preocupados, não só com a solidariedade aos parentes dos que estavam presos, como com a solidariedade intercela, com as pessoas que estavam mais deprimidas, que não conseguiam levar a vida carcerária de uma forma razoável e sentiam-se deprimidos ${ }^{492}$.”

Os presos transferidos do Tiradentes para o Pavilhão 8 da Casa de Detenção, foram alojados no $5^{\circ}$. andar juntamente com os presos comuns, incursos na Lei de Segurança Nacional por assalto a banco. Esse convívio fez com que adquirissem traquejo no relacionamento com os presos comuns. Nesse período, as condições carcerárias pioraram consideravelmente, em especial com relação ao acesso a livros e jornais, mas eles conseguiram burlar a censura de maneira inusitada, conforme Carlos Alberto Lobão Cunha:
“A gente ficou em cela individual, com lâmpada de 40 velas e só podia entrar lápis e papel, mais nada. O jornal chegava da página de esporte em diante. Naquela época, o responsável por cada Pavilhão era chamado de Chefe de Disciplina. O do Pavilhão 8 tinha o apelido de Mané Caixa, era magrinho e usava bigode. Ele falava para gente assim: '- Vocês acham que vão saber o que acontece com a Guerra do Vietnã para ficarem contentes, aqui? Não vão não!' A gente não sabia nada e não tinha direito a ter rádio.
[...] Num dos banhos de sol aconteceu, como diz o Rubens Fonseca numa frase que eu acho legal: houve uma "combinação aleatória de circunstâncias imprevisíveis" (no conto designado "Romance Negro"). Numa dessas circunstâncias imprevisíveis de uma combinação aleatória, a gente descobriu que o chefe do tráfico de maconha no pavilhão,

\footnotetext{
${ }^{491}$ MACHADO, Luiz Raul, em Tiradentes, op.cit., p.70.

${ }^{492}$ Entrevista concedida por Aytan M. Sipahi à autora. Idem, ibidem.
} 
[...] tinha sido colega de primário do Paulo de Tarso Venceslau, na cidade de Taubaté. Chamava-se Estrelinha.

O Paulo passou alguns dias explicando para ele o que a gente estava fazendo ali. Aí caímos nas graças do Estrelinha, porque quem manda no pavilhão é o chefe do tráfico. A gente chegou para ele e falou: '- Pô, Estrelinha, precisamos ler jornal, revista, receber livros, como a gente faz?' Ele passou uma lista de pessoas que receberiam os jornais para nós. No meio da tarde, o jornal chegava inteiro para nós, sem censura e, semanalmente, chegava a Veja. Os livros vinham de vez em quando. [...] As famílias faziam a assinatura na banca de jornal da frente [...] a revista também chegava por assinatura. [...] $O$ Estrelinha mandava trocar as lâmpadas de 40 para 100 velas nas nossas celas e, assim, você podia ler à noite. Enfim, nós montamos uma biblioteca razoável! No começo, a gente arriscava pedindo romances [...], depois pedimos alguns livros de política e chegavam todos pelos presos comuns ${ }^{493}$."

Durante a fase em que os presos políticos ficaram no Pavilhão 5 da Casa de Detenção de São Paulo, a partir de 1972, o tratamento melhorou, aumentando o acesso aos livros. Não obstante, os periódicos chegavam mutilados pelos censores do presídio. Eventualmente, os presos chegaram a pedir aos presos comuns para solicitarem os livros que sabidamente não passariam pela censura da administração:

"Neste período, qualquer livro que tivesse à venda em livrarias entrava junto com a nota fiscal, [...] então qualquer livro à venda entrava, não precisava usar aquele esquema de preso comum como a gente usou no Pavilhão 8. Organizamos um Curso de Madureza para os presos comuns com apoio da direção da Casa de Detenção. É certo que o Curso de Madureza durou pouco tempo. O juiz Nelson Machado mandou acabar, porque ele percebeu que se a gente desse um curso desses ganhávamos o pavilhão inteiro. Imagine, você dando um Curso de Madureza para 30 presos comuns que podiam ficar soltos à noite para assistir aula! Com o respeito que a gente havia conquistado depois da greve de fome... ${ }^{494,}$

Nesse período, foi possível driblar a censura e estudar até mesmo O Capital de Karl Marx na Casa de Detenção. Na gíria dos presos políticos era possível “preparar” um livro para poder disfarçá-lo enquanto o estudavam. Scavone, por exemplo, relatou como estudou os dois primeiros volumes d'O Capital com outros dois companheiros. De acordo com suas palavras:

"Você não podia ter O Capital dentro da cadeia, então a gente recebia o livro desmontado e o remontava com a capa do livro do Paul Swezzy, por exemplo. [...] Eu não me lembro como o livro vinha desmontado, talvez, viesse com outra capa e, assim, o livro conseguia passar e o remontávamos. Não me lembro [...]. Fazíamos isso para poder ficar com ele lá dentro como um livro de economia desconhecido" ${ }^{495}$.

\footnotetext{
${ }^{493}$ Entrevista concedida por Carlos Alberto Lobão Cunha à autora. Idem, AAPP/AEL-LEI.

${ }^{494}$ Idem, ibidem.

${ }^{495}$ Entrevista concedida por Artur M. Scavone à autora. Idem, ibidem.
} 
Preparar um livro para que pudesse ser lido na prisão por vários presos sem despertar a atenção dos carcereiros dispendia muito tempo e certa habilidade, conforme o relato de Manoel Cyrillo:

\begin{abstract}
"Vou falar da ALN [...], por exemplo, a gente pegava O Capital e desmembrava o livro, pegava cada caderninho daquele de uma encadernação costurada e enxertava dentro de outro livro costurado, que não tinha nada a ver com a estória. Era relacionado àquele tema, um livro de economia, por exemplo, mas um livro qualquer e, a gente enxertava pedaços de $O$ Capital ali dentro. Caderninho por caderninho era colocado dentro de outro livro. Houve outros, lembro-me de um que não era um clássico, aliás, era um livro banal, mas a administração não ia deixar entrar. Era o livro do Cardernal sobre a visita dele à Cuba e o primeiro capítulo tratava do desembarque em Havana. A gente fez uma capa falsa, você abria o livro estava escrito No Aeropuerto. E que é que a gente fez? Fizemos uma capa falsa, bonita, com uma fotografia colorida e escrito havia o título Aeropuerto (risos). Era uma foto de um avião qualquer da Varig com escada, num aeroporto qualquer. Forravamos com papel contact, ficava lindo, um puta de um livro sobre comunismo. Outros a gente fazia enxertos, por exemplo, com o livro 'A sagrada família', escavamos suavemente algumas camadas do papel da capa, botamos um santinho de Nossa Senhora com Jesus e o senhor José do lado, e ali estava a sagrada família. Revestíamos a capa com papel contact e pronto. [...] Eu fazia isso, porque eu tinha muito jeito para desenho e mexia muito com nanquim, então eu fazia os 'bigodinhos', [...] que é aquela vinhetinha gráfica para enfeitar a página, o fio de um texto, aquilo chama bigodinho. A gente fazia aquela vinhetinha página por página do livro. Onde estava escrito Karl Marx, por exemplo, para esconder o nome dele, faziamos uma brincadeira, colocávamos em 'art decor' uma lista mais grossa que tampava o nome dele, duas mais fininhas embaixo com um arabesco do lado, página por página. Coisa de preso, para esconder um livro. Mesmo assim a gente carimbava com o carimbo da auditoria que eu roubei. Esse carimbo a gente guardava num colar de couro no estilo hippie, um cordão de couro que era fácil de abrir e está fechado em casa até hoje.

[...] Tínhamos um esquema de trazer livros para a cadeia e legalizá-los. Uma vez fui à Auditoria Militar e roubei o carimbo que legalizava os livros. Eles me puseram algemado do lado de uma banquetinha onde estava o berçinho dos carimbos com dois ou três deles. Eu peguei um, tirei a borrachinha, fiquei com ela na mão, depois [...] participei da audiência [...] e a levei para a cadeia. A gente carimbava e legalizava todos os nossos livros, isso era coisa [...] nossa, da organização. A gente só abriu esse carimbo, sem dizer o que a gente tinha ou não, mas que a gente legalizava os livros, para o pessoal do PC do $\mathrm{B}$, que eram aliados, companheiros nossos. [...] Eles estudavam e precisavam ter bons livros e legalizados, então, a gente legalizava. Para os outros não, lógico (risos), a gente tinha que cuidar dos nossos interesses estratégicos [...]. Fizemos isso com todos os clássicos como 'O estado e a revolução'. A gente tinha todos os livros do Mao Tse-tung, a gente tinha de tudo. [...] acabamos montando uma biblioteca incrível! ${ }^{496,}$
\end{abstract}

Na Penitenciária do Estado de São Paulo, a maioria dos livros e materiais de leitura que pudessem auxiliar ou aprofundar a organização e sistematização de ideias e o exercício da inteligência era proibida. Os presos políticos tinham direito a ler gibis e os livros disponíveis na biblioteca do presídio ${ }^{497}$. A instabilidade gerada pelas transferências

\footnotetext{
${ }^{496}$ Entrevista concedida por Manoel Cyrillo de Oliveira Netto à autora. Idem, ibidem.

${ }^{497}$ Entrevistas concedidas por Artur M. Scavone, e Pedro Rocha Filho à autora. Idem, ibidem.
} 
de presídios e as revistas violentas nas celas fizeram com que os presos copiassem textos marxistas e maoístas em cadernos, principalmente, no Carandiru; uma medida preventiva para situações e lugares que impusessem maior coerção disciplinar. Desse modo, puderam lidar com as rígidas restrições de leitura da Penitenciária em 1974, conforme testemunho de Manoel Cyrillo:

“[...] a gente sabia que lá não tinha repressão a coisas escritas, mas em compensação você não podia ter livros. Podia-se ler só um livro por semana da biblioteca. No entanto, eles não reprimiam nada escrito, o que nós fizemos? [...] Todo o nosso coletivo [...], fundamentalmente, a ALN, o PC do B e as áreas próximas [...] nós pegamos todos os clássicos que tínhamos na cadeia e fizemos cópias manuscritas, cadernos e mais cadernos de cópias. [...] Cada livro tinha um grupo de dois ou três companheiros que era responsável por copiar aquilo. Aí você tem [...] que ter disciplina militar, no bom sentido [...]! A gente copiou dezenas e dezenas de livros. Eu ainda tenho um em casa que foi copiado pelo Genoíno e eu guardei de recordação [...]. A gente fez isso com todos os $\operatorname{livros}^{498}$,"

Os livros eram objetos muito valorizados na prisão, por isso, quando um preso era libertado recebia um de presente com uma dedicatória e as assinaturas de todos que ficavam. Alguns entrevistados mantêm guardados esses livros como uma boa lembrança de um tempo difícil ${ }^{499}$.

No presídio do Hipódromo, a partir de 1975, os presos organizaram a leitura de jornais de uma forma que pudessem compartilhá-la com os demais, criaram uma espécie de jornal mural, conforme relatou Sérgio Gomes, militante do PCB preso em outubro de 1975:

\begin{abstract}
"Criou-se uma espécie de jornal chamado $O$ parcial. Sempre às 6 horas da tarde, antes do jantar, um ou dois de nós liam todos os jornais e fazíam uma espécie de resumo. Contavam-se as principais notícias e depois se comentava. [...] Havia pessoas muito engraçadas, muito interessantes conosco, caso do Milton Coelho da Graça que estava lá cumprindo pena, porque era o editor de uma publicação chamada 'Notícias Censuradas'. Ele foi condenado a 6 meses. [...] Ele contribuiu muito com o nosso jornal diário e nos debates, pois nós realizávamos entrevistas com os presos. E promovíamos debates sobre os mais diversos temas, em geral, sobre a especialidade de cada preso. Transformamos a cela que era a cozinha durante o dia numa escola à noite para ensinar português, matemática, desenho etc. Muitos presos eram analfabetos. A ideia era que, durante aquele tempo, a gente não se deixasse embrutecer, por isso fazíamos essas coisas ${ }^{500}$.”
\end{abstract}

\footnotetext{
${ }^{498}$ Entrevista concedida por Manoel Cyrillo de Oliveira Netto à autora. Idem, ibidem.

499 Entrevista concedida por Reinaldo Morano Filho à autora. SP, 14/03/2011; SÁ, Ayberê Ferreira de. op.cit., p.217.

${ }^{500}$ Entrevista concedida por Sérgio Gomes à autora. SP, 29/01 e 11/03/2009. AAPP/AEL-LEI; e COELHO, Marco Antonio Tavares, op.cit., p.450-51.
} 
Na Penitenciária de Linhares o acesso à leitura dos presos políticos também era bastante controlado. De acordo com Gilney A. Viana, os livros e os jornais eram muito censurados e só se podia ler no horário de acesso ao pátio ${ }^{501}$.

A produção de documentos de conteúdo político contendo denúncias e manifestos ou aqueles escritos para estabelecer a troca de ideias e promover o debate político entre os presos e as organizações de esquerda era outro importante meio de comunicação e um dos expedientes utilizados para burlar o isolamento imposto pelo sistema carcerário. Em geral, as denúncias e manifestos eram escritos em papel de seda com letras miúdas, embalados e colocados em carteiras de cigarro, fundos de bolsas, canetas ou enrolados em forma de pequenas bolas e transportados na boca de familiares ou advogados, protegidos por uma camada fina de plástico ${ }^{502}$. Algumas peças de artesanato eram confeccionadas especialmente para driblar a vigilância. Havia várias formas de guardar e transportar esses documentos.

Os presos políticos do Tiradentes, antes de serem transferidos para o Carandiru em 1970, foram avisados e conseguiram encontrar maneiras de esconder e preservar os documentos que estavam elaborando, conforme relatou Carlos Alberto Lobão Cunha:

\begin{abstract}
"Mesmo nas condições mais adversas a gente conseguia encontrar brechas. Quando a gente foi transferido do Tiradentes para o Pavilhão 8, eles avisaram com alguma antecedência. Eu preparei o fundo falso de uma caixa de figo, que ficou perfeita, nele foram vários documentos que a gente estava escrevendo, de discussão. Esses textos de debates entre nós foram todos para o Carandiru, passaram pela revista deles e não aconteceu nada.

Eu não lembro o que havia nesses documentos, mas era alguma coisa de discussão nossa, enfim, algo sobre o momento atual. Comunista sempre discute o momento atual, a situação nacional e a internacional. O Carlos Talaoka, por exemplo, tinha experiência anterior de prisão e usava óculos. Então, ele pegou metade de uma gilete e botou sobre do aro dos óculos e fixou com fita durex. Assim, tínhamos gilete lá dentro [no Carandiru] para cortar alguma coisa quando precisava. A criatividade é muito grande, quando se está preso $^{503}$."
\end{abstract}

Apesar da grande criatividade e paciência dos presos políticos, às vezes, seus documentos eram descobertos durante uma revista policial às celas, levando à instauração de inquéritos para apurar a procedência e autoria do documento, além de punições diversas, tais como a suspensão das visitas e do banho de sol ou transferência para outro

\footnotetext{
${ }^{501}$ Entrevista concedida por Gilney A.Viana à autora. Idem, ibidem.

${ }^{502}$ V. entrevistas concedidas por Airton Soares e Reinaldo Morano Filho à autora. Idem, ibidem.

${ }^{503}$ Entrevista concedida por Carlos Alberto Lobão Cunha à autora. Idem, AAPP/AEL-LEI.
} 
presídio ou quartel. Sobretudo, estas descobertas geravam tensões internas, relativas aos cuidados necessários à segurança dos presos ${ }^{504}$.

Alguns presos políticos eram professores, historiadores, escritores ou poetas e escreveram parcelas ou livros inteiros durante o período em que estiveram confinados nos presídios, tais como Jacob Gorender (O escravismo colonial), Augusto Boal (Milagre no Brasil), Renato Tapajós (Em câmara lenta), Alex Polari (Inventário de cicatrizes e Camarim do prisioneiro), Hamilton Pereira da Silva (Poemas do povo da noite), Aldo Arantes e Haroldo Lima ( $D a A P$ ao PCdoB), Gilney A. Viana e Perli Cipriano (Fome de Liberdade), Joel Rufino dos Santos [SANTOS, 2000: 39] e Marcelo de Mário Melo, entre outros $^{505}$. Apesar das adversidades, os cárceres políticos foram espaços onde os presos exerceram sua criatividade e foram produtivos.

\subsubsection{Os trabalhos manuais e artísticos}

A prática de confeccionar trabalhos manuais regularmente para vender iniciou-se na cela 7 do presídio Tiradentes; o rendimento era usado para ajudar no sustento das famílias de presos, no pagamento de advogados e outras necessidades diárias. A atividade ajudava a combater a monotonia do cotidiano na prisão e estimulava a criatividade. Um dos primeiros trabalhos criados foi um tapete tecido, por vários presos, sobre uma natureza morta desenhada por Alípio Viana Freire. As famílias tentaram organizar uma rifa para vendê-lo e arrecadar dinheiro, mas não foi necessário, pois a cantora Elis Regina comprou o tapete rapidamente. Devido à insistência do preso e advogado Renato Guedes Siqueira, os presos da cela 7 começaram a fazer artesanato em couro. A prática se espalhou e vários presos aprenderam a trabalhar com couro, pedras, miçangas, assim como, serigrafia, xilogravura e pirogravura. No Tiradentes não havia um local especialmente destinado ao artesanato, mas homens e mulheres dedicaram-se com paciência ao artesanato. Em 1972, os presos que ficaram no pavilhão 5 do Carandiru organizaram uma oficina de artesanato numa cela para tal finalidade, conforme relato de Lobão, que, com Joseph Bartholo Calvert e Denison Oliveira, era um dos coordenadores:

\footnotetext{
${ }^{504}$ CunHA, Carlos Alberto Lobão, em Tiradentes, op.cit., p.240-41.

${ }^{505}$ Entrevista concedida por Marcelo de Mário Melo à autora. Idem, ibidem; VIANA, Gilney A. e CiPRIANO, Perli, op.cit.; SÁ, Ayberê Ferreira de. op.cit., p.217; e FrEIRE, Alípio V. "Um acervo de imagens dos presídios políticos: o cotidiano através das artes plásticas”, op.cit.
} 
“Não era obrigatório fazer trabalho manual, nem entre os presos da ALN. A gente fazia, porque havia várias famílias que passavam necessidade, então, produzindo alguma coisa, dava para vender e levantar um dinheiro. [...] E foi positivo, pode perguntar para algumas famílias, como a Dona Isabel, mãe do 'Jonas’ [Virgílio Gomes da Silva] e do Chiquinho, se não ajudou esse dinheiro. [A família foi obrigada a se exilar, mas] ela ficou no Brasil e a gente ajudava muito a Dona Isabel, imagino que ela deva ter falecido. [...] Além disso, com o artesanato de couro, por exemplo, os manifestos das greves de fome saíram todos embutidos em artefato de couro, porta cigarro, em várias coisas que a gente fazia.

[...] Quando nós voltamos para a Detenção e fomos para o Pavilhão 5, [...] havia uma administração diferente [...] e discutindo com o diretor, nós conseguimos montar um ateliê de trabalhos manuais numa cela, que tinha até faca, uma faca que daria para matar uma pessoa! Havia material de couro, mesa, tudo ${ }^{506}$."

Os familiares e amigos de presos políticos foram os que mais se empenharam na venda do artesanato produzido nos cárceres políticos. Em solidariedade aos presos, muitas pessoas compraram bolsas, carteiras e chinelos de couro e batique, tapetes, colares, biquínis e ponches de tricô e crochê, e camisetas pintadas em batique ou serigrafia; colares e gargantilhas de miçangas feitos em pequenos teares improvisados em caixas de uva $^{507}$. Os presos e a rede de solidariedade, que se formara e se ampliava, acabaram assumindo a estética hippie. Alguns presos revelaram-se verdadeiros artesãos e produziram artefatos bonitos ou de valor artístico. Alberto Becker, Manoel Porfírio, Paulo Radke, Artur Scavone e Altino Dantas, por exemplo, tornaram-se exímios artesãos e produziram bolsas e outros artefatos de grande qualidade e beleza ${ }^{508}$. Muitas pessoas queriam ajudar e prestar solidariedade, assim, os objetos produzidos pelos presos, desde os menos elaborados e simples até os mais bonitos, eram vendidos com facilidade ${ }^{509}$.

As presas políticas, por outro lado, especializaram-se na criação de trabalhos em crochê, tricô, bordados e de costura. Embora para muitas fosse um lazer, em determinados períodos a produção semanal de artesanato obrigava a uma rígida disciplina para conseguir entregar a tempo a produção de encomendas. Certa vez, as presas vestiram e enfeitaram cem bonecas caracterizadas de baianas para um Congresso Internacional de Educadores realizado em Petrópolis. Com as presas comuns conseguiram uma velha máquina de costura; foram necessárias jornadas de revezamento na linha de produção, mas as bonecas foram concluídas a tempo e embaladas em saquinhos com etiquetas nas quais estava grafada a sigla do presídio Tiradentes - ala feminina ${ }^{510}$.

\footnotetext{
${ }^{506}$ V. entrevistas concedidas por Carlos Alberto Lobão Cunha à autora. Idem, AAPP/AEL-LEI.

${ }^{507}$ V. Tiradentes, op.cit., p.380.

${ }^{508}$ Entrevista concedida por Alberto H. Becker à autora. SP, 11/03/2011.

${ }^{509}$ Entrevista concedida por Maria Amélia de A. Teles à autora. Idem, ibidem.

${ }^{510}$ LoBo, Elza F., em Tiradentes, op.cit., p.219-20.
} 
Vários prisioneiros políticos desenvolveram também um trabalho artístico mais elaborado e criativo no presídio Tiradentes. Com a chegada de arquitetos e artistas plásticos ao presídio, ampliou-se o interesse e muitos passaram a dedicar-se à atividade artística. O trabalho criativo era uma importante maneira de recuperação de identidade e da sanidade física e mental. Para Sérgio Sister, então estudante de arquitetura, foi um meio “de elaboração de um senso de apropriação de um espaço espiritual”. Ao ganhar uma caixa de crayon e um caderno de desenho, Sister passou a desenhar todos os dias, criando uma crônica do cotidiano na cadeia, um “testemunho ilustrado”, que buscava não esquecer tudo o que se passava ${ }^{511}$.

Sérgio Ferro e Júlio Barone, em especial, fizeram entrar no presídio as encomendas de novos materiais trazidos pelos amigos e familiares como tinta acrílica, papéis, telas, pincéis, fitas, colas, arames etc. Na “cela dos burgueses”, onde Sérgio Ferro ficou preso, formou-se um verdadeiro ateliê. O estudo teórico e a troca de ideias com Alípio V. Freire, Carlos Takaoka, José Wilson e os arquitetos Rodrigo Lefèvre, Carlos Henrique Heck e Sérgio Souza Lima, permitiram a diversificação de linguagem e a experimentação artística. Na ala masculina e na feminina, vários se dedicaram a essa atividade e alguns, como Sister, embarcaram na pop art, bastante influente nos anos $1960^{512}$. De acordo com Sérgio Ferro, a pintura era um meio poderoso para extravasar a angústia gerada pela experiência da tortura e de prisão:

"Escoavam ali ataques de raiva ou desabafo, inventava jeito para contar e vigiar meu
desconforto. Começou a se fincar então a maneira de pintar que ainda guardo, atenta aos
outros. Vinham ver o que eu fazia companheiros de toda origem, nem sempre letrados em
arte. O que mais esperavam - acho - era que pusesse lá fora o que trazíamos por dentro:
carinho recolhido, revolta calada, desamparo, espera teimosa de um outro amanhã.
[...] 17/09/71. Dia de escuridão. Pus-me a pintar o amigo assassinado (mania minha: reagi
assim na morte do Pedrinho, de minha mãe, do Rodrigo, do Flávio). Largo terno branco
todo de céu por dentro, vazio já do corpo, lanhado, lacerado, atravessado por uma lança
vinda por trás, de traição, tarja preta e uma pomba/carcará se escapando para voltar
depois. Quando o quadro foi levado embora, pareceu quase em procissão leiga, olhado no
silêncio de gargantas apertadas. Foi um nosso modo de abraçar Lamarca ${ }^{513 . "}$

${ }^{511}$ SISTER, Sérgio. “Cadeia só funciona para inocentes que nem eu”, em Tiradentes, op.cit., p.208. V. tb. FREIRE, Alípio. “Quem pintou na cadeia”. In: Teoria e Debate, n. 27, p.52-57, dez 94/e jan/fev 1995; e "Um acervo de imagens dos presídios políticos: o cotidiano através das artes plásticas”. op.cit.

512 SISTER, Sérgio, op.cit., p.210-11; e FERRO, Sérgio. “Auto-retrato a chicotadas" em Tiradentes, op.cit., p.215.

${ }^{513}$ FerRo, Sérgio. “Auto-retrato a chicotadas" em Tiradentes, op.cit., p.215. Na atualidade, este quadro pertence ao acervo do Museu de Arte Contemporânea - MAC, da USP. V. FreIRE, Alípio V. "Quem pintou na cadeia”. op.cit. 
A partir de 1972, foi possível produzir trabalhos artísticos no Carandiru também, conforme os trabalhos feitos por Carlos Takaoka e Bartolomeu José Gomes, o Bartô. Artur Scavone e Manoel Cyrillo, entre outros, passaram a fazer xilogravuras a partir de desenhos com temas debatidos coletivamente, cuja execução era compartilhada com os companheiros. Essa atividade ganhou impulso no presídio político Barro Branco, a partir de $1975^{514}$. No Hipódromo, Henrique Buzzoni começou a realizar trabalhos artísticos em 1976, depois de frequentar um curso organizado pela jornalista Radhá Abramo para os $\operatorname{presos}^{515}$. Essas atividades ajudaram a enfrentar o isolamento imposto pelo sistema prisional, mas também a divulgar o que se passava nos cárceres da ditadura.

A situação vivida sob o sistema carcerário da ditadura produziu formas de socialização peculiares, tal como exposto neste item. Estas formas de socialização tiveram como seu aspecto mais notável a criação dos “coletivos” e, a partir destes, de formas de solidariedade que envolveram práticas cuja amplitude conjugou os mais diversos aspectos da vida destas pessoas e que, porventura, vieram a marcar-lhes a vida terminantemente. Como é de se supor, esta situação peculiar não poderia ter existido sem que tensões internas existissem. Divisões, convergências e divergências, nos coletivos representam aspectos importantes para a compreensão da maneira como se organizaram no período, tal como veremos a seguir.

\subsection{Os coletivos de presos políticos: convergências e divergências}

O convívio nos presídios políticos exigia constantes exercícios de tolerância, cujos malogros pontuais faziam aflorar as divergências entre as diversas correntes políticas em determinados períodos e lugares. No auge das lutas de resistência, os conflitos nas fileiras das esquerdas para rever posições e traçar novos caminhos foram contundentes e desgastantes, principalmente, entre os militantes presos que viviam em péssimas condições carcerárias e em maior número como os detentos do Presídio Tiradentes, em São Paulo, ou os da Ilha Grande, no Rio de Janeiro. Com os presídios cheios, a rotina era necessariamente agitada e o debate político intenso, conforme relato de diversos expresos políticos do presídio Tiradentes:

\footnotetext{
${ }^{514}$ Entrevista concedida por Artur M. Scavone e Manoel Cyrillo de Oliveira Netto à autora. Idem, ibidem.

${ }^{515} \mathrm{O}$ artista plástico Carlos Zílio esteve preso no Rio de Janeiro e realizou trabalhos artísticos durante o período de prisão, que foram tema da exposição “Arte e Política” no Museu de Arte Moderna de São Paulo, em 1997. FreIRE, Alípio V. “Quem pintou na cadeia”. op.cit.
} 
“Além do básico [...] os dias eram preenchidos [...] com a discussão das notícias que chegavam, com o acompanhamento das brigas e tensões internas entre os presos, com os grupos de estudo, com as reuniões das organizações remanescentes. [...] o cotidiano se transformava numa continuação da militância. Com todas as contradições entre as várias linhas políticas ali representadas"

Participar do coletivo exigia disposição, despreendimento e espírito colaborativo. O coordenador ficava com "a responsabilidade de fazer contato com a carceragem, com o diretor do presídio, de defender os interesses do preso numa situação difícil, porque estávamos sempre em posição de inferioridade” [BENEDITO; REZENDE, 2000:136-7]. E, nem sempre, era fácil convencer a minoria a acatar uma posição majoritária. Em diversos períodos, tanto em São Paulo quanto no Rio de Janeiro, houve dois coletivos atuando separadamente, bem como havia presos que não aceitavam participar de nenhuma das instâncias constituídas pelos presos políticos. Os locais onde havia maior quantidade de presos políticos e variedade de organizações ficaram mais sujeitos a conflitos e divisões. Não obstante, os presos sempre encontravam maneiras de organizar algum tipo de coletivo, de acordo com Artur Scavone:

"Em todos os momentos houve uma instância de decisão, que não era uma coisa burocrática. [...] Nos 'coletivos' das respectivas organizações, o pessoal se reunia, discutia, conversava, tendo ou não contato com o exterior da cadeia. Agora, no coletivo da cadeia, nós tínhamos organização para lavar a louça, para distribuir comida, para receber as coisas que os parentes traziam, para se defender, para ajudar companheiros [...] e para isso houve um enorme apoio das famílias. [...] E havia coisas interessantes, por exemplo, a família trazia chocolates, bombom, e tínhamos uma política: '- Você recebeu chocolate?', vamos juntar tudo e a gente distribui ao longo da semana. Eu nunca me esqueço, uma vez pegaram um companheiro que tinha guardado uma barra de chocolate debaixo do colchão. A discussão que foi feita, se a gente pensar nos dias de hoje: 'Companheiro, você está guardando um chocolate debaixo do colchão, que a gente vai dividir. Como é que você vai fazer no dia em que for governo, um ministro, ou seja, quando estiver dirigindo um país?’ Dá o que pensar uma conversa dessas (risos)!”517

Em São Paulo formaram-se diversos coletivos de presos de acordo com o período e o local de prisão. No início, entre 1969 a 1973, a maioria dos detentos ficou confinada no presídio Tiradentes. Lá havia coletivos por cela que, em certos momentos, interligavam-se com os das outras celas formando uma espécie de "conselho de coletivos” ${ }^{\$ 18}$. De acordo com Alípio Viana Freire, o convívio nos coletivos do presídio Tiradentes era conflituoso, mas bastante rico, a relação com a diversidade de militantes e agrupamentos era necessária e positiva:

\footnotetext{
516 TAPAJÓs, Renato. “A floresta de panos”, em Tiradentes, op.cit., p.345.

${ }^{517}$ Entrevista concedida por Artur M. Scavone à autora. Idem, ibidem.

${ }^{518}$ V. Tiradentes, op.cit.
} 
“[...] no coletivo de cela, discutia-se dentro da cela, e havia, proporcionalmente ao número de presos, um número de representantes que participava do coletivo inter-celas. O inter-celas começou em meados para o fim de 1970. [...] A gente brincava conosco mesmo: hoje tem reunião do 'execrável', que era o coletivo da cela, porque, às vezes, certas discussões eram um saco. E quando ocorria o inter-celas alguns diziam: '- Ih, hoje tem reunião do ‘abominável’'. Eram o execrável e o abominável! Nos dois, havia gente de várias organizações e gente que não era de nenhuma. Por exemplo, eu nunca fiquei numa cela só de Ala. Só teve uma cela apenas com pessoas de Ala, num momento que a gente precisava ter 4 companheiros juntos. Por causa do nosso processo de auto-crítica, eles precisavam trabalhar mais e juntos, sem ninguém em volta. Isso aconteceu na segunda metade de 1972.

[...] Agora, onde a Ala estava, sempre fazíamos isso [...] não ficávamos separados em celas 'puro-sangue'. [...] Era meio a meio na cela quase sempre. [...] Onde nós tínhamos direito a dois representantes por coletivo, a gente sempre escolhia um de Ala e outro que não era ${ }^{519}$.

Não obstante, os rearranjos feitos pelos presos políticos no Tiradentes para unir militantes com a mesma origem partidária numa cela comum, ajudavam a organizar o coletivo e as discussões políticas, conforme o relato de Antônio Roberto Espinosa:

“[...] quando voltamos do Carandiru [...] a gente aos poucos foi se rearranjando nas celas, que no Pavilhão II do Tiradentes eram menores, mas a gente foi formando celas mais homogêneas. [...] E para a maior parte dos presos políticos era uma questão crucial fazer uma avaliação do que tinha acontecido, para mim, por exemplo, já era certo que nós havíamos perdido, a luta armada estava derrotada. As organizações tinham se desmilinguido, o que havia fora eram apenas poucas pessoas que nós considerávamos condenadas. Então, esse era um momento de fazer um balanço. Também tínhamos críticas à União Soviética, à China, coisas que nós não aceitávamos. Achávamos que era preciso fazer um ajuste com as nossas próprias cabeças, cada um num processo. Isso acontecia com a Ala, acontecia conosco e acontecia menos com a ALN, porque [...], a informação que a gente tinha na cadeia era que o Carlos Eugênio estava agindo, mas ele era garoto. Não sei, [...] mas pra gente, esse pessoal já estava meio que fora do tempo, o sonho que nós tínhamos dirigido se transformara num pesadelo e eles não queriam reconhecer. Estes eram os últimos espasmos de um pesadelo. O que nós lastimávamos enormemente, mas não tínhamos nenhuma dúvida de que isso acabaria mal, como acabou. Não precisava ser gênio para saber ${ }^{520}$."

No presídio Tiradentes juntamente com os coletivos de cela e inter-celas coexistiam outros coletivos. Estes estruturados conforme a organização política de origem do preso, como o da ALN, do PCdoB, do PCB, AP, PCBR e de outras organizações ainda estavam ativas fora das prisões. No período de maior concentração de presos foi muito difícil conciliar a convivência de todas essas instâncias de decisão. O relato de José Olavo Ribeiro, por outro lado, retrata um pouco da atmosfera vivida no Tiradentes, na cela 5, onde permaneceu a maior parte do tempo e conviveu com os demais num ambiente de certa tolerância para com as divergências:

\footnotetext{
${ }^{519}$ Entrevista concedida por Alípio Viana Freire à autora. Idem, ibidem.

${ }^{520}$ Entrevista concedida por Antônio Roberto Espinosa à autora. Idem, ibidem.
} 
“[...] para dar uma ideia do clima político no presídio, dou um exemplo. Isso ocorreu durante um sequestro [...] de um Caravelle, [...] da Cruzeiro do Sul [...]. O sequestro fracassou e foi morta uma militante ou a mulher foi presa, não sei. [...] As forças da repressão entraram no avião e, quando saiu a notícia [...] - a gente assistia o noticiário todo dia, na TV da cela - o Costinha, que era um militante do partidão, exclamou: '- $A h$, esses terroristas!' Aí foi um quebra pau na cela. O Jorge Batista, um militante da VAR de Minas Gerais, partiu para cima do Costinha e nós tivemos que segurar. E ficou um clima muito ruim, mas a gente tinha uma convivência muito boa nessa cela, inclusive, com o pessoal do partidão. O Lourival Villar comandava o grupo deles na cela, um antigo comunista que tinha participado de 1935. Ele já deve ter falecido, hoje acho que estaria beirando os 90 anos. Pode estar vivo, não sei. Ele fez uma reunião, enquadrou o Costinha e o obrigou a se retratar, a fazer uma autocrítica. E foi legal, no fim, acho que nós saímos até mais unidos dessa crise pela reação que eles tiveram. Ele realmente pediu desculpas, falou que foi algo do momento. Falou que todo mundo estava sofrendo muito com a repressão, que a organização dele também tinha perdido muitos quadros e tudo voltou às boas.

É lógico que as divergências continuaram, mas essa cela para mim me ensinou muito a conviver com as pessoas que pensavam um pouco diferente. Eu tinha um relacionamento muito bom com o pessoal do partidão, eles eram mais velhos, eram uma espécie de professores. Depois, eu estive na cela com o Eloi Martins que é outra figuraça! Todo dia era o primeiro a acordar e fazer ginástica. Na época, era um velho porque ele tinha 60 anos, a gente achava que um cara de 60 anos era velho! [...] Depois lia, estudava e participava de tudo. Era um cara excelente, conhecia tudo da esquerda brasileira. Era um cara que tinha militado desde jovem. O irmão dele foi assassinado muito antes, na época do Getúlio [...]. Foi uma experiência muito boa. ${ }^{521}$.”

No Rio de Janeiro, onde também havia grande número de presos de diversas origens políticas, durante a fase em que ficaram na Ilha Grande surgiram divergências que levaram a divisões e à formação de dois coletivos distintos. De acordo com José Roberto Rezende:

“[...] Organizamos um "coletivão" para tratar dos nossos interesses de presos, porque mesmo encarcerados continuávamos militando, escrevendo documentos, participando do debate político, fazendo chegar nossas posições até o lado de fora do presídio, na sociedade civil. [...] Na Ilha Grande, com uns quarenta presos, algumas pessoas não participaram do coletivo, e em certo momento houve um coletivo dissidente. No presídio da Frei Caneca, durante a greve de fome [de 1979], conseguimos, enfim, um coletivão só” [BENEDITO; REZENDE, 2000:137].

Enquanto em São Paulo e no Rio de Janeiro as organizações se mantinham mais estruturadas nas prisões, na Bahia e em Pernambuco, por exemplo, foram organizados coletivos para tratar da vida carcerária e dos interesses dos presos, sob uma perspectiva política, mas sem definição partidária ${ }^{522}$. Theodomiro Romero dos Santos, militante do

\footnotetext{
${ }^{521}$ Entrevista com José Olavo Ribeiro à autora. Idem, ibidem.

${ }^{522}$ Entrevista concedida por Marcelo Mário de Melo à autora. Idem, ibidem.
} 
PCBR, ficou preso quase nove anos na Bahia, entre 27 de outubro de 1970 e 17 de agosto

de 1979, e relatou como funcionava o coletivo de presos políticos naquele estado:

“[...] A gente tinha um coletivo na prisão que sempre funcionou muito bem, porque a gente nunca permitiu que as diferenças de origem organizacional interferissem no funcionamento da nossa organização carcerária. As pessoas, de uma forma geral, valorizaram muito a vida coletiva, aquela organização coletiva, com as dificuldades de uma vida numa penitenciária. Ali, as grandes qualidades e os grandes defeitos aparecem muito rapidamente. As pessoas não conseguem esconder por muito tempo, nesse tipo de convivência de seis anos ou mais, as suas características essenciais de personalidade. Mas todo mundo tinha a compreensão de que todos tinham qualidades e defeitos, [...] e, na medida do possível, tentou-se construir um modo de vida comum de muita solidariedade. Eu tenho um sentimento de orgulho por ter participado da construção e da manutenção do coletivo de presos políticos da Penitenciária Lemos de Brito. Foi muito legal, muito mesmo.

[...] O coletivo sempre teve uma atitude muito presente, não havia nenhuma questão que não pudesse ser discutida lá. A única coisa que era proibida discutir no coletivo era as que envolviam questões de política partidária. Todas as demais, tais como relacionamento entre colegas, enfrentamento com a direção, manifestação do coletivo, todas essas questões eram tratadas nas reuniões do coletivo. A gente tinha tarefas conjuntas, cozinha, lavagem de prato, lavagem dos sanitários que eram de uso coletivo, distribuição de jornais etc.

[...] A gente passou um período de tempo longo em situações muito difíceis, submetidos ao regime de prisão dos presos comuns. [...] Depois, começou a melhorar, [...] e ficávamos trancados nas celas somente à noite e passamos a poder trabalhar. [...] Assim, podíamos comprar a alimentação para reforçar a do presídio e montamos uma cozinha ${ }^{523}$."

No início do convívio no presídio Tiradentes havia muito debate político e os militantes mais velhos, em especial, organizavam cursos sobre diversos temas. Nesse período aconteceu o famoso curso de Jacob Gorender, como relembrou Ricardo Azevedo, militante da AP preso em 1969, que marcou a formação política dele e diversos outros presos:

“O Jacob Gorender, além das aulas de história do Brasil, ele estava fazendo uma análise do desenvolvimento do capitalismo do Brasil, naquele momento, e ele tinha chegado à conclusão, e demonstrava isso, que estava se gerando um novo surto de crescimento capitalista, o que contrariava a tese de, talvez, com exceção do PCB, de toda a esquerda. A esquerda achava que era impossível o desenvolvimento do país em termos capitalistas. As forças produtivas estavam estagnadas, o imperialismo impedia e, portanto, estavam maduras as condições para a revolução. Assim, tudo se tratava das condições subjetivas, ou seja, da existência de uma vanguarda organizada em um partido, ou uma guerrilha, uma coluna, enfim. E o Jacob começa a demonstrar que não, que havia condições do país crescer em termos capitalistas e isso começava a se manifestar, o boom da indústria automobilística, essas coisas, e que isso levaria à neutralização de setores da classe média e, portanto, a perda de uma importante base de apoio da esquerda ${ }^{524}$.”

\footnotetext{
${ }^{523}$ Entrevista concedida por Theodomiro Romero dos Santos à autora. Recife (PE), 19/03/2010.

${ }^{524}$ Entrevista concedida por Ricardo Azevedo à autora. SP, 27/01/2010. AAPP/AEL-LEI.
} 
Por outro lado, o relacionamento no presídio era dificultado, porque havia muita cobrança para que os militantes da ALN explicassem o assassinato de Carlos Marighella. As cobranças e divergências também provinham dos próprios militantes da organização, assim como de parte considerável das esquerdas que se encontravam na prisão. A cobrança recaía sobre o comportamento na tortura dos militantes da ALN, que teriam resultado na "queda" de seu principal líder. Alguns se sentiam particularmente injustiçados e se sucedeu um período de acusações mútuas. Essas pressões geraram muitos conflitos e resultaram num processo de reorganização da ALN na prisão. Carlos Alberto Lobão Cunha relatou como foi o início da organização do coletivo na cela 7, a maior do presídio, e onde predominavam os militantes da ALN:

\begin{abstract}
"Na verdade, nessa época, você tem um coletivo por cela. Eu lembro que no começo não havia uma coordenação na cela 7 , que era quase 'inadministrável'. [...] lá havia uma cozinha grande e nós montamos turmas de cinco se revezando durante a semana. A cada dia da semana tinha uma equipe de cinco para cuidar da limpeza e da comida. Eu não sei quando é que nós elegemos a primeira coordenação, imagino que foi depois do sequestro do embaixador alemão, em julho [de 1970]. Esse coletivo era para consumo interno, organizar o dia-a-dia da cela. Não tinha um coletivo do presídio, mesmo porque havia o Pavilhão I e o Pavilhão II. Aos poucos os presos vão sendo encaminhados para o Pavilhão II, porque não cabiam mais no Pavilhão I. Então [...] você tem as posições das celas e, paralelamente, a isso você tem as coordenações ou as responsabilidades de cada organização ou do que sobrou de cada uma delas.

Na cela 7 havia predominantemente o pessoal da ALN. E quem respondia pela ALN, naquele momento, eram o Jeová e o Fleury, pois era mantida a hierarquia que existia fora da cadeia. A bem da verdade, a coordenação era do Fleury, porque o [...] Jeová sempre teve um grau de autonomia muito grande. Ele estava mais preocupado em ver como é que a gente ia sair da cadeia do que ter que ficar negociando com cada organização para explicar uma coisa ou outra. [...] Sem nenhuma formalidade era o Fleury que respondia pela ALN no Pavilhão I. [...] Mas havia muitos 'caciques' [...]. Depois, eles saíram da prisão a partir dos sequestros [...] e tivemos que nos reorganizar [...] sem os 'chefes' [...] o que acabou sendo positivo ${ }^{525}$.”
\end{abstract}

Alguns ex-presos entrevistados relembraram como se desenvolveram as discussões e análises políticas entre os militantes da ALN no período que antecedeu a morte de Joaquim Câmara Ferreira - outubro de 1970 - seu principal dirigente após o assassinato de Carlos Marighella. De acordo com Cloves de Castro e outros, a preocupação central da organização estava direcionada para a preparação da guerrilha rural:

“[...] Havia grupos com posições definidas, por exemplo, a ALN [...] considerava que foi correto pegar em armas. Agora, tinha um pessoal que já iniciava um processo de autocrítica pelo fato de ter entrado na luta armada. [...] Na cadeia, essa discussão se

\footnotetext{
${ }^{525}$ Entrevista concedida por Carlos Alberto Lobão da Cunha à autora. Idem, AAPP/AEL-LEI.
} 
desenvolveu. Não nos colocávamos contra a guerrilha urbana, mas esta deveria ter o objetivo de organizar a luta armada no campo. E nós achávamos que o velho Toledo iria realmente ter condições de fazer isso, porque ele tinha um trânsito muito grande com as outras organizações em armas, no caso, a VPR, o próprio PCBR e, também com as pequenas organizações, o MRT, a Ala Vermelha... Ele tinha muita habilidade e nós achávamos que o Velho teria condições de fazer aquilo a que se propunha, ou seja, organizar a guerrilha rural.

[...] o Toledo falava da proposta de tirar os companheiros do país através de sequestros, assim eles retornariam para fazer um trabalho no campo, então, era preciso se organizar no campo para recebê-los, o que infelizmente, não se deu. [...] A gente achava que [...] era importante ter uma proximidade maior, o que, às vezes, chegou a ocorrer, os companheiros de várias organizações saíram nesses sequestros. Acho que isso indicava uma proximidade, o que poderia ter levado a uma discussão mais aprofundada ${ }^{526}$."

Os presos políticos encontraram maneiras muito distintas de se reorganizar. Elas estavam diretamente relacionadas à continuidade, ou não, das perspectivas dos partidos e agrupamentos fora da prisão. Por algum tempo, predominou a esperança de que os militantes poderiam sair da prisão por meio de sequestros de diplomatas, ou fugas, e retomar o projeto de preparar a guerrilha rural, conforme relato de Carlos Alberto Lobão Cunha:

“[...] Para algumas pessoas já estava claro que as organizações delas não existiam mais, ou seja, tinham sido derrotadas. A ALN, o PCB e o PC do B ainda não tinham sido derrotados. A ALN vai ser derrotada no final de 1973, a partir dos assassinatos do Mateuzinho [Antonio Carlos Bicalho Lana] e da Sônia [Maria Angel Jones de Moraes]; ou no início de 1974, possivelmente, quando são assassinados a Ana Rosa Kucinski e o marido dela. No primeiro semestre de 1974 ainda é assassinado o Issami Okano ${ }^{527}$. Enfim, aí não tem mais ninguém ou restaram poucos sobreviventes. O nosso comportamento, o da ALN, não era de quem desse a luta por encerrada. Para nós, não estava.

[...] Nós escrevemos um texto expondo o que pensávamos, chamava-se "A nossa linha geral”. Algo em torno da ideia de que dentro da cadeia, o primeiro objetivo era sobreviver, mas sobreviver com dignidade. Não vou lembrar agora do texto, mas estou querendo chamar a atenção para essa situação, que era diferente das demais organizações. Para você ter uma ideia, o pessoal que voltou [em 1971], (os 28 que voltaram de Havana... e constituíram o Molipo) [...] designaram o tio do Mané Cyrillo, o João Carlos [Cavalcanti Reis] ${ }^{528}$, para fazer somente uma coisa no Brasil: apresentar para a direção do Molipo um plano para tirar a gente da cadeia, fosse com sequestro ou sei lá como... [...] Então, na verdade, a gente se preparava para sair da cadeia, mas não pela porta! Por isso, a gente cuidava da preparação física, estudava bastante e se disciplinava. [...] Não tínhamos sido julgados ainda, mas a nossa expectativa era que seríamos condenados a penas altíssimas ${ }^{529}$.”

\footnotetext{
${ }^{526}$ Entrevista concedida por Cloves de Castro à autora. Idem, ibidem.

527 O dirigente da ALN, Antonio Carlos Bicalho Lana, e Sônia Maria Angel Jones de Moraes foram assassinados em 30/11/73. Os últimos militantes da ALN a serem assassinados foram Ieda Santos Delgado, desaparecida em 11/04/74; Ana Rosa Kucinski e seu marido, Wilson Silva, que desapareceram em 22/04/74. Em seguida, desapareceram o dirigente da ALN Thomas Antônio da Silva Meirelles Neto, em 07/05/74; e Issami N. Okano, em 14/05/74. V. Dossiê Ditadura, op.cit., p.500-6, 565-66, 569-71, 573-75, 575-76.

${ }^{528} \mathrm{O}$ militante do Molipo, João Carlos Cavalcanti Reis, foi assassinado por agentes do DOI-Codi/SP em 30/10/72. Dossiê Ditadura, op.cit., p.386-7.

${ }^{529}$ Entrevista concedida por Carlos Alberto Lobão da Cunha à autora. Idem, AAPP/AEL-LEI.
} 
No final dos anos 1960 e na década seguinte, algumas tentativas de fuga de presos políticos foram bem sucedidas no Brasil. Duas fugas, em especial, foram espetaculares: uma, na qual presos políticos escaparam da penitenciária Lemos de Brito, no Rio de Janeiro, em 1969; e, a outra, ocorreu em agosto de 1979, quando Theodomiro Romero dos Santos fugiu da penitenciária Lemos de Brito, em Salvador ${ }^{530}$. Pensar ou planejar fugas era uma possibilidade concreta, conforme relatou Carlos Lichtszteyn, militante da ALN preso em 24 de setembro de 1969, quando foi atingido à bala numa emboscada organizada na alameda Campinas, em São Paulo:

“A gente conversava sobre fuga. Era para eu fugir numa das minhas idas ao hospital, no dia 4 de novembro de 1970, quando seria organizado um monte de homenagens a Marighella. E esse plano de fuga estava no papel encontrado com o Toledo [Joaquim Câmara Ferreira], quando ele foi morto.

Avisaram: ‘- Você vai sair em tal circunstância!' [...] No primeiro período em que fiquei preso, passei praticamente no gesso sendo tratado pelos companheiros. [...] Eu teria que ter tido um acompanhamento [...] e daí surgiu uma gangrena no calcanhar. E um cara cortou, até chorou, foi um negócio horrível, ficou um buraco daqueles! E ele me escreveu o que eu tinha que fazer. Voltei e fiquei um tempão, praticamente seis meses sem nenhum tratamento. [...] daí, com uns meses foi cicatrizando. Quando da visita de d. Vicente Scherer, eu estava numa situação muito ruim, sem tratamento, ele era favorável à ditadura, mas os padres da cela 7 reclamaram, levavam ele para me ver. Era uma visita de uma autoridade e eles disseram: "- Olha, veja esse cara todo arrebentado. Estão lhe negando tratamento, uma coisa desumana!” Com isso, consegui um tratamento na Santa Casa. [...] Tiraram o gesso [...] e estava tudo podre! No dia, chorei, achava que nunca mais ia andar, a minha perna era um pau, aquilo não se mexia. Consegui ficar quinze dias na Santa Casa [...].

Voltei, com o tempo os advogados fizeram petição, d. Paulo começou a aparecer na história, consigo fazer fisioterapia no HC, aí apareceu essa história de fuga, em meados de 1970, e tenho uma perspectiva de sair. Falaram: “- Olha, vão te tirar, fica atento, o pessoal vai entrar lá [no HC] e te tirar”. Claro, todo mundo que está preso quer sair, quer fugir, quer organizar uma fuga de qualquer jeito, quer que a organização tome o presídio e solte todo mundo. Isso é evidente, é o prato do dia. Todo mundo que está preso, digamos, uma boa parte sonha com isso. E sempre há propostas: coisas factíveis ou ideias mirabolantes. Ninguém gosta de ficar preso. Agora, continuávamos dentro daquela ideia de manter a dignidade, a atividade política etc. [...] Eu estava aguardando, não sabia se ia acontecer, daí o Toledo foi assassinado e acabou. [...] Foi um caso de infiltração, muita gente foi presa [...] e acabou. No bilhete encontrado com ele, tinha algumas anotações [...]. Só sei que haveria algum tipo de homenagem ao Marighella [...] com várias ações, mas não sei quais $[\ldots]^{531}$."

\footnotetext{
${ }^{530}$ V. a descrição da fuga na entrevista concedida por Antônio Duarte à autora. RJ, 20 e 24/11/2008, AAPP/AEL-LEI. E entrevista concedida por Theodomiro Romero dos Santos à autora. Idem, ibidem. Em 1969, a presa política Zilda Xavier Pereira, fugiu de um hospital no Rio de Janeiro. V. entrevista concedida por Zilda Xavier Pereira à autora. RJ, 15/02/2002. Em julho de 1977, o ex-marinheiro Claudio Ribeiro, fugiu do presídio de segurança máxima da Ilha de Itamaracá (PE). JosÉ, E. op.cit., p.223.

${ }^{531}$ Entrevista concedida por Carlos Lichtsztejn à autora. SP, 07/05/2010, AAPP/AEL-LEI. Após a visita, d. Vicente Scherer declarou à imprensa que tinha visitado os presos políticos e podia atestar a inexistência de torturas no Brasil. Mesmo depois de ouvir uma descrição detalhada de Lichtsztejn sobre as torturas que sofreu, apesar de gravemente ferido. V. CunHA, Carlos A. L. "Desesperar Jamais", em Tiradentes, op.cit., p.243.
} 
Com o fim dos sequestros de diplomatas que, entre os anos 1969 e 1971, conseguiram a libertação de várias lideranças das principais organizações de luta armada, intensificou-se o processo de balanço e avaliação em vários grupos. No exterior foi organizada uma pequena dissidência da ALN chamada Tendência Leninista que criticava o militarismo, propunha cessar as ações armadas e voltar ao trabalho político com os setores populares da sociedade. O documento “Uma autocrítica necessária”, de agosto de 1971, afirmava que estava “[...] fora de cogitações o raciocínio simplista de que o surto de desenvolvimento econômico alcançado nos centros industriais do país [... fosse] o responsável pelo afastamento progressivo do povo do movimento de luta armada. [...] a verdade é que nem a repressão brutal, nem o surto desenvolvimentista podem ser

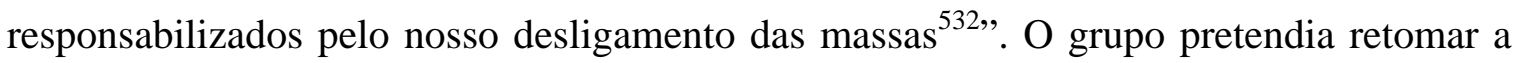
linha política do Agrupamento Comunista de 1967 e reorganizar um partido político numa reunião no exterior. O debate sobre esse texto chegou com certo atraso aos militantes da prisão ${ }^{533}$.

Entre 1970 e 1971, outra dissidência da ALN, chamada Molipo, formada especialmente a partir do grupo que havia treinado guerrilha em Cuba (no 'III Exército' da ALN), preocupava-se com a falta de inserção social e a ausência de trabalho político, mas sem deixar de lado o projeto de preparação da guerrilha rural, conforme Pedro Rocha Filho, militante do Molipo preso em São Paulo em março de 1972:

“[...] nós da 'frente de massas' da ALN, [da qual fazia parte o Hiroaki Torigoe], achávamos que ainda existia uma alternativa, que seria a mudança de ênfase, não fazer tantas ações para conseguir dinheiro e tal, e fazer mais trabalho para conseguir apoio, logística, o 'trabalho de massa'. E fazer ações, principalmente, de propaganda. Na verdade a gente nunca conseguiu deixar de fazer as ações de sobrevivência, porque se precisava de dinheiro para sustentar o pessoal clandestino, para comprar roupa e não andar como marginal na rua para não chamar muito a atenção. Nesse processo, aconteceu a chegada do chamado Grupo dos 28 de Cuba, e a frente de massas, através de alguns dos seus dirigentes, fez contato com esse pessoal que vai resultar no rompimento de uma parte da 'frente de massas' com a direção da ALN, e a fusão com esse pessoal que dá na constituição do Molipo, Movimento de Libertação Popular, onde eu passo a militar, [em meados de 1971].

[...] Na minha cabeça, [...] eu não achava que o Molipo tivesse uma definição mais precisa de qual deveria ser a linha política ou mesmo a prática de ação armada. [...] Mas nós [...] pensávamos [...] que poderia haver um processo de discussão para uma formulação mais acabada. E me parecia, na época, que existia mais preocupação do Molipo com a questão do movimento de massas. [...] a única convergência básica que acho que existia era a necessidade de continuar agindo, de continuar praticando a luta armada [...]. Havia uma confrontação prática e teórica do Molipo com outras posições [...], em especial, com a

\footnotetext{
${ }^{532}$ Del RoIO, José Luiz. Zarattini, a paixão revolucionária. São Paulo, Ícone, 2006, p.291 e 293-4.

${ }^{533}$ Entrevista concedida por Pedro Rocha Filho à autora. Idem, AAPP/AEL-LEI.
} 
Tendência Leninista, o grupo do Zarattini [...]. O ‘Grupo dos 28’ procurava se diferenciar da posição que deixava a luta armada para depois ${ }^{534}$.”

A partir do final de 1971, quando os presos políticos mantidos na Casa de Detenção foram transferidos novamente para o presídio Tiradentes, estes começaram a se reestruturar e a se preparar para uma convivência prolongada nos cárceres (apesar do surgimento de dissidências em outras organizações e da tensão interna existente na ALN), dividindo tarefas e enfrentando as cobranças sobre a morte de Marighella, por meio de um processo de avaliação das prisões e mortes de seus companheiros:

“[...] em que consistiu esse processo especial de unificação e de reorganização? O pomo da discórdia era o problema da autocrítica do comportamento na tortura [principalmente, no caso do Marighella]. Companheiros novos que chegaram à cadeia, de outras origens e de outra leva de quedas, distantes daquela problemática, conseguiram convencer todo mundo, de que a gente devia ter um mínimo de organização para promover um processo interno de crítica e autocrítica. E, depois desse processo, ver o que fazer. [...] Estabelecemos, então, três coordenações da ALN no presídio de Tiradentes. Uma do pavilhão I, que se chamava 'dez', outra no pavilhão II, e é por causa do número do pavilhão que surgem os nomes, que era a 'vinte', e a da torre, entre as meninas, que era a 'trinta'. As coordenações 10, 20 e 30 entraram em acordo e iniciaram esse processo para reestabelecer a verdade. A gente chegou à nossa verdade ali. A partir daí tentamos superar os problemas que existiam e nos unificarmos. [...] Fizemos todo um processo de crítica e autocrítica dentro das condições de cadeia. A gente chegou a concluir esse processo entre os homens, na Detenção, depois da transferência arbitrária [...], que gerou a greve de fome de $1972^{535}$."

Fora das prisões, no entanto, as divergências que despontavam nas fileiras da ALN e de outras organizações revelavam, simultaneamente, a presença de propostas díspares e certa incapacidade para levar à frente o debate relativo aos seus problemas e eventuais soluções. Neste período, ocorreram alguns “justiçamentos” de militantes, supostamente traidores. Nas fileiras dos grupos armados ecoavam propostas que íam da realização de um imediato recuo, tático ou estratégico, à desistência da luta. Estas propostas por vezes confundiam-se com o trabalho eficiente de agentes policiais infiltrados, que resultaram em várias mortes e desaparecimentos de militantes. O “justiçamento" chocou parte considerável dos militantes, apressou o rompimento dos dissidentes do Molipo com a ALN, por exemplo, e criou uma atmosfera de medo. Assim,

\footnotetext{
${ }^{534}$ Entrevista concedida por Pedro Rocha Filho à autora. Idem, AAPP/AEL-LEI.

${ }^{535}$ Entrevista concedida por Manoel Cyrillo de Oliveira Netto à autora. Idem, ibidem.
} 
quando o dirigente do Molipo, Hiroaki Torigoe, foi assassinado em 5 de janeiro de 1972,

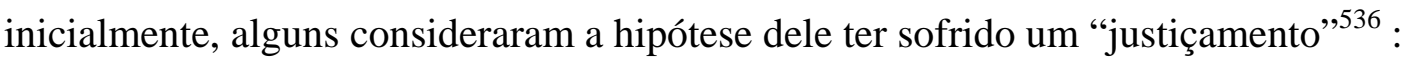

\begin{abstract}
"Havia, de certa forma, na época, um tabu de falar em recuo [...]. Eu me lembro que em determinado momento, ainda na ALN, quando estávamos fazendo a discussão que acabou dando na fusão [que criou o Molipo], aconteceu um incidente lamentável que foi o fuzilamento de um militante da ALN, o Márcio de Leite Toledo ${ }^{537}$. Nesse momento, a gente estava numa situação meio desesperadora dentro da 'frente de massas'. E esse episódio acabou fazendo parte da disputa política que estava acontecendo na direção da ALN com a posição dos '28', particularmente, e com a frente de massas. Eu me lembro de uma situação, quando estávamos dentro de um carro eu, o Giannini, o Scavone e o Torigoe, os quatro dentro de um fusquinha (não sei se isso aconteceu na época da prisão do Torigoe), mas com certeza estávamos nós três, e meio que brincando, meio que a sério, falamos: '- Vamos sobrar nós três (ou nós quatro), o que nós vamos fazer?’ E a disposição nossa foi de ir até o fim naquela situação de crise, de prisão, de morte, de briga, de ameaças de justiçamento. A nossa disposição era de ir até o fim, qualquer que fosse a consequência. Até o fim ali no caso era até morrer, porque não tinha outro fim visível ${ }^{538}$."
\end{abstract}

O tema dos “justiçamentos” foi lembrado espontaneamente em duas entrevistas

nesta pesquisa, indicando que permanece a dificuldade de tratar do assunto. Manoel

Cyrillo relatou como reagiu na prisão à morte de Márcio Toledo e aos “justiçamentos”:

“[...] eu abstraia, punha uma pedra em cima: morreu o Márcio Toledo, mas não me sentia obrigado a achar ou analisar se isso foi assassinato ou justiçamento, [...], porque não tinha elementos para fazer isso. E, fundamentalmente, por melhores que fossem os contatos, eles eram precários, [...] era dificílimo fazer chegar a nós um relato completo sobre o episódio "Marcio Toledo" e as posições assumidas, que fosse isento. [...] Era melhor ficar quieto, porque é muito mais honesto, mais decente, não cabia à gente interferir. Eu levei esse raciocínio ao extremo de forma que até hoje não me posiciono. Não vou dizer: '- Tá certo, tinha que matar [...].' Ou: '- O [...] que aconteceu foi um crime. [...] Eu não me posiciono, não me posicionei antes e continuo sem saber, [...] pois hoje o tema está cheio de elementos de outra natureza, o que complica ainda mais. Então, continuo quieto e acho que a nossa posição foi correta, porque se tivéssemos nos posicionado, [...] quando chegassem os remanescentes do Molipo na prisão, imagine o nosso comportamento, o nosso rancor, com relação àqueles caras que racharam a nossa organização? Por fim, tivemos um comportamento, na medida do possível, amistoso e solidário [... ${ }^{539}$."

No período imediatamente anterior e durante a Guerrilha do Araguaia, Criméia de Almeida ponderou que os “justiçamentos” foram sugeridos no PCdoB, em função da desconfiança da existência de dois casos de infiltração. A primeira infiltração teria sido responsável pela descoberta da localização da área onde o PCdoB preparava seu projeto

\footnotetext{
${ }^{536}$ Entrevista concedida por Pedro Rocha Filho à autora. SP, 24/02/2011; e Dossiê Ditadura, op.cit., p.3045. Gorender contabilizou 4 justiçamentos realizados pela esquerda revolucionária entre os anos de 1971 a 1973, 3 sob responsabilidade da ALN e 1 do PCBR. V. GORENDER, Jacob. op.cit., p.278-82.

${ }^{537}$ Márcio Leite de Toledo foi “justiçado” pela ALN em 23/03/71; V. MARTINELLI, Renato. Um grito de coragem. Memórias da luta armada. São Paulo, Com-Arte, 2006.

${ }^{538}$ Entrevista concedida por Pedro Rocha Filho à autora. Idem, AAPP/AEL-LEI.

${ }^{539}$ Entrevista concedida por Manoel Cyrillo de Oliveira Netto à autora. SP, 20/03/2011.
} 
de guerrilha rural. A segunda teria municiado os militares de informações sobre os guerrilheiros, durante o ano de 1973. Tratava-se de um guerrilheiro, “cujo comportamento havia se mostrado indesejável desde o início dos combates, quando se fingiu doente e com um ferimento, que, mais tarde, constatou-se ser apenas um pequeno arranhão ${ }^{540 \text { ", }}$

No primeiro caso, a direção do partido na guerrilha decidiu que não havia provas conclusivas sobre a possível infiltração e, na segunda, o coletivo dos guerrilheiros debateu a questão e concordou que não havia provas para realizar o justiçamento. Nestas condições, o justifiçamento criaria um profundo mal-estar entre os combatentes. De acordo com Almeida, não é possível saber “o que os militantes pensaram depois que esse indivíduo desertou da guerrilha, porque eu não estava mais na região ${ }^{541 ”}$ - tal sendo um dos vários enigmas não esclarecidos da Guerrilha do Araguaia.

As condições adversas nas quais os militantes viviam, submetidos à lógica da sobrevivência na clandestinidade, assim como as dos presos políticos, isolados no confinamento dos presídios, dificultavam muito o intercâmbio de informações e a organização e articulação da atividade política dentro e fora das prisões. As tentativas de organizar o debate e agir exigiam cuidados redobrados com a segurança das pessoas envolvidas em tarefas de transporte de material e mensagens para os partidos clandestinos e legais, sindicatos, entidades estudantis e de direitos humanos, para autoridades e a imprensa no Brasil e no exterior. Essas tarefas acarretavam grande risco e a disseminação do sentimento de medo.

É de se ter em vista que, se por um lado, as características inerentes ao confinamento eram notoriamente contrárias à disseminação das informações de interesse das esquerdas, por outro, várias das entrevistas aqui compiladas sugerem a existência de dificuldades suplementares, representadas por barreiras ao diálogo no interior das organizações estruturadas nas prisões. A despeito do predomínio da solidariedade entre os presos, diversos testemunhos apontam para dificuldades na conjugação de projetos, posturas e interesses, conforme o sectarismo fazia-se prática relativamente comum.

Parte da ALN e de outras organizações percebiam o próprio isolamento e procuravam maneiras de mudar sua atuação. Nesse sentido, o dirigente da ALN, Luiz José da Cunha (o Crioulo), foi ao Chile em 1972 conversar com membros da Tendência Leninista. De acordo com José Luiz Del Roio,

\footnotetext{
${ }^{540}$ Entrevista concedida por Criméia A. S. de Almeida à autora. SP, 27/07/2000, 28 e 30/11/2001, e 20/10/2004.

${ }^{541}$ Idem, ibidem.
} 
"O Crioulo era mais velho, tinha sido quadro da seção juvenil nacional do PCB, tinha uma formação política maior. Neste momento, quando o Crioulo se encontra conosco, membros da TL, a ALN estava tentando aprofundar um processo de autocrítica, que não foi possível por vários motivos, mas, principalmente, porque eles estavam submetidos às necessidades da sobrevivência na clandestinidade. Eles criaram um jornal chamado 'Guerrilha Operária', o que representava uma tentativa de voltar a realizar um trabalho de massas. Por outro lado, eles tinham um grupo de jovens militantes que era realmente militarista. A ALN não aceitava a ideia da existência de uma tendência dentro da organização, o que demonstra que eles eram mais leninistas do que admitiam. E não aceitavam a convocação de um Congresso no exterior, o que na prática significava não aceitar a proposta, porque era um risco muito grande juntar vários quadros no Brasil para conversar $^{542,}$.

No final de 1971, de acordo com Darci Miyaki, a ALN havia iniciado estudos e levantamentos para implementar um trabalho de organização da guerrilha rural a médio ou longo prazo:

\begin{abstract}
"Do ponto de vista estratégico, havia uma preocupação com a subdivisão do Brasil em áreas, visando à intensificação do trabalho de guerrilha rural, que já estava se instalando em vários pontos... Em 1971, militantes estavam em Imperatriz (MA) e em várias regiões do Brasil. [...] Mas um dos que estavam se dirigindo para Imperatriz, por exemplo, foi, lamentavelmente, o Severino... que entregou o Toledo.

[...] Esses trabalhos foram iniciados, mas não prosseguiram. Justamente, por isso é que tínhamos de fazer o primeiro trabalho, que era o de inteligência, que não era o de coletar informação simplesmente. Era necessário realizar uma análise dos dados que você colheria de geopolítica, geografia, economia etc, que nunca tínhamos feito ou tínhamos feito de uma forma muito superficial. Em termos estratégicos, haveria gente em várias regiões que mandariam informação. Eu estava começando a estruturar uma forma, uma estrutura para isso acontecer, dentro daquela realidade que nós estávamos vivendo na época. A partir das informações desse grupo de áreas específicas do conhecimento, nós juntaríamos tudo para ter uma visão geral de cada região. E, a partir disso, aprofundaríamos o trabalho rural que já existia ou passaríamos para outras áreas. [...] Já havia pessoas 'implantadas' em outros lugares, inclusive, são dados pouco conhecidos.

[...] Do ponto de vista tático, seguia assim: sairmos da situação de fazer ação pela ação, que era uma realidade na qual tínhamos caído. Havia divergências dentro da organização, foi cogitado, inclusive, um recuo tático, para nos reestruturarmos, estávamos numa fase de intensa discussão política. Havia uma ala mais militarista, outra ala que tinha uma visão político-militar, mas havia pouca atividade política propriamente dita. Nós tínhamos perdido os contatos com as massas. O trabalho, digamos, nos centros urbanos, [...] praticamente inexistia. [...] Na época, havia uma propaganda maciça da ditadura militar: a imagem do Brasil que ganhou a copa foi muito explorada. A ditadura tinha uma estrutura de propaganda muito organizada e atingia as mais variadas classes. O que não significa que outras organizações não fizessem trabalho político. A ALN não tinha, mas havia 'trabalho de massas', reduzido em função da repressão!

[...] Nós debatemos as críticas feitas pela Tendência Leninista e o Molipo, mas, concretamente, do ponto de vista prático, não foi feito nada. [...] Mas havia também o problema da interferência estrangeira em nossos assuntos, como a de Cuba ${ }^{543}$.”
\end{abstract}

\footnotetext{
${ }^{542}$ Entrevista concedida por José Luiz Del Roio à autora. SP, 20/03/2010.

${ }^{543}$ Entrevista concedida por Darci Miyaki à autora. SP, 10/03/2011.
} 
Este projeto poderia garantir a retirada de seus principais quadros dos centros urbanos e os protegeria por tempo determinado, mas a conjuntura política e o avanço da repressão não permitiam mais tal tipo de preparação prolongada, como a que foi realizada a partir de 1966, no sudeste do Pará, pelo PCdoB.

A heterogeneidade das posições políticas existentes no presídio Tiradentes, inserida nesta atmosfera mais ampla definiu antagonismos entre as duas posições predominantes nos coletivos de presos de São Paulo, ao longo da primeira metade da década de 1970. Enquanto uma priorizava a elaboração de um balanço crítico e teórico da atuação das esquerdas revolucionárias no Brasil ${ }^{544}$, a outra focava a produção de textos de denúncia e a organização de movimentos e lutas de resistência à ditadura a partir dos cárceres.

Embora muitos presos tenham aderido de sobremaneira à polarização, é de se ter em vista que as duas posições acabaram por oferecer contribuições importantes ao desenvolvimento da conjuntura política do país nos anos 1970, convergindo em determinados momentos, em que o empenho para a realização de balanços críticos encontrou o passo das estratégias de sobrevivência e articulação dos movimentos de protesto e resistência, que visavam desgastar o regime.

Passados mais de quarenta anos, desponta a inexistência de contradições efetivas entre as duas propostas e, de maneira geral, entre os esforços gerais das esquerdas para levar a cabo avaliações aprofundadas da sua atuação e a adoção de práticas de resistência às imposições coercitivas da direção dos presídios e da ditadura, em termos mais amplos.

\subsection{As mulheres e a reorganização do cotidiano na prisão}

Nos anos 1960 e 1970 ocorre uma ascenção da presença da mulher na sociedade em todo o mundo. Estava em andamento uma transformação social e cultural, na qual o papel tradicional atribuído às mulheres foi seriamente questionado. As organizações de esquerda no Brasil, nesse período, eram compostas majoritariamente por homens, mas uma presença significativa de mulheres nessas organizações se fez notar, em particular, nos grupos de luta armada urbana. Elas representavam, em média, 18\% do contingente desses grupos, de acordo com os dados referentes aos processados na justiça militar, um

\footnotetext{
${ }^{544}$ V. tb. ConçALVES, Francisco Luiz Salles. “A correção política é o ópio dos intelectualerdas”, em Tiradentes, op.cit., p.88-95.
} 
porcentual acima do correspondente número de mulheres existente nos demais partidos [RIDENTI, 1993: 196-98].

As militantes de esquerda, entretanto, enfrentaram não somente a ditadura, mas a ordem estabelecida no que se refere aos costumes que impunham o estereótipo da mulher submissa na política e restrita ao espaço privado e doméstico. Elas tomaram parte ativa nas lutas políticas e enfrentaram a ordem vigente em todos os níveis, embora suas reivindicações não tivessem ainda um caráter abertamente feminista [Idem, ibidem]. O movimento feminista no Brasil se constituiu enquanto tal em meados dos anos 1970 impulsionado e influenciado, em grande medida, por essas militantes, tanto pelas exiladas quanto pelas ex-presas políticas que se mantiveram no país ${ }^{545}$.

Testemunhos coletados nesta pesquisa relataram que essas militantes tiveram de enfrentar a discriminação por serem mulheres dentro de suas organizações ${ }^{546}$. Algumas mulheres chegaram a ocupar cargos de direção ${ }^{547}$. No cotidiano da militância foi possível questionar a divisão das tarefas domésticas, o tabu da virgindade e a monogamia. Não obstante, embora o discurso da igualdade política e social entre os sexos estivesse se disseminando nas esquerdas, no campo das práticas dos militantes havia pouco respeito às diferenças de gênero. Houve avanços na militância das novas esquerdas, se comparadas às da esquerda tradicional [RIDENTI, 1993: 203], mas foi necessária grande determinação das militantes para questionar o machismo predominante. Elas próprias reproduziam muitos valores da educação vigente ${ }^{548}$.

Nos grupos guerrilheiros, as militantes tiveram de romper também com a visão historicamente assentada de que "era mais difícil converter as mulheres em soldados" [RIDENTI, 1993: 198]. Várias mulheres, gradualmente, conseguiram se transformar em boas ou excelentes guerrilheiras, na cidade ${ }^{549}$ e no campo, conforme o testemunho de Criméia A. S. de Almeida, a primeira militante enviada - janeiro de 1969 - para a região onde se deu a Guerrilha do Araguaia:

\footnotetext{
${ }^{545}$ V. entrevista concedida por Criméia A. S. de Almeida à autora. SP, 07/11, 12 e 19/12/2008. AAPP/AELLEI; entrevista concedida por Iara Areias Prado à autora. SP, 18/09/2009. AAPP/AEL-LEI; entrevista concedida por Rosalina Santa Cruz à autora. Idem, ibidem; entrevista concedida por Maria Amélia de Almeida Teles à autora. Idem, ibidem; e TelEs, Maria Amélia de A. Breve história do feminismo no Brasil. São Paulo, Brasiliense, 1993, p.82-102 e segtes.

${ }^{546}$ Idem, ibidem.

${ }^{547}$ V. entrevista concedida por Beatriz Bargieri à autora. Idem, ibidem.

${ }^{548}$ V. depoimento de Regina em Memórias das mulheres no exílio, op.cit., p.416 apud RiDENTI, M. op.cit., p.203.

549 V. entrevista concedida por Carlos Alberto Lobão Cunha à autora. SP, 10/10/2010; e entrevista concedida por Suzana K. Lisboa à autora. RJ, 10 e 11/02/2003.
} 
“[...] Quando eu fui, o João Amazonas me disse: '- Depende de você a ida de outras mulheres'. E eu respondi: '- E se os homens não derem certo? Não vai haver guerrilha, não vai haver luta armada, não vai haver resistência? Porque isso não pode depender de mim; eu posso não dar certo, mas outras sim. Como você coloca assim?' Ele disfarçou e disse: '- Não, é modo de dizer'.

[...] Eu senti que não estava sendo muito bem vinda pelos mais jovens, quando cheguei; porque a Elza Monnerat estava lá, mas ela não participou das atividades militares do destacamento, do treino etc. O treinamento seria feito lá e eu fiz. Aprendi a dar tiro, algumas coisas militares, orientar-se na mata, achar o tal do azimute; que era... uma arte complicada. E achar pelo sol, pelos pauzinhos, pelo solstício. Ver qual era o azimute daquele fim de mundo era... Naquele tempo, não tinha GPS, ou pelo menos, a gente não tinha acesso, talvez, os militares já tivessem alguma coisa mais sofisticada.

[...] Eu aprendi a plantar, caçar, orientação, atirar; basicamente, todos os exercícios de sobrevivência na selva. Mas enfrentei resistência dos companheiros, porque eles achavam que a mulher seria um peso para a guerrilha. Eles não falavam abertamente, mas faziam assim: “- Tem um saco de $60 \mathrm{~kg}$, traz esse saco”. Alguns deles conseguiam, nem todos. Era óbvio que eu, que naquela época, [...] pesava 48 quilos, [...] não ia conseguir [...]. Eles respondiam com sarcasmo [...]: ‘- Como? Você não é guerrilheira?’ [...] Uma vez chegou um carregamento de barco e lá chovia muito [...]. Não tinha mais ninguém, [...] abri os sacos, ia pegando aos pouquinhos e levava; fiz 'trocentas' mil viagens. E, depois, [...] costurei os sacos como se não tivessem sido abertos. [...] E nunca falei para ele que trouxe aos pouquinhos. [...] Também havia solidariedade; uns eram solidários e, outros, discriminavam com a super proteção. [...] Tinha os dois tipos de discriminação. A gente foi vencendo; sozinha foi mais difícil, mas depois vieram outras mulheres. [...] As primeiras começaram a chegar em 1970. [...] Eu senti que eles não me desaprovaram $100 \%$, quando começaram a trazer outras. Essa foi a prova.

[...] A adaptação foi relativamente fácil para mulheres e homens; uns tiveram mais dificuldades, outros menos. Á medida que aumentava o número de mulheres, a gente reclamava mais. A questão da mulher era muito discutida, por causa dessas discriminações. [...] Eram coisas muito pequenininhas, mas era o nosso dia a dia [...], a gente brigava para poder caminhar na mata sozinha etc ${ }^{550}$."

Nas cidades, em grupos armados como a ALN e a VPR, as relações entre homens e mulheres romperam também com preconceitos e práticas tradicionais. As mulheres tiveram papel destacado como guerrilheiras, não cumpriram apenas funções de levantamento de informações para a realização de ações armadas e de preparação do apoio logístico, mas atuaram em todo tipo de atividades, conforme relatou Carlos Alberto Lobão Cunha:

"Logo no início da minha atuação no GTA eu já tive contato com mulheres. Havia duas companheiras que usavam perucas louras nas ações de expropriação de banco. Elas tinham mais experiência do que eu. Exemplificando: numa ação de banco da qual participei, a voz de comando para começar a ação foi dada por uma das louras. E foi muito bem sucedida. Depois das quedas de setembro de 1969 da ALN, o GTA passou a ser comandado por uma mulher. Ela demonstrou ser excelente comandante. As mulheres no nosso GTA exerciam as mesmas atividades dos homens.

Durante o tempo em que atuei não tive conhecimento de qualquer discriminação de gênero, não me defrontei com questões de divisão de tarefas domésticas etc. Só tenho

${ }^{550}$ Entrevista concedida por Criméia A. S. de Almeida à autora. Idem. AAPP/AEL-LEI. 
elogios a fazer às companheiras com quem militei, seja do ponto de vista político, de disciplina ou 'militar, ${ }^{551}$."

O machismo e a discriminação, no entanto, revelaram-se também nas organizações armadas urbanas. A militância das mulheres implicava em rupturas com os valores e a visão tradicional de família, com o papel de dona de casa, mãe e esposa. Representou um marco na vida das militantes, pois exigiu grande capacidade de superação e de transformação, conforme relato de Suzana K. Lisbôa, militante da ALN que realizou treinamento guerrilheiro em Cuba entre 1970 e 1971:

"Quando fui para Cuba meu objetivo era treinar, me especializar para voltar e lutar. O Ico [Luiz Eurico Tejera Lisbôa], por exemplo, queria que eu tivesse um filho e tivemos uma grande briga. Eu disse: '- Não, estou indo para Cuba para treinar, não para ter filho.' Nós queríamos ter um filho, ele queria aproveitar esse período para treinar enquanto eu teria um filho [...]. Foi um rolo e nós nos distanciamos muito nessa época, até porque, chegando lá, era um outro mundo. Havia muita gente, [...] de outras nacionalidades também. Foi uma experiência muito rica tanto do ponto de vista pessoal quanto político.

[...] Em Havana, tentávamos organizar a casa, mas era bem difícil manter a limpeza, a organização e fazer a comida, havia sempre o coordenador que tentava fazer isso. [...] Não me lembro dos homens fazendo comida. Eu lembro que fiz comida muitas vezes. [...] Mas eu não sabia cozinhar direito.

[...] Houve descriminação na primeira parte do treinamento, no Ponto Zero, mas a parte do campo foi mais complicada. No princípio, não queriam que as mulheres treinassem no campo. As mulheres conseguiram treinar no campo de forma efetiva somente no grupo anterior, no do Molipo. [...] Na tornearia, por exemplo, não havia mulheres, era um setor dos homens. [...] Eu fiz mais de uma vez o treinamento de tiro, para me especializar melhor [...].

[...] No campo, reduziu-se ainda mais o número de mulheres. [...] E foi muito complicado [...]. No começo foi muito difícil para mim. Tinha uma companheira que estava lá, que nada era difícil para ela. [...] Ela era pequena, mas fazia o campo de obstáculos em tempo menor do que qualquer um dos homens. [...] Ela me ajudava muito e havia mais gente que me ajudava.

[...] Para mim foi uma experiência super importante, do ponto de vista pessoal e militar, e, principalmente, serviu para eu me colocar enquanto mulher e guerrilheira nessa luta. Acho que não teria tido a sobrevida que eu tive, não teria conseguido conviver com relativa 'facilidade' na clandestinidade, se eu não tivesse passado por isso, porque essa foi uma experiência muito forte no sentido de tu te superar. [...] Eu não tinha a mínima constituição física, nem formação, mas fiquei durante quase seis meses no campo fazendo um treinamento físico complementar para mim, diário e constante, fora do treinamento regular. [...] E essa foi uma iniciativa minha. [...] Eu passei a mexer com armas melhor do que a maior parte das pessoas. Eu tinha uma pontaria melhor que a de todos do meu grupo. Não que eu fosse excelente, mas era a melhor do meu grupo. [...] E toda essa experiência me ajudou muito ${ }^{552}$.”

Suzana K. Lisbôa foi uma das poucas militantes que sobreviveram à repressão após retornarem ao país de um treinamento de guerrilha em Cuba. Todos estavam

\footnotetext{
${ }^{551}$ Entrevista concedida por Carlos Alberto Lobão Cunha à autora. SP, 10/10/2010.

${ }^{552}$ Entrevista concedida por Suzana K. Lisboa à autora. Idem, ibidem.
} 
marcados de morte pelos órgãos de informação e segurança. Ao retornar, Suzana e seu marido se estabeleceram em Porto Alegre (RS) com a tarefa de reorganizar a ALN no Rio Grande do Sul, mas em 2 de setembro de 1972 Luiz Eurico se tornou mais um desaparecido político [Dossiê Ditadura, 2009: 367-71].

Nesse contexto, algumas mulheres tentaram se aproximar do modelo masculino de combatente, acreditando que dessa forma seu desempenho militar seria melhor. Para muitos, a sexualidade da mulher estava intrinsicamente ligada à função tradicional de reprodução e à maternidade, e as militantes tiveram de romper com esse e outros preconceitos, costumes e, inclusive, com suas famílias:

“[...] Antes de 1967, eu já tinha tido um namorado com quem eu transava, [...] ele queria casar comigo, mas eu não. [...] Sempre foi uma coisa muito conflituosa, porque a minha geração estava bem na metade do caminho, a gente rompeu com tudo e era muito difícil, para os pais e para a gente também.

[...] Entre mim e a minha mãe, é claro, houve muita briga. Ela começou a ter medo de me perder, [...] para algo que ela não estava entendendo [...]. Muitas brigas e muitas por questão moral, o meu pai não se metia. [...] Eu me lembro que, logo depois que fiquei clandestina, fiz um aborto, fiquei com medo e liguei para ele e pedi ajuda [...]. Ele ficou arrasado, o papai era daqueles médicos das antigas, ele podia ser um liberal progressista, mas era das antigas. Não esqueço o que ele me falou ao telefone e que foi muito engraçado [...]: '- Você não saiu de casa para isso!' Ou seja, assaltar bancos e sequestrar, tudo bem, ele tinha o maior orgulho, mas fazer abortos, não. Era muito difícil, moralmente, aquilo tudo para eles, muito mais difícil do que a questão política. [...] O meu pai nunca foi a favor da luta armada, mas estava do mesmo lado, digamos assim. A mamãe, depois, foi se aproximando da Teologia da Libertação, quer dizer, ela vai entender mais o lado moral, talvez, por ser mulher, por todo o sofrimento e a vivência dela, ela vai, num certo sentido, no moral, além do papai. No final da vida, ela era outra pessoa $^{553}$."

Em muitas organizações de esquerda, as mulheres tiveram de enfrentar questões polêmicas sobre a sexualidade e a maternidade, que era considerada um empecilho para a militância e a guerrilha. “O ideal era a abstinência sexual. Como na prática isso era inviável, buscou-se negar a sexualidade, particularmente da mulher guerrilheira [TELES, 1993: 72].” Não obstante, essas mulheres enfrentaram a violência policial na militância clandestina e, quando presas, a violência da tortura sexual e da tortura durante a gravidez. A maternidade nas prisões ou depois foi sentida pelas presas como uma vitória e um alento, conforme Criméia A. S. de Almeida: “Quando meu filho nasceu, senti que no mesmo lugar onde eles queriam nos destruir, eu produzia vida ${ }^{554}$.” “[...] Nessas

\footnotetext{
553 Entrevista concedida por Lúcia Murat à autora. Idem, ibidem.

${ }^{554}$ V. “Que bom te ver viva”. Filme da ex-presa política Lúcia Murat, 1989.
} 
condições, a mulher pode dar uma resposta inesperada - à ameaça de morte, podemos responder com uma nova vida [TELES, 1993: 72]”.

As mulheres militantes enfrentaram os conflitos relacionados à monogamia e à sexualidade também em função da prisão de seus companheiros e maridos:

“[...] a luta armada aconteceu antes de 1975, antes das ideias feministas terem se desenvolvido e se espalhado pelo mundo e no Brasil. [...] Foi a esquerda quem levou as questões do feminismo no Brasil, em outros lugares não. [...] As organizações de luta armada eram revolucionárias em relação à política, à forma tradicional de fazer política [...]. Havia uma rebeldia em relação [...] à ideia de partido hierarquizado [...], que quebrava com o parâmetro do centralismo democrático. Mas a questão do machismo continua, essa questão era muito forte e enraizada [...]. Não era uma coisa só dos grupos de esquerda, [...] que até eram mais liberais ou menos preconceituosos. [...] Uma das coisas que mais questionamos foi a das relações de casamento e de fidelidade de um casamento monogâmico. [...] Os casais eram separados pela prisão e você era separado numa condição não de opção, você estava numa relação e um deles era preso e por muito tempo, e a outra pessoa ficava na organização e num aparelho sozinha com outro companheiro, às vezes, fingindo até que era um casal. Isso foi criando muitas situações que questionavam o casamento monogâmico e as relações de fidelidade como eram instituídas.

Eu acho que esse questionamento foi construindo uma nova moral entre as pessoas que participaram da resistência à ditadura militar, mas isso não garantiu uma profunda transformação da relação homem/mulher. [...] Nós éramos mulheres que estavam participando de um espaço masculino, [...] e as mulheres estavam em número menor [...]. Quando fui presa eles esperavam, [...] uma mulher conduzida ou influenciada por um homem, quando viam que não, você passava a ser mais perseguida e mais torturada, porque era como se você tivesse negado o que eles esperavam de você. [...] Você era duplamente castigada, porque rompeu dois códigos, o de ser contra o sistema e o de ser uma mulher que se rebelava contra os padrões ${ }^{555}$."

Nas prisões, as mulheres tiveram de aprender a lidar com os traumas vividos na clandestinidade, nos centros de tortura e extermínio e reaprender a viver nessa nova realidade de confinamento forçado. Os testemunhos coletados nesta pesquisa registram que no presídio Tiradentes, entre as presas políticas havia uma preocupação constante de promover a integração das que chegavam, através de gestos que favoreciam a reconquista da auto-estima, a superação do medo e da depressão. Predominavam os esforços para manter as relações equilibradas e preservar a unidade. Em determinados períodos e situações, porém, as presas criaram, “formas de exclusão e isolamento veladas ${ }^{556 \text { ”. }}$

De acordo com Robeni B. da Costa, militante da ALN presa em 18 de fevereiro de 1971, ao chegar na “Torre” do Tiradentes, muitas mulheres ficavam alojadas no “celão”, cujas janelas devassadas davam para a passarela por onde circulavam, dia e noite, as sentinelas do presídio. O “celão” era “[...] uma espécie de quarentena, reservada ao

\footnotetext{
${ }^{555}$ Entrevista concedida por Rosalina de O. Santa Cruz à autora. Idem, ibidem.

${ }^{556}$ KoBASHI, Nair Yumiko. "Pequenas estratégias de sobrevivência”, em Tiradentes, op.cit., p.312.
} 
segundo e terceiro escalões das organizações ou então àquelas presas cujo comportamento havia se desviado das certezas do manual do guerrilheiro urbano ${ }^{557}$." Segundo Nair Kobashi, militante do PCdoB que havia se desligado do partido quando da sua prisão em fevereiro de $1972^{558}$, essas decisões, geralmente, eram tomadas no âmbito das organizações e não no do coletivo das presas ${ }^{559}$.

$\mathrm{Na}$ ala feminina do presídio Tiradentes uma das primeiras providências tomadas para reorganizar a vida cotidiana foi a de conquistar a simpatia das presas comuns ${ }^{560}$. Havia também reuniões para deliberar sobre a organização das celas e cozinha, dividir tarefas, estudar teoria marxista e outros conteúdos e discutir política. Era possível circular livremente entre as celas, o que concorria para tornar o ambiente melhor e para a formação de relações com maior qualidade e afeto. O portão que dava acesso ao pátio era fechado às 18hs, mas as luzes permaneciam acesas durante toda a noite. As diferenças individuais, de perspectiva política e de como reagir aos reveses e contingências da prisão, contudo, estavam muito presentes na maneira de reorganizar o cotidiano, conforme Lenira Machado:

“[...] A minha cela era uma muito especial, porque era uma cela light. Não era uma cela onde estavam aquelas que, naquele momento, não quero fazer pré-julgamento de ninguém, mas tinha uma cela que era quase um depósito de 'desbundados'. Havia as outras celas que eram as das 'radicais' e nós éramos 'light'. Era a turma que mais gostava de viver, a gente fazia tudo para viver bem, tudo, até contrabandear um conhaque para dentro do presídio. Fazíamos muitos campeonatos de baralho, escutávamos muita música. Líamos muito e a gente era muito unida, era um grupo com muita identificação naquela cela. [...] Acho que nós éramos umas doze ou quinze, muito vaidosas. Viver bem na 'Torre' era isso, primeiro: nós nos rebelávamos contra aquela disciplina rígida que a maioria das companheiras impunha... como levantar cedo etc. [...] Nós éramos contra, a nossa cela era muito devagar, nós tínhamos intensa vida noturna. [...] É claro que a equipe que ia para a cozinha fazer a comida tinha que levantar cedo [...].

[...] Então, a primeira coisa contra a qual a gente se rebelava era essa: '- Por que é que eu tenho de levantar cedo? [...] Eu tomo banho de sol na hora que me der na telha [...]!’. A gente tinha muito conflito com esse tipo de disciplina dentro do presídio. Logicamente, que a disciplina com relação às questões de segurança, essas eram comuns a todas e, todas aceitavam sem questionar, mas determinar o ritmo da vida da gente, tantas horas de trabalho manuais, ora bolas, e se eu quisesse fazer trabalhos manuais à noite? [...] A gente argumentava muito nesse sentido. [...] Havia uma visão de que a única forma da gente se manter fortalecida era ter disciplina. Eu achava que não, que quanto mais a gente tivesse condições de ser a gente mesma dentro do presídio, ter liberdade com as companheiras, [...] mais você estaria se sentindo bem, mais você estaria recompondo as suas forças para a enfrentar aquilo que ninguém sabia o que era. Quer dizer, a gente levantava às sete horas da manhã..., no outro dia, chegava uma equipe para te tirar de dentro do presídio

\footnotetext{
${ }^{557}$ CostA, Robeni B. da. “A cozinha enquanto peça de resistência.”, em Tiradentes, op.cit., p.315-6.

${ }^{558}$ V. entrevista concedida por Nair Yumiko Kobashi à autora. SP, 19/09/2008. AAPP/AEL-LEI.

${ }^{559}$ KoBASHI, Nair Yumiko. "Pequenas estratégias de sobrevivência”, em Tiradentes, op.cit., p.312.

${ }^{560}$ SANTOS, Maria Aparecida dos. "O ofício da tolerância”, em Tiradentes, op.cit., p.275.
} 
para apanhar! Eu acho que a gente precisava de um pouco de plumas e paetês ali dentro para sentir um aconchego, um colo, um agrado no cabelo, um ombro pra chorar. Ali era o lugar onde você podia se desmontar um pouco e essa rigidez para mim não era legal. E não era só para mim, para outras companheiras também não era ${ }^{561}$.”

Outras percepções sobre a atmosfera política vivida entre as presas dão conta das diferenças de avaliação que mobilizavam as discussões e conflitos sobre continuar a defender a luta armada imediata, ou não, e como organizar a luta de resistência. Essas diferenças estavam relacionadas também à perspectiva de sair da prisão a curto prazo, ou não, conforme o relato de Maria Aparecida dos Santos - militante da ALN presa em São Paulo no dia 29 de setembro de 1969:

“[...] algumas companheiras, do alto de suas sabedorias, emparedadas dentro de seus horizontes políticos, não reconheciam nos militantes de organizações de luta e resistência como a ALN pessoas que acreditaram, sonharam e, em função desse sonho, puseram em risco o que tinham de mais precioso: a vida. E quantos a perderam! Se era certo ou errado o caminho que escolhermos, era uma outra discussão, mas tentar negar o nosso papel na busca da liberdade, da felicidade, era inconcebível. Negar que com nossas atitudes denunciamos ao país e ao mundo o que o governo militar instalado no país promovia era, no mínimo, falta de conhecimento, de sensibilidade política. Essas discussões nem sempre eram tranquilas [...].

Havia situações constrangedoras [...]. Certo dia apareceu para nos 'visitar', [...] um cidadão [...] militar, não me lembro de que patente. [...] Era visível o [seu] estado emocional alterado [...]. Nos ofendia e nos acusava de terroristas.

De repente, naquela situação tensa, uma das presas ali presente disse a ele: 'Isso o senhor não deve dizer para todo mundo. Tem que dizer para elas.' - e nos apontou. [...] Demorei a superar o episódio.

[...] nos tiraram a liberdade física, mas ficou a nossa capacidade de criar e romper a grande custo as barreiras que nos impunham. [...] O presídio Tiradentes foi para mim, durante os três anos e meio de prisão, o grande campo de batalha contra os militares ditadores ${ }^{562}$."

Os testemunhos das presas políticas registrados aqui e em outros trabalhos indicam que elas procuravam conduzir as relações e conflitos de maneira mais sensível, equilibrada e madura do que os presos ${ }^{563}$. As mulheres expuseram e elaboraram mais sua subjetividade, falando mais sobre seus sentimentos, as dores e os traumas relacionados à tortura (conforme já mencionado no testemunho de Rosalina Santa Cruz e Pupi), às perdas e aos sofrimentos decorrentes do período de clandestinidade ou de prisão. Nesse sentido, vale ressaltar os testemunhos contundentes das ex-presas políticas apresentados no documentário fundamental de Lúcia Murat, “Que bom te ver viva” (1989).

\footnotetext{
${ }^{561}$ Entrevista concedida por Lenira Machado à autora. Idem, ibidem.

${ }^{562}$ SANTOS, Maria Aparecida dos. "O ofício da tolerância”, em Tiradentes, op.cit., p.276-80.

${ }^{563}$ Oliveira, Eleonora Menicucci. "Reconstruindo práticas de liberdade”, em Tiradentes, op.cit., p.296; e entrevista concedida por Lenira Machado à autora. Idem, ibidem.
} 
Rosalina Santa Cruz relatou um episódio que ilustra a presença de certa tolerância na convivência entre as mulheres. Numa ocasião, ela foi levada novamente para o DOICodi/RJ e suas companheiras, presas com ela na Vila Militar, fizeram uma greve de fome exigindo seu retorno. Uma presa não participou da greve e expôs suas dificuldades e limites e a recusa foi encarada de maneira ponderada, conforme depoimento de Santa Cruz:

“[...] quando entrei na cela de volta uma das três companheiras disse: desde que você foi retirada do coletivo e levada para o interrogatório, nós fizemos uma greve de fome para garantir que você voltasse [...]. Uma das três disse: '- Eu não fiz a greve, eu comi. Tenho pouco tempo [de pena], não estou num processo 'grande' e achei que não tinha condições de fazer a greve de fome'. E eu, naquele momento, olhei para elas [...] e tive a noção de que a menina tinha todo o direito de fazer aquilo [...]. Eu abracei as três e disse: '- Não importa, importa é que a gente está aqui’. E acho que isso é uma coisa muito difícil da gente fazer, [...] mas ela disse: '- Eu estou muito solidária, queria que você voltasse, mas não consegui fazer’. Acho que isso a gente teria de ver, olhar [...] esse limite humano [...], a gente era muito rigoroso $[\ldots]^{564}$.”

Em determinados momentos e lugares, no entanto, as presas políticas vivenciaram experiências de grande desgaste nas relações, que resultaram em rompimentos e divisões do coletivo, conforme relato de Lúcia Murat sobre a convivência no presídio de Bangu, no Rio de Janeiro:

\begin{abstract}
"Depois, mais tarde, teve uma experiência muito ruim em Bangu, que foi quando a gente se separou [...]. Eu até já tinha saído, mas vivi o início dessa história que foi horrível, acho que teve muito a ver com a prisão, com o desgaste das pessoas, ver os anos passando, o que era diferente da Vila Militar, onde tivemos uma experiência de sobrevivência muito forte. Em Bangu, começamos a viver numa situação muito melhor objetivamente, a gente tinha banho de sol todos os dias, cada uma tinha uma cela, a visita era o dia inteiro, livros, outra situação... Eu me lembro que quando cheguei em Bangu, falei: '- Pô, cheguei numa colônia de férias'. Realmente, fiquei feliz, feliz mesmo.

[...] Depois, começou a ter um pau muito grande, hoje não vejo aquilo como divergência política, mas se transmutava em divergência política. Acho que era resultado de um grau de desgaste, algumas pessoas estavam muito mal, era impossível a convivência, foi muito ruim, muito ruim mesmo. [...] Nesse final tinha pouca gente, umas seis presas. [...] depois que eu saí houve uma separação e criaram-se dois coletivos em Bangu. [...] É difícil falar sobre isso, $[\ldots]$ acho que teve uma coisa de desgaste humano triste $[\ldots]^{565}$."
\end{abstract}

A maioria das presas políticas fazia parte da nova esquerda, segmento bastante influenciado pelas transformações culturais que estavam ocorrendo. O comportamento das mulheres militantes questionava os valores burgueses, a família, a política e influenciava a sociedade. Esta proposta de vida supunha uma concepção feminista,

\footnotetext{
${ }^{564}$ Entrevista concedida por Rosalina de O. Santa Cruz à autora. Idem, ibidem.

565 Entrevista concedida por Lúcia Murat à autora. Idem, ibidem; entrevista concedida por Rosalina de O. Santa Cruz à autora. Idem, ibidem; Entrevista concedida por Manoel Cyrillo de O. Netto à autora. Idem, AAPP/AEL-LEI; entrevista concedida por Alberto Becker à autora. Idem, AAPP/AEL-LEI; entre outros.
} 
embora nesse período isso não estivesse claramente colocado para as militantes. Algumas presas políticas, no entanto, começaram a repensar sua militância no período em que estiveram detidas, conforme nos contou Rosalina Santa Cruz:

“[...] No coletivo da cadeia, acho que a convivência só com mulheres, fechadas num mesmo espaço em tempo integral, implicou no fato de que [...], nunca discutimos tanto 'o ser mulher', as nossas relações e a gente foi se descobrindo. E, depois, a gente entrou no Movimento de Mulheres, entendemos que havia diferenças na militância, [...] que era até subalterna ao homem e que [...], as mulheres não eram dirigentes na guerrilha etc, porque não era próprio, entre aspas, da condição feminina, estar na linha de frente. [...] E não se discutia o papel da mulher nas organizações [...]. Na cadeia, acho que a gente começou a discutir isso, nós estávamos só as mulheres e começamos discutir nossa sexualidade, relações etc. [...] ,

A gente percebeu que no pau de arara, na tortura, homens e mulheres eram iguais. [...] a gente apanhava tanto quanto os companheiros [...]. Eu acho que isso aprofundou a nossa visão feminista, [...] mas a militância feminista foi uma opção de algumas mulheres. Outras continuaram fazendo outro tipo de militância e outras encerraram a militância a partir da experiência da cadeia. [...] Tem uma diferença entre ser feminista e ser militante do movimento, mas acho que todas nós éramos e somos feministas ${ }^{566}$."

A prisão provocou grandes transformações na vida dos militantes, mas também na das mães e os demais familiares de presos políticos. Especialmente as mães ${ }^{567}$ desempenharam um papel fundamental na luta diária de solidariedade aos presos, dando afeto, trazendo mantimentos, mantendo relação com os presos dos diversos estabelecimentos prisionais, informando quem foi preso ou repassando informações das organizações, dos advogados de defesa e das Auditorias Militares. Incomodando juízes e autoridades com petições, cartas e denúncias contra a tortura, os assassinatos e as condições carcerárias impostas aos seus filhos, elas se politizaram e algumas até mudaram profundamente sua visão sobre as esquerdas, a liberação feminina e o feminismo, conforme o relato de diversos entrevistados, assim como no de Manoel Cyrillo:

“[...] A minha mãe nunca trabalhou, ela veio a trabalhar, [...] com a minha prisão. A partir da doença e a subsequente morte do meu pai, ela teve de trabalhar e ela não sabia fazer nada. Conversando nas visitas da cadeia, a gente chegou a conclusão que [...] ela era um excelente motorista e que tinha uma profissão: era motorista particular. Ela arrumou um emprego com uma senhora, Dona Odete, e contava essas histórias para a patroa. [...] Moral da história: virou patroa e amiga de minha mãe [...] e me visitou várias vezes na cadeia, inclusive, depois que a minha mãe deixou de trabalhar para ela. [...] Acho que minha mãe tinha uns 50 e tantos anos, era uma figura fantástica [...]. Ela era uma pessoa de classe média, que não sabia nada da minha militância e, de repente, descobriu todo aquele novo mundo, tendo que me visitar na cadeia, me assistir, brigar pra entrar na cadeia, para a gente ter melhores condições, passando por aquelas revistas vexatórias e

\footnotetext{
${ }^{566}$ Entrevista concedida por Rosalina de O. Santa Cruz à autora. Idem, ibidem.

${ }^{567}$ Entrevista concedida por Lúcia Murat à autora. Idem, ibidem.
} 
engajada na nossa luta de presos. Ela foi uma das grandes expoentes do grupo de familiares de presos. Ela era muito atirada, por características pessoais, de personalidade e tal, e cumpriu um papel fantástico, arregimentando famílias. Muita gente pode falar o nome dela nessas andanças em solidariedade e de engajamento na nossa luta que também era uma luta deles, os familiares [...]. Seu nome era Raimunda Partenostro Reis de Oliveira ${ }^{568}$.”

Como se revela ao longo deste item, a posição das mulheres na luta contra a ditadura de certo modo refletiu o espectro mais amplo de transformação e de espaços para a subjetivação da mulher, neste período de agudas transformações dos costumes, cobrindo disposições amplamente diversas, mas complementares, desde a guerrilheira imersa na prática diária do confronto com as forças repressivas até as mães, cuja solidariedade aos presos fez-se fundamental em todos os níveis e, principalmente político, para o enfraquecimento da ditadura.

${ }^{568}$ Entrevista concedida por Manoel Cyrillo de O. Neto à autora. Idem, AAPP/AEL-LEI. V. livros de ou sobre as mães: Viana (1998), Sattamini (1999) e Paiva (1996) e Benjamin (1982). 


\section{Capítulo IV}

\section{As lutas por melhores condições carcerárias e as denúncias de abusos aos direitos humanos}

\section{As denúncias de tortura e de graves violações de direitos humanos}

Conforme apresentado no último item do capítulo anterior, a experiência da tortura moldou formas de entendimento e elaboração discursiva sobre a realidade que se tornou parte fundamental da subjetivização e da reflexão política da militância das esquerdas. Neste capítulo consideraremos a perspectiva de que esta realidade psíquica e discursiva representou o eixo noteador das denúncias de tortura e desaparecimento que, em grande medida, vieram a desestabilizar a ditadura civil-militar.

A tortura tornou-se prática sistemática e institucionalizada desde o início do período ditatorial, mas as lideranças e os órgãos repressivos sempre negaram sua prática. Em 1964, milhares de pessoas foram presas nos primeiros meses após o golpe [ALVES, 1984: 59], mas apenas em 13 de setembro, o jornalista Márcio Moreira Alves conseguiu atrair a atenção da opinião pública para as denúncias de tortura. Na edição de domingo, do jornal Correio da Manhã, revelou a morte do $2^{\circ}$ sargento do Exército Manuel Alves de Oliveira. Retido no Regimento Andrade Neves, em abril de 1964, onde respondia a Inquérito Policial Militar, apareceu morto em 8 de maio, no Hospital Central do Exército (HCE), no Rio de Janeiro, em circunstâncias não esclarecidas.

O caso foi o estopim que originou a investigação sobre as torturas encaminhada de forma sumária pelo governo de Castelo Branco, entre setembro e outubro de 1964, pela Missão Geisel, organizada pelo então chefe do Gabinete Militar - Ernesto Geisel. Neste período, estabeleceu-se também uma Comissão Civil de Investigação, em Pernambuco. Ninguém foi punido, mas serviu para diminuir ou mitigar as práticas de tortura no Recife por quase um ano [ALVES, 1967: 49-51, 223-241].

Em 1964 foram registradas 28 mortes de perseguidos políticos (sendo oito decorrentes de supostos “suicídios”) [ALMEIDA, 2009: 63-90] e 203 denúncias de torturas, 
na justiça militar. Nos anos seguintes os números das denúncias diminuíram ${ }^{569}$ mas, em 1966, novamente a opinião pública se mobilizou em torno da morte do ex-sargento Manoel Raimundo Soares. Preso em março, em Porto Alegre (RS), Soares apareceu morto no Rio Guaíba com as mãos amarradas, apresentando marcas de torturas [DossIÊ, 2009: 101-4]. Em 1968, a morte de Edson Luis e de outros estudantes vítimas da violência policial em manifestações públicas, levaram milhares de pessoas a protestar nas ruas contra a violência da ditadura.

Após a edição do AI-5, porém, com o recrudescimento da repressão, os crimes do regime vão se tornando tema central das denúncias divulgadas pelas esquerdas e oposicionistas em geral. A morte do assistente de d. Hélder Câmara, padre Antônio Henrique, em maio de 1969, no Recife, vítima de torturas efetuadas pelo CCC, mobilizou a Igreja progressista e ganhou repercussão nacional e internacional [DossiÊ, 2009: 13940]. Ainda em dezembro de 1969, uma denúncia de tortura conseguiu grande repercussão na imprensa brasileira: as matérias de capa da revista Veja sobre a tortura no país e o assassinato de Chael Schreier, em novembro no Rio de Janeiro [GASPARI, 2002b: 163-69; 275].

Entre 1969 e 1970, ousados sequestros de diplomatas libertaram militantes dos cárceres da ditadura, obrigando os militares a divulgarem notas dos grupos armados nas TVs e rádios ${ }^{570}$. Os militantes banidos divulgaram denúncias de torturas e assassinatos no exterior que exerceram grande influência internacional. Ainda em maio de 1970, a morte sob tortura de Olavo Hansen no DEOPS/SP, um dirigente trotskista que atuava no movimento sindical, conseguiu alguma repercussão na imprensa e no Congresso Nacional [DossiÊ, 2009: 192-95]. Depois deste fato, o desaparecimento do ex-deputado federal Rubens Paiva teve alguma repercussão, mas se tornou muito difícil furar o cerco da censura no país e denunciar as torturas e as condições carcerárias dos prisioneiros políticos.

Os militantes banidos e os exilados passaram então a mobilizar uma ampla campanha de denúncias dos crimes da ditadura brasileira e a cobertura da mídia internacional. As trocas de prisioneiros políticos por diplomatas sequestrados amplificaram o que viria a ser o eixo principal da luta dos exilados, dos presos políticos e

\footnotetext{
${ }^{569}$ Foram 84 denúncias, em 1965, e 66 no ano seguinte, v. GASPARI, E. A ditadura envergonhada, op.cit., p.150.

${ }_{570}$ A cronologia dos sequestros: Em 04/09/69 ocorreu o do embaixador norte-americano; 11/03/70, o do cônsul japonês; em 11/06/70, o do embaixador da Alemanha ocidental; e em 07/12/70, o do embaixador da Suíça. Dessa forma, 130 prisioneiros políticos foram libertados e banidos.
} 
dos milintantes que ficaram no Brasil: a denúncia dos crimes do terrorismo de Estado. A guerrilha urbana e rural persistia, embora bastante enfraquecida, o eixo da luta deslocavase e assumia lugar central. As ações em defesa dos direitos humanos se avolumavam e com os anos esta temática ganhou força culminando com a luta pela anistia aos perserguidos políticos. A contrapartida do regime, a partir de 1970, foi elaboração de uma propaganda política elaborada, que também exibia militantes “arrependidos” na TV declarando seu repúdio às esquerdas e reafirmando a inexistência da prática de tortura no país.

Os setores progressistas da Igreja Católica se engajaram nas campanhas de denúncias de torturas e assassinatos do regime desde a morte de padre Antônio Henrique, em Recife (PE), e a prisão dos frades dominicanos em São Paulo, em 1969. Neste campo, a atuação da Comissão Justiça Paz de São Paulo (criada em agosto de 1972) foi fundamental para sistematizar e divulgar as denúncias e apoiar as vítimas e suas famílias [BENEVIDES, 2009]. Nesta conjuntura começaram a se formar e se tornar públicas as articulações dos presos políticos e de sua rede solidariedade com os movimentos de defesa dos direitos humanos. A divulgação de denúncias de torturas, assassinatos e das péssimas condições carcerárias feitas desde o início da ditadura vão ganhando centralidade nas demandas políticas das esquerdas e dos oposicionistas e repercussão internacional.

\section{As greves de fome e as lutas por melhores condições carcerárias}

Na primeira metade da década de 1970, principalmente, as lutas dos presos políticos se voltaram para conseguirem melhores condições carcerárias e o reconhecimento da sua condição de "prisioneiros de consciência”. Além das estratégias de sobrevivência utilizadas no cotidiano, os presos empregaram com frequência outros instrumentos de luta como a divulgação de manifestos de protesto, abaixo-assinados, denúncias e as greves de fome. Para enfrentar as situações-limite vivenciadas nos cárceres da ditadura, fizeram uso desse recurso extremo visando garantir condições dignas de sobrevivência e denunciar as arbitrariedades do regime. A greve de fome foi um veículo de protesto e que, muitas vezes, alcançou maior repercussão.

Algumas greves de fome assumiram contornos dramáticos devido a sua longa duração. Durante os anos de 1970 foram organizadas pelo menos 21 greves de fome, 
sendo que duas delas tiveram caráter nacional. Essas greves alcançaram grande repercussão nacional. A primeira greve nacional ocorreu entre abril e maio de 1978 e foi iniciada no presídio da Ilha de Itamaracá/PE, com o objetivo de romper o isolamento imposto à Carlos Alberto Soares e Rholine Sonde Cavalcante, condenados à prisão perpétua. A outra greve nacional foi organizada com o objetivo de conquistar uma anistia ampla, geral e irrestrita a todos os perseguidos políticos. Foi a mais prolongada, com duração de 32 dias entre os meses de julho e agosto de $1979^{571}$.

Em São Paulo, no início da década de 1970, as greves de fome foram realizadas contras as péssimas condições carcerárias e por um presídio exclusivo para os prisioneiros políticos. Em 1975, os presos de São Paulo e Rio de Janeiro conquistaram esse objetivo. Em 1974, os presos aproveitaram a atmosfera criada em torno da “distensão política” e a as eleições nacionais que levaram à vitória do MDB e realizaram pressões e greves de fome para conseguir melhorias nas prisões. Em maio de 1975, aproveitando o novo cenário político, os presos do presídio da Ilha Grande, no Rio de Janeiro, fizeram uma greve de fome de 10 dias e conquistaram um setor exclusivo no presídio da PE, no Rio de Janeiro $^{572}$. Diversas greves de fome, no entanto, não foram vitoriosas apesar da mobilização política e da divulgação que provocaram.

Entre 1970 e 1971, os presos políticos de diversos estados do país iniciaram greves de fome para conseguir condições dignas nas prisões e alojamentos, alas ou presídios exclusivos, separados dos presos comuns, como ocorreu na Ilha Grande/RJ, quando ficaram 17 dias sem comer [Viana; Cipriano, 1992: 41-5]. Em Recife, os presos queriam ser transferidos do DEOPS para algum presídio e legalizarem sua prisão, após o assassinato sob tortura de Odijas de Carvalho, em fevereiro de 1971, conforme relato de Carlos Alberto Soares:

"O Odijas morreu durante o espancamento, eles faziam uma roda de pessoas, que chamavam de ciranda, e ficavam batendo, batendo, batendo, batendo na pessoa. Eu passei por uma situação semelhante a essa. Depois, nós voltamos para a cela e ficamos lá. Eles estavam esperando que o negócio da morte do Odijas se resolvesse para vir a curto prazo em cima da gente, novamente. Foi quando nós fizemos a primeira greve de fome. A nossa reivindicação era sair da Secretaria de Segurança Pública. As famílias já sabiam de nossa prisão, minha mãe já tinha ido lá e minha mãe conseguiu me ver. Levaram-me até o corredor e a minha mãe me viu lá, então, para desaparecer comigo, depois da morte de Odijas, era mais complicado. Nós fizemos a primeira greve de fome para sair da Secretaria e ir para outro local. Eles não tinham muita experiência com greves de fome,

\footnotetext{
${ }^{571}$ VIANA, G.; CIPRIANO, P., op.cit., p. 41-5; e JosÉ, Emiliano, op.cit.; e entrevistas concedidas por Carlos Alberto Soares e Marcelo Mário de Melo à autora. Idem, ibidem.

572 "Presos Políticos. Depois da greve, um relatório ao STM.” Opinião, 10/05/75. Nesta greve, 6 prisioneiros políticos não aceitaram participar do movimento.
} 
quando passou um dia, dois dias, eles ficaram apavorados e disseram que iam nos transferir. Não fizeram isso, dias depois, nós voltamos a greve de fome. Dessa vez, ficamos três dias e aí eles resolveram nos transferir de fato ${ }^{573, \text {. }}$

Na Penitenciária Regional de Linhares, em Juiz de Fora (MG), os presos políticos fizeram duas greves de fome. O primeiro movimento foi deflagrado em março para conseguir o fim das visitas no parlatório e da rigidez dos horários estabelecidos pela administração carcerária. Essa greve durou treze dias e foi vitoriosa, mas outras greves não obtiveram sucesso, como a que foi deflagrada em setembro, e que não contou com a adesão de todos os prisioneiros políticos ${ }^{574}$.

Uma nova greve de fome foi iniciada em Linhares, em setembro de 1971, mas, dessa vez, a repressão ao movimento foi bastante severa. Os detentos reclamaram da falta de carne na alimentação, negando-se a almoçar e exigindo contato com o diretor da penitenciária. A atitude foi considerada uma rebelião e a Polícia Militar invadiu o presídio, espancando alguns prisioneiros. Os presos políticos foram isolados na ala feminina do presídio que, naquele momento, estava desativada, pois as presas haviam sido removidas para a Penitenciária Feminina, em Belo Horizonte (MG). Em protesto contra a violência da PM e a transferência arbitrária das presas, os presos políticos iniciaram a greve de fome. A greve, contudo, não alcançou seus objetivos e os presos políticos continuaram isolados na área anteriormente reservada à ala feminina ${ }^{575}$.

\subsection{A greve de fome do presídio Tiradentes em São Paulo}

Entre maio e julho de 1972, uma greve de fome organizada por parcela dos presos políticos do presídio Tiradentes conseguiu romper o cerco de isolamento imposto pela ditadura no país e no exterior. Eles reivindicavam melhores condições carcerárias, o reconhecimento de sua condição de prisioneiros políticos e a reunificação de todos num mesmo estabelecimento penal. A repercussão da greve na sociedade civil e na imprensa brasileira e internacional representou um avanço na divulgação das denúncias dos abusos

\footnotetext{
${ }^{573}$ Entrevista concedida por Carlos Alberto Soares à autora. Idem, Ibidem. Odijas Carvalho de Souza, militante do PCBR, morreu em consequência das torturas sofridas no DEOPS/PE, em 08/02/71. V. Dossiê Ditadura, op.cit., p.230-1.

${ }^{574}$ Uma pequena parcela dos prisioneiros não aceitou participar do movimento. V. RiBEIRO, Flávia Maria F. op.cit., p.155-6, 187, 241.

${ }^{575}$ Idem, ibidem, op.cit., p. 241. V. tb. entrevista concedida por Gilney Amorim Viana à autora. Idem, ibidem.
} 
da atuação repressiva do regime e um passo importante para o reconhecimento da existência de presos políticos no país.

Em novembro de 1971, a direção do presídio Tiradentes começou a transferir os presos comuns, inclusive aqueles que estavam incursos na LSN, para outros estabelecimentos penais. O Pavilhão I passou por uma pequena reforma e os presos políticos que estavam em outros presídios foram enviados para o Tiradentes. Uma portaria assinada pelo juiz corregedor dos presídios, Nelson Fonseca, no mês de dezembro determinou que o presídio Tiradentes passava a ser o estabelecimento destinado à custódia exclusiva de presos políticos no estado [POLITI, 2009: 20].

No início de 1972, porém, uma série de medidas adotadas pelo diretor do presídio Tiradentes, Olinto Denardi, e pelos juízes auditores da justiça militar deterioraram consideravelmente as condições carcerárias. Em janeiro, 12 prisioneiros do pavilhão I e outros 20 do pavilhão II foram alojados em 3 celas no pavilhão II, conforme determinação dos juízes-auditores Nelson Machado Guimarães e José Paiva. Eles foram submetidos a um regime de isolamento, o banho de sol e as visitas deles passaram a ocorrer em dias e horários diferentes dos demais presos políticos [POLITI, 2009: 24].

No dia 5 de março, a direção do presídio Tiradentes impediu a abertura das portas das celas do Pavilhão I impossibilitando o acesso ao “café da manhã” e impedindo que os "faxinas" (presos comuns) fizessem a limpeza semanal dos corredores. A direção propôs aos presos políticos que fizessem a limpeza do corredor em troca do fornecimento do pão e leite. Os presos comuns haviam sido transferidos do presídio e não havia gente suficiente para o trabalho. Os presos políticos recusaram a proposta e, no dia seguinte, o pavilhão I foi ocupado pela tropa de choque da Polícia Militar. Todos foram transferidos para o pavilhão II sob a ameaça de ataques de gás lacrimogêneo e a ostentação de metralhadoras. Um “corredor polonês” foi montado e alguns prisioneiros foram agredidos com cassetetes ${ }^{576}$. As visitas foram suspensas [POLITI, 2009: 25].

A direção justificou a intervenção da PM acusando os presos políticos de terem realizado um "motim” com tentativa de fuga e instaurou um inquérito para verificar responsabilidades. A suposta prova da tentativa de fuga seria a existência de um cano de água que ligava uma cela dos presos políticos a um escritório do presídio. O cano estava

\footnotetext{
576 "Abaixo-assinado dos presos políticos do Recolhimento de Presos Tiradentes (presídio Tiradentes)" dirigido ao STM e às I e II Auditorias de Guerra da II $^{\mathrm{a}}$. Região Militar, 28/03/72; em POLITI, M. op.cit., p.133-4.
} 
quebrado havia tempo e tinha 15 centímetros de diâmetro, o que tornava impossível a passagem de qualquer preso por ele ${ }^{577}$.

Os presos políticos começaram a articular e organizar movimento para reverter a situação. No dia 16 de março, oito advogados subscreveram uma representação dirigida ao STM denunciando os abusos aos direitos humanos e o descumprimento da lei promovidos pelos Juízes Auditores da 2a . Circunscrição Judiciária Militar (2ª CJM). Na representação, os advogados Belisário dos Santos Jr., Rosa M. Cardoso da Cunha, Virgílio Egydio Lopes Enei, Idibal Almeida Pivetta, Airton Soares, Maria Regina Pasquale, Iberê Bandeira de Melo e Hélio Navarro relataram a situação dos presos e solicitaram providências para assegurar a vida de seus clientes, denunciando

“[...] as ações ilegais praticadas pelos diretores do Presídio Tiradentes, srs. Olinto Denardi e José Marconi Júnior, que não cumprem a Lei de Segurança Nacional no que se refere ao tratamento dado a presos políticos [...] e o total desacordo com os critérios de apreciação da Lei, adotados pelos Excelentíssimos Senhores Auditores da 2a ${ }^{\mathrm{a}}$. CJM, especialmente nas questões administrativas, [os signatários] vêm, respeitosamente, representar a esse Colendo Pretório para que se ponha cobro a atos e medidas reiteradas que, em absoluto, condizem com o equilíbrio, a firmeza e o respeito à Lei, característica primeira dos representantes do Poder Judiciário ${ }^{578}$.”

Em seguida, os presos políticos do Tiradentes redigiram um abaixo-assinado, contendo 130 assinaturas, divulgado no dia 28 de março, no qual protestavam contra as condições carcerárias em que viviam e, em especial, contra as medidas administrativas adotadas pela direção do presídio e a transferência arbitrária de dois prisioneiros condenados à pena de morte, que se encontravam em “condições infra-humanas”: Ariston de Oliveira Lucena, preso na cela solitária da Casa de Detenção de São Paulo, e Diógenes Sobrosa de Souza, confinado no "isolamento do II Batalhão de Polícia do Exército, em São Paulo"579.

O documento apresentava denúncia contundente sobre a precariedade do antigo edifício; a superlotação das celas; a ausência de condições básicas de higiene; a proibição de movimentação entre as celas (os presos ficavam trancados 158 horas por semana); a precariedade do espaço destinado ao banho de sol (uma "gaiola” de apenas 10 por 16 metros), apesar da existência de 3 pátios amplos no presídio; a recusa em fornecer comida

\footnotetext{
${ }^{577}$ Idem, ibidem.

${ }^{578}$ V. Politi, Maurice. op.cit., p.26.; e o Habeas Data de Idibal Matho Gomes de Almeida Pivetta em VIEIRA, César. Em busca de um teatro popular. 4a. ed., São Paulo, Funarte, 2007, p.299.

579 “Abaixo-assinado dos presos políticos do Recolhimento de Presos Tiradentes”, em PoLiTI, M. op.cit., p.134. De acordo com Maurice Politi, dos 160 presos no Tiradentes, 130 assinaram o documento. Idem, ibidem, p.25.
} 
“in natura”; as revistas violentas da PM nas celas; a proibição de terem uma oficina de trabalhos manuais; as longas filas nos dias de visitas provocadas pelas demoradas revistas desrespeitosas e ofensivas aos seus familiares; o sumiço dos mantimentos fornecidos pelos visitantes; a inexistência de abrigo para as visitas no pátio; a separação do horário de visita entre as alas masculina e feminina; e a ausência de assistência médica regular. Além das questões e reivindicações relacionadas às condições carcerárias e a denúncia da atuação do Esquadrão da Morte no presídio, os presos denunciaram a morosidade na condução de seus processos na justiça militar e as dificuldades encontradas para conseguir convocar seus advogados. Por fim, os presos relataram os acontecimentos do mês de março, denunciaram a "farsa” da "existência de um motim”, afirmando que todas as suas denúncias eram facilmente comprováveis; e finalizaram o documento com as seguintes palavras:

"Só podemos entender isso como um prolongamento das torturas e do terror a que fomos
submetidos na fase de inquérito policial. Evitamos citar exemplos nominais na descrição
para não alongá-la, mas eles são inúmeros, evidentes e jamais haveremos de esquecê-los,
pois aqui a vida de todos é a vida de cada um e o que ocorre a um atinge a todos ${ }^{580}$."
O abaixo-assinado foi enviado para os principais jornais do país, para entidades de defesa dos direitos humanos, para as embaixadas estrangeiras e grupos de exilados no exterior, conseguindo considerável repercussão internacional. No dia 14 de abril de 1972 foi publicado um artigo no Washington Post comentando o documento, no qual foi reproduzida a carta da presa política Marlene Soccas dirigida aos juízes auditores de São Paulo, relatando a difícil situação dos detidos no presídio Tiradentes [POLITI, 2009: 26-7].

As investigações das denúncias feitas contra o Esquadrão da Morte pelos presos políticos, que vieram a público em 1970, resultaram na decretação da prisão preventiva de diversos policiais e do diretor do presídio Tiradentes, o delegado Olinto Denardi, no dia 25 de abril de 1972. Um juiz de Guarulhos pediu sua prisão, pois eram acusados de pertencer ao Esquadrão da Morte e de retirarem 8 presos comuns do presídio para serem assassinados. Denardi ficou em prisão domiciliar e foi obrigado a transferir seu cargo para o assistente José Marconi Jr. ${ }^{581}$. Isso motivou novas represálias contra os presos políticos.

Nesse período, avançavam os preparativos do movimento que resultaria na greve de fome. Foi um tenso processo de discussão e de consultas entre os prisioneiros do

\footnotetext{
${ }^{580}$ Idem, idem.

581 “Carta das mães dos presos políticos”. SP, jun/72, em PoliTI, M., op.cit., p. 27, 161; e "Relatório sobre as acusações de tortura no Brasil”. Anistia Internacional, 1972, p.90. Arquivo CEDEM/UNESP, Asmob 03.15, 2.
} 
presídio Tiradentes. Um processo em que acabaram prevalecendo as divergências a respeito das análises sobre a direção das lutas de resistência à ditadura dentro e fora das prisões, e também quais as estratégias a serem adotadas.

Carlos Alberto Lobão Cunha relembrou a análise daqueles que propuseram e organizaram a greve de fome, em decorrência do processo de recrudescimeno repressivo no país e no presídio Tiradentes e das ameaças de novas transferências de presos políticos para outros estabelecimentos, que se avolumaram no mês de abril:

“[...] Boa parte das pessoas da ALN e mais alguns outros já haviam passado por essa experiência muito ruim de ficar no Carandiru. Aí surgiu uma ameaça de transferência de vários presos [...] e, de fato, inicialmente, 5 foram levados para outra prisão. A gente ficou sabendo da ideia da repressão de colocar os presos em vários presídios espalhados pelo estado, 10 num presídio, 10 em outro e 5 noutro. Se eles não tinham conseguido fazer isso no Carandiru em 1970 e 1971, era razoável supor que eles pudessem ter sucesso em 1972. Então, a gente falou: '- Bom, não tem jeito, a nossa segurança é estar todo mundo junto'. Lembro perfeitamente bem o que pensamos: não podemos deixar que eles nos dispersem, porque [...] aí poderia dar certo aquele plano de provocar brigas com presos comuns. A ideia que nos orientou nesse tempo foi: não podemos deixar que eles nos separem. [...] Estava muito claro que a greve de fome era o último recurso. [...] Segundo: a ALN pensava que a decisão sobre a greve de fome não era do coletivo, mas do que ainda havia das organizações no presídio, porque não se podia obrigar um coletivo, por decisão de maioria, a fazer uma greve de fome sabendo-se dos riscos. Havia a questão do quanto a repressão eventualmente poderia explorar das defecções da greve de fome, como já explorava os casos daqueles que foram para a televisão [...] dizer que não havia tortura no Brasil e tinham sido bem tratados. Naquele contexto, era impossível decidir uma proposta dessas por consenso!

[...] Do nosso ponto de vista, a greve de fome era para ser feita pelas organizações, [...] quer dizer, quem ia fazer a greve de fome? Quem efetivamente estivesse se sentido ameaçado de ser assassinado e, quem tivesse com uma concepção política e ideológica que achasse que valia a pena fazê-la para desgastar o governo. E mesmo com o apoio de quem ainda estava organizado, não obteríamos a maioria ${ }^{582}$."

Lenira Machado apresentou outra perspectiva a respeito da discussão feita durante

a preparação da greve de fome deflagrada em maio e que acabou por dividir o coletivo dos presos políticos de São Paulo por muitos anos:

“[...] as posições foram radicais, quando começou a discussão de que iam pulverizar os presos, que aqueles com maiores sentenças seriam isolados, houve uma mobilização quase geral para que isso não acontecesse. A minha cela, por exemplo, entrou na discussão da greve de fome numa boa. Até que surgiu a questão da greve ir até as últimas consequências. Aí nós paramos, nos olhamos e dissemos: '- Quem quer virar santa?’, ‘Eu não quero!' Numa greve de fome até as últimas consequências, se nós não conquistarmos o que nós estamos pleiteando, morremos. [...] Para ser coerente, se eu entrasse numa greve de fome dessas - e não vou falar dos outros, estou falando de mim -, eu deveria saber que estaria entrando na greve para morrer.

${ }^{582}$ Entrevista concedida por Carlos Alberto Lobão Cunha à autora. Idem, AAPP/AEL-LEI. 
Porra, eu tinha feito de tudo para sobreviver. No sentido de não me entregar à tortura, de me manter com dignidade. Eu tinha feito tudo para sobreviver, não tinha vendido a minha vida ou comprado algo, mas me mantive íntegra e querendo viver. Eu tinha um filho para criar e pensava: “- Eu vou sair dessa inteira. Vou aguentar as porradas e tudo mais o que a repressão mandar. Não vou me deixar quebrar pela repressão.” [...] Porque viver e sair rastejando, eu também não queria. Se fosse para isso, eu preferia morrer. Com a proposta de greve até as últimas consequências, eu fiz a pergunta: '- Quantas pessoas vão estar do lado de fora do presídio, defendendo as nossas vidas? '- Qual o nível de mobilização existente lá fora que garanta a nossa vida e que o que nós estamos pleiteando seja ao menos em parte negociado?' Essas questões não foram respondidas. Alguém disse: 'Tem dom Evaristo Arns'. Eu falei: '- Eu sei, mas qual é a capacidade de mobilização de dom Evaristo [...] para garantir a nossa vida?', 'Ah, não sabemos!', '- O que a repressão vai permitir ou o que a repressão vai estar disposta a negociar?', '- Ah, não sabemos'. Respondi: '- Estou fora, não faço política assim'.

Eu tenho que analisar a correlação de forças, a capacidade de mobilização. Como eu não sou cristã e não quero ser mártir, então, preciso ter outro tipo de análise política e sem essa análise não entro numa aventura. Essa foi a minha argumentação, outras apareceram e o presídio rachou. A 'torre’ rachou em três, as que entraram na greve de fome; as que não entraram na greve, por achar que não havia condições políticas para fazer uma greve de fome até as últimas consequências; e as outras, que achavam que tudo era uma loucura $^{583}$."

Não obstante, de acordo com Carlos Alberto Lobão Cunha, antes de iniciarem a segunda fase da greve de fome, os presos articularam contatos políticos no país e no exterior e debateram as possibilidades e implicações de levar a greve às últimas consequências:

“A gente só tomou uma decisão dessas, depois que a gente [...] se certificou de que os
nossos manifestos já estavam no Chile, na Europa e que a Igreja leria o manifesto nas
missas dominicais, aí achamos que conseguiríamos fazer a greve de fome. [...] Para nós, a
primeira questão a destacar era a de que existia preso político no Brasil. Era importante
reconhecer que havia prisioneiros políticos e reuni-los num presídio, não queríamos ser
dispersados.
Os freis dominicanos e os nossos militantes que tinham relações com os padres [...] e
conseguiram fazer os contatos. [...] Eu lembro que na retomada da greve de fome, Dom
Paulo foi nos visitar no Carandiru, [...] para tentar dizer que não valia a pena entrar em
greve. Reuniu todos, lembro do local onde ele conversou com a gente, em pé lá no fundão
do $2^{\circ}$. andar do Pavilhão 5. [...] Argumentou que era uma tentativa de suicídio e que a
igreja era contra. Acho que um dos freis ou alguém contra argumentou dizendo que Cristo
havia jejuado 40 dias e 40 noites no deserto e que aquilo não foi uma tentativa de suicídio.
Dom Paulo argumentou que pensaria, mas gostaria que ninguém morresse. Ele perguntou
se a gente poderia prometer que se alguém estivesse correndo risco de vida, a gente
pediria para a pessoa parar. Nós asseguramos a ele que sim, mesmo porque o que a
repressão queria era que algum de nós morresse. Eles queriam nos dispersar para nos
assassinar, não fazia sentido a gente cumprir o desejo da repressão. Nós garantimos para
ele que ninguém morreria.
[...] Dom Paulo insistiu nesses dois aspectos, foi uma conversa demorada, mas bem
tranquila. Dura em alguns aspectos, porque dom Paulo insistia que isso era tentativa de
suicídio. Ele saiu convencido que não era e, não era mesmo, que a proposta não era anti-
cristã e que a gente não ia morrer [...]. Aí ele falou que nos apoiaria. Nós dependíamos

${ }^{583}$ Entrevista concedida por Lenira Machado à autora. Idem, ibidem. 
disso, porque, na verdade, o manifesto da greve seria lido nas missas dominicais no intervalo da leitura do evangelho e a gente dependia da influência da igreja na Europa. O manifesto já estava na Europa e no Chile também, mas a gente precisava de apoio ${ }^{584}$."

Não havia consenso entre os presos políticos quanto à avaliação do momento político e sobre como conduzir suas lutas dentro da prisão. Nas entrevistas aqui registradas, as críticas mútuas se apresentaram ácidas, mesmo passados tantos anos após os fatos. Alguns presos questionaram os métodos de discussão e de decisão da greve. Muitos consideraram que este era um tipo de ação política que estabelecia um confronto desnecessário e bastante desigual com a ditadura. Para outros presos a militância política deveria ser retomada fora da prisão, nos cárceres a postura mais adequada seria a de voltar-se prioritariamente para o estudo, a reflexão e a autocrítica, conforme o relato de Antônio Roberto Espinosa:

“[...] Para nós tratava-se de fazer um balanço do que nós tínhamos, do que nós éramos, do que pensávamos, ajustar as nossas consciências, inclusive, os nossos comportamentos dentro da prisão, acabar com esse negócio de heroísmo. [...] Vários grupos, a Ala, a VAR, o POC estavam fazendo esse processo de reavaliação da militância. [...] achávamos que o nosso dever na prisão era estudar, ler os clássicos, discutir [...]. É claro que havia diferenças enormes [...], mas a Ala e a Var estavam unificados nessa postura de fazer esse balanço crítico, de estudar o marxismo. Alguns caras, [...] o resto da ALN e [...] o PC do $\mathrm{B}$, ao contrário, entraram numa onda de radicalização, propondo fazer greves de fome, confrontando carcereiros. [...] Para esse pessoal, o papel dos presos políticos era o de fazer a revolução dentro da cadeia [...]. Isso também era [...] uma maneira de se credenciar para as listas de 'trocáveis'.

[...] O grupo de transferidos era pequeno [...]. A reivindicação de que os presos fossem trazidos de volta era comum, todo o coletivo os queria de volta. Agora, a proposta de fazer uma greve de fome, uma proposta definitiva, ir até o final, isso só alguns defendiam. Essa discussão rolou dentro do presídio, escrevemos documentos [...], eu, junto com o Max [Carlos Paixão], escrevemos documentos contrários. Brigar pela volta dos companheiros sim, mas como? Podemos fazer abaixo assinado, podemos divulgar notícias no exterior, buscar solidariedade com alguns setores mais avançados da igreja católica [...]. Agora, a greve de fome nesses termos: ou eles voltam ou morremos todos de fome é uma coisa extrema. Isto não, mesmo porque tínhamos coisas a preservar. Nós tínhamos, a duras penas, formado as nossas bibliotecas, a nossa prioridade era fazer um balanço. Eu, por exemplo, o Max, a nossa cela, nós estávamos estudando [...] o que representava uma lufada de ar fresco na teoria do stalinismo, naquelas posturas que nos eram comuns. [...] Pra gente, dentro da cadeia isso era prioridade, [...] nós queríamos reformular as nossas ferramentas intelectuais. [...] Isso e nos manter o mais unidos possível, mas a greve de fome nos dividiu, esfacelou tudo [...].

[...] Isso foi discutido e votado [...]. Nós fomos contra, a proposta de greve de fome foi derrotada por ampla maioria. [...] Então, combinaram entre eles uma coisa que no presídio chamávamos de 'fato consumado': sempre que eram minoria e perdiam, faziam a tal proposta do mesmo jeito, aí a maioria, para que eles não ficassem isolados, fazia também, embora, fosse contrária ${ }^{585}$.”

\footnotetext{
${ }^{584}$ Entrevista concedida por Carlos Alberto Lobão Cunha à autora. Idem, AAPP/AEL-LEI.

${ }^{585}$ Entrevista concedida por Antônio Roberto Espinosa à autora. Idem, ibidem.
} 
Os que organizaram a greve de fome, por outro lado, insistiam que resistir era fundamental para evitar a dispersão dos presos nos diversos presídios de São Paulo e garantir a sobrevivência naquele período mais repressivo da ditadura. Para eles, resistir significava usar todas as maneiras e instrumentos políticos disponíveis, os contatos com as organizações ainda existentes fora da prisão e setores da sociedade civil. Era muito difícil conseguir chegar a um consenso sobre quais as formas de luta adotar e como assumir uma postura de enfrentamento e de combate à ditadura dentro da prisão, segundo Carlos Alberto Lobão Cunha:

\begin{abstract}
“[...] Do ponto de vista da ALN, a greve era para ser feita pelos militantes que se sentiam ameaçados realmente. Não me lembro da gente ter discutido que nós nos subordinaríamos a um colegiado inter-celas. A greve era para ser feita por organização, se houvesse adesões, ótimo! Havia organizações com militantes que tinham participado de ações armadas, testados, que sabiam que poderiam ser assassinados. Essas pessoas deveriam fazer a greve de fome. Houve organizações ou militantes que colocaram a coisa da seguinte forma: '- A gente só topa participar se a maioria participar'. Não era essa a posição da ALN. [...] Naquela situação, se houvesse uma votação em algum coletivo e nós perdessemos, essa votação não representaria a ALN. A gente tinha certeza que a greve de fome era para ser feita por nós, não era para estar subordinada a qualquer decisão coletiva dos presos.

[...] alguns dos nossos manifestos da greve de fome foram escritos com a colaboração dos companheiros da Ala Vermelha e do PC do B, demos palpites, mas não fomos nós que escrevemos muitos dos manifestos. O teor, acho, era [...] afirmar que existia uma ditadura, protestar contra as condições carcerárias e denunciar que a gente estava sofrendo maus tratos. Afirmar que existia presos políticos no Brasil e que não queríamos ser dispersados. [...] A Ala Vermelha, por exemplo, quis montar uma frente política e até ajudou a escrever manifestos, mas, na última hora, não fez a greve. Eles se comprometeram a fazêla, mas achavam que a decisão devia ser do coletivo, como o coletivo decidiu que não faria, eles se submeteram a essa decisão e nós não. Esta posição criou um mal estar recíproco. Um mal estar grande, principalmente, porque se contava com mais gente, o peso da greve teria sido muito maior. Eu não sou das pessoas que ficou com rancor perpétuo e intransferível por isso, mas muitos companheiros ficaram ${ }^{586}$.”
\end{abstract}

Para os que apoiavam a proposta de greve de fome, a prioridade era sobreviver e resistir utilizando todos os instrumentos de luta disponíveis, mas também combater e desgastar a ditadura, sistematizando e divulgando as denúncias o que ocorria nos cárceres e os crimes do regime. Todos na prisão ocupavam grande parte de seu tempo estudando e debatendo em busca de explicações para os erros e derrotas das esquerdas ${ }^{587}$. Não obstante, alguns militantes presos avaliavam que não tinham condições para desenvolver um debate e um balanço político e teórico exaustivo sobre a sua atuação, sobre os diferentes projetos das esquerdas ou a situação do país. Em meio a tantas incertezas e

\footnotetext{
${ }^{586}$ Entrevista concedida por Carlos Alberto Lobão Cunha à autora. Idem, AAPP/AEL-LEI.

${ }^{587}$ Entrevista concedida por Alberto Becker à autora. SP, 11/03/2011; e entrevista concedida por Pedro Rocha Filho à autora. Idem, AAPP/AEL-LEI.
} 
cisões entre os grupos remanescentes fora das prisões, o combate à ditadura era um denominador comum que poderia mobilizar a todos, conforme relato de Reinaldo Morano:

"Lembra aquela história de que não precisa pedir licença pra fazer a revolução? Em nenhum momento, eu acho que a gente fugiu do que seria uma política congruente com o que a ALN defendia. Fazíamos uma política de presos congruente com o ideário da ALN. [...] Não tínhamos como meta interferir na organização de fora. O que a gente tinha, sempre, era uma postura de fazer um apelo, um esforço por unidade em relação aos grupos divergentes que surgiram na ALN. Nesse sentido, eu acho que a gente teve uma posição que, hoje, avalio como muito pertinente, que era assim: um grupo de militantes de uma organização, presos, tentando manter o seu compromisso ideológico, político, desenvolvendo uma linha de resistência, basicamente, de resistência dentro da cadeia; e o que se podia fazer de divulgação, daí os contatos com as organizações religiosas, não só da igreja católica, mas também protestante, no Brasil e no exterior, para divulgar documentos da nossa luta, de denúncia. Eu penso que isso era um modo de participar da luta geral. Eu acho que essa era a contribuição mais efetiva, mais eficaz. [...] Estando presos, a gente se preocupava, mas tinha que ter muito cuidado para não palpitar em coisas..., em discussões de funcionamento da organização, de análise tática, estratégica, política...

[...] Muitas dessas coisas a gente não sentava e decidia [...]. Era uma questão de feeling, do ver. As questões de cadeia, propriamente, a luta de resistência e de sobrevivência na cadeia ocupavam muito o tempo da gente. Assim, nós não tínhamos nenhum compromisso com o suicídio, tínhamos compromisso com a vida. E com isso nós precisávamos denunciar as investidas da repressão, as transferências de companheiros [...]. Fazia parte do nosso compromisso com a vida, lutar por melhores condições de cadeia $^{588, "}$

As críticas mútuas e as posições se radicalizaram, dificultando o diálogo. Uma

divisão duradoura foi cunhada entre os presos políticos de São Paulo. De acordo com

Vicente Roig:

“[...] Quando a gente volta da Casa de Detenção para o Tiradentes, ficamos no pavilhão 2 - mas existia ainda o pavilhão 1. A discussão política e a camaradagem estão mais esgarçadas. [...] Ficam muito claras duas posições nesse momento, que são as seguintes: uma, da ALN, dizia que [...] o dever do revolucionário é fazer a revolução, e fazer a revolução em qualquer lugar e em qualquer circunstância [...]. Tem uma outra posição que, [...] englobava o PCBR e a Ala [...] que entende que isso é uma loucura, que na cadeia você não faz revolução, e isso coincide com o processo de auto-crítica, em que a gente estava.

[...] Tínhamos começado um texto na primeira passagem pelo Tiradentes, com o Renato Tapajós, o Takaoka etc [...], quando se juntaram o Alípio Freire e o pessoal das outras celas, a gente começou a esboçar essa questão. A autocrítica apontava, fundamentalmente, a nossa falta de imersão social, o descolamento que a gente tinha em relação ao proletariado e com as bases que a gente deveria mobilizar. E com esse grau de isolamento você não conseguiria mobilizar ninguém. Enfim, tem uma série de outras coisas [...], mas acho que o texto toca em um ponto crucial: todas essas concepções se baseiam na teoria do exemplo, o revolucionário dá o exemplo e as massas seguem. [...] Enquando a gente está rebatendo isso, embora este aspecto fique um pouco camuflado,

${ }^{588}$ Entrevista concedida por Reinaldo Morano Filho à autora. Idem, AAPP/AEL-LEI. 
[...] o pessoal de ALN continua na teoria do exemplo. Então, eles têm que dar o exemplo de dentro da cadeia e, colocam no coletivo inter-celas, inúmeras vezes, a proposta de fazer uma greve de fome. [...] Tinha chance de ter uma boa repercussão internacional e, obviamente, uma greve de fome em um presídio em São Paulo teria uma divulgação grande fora. Foi colocado em votação no coletivo e a proposta perdeu, não passou. [...] a ALN se retira do coletivo, o que é uma posição razoavelmente coerente: não há motivo para que uma organização sujeite as suas concepções políticas às concepções de um coletivo de celas, onde tem de tudo. Aí eles se retiraram. Ficou uma coisa estremecida, [...] e eles já estavam bem afastados da gente.

[...] Eis que chega outra relação de transferência para a Penitenciária do Estado. [...] Saem os primeiros cinco em uma lista de vinte, [...] esse se torna o pretexto para eclodir a greve de fome. [...] Todo o pessoal da ALN e outras organizações que, naquele momento, formavam um conjunto, num contexto. Aí o coletivo ficou bem dividido, dois blocos bem $\operatorname{distintos}^{589}$."

Enquanto os presos do Tiradentes não conseguiam chegar a um entendimento sobre o encaminhamento de suas lutas, no dia 10 de maio, o juiz auditor Nelson Machado Guimarães assinou uma portaria na qual ordenou a transferência de presos políticos para a Penitenciária do Estado de São Paulo, os quais seriam submetidos ao "regimento

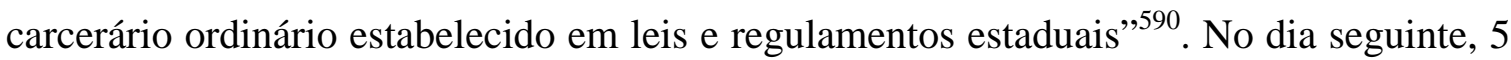
presos políticos foram transferidos para a penitenciária.

Depois das transferências, parcela dos presos políticos decide iniciar a greve de fome. O movimento contou com a participação de presos do Tiradentes e daqueles que foram transferidos para a penitenciária, somando 38 homens e 13 presas políticas [POLITI, 2009: 28]. Os grevistas eram militantes da ALN, PCdoB, PRT, VPR e contou com a adesão de outros sem militância partidária. No dia 12 de maio, todos eles colocaram os mantimentos nos corredores, recusaram a alimentação oferecida pela instituição e condicionaram as negociações do movimento à mediação de d. Paulo E. Arns. Nesse dia divulgaram três manifestos anunciando à opinião pública as razões da greve:

“[...] vimos [...] comunicar nossa decisão de, a partir desta data, permanecer em greve de fome, até que a nós se reúnam nossos companheiros que daqui, arbitrariamente, foram retirados e confinados em regime de isolamento na Penitenciária do Estado.

Não bastasse a série de arbitrariedades a que somos submetidos - como, por exemplo, o total desrespeito por parte do governo à Lei Café Filho, ainda em vigor e que garante aos presos políticos regime de prisão especial, sem rigor carcerário -, não bastasse a ilegalidade da medida de isolamento entre marginais na Penitenciária [...] - para este estabelecimento penal só são enviados os presos comuns condenados e, no caso dos nossos companheiros, além de se tratar de presos políticos, muitos deles, apesar de detidos há quase três anos, não foram sequer julgados -, vemo-nos à mercê de uma política que, alegando razões administrativas as mais diversas, lança as bases para que seja possível, a médio e a longo prazos, a aplicação de uma série de "medidas mais violentas.

\footnotetext{
${ }^{589}$ Entrevista concedida por Vicente Roig à autora. SP, 22/09/2009. AAPP/AEL-LEI.

${ }^{590}$ Portaria n $^{0} .10 / 72$, em PoliTI, M. op.cit, p.134.
} 
Ninguém hoje em dia ignora a verdade a respeito das mortes de companheiros que o regime faz publicar sob a versão de 'mortes em tiroteio no ato da prisão'. [...] não foi esquecido o assassinato do companheiro EDUARDO LEITE, o BACURI, o qual foi retirado da cela 1 do Deops no dia 27/10/70, sob protesto de mais de 60 presos, e levado aos cárceres do Esquadrão da Morte para ser massacrado e morto no dia 08/12/70. Para justificar essa morte e da de uma centena de companheiros, usam a velha e surrada farsa da 'tentativa de fuga'. Não há, do mesmo modo, quem desconheça a política empregada pelos nazistas durante a II Guerra Mundial em relação aos judeus, principalmente os da Polônia, confinando-os primeiramente no Gueto de Varsóvia - isolando-os do convívio da população - para depois exterminá-los com menos problemas no próprio gueto ou em campos de concentração de maior 'avanço tecnológico', tudo isso em nome de uma 'Alemanha Grande'.

É exatamente por entendermos as consequências futuras do isolamento a que são submetidos companheiros [...] que condicionamos o fim de nossa GREVE DE FOME ao fim concreto desses isolamentos, e aproveitamos para nos antecipar, responsabilizando, desde agora, as autoridades impostas pelo atual regime por qualquer 'tentativa de fuga' ou outra medida de retaliação que possa ser levada a cabo ${ }^{591}$."

O conteúdo dos manifestos das presas e dos presos grevistas confinados na penitenciária era similar, sendo que estes salientaram que a reivindicação de retorno ao convívio com os demais presos políticos era a única maneira, mesmo que precária, de garantir sua sobrevivência física e inibir os riscos de retaliações.

No dia 12 de maio, o juiz Nelson Machado Guimarães assinou outra portaria, na qual determinou que todos os que participassem da "rebelião ilegal” seriam removidos para a penitenciária. Assim, nesse dia 11 presos foram transferidos para lás92. Ele enviou também um documento ao Comandante do II Exército explicando que havia transferido para a penitenciária presos, “condenados a penas elevadas, por crimes previstos na LSN e [...] apontados como cabeças do ilegal movimento ${ }^{593}$.”

No dia 15 de maio foram levados para a Casa de Detenção mais 17 presos políticos grevistas para a Casa de Detenção. No dia 15 mais dois grevistas foram transferidos para o $3^{\circ}$. andar do pavilhão 2 da penitenciária, onde ficaram durante 7 $\operatorname{dias}^{594}$. Nesse mesmo dia, Ivan A. Seixas, grevista e menor de idade, foi transferido para a Oban e colocado à disposição do Juizado de Menores pelo juiz Nelson Machado. Em seguida, seis presas políticas grevistas foram levadas para a penitenciária feminina. Uma

\footnotetext{
591 “Manifesto dos presos políticos do Recolhimento de presos Tiradentes”. SP, 12/05/72. V. PoLITI, M. op.cit, p.137.

${ }^{592}$ V. Portaria $n^{0} .11 / 72$, de 12/05/72, em PoliTI, M. op.cit, p.141-3.

593 Inicialmente, foram transferidos Alberto Henrique Becker, Altino Rodrigues Dantas Jr., Celso Antunes Horta, Francisco Gomes da Silva e Manoel Cyrillo de Oliveira Netto. V. Politi, M. op.cit; e BetTo, Frei. Diário de Fernando, op.cit, p.181. Vicente Roig afirmou, porém, que os primeiros a serem transferidos foram ele, Antonio Roberto Espinosa, Altino Rodrigues Dantas Jr., Manoel Porfírio e mais um. V. entrevista concedida por Vicente Roig à autora. Idem, ibidem.

${ }^{594}$ BETTO, Frei. Cartas da prisão. op.cit., p.45 e 52, 56.
} 
das grevistas, Marli Gomes Carvalheiro foi levada ao DEOPS e outras seis presas foram transferidas para o Hospital Geral do Exército de São Paulo [POLITI, 2009: 30].

Desde o início, d. Paulo E. Arns tentou conseguir autorização para avistar-se com os presos políticos em greve, mas não obteve resposta. No dia 17 de maio, ele enviou telegrama ao Ministro da Justiça, Alfredo Buzaid, mas também não conseguiu resposta. A greve então seguiu um encaminhamento inesperado. Werner Rodrigues, o Diretor do Departamento dos Institutos Penais do Estado (DIPE/SP), foi à Casa de Detenção comunicar aos grevistas que todas suas reivindicações seriam atendidas, e os presos políticos seriam reunificados ${ }^{595}$. Os grevistas ficaram surpresos com a rapidez da apresentação da proposta, inexperientes e sem planejamento de como encaminhar o movimento, aceitaram o compromisso de cessar a greve mesmo sem garantias e sem a mediação de d. Paulo E. Arns. De acordo com Carlos Alberto Lobão Cunha, “[...] o que acontece depois, o que do meu ponto de vista é tão grave quanto ter se comprometido a fazer a greve e não ter feito, é que os companheiros que estavam no Tiradentes, explicitamente, disseram que não queriam ir para a Detenção ${ }^{596}$.”

Na mesma noite, o diretor do DIPE fez uma visita aos presos em greve da penitenciária e comunicou a decisão. No dia seguinte, as grevistas também foram informadas das negociações e resolveram interromper o movimento, mas não sem contrariedade, conforme relatou Márcia Y. Mafra:

“[...] Eu acho que na greve de fome essa coisa da diferença [entre homens e mulheres] aconteceu. [...] não houve consenso na ala feminina sobre a primeira greve de fome. [...] $\mathrm{Eu}$, por exemplo, entrei: eu, Lelé, Robeni, Áurea, Zoraide etc. [...] entramos em greve. Depois de uns dias, eu me desidratei, outras pessoas também ficaram mal, eu caí desmaiada. Resolveram levar todas nós para o hospital militar. Fomos e continuamos em greve. Tudo bem, podiam até dar soro, mas eu não ia comer. E lá estávamos, quando começaram a tirar o maior sarro da gente. Acho que foi o pessoal do DEOPS, não sei se foi da OBAN, que falou com a gente. Os próprios médicos, os enfermeiros falaram: 'Vocês são todas malucas, essa greve acabou'. $\mathrm{E}$ a gente não acreditava. Até que os advogados tiveram que ir lá [explicar] e, enfim, a greve acabou. A gente sentiu isso como uma grande traição. E na segunda greve a gente não entrou. Ou é junto ou não é. Nós discutimos, discutimos. $\mathrm{E}$ isso não foi muito bem aceito não (risos). $\mathrm{O}$ aprendizado na ocasião foi esse, quer dizer, agora nós vamos fazer as coisas em conjunto com as mulheres... Não é assim, entra e depois 'desentra' [...] A gente isolada na nossa ala, [...] para, depois, a gente ficar sem o menor controle do que estava acontecendo! ${ }^{597,}$

\footnotetext{
595 Segundo uma carta dos presos da Casa de Detenção, o Dr. Werner Rodrigues teria dito que o presídio Tiradentes seria desativado para que se iniciassem as obras do metrô. V. "Carta dos presos políticos da Casa de Detenção”. SP, 03/06/72, em POLITI, M. op.cit., p.148-9.

${ }^{596}$ Entrevista concedida por Carlos Alberto Lobão Cunha à autora. Idem, AAPP/AEL-LEI.

${ }^{597}$ Entrevista concedida por Márcia Y. Mafra à autora. Idem, ibidem.
} 
Em seguida, no dia 19 de maio, os presos que estavam na penitenciária foram transferidos para o Pavilhão 5 da Casa de Detenção, alojados entre 5 mil presos comuns e submetidos ao rigor carcerário. As presas que estavam no hospital militar foram levadas para a penitenciária feminina e juntaram-se às demais grevistas. Nesse mesmo dia, d. Paulo E. Arns fez com que sua carta em favor dos presos políticos grevistas fosse afixada em todas as igrejas de São Paulo com o seguinte teor:

“[...] Uma vez que nada transpirou pelos meios de comunicação social, achamos necessário informá-lo que de fato eclodiu uma greve de fome na sexta-feira, dia 12 de maio, que esta se prolongou até o final do dia 17.

[...] nenhuma das autoridades, consultadas pessoalmente por nós, pode permitir-nos entrar em contato direto com os presos. É lamentável que neste país cristão [...] aquele que de Deus recebeu o múnus de Pastor seja impedido de cumprir sua missão específica, aliás, garantida pela nossa Carta Magna. [...] Só o respeito ao homem e à sua dignidade nos garante o clima de Paz e verdadeiro progresso, de que tanto necessitamos ${ }^{598}$."

Em represália ao movimento dos presos políticos, entre os dias 19 e 20 de maio de 1972, oito advogados foram sequestrados e levados para o DOI-Codi/SP, entre eles Idibal Almeida Pivetta, Virgílio Egydio Lopes Enei, Iberê Bandeira de Melo, Hélio Navarro, Belisário dos Santos Jr., Maria Regina Pasquale e Airton Soares. Rosa M. Cardoso da Cunha foi intimada a comparecer posteriormente ao DOI-Codi para prestar esclarecimentos $^{599}$. Preso, Pivetta prestou declarações no DOI-Codi e negou ter participado da redação e divulgação do documento dos presos políticos, distribuído no dia 28 de março, no qual protestavam contra as medidas administrativas adotadas pela direção do Presídio Tiradentes. Ele confirmou, apenas, que, juntamente com os demais advogados presos, subscrevera a mencionada representação redigida em 16 de março, dirigida ao STM contra os Juízes Auditores da 2a . CJM, na qual relataram a situação dos presos políticos e solicitaram providências para assegurar a vida de seus clientes ${ }^{600}$.

Esse documento chegou ao conhecimento do DOI-Codi por meio do Juiz auditor José Paulo Paiva, o que provocou a prisão dos advogados. A repercussão foi expressiva, a representação foi enviada à imprensa e, no dia 30 de maio de 1972, o jornal O Estado de S. Paulo divulgou-a reforçando os protestos contra as arbitrariedades no tratamento dispensado aos presos políticos. Semanas antes, o comandante do I Exército, general Sizeno Sarmento, havia liderado um grupo de comandantes militares que se reuniu com

\footnotetext{
${ }^{598}$ V. Carta de d. Paulo E. Arns. SP, 19/05/72. PoliTi, Maurice. op.cit., p.143-4.

${ }^{599}$ V. BeTtO, Frei. Diário de Fernando. op.cit., p.206; e entrevistas concedidas por Virgílio Egydio Lopes Enei e Belisário dos Santos Jr. à autora. SP, 29/01/2011 e 19/02/2011.

${ }^{600}$ V. o Habeas Data de Idibal Matho Gomes de Almeida Pivetta em VIEIRA, César. Em busca de um teatro popular. $4^{\mathrm{a}}$. ed., São Paulo, Funarte, 2007, p.299; POLITI, Maurice. op.cit., p.26.
} 
ministros do STM para solicitar-lhes penas mais altas aos perseguidos políticos, queixando-se que esses militantes voltavam à atividade política quando saíam da cadeia, não restando alternativa aos órgãos de segurança senão matá-los quando reincidiam [BETTO, 2007: 207]. Uma reunião da cúpula militar do II Exército realizada no dia 16 de maio, presidida pelo general Souza Melo, decidiu que as leis especiais para presos políticos seriam revogadas ${ }^{601}$.

No dia 20 de maio, as presas políticas que haviam participado da greve de fome foram novamente removidas e levadas de volta para o presídio Tiradentes.

Após alguns dias de espera, no dia 3 de junho os presos políticos da Casa de Detenção redigiram um abaixo-assinado reiterando o pedido de reunificação dos presos políticos em qualquer estabelecimento e solicitando o cumprimento do compromisso assumido ao final da primeira greve de fome. O documento estabelecia um prazo até o dia 10 de junho para o cumprimento do acordo e protestava contra a imposição feita aos presos políticos do Tiradentes, que condicionava a reunificação e remoção dos mesmos à assinatura de um termo, no qual deveriam aceitar se submeter ao regime carcerário ordinário $^{602}$.

Não obstante, os presos políticos contrários à greve de fome, confinados no Tiradentes, explicitaram que eram contrários a reunificação dos presos na Casa de Detenção, conforme Vicente Roig:

“[...] As condições carcerárias melhores que a gente queria era ficar no Tiradentes. O Tiradentes era o pior presídio do mundo, só era bom porque a gente ficava junto em celas coletivas. O problema era que o vai e volta acontecia muito. Eu estive duas vezes no Tiradentes, três na penitenciária, mas a maior parte do tempo eu fiquei na Casa de Detenção. Acabou a greve de fome, eles ficaram na Casa de Detenção, sem juntar ninguém, nas mesmas condições que estavam antes, ou seja, perdendo uma série de coisas.

[...] não era reivindicação de ninguém sair do Tiradentes para ir para a Detenção. [...] o diretor da Detenção não apitava nada. O juiz auditor e o comando do II Exército que decidiam e ninguém tinha acesso ao comando do II Exército e nem ao juiz auditor para dizer: "Nós queremos ficar todos juntos". Ele falou isso, quis que ficássemos todos juntos num mesmo lugar, mas só que não no Tiradentes. A nossa reivindicação era ficarmos todos juntos no Tiradentes.

[...] Lá havia um regime onde você cozinhava, fazia a própria comida. [...] A gente estudava, discutia e tinha uma vida coletiva ${ }^{603}$.”

\footnotetext{
601 "Apelo urgente em favor dos presos políticos em São Paulo". Comitê de Solidariedade aos presos políticos Brasileiros. SP, 12/05/72, em PoLITI, M., op.cit, p.145-6.

${ }_{602}$ "Carta dos presos políticos da Casa de Detenção ao Dr. Werner Rodrigues”. SP, 03/06/72, em PoLITI, M., op.cit, p.148; BETTO, Frei. Diário de Fernando, op.cit., p.205.

${ }^{603}$ Entrevista concedida por Vicente Roig à autora. Idem, ibidem.
} 
Os presos políticos da Casa de Detenção continuaram articulando a nova greve de fome. Os militantes da ALN presos enviaram correspondência à direção da organização contendo uma avaliação da situação na prisão e pedindo apoio para organizar protestos em favor da greve e dos militantes da VPR, Ariston de Oliveira Lucena e Diógenes Sobrosa de Souza, condenados à pena de morte, cujo recurso seria julgado, possivelmente, no dia 11 de junho. O dirigente da ALN Iuri Xavier Pereira foi assassinado no dia 14 de junho numa emboscada organizada pelo DOI-Codi/SP num bar localizado na Mooca, junto com ele teria sido encontrado o documento ${ }^{604}$ com o seguinte teor:

“A Igreja parece que está mais difícil de ser mobilizada. Nossas famílias também. Mas sabemos que o problema é retornar à luta, só que dessa vez ainda faltam algumas condições; precisamos antes ter certeza que o arcebispo vai se mobilizar e apoiar a nossa luta, como fez até agora. Pelo fato dele ter participado da primeira fase dela, ele está sentindo-se no direito de achar que nós não devemos retornar à greve de fome; e nós estamos achando perigoso atrapalhar nossa aliança estratégica com a Igreja, se a gente forçar a barra. Por enquanto, estamos fazendo documentos escritos, pressionando-os a cumprir um acordo. Nesses dias próximos, definiremos se retornamos à greve de fome. Se retornarmos temos certeza que vamos precisar muito de propaganda (na próxima oportunidade enviamos o manifesto). Sei que vocês não devem fazer nada sem ter a certeza de que nós estamos em greve de fome.

[...] Pedimos a vocês que queimem os manifesto que enviamos etc. [...] Voltamos a lembrar aos companheiros a importância política que terá esse julgamento e a importância de uma participação da O. nele com propaganda, a dita ação e, se possível, uma ação de envergadura ${ }^{605 ”}$.

Ao receberem a visita de d. Paulo e d. Luca Moreira Neves, frisaram que o compromisso de unificar todos os presos políticos num mesmo local ainda não havia sido cumprido, nem o de cessar o isolamento do preso político, Ivan A. Seixas, de 17 anos, no DOI-Codi/SP. A Auditoria Militar determinara que ele retornasse ao presídio Tiradentes, mas isso não havia acontecido. O arcebispo aceitou apoiar e prosseguir como mediador dos presos, mas salientou que deveriam pedir somente o que tivesse base legal. D. Lucas contou aos dominicanos que estivera com o papa Paulo VI no dia 8 de maio, o qual fez menção ao livro de cartas de Frei Betto e enviou-lhes sua benção [BETTO, 2009: 206-8].

\footnotetext{
${ }^{604}$ De acordo com Carlos Alberto Lobão Cunha, depois da greve de fome, d. Paulo esteve na Casa de Detenção e se referiu ao fato do DOI-Codi tê-lo questionado sobre o manuscrito. Os presos desmentiram a existência do mesmo. De fato, uma correspondência com conteúdo similar foi enviada para a ALN, mas não há certeza de que o trecho em questão seja autêntico. No período, os militares tentaram indispor a Igreja contra os presos políticos. Entrevista concedida por Carlos Alberto Lobão Cunha à autora. SP, 10/10/2010.

${ }^{605}$ Trecho do documento citado na matéria intitulada "Procurador esclarece greve em presídios de São Paulo”. Jornal da Tarde, 22/07/72, em PoliTI, M., op.cit, p.194. Ana Maria Nacionovic Correa e Marcos Nonato da Fonseca morreram na emboscada com Iuri, mas Antonio Carlos Bicalho Lana sobreviveu. V. Dossiê Ditadura: op.cit., p. 348-53.
} 
Antecipando-se à ameaça de greve de fome, no dia 7 de junho o juiz auditor Nelson Machado Guimarães determinou a transferência de sete presos políticos da Casa de Detenção para a penitenciária de Presidente Venceslau, no interior de São Paulo próximo a fronteira com o estado do Mato Grosso. Foram enviados para lá os três frades dominicanos, Frei Betto, Ivo e Fernando, e Manoel Porfírio de Souza, Maurice Politi e Wanderley Caixe. Mário Bugliani não foi levado devido ao seu precário estado de saúde. De acordo com a justificativa do governo brasileiro enviada à CIDH da OEA, a remoção dos dominicanos se deu porque Frei Fernando encabeçava o referido abaixo-assinado, o que foi interpretado como um indicativo de que os frades dirigiam o movimento. Para não configurar uma perseguição à Igreja, outros 4 presos condenados em primeira instância foram encaminhados com os religiosos para um presídio distante ${ }^{606}$. De fato, os órgãos repressivos articularam o afastamento dos dominicanos visando enfraquecer o contato dos grevistas com d. Paulo E. Arns e a igreja progressista e dificultar a repercussão no exterior, conforme ofício dirigido pelo juiz auditor Nelson Machado ao STM:

\begin{abstract}
“Afastados desse centro nervoso da vida nacional, que é a capital de São Paulo, terão eles diminuída, certamente, a sua agressividade e a expectativa de 'cobertura' externa, que sempre tiveram por um setor desavisado e malicioso do clero de São Paulo que insiste em qualificá-los como HERóis, MÁRTIRES E VÍTIMAS de um regime iníquo. O próprio órgão da arquidiocese de São Paulo, o jornal 'O São Paulo', tem sido incansável em apresentálos como vítimas inocentes de uma clamorosa injustiça”607.
\end{abstract}

Não obstante, d. Paulo e os setores progressistas da Igreja se aproximaram dos presos políticos e da luta em defesa dos direitos humanos. A Igreja Católica dava passos efetivos no sentido de se contrapor à ditadura. No dia 8 de junho, os bispos e arcebispos da regional sul da CNBB divulgaram um documento em Brodósqui (SP) durante o encerramento de sua assembleia anual, intitulado “Testemunho de Paz”, onde defenderam o retorno do direito ao habeas corpus e se manifestaram contrários às prisões arbitrárias e às torturas aos perseguidos políticos. O texto destacou ainda que caberia “[...] aos arbitrariamente punidos e injustiçados a devida reparação pelos danos morais e sociais infligidos à sua pessoa (cf. Mateus 7, 1-2)” [BETTO, 2009: 215-6]. No dia seguinte, o texto foi publicado no jornal O Estado de S. Paulo com o título "Bispos defendem o habeas corpus" [POLITI, 2009: 46].

\footnotetext{
${ }^{606}$ V. PoLiTI, M., op.cit, nota 37, p.37.

${ }^{607}$ V. documento encontrado por Maurice Politi no Arquivo Nacional (Brasília), citado na nota 63, em Politi, M., op.cit, p.65. V. tb. BETTO, Frei, op.cit., 227.
} 
Em protesto a essa situação e à nova transferência arbitrária, os presos políticos iniciaram uma greve de fome no dia 9 de junho. O movimento contou com a participação de 36 presos, incluindo os que foram transferidos. Contudo, dois presos confinados na Casa de Detenção foram contrários à greve. De acordo com o Vicente Roig, esta situação gerou muito constrangimento:

\begin{abstract}
"Eu confesso que estava me sentindo muito desconfortável, muito mesmo. Uma coisa era a questão da autocrítica, outra era você estar em um movimento... Eu nunca me vi em um movimento que não tivesse assumido as linhas de frente. $\mathrm{E}$ por mais equivocado que fosse, eu nunca fui raivoso em relação às posições à minha esquerda. [...] Imagine, você está em um lugar em que só você é diferente. Embora, eu não concordasse com a posição política deles e não concordasse com o que se pretendia, porque aquilo era fazer uma ação meramente propagandística para 'fora', sem ter um objetivo, uma reivindicação muito clara: 'Melhores condições', era vago! [...] Eu pedi autorização, liguei [...] para pedir autorização ao pessoal para entrar em greve de fome. Eles foram taxativos e peremptórios: “- De jeito nenhum!”. Eu não podia entrar em greve de fome, porque a posição do coletivo da Ala não era essa. Os argumentos eram muitos, mas o meu era que éramos fracos para entrar numa greve de fome ${ }^{608}$."
\end{abstract}

Apesar do clima de tensão e divisão entre os presos políticos, gradualmente a greve de fome foi ganhando espaço e ganhou repercussão nacional e internacional. Um manifesto intitulado "Manifesto ao povo brasileiro" relatando os fatos e explicando os motivos da greve foi distribuído para a imprensa, entidades estudantis, partidos e organizações de esquerda.

A repressão aos grevistas foi brutal, no dia 9 de junho, Paulo de Tarso Venceslau e Paulo Vannucchi foram levados ao DOI-Codi/SP e torturados durante 3 dias para comerem. No dia 13 de junho, Vannucchi compareceu à Auditoria Militar para depor como testemunha num processo. Na ocasião, sua advogada Eny Raimundo Moreira denunciou as torturas que havia sofrido no DOI-Codi/SP, mostrando ao juiz auditor Nelson Machado o hematoma no olho esquerdo e os sinais de enforcamento e ainda pediu que tirasse a camisa para mostrar outros hematomas e escoriações. Vannuchi declarou que em função de sua recusa a ingerir alimentos os torturadores introduziram um tubo em sua boca por onde injetaram leite, enquanto lhe davam pontapés:

"Lembro-me de que fomos recepcionados pessoalmente pelo major Carlos Alberto Brilhante Ustra [...], que nos recebeu berrando: 'Acabou sua greve de fome. Aqui vocês vão comer, nem que seja pelo cu.' Não houve, pelo menos para mim, tortura tipo pau-dearara ou choque elétrico, que eram comuns lá. Foi muito mais uma humilhação e tentativa de nos desmoralizar frente aos outros presos. Nos colocaram uma camisa de força, iguais às usadas em loucos, com um funil na boca, através do qual alguns carcereiros jogavam

${ }^{608}$ Entrevista concedida por Vicente Roig à autora. Idem, ibidem. 
leite. Riam e se divertiam vendo como nos debatíamos dando pontapés. [...] Quando voltei à Casa de Detenção, o médico [...] fez um exame de corpo de delito tão completo que permitiu à advogada Eny Moreira entrar com um recurso no STM. [...] Eny valentemente exigiu que o juiz [...] visse [...] e ele cinicamente refutou: '- Mas eu só mandei eles para lá para que se alimentassem!,609 ",

O Comitê de Solidariedade aos Presos Políticos de São Paulo e a Liga em Defesa dos Presos Políticos não existiam realmente. Na verdade eram grupos criados pela ALN para divulgar os manifestos e as denúncias do movimento dos presos. Não chegaram a se transformar em grupos de solidariedade organizados ${ }^{610}$.

Desde o início de junho, a repercussão da representação apresentada ao STM pelos advogados de presos políticos contra os juízes auditores de São Paulo (2ª CJM) e a prisão dos mesmos continuava na imprensa. No dia 7, o "Jornal da Tarde” publicou um editorial com o título "Liberdade para o advogado exercer sua profissão", onde fazia referência ao vexame sofrido pelos advogados presos e à transferência de prisioneiros políticos “para lugares inadequados”.

Em 13 de junho, em prosseguimento ao processo iniciado pelos advogados, os juízes auditores de São Paulo (2a . CJM) enviaram um documento ao STM, onde explicitavam a política carcerária no estado, justificando assim o tratamento dispensado aos presos:

“[...] 8.1 - Os presos de escassa periculosidade, de fácil recuperação, de penas leves, permanecerão no Recolhimento Tiradentes ou estabelecimentos congêneres da capital, com as mais amplas regalias já mencionadas, que lhes propiciem a mais rápida readaptação ao convívio social.

8.2 - Os presos de elevada periculosidade, de recuperação imprevisível e de penas elevadas, serão entregues à rede oficial de presídios e penitenciárias do Estado de São Paulo, sob fiscalização direta [...] da E. Vara da Corregedoria Geral dos Presídios, órgão do Poder Judiciário Estadual, em permanente contato com as Auditorias Militares, que preservam, em qualquer circunstância, a sua competência legal quanto à execução das penas dos presos seus condenados (concessão de livramento condicional etc).

9 - Com tais providências, Senhor Ministro Presidente, objetiva-se a aplicação da JUSTIÇA aos presos, e o DESMONTE do que a gíria subversiva já chamava de 'APARELHÃO', isto é o desmonte do FOCO SUBVERSIVO, de já elevada agressividade antissocial, organizado no interior do PRESÍDIO TIRADENTES. ${ }^{611}$,

\footnotetext{
${ }^{609}$ Entrevista concedida por Paulo de Tarso Vannucchi à M. Politi. V. Politi, M., op.cit, nota 48, p.55. V. tb. "Denúncia: Presos políticos em greve de fome são torturados na Oban.” Comitê de Solidariedade aos Presos Políticos de São Paulo, SP, 18/06/72. V. POLITI, M., op.cit, p.164; e BETTO, Frei. op.cit., p.214.

${ }^{610}$ Entrevista concedida por Reinaldo Morano Filho à autora. SP, 14/03/2011.

${ }^{611}$ V. POLITI, M., op.cit, p.27. Destaques no original.
} 
No dia seguinte, O Estado de S. Paulo publicou uma pequena matéria na qual afirmava que a OAB só interviria em relação à prisão dos advogados caso fosse solicitada e mencionava as transferências de presos políticos do Tiradentes ${ }^{612}$.

Os dominicanos em greve de fome na penitenciária de Presidente Venceslau (SP) aguardavam o julgamento do recurso impetrado no STM pelo advogado Mário Simas solicitando o retorno deles para a cidade de São Paulo, no qual alegava que eles já haviam sido transferidos oito vezes, o que dificultava a sua defesa e aumentava o sofrimento de suas respectivas famílias. O advogado Virgílio Egídio Lopes Eney impetrou vários habeas corpus em favor de seus clientes grevistas visando obter autorização para a realização de visitas de familiares e advogados, entre eles Antenor Meyer, Antônio Bernardes, Manoel Cyrillo de Oliveira Netto, Joaquim dos Santos e Geraldo Magela [Politi, 2009: 56, 78].

No dia 15 de junho, duas presas políticas do presídio Tiradentes, Áurea Moretti e Marlene Soccas, entraram em greve de fome em solidariedade aos demais. Elas foram removidas para o DEOPS/SP e ameaçadas de torturas caso não desistissem da adesão. Pouco depois, o delegado Carlos Alberto Augusto, conhecido como Carlinhos Metralha, iniciou as torturas. Isoladas, no dia 19 de junho elas cessaram a greve e denunciaram os maus tratos aos presos, advogados e familiares. De acordo com Marlene Soccas:

"Eu me lembro que uma presa comum que esta lá [no DEOPS], parece que no fundão, ao
ouvir nossa história, também se declarou em greve, pelos motivos dela, os quais não me
lembro. Acho que isso piorou a nossa situação. Imagina uma greve se espalhando pelo
Deops! Então, trataram de nos levar novamente para a tortura, inclusive a tal moça.
Apanhamos um bocado e logo decidimos que íamos parar. Nós não estávamos muito
fortalecidas. Acho que a Áurea e eu fomos separadas após um dia ou dias, não me lembro
muito bem. [...] imediatamente, mandei uma nota aos meus advogados, que fizeram
circular a notícia da greve. Eu acabei sendo solta no dia 22 de julho direto do DEOPS ${ }^{613}$.”

Áurea Moretti foi levada para a Penitenciária Feminina do Tremembé onde ficou de castigo, isolada por vários dias. As presas comuns a reconheceram do período em que esteve na Penitenciária do Estado e foram muito solidárias. Depois de algum tempo, ela voltou ao convívio com as presas comuns. Em seguida, sua pena de seis anos de prisão foi reduzida para quatro anos e meio e dali conseguiu sair em liberdade condicional em 1973 [POLITI, 2009: 45].

\footnotetext{
${ }^{612}$ V. POLITI, M., op.cit, nota 50, p.56.

${ }^{613}$ Entrevista concedida por Marlene Soccas a Maurice Politi em nov./2007. V. PoLITI, M., op.cit, nota 43, p.45.
} 
Um preso paraense, que militava em Minas Gerais e havia sido transferido para São Paulo, chamado Humberto Rocha Cunha foi transferido para Belo Horizonte, onde passou mais de uma semana sendo torturado, não obstante continuou em greve de fome mesmo quando lhe disseram que os presos em São Paulo haviam paralisado a greve. Diante de sua resistência foi trazido de volta à capital paulista e continuou com os presos que prosseguiram em greve de fome $e^{614}$.

No dia 17 de junho, o jornal O São Paulo, da Cúria Metropolitana, divulgou uma carta aberta dirigida ao ministro da Justiça, e à população, divulgando e apoiando a greve de fome dos presos políticos nos termos da Carta de Brodósqui, da CNBB. No dia seguinte, o jornal O Estado de S. Paulo conseguiu publicar uma matéria com o título “A CNBB por presos intercede”, na qual informou que o secretário-geral da CNBB, d. Ivo Lorscheider, havia entregado, no dia anterior, uma carta ao ministro da Justiça, Alfredo Buzaid, pedindo sua intervenção para solucionar os problemas dos presos paulistas em greve de fome. A matéria noticiava também que d. Paulo havia se reunido com o Conselho de Presbíteros de São Paulo para debater propostas de apoio a greve de fome dos presos políticos ${ }^{615}$. Os grevistas continuavam sob regime de total incomunicabilidade [BETTO, 2009: 217].

Um abaixo-assinado com o mesmo teor foi divulgado a partir do dia 21 de junho e encaminhado às autoridades brasileiras:

\begin{abstract}
"Nós, abaixo-assinados, democratas, cientes da situação atual dos presos políticos [...] e conscientes de que a garantia dos Direitos Humanos é um dos pressupostos para a existência da Democracia, bem como as declarações que foram recentemente firmadas pela CNBB [...].

Salientamos às autoridades responsáveis que as reivindicações dos presos políticos sejam atendidas - condições humanas de vida e que sejam instalados em um mesmo presídio -, observância ao que lhes assegura a Declaração Universal dos Direitos do Homem, da ONU, e a própria Constituição Federal."
\end{abstract}

O documento contou com as assinaturas de representantes de dezenas de centros acadêmicos de faculdades de São Paulo e do Rio de Janeiro; de professores universitários, de escritores e atores, tais como Ruth Escobar, Antônio Fagundes, Othon Bastos, Eva Wilma, Ester Goes, Claudio Correa e Castro, Silnei Siqueira, Sábato Magaldi, Fernando Peixoto, Jonas Bloch, Lygia Fagundes Telles, Paulo Emílio Salles Gomes, Madre Cristina, Maria Nilde Mascellani, Ana Maria de A. Camargo, Ulpiano Bezerra de

\footnotetext{
${ }^{614}$ Entrevista concedida por Carlos Alberto Lobão Cunha à autora. Idem, AAPP/AEL-LEI.

615 “A CNBB por presos intercede”. OESP, 18/06/72. V. PoliTI, M., op.cit, nota 54, p.57. O Jornal do Brasil também publicou a notícia. V. BETTO, F. Diário de Fernando, op.cit.., p. 218.
} 
Menezes, Ruth C. L. Cardoso, Eunice Durham, entre outros. Contou também com as assinaturas de padres e vigários de diversas regiões episcopais da cidade de São Paulo ${ }^{616}$.

Naquela semana, o jornal O São Paulo divulgou o manifesto das mães dos presos políticos em greve de fome e informou que este seria o tema das missas do dia seguinte, onde seriam lidos os documentos "Mensagem do Episcopado Paulista”, de d. Paulo, e a liturgia sobre o “Testemunho de Paz”, da CNBB [Politi, 2009, 110]. A carta das mães fazia um contundente apelo pela rápida resolução dos problemas de seus filhos ao presidente da República e ao juiz-auditor Nelson Machado Guimarães:

“Não estamos pedindo a sua libertação. Estamos clamando apenas pelas suas vidas. Que
como homens tenham direito à existência e à integridade física. Desde que foram detidos,
temos compartilhado o sofrimento de vê-los vítimas de exorbitante abuso de autoridade,
seja sendo seviciados pela polícia (Deops), seja pelo Exército (Oban, hoje Codi), onde
inúmeros foram cruelmente torturados até a morte. Citamos o caso de uma de nós, cujo
filho foi brutalizado e finalmente assassinado pela Oban, que negou o cadáver à família,
ou até mesmo um simples atestado de óbito. Hoje esta mãe luta conosco. Tenta evitar que
seu segundo filho, também detido, sofra idênticos riscos.
[...] Assim, caracteriza-se a constante insegurança de vida que pesa sobre nossos filhos.
[...] Nossos filhos, já debilitados por uma primeira greve de fome, retomando-a num ato
de desespero e de resguardo de sua dignidade humana.
[...] Não são só os nossos filhos que estão cumprindo uma pena. Somos todos nós,
atingidos diariamente pela crueldade com que ela é imposta, transcendendo os limites da
lei para atingir esta desumanidade. Não sabemos se esta triste peregrinação em defesa de
nossos filhos (que para alguns de nós já dura anos) não terá um final trágico.
Esperando amor, compreensão e justiça, aguardamos confiantes ver nosso apelo
atendido”,617. Este apoio foi organizado, em grande medida, por integrantes do "Grupo das Sextas-Feiras” formado por leigos e religiosos que tinham um posicionamento crítico em relação à Igreja Católica em São Paulo. Composto majoritariamente por pessoas que habitavam a zona sul da cidade, tinha também integrantes oriundos da zona leste. Organizado no final de 1970, o grupo era formado pelo padre Luis Giuliani, Iara Spadinni (ex-freita), Júlio Viccini (ex-padre), Aurélio Peres, Irma Passoni, Santo Dias da Silva, Mario Carvalho de Jesus, entre outros. Alguns deles haviam estado presos no Tiradentes. Em geral, o grupo reunia-se regularmente no Buraco Quente, uma favela próxima ao aeroporto de Congonhas, no Campo Belo. O padre Giuliani integrava também o Conselho Arquidiocesano de Presbíteros, composto por representantes eleitos de cada região da cidade e que ajudava d. Paulo e os três bispos auxiliares nos trabalhos da arquidiocese.

\footnotetext{
616 “Carta aberta sobre a greve de fome dos presos políticos”. SP, 17/06/72, em PoliTi, M. op.cit., p.171-2.

${ }^{617}$ V. Politi, M., op.cit, p.161-2. O manifesto se refere à mãe de Virgílio Gomes da Silva, dirigente da ALN assassinado sob tortura no DOI-Codi/SP em 29/09/69. V. Dossiê Ditadura, op.cit., p151.
} 
Esse grupo desempenhou um papel decisivo no apoio à greve de fome e na mobilização da Igreja Católica [PoLITI, 2009: 110-12].

Com o agravamento da greve, as reuniões do grupo se tornaram mais frequentes, quando divulgavam informes sobre as condições de saúde dos grevistas, faziam leituras de cartas de familiares e advogados dos presos e discutiam propostas de solidariedade ao movimento. O grupo organizou liturgias especiais sobre a greve de fome nas missas de domingo; mimeografou documentos e cartas das mães e de advogados para distribuição; e promoveu reuniões e contatos constantes com os bispos auxiliares [POLITI, 2009: 112]. Mais tarde, esse grupo viria a ser um dos embriões do Movimento do Custo de Vida.

Outro grupo ligado aos setores progressistas da Igreja Católica em São Paulo também ajudava na divulgação de denúncias e demandas dos presos políticos. O grupo era articulado por Maria Nilde Mascellani, que criou em 1970, o RENOV (Relações Educacionais e do Trabalho), uma entidade pensada para formar educadores e jovens de grupos populares, voltado à defesa dos direitos humanos e dos perseguidos políticos. Aposentada com base no AI-5, em janeiro de 1970, ela criou o RENOV, onde também promovia reuniões clandestinas para organizar atividades de solidariedade aos perseguidos políticos, como divulgação de documentos e denúncias no país e no exterior e esconder militantes, que contava com a participação de Luiz Eduardo Greenhalgh, Ana Maria de Almeida Camargo, entre outros ${ }^{618}$. Desde 1962, Mascellani colaborava com os programas educacionais da CNBB. Ligou-se ao Instituto Sedes Sapientiae e à Madre Cristina; e a partir de 1972, implantou um programa para mulheres de baixa renda na Favela Buraco Quente, junto à paróquia Nossa Senhora do Guadalupe, também prestava assessoria ao projeto Educacional junto a Favela do Jaguaré, na capital paulista.

No dia 22 de junho, o novo diretor do presídio Tiradentes, Geraldo Ribeiro Garcia, informou em ofício a existência de duas solicitações sem assinaturas, uma das mulheres e outra dos homens, encaminhadas ao juiz Nelson Machado Guimarães pedindo que os presos políticos fossem reunidos num mesmo estabelecimento. De acordo com o documento, os presos haviam sido “[...] consultados pelo Dr. Werner, se queriam ir todos para a Detenção, isto quando da primeira greve, e os que se encontram aqui recolhidos ficaram em dúvida, não expressando claramente se desejavam ou não aqui permanecer, isto do lado masculino, enquanto que, na ala feminina, foram todas unânimes em se

\footnotetext{
${ }^{618}$ Mascellani era coordenadora do Ensino Vocacional do Estado de São Paulo. Em 12/12/69, orientadores, professores, funcionários e alunos dos Ginásios Vocacionais foram presos, após uma invasão coordenada da PM em todos os Vocacionais. Essa intervenção pôs fim a uma revolucionária experiência pedagógica. V. entrevista concedida por Ana Maria de Almeida Camargo à autora. SP, 14/04/2011.
} 
manifestarem favoráveis à transferência para o outro presídio.” Neste momento, o número de presos políticos alojados no Tiradentes havia se reduzido, eles somavam 80 homens e 19 mulheres. Em março, esse número totalizava 160 presos $^{619}$.

O movimento dos grevistas transformou-se em assunto relevante para os principais jornais de São Paulo, que lhe dedicaram alguns editoriais. O Estado de $S$. Paulo publicou no dia 25 de junho um editorial intitulado “A punição dos presos políticos”. O texto reconhecia a existência de presos políticos no Brasil e que a solução de seus problemas deveria ser buscada à luz dos princípios internacionais que regem a questão. Era favorável à punição de crimes políticos desde que se comprovasse a autoria dos delitos em processos regulares com ampla defesa. Segundo o jornal, os presos políticos não mereciam a mesma terapia aplicada aos presos comuns, pois que a conceituação de crimes políticos varia de acordo com o tempo e os regimes políticos. O texto, por fim, fazia uma descrição das péssimas condições carcerárias vividas pelos presos políticos em São Paulo ${ }^{620}$.

Um significativo apoio surgiu com a publicação do artigo "O canto na fogueira” do escritor católico Tristão de Athayde no dia 29 de junho, no Jornal do Brasil, onde ele se solidarizava com os presos políticos, mencionando especialmente a situação dos dominicanos mantidos isolados no interior de São Paulo, e pedia por uma anistia política:

\footnotetext{
"Penso [...] em todos aqueles que são vítimas diariamente, sobretudo numa época violenta como a nossa, [...] de julgamentos precipitados, de prisões injustas e da denegação dos mais comezinhos direitos da criatura humana. Sejam quais forem os crimes que lhes foram imputados. E tanto mais dolorosos esses sofrimentos quanto as vítimas nada mais pedem senão o cumprimento da lei, nacional e internacional, e o respeito mais elementar à dignidade do ser humano.

Refiro-me especialmente ao caso dos três jovens dominicanos e, creio, de alguns outros companheiros, condenados a alguns anos de prisão, já em parte cumpridos, por delitos políticos. Não quero, nem devo, entrar na apreciação de sua culpa. [...] Quero, apenas, referir-me à greve de fome a que recorreram, como último recurso contra o tratamento inumano que vêm sofrendo na prisão. Transferidos já, por várias vezes, de presídio em presídio, perdendo em cada transferência a notícia da sobrevivência de companheiros e amigos, enviados agora a uma remota masmorra na fronteira de São Paulo-Mato Grosso, onde é quase impossível a visita das famílias, acham-se cada vez mais afastados de todo convívio humano e cercado pelo terrível silêncio de um abandono, que os leva a recorrer a um holocausto que temos o dever de evitar, por mais admirável que possa ser como exemplo de fidelidade a um ideal.

[...] Acredito, porém, que suas vidas serão ainda mais preciosas que suas mortes por imolação espontânea. E por isso é que devemos pugnar para que lhes sejam concedidos os direitos elementares de sobreviver dignamente [...].
}

\footnotetext{
${ }^{619}$ Ofício n ${ }^{0}$.1.123/72, em POLITI, M. op.cit., p.176.

${ }^{620}$ V. tb. editorial do Jornal da Tarde de 28/06/72, citado em POLITI, M. op.cit., p.178-9.
} 
Não se trata, porém, de uma revisão do processo. Mas de uma revisão de processos, de métodos penais, que, longe de concorrerem para que nosso progresso material não esteja, em contradição com o nosso progresso moral e espiritual, só fazem agravar esse contraste, que é um dos escândalos de nossa vida nacional presente. Mais uma vez levanto minha voz [...] em favor de uma anistia política honesta e global que será, no próximo dia 7 de setembro, a verdadeira comemoração de nossa independência. Mas até lá procuremos proteger a dignidade e mesmo a vida de uma juventude que o sofrimento temperou [...] [POLITI, 2009:184-5].”

Não obstante, a manifestação da Folha de S. Paulo veio através do editorial no dia 30 de junho, cujo título era bastante sugestivo: “Presos Políticos?” O jornal tratava as transferências de presos apenas como uma possibilidade e questionava a existência de presos políticos no Brasil, pois segundo a Folha, o país tinha oposição no Congresso e nenhum deputado ou jornalista era preso por haver criticado o governo na tribuna ou nos jornais:

\footnotetext{
"Ninguém neste país ignora a existência de pessoas que professam ideologias de esquerda, de todos os matizes, e que se mantendo apenas no terreno intelectual de suas próprias ideias e convicções vivem sem ser incomodadas. Ninguém conhece a existência de um só homem de esquerda que esteja preso em decorrência exclusiva de seu pensamento.

[...] as exigências de comprovação de culpa e do direito de defesa estão claramente configuradas nas inúmeras absolvições registradas nos diversos foros, como nesta semana mesmo tanto se noticiou.

[...] Mas como tornar desiguais no cárcere criminosos iguais no assalto, no sequestro, no saque, no roubo, no incêndio e no assassínio?

[...] é evidente que [...] a finalidade da prisão deve visar muito menos à tentativa de recuperação que à proteção da sociedade contra a sua criminosa atuação.

[...] É sabido que esses criminosos que o matutino [o OESP] qualifica tendenciosamente de presos políticos, mais não são que assaltantes de bancos, sequestradores, ladrões, incendiários e assassinos, agindo, muitas vezes, com maiores requintes de perversidade que os outros, pobres diabos, marginais da vida, para os quais o órgão em apreço julga legítimas todas as promiscuidades ${ }^{621}$."
}

Desde o dia 18 de junho, gradualmente, os grevistas mais debilitados eram levados para o hospital da penitenciária e forçados a tomar soro e receber transfusões de sangue em alguns casos. Os militares e o juiz-auditor Nelson Machado, preocupados com a repercussão internacional do movimento, exigiam relatórios detalhados das condições de saúde de cada prisioneiro em greve.

A Anistia Internacional e diversas organizações no exterior se mobilizaram enviando manifestações de apoio aos grevistas e cartas às autoridades brasileiras. Muitas denúncias sobre a situação dos presos políticos estavam sendo reproduzidas pelas

${ }^{621}$ V. “Presos Políticos?”, Folha de S. Paulo, 30/06/72, em POLITI, M. op.cit., p.181-2. 
principais agências internacionais de notícias ${ }^{622}$. Um fator decisivo para a repercussão da greve de fome foi a participação dos dominicanos, o que atraiu maior apoio de setores da Igreja Católica. No final de junho de 1972, militantes exilados fizeram uma ampla divulgação da carta dirigida ao papa, dos três dominicanos em greve, onde relatavam sua situação e a dos presos políticos no Brasil. A carta foi traduzida em diversas línguas e se espalhou por todo o mundo, principalmente, na Europa e América Latina ${ }^{623}$.

Nesse período, a precária condição de saúde de vários grevistas começava a inspirar preocupação. No dia 23 de junho, o recurso em favor dos dominicanos presos em Presidente Venceslau foi negado por unanimidade pelo STM. Inicialmente, o tribunal superior emitiu parecer favorável aos presos, mas após receber uma mensagem do comandante do II Exército, general Humberto de Souza Mello, e a visita do promotor militar Durval Airton de Moura Araújo e do delegado do DEOPS, Alcides Cintra Bueno, em sessão secreta voltou atrás e aceitou a argumentação do juiz-auditor e do promotor de que os dominicanos eram lideranças e parte do "aparelho" subversivo existente no Presídio Tiradentes e por isso deveriam permanecer afastados do convívio com os demais $^{624}$.

Os presos em greve se encontravam num impasse, pois os militares demonstravam claramente que não cederiam apesar da repercussão do movimento. No final de junho e começo de julho, os bispos auxiliares de d. Paulo e o núncio apostólico d. Umberto Monzzoni, o representante do papa, conseguiram autorização para visitar os grevistas no hospital da penitenciária do Estado e manifestaram preocupação com a situação ${ }^{625}$. O núncio apelou para que cessassem a greve e prometeu se empenhar pela reunificação dos presos políticos [BETTO, 2009: 224].

No dia 2 de julho, o abaixo-assinado dos artistas, intelectuais e estudantes em apoio aos grevistas foi publicado pelo O Estado de S. Paulo [BETTO, 2009: 221]. A repercussão do movimento se ampliou com a publicação de um artigo sobre a greve no jornal britânico Financial Times, no dia 7 de julho, assinalando uma posição favorável às reivindicações dos presos políticos e as tensões existentes dentro da Igreja Católica e desta com os militares:

\footnotetext{
${ }^{622}$ Entrevista concedida por Carlos Alberto Lobão Cunha à autora. SP, 10/10/2010; e POLITI, M. op.cit., nota 72, p.73.

${ }^{623}$ Entrevista concedida por José Luiz Del Roio à autora. SP, 20/03/2010.

${ }^{624}$ V. BetTo, op.cit., p.220 e nota 63, em POLITI, M. op.cit., p.65.

${ }^{625}$ V. nota 84, em POLITI, M. op.cit., p.85.
} 
"Um advogado representando alguns dos 36 presos políticos em greve de fome em São Paulo disse ontem ter recebido um relatório médico que sugere que os homens estão em um estado de saúde tão deplorável que muitos deles poderiam falecer em espaço de uma semana.

O governo do presidente Médici dificilmente vai intervir para salvar estes presos que estão em greve de fome por quase quatro semanas. As esperanças das forças liberais estão centradas na Igreja Católica.

[...] Note-se que está havendo muita intranquilidade entre a Igreja Católica com referência às políticas do governo em relação à liberdade política. Alguns bispos, especialmente os cardeais do Rio e de Porto Alegre, porém, estão muito interessados em preservar a influência especial que têm com o governo.

No entanto, nesta questão da greve de fome, a Igreja está mais comprometida [...]. Uma autoridade na sede da CNBB afirmou que os fatos mencionados pelos que simpatizam com os prisioneiros são 'substancialmente corretos ${ }^{\text {, }}{ }^{26}$."

Apesar da repercussão da greve de fome, os militares não cederam às reivindicações dos presos políticos. Ao final de duas semanas em viagem pela Europa e Estados Unidos, d. Paulo conseguiu angariar apoio aos grevistas e à temática dos direitos humanos no Brasil. Tentou reunir-se com os presos políticos, mas não obteve autorização [Betto, 2009]. No dia 9 de julho, o jornal O Estado de S. Paulo divulgou uma comunicação feita pelo arcebispo, onde ele reafirmou a posição da Igreja Católica favorável ao jejum, mas contrária, do ponto de vista do Evangelho, à greve de fome. D. Paulo assinalava que a Arquidiocese compreendia e assumia “[...] a angústia, as necessidades e as aspirações, quando legítimas, dos presos empenhados nesta atitude extrema"; mas defendia "o jejum interrompido e recomeçado quando a razão e a prudência o recomendam”. Ele pedia pelo fim do sofrimento e sacrifício dos presos políticos, assim como segurança e paz para todos eles [POLITI, 2009: 189].

Em 10 de julho, porém, a situação dos grevistas de São Paulo se tornou insustentável e, apesar das dificuldades de comunicação entre eles, após 32 dias sem comer decidiram suspender o movimento, conforme relato de Carlos Alberto Lobão Cunha:

“[...] em algum momento você tinha que acabar a greve, a gente tinha prometido ao d. Paulo que não ia morrer, um ou dois tinham desistido em função de fraqueza física. A gente mesmo falou: '- Pára, pára, não continua'. E você sabe quando os seus limites estão chegando, porque, naquele momento, morreu um pessoal do IRA numa greve de fome, em 32, 33 dias. Eles foram até o fim, o Exército Republicano Irlandês e alguns que morreram. A gente não tinha se predisposto a morrer.

Nós éramos contra tomar soro, sal e sangue. A gente fez uma greve apenas com água, mas aí você está lá [...], fraco, tenta brigar, chegam cinco, seis caras, te amarram todo na cama, te amarram com cinto como me amarraram e eu tomei um litro de soro e acho que meio

\footnotetext{
626 "Prisioneiros em greve de fome podem morrer". Financial Times, 07/07/72. Tradução livre de M. Politi, em Politi, M. op.cit., p.191.
} 
litro de sangue. [...] Nós estávamos todos no hospital da penitenciária, a gente conseguia falar apenas com as mãos. Acho que pedimos para ser levados para baixo, [...] e conversamos entre nós e resolvemos parar. Eram 32 dias [...] combinamos de acabar a greve [...]. Só depois soubemos da repercussão na imprensa. No hospital da penitenciária você não sabia de nada, nada ${ }^{627}$."

Em seguida, no dia 11 de julho, d. Paulo divulgou que a Anistia Internacional ofereceu ajuda aos presos políticos em greve e foi duramente criticado pelos militares por ter pedido auxílio à entidade. A Anistia solicitou ao ministro da Justiça que intercedesse em favor dos presos políticos [PoLiTI, 2009: 90]. No final do dia, Frei Betto recebeu a ligação de Paulo de Tarso Venceslau, grevista que estava no hospital da penitenciária, comunicando a decisão dos presos da capital de cessarem a greve de fome, "por razões impossíveis de ser explicadas por telefone”. Estava muito presente a possibilidade de ocorrer desistências e um dos grevistas sofrera uma grave crise psiquiátrica ${ }^{628}$.

Frei Betto conversou novamente com os companheiros. Pouco depois voltou a se comunicar com os presos de São Paulo: Paulo de Tarso reafirmou que era unânime a posição de que todos deveriam terminar imediatamente a greve para poder dar continuidade às negociações em favor da reunificação dos presos. Assim, depois de 33 dias, a greve de fome em Presidente Venceslau terminou com um forte sentimento de humilhação e derrota [PoLiTI, 2009: 92].

No dia seguinte, em 12 de julho, o procurador Durval Ayrton de Moura Araújo concedeu uma entrevista coletiva na qual explicou que as transferências dos presos visaram desmantelar uma "base de organização subversiva" dentro das dependências do presídio Tiradentes e que os grevistas pretendiam rearticular o terrorismo na prisão. O promotor afirmou que "os terroristas” eram “irrecuperáveis” e queriam com a greve “deformar a boa imagem do Brasil no exterior”. Essa entrevista foi publicada nos principais jornais do país e teve grande repercussão [BETTO, 2009: 227], prenunciando que a remoção dos presos políticos da penitenciária de Presidente Venceslau não ocorreria.

Logo após, em 15 de julho, chegou ao Brasil em missão de inquérito o advogado francês Georges Pinet, representando o Secretariado Internacional de Juristas Católicos e a Associação Internacional de Juristas Democráticos. A missão foi solicitada em face da greve de fome de presos políticos de São Paulo, que se prolongava havia muitos dias. Pinet se encontrou com personalidades como d. Paulo, o secretário-geral da CNBB, d. Ivo

\footnotetext{
${ }^{627}$ Entrevista concedida por Carlos Alberto Lobão Cunha à autora. Idem, AAPP/AEL-LEI.

${ }^{628}$ Entrevista concedida por Manoel Cyrillo de O. Netto à autora. Idem, AAPP/AEL-LEI.
} 
Lorscheider, um representante do comitê de assistência aos prisioneiros, com parentes de presos e desaparecidos políticos. Encontrou-se com o presidente do Tribunal Militar em São Paulo, após o adiamento de uma sessão. Tentou visitar os presos políticos, mas não obteve autorização para entrar em nenhum presídio. Ele visitou o Rio de Janeiro e ficou no Brasil até o dia 22 de julho.

Seu relatório foi incluído como um adendo ao "Relatório sobre as acusações de torturas no Brasil”, da Anistia Internacional, publicado em outubro de 1972, que teve grande repercussão. Pinet destacou que a greve de fome havia terminado em 12 de julho, decorridos 33 dias, sem que nenhuma segurança fosse dada aos presos de que suas reivindicações seriam cumpridas. Para ele era

“[...] significativo que 36 homens, tendo em vista sua situação de prisioneiros, tenham arriscado suas vidas e saúde a fim de protestar contra a transferência de seis pessoas [...]. tais transferências criam ansiedade e insegurança entre os prisioneiros [...]. A natureza arbitrária destas transferências [...] torna-se um instrumento de terror. A greve de fome de São Paulo tinha como objetivo e causa primária a proteção das vidas e saúde dos prisioneiros. Apesar da censura, o povo brasileiro compreendeu estas razões e comoveuse profundamente. A greve não foi um meio de agitação política nem uma ação controlada do exterior, mas tão somente um ato 'existencial' como tem sido muito enfatizado no Brasil’,629.

Na Europa, a Anistia Internacional investigava as violações de direitos humanos no Brasil desde 1969. Depois de tentar várias vezes obter autorização do governo brasileiro para conferir in loco as denúncias recebidas, em setembro de 1972 publicou, em Londres, o Report on Allegations of Torture in Brazil ${ }^{630}$. O extenso documento de 104 páginas relaciona 1.081 vítimas de tortura, mas relata as circunstâncias de tortura de alguns casos apenas, sem detalhar quais eram os casos de mortos e desaparecidos políticos. Informa também que as investigações haviam levantado 472 nomes de torturadores, cuja lista não seria divulgada até que o governo brasileiro apreciasse o relatório. Em resposta, os militares proibiram qualquer divulgação a respeito do

\footnotetext{
629 "Relatório sobre as acusações de torturas no Brasil”, da Anistia Internacional, de outubro de 1972. Asmob 03.15,2, Arquivo do CEDEM/UNESP, p.107-8.

${ }^{630}$ No prefácio do Relatório sobre as acusações de tortura no Brasil, assinado por Seam MacBride, presidente do Comitê Executivo da Anistia Internacional, informa-se que a investigação foi realizada entre maio e abril de 1972, e que trata de fatos ocorridos entre 13/12/68 e 15/07/72. É dito também que como o governo brasileiro "recusou repetidamente" a entrada de representantes de organizações internacionais para investigar as alegações de tortura, "o presente relatório foi compilado a partir de material disponível na Europa e na América do Norte. Um representante da Anistia Internacional estudou cuidadosamente os documentos disponíveis num esforço de selecionar apenas as elegações mais fundamentadas para inlcusão neste relatório". "Relatório sobre as acusações de torturas no Brasil”, "Prefácio”, p. 5.
} 
relatório $^{631}$. Durante as comemorações do Sesquicentenário da Independência, cujo símbolo foi Joaquim José da Silva Xavier, o Tiradentes, o slogan oficial utilizado era Tudo começou com Ele (Tiradentes ${ }^{632}$ ). Na ocasião, a Anistia Internacional reivindicou que os presos políticos fossem libertados ${ }^{633}$.

Em 24 de julho, possivelmente pressionados pela repercussão da greve de fome, ocorreu a sessão do STM que decidiu sobre a representação dos advogados de presos políticos de São Paulo, na qual Heleno Fragoso fez a sustentação oral, conforme lembrou Belisário dos Santos Jr.:

“[...] A Rosa Maria Cardoso da Cunha tinha feito o esboço da representação e, enquanto terminávamos o texto, ela falou uma frase maravilhosa e eu sugeri que ela se tornasse a epígrafe. Ela observou: ‘- Não posso me citar na epígrafe”. Então, nós a citamos como se fosse de autoria de um tal "Vega", que era a marca de uma lata de pêssego que vimos ali na hora. O Heleno Fragoso fez a sustentação oral da representação no STM, que, na época, era ainda no Rio de Janeiro. Ele a sustentou oralmente e cunhou uma expressão que correu pelo país depois: 'Em São Paulo, terrorista é a Justiça Militar!' Ele falou isso porque os juízes tinham feito algumas referências a nós advogados dizendo: 'Eles são advogados de terroristas', alguma coisa assim. O Heleno, então, falou essa frase genial: 'Em São Paulo, terrorista é a Justiça Militar! '634,’

O STM decidiu por uma moção de censura aos juízes de São Paulo recomendada pelo relator, o ministro Nelson Barbosa Sampaio ${ }^{635}$. Esta moção recomendava que “[...] fossem observadas as normas de mútuo respeito entre juízes e advogados em São Paulo, tal como estabelecido nos estatutos da Ordem dos Advogados do Brasil”, conforme publicado no Jornal do Brasil do dia 26 de julho [PoLITI, 2009: 26]. O clima, contudo, era de muito medo. Foi preciso esperar alguns meses e a apreciação do STM para que a OAB (SP) realizasse uma sessão pública de desagravo aos advogados presos. Em 22 de agosto de 1972 ocorreu na OAB (SP) a sessão de desagravo, quando compareceram muitas pessoas e foram registrados veementes protestos contra as prisões dos advogados, ocasião em que se reafirmaram suas denúncias sobre as péssimas condições carcerárias

\footnotetext{
${ }^{631}$ BiocCA, Ettore. Estratégia do Terror. A face oculta e repressiva do Brasil. Lisboa/Portugal, Iniciativas Editoriais, 1974, p.9; e "Relatório de Alegações de Torturas no Brasil”, Anistia Internacional, set./1972.

${ }^{632}$ A presa política Marlene Soccas, em sua carta denúncia enviada ao juiz auditor em março de 1972 e amplamente divulgada no exterior, fez menção à ironia vivida pelos prisioneiros por estarem confinados em um presídio com o nome de Tiradentes, um dos mártires da independência do Brasil. "Relatório de Alegações de Torturas no Brasil”, idem, ibidem.

${ }^{633}$ Idem, idem. E VALLI, Virgínia. op.cit., p.87, 91, 93 e 100. O hino do Sesquicentenário chamava-se A festa de Amor e Paz.

${ }_{634}^{63}$ Entrevista concedida por Belisário dos Santos Jr. à autora. Idem, ibidem.

${ }^{635}$ Idem, ibidem.
} 
dos presos políticos e as arbitrariedades da Justiça Militar ${ }^{636}$. De acordo com Belisário dos Santos Jr., “A Ordem não quis nos desagravar imediatamente, só o fez depois que o STM censurou os juízes”637.

Em julho de 1972 foi editado pela Ação Popular Marxista-Leninista, o Livro negro da ditadura militar, um levantamento sobre as violações de direitos humanos cometidas pela ditadura. Ao final, o livro apresenta no capítulo "Assassinos e Torturadores” uma pequena listagem de nomes de torturadores, agentes policiais e militares dos órgãos de segurança, e seus locais de atuação ${ }^{638}$. Tratava-se de uma publicação clandestina e que, ao que tudo indica, teve circulação muito restrita no Brasil. É possível supor, que, talvez, o livro tenha conseguido uma circulação melhor no exterior $^{639}$.

A greve de fome não foi vitoriosa, não conseguiu a reunificação dos presos políticos, mas resultou na conquista de melhores condições carcerárias para os que ficaram na Casa de Detenção. Com a realização do movimento se ampliou e se fortaleceu a rede organizada em apoio aos presos políticos, no Brasil e no exterior. O setor progressista da Igreja Católica forneceu o apoio político decisivo aos presos e importante suporte às suas famílias. Pouco depois, em agosto de 1972, D. Paulo E. Arns articulou as primeiras reuniões da Comissão Justiça e Paz de São Paulo (CJP/SP), “um organismo de reação legal e legítima ao terrorismo do regime" ${ }^{640}$, no qual participavam advogados, operários, estudantes, sociólogos, jornalistas e intelectuais, e se transformou em importante instrumento de solidariedade aos perseguidos e prisioneiros políticos. A sociedade civil se reorganizava em novos termos e condições.

\subsection{Novo período de adaptação: o convívio na Casa de Detenção}

Os presos políticos de São Paulo permaneceram separados e espalhados entre vários estabelecimentos, sob diferentes regimes carcerários, após a greve de fome de

\footnotetext{
${ }^{636}$ VIEIRA, César. op.cit., p.299; e entrevista concedida por Airton José Esteves Soares à autora. SP, $10 / 02 / 2011$.

${ }^{637}$ Entrevista concedida por Belisário dos Santos Jr. à autora. Idem, ibidem.

${ }^{638}$ AP-ML. Livro negro da ditadura militar. Editora Libertação, 1972, p.179-85.

${ }^{639}$ V. MAUÉS, Flamarion. "Os livros de denúncia da tortura após o golpe de 1964”. Cadernos Cedem, Vol. 2, $\mathrm{n}^{\mathrm{o}} 1,2011$.

${ }^{640}$ V. Benevides, Maria Victória de M. Fé na Luta: Comissão Justiça e Paz de São Paulo da ditadura à democratização. São Paulo, Lettera, 2009, p.45-52.
} 
1972. Nesse período, o número de presos políticos se reduz consideravelmente. Diante desta nova conjuntura era necessário aprender a lidar com a situação e reorganizar a convivência. Durante a organização do movimento que resultou na greve de fome, ampliaram-se e se fortaleceram o apoio e a solidariedade aos presos políticos, mas também se acentuaram as diferenças de perspectiva sobre como resistir e combater a ditadura. Enfraqueceram-se a capacidade comum de resistir, manter as normas de convivência e de enfrentar as tarefas da sobrevivência na prisão. O desgaste da relação entre os presos chegou ao limite e eles passaram a se organizar em dois coletivos distintos na Casa de Detenção, conforme relato de Vicente Roig:

“[...] Naquele momento, então, [...] formaram-se dois blocos bem distintos. Um era formado pela ALN, MRT, Rede, basicamente a ALN e as organizações pequenas que gravitavam em torno dela. De outro lado estava a Ala, o PCBR, os avulsos, e o que ainda tinha de VAR [Palmares]. E aí o negócio 'racha'.

[...] Depois da greve [...] amigos de toda a vida não conversavam mais comigo [...].

[...] Tínhamos [...] tudo em separado. [...] Aí ficamos nós dois, eu e o Espinosa, em um convívio muito intenso. [...] eles jogavam futebol, faziam artesanato, cantavam e eu e o Espinosa ficávamos de fora, sem participar de nada. Recebíamos a visita juntos, eles falavam com os nossos familiares, mas não com a gente. E ficou assim, até o fim. Tudo era separado. Depois, quando juntou todo mundo na Detenção, ficou mais ou menos meio a meio, aí nós tinhamos uma sala de artesanato, eles tinham outra, tudo separado ${ }^{641}$."

As perpepções e memórias sobre como os presos reorganizaram o convívio e o

novo coletivo depois da greve de fome ficaram registradas de maneiras distintas pelos entrevistados nesta pesquisa, conforme se depreende do relato de Pedro Rocha:

"Na verdade, havia um coletivo e um pessoal que não queria participar dele. Eu acho que esse pessoal que não participava preferia não se estruturar. No Carandiru, quando eu cheguei [depois da greve], estava desse jeito. Eram poucos os que estavam fora do coletivo, porque a maioria do pessoal divergente, a turma contra a greve de fome, ainda estava no Tiradentes.

[...] Se discutia muito no coletivo qual tipo de relacionamento se deveria ter com o pessoal que estava fora, que não participou da greve. [...] Bom, encontrei uma situação dada. No começo havia propostas diversas: umas a favor do isolamento, outras achavam que não, que não deveria ter isso; uns achavam que deveríamos conversar, outros achavam que não, deveriamos manter apenas uma relação formal de um representante de lá com o representante do coletivo. A posição que acabou predominando no Carandiru foi a de manter a atividade de coletivo, com discussões, deliberações e tudo, e ter um relacionamento amigável com o pessoal que estava fora do coletivo.

[...] não vou me lembrar, mas havia um ou outro no Carandiru com posição um pouco mais radicalizada em relação a eles, de não conversar, de mantê-los em isolamento. Eu não me lembro quem eram essas pessoas, mas isso era fruto do comportamento durante a greve, [...]. Eu particularmente [...] sempre defendi no coletivo que deveríamos ter um relacionamento normal com o pessoal, mesmo não participando do coletivo. Eu só fui ficar um pouquinho mais irritado contra esse pessoal quando tive de fazer uma greve de

${ }^{641}$ Entrevista concedida por Vicente Roig à autora. Idem, ibidem. 
fome e eles não quiseram fazer novamente. Aí deu pra perceber melhor como era essa questão... Isso foi na penitenciária $[. . .]^{642}$.”

Os distintos coletivos de presos conseguiram se reestruturar e passaram a produzir sistematizações de denúncias e textos teóricos. O coletivo da ALN após longo processo que implicou duras e difíceis conversas conseguiu terminar seu balanço das prisões e mortes de seus militantes. A partir desse processo, produziram um texto interno chamado “Quedograma” que buscou registrar as circunstâncias das prisões e mortes de seus companheiros, conforme relato de Manoel Cyrillo:

“[...] Na Detenção, a gente acabou vivendo este processo de crítica e autocrítica e nos estruturamos. Aí a gente criou o que passamos a chamar de '60', que era a soma da 10, da 20 e da 30, a direção da ALN na cadeia.

[...] Eu era um dos caras da '60’ [...]. Depois, começaram a acontecer transferências e [...] muita gente foi saindo da cadeia com o passar dos anos [...] e, a partir de uma certa data, não chegou mais ninguém da ALN [...] porque todos eram assassinados. Nosso grupo vai minguando em número e a gente nunca mais voltou a reorganizar a '60'. [...] A gente sabia e organizou [...] as informações do processo de quedas que levaram à morte do Marighella [...]. O Paulo de Tarso Venceslau assumiu as responsabilidades dele. [...] As pessoas que divergiam quanto a essa questão estavam afastadas ou mortas. Os frades dominicanos estavam em Presidente Venceslau, o Carlos P. Fleury já havia morrido. [...] E a partir daí [...] a gente fez o 'quedograma' (mas há uma versão que circula por aí que eu não reconheço). [...] Nós explicamos, contamos e relatamos o nosso processo de quedas e das pessoas que ‘caíram’ em função do nosso comportamento. [...] E mandamos para a organização. [...] Tudo se esclarece, a gente supera isso e estrutura [...] uma direção na cadeia" ${ }^{\prime 643}$.

Nesse período, os militantes da ALN presos consolidaram sua reestruturação interna na prisão e também a sua relação com os militantes remanscentes do Molipo. De acordo com Pedro Rocha,

“[...] nós éramos poucos na cadeia, 4 pessoas apenas. E como o Molipo levou um golpe muito forte, a nossa tendência era não ter mais vínculo com nada, não tinha mais direção e nem política. Alguns se aproximaram de outras posições, e algumas aproximações foram fortes, e outros não. [...] Quando nós chegamos na prisão, o pessoal da ALN tinha uma posição a respeito do racha que gerou o Molipo. Eles tinham amigos e pessoas que eles respeitavam tanto na ALN quanto no Molipo. Então, eles optaram por não se posicionar a respeito do racha, não tomar partido. Pelo menos essa foi a posição majoritária, oficial, do coletivo de presos da ALN. Eles achavam que a gente tinha que esquecer a briga de fora e na cadeia se estruturar enquanto um grupo só. E nós acabamos fazendo isso, os poucos do Molipo e mais um pessoal da ALN constituímos uma coisa que a gente chamava de 'Eixo', na época. Conversávamos, discutíamos juntos como se fosse uma única organização. Isso durou bastante tempo, enquanto o Molipo ainda era alguma coisa que podia continuar fazendo política na 'rua'. Num determinado momento se acabou com o 'Eixo', porque não tinha mais razão de existir dentro da cadeia o que não existia na 'rua'.

\footnotetext{
${ }^{642}$ Entrevista concedida por Pedro Rocha Filho à autora. SP, 05/03/2010. AAPP/AEL-LEI.

${ }^{643}$ Entrevista concedida por Manoel Cyrillo de Oliveira Neto à autora. SP, 20/03/2011.
} 
[...] Eu não sei te dizer quando, mas isso foi no Romão Gomes [...]. Por algum tempo, no Romão Gomes a gente ainda permaneceu estruturado dessa forma, mas eu não sei te dizer quanto tempo durou o 'eixo, 644 ."

Pedro Rocha se recorda que o debate político e teórico era intenso na prisão, mas o balanço autocrítico em relação à atuação das organizações revolucionárias nem sempre era bem aceito:

“[...] Na cadeia, por exemplo, achei bom o texto de autocrítica da Tendência Leninista, mas ficaram putos comigo. Eu gostei da proposta de fazer um recuo para realizar um trabalho de massas e, somente depois, retomar o projeto de luta armada. Algo parecido com o que eu pensava e me preocupava quando entrei no Molipo. Essa posição, porém, não era bem aceita na cadeia. [...] Eu estava aberto a qualquer proposta de recuo, embora o Molipo não tivesse a intenção de interromper seu projeto de luta armada imediata. Era possível pensar, no entanto, que a preparação da guerrilha rural representaria, naquelas circunstâncias, um recuo tático. [...] Acho que a ALN admitia a proposta de recuo tático, mas de qualquer forma este era um tema difícil.

[...] Acho que esse debate era dificultado, também, porque, para o pessoal da ALN, o peso dos mortos era maior. Os militantes mortos do Molipo eram jovens e brilhantes companheiros, mas representavam um peso simbólico menor do que o de Marighella e Câmara Ferreira ${ }^{645 ”}$.

A realização do balanço e a consequente reestruturação do coletivo da

ALN/Molipo se mostrou fundamental para que seus militantes conseguissem prosseguir e se adaptar ao novo presídio e à perspectiva de permanecer longos anos na prisão. Neste momento, eles retomaram a redação e o levantamento das denúncias de tortura e de casos de mortos e desaparecidos políticos, a partir da troca de informações com outros prisioneiros e de notícias publicadas na imprensa, que resultaram na formação de dossiês detalhados sobre cada caso e em vários documentos de denúncia, escritos em conjunto com outros presos, militantes do PCdoB e outros agrupamentos. A atividade de organizar arquivos foi descrita por Manoel Cyrillo:

“[...] Nós fizemos o primeiro levantamento dos mortos e desaparecidos, ainda com o pessoal da cela sete, e [...] a gente o manteve atualizado durante todo o longo período [...] de cadeia. [...] Centenas de pessoas de várias partes do país terminaram entrando nesse processo [...]. A gente anotava e mantinha escrito, havia uma organização de cela fantástica [...]. Tinha um companheiro escalado para fazer a leitura coletiva dos jornais, então, a gente instalou um beliche [...] onde todos podiam ficar próximos e ouvindo [...]. Lia-se sobre todos os assuntos [...] e também sobre alguma denúncia de morte [...], um incidente qualquer. [...] Tínhamos companheiros, [...] responsáveis por 'clipar’ os jornais sobre vários assuntos: política nacional, questão agrária, política internacional, América Latina etc. Ele era responsável por recortar, fazer as anotações [...] sobre qual era a página, a data e isso tudo era arquivado. Tinha outro responsável por cada pasta. A gente

\footnotetext{
${ }^{644}$ Entrevista concedida por Pedro Rocha Filho à autora. Idem, AAPP/AEL-LEI.

${ }^{645}$ Entrevista concedida por Pedro Rocha Filho à autora. SP, 24/02/2011.
} 
fez isso ao longo de dez anos de cadeia, é um tesouro [...]. Organizar as informações sobre os mortos e desaparecidos fazia parte dessa preocupação em ter os registros e arquivá-los [...], para denunciar, para fazer os nossos documentos, e fizemos vários documentos na prisão [...], cuja base de dados veio desses arquivos [... $]^{646}$."

O primeiro desses textos de denúncia foi elaborado para ser divulgado na XIII Assembleia Geral dos Bispos do Brasil, que ocorreu em fevereiro de 1973, onde a temática referente à Declaração Universal dos Direitos da Pessoa Humana foi debatida. Procurando dar continuidade aos contatos feitos com a Igreja Católica durante a greve de fome, os presos aproveitaram a atmosfera gerada pela grande divulgação do caso da condenação (em sessão secreta) dos militares acusados de torturar e matar quatro soldados que serviam no $2^{\circ}$. BIB, em Barra Mansa (RJ), durante o mês de janeiro. Na ocasião, o governo divulgou que as Forças Armadas não toleravam a prática de tais crimes e que, por isso, aplicavam punição exemplar aos responsáveis.

Um simpatizante da ALN, frei Giorgio Callegari ${ }^{647}$, ex-preso político detido no presídio Tiradentes entre 1969 e 1970, foi o principal responsável pela difusão do documento intulado “Aos bispos do Brasil” no evento. Em 1971, ele havia criado o Centro Pastoral Vergueiro, com o objetivo de resgatar as memórias das lutas populares, onde se constituiu também um núcleo de educação popular reunindo padres, seminaristas, estudantes, militantes de esquerda que buscava empreender a resistência à ditadura ligando-se às bases dos movimentos sociais ${ }^{648}$.

O texto descreve os assassinatos e desaparecimentos de 28 perseguidos políticos de diversos partidos e agrupamentos, cujos casos eram mais bem documentados. Lista outros 21 casos, dos quais havia menos informações e denuncia o uso recorrente da versão de "morte em tiroteio" para ocultar mortes sob tortura. Lista os nomes de outros 15 perseguidos políticos que teriam morrido nessa circunstância. O texto indica o nome de 30 militantes que teriam sido vítimas de execução sumária, em diversos estados, e descreve os principais tipos de tortura conhecidos no país. Os presos pediam apoio para obter a apuração dos fatos relacionados, considerando que haviam transmitido apenas uma "[...] pálida ideia dos sofrimentos infligidos a milhares de resistentes brasileiros". “[...] Conscientes da imensa força moral que a Igreja representa[va]” apelavam para que

\footnotetext{
${ }^{646}$ Entrevista concedida por Manoel Cyrillo de O. Neto à autora. Idem, AAPP/AEL-LEI.

${ }^{647}$ Entrevista concedida por Reinaldo Morano Filho à autora. SP, 14/03/2011.

${ }^{648}$ SADER, Eder. Quando novos personagens entraram em cena. Esperiências e lutas dos trabalhadores da grande São Paulo (1970-1980). 2a. Ed., São Paulo, Paz e Terra, 1988, p.148.
} 
ocorresse a "eliminação da prática de torturas nas prisões do Brasil e a punição dos responsáveis pela sua prática sistemática”649.

Pouco depois, uma série de prisões de militantes da ALN e de estudantes da USP impulsiona a organização de protestos expressivos na universidade, pois um deles, Alexandre Vannucchi Leme, acabou assassinado sob tortura em 17 de março de 1973, no DOI-Codi/SP. Vannucchi Leme era representante dos estudantes na Congregação do Instituto de Geociências. Os centros acadêmicos espalharam a notícia rapidamente. Da reunião do Conselho de Centros Acadêmicos (CCA), as lideranças partiram para as suas respectivas escolas, onde novas reuniões foram organizadas para discutir a situação. O Conselho encampou as propostas da assembleia da Geologia e declarou a universidade em luto ${ }^{650}$.

As divergências políticas se neutralizaram ante este fato catalisador que exigia uma resposta conjunta. Várias assembleias ocorreram com a participação de até 500 pessoas. Na noite do dia 28, uma assembleia no prédio da Faculdade de História e Geografia exigiu da reitoria da USP a apuração dos fatos junto aos órgãos de segurança e ao governador. Pressionado, o reitor Miguel Reale criou a comissão de investigação e enviou o ofício às autoridades pedindo esclarecimentos sobre o caso. Os estudantes articularam uma missa celebrada por D. Paulo E. Arns no dia 30, na Catedral da Sé, quando nova série de prisões ocorreu, enquanto os estudantes saíam da USP para a missa. Não obstante, a celebração contou com a participação de cerca de 3 mil pessoas [Idem, ibidem].

Em seguida, no dia 6 de abril, Ronaldo Mouth Queiroz, responsável pelo trabalho da "frente de massas" da ALN em São Paulo, foi fuzilado enquanto esperava um ônibus na avenida Angélica. Também estudante de geologia da USP, ele havia sido presidente do DCE na gestão 1970-1971, mas naquele momento atuava na clandestinidade. Os estudantes que organizaram a mobilização em protesto contra a morte de Vannucchi, cuja composição incluía militantes da $\mathrm{ALN}$, do $\mathrm{PCB}^{651}$ e trotskistas, decidiram que não havia condições para divulgar uma denúncia, por falta de informações e de segurança. Em

\footnotetext{
${ }^{649}$ Comitê de Solidariedade aos Presos Políticos do Brasil. “Aos bispos do Brasil”, fev./73. Arquivo do Estado de São Paulo, Série Dossiês - DEOPS/SP, 30-Z-160-12711-12687. Documento encontrado no “aparelho" de Ronaldo Mouth Queiroz, quando foi assassinato em 06/04/73; Dossiê Ditadura, op.cit., p.433-5.

${ }^{650}$ CosTA, Caio Túlio. Cale-se. A saga de Vannucchi Leme. A USP como aldeia gaulesa. O show proibido de Gilberto Gil. São Paulo, Girafa, 2003, p.75-85; Dossiê Ditadura, op.cit., p.427-31.

${ }^{651}$ Entrevista concedida por Sérgio Gomes à autora. Idem, Idem.
} 
maio, contudo, ocorreram novas prisões de militantes da ALN e estudantes da USP [CosTA, 2003: 150].

No dia 9 de maio, um comunicado do Centro Acadêmico das Ciências Sociais divulgou 36 nomes dos presos no DOI-CODI/SP. A lista excluía, no entando, o nome de Queiroz, e de alguns outros que haviam sido presos na véspera, sobre os quais ainda não se tinha conhecimento. No mínimo, foram presos 44 estudantes ao todo, sem contar os estudantes detidos no dia da missa de Vannucchi. A escola entrou em estado de greve e novas assembleias foram organizadas. Por fim, um show de Gilberto Gil foi organizado no anfiteatro da Escola Politécnica para divulgar as prisões e arrecadar dinheiro para ajudar os presos. O show foi censurado, mas ocorreu sem microfones [CosTA, 2003: 150]. As mobilizações foram se enfraquecendo, mas o movimento estudantil se reorganizava.

Na Casa de Detenção, os presos voltados para realizar um balanço teórico e autocrítico das práticas e projetos das organizações de luta armada encontraram melhores condições para produzir seus documentos. Nesta fase, a Ala Vermelha terminou de redigir o texto “Autocrítica 1967-1974”. A exemplo de outros agrupamentos, os militantes da Ala avaliaram que era necessário interromper as ações armadas e retornar ao trabalho político junto às bases dos movimentos sociais ${ }^{652}$. O texto de autocrítica rompe com a proposta de luta armada imediata e aprofunda o diálogo com os remanescentes do PCBR na prisão, iniciado durante o período de convívio no Tiradentes, conforme lembrou Vicente Roig:

"Não sei quanto tempo depois, chegou o pessoal da Ala e [...] como eram celas pequenas, nós ficavamos dois em cada cela. [...] A gente [...] fechou as discussões e este é o momento mais produtivo, mais profícuo em termos de escrever, porque ficavam dois e dois e a gente passou a ter condições de escrever e acabar o nosso documento. Eu perdi uma parte da discussão, peguei o começo e o fim, não participei do meio do processo, porque eu estava fora, em outros presídios, mas ainda peguei a fase do texto final e o mandamos para fora.

Discutíamos e redigíamos por pedaços. Você discute, fecha e tem um relator, alguém que vai fazer aquele trecho, depois volta com o texto, todos lêem e comentam [...]. Era tudo feito às escondidas em papel de seda. [...] Esse período da Casa de Detenção é bom, porque, como eles não eram acostumados com presos políticos, nos achavam ótimos, [...] pois ninguém mexia com drogas, facas, e isso, para eles, era uma maravilha. [...] As revistas eram menos rigorosas, nesse particular [os livros], e se conseguia fazer fundos falsos, em objetos que depois voltavam. [...] Era uma fase boa, estávamos sossegados,

\footnotetext{
652 SADER, Eder. op.cit., p.170-1; e GORENDER, Jacob. op.cit., p.229-31 , entre outros. Além da Tendência Leninista, em dezembro de 1972, o MR-8 realizou seu congresso no Chile que decidiu cessar as ações armadas, conforme mencionado. Neste momento, parte dos militantes da antiga DI-GB saiu do grupo.
} 
esperando a pena acabar. Eu fui julgado quando estava lá, em 1973. [...] Depois do julgamento, o pessoal da Ala foi transferido do Tiradentes para a Detenção.

[...] O documento de autocrítica, em síntese, dizia que todo o nosso processo foi isolado, a gente atuou sem contato com as massas, [...] com a classe operária. Estávamos absolutamente descolados, o que era uma obviedade. E o que se propunha era uma imersão no social, quer dizer, um revolucionário não pode ficar isolado, ele tem de ficar dentro do tecido social e ali desenvolver o seu trabalho, que é o que vai dar os frutos posteriormente. Era um avanço para aquele contexto. Não se questionava nenhum daqueles valores clássicos da esquerda. Nem a questão da luta armada, nem nada, tudo estava correto, para nós só estávamos equivocados com relação ao isolamento, o fato de ter saído isoladamente e ter se mantido isolado e cada vez mais isolados, o que era um prenuncio claro de fracasso. É um documento bastante longo onde se faz uma análise clássica, típica desses documentos: uma análise de classe da sociedade brasileira e as formas de luta que se propõe. Mantêm-se a questão da luta armada, mas é uma proposta de luta armada sempre vinculada a uma imersão no social, ao movimento da classe ${ }^{653}$."

Naquele período, uma profunda crise se abatia sobre as esquerdas em função dos golpes desfechados pela repressão estatal e pelo fato de que a derrota se produziu em enfrentamentos nos quais os setores populares tiveram pouca ou nenhuma participação. As ações armadas tinham sentido, naquele contexto anterior, porque serviriam para abrir espaço para a intervenção dos movimentos populares [SADER, 1988: 170-1]. Não tendo ocorrido esta passagem à partipação e com a derrota, os militantes, presos ou não, debatiam-se com essa crise de identidade.

Recuperando práticas políticas anteriores ao golpe de 1964, parte das esquerdas voltou-se para o trabalho de alfabetização popular ${ }^{654}$ e até de assistencialismo em busca de uma alternativa à derrota da proposta de confronto armado. O PCdoB, por exemplo, tentou conciliar este tipo de trabalho político juntamente com a fase de preparação da Guerrilha do Araguaia ${ }^{655}$, mas foi derrotado. Nesse período, atuava também na periferia de São Paulo e na Pastoral Operária, de onde incrementou sua participação na Oposição Sindical Metalúrgica.

Pequenos grupos de militantes de uma esquerda dispersa pela derrota e de partidos que sobreviveram à repressão iniciaram um trabalho político na periferia de São Paulo, junto às estruturas da Igreja Católica ou por meio de iniciativas autônomas [SADER, 1988: 167, 243]. Os militantes independentes, por exemplo, “[...] não negavam a necessidade teórica de um partido de vanguarda e de uma estratégia revolucionária, mas, como não os encontrassem no momento, deixavam a questão entre parênteses e atuavam sobre aquilo

\footnotetext{
${ }^{653}$ Entrevista concedida por Vicente Roig à autora. Idem, ibidem.

${ }^{654}$ V. as entrevistas concedidas por Criméia A. S. de Almeida e Gilney V. Amorim à autora, entre outras. Idem, ibidem.

${ }^{655}$ V. a entrevista concedida por Criméia A. S. de Almeida à autora. Idem, AAPP/AEL-LEI.
} 
que lhes aparecia, de qualquer modo, como condições indispensáveis para a continuidade da luta [SADER, 1988: 174]”.

Esta era uma fase em que atividades sindicais simples envolviam grandes cuidados de clandestinidade e a oposição sofreu nova derrota eleitoral no Sindicato dos Metalúrgicos de São Paulo [SADER, 1988: 236]. Em 1972, o PCB foi durante atingido por uma série de prisões no Rio de Janeiro e em outras cidades próximas que interromperam ou refrearam seu trabalho sindical na região ${ }^{656}$. Entre este ano e 1973, a direção do partido sofreu uma crise ${ }^{657}$ em decorrência da ação repressiva.

O período entre os anos de 1973 até 1975 se constituiu num momento decisivo para a oposição sindical metalúrgica em São Paulo. Dispersados pela repressão, os militantes passaram a atuar em mobilizações locais que constituíram as bases da retomada do movimento em 1976. Grupos de esquerda como a Ação Popular (AP), os trotskistas (Partido Operário Revolucionário e Organização Comunista $1^{\circ}$ de Maio), a Polop (Política Operária), dissidentes do PCB e militantes do PC do B valorizaram a mobilização operária autônoma nas fábricas como parte de sua estratégia revolucionária e visando constituir uma base social que sustentasse a luta contra a ditadura [SADER, 1988: 234].

Esse trabalho se somava ao realizado nas periferias junto aos Clubes de Mães e Comunidades de Base, envolvendo reivindicações ligadas a transportes, escolas etc. e que originaram o Movimento do Custo de Vida e o Movimento por Creches [SADER, 1988: 236-7]. Alguns agrupamentos se voltaram para esse trabalho sem realizar, contudo, uma avaliação ou autocrítica profunda de sua atuação na luta armada, como o PCdoB, por exemplo, que vivia os estertores da Guerrilha do Araguaia. Independentemente dos rumos tomados por esse movimento de autocrítica ou “[...] da delimitação dos campos de alianças políticas definidas por cada organização, houve um claro movimento no sentido de ligar-se às formas elementares de reaglutinação do movimento operário e, em menor medida, da organização popular nos bairros” [SADER, 1988: 171].

\footnotetext{
${ }^{656}$ Entrevistas concedidas por Frederico Pessoa da Silva e José Raimundo da Silva à autora. SP, 26, 27 e 28/08/2008 e RJ, 24/03/2010. O militante do PCB Célio Guedes, irmão do dirigente Armênio Guedes, foi morto sob tortura na sede do Cenimar no Rio de Janeiro, em 15/08/72, após ser preso enquanto auxiliava outro militante a entrar clandestinamente no país através da fronteira com o Uruguai. V. Dossiê Ditadura, op.cit., p.363.

${ }^{657}$ KUCINSKI, Bernardo. Jornalistas e Revolucionários. op.cit.
} 


\subsection{Os julgamentos por motivos políticos na Justiça Militar}

Os julgamentos de dissidentes políticos na Justiça Militar ${ }^{658}$ cumpriram um papel central na estratégia de legitimação da ditadura perante a opinião pública nacional e internacional. Caracterizada por arbitrariedades e manipulações jurídicas, a Justiça Militar representou um importante instrumento de desmobilização dos movimentos sociais e daqueles que se opuseram ao regime, e de difusão da "cultura do medo"659. Mas, apesar das limitadas possibilidades, os tribunais militares foram um espaço da luta de resistência, onde se destacaram a coragem e a atuação dos advogados de defesa, assim como dos prisioneiros políticos. Os advogados e as redes de solidariedade aos presos estiveram entre os principais agentes que impulsionaram a luta em defesa dos direitos humanos e a construção de um discurso e uma consciência pública voltadas ao tema. Gradualmente, durante os anos 1970, os esforços de presos políticos, familiares e advogados sensibilizaram e mobilizaram a sociedade, contribuindo decisivamente para o desgaste da ditadura.

Os advogados foram, em diversas ocasiões, responsáveis pela divulgação das denúncias das torturas sofridas pelos prisioneiros políticos. Frequentemente, permitiram que informações cruciais entrassem e saíssem dos presídios, o que foi fundamental para a divulgação das torturas e das péssimas condições carcerárias às famílias das vítimas e às entidades de defesa dos direitos humanos, as quais igualmente encontraram nestes advogados um veículo para a transmissão de notícias e mensagens de apoio.

Estes advogados possibilitaram ainda que denúncias escritas e assinadas contra as torturas, assassinatos e desaparecimentos políticos saíssem dos presídios anonimamente, as quais, em muitos casos, foram publicadas em jornais (onde alguns jornalistas contribuíram com as esquerdas revolucionárias através da divulgação de prisões e de datas de audiências de processos contra presos políticos nas Auditorias Militares).

Os advogados de defesa desempenharam um papel fundamental, mitigando os sofrimentos dos presos, acolhendo-os em momentos de grande desamparo, o que adquiriu relevo especial diante da terrível violência que se abatia sobre os perseguidos políticos. Os advogados empenharam-se não somente em ajudá-los, mas também em proteger os parentes dos presos das perseguições e ameaças, das revistas rigorosas e vexaminosas,

\footnotetext{
${ }^{658}$ Com a edição do AI-2, em 27/10/65, a Justiça Militar passou a ter competência exclusiva para julgar os crimes contra o Estado e contra a ordem política e social. V. BNM, op.cit., p.170.

${ }^{659}$ PereirA, Anthony W. op.cit.; e Alves, Maria Helena M. op.cit.
} 
que ocorriam durante as visitas aos presídios. Eles apoiaram as famílias mais necessitadas e as que viviam em cidades distantes. Muitas vezes, erigiram-se ao papel simbólico de familiares dos presos políticos, amparando-os emocional e materialmente ${ }^{660}$. Nas palavras de Idibal Pivetta, “o advogado de defesa era o padre, o confessor, o amigo e o advogado" dos acusados. Essa “[...] era uma forma de advocacia altamente perigosa... mas era nossa maneira de trabalhar para tentar estabelecer a lei” [PEREIRA, 2010: 215].

Não obstante, é de se ter em vista que não foram muitos os advogados que assumiram a tarefa de defender prisioneiros políticos no Brasil. Esta tarefa exigia muita coragem, independência e capacidade de luta para lidar com a restrição dos meios disponíveis, o que muitas vezes levou à frustração e ao sentimento de impotência diante da rigidez das leis de exceção do período - não havia instrumentos processuais que permitissem reclamar a observância dos direitos dos presos. Muitos destes advogados inspiraram-se no exemplo de Heráclito Sobral Pinto, que advogara em favor de Luis Carlos Prestes durante a ditadura do Estado Novo ${ }^{661}$ e que também defendera outras dezenas de perseguidos políticos, após o golpe de 1964.

No Rio de Janeiro, havia um pequeno grupo de advogados de presos políticos atuantes, entre os quais estavam os criminalistas mais velhos e experientes do país. Lino Machado chamava esse grupo de “escrete”. Heleno Fragoso cita os nomes de Augusto Sussekind de Moraes Rego, Evaristo de Moraes Filho, Modesto da Silveira, Oswaldo Mendonça, George Tavares, Marcelo Cerqueira, Lino Machado e Nilo Batista. Entre os mais jovens, Nélio Machado, Técio Lins e Silva, Eny Raimundo Moreira e Rosa Maria Cardoso da Cunha [Fragoso, 1984:147]. Poderíamos citar ainda, Werneck Vianna, Ana Müller, Abigail Paranhos, entre outros ${ }^{662}$.

Já em São Paulo, a maioria dos advogados que atuaram na defesa de perseguidos político era jovem, à exceção do criminalista Aldo Lins e Silva, do diretor de teatro Idibal Pivetta, de Mário Passos Simas, Hélio Navarro e de Tales Castelo Branco. José Carlos Dias também atuou como advogado de presos políticos mas, apesar de jovem, diferenciava-se do perfil da maioria, uma vez que já se fazia bastante reconhecido nos meios jurídicos. Além desses, foram muito atuantes os advogados Airton Soares, Paulo Gerab, Belisário dos Santos Júnior, Antonio Mercado Neto, Maria Regina Pasquale,

\footnotetext{
${ }^{660}$ SANTOS JR., Belisário dos. “O advogado, o bêbado e a equilibrista (um tempo necessitado de anistia)”. In: Anistia 20 anos. Revista Cultural, ano I, no.5, set./99, p.9.

${ }^{661}$ FrAGoso, Heleno Cláudio. Advocacia da liberdade: a defesa nos processos políticos. Rio de Janeiro, Forense, 1984, p.146-7.

${ }^{662}$ Entrevista concedida por Ana Müller à autora. RJ, 06/04/2004.
} 
Virgílio Egydio Lopes Enei, Rosa Maria Cardoso da Cunha, Iberê Bandeira de Melo, Maria Luiza da Cunha Flores Bierrenbach, Luis Eduardo Greenhalgh, Annina Alcantara de Carvalho, Miguel Aldrovando Ait, entre outros.

No Nordeste também havia alguns advogados que auxiliaram como puderam os presos políticos de Salvador, Recife e Fortaleza, como Augusto de Paula, José Borba Pedreira Lapa, Jaime Guimarães, Inácio Gomes, Ronilda Noblat ${ }^{663}$.

As denúncias dos crimes supostamente cometidos contra a Segurança Nacional na Justiça Militar eram, em geral, vagas e mal formuladas. Na maioria das vezes, era evidente a imprecisão das definições, o que permitia o alargamento excessivo da tipificação desses crimes e a violação dos direitos fundamentais. Pretendia-se com isso, fundamentalmente, punir a divergência política. Em 1971, quando consolidou-se o sistema DOI-Codi, a legalidade de exceção era um sistema inchado, onde sobrepunhamse 160 atos legislativos distintos, entre atos institucionais, Constituição Federal, leis complementares aos atos institucionais, decretos-leis e leis complementares e ordinárias [Pereira, 2010:125]. Os advogados de defesa tinham que lidar com todo este arsenal da legalidade de exceção na Justiça Militar, que sistematicamente desrespeitava os direitos dos prisioneiros políticos ${ }^{664}$.

Nos processos por crimes políticos na Justiça Militar, a acusação mais comum dirigida contra os 7.367 denunciados referia-se ao crime de militância em organizações partidárias clandestinas, no qual foram enquadradas 4.935 pessoas (66,9\%), em especial, a partir de $1969^{665}$. Neste período, aumentou significativamente a quantidade de acusações de participação em ação violenta ou armada, quando 1.464 réus (19,9\%) foram enquadrados neste tipo de crime ${ }^{666}$. Havia, contudo, vários casos de pessoas acusadas, cumulativamente, em mais de um crime.

Do total de denunciados, 3.555 pessoas (48\%) foram absolvidas em primeira instância, sendo que, em diversos casos, isso ocorreu apenas depois de passarem meses

\footnotetext{
${ }^{663}$ Entrevista concedida por Airton Soares à autora. SP, 29/02/11; JosÉ, Emiliano. op.cit.; Depoimento de Theodomiro Romeiro dos Santos no site da Fundação Perseu Abramo, em http://www2.fpa.org.br/o-quefazemos/memoria-e-historia/exposicoes-virtuais/theodomiro-romeiro-dos-santos

${ }^{664}$ V. BNM, op.cit.

${ }^{665}$ Perfil dos atingidos, op.cit., p.12. Cabe destacar que os dados totalizados pelo BNM incluem nomes repetidos (de pessoas que foram indiciadas em mais de um processo). M. Ridenti reprocessou esses dados, com o auxílio de uma equipe da Universidade Estadual de Londrina, com o objetivo de identificar os nomes repetidos, de modo a extrair a informação de quantos indivíduos de fato foram indiciados na Justiça Militar. O que resultou na redução de $15 \%$ a $20 \%$ do universo relacionado à luta armada urbana com o qual ele trabalhou.

${ }^{666}$ V. entrevista concedida por Belisário dos Santos Jr. à autora. Idem, ibidem; e Perfil dos atingidos, op.cit., p.12.
} 
confinados cumprindo determinação de prisão preventiva. Há dados seguros nos autos de que 5.104 réus $(69,2 \%)$ foram formalmente presos. Entre os denunciados, menos da metade, ou seja, 2.828 réus (38,3\%) foram condenados, sendo que destes, 1.948 (26,4\%) foram punidos com penas de até 5 anos de reclusão ${ }^{667}$. Em alguns casos, os recursos dos advogados foram considerados pelo Superior Tribunal Militar (STM) ou pelo Supremo Tribunal Federal (STF), a instância de recurso da justiça civil ${ }^{668}$.

Os militares brasileiros não retiraram por completo os julgamentos de presos políticos da alçada do Judiciário civil. As Auditorias da Justiça Militar eram compostas de cinco juízes, sendo quatro oficiais militares e um juiz togado, um civil formado em Direito. Havia um promotor do Ministério Público Militar e um advogado de defesa indicado pelo tribunal, o advogado dativo. Era possível recorrer das sentenças no STF, após a apreciação dos recursos por parte do STM, mas ambos eram bastante controlados $^{669}$. Cabe destacar que, no Brasil, as lideranças da ditadura não optaram por uma estratégia repressiva inteiramente extrajudicial, como a que os militares argentinos adotaram contra a maioria dos perseguidos políticos, após o golpe de março de $1976{ }^{670}$.

Os processos por motivos políticos na Justiça Militar foram um importante instrumento de repressão contra dissidentes políticos e de difusão do medo, mas também de legitimação da ditadura. A condução da repressão judicial mesclava a busca de institucionalização do regime com a aplicação seletiva do poder coercitivo sobre a sociedade civil [ALVES, 1984:186], a exemplo do que ocorreu no âmbito da repressão extrajudicial, norteada pela condução seletiva de assassinatos e desaparecimentos forçados de perseguidos políticos [TELES, 2005].

O perfil dos acusados mencionados no primeiro capítulo e a quantidade relativamente pequena de condenações ${ }^{671}$ sugerem que "os processos contra perseguidos políticos foram uma iniciativa ampla que visava intimidar e silenciar um grande número

\footnotetext{
${ }^{667}$ Perfil dos atingidos, op.cit., p.11-2, e WESCHLER, op.cit., p. 23, 51.

${ }^{668}$ V. entrevista concedida por Rosa Cardoso da Cunha à autora. RJ, 25/02/11; Entrevistas concedidas por Airton Soares, Idibal Pivetta e Belisário dos Santos Jr. à autora. Idem, ibidem.

${ }^{669}$ O STM era composto de 15 ministros vitalícios indicados pelo presidente da República, com a prévia aprovação do Senado Federal. Era integrado por 3 generais da ativa da Marinha, 3 da Aeronáutica, 4 do Exército e 5 juízes civis. Destes, 2 vinham do quadro de juízes auditores ou do Ministério Público (promotores) das Auditorias Militares e 3 avulsos, indicados pelo presidente da República. O STF era composto por 11 ministros civis vitalícios. V. BNM, op.cit., p.171-2. Em 19/01/69, foram cassados dois senadores, 35 deputados federais, três ministros do STF - Hermes Lima, Vítor Nunes Leal e Evandro Lins e Silva - e um ministro do STM - Peri Constant Bevilacqua. V. http://www1.folha.uol.com.br/folha/treinamento/hotsites/ai5/ai5/index.html.

${ }_{670}$ Na ditadura chilena, após o golpe de 1973, os julgamentos de perseguidos políticos ficaram totalmente sob controle dos militares. PEREIRA, Anthony W. Ditadura e repressão, op.cit., p.123.

${ }^{671}$ V. tb. O perfil dos atingidos, op.cit.
} 
de pessoas” [PEREIRA, 2010: 128-9]. Os índices relativamente altos de absolvição na $1^{\text {a }}$. instância da Justiça Militar mencionados acima sugerem que o objetivo dos tribunais de exceção não era condenar o maior número possível de dissidentes, mas "elevar o ônus das posturas oposicionistas e amedrontar aqueles que, em outras circunstâncias, tenderiam a partir para a contestação do regime” [PEREIRA, 2010:133].

As lideranças da ditadura mantiveram com relativa eficiência a aparência da existência de uma esfera pública em que a oposição moderada era permitida, mantendo em funcionamento o Congresso Nacional e um sistema judiciário de exceção, embora bastante controlados. A utilização em grande escala da repressão judicial era parte importante da conquista de uma "[...] aquiescência passiva, ou mesmo o apoio ativo da 'maioria silenciosa' dos brasileiros” [PEREIRA, 2010: 128-9]. A ditadura civil-militar conseguiu por um período considerável, possivelmente até 1975 ou 1976, “[...] retratar esses julgamentos como medidas necessárias para proteger a segurança e o bem estar dos cidadãos comuns e cumpridores da lei contra terroristas perigosos, subversivos, comunistas e seus cúmplices” [PEREIRA, 2010: 138], ao menos internamente, pois no exterior tais julgamentos foram constantemente denunciados pelos opositores da ditadura brasileira e por seus apoiadores.

Na fase repressiva extrajudicial conduzida nos centros de tortura e de extermínio, os presos eram interrogados, torturados e severamente punidos - em alguns casos com a morte. Nos tribunais militares, setor mais visível da máquina repressiva, buscava-se punir com condenações os mais comprometidos com as oposições e as esquerdas revolucionárias. Buscava-se, também, legitimidade fazendo uso da legalidade de exceção, a qual fora importante para a manutenção de uma certa imagem de funcionamento regular da justiça, da mesma maneira como serviu como uma espécie de ameaça. Parte considerável dos denunciados foi poupada de condenações judiciais, mas somente após serem alertados pela experiência extrema de passar horas, dias ou meses presos nas instalações dos órgãos de segurança interna e no sistema carcerário ordinário.

Nesta luta desigual e arbitrária, os advogados, as famílias e alguns setores da Igreja Católica representaram suporte imprescindível aos presos políticos, sem o qual dificilmente teriam empreendido tamanha resistência nos cárceres, organizando denúncias e embaraçando o regime dentro e fora do país. As famílias enfrentaram muitas dificuldades para se manterem sem o auxílio de pais, maridos e irmãos ajudando no sustento da casa. Para muitos presos não era possível pagar advogados, o que, em geral, não impediu que fossem defendidos. Prevaleceu a solidariedade, como no caso do coronel 
da Polícia Militar Vicente Silvestre, militante do PCB preso em São Paulo no dia 9 de julho de 1975, durante a Operação Radar organizada pelo CIE:

"O meu advogado foi procurado pela minha família, ele era do Rio de Janeiro, o Sobral Pinto. Ele veio a São Paulo para me defender, mas não deu para manter o Sobral Pinto, porque cada vez que ele vinha para uma audiência eu tinha que pagar a passagem de avião de ida e de volta. Estava ficando insuportável, porque eu não tinha dinheiro para isso. Ele passou o caso para o dr. Luís Eduardo Greenhalgh, que passou a ser o meu advogado. Até o julgamento o meu advogado foi o Sobral, mas no dia ele não compareceu e mandou uma advogada assistente dele, a Eny. Ela fez a defesa e perdeu-se um pouco [...]. Nesse meio tempo ela desistiu da defesa e passou o caso para o Luís Eduardo. Condenaram a mim, ao Machado e ao cabo Zacarias, que foi presidente, numa época, do Clube dos Cabos e Soldados da Força Pública. Os trinta militantes foram todos liberados. Inicialmente, foram presas umas cem pessoas, mas como não tinham nada, foram liberando. Responderam ao primeiro inquérito umas trinta, depois ficaram umas 18 pessoas. [...] Então, fui para o [presídio do] Hipódromo [...] depois de condenado na Justiça Militar, [...] em meados de 1976, para cumprir mais um ano de prisão [...]., ${ }^{, 72}$

Ariston de Oliveira Lucena também passou por dificuldades, estava isolado na prisão e sem condições de pagar um advogado, pois sua família era de origem humilde e foi banida quando libertada em troca do cônsul japonês, Nabuo Okuchi, em março de 1970, passando a viver em Cuba ${ }^{673}$. Lucena não deixou de receber auxílio jurídico durante os mais de 9 anos em que permaneceu nos presídios da ditadura, cumprindo as sentenças determinadas pela Justiça Militar:

"O advogado foi aparecer quando eu já estava na Detenção. Um dia uma pessoa falou assim: '- Olha, o Virgílio vai ser o seu advogado'. Virgílio Egydio Lopes Enei foi o meu primeiro advogado. Eu falei: '- Mas eu não posso contratar advogado, porque não tenho grana. A minha família está fora do Brasil'. Responderam-me '- Não, você vai ter um advogado.' Aí o Virgílio começou [o trabalho], logo depois veio a mulher dele, a Rosa [Cardoso], que virou minha advogada. Aliás, eles eram um casal muito gente fina.”674

Foram os advogados alguns dos que mais deram suporte aos presos políticos nas diversas manifestações, protestos e greves de fome organizadas com o objetivo de conquistar melhores condições carcerárias, mas também de denunciar as violações de direitos humanos cometidas pela ditadura. Em função dessa atuação tiveram suas correspondências censuradas, seus telefones grampeados, eram seguidos, tendo de conviver com a total ausência do direito à privacidade. Seus honorários eram escassos ou inexistentes e sofriam sistematicamente vários tipos de ameaças, além de terem sido

\footnotetext{
${ }^{672}$ Entrevista concedida por Vicente Silvestre à autora. SP, 16/09/2009, AAPP/AEL-LEI.

${ }^{673}$ A mãe de Ariston, Damáris Lucena, e seus três irmãos, assim como Shizuo Ozawa (Mário Japa), madre Maurina Borges, Diógenes José de Carvalho de Oliveira e Otávio Ângelo foram libertados em troca do cônsul japonês. Na ocasião, foram banidos e levados para o México.

${ }^{674}$ Entrevista concedida por Ariston de Oliveira Lucena à autora. Idem, ibidem
} 
detidos diversas vezes e até torturados. Neste clima de medo generalizado, alguns advogados foram presos por sua militância partidária, enquanto muitos outros foram detidos por horas ou dias simplesmente porque tiveram a coragem de exercer a defesa de seus clientes, numa clara tentativa dos órgãos de segurança de intimidá-los e desmoralizálos.

\subsection{Informando as prisões e localizando os presos políticos}

Embora fosse um importante instrumento de repressão política da ditadura, o sistema de justiça militar (responsável pelo julgamento dos presos políticos) não era o local ou a instância de poder que decidia sobre a vida ou a morte dos perseguidos políticos. Conforme vimos no $2^{\circ}$. capítulo, as entrevistas registradas nesta pesquisa sugerem que, em geral, o preso demorava de um a três meses para ingressar no sistema de justiça militar, quando era encaminhado para as dependências da polícia política (os Deops), que então iniciava o Inquérito Policial Militar que embasava a denúncia encaminhada para o Ministério Público Militar ${ }^{675}$. Havia casos, contudo, em que mesmo quando o preso era levado aos Deops, permanecia seis meses ou mais incomunicável e sem formalização da sua prisão.

Os advogados de presos políticos empenhavam-se para tentar conseguir sentenças mais brandas ou a absolvição de seus clientes, mas, antes, era necessário fazer chegar às autoridades a informação de que a prisão de alguém não era mais segredo. Desde dezembro de 1968, quando o AI-5 eliminou o habeas corpus, os advogados tiveram que atuar de forma criativa para conseguir localizar e oficializar a prisão de perseguidos políticos. O direito de petição não havia sido extinto do ordenamento jurídico ditatorial, assim, muitos advogados apresentavam petições simples no lugar do habeas corpus (eventualmente, sob outro título). Alguns advogados disfarçaram seus pedidos de habeas corpus apresentando-os como mandados de segurança, uma garantia constitucional de proteção de “direito liquido e certo” mantido na Constituição de $1969^{676}$.

\footnotetext{
${ }^{675}$ Note-se que não há estatísticas a respeito, em função das dificuldades de registrar-se dados da fase secreta ou clandestina das prisões, naquele período.

${ }^{676}$ V. Emenda Constitucional no.1, de 1969, par.21 do art.153; e BonAVIDES, Paulo. Curso de direito constitucional. 11 a . Ed., São Paulo, Malheiros, 2001, p.501-6. V. entrevista concedida por Virgílio Lopes Enei. Idem, ibidem; e entrevista concedida por Belisário dos Santos Jr. à autora. Idem, ibidem
} 
Estas petições, denominadas por alguns de “habeas corpus de localização”677 obrigavam o juiz auditor a consultar o promotor de justiça encarregado do IPM e requisitar informações às autoridades sobre onde estaria preso determinado dissidente político. Por vezes, os órgãos de segurança reconheciam a prisão de pessoas quando ainda estavam no período de torturas e, assim, os advogados e suas famílias conseguiam garantir a integridade física do preso e, eventualmente, levar-lhe carinho, roupas e comida $^{678}$.

Belisário dos Santos Jr., então um jovem advogado que atuou na defesa de presos políticos entre 1970 e 1983, destacou o papel desempenhado pelos advogados, os quais tiveram de atuar como equilibristas, promovendo acrobacias jurídicas e estabelecendo elos entre os presos políticos e o Estado, buscando oficializar o máximo possível sua condição de prisioneiro e ampliar as possibilidades de terem seus direitos garantidos. De acordo com as palavras de Belisário:

“[...] O advogado, na realidade, andava na corda bamba [...] das relações, ele era o meio termo entre [...] o preso e o Estado, entre o preso e o torturador, entre o preso e os juízes. Ele era um equilibrista, nós tínhamos que produzir um discurso que fizesse sentido ante o universo do poder judiciário a quem a gente se dirigia, mas que produzisse um sentido para o preso também ${ }^{679}$."

Eventualmente, algumas brechas foram utilizadas para salvar vidas por meio da atuação corajosa dos advogados, conforme ocorreu com Inês Etienne Romeu. Seu advogado, Augusto Sussekind de Moraes Rego, precisou usar de astúcia para encontrar uma maneira de oficializar a sua prisão. Inês fora deixada em Belo Horizonte (MG), em frente da casa de uma irmã, depois de ter sido torturada por 96 dias na "Casa da Morte", em Petrópolis (RJ). Pesando pouco mais de quarenta quilos, estava muito debilitada, desse modo, os familiares a levaram para um hospital particular. Durante um mês, ela permaneceu cercada pelos órgãos de segurança que, às vezes, invadiam o hospital para tentar sequestrá-la novamente, ameaçando-a de morte:

“[...] Ela tinha duas tias que eram freiras e toda a família ficava lá fazendo um revezamento durante 24 horas, quando os militares chegavam, as tias e a família deitavam na cama e diziam: '- Vocês vão ter que prender todo mundo! Vão ter que atirar em todo mundo!' Aí, eles recuavam. Todas as pessoas que entravam no hospital passaram a ser revistadas, eram chamadas para depor e ela ficou numa situação [...] de impasse. Aí o

\footnotetext{
${ }^{677}$ FeRNANDES, Fernando Augusto Henriques. A voz humana: a defesa perante os tribunais da República. Rio de Janeiro, Revan, 2004, p.224.

${ }^{678}$ MoReIRA, Fernanda Machado. "Modesto da Silveira: um soldado humano". In: SÁ, Fernando; Munteal, Osvaldo e Martins, Paulo Emílio. Op.cit., p.54; e Lins E SiLva, Técio. O que é ser advogado. Rio de Janeiro, Record, 2005, p.86-7.

${ }^{679}$ Entrevista concedida por Belisário dos Santos Jr. à autora. Idem, ibidem
} 
Sussekind teve uma brilhante ideia. Ele propôs o seguinte: '- Escreva uma carta do seu próprio punho contando o que o Exército brasileiro fez contra você'. Então ela escreveu aquele testemunho famoso de dentro do hospital, que não existe mais em papel, foi destruído. [...] Ela descreveu tudo o que tinha acabado de sofrer em Petrópolis, um mês antes. O Sussekind pegou a carta e voltou para o Rio de Janeiro. Como ele era decano da Justiça Militar, tinha acesso ao Ministério do Exército. Ele foi até o gabinete do Ministro do Exército, o Orlando Geisel, dirigiu-se ao Protocolo e falou: '- Eu gostaria de protocolar esta carta para o Ministro'. O cara carimbou tudo sem nem abrir e entrou. O Sussekind não foi embora, sentou e esperou para ver o que ia acontecer. Depois de uma hora, mais ou menos, começou um corre-corre, uma agitação no gabinete. Veio um oficial falar com ele e disse: 'Doutor Sussekind, o senhor pode se retirar, pois nada vai acontecer à sua cliente'. No dia seguinte, o tenente Marcelo Paixão, um dos torturadores mais temidos de Belo Horizonte, chegou ao hospital onde estava a Inês e todo o mundo ficou apavorado. Ele disse: 'Eu estou aqui com um decreto de prisão de Inês Ethiene Romeu!’ A família olhou a carta e viu que ela fora assinada pelo próprio Orlando Geisel! A Inês foi levada para o Rio de Janeiro e ficou presa num quartel militar. Assim, o Sussekind oficializou a prisão da Inês e, certamente, a salvou! ${ }^{680,}$

A oficialização da prisão de Lúcia Murat também ocorreu em condições bastante incomuns. Provavelmente, ela sobreviveu porque seu advogado conseguiu tirá-la momentaneamente do quartel da Rua Barão de Mesquita, sede do DOI-Codi (RJ). O isolamento imposto pelos DOI-Codi raramente era rompido antes do preso ser enviado ao Deops; contudo, isso ocorreu em algumas ocasiões. Quando foi presa em 31 de março de 1971, no Rio de Janeiro, Lúcia Murat era dirigente do MR-8 (DI-GB) e bastante procurada pelos órgãos de segurança. Assim que soube da prisão da filha, sua mãe, Ninah Vasconcelos, procurou seu advogado, Técio Lins e Silva. Ambos sabiam que era necessário oficializar sua prisão com urgência, pois ela certamente estava sendo torturada e corria o risco de se tornar mais uma desaparecida política. Murat era denunciada em mais de 10 processos na Justiça Militar e havia uma audiência para dar prosseguimento a um deles marcada na Auditoria da Marinha. Quando soube dessa informação, Técio comunicou a prisão de Lúcia Murat nessa Auditoria e pediu para que ela

“[...] fosse requisitada para comparecer no dia e na hora marcada. O juiz-auditor mandou requisitar a presa. Pela maneira como Lúcia foi apresentada à auditoria, com uma escolta armada até os dentes e os nomes nos uniformes coberto com esparadrapo, parecia até que fora encaminhada por engano, como se requisitada pelo Cenimar, e não pela Justiça. Ainda apresentava sinais da tortura no pau-de-arara, com lesão visível no pé devido à ruptura de nervo ciático, que a obrigou ao uso de bota ortopédica por muito tempo" ${ }^{\text {,81 }}$.

Técio Lins e Silva era advogado de Lúcia Murat desde sua prisão no Congresso da UNE, em Ibiúna (SP), em 1968; ele havia militado no movimento estudantil de forma

\footnotetext{
${ }^{680}$ Entrevista concedida por Sérgio Ferreira à autora. RJ, 20/03/10.

${ }^{681}$ LiNS E SILVA, Técio. O que é ser advogado. Rio de Janeiro, Record, 2005, p.133.
} 
discreta e tornara-se um amigo. Murat contou-nos como foi salva ao ser retirada do DOI-

Codi (RJ) para comparecer à audiência da Marinha, em 1971:

“[...] Eu tinha um super advogado [...]. Eles [o DOI-Codi] negavam a minha prisão e estava todo mundo desesperado. Técio e a minha família ficaram como loucos, mas ele conseguiu que me apresentassem na auditoria da Marinha [...]. Eu não sei porque cargas d'água eles fizeram isso, se foi uma dessas circunstâncias de justiça ou foi erro mas, de repente, chegou uma ordem no DOI-CODI para me apresentarem, depois de dois meses presa!

[...] De repente, no meio dessa história, eu fui levada para a auditoria, nego chega, me deu uma roupa. Aí eu cheguei na auditoria, eu não andava, a minha perna era enorme e o meu pé também, essa minha perna direita era fininha, porque tinha perdido toda musculatura e o pé torto, ainda estava todo cheio de crostas, estava cicatrizando e tinha toda aquela crosta nos punhos, nos dedos, nos peitos. Até hoje, eu tenho uma marca na perna e tenho outra pequena no pé, mas, na época, era grande. Eu não sabia para onde estava indo, cheguei lá e, de repente, entra o Técio e eu me descontrolei inteiramente. Eu falei: 'Técio, me tira daqui, me leva para o hospital'. Ele falava: '- Calma'. E eu fui para lá fazer declaração revolucionária no processo. Nessa altura não tinha mais sequestro, não tinha nada, eu estava ferrada. Aí foi engraçado, foi uma coisa assim total de cumplicidade entre mim e o Técio, cheio de PE do lado, [...] eu falava assim: '- Eu só quero saber onde é que eu digo que eles me torturaram, porque eu vou denunciar a ditadura'. O Técio me olhava e falava: '- Lúcia, aqui você vai dizer que não fez isso que a acusação está afirmando, está entendendo Lúcia? Acabou, você não fez isso está entendendo? Denuncie o que você quiser, mas não diga que você fez, porque esta é a única chance que a gente vai ter daqui para frente, a via jurídica'.

[...] Aí o meu pai e a minha mãe entraram. A minha mãe parecia 150 anos mais velha do que quando ela morreu. Estava um lixo! Eu me lembro que [...] essa foi a única vez que ouvi meu pai brigar com ela. Foi muito bonito, porque ela virou para mim e começou a chorar e falou: '- Por favor, não fala nada, por favor, não fala nada'. Ele virou-se para ela e disse: '- Deixa ela falar, porque ela sabe o que está fazendo'. Eu nunca esqueço, foi muito bonito! [...] Foi um horror, cheguei mancando, os juízes militares não tiveram coragem de me olhar, eles abaixaram a cabeça! Eu nunca me esqueço, eles abaixaram a cabeça sem graça. O Técio pediu para que eu sentasse, eu não podia ficar em pé, fui mancando e sentei. Neguei a acusação que nem me lembro qual era, acho que era o processo da DI, um processo por pertencer a uma organização [proscrita], e na hora que eu podia denunciar, denunciei a tortura. Fiz um depoimento emocionadíssimo denunciando que eu tinha sido torturada, falando sobre os direitos humanos. Eu estava extremamente emocionada e o Técio falou: '- Tudo bem, eu vou te levar para o hospital'. Mas chegou no final e o cara disse '- Ah não, vai ser examinado o pedido de ida para 0 hospital'. E eu voltei para o DOI-CODI. Eu olhei para ele e falei: ‘- Técio, eles vão me matar'. Mas ao mesmo tempo eles não podiam mais me matar, porque eu tinha sido apresentada daquela maneira. Essa jogada do Técio [...], foi algo raríssimo, tanto é que era raríssimo ter provas de tortura, e por isso eu tinha! [...] Eu me lembro da cara do Técio de horror, de angústia! Eu nunca me esqueço, porque acho que eu via na angústia dele o horror que eu ia passar, quando o juiz disse que ia ser examinado o caso de ir para o hospital, mas que não podia ser imediatamente. Lembro-me que ele quase chorou mais do que eu. [...] quando cheguei de volta ao DOI-Codi, foi um horror! Acho que foi o pior de tudo, porque aí eles fizeram uma coisa que foi uma das piores coisas que eu vivi na vida! [...] Eles me fizeram representar o que eu tinha feito na auditoria, mas como se tivesse sido uma palhaçada.” ${ }^{682}$

${ }^{682}$ Entrevista concedida por Lúcia Murat à autora. RJ, 25/03/2010, AAPP/AEL-LEI. 
Outro caso ilustrativo da importância da atuação dos familiares e advogados na busca para localizar e informar a detenção dos militantes sequestrados pelos órgãos de segurança, versa sobre a prisão de Fernando Casadei Salles, membro do "grupo de fogo" da ALN, tal como relatou seu advogado, Virgílio Lopes Enei:

\begin{abstract}
"Eu fui procurado pelo pai do Fernando Casadei, o Itagiba Salles. Ele era amigo do Davi Honovich, que era outro cliente meu do partidão. Eles insistiram para que eu defendesse o Fernando. Consegui tirá-lo da cadeia da primeira vez e ele tornou-se meu amigo, ele e a mulher dele, a Albertina, que também foi minha cliente.

[...] O pai dele era muito meu amigo e era gerente do Bradesco. [...] Quando surgiu o problema do Fernando, ele ligou para o Amador Aguiar, dono do Bradesco [...], pois ele mandava no país, certo? O Amador ligou para o Clube do Exército, no Ibirapuera, e disse: '- Quero falar com o seu Alfredo! - Seu Alfredo, quero que o senhor faça o que pode e, de preferência, o que não pode pelo Fernando Casadei Salles, está bem?’ E foi só isso.

Ele salvou, de fato, a vida do Fernando, porque ele estava condenado à morte. O que o seu Alfredo informou foi '- Ele vai continuar preso e não vai apanhar mais e vai viver'. [...] Acho que isso foi em outubro ou novembro de 1973.

[...] Eu tinha conta no Bradesco e todos os cheques que eu apresentava, o Itagiba pagava. Ou seja, ele não me pagou um tostão pela minha atuação como advogado, mas pagou muito cheque meu sem fundo. Digamos que eu estou conversando com você aqui e você está meio sem dinheiro ou eu estou sem dinheiro e eu digo: '- Dá uma chegadinha no Bradesco, lá encostado no edifício Copan, procura o Itagiba e peça tanto emprestado. Ele vai lhe dar um dinheiro e vai dizer: '- Eu preciso da assinatura do Virgílio'. Aí você diz 'Ele me mandou assinar por ele’. E você assinava por mim. Ele era correto. [...] Esse dinheiro eu não pagava, certo? ${ }^{683}$,
\end{abstract}

Os advogados de defesa faziam questão de manter sua independência política; não obstante, ajudaram seus clientes de diversas maneiras, muitas das quais transcenderam a atividade estritamente advocatícia. Em outubro de 1971, a atitude corajosa de advogados de presos políticos, provavelmente, salvou outra vida. Belisário dos Santos Jr. e Antônio Mercado foram procurados por Faid Tahan Saab, que era advogado em Minas Gerais e pediu-lhes ajuda, pois militantes da ALN o procuraram para tentar salvar seu irmão, Monir Tahan Saab, um guerrilheiro do "grupo de fogo", resgatado pela organização depois de ser baleado em um confronto durante uma ação havia dez dias. Era preciso levá-lo à emergência de algum hospital, mas Monir figurava nos cartazes que estampavam as fotos dos perseguidos políticos com a palavra "procura-se”. Além disso, durante o tiroteio Monir atingira um sargento do DOI-Codi/SP, o que atiçou ainda mais o ódio dos agentes de segurança ${ }^{684}$.

Os advogados conseguiram fazer um acordo com um procurador e Monir entregou-se depois de internado em um hospital localizado no alto da Lapa, em São

\footnotetext{
${ }^{683}$ Entrevista concedida por Virgílio Egydio Lopes Enei à autora. SP, 29/01/11.

${ }^{684}$ Entrevista concedida por Belisário dos Santos Jr. à autora. Idem, ibidem
} 
Paulo, em outubro de 1971. “O Ministério Público Militar recebeu a rendição, o Monir fez uma carta escrita em um guardanapo e o Dr. Durval Airton Moura Araujo [...] mandou que ele fosse imediatamente operado. O Dr. Durval se pôs na frente da sala de operação, meia hora depois chegou o pessoal do DOI-CODI, mas ele não os deixou entrar ${ }^{685, "}$.

Este fato provocou a prisão de Belisário, Antônio Mercado e de Maria Regina Pasquale, que não tinha conhecimento do resgate de Monir. Custou, também, a carreira do procurador, pois ele era cogitado para ser nomeado ministro do STM, o que não aconteceu $^{686}$. Em fevereiro de 1972, contudo, Monir Tahan Saab protagonizou uma retratação pública de sua participação na luta armada, que ganhou certa repercussão na imprensa, na qual dizia-se decepcionado com o tratamento recebido pela direção da ALN. A organização não garantiu-lhe proteção e assistência médica, o que, segundo ele, teria ocorrido em função de suas críticas feitas ao grupo. Em janeiro, Saab já havia escrito uma “declaração de próprio punho” aos órgãos de segurança, criticando duramente a ALN e elogiando o tratamento recebido pelo DOI-Codi, mas sem dizer-se "arrependido". Este documento, porém, não chegou a ser divulgado ${ }^{687}$.

Idibal Pivetta, Airton Soares e outros advogados atuaram, muitas vezes, na clandestinidade para tentar salvar a vida de seus clientes. Pivetta, por exemplo, levava mensagens e informações para militantes da ALN no exterior, quando viajava para divulgar suas peças ou quando acompanhava as turnês do grupo Teatro União Olho $\mathrm{Vivo}^{688}$. Alguns advogados davam fuga aos clientes escondendo-os em suas residências, estabelecendo contato com militantes dos agrupamentos clandestinos, os quais organizavam rotas para o exterior. Pivetta e Airton Soares foram alguns dos que ajudaram

\footnotetext{
${ }^{685}$ Idem, ibidem. Araujo é o promotor que criticou duramente os presos políticos em greve de fome, em julho de 1972, e que tentou indispor d. Paulo e a Igreja com os grevistas.

${ }^{686}$ Idem, ibidem.

${ }^{687}$ V. Correio do Povo, 19/10/71, p.5 e "Terroristas enganam os próprios companheiros”. Correio do Povo, 09/02/72, p.22; citado em GASPAROTTO, Alessandra. O terror renegado. Uma reflexão sobre os episódios de retratação pública protagonizados por integrantes de organizações de combate à ditadura civil-militar no Brasil (1970-1975), p. 95, 159.

${ }_{688}$ Pivetta tornou-se um ativo advogado de presos políticos após a prisão de centenas de estudantes no XX Congresso da UNE, em Ibiúna, em outubro de 1968. Desde 1967, escrevia e montava peças de teatro, usando o pseudônimo de César Vieira. Sua primeira peça encenada pelo grupo de teatro do Centro Acadêmico XI de Agosto da Faculdade de Direito da USP chamou-se O Evangelho segundo Zebedeu, baseada na história da Guerra de Canudos. Encenada sob a direção de Silney Siqueira, ela foi apresentada no circo do Centro Acadêmico, localizado no Ibirapuera. Proibida, a peça foi liberada com cortes, tornandose um símbolo de rebelião na época. Entre 1957 e 1958, na qualidade de vice-presidente da UNE, Pivetta acabou por assumir a presidência da entidade, indo morar na sua sede, na praia do Flamengo, no Rio de Janeiro. V. entrevista concedida por Idibal de Almeida Pivetta à autora. SP, 12/11 e 04/12/2008, AAPP/AEL-LEI. A peça ficou em cartaz por dois anos e foi considerada o melhor espetáculo no Festival Mundial de Teatro de Nancy, na França, em 1971.
} 
a transportar militantes perseguidos até as fronteiras do país, conseguindo dessa maneira evitar a prisão e o assassinato de alguns de seus clientes ${ }^{689}$. Pivetta contou-nos como começou a advogar para militantes da ALN e de que maneira ajudava seus militantes e os de outras organizações:

"Eu não sei como esse pessoal veio a ser meu cliente. Tenho a impressão que isso funcionou pelo fato dos caras e seus familiares fazerem cartões, impressos por eles mesmos, onde tinha escrito Idibal de tal, advogado, e dois números de telefones, sendo que um desses números era normalmente usado pelas famílias que me procuravam quando alguém estava preso.

[...] Eu era advogado do Paulo [de Tarso Venceslau] e ele me deu várias mensagens para serem levadas para a França, por exemplo, quando fui com a minha peça $O$ Evangelho Segundo Zebedeu para Nancy, na França. [...] Eu levei várias mensagens para pessoas de lá, não sei se foi para o Aloysio Nunes [Ferreira Filho] [...]. Lembro-me que levei várias mensagens dele para uma porrada de caras [...], inclusive, [mensagens] de alguns padres para outros padres. Isso era uma coisa que não me cabia ler, as mensagens vinham fechadas e a gente assumia o risco de confiar no que estava escrito, que era algo em benefício de uma causa nobre [...].

[...] Outras vezes a gente colaborou decisivamente na fuga de pessoas. [...] Teve a companheira do Luiz Alberto Sanz, a Didi. Quando ele foi preso, o casal morava numa pensãozinha ali na Santa Cecília. Ela viu ele ser preso, fugiu pela janela e me ligou de madrugada: ' - Eu estou aqui e não tenho para onde ir, minhas coisas estão presas'. A gente foi buscá-la, levamos para casa de um amigo na Rua Cubatão, e ela ficou dois dias lá. Muito esperta, conseguiu imediatamente emprego trabalhando no consultório de um dentista, em 3 dias ela já estava morando por conta própria e se sustentando. Depois nós a ajudamos a fugir para o Chile. [...] Você dava uma verba, levava até o ônibus, o ônibus ia para Porto Alegre onde fazia uma triangulação e ia parar em Santiago, na época, era o governo do Allende.

[...] Teve o problema da família Horta, eles são de Taubaté, e da Cida Horta [a quem eu ajudei a fugir]. [...] Ela era namorada de um professor de muito destaque e que foi assassinado pela repressão [o Antônio Benetazzo ${ }^{690}$ ] [...]. Ela me apareceu de madrugada e eu não sabia quem ela era. Peguei o carro e fiquei andando com ela e perguntando várias coisas, ela podia ser uma infiltrada [...], até que ela confirmou que era parente de fulano [Celso Antunes Horta]. E essa não tinha nenhuma chance, porque se não [ajudássemos], ela ia ser morta, o cara tinha acabado de ser assassinado. A gente a mandou via Porto Alegre também, eu tinha uns contatos lá e o pessoal se virava. Você pagava despesas, isso por minha exclusiva vontade, não era organizado em nenhum grupo [...]. Eu tive vários casos assim.

A gente fazia contato com a organização e aí [...] você levava a pessoa na rodoviária, colocava num ônibus, dava um dinheiro para dois ou três dias e ia embora. Depois, você até encontrava-se com essas pessoas em Cuba [...]. No fim formou-se uma rede de [solidariedade] tão maluca que misturava teatro com advocacia. [...] No Congresso Mundial da Juventude [em julho de 1978], fiquei no Hotel Riviera, em Havana, onde havia uns 150 brasileiros querendo consulta jurídica. Era um hotel luxuoso que a revolução tinha tomado [...], então o que eu fiz? Falei: '- Eu também tenho direito a um pouco de sol!' Pus uma mesa do lado da piscina, uma garrafa de rum, gelo e limão para

\footnotetext{
${ }^{689}$ Entrevista concedida por Airton Soares à autora. Idem, ibidem

${ }^{690}$ Benetazzo era dirigente do Molipo e professor de História e Educação Artística. Foi preso no dia 28/10/72 e assassinado sob tortura no DOI-Codi/SP, em 30/10/72. V. Dossiê Ditadura, op.cit., p.384-6.
} 
fazer mojito e fiquei atendendo os caras! [...] Eu dava a procuração e eles [assinavam], atendi uns 100 desse modo."

Havia muito respeito e cumplicidade na relação entre alguns presos políticos e seus advogados. E, mais do que isso, existia uma relação de muita confiança entre eles, o que possibilitou salvar a vida de militantes ou impedir que fossem presos, conforme o relato de Carlos Alberto Lobão da Cunha:

\begin{abstract}
“A relação de confiança era tanta que beirava a cumplicidade em um ou outro caso. Certa vez, depois de solto, acho que em 1976, chegou até mim, por um advogado, uma informação de dentro do DOI-Codi ou Deops, já não lembro bem. Alguém que havia 'caído' recentemente entregou, sob tortura, a informação de um 'ponto' em tal lugar com uma pessoa. Tinha sido aberto, portanto, um ponto que era verdadeiro. Nós ficamos desesperados. Inclusive, era um ponto de uma organização que não participara da luta armada, envolvendo militantes que eu não conhecia. Eu não conseguiria uma maneira de avisar a tal pessoa de que não era para ela comparecer ao ponto. Então, bolamos um alternativa meio maluca. Combinamos de ligar para os bombeiros e para um hospital - os mais perto possível do ponto. Avisamos - de telefones públicos distintos - que próximo ao horário marcado do ponto, estava começando um incêndio e que havia um acidente grave com feridos próximo ao local. A pessoa deve ter percebido a grande agitação com sirenes e engarrafamento naquela região e não entrou no ponto. O que soube é que a pessoa não foi presa ${ }^{692}$.”
\end{abstract}

Em meio a tanta tensão e perigo, tais gestos revelam a importância da relação existente entre os advogados de defesa, os presos políticos e seus familiares, naquele período. Os advogados cumpriram um papel fundamental, ao se constituírem como seus interlocutores com a sociedade civil, colaborando para que os presos saíssem da sua condição de isolamento imposta pelos órgãos de segurança e a ditadura, que negava a existência de presos políticos no país.

O setor progressista da Igreja Católica forneceu um importante apoio político à atuação dos advogados de defesa. Vários entrevistados nesta pesquisa relataram que d. Paulo Evaristo Arns e a CJP/SP deram um suporte fundamental às famílias de presos políticos, mas não atuavam ou apoiavam diretamente os advogados ${ }^{693}$. Coube a alguns dos advogados mais ligados à Igreja Católica uma participação ativa no trabalho da CJP/SP, tais como José Carlos Dias, Mário Simas e Belisário dos Santos Jr.

No final de 1971, a morte de um militante da AP levaria d. Paulo a enfrentar mais uma vez a violência repressiva da ditadura. Luiz Hirata havia sido preso pela equipe do delegado Fleury, em 26 de novembro e assassinado sob tortura em 20 de dezembro de

\footnotetext{
${ }^{691}$ Entrevista concedida por Idibal Pivetta à autora. Idem, ibidem. V. tb. VIEIRA, César. Op.cit., p.305-6.

692 Entrevista concedida por Carlos Alberto Lobão Cunha à autora. SP, 20/08/2010.

${ }^{693}$ V., por exemplo, as entrevistas concedidas por Rosa Cardoso da Cunha, Airton Soares e Virgílio Lopes Enei à autora. Idem, ibidem.
} 
1971. Apesar das solicitações de outros presos, que testemunharam sua deterioração física por causa das torturas sofridas, Hirata foi levado ao Hospital das Clínicas quando já estava em estado terminal. A requisição de exame ao IML, marcada com o "T" característico utilizado para identificar os presos políticos, afirmava que teria morrido por “morte natural”, sendo diagnosticada insuficiência renal crônica.

Hirata havia abandonado os estudos em Agronomia na Escola Superior de Agricultura Luiz de Queiroz, de Piracicaba (SP), em 1969, em função da perseguição política de que era alvo. Passou a atuar no movimento sindical e tornou-se um dos cinco coordenadores da Oposição Metalúrgica de São Paulo, ao lado de Waldemar Rossi, Cleodon Silva, Vito Gianotti e Raimundo Moreira ${ }^{694}$.

Com a morte de Hirata, d. Paulo reuniu-se com a Pastoral Operária para discutir a melhor maneira de tratar da situação. Meses depois, em agosto de 1972, surgia a Comissão Justiça e Paz de São Paulo, transformando-se num instrumento fundamental de denúncia dos crimes da ditadura e de suporte aos perseguidos políticos e suas famílias ${ }^{695}$.

Margarida Genevois começou sua participação na CJP/SP como sua secretária e relatou como começou a ser organizado o trabalho de apoio aos perseguidos políticos e seus familiares, assim como a organização das informações para sua realização:

“[...] Os primeiros convidados foram o Hélio Bicudo, o Dalmo Dallari, o Fábio K. Comparato, Mário Simas, José Carlos Dias. Na época, precisávamos muito de advogados em razão dos problemas com os presos políticos.

[...] D. Paulo era muito visado e tudo era considerado subversivo. [...] Muitos advogados de São Paulo não queriam se ocupar desses casos. [...] houve uma época que eram apenas cinco na cidade de São Paulo.

[...] Era uma coisa clandestina, nós tomávamos o cuidado para não ter muita coisa escrita, porque se algo fosse descoberto comprometeria uma série de pessoas. Nós atuávamos, sobretudo após as reuniões. Tomávamos conhecimento dos casos e dos problemas e [...] procurávamos ajudar essas famílias. Os advogados é que tinham muito trabalho.

Muitas vezes, d. Paulo interveio pessoalmente. [...] ele era um dos poucos membros da Igreja que atendia presos políticos, a maioria dos bispos, com algumas exceções, não queria nem saber, estavam apavorados com o problema ou não acreditavam. Mas d. Paulo sempre foi muito aberto para isso, não importando o partido, a ideologia política ou a religião.

[...] De início, eu comparecia uma vez por semana, depois duas, depois passei a comparecer todos os dias. [...] As pessoas vinham e contavam seus problemas e nós procurávamos ajudar sempre, sabendo que o que poderíamos fazer era muito pouco. [...] [mas] fazíamos muitas denúncias, sobretudo no exterior.

[...] Eu pessoalmente anotava os casos e tinha cuidado, porque a qualquer momento estávamos sujeito a ser presos. A polícia poderia entrar, como aconteceu. Em geral, eu

\footnotetext{
${ }^{694}$ V. Dossiê Ditadura, op.cit., p.295-7; e entrevista concedida por Waldemar Rossi à autora. SP, 12/01 e 04/02/2009, AAPP/AEL-LEI.

${ }^{695}$ V. BENEVIDES, Maria Victória de M. Fé na Luta, op.cit., p.45-52.
} 
dizia: você me dá um codinome, eu prefiro não pôr seu nome e nem saber, porque amanhã ou depois sou presa e chegam em você. As notas que eu tomava ficaram falhas.

[...] Alguns advogados chegaram a ter mais de 70 clientes. Então, não davam conta [...] eram muitos casos e, na medida do possível, os advogados membros procuravam outros de confiança para ajudar [...]. Teoricamente nós devíamos atuar na solução dos casos em São Paulo, mas, na prática, vinha gente do Brasil todo, porque eles não tinham a quem recorrer.",696

Em outro relato, Genevois retratou o clima de medo e o impacto que este trabalho de solidariedade tinha sobre as pessoas envolvidas e nas famílias de perseguidos políticos auxiliados pela CJP/SP:

"Lembro-me que, quando comecei a ver os detalhes do que se passava nas prisões, contados nas reuniões, voltava apavorada, nem dormia direito de tão angustiada, e os jornais não contavam nada, evidentemente. As reuniões eram na casa de d. Paulo, mas como o número de pessoas era cada vez maior, ele pediu que eu ajudasse e passei a atender na Cúria. [...] As pessoas chegavam aflitíssimas, pedindo auxílio [...] Providenciávamos advogados que se desdobravam para obter a proteção judicial possível e ajudar na busca dos desaparecidos, escondíamos pessoas em perigo de vida, encaminhando-as para o exterior, fazíamos denúncias nos organismos internacionais. E, sobretudo, ouvíamos as pessoas, pois às vezes não tínhamos nada a fazer, senão ouvir e chorar junto. Mas o simples fato de ouvir já ajudava. [...] Nunca perguntávamos a quem nos procurava o porquê de sua prisão ou da de seus parentes; isso não importava. Eram dramas de vida e morte."

Naquele início de década, os setores progressistas da Igreja no Brasil, em especial a Comissão Justiça e Paz/SP, realizaram um importante trabalho de assistência aos perseguidos políticos e suas famílias, além da divulgação das denúncias de torturas, assassinatos e desaparecimentos forçados no exterior, que teve grande relevância e contribuiu para efetivar uma mobilização jurídica transnacional em defesa dos direitos humanos.

Como pudemos considerar, advogados de defesa de presos políticos e setores progressistas da igreja católica tiveram um papel essencial na divulgação das denúncias de prisões e torturas e, no caso dos advogados, na sistematização dos dados acerca da localização destes presos e das violações dos direitos humanos a que estavam sendo submetidos. A postura destas minorias é louvável - o que vem sendo reconhecido pela sociedade - mas dizem respeito também aos atributos e as funções sociais que exerciam. O Brasil é um país onde, tradicionalmente, membros do clero e da magistratura têm grande ascendência sobre as disposições sócio-políticas levadas à cabo pelos setores mais

\footnotetext{
${ }^{696}$ Depoimento concedido em 21/08/2000, disponível no arquivo da CJP/SP, (s/ autor).

${ }^{697}$ Depoimento concedido a Maria Victória de M. Benevides, em dez./2000; em BENEVIDES, Maria Victória de M. Fé na Luta. op.cit., p.50-2.
} 
amplos da sociedade. Assim, mesmo durante a ditadura civil-militar - período no qual o executivo exerceu seu poder de maneira vertical sobre o legislativo, o judiciário e quaisquer instâncias sociais que porventura se opusessem a seus desígnios - a aplicação de métodos controversos de silenciamento sobre membros do clero e da magistratura (prisões arbitrárias, tortura) tinha um peso desproporcional em relação à aplicação dos mesmos princípios sobre a população que mais amplamente se opunha ao regime.

Neste sentido, dir-se-ia que alguns advogados e membros de setores progressistas da igreja alinhavam-se sob o mote de representarem setores da sociedade que tiveram a coragem de utilizar sua posição e prerrogativas na luta de resistência à ditadura, muitas vezes com enormes custos pessoais (tais como reprimendas, supressão do processo de ascensão na carreira, entre outros ainda mais altos).

Com este sub-capítulo podemos considerar não apenas os meandros de algumas das principais maneiras pelas quais a resistência pode se escorar no apoio desses grupos de setores progressistas e privilegiados da sociedade, mas também a existência de um denominador comum para a atuação de advogados de defesa e membros progressistas da igreja católica (a despeito do fato de, em grande medida, não terem se unido objetivamente, tal como sugerem os depoimentos alinhavados neste sub-capítulo), o qual ainda é pouco conhecido.

\subsection{Resistindo à ditadura, defendendo presos políticos}

Os advogados de defesa dos presos políticos tinham uma posição privilegiada na sociedade brasileira, mas é de se considerar que houve casos em que esta não impediu graves violações aos seus direitos e prerrogativas. Constantemente, os órgãos de segurança interna procuravam implicar politicamente os advogados e intimidá-los e, ao longo da ditadura, muitos deles foram sequestrados e detidos. Heráclito Sobral Pinto, então o mais antigo e famoso criminalista do país, foi detido no dia seguinte à edição do AI-5, em Goiânia (GO), onde seria o paraninfo de uma turma de estudantes de Direito. Pouco depois, Evaristo de Moraes Filho também foi preso quando visitava um cliente na Ilha das Flores, no Rio de Janeiro ${ }^{698}$. Em 1970, Modesto da Silveira foi sequestrado quando já era um advogado reconhecido internacionalmente. Nesta ocasião, foi levado ao

\footnotetext{
${ }^{698}$ FERnANDES, Fernando Augusto Henriques. Voz Humana, op.cit., p.223.
} 
DOI-Codi/RJ, onde sofreu ameaças e torturas psicológicas; no dia seguinte, a OAB reagiu, indicando Evaristo de Moraes Filho e George Tavares como seus advogados de defesa, os quais por sua vez conseguiram libertá-lo rapidamente ${ }^{699}$.

Outros advogados foram presos e torturados antes do AI-5, tais como Vivaldo Vasconcellos, Wellington Cantal e Dimas Perrin. De acordo com Modesto da Silveira, até então a $\mathrm{OAB}(\mathrm{RJ})$ era dirigida por advogados ricos e de inclinação de direita. Mas, a partir de 1969, os advogados mais à esquerda uniram-se e renovaram a OAB (RJ), apresentando uma chapa de oposição com seis conselheiros liberais e progressistas. A maioria continuou sendo composta de conservadores, mas a conduta da OAB mudou e tornou-se mais atenta à proteção dos advogados de presos políticos ${ }^{700}$.

No início de novembro de 1970, uma prisão de advogados acabou por ter grande repercussão. Heleno Fragoso, George Tavares e Augusto Sussekind de Moraes Rego foram sequestrados no Rio de Janeiro. Fragoso foi preso em casa, durante a madrugada, quando dois homens, que diziam-se da Polícia Federal, o levaram para prestar esclarecimentos. Encapuzado, enfiaram-no num carro e o transportaram para local desconhecido, onde permaneceu encarcerado por dois dias. Lá ouviu as vozes dos outros dois advogados, mas ninguém apareceu para interrogá-los.

Na ocasião, Fragoso desempenhava o cargo de vice-presidente do Conselho Seccional da OAB. Em sessão permanente, a entidade enviou representantes à sede do I Exército para falar com o comandante, o general Sizeno Sarmento, mas não foram recebidos. Sarmento, entretanto, teria designado três equipes para localizar os advogados. A OAB enviou ao presidente Emílio G. Médici um ofício pedindo a libertação dos colegas $^{701}$. Na terceira noite, Fragoso foi levado encapuzado e deixado em lugar ermo no bairro de Laranjeiras, durante a madrugada. Os outros dois advogados foram libertados na mesma noite, em outros pontos da cidade [FrAGOSO, 1984:148].

A OAB fez um desagravo em sessão pública na qual houve discursos contundentes, os quais foram noticiados pela imprensa. As prisões galvanizaram os advogados, a OAB dirigiu-se ao Procurador-Geral da Justiça, Leopoldo Braga, solicitando a instauração de um inquérito policial. Este, o requisitou, mas não foi

\footnotetext{
${ }^{699}$ MoReIRA, Fernanda Machado. Modesto da Silveira: um soldado do humano. In: SÁ, Fernando; Munteal, Osvaldo e Martins, Paulo Emílio. Os advogados e a ditadura de 1964. A defesa dos perseguidos políticos no Brasil. Rio de Janeiro, Vozes, 2010, p.60-2.

${ }^{700}$ Idem, ibidem.

701 RochA, Jorge Luís. Heleno Cláudio Fragoso: um mestre nos tribunais de exceção. In: SÁ, Fernando; MunTeal, Osvaldo e Martins, Paulo Emílio. Op.cit., p.95.
} 
atendido. A partir desse episódio, de acordo com Heleno Fragoso, a OAB passou a adotar uma posição mais firme em defesa do retorno ao Estado de Direito [FRAGOSO, 1984:149].

Heleno Fragoso era ligado à Comissão Internacional de Juristas (CIJ), que apresentou a denúncia dessas prisões à Comissão Interamericana de Direitos Humanos (CIDH) da OEA. O Estado brasileiro defendeu-se por meio do diplomata Carlos Alberto Dunshee de Abranches alegando que não havia provas de que os advogados haviam sido sequestrados por agentes estatais [FRAGOso, 1984:149]. A investigação não prosseguiu $^{702}$. A prisão, contudo, valeu a Heleno Fragoso a perda da cadeira de Direito Penal na Faculdade Nacional de Direito (atual Faculdade de Direito da UFRJ) ${ }^{703}$.

Diversas prisões de advogados de presos políticos ocorreram com o objetivo de verificar possíveis ligações com organizações clandestinas e intimidá-los, mas os advogados não tinham militância partidária e nem atuavam como um grupo organizado, conforme nos contou Airton Soares:

\begin{abstract}
"Nunca houve um fórum de discussão entre advogados de presos políticos. Nós nunca nos reuníamos, às vezes, almoçávamos depois de uma audiência ou saíamos para beber no final do dia, mas era só isso. Cada um cuidava dos interesses do seu cliente, mesmo quando atuávamos no mesmo processo. Nós temos origens diversas. Havia advogados de presos políticos que mantinham toda uma estrutura profissional, com seus comprometimentos, seus escritórios, onde a advocacia de presos políticos era feita com prejuízo de eventuais clientes, por exemplo, a advocacia do José Carlos Dias, do Heleno Fragoso. A advocacia como a minha e a do Idibal, ou a do Virgílio era diferente, porque nós nunca tivemos grandes clientes, empresários, etc. O que nós tínhamos eram casos de família, casos trabalhistas, casos da justiça comum ou criminal. Toda aquela idiossincrasia que vinha contra você ser um advogado de presos políticos, como é que você vai prestar serviço para um empresário que tem um interesse controlado pelos caras que estavam sustentando a ditadura? Não ia, nunca. Nós tínhamos certeza disso, então, não tínhamos limites na nossa atuação, nós atuávamos dentro da auditoria militar e também fora da auditoria [...] para evitar outros assassinatos, que eram de fato cometidos $^{704}$."
\end{abstract}

Outra prisão que gerou tensão entre os advogados de presos políticos foi a de Maria Luiza Flores Cunha Bierrenbach no dia 8 de novembro de 1971, em São Paulo. Maria Luiza atuava no escritório de José Carlos Dias, onde ingressou em 1967, quando ainda cursava o $2^{\circ}$. ano da faculdade de direito, na PUC/SP. O escritório atendia perseguidos políticos antes mesmo de 1968. Maria Luiza foi detida por agentes do DOICodi/SP, onde a mantiveram até o dia 12. Inicialmente, ela levou bofetadas e foi

\footnotetext{
${ }^{702}$ V. sobre os dois principais casos na CIDH da OEA em TELES, Janaina. Os herdeiros da memória, op.cit.; e GreEn, James N. Apesar de Vocês. op.cit., p.278-306. V. tb. resumos dos casos brasileiros na OEA. Agradeço a James Green por fornecer esses dados.

${ }^{703}$ SÁ, Fernando; MunTEAL, Osvaldo e MARTINS, Paulo Emílio. op.cit., p.94.

${ }^{704}$ Entrevista concedida por Airton Soares à autora. Idem, ibidem.
} 
interrogada sem capuz pelas três equipes de interrogatório e, em especial, por "Jesus Cristo”, o delegado de polícia Dirceu Gravina. Ela relatou-nos que descobriu o motivo da sua prisão apenas no quarto dia, quando já haviam confirmado que não estava envolvida com qualquer grupo guerrilheiro. Mesmo depois de esclarecida esta informação, foi torturada por “JC” com choques elétricos, sentada e amarrada a uma cadeira ${ }^{705}$ :

\begin{abstract}
"Ele me disse: 'Se você sair viva daqui, o que não vai acontecer, você pode me procurar no futuro. Eu sou o chefe, sou o Jesus Cristo'. Ele falava isso e virava a manivela para dar choque. Ele também dizia: 'Que militante de direitos humanos coisa nenhuma, nada disso, vocês estão envolvidos'. [...] Havia umas ameaças assim: 'Vamos prender todos os advogados de direitos humanos, colocá-los num avião e soltar na Amazônia.' Nos outros interrogatórios, eles perguntavam qual era a minha opção política, o que eu pensava, quem pagava meus honorários, quais eram os meus contatos no exterior, o que eu pensava do comunismo. [...] Eu fui presa sem nenhuma acusação, fiquei três dias lá sem saber porque estava presa. No terceiro ou quarto dia, eu descobri o motivo: teriam achado num ‘aparelho' um manuscrito do Carlos Eduardo Pires Fleury, que tinha sido banido do país e que foi meu colega e cliente no escritório. ${ }^{706,}$
\end{abstract}

Carlos Eduardo P. Fleury era dirigente do Molipo e havia sido banido, após ser libertado juntamente com outros 39 militantes, em troca do embaixador alemão no Brasil, Ludwig von Holleben, sequestrado em junho de 1970 pela VPR e a ALN. Ele e outros militantes do Molipo retornaram ao país clandestinamente no segundo semestre de 1971. No dia 4 de novembro, um “aparelho” do Molipo, localizado na Vila Prudente, em São Paulo, foi descoberto e invadido por agentes do DOI-Codi. Na casa, encontraram um papel, enrolado dentro de um pincel de barbeador, contendo oito nomes, entre os quais estava o de Maria Luiza, com o antigo número da casa dela indicado ao lado. A família de Fleury era vizinha e amiga da de Maria Luiza, assim, alguns dias depois, os agentes de segurança convenceram-se de que ela de fato era apenas sua advogada e amiga ${ }^{707}$.

Neste local foram presos dois militantes do Molipo, Aylton Adalberto Mortati e José Roberto Arantes de Almeida, mas apenas a morte de Arantes foi divulgada na imprensa no dia 9 de novembro. Maria Luiza sofreu torturas e ameaças, porque os órgãos de segurança queriam informações que levassem à localização de Carlos Eduardo Pires Fleury, assassinado no dia 10 de dezembro de 1971, no Rio de Janeiro [Dossiê Ditadura, 2009].

\footnotetext{
${ }^{705}$ Entrevista concedida por Maria Luiza Flores Cunha Bierrenbach (Maria Luiza Bierrenbach) à autora. SP, 19/02/2011.

${ }^{706}$ V. Depoimento de Maria Luiza Flores Cunha Bierrenbach, em MERLino, Tatiana e OJEDA, Igor. Direito à memória e à verdade: Luta, substantivo feminino. São Paulo, Caros Amigos, 2010, p.69.

${ }^{707}$ Entrevista concedida por Maria Luiza Flores Cunha Bierrenbach à autora. Idem, ibidem
} 
Muitas prisões de advogados de presos políticos ocorreram em São Paulo. Um dos jovens advogados mais atuantes em São Paulo, Virgílio Egydio Lopes Enei, ficou preso por vários dias no DOI-Codi (SP), em 1972. Formado pela Faculdade de Direito da USP, ingressou na carreira trabalhando no escritório de Aldo Lins e Silva, que advogava para comunistas do PCB, como Luis Carlos Prestes e Moacir Longo, vereador em São Paulo quando do golpe de 1964. Desde 1967, ainda estudante, trabalhou na defesa de presos políticos, mas passou à defesa sistemática de militantes perseguidos depois de terminados os estudos, a partir de 1969. Detido diversas vezes, em 1972, porém, Virgílio foi levado da II Auditoria Militar para o DOI-Codi (SP), onde ficou 18 dias preso por ter tentado levar dos autos de um processo o atestado de óbito de Aylton Adalberto Mortati, militante do Molipo considerado desaparecido desde 4 de novembro de 1971, apesar de diversos presos políticos terem ouvido dos torturadores que Mortati havia sido assassinado nas dependências do DOI-Codi [Dossiê Ditadura, 2009: 285-6].

Virgílio era advogado da mãe de Aylton, Carmen Sobrinho Mortati. Desesperada, ela procurava informações sobre o filho em todos os lugares. De acordo com Virgílio: “[...] ela fez de tudo, tudo, tudo por esse filho. Chateava o pessoal da Auditoria, chateava o Fleury, chateava o Nemer Jorge ${ }^{708}$. Ela me encantava, eu gostava muito dela. Ela tinha uma pensão aqui perto, na rua Rafael de Barros, se você descesse um pouquinho já estava na Oban [DOI-Codi]. [...] Eu sempre comia lá.” Virgílo Enei contou-nos como foi levado preso e interrogado:

"Eu conhecia muita gente, bebia e jogava cartas com militares e policiais nos bares próximos da Auditoria Militar e do DOI-Codi. Eu dava um dinheirinho para o Salaberry e outros e ficávamos conversando e jogando caxeta. [...] Um dia, cedo ainda, estava conversando com ele na II Auditoria, não tinham nem começado as audiências, e não havia ninguém. Eu vi uma série de documentos numa mesinha e pedi para ele se não dava para quebrar um galho e tirar o xerox de um documento. Ele foi tirar, eu fiquei sozinho na sala e catei o atestado do Aylton. Na saída da Auditoria fui surpreendido com o atestado no bolso pelo sargento Roberto, que era meu amigo também. E fui parar na Oban.

[...] Em mim eles deram uns 'encontrões', desses que você dá até em filhos grandinhos. Essas bobagens assim, mas vi muita gente ser torturada [...]. Colocaram-me o capuz preto, que com um certo jeito você vê tudo. Eu fiquei em vários lugares, assisti interrogatórios, mas não fiquei em cela com os presos, fiquei na secretaria.

[...] Eles me ameaçaram muito durante os interrogatórios [...]. Tinha uns lugares onde se interrogava sem tortura, uma espécie de secretaria. Eles ameaçavam de trazer a cadeira do dragão, o pau de arara. [...] Havia uns banquinhos que você podia dormir.

Eles perguntavam também do meu imposto de renda, porque eu era meio enrolado com essas coisas [...]."

\footnotetext{
${ }^{708}$ Delegado Nemer Jorge, diretor da D.I. do Deops/SP, ficou famoso em 1967, quando prendeu o Bandido da Luz Vermelha.

${ }^{709}$ V. entrevista concedida por Virgílio Egydio Lopes Enei à autora. Idem, ibidem.
} 
Os órgãos de segurança sempre tentavam implicar politicamente os advogados de presos políticos tentando forjar uma identificação partidária com seus clientes. Idibal Pivetta e outros advogados eram taxados de "comunistas" ou de "advogados de terroristas". ${ }^{710}$ Pivetta atuou na defesa de mais de 600 pessoas e embora não fosse militante organizado em algum partido político, era solidário aos perseguidos políticos. Não raro, era difícil criar condições para advogar ou mesmo constituir-se como advogado de determinado cliente, conforme seu relato:

"Eu tive vários casos, dos quais não vou citar nomes, de caras que foram ministros de estado, muito ricos, cujos filhos foram meus clientes. Um dia, um deles vai ao meu escritório com um puta aparato, com seguranças, na época já havia essa coisa de usar segurança, falar comigo se eu podia deixar a causa do filho dele de lado, porque eu deveria compreender que com um advogado comunista, certamente, os militares iam condenar o filho. Eu falei: '- A decisão é do seu filho, não é minha. Quem me chamou foi o seu filho'. O cara não aceitou, 'o garoto', o filho dele, não aceitou. Falou: 'Não, eu quero continuar com o Idibal, ele é o meu advogado. O pai ainda disse '- Mas a gente acerta'. E eu falei: ‘- Agora o senhor está engrossando, acerta o quê?’ Ele queria me dar dinheiro para eu deixar de ser advogado do filho dele. Esse cara foi absolvido depois."711

Alguns presos haviam experimentado processos de tortura avassaladores, nos quais foram mantidos isolados longos períodos de tempo. Além de ter de suportar essa situação de grande pressão e insegurança, persistia entre muitos presos políticos o sectarismo político. Jesus Paredes Sotto deu-nos um exemplo do clima vivido naquele período. Depois de algum tempo preso, ele teve contato com uma advogada, mas recusava-se a falar com ela ou qualquer outra pessoa: “- Eu me lembro que ela queria que eu falasse e eu não falava. Aí eu, na minha simplicidade operaria, perguntei: '- Você tem consciência da luta de classes?' Ela começou a rir e disse: '- Eu sou chamada de 'cadela comunista!' (risos) ${ }^{712}$."

Inicialmente, Idibal Pivetta montou um escritório sozinho, mas a demanda para atuar como advogado de presos políticos cresceu muito após o AI-5 e ele convidou Airton Soares para trabalhar com ele. Desde o início, foi necessário cercar-se de recursos que assegurassem a legalidade da atuação dos advogados, conforme nos relatou Airton Soares:

\footnotetext{
${ }^{710}$ Entrevista concedida por Virgílio Lopes Enei à autora. Idem, ibidem.

${ }^{711}$ Entrevista concedida por Idibal Pivetta à autora. Idem, ibidem.

${ }^{712}$ Entrevista concedida por Jesus Paredes Sotto à autora. Idem, ibidem.
} 
“[...] Comecei com outros como o Marco Aurélio Ribeiro, que era o presidente do XI de Agosto, e depois participou também desse processo de dar assistência jurídica àqueles que não podiam pagar advogado e atuavam no departamento jurídico do Centro Acadêmico. Bom, saio da faculdade, [...] e sou convidado pelo Idibal Pivetta, nós tínhamos amigos comuns, para ir trabalhar no escritório dele. Ele levava esse escritório praticamente sozinho, só com uma recepcionista, e ficava próximo ao Largo São Francisco. Foi lá, então, que comecei a atuar como advogado de preso político. O Idibal tinha várias atividades, ele era um teatrólogo acima de tudo, mas era um advogado que atendia causas as mais variadas, tudo no interesse dos setores populares. O Idibal era um advogado que fez da atuação nas Auditorias Militares um sacerdócio, porque ele não perguntava para os clientes se podiam pagar ou não, ele primeiro procurava assegurar-se de que poderia ajudar, desde a localização do preso até obter conforto para as famílias. E foi nessa linha que nós simplesmente contribuíamos com ele. Mais tarde, surgiu um outro estudante que queria advogar para presos políticos [...], o Luiz Eduardo Greenhalg. [...] Primeiro tínhamos um escritório pequeno, depois transferimo-nos para uma casa na rua Adoniran Barbosa, antiga travessa Brigadeiro, creio que em 1970. O escritório passou a ser uma espécie de bastião da luta contra a ditadura, porque lá funcionava o escritório de advocacia para presos políticos, o escritório do teatro do Idibal, o União Olho Vivo, e funcionava também, dando um pano de fundo para a coisa toda, o diretório distrital do MDB. Muito depois, passou a funcionar a sede do CBA.

[...] eu era do setor jovem do MDB, porque sempre achei que nós tínhamos que transformar o MDB em um partido de oposição, coisa que não era. O escritório era a sede do diretório do MDB da Bela Vista, que era uma fachada legal, assegurada, não é? E foi por aí que entrei nessa atividade e fui eleito deputado federal em $1974^{713}$."

Outra prisão de um advogado que gerou repercussão foi a de Idibal Pivetta, no dia 6 de maio de 1973, em São Paulo. Este, talvez, tenha sido o caso de confinamento mais longo de um advogado, que atuava apenas no exercício da profissão. Pivetta foi preso pelo DOI-CODI (SP), depois da apresentação do espetáculo Rei Momo, quando levava para casa uma atriz do grupo “Teatro União Olho Vivo”, dirigido por ele ${ }^{714}$. Tânia Mendes e o seu namorado, Gabriel, eram militantes da ALN e estavam sendo procurados pelos órgãos de segurança. Vários militantes e estudantes haviam sido presos desde março daquele ano, quando foi assassinado Alexandre Vannucchi Leme, estudante da USP e membro da ALN. Pivetta permaneceu preso pouco mais de 2 meses, tendo ficado 8 dias no DOI-Codi sendo interrogado. No dia 14 de maio foi encaminhado ao DEOPS e indiciado no Inquérito Policial no.14/73. Voltou ao DOI para prestar declarações e em junho foi levado para o Presídio do Hipódromo, localizado no bairro da Mooca [VIEIRA, 2007: 300-1]:

“[...] eu e um cara, que depois veio até a ser conselheiro [da OAB], o Roberto Cunha Azzi, fomos levar esta menina para casa dela. Quando chegamos [...] eles entraram dando

\footnotetext{
${ }^{713}$ Entrevista concedida por Airton Soares à autora. Idem, ibidem.

${ }^{714}$ Rei Momo estreou em 06/11/72. O “Teatro União Olho Vivo” ganhou este nome quando separou-se amigavelmente do CA XI Agosto, em fevereiro de 1973, assumindo um caráter e atuação mais popular. V. VIEIRA, César. Em busca de um teatro popular. op.cit., p.96-7, 105.
} 
porrada para tudo quanto é lado e nos prenderam, não sabiam que eu era advogado de preso político e levaram-nos para o DOI-CODI. Quando chegamos lá, dei o meu nome e eles deram um pique-pique! Estavam presos lá 18 clientes meus. Tinha uns 30 presos, o Adriano Diogo, esse pessoal todo...

[...] Eles foram para a sede do grupo [União Olho Vivo], que era numa fábrica aqui no Itaim de um amigo nosso que cedia o espaço para a gente ensaiar, pegaram todo o material de luz, som e sumiram com tudo. Vieram aqui na minha casa, estavam a minha mãe e minha tia, elas levaram um puta susto. Entraram no meu quarto e pegaram um revólver 32 que eu tinha, pegaram tudo quanto era livro. [...] disseram que eu estava andando armado durante o espetáculo. Eu escrevia e fazia luz do espetáculo, imagine, com um revólver! [...] Eles não me bateram mais, além do primeiro dia, quando eu cheguei fiquei com o olho pulado para fora, [levei] uma puta porrada, [fiquei] todo machucado. Quando [...] eles pegaram o livro-caixa do meu escritório e tinha apenas um cara que tinha pago \$ 5.000 'dinheiros' e eu fui considerado um ladrão! Mas se não tinha ninguém anotado era porque praticamente ninguém pagava! Eles disseram que eu recebia ouro de Moscou [...]. A fixação desses caras era saber de dinheiro e mulher [...] era um negócio terrível, que me marcou [...]. A outra coisa que eles perguntavam muito era a questão da corrupção entre eles. Eles queriam saber quem tinha levado dinheiro para abrandar a prisão de militantes. Eu negava terminantemente [...], mas deve ter acontecido alguma coisa, porque eles me interrogaram muito sobre isso. Eles queriam saber: '- Quem leva dinheiro aqui? Quem vocês conseguem tirar de processo?'

[...] Desde esse momento, quando descobriram que eu era advogado de presos políticos, não me bateram mais com porrada, mas me deixaram de pé por horas, sempre com capuz, nos interrogatórios. Durante uma semana foi bem fodido mesmo, com capuz sempre, e horas e mais horas de pé $[\ldots]^{715}$."

No Presídio do Hipódromo, o diretor da instituição era um antigo colega de peladas de futebol de Pivetta, o qual propôs deixá-lo preso na sala da diretoria, onde havia um pouco mais de conforto. Ele consultou os demais presos políticos sobre se deveria aceitar a proposta:

“Subi e conversei. [...] Eu disse: ‘- Pessoal, [o diretor] está querendo que eu fique lá, mas não quero, quero ficar aqui com vocês, o que vocês acham?’. [Para mim], ficar lá em cima com o pessoal todo era muito mais gostoso (risos). Eles discutiram e falaram: '- Fica lá que você pode ver muita coisa e contar pra gente’. Eu desci e [...] fiquei lá embaixo, na sala da diretoria e dormia junto com um médico que era drogado e tinha alucinações. Eu pensava: quero sair daqui porque esse cara é pior que tudo, ele gritava de noite. [...] Eu via tudo que acontecia ali, via, por exemplo, os caras do DOI-CODI chegando. No final, eu tinha acesso ao telefone, mas não falava essas coisas por telefone. Numa visita, combinei com o Airton [Soares] e o Paulo Gerab: '- Quando tinha que deixar um recado $\mathrm{X}$, [eu ligava e dizia] vem para cá, porque é coisa urgente’. Daí eles iam para o Hipódromo e eu passava: '- Fulano de tal foi devolvido para o DOPS ou para o DOICODI'. Isso era um negócio importante. Ou então eu dizia: '- Chegou fulano de tal aqui', porque você não conseguia esse tipo de informação facilmente. No final, eles me deram uma grande possibilidade de fuga, deixaram a porta aberta, se eu saísse andando poderia ir embora. Mas não fui, por vários motivos, primeiro porque eu sabia que eles não poderiam me condenar. Ali não tinha tortura e eles não iam me condenar. O que de fato aconteceu, fui processado mas não condenado. Eu não ia me meter a fugir bestamente,

\footnotetext{
${ }^{715}$ Entrevista concedida por Idibal Pivetta à autora, Idem, ibidem.
} 
podia ser uma cilada, um pretexto para te dar um tiro na saída, mas acho que não. $\mathrm{Na}$ minha saída, lembro-me do pessoal cantando a Internacional na janela., ${ }^{716}$

Libertado em 11 de julho de 1973, Idibal Pivetta foi processado na Justiça Militar acusado de ser um dos organizadores de "um grupo subversivo independente que mantinha estreitas ligações" com membros da ALN e do Molipo, chamado "Comitê de Solidariedade Revolucionária” (CSR) [VIEIRA, 2007: 300]. De fato, em meados de 1972, surgiu em São Paulo uma articulação de um pequeno grupo de ex-militantes com este nome, que procurava uma resposta para a desarticulação de diversas organizações de esquerda em curso naquele momento. O objetivo do grupo era desenvolver um trabalho de solidariedade aos presos políticos paulistas. Este projeto surgiu após a greve de fome de 33 dias realizada por um setor dos presos políticos de São Paulo, em junho de 1972. A abrangência das propostas ampliou-se, o grupo pretendia também “dar assistência política e ideológica às grandes massas, forjando os seus instrumentos de luta (legais) contra a ditadura militar fascista". 717

O grupo era heterogêneo, seu principal articulador foi Delamare Machado da Silva, um antigo militante do PCB. Uma de suas filhas, Lenira Machado Dantas, e seu genro, Altino Rodrigues Dantas, eram militantes do PRT e estavam presos. Outro integrante do grupo era um ex-preso político, César Augusto S. Castiglioni, havia militado na ALN e saíra da prisão um ano antes. Dois militares também compunham o grupo que realizava contatos esparsos com militantes do Molipo, ALN e PORT. O grupo pretendia lançar, conjuntamente com o Molipo, uma revista com o título "Luta Ideológica”. As prisões de maio de 1973, contudo, desbarataram o grupo. De acordo com o projeto BNM, essas prisões desencadearam outras, acarretando “[...] a localização do último núcleo de militantes do Molipo [...] sendo então assassinados [...] Márcio Beck Machado e Maria Augusta Thomaz, que estavam vivendo como lavradores no sul de Goiás, entre as cidades de Jataí e Rio Verde $[. . .]^{718}$.”

Em 8 de fevereiro de 1974, a ação penal foi considerada improcedente e o réu foi absolvido por unanimidade pela II Auditoria da 2a . CJM. O advogado de Pivetta, Miguel Ait, redigiu a defesa e o réu fez a contestação oral. ${ }^{719}$ Em seguida, o Centro Acadêmico XI de Agosto reproduziu o memorando de Pivetta entregue ao Conselho de Justiça

\footnotetext{
${ }^{716}$ Idem, ibidem.

${ }^{717}$ Perfil dos atingidos. op.cit., p.105-6.

${ }^{718}$ Perfil dos atingidos. op.cit., p.106. V. Apelação 40.259, AEL.

${ }^{719}$ Entrevista concedida por Idibal Pivetta à autora. SP, 06/02/2011.
} 
Militar, com o sugestivo título de "Da defesa do exercício profissional da advocacia”, com seus argumentos apresentados em juízo. De acordo com Pivetta, uma das motivações que norteou o IPM e a denúncia do Ministério Público Militar foi a detenção dele e mais sete advogados, em maio de 1972, que culminou com o ato de desagravo na OAB/SP, em agosto daquele ano. Ele demonstrou a inconsistência e ilegalidade das provas apresentadas na denúncia, destacou o pedido de absolvição do promotor do Ministério Público Militar, Henrique Vailati Filho, o qual reconheceu que Pivetta não poderia ser condenado pelo art.14 da LSN, pois: "Não formou, não filiou-se, não manteve, não organizou, nem tentou reorganizar” qualquer tipo de associação ou partido político ${ }^{720}$. Pivetta, então, fez suas considerações finais, reputadas "radicais", mas que dão um exemplo do tom de suas defesas nas Auditorias Militares e do clima vivido pelos advogados de presos políticos naquele período:

\begin{abstract}
“Alguém, qualquer um, poderá então argumentar: - Mas, afinal, fez-se justiça. A absolvição foi pedida! Não. Não se trata apenas de um indivíduo. O que está em causa é a própria essência do Direito. Do Direito de Defesa e Assistência dos que poderão vir a ser submetidos às mesmas humilhações. $\mathrm{E}$ - culpados ou inocentes - não terão, talvez, escudo algum.

Danos, e danos irreparáveis, já sofreu este defensor: a publicidade negativa; o temor de futuros clientes em tê-lo como patrono; as pesquisas sobre textos teatrais apreendidas; a autocensura no ato de criar uma peça teatral; a impossibilidade de enviar textos teatrais para análise dos órgãos de censura na certeza de pré-julgamento motivado pela prisão...

Srs. membros do Conselho de Justiça:

A origem de todos esses desmandos não está em determinado órgão policial. Não está em agentes que cumprem ou deixam de cumprir incisos legais.

A origem está na lei!

Na lei que permite esses erros. Na lei que estabelece procedimentos inumanos. Em épocas anteriores denunciamos falhas de outras leis e o fizemos publicamente. E essa lei - que reputamos iníqua - não é hoje a primeira vez que a denunciamos. Já o fizemos desta tribuna, junto à Ordem dos Advogados do Brasil e também junto ao Ministério da Justiça. Uma lei que deixa dúvidas sobre o prazo para a comunicação de prisões é imperfeita. Uma lei que deixa dúvidas sobre a forma de contato do preso com seu defensor fere o Direito. E ao renovar, hoje, nossa denúncia contra a iniquidade dessa lei, contra a ilegitimidade dessa lei, estamos obedecendo o preceito legal (art.87 - 1 - da lei 4.215 "Contribuir para o aperfeiçoamento das Instituições Jurídicas”) que é coletivo e o preceito moral que é nosso.

[...] Peço a máxima atenção para as palavras que agora vou ler. Palavras que não são minhas. [...] palavras de um militar:

[...] 'O primeiro dos nossos problemas a ser revisto, no tempo e na significação, é o da normalidade legal. A lei no sentido secular - da vontade do povo, como na definição romana de Caio ou de Justiniano. O máximo problema que se nos depara é o da recuperação definitiva da liberdade. Porque dele dependerão todos os outros: a liberdade sindical, o direito de greve, o sufrágio liberto de quaisquer constrangimentos, a plenitude do habeas corpus, a gratuidade do ensino em todos os graus. É na força dos regimes legais
\end{abstract}

\footnotetext{
720 "Razões Finais orais do advogado Idibal Almeida Pivetta (César Vieira) no proc. 23/73 da 2a. Auditoria da 2ª . CM- S. Paulo”, 1974. Arquivo Pessoal de Idibal Pivetta; e VIEIRA, C. op.cit., p.300.
} 
em que a vontade dos governantes tenha por base a lei, lei no sentido filosófico de que é necessário que a legislação tenha sua BASE NA SOBERANIA POPULAR, QUE TODOS ESSES DONS FRUTIFICARÃO'.

O autor dessas palavras, srs. membros do Conselho de Justiça, é o Marechal do $\mathrm{Ar}$ Eduardo Gomes.

Confiantes na justiça e no direito esperamos mais do que a vossa decisão, esperamos a vossa atenção para a iniquidade das leis, para a ilegitimidade das leis. Hoje nos curvamos diante de decisões oriundas dessas leis. Amanhã nos levantaremos diante da soberania pura e serena do Estado de Direito ${ }^{721}$."

Em 1974, outro fato ocorreu visando intimidar os advogados de presos políticos.

O escritório de Belisário dos Santos Jr., Regina Pasquale e Rosa Cardoso, localizado na

av. Brigadeiro Luiz Antônio, foi invadido:

"Foi intimidação. Na realidade, eles destruíram a porta e espalharam os papéis. Havia vários núcleos de papéis espalhados, também pegaram dinheiro e deixaram à vista, para mostrar que eles não tinham pegado dinheiro. Alguns meses depois, recebi um recado de um oficial do DOI-Codi/SP, são essas coisas engraçadas que aconteciam... Ele disse que ficou muito aliviado de não descobrir nada ligado às organizações clandestinas no meu escritório!

[...] Nós representamos à Ordem dos Advogados e tiramos foto. Chamei um colega fotógrafo, que era meu amigo, e tiramos todas as fotos. Anexamos tudo e representamos à Ordem dos Advogados imediatamente. A Ordem não tomou nenhuma providência, o encarregado do processo era um cidadão assessor jurídico do II Exército e membro da Ordem, mas só posteriormente eu soube. Não me recordo o nome dele, já falecido, mas ele ficou anos com o processo, sentou em cima do processo. O processo só veio a ter algum acompanhamento em 1976, quando o Zé Carlos Dias entrou na Ordem e me perguntou se eu queria dar prosseguimento. Mas anos depois, não tinha o menor sentido tentar apurar o que aconteceu. Eu tenho as fotos até hoje ${ }^{722}$."

José Carlos Dias, que atuara como advogado de Idibal Pivetta, tendo procurado por ele pessoalmente na sede do DOI-Codi/SP, quando assumiu a presidência da $\mathrm{OAB} / \mathrm{SP}$, tomou a iniciativa de realizar um ato público de desagravo à prisão de Pivetta, em 1973. O que somente veio a ocorrer em 26 de outubro de 1976, ocasião em que Pivetta repetiu seu discurso feito no julgamento do recurso da promotoria no STM, onde foi absolvido por unanimidade ${ }^{723}$. A solenidade transcorreu em clima de tensão, com a presença acintosa de policiais e ameaça de atentado a bomba. O pronunciamento de Pivetta foi crítico e contundente, mais uma vez. Ele citou Miguel Seabra Fagundes, mas também Eduardo Gomes e Júlio de Mesquita Filho, motivo pelo qual foi criticado:

\footnotetext{
${ }^{721}$ Idem, ibidem. Grifos do autor.

${ }^{722}$ Entrevista concedida por Belisário dos Santos Jr. à autora. Idem, ibidem.

${ }^{723}$ Nos casos de absolvições decretadas pelo Conselho de Justiça, o procurador, ainda que concordasse com a absolvição, era obrigado a recorrer da decisão ao STM, conforme o Artigo 73 do D.L. n 898/69. Poderia recorrer das condenações se as considerasse brandas.
} 
“[...] Vivemos hoje a dura realidade de um sistema legal de encomenda. Um sistema legal feito 'a pedidos', por juristas de aluguel e por homens das fórmulas salvadoras do momento. Um sistema que fechou partidos, amordaçou a imprensa, transformou o Congresso num conglomerado submisso e apático; que estremeceu o judiciário; desvalorizou o exercício do voto; extinguiu o habeas corpus; tentou alienar os estudantes e marginalizou a maior parte da população de uma vida digna e de uma participação nos destinos nacionais.

Com base em meras ordenações e não em leis, esse sistema legal de encomenda gerou leis de segurança, leis de imprensa e decretos do teor de um $477 . .$. Ordenações, sim! Pois que nenhuma delas traz em si a marca que as legitime: a de terem se originado na única e verdadeira fonte de lei que é a vontade popular.

[...] E o coronel, encarregado do 'inquérito' queria saber qual a nossa organização subversiva? Onde ficava o nosso aparelho? [...] Como convencê-lo de que nossa organização era a OAB? Era a SBAT (Sociedade Brasileira de Autores Teatrais), onde estávamos registrados com o nome artístico de César Vieira, para tentar escapar da censura?

[...] E a sentença trouxe candente, gritante, a assertiva de que o AUTO DE BUSCA E APREENSÃO - motivo de nossa detenção e de todo o feito - FORA FORJADO PELA AUTORIDADE!!!

[...] O que visavam com a prisão e a intimidação de quase todos os advogados que militam na Justiça Militar? Almejavam que nós deixássemos de exercer a profissão nessa área. E nesse afã prenderam, intimaram, invadiram, algemaram e processaram. Mas não conseguiram. Nós continuamos. Nós continuamos resistindo. [...] E nunca, no decorrer dessa tumultuada trajetória, estivemos sós.

[...] É o momento de ver, com a clareza de um Aliomar Baleeiro e a objetividade de um Rodrigo Octávio, que '[...] nenhum ditador, no correr da história, abriu mão espontaneamente de seus poderes discricionários.' E '[...] que é a hora da volta à normalidade democrática, onde o poder deixará de ser lei e a lei voltará a ser poder., "724

Apesar das enormes dificuldades, a resistência empreendida de dentro dos cárceres somou-se à dos advogados de defesa e dos familiares de presos políticos, estabelecendo uma rede de solidariedade que, pouco a pouco, conseguiu sensibilizar a sociedade civil e impor desgastes à ditadura. Advogados e familiares assumiram um papel crucial ao estabeleceram a interlocução dos presos políticos com “o mundo exterior”, com os grupos de defesa dos direitos humanos, autoridades religiosas e, em especial, a Comissão Justiça e Paz, a CNBB e a OAB, assim como com as organizações internacionais, que contribuíram para divulgar que no Brasil havia presos políticos e, dessa maneira, tirá-los do isolamento imposto pela ditadura.

Neste sub-capítulo, pudemos considerar a maneira como advogados, engajados na luta contra os abusos dos direitos humanos e, mais amplamente, na luta de resistência à ditadura por meio do apoio à militância, muitas vezes sofreram diretamente as consequências de seus atos. O que se destaca para além deste truísmo, pudemos considerar que as interfaces entre o exercício da magistratura (dentro dos limites

\footnotetext{
${ }^{724}$ PivetTA, Idibal de Almeida. O advogado nos tempos da cólera. Discurso do ato de desagravo a Idibal Pivetta, OAB/SP, 26/10/76. Grifos do autor. Arquivo pessoal de Idibal Pivetta.
} 
outorgados pelo momento político) e a atuação militante foram, em alguns casos, particularmente engajadas, gerando condutas que entrelaçaram luta de resistência e atuação profissional - não sendo de se desconsiderar o papel paradigmático de alguns destes advogados na consolidação de redes de solidariedade aos perseguidos políticos ainda pouco difundido - que salvaguardaram a militância em diversas ocasiões.

\subsection{As estratégias de defesa na Justiça Militar}

Na Justiça Militar, as denúncias por crimes supostamente cometidos contra a Segurança Nacional eram, em geral, vagas e mal formuladas. Eram evidentes as imprecisões das definições dos crimes, o que permitia o amplificação de sua tipificação e a violação de direitos fundamentais. A legalidade de exceção gradualmente imposta, constantemente desrespeitava os princípios da reserva legal e da taxatividade, o quais respectivamente ganham sentido à luz do princípio da inexistência de crime sem enquadramento legal previamente definido e do princípio de que um crime deve ser definido de maneira clarividente e precisa [BNM, 1989]. A ruptura com tais princípios visava, entre outros objetivos, inibir divergências políticas.

Nos processos por crimes políticos na Justiça Militar, a acusação mais comum dirigida contra os denunciados referia-se ao crime de militância em organizações partidárias clandestinas ${ }^{725}$. Este crime estava previsto nos artigos 14 e 43 da Lei de Segurança Nacional (Decreto-lei 898/69). O artigo 43 punia as tentativas de ou a efetiva reorganização de grupos, associações ou partidos políticos dissolvidos ou suspensos por lei que exercessem atividades “perigosas ou prejudiciais à segurança nacional”726. A pena estabelecida para esse delito variava de 2 a 5 anos de reclusão. Neste caso, os militantes do antigo PCB e os ativistas de entidades como a UNE eram os principais atingidos.

$\mathrm{O}$ artigo $14^{\circ}$., por seu turno, previa a punição às atividades de formar, filiar-se ou manter associação ou partido político que exercessem uma atuação perigosa ou prejudicial à segurança nacional. As penas para esses delitos eram de 2 a 5 anos de reclusão para seus organizadores e de 6 meses a 2 anos para seus filiados e

\footnotetext{
${ }^{725}$ Perfil dos atingidos. op.cit., p.12.

726 "Reorganizar ou tentar reorganizar, de fato ou de direito, ainda que sob nome ou forma simulada, partido político ou associação, dissolvidos por força de disposição legal, ou que exerça atividades prejudiciais ou perigosas à segurança nacional, ou fazê-lo funcionar nas mesmas condições, quando legalmente suspenso.” O Decreto-Lei 898/69 foi a LSN mais dura, foram utilizadas outras versões anteriores, a 314 e a 510. Estas são as três LSN, nas quais foram enquadrados os presos políticos desse período.
} 
mantenedores $^{727}$. Eram enquadrados neste artigo os militantes de agrupamentos armados e demais grupos que organizaram-se após o golpe de 1964 ou que nunca tiveram existência legal. ${ }^{728}$

A partir de 1969, com o crescimento das organizações de luta armada, muitos réus foram enquadrados no art.14, mas eram acusados, cumulativamente, em mais de um crime, em função de sua participação em ações armadas como assalto a banco e sequestro, definidos em outros artigos. Os artigos 26, 27 e 28, por exemplo, eram bastante similares, sobrepunham-se e não definiam claramente os crimes que pretendiam punir ${ }^{729}$ o que abria espaço para uma vasta gama de possibilidades de interpretação da lei, a várias condenações pelo mesmo crime e punições mais severas.

Apesar das dificuldades e riscos pessoais que os advogados enfrentavam, comumente demonstravam tecnicamente que os artigos 14 e 43 eram inaplicáveis a muitos dos casos analisados em diversos processos políticos [FRAGOSO, 1984:156]. Esses argumentos, muitas vezes, não eram aceitos nas Auditorias Militares, não obstante, os advogados conseguiam sensibilizar alguns juízes togados ou os tribunais da instância de recurso, o Superior Tribunal Militar (STM) ou o Supremo Tribunal Federal (STF) ${ }^{730}$.

Os presos políticos incursos em diversos processos na Justiça Militar, em geral aqueles ligados à luta armada urbana, eram levados muitas vezes às Auditorias Militares, pois normalmente para cada ação penal o acusado deveria comparecer pelo menos a quatro audiências: a de interrogatório, a de oitiva de testemunhas de acusação, a de oitiva de testemunhas de defesa e a do julgamento. Alguns prisioneiros chegaram a responder trinta processos e compareceram mais de cem vezes às Auditorias. Essas passagens pelas auditorias militares, não raro, podiam converter-se em parte dos castigos, pois alguns trajetos eram feitos, propositalmente, nas piores condições possíveis ou sob ameaças [REZENDE; BENEDITO, 2000: 146].

A principal estratégia de defesa estabelecida pelos advogados de presos políticos era a de questionar a prova do inquérito policial, quando esta era constituída exclusivamente pela confissão do acusado e dos co-réus. Os advogados argumentavam que elas haviam sido feitas mediante coação irresistível. Muitos acusados retratavam-se

\footnotetext{
727 “Formar, filiar-se ou manter associação de qualquer titulo, comitê, entidade de classe ou agrupamento que, sob a orientação ou com o auxílio de governo estrangeiro ou organização internacional, exerça atividades prejudiciais ou perigosas à Segurança Nacional”. V. Decreto-Lei 898/69.

${ }^{728}$ V. FraGoso, Heleno C. op.cit., p.155; e entrevista concedida por Airton Soares, op.cit.

${ }^{729}$ V. Decreto-Lei 898/69. E entrevista concedida por Belisário dos Santos Jr. à autora. Idem, ibidem.

${ }^{730}$ V. entrevista concedida por Airton Soares à autora. Idem, ibidem; e entrevista concedida por Rosa Cardoso da Cunha à autora. Idem, ibidem.
} 
da confissão em juízo, alegando tortura, embora, eventualmente, estas denúncias não fossem registradas nos autos. Conforme mencionou Heleno Fragoso, "tecnicamente, o inquérito policial constitui apuração sumária do fato, tendo o caráter de instrução provisória, que serve apenas para permitir ao Ministério Público a apresentação da denúncia, dando início à ação penal” [Fragoso, 1984:150]. O Código de Processo Penal Militar estabelecia que o juiz deveria formar a sua convicção pelas provas produzidas em juízo. A ratificação da prova deveria ser feita em juízo:

“A prova colhida sem participação da defesa, comumente viciada pela violência e pelo temor, com o réu preso, jamais poderia fundar uma sentença condenatória. Nos processos por crimes políticos com mais razões, essa prova é absolutamente imprestável [...] E isso em obediência a um princípio constitucional, o princípio do contraditório. Existe uma extensa jurisprudência nesse sentido. [...] Os juristas de todos os tempos e os grandes tratadistas da prova sempre afirmaram que a confissão, para ser válida, tem de ser: a. livre e espontânea; b. confirmada reiteradamente, ou seja, persistente; c. realizada ou confirmada em juízo". ${ }^{731}$

A distância temporal em relação aos fatos relembrados nas entrevistas marcou os relatos aqui registrados, os ex-presos políticos entrevistados fizeram muitas referências às dificuldades de lembrarem-se dos meandros dos processos judiciais que tiveram de enfrentar na Justiça Militar, conforme manifestação de Carlos Alberto Lobão da Cunha, membro do "grupo de fogo" da ALN, preso em novembro de 1969:

"Nesse período, no ano de 1970 todo, mantive contato com o meu advogado, que era o Idibal, mas o processão [da ALN] foi julgado em 1975, eu já tinha sido libertado. [...] Eu passei quatro anos, um mês e um dia preso sem condenação. E fui processado também no IPM do CRUSP, que [...] se não estou enganado, nem foi julgado.

Eu mantinha contato [...] depois também com o Airton Soares, que tornou-se sócio do Idibal.

Não me lembro qual era a orientação deles, qual era o objetivo do ponto de vista da atuação na justiça militar. Acho que a gente ficou esperando o inquérito ser enviado para a auditoria militar, mas não sei quando. Eu sei que ele foi desmembrado ou foi feito um inquérito à parte, aquele que incluiu os dominicanos e algumas pessoas que foram presas na época do assassinato do Marighella. [...] Mas o apoio do Idibal e do Airton, naquele momento, e, mais tarde, do Luis Eduardo Greenhalgh, que juntou-se ao escritório também, era muito importante. Não lembro bem como eles ajudavam, mas só o fato de ir visitar, conversar alguma coisa... Essa época do Carandiru, por exemplo, foi muito complicada, porque estávamos com os presos comuns mais perigosos." ${ }^{\text {,732 }}$.

A maioria dos ex-presos políticos entrevistados manifestou profunda admiração e gratidão pela dedicação e coragem de seus advogados; contudo, vários deles registraram a

\footnotetext{
${ }^{731}$ Essas regras foram desenvolvidas pelo Direito Canônico a partir no século XIII. V. FRAGOSO, Heleno C., op.cit., p.150-2.

${ }_{732}$ Entrevista concedida por Carlos Alberto Lobão da Silveira Cunha à autora. SP, 05/05 e 17/09/2009. AAPP/AEL-LEI.
} 
sensação de que, apesar de seus esforços, havia muito pouco a se fazer no sistema judiciário daquele período. Especialmente, os ex-presos condenados a penas mais longas manifestaram a convicção de que não havia muitas possibilidades de utilizar-se as brechas das leis e tribunais de exceção. Além disso, um aspecto recorrente destaca-se nos relatos de ex-presos políticos, em geral não registrado nas entrevistas a pedido dos depoentes: a queixa de que, em certas ocasiões, havia conflitos e divergências entre o advogado e o preso quanto às escolhas sobre a melhor estratégia de defesa a ser adotada nas Auditorias Militares, conforme o depoimento de Artur M. Scavone:

\begin{abstract}
"Quem fez a primeira defesa no meu processo na Justiça Militar, eu ainda estava no [presídio] Tiradentes, foi o Hélio Navarro. Eu já tinha na minha cabeça, de aprendizado junto aos meus companheiros, que com o advogado você tem que ter cuidado, porque a tendência dele é se render às regras do regime e você precisa fazer a sua defesa com aquilo que você pensa. Daí [...] que escrevi um texto, dá umas três folhas manuscritas, [...] em que faço a minha defesa perante a corte militar. A corte militar faz o julgamento, fui condenado por 13 ações militares: assalto a rádio-patrulha, assalto de máquina de impressão, mimeógrafo, offset, assaltos a carteira de trabalho, aquelas coisas todas. Condenaram-me a 13 anos de cadeia.,733
\end{abstract}

As divergências na condução da defesa dos presos geraram, algumas vezes, conflitos ásperos, conforme o depoimento de Carlos Gilberto Pereira, metalúrgico e militante da AP, preso duas vezes durante a ditadura:

“[...] um advogado que estava disponível para todo mundo era o Virgilio [Enei] [...], mas era o seguinte... O Virgílio, particularmente, eu não quis [como advogado], porque se eu tivesse pedido para ele me atender, ele atenderia. [...] O pessoal tinha mil críticas a ele, mas o Virgílio era um cara extremamente disponível. A crítica que eu tinha a ele era a seguinte: o Virgílio não escutava ninguém, não explicava as dúvidas [...]. E as defesas que ele fazia eram meio no sentido de desqualificar o preso, tá entendendo? [...] [Tinha] um pessoal, que o Virgílio defendeu da seguinte forma: '- Excelência, olha a cara deles, vê se eles tem condições de meter medo em qualquer pessoa, são pessoas simples, sem qualificação. Eram pessoas levadas a fazer o que fizeram, mas não tinham consciência de nada'. Em síntese, era uma defesa desqualificando o cliente. O único que, vamos dizer assim, não tinha nada a ver com ninguém, era um advogado chamado Amazonas

Eu convidei esse Amazonas para falar comigo, e disse: '- [...] saiu a minha denúncia e preciso de um advogado, queria saber se você pode me defender. Mas, antes de mais nada, tenho que te avisar que não tenho grana, mas vou te pagar até o último centavo. [...] Saindo daqui, vou trabalhar e te pago, tudo bem?' Ele respondeu '- Tudo bem'. E falei para ele: "Só que tem algumas condições. [...] Primeiramente, eu não te dou autorização para fazer a defesa política, quem faz sou eu. Você é meu advogado e faz a defesa jurídica. [...] Das minhas conviç̧ões, quem fala sou eu. Você fala sobre o ponto de vista da ilegalidade da minha prisão e não faça diferente que eu te desautorizo na frente do juiz. Se você quiser, muito bem, se não quiser também, continuamos amigos'. [...] E assim foi feito, tem as razões finais e lá você pode ver [...] que ele seguiu rigorosamente isso." ${ }^{734}$

\footnotetext{
${ }^{733}$ Entrevista concedida por Artur Machado Scavone à autora. Idem, ibidem.

${ }^{734}$ Entrevista concedida por Carlos Gilberto Pereira. SP, 27/04 e 13/08/2009. AAPP/AEL-LEI.
} 
Diversos prisioneiros não abriram mão de fazer um depoimento em juízo no qual defendiam sua atuação política. Para alguns, essa foi uma importante maneira que encontraram de recuperação de sua identidade de militante e do sentido de sua luta. A recuperação desta identidade era condição fundamental à reconstituição de sua integridade moral e psíquica. Ao enfrentar a força dos militares na Justiça Militar negando o conteúdo da sua confissão da fase de inquérito, denunciando que esta fora produzida sob tortura, reafirmando seus princípios políticos, os prisioneiros reforçavam sua autoestima diante dos opressores, mas também diante dos próprios companheiros ${ }^{735}$.

As defesas orais feitas em juízo pelos próprios prisioneiros nos interrogatórios de instrução foram utilizadas por parte dos presos na luta de resistência à ditadura: cerca de um quarto de todos os indiciados aproveitaram o espaço das auditorias militares para denunciar assassinatos sob tortura e as arbitrariedades do regime, conforme o relato de Beatriz Bargieri:

“[...] meu contato era somente com o advogado e a família. Os nossos advogados [meu e de meu marido] eram o Belisário, o Mercado, a Regina e a Rosa. No Rio era o Modesto. O Modesto foi ótimo, [...] porque, quando a minha mãe foi falar com ele que eu estava presa e ele a viu, falou: "Dona Sylla, tenho uma ótima notícia, estou aqui com a absolvição da Beatriz". E ela falou: "E eu tenho uma outra péssima, ela está presa em São Paulo". [...] Eles apareceram muito em função do advogado do Rio de Janeiro, a Rosa era advogada junto com o Modesto no Rio. Depois, ela veio para São Paulo e ficou ligada ao escritório do Mercado. Quem chegou ao Modesto foi a minha mãe, não fui eu, porque eu nem tinha acesso a ele.

[...] A nossa relação com os advogados era ótima, discutíamos muito, tinha que decidir a defesa e havia divergências, porque tinha o lado jurídico e o lado político, mas eu logo falei: "O lado político eu vou decidir e ponto". Essa questão do assassinato do Paulo Wright foi uma decisão definida, em função do que eu pude ver e observar. Eu tinha certeza que ele tinha sido assassinado, eu não tinha a menor dúvida. O Otto [Filgueiras], que já estava solto, também tomou essa posição. Eu falei: "Olha, eu vou afirmar que ele foi assassinado". O pessoal dizia que eu devia dizer "desaparecido", mas não demos certeza, porque sempre fica aquela esperança, é lógico. Tinha uma discussão que é real, de que dizer que era "desaparecido" poderia abrir um espaço para, de repente, alguém querer dar uma informação etc. Mas, em termos de resultado, o Otto e eu achamos que era mais contundente a denúncia de assassinato. Eles [os torturadores] nunca me perguntaram nada sobre o Paulo e esse silêncio foi o que me deu a convicção de que ele tinha sido assassinado. Eu declarei na Justiça Militar que ele foi assassinado, na ocasião da minha condenação, por meio da minha advogada que, aliás, não concordava, achava que eu deveria denunciar o "desaparecimento". A estratégia ali era denunciar a tortura e fazer uma defesa política, dizer que eu acreditava no que estava fazendo, enfim, [...] que havia necessidade de uma oposição, que era uma opção, não era para dizer "eu estou aqui por engano"! Era o momento de fazer uma defesa política, de denunciar a tortura, denunciar os desaparecidos e o assassinato do Paulo, porque os outros a gente não tinha a informação, mas sobre o Paulo dava para a gente concluir isso.

\footnotetext{
${ }^{735}$ Entrevista concedida por Rosa Cardoso da Cunha à autora. Idem, ibidem.
} 
Eu não via os advogados constantemente, porque eles iam mais para o presídio masculino, lá eles pegavam muitos clientes. Eles não davam conta, era muito difícil mesmo, mas acho que nos momentos essenciais eles estavam presentes. Eu me sentia muito contente com essa minha escolha, porque eles respeitavam muito as minhas decisões. Diziam concordo, não concordo, acho que tinha que ser menos ou mais, dá para fazer isso ou aquilo, mas a decisão era minha, o que, às vezes, podia não acontecer em outras situações com outras pessoas. Mas comigo foi assim, muito legal, muito tranquilo" ${ }^{\text {736 }}$.

A adoção da defesa das posições políticas, de denúncia e enfrentamento aberto ao regime diante dos tribunais militares contrasta com os dados de algumas pesquisas, tais como a de Anthony Pereira (2010), na qual ele afirma que a maioria dos réus “[...] não costumava fazer defesas apaixonadas de suas opiniões políticas diante dos juízes. [...] Essas defesas eram punidas com severidade, em geral com pena máxima, porque os juízes as viam como prova da periculosidade e da incorrigibilidade do réu, mesmo que ele ou ela não houvesse participado de ações violentas”737. O advogado Airton Soares também avalia que a maioria de denunciados negava sua militância ou não fazia a defesa de suas crenças políticas em juízo ${ }^{738}$.

Essa percepção a respeito das diferentes posturas adotadas pelos réus que enfrentaram os processos políticos nos anos 1970 sugere que, devido ao fato da amostra utilizada nesta pesquisa ser composta de entrevistas com presos políticos que cumpriram penas mais longas, a experiência registrada aqui diz respeito a pessoas com um perfil considerado de maior “periculosidade” pela Justiça Militar - um grupo de presos que, ao longo das entrevistas, foram percebidos como representativos da amostra que justamente adotou a mencionada postura de confronto nos tribunais militares ${ }^{739}$.

De acordo com os relatos de alguns advogados de presos políticos entrevistados nesta pesquisa, a partir do que constava nos autos do processo e da disposição do cliente construía-se uma estratégia de defesa, que era simultaneamente jurídica e política, conforme o relato de Belisário dos Santos Jr.:

\footnotetext{
${ }^{736}$ Entrevista concedida por Beatriz Bargieri. Idem, ibidem. Grifos meus.

${ }^{737}$ PereirA, Anthony W. op.cit., p. 213. Pereira não fez um levantamento estatístico sobre esta questão. No apêndice I, ele explica que sua amostra é uma compilação de dados sobre 257 casos (36\% do total) que englobam 2.109 acusados (29\% do total). Embora a amostra seja expressiva, ele não explica os critérios utilizados para estabelecê-la. Além disso, para analisar as estratégias de defesa trabalhou com 50 casos (ver capítulo 7), sobre as quais não apresenta estatísticas.

${ }^{738}$ Entrevista concedida por Airton Soares à autora. Idem, ibidem.

${ }^{739} \mathrm{O}$ projeto BNM não produziu estatísticas a respeito, mas, possivelmente, os 1.843 réus que denunciaram torturas em juízo faziam parte do universo dos condenados. Caso venha a se confirmar esse dado, isso significaria que a postura de confronto foi adota por $65,17 \%$ dos 2.828 condenados.
} 
"A defesa ante a Justiça Militar nunca foi só uma defesa jurídica, nem somente uma defesa política. Havia em alguns casos, a possibilidade de que a importância daquele preso não tivesse sido percebida ou que não houvesse respaldo qualquer da acusação ou que, dependendo da época, aquela fração política não fosse o alvo. Havia um equilíbrio entre três pontos: primeiro uma defesa jurídica que era, de alguma forma, também uma defesa política, pois sustentava-se que aquela prisão não era legal. E ainda que a pessoa não fosse solta, isso era importante. Era necessário dizer que a lei que vigorava na época da ditadura não era respeitada, e era importante tentar fazer com que ela fosse respeitada. [...] Houve decisões por maioria, então, às vezes, era possível obter algo com a defesa jurídica, mas além disso, aquilo era uma denúncia de que havia que se respeitar a lei [...]. Em segundo lugar, a defesa era seguramente uma denúncia da tortura, [...] a própria e a denúncia da tortura de outros, da morte de outros. Era uma exigência quase pessoal nossa que assim fosse, mas também os presos exigiam que houvesse uma reportagem sobre o que eles haviam visto e isso também se traduzia em uma questão jurídica. [...] E, em terceiro lugar, havia a defesa do ideal, a defesa da posição política, a defesa da militância política dos presos. ${ }^{70,}$

\section{Carlos Alberto Lobão da Cunha lembra-se que, dependendo dos elementos}

presentes nos autos, era possível assumir posturas diferentes na fase de instrução do processo. Alguns grupos de presos políticos, como os militantes da ALN de São Paulo, decidiam coletivamente qual a posição a ser assumida por cada um perante o juiz:

“[...] os caras não tinham provas, além das confissões sob tortura, não tinham provas de praticamente nada. Eventualmente, em alguma situação como no caso da PM, que houve tiroteio e um morto ou alguma outra situação desse tipo. Prova de ações não havia: eram confissões sob tortura ou alguém, uma testemunha, ia na auditoria e dizia que você estava naquela cena. $\mathrm{O}$ que a gente fez foi planejar todos os nossos depoimentos, estabelecemos aquelas pessoas que na auditoria assumiriam a prática de ações armadas e aquelas que não assumiriam. Separávamos os casos, examinando a situação de cada um de nós no processo.

Havia alguns que não tinham como negar e, outros, que podiam negar. Enfim, eu era uma das pessoas que podia negar. Eu me lembro do juiz Nelson Guimarães, perguntando: '- O senhor não fez isso?’ E eu respondi ‘- Não, não’. Aí ele falou: ‘- O que o senhor acha das ações armadas de pequenos grupos que estão atuando no Brasil?’ [...] Aí comecei a falar da revolução francesa, depois passei a falar da resistência francesa na Segunda Guerra Mundial, dos grupos de partisans... Fiquei falando uns 20 minutos. Então, ele perguntou de novo: '- O que o senhor acha da ação de pequenos grupos armados que constituíram-se contra o governo?' Comecei de novo a falar da revolução francesa. Na quarta vez em que eu estava falando dos partisans, disse que era a favor deles naquela situação. Ele perguntou: '- E no Brasil, o que o senhor acha?' Eu respondi: '- Olha, não dá para achar nada, porque é tudo censurado e nós [presos] não temos direito a rádio, jornal, televisão, nada, então, eu realmente não acho nada, não tenho elementos para achar'. Ele queria me matar de raiva! O Airton Soares conta muito bem essa história, porque ele morria de dar risada lá atrás, eu ficava com a maior cara dura, na maior calma [...]. Enquanto estava preso participei apenas dessa audiência [de interrogatório] para montar, preparar o processo na Justiça Militar. [...] O julgamento foi apenas em 1975 ou 1976, quando eu já estava solto $^{741 \text { ”. }}$

\footnotetext{
${ }^{740}$ Entrevista concedida por Belisário dos Santos Jr. à autora. Idem, ibidem.

${ }^{741}$ Entrevista concedida por Carlos Alberto da Cunha Lobão à autora, Idem, ibidem
} 
A posição política e as necessidades do cliente influenciavam a estratégia de defesa adotada; era possível dar mais ênfase aos aspectos técnicos e jurídicos ou fazer uma defesa de cunho mais político, como destacou Idibal Pivetta:

\begin{abstract}
"Fazia-se a defesa jurídica, tudo o que pudesse ser incluído de jurídico você acrescentava, menos quando o cara chegava na Auditoria e aí perguntavam o nome dele, ele dava o nome; pediam a profissão e o cara falava: ‘- Revolucionário profissional’. Este já estava condenado a dois anos e mesmo assim você tinha de fazer a defesa, dentro dos princípios do cara. Vou dar um exemplo: o Ricardo Zarattini [Filho] chegou para mim e falou: '- Eu vou fazer isso'. Eu respondi: '- Então, você está condenado a dois anos, não venha me encher o saco depois'. Eu fazia a defesa dele como o herói revolucionário, eu tinha de falar que ele estava defendendo os princípios dele etc. Ele não tinha matado ninguém, não tinha assaltado, mas lutava contra o regime, que era o que o cara queria. Era como a defesa do Fidel Castro em 'A história me absolverá' (risos). Você tinha de encarar isso. O problema é que a gente tinha um nome como advogado e a família enchia o saco. $\mathrm{O}$ ator Carlos Zara, irmão dele, me enchia muito. Ele falou: '- Como você deixa ele falar isso?' Eu respondi: '- Fala com o teu irmão, eu o estou apoiando dentro do que eu posso. Agora, você fala com ele, se ele vai lá e diz que é revolucionário profissional, o que eu posso fazer?’ E não foi só ele, muita gente fez isso. O juiz falava: ‘- Ele está condenado a dois anos, porque a lei condena quem participa de organização subversiva.' E perguntava: 'Você pertence a tal organização?' O cara respondia 'Pertenço.' Então, estava acabado”. ${ }^{742}$
\end{abstract}

A defesa aberta da militância revolucionária de parte dos presos políticos perante os tribunais de exceção exigia que os advogados fizessem malabarismos para conciliar o respeito à postura de seus clientes e uma defesa eficiente no sentido de tirá-los da prisão, absolvê-los ou obter uma condenação reduzida. Muitos advogados, porém, conseguiram conciliar estes conflitos, defendendo o direito à resistência contra a força das ditaduras ${ }^{743}$ e denunciando as torturas, conforme o relato da advogada Rosa Maria Cardoso da Cunha. Rosa foi uma das poucas advogadas de presos políticos. Em 1965, com apenas 16 anos, ingressou na Faculdade Federal de Direito de Recife. Neste mesmo ano, transferiu-se para a Universidade Federal do Rio de Janeiro (UFRJ) e, em 1968, Modesto da Silveira a convidou para trabalhar no seu escritório. Como estudante, ela assistia regularmente aos julgamentos de presos políticos no auditório do Superior Tribunal Militar (STM), que situava-se perto da Faculdade de Direito, onde era possível acompanhar as defesas de professores de direito penal como Heleno Fragoso, além de advogados como Modesto e Werneck Vianna.

\footnotetext{
${ }^{742}$ Entrevista concedida por Idibal Pivetta à autora. Idem, ibidem.

${ }^{743} \mathrm{O}$ art. 27 da Declaração dos Direitos do Homen e do Cidadão, de 1793, afirma que "todo indivíduo que usurpe a soberania seja assassinado imediatamente pelos homens livres”. O art. 20, par. V, da Constituição alemã reafirma o "direito à resistência” (Recht zum Widerstand). Há ainda um direito semelhante presente em várias constituições de estados norte-amerianos, tais como New Hampshire, Kentucky, Tennesse, Carolina do Norte, entre outros. V. SAFATLE, Vladimir. "Do uso da violência contra o estado ilegal”, op.cit., p.247-8.
} 
De acordo com Rosa Cardoso, o escritório de Modesto Silveira era pobre, lugar onde se trabalhava sem cobrar da maioria dos clientes. Heleno Fragoso advogava para a criminalidade comum e cobrava profissionalmente, embora tivesse alguns clientes que não pagavam ou pagavam valores insignificantes. O escritório de Modesto privilegiou os casos de perseguição política e, por isso, Rosa escolheu trabalhar no seu escritório e recusar o convite para ser estagiária do escritório de Heleno Fragoso, a quem admirava ${ }^{744}$. Modesto da Silveira foi quem trabalhou com o maior número de causas no Rio de Janeiro [Fragoso, 1984:147]. Em 1970, Rosa transferiu-se para São Paulo, onde passou a atuar como advogada de presos políticos juntamente com Virgílio Egydio Lopes Enei ${ }^{745}$ :

“Tanto como na Justiça Criminal comum, a principal estratégia de defesa dos presos políticos era negar a autoria dos fatos pelos quais eram acusados. Contudo, [...] os presos políticos defendiam em tese os fatos que lhes eram imputados. Por razões de segurança pessoal e segurança dos companheiros, tentavam eximir-se de dar informações sobre ações concretas passadas, presentes ou futuras, mas afirmavam concordar com as mesmas. Este posicionamento dos presos políticos era, inclusive, uma forma de recuperação de sua identidade de "esquerda", de seu alinhamento contra o regime militar e ditatorial e de sua crença numa sociedade sem desigualdades sociais [...]. Recorde-se que as pessoas que se opunham aos governos militares [...], em geral, eram detidas e torturadas. Na tortura, por conveniência ou imposição eram quase sempre obrigadas, por diferentes formas, a negar as suas crenças e posições. Por isso, na primeira oportunidade que tinham de se expressar publicamente, no ambiente da Justiça Militar, um lugar em tese sem violência física, os presos queriam reafirmar sua identidade e sua história, apesar de tudo que haviam sofrido.

[...] Certamente, cada advogado conciliava de modo diverso estas questões, pois tinha posições ideológicas e compromissos políticos diferentes. Eu, particularmente, preocupava-me muito com a recuperação desta identidade, da autoestima e do respeito e afeto do coletivo por cada preso, independentemente da organização a que pertencia. Ressalte-se, também, que havia alguns juízes togados, não militares, que possuíam uma formação liberal e com os quais era possível conversar, argumentar e convencer. Eu sempre lhes recordava lições de nossa cultura humanística, como o direito de rebelião contra as leis injustas e os regimes de força. A eles devo muitos dos bons resultados que obtive. Mas eu também gostava muito de reforçar em minhas defesas o vínculo de solidariedade e de civilidade que existe entre nós, humanos. A oposição política não justificava, assim, a desumanização dos gestos dos contendores. Os julgadores não podiam julgar de uma forma desumana ou bárbara, não civilizada. Creio que muitas vezes minhas defesas enveredaram por esses caminhos bem reflexivos." ${ }^{\text {746 }}$

Idibal Pivetta também relatou que defendia o direito de resistência em processos contra prisioneiros políticos, em especial naqueles nos quais estavam envolvidos militantes da luta armada:

\footnotetext{
${ }^{744}$ Entrevista concedida por Rosa Maria Cardoso da Cunha à autora. Idem, ibidem.

${ }^{745}$ Idem, ibidem.

${ }^{746}$ Idem, ibidem. Grifos meus.
} 
"Em geral, eu fazia uma defesa sem especificar os fatos, pois caso fizesse a defesa especificando o fato, eles tinham o depoimento de um guarda de banco, de um bancário etc. e você não ia conseguir derrubar isso juridicamente. Você fazia a defesa da ideia total, não assumia o assalto e dizia que essa informação tinha sido obtida sob tortura, quando o cara 'confessava'. E não vamos entrar na questão de quem falou o que ou quem não falou, porque isso tudo é muito relativo. Às vezes, eles punham num depoimento coisa que o cara não falou e o obrigavam a assinar e o cara assinava. O cara não vai discutir com cinco folhas de papel na frente e dizer: '- Isso eu não vou assinar!' Quando assinava, aquilo era a prova, não precisava mais de testemunhas. Mesmo assim eles traziam testemunhas para depor, um guarda ou segurança de banco, um caixa de banco. Eu fazia a defesa dos presos genericamente, dizia que era um estado de guerra latente e que até o direito e a justiça reconhecem o direito de rebelar-se contra a iniquidade, contra a injustiça. É por isso que Tiradentes ainda hoje é conhecido e os caras que representavam a lei e o mataram ninguém sabe quem foi. E ele advogou a luta armada!»747

Presos políticos e seus advogados estabeleceram uma estratégia de defesa que, em geral, negava em juízo as “confissões” feitas na fase de inquérito, negando a autoria das ações armadas ou mesmo a militância, alegando que estas informações haviam sido obtidas sob tortura. Outros militantes adotavam a postura de negar a autoria das ações, mas não negavam a militância. E havia militantes, que por diversas circunstâncias, em função da ausência ou insuficiência de informações obtidas na fase do inquérito, tinham possibilidades de negar tanto a militância quanto eventuais atividades ou ações armadas. Algumas organizações decidiam que apenas os dirigentes assumiriam as ações armadas ou a militância.

Os prisioneiros políticos, com frequência, assumiam os fatos materiais do caso, mas negavam que estavam infringindo as leis, para eles esses fatos não se constituíam como crimes. Constantemente, os erros legais das denúncias apresentadas pela promotoria possibilitavam aos advogados de defesa alegarem a inconstitucionalidade das acusações. Havia insuficiência de provas ou contradições gritantes entre elas. Outros prisioneiros negavam ter conhecimento de que tinham auxiliado grupos clandestinos, tendo apenas ajudado amigos ou conhecidos [PEREIRA, 2010:213]:

"Cada caso era um caso, dependia da prova que vinha nos autos, obviamente. A grande base de defesa era que a prova era ilegítima, ela não podia ser utilizada, por isso devia prevalecer o depoimento feito em juízo. Os depoimentos feitos em juízo, na maioria absoluta deles, eram feitos negando o que havia sido dito na fase do inquérito ${ }^{748}$."

O caso do médico Aytan M. Sipahi, dirigente regional do PCBR, preso em 16 de janeiro de 1970 pelo DEOPS/SP, juntamente com a esposa e os cunhados, sintetiza diversas histórias de processos políticos na Justiça Militar. Sua esposa foi libertada 25

\footnotetext{
${ }^{747}$ Entrevista concedida por Idibal Pivetta à autora. Idem, ibidem.

${ }^{748}$ Entrevista concedida por Airton Soares à autora. idem, ibidem.
} 
dias depois e contatou o advogado Mário P. Simas para defendê-lo. Aytan Sipahi foi torturado e mantido incomunicável até o dia 3 de fevereiro, quando suas declarações foram registradas e sua prisão preventiva decretada a pretexto do interesse da ordem pública. Desde o início, seu chefe na Universidade de São Paulo pressionou a seu favor junto a autoridades e pessoas notáveis, e, em especial, ao ministro da justiça, Alfredo Buzaid, pois era médico de diversos deles. Depois de 90 dias da prisão, a denúncia foi oferecida pela Promotoria Pública Militar, atribuindo a Aytan Sipahi e a seis outros acusados a prática dos crimes definidos pelos artigos 43 e 45 (inciso I), da LSN ${ }^{749}$.

A denúncia era inepta, não precisava no tempo e no espaço os fatos narrados e faltava-lhe justa causa. Sipahi foi acusado de tentar reorganizar o PCB, sob a denominação de PCBR, a denúncia não distinguia que, de fato, tratava-se de um outro partido criado em 1968, a partir de uma dissidência do antigo PCB. Constituía prova da prática desses crimes o fato de o réu possuir alguns livros considerados comprometedores e conhecer ou relacionar-se com pessoas que haviam sido condenadas em processos políticos [SimAs, 1986: 170]. Sipahi contou-nos como estabeleceu, juntamente com o advogado, sua defesa e denunciou em juízo as torturas que sofrera:

"Eu tive contato com meu advogado, depois de sair do DOPS, lá no Tiradentes. Ele foi um bom advogado. [...] ele visitou-me uma semana ou duas depois de eu chegar ao Tiradentes.”

[...] Nós discutimos a estratégia de defesa. No meu caso, a acusação era de tentar reorganizar partido político sob falso nome. Eu não tinha acusações de ações armadas, não tinha nada. [...] A linha de defesa foi a de negar as coisas de organização, nunca assumi que era membro de partido nenhum, de coisa nenhuma. Quer dizer, eles tinham evidências fortíssimas... E o outro aspecto era não assumir nenhum grau de conciliação com a ditadura, ou seja, abjurar suas ideias. Sou um homem de esquerda, progressista, fui da UNE, continuo com as mesmas ideias.

Na audiência, era mais objetivo, as perguntas eram: '- Você está organizado com tal? Você fez isso? Roubou banco? Você fez não sei o quê? As audiências eram ridículas, eram semelhantes ao um teatro de ópera bufa, porque as perguntas eram loucas, era um segundo interrogatório do DOPS! [...] No meu depoimento, não tinham muito do que me acusar. Em outros casos havia maior carga política [...]. A maioria das pessoas negava as ações e criticava a ditadura. A gente denunciava as torturas, acabava com qualquer depoimento. O juiz perdia a calma, quando eu chegava e dizia: '- Eu fui torturado assim e assim. Eu sou médico nunca tive atividade clandestina, numa bela hora fui preso, meu filho ficou doente'. Você botava os caras na defensiva. E a visão deles era [...] assim: 'Puxa, como um cara formado, doutor, se meteu nessa?' [...]'- Como se mete nisso, se ele tem um futuro?'

[...] Eu fiquei mais dois anos na cadeia, porque denunciei as torturas na auditoria. Quando eu denunciei a tortura, o promotor, que era jovem, pediu a prisão do Fleury. Aí ele foi preso na hora. Acho que foi 1970. Isso foi uma coisa assim non sense. Chego lá e denuncio o Fleury, o cara tinha acabado de assumir o cargo de promotor da Justiça

\footnotetext{
${ }^{749} \mathrm{O}$ processo de Aytan M. Sipahi recebeu o no.34/70 e foi distribuído à IIa. Auditoria Militar. V. SIMAS, Mário. Gritos de justiça: Brasil (1963-1979). São Paulo, FTD, 1986, p.169-70.
} 
Militar, havia passado em concurso. Ele disse assim: '- Senhor juiz, eu peço a prisão do delegado Fleury por tortura'. Foi um rebuliço e ele saiu preso para o DOI-CODI. Acho que foi solto logo, mas deve ter acabado com a carreira de promotor dele.

[...] Essa resistência logicamente surtiu efeito, porque, de certa maneira, a luta política de se preparar para falar na auditoria e criticá-los... Era um ambiente restrito, porque não tinha jornalista, mas a forma de resistência não deve ser pautada pela sua repercussão, mas pelo fato de você ter se comportado bem diante do juiz, se soube se defender, [...] a comunidade acabava sabendo disso ${ }^{750}$."

Durante a instrução processual, Aytan Sipahi foi interrogado pelo juiz e suas denúncias de tortura ficaram consignadas no termo de inquirição, mas nenhuma providência no sentido de investigá-las foi tomada. Em alguns casos, os investigadores que haviam praticado torturas figuravam como testemunhas de acusação. No seu processo, os depoimentos dos policiais foram bastante contraditórios, assim o juiz determinou a inquirição das testemunhas de defesa, quando sua esposa depôs denunciando também as torturas que ela e o marido haviam sofrido [SIMAS, 1986: 172].

No julgamento, Simas alegou a improcedência da acusação e a imprestabilidade da prova. Sustentou que tentava-se punir alguém que apenas cogitara estruturar uma agremiação política e nada existia que fundamentasse uma condenação. Lembrou ainda que o jornal referido pela denúncia, segundo a qual Sipahi seria um dos responsáveis, nunca "[...] chegou a ser impresso, nem mesmo esboçado" [SIMAS, 1986: 172]. Sipahi foi condenado a 2 anos de reclusão, por 4 votos contra 1, considerado incurso no artigo 37 do Decreto-lei 510/69, da LSN que antecedeu o DL 898/69. A sentença foi publicada no dia 3 de fevereiro de 1971 [SIMAS, 1986: 172]. O advogado apresentou recurso no STM, que não acolheu a apelação.

Havia diversas maneiras de resistir e sobreviver, seja nos tribunais militares ou nos cárceres. Durante esse período, a direção do Presídio Tiradentes exigiu de Sipahi que tratasse dos presos feridos. Ele concordou em ajudar, desde que o diretor comunicasse ao juiz competente, ao corregedor da Polícia e dos presídios o fato de terem recebido um preso torturado. Imediatamente, como represália, foi transferido para o pavilhão 8 da Casa de Detenção, destinado aos presos comuns mais violentos.

A sentença de Aytan Sipahi foi confirmada quando ele já havia cumprido mais da metade da pena, o que lhe permitia solicitar o livramento condicional. Aos presos políticos não eram concedidos o direito a sursis, prisão albergue e nem prisão domiciliar. Para o deferimento da condicional era necessário ter bom comportamento carcerário, primariedade, promessa de trabalho lícito e impressão pessoal do juiz, a ser formada em

${ }^{750}$ Entrevista concedida por Aytan M. Sipahi à autora. SP, 29/04/2009. AAPP/AEL-LEI. Grifos meus. 
audiência prévia. Sipahi, ao saber que o juiz faria perguntas a respeito de seu posicionamento ideológico, disse que preferia cumprir o restante de sua pena, pois não “trairia, sob forma de barganha, sua maneira de pensar” [SIMAS, 1986: 174].

Era prática comum entre os advogados questionar nos tribunais militares, principalmente na $1^{\mathrm{a}}$. instância, a legitimidade da LSN e a competência da Justiça Militar para julgar crimes políticos, mas de acordo com Airton Soares, os advogados de defesa tinham poucas possibilidades de interferir nos resultados da Justiça Militar:

“[...] Eu nunca admiti a Lei de Segurança Nacional como uma lei justa. Era uma legalidade de exceção, o que para mim é uma ilegalidade. [...] Em juízo, você questionava a licitude da LSN, a origem da lei etc. Sempre considerei a Justiça Militar, quando passou a ser utilizada pela ditadura para processar dissidentes do regime, como uma justiça de exceção e seus tribunais, em todos os níveis, como tribunais de exceção, que convalidaram a repressão da ditadura. Ao aplicar aquela LSN, a Justiça Militar transformou-se em Tribunal de Exceção.

Tenho minhas dúvidas sobre o papel dos advogados nas auditorias e tribunais militares, porque, ao mesmo tempo em que nós prestávamos serviço aos que nós estávamos defendendo, estávamos dando às cortes militares legitimação internacional. Mas prevaleceu na nossa consciência, pelo menos na minha, que mais valia a pena socorrer aqueles que estavam ao seu alcance, ou seja, atuar em defesa dos presos, do que pensar em um contexto internacional ou como a ditadura divulgava seus métodos repressivos no exterior, afirmando: 'Não, aqui tem tribunal, tem justiça!' E essa coisa toda...

[...] Sem dúvida, cumprimos o objetivo de minorar o sofrimento. Afinal, a quem os familiares dos presos podiam recorrer, ou as possíveis vítimas da repressão, que ainda não tinham sido presas? A nós, mas acho que se conseguia pouco, perto daquilo a que os presos eram submetidos, era muito pouco. Muito pouco. Você, quando conseguia reenquadrar alguém no artigo $\mathrm{X}$, este artigo era tão ilegal quanto o outro. Podia-se conseguir uma dosagem de pena menor ou maior, mas não alterava tanto assim.

[...] Para que as absolvições decorressem do trabalho dos profissionais do Direito, teríamos que admitir que na instrução processual fossem apresentadas provas acolhidas pelo direito, obtidas de uma instrução criminal realizada com o respeito aos direitos do preso. O mais elementar deles é o de estar acompanhado de defensor perante a autoridade policial ou militar. Não tenho conhecimento de condenado ou absolvido que tenha sido acompanhado de advogado quando submetido a interrogatório. Além disso, não tenho conhecimento de absolvição que tenha ocorrido porque o Conselho de Justiça da Auditoria Militar tivesse acolhido a tese de que o interrogatório do réu não poderia ser utilizado contra ele, porque o interrogatório é peça de defesa. E, além do mais, que algum Conselho de Justiça tivesse acolhido a tese de que interrogatório obtido mediante tortura e retratado em juízo era nulo, não servindo de base para condenação. Não tenho conhecimento também de que tenham acolhido requerimento de advogados para que documentos utilizados como prova fossem submetidos a perícias que comprovassem sua autenticidade, e muito menos que tenham deferido pedido de exame de corpo de delito para constatação de torturas na fase do inquérito relatadas pelo próprio denunciado. Aliás, não tenho conhecimento de denúncia de tortura feita por denunciado ou seu advogado que tenha sido objeto de apuração por parte do Conselho de Justiça Militar.

Ora, se o Conselho de Justiça era parcial e faccioso e ignorava as denúncias feitas pela defesa sobre a nulidade das provas, que comprometiam o devido processo legal, e quase a totalidade das provas juntadas aos autos eram nulas de pleno direito, como eu poderia concluir que o advogado pudesse obter resultado favorável a este ou aquele cliente perante este mesmo Conselho? Acho complicado. O mesmo comando militar da região 
que designava os militares para atuar nos órgãos de repressão também designava os militares que deveriam compor os Conselhos nas Auditorias, com um Juiz togado designado da mesma forma.

O que ocorria é que eram absolvidos aqueles que os órgãos de segurança entendiam, como regra geral, certa ou erradamente, que não ofereceriam mais risco à segurança do regime. Eram absolvidos aqueles contra os quais nem mesmo seus depoimentos, obtidos mediante coação ou tortura, demonstravam comprometimento e, também, aqueles cujas provas juntadas aos autos não tinham relação com os acusados ${ }^{751}$."

Em geral, os presos políticos condenados a cumprir longas penas eram os mais descrentes das possibilidades de se alcançar vitórias no âmbito jurídico, mas eles frequentemente faziam reivindicações e petições exigindo melhores condições carcerárias, o que demandava dos advogados presença constante nos presídios e nas Auditorias, tornando o trabalho dos advogados bastante atribulado. Protestar e denunciar assumia um sentido de resistência mais amplo, inserido no contexto da luta contra a ditadura. E tinha um sentido vinculado à sobrevivência, era necessário manter suas vidas ativas, combatendo as mais diversas formas de controle e punição que buscavam anulálos e subordiná-los e, assim, suportar melhor o confinamento.

Advogados e presos constantemente questionavam a legitimidade e a legalidade da LSN, muitas vezes com o objetivo de reafirmar princípios que consideravam dirigidos ao registro histórico e à memória, pois não acreditavam que houvesse possibilidades concretas de influenciar no desfecho dos julgamentos. É isso o que chama a atenção no depoimento feito em juízo por Artur M. Scavone, no dia 28 de setembro de 1973:

"Não escrevo aos srs. para fazer minha defesa. Não é meu objetivo pedir-lhes clemência e liberdade, pois, coerente com minha consciência, sou um homem livre. Pelo contrário, venho declarar-me responsável pela minha militância nas organizações guerrilheiras Ação Libertadora Nacional e Movimento de Libertação Popular, pelas ações revolucionárias de que já fui confesso nessa Auditoria e defender essa prática segundo meu ponto de vista.

Por outro lado, a função desse Tribunal é buscar elementos jurídicos que possibilitem minha permanência na cadeia, a fim de que exista menos um propagandista das ideias revolucionárias entre o povo, a quem tanto teme a atual Ditadura Militar. [...] Não será permitida a divulgação deste texto, nem será permitido o debate que busque a essência da luta de libertação do povo brasileiro. Trata-se de condenar.

Assim sendo, este texto não se dirige aos membros do Conselho nem ao sr. Juiz, mas tão somente à anexação ao processo, o que permitirá que a História nos julgue, a mim e a esse Tribunal.

[...] Perante uma situação como esta, em que nossa riqueza é roubada pelos estrangeiros e seus cúmplices locais, e em que o povo perdeu todas as suas organizações de classe por força da violência terrorista da Ditadura Militar, pouca alternativa restou que não a luta frontal, e armada, contra aqueles que são e que representam os interesses estrangeiros em nosso país.

[...] Hoje os jornais falam de tortura nos mais diversos pontos do país, sem que nenhuma reação se esboce. As mortes "acidentais" nos órgãos repressivos proliferam. Dezenas de

${ }^{751}$ Entrevista concedida por Airton Soares à autora. Idem, ibidem. 
companheiros que dedicaram sua vida à libertação de nosso povo já tombaram, quer no combate, quer na tortura. Ayrton Adalberto Mortati, Flávio Carvalho Molina, Hiroaki Torigoe, Frederico Eduardo Mayr, Antônio Benetazzo, Alexandre Vannucchi Leme, José Júlio de Araújo, todos revolucionários assassinados pela tortura no Destacamento de Operações e Informações - DOI/SP (ex-OBAN), somente para citar os companheiros mortos mais recentemente.

[...] Mas é na mesma medida em que se dá combate, que se forjam e se enriquecem com o sangue revolucionário as novas etapas do processo de libertação.

[...] Expropriações foram realizadas pelos organismos revolucionários, tirando dos patrões o roubo que realizaram sobre seus empregados, para fornecer meios de combate e de propaganda dos ideais de libertação e organização popular. De nada adiantará buscar caracterizar-nos como 'terroristas assassinos' que assaltaram e mataram pais de família, por isso não ser verdade. Quem hoje mata, pela fome e pela tortura, e não só pais de família; quem hoje rouba o trabalhador no seu trabalho; quem aplica o terror contra o povo, são as forças alienígenas no país, representadas pela Ditadura Militar. Mas os torturadores assassinos do povo não ficarão impunes. As forças da Revolução os julgarão e os justiçarão.

[...] Ou ficar a Pátria livre, ou morrer pelo Brasil!"》752

Outro militante, José Rezende, membro da VPR, relatou os conflitos que teve com seu advogado, Nilo Batista, em função da estratégia de defesa estabelecida por este. Conduzido com celeridade, o julgamento teve duração de apenas quatro meses, e pairava a possibilidade de que Rezende fosse condenado à morte. Batista queria que seu cliente negasse em juízo que estivesse implicado no sequestro do embaixador alemão. Rezende, entretanto, adotou uma conduta de confronto no julgamento, assumindo a sua participação no sequestro “[...] não por romantismo nem heroísmo, mas por convicção política e por pensar que, assumindo ou não, o resultado do julgamento seria o mesmo $^{753}$.” Assim como os outros réus do processo, Rezende denunciou as torturas a que havia sido submetido, mas o juiz insistia em registrar que o réu sofrera “constrangimentos”. Por insistência do réu, o juiz teve de registrar a denúncia de Rezende.

Nilo Batista descreveu qual era o clima no dia em que concluiu o memorial de defesa do caso de Rezende, que seria lido junto ao Conselho Permanente de Justiça no dia 29 de março de 1972:

“[...] eu permanecia inseguro [...]. Meu desconforto provinha da circunstância, inédita em minha vida profissional, de ter empregado no memorial uma linha narrativa que contrariava frontalmente a vontade do cliente. [...] Recordei-me do destemor do cliente, confessando serenamente ter participado do sequestro do embaixador alemão para outorgar credibilidade ao relato das torturas que sofrera, intervindo com firmeza no ditado sempre macio mediante o qual o juiz-auditor tentava impedir que os porões do DOI-Codi

\footnotetext{
752 Depoimento escrito de Artur Machado Scavone lido por ele na II Auditoria Militar de São Paulo em 28/09/73. Arquivo pessoal de Artur M. Scavone. Grifos meus.

${ }^{753}$ REZENDE, J.; e BENEDITO, M., op.cit., p.113.
} 
fossem retratados (jamais esquecerei sua decepção quando o interrogado, instado a declinar os demais coautores do sequestro, mencionou meticulosamente o nome de todos os companheiros... mortos).

[...] utilizado politicamente para reduzir a mero desajuste o inconformismo da juventude do anos 60 [...] tudo me permitia acessar uma certa veia na sensibilidade dos juízes, que conduziria a uma atenuação da pena, descartando a pena capital.

[...] José Roberto ficou horrorizado com minha proposta, que implicava em desmerecer sua escolha, atribuindo-a a uma falsa motivação; discutimos muito, nos planos político e ético. [...] Qual era meu dever? Emprestar muda assistência a uma ortotanásia cívica? Ou contar uma história verdadeira, atribuindo-lhe propriedades falsas, para salvar sua vida?

Até hoje não sei como responder a essas questões, mas nunca esquecerei aquele dia [...]. Não houve condenação à morte. Tempos depois, logo após o julgamento da apelação e interrompida a sessão, um ministro do STM me disse: 'Esse rapaz queria se matar.' Acenei a cabeça, concordando, envergonhado e feliz. Nada mais falso. José Roberto queria viver, e queria que todos pudessem viver. Mas não era outra coisa o que eu queria.

[...] agora mentiras sinceras já não interessam à preservação da vida fecunda de um revolucionário $[. . .]^{754}$.”

De acordo com José Roberto Rezende, não houve surpresa, ele e todos os réus esperavam pela condenação à prisão perpétua, pois “[...] infelizmente morreu um policial que fazia a segurança do embaixador e [...] o artigo 28 [da LSN] previa [...] a pena de morte, em grau máximo, e prisão perpétua, em grau mínimo. Nós tínhamos certeza de que seríamos condenados em grau mínimo, porque a pena de morte estaria reservada para quem fez o disparo, o Bacuri. [...] torturado até a morte pela quadrilha do delegado Sérgio Paranhos Fleury”. Após o julgamento, conforme suas palavras, dormiu bem e tranquilo:

\footnotetext{
"No fundo acho que tinha medo da pena de morte, então foi até um alívio. Naquele clima de terror que a gente vivia, tudo era possível. E eu tinha uma grande certeza: não ficaria na cadeia mais do que dez ou onze anos. Do jeito que o mundo caminhava, as ditaduras tinham vida curta. Então, sairia não por uma decisão judicial, mas por um processo político. E assim aconteceu.

A condenação de todos nós demonstrou que eu estava certo assumindo o sequestro. Quem assumiu, quem não assumiu e até quem não estava preso recebeu a mesma pena. $\mathrm{E}$ ao assumir pude afirmar, quando me perguntavam porque sequestramos: 'Sequestramos porque era a única forma de livrar os companheiros que estavam sendo torturados nos porões da ditadura. A única forma que a sociedade tem de dialogar com o governo, hoje, é ação armada.' Se não assumisse, não podia ter feito essa defesa política da ação.

Os outros julgamentos foram como cópias autenticadas desse primeiro. Fui condenado em onze processos, peguei duas penas de prisão perpétua, como se pudesse morrer duas vezes, e mais 69 anos de reclusão ${ }^{755}$."
}

Posturas como a de Scavone ou Rezende geravam uma reação desfavorável ao réu, segundo Airton Soares, muitas vezes, a estratégia de negar em juízo o que havia sido dito na fase de inquérito não era mais eficiente, pois nos tribunais militares prevaleciam os interesses dos órgãos de segurança. Caso fosse do interesse do sistema DOI-Codi

\footnotetext{
${ }^{754}$ Idem, ibidem, p.118-9.

${ }^{755}$ Idem, ibidem, p.119.
} 
condenar determinado militante, ele era enviado novamente aos centros de tortura para que se arrancasse dele alguma informação útil para as investigações ou para o processo judicial, conforme aconteceu com Anivaldo Padilha. De acordo com Airton Soares, provavelmente a maioria das condenações também ocorreu sustentada em provas inválidas do ponto de vista jurídico:

“[...] afinal de contas, para que serviam esses julgamentos? Para formalizar perante a opinião pública nacional que havia uma justiça funcionando na repressão aos dissidentes políticos. Nós éramos participantes da justiça? Não. Nós utilizávamos desse expediente, a justiça militar, para minorar o sofrimento dos presos, procurar brechas na legislação para diminuir as penas, tanto na primeira como na segunda instância. E, por último, como última hipótese mesmo, tentávamos libertá-los.

[...] E não dava certo, os Conselhos de Sentenças eram compostos por militares da ativa, muito ligados à tropa do lugar onde acontecia o julgamento [...], aos colegas que estavam atuando na repressão. [...] Eles tinham informação de coxia sobre o que acontecia. O juiz Nelson Machado, por exemplo, era um homem de confiança deles, que recebia as informações assim que eram obtidas ${ }^{756}$."

Artur Scavone relatou um fato que vivenciou no qual ficaram evidentes a ligação e o compromisso do juiz auditor Nelson Machado com o DOI-Codi/SP. Scavone estava no presídio Tiradentes havia alguns meses, quando foi levado novamente ao DOI-Codi/SP. Nesta ocasião, presenciou o início de uma operação que resultou no assassinato dos últimos remanescentes do Molipo, agrupamento do qual fazia parte. Entre os militantes procurados estava Maria Augusta Thomaz, antiga namorada de Scavone:

“[...] fui chamado de volta para o DOI-CODI. Fiquei apavorado, fiquei nas celinhas reservadas, quando soube que a Maria Augusta Thomaz ia ser assassinada. Eu sabia que ela estava solta e sendo perseguida e eu ouvi os caras saindo em uma expedição para Goiás para pegar a ela e o Márcio Beck Machado. Eu não tinha como avisar ninguém, [...] O DOI-CODI tinha as celas normais e tinha umas celinhas que ficavam no andar de cima, que eles reservavam para situações diferentes [...] para não entrar em contato com os outros e não passar informações para fora. Fiquei lá [...] alguns dias, [...] uma semana, acho. [...] pela janela consegui ver chegar o juiz militar, o [...] Nelson Machado. [...] Me chamaram para a mesma sala de tortura de sempre e um deles, não lembro qual, falou: 'E aí Betão, [...] agora você está lá no presídio, tranquilo e quando você esteve aqui com a gente?' Eu respondi: '- O que você quer saber?' '- Aconteceu uma coisa muito complicada, o que você falou sobre essas ações que você fez, é verdade ou mentira?'. Respondi: “- Ah, você sabe, tudo o que a gente fala aqui é na porrada”. '- Não, mas você falou por causa da porrada?’. Eu disse: “- Lógico, cara, você acha que falei como?’.

Nesse momento, me dei conta de que o Nelson Machado foi lá, não tenho como provar, mas ele foi lá e pediu para que a gente fosse chamado e ele pudesse ver e saber se a gente dizia, de fato, que tinha feito aquelas coisas ou não. Se tinha sido sob tortura ou era tudo mentira. Tanto assim, que ele me condenou a 13 anos, mas [...] não me lembro bem, [...] mas ele acabou achando que falei uma parte sob tortura. E de ação, eu nunca me recusei a falar, eu achava que a condenação não fazia diferença para mim, eu me recusava a falar onde estavam os companheiros e quem eram eles [...]. Digo: '- Fiz isso, fiz aquilo', isso

\footnotetext{
${ }^{756}$ Entrevista concedida por Airton Soares à autora. Idem, ibidem
} 
eu falei no DOI-CODI sem peias. Mas [...] ele foi lá [...] para ter alguma segurança do que estava fazendo, o quanto era tortura ou não [...].

[...] Nessa mesma época que eu voltei lá, se eu não estou errado, [...] eu encontro o Gabriel [...] e a companheira dele, a Tânia. [...] Eles fizeram acareação entre mim e o Gabriel. [...] Prenderam o Índio, um antigo militante do Partidão, e ele entregou o trabalho que estava sendo feito lá em Goiás. Não me lembro o nome da cidade... Verde, não é Campo Verde. E ele entregou a informação de que a Maria Augusta e o Márcio Becker estavam lá. Eu vi os caras do exército saindo armados, com jipe, e acho que foi quando se deslocaram para lá. Logo depois, ela e o Márcio Becker são pegos e assassinados lá. Não saí do DOI-Codi enquanto isso não aconteceu ${ }^{757}$."

Os testemunhos feitos no âmbito desta pesquisa, assim como os dados disponíveis pelo projeto Brasil: Nunca Mais, sugerem que a justiça militar era submetida aos órgãos de segurança interna e à dinâmica do "poder torturador”, justificado pela Doutrina de Segurança Nacional. Sabe-se que nenhum juiz chegou a solicitar investigação sobre as denúncias de tortura feitas nas Auditorias Militares, com exceção do ministro do STM, general Rodrigo Octávio, que, em 1978, pediu a investigação dos casos de Carlos Nicolau Danielli e Alexandre Vannucchi Leme, assassinados sob tortura em 1972 e 1973, respectivamente $^{758}$. A solicitação, porém, não foi aceita pelo STM [BNM, 1989].

Os altos níveis de cooperação existente entre civis e militares no sistema judiciário brasileiro durante a ditadura ${ }^{759}$ indicam uma ligação orgânica com os órgãos de segurança e os DOI-Codis. A justiça militar era parte constitutiva do aparelho repressivo e transitava na zona de indistinção entre o legal e a situação de fato do estado de exceção, assentada em 160 atos legislativos distintos [PEREIRA, 2010], que se sobrepunham e se confundiam. Esta cooperação veio a favorecer a diretriz das lideranças do regime de implementar uma repressão judicial seletiva.

Os dados da amostra compilados por Anthony Pereira sugerem que os réus eram tratados de forma diferente dada a região, estado da federação e o ano em que o suposto crime fora cometido [PEREIRA, 2010: 130-3]. Sobretudo, ele destaca que os índices de absolvição em primeira instância foram maiores do que o de condenações, chegando a 62,65\% no período que compreende o auge da repressão estatal (1969-1973), o que interpreta como um indício de que a esfera judicial gozava de “certa autonomia relativa” com relação à esfera política [PEREIRA, 2010: 135].

\footnotetext{
${ }^{757}$ Entrevista concedida por Artur M. Scavone, op.cit. Maria Augusta Thomaz e o Márcio Becker Machado desapareceram em 17/05/73, num sítio onde viviam próximo a Rio Verde (GO). V. Dossiê Ditadura, op.cit. ${ }^{758}$ Como já mencionado, em seu testemunho, Aytan Sipahi relatou que durante seu julgamento um jovem promotor concursado solicitou a investigação do delegado Fleury e foi imediatamente preso. Pereira faz referência a um juiz que absolveu um réu por considerar que as provas haviam sido obtidas sob tortura, no final da década de 1970, mas não citou o caso. PEREIRA, Anthony W. op.cit., p.289.

${ }^{759}$ PereirA, Anthony W. op.cit., p.142-2, 212; e PEREIRA, Anthony W. "Sistemas judiciais e repressão política no Brasil, Chile e Argentina”, op.cit., p.203-24.
} 
Por outro lado, é possível inferir que Pereira desconsidera o fato de que as condenações mais severas, com penas acima de 5 anos, concentraram-se neste período, quando ocorreu também a maioria dos assassinatos sob tortura e desaparecimentos forçados de militantes. As condenações severas dirigidas aos prisioneiros mais comprometidos com a oposição à ditadura, especialmente aqueles ligados à luta armada, assim como as execuções extrajudiciais, constituíram-se em casos exemplares que cumpriram um importante papel de dissuasão e desmobilização da contestação política.

Enfrentando a rigidez dos tribunais militares dirigida às esquerdas revolucionárias e sem ignorar suas ligações com os órgãos de segurança, presos políticos e advogados de defesa souberam explorar a exígua margem de manobra existente no interior do sistema judiciário de exceção. Recorrer das sentenças era parte da estratégia de defesa dos advogados, utilizando todas as possibilidades e brechas da justiça militar como meio de possibilitar a sobrevivência dos presos e de contribuir para a luta de resistência à ditadura.

Da parte dos indiciados, cabe destacar o importante papel que cumpriram ao utilizarem os tribunais de exceção para denunciar os crimes cometidos pelos agentes dos órgãos de segurança, vicissitude a qual muitas vezes reverteu-se em implicações penais. Neste sentido, o presente sub-capítulo lança luz sobre maneiras de atuação de presos e advogados que reverteram, ao menos parcialmente, o silenciamento acerca dos crimes e arbitrariedades da ditadura, denunciando-os em seu próprios espaços e contribuindo para o desgaste político do regime. Ressalte-se que estas denúncias foram cruciais para o conhecimento a respeito da repressão estatal do período, cujas informações, à época, serviram de base para campanhas divulgadas no Brasil e no exterior e, posteriormente, para os dados compilados pelo Projeto Brasil: Nunca Mais.

\subsection{Os recursos de julgamentos por crimes políticos nos tribunais superiores}

No Brasil conhecemos pouco sobre a atuação dos tribunais superiores como instância de recursos da justiça militar no período ditatorial. De acordo com as entrevistas analisadas, os tribunais superiores tinham a reputação de serem mais independentes do que as auditorias militares. Não obstante, é de se considerar que este ponto de vista não é universal; segundo Walter Cruz Swensson Jr., entre os anos de 1969 e 1979 foram julgados 533 recursos ordinários criminais no Supremo Tribunal Federal (STF), sendo que apenas 87 deles foram julgados favoravelmente e outros 58 tiveram provimento 
parcial. A maioria das decisões deu-se por unanimidade e apenas 42 recursos foram decididos por maioria de votos. Nesse período, após cassações e casuísmos para mudar sua composição, o STF tornou-se uma instituição confiável para o poder Executivo e não incomodou os militares ${ }^{760}$.

Sobre a atividade do Superior Tribunal Militar (STM), porém, há apenas informações provenientes de estudos de caso, com dados ordenados por amostragem, como os de Anthony W. Pereira. Para sua análise, ele baseou-se numa amostra de 40 casos apenas, os quais apresentaram um índice de absolvição de 60\%, superando o da primeira instância [PEREIRA, 2010: 129]. Esta percentagem confirma a percepção de que o STM era sensível aos argumentos dos advogados de defesa. De acordo com Pereira, no STM a percentagem de absolvição para os supostos crimes não violentos era de $57 \%$, enquanto que para os crimes violentos era de apenas 43\% [PEREIRA, 2010: 129].

Entre os advogados entrevistados destaca-se a preocupação com os condenados a longas penas ou prisão perpétua e com o sofrimento decorrente da perspectiva de permanecerem vários anos confinados. Estes casos exigiram dos advogados de defesa uma atuação mais detida nos tribunais superiores. De acordo com Belisário dos Santos Jr. havia uma preocupação constante com as condenações mais severas, o que reforçava a importância de incutir o sentimento de esperança entre seus clientes:

\begin{abstract}
"Eu achava que, sempre, uma parte do nosso discurso deveria ser o de um discurso de convencimento. Eu achava que confrontando a denuncia com a lei vigente e, mais do que isso, com os princípios internacionais, com a Constituição, com os princípios do direito, era possível passar ao cliente uma noção de esperança jurídica. Ele tinha uma esperança política que ele sabia, todos sabiam - hoje é fácil dizer, mas na época, não - eu sou testemunha disso, todos sabiam que aquilo duraria por um tempo limitado, havia um limite no tempo e, portanto, aquilo não ficaria para sempre. Aquelas penas elevadíssimas não resistiriam. Então, eu sempre achei que era necessário manter essa esperança, manter a esperança em uma saída, fosse jurídica, fosse política. A saída jurídica para a situação macro ou para a do caso em questão era fundamental, porque o preso precisava estar concentrado para cuidar da sua família ou do que restava dela, cuidar da sua formação, cuidar do seu preparo para o futuro. [...] Aqueles anos passados na prisão deviam ser anos de reflexão, de aproveitamento, de convivência, era necessário tentar dar uma noção, a palavra não é boa, mas uma noção de valor para aquele período, porque ele era passado atrás das grades. Para alguns presos a prisão resultou em livros, em reflexões, em alternativas para o futuro, mas outros conviveram mais com a depressão, com a dor da perda, não superaram. É muito difícil superar as marcas da tortura, como na frase famosa "A tortura é uma marca que não sai". O papel do advogado era um pouco esse, eu queria convencê-los de que era possível defender aquilo. Eu falei de convencimento, mas eu tinha um olho nos juízes também...,761
\end{abstract}

\footnotetext{
760 SwenSSON JR., Walter Cruz. Os limites da liberdade. A atuação do STF no julgamento de crimes políticos durante o regime militar (1964-1979). Doutorado/História-USP, 2006, p.243.

${ }^{761}$ Entrevista concedida por Belisário dos Santos Jr. à autora. Idem, ibidem.
} 
Embora houvesse muito ceticismo entre os presos políticos quanto às possibilidades de obterem vitórias jurídicas na justiça militar há, entre alguns presos entrevistados, a percepção de que havia diferenças de comportamento por parte dos tribunais superiores, conforme o relato de Beatriz Bargieri:

“[...] A minha pena foi diminuída porque, geralmente, o STM baixava as penas. Eu acho que era uma desclassificação, na verdade, eles não tinham provas. A condenação em primeira instância era uma condenação mais política, aí o STM [...] dava uma roupagem mais legalista. Era bem isso.,762

Apesar dos obstáculos impostos pela justiça militar e do ceticismo dos presos, os advogados souberam aproveitar as poucas brechas existentes no sistema judicial e conquistaram vitórias efetivas nos tribunais superiores. Rosa Cardoso em seu depoimento recordou-se em linhas gerais da sua atuação na justiça militar, cuja tônica era confrontar a legalidade de exceção com a anterior e demonstrar a ausência de consistência e legitimidade das leis do período ditatorial:

"Eu tive muitos bons resultados nos tribunais superiores [...]. Na primeira instância, normalmente, eu fazia defesas mais técnicas, mostrando que aquilo que o Ministério Público Militar estava invocando eram uma legislação e uma doutrina totalmente insubsistentes, que era uma bobagem o que estava sendo dito. Eu fazia uma análise das leis de segurança, por que tal figura foi criada, por que tal artigo não pode ser aplicado, o que estava sendo manipulado... Na primeira instância, eu procurava mostrar que aquilo era uma farsa técnica, que o tribunal, caso atendesse ao que o Ministério Público estava pedindo, estaria montando uma farsa jurídica grosseira.

[...] Na primeira instância você tem mais tempo para a defesa. Na segunda instância você tem quinze minutos para a defesa, então você tem de ser bem sintética e ir ao ponto. Nas defesas de primeira instância procurava ser mais técnica, porque o nível de discussão política e filosófica que eu poderia fazer não teria sentido diante daqueles militares de caserna, ligados aos órgãos de segurança. No Superior Tribunal Militar e no Supremo Tribunal Federal, eu encontrava gente inteligente. Alguns, como o Siciliano Sarmiento, eram pessoas extremamente limitadas, mas tinha o Fragoso, que era capaz de entender as coisas... Eu focava em algumas questões técnicas, mas procurava discutir o que o regime tinha feito com aquelas pessoas, em matéria de incivilidade e barbaridade, e dizia que os julgadores tinham ali a oportunidade de tentar equilibrar as coisas, fazendo uma compensação com essa brutalidade, que não podia nunca ter sido feita por um regime que se dizia civilizado. Era um discurso político e moral, cobrando dos julgadores que se estabelecesse um equilíbrio moral, até para que o regime assumisse uma aparência de legalidade e tivesse coerência com o que eles queriam ser, então que se julgasse com outros critérios...

[...] No Superior Tribunal Militar, creio que a composição era de onze ministros, seis eram "linha dura", como a gente dizia, e cinco eram liberais. Sendo que entre esses de "linha dura", um ou outro que era mais independente podia ser convencido. Eu sempre ganhava por essa maioria. Sempre era atendida nos meus pedidos, podia não soltar a pessoa... Mas havia muita revogação de prisão preventiva no STM e, também, acho

\footnotetext{
${ }^{762}$ Entrevista concedida por Beatriz Bargieri à autora e a Marcelo Ridenti. Idem, ibidem. Destaques meus.
} 
reduzia-se as penas, porque eles efetivamente gostavam das minhas defesas, pois eu procurava não dizer coisas em que eu não acreditasse."763

Airton Soares ressaltou que as vitórias jurídicas nos tribunais superiores eram possíveis quando havia votos divergentes entre os juízes dos Conselhos de Justiça das Auditorias Militares ou entre os ministros do STM, como ocorreu no caso de Paulo de Tarso Venceslau, um dos militantes da ALN que participaram do sequestro do embaixador norte-americano em 1969:

\begin{abstract}
"Não se conseguia nada na primeira instância e, na segunda, conseguíamos algumas vitórias. [...] Quando você tinha uma decisão no Conselho de Justiça que tinha uma votação divergente, então, aproveitava-se essa divergência, por exemplo: uma votação de três a dois... eram quatro, mais o juiz togado, dava cinco. E aí você aproveitava os defeitos das sentenças, os equívocos legais que o juiz cometia quando dava a sentença, e recorria dessa decisão. Quando chegava no STM, você tinha lá relatores que eram mais ou menos liberais e você se aproveitava disso. No Supremo, então, você se aproveitava dos votos divergentes no Superior Tribunal Militar. Assim, era mais fácil para um ministro do Supremo basear-se num voto divergente de um general do STM e dar uma sentença mais compatível.

[...] Por exemplo, houve um caso interessante, o do Paulo de Tarso Venceslau que chegou ao STF. O Paulo tinha sido condenado em São Paulo e, no Superior Tribunal Militar a sentença foi mantida com o voto discordante do Rodrigo Otávio Jordão, que pediu a diminuição da pena. A gente apontava as questões técnicas, os erros jurídicos e eles, às vezes, se sensibilizavam diante disso. Assim, nós fizemos um recurso para o Supremo, que caiu com o Bilac Pinto. E tinha o recurso do Ministério Publico contra a procuradoria também. Apoiado no voto do Rodrigo Octávio, a sentença foi modificada no Supremo Tribunal Federal pelo Bilac Pinto, diminuindo a pena dele, acho que de dezesseis anos para doze, ou alguma coisa assim. Havia muitos exageros nas condenações, eram um absurdo! ${ }^{764}$,"
\end{abstract}

Belisário dos Santos Jr. também mencionou em seu depoimento o uso de votos divergentes entre juízes e ministros para recorrer das decisões e obter uma pena mais branda ou a absolvição. Ele destacou o papel desempenhado pelos advogados, cuja atuação forçou os limites da legalidade de exceção em diversas ocasiões, como no caso de Altino Rodrigues Dantas Jr., dirigente do PRT preso pelo DOI-Codi/SP em 1971:

“[...] Eu tenho um exemplo clássico, que é o do Altino Rodrigues Dantas Junior, ele brincava muito comigo, apresentava-me como o advogado que arrumou-lhe 86 anos de pena! Ele dizia rindo: '- Com esse advogado eu recebi 86 anos de prisão!' Era uma brincadeira entre nós, havia muito carinho. Eu temia no começo, pois tinha lido Marcel Vilar, que houvesse uma relação um pouco pesada dos presos com os seus advogados, mas pelo menos naquilo que eu vivi, não havia. Havia muito carinho, carinho que se arrasta até hoje.

[...] Mas dou o exemplo do Altino, porque ele foi condenado a 86 anos, no Tribunal isso baixou para 60 e então falei: “- Temos um recurso antes de ir ao Supremo, nós vamos

\footnotetext{
${ }^{763}$ Entrevista concedida por Rosa Cardoso da Cunha à autora. Idem, ibidem.

${ }^{764}$ Entrevista concedida por Airton Soares à autora. Idem, ibidem.
} 
reduzir a sua pena de 60 para 45 . E, assim, nós vamos caminhando.” Ele riu e falou: “Ah, muito bom, 45 anos, muito bom!” Para que ele pagasse a língua, quando veio a lei de anistia o caso dele não tinha transitado em julgado ainda no STM, porque eu estava lutando para abaixar as penas dele e, justamente por isso, ele conseguiu sair da prisão antes do que os outros. Havia uma expressão na lei de Anistia que excluía os "presos condenados". É possível que algum setor do regime tenha entendido como presos condenados qualquer condenação, mas parte dessa articulação, mesmo governamental e, depois, o próprio Supremo, entendeu de outra forma.

O segundo caso analisado [depois da lei de anistia] pelo Supremo Tribunal Federal foi exatamente o do Altino. O relator, Leitão de Abreu, quando o julgou disse: '- A tradição jurídica brasileira diz que preso condenado é preso condenado definitivamente’. Portanto, o Altino saiu antes e eu, sem querer perder o amigo, não pude perder a piada, disse a ele: “- Sem aquele recurso que você brincou tanto comigo, você estaria lá dentro na prisão!'

No caso do Altino, o STM abaixou a pena dele para 40 ou 45 anos, mas havia um voto vencido. E assim recorríamos usando várias teses, enfim, o Altino era réu primário, praticamente todos eram... A gente usava todos os argumentos do arsenal jurídico, todos: o preso era réu primário, a pena mínima já afeta o crime, ele cometeu o crime por uma razão que não leva ao exacerbamento da pena, mas sim à sua diminuição, pois o motivo era nobre, ele havia cometido um crime político. A ditadura negava-se a 'entender' que aquelas ações todas tinham a ver com o regime ditatorial que existia no país e a gente tinha que estabelecer a relação: o crime era político e pela tradição ele sempre é considerado como uma atenuante, quem pratica o crime com um fim torpe tem a pena é agravada, mas quando o fim é nobre, e o crime político tinha um fim nobre, havia uma atenuante $^{765}$."

A situação exigia dos advogados astúcia, sutileza e conhecimento das predileções pessoais e políticas de juízes e ministros dos tribunais superiores, que em conversas informais tentavam apressar a tramitação dos pedidos, mas também chamar a atenção para petições e recursos a serem lidos, conforme o relato de Virgílio Enei a respeito de um recurso feito ao STM em favor de Cida Costa, militante do "grupo de fogo" da ALN, presa em 1969:

"Eu consegui coisas estranhas no STM. Aí a poesia entrava muito... Teve uma moça famosa, [...] era a popular loira dos assaltos. [...] Ela foi minha colega na Faculdade de Direito, no Largo da São Francisco, e era minha cliente. [...] Primeiro, eu requeri a revogação da prisão preventiva dela para que ela ficasse sob ménage. Em geral, o preso saía, mas tinha que passar uma vez por semana ou mês pelo DOPS, Oban ou pela auditoria e assinava o livro preto. Com ménage você saia direto sem essas coisas. Requeri e isso foi negado. Em cima desta negativa, entrei com recurso no STM dizendo que ela estava presa havia muito tempo, que as prisões eram a universidade do crime, ela acabaria se tornando subversiva mesmo etc. [...] Enfim, argumentei que não havia provas de que ela tinha feito as ações armadas e mais ou menos fazia alguma gozação muito poética. Usava o Camões. Ele termina um dos cantos falando "Ah indigno céu sereno/ contra um bicho da terra tão pequeno”. Eu dizia que o céu sereno era a justiça e o bicho tão pequeno era a coitada da minha cliente que devia ser solta. Em cima do Camões eu construí o recurso, que era bem poético.

[...] Por uma coincidência daquelas, o relator era o Amarílio Lopes Salgado, um civil, que era considerado um grande especialista em Augusto dos Anjos. [...] Eu liguei para ele e puxei um papo sobre o poeta. [...] Comecei a falar [...] e depois declamei uns sonetinhos

${ }^{765}$ Entrevista concedida por Belisário dos Santos Jr. à autora. Idem, ibidem. 
do Augusto dos Anjos. Então falei: “- O Ministro vai julgar um caso meu que se assemelha ao caso de fulana de tal.” Ele respondeu: "- O senhor me liga daqui a dois ou três dias, que eu vou estudar isso.”. [...] Eu liguei [...] e ele lembrou-se do caso: “- É doutor, o que eu vejo sobre ela e os assaltos é que não tem prova nenhuma. Há alguma prova sobre a ligação dela com o grupo. Pode deixar. Vou lhe pedir um favor: não venha fazer sustentação oral. Ou se vier, venha falar comigo fora do STM”. Daí eu fui e não sustentei, assisti à sessão e ela ganhou o recurso. Saímos, eu e ele, e fomos tomar qualquer coisa [...].

[...] Havia três civis e se o recurso caísse com esses três como relatores, ou se caísse com o Romero Neto... Ele era um advogado que defendeu o Gregório da acusação de ser o mandante do atentado da rua Toneleiros e virou ministro, mas continuava a favor da defesa. Então, quando caía com eles, geralmente, modificava-se alguma coisa. Acho que isso ocorreu em 1972. Nesse dia, foi dada a liberdade provisória para ela, pois ela já havia ficado presa uns três anos.

[...] Anos depois, ela foi condenada por pertencer à organização clandestina, mas era acusada também de assaltar joalheria etc. Como ela já tinha cumprido o tempo, ficou livre. Acredito que ela foi denunciada pelo artigo 14. A lei mudava sempre e os promotores eram muito zelosos, denunciavam por tudo, mesmo sem provas ${ }^{766}$ !"

O tratamento dado pela justiça militar aos presos políticos sofreu alguma contestação por parte da opinião pública, mesmo na fase mais intensa da repressão estatal. Em 1971, Theodomiro Romeiro dos Santos foi condenado à pena de morte pela Justiça Militar da Bahia, o que mobilizou a sociedade civil, pressionando o STM. Theodomiro e Paulo Pontes eram militantes do PCBR e foram presos em Salvador (BA), no dia 27 de outubro de 1970. Ao tentar fugir do carro onde estava algemado, Theodomiro matou um sargento da Aeronáutica e feriu outro.

Depois de doze dias sendo torturado, Theodomiro recebeu a visita de um capitão do exército do Rio Grande do Norte, amigo de seu pai, que se ofereceu para levar notícias a sua mãe. Ele escreveu-lhe uma carta, cuja leitura deu início à movimentação da família e militantes para divulgar sua prisão:

“[...] algumas situações e fatos indicaram qual era a pretensão deles. A pessoa que é processada pela morte de alguém tem um julgamento sumário, o Código do Processo Penal Militar e a Lei de Segurança Nacional previam um rito sumário com prazos muito pequenos. Então, logo eles me levaram e me apresentaram à Auditoria Militar, esse foi outro indício de que eu não seria morto, porque lá tinha imprensa, todo o mundo. Para me matar ficou mais difícil, não era impossível, eles podiam ter dito que eu havia tentado fugir etc. Mas, aparentemente, eles não tiveram essa vontade na Bahia. Fala-se, mas nunca tive a confirmação de ninguém, mas fala-se que houve uma reunião dos comandantes do DOI-CODI na Bahia para discutir se me matariam ou não e que teriam decidido me manter vivo por um voto de um brigadeiro da aeronáutica chamado Lima Araújo. [...] Depois que eu consegui escrever a carta para a minha mãe, eu melhorei, [...] ela apareceu uns três ou quatro dias depois.

Acho que a primeira audiência na justiça militar, aconteceu uns três ou quatro meses depois da prisão. Acho que foi em fevereiro de 1971 ou início de março. A gente estava muito machucado ainda, eu levei muita porrada nesse joelho esquerdo e ele ficou muito

\footnotetext{
${ }^{766}$ Entrevista concedida por Virgílio Lopes Enei à autora. Idem, ibidem.
} 
inchado. Eu levei cortes enormes na cabeça... e para cicatrizar... [...] quando cheguei na auditoria, eu estava com várias feridas abertas e mancando, porque o meu joelho também não ficou completamente bom, mas quem ligava para isso?

Inicialmente, tive um advogado dativo, com quem nunca tive a oportunidade de conversar, só quando eu ia à auditoria. Ele não queria falar comigo. Só depois da condenação e da confusão armada pela minha mãe, ela ficou procurando um advogado na Bahia, mas ninguém queria assumir a minha defesa, aí o Sobral Pinto se apresentou para vir me defender se mamãe quisesse. Depois disso, alguns advogados tomaram de brio a questão e aceitaram o caso. Fui defendido pelo Inácio Gomes, que não era um advogado brilhante, mas era uma pessoa correta comigo. E, depois, pela Ronilda Noblat, que foi uma grande advogada, muito eficiente, muito batalhadora ${ }^{767}$."

Em 18 de março de 1971, com apenas 19 anos, Theodomiro foi condenado à pena de morte, e Paulo, à prisão perpétua. A condenação provocou uma onda de críticas que teve repercussão na imprensa brasileira, na qual tiveram um papel importante advogados, familiares, defensores dos direitos humanos e setores da Igreja Católica. O arcebispo de Salvador, dom Eugênio Sales, declarou-se contra a pena de morte, assim como o secretário-geral da CNBB, dom Ivo Lorscheider. O advogado Heleno Fragoso, à época autor do então recente código penal, condenou a pena de morte, por considerá-la incompatível com a dignidade humana. Sobral Pinto somou-se ao protesto. O Jornal do Brasil chegou a publicar um editorial contrário à pena capital ${ }^{768}$. Houve pressão internacional contra a sentença com a realização de grandes manifestações de exilados na frente das embaixadas brasileiras na França, na Suécia, entre outros países ${ }^{769}$.

A resposta dos militares e seus aliados foi agressiva, no funeral do sargento, o então governador da Bahia, Antônio Carlos Magalhães, advertiu os "céticos que, por complacência ou omissão, contribuíram com os objetivos dos criminosos”. Foram feitos pedidos ao governador para que criasse um esquadrão da morte no estado para "liquidar os comunistas” [PEREIRA, 2010:139].

Theodomiro contou-nos como enfrentou a condenação e qual era o ambiente nos meses que antecederam o julgamento do recurso no STF:

"Eu tinha certeza absoluta que não ia ser condenado à pena de morte, assim como tinha
certeza de que não ia ser executado, porque eu era a pessoa menos indicada para
inaugurar a pena de morte no país. Eu tinha dezoito anos, era menor de vinte e um quando
fui preso, então, isso era uma atenuante pelo código de processo penal militar. Eu tinha,
do ponto de vista jurídico, bons antecedentes, sempre fui um estudante muito aplicado,
muito responsável, estudioso. Eu tinha uma família que tinha vínculos com a instituição
militar. Não haveria a menor possibilidade de eu ser morto através dos trâmites legais, ser
condenado ao pelotão de fuzilamento, então, isso estava completamente fora de cogitação.

\footnotetext{
${ }^{767}$ Entrevista concedida por Theodomiro Romeiro dos Santos à autora. Idem, ibidem.

${ }^{768}$ PEREIRA, Anthony W. op.cit., p.139; JosÉ, Emiliano. Op.cit., p.122-4.

${ }^{769}$ Entrevista concedida por Theodomiro Romeiro dos Santos à autora. Idem, ibidem.
} 
Tanto foi uma estupidez sem tamanho que, acho que a primeira grande manifestação contra a ditadura militar depois do AI-5 foi quando fui condenado à pena de morte. Aconteceu uma movimentação grande aqui no país, posicionamentos de parte da imprensa contra e grandes manifestações em frente às embaixadas brasileiras no exterior. [...] Tanto é que o tempo de tramitação do meu recurso foi insignificante. Entre a leitura da sentença e a reforma dela no STM tudo foi muito rápido, não era normal na época.

No STM, eles comutaram a pena de morte em prisão perpétua e Paulo Pontes foi absolvido, mas ficaram os processos pelo assalto ao banco e por pertencer ao partido. Foram três processos, a gente foi condenado a cinco anos cada um por conta do PCBR. A tese da defesa era a da conexão de ações, de atos, juridicamente seria um processo só e não dois. Na verdade, haveria conexão entre os três. A morte do sargento, o assalto do banco e a filiação ao partido, mas naquela época eles não dariam nunca a interpretação mais favorável aos militantes de esquerda.

Mas depois que fui condenado à morte a minha situação carcerária não mudou um milímetro. A situação carcerária da época era uma merda e continua sendo, não mudou para pior nem para melhor. ${ }^{770,}$

A mobilização surtiu efeito, em 14 de junho de 1971 o STM converteu a pena de Theodomiro em prisão perpétua e, mais tarde, em 7 de março de 1975, o STF a reformou para trinta anos de prisão. Ele foi condenado em outros processos, enquadrado nos crimes de assalto a banco e de organizar partido clandestino. Depois de impetrar diversos recursos e da readequação de penas, sua advogada, Ronilda Noblat, conseguiu baixar sua pena de 48 para 16 anos e 6 meses $^{771}$.

Antes da condenação de Theodomiro, um promotor do tribunal militar de Juiz de Fora (MG), pediu a pena de morte num outro caso. Dias depois, um promotor do Ceará pediu a pena de morte para nove acusados, e um outro promotor, de Recife, fez o mesmo pedido contra três militantes acusados de matar um oficial da Aeronáutica [PEREIRA, 2010: 140].

Apesar da revogação da pena capital imposta a Theodomiro, em novembro do mesmo ano, Ariston de Oliveira Lucena e Diógenes Sobrosa de Souza foram condenados à pena de morte pela Justiça Militar de São Paulo ${ }^{772}$. Lucena foi acusado de matar o tenente Mendes Jr. durante o cerco militar aos guerrilheiros da VPR, no Vale do Ribeira, em 1970. Ele foi acusado de cometer diversos crimes em vários processos na Justiça Militar, o que exigiu grande empenho e trabalho de seus advogados. Rosa Cardoso e os demais advogados sabiam da importância de visitar constantemente seus clientes, principalmente, aqueles que não tinham família ou cujos parentes vivessem afastados. Por isso, Josefina Bacariça, uma ex-presa política que passou a trabalhar como assistente no

\footnotetext{
${ }^{770}$ Entrevista concedida por Theodomiro Romeiro dos Santos à autora. Idem, ibidem.

${ }^{771}$ PereirA, Anthony W. op.cit., p.138-9; JosÉ, Emiliano. Op.cit., p.122-4.

${ }^{772}$ SILVA, Angela Moreira Domingues da. "Ditadura militar e repressão legal: a pena de morte rediviva e o caso Theodomiro Romeiro dos Santos (1969-1971), em http://br.dir.groups.yahoo.com/group/politicabr/message/91905?l=1.
} 
escritório de Rosa Cardoso e Virgílio Enei, dispensou especial atenção a Ariston Lucena, visitando-o assiduamente no presídio ${ }^{773}$. Estabelecer a estratégia de defesa no caso dele não foi tarefa fácil, conforme o relato de Lucena:

“[...] A minha primeira condenação foi de trinta anos, por causa do sequestro do caminhão do Exército. Depois, fui condenado à morte, em função da morte do tenente. Em seguida, fui condenado a vinte anos por fazer panfletagem, participar de tiroteio, assalto a banco, uso de bomba, enfim, um monte de coisas assim.

Acho que a primeira condenação foi em 1971, [...] e neste mesmo ano fui condenado à morte. [...] [Neste processo], o Lamarca e o Fujimori já tinham morrido e o Faria Lima foi condenado à revelia [...].

[...] A estratégia de defesa da Rosa foi interessante, porque sou réu confesso. Fui para a Auditoria Militar, confirmei e defendi tudo, embora eu não tivesse uma grande formação política. [...] Eu falei: '- Fiz isso'. Aí [o juiz] perguntou: '- Você matou o tenente?'. Eu falei: '- Não, não matei o tenente, mas eu concordei que ele deveria ser executado'. Na verdade, não concordava [...], mas disse isso. [...] O juiz perguntou '- Você participou de ação armada?’, respondi '- Participei'. Ele perguntou '- Participou do tiroteio?’, disse 'Participei'. Perguntou '- Participou de assalto?', respondi '- Participei'. Eu confirmei tudo, sou réu confesso, mas o negócio do tenente, eles me condenaram porque queriam me usar de exemplo. Eu tinha certeza que eles não iam me executar. Legalmente, não tinha como justificar isso. Eu era um moleque de 18 anos, como é que você justifica a execução de um moleque, quando nem está provado que ele matou o tenente? Eu nunca confessei isso, nem no pau, porque realmente eu não tinha participado! Eu estava tranquilo com relação a isso, eu tinha os meus medos, mas não era medo de ser executado. Eu tinha medo de voltar para a tortura, disso eu tinha mesmo, tinha pavor de voltar para a tortura, pra mim seria um terror, mas ser fuzilado eu estava cagando e andando! Eu sabia que eles não iam fazer isso, não tinha condições políticas, a conjuntura não era favorável para fazer isso. Mesmo em 1971, no auge da repressão, eles matavam como mataram um monte de gente, ilegalmente [...]. Mas eu já estava preso, como é que você mata um cara, legalmente?

[...] A Rosa teve muita dificuldade para me defender [...]. Na verdade, ela foi uma brilhante advogada, mas tinha muito pouca margem para manobrar. Eu me lembro que numa das audiências ela pediu para tirarem as algemas e eu resolvi aterrorizar mesmo... Eu não tomava banho, não cortava o cabelo, ia lá pra encher o saco dos caras mesmo! Eu tenho o cabelo crespo, ficou aquele cabelão, roupa rasgada, suja, [...] passei meses sem tomar banho! [...] Aí cheguei lá e falei que não reconhecia a idoneidade política daqueles caras para me julgar, tanto é que na minha sentença consta: rebelde, avesso à autoridade, aquele monte de bosta que eles adoram falar dos outros.

Depois dos meus julgamentos e das minhas condenações eu fiquei tranquilo, achei que nunca mais ia sair da cadeia. O meu medo era de voltar para a tortura, [...] mas a partir de certo momento fui trocando de advogado e o último foi o Belisário, que atuou junto com a Regina Pasquale. Eles foram meus últimos advogados. Aí comecei a pensar seriamente nessa questão de sair da cadeia. [...] Aí virou uma possibilidade real poder sair da cadeia [...] Isso foi um ano e meio antes de eu sair. [...] eu não tinha preocupação de sair, porque sabia que os caras não iam me soltar porra nenhuma, sabia o que eu tinha nas costas, o nível de comprometimento e o fato de ser réu confesso...

Mas a pena de morte virou prisão perpétua e depois virou [uma condenação de] 30 anos, aí somaram todas as penas e virou algo em torno de 50 anos. A Rosa e o Belisário

\footnotetext{
${ }^{773}$ Entrevista concedida por Josefina Bacariça à autora. SP, 11/11/2008. AAPP/AEL-LEI.
} 
começaram a alegar crime continuado, réu primário ${ }^{774}$, não sei mais o que e aí virou 30 anos. Eu já tinha 'puxado' um terço, 9 anos, e, assim, saí em liberdade condicional. Crime continuado é uma figura jurídica que tem no Código de Processo Penal em que você unifica as penas, que beneficia o preso ${ }^{775}$.

Eu não fui beneficiado pela redução das penas da Lei de Segurança Nacional de 1978, mas pela tese de crime continuado, pelo fato de ser réu primário e ser menor de 21 anos, tudo isso terminou me beneficiando $[\ldots]^{776,}$.

Inicialmente, Virgílio Enei atuou como o advogado de defesa de Ariston Lucena. Ele nos relatou quais foram os seus argumentos utilizados durante o julgamento na Auditoria Militar de São Paulo:

"Eu defendi o Ariston argumentando que, na realidade, ele não havia matado o tenente, mas se tivesse matado, se tivesse participado do ato, era preciso considerar que ele tinha sido feito por muitas outras pessoas. Então, seria um crime múltiplo. Digamos, por exemplo, um linchamento é um crime múltiplo, pois são trezentas pessoas que lincham e, então, não podemos condenar um, é preciso condenar vários. Além disso, não podiam condená-lo por falta de provas... Ele havia sido torturadíssimo, inclusive, eu pedi diversas vezes o exame de corpo de delito, mas em nenhuma vez isso foi feito.

Enfim, todos deveriam ter sido processados juntos, mas eu sabia que isso seria negado e a falta de prova também. [...] A gente questionava sobre o porquê deles não fazerem o exame de corpo de delito nele... Na verdade, na primeira apresentação do Ariston ele estava todo arrebentado. Não precisava nem fazer o exame... Ele sustentou que foi torturado, mas foi condenado a morte assim mesmo. Todos os cinco juízes da auditoria o condenaram a morte. [...] Eles estavam com medo da repercussão internacional, mas condenaram. E, de fato, houve muita repercussão do caso. A condenação dele saiu em quase todos os jornais ${ }^{777}$."

\section{Depois, Rosa Cardoso fez a defesa oral de Ariston Lucena no STM e conseguiu} revogar a sentença de pena de morte por unanimidade. Sua defesa foi marcada por seu brilhantismo. Considerada excelente advogada, certa vez o ministro do STM Alcides Carneiro contou a Heleno Fragoso que o ministro Rodrigo Octávio considerava-a melhor do que o próprio Fragoso. De acordo com seu relato, este elogio não era decorrência da antipatia que Octávio devotava-lhe, mas do grande talento de Rosa [FRAGOSO, 1984:147]. Belisário dos Santos Jr., que também atuou no caso de Lucena, lembra-se da defesa oral de Rosa Cardoso feita no STM, quando conquistou uma decisão histórica:

"Lembro-me que a Rosa fez voltar ao plenário do Superior Tribunal Militar o ambiente em que as coisas se passaram. O tenente Mendes Junior, que teve o seu grau de heroísmo

\footnotetext{
${ }^{774}$ Em 30/06/78 foi promulgada uma lei que alterava o art. 527 do Código de Processo Penal Militar, estabelecendo que o réu tinha o direito de apelar sem recolher-se à prisão, desde que a sentença reconhecesse que ele era primário e com bons antecedentes [FRAGOSO, 1984: 174].

${ }^{775} \mathrm{O}$ crime continuado no Código de Processo Penal Militar diz respeito à derrogação da cumulatividade das penas.

${ }^{776}$ Entrevista concedida por Ariston de O. Lucena à autora, Idem, ibidem.

${ }^{777}$ Entrevista concedida por Virgílio Lopes Enei à autora. Idem, ibidem.
} 
bastante mencionado, não sem alguma razão, pois, afinal, ele trocou-se pelos seus homens e isso é uma coisa que todos reconhecemos, tentou levar os autores de sua prisão a uma armadilha, quer dizer, ele foi uma pessoa que fez valer o seu juramento e a causa que ele defendia. Isso era algo que deveria ser entendido, mas curiosamente a Rosa descreveu com tanta inteligência e sensibilidade o ambiente vivido [no vale do Ribeira], que o ministro Alcides Carneiro, quando tomou a palavra, disse que a pena de morte não podia ser sustentada, acho que ele usou outros argumentos históricos do direito brasileiro, mas em especial ele argumentou que havia uma situação de guerra a ser considerada. Então, aquela questão toda da maneira como se deu a morte do tenente Mendes Jr., ele justificou como sendo a única apropriada para aquele momento. Ele não podia ser morto com as honrarias de um herói que ele foi, e que todos aceitavam, mas era a forma que havia sido possível naquele ambiente de guerra. A forma como ele foi morto havia sido o motivo que deflagrou a pena de morte, o que horrorizou foi a forma da morte, a coronhadas etc. $\mathrm{O}$ ministro Alcides Carneiro aceitou os argumentos da defesa, entendeu o ambiente em que eles estavam, ajudou a levar o tribunal para aquele momento e o tribunal em uma decisão que me pareceu uma decisão histórica... Você poderia falar: '- Condenou-o a trinta anos!' Mas, na verdade, deixou de condená-lo à morte. Hoje, analisando com mais frieza, a pena de morte era um problema, era uma possibilidade, mas, ao mesmo tempo, era um problema para a Justiça Militar executar a pena de morte no Brasil. Executar a pena de morte, num regime que estava em guerra com o seu próprio povo, [...] o inimigo interno e aquelas questões de segurança nacional, seria difícil. De qualquer forma, o STM entendeu aquilo e, por unanimidade, recuou da pena de morte e atribuiu-lhe a pena de trinta anos. Eu acho que foi um julgamento histórico, que firmou o STM como uma instância mais branda, vamos chamar assim, de poder da República. Era uma instância que exercia o poder que lhe era dado, o poder de condenar e absolver, mas exercia de uma forma mais branda. Houve outros episódios que fizeram com que realmente se firmasse essa história de que o Superior Tribunal Militar, ainda que composto por oficiais generais, era composto por pessoas, cuja distância do poder político efetivo podia atuar de uma forma menos agressiva ${ }^{778}$."

De acordo com Rosa Cardoso, os ministros dos tribunais superiores tinham consciência do papel de legitimação do regime exercido pelo sistema judicial. Ao diminuírem as penas e concederem absolvições eles sinalizavam que compreendiam a eficiência de uma política repressiva baseada na coerção seletiva e na exemplaridade das punições para difundir o medo e obter submissão:

“[...] Acho que eles tinham consciência de que soltavam as pessoas ou amenizavam penas. E eram conscientes de que elas tinham passado por um processo que, associado à tortura e a tudo que tinham sofrido, já havia obtido o impacto necessário. Acho que na primeira instância, eles não faziam esse tipo de cálculo. Às vezes, até faziam o seguinte raciocínio: 'Mais vale absolver do que deixar criar a oportunidade'. O militante passou pela prisão, já viu que a coisa não é brincadeira. Ele já está assustado e traumatizado. Esse trauma ele vai carregar. Então, é melhor, e até mais inteligente absolvê-lo, porque ele reintegra-se melhor à sociedade, pois já cumpriu uma pena, do que condená-lo. Esse cálculo, os tribunais superiores faziam bem mais do que na primeira instância, mas na primeira instância alguns juízes também pensavam nisso, havendo algumas absolvições de gente que ficou um tempo presa com prisão preventiva. Havia prisões de pessoas que foram soltas rapidamente, porque não tinham nenhuma ligação com aqueles fatos, mas

\footnotetext{
${ }^{778}$ Entrevista concedida por Belisário dos Santos Jr. Idem, ibidem.
} 
também porque tinham colaborado, porque falavam... E eles faziam todas essas distinções." ${ }^{\text {,79 }}$.

De fato, a repressão judicial era parte importante da estratégia de legitimação da ditadura. De acordo com Anthony Pereira, a judicialização da repressão foi possível porque a ditadura pode “[...] contar com tribunais 'dignos de confiança' - tribunais civis ou militares cujos veredictos” harmonizaram-se com a legalidade de exceção adotada pelo regime, sem contestar as bases de seu poder [PEREIRA, 2010: 284]. A ditadura conseguiu, por um tempo considerável, manipular a lei e subjugar os tribunais em benefício próprio e impor soluções institucionais para a organização da repressão estatal, reorganizando os sistemas judiciários, baseada "nos vínculos históricos estabelecidos entre esses dois grupos" [PereIRA, 2010: 283]. Havia, no Brasil, "fortes elementos de continuidade com o sistema judicial 'normal'[...]”, anterior ao golpe [PEREIRA, 2010: $130]$.

A Justiça Militar contribuía para a difusão de uma imagem política positiva do regime e, mais amplamente, para a sua própria legitimação ao difundir uma aparência de funcionamento regular do Estado, sob o mote da existência de um judiciário supostamente independente. Internamente, tratava-se de um sistema vantajoso do ponto de vista da dinâmica e administração da disputas existentes entre as diversas facções do regime, o qual contribuía à divisão de responsabilidades e fatias do poder entre os setores efetivamente envolvidos nas tomadas de decisão e estruturação burocrática do Estado. As manipulações jurídicas e a prática de levar à justiça os dissidentes atuaram como fatores de desmobilização dos movimentos sociais e oposicionistas, contrabalanceado o uso estratégico da força.

No Brasil foi possível manter o sistema híbrido de justiça militar, forjado antes do golpe de 1964 [PEREIRA, 2010: 287], que a partir do AI-2 foi aperfeiçoado para levar dissidentes civis aos tribunais de exceção. A repressão judiciária respondia a uma estratégia de poder que se acreditava ser de longa duração e que se demonstrava preocupada com sua própria legitimação. Confiante no seu projeto, o funcionamento do regime impôs e favoreceu a manutenção de registros sobre a atividade do aparato repressivo.

Este amplo consenso firmado entre as lideranças civis e militares com relação à maneira de organizar a repressão estatal teve nos tribunais militares sua expressão

\footnotetext{
${ }^{779}$ Entrevista concedida por Rosa Cardoso da Cunha. Idem, ibidem.
} 
institucional mais visível. A justiça militar, contudo, era a contrapartida dos centros de tortura e extermínio - sua porção institucional menos visível, que alimentava e controlava a engrenagem dos tribunais de exceção. Os altos níveis de cooperação entre civis e militares e a existência de instituições híbridas como a justiça militar favoreceram a institucionalização da tortura, assim como a adoção de um modelo repressivo seletivo.

A atuação dos advogados de defesa obteve resultados concretos forçando os limites das leis de exceção, contudo os relatos aqui analisados não permitem concluir que eles “contribuíram para a formulação da legalidade de segurança nacional” [PEREIRA, 2010: 230]. Os testemunhos de presos e advogados, assim como os dados disponíveis, não coincidem com a afirmação de que a orientação legal adotada pela ditadura tenha afetado seus padrões repressivos [PEREIRA, 2010: 230]. Ao contrário, os objetivos políticos delineados nas diretrizes a respeito da condução do aparelho repressivo orientaram a configuração da legalidade de exceção e as práticas do judiciário, principalmente, após a criação do sistema DOI-Codi. A busca constante do regime por institucionalização e legitimação estava submetida à dinâmica da luta política e às pressões e resistências da sociedade civil, assim como às ligações históricas entre civis e militares.

No contexto da luta de resistência à ditadura, presos políticos e seus familiares, advogados de defesa e as redes de solidariedade constituídas em torno dos prisioneiros tiveram um importante papel na sistematização e divulgação das denúncias sobre os aspectos mais violentos e arbitrários da ditadura, o que sensibilizou a opinião pública e gerou desgaste ao regime. 


\section{Capítulo V}

\section{Rompendo o isolamento: as lutas pela redemocratização e a anistia}

\section{A greve de fome na Penitenciária do Estado de São Paulo}

O ano de 1974 se iniciou com a posse do novo presidente, o general Ernesto Geisel, mas também com o recrudescimento da repressão à Guerrilha do Araguaia e aos remanescentes da luta armada urbana, assim como aos membros e dirigentes do PCB, da AP-ML, da Patoral Operária e de militantes católicos ${ }^{780}$. No dia 21 de janeiro, o líder metalúrgico da Patoral Operária e da Oposição Sindical Metalúrgica de São Paulo, Waldemar Rossi foi preso pelo DEOPS/SP. Ele, pessoas da coordenação da Oposição Sindical como Vito Gianotti e Antonio Flores e mais cerca de 70 militantes foram presos [SADER, 1988: 238]. Rossi também pertencia à CJP/SP. Para o regime era necessário eliminar toda e qualquer forma de oposição, intimidar os setores que apoiavam e atuavam com d. Paulo E. Arns e a base social onde a ala progressista da Igreja Católica e as esquerdas atuavam. De acordo com Rossi:

“[...] A gente aglutinava pessoas de várias tendências, alguns que vieram da antiga AP, do Partido Comunista etc e que já buscavam outro caminho, e o pessoal nosso da pastoral e outros ligados ao movimento de base. [...] Nós dizíamos claramente: não éramos um partido, eramos um movimento de organização e despertar da consciência e para formação política da classe trabalhadora. [...] Fomos levados para o DOPS e no dia seguinte eu fui interrogado. [...] D. Paulo denunciou em seguida, [...] mas acho que [o fato de não sermos de partido] fez com que no julgamento, quatro anos depois, fôssemos absolvidos por total falta de provas. Com isso ficamos sub judice, que era o que eles queriam, e, por isso, em 1975 não houve chapa da oposição, só em 1978. Fiquei preso quatro meses e 8 dias. Fui torturado, pendurado no pau-de-arara, levei muito choque, choque no corpo inteirinho. Fiquei todo queimado, porque foram várias horas, perdi o movimento nas pernas, [...] era um negócio horrível [...], mas tive que aguentar a mão. [...] Eles estavam atrás de outra pessoa quando nos prenderam, que era o De Lellis, antigo presidente do Sindicato dos Metalúrgicos [...].

\footnotetext{
${ }^{780}$ Rosalina Santa Cruz, ex-militante da Var-Palmares, foi presa novamente em 1974, pouco depois do desaparecimento de seu irmão Fernando Santa Cruz e Eduardo Collier Filho, militantes da AP-ML, em 23/02/74. Jesus Paredes Sotto, militante do MR-8, foi preso em 1974. V. as entrevistas concedidas por Rosalina Santa Cruz e Jesus Paredes Sotto à autora. Idem, ibidem.
} 
[...] D. Paulo [...] fez a denúncia pública, deu uma entrevista, fez uma carta que mandou ser lida em todas as paróquias e comunidades denunciando e começou a pressionar o DOPS, através da Comissão de Justiça e Paz. Ele pediu para o doutor Mário Passos Simas e o José Carlos Dias assumirem o nosso caso. [...] D. Paulo começou a fazer pressão e exigir uma visita. Como negavam, ele foi fazer uma caminhada na frente do DOPS paramentado e lendo o seu breviário, chamando a atenção da opinião pública. E um dia ele ousou mais, [...] entrou de surpresa na sala dos delegados e cobrou a nossa libertação. Enfim, ele conseguiu marcar a visita. D. Paulo nos visitou depois de [...] 25 dias que eu estava preso e [...] ainda tinha marcas, mas dava para disfarçar. Fui levado para conversar com o d. Paulo e d. Francisco [...] e ele só de olhar falou: '- Olha o jeito deste rapaz, vocês torturaram ele'. Ele fez a acusação. [...] depois disso as famílias começaram nos visitar uma vez por semana, às quintas-feiras. Depois de três meses, o De Lellis, eu, a Sônia Lins e a Pilar, fomos levados para [...] fazer o depoimento oficial [...]. Depois [...] nos mandaram para o presídio do Hipódromo e lá nós ficamos vários dias [...] e fomos soltos. Mas cobraram de nós voltarmos a cada semana para assinar algo, depois nós paramos de ir por conta própria. Mas a pressão psicológica continuou e eles nos seguiam [...]. E isso aconteceu por vários meses ${ }^{781}$."

Em seguida, no dia 18 de fevereiro de 1974, outra personalidade ligada aos setores progressistas da Igreja Católica de São Paulo foi presa. A professora e pedagoga Maria Nilde Mascellani, educadora que impulsionou o Ensino Vocacional nos anos 1960, foi presa e torturada no DEOPS/SP. Seu escritório foi invadido por policiais militares e ela e seus companheiros ficaram presos por cerca de um mês. Mascellani era acusada de ter redigido um relatório considerado subversivo pelo regime contra a obrigatoriedade do ensino de Educação Moral e Cívica no Brasil a partir de $1971^{782}$. Este documento fora encomendado pelo Conselho Mundial de Igrejas, com sede na Suíça, e teve grande repercussão na Europa. Apenas em 6 de junho de 1977, o Conselho Permanente da $2^{\text {a }}$ Auditoria de Guerra da Justiça Militar, em São Paulo, absolveu Mascellani, o jornalista Dermi Azevedo e Darcy Andória Azevedo. Mas ela obteve o direito de voltar a lecionar somente em 1984, por meio de despacho do governador Franco Montoro ${ }^{783}$.

Nesse contexto, em resposta às diversas prisões que ocorreram nesta fase foi criado o Comitê de Defesa dos Presos Políticos no dia 5 de abril de 1974, numa assembleia realizada no anfiteatro do prédio da Ciências Sociais da Universidade de São Paulo. O DEOPS/SP iniciou um IPM para investigar a atuação dos estudantes e alguns dos presentes à reunião foram ouvidos pela delegacia de Ordem Política ${ }^{784}$. O comitê era um dos desdobramentos dos protestos organizados na USP no ano anterior contra a a

\footnotetext{
${ }^{781}$ Entrevista concedida por Waldemar Rossi à autora. SP, 12/01 e 04/02/2009, AAPP/AEL-LEI.

782 V. entrevista concedida por Ana Maria de Almeida Camargo à autora. Idem, Ibidem.

783 V. MARKUn, Eliana. "Biografia de Maria Nilde Mascelani”, e outros textos em http://www.gvive.org/cantinho-biografia.

${ }^{784}$ V. documento no Arquivo do Estado de SP, Série Dossiês do DEOPS/SP, s/n., 14/06/74.
} 
morte sob tortura do militante da ALN, Alexandre Vannucchi Leme e a prisão de diversos estudantes.

Nesse período, a Fundação Lélio e Lisli Basso se constituiu num importante apoio aos exilados e perseguidos políticos brasileiros na Europa. A relação com Pier Lélio Basso, figura histórica do socialismo italiano ${ }^{785}$, e a fundação se iniciou em 1964 e se fortaleceu a partir de 1970 por meio de contatos com o Partido Comunista Italiano (PCI). Renato Sandri era o responsável do PCI pelas relações com a América Latina e deu um suporte consistente à ALN e aos exilados brasileiros nos anos 1970. Em meados de 1972, Lélio Basso estava muito interessado em discutir a política norte-americana e sua política para a América Latina. E por isso organizou um seminário sobre a Declaração Monroe. Neste período, a fundação passou a priorizar as atividades sobre o Brasil, porque ele considerava que o país se tornara um importante instrumento do imperialismo na América Latina, que tinha o objetivo de instalar regimes ditatoriais na região. Assim, era necessário divulgar os crimes da ditadura brasileira para impedir ou refrear o avanço dessas ditaduras. A fundação, então, organizou uma nova versão do Tribunal Bertrand Russell $^{786}$.

A primeira versão do Tribunal Russell havia tratado dos crimes da guerra dos EUA no Vietnã e ganhou grande repercussão mundial ${ }^{787}$. A nova versão foi pensada, inicialmente, para julgar os crimes da ditadura brasileira, mas acabou por abordar as demais ditaduras da América Latina em três sessões entre 1974 e 1976, em Roma e Bruxelas. A católica Linda Bimbi foi a secretária-geral do Tribunal Russell de Roma, entre os dia 30 de março e 5 de abril de 1974. Composto por juristas, professores, escritores e personalidades de renome como Júlio Cortázar, o Tribunal era independente de governos e buscou legitimidade na autoridade moral e consciência pública da opinião pública mundial $^{788}$.

Denúncias oriundas de diversas iniciativas sobre torturas, assassinatos e desaparecimentos forçados ocorridos no Brasil foram divulgadas no Tribunal Russell.

\footnotetext{
${ }^{785}$ A Fundação Lélio Basso possui um arquivo da história do movimento operário e socialista europeu com coleções dos jornais, documentos e arquivos do Partido Socialista italiano. Basso foi secretário-geral do Partido Socialista após a II Guerra Mundial e fundador de uma dissidência de esquerda, o PSIUP. V. entrevista concedida por Tullo Vigevani à autora. SP, 03/07/2009. AAPP/AEL-LEI.

${ }^{786}$ Entrevista concedida por José Luiz Del Roio à autora. Idem, ibidem; e entrevista concedida por Tullo Vigevani à autora. SP, 03/07/2009, AAPP/AEL-LEI.

${ }^{787}$ O Tribunal ocorreu em três audiências em Londres entre novembro de 1966 e dezembro de 1967 e contou com a participação de muitos intelectuais tais como Jean-Paul Sartre, entre outros. V. http://www.oabsp.org.br/tribunaldospovos.

${ }^{788}$ V. TELES, J. Os herdeiros da memória, op.cit.; e entrevista concedida por José Luis Del Roio, exmilitante do PCB, ALN e TL, à autora. SP, 08/01/2002, 13/02/2002, 08/01/2003 e 20/03/2010.
} 
Conscientes da importância da divulgação dessas denúncias na formação da opinião pública, o coletivo de presos políticos que defendeu a greve de fome elaborou outro documento em fevereiro 1974 para ser enviado ao Tribunal. Dessa vez, o relatório foi preparado com informações mais detalhadas do que aquele feito em 1973. O texto foi assinado pelo Comitê de Solidariedade aos Revolucionários do Brasil, uma organização inventada pelos presos exclusivamente para este fim. De acordo com o texto,

“[...] $\mathrm{O}$ ato de dedicarmos nosso trabalho ao Tribunal Russell representa nosso testemunho de reconhecimento pela atividade sem descanso que o mesmo vem desenvolvendo e demonstra nossa identificação com todos os povos do mundo que, diuturnamente, são pisoteados e escarnecidos pelas botas do imperialismo ianque e de seus aliados, os tiranos de todos os regimes facistas que enodoam nossa condição de seres humanos. Identificamo-nos, sim, com o camponês cambojano, vietnamita ou laosiano, queimado vivo por napalm, com os povos africanos mantidos sob bestial jugo colonialista, com o operário chileno massacrado em seu local de trabalho, enfim, com todos os que resistem e lutam e morrem nos combates diários contra a opressão e a exploração.

Consagrando nosso trabalho à denuncia dos crimes da ditadura militar fascista brasileira, acreditamos etar contribuindo para o avanço da luta anti-imperialista e antifascista que se trava em escala mundial. Dentro disso, manifestamos nossa mais firme solidariedade ao heroico povo chileno, cujos terríveis sofrimentos por que ora passa estão bastante vivos e presente em nós $[\ldots]^{789}$."

O relatório foi dividido em duas partes, sendo a primeira dedicada ao "Sistema Nacional de Repressão Política”, na qual ao final são descritos os instrumentos e métodos de tortura, seguido de uma listagem de 326 nomes dos mandantes das práticas de tortura e torturadores, com os locais onde atuavam ${ }^{790}$. A segunda parte apresenta uma lista de 155 perseguidos políticos assassinados pela repressão estatal subdividida entre os mortos "sob tortura”, com 32 casos descritos em detalhes e 48 nomes, cujos casos não dispunham de muitas informações; e aqueles "fuzilados ou mortos em combate”, com 75 nomes, inclusive, os de vários desaparecidos da Guerrilha do Araguaia ${ }^{791}$. A conclusão do documento ressalva que esta é uma lista incompleta, pois a ditadura tudo fazia

“[...] para encobrir seus crimes: divulga informações falsas ou simplresmente não as divulga, simula tiroteios e fugas de prisioneiros, corrompe e aterroriza médicos para que forneçam laudos periciais incompletos ou falsos, desaparecem com corpos mutilados de combatentes mortos [...]. De nossa parte, arrolamos em nosso relatório os [...] casos conhecidos de assassinatos políticos perpretados pela ditadura;; e ali onde a verdade completa é ainda um segredo do facismo brasileiro, demos todas as indicações possíveis, de forma que todas as pessoas, entidades, congressos e comissões internacionais [...], especialmente o Tribunal Bertrand Russell, disponham de elementos mínimos que os

\footnotetext{
789 “Apresentação”, em COMITÊ pró-aministia geral dos presos políticos no Brasil. Dos presos políticos brasileiros. Acerca da repressão fascista no Brasil. Lisboa, Ed. Maria da Fonte, 1976, p.15-6.

${ }^{790}$ V. Dos presos políticos brasileiros. op.cit., p.50-77.

${ }^{791}$ Idem, ibidem, p.79-154.
} 
orientem em sua incansável latuta de pesquisa e investigação e de posterior denúncia dos crimes praticados contra os povos explorados e oprimidos do mundo.

Mas não temos dúvida, cedo ou tarde a verdade virá, integralmente, à tona $[. . .]^{792}$."

A boa receptividade da mídia foi fundamental para a formação da opinião pública a respeito da ditadura brasileira. Estima-se que mais de dez emissoras de televisão e cerca de cento e oitenta jornalistas italianos e estrangeiros acompanharam as sessões ${ }^{793}$. O tribunal ganhou particular repercussão ao denunciar os crimes cometidos pela ditadura de Pinochet no Chile.

O relatório do juiz italiano Salvatore Senese apresentou um quadro do direito e da legislação no Brasil a partir do golpe de 1964. Miguel Arraes fez o ato de acusação ao governo brasileiro argumentando que, além de instaurar o terror, a ditadura implementou uma política econômica responsável pelo agravamento das desigualdades sociais. Muitos levaram materiais e informações sobre as condições carcerárias no Brasil, listas de atingidos, bem como de torturadores e centros de tortura. Vários ex-presos políticos testemunharam, tais como Dulce Maia de Souza, Fernando Gabeira, Carmela Pezzuti, Rolando Frati, Frei Tito e Tullo Vigevani.

Vigevani era dirigente do PORT e foi preso no dia 2 de agosto de 1970, em São Paulo. Em seguida sua esposa, que estava grávida, também foi presa. O casal permaneceu incomunicável durante 3 meses e 18 dias e passaram pelo DOI-Codi/SP, DEOPS e foram levados para o presídio Tiradentes. Sua esposa estavava grávida e no dia 10 de dezembro foi solta sob o fundamento de "respeito ao direito ou proteção legal conferido ao nascituro"794. Vigevani cumpriu a pena de 1 ano e 6 meses e se exilou na Itália, pois era cidadão italiano. Ele nos contou como se deu sua participação no Tribunal Russell em Roma:

“[...] Basso teve a ideia de [...] utilizar o nome do lorde para criar um novo Tribunal Russell [...]. A partir disso, ele reuniu algumas pessoas de notório saber jurídico e referências jurídicas [...]. Certamente, isso foi estimulado pelo clima de compromisso histórico que havia na Itália, porque o tribunal foi uma atividade grande, e [...] foi financiado, se eu não estou enganado, com recursos diretos ou indiretos do governo italiano. Basso chamou todas essas personalidades para criar o tribunal [...] e chamou uma série de brasileiros [...] que fizeram depoimentos e [...] eu e a Maria do Socorro também. [...] Eu não me lembro exatamente, mas se não me engano o evento foi num dos auditórios do Senado, porque Lélio Basso era senador [...]. Foi um momento importante, porque você estava falando para a opinião pública mundial, eles tinham trazido jornalistas

\footnotetext{
${ }^{792}$ Idem, ibidem, p.155-6.

${ }^{793}$ V. a documentação sobre o Tribunal Bertrand Russell II do ASMOB, no Arquivo do CEDEM/UNESP; e Dossiê Ditadura, op.cit., p.604.

${ }^{794}$ SiMAS, Mário. Gritos de Justiça (1963-1979). São Paulo, FTD, 1986, p. 176-84.
} 
de vários lugares e havia uma certa capacidade de divulgação [...]. A sensação que eu tinha não era só a de expor uma situação pessoal, [...] mas a possibilidade de você fazer uma denúncia contra o governo brasileiro. Agora, me lembro que as palavras deveriam ser cuidadas, porque o governo brasileiro e a ditadura acompanhavam aquilo [...]. Você não podia citar nomes, acredito que no meu depoimento não tem nome nenhum, a não ser o da minha mulher e o do meu filho [...]. [...] Participei da organização do tribunal, mas não tive uma participação de destaque. [...] a partir dessa época trabalhei direto com a Fundação Basso até vir para cá. [...] Lá era o nosso local de organização de muitas reuniões e de atividades, quando havia um seminário, uma discussão, usava-se a Fundação Basso. E foi a partir da fundação que nós organizamos a Conferência de Anistia [em 1979].

[...] Basso e Bimbi tinham muito contato com um grupo que existia em Massa Carrara, uma cidadezinha perto de Florença, que publicava um boletim, cujo nome acho que era Frente Brasileira de Informação, [...] estimulado e [...] financiado pelo Arraes, que estava na Argélia. Esse grupo [...] foi um dos estimuladores do Tribunal Russell. [...] Havia uma convergência de interesses [...]. No fundo, isso era uma interpretação minha, [...] havia a ideia do compromisso histórico de se vincular com os que poderiam vir a ser os líderes do Brasil quando caísse a ditadura militar. E o Arraes certamente era um cara muito importante, porque ele trazia toda a história pré-1964 etc. [...] Outro que estava envolvido nisso, [...] era deputado do Ato 5, o Márcio Moreira Alves. [...] ele era muito amigo da Linda Bimbi e teve um papel importante também. A ideia no fundo era essa, [...] manter vínculos com as figuras políticas importantes que viriam a liderar o processo de redemocratização do país [...].

[...] a grande imprensa não acompanhou de perto, no caso italiano era o Corriere Della Siera. Mas quem acompanhou de perto e deu bastante matéria foram os jornais partidários, o L’Unitá, os jornais do Partido Comunista; do Partido Socialista, da Democracia Cristã, deram bastante repercussão. Na Europa, quem repercutiu foi o Le Monde, $[. .$.$] mas acredito que fora isso não teve repercussões maiores [. . .]^{795}$.”

As testemunhas e o júri enfatizaram as violações aos direitos humanos, explicitando que o uso da tortura era sistemático e uma política de Estado no Brasil. Analisando a documentação apresentada, a legislação e os testemunhos, o júri considerou comprovado que o governo brasileiro era responsável por graves violações dos direitos humanos. O relatório do antropólogo Ettore Biocca descreveu as torturas, os locais onde ocorriam, divulgou listas de mais de mil atingidos e de torturadores baseado no relatório da Anistia Internacional (do qual foi o redator também ${ }^{796}$ ), bem como no documento enviado pelos presos políticos de São Paulo, entre outros. No relatório, Biocca mencionou também a ação do Esquadrão da Morte e as violações anteriores ao golpe.

O Tribunal sentenciou que a amplitude das violações aos direitos humanos verificadas no Brasil, configurava-os como crimes contra a humanidade. O encontro contribuiu, através dos dados colhidos, para a elaboração de novos dossiês utilizados na divulgação de denúncias e incentivou a formação de comitês e grupos de solidariedade aos perseguidos políticos do Brasil. O documento dos presos de São Paulo, por exemplo,

\footnotetext{
${ }^{795} \mathrm{~V}$. entrevista concedida por Tullo Vigevani à autora. Idem, ibidem.

${ }^{796}$ Entrevista concedida por José Luiz Del Roio à autora. Idem, ibidem.
} 
foi publicado parcial ou integralmente nas publicações da Fundação Lélio Basso, as revistas Dossiê e Boletim, e em diversas outras pela Europa ${ }^{797}$.

As duas sessões seguintes analisaram o papel das multinacionais na instauração e manutenção das ditaduras latino-americanas. E na $2^{\text {a }}$ sessão, em Bruxelas, o Tribunal condenou o governo brasileiro pelo crime de genocídio [ROLlEMBERG, 1999]. Para o CIE, assim como os comunistas, o Tribunal e a Anistia Internacional realizavam uma campanha de difamação internacional contra o Brasil ${ }^{798}$.

No Brasil, os prisioneiros políticos da Bahia haviam conquistado uma galeria reservada apenas para eles, mas continuavam vivendo num ambiente de incertezas e restrições. No mês de abril de 1974, os presos políticos deflagraram uma greve de fome em protesto contra o diretor da penitenciária Lemos de Brito, que se recusou a dar atendimento médico a um dos presos com uma crise de otite. A greve de fome durou onze dias e cessou quando as reivindicações dos presos foram atendidas [José, 2000: 116]. Na Casa de Detenção, em São Paulo, os presos políticos da haviam conquistado alguns direitos e condições carcerárias que lhes asseguravam certa dignidade e estabilidade, embora não fossem reconhecidos como "presos de consciência”.

Em julho de 1974, o Secretário de Segurança Pública do Estado de São Paulo, Erasmo Dias, foi à Casa de Detenção e ficou indignado com o que presenciou. Exigiu a imediata transferência de todos os presos políticos para a Penitenciária do Estado, argumentando que "preso tinha que sentir o castigo e o peso da cadeia senão não se recuperava [SÁ, 2007: 209].” Ele classificou e dividiu novamente os presos políticos em dois grupos: o grupo dos considerados “recuperáveis” foi enviado para o presídio do Hipódromo; o outro grupo, composto pelos “irrecuperáveis”, foi transferido para a penitenciária. No dia 16 de julho, os presos foram levados à penitenciária [Idem, ibidem], mas já pensando em encontrar maneiras de articular sua volta e conquistar um presídio exclusivo de prisioneiros políticos.

O regimento interno da penitenciária era extremamente rigoroso, mas a direção do presídio usava de artimanhas para infligir ainda mais sofrimento e desconforto. Era inverno, mas quando chegaram os presos políticos receberam apenas o uniforme de verão, que não era suficiente para protegê-los do frio de São Paulo. No banho de sol, principalmente em dias de chuva, sentia-se mais frio. No pátio, os presos se reuniram para

\footnotetext{
${ }^{797}$ Idem, ibidem.

${ }^{798}$ FICO, Carlos. Como eles agiam. Os subterrâneos da Ditadura Militar: espionagem e polícia política, Rio de Janeiro, Record, 2001, p.201-3.
} 
discutir como sair daquela situação. Fizeram uma série de reclamações e reivindicações à direção do presídio, ao juiz auditor e a todas as autoridades competentes, sem conseguir que seus pedidos fossem atendidos. O juiz dizia que o problema era da direção do presídio; a direção da penitenciária, por sua vez, culpava a auditoria argumentando que aquele era um estabelecimento direcionado a presos comuns e que não poderia mudar o regulamento interno para atender as reivindicações dos presos políticos [SÁ, 2007: 210].

Os presos exploraram todas as possibilidades legais e institucionais para solicitar condições carcerárias melhores - havia mais de 20 dias que reivindicavam os casacos de inverno do uniforme da penitenciária e recebiam como resposta que o alfaiate não havia terminado de costurá-las. Diante desta situação, os presos combinaram que no dia seguinte desceriam para o banho de sol agasalhados de qualquer maneira:

\begin{abstract}
"No outro dia, a uma hora da tarde, pegamos nossas mantas, quer serviam de cobertas e com uma gilete fizemos um buraco no meio, que desse para passar nossas cabeças. Quando o carcereiro veio abrir as celas, cada um pegou sua manta e a enfiou na cabeça. Descemos para o pátio todos fantasidados de gaúchos. Foi uma ótima ideia, ficamos agasalhados e bonitos. Parecia mais que o presídio havia sido invadido pela gauchada. Quando o chefe da segurança viu aquele espetáculo, ficou louco. Não achou graça nenhuma no nosso protesto e imediatamente mandou suspender o banho de sol.

Acontece que nós nos recusamos a voltar ao xadrez, a nãos er depois de conversarmos com a direção da penitenciária, ou recebermos nossas japonas. A situação engrossou, porque o diretor disse que não falava com bandidos indiscplinados e que não tinha japonas para nós. Então, nos recusamos a abandonar o pátio. O resultado é que a direção mandou reforçar a guarda e, quando menos esperávamos, nas amuradas da cedia tinham mais de dez soldados armados de metralhadoras nos ameaçando de morte se nós não subíssemos imediatamente.

Discutimos e resolvemos resistir, ou seja, desacatar qualquer ordem da repressão. Íamos ficar ali até recebermos as japonas do diretor do Presídio. Depois de amis de duas horas de luta, o diretor mandou dizer que receberia uma comissão de três a cinco pessoas para discutir o problema. Recusamos, alegando que o diretor é que devia vir falar conosco e só iríamos falar com ele se fossem todos os presos. A nossa comissão era um por todos e todos por um, logo não havia direção nem líder entre nós, todos estavam conscientes do risco assumido e de suas reivindicações.

Ás 16:30hs chegaram Erasmo Dias e toda uma comissão para examinar in loco a sitauação e nos ameaçar a subir. Foi tudo inútil, continuávamos irredutíveis. Quando deu 17:30hs o diretor cedeu e veio falar conosco. Ele garantiu que no outro dia receberíamos as japonas se subíssemos imeidatamente para nossas celas. Aceitamos, mas visamos que se não fossemos atendidos íamos fazer coisas piores do que rasgar as mantas [SÁ, 2007: 210-11] $]^{799}$."
\end{abstract}

Naquela noite, às 21 hs, os funcionários do presídio distribuíram os casacos para todos os presos políticos em suas celas. Foi a primeira vitória que abriu o caminho para outras, durante o período em que estiveram confinados na penitenciária [SÁ, 2007: 211].

\footnotetext{
${ }^{799}$ V. tb. entrevista concedida por Reinaldo Morano Filho à autora. SP, 14/03/2011.
} 
A partir deste episódio, os presos começaram a encaminhar a luta pela melhoria de suas condições carcerárias que implicavam na mudança do regimento interno da penitenciária ou o retorno para a Casa de Detenção, nas mesmas condições com as quais viviam no período de confinamento no pavilhão 5; mas, principalmente, pela conquista de um presídio exclusivo para presos políticos SÁ, 2007: 211-12]. A questão era como preparar-se para deflagrar uma greve de fome por tempo indeterminado que fosse vitoriosa.

Apesar da grande dificuldade de comunicação na penitenciária, os presos políticos começaram a divulgar as denúncias de abusos aos direitos dos presos comuns visando o desgaste da direção da penitenciária. De acordo com Pedro Rocha Filho: “[...] nós procuramos um entrosamento com os presos comuns, [...] e chamar advogados para defendê-los. O objetivo não era tanto humanitário, mas era de deixar claro que onde a gente estivesse iriamos incomodar ${ }^{800}$."

Nas palavras de Manoel Cyrillo, a movimentação dos presos políticos visava obter o máximo de apoio político para, depois de esgotadas todas as possibilidades institucionais, assumir a realização da greve de fome:

“[...] a gente preparou todo um esquema, fizemos um planejamento de luta que desembocou na greve de fome. [...] A gente tinha que demonstrar à repressão, que era muito desgastante para eles manter a gente lá. [...] Através do 'telefone', a conversa feita via esgoto, cada um de nós identificou quais eram os presos que estavam lá embaixo nas celas fortes, o nome completo, quanto tempo eles estavam lá e porque razão. Nós mobilizamos os nossos advogados para que eles fizessem uma mobilização junto aos centros acadêmicos das faculdades de direito, que se prontificassem a ir até à penitenciária requisitar aqueles presos comuns. Em dois ou três dias todos eles foram várias vezes requisitados por advogados, uma coisa inusitada. Aquilo pavorou a cadeia. Eles iam para lá porque não tinham família, assistência jurídica, eram abandonados [...]. Foi uma grande novidade a direção descobrir que eles passaram a ter advogados. Isso foi um pepino para a direção da cadeia! [...] A gente começou a criar esse tipo de coisa e sempre procurando agir coletivamente, sempre mobilizando. [...] Isso foi no final do ano, próximo à famosa eleição de 1974. Nós sabíamos que diversos companheiros [...] estavam apoiando candidaturas no comitê de vários candidatos da oposição. [...] A gente estava programando para o caso de vir a ser necessário uma greve de fome que ela acontecesse durante esta campanha política, porque aí nós teríamos muito mais espaço e palanque para denunciar a nossa situação e angariar apoio à nossa luta. [...] As famílias foram à Brasília, de ônibus, para denunciar no Congresso Nacional [e tentar falar com autoridades do STM] a situação que a gente estava vivendo na penitenciária, o absurdo que era o regime penitenciário. Enfim, esgotamos todos os caminhos legais

[...] o planejamento era esse: fazer a greve na hora em que a campanha estivesse pegando fogo. E se possível quando estivesse na televisão, enfim, para o pessoal falar na tv. A greve teve muita solidariedade [...]. Buscávamos romper o cerco de silêncio e você faz isso, ainda mais sob uma ditadura, de várias maneiras, não somente com a imprensa.

${ }^{800}$ Entrevista concedida por Pedro Rocha Filho à autora. Idem, AAPP/AEL-LEI. 
Poderia ser também com um comício de um candidato do MDB, não é verdade? [...] o importante é que chegou ao público mais amplo, coisa que não interessava de maneira alguma à ditadura ${ }^{801}$.”

Um incidente antecipou a deflagração da greve de fome: quando faltavam cerca de 10 dias para o início da greve, uma punição ao preso político Carlos Takaoka, antecipou os fatos. De acordo com o relato de Aybirê Ferreira de Sá, os presos militantes da Ala Vermelha não aceitavam a proposta de organizar a greve de fome. Ele, então, decidiu mandar uma longa carta a Takaoka (militante da Ala Vermelha) explicando as razões do movimento e pedindo adesão. Takaoka recebeu a carta por meio de uma 'teresa', mas um guarda viu e se dirigiu à cela para pegá-la. Como Takaoka se recusou a entregá-la, o guarda entrou na cela, mas ele rapidamente a jogou na privada turca. Foi punido com 10 dias de isolamento. No dia seguinte, quando os guardas abriram as celas para os presos descerem ao pátio no horário do banho de sol, os demais prisioneiros se recusaram a sair das celas em solidariedade a Carlos Takaoka [SÁ, 2007: 212-3].

Ao tomar conhecimento dos acontecimentos, a direção decidiu estender o castigo a todos e abriu um inquérito para apurar os fatos. Depois de 5 dias trancados nas celas, os presos decidiram iniciar a greve de fome. Os detalhes foram acertados por meio de mensagens em código morse transmitidas pelas paredes das celas. Ás vésperas das eleições nacionais de 1974, no dia 24 de outubro ${ }^{802}$, os presos políticos confinados na penitenciária iniciaram nova greve de fome. Três prisioneiros, militantes da Ala Vermelha, recusaram-se a aderir à greve [SÁ, 2007: 214]. Neste dia, por meio de sua rede de apoio, fizeram divulgar um manifesto, no qual salientavam a existência da prática institucionalizada da tortura e de presos políticos no Brasil. O manifesto foi enviado para diversas entidades e a imprensa internacionais.

Durante à tarde do dia 24 de outubro, a redação da Folha de S. Paulo foi informada de que estava proibida a divulgação de toda e qualquer forma de notícia, comentários, editoriais sobre a greve de fome dos presos políticos de São Paulo ${ }^{803}$. De fato, nada foi publicado a respeito neste periódico. O Expresso, jornal de grande circulação em Portugal na época, divulgou o manifesto vários dias depois, em 30 de novembro de 1974:

\footnotetext{
${ }^{801}$ Entrevista concedida por Manoel Cyrillo de Oliveira Neto à autora. Idem, AAPP/AEL-LEI.

802 "Atestado de permanência e conduta” de Reinaldo Morano Filho. Idem, ibidem.

${ }^{803}$ V. o site http://almanaque.folha.uol.com.br/ilustrada_05mar1978.htm.
} 
"Desde que se intalou no país o regime de exceção de 1964 caracterizado por atos institucionais e complementares à Constituição, todos os atos atentatórios contra os princípios básicos que regem os Direitos Fundamentais do Homem são possíveis e legitimados pelo poder repressivo que leva de roldão vidas de trabalhadores, estudantes, professores, intelectuais, religiosos e, em consequência dispersa famílias, desagrega quaquer tentativa de defesa da PESSOA HUMANA, instalando um clima de terror em todo o país. [...] emerge para o nosso conhecimento [...] o sub-mundo do aniquilamento humano no seu mais profundo sentido. [...] a maneira como o governo tem tratado aqueles que dentro dos presídios são qualificados como Presos Políticos. PRESO POLÍTICO É AQUELE QUE LUTA POR LIBERDADE, POR UMA SOCIEDADE MAIS JUSTA, POR UM PAÍS AUTENTICAMENTE DEMOCRÁTICO. O que nos preocupa é a intenção dos órgãos de informação de tentar confundir presos políticos com presos comuns, com o objetivo de demonstrar à opinião pública [...] que não há presos políticos no Brasil, [...] de que não existem opositores ao regime. [...] O meio mais frequentemente utilizado para a consecução de tal objetivo é a dispersão dos presos políticos em diversos presídios e estabelecimentos penais [...] facilitando seu 'desaparecimento'. [...] Nova investida surge em julho do corrente ano, quando abruptamente os presos políticos foram removidos da Casa de Detenção para a Penitenciária do Estado sob alegações fabricadas e inconsistentes. [...] Há 105 dias estão os presos políticos confinados em cubículos individuais sem nenhum dos direitos que a LSN lhes confere e sujeitos a toda sorte de provações [...].

Acresce ainda, a situação de absoluta restrição de visitas de familiares, recebimento de alimentos, agasalhos, leituras e a precariedade das condições de higiene. Contra tais fatos mobilizaram-se as famílias e os advogados. [...] receberam promessas que não se concretizaram. [...] Os advogados também tentaram demonstrar aos Srs. Juízes Auditores através de petição, a gravidade dos fatos. [...] mas promessas não se concretizaram ${ }^{804}$.”

Diante dessa situação, os presos políticos da penitenciária iniciaram a greve de fome. O primeiro dia de greve transcorreu bem, sem que os presos sentissem muita fome ou mal estar. Havia muita expectativa e agitação, todos beberam apenas água. Os estudantes empenharam-se em divulgar ao máximo a greve de fome. Na USP organizaram um mural onde manifestaram seu apoio ao movimento e divulgaram manifestos e os nomes dos presos em greve.

No segundo dia, alguns presos começaram a sentir tonturas. A BBC de Londres noticiou a greve de forme dos presos políticos no Brasil em protesto pelas más condições carcerárias, destaque do resumo das notícias mais importantes da semana. Havia brasileiros trabalhando na BBC de Londres com os quais os exilados brasileiros matinham contato regular e que sempre que possível divulgavam notícias sobre a ditadura brasileira $^{805}$. Outro contato privilegiado dos brasileiros foi estabelecido com a Anistia Internacional em Londres por meio do dramaturgo Gerald Thomas, que militava na entidade $^{806}$.

\footnotetext{
804 “Brasil: um panfleto sobre a tortura e o resto do 'milagre’”, Expresso, 30/11/74, p.8.

${ }^{805}$ Entrevista concedida por José Luiz Del Roio à autora. Idem, ibidem.

${ }^{806}$ José, Emiliano. As asas invisíveis de padre Renzo, op.cit.
} 
No terceiro dia de greve, o papa Paulo VI declarou que 36 prisioneiros políticos estavam em greve de fome, em protesto contra os maus-tratos recebidos nos cárceres brasileiros: "São os presos políticos do Brasil, por quem peço a todos os irmãos: rezem por eles [SÁ, 2007: 214].” Os contatos com o Vaticano eram feitos por meio de diversos grupos católicos, mas, muitas vezes, ocorriam através do famoso jornalista católico italiano da RAI, Ettore Masina, um amigo pessoal do cardeal Montini, de Milão, que veio o ser o papa Paulo $\mathrm{VI}^{807}$. A pessoa que realizava o contanto com Masina, em geral, era Flávio de Médici, um militante da ALN e um dos fundadores da Tendência Leninista (TL), exilado em Roma desde a morte de Marighella em 1969. Eventualmente, José Luiz Del Roio, outro fundador da TL exilado na Itália, também realizava esses contatos ${ }^{808}$.

O elo de ligação estabelecido com a Igreja Católica e o Vaticano na Itália pelos exilados brasileiros foi constituída também por meio de Marcela Glisenti, uma influente católica do Partido Democrata Cristão. Frequentemente, Médici se encontrava com Glisenti na livraria que ela possuía no centro de Roma, chamada Livraria Terceiro Mundo. Essas duas pessoas eram canais de contato privilegiados com o Vaticano e as diversas redes de jornalistas e de partidos católicos na Europa, que sempre auxiliavam de diversas maneiras os movimentos de resistência à ditadura brasileira ${ }^{809}$.

Apesar da censura imposta pela ditadura, a opinião pública brasileira tomou conhecimento da greve de fome. Deputados do MDB denunciaram os maus-tratos sofridos pelos presos políticos na Câmara Federal e no Senado. Os familiares e os advogados ficaram apreensivos, mas pressionaram o juiz-auditor, Nelson Machado Guimarães, para que atendesse as solicitações e reivindicações dos presos [SÁ, 2007: 215].

Até o quarto dia da greve, a direção do presídio exigia que os presos cessassem a greve para iniciar o diálogo. Os presos mantinham-se irredutíveis, defendiam a posição de parar a greve somente depois de atendidas suas reivindicações. A direção da penitenciária então solicitou uma conversa com o representante dos grevistas para discutir um possível

\footnotetext{
${ }^{807} \mathrm{O}$ jornalista, escritor e ex-deputado federal Ettore Masina passou a se interessar pela situação do Brasil em 1970, quando tomou conhecimento da história dos dominicanos presos através de padre Renzo, um florentino que atuava na periferia de Salvador desde 1965. Masina foi eleito deputado diversas vezes pela lista de independentes do PCI. Em 1976 organizou um livro de poesias brasileiras que tratavam da vida sob ditadura no país, chamado La parole sepolte fioriranno - I canti della Resistenza Brasiliana. José, Emiliano, op.cit, p.160.

${ }^{808}$ Entrevista concedida por José Luiz Del Roio à autora. Idem, ibidem.

${ }^{809}$ Idem, ibidem.
} 
acordo. Os presos responderam que não tinham um representante e o único acordo possível seria atender às suas solicitações [SÁ, 2007: 215].

No quinto dia, o diretor aceitou conversar com uma comissão de grevistas para tratar dos problemas indicados pelos presos políticos. Os presos mantiveram sua posição e responderam que só aceitariam conversar desde que os 36 grevistas fossem recebidos. $\mathrm{O}$ dia transcorreu neste impasse, mas às 19 hs o diretor da penitenciária cedeu e chamou todos os grevistas ao seu gabinete para negociar. Pouco depois, chegou-se a um acordo, a greve seria suspensa desde que fossem transferidos para a Casa de Detenção, com a manutenção de todos os direitos conquistados anteriormente e acordo de que seriam transferidos para um presídio exclusivo para presos políticos. Todos ficaram emocionados e, às $21 \mathrm{hs}$, chegou às celas a primeira refeição depois de 5 dias sem comer. Dois ou três dias depois, no dia 5 de novembro de $1974^{810}$, os presos políticos foram transferidos novamente para a Casa de Detenção [SÁ, 2007: 215-6], enquanto se ultimavam os preparativos para o presídio exclusivo para presos políticos.

Nas eleições nacionais de novembro de 1974, o ativo deputado federal e ‘autêntico’ do MDB, Lysâneas Maciel, ganhou apoio de diversos partidos de esquerda tais como o PCB, a AP e, especialmente, o MR-8, que tinha dois militantes como seus principais assessores. Ele teve expressiva votação com cerca de 100 mil votos. Outros partidos como o PCdoB, porém, dividiram-se entre as posições que apoiavam a proposta de voto nulo, repetindo a campanha feita por diversos grupos de esquerda em 1970, e a de apoiar o MDB. Devido aos conflitos gerados pelo processo inconcluso de fusão entre a AP e o PCdoB, em São Paulo, o grupo ligado ao operário Aurélio Peres insistiu em votar no partido de oposição legal [KUCINSKI, 2003: 331, 349].

Nestas eleições, o advogado de presos políticos Airton Soares se candidatou a deputado federal pelo MDB e conseguiu expressiva votação. Presos que haviam sido libertados, seus clientes ou não, ingressaram no MDB e, em especial, no diretório da Bela Vista, na região central da capital, onde Airton Soares atuava ${ }^{811}$. Militantes de uma esquerda dispersa ${ }^{812}$, os militantes de partidos e agrupamentos de esquerda que sobreviveram à repressão, estudantes do incepiente movimento estudantil e familiares de presos políticos tiveram um importante papel na sua vitória eleitoral e na de outros deputados 'autênticos' do MDB, conforme seu relato:

\footnotetext{
810 “Atestado de permanência e conduta” de Reinaldo Morano Filho. Idem, ibidem.

${ }^{811}$ Entrevista concedida por Aytan M.Sipahi à autora. Idem, ibidem.

${ }^{812}$ SADER, Eder. Quando novos personagens entraram em cena. op.cit., p.167-78.
} 
"O que me levou a ser advogado de presos políticos foi muito mais a relação que eu tinha com vários companheiros estudantes que ingressaram nos grupos organizados de luta contra a ditadura [...]. Enfim, uma relação estabelecida em decorrência de uma militância comum na UEE de São Paulo e na UNE, atuei na organização do Congresso de Ibiúna. Desde esse congresso da UNE, iniciou-se um período de perseguição aos estudantes. Essa proximidade fez com que eu passasse a ser procurado para dar informações de como funcionava o sistema jurídico; eu era diretor jurídico do Centro Acadêmico XI de Agosto da faculdade de Direito da USP e estava me formando. Nós tínhamos também trabalhos de assistência jurídica organizados na periferia de São Paulo, ligados a programas de loteamentos clandestinos, o embrião disso se desenvolveu na Zona Sul e originou o Movimento Custo de Vida. Tinha o trabalho na Oposição Sindical...

[...] Com essa bagagem, nós surgimos e ocupamos o espaço para fazer a defesa de presos políticos. A atuação dos advogados galvanizou em parte a opinião pública, mas isso foi um fato político que se somou a outros. Eu me elegi em função dessa atividade também, claro. Tive votos em lugares que nunca poderia imaginar, quarenta e oito mil e poucos votos. Sem ter sido vereador... Eu diria que esse trabalho como advogado se somou a outro que eu vinha fazendo desde 1970 no MDB. Quer dizer, trazer o pessoal para votar no MDB para transformá-lo num partido verdadeiramente de oposição à ditadura e não um partido consentido. A proposta que apresentei no manifesto do meu programa de 1974 era que nós tínhamos de transformar o partido para que a criatura se voltasse contra o criador. Isso mobilizou muita gente a votar no MDB e, entre os que podiam ser votados, eu era um nome que aparecia mais, porque estava dentro desse movimento: 'Não anule o seu voto, vamos fazer desse voto um instrumento contra a ditadura'. Somou-se a isso um pessoal que também tinha militância política de confronto com a ditadura, que entendeu que também devia usar o MDB e passou a votar no MDB.

[...] E esse trabalho se somou ao de advogado, te dou um exemplo claro: eu advogava para o Reinaldo Morano. O pai dele é de Taquaritinga, ele era uma pessoa muito simpática, um fotógrafo conhecido na cidade inteira, de repente, eu tive em Taquaritinga uma votação que todo mundo ficou estupefato! Graças ao pai do Reinaldo e a outros familiares de presos políticos da cidade. Eu tinha ido lá acho que uma vez e tive quase setecentos votos. Tudo isso repercutiu muito ${ }^{813}$."

Até 1974, o jornalismo complacente da grande imprensa era justificado pela euforia do "miligre econômico". Ela se omitiu perante a intensificação das violações de direitos humanos no país [KUCINSKI, 2003: 77, 80] e a imprensa alternativa se tornou um dos mais importantes veículos de denúncias dos perseguidos e presos políticos. Nesse período, foram criados cerca de vinte jornais alternativos, entre eles estavam cinco dos mais influentes. Alguns deles se propunham a contribuir para a constituição de uma frente ampla de oposições na sociedade civil, como o jornal Opinião [KUCINSKI, 2003: 82, 84].

Com a centralização da censura prévia dos jornais alternativos em Brasília, a partir de 1973, estes jornais foram duramente atingidos. A censura recaiu com mais rigor sobre eles, mas parte da imprensa alternativa, muitas vezes, conseguiu apoiar os presos políticos e divulgar as lutas dos movimentos sociais que surgiram, tornando-se a expressão e parte fundamental de articulação da resistência da sociedade civil à ditadura [KUCINSKI, 2003: 94]. A partir dos abalos sofridos pelo regime com o colapso do "milagre econômico" e a

${ }^{813}$ Entrevista concedida por Airton Soares à autora. Idem, ibidem. 
derrota nas eleições de novembro, a imprensa alternativa ganhou nova dimensão, aumentou sua influência e poder de divulgação das lutas populares e de denúncias dos abusos aos direitos humanos cometidos pela ditadura. A imprensa alternativa se consolidou como um lugar de atuação da militância partidária e, inclusive, espaço para empregar ex-presos políticos.

Nessa conjuntura, em 4 de março de $1975^{814}$, os presos políticos inauguraram o presídio Romão Gomes, no Barro Branco, na zona norte de São Paulo. Embora fosse administrado pela Polícia Militar, oferecia melhores condições carcerárias e era composto exclusivamente por presos políticos. Uma nova fase de adaptação e convívio se iniciava para os presos políticos transferidos para este presídio, onde conseguiram se organizar melhor e ampliar seus contatos políticos com a sociedade civil.

\section{O Presídio Político de São Paulo}

A inauguração do Presídio Político Romão Gomes foi acompanhada de uma tentativa de retaliação contra os presos, ao nomearem como seu diretor o capitão da PM Devanir Antonio Castro Queiroz, um torturador do DOI-Codi/SP conhecido por "Bezerra”. Os presos reagiram de maneira contundente à nomeação, atitude que prontamente encontrou respaldo na opinião pública. Os militares recuaram. No primeiro dia no novo presídio, em 4 de março de 1975, diante da presença de várias autoridades, o secretário da Segurança Pública de São Paulo, coronel Erasmo Dias, aos gritos, chamou os presos políticos de bandidos e assassinos e afirmou que não vacilaria em matá-los.

O presídio oferecia melhores condições carcerárias, mas predominava uma atmosfera de represália com constantes provocações e ameaças. Ainda em março de 1975, um tenente da PM de nome Ênio, chefiando a tropa de choque que escoltaria alguns presos até um hospital, incitou seus subordinados a arrancarem a roupa de dois dos presos políticos - sob a justificativa de revistá-los -, ameaçando-os e afirmando que poderiam morrer atropelados, fazendo alusão aos assassinatos encobertos pela farsa dos atropelamentos. Diante do protesto dos demais presos, os policiais militares empunharam suas armas e invadiram o interior do presídio aos berros, sendo contidos, com dificuldade,

814 “Atestado de permanência e conduta” de Reinaldo Morano Filho. Idem, ibidem. 
por outro PM de patente superior, que recolheu as armas dos invasores, refreando os ânimos dos policiais.

O presídio composto exclusivamente por presos políticos inaugurava uma nova fase, na qual os presos conseguiram ampliar seus contatos políticos iniciados na Casa de Detenção. No Romão Gomes receberam, por exemplo, a visita de D. Pedro Casaldáliga, entre os outros ${ }^{815}$. Os presos ficavam divididos em quatro celas, que ficavam abertas para livre circulação. A população carcerária variou entre 30 e 60 presos. Havia um refeitório e um pátio reservado ao banho de sol e ao futebol diariamente. As três celas fortes existentes foram utilizadas como bibliotecas, abastecidas com livros, revistas e documentos. Uma oficina foi reservada aos trabalhos manuais e artísticos. A produção em couro aumentou e as sandálias, cintos, bolsas eram facilmente vendidos para ajudar as famílias dos mais necessitados.

A organização do coletivo dos presos foi estruturada conjugando a representação de partidos e grupos com a representação de cela. Muitos presos haviam sido libertados, mas a divisão do coletivo em função dos embates em torno da greve de fome de 1972 permaneceu. Naquele momento, porém, as divergências e conflitos eram menos intensos e uma pequena parcela contrária àquela greve ou que não queria se manter organizada no coletivo ou em partidos políticos ficou alojada na cela $4^{816}$. De acordo com Scavone, as lembranças do período em que os presos ficaram no presídio Romão Gomes (no Barro Branco) são positivas:

“[...] No Presídio do Barro Branco, em particular, [... havia] um 'coletivo’ de organização da vida em comum, não era um 'coletivo' no sentido, digamos... político. [...] Era um presídio político e a gente tomou conta [...]. A gente sentava, discutia, conversava, mas a maior parte das coisas era decidida por consenso, porque não havia decisões a serem tomadas tão dramáticas que demandassem uma votação [...]. A vida na cadeia era uma vida muito organizada, em particular no Barro Branco, no qual fiquei mais tempo. Lá havia celas grandes com dez a quinze pessoas [...], mas a gente se apropriou daquela cadeia. [...] os policiais [...] entravam só à noite na hora de fechar e abriam as portas de manhã. Eles traziam a comida em contêineres grandes e botavam para dentro e a gente levava, fazia [as melhorias] e distribuía ${ }^{817}$."

Os momentos de tensão, contudo, foram muitos. Em maio de 1975, o sindicalista Oswaldo Pacheco da Silva, membro do Comitê Central do PCB e ex-deputado constituinte de 1946, chegou ao presídio depois de ter sofrido torturas no DOI-Codi/SP

\footnotetext{
${ }^{815}$ Entrevista com Hamilton Pereira. SP, 10/01/2007 e Brasília, 23/03/2007, em ForTES, Alexandre e FERREIRA, Marieta de Moraes (orgs.) op.cit.

${ }^{816}$ Entrevista concedida por André Ota à autora. Idem, ibidem.

${ }^{817}$ Entrevista concedida por Artur M. Scavone à autora. Idem, ibidem.
} 
desde o dia 14 de fevereiro, quando foi preso. Seu corpo estava repleto de marcas e ele apresentava um quadro de profundo abalo psíquico. No dia 2 de julho, quando Pacheco começava a se recuperar, foi removido por agentes do DOI-Codi, tarde da noite, apesar da resistência dos presos. Em protesto, no dia seguinte os presos enviaram um documento de denúncia à II Auditoria Militar de São Paulo. Preocupados com a possibilidade de vir a ser assassinado como Bacuri, entre outros, os presos registraram e divulgaram o fato, enviando cópias da carta ao STM, STF e demais autoridades judiciárias e entidades pedindo pela sua integridade física ${ }^{818}$. Pacheco foi finalmente transferido novamente para o presídio político, onde terminou de cumprir sua pena.

Em 1975, o governo Geisel adotou uma postura mais ostensiva em relação ao seu projeto de abertura política gradual e controlada. A atmosfera política entre as oposições era de otimismo em face da vitória do MDB, do crescimento da participação popular das periferias das grandes cidades, do surgimento do Movimento do Custo de Vida, criado em 1973, e da rearticulação da participação sindical, especialmente, entre os metalúrgicos.

Em junho de 1975, surgiu um novo jornal alternativo, Movimento (fruto de uma dissidência dentro da redação de Opinião), que contou com grande apoio dos autênticos do MDB, intelectuais e artistas. Formou-se uma empresa coletiva de jornalistas demarcada por um programa político de frente ampla, que atraiu grande número de ativistas e ex-presos políticos. O surgimento do jornal foi encarado como um espaço onde era possível a ação política no plano legal. Militantes de diversos grupos apoiaram o jornal: antigos militantes da Polop, das DIs e da Ala Vermelha, do Colina, da ALN, da AP e intelectuais do PCB. Movimento era objeto de discussão regular em coletivos de presos políticos $^{819}$.

Ampliava-se a participação da mulher na política, e 1975 foi proclamado o Ano Internacional da Mulher pela ONU. Em julho daquele ano, Theresinha Zerbini formou o Movimento Feminino pela Anistia (MFPA), ela própria uma ex-presa política esposa de um general cassado. A entidade não era feminista, mas contou com uma participação significativa de mães e de familiares de presos, mortos e desaparecidos políticos. Em outubro, o movimento feminista ganhou novo impulso com a realização do "Encontro para o Diagnóstico da Mulher Paulista” na Câmara Municipal de São Paulo com apoio da ONU, da Cúria Metropolitana e de associações femininas.

\footnotetext{
818 “Carta ao Sr. Juiz Auditor da 2ª Auditoria Militar da 2a. CJM/SP”. SP, 02/07/75. Arquivo pessoal de Reinaldo Morano Filho.

${ }^{819}$ Kucinski cita uma entrevista feita com Jair Borin, de 20/06/90. Entre 1975-1976, Borin estava preso no Romão Gomes. V. KUCINSKI, B. op. cit., p.344-7.
} 
Ainda no mês de julho, os presos políticos da Penitenciária Professor Barreto Campelo, localizada na ilha de Itamaracá, em Recife, deflagraram uma greve de fome contra a transferência de alguns presos para quartéis no continente. A greve durou 15 dias e cessou depois que os presos conseguiram o compromisso formal do Superintendente do Sistema Penitenciário de Pernambuco de que suas reivindicações seriam atendidas ${ }^{820}$.

Durante o período de março a agosto de 1975, ocorreram no Presídio Romão Gomes em São Paulo repetidos incidentes e provocaçãoes causados pelo sargento Sousa da PM, cuja truculência atingiu familiares e advogados. Entre outubro e novembro, o sargento comandante da Guarda, respaldado pelo diretor do presídio, o capitão Lício de Arruda, protagonizou grave episódio de agressão no presídio, que incluiu disparos de arma de fogo pelas sentinelas das muralhas em duas oportunidades, uma delas durante o dia de visitas dos familiares.

No final do mês de outubro, os presos conseguiram burlar a segurança e fizeram sair do presídio um documento de denúncia das torturas e assassinatos do regime, durante uma visita de D. Paulo E. Arns. A iniciativa era uma resposta a uma declaração do presidente do Conselho Federal da OAB, Caio Mário da Silva Pereira, que lamentava não ter conseguido dados objetivos, por parte das vítimas, sobre prisões irregulares e arbitrariedades policiais, conforme publicado na Folha de S. Paulo do dia 1 de agosto daquele ano.

$\mathrm{Na}$ introdução do texto, os presos manifestaram sua intenção de fornecer um relatório objetivo acerca dos crimes cometidos pelos órgãos de segurança e informação ao Conselho Federal da entidade, com o fim de que não ficasse nenhuma dúvida e fosse realizada a devida apuração dos mesmos:

\footnotetext{
"Embora cientes das muitas denúncias concretas já havidas - inúmeras delas inclusive divulgadas mais recentemente por jornais brasileiros -, vimo-nos na obrigação, como vítimas, sobreviventes e testemunhas de gravíssimas violações aos direitos humanos no Brasil, de encaminhar a V. Sa. um relato objetivo e pormenorizado de tudo o que nos tem sido infligido, nos últimos seis anos, bem como daquilo que presenciamos e acompanhamos pessoalmente dentro da história recente do país.

Por outro lado, temos bem presente a mais importante tese apresentada à V Conferência da Ordem dos Advogados do Brasil, de autoria do senhor Miguel Seabra Fagundes, onde se afirma enfaticamente ser dever do advogado denuncar 'a todas as entidades qualificadas para tal pelas suas atribuições e idoneidade, as violações dos Direitos Humanos, quaisquer que elas sejam, resultantes de leis ou medidas para as quais se invoque razão de Segrança Nacional ${ }^{821}$. Baseados nisso, então, tomamos a liberdade de

${ }^{820}$ Entrevistas concedidas por Carlos Alberto Soares e Marcelo Mário de Melo à autora. Idem, ibidem.

${ }^{821}$ Cf. Jornal do Advogado. Órgão Oficial da Ordem dos Advogados do Brasil - Seção de São Paulo, Ano I, no. 12, maio/75, ultima página, em Dos presos políticos do Brasil. op.cit., p.160.
} 
solicitar a V. Sa. o envio de cópia do presente documento a todas as entidades que se têm empenhado na defesa dos direitos humanos.

[...] Como sobreviventes e testemunhas, são vivas em nossa lembrança as torturas sofridas

[...]. Por isso, entendemos perfeitamente a seriedade das denúncias de torturas surgidas em cartas divulgadas na imprensa. De nossa parte, nos últimos anos foram inúmeras as denúncias que formulamos - por meio de depoimentos judiciais, de abaixo-assinados, ou de nossos advogados [...].

[...] É possível que, a despeito de nosso cuidado na elaboração deste texto incorramos em algumas pequenas imprecisões [...]. Fizemo-lo preocupados com a exatidão dos fatos narrados e dispomo-nos a testemunhar perante qualquer comissão ou tribunal idôneo - e realmente interessados em apurar o que aqui se descreve -, quanto ao que relatamos ${ }^{822, "}$

Ainda na introdução do texto, os presos denunciaram a política de ocultação de cadáveres e de desaparecimentos forçados e a resposta mentirosa do ministro da Justiça, Armando Falcão, dirigida em fevereiro de 1975 aos reclamos dos familiares para esclarecer estes casos, o que acabou gerando a “Crise dos Desaparecidos” e o veto à consituição da CPI dos Direitos Humanos durante o primeiro semestre. Fizeram um histórico das greves de fome de que participaram em São Paulo e as que ocorreram em outros estados, visando melhorias nas condições carcerárias. E denunciaram que novamente os presos políticos de Pernambuco estavam em greve de forme em função do não cumprimento do acordo feito após outra greve realizada no mês de julho.

Por fim, o texto faz uma ampla descrição dos métodos e instrumentos de tortura, acompanhado do levantamento dos nomes de 233 torturadores, os quais participaram diretamente das sessões de tortura $^{823}$. Em seguida faz uma apresentação do funcionamento dos órgãos repressivos, das irregularidades jurídicas praticadas contra os presos políticos, mostrando que nem as leis de exceção eram cumpridas, e das condições carcerárias de cada presídio. E ao final traz uma detalhada descrição de 16 casos de perseguidos políticos assassinados sob tortura, presenciados por eles, entre os quais os de dois guerrilheiros desaparecidos no sul do Pará. A seguir, descreveram 19 casos de desaparecidos políticos, citando o abaixo-assinado enviado ao STM em 18 de fevereiro de 1975 em protesto à resposta de Armando Falcão às solicitações dos familiares de desaparecidos. Apresentaram também uma lista com os nomes de outros 20 presos políticos assassinados sob tortura, considerados desaparecidos. Detalharam ainda os casos de desaparecimento de Fernando Santa Cruz e Eduardo Collier, Joaquim Pires Cerveira e Edgar Aquino Duarte. Os casos de presos que tiveram sequelas físicas e psíquicas são

\footnotetext{
${ }^{822}$ V. Dos presos políticos do Brasil. op. cit., p.160-4.

${ }^{823}$ Idem, ibidem, p.164-90.
} 
citados, entre eles o de Frei Tito Alencar, que havia se suicidado pouco mais de um ano antes.

Ao final, o documento ressalta o fato desses assassinatos não serem práticas do passado e fazem menção às notícias de jornais sobre um militante do PCB de Fortaleza, Pedro Jerônimo de Souza, assassinado em setembro de 1975; e à morte de dois presos, incluídos no IPM contra 63 integrantes da Policia Militar de São Paulo que eram militantes do PCB. Os signitários do documento destacaram que a versão oficial da morte de José Ferreira de Almeida, em agosto de 1975, sustentava que ele havia se suicidado; e que José Maximiniano de Andradade Neto teria tido um enfarto no hospital, também no mês de agosto. Poucos dias depois de terminado, o documento recebeu um adendo, onde os presos acrescentaram a denúncia do assassinato sob tortura de Vladimir Herzog, no dia 25 de outubro ${ }^{824}$.

Esta denúncia foi redigida e assinada por 35 presos políticos do presídio Romão Gomes e foi enviada oficialmente para a OAB, através do advogado Luiz Eduardo Greenhalgh. Dom Paulo se preocupava com o aspecto legal das denúncias que chagavam a ele, assim, foi elaborada uma estratégia para fazer com que o documento chegasse até ele sem despertar suspeitas. Dom Paulo chegou ao presídio e uma comissão de presos se reuniu com ele na sala reservada às visitas com os advogados, que era separada por uma grade e duas portas do setor das celas. Perguntaram-lhe se desejava um café, como respondeu afirmativamente, um preso trouxe do setor das celas uma garrafa térmica com café. A sala era pequena, mas tinha um banheiro anexo, onde o preso retirou de dentro da garrafa um saco plástico com o documento e, em seguida, serviu o café. Durante a reunião, d. Paulo recebeu a carta e explicaram-lhe do que se tratava ${ }^{825}$. Cópias do documento foram enviadas para entidades e personalidades e municiaram outras denúncias, ganhando certa repercussão, apesar da omissão da OAB.

Em seguida, deu-se a grande reação ao assassinato do jornalista e militante do PCB, Vladimir Herzog. Os estudantes da USP e da PUC entraram em greve e o Sindicato dos Jornalistas iniciou uma vigília, culminado com a celebração de uma missa ecumência na Catedral da Sé que se tornou uma emblemática manifestação de protesto com a participação de 8 mil pessoas, entre estudantes e jornalistas [Dossiê Ditadura, 2009: 625-

\footnotetext{
${ }^{824}$ Dos presos políticos do Brasil. op. cit., p.224-27. V. tb. Dossiê Ditadura, op. cit., p.616-18, 621-22.

${ }^{825}$ Entrevistas concedidas por César Augusto Teles e Reinaldo Morano Filho à autora. Idem, ibidem. E entrevista concedida por Roberto Ribeiro Martins à autora. SP, 01/04/2009. AAPP/AEL-LEI.
} 
7]. Manifestaram-se profissionais liberais, intelectuais e entidades de defesa dos direitos humanos em favor das liberdades individuais e do direito de expressão.

Em represália ao documento escrito pelos presos, em novembro, em meio a outras arbitrariedades, o diretor do presídio Romão Gomes criou um entrevero com um dos presos políticos, José Genoino Neto, acusando-o de ter tentado desferir um pontapé num soldado integrante da guarda, trancafiando-o na cela forte, o que provocou outros desdobramentos, que atingiram os familiares. Pouco depois, como punição, Genoino foi transferido para o presídio de Fortaleza (CE), com o objetivo de mantê-lo o mais isolado possível.

Em dezembro de 1975, os presos políticos receberam cartas anônimas contendo ameaças, impressas em mimeógrafo com a assinatura de “A REPRESSÃO”, nas quais se podia ler:

"Este é um Documento de algum órgão de Informação. Pode ser da OBAN, DOPS ou qualquer outro por onde tiveram a oportunidade de passar, em decorrência de suas condições de terroristas.

[...] tomamos conhecimento do Documento redigido sobre nós e enviado à OAB. Este é o segundo num espaço de dois anos que nos chega às mãos.

Pô, como vocês foram violentos e até injustos!

Por que não citaram novamente como torturadores os Generais Orlando Geisel, Silvio Frota, Oscar Luiz da Silva, Humberto de Souza Melo, Darcy Lazaro, Almirante Januário de Araújo Coutinho Neto e outros?

[...] Por que o nome do Ten. PM Alberto Mendes Junior e do Maj. José Júlio Toja Martinez Filho, ambos assassinados por vocês não apareceram no novo Documento?

Infelizmente, isto não nos revolta, porque "Guerra é Guerra”, e eles estavam nela.

A morte é a sublimação de um guerreiro!

Não fiquem apavorados que não iremos apanhá-los após saírem da prisão. Não somos da KGB, por isso respeitamos a sua futura condição de 'ex-presos políticos' (terrorista).

[...] Que tal [se] mandássemos para a Comunidade Internacional Comunista, ou melhor, para os seus companheiros que ainda se encontram soltos, como 'CLEMENTE', 'ROGERIO' e outros 'Justiçadores', o que vocês falaram [nos interrogatórios]?

'O PIOR CEGO É AQUELE QUE NÃO QUER VER' [...]”,

Ainda em dezembro, os presos políticos receberam telefonemas anônimos, de igual conteúdo, com o objetivo de espalhar o clima de terror. A direção do presídio colaborava ativamente comunicando todas as ameaças aos detidos.

Em janeiro de 1976, a Folha da Tarde dedicou uma página inteira do jornal aos presos políticos, na qual se referia ao documento dirigido ao presidente do Conselho Federal da OAB como uma de suas atividades criminosas. E em março, as Auditorias Militares de São Paulo expediram o ofício n ${ }^{\circ}$ 427, dirigido ao capitão-diretor do presídio,

826 “Aos ‘presos políticos””, s/d. Arquivo pessoal de Reinaldo Morano Filho. 
instituindo uma espécie de pena acessória aos presos ali confinados, instituindo nova fase de censura a livros e revistas, infernizando suas vidas quanto ao recebimento de publicações por ele julgada de cunho político.

Em setembro daquele ano, o diretor fez chegar aos presos panfletos supostamente espalhados nas imediações do presídio, assinados por uma organização chamada “Aliança Anticomunista Brasileira”, com o seguinte teor:

"Aos presos políticos

O passado é o juiz de vossas ações. Os que não morreram nas celas, morrerão ao obterem a liberdade. Não instruam seus descendentes em vosso passado criminoso, pois terão destino certo - 'Morte ou prisão'. [...] Que tal fuzilamento ou banimento? Os chefes do Kremlin não vos reconhecem como heróis, e sim como traidores da pátria brasileira. Saibam que vossos filhos são brasileiros. Deverão portar como tal... Isto é um alerta. (A.A B. - São Paulo - 1976)”,827

Vários tipos de ameaças e vicissitudes foram impostas aos presos políticos do Romão Gomes nesse período. Entretanto, vários presos acabaram sendo soltos, a despeito dos pedidos de livramento condicional tramitarem com a morosidade usual da Auditoria Militar.

O debate e as disputas políticas eram intensas fora das prisões, os grupos e partidos remanescentes se rearticulavam em torno de propostas e avaliações e buscavam influenciar as opiniões dos presos políticos para divulgá-las e se legitimar também, conforme o relato de Criméia A. S. de Almeida sobre a avaliação da Guerrilha do Araguaia no interior da direção do PCdoB. Naquele momento, José Genoino ainda estava preso e Ozeas Duarte, membro do Comitê Central do partido, tinha sido libertado havia apenas três meses:

“[...] Em 24 de junho de 1976, fui me encontrar com João Amazonas num aparelho onde ele me deu para ler naquele momento, o que mais tarde vim a saber era o Relatório do Angelo Arroyo sobre a Guerrilha do Araguaia. Depois que eu li, ele me perguntou qual a minha opinião sobre a guerrilha. Eu lhe respondi que no meu entender a guerrilha estava praticamente terminada. Ele retrucou e foi taxativo ao dizer que não, segundo ele a guerrilha continuava, pois além dos 25 guerrilheiros vivos descritos pelo Arroyo, havia outros que perderam o contato e não participaram da ultima reunião em janeiro de 1974 . Ele, então, me incumbiu de passar esta informação aos presos políticos de São Paulo, quando eu os visitasse. Ele sabia que meu cunhado estava preso no Barro Branco. Eu fiquei bastante surpresa e lhe perguntei como eu afirmaria isso, sem poder contar a ninguém que havia tido contato com ele. Ele me respondeu que todo revolucionário é criativo, sem discutir como eu faria isso. Eu fiquei indignada, mas não briguei com ele. Fui embora pensando em como passar a informação, mas ao sair do aparelho fui seguida. Acho que a duras penas consegui despistar quem me seguia. Passei a informação de que havia sido seguida para o meu contato com a direção. Depois de uma apuração, a direção

${ }^{827}$ Destaques no original. Idem, ibidem. 
respondeu de forma bastante desencontrada: eu havia sido indisciplinada e feito contato com um militante infiltrado. Por esse motivo fui afastada do partido. Logo depois, em 16 de dezembro o Comitê Central foi assassinado na "Chacina da Lapa" e o motorista da direção, nesta reunião, era o mesmo que havia me levado até ao João Amazonas em junho. Durante todo o período em que visitei os presos no Barro Branco não discuti nada sobre a guerrilha, além do que havia presenciado enquanto estive lá e o que vi no PIC de Brasília. Os presos tinham interesse em saber notícias sobre a guerrilha, mas não me perguntavam muito, pois sabiam que eu era uma pessoa marcada e, supostamente, não faria contato com a direção. Continuei nesta situação, sem saber o que havia acontecido com a guerrilha e com essa reunião secreta até a volta dele em 1979. Ele, então, me disse que eu havia falado demais, pois ninguém deveria saber daquele encontro. Depois, entendi que ele havia tentado me usar numa disputa dentro do Comitê Central. Para mim, esta disputa só ficou totalmente esclarecida quando em 1998, o jornalista Amaury Ribeiro Jr. encontrou as anotações da reunião da Lapa nos arquivos do general Bandeira ${ }^{828}$."

Com o passar dos anos, porém, o contato com as organizações estruturadas fora da prisão se fragilizou ou acabou e alguns presos ficaram abatidos e pessimistas, o peso dos anos de confinamento repercutiu na sua disposição psicológica, conforme o relato de Manoel Cyrillo:

“A gente vai ficando tremendamente pessimista. Eu vou te contar [...] algo que vivi no presídio político, no Romão Gomes: comecei a passar por um processo de crítica da nossa prática bastante radical [...]. E, por sorte, uma prima minha que me visitava, a Lucia Teixeira, [...] era psicóloga e começou a fazer uma espécie de tratamento comigo, porque comecei degringolar na cadeia. [...] Comecei a ter uma visão bastante dura em relação à minha prática política e comecei a desmoronar. [...] Ela me disse para pôr uma pedra em cima: '- Não pense nisso preso, se agarre ao que você tem'. [...] Eu me lembro dela falando: '- É a coisa do afogado, se agarre a essa sua bóia e não critique, defenda com unhas e dentes a sua posição e esqueça os outros. Você não está fazendo revolução nenhuma aqui dentro, está aqui nessa geladeira, fique e segure a sua peteca, porque se você não tiver razão para estar aqui, se você destrói a razão de estar aqui, você pode sofrer muito. [...] Você precisa ser firme com aquilo que pensa e pensava [...].' Essa visão dela [...] foi genial! [...] Segui esse conselho e foi o que me salvou, porque [...] as coisas são muito rápidas naquelas circunstâncias de cadeia, é complicado! Eu pus uma pedra em cima, acho que o preso por definição, não precisa de grandes orientações políticas [...], porque o comportamento na prisão é o de resistência, [...] você tem de encontrar artifícios e possibilidades de manter a sua posição e é possível fazer isso, sempre. [...] Manter a postura de dignidade de lutar por livro, por condições melhores, de ter um companheiro do lado, não deixar que se desgarre [...] alguém etc., ${ }^{, 29}$

Para combater essa atmosfera de ameaças e provocações ou de desânimo, os presos começaram a organizar atividades para ampliar seus contatos com o mundo fora da cadeia. Alguns presos decidiram escrever regularmente para personalidades - escritores, músicos, religiosos e políticos - contando sobre o

\footnotetext{
${ }^{828}$ Entrevista concedida por Criméia A. S. de Almeida à autora. SP, 27/07/2000, 28 e 30/11/2001, e 20/10/2004.

${ }^{829}$ Entrevista concedida por Manoel Cyrillo de O. Netto à autora. Idem, ibidem. AAPP/AEL-LEI.
} 
cotidiano do presídio e outros temas. A escolha do interlocutor ficava a critério de cada um. Além disso, decidiram confeccionar cartões de Natal ou de outras datas comemorativas com a produção artística própria, sempre com mensagens políticas. Os presos do Hipódromo também começaram a organizar este tipo de atividade. Depois, os presos do Romão Gomes passaram a produzir cartazes com uma temática política ${ }^{830}$ e a convidar músicos, intelectuais e artistas para visitálos e realizar shows ou apresentações como Sérgio Ricardo e o grupo de teatro União Olho Vivo que encenou o espetáculo Rei Momo ${ }^{831}$, entre outros. As visitas de outras pessoas além dos familiares foram ficando mais frequentes, o debate com os diversos grupos políticos atuantes fora das prisões foram tirando os presos do isolamento a que estavam forçados desde a primeira metade da década de 1970.

\section{Saindo da prisão: refazendo a vida e a política}

A libertação representava uma ocasião de extrema alegria e alívio, em que se poderia finalmente desfrutar dos prazeres e hábitos mais simples da vida, uma oportunidade de rever e voltar a conviver com as pessoas mais queridas, a família e os amigos, e de poder cuidar e ser cuidado por eles. A libertação foi vivida de diversas maneiras pelos presos políticos, e envolvia muita ansiedade e apreensão, mas as reações variavam conforme o momento em que ela ocorreu. No auge da repressão, este acontecimento foi vivido com muito medo por algumas pessoas, o que era justificado pelas ameaças que recebiam antes de serem liberados. Testemunhos compilados aqui dão conta de que, em geral, os presos eram encaminhados ao DEOPS e ameaçados antes de serem soltos. Este fato se repetia quando eram levados ao juiz auditor. Vários ouviram a promessa de que se voltassem a atuar na política seriam mortos ${ }^{832}$. Para alguns presos políticos, o momento da libertação “coincidiu com uma fase de angústia” [LEVI, 1990: 39].

A ocasião mais esperada pelo prisioneiro, o dia de sair da prisão, teve um significado devastador para José Olavo Ribeiro. Ele foi libertado no final de março de

\footnotetext{
${ }^{830}$ Entrevista concedida por Artur Scavone à autora. Idem, ibidem.

${ }^{831}$ Entrevista concedida por Idibal Pivetta à autora. Idem, ibidem.

832 Entrevista concedida por Criméia A. S. de Almeida à autora. Idem, AAPP/AEL-LEI; entrevista concedida por Darcy Miyaki à autora. Idem, ibidem.
} 
1972 e este momento foi marcado pela tomada de consciência profunda da perda de sua companheira, Heleny Telles Guariba, desaparecida desde 12 de julho de 1971:

“[...] Quando saí, para mim foi uma experiência péssima, porque todo o tempo em que você está preso, você não vê a hora de sair e quando sai, sua vida muda totalmente de novo. [...] Para mim foi quando eu senti mais à morte da Heleny, porque no presídio é uma coisa um pouco mais política e menos pessoal. [...] Mas quando saí, acho que, vamos dizer, caí na real. [...] Depois, fui rever os parentes dela, a mãe. Foi uma visita muito difícil para mim, porque a mãe não acreditava na morte dela. Ao mesmo tempo, eu não podia abrir o jogo, não podia falar exatamente o que tinha acontecido com ela. Mesmo porque eu também não tinha muita certeza. [...] Sofri um baque maior quando saí [...]. [Havia] um sentimento de perda, de perda mesmo, [...] porque quando eu estava preso, ficava vivendo muito o dia-a-dia do presídio. Você está ali e há discussões muito intensas, a gente fazia uma espécie de trabalho de autoajuda, uns apoiando os outros. Quando você sai, muda a realidade, [...] não tinha mais amigo nenhum, praticamente. Tinha sumido todo mundo, estavam presos, no exterior ou tinham sido mortos. Eu estava com a minha vida política completamente desarticulada, saí em fim de março de 1972.

[...] a minha família se mexeu [atrás de informações] de um lado, o general de outro. Eu não sei se eles chegaram alguma vez a se encontrar, acho que uma vez se encontraram.

Depois de solto, praticamente, a gente não estava mais se mexendo, porque a gente tinha certeza de que ela tinha morrido. O negócio era tentar descobrir onde. Tínhamos uma noção de que era um local clandestino da repressão no Rio, mas ainda não se falava na Casa de Petrópolis. [...] só vim a ter certeza depois que conversei com a Inês [Etienne Romeu], apesar do José Carlos Dias ter conversado com ela antes [...] $]^{833, "}$

Para alguns militantes, o tempo de prisão, embora muito difícil, constituiu-se num período de amadurecimento político, o que não implicou necessariamente em retomar a militância ou em realizar um trabalho político com outras referências após a libertação da prisão. Vários militantes saíram da cadeia e não voltaram à atividade política. Alguns necessitaram de anos para voltar a se envolver com política, conforme aconteceu com Jorge Eduardo Saavedra Durão, solto em dezembro de 1972:

“[...] eu tive um período de convívio muito bom com o pessoal da VAR[-Palmares], os seis do comando que ficaram no QG da terceira zona aérea, porque ali nós discutíamos sobre a percepção da realidade, amadurecemos muito politicamente [...], começamos a refletir sobre o nosso isolamento social. E tínhamos uma certa facilidade para ter livros. [...] Eu acho que nós saímos dali com a cabeça muito diferente de quando entramos. [...] Nossa perspectiva era a de tentar entender o que estava acontecendo. [...] não era uma autocrítica em tese da luta armada, porque [...] eu acho que há situações em que não há outra solução, como é que você ia resistir ao nazismo? Simplesmente, aquele caminho de luta [...] não estava em sintonia com o momento que a sociedade brasileira estava atravessando, o processo de modernização capitalista que a ditadura realizou. Aliás, antes de ser preso eu já percebia isso, no dia em que mataram o Chael Schreier, saí sozinho pelas ruas de Copacabana, enquanto o povo vibrava sei lá com o que, o tempo todo tinha vibração e Copa do Mundo etc. Nós estávamos no isolamento total.

Eu acho que outra coisa muito importante que a gente aprendeu foi a de repensar o valor da democracia. Não só na cadeia, mas na cadeia também. Eu acho que a esquerda que resistiu à ditadura não tinha um compromisso com a democracia como um valor universal

${ }^{833}$ Entrevista concedida por José Olavo Ribeiro à autora. Idem, ibidem. 
[...]. E nós tínhamos uma visão um tanto quanto reducionista, quer dizer, como [...] se só pudesse haver algum tipo de democracia com o fim do capitalismo. [...] hoje a gente vê que a democracia que se tem está sob domínio do capital financeiro, do agronegócio e não é propriamente a democracia com que eu sempre sonhei, mas é claro que é relevante ter instituições democráticas e liberdades públicas. Eu acho que a esquerda também era intrinsecamente autoritária.

[...] nós saímos [da prisão] sem nenhuma proposta política ou de reorganização. Eu, inclusive, fiquei sem ter nenhuma militância política de 1972 até a campanha da anistia, quando fui membro do Comitê Brasileiro pela Anistia [do Rio de Janeiro, em 1978]"834.

Retomar a militância estava diretamente relacionado ao período em que eram libertados e à continuidade ou não da organização a que pertenciam. Alguns ex-presos retomaram o contato com sua organização e a militância rapidamente, conforme nos contou Cloves de Castro, solto no final de 1971. Devido às novas condições e dificuldade inerentes à condição de todo ex-preso político em plena vigência da ditadura (muitos continuaram a ser vigiados), a sua maneira de militar politicamente forçosamente sofreu mudanças:

“[...] Eu saí do presídio, do Carandiru, com ponto para recontactar a minha organização, a ALN, o que fiz depois de ficar um mês e pouco só curtindo a família e os filhos. [...] Fui recebido aqui fora por um companheiro, de Minas Gerais, não me lembro o nome, acho que é Careca. Ele [...] me recebeu, deu um quadro de como as coisas estavam, as quedas, os nossos passos futuros, a continuidade. [...] Cobri vários outros pontos, aí eu falei pra ele [...]: '- Tem um pessoal, um grupo de ex-presos que está fazendo um trabalho de alfabetização de adultos em paróquias, [...] uma das paróquias era organizada pelo Giorgio Callegari, [...] na região do Jabaquara, [...] vou dar uma esfriada, vou fazer esse trabalho'. Ele falou: '- Legal'. Nos pontos seguintes, ele colocou [...] que os cubanos estavam chegando e que ia haver uma conferência, que eu seria convidado a participar. E que havia uma dúvida se eu iria para um grupo de fogo ou se eu ficaria nos comandinhos [...]. E eu continuava o meu trabalho, fui para a fábrica, em 1972 [...] de forma bem camuflada para não dar bandeira. [...] E voltei ao meu trabalho no funcionalismo público [...]. Assumi, mas esse período foi o pior momento da minha vida. Na cadeia você está entre amigos, companheiros, ali você não sabia aonde estava. [...]. Eu saía de casa cinco, quatro e pouco da manhã pra cobrir um ponto às nove, foi terrível. Aí [...] fui demitido. [...] Os pontos continuam, num ponto esse companheiro fura, no segundo e no terceiro [...], mas o nosso trabalho de alfabetização estava muito bem, com muitos companheiros de outras organizações, [...] gente da Ala Vermelha, PCB, tinha de tudo [...].

Eu consegui recontatar a ALN através de gente da VAR-Palmares. Nesse período, vários companheiros morreram; era 1974, 1975 e estava configurado que a gente tinha sido derrotado. Mesmo assim, a gente continuou desenvolvendo uma série de trabalhos e contatos com companheiros da ALN em vários estados. [...] E aí o pessoal da organização falou: '- Dá um tempo, até para a sua segurança. [...] Continua fazendo este trabalho, porque está bom'. [...] Eu já estava me organizando com o pessoal de fábrica, não ficava no sindicato, quando ia, ficava quieto, não fazia discurso. Comecei a fazer isso a partir de 1977. Em 1978, eu era coordenador da chapa [da oposição sindical], mas não saí nela, porque tinha sido processado ${ }^{835}$."

\footnotetext{
${ }^{834}$ Entrevista concedida por Jorge Eduardo Saavedra Durão à autora. Idem, ibidem.

${ }^{835}$ Entrevista concedida por Cloves de Castro à autora. Idem, ibidem.
} 
A ausência de amigos, a sensação de solidão e a percepção das enormes mudanças existentes na atmosfera política e econômica do país se tornaram situações e sentimentos recorrentes para muitos presos libertados. Os modelos dos carros que passavam na rua eram irreconhecíveis, assim como os bares, cinemas e livrarias ${ }^{836}$. Muitos não puderam retomar os estudos na universidade ou a sua profissão original, alguns haviam passado mais de 10 anos entre a clandestinidade e o tempo de cumprimento de pena na prisão. Tiveram de aceitar empregos com salários mais baixos para sobreviver. Outros perderam empregos em consequência das ameaças feitas aos empregadores pelos órgãos de segurança.

Durante a primeira metade da década de 1970 predominava uma atmosfera política pesada e de medo, muito diferente da que exisita até 1968, quando vários militantes iniciaram sua atividade política na clandestinidade. A adaptação a essa nova realidade foi muito difícil para alguns ex-presos, conforme o relato de Beatriz Bargieri. Presa duas vezes nos anos 1970, ela foi libertada pela última vez em 1975:

"Sair da prisão foi muito difícil, porque fiquei muito sozinha na cadeia. É a tal história, [...] tinha a Ângela, mas eram apenas duas pessoas, o que é completamente diferente de ficar com 15 ou 20. Primeiro, passei um mês sem conseguir atravessar a rua, porque o movimento era uma coisa pirante. Você sai e vê aquele espaço enorme e não sabe onde está pisando. Quando você saía da penitenciária e ia para o DEOPS para assinar o alvará de soltura, os caras faziam um monte de ameaças, aquela coisa: '- Quando você atravessar a rua, pode acontecer não sei o que.' Aquelas coisas bem sutis que eles sempre faziam. Fiquei muito atordoada, meio zonza, muito zonza. Eu fui para o Rio, fiquei lá um tempão, mas as pessoas chegavam para me ver e eu queria ficar sozinha, porque fiquei tanto tempo sozinha e só queria ficar sozinha. Foi um período difícil.

Agora, mais difícil ainda foi retomar a vida legal, porque eu tinha um diploma. Eu me formei em 1967, 8 anos depois, com esse diploma na mão, abriu-se um espaço, porque eu tinha experiência até 1968: '- Mas e agora? Quem sou, para onde vou, o que eu vou fazer da minha vida?’ Não dava para ter uma militância orgânica. [...] Eu era absolutamente visada e se eu fosse atuar iria prejudicar quem estava na organização [...]. Eu estava pronta para voltar, para mim [...] o desdobramento era a continuidade, [...] ter uma atuação política. [...] Mas, era muito claro que eu iria ser vigiada, como realmente aconteceu. [...]. Então, isso eu já tinha decidido, ia atuar no movimento de mulheres, no Movimento Feminino pela Anistia. E essa decisão foi uma coisa que até me ajudou, mas eu fiquei quase um ano sem emprego, fazendo artesanato [que eu aprendi a fazer na cadeia] e que outras pessoas vendiam, porque eu não conseguia vender. Foi uma fase muito difícil, foi a fase mais difícil para mim. Foi muito difícil a retomada da vida legal e do cotidiano" ${ }^{837}$.

A atmosfera de medo predominava e as ameaças de grupos clandestinos como o CCC se prolongaram até pelo menos $1981^{838}$. Muitos presos vivenciaram o sentimento de

\footnotetext{
${ }^{836}$ Entrevista concedida por Reinaldo Morano Filho à autora. Idem, ibidem.

${ }^{837}$ Entrevista concedida por Beatriz Bargieri à autora. Idem, ibidem.

${ }^{838}$ Entrevista concedida por Sérgio Ferreira à autora. Idem, ibidem.
} 
angústia, ansiedade e insegurança em relação ao que lhes acontecereria após a saída da prisão, conforme nos contou Lúcia Murat:

"E aí começou 1974, entrou o Geisel. [...] O Cordeiro de Farias era primo da minha mãe e pertencia à Sorbonne Militar [...]. Houve uma pressão familiar e o Cordeiro fez aquela carta, que é uma das poucas que denunciam a tortura feita por um militar [...]. Ele deu para mamãe, que a levou para ao ministro Rodrigo Otávio, [...] do Superior Tribunal Militar [...]. Estava para ser julgada uma apelação de uma condenação minha de 12 anos, o Técio [SOBRENOME] tinha conseguido me dar relaxamento de prisão em todas as outras. Era uma briga [...] mas era fundamental que os 12 anos caíssem. Então, o Rodrigo Otávio pediu uma investigação sobre tortura em relação ao meu caso em função dessa carta, julgaram a apelação e me deram dois anos. Eu já tinha cumprido mais de três. O Técio conseguiu que eu fosse solta, foi uma loucura. [...] O fato de, na primeira vez, na Auditoria [...] eu ter negado as acusações me deu alguns meses de liberdade, talvez até alguns anos.

Em junho ou julho de 1974, por aí, fui libertada. Depois, continuei respondendo outros processos em liberdade. Em um, fui absolvida, mas, no resto, [...] respondi em liberdade até a anistia. E eu fui anistiada e até lá tive de ir várias vezes à auditoria. Eu tenho a impressão de que no dia seguinte ou três dias depois da redução da pena eu saí [...]. E quando saí todo mundo teve medo de eu ser sequestrada, porque ainda estava muito tenso. A briga entre 'eles' [o pessoal da repressão,] estava comendo solta, ninguém queria que eu saísse. O pessoal foi me pegar e eu estava morrendo de medo, eu jurava que ia ser sequestrada. Eu saí e o Técio estava num carro, a mamãe e o papai noutro carro e o meu irmão Heitor estava lá também. Todos com medo de que acontecesse alguma coisa”,839.

O terror instaurado pela ditadura dentro e fora das prisões disseminou a insegurança entre os militantes. As vivências de isolamento na clandestinidade, depois, o sentimento profundo de solidão, mas também o sentimento de desapontamento causados pelo comportamento esperado na tortura marcaram vários presos de tal forma que o momento de sair da prisão despertou o desespero e a insegurança, levando ao desejo de não sair. Alguns se sentiram mais seguros nos cárceres, conforme nos contou Darci Miyaki, libertada em junho de 1973:

“[...] o Virgílio [Enei] fez a minha defesa, entrou com uma petição normal por excessos de prazos, mas fiquei louca da vida, porque não queria sair da cadeia, realmente não queria. Eu achava que estava muito mais segura presa do que solta e achava que eles iam me seguir para ver se eu faria contato com a organização. Eu achava que poderiam sumir comigo. [...] Na verdade, não é que eu achava, eu tinha plena certeza de que iam sumir comigo. [...] Eu saí sem ter onde morar, sem emprego, sem roupa, sem comida. Eu não tinha contato com a família.

[...] Depois da prisão, eu entrei em depressão, não são quarenta anos de depressão, são crises, fases, mas acho que até a formação da gente tem muito a ver com o tipo de reação que temos. Eu fui criada em colégio de freiras, enclausurada, não sei [...]. Foi muito difícil.

[...] quando voltei para a faculdade, não gravava nada, mas não sei, foi importante para a minha cabeça, eu acho.

${ }^{839}$ Entrevista concedida por Lucia Murat à autora. Idem, ibidem. 
[...] O dia em que eu saí foi terrível. O pai e a mãe da Maria Aparecida viram a minha situação, que não tinha ninguém me esperando e [...] acabei ficando uns dias lá na casa deles. [...] Aí fui morar perto da Rua Treze de maio, [...], num quartinho [...] Morei uns tempos lá, mas não consegui emprego, e a Fani Seixas, naquela pobreza toda, elas dividiam a comida comigo. São coisas que te marcam. Em qualquer lugar que eu ia procurar emprego pediam um tal de atestado de antecedentes e eu não conseguia emprego. Aí a Iara Seixas conseguiu um na IBM e eu acabei conseguindo também. [...] Passei anos fazendo terapia com a Madre Cristina no Sedes Sapientiae, mas foi muito difícil $[\ldots]^{840}$.”

Muitos outros militantes, contudo, experimentaram o momento da saída da prisão com extrema alegria e conseguiram se adaptar rapidamente à vida em sociedade e em família. Conseguiram reingressar em suas carreiras profissionais anteriores ou voltar a estudar. Alguns, em função de contatos e relações constituídas durante os anos de prisão, conseguiram bons empregos em seguida à sua libertação. Em diversos momentos, várias pessoas, em solidariedade, ofereceram ajuda ou empregos para facilitar a adaptação dos ex-presos, conforme aconteceu com Vicente Roig, libertado em setembro de 1974. Depois de algum tempo, ele retomou os estudos e se tornou advogado, especializado em direito trabalhista:

"Eu saí numa sexta-feira, no fim da tarde. [...] A gente saiu e foi para casa de outras pessoas e começaram as festas, recepções, jantares e essas coisas. A gente sai muito atordoado, tonto, tonto. O mundo roda. Depois de muitos anos sem ver nada, com um horizonte de no máximo três metros, você fica muito atordoado, mas foi muito legal sair, muito bom!

A minha adaptação foi rapidíssima. Saí procurando emprego, eu já tinha algumas promessas, pois quando você sai na condicional, tem que ter uma promessa de emprego formal. Eu tinha, mas não era verdadeira, era um ato de solidariedade. O João Miguel me deu um documento atestando que ele iria me contratar [...]. Logo que saí quem assinou a minha carteira foi um pessoal que tinha uma pequena editora, acho que ainda tem, a "Esquema”, e o Vicente Wissembach assinou a carteira para mim, carimbou, me deu o PIS, o fundo de garantia, tudo direitinho. Ficou assim até eu ir trabalhar na [editora] Abril, todo mundo ia trabalhar lá. Eu fui em janeiro de 1975.

Quando saí da prisão, eu e os demais companheiros de Ala fomos fazer o que a gente propunha no documento de autocrítica. Continuamos a militância e a Ala continuou existindo. [...] No total, trabalhei na Abril [...] até fevereiro de 1984. Nesse período, me mudei para a periferia de Guarulhos e montei um jornal lá, [...] fiz um "freela" no Jornal da Tarde, mas mantinha um trabalho político de bairro e outro junto à Oposição Sindical Metalúrgica de Guarulhos. Era exatamente a proposta que a gente tinha. E isso foi até $1982^{\prime 841}$.

Outros ex-presos tiveram menos sorte e retornaram à prisão depois de soltos, conforme aconteceu com o militante do PCB Vicente Silvestre, coronel da PM. Preso em julho de 1975, cumpriu um ano de prisão. O julgamento de seu processo ocorreu quando

\footnotetext{
${ }^{840}$ Entrevista concedida por Darci Miyaki à autora. Idem, ibidem.

${ }^{841}$ Entrevista concedida por Vicente Roig à autora. Idem, ibidem.
} 
já estava em liberdade, mas ao analisar o recurso do advogado, o STM aumentou sua pena para dois anos de reclusão:

“[...] quem me condenou foram os militares do Exército, o juiz auditor civil [...] votou pela minha absolvição. [...] Depois, o advogado recorreu ao STM, em Brasília, [...] e ao invés de anularem a pena, ela foi aumentada para dois anos de prisão. A essa altura eu já tinha cumprido um ano e estava em liberdade [...]. Voltei para o Hipódromo e fiquei mais um ano na prisão. [...] Fui condenado pela LSN, porque admitir que um trabalhador, um operário, um intelectual pudesse aderir ao Partido Comunista, tudo bem, mas um militar, jamais! Militar deixava de ser um militante para ser um traidor da pátria, então, eu fui visto assim, como um traidor da pátria, da pátria deles, não da minha!

[...] Quando aconteceu a nossa prisão e expulsão, o d. Paulo procurou o governador Paulo Egydio Martins e conseguiu dele uma lei da Assembleia Legislativa dando uma pensão para a nossa família. Essa lei dizia que eu não poderia exercer nenhuma atividade remunerada pública ou privada, mesmo depois de cumprir a pena, e a minha mulher seria considerada viúva de marido vivo. Ela receberia uma pensão da Caixa Beneficente da Polícia Militar e eu [...] era considerado um morto-vivo. Isso durou quase dez anos, até $1984^{\prime 842}$.

A insegurança era uma realidade bastante presente na vida de diversos ex-presos políticos, viver com livramento condicinal implicava numa grande limitação da suas atividades. Não era possível viajar sem autorização e havia aobrigação de assinar um livro na Auditoria Militar regularmente. Os ex-presos estavam submetidos ao risco de ver outro processo na Justiça Militar reaberto ou restava a dúvida e a espera em relação ao andamento do julgamento de recursos de outros casos nos tribunais superiores, conforme aconteceu com Pedro Rocha:

"Eu saí da prisão em 1977 [em livramento condicional] e lá pelo meio do ano, fui condenado de novo. Fiquei escondido até o finalzinho de 1979, quase dois anos mais ou menos.

Eu trabalhei nesse período, tentei emprego aqui, ali. Consegui trabalhar, dei uma de autodidata em Goiás e me inscrevi numa vaga de auxiliar de almoxarifado numa empresa grande [...], com outro nome, clandestino. [...] O salariozinho que eu ganhava era pequenino, mas os amigos ajudavam, [...] faziam uma coleta e tinha um ou outro que servia de intermediário para me levar um dinheirinho, de vez em quando.

[...] algumas organizações me ofereceram ajuda para me manter na clandestinidade, pensando em preparar um trabalho de implantação rural para desenvolver a luta armada. Eu não aceitei. Mas, o fato é que não tinham desistido, [...] ainda não haviam aceitado a derrota" ${ }^{843}$.

As maneiras encontradas pelos ex-presos para sobreviver fora da prisão ou para voltar a atuar politicamente variaram conforme o indivíduo, a organização a que pertencia e o período. Para algumas mulheres ex-presas, a organização e participação no movimento de mulheres e a descoberta do feminismo representaram uma grande

\footnotetext{
${ }^{842}$ Entrevista concedida por Vicente Silvestre à autora. SP, 16/09/2009. AAPP/AEL-LEI.

${ }^{843}$ Entrevista concedida por Pedro Rocha Filho à autora. Idem, ibidem.
} 
transformação existencial e política. Algumas ex-presas políticas passaram a fazer parte da equipe de redação do jornal Brasil Mulher, que começou a circular em 9 de outubro de 1975 para divulgar a luta pela anistia aos presos e perseguidos políticos, um periódico do Movimento Feminino pela Anistia (MFPA). Divergências quanto ao seu conteúdo feminista dividiram a redação e o jornal se desvinculou do MFPA. Sua tiragem oscilava entre 5.000 e 10.000 exemplares e sua periodicidade era irregular, bimestral ou trimestral. Inicialmente, era editado em Londrina com uma equipe de sete mulheres, que se ampliou para vinte e cinco. A partir de seu segundo número, publicado no início de 1976, começou a ser editado em São Paulo e introduziu a temática do feminismo. O jornal se voltou para as mulheres dos movimentos populares e circulou até março de $1979^{844}$.

Algumas ex-presas entrevistadas nesta pesquisa participaram do jornal e relataram como foi essa experiência e o significado político do Brasil Mulher. Para Beatriz Bargieri, os jornais e as lutas feministas modificaram a face política do país:

"O trabalho no Brasil Mulher começou em cima [...] da questão da anistia e depois do movimento de mulheres e feminista. E ele ia além, porque incorporava a rede democrática, [...] que abria espaço para um novo tipo de militância, que não era clandestina, mas que ainda estava na [...] ditadura. Passava a incorporar setores da sociedade que de alguma maneira também vinham retomando [...] a atividade política. [...] Várias mulheres participaram, de várias organizações, partidos políticos, com diferenças, mas que tinham um objetivo comum muito maior, não passava só pela questão geral do país, mas também pela luta de emancipação das mulheres, que hoje se coloca como uma questão da relação da igualdade de gênero. $E$ isso implicou num relacionamento muito forte, principalmente, entre as três entidades existentes na época: o Brasil Mulher, o jornal Nós Mulheres e o Centro da Mulher Brasileira. As diferenças entre elas se somavam em torno de alguns temas e a relação era muito positiva, muito rica e cada uma foi incorporando o que a outra tinha de mais forte nas suas características. Eu acho que essa experiência teve um impacto muito grande no Brasil, inclusive, eram três entidades de São Paulo, mas que tinham ramificações no Brasil inteiro [...]. E isso veio a refletir na maneira como se desenvolveu a luta das mulheres. »455.

De acordo com Rosalina Santa Cruz, o fato das companheiras do jornal Nós Mulheres terem se exilado fez diferença na sua aproximação com o feminismo e na linha editorial dos periódicos, mas essa diferença foi fundamental para o crescimento da consciência das militantes dos dois jornais, naquele período:

"O núcleo básico do Nós Mulheres era composto por um pessoal que tinha ido para o exílio e ficado no Chile, na França. Elas vinham com outra formação, lá o movimento feminista estava noutra situação. A gente do Brasil Mulher entendia o feminismo como uma questão ligada à emancipação e à luta das mulheres e do povo. Estávamos muito

\footnotetext{
${ }^{844}$ Teles, M. A. de A., op.cit., p.87-9; KUCISNKI, B. op.cit., p. 124-30.

${ }^{845}$ Entrevista concedida por Beatriz Bargieri à autora. Idem, ibidem.
} 
mais voltadas para a questão política e não para a da especificidade da condição da mulher. Foi muito engraçado, porque quando a gente se deparou com essa situação sobre a qual não tínhamos o menor conhecimento, [...] quando vimos isso foi muito legal, porque não só a gente aprendeu muito com elas, como elas também com a gente. Houve uma troca muito grande e [...] há um carinho muito grande entre nós. A gente até leva um susto, porque [...] nunca disputamos, tínhamos espaços comuns, mas sempre somamos. Eu acho que isso também é uma característica feminina, [...] a mulher soma. Lógico, há também, culturalmente, a disputa do poder, de espaço e quando tem é barra pesada, igual a qualquer outra, mas em determinadas situações, acho que as mulheres se somam. Nesse caso, somamos realmente. No Brasil Mulher, a gente brigava muito na hora de fazer o jornal, a pauta [...] etc. Todo mundo achava que a gente não ia se ver nunca mais e, depois, acabava, fechava, a gente ia almoçar, jantar e era tudo muito tranquilo. Acho que tive o privilégio de poder trabalhar com essas mulheres incríveis” ${ }^{\text {(846. }}$.

O jornal Nós Mulheres foi publicado pela primeira vez em junho de 1976 e deixou de circular em 1978. Teve grandes oscilações nas tiragens e na periodicidade. Tinha como proposta, a exemplo do Brasil Mulher, defender e divulgar a socialização do trabalho doméstico através da criação de equipamentos sociais como creches, lavanderias e refeitórios públicos. Essas proposições, entretanto, enfrentaram a resistência até de ativistas de esquerda, que consideravam a fome e a falta de liberdade os problemas prioritários dos brasileiros. Essas ideias, contudo, incentivaram e propiciaram debates em escolas e bairros das periferias das grandes cidades. O jornal Nós Mulheres tinha uma linha editorial mais voltada para as questões específicas da realidade das mulheres e o feminismo, e sua redação era composta por algumas exiladas ${ }^{847}$.

Os testemunhos das ex-presas políticas compilados aqui enfatizam a qualidade desses jornais feministas, as dificuldades de realizar o trabalho político com as mulheres nas periferias e sua importância na campanha da anistia e na transformação da conjuntura política da segunda metade dos anos 1970. De acordo com Bargieri:

“[...] quando o jornal Movimento era censurado, nós publicávamos a matéria no Brasil Mulher, porque 'eles' não davam tanta bola para o Brasil Mulher e nem para o Nós Mulheres. No entanto, se você pegar o conteúdo dos jornais é um conteúdo tão forte quanto. Teve matérias inteiras que foram censuradas e que a gente publicou. A gente via [...] que era possível trabalhar isso. [...] Mas poucos entre os mais próximos, na época, achavam que era algo importante a ser feito, olhando com os olhos de hoje as mudanças foram muito grandes.

[...] A gente se encontrava, levava o jornal, o padre o colocava dentro da sacristia, do confessionário e a gente distribuía nos grupos de mulheres ou na rua. Era um negócio muito estranho, porque era uma atividade semiclandestina, mas a gente fazia o jornal abertamente, a gente tinha registro, tinha expediente, nome, jornalistas responsáveis, tudo certinho, mas a sua divulgação tinha que ser meio 'de bastidores'.

\footnotetext{
${ }^{846}$ Entrevista concedida por Rosalina Santa Cruz à autora. Idem, ibidem.

${ }^{847}$ Teles, M. A. de A., op.cit., p. 90-2; KuCISNKI, B. op.cit., p. 124-30; e as entrevistas concedidas por Rosalina Santa Cruz, Beatriz Bargieri e Iara Prado à autora. Idem, ibidem.
} 
[...] As nossas entidades estavam representadas por pessoas muito comprometidas e isso refletia no trabalho. Hoje, quando se fala das entidades que participavam do CBA, as entidades feministas e de mulheres não são as principais, destacam a $\mathrm{OAB}$, a Associação Brasileira de Imprensa, enfim, entidades que tinham respaldo, força. As entidades de mulheres não tinham tanta força, mas elas estavam presentes o tempo inteiro, reforçando e ampliando o espectro da sociedade ali representado. E acho que isso teve uma importância fundamental" ${ }^{\prime 848}$.

De acordo com Iara Prado, o trabalho político feito pelas feministas nas periferias

de São Paulo, nesse período, mudou profundamente a vida das mulheres e do país:

"Entrei no movimento feminista primeiro, em 1978, [...] com a Raquel Moreno [...]. No Brasil Mulher, a anistia era uma das lutas que nós fazíamos junto aos Clubes de Mães, quando visitava o pessoal da igreja, da mesma forma que levávamos a luta contra a carestia. Era um momento de muita força da igreja e a gente trabalhou bastante com eles. [...] Naquela conjuntura, o nosso papel era o de apoiar as mulheres que estavam na periferia e as mulheres cresceram muito. Nesse sentido, a AP, o PC do B e a gente tinham uma visão parecida. Eu [...] não queria participar mais de grupelho, para mim a luta tinha sido o máximo, mas do ponto de vista político [...] não éramos como Cuba [...], éramos uma sociedade muito mais complexa [...]. Então, todo domingo a gente ia para a periferia. Eu fico superorgulhosa, [...] a coisa caminhou, o Parque São Rafael era um loteamento clandestino, não tinha rua, não tinha nada. E aquela coisa da organização dos congressos, mesmo que fosse conflitante, nunca vou me esquecer que a gente fazia reuniões de organização dos congressos. [...] E da periferia ou não estava todo mundo junto [...].

Na minha opinião, a velha tradição da esquerda da década anterior teria rachado em 5 mil pedacinhos. [...] O movimento feminista teve o seu ápice na luta por creche, acho que foi o melhor momento da nossa atuação política, porque nós conquistamos 315 creches [em São Paulo], coisa que nenhum governo democrático nos deu depois. Foi aquela nossa luta, com todas aquelas mulheres, que deu [...] nessa coisa inacreditável. [...] A luta das mulheres foi a melhor coisa que a gente fez, que eu fiz, politicamente" ${ }^{349}$.

Entre 1975 e 1976, outros militantes voltaram ao país clandestinamente para

retomar a militância política. Ricardo Azevedo, um desses militantes, esteve preso no

Tiradentes entre 1969 e 1970, e exilou-se no Chile em junho de 1972:

“[...] No Chile, havia um conjunto muito grande de brasileiros, milhares, nunca se soube quantos e havia uma permanente discussão entre as organizações e os militantes brasileiros que estavam lá. Havia fóruns de discussão, uma tremenda atividade, além da atividade de denúncia da ditadura e da repressão. Tinha um boletim, o "FBI" (Frente Brasileira de Informações), que o [José] Serra coordenava. Havia a Associação Chilena e Brasileira de Solidariedade, que fazia um trabalho de recepção aos brasileiros que chegavam, para arrumar emprego, escola, ajuda, legalização, essas coisas. E havia um fórum chamado Grupão, um fórum da esquerda brasileira no Chile, que se reunia acho que uma vez por mês e debatia temas, o caráter da revolução, conjuntura, luta armada, e estava praticamente todo mundo ali, acho que menos a VPR [...] e o PC do B.

[...] Nós da AP estávamos desenvolvendo uma política de revisão da nossa linha, uma autocrítica e uma aproximação com o MR-8 e a P.O. (Política Operária). Isso se intensificou no Chile. E [...] eu me engajei, paulatinamente, no processo chileno. Eu militava no MAPU, Movimento de Ação Popular Unitária, que era uma organização irmã

\footnotetext{
${ }^{848}$ Entrevista concedida por Beatriz Bargieri à autora. Idem, ibidem .

${ }^{849}$ Entrevista concedida por Iara Areias Prado à autora. SP, 18/09/2009, AAPP/AEL-LEI.
} 
da AP, mesma origem, mesmo processo e com relações pessoais. O principal dirigente do MAPU, Rodrigo Ambrósio, era amigo pessoal do Jair [Ferreira de Sá]. [...] E o MAPU vivia um processo autocrítico parecido com o da AP também» ${ }^{\text {" }}$.

Com o golpe de Pinochet, em setembro de 1973, Azevedo foi preso e torturado no Estádio Nacional, de Santiago. Depois de um mês, conseguiu ser libertado e se exilou na Argentina e, depois, França. Entre 1973 e 1976 participou de grupos que prestavam solidariedade aos perseguidos políticos brasileiros e organizavam discussões sobre a situação política e as propostas das esquerdas para combater a ditadura no Brasil ${ }^{851}$.

Na França desde 1974, Azevedo fez parte da revista Brasil Socialista, que era uma atividade que dava continuidade à frente de atuação política formada pela AP, MR-8 e a Política Operária (P.O.) no Chile. Seu comitê de redação em Paris era o composto por Franklin Martins, Eder Sader e Azevedo. De acordo com ele, além da autocrítica dos erros cometidos, existiam pontos de convergência entre as propostas e análises políticas debatidas no exílio. Ao voltar ao Brasil no final de 1976, o debate se movia em torno de cinco aspectos principais:

"Em primeiro lugar, a defesa do caráter socialista da revolução brasileira, negando a ideia
de qualquer tipo de etapa anterior, como postulavam o PCB e o PCdoB. Segundo, a
defesa do papel do proletariado urbano como força principal e dirigente desse processo, e
não o campesinato, como defendia o PCdoB. Terceiro, a compreensão da necessidade da
construção de um novo partido revolucionário que conduzisse esse processo. Quarto, a
visão da luta armada como forma principal de luta para se chegar ao poder, negando o
pacifismo do PCB. E quinto, a defesa de uma plataforma de lutas democráticas
antiditadura como elemento central de acúmulo de forças na luta pelo socialismo naquele
momento",852. A defesa de plataforma de lutas pelas liberdades democráticas contra a ditadura, porém, representava um problema, pois era considerada burguesa pela Política Operária e pelo que veio a se constituir no MEP (Movimento de Emancipação do Proletariado, uma dissidência da P.O.). Eles aceitavam apenas palavras de ordem como "liberdade de organização e expressão para os trabalhadores e suas organizações”. E estes temas dominaram o cenário político das esquerdas nos anos seguintes [AZEVEDO, 2010: 158-9].

No exílio, além do debate sobre as plataformas de luta a serem defendidas no Brasil, duas visões diferentes do processo de reconstrução das esquerdas brasileiras estavam em conflito. Uma parte dos grupos entendia que as esquerdas estavam praticamente destruídas no Brasil e que “o processo de construção de um novo partido se

\footnotetext{
${ }^{850}$ Entrevista concedida por Ricardo Azevedo à autora. SP, 27/01/2010, AAPP/AEL-LEI.

${ }^{851}$ Entrevista concedida por Ricardo Azevedo à autora. Idem, ibidem.

${ }^{852}$ AzEVEDO, Ricardo. Por um triz, op.cit., p.157-59.
} 
daria fundamentalmente no exterior”, em decorrência do fato de que os melhores quadros remanescentes estavam no exílio, onde havia também mais acesso ao que a esquerda mundial produzia. De acordo com Azevedo, ele e outros, como Eder Sader e os militantes do MR-8, pensavam diferente. A despeito das dificuldades, o centro da reorganização das esquerdas estava no Brasil, pois não era possível formar um partido e uma teoria revolucionária distante da luta social. Para eles era necessário partir das organizações que estavam desenvolvendo um processo de autocrítica e uma retomada de suas relações com os movimentos sociais [AZEVEDO, 2010: 159].

No Brasil, este debate tinha repercussões e dinâmica própria. Durante as eleições municipais de novembro de 1976, alguns partidos e grupos clandestinos apoiaram candidatos do MDB voltados para a defesa dos direitos humanos, da anistia e dos movimentos populares, tais como Benedito Cintra, ligado ao PCdoB em São Paulo, e Tonico, militante do MR-8 no Rio de Janeiro ${ }^{853}$. Outros agrupamentos das esquerdas, militantes e ex-presos políticos se engajaram nesse novo processo eleitoral, o que se intensificaria nas eleições de 1978.

\section{As greves de fome nacionais e as lutas pela anistia}

Nas comemorações do natal de 1974 na Cúria Metropolitana, D. Paulo E. Arns chamou militantes de diversas vertentes políticas para propor a organização de uma campanha em defesa da anistia ${ }^{854}$. Desde junho de 1971, os autênticos do MDB haviam articulado o apoio à proposta em defesa da anistia aos perseguidos políticos e a incluíram na Carta de Recife, aprovada pelo partido.

Em janeiro de 1975, o Comitê Central do PCdoB escreveu uma resolução na qual fez um tributo à Guerrilha do Araguaia, sem mencionar explicitamente sua derrota, e propôs uma aliança com todos os defensores da democracia, por uma Constituinte livremente eleita, a abolição dos atos e leis de exceção e uma anistia geral. Era necessário defender a instituição do Estado de Direito e a liberdade dos perseguidos políticos como

\footnotetext{
${ }^{853}$ Entrevistas concedidas por Sérgio Ferreira e Ricardo Azevedo à autora. Idem, ibidem.

${ }^{854}$ Entrevistas concedidas por Maria Amélia de A. Teles e Sérgio Gomes à autora. Idem, ibidem.
} 
pressuposto essencial para convocar uma Constituinte com poder de fato e construir um sistema político democrático ${ }^{855}$.

No início da luta pela anistia, entre 1975 e 1977, havia certa resistência de parcela dos presos políticos em relação à defesa dessa bandeira, de acordo com as palavras de Maria A. de Almeida Teles:

“[Eu] discutia com os presos políticos, onde havia um setor significativo que era contrário a esta bandeira. Não aceitavam a Anistia mesmo sendo qualificada como ampla, geral e irrestrita. Eles achavam que a anistia era pedir perdão e eles não aceitavam a ideia. Afinal, eles não tinham cometido crimes. Era o Estado que havia cometido crime contra o povo brasileiro.

Eu argumentava que a anistia significava um passo fundamental para a democracia. Assim, poderíamos conquistar liberdades políticas etc., mas minha conversa não entusiasmava muito esses presos. Minhas ideias eram muito conciliadoras.

[...] Os mais entusiastas eram mesmo os estudantes e alguns advogados. Os primeiros viam nesta bandeira uma possibilidade de retomar, nas ruas, o movimento estudantil, que estava bastante acuado. Houve momentos em que os estudantes tomaram a iniciativa de fazer a defesa da Anistia na USP e os familiares de presos políticos foram desautorizados de se manifestarem de maneira favorável a essa bandeira.

Talvez, os anos de 1975 a 1977 tenham sido os mais difíceis para convencer aqueles que deveriam ser os mais beneficiados com a conquista da Anistia [...]”856.

De fato, alguns presos políticos haviam argumentado, perante a justiça militar, que eles não consideravam que tivessem cometido crimes, conforme observou Maurício Segall. De acordo com ele, embora tenha cumprido pena nos anos 1970, não se sentiu condenado, nem anistiado ou perdoado pelo fato de ter sido um militante revolucionário preso:

"Preso em 1970, fui condenado no primeiro semestre de 1973, pelo Tribunal Militar de São Paulo, a dois anos de prisão, tendo a ela retornado, após uma interrupção em liberdade condicional (“menage”) e a confirmação da minha sentença pelo Superior Tribunal Militar, e terminado de cumprir pena em fins de 1973, no Presídio Tiradentes em São Paulo. [...] Moralmente, eu era credor; o devedor era a Ditadura. [...] A lei da Anistia, a despeito da generosa campanha pública que acelerou um desfecho já previsível foi, [...] formal. Não me senti, portanto, anistiado (assim como não tinha me sentido condenado em 1973) por não ter lavrado procuração, seja para quem fosse, sobretudo os ligados à Ditadura, para me 'perdoar' de atos de militância na oposição a ela, que me 'condenou' com base na sua lei ilegal e, ainda por cima, no mesmo pacote que anistiou seus verdugos de plantão, inclusive, aqueles que me torturaram”857.

\footnotetext{
855 "Levar adiante e até o fim a luta contra a ditadura", Mensagem aos Brasileiros, mimeo. do CC do PCdoB, jan.75, arquivo Ozéas Duarte, citado em KUCINSKI, Bernardo. op.cit., p.163.

${ }^{856}$ TELES, Maria Amélia de A. “Anistia: um sonho vivido!”, 23/04/2006, em http://www.fpabramo.org.br/oque-fazemos/memoria-e-historia/exposicoes-virtuais/amelinha-telles.

${ }^{857}$ Segall, Maurício. “Depoimento de Maurício Segall”. Fundação Perseu Abramo,1999. Disponível: http://www.fpa.org.br/o-que-fazemos/memoria-e-historia/exposicoes-virtuais/mauricio-segall
} 
Inicialmente, vários presos se mostraram céticos e argumentavam que esta luta deveria partir da sociedade civil, não deles ${ }^{858}$. De acordo com José Rezende, preso no Rio de Janeiro,

“[...] No começo me mantive contra a entrada dos presos [na campanha da anistia]. Pensava que entrar nessa luta era advogar em causa própria.

É claro que estava errado. Nós tínhamos que ser os primeiros a lutar para sair da prisão. Acabei me convencendo e achando que nós, os presos, devíamos ter um papel ativo, até de vanguarda mesmo, nesse movimento. Afinal, se fomos vanguarda na luta contra a ditadura, não poderíamos ficar de fora naquele momento" ${ }^{\text {859 }}$.

No presídio Romão Gomes, em São Paulo, havia posições divergentes entre os presos sobre quais conteúdos e consequências políticas envolviam a luta pela anistia, se ela implicaria num projeto de transição política com hegemonia da proposta de conciliação com setores que apoiaram a ditadura e o sistema repressivo. Havia presos que desde o primeiro momento abraçaram com força a ideia da anistia, e outros que, inicialmente, foram refratários à proposta, conforme relato de Pedro Rocha:

“[...] Para alguns, talvez, a anistia significasse o fim, terminou a luta agora estamos no momento da reconciliação, então, vamos partir para a luta pela anistia. Para outros não tinha esse significado, ela fazia parte da luta democrática. [...] Muito claramente o PC do B teve, desde o começo, uma posição favorável a encampar e reforçar o movimento de anistia, mais do que a ALN ou o Molipo, que relutaram em assumir essa bandeira. A alegação era do tipo: na mão de quem está o movimento? Quem está liderando [...]? Acho que existiam diversas visões. O concreto é que a partir de um determinado momento todo mundo abraçou a luta pela anistia e contribuiu do jeito que foi possível, principalmente, com documentação, inclusive, teórica [...]. Muita documentação em relação à anistia foi elaborada dentro da prisão e foi mandada para fora. Mandava-se textos para as pessoas de mais destaque na vida pública, políticos, entidades, o Movimento Feminino pela Anistia, da Zerbini. A gente fazia o que era possível e [...] que a gente podia mandar para fora. Era uma coisa de duas mãos, a gente fornecia alguns elementos para o pessoal da luta democrática 'na rua' poder continuar e efetuar alguma ação, denúncia, enquanto a gente esperava que isso oferecesse uma segurança maior pra gente como preso.

[...] No começo, eu era uma pessoa que olhava esse movimento com certa suspeição.[...] Mas essas [...] divergências, acho que [...] melhoraram a luta pela anistia, [...] fizeram da anistia uma luta que se inseriu dentro de um processo de avanço da democratização, [...] esses questionamentos evitaram que o reformismo baixasse com muita força [...]”660.

Com o tempo, os presos passaram a apoiar a campanha em defesa da anistia, com a intenção de interferir no processo de luta e tentar mudar a correlação de forças no cenário político nacional. Um dos aspectos mais polêmicos a respeito de qual proposta apoiar estava relacionada à abrangência da anistia, era preciso convencer diversos setores

\footnotetext{
${ }^{858}$ Entrevista concedida por Reinaldo Morano Filho à autora. SP, 14/03/2011.

${ }^{859}$ REZENDE, J. e BENEDITO, M. op.cit., p.164.

${ }^{860}$ Entrevista concedida por Pedro Rocha Filho à autora. Idem, ibidem.
} 
das oposições de que os presos políticos que particiaparam da luta armada deveriam ser contemplados, conforme o relato de Manoel Cyrillo:

"A polêmica entre quem era preso de consciência ou não aconteceu [...] quando a luta pela anistia começou a ganhar corpo [...] e se começou a discutir por qual anistia a gente ia lutar, se era pela ampla, geral e irrestrita [...]. O Dalmo Dallari foi visitar a gente no Romão Gomes para discutir conosco a luta pela anistia e apresentar a posição dele, [...] e a gente conseguiu convencê-lo a mudar de posição, porque ele defendia que a anistia tinha de ser só para quem tinha praticado crimes de consciência e não para quem tinha pegado em armas. Ele, por profunda e grande honestidade intelectual, mudou de posição [...]. A gente cumpriu um papel importantíssimo na luta pela anistia, porque fizemos toda uma pesquisa com os materiais que a gente conseguiu através dos nossos familiares e dos advogados que nos assistiam, para que levassem livros de história e documentos de toda a espécie para estudar sobre Anistia. [...] Fizemos uma super pesquisa sobre o que era a anistia, o que era o indulto, o perdão, enfim, todos os conceitos, a gente estudava tudo, punha tudo no papel e discutia internamente. Não me lembro se essa tarefa foi conjunta com o PCdoB ou se a gente descobriu que ambos os grupos estavam fazendo isso [...]"861.

Desde o final de 1976, por exemplo, Roberto Ribeiro Martins, militante do PCdoB preso no Romão Gomes, havia iniciado pesquisas sobre a história da anistia no Brasil, que dariam origem ao seu livro Liberdade para os brasileiros: Anistia ontem e hoje, publicado em 1978 pela editora Civilização Brasileira ${ }^{862}$.

Em abril de 1977, o presídio Romão Gomes estava alojando um número reduzido de presos políticos e os militantes do PCB que estavam no presídio do Hipódromo desde 1975 foram transferidos para lá.

A edição do Pacote de Abril naquele ano e as tensões acumuladas com o fortalecimento dos movimentos sociais levaram os estudantes universitários às ruas em protesto contra as prisões de operários e estudantes trotskistas, às vésperas do $1^{0}$. de maio. No começo de 1977 o movimento estudantil estava se reorganizando e os estudantes da USP haviam realizado no dia 30 de março uma manifestação contra o corte nas verbas federais para a educação. Foi uma das primeiras grandes passeatas de estudantes desde 1968. A passeata aconteceu, apesar de toda a repressão montada pela polícia de São Paulo, e cerca de 5 mil estudantes caminharam da Cidade Universitária até o largo de Pinheiros, na zona oeste de São Paulo ${ }^{863}$.

\footnotetext{
${ }^{861}$ Entrevista concedida por Manoel Cyrillo à autora. Idem, ibidem.

${ }^{862}$ Entrevista concedida por Roberto Riberio Martins à autora. SP, 01/04/2009. AAPP/AEL-LEI; MAUÉS, Flamarion. "Livros na campanha pela anistia". Perseu-História, Memória e Política, no 6, abril 2011, p. 257-77, São Paulo, Centro Sérgio Buarque de Holanda da Fundação Perseu Abrano.

${ }^{863}$ SIQUEIRA, Geraldo. “A eleição para o DCE da USP”. In: MAUÉS, Flamarion e ABRAMO, Zilah (orgs.). Pela democracia, contra o arbítrio: A oposição democrática, do golpe de 1964 à campanha das Diretas Já. São Paulo, Editora Fundação Perseu Abramo, 2006, p. 177-78. Marcos Napolitano diz que esta manifestação fora realizada também como forma de protesto contra o aniversário do golpe de 1964 .
} 
No dia 28 de abril de 1977 seis pessoas, estudantes e operários, foram detidas nas proximidades da fábrica da General Motors, na região do $\mathrm{ABC}$ paulista, acusadas de distribuir panfletos “subversivos”. Os presos eram: Celso Giovanetti Brambilla, José Maria de Almeida, Márcia Basseto Paes, Antônio de Oliveira Lopes, Anita Maria Fabri e Adanir Marini, militantes da organização trotskista Liga Operária, que originou a Convergência Socialista ${ }^{864}$. O então secretário de Segurança de São Paulo, Erasmo Dias, procurou ligar o grupo à luta armada tentando justificar a brutalidade do tratamento dado aos presos e afirmou que eles integravam uma organização recém-descoberta “[...] nascida da fusão dos remanescentes de duas extintas organizações clandestinas”, cujos “cabeças” eram “ex-integrantes da VPR e da VAR-Palmares”865.

Os panfletos encontrados com eles continham críticas ao governo, proclamações sobre o $1^{\mathrm{o}}$ de Maio e reinvindicações trabalhistas ${ }^{866}$. Já no dia $1^{\circ}$ de maio Dom Angélico Sândalo, em um ato da Pastoral Operária da Zona Leste paulistana, fez um protesto público contra as prisões do ABC [NAPOLITANO, 2006: 33].

No dia 5 de maio outra manifestação convocada pelos estudantes aconteceu no centro da cidade, dessa vez tendo como motivo principal o protesto contra a prisão dos presos do $\mathrm{ABC}^{867}$. Esta manifestação reuniu cerca de 10 mil pessoas e houve enfrentamento com a polícia ${ }^{868}$. Os protestos contra as prisões do ABC “[...] acabaram por estimular a ampliação das demandas do movimento e a 'questão democrática' emergia com força total, dando um conteúdo mais politizado às manifestações estudantis” [NAPOLITANO, 2006: 34]. O movimento estudantil passava por um processo de renascimento e politização: "Primeiro, foram as manifestações dentro do campus. Contra diretores de faculdades autoritários, contra a política educacional do governo, por melhorias no restaurante universitário ('feijão sem repressão', gritávamos numa animada

NAPOLITANO, Marcos. Cultura e poder no Brasil contemporâneo (1977-1984). Curitiba, Juruá, $2^{\circ}$ ed., 2006, p. 34.

${ }^{864}$ V. entrevistas concedidas por Celso Giovanetti Brambilla e Márcia Basseto Paes à autora. Idem, ibidem. “Explicação para prisões no ABCD”. Folha de S. Paulo, 01/05/77, p. 33. Disponível em:< http://acervo.folha.com.br/fsp/1977/5/1/387/4239086>. Além dos seis mencionados, foram presos depois Fátima Dwek e Cláudio Lúcio Gravina. “Novas figuras na política”. Veja, 11/05/77, p. 22.

865 “Novas figuras na política”. Veja, 11/05/77, p. 20-26.

${ }^{866}$ Brasil dia-a-dia. São Paulo, Editora Abril, 1990, p. 115.

${ }^{867}$ SIQUEIRA, Geraldo. “A eleição para o DCE da USP”. In: MAUÉS, F. e ABRAMO, Z. op.cit., p.177-8; ABRAMO, Helena. “A retomada das ruas”. In: MAUÉS e ABRAMO, op. cit., p. 165.

${ }^{868}$ TIBIRIÇÁ, Beatriz. "Memória: O movimento estudantil na USP”. Teoria e Debate, $\mathrm{n}^{\circ}{ }^{35}$, julho/agosto/setembro de 1997. Disponível em <http://www.fpa.org.br/o-que-fazemos/editora/teoria-edebate/edicoes-anteriores/memoria-o-movimento-estudantil-na-usp>. 
passeata), elas se multiplicavam. Até chegar a reivindicações mais politizadas, como as das passeatas pela libertação dos presos políticos”869.

Esta movimentação impulsionou as lutas em defesa da anistia para os perseguidos políticos. Pouco depois, no dia 19 de maio de 1977, os estudantes convocaram novos atos públicos tendo como palavra de ordem a realização do primeiro "Dia Nacional de Luta pela Anistia” [NAPOLITANO, 2006: 37-8].

Nesse período, as esquerdas articuladas nos jornais alternativos começaram a se dividir em dois grandes campos. O PCdoB e, a seguir, o MR-8, ainda influenciados pela visão “etapsita” da revolução, defendiam a aliança com os liberais que viriam a divulgar a Carta aos Brasileiros, em agosto de 1977, propunham a luta em defesa da anistia e das liberdades democráticas e da realização de uma Assembleia Nacional Constituinte.

A outra corrente, ligada ao ideário do caráter socialista da revolução, defendia que a organização autônoma dos trabalhadores era a única garantia de uma saída nãoautoritária e elitista à crise da ditadura. Esta corrente era formada pela parte da AP que não aderiu ao PCdoB e por vários grupos trotskistas, entre outros. Eles rejeitavam a prioridade dada à proposta de "frente democrática" pelo PCdoB e outros, pois a consideravam sob a hegemonia das correntes liberais-burguesas, o que enfraqueceria a possibilidade de organização autônoma do movimento operário.

Em abril daquele ano se deu o confronto entre essas correntes. A direção do jornal Movimento e os ativistas que o apoiavam se dividiram. Desse 'racha' surgiu o jornal Em Tempo, que, depois, sofreu novas divisões. A caracterísitca comum de parte desses novos jornais alternativos que surgiram após a divisão era a proposta de "subsidiar a organização dos trabalhadores” [KUCINSKI, 2003: 162, 166-7].

A luta pela anistia ficou polarizada entre esses dois campos. Os críticos da ênfase dada à luta pelas franquias democráticas e pela convocação da Assembleia Constituinte argumentavam que esta proposta contribuiria para uma "saída elitista” para a crise da ditadura. Este campo propunha investir prioritariamente na organização das classes trabalhadoras para construir uma "saída democrática" para essa crise, conforme as palavras de Chico de Oliveira ${ }^{870}$.

O ano de 1977 termina com duas mobilizações em torno das reivindicações dos presos políticos, dessa vez, no Rio de Janeiro e em Pernambuco. No dia 27 de outubro as

\footnotetext{
${ }^{869}$ MARCONDES, Celso. "Memória: Anos incríveis”. Disponível em: <http://www.fpa.org.br/memoriaanos-incriveis>.

${ }^{870}$ OliveIRA, Chico de. "Sobre a conjuntura e as tarefas de uma publicação democrática”, 1977, mimeo., arquivo de Bernardo Kucinski, citado em KUCINSKI, B. op.cit., p.166-7.
} 
prioneiras políticas da penitenciária Talavera Bruce, em Bangu, no Rio de Janeiro, iniciaram uma greve de fome reivindicando sua transferência para uma ala especial do presídio da Frei Caneca (na Divisão de Segurança do presídio Milton Dias Moreira) onde estavam os presos políticos. Eles aderiram à greve de fome, assim como os presos da penitenciária Lemos de Brito, de Salvador. O movimento, contudo, não conseguiu maior repercussão e as presas cessaram a greve no dia 11 de novembro sem obter a transferência ${ }^{871}$

No dia 14 de novembro, os presos políticos da penitenciária Barreto Campelo, em Itamaracá (PE), Rholine Sonde Cavalcanti e Carlos Alberto Soares, continuavam em isolamento e decidiram iniciar novamente uma greve de fome [JosÉ, 2000: 259]. Uma semana depois, os demais presos políticos da penitenciária aderiram à greve, um movimento que durou 17 dias e ganhou grande repercussão e solidariedade, conforme relato de Marcelo Mário de Melo:

"Foi um longo trabalho de preparo para se chegar à greve de fome de 1977 [...]. A gente colocou como reivindicação central o retorno ao convívio de Rholine e Carlos Alberto. A greve de 1977 durou 17 dias e meio e teve repercussão nacional, muita solidariedade dos outros presídios e ocupou espaço na mídia nacional. Aí então, o caso de Carlos Alberto e Rholine ficou muito conhecido nacionalmente. Envolveram-se na questão a $\mathrm{OAB}$ nacional, Airton Soares, Beth Mendes. E nesse momento, a imprensa se abriu para noticiar os assuntos sobre presos políticos e, pela primeira vez, a imprensa visitou os presídios, tirou fotos etc. A direção do presídio assumiu compromissos com a gente que, mais uma vez, não cumpriram. Paramos a greve com 17 dias e meio com o compromisso, e ele não foi cumprido. Então, a gente entendeu que para enfrentar essa situação teria que ter uma articulação nacional”, ${ }^{772}$.

As duas greves de fome de 1977 não tiveram êxito e demonstraram que as articulações entre os pesos políticos ainda era incipiente, mas apontaram para o crescimento do interesse da sociedade para sua realidade e para as novas possibilidades de ampliação de sua luta. As passeatas estudantis favoráveis à anistia aos presos políticos e a movimentação que levou à divulgação da Carta aos brasileiros de Gofredo da Silva Telles, em agosto, elevaram o patamar da organização da sociedade civil e das disputas políticas no país.

\footnotetext{
${ }^{871}$ JOSÉ, Emiliano. op.cit., p.244-51; VIANA, G.; CIPRIANO, P. op. cit., p.41-5.

${ }^{872}$ Entrevista concedida por Marcelo Mário de Melo à autora. Idem, ibidem.
} 


\subsection{A primeira greve de fome nacional}

A primeira greve de fome nacional teve início em 16 de abril de 1978 no Presídio Campelo Barreto, em Itamaracá (PE), em protesto contra o isolamento a que estavam submetidos havia mais de três anos os dois presos condenados a prisão perpétua, Carlos Alberto Soares e Rholine Sonde Cavalcanti. De acordo com Marcelo Mário de Melo:

“Articulamos a greve nacional dos presos políticos pelo retorno de Rholine e de Carlos Alberto ao convívio com os demais presos. Foi a primeira [...]. A gente fez uma coisa gradativa: primeiro Carlos Alberto e Rholine entraram em greve sozinhos; uma semana depois, a gente entrou para ver se dava mais tempo de negociar. Saiu o primeiro documento dos dois, até porque setores do movimento de apoio achavam que essa greve podia ser precipitada. A gente tinha que buscar uma sintonia com o movimento externo. [...] Entramos em greve e os outros presídios vão entrando depois [...]. Chegou um momento que todos os presídios do Brasil estavam em greve ${ }^{873,}$.

O movimento grevista contou com expressiva solidariedade tanto no país como no exterior. A Assembleia Geral Extraordinária da Conferencia Nacional dos Bispos do Brasil, reunida em Itaici, aprovou, com o voto de 240 dos 244 bispos participantes do encontro, documento em favor da Anistia ${ }^{874}$.

Outras iniciativas foram organizadas em apoio aos presos políticos em greve, como a publicacão de diversos documentos denunciando e repudiando a prática da violação dos direitos humanos: uma Carta Aberta à População subscrita pelo Instituto de Estudos Políticos, Econômicos e Sociais (IEPES/PE), Comissão de Justiça e Paz Arquidiocese de Olinda e Recife; Pastoral da Juventude; Diretório Central da UFPE; Diretório Central da UNICAP; Diretório Central da Universidade Rural; MDB - bancada de Pernambuco; Setor jovem do MDB/PE; Movimento Feminino pela Anistia, núcleo de Pernambuco; Diretório Acadêmico do Instituto de Teologia do Recife - CNBB; outra do jornal Movimento, e também do Centro de Estudos e Ação Social, de Recife ${ }^{875}$. A ABI, o MFPA, políticos do MDB, além de artistas de teatro, advogados, religiosos, jornalistas e a Associação dos Docentes da Universidade de São Paulo (ADUSP) também manifestaram solidariedade.

O secretário geral da Anistia Internacional, Martin Ennals, e a representante da entidade, Patrícia Freeneym, enviaram telegramas ao presidente da República e ao

\footnotetext{
${ }^{873}$ Entrevista concedida por Marcelo Mário de Melo à autora. Idem, Ibidem.

874 “Arcebispo diz que a Igreja quer anistia”. Folha de S. Paulo, 28/04/78, p.8.

875 “Carta repudia arbitrariedades em Pernambuco”. Folha de S. Paulo, 21/04/78, p.6.
} 
almirante Hélio Leite, presidente do Superior Tribunal Militar, apelando para que eles interviessem na greve de fome dos presos políticos de Itamaracá ${ }^{876}$.

No dia 25 de abril, os 26 presos políticos do Presídio Frei Caneca, no Rio de Janeiro, entraram em greve de fome de solidariedade aos presos de Itamaracá. Dois dias depois, as duas presas do Presídio Talavera Bruce, no Rio de Janeiro, também aderiram ao movimento.

A participação dos presos políticos de São Paulo foi discreta ${ }^{877}$. Na tarde do dia $1^{\circ}$ de maio, 18 presos do Presídio Político Romão Gomes entraram em greve de fome em solidariedade ao movimento grevista de Itamaracá. Três deles, embora solidários, não aderiram por motivo de saúde ${ }^{878}$. No dia 5 de maio, os 10 presos políticos de Fortaleza (CE) também entraram em greve de fome ${ }^{879}$.

No dia 7 de maio, uma comitiva composta de 30 familiares de presos políticos do Estado de São Paulo foi para Brasília, onde visitou o Congresso e o presidente do STM, e tentou encaminhar uma carta ao presidente Geisel solicitando a sua intervenção para que as reivindicações dos presos em greve fossem atendidas. A viagem foi antecipada em virtude do estado de saúde de alguns dos presos ter se agravado ${ }^{880}$.

No dia 8 de maio, dois mil estudantes da Faculdade de Filosofia da UFMG, em Belo Horizonte, entraram em greve, em solidariedade aos presos políticos em greve de fome e, em Olinda, dom Helder Câmara, presidiu uma vigília de orações, que teve início às 20 horas. Em São Paulo, uma vigília de solidariedade convocada pelo CBA reuniu 700 pessoas.

Os familiares percorreram os gabinetes oficiais do Palácio do Planalto, do Supremo Tribunal Militar, do Ministério da Justiça e das lideranças da Câmara e do Senado sem encontrar soluções para o problema que enfrentavam havia 22 dias, e, invariavelmente, ouviram a mesma desculpa das autoridades: “O assunto não diz respeito a esta área" ${ }^{881}$.

Os 25 presos políticos de Itamaracá, em Recife, terminaram no dia 9 de maio a greve de fome que mantiveram por 24 dias. A decisão foi tomada após a mediação do

\footnotetext{
876 “Anistia apela a Geisel pelos presos de Recife”. Folha de S. Paulo, 28/04/78, p.8.

${ }^{877}$ Manoel Cyrillo relatou que não se recorda como foi a greve de fome de 1978. Ele é o único entre os entrevistados que participou desse movimento. Entrevista concedida por Manoel Cyrillo de O. Neto à autora. Idem, Ibidem.

878 “A greve de fome recebe adesão de presos paulistas”. Folha de S. Paulo, 02/05/78, p.7.

879 “Presos do Ceará aderem à greve”. Folha de S. Paulo, 02/05/78, p.8.

880 “Estado de saúde dos grevistas já preocupa médicos”. Folha de S. Paulo, 08/05/78, p.4.

881 “Os familiares não obtêm do governo solução para o problema”. Folha de S. Paulo, 09/05/78, p.10.
} 
deputado federal Airton Soares, presidente da Comissão de Direitos Humanos do MDB, que lhes revelou a promessa feita pelo auditor José Bolívar Regis, da $7^{\text {a }}$ Circunscrição da Justiça Militar, de que em uma semana atenderia parcialmente as reivindicações dos presos políticos $^{882}$. Marcelo Mário de Melo contou como ocorreu o desfecho da greve de fome:

\begin{abstract}
"Houve uma negociação localizada em Itamaracá e a gente achou que dava para terminar a greve. Efetivamente, depois, houve um compromisso de que eles tivessem, pelo menos, o direito de ter um convívio de quatro dias da semana com a gente. Mesmo que não voltassem totalmente, e aí eles passaram a vir nos encontrar. E, um dia, depois desse processo, devolveram os dois pra gente e pronto, passou. Foi uma conquista, fruto desse processo de luta.

[...] Mas quando houve a negociação do fim da greve e o convívio dos dois foi acertado, já havia sido marcado um ato de solidariedade aos presos políticos, parece-me que numa faculdade do Rio. O negócio ia ser arretado, mas precisaria de mais uns quatro dias de greve. Aí alguns companheiros disseram o seguinte: '- A greve deixou de ser específica de presos políticos contra o isolamento de Rholine e Carlos e passou a ser de luta contra a ditadura'. Eu e outros companheiros, que predominaram, dissemos: '- Não, a greve continua a ser por um objetivo específico [...]. Engrossou o caldo da solidariedade, ótimo, a vigília que está marcada passará a ser uma vigília de festa, de comemoração. Temos que encerrar agora. A gente tem um objetivo, não é possível querer esticar a greve, isso é criar um artifício'. Foi aprovada esta posição, mas os companheiros que defenderam a outra posição disseram que foi capitulação, estreiteza, que nós não estivemos à altura do momento histórico.

[...] Tinha que parar mesmo, era artificial querer dar uma injeção na greve. [...] O clima ficou péssimo, uma greve vitoriosa que incorporou o movimento popular do Brasil todo, mas o clima dentro da cadeia era de enterro, porque alguns companheiros que ficaram em minoria, [...] ficaram naquele mal-estar. A ponto de [...] quererem uma entrevista nossa [...] e nós não tivemos condições de dar, porque não havia consenso. [...] Houve o predomínio da posição que eu acho a mais correta, mas com uma grande insatisfação de companheiros importantes, expressivos [...], mas foi ótimo "»83.
\end{abstract}

Nessa conjuntura de crescimento da crise de legitimidade da ditadura surgiram os Comitês Brasileiros de Anistia (CBA), que lançaram e impulsionaram a Campanha pela Anistia ampla, geral e irrestrita. Um movimento eminentemente político que recebeu certo apoio popular e cuja adesão foi mobilizada pela extensa divulgação pública das denúncias a respeito dos crimes cometidos pela ditadura. O CBA do Rio de Janeiro foi criado no início de 1978, seguido pelo de São Paulo e demais estados, compostos por entidades da sociedade civil e de um amplo espectro das esquerdas e oposições [TELES, 2005].

Em 12 de maio de 1978 eclodiram as primeiras greves operárias desde 1968, que partiram de um movimento autônomo em relação às organizações tradicionais das

\footnotetext{
882 “Os 15 presos suspendem a greve de fome (ontem).” Folha de S. Paulo, 10/05/78, p.1.

${ }^{883}$ Entrevista concedida por Marcelo Mário de Melo à autora. Idem, Ibidem.
} 
esquerdas [KUCINSKI, 2003: 384-8]. O processo de abertura escapava ao controle dos militares. Em junho acabou a censura prévia nos últimos três veículos ainda submetidos a ela, a Tribuna da Imprensa, O São Paulo e o Movimento, marcando um momento importante para o fim do autoritarismo na atividade jornalística. Iniciaram-se, nesse período também, as greves dos professores da rede pública de ensino.

Em 1978 surgiu a proposta de Frente Nacional pela Redemocratização, com a qual o MDB lançou a candidatura do general Euler Bentes Monteiro à Presidência da República. A FNR defendendia o restabelecimento das franquias democráticas, a anistia plena e a revogação dos atos de exceção. Um de seus principais articuladores foi o deputado cassado Chico Pinto, que contou com o apoio de dissidências militares e, em menor escala, da oposição civil liberal, do jornal Movimento e de parte do PCdoB ${ }^{884}$, assim como o PCB. A maioria de organizações que compunha o jornal Em Tempo terminou por apoiar a proposta também. De acordo com Tarso Genro: “não se tratava de optar pela hegemonia liberal sacrificando o esforço pela livre organização dos trabalhadores, também não era preciso antagonizar a FNR para priorizar essa organização $^{885, " . ~ A ~ i n i c i a t i v a ~ s e ~ f r u s t r o u ~ e ~ o ~ g e n e r a l ~ F i g u e i r e d o ~ f o i ~ c o n f i r m a d o ~ p e l o ~}$ Colégio Eleitoral como presidente.

Os jornais alternativos se destacaram pela cobertura sobre a luta pela anistia. O Em Tempo desde os primeiros números também deu atenção à campanha. A edição de número 3 possui várias manchetes sobre o tema e uma, em especial, destacava: “Todos de volta até o natal”. A edição de no. 17, de junho de 1978, estampou na manchete "Presos denunciam 233 Torturadores”. A reportagem divulgava o documento elaborado pelos 35 presos políticos do Romão Gomes, em 1975. Na capa aparecem destacados os nomes dos torturadores mais conhecidos: delegado Fleury, general Antonio Bandeira, os delegados mineiros David Hazan e Tacir Menezes Sai e o deputado federal arenista Ivahyr de Freitas Garcia. O jornal atingiu seu apogeu de vendagem ${ }^{886}$. Destacava na capa a frase dos presos políticos: "Estamos disposto a testemunhar perante qualquer comissão ou tribunal idôneos, tudo quanto relatamos”, antecipando a retomada da propota de CPI dos Direitos Humanos de 1975. Os movimentos em defesa da anistia ampla, geral e irrestria colocavam em pauta na cena pública a luta para esclarecer os crimes da ditadura e por justiça.

\footnotetext{
${ }^{884}$ Entrevista concedida por Criméia A. S. de Almeida à autora. SP, 27/07/2000, 28 e 30/11/2001, e 20/10/2004.

885 “Encarando a Frente Ampla”, Em Tempo, 25/06/78, citado em KUCINSKI, B. op.cit., p.422.

${ }^{886}$ KuCINSKI, B. op.cit., p. 418; e Em Tempo, no. 17, 28/6 a 02/07/78, p.6-7.
} 
Os bons resultados do MDB nas eleições de 1974 e 1976 atraíram vários grupos de esquerda para as eleições nacionais de 1978. Aproveitaram-se do espaço aberto e a cobertura legal fornecida pelo MDB, uma das poucas instâncias onde a atividade política era possível após a derrota da guerrilha. Diversos grupos e partidos clandestinos como PCB, PCdoB, a Ação Popular e o MR-8 apoiaram candidatos do grupo dos autênticos do MDB, ativistas políticos diretamente ligados a movimentos populares ou candidatos próprios nessas eleições ${ }^{887}$. De acordo com Ricardo Azevedo, dirigente da Coordenação Nacional da AP naquele período:

“[...] a AP acertou na tática. Em 1974, quando ela mudou e resolveu participar do processo eleitoral através do MDB, o que lhe deu uma audiência muito mais ampla do que o que ela tinha na candestinidade defendendo o voto nulo. Mais do que isso, em 1976 a AP também participou [...] e, em 1978, elegeu o Gerado Siqueira deputado estadual em São Paulo e o José Eudes deputado estadual, no Rio de Janeiro. Então, isso deu uma audiência, deu um crescimento para a organização muito grande. [...] Com isso a AP ganhou uma sobrevida, então, ela se reorganiza, cresce em termos relativos, embora com muito pouca penetração no movimento operário",888.

O voto de protesto mudou a composição das bancadas do MDB, que consolidou e ampliou sua posição, obentdo $47 \%$ dos votos para o Senado (42\% em 1974) e 39,3\% dos votos para a Câmara Federal (38\% em 1974). O grupo autêntico do MDB dobrou de tamanho, passou a ter cerca de noventa deputados na Câmara Federal. Cerca de duas dezenas de deputados federais se elegeram apoiados pelos partidos da esquerda clandestina. O partido conquistou ainda a maioria nas assembleias legislativas dos estados do Rio de Janeiro, São Paulo e Rio Grande do Sul [KUCINSKI, 2001:74].

A ênfase do debate em muitos grupos de militantes e exilados era a articulação pela formação de um partido à esquerda do MDB e de um movimento autônomo dos trabalhadores, sendo que parte da esquerda dava destaque à bandeira da convocação da Assembleia Nacional Constituinte [KUCINSKI, 2003: 423]. As questões em debate para as esquerdas e oposições focalizavam a maneira de acumular forças para poder propor e interferir na construção política que sobreviria ao fim da ditadura:

"Em primeiro lugar, o que seria posto depois do fim da ditadura, o que colocar no seu lugar, ou seja, a questão da Assembleia Nacional Constituinte. Era mais ou menos claro, para grande maioria da esquerda, que não era o socialismo, não era a ditadura do proletariado ou o governo dos trabalhadores que viria no lugar, mas então o quê? A maioria da esquerda defendia a Assembleia Constituinte como resposta para o fim da ditadura. O PC, o PC do B, o MR-8 e diversos outros setores. Havia um setor que resistia,

\footnotetext{
${ }^{887}$ KUCINSKI, Bernardo. O fim da ditadura militar. São Paulo, Contexto, 2001, p.73.

${ }^{888}$ Entrevista concedida por Ricardo Azevedo à autora. Idem, ibidem.
} 
porque considerava a Constituinte a saída burguesa para a crise e que, portanto, não deveria ser defendida, basicamente, o MEP e a POLOP. A AP vacilava entre uma posição e outra [...] e não tinha posição sobre esse tema. Que vai crescentemente polarizando não só as organizações de esquerda como o movimento social. Então isso é um impasse.

Em segundo lugar, é que a partir de um certo momento estava clara a questão da reorganização partidária, ou seja, Arena e MDB não dá mais, e abre-se um espaço para a organização de um partido mais a esquerda, digamos assim, que representasse os movimentos populares. A AP, junto com o PC do B, lançou a proposta de um partido popular, que seria uma frente, não se tratava do partido revolucionário, do proletariado, do partido que iria defender o socialismo e fazer a revolução. Seria uma frente mais à esquerda que englobasse organizações de esquerda, setores avançados do movimento social, em particular do movimento sindical que vinha despontando naquela época a partir das greves do ABC, setores da Igreja, intelectuais e um setor dos autênticos do MDB. [...] E aí os sindicalistas começaram a falar de um Partido dos Trabalhadores. No início, de um jeito muito confuso. [...] Nos pareceu uma proposta estreita [...] obreirista [...]”889.

Este cenário impulsionou a campanha pela anistia ampla, geral e irrestrita no ano de 1979. A efervescência da sociedade civil crescia, mas no início do mandato do general João Batista Figueiredo na presidência, a ditadura buscava retomar o controle do processo de abertura política.

\subsection{A greve de fome nacional pela anistia ampla, geral e irrestrita}

A greve de fome nacional pela anistia ampla, geral e irrestrita foi uma iniciativa organizada, principalmente, pelos presos políticos do Rio de Janeiro e ocorreu nos meses de julho e agosto de $1979^{890}$. A greve representou um momento decisivo na ocupação dos espaços públicos conduzida pelos movimentos de anistia. A greve foi utilizada mais uma vez para denunciar as arbitrariedades da ditadura e forçar os limites da proposta de lei de anistia, aumentando o leque de beneficiários da anistia - incluindo os que participaram da luta armada ou conforme a expressão militar, os que "cometeram crimes de sangue”, de acordo com a proposta do governo apresentada no Congresso. Anistiá-los legitimaria a luta armada como uma das formas de oposição à ditadura [GRECO, 2003: 179, 205].

O projeto do governo chegou ao Congresso nacional no dia 27 de junho de 1979 e tinha 40 dias de prazo para tramitar, contados a partir do final do recesso parlamentar, que acabava no dia 2 de agosto. O projeto possuía dois dispositivos conhecidos e combatidos pelo movimento de anistia: a noção de reciprocidade implícita visando garantir a

\footnotetext{
${ }^{889}$ Entrevista concedida por Ricardo Azevedo à autora. Idem, ibidem.

${ }^{890}$ Entrevista concedida por Paulo Henrique Lins à autora. RJ, 23/11/2008. AAPP/AEL/LEI; e entrevista concedida por Gilney Viana à autora. Idem, ibidem.
} 
inimputabilidade dos agentes da repressão estatal e a exclusão dos guerrilheiros condenados em processos transitados em julgado, nomeados de “terroristas”, jargão policial incorporado pela mídia ${ }^{891}$.

No início dos trabalhos Comissão Mista do Congresso Nacional ${ }^{892}$ encarregada de analisar o projeto de lei de anistia, os presos políticos convidaram seus membros para visitá-los. O presidente da comissão, senador Teotônio Vilela, aceitou o convite e iniciou as visitas aos presos de todo o país no mês de julho, durante o recesso parlamentar ${ }^{893}$. Nesse sentido, foi fundamental a declaração de Teotônio Vilela à Folha de S. Paulo ao afirmar não ter encontrado nenhum "terrorista" nas visitas aos presídios, depois da primeira visita realizada aos presos de São Paulo, no dia 9 de julho ${ }^{894}$, conforme nos contou Maria Auxiliadora Arantes, uma das lideranças do CBA/SP:

\begin{abstract}
"Os presos foram combativos dentro da prisão, as greves de fome que fizeram [...] durante a campanha. [...] Muitas coisas eram discutidas com eles. [...] Foi uma campanha de uma maturidade, de uma violência nas denúncias, de coragem no enfrentamento, [...] a ponto de se juntar a nós uma figura da Arena que foi o Teotônio Vilela e que se tornou um grande companheiro, criando um elo entre os presídios. Ele começou visitando o presídio político do Barro Branco. [...] Foram designadas duas pessoas do Movimento da Anistia, a Celeste Fon e eu, o Severo Gomes e o Fernando Henrique e fomos encontrar o Teotônio no Hotel Jaraguá e o levamos [...]. Ficamos lá não sei se 2, 3, 4, 5 horas conversando com os presos políticos que se organizaram para recebê-lo. Acho que eles designaram um ou dois presos para falar, entregaram documentos etc. Ele saiu de lá, a imprensa presente, ele disse: '- Não encontrei aqui nenhum lobo das estepes e nenhum terrível homem das neves, encontrei aqui homens abraçados aos seus ideais pelos quais sofreram'. E a partir daí ele passou a visitar todos os presídios do Brasil e [...] teve um papel importante na luta pela anistia. Embora a anistia não tenha sido aquela pela qual nós lutamos, nem ampla, nem geral e nem irrestrita. Eu acho que a campanha de anistia foi uma campanha [em] que a gente foi aprendendo a fazer trabalhos massivos com o que cada um trazia das suas origens de militância, [...] e fomos ampliando essa luta”, ${ }^{\text {,95 }}$.
\end{abstract}

Teotônio Vilela e os autênticos do MDB passaram a receber as diversas denúncias que foram compiladas pela Comissão Mista, visando criar uma atmosfera favorável à

\footnotetext{
${ }^{891}$ V. GRECO, H. op.cit., p.211. Os que não haviam sido condenados teriam seus processos cancelados ainda que acusados dos mesmos crimes que os presos remanescentes. Para os presos que estavam cumprindo pena havia quase 10 anos acenou-se com a perspectiva de indulto, após a análise de cada caso e dos recursos existentes no STM, segundo a vontade do Presidente da República.

892 A Comissão Mista, constituída na Sessão Conjunta de 28/06/79, tinha a seguinte composição: 7 senadores e 6 deputados da Arena; pelo MDB, 4 senadores e 5 deputados. Era presidida pelo senador Teotônio Vilela, o senador biônico Murilo Badaró era o vice e Ernani Satyro, o relator.

${ }^{893}$ Ata da $1^{\text {a }}$ reunião realizada em 02/08/79. In: CONGRESSO NACIONAL. COMISSÃo MiSTA SOBRE ANISTIA. Anistia. Brasília/DF, 1982, V.I, p.443-4. VianA, G. e CiPRiAnO, P., op. cit., p.100-1 e 114-7; “Teotônio: 'não vi terroristas'”. Folha de S. Paulo, 20/07/79; "Vilela termina visita aos presos”. Folha de S. Paulo, 26/07/79.

${ }^{894}$ Alves, Márcio Moreira. Teotônio, Guerreiro da Paz. Petrópolis/RJ, Vozes, 1983, p.179-81.

${ }^{895}$ Entrevista concedida por Maria Auxiliadora Arantes à autora. SP, 27/03/2009. AAPP/AEL/LEI
} 
recuperação da proposta de instalação de uma CPI dos Direitos Humanos, que fora inviabilizada em maio de $1979^{896}$.

A greve de fome se propunha a enfrentar a estratégia da ditadura de estabelecer uma abertura política controlada tendo como base sua institucionalização e repudiar seu projeto de lei de anistia, conforme a carta dos presos políticos do Rio de Janeiro propondo a greve aos demais presos. Eles submeteram três datas possíveis à apreciação dos companheiros para iniciar o movimento:

“[...] defendemos a Anistia Ampla, Geral e Irrestrita, mas sem colocar no centro da nossa greve a conquista da mesma, porque isto poderia nos levar à morte, se quiséssemos ser consequentes [...]. Contudo, não menosprezamos as possibilidades de conseguir uma ampliação nesta anistia da ditadura, já que no projeto deles, admitiram e incluíram o pessoal da luta armada: a grande maioria dos banidos (os não condenados), o pessoal que apenas militou nas organizações guerrilheiras sem ação armada, e até mesmo fala-se na sustação de processos em andamento.

[...] Em função dessas vacilações da ditadura há possibilidades de seu recuo. Mas, ao nosso ver, isto só ocorreria se houvesse um clima de agitação política nacional. E que essa agitação tomasse o caráter de massa. Temos dúvida a este respeito, porque não sabemos se assumirá a proporção exigida para pressionar e forçar o recuo dos homens. Mas pelo menos em termos de neutralizar a capitalização deles, é possível. É onde jogamos”897.

Os presos de São Paulo não concordavam com esse encaminhamento da luta e pediram que a greve de fome não fosse deflagrada nos dias 18 ou 20 de julho, mas sim numa data próxima à da votação da lei no Congresso Nacional:

“[...] não podemos nos colocar como centro ou mesmo tentarmos ser a direção do movimento que vai se estruturando em pressão ao Congresso Nacional. Nos parece, no entanto, que podemos e devemos desempenhar um papel importante nessa mobilização, e é nesse sentido que estamos fazendo uma proposta que se articula com todo um processo em curso. Estamos desenvolvendo um trabalho junto a personalidades, juristas, advogados e parlamentares, inclusive convidando vários deles para comparecerem ao Presídio onde travamos uma discussão que tem a finalidade ou de quebrar resistências ou mesmo fornecer argumentos e dados a sua melhor atuação. Isto já surtiu efeitos. Estamos propondo uma carta ao Congresso Nacional a ser assinada por todos os presos políticos do Brasil. Estamos incentivando a organização de caravanas de familiares, artistas, estudantes, dirigentes sindicais, etc. para durante o mês de agosto se dirigirem ao Congresso Nacional. Culminando com uma grande caravana que lote o Congresso (suas galerias, corredores e salões) durante a votação do projeto. É nesse período com todos os dados e com uma visão clara do processo de agitação e mobilização em torno do projeto que para nós se situa uma Greve de Fome (que deverá ter início nas vésperas da votação e permanecer durante o seu processamento). Isto se dará como culminância do processo de mobilização e terá um efeito de pressão em consonância com todo o processo em curso.

[...] uma Greve de Fome agora poderá atrapalhar em lugar de ajudar toda a movimentação, pois este instrumento extremo dos presos deve ser acionado em cima de

\footnotetext{
${ }^{896}$ Teles, J., 2005; “Continue a luta, senador” e “Teotônio: ‘não vi terroristas””, Folha de S. Paulo, 20/07/79.

897 “Carta dos presos políticos da Frei Caneca (Rio) aos presos políticos de outros presídios”, em VIANA, Gilney e CIPRIANO, Perly. op.cit., p.219-21.
} 
toda uma preparação política. [...] resolvemos enviar um apelo aos companheiros do Rio de Janeiro para que reflitam no sentido de buscarmos a unidade de todos os presos políticos em sintonia com o processo que está se desenvolvendo aí fora. Qualquer medida isolada, entendemos, não contribuirá em nada”, ${ }^{\text {,98 }}$.

A despeito das divergências, os presos políticos do Rio de Janeiro adotaram a postura de tentar catalisar os movimentos em defesa da anistia e da opinião pública. A greve foi iniciada no dia 22 de julho de 1979 pelos 14 detentos do presídio da Frei Caneca, no Rio de Janeiro, e acabou por envolver 35 presos (dos 53 existentes) de seis estados brasileiros ${ }^{899}$. Tinham como objetivo o amplo reconhecimento público e institucional do estatuto de presos políticos para todos.

Com o início da greve de fome, a imprensa, antes voltada para as articulações do governo, passou a se interessar pelo movimento dos presos políticos e as mobilizações das oposições em repúdio ao projeto de anistia parcial. As emissoras de televisão continuaram ignorando o evento conforme o editorial da Folha de S. Paulo, naquele momento, simpática aos grevistas, ao contrário do que ocorreu na greve de fome de $1972^{900}$. Logo no início, a greve conseguiu grande repercussão, com manchetes e chamadas na primeira página. Pela primeira vez a luta pela anistia ganhava ampla divulgação. A imprensa alternativa assumiu o apoio ao movimento, a denúncia do caráter restrito do projeto de anistia do governo e de que ele representava a impunidade para os crimes do Estado ${ }^{901}$.

Acumularam-se manifestações de apoio por todo o país. No dia 8 de agosto, um ato foi organizado na Praça da Sé em apoio à greve e reuniu 8 mil pessoas. Neste dia, cinco presos de São Paulo aderiram à greve de fome. A adesão, porém, ocorreu depois de um processo difícil de discussão. De acordo com Manoel Cyrillo:

\footnotetext{
“A gente tinha uma posição que era a de que não podíamos interferir tanto no movimento social, provavelmente, porque, em São Paulo, [...] o movimento estava muito mais ativo, na rua, diferentemente do Rio, onde a participação deles foi decisiva para a coisa tomar mais corpo. A gente achava que em função da nossa realidade política, [...] não era preciso interferir para despertar os movimentos como era o foco deles, no Rio.

Foi legal por causa da realidade deles, mas a nossa era um pouco diferente, era mais favorável. A gente recebia visita até do candidato do MDB ao senado, o Fernando Henrique Cardoso, do Dalmo Dallari, de todo o mundo. Eles também recebiam visitas muito importantes, mas aquela greve foi decisiva para o movimento de anistia do Rio, não
}

\footnotetext{
898 “Carta dos presos políticos de Barro Branco (São Paulo) aos presos políticos do Rio de Janeiro”, em VIANA, Gilney e CIPRIANO, Perly. op.cit., p.221-3.

${ }^{899}$ V. GRECO, H., op.cit., p.212-3 e nota 391.

${ }^{900}$ Intolerância (Editorial), Folha de S. Paulo, 23/08/79; e GRECO, Heloísa. op.cit., p.216.

901 "Presos políticos partem pro pau”, Em Tempo. 26/07 a 01/08/79; “A greve de fome”, Movimento, 20 a 26/08/79.
} 
pra nós. O pessoal na USP, do CBA daqui, enfim, tinha muitas outras ações e atividades ligadas ao movimento social. Não era um problema interferir, mas passar por cima dos movimentos.

[...] Nós éramos contra a greve e por isso não entramos simultaneamente, mas [...] a gente entrou, mesmo com a denúncia dos cinco presos que não quiseram entrar [...].

O que eu acho é que eles atribuíram uma importância muito superior ao papel dos presos do que nós achávamos que era o correto. Isso pode até ser considerado como um vanguardismo da parte deles ${ }^{\prime 902}$.

Apesar das diferenças de perspectivas, os presos de São Paulo haviam declarado que entrariam em greve no dia 13 de agosto, mas com a manifestação da Praça da Sé anteciparam sua decisão: cinco dos doze presos do Romão Gomes aderiram à greve (Aldo Silva Arantes, Aton Fon Filho, Carlos Alberto Soares, Francisco Gomes da Silva e Manoel Cyrillo de Oliveira Neto). Apenas Altino Rodrigues Dantas Junior manteve a decisão e aderiu ao movimento no dia 13, conforme combinado.

Ricardo Zarattini Filho foi um dos articuladores da carta dos presos políticos que não aderiram à greve. Banido depois do sequestro do embaixador norte-americano, em 1969, ele se tornou um dos organizadores da Tendência Leninista e voltou ao Brasil clandestinamente em 1976 como militante do MR-8. Em 1978 foi novamente preso e bastante torturado. Juntamente com David Gongora Júnior, Diógenes Sobrosa de Souza, Nelson Chaves dos Santos e Newton Cândido divulgaram a carta contendo duras críticas à greve e aos Comitês Brasileiros de Anistia, tachados de "esquerdistas" e "vanguardistas":

“[...] diante da ascensão do movimento popular e do crescimento da exigência dos setores democráticos da sociedade brasileira, o governo foi obrigado a admitir uma anistia, se bem que parcial e restrita. Portanto, o envio desse projeto ao Parlamento, apesar de suas limitações, reflete já uma vitória democrática do povo brasileiro.

No curso da luta pela Anistia Ampla, Geral e Irrestrita (AAGI), vem se manifestando mais uma vez a mesma concepção profundamente errônea que se acentuou no seio das forças democráticas após o golpe reacionário de 64. Referimo-nos à concepção "esquerdista”, que menospreza as massas populares e a necessidade da formação de uma ampla frente democrática, englobando desde os trabalhadores da cidade e do campo até setores das classes dominantes que se opõem ao regime militar fascista. [...] Essa orientação vanguardista, como regra, não leva em conta o nível de correlação de forças para a colocação de suas reivindicações e as formas de lutas para conquistá-las [...].

Nesse período, essa concepção vem se manifestando de diferentes formas; na substituição das lutas das grandes massas pela ação direta de pequenos grupos armados; preconizando o boicote aos pleitos eleitorais quando se mostrava justa a participação neles; no menosprezo às entidades legais, a exemplo do MDB, como instrumento de luta e mobilização pela democracia; na tentativa de organizações sindicais paralelas, através das chamadas "oposições sindicais"; na tentativa de fragmentação da oposição democrática, através da criação prematura de partidos "trabalhistas"; e agora discriminando setores e personalidades, na luta pela AAGI.

${ }^{902}$ Entrevista concedida por Manoel Cyrillo de O. Neto à autora. SP, 20/03/2011. 
[...] Todavia, um grupo de presos políticos, sob a influência dessa concepção errônea e contando com a aquiescência de alguns CBAs, aprestou, como um fato consumado, sua decisão de entrar em greve de fome, arrastando atrás de si a esmagadora maioria dos presos. [...] estaríamos admitindo que a ação de um grupo de presos pudesse complementar ou suprir as ações de massas. Mas a necessidade de enfrentar as concepções errôneas, a sistemática quebra da unidade de ação, dentro e fora do presídio a exemplo do que aconteceu na Praça da Sé - nos levou a não entrar em greve de fome, conforme havíamos decidido anteriormente.

Estamos convencidos de que não entrando em greve de fome, contribuímos para ajudar as forças democráticas a identificar e isolar estas concepções sectárias e divisionistas, que no curso da luta contra o regime militar fascista só têm causado prejuízos e entraves à mobilização e a união das forças populares democráticas. E ao combater essas concepções errôneas e nocivas [...] estamos certos de contribuir [...] para a plena redemocratização do país"

Os presos em greve capitalizaram ao máximo a situação, apresentando-se como “presos políticos” perante a opinião pública. As manifestações públicas continuaram se expandindo, um ato público organizado no dia 14 de agosto, no Rio de Janeiro, contou com a presença de 20 mil pessoas. Outro ato organizado na Praça da Sé no dia 21 de agosto teve a participação de cerca de 30 mil manifestantes ${ }^{904}$. Diversas pessoas, personalidades e representantes de entidades foram aos presídios visitar os grevistas, atuando como formadores de opinião.

Os presos políticos de Salvador demoraram a aderir à greve de fome porque tinham que esperar o desenlace da fuga de Theodomiro Romeiro dos Santos. No dia 19 de agosto ele fugiu da penitenciária Lemos de Brito, de Salvador, onde cumpria pena havia oito anos e oito meses. Theodomiro, o preso político “menos anistiável”, reapareceu somente no dia 30 de outubro na Nunciatura Apostólica, em Brasília, onde, asilado, obteve salvo-conduto para poder sair do país ${ }^{905}$.

Durante o processo de tramitação do projeto de anistia do governo no Congresso Nacional, o governo assumiu a iniciativa política, tentou ganhar tempo, mas os movimentos de anistia buscaram conquistar os espaços públicos. Desde o início, o projeto de anistia do governo foi apresentado como uma concessão destinada a promover a conciliação [GRECO, 2003: 229].

O projeto apresentado com alarde ao Congresso Nacional no dia 27 de junho de 1979 teve a cerimônia boicotada pelo MDB. Mesmo sem a possibilidade de questionamento, discussão ou retoques ao projeto, a Comissão Mista conseguiu ouvir e

\footnotetext{
903 “Porque não participamos da greve de fome pela Anistia”, em VIANA, Gilney e CIPRIANO, Perly. op.cit., p.241-6.

${ }_{904}^{904}$ ViANA, Gilney e CiPRIANO, Perly. op.cit., p.136-7 e p.168-9.

${ }^{905}$ V. entrevista concedida por Theodomiro Romeiro dos Santos à autora. Idem, ibidem.
} 
dar visibilidade às denúncias de diversos setores da sociedade civil, durante as 8 sessões em que funcionou, entre 2 e 16 de agosto. As tentativas da oposição em debater propostas e aprovar emendas foram reiteradamente derrotadas em função da maioria numérica do partido do governo na Comissão Mista ${ }^{906}$.

O anteprojeto de decreto legislativo aprovado pelos Movimentos de Anistia foi adaptado e apresentado à Comissão Mista pelo autêntico Marcos Freire (senador do $\mathrm{MDB} / \mathrm{PE}$ ), através da Emenda no.1 (substitutivo). As discussões, no entanto, evoluíram para um acordo entre o MDB e os CBAs que, juntamente com os presos políticos e outras entidades representativas da sociedade, passaram a apoiar a Emenda no.7 (substitutivo), assinada pelos deputados Ulysses Guimarães (presidente do MDB), Freitas Nobre (líder da minoria na Câmara) e pelo senador Paulo Brossard (líder da minoria no Senado), apresentada em 9 de agosto de 1979. ${ }^{907}$

Dalmo Dallari, jurista da CJP/SP, e João Paulo Sepúlveda Pertence, presidente do Conselho Federal da $\mathrm{OAB}$, participaram da sua redação, que regularizava a situação trabalhista de todos os perseguidos políticos e tinha como principal aspecto a rejeição explícita da reciprocidade (art.1 $1^{\circ}, \S 2^{\circ}$ ): "Excetuam-se dos benefícios da anistia os atos de sevícia ou de tortura, de que tenha ou não resultado morte, praticados contra presos políticos” ${ }^{908}$.

A tática estabelecida pelo MDB para ser seguida nas sessões conjuntas do Congresso Nacional durante a discussão do projeto foi a de propor destaque para o substitutivo do partido, mas sabia-se que dificilmente ele seria aprovado. Assim, pediriam destaque para a emenda do deputado Djalma Marinho (Arena/RN), presidente da Comissão de Justiça da Câmara. Essa emenda poderia derrubar as exceções da anistia oficial e conseguir a adesão de dissidentes do partido do governo, conforme tática discutida com presos políticos do Rio de Janeiro por Waldir Pires e Ulysses Guimarães, numa visita feita a eles no $23^{\circ}$ dia da greve de fome ${ }^{909}$.

\footnotetext{
906 “As principais alterações”, Folha de S. Paulo, 23/08/79.

${ }^{907}$ Emenda 1, p.53-7, e Emenda 7, de 09/08/79, p. 71-4. In: CONGRESSO NACIONAL - COMISSÃO MistA SOBRE A ANISTIA. Anistia, v.I, Op.cit.

908 E a proibição da utilização de informações do aparelho repressivo sobre o anistiado; instauração de inquérito para apurar as circunstâncias dos desaparecimentos políticos, mediante representação dos familiares (art.15); concessão de declaração de morte presumida para os familiares dos desaparecidos políticos (art.16), entre outros. Emenda 7, CONGRESSO NACIONAL - COMISSÃO MistA SOBRE A ANISTIA. Anistia, v.I, op.cit., p.71-4.

909 "Substitua-se os parágrafos $1^{\circ}$ e $2^{\circ}$ do artigo $1^{\circ}$ por: Parágrafo único. Consideram-se conexos aos crimes políticos, para os efeitos da presente anistia, além dos atos preparatórios e complementares de crime político, os crimes de qualquer natureza praticados por motivação política”. Emenda Djalma Marinho (Arena/RN), em Anistia, op.cit., p.115; VIANA, Gilney e CIPRIANO, Perly. op.cit., p.159-60 e p.163-4.
} 
O movimento pela anistia considerou inviável sua aprovação e questionou o seu mérito considerando-o uma "forma enviesada" de estender a anistia a todos. Os presos políticos da Frei Caneca propuseram que o MDB não aprovasse a emenda Djalma Marinho, pois “[...] não se tratava apenas de suprimir o parágrafo $2^{\circ}$., do artigo $1^{0}$, mas também [de] incorporar uma série de outras emendas parlamentares e reivindicações populares, que não foram incorporadas ao projeto oficial” [VIANA e CIPRIANO, 1992: 159]. De acordo com Djalma Marinho, a emenda de fato confirmava a reciprocidade da lei, mas beneficiaria também os guerrilheiros condenados.

Roberto Freire e outros deputados federais ligados ao PCB defenderam a primazia da racionalidade política que priorizava a mudança da correlação de forças das oposições, à custa de uma proposta de anistia irrestrita para todos os perseguidos políticos. De acordo com Freire:

\begin{abstract}
"Ninguém no Congresso discutia outra coisa que não fosse a anistia. Porque a anistia é que iria condicionar a solução de muitos outros problemas. Ali nós estávamos mexendo em um dos aspectos do poder. E eu dizia: no momento em que tivermos de volta ao Brasil Luís Carlos Prestes, o Arraes e o Brizola, estaremos mudando a correlação de forças políticas muito concretamente. Logo, mesmo que alguns dos nossos companheiros de lutas contra a ditadura continuem presos não podemos votar contra uma lei que trará de volta ao país essas pessoas”[ALVEs, 1983:186-7].
\end{abstract}

Os CBAs e os presos políticos estavam convictos da necessidade de repúdio à anistia parcial no parlamento através do voto ${ }^{910}$, mas o MDB tinha muitas dúvidas a respeito. Durante o mês de agosto, a aprovação da emenda Djalma Marinho foi aceita pelos presos políticos, pois certamente o substitutivo do MDB seria derrotado. Essa foi, nas palavras de Heloísa Greco, a maior surpresa entre as modificações de posição dos movimentos de anistia. A aceitação da emenda tornou-se um consenso, mas os CBAs de Minas e de São Paulo não concordaram com a reciprocidade implícita na proposta ${ }^{911}$.

A maioria numérica do governo no Congresso certamente garantiria sua vitória na votação da Câmara. A tensão e as contradições do legislativo atingiram seu ápice no dia da votação do projeto, 22 de agosto de 1979. A greve de fome dos presos alcançava sua fase crítica, eles estavam havia 32 dias sem comer $^{912}$.

\footnotetext{
${ }^{910}$ Documento do IV Encontro Nacional dos Movimentos pela Anistia: Anistia Ampla, Geral e Irrestrita: reafirmação do compromisso nacional, São Paulo, 07/07/79; Relatório do I Encontro Nacional de Atingidos, Rio de Janeiro, 11 e 12/08/79.

${ }^{911}$ GRECO, Helena. op.cit., p.246; VIANA, G. e CiPRIANO, P. op.cit., p.208; “Até o final, presos mantinham esperança”, Folha de S. Paulo, 23/08/79.

${ }^{112}$ Anexo à ata da $8^{\text {a }}$ reunião da Comissão Mista, realizada em 16/08/79. In: CONGRESSO NACIONAL COMISSÃo Mista SOBRE A ANISTIA. Anistia, v.I, op.cit., p.657-60.
} 
No dia 22 de agosto, a revista Isto É desmascarou o regime ao revelar a comprovação de que dois desaparecidos políticos estavam enterrados em Perus com nomes falsos, Luiz Eurico Tejera Lisboa e Denis Casemiro ${ }^{913}$.

Os CBAs organizaram caravanas para acompanharem as votações no Congresso Nacional em Brasília. Na manhã do dia 22 de agosto, a imprensa divulgou a ordem emitida pelo Palácio do Planalto: era imprescindível votar o substitutivo de Ernani Satyro tal qual ele chegou ao Congresso, caso contrário, haveria veto total do presidente ao projeto de anistia $^{914}$.

A vitória do governo foi garantida em função das rígidas normas regimentais e do complicado ritual de votação e, ainda, devido à utilização do dispositivo regimental que determinava a perda de mandato para os parlamentares que desrespeitassem as diretrizes partidárias, mesmo que essa medida não pudesse ser utilizada, pois não estava registrada no Tribunal Superior Eleitoral. O resultado da votação surpreendeu, revelando certa perda de controle do governo e, também, vacilação e confusão política por parte da oposição. A votação que daria destaque para o substitutivo do MDB foi derrotada por 209 a 194 com os votos de 12 arenistas dissidentes.

A emenda Djalma Marinho recebeu, em seguida, 201 votos a favor e 206 contra, sendo derrotada apesar de ter contado com o apoio de 14 arenistas. A anistia parcial foi aprovada em bloco, pela votação dos líderes dos dois partidos, com a discordância silenciosa de 12 dos 26 senadores do MDB e a declaração de voto contrário de 29 dos 189 deputados emedebistas. Outras manifestações da oposição não chegaram a ser formalizadas, pois os líderes na Câmara e no Senado, Freitas Nobre e Paulo Brossard, aprovaram a matéria, inviabilizando a votação nominal. Esta atitude da liderança provocou críticas dos CBAs e do senador Teotônio Vilela, que anunciou a continuidade da luta pela anistia [ALVES, 1983: 187].

Na declaração de voto, os deputados descontentes destacaram que a lei era recíproca (sem analisar a questão da inexistência de conexão jurídica entre o crime político e o comum) [TELES, 2005], registrando seu protesto e crítica à intenção do governo de anistiar os torturadores, e ressaltaram a necessidade de continuidade da luta:

“[...] está em pauta no Congresso Nacional mais um projeto discriminatório. Através dele, anistia-se irrestritamente os torturadores e parcialmente os opositores do regime.

\footnotetext{
913 TELES, Janaina de A. Os herdeiros da memória, op.cit.; AlMEIDA, 2009; e entrevista concedida por Suzana Lisboa à autora. Idem, ibidem.

914 “Governo não aceita novas emendas”, Folha de S. Paulo, 22/08/79, p.4.
} 
Ignora-se a existência de trabalhadores punidos e condena-se duplamente os funcionários civis e militares, submetendo-os a uma nova inquisição, ao [mesmo] tempo em que deixa apodrecendo nos cárceres a grande maioria dos prisioneiros políticos. Coerentes com o comportamento anterior de não compactuar com a farsa governamental, nos manifestamos contra o substitutivo ao projeto de 'anistia' do governo. Recusando nosso voto para sua legitimação, nos comprometemos a continuar a batalha pela anistia ampla, geral e irrestrita, como quer o povo consciente do Brasil na sua luta de libertação." ${ }^{915}$

De acordo com o senador Teotônio Vilela, foi importante insistir nas críticas ao projeto e fazer a declaração de voto contrária à lei, para ele: “O líder tem de pedir tudo. Se chega moderado, com régua e esquadro, medindo as concessões que pode e as que não pode fazer, não consegue nada”. O projeto foi sancionado no dia 28 de agosto pelo general Figueiredo ${ }^{916}$. Segundo a avaliação do deputado Airton Soares a votação ocorreu no final de agosto para desmobilizar o Congresso pela Anistia organizado em Roma no dia 30 de agosto, onde esteve presente toda a oposição exilada:

“[...] não questionamos a questão da conexão dos crimes, batemos na tecla que aquela não era a Anistia que nós queríamos, era parcial e não atingia a totalidade dos presos, não tinha amplitude e deixava muitos presos a mercê da nova LSN, que reduzia as penas [...]. Nosso argumento era de que a lei não tinha sido votada no parlamento, mas imposta pelo governo.

[...] Lá fora haveria o Congresso de Anistia, em Roma, organizado pelos exilados, que, na prática, foi abortado, pois a lei de anistia caiu em cima deles. Eu cheguei lá com a lei e os caras olharam para mim e falaram: 'Te mandaram aqui para você dizer que tem Anistia no Brasil!?’ Estavam lá todas as organizações políticas e a lei de Anistia era tão absurda, que quem não tinha processo com trânsito em julgado, ou seja, quem tinha sido banido, podia voltar para o Brasil, mas quem tinha condenação não... Ninguém acreditava naquilo. Para mim foi uma experiência bastante difícil... A sorte é que as pessoas me conheciam, senão podia parecer que eu estava fazendo o papel do governo. A lei saiu nas vésperas, cheguei em Roma com o projeto de Anistia aprovado. [...] Havia gente de toda a Europa ali, observadores de todos os partidos. O Petrônio Portella, competentíssimo, armou isso para desmobilizar o congresso de Roma e as oposições no exílio. Era uma das maiores reuniões que juntou toda a esquerda [...]”,917.

A Lei de Anistia parcial incluiu, assim, "aqueles que cometeram crimes políticos ou conexos com estes”, texto que, desde então, tem sido interpretado como o enunciado da reciprocidade, confundindo deliberadamente o que seriam crimes conexos, e excluiu

\footnotetext{
915 Os autores: Airton Soares, Elquisson Soares, José Carlos Vasconcelos, Edson Khair, José Costa, Francisco Pinto, Jorge Viana, Freitas Diniz, Aurélio Peres, João Cunha, Santilo Sobrinho, Iranildo Pereira, Benedito Marcílio, Maurício Fruet, Mendonça Neto, JG de Araújo Jorge, Gilson de Barros, Otacílio Queiroz, Sérgio Murilo, Cristina Tavares, Hélio Duque, Fernando Cunha, Hilério Oliveira. Anistia, op.cit., “Ata da $163^{\mathrm{a}}$ sessão conjunta, realizada em 22/08/79 (aprovação da matéria)”, v.II, p.237-8.

${ }^{916}$ Com um veto parcial ao caput do Artigo $1^{\circ}$, tornando a lei ainda mais restrita. Sob a argumentação de que a medida teria sido tomada para evitar a inclusão de criminosos comuns, foi retirada e expressão "[...] e outros diplomas legais" do texto original. "Substitutivo da Comissão Mista ao Projeto de Lei $\mathrm{n}^{0}$ 14, de 1979-CN (aprovado pelo Congresso Nacional em 22/08/79)”. Anistia. op.cit., v.I, p.402.

${ }^{917}$ Entrevista concedida por Airton Soares à autora. Idem, ibidem.
} 
os condenados por crimes de terrorismo, assalto, sequestro e atentado pessoal (art. $1^{0}$, par. $2^{\circ}$ ). Os torturadores poderiam ter sido enquadrados neste parágrafo, mas, para muitos, não haviam sido condenados pelos crimes definidos na lei, os quais, no entanto, efetivamente haviam praticado.

A greve de fome terminou no dia da votação no Congresso, em 22 de agosto ${ }^{918}$. Apesar da derrota sofrida, o movimento avaliou de maneira positiva da greve: divulgou as contradições do projeto de anistia transformado em lei e colaborou para o alargamento da base social da campanha pela anistia, abrindo novas perspectivas. Demonstrou-se, assim, a possibilidade de unidade de diversos setores sociais em torno anistia e generalizou-se o entendimento de que os presos eram opositores políticos e não "terroristas” [VIANA e CIPRIANO, 1992: 214].

A mobilização gerada pela campanha conseguiu impor desgaste ao regime no plano político devido ao caráter excludente e impopular da lei. A continuidade da luta passou a ser discutida, no âmbito político, do Judiciário e da administração pública ${ }^{919}$.

O governo, contudo, assumiu novamente a iniciativa política quando apresentou um projeto de reforma partidária, em 17 de outubro de 1979, propondo a formação de novos partidos. A lei foi aprovada no mês de novembro e a rearticulação partidária monopolizou as discussões políticas e institucionais.

Naquele momento, quase todos os presos políticos foram libertados ${ }^{920}$, nem todos por meio da lei de anistia, algumas centenas de militantes saíram da clandestinidade e milhares de exilados retornaram ao país. A continuidade da luta ficou condicionada à capacidade do movimento de anistia em assimilar a derrota e, na mesma medida, capitalizar a vitória.

\footnotetext{
918 "Presos suspendem a greve após a votação do projeto”. Folha de S. Paulo, 22/08/79; “Em São Paulo, os presos políticos lançam manifesto"; “No Ceará e Recife também chega ao fim o movimento”. Folha de S. Paulo, 24/08/79.

919 “OAB condena a 'odiosa discriminação' da anistia”, Folha de S. Paulo, 25/07/79; "OAB tentará tornar anistia mais ampla através da Justiça”, Folha de S. Paulo, 05/09/79; SoBRINHO, Barbosa Lima. "Jesus Cristo e a anistia”. Jornal do Brasil, 30/09/79.

${ }_{920}$ Dos presos políticos existentes naquele momento, cerca de 14 foram anistiados e o restante se beneficiou da liberdade condicional e da redução de penas prevista na LSN (lei 6.620/78).V. GRECO, 2003, p.279.
} 


\section{O balanço e a continuidade da luta}

A aprovação da lei de anistia parcial do governo transformou a atmosfera política do país. Para muitos militantes e sobreviventes este foi o momento em que se entrelaçaram os sentimentos de alívio e de euforia pela vitória parcial e pelo retorno dos companheiros clandestinos, exilados e banidos. O retorno à vida na legalidade ou a volta ao Brasil foram atribulados e conflitantes, mas gratificantes também, conforme nos contou Dulce de Souza Maia, banida após ter sido trocada pelo embaixador alemão juntamente com 39 companheiros em 1970:

"Eu estava querendo voltar de qualquer maneira ao Brasil antes mesmo da Lei de Anistia.
Eu estava acreditando que eu fosse morrer e queria morrer no Brasil. Meu estado de saúde
era [...] de stress crônico, complicado e não diagnosticado. [...] A minha família
considerou que essa não era a coisa mais certa que eu devesse fazer, mas o meu desespero
era tal [...]. Nós sabíamos desde lá o que estava sendo feito e organizado aqui, era de nos
entusiasmar e de dar esperança na volta. [...] Eu fui a primeira ex-presa política a voltar ao
Brasil. Eu cheguei e ainda tive o passaporte apreendido no aeroporto [...]. Eu digo que
quando cheguei, pra mim, foi como se eu tivesse vivido 300 anos e dado a volta ao
mundo [...] e chegado ao ponto de partida. É muito difícil, é complicadíssimo, [...] foram
muitas idas e vindas de grandes modificações, de grandes impactos. E eu cheguei e tive
muito atrito na minha chegada com meus irmãos que não queriam de maneira alguma que
eu voltasse, porque eles queriam me proteger. [...] Eles tinham pavor de que eu fosse
sofrer voltando ao Brasil, e eu necessitando chegar pra poder acabar com aquele
sofrimento! [...] Mas tudo isso pra mim foi muito rico, eu ganhei muito, [...] aprendi
muito nesses anos de exílio [...]. Eu queria abraçar o Brasil todo de uma vez [...], fui
procurar o CBA e fiquei com eles de uma maneira incrível. Eu tinha tal admiração,
gratidão, pelos companheiros todos que nos trouxeram de volta. Daí eu passei a ir para o
aeroporto esperar os companheiros, era tão bonita a recepção, a chegada de cada um. Fui
receber o Betinho, por exemplo, e tudo isso foi me dando força me dando ânimo, eu
estava renascendo. Depois criamos um Comitê Brasileiro de Solidariedade à América
Latina, no qual eu tive também uma atuação, [...] tudo isso, acho que me fez enfrentar o
Brasil com outros olhos. [...] Eu estava muito desenraizada e chegar e começar a militar
[...] foi muito bom. Poder responder um pouco à solidariedade que recebi [...] $]^{921 . ” . ~}$
O capital político acumulado pelo movimento de anistia implicava na continuidade e no encaminhamento de suas reivindicações específicas, mas para muitos militantes e grupos de esquerda o movimento deixou de ser prioridade, segundo o relato de Jorge Eduardo Saavedra Durão:

“[...] o CBA do Rio de Janeiro se esvaziou depois que a Lei da Anistia foi aprovada. Teve aquela etapa em que, vamos dizer assim, se conseguiu repercutir essa vitória. Eu acho que foi uma vitória, não vou entrar nessa do copo meio cheio e meio vazio, para mim foi mesmo uma vitória, que não foi aquela esperada, mas foi significativa. E teve aquele processo de receber os exilados, fui dezenas de vezes ao aeroporto. Acho que aquilo teve

${ }^{921}$ Entrevista concedida por Dulce de Souza Maia à autora. Idem, ibidem. 
um sentido político também, o de chamar a atenção da sociedade para a quantidade de pessoas que tinham ido parar no exílio. E de legitimar a participação de quem estava excluído da vida política. Mas, depois, já estávamos noutra, alguns estavam no processo de criação do PT, outros não, [...] teve a luta pelas Diretas ${ }^{922 . ”}$

Havia muitas diferenças de vivência e de perspectiva política entre os militantes que ficaram no país e os que se exilaram. Para vários ex-presos, o reencontro com os antigos companheiros não aconteceu ou foi adiado por anos, conforme nos contou Laurindo Junqueira, dirigente do POC preso em São Paulo em 1971:

\begin{abstract}
"Inicialmente, eu me afastei das pessoas, tinha uma visão muito crítica a respeito do comportamento dos meus companheiros na prisão [...]. Fiquei completamente isolado, querendo voltar para a fábrica, não voltei por um monte de circunstâncias. Fiquei completamente desarticulado e não vendo o PT como saída. Outros dos meus companheiros se filiaram ao PT, [...] alguns quadros são dirigentes hoje, o Marco Aurélio Garcia era companheiro nosso de POC, o Matoso [...], enfim, muitos deles. Mas me afastei e tive uma militância muito dentro do Metrô, ajudei a fundar o sindicato [...].

Virei um técnico ressentido com muita coisa que vi. E muito sofrido também, porque paguei caro por isso, pessoalmente, fisicamente, embora tenha sobrevivido. Dessa experiência de prisão, ficou uma impossibilidade que durou décadas de fazer o que estou fazendo agora, falar no assunto.

[...] Talvez, o que mais me impedia de falar era exatamente o fato de ter críticas aos meus companheiros, então, é preferível silenciar do que contar o que se sabe. [...] Com o passar do tempo, [...] voltei a me reunir com alguns companheiros [...], mas a convivência não foi boa, exatamente por causa das críticas [...].

Eu tinha uma visão sobre os exilados, [...] que muitos de nós na prisão tivemos, de que essa turma fugiu. Hoje, não vejo mais dessa maneira e até repenso, eu também deveria ter ido pra fora, estudado, enfim, criado condições lá fora muito melhores pra poder voltar um dia e ajudar melhor. [...] Mas a gente via muitos dos exilados como sendo pessoas que de fato fugiram. Eu tenho essa visão ainda, muitos deles que estão no governo se mandaram e na hora H livraram a pele e largaram tudo pra trás ${ }^{923}$."
\end{abstract}

Para alguns militantes que participavam do movimento de anistia, o reencontro com os que voltavam realimentava as esperanças e discussões sobre as perspectivas políticas, mas a questão que se colocava era como prosseguir e combater a suposta reciprocidade da lei de anistia, como criar condições para investigar e esclarecer as mortes e desaparecimentos políticos e as torturas cometidas pelo regime.

Outros consideravam que a correlação de forças não era favorável e que este tema teria de ser tratado em outra fase, conforme Marcelo Cerqueira, muito criticado pelos CBAs por ter dito que "não se fala em Tribunal de Nuremberg com a Gestapo no poder”, quando se declarou contrário à criação da CPI dos Direitos Humanos para apurar a tortura e os crimes da ditadura, em maio de 1979 [ALVES, 1983: 186].

\footnotetext{
922 Entrevista concedida por Jorge Eduardo Saavedra Durão à autora. Idem, ibidem .

${ }^{923}$ Entrevista concedida por Laurindo Junqueira à autora. Idem, ibidem.
} 
A Comissão Executiva Nacional dos CBAs, reunida em setembro de 1979, considerou que a continuidade da luta deveria ser organizada em torno de cinco eixos: voltar-se para os que não haviam sido anistiados e intensificar a campanha pela libertação de todos os presos políticos; repudiar a anistia parcial e monitorar sua aplicação; aprofundar a campanha pelo esclarecimento das mortes e desaparecimentos e pela responsabilização criminal do Estado e seus agentes; lutar pelo desmantelamento do aparelho repressivo e pelo fim das leis de exceção; e incrementar a vinculação da luta pela anistia com o movimento operário e popular [GRECO, 2003: 295].

Em 25 de outubro de 1979, o CBA/SP lançou, juntamente com o Sindicato dos Jornalistas, o Prêmio Vladimir Herzog dedicado às dez melhores matérias sobre direitos humanos publicadas na imprensa escrita, como forma de homenagear Vlado na data de sua morte, e que se transformou no Dia Nacional dos Mortos e Desaparecidos.

O II Congresso Nacional pela Anistia, realizado em Salvador, em novembro de 1979, foi um momento de reencontro dos ex-exilados, ex-clandestinos e militantes, onde compareceram 60 entidades e mais de 2.500 pessoas. A presença pouco significativa de políticos do MDB marcou as discussões sobre a nova política de alianças do movimento. Apesar das discussões e divergências sobre o encaminhamento da luta pela formação da Assembleia Constituinte e a reforma partidária, surgiram proposições específicas do movimento. Além das apontadas acima, destacaram-se a de continuar a denunciar e identificar os torturadores, com a ampla divulgação de seus nomes, endereços, locais de trabalho e de suas fotos; lutar pela constituição de uma CPI dos Direitos Humanos; e lutar pela instauração de um tribunal de denúncia dos crimes da ditadura, responsabilizando politicamente os culpados por estes crimes perante a opinião pública ${ }^{924}$.

Uma representativa delegação de familiares de desaparecidos da Guerrilha do Araguaia esteve presente propondo a intensificação da luta pelo esclarecimento do que aconteceu aos guerrilheiros do PCdoB e a organização de uma caravana dos familiares à região da guerrilha ${ }^{925}$. A atmosfera do II Congresso de Anistia, porém, era ambígua, pois muitos consideravam, naquele momento, que o protesto contra a anistia parcial e a apuração dos crimes da ditadura poderiam provocar um retrocesso no processo de “abertura política”. De acordo com Suzana K. Lisbôa:

\footnotetext{
924 "Relatório do II Congresso Nacional pela Anistia - Campanhas e outras atividades prioritárias", Salvador, 18/11/79, p.3-4. Destaque meu.

925 "Manifesto dos familiares dos mortos e desaparecidos na guerra do Araguaia”, II Congresso Nacional pela Anistia, nov./1979, Salvador.
} 
"As diferenças de interpretação e comportamento em relação à anistia começaram desde o dia da votação. [...] Os exilados que voltaram, na sua quase totalidade, desconheciam o fato de que o Brasil ainda tinha presos políticos e que os mortos e desaparecidos eram desconsiderados no projeto do Figueiredo. O II Congresso de Anistia se realizou nesse clima, [...] alguns eram contra a proposta de organizar uma caravana ao Araguaia. Tudo isso já era considerado revanchismo. [...] De resto, a posição era a de continuar a luta pelos princípios definidos desde o início. Imaginava-se que os CBAs iriam prosseguir na luta, mas sabíamos que isso seria difícil, porque a reformulação partidária carregou a maior parte dos militantes e que a anistia parcial conseguiria desmobilizar o movimento. Também já estava claro que os exilados não se integrariam na luta, com raras exceções [...]." ${ }^{, 926}$

A luta proposta pelos movimentos de anistia implicava em vasculhar o "submundo da repressão”, como afirmou Bernardo Kucinski, ele próprio familiar de desaparecidos políticos $^{927}$, o que para muitos não era possível fazer em decorrência da correlação de forças desfavorável. Durante o II Congresso pela Anistia muitos questionaram as possibilidades de continuidade dessa luta, em função também das enormes dificuldades de manter a sua característica de frente política. O jornalista Perseu Abramo, membro do CBA/SP, expressou essa preocupação, que refletia alguns dos dilemas postos para a continuidade do movimento:

“[...] Como conciliar a necessidade de se manter a frente política do CBA/SP, constituído por representação de entidades, e o fato inelutável de que já estão se organizando os partidos políticos, com ou sem expressão eleitoral? Por outro lado, não tenderão os partidos a assumir parte das lutas que vinham sendo travadas pelos movimentos de Anistia? Não procurarão os partidos políticos chamar a si a tarefa de libertar os seus presos, trazer de volta os seus exilados, responsabilizar os torturadores de seus correligionários e procurar reintegrar na vida política os seus egressos da prisão ou da clandestinidade? De que forma poderão os movimentos de Anistia ligar-se a essas lutas partidárias de Anistia sem perder seu caráter de frente política?"928

Este questionamento apresentava o que, na prática, já estava acontecendo, as organizaçãoes da oposição e das esquerdas engajaram-se na reorganização partidária ou no trabalho de enraizamento e fortalecimento de sua atuação junto aos movimentos sociais. A despeito dessas divergências sobre a prioridade a ser dispensada à continuidade do movimento da anistia, as atividades caminharam no sentido de continuar na organização de campanhas e atividades como a da libertação dos dois últimos presos políticos brasileiros, Flávia Schilling e José Salles; pelo retorno de exilados e estrangeiros

\footnotetext{
${ }^{926}$ Entrevista concedida por Suzana K. Lisbôa à autora, citado em TELES, 2005.

${ }^{927}$ KUCINSKI, Bernardo. “Golbery e o governo na parede”. Em Tempo, 46, 11 a 17/01/79, p.5. “A questão dos desaparecidos”, Comitê Brasileiro pela Anistia - Seção do Rio de Janeiro, maio/1979. In: CABRAL, Reinaldo e LAPA, Ronaldo. Op.cit., p.19-22.

${ }_{928}$ ABrAmo, Perseu. "Questões da continuidade da luta pela anistia”, out./nov. de 1979, Dossiê Anistia, Centro de Documentação Sérgio Buarque de Holanda, Fundação Perseu Abramo.
} 
expulsos do Brasil e contra a Lei de Segurança Nacional. Deliberou-se pela criação da Secretaria Nacional para Mortos e Desaparecidos Políticos e a realização da caravana à região da Guerrilha Araguaia com o objetivo de buscar vestígios da localização dos restos mortais dos guerrilheiros [GRECO, 2003: 310].

O movimento de anistia remanescente propôs a criação de datas e lugares de memória relacionados à questão dos mortos e desaparecidos e a articulação da proposta de criação de um tribunal para julgar os crimes da ditadura como parte da campanha de constituição de uma Corte Internacional de Direitos Humanos, discutida na Conferência Internacional de Direitos Humanos de São José da Costa Rica, em fevereiro de 1980. Propô-se uma mobilização em torno de um projeto de lei anti-tortura e deliberou-se pelo estímulo à denúncia dos crimes da ditadura como forma de dar sequência ao debate gerado em torno da ação declaratória do caso de Vladimir Herzog [GRECO, 2003: 310$11]$.

No confronto direto com a ditadura, os Comitês Brasileiros de Anistia compuseram o mais importante movimento legal organizado em âmbito nacional, cujo programa propugnava a criação das condições plenas para o exercício da cidadania e a ampliação do espaço público rompendo a capa de silenciamento imposta pela ditadura. $\mathrm{O}$ movimento adotou como princípio de ação um programa de conteúdo político visando criar o dissenso e, dessa forma, mudanças profundas no funcionamento do governo e do Estado $^{929}$.

O movimento de continuidade da luta pela anistia não conseguiu consolidar-se e popularizar suas bandeiras específicas. Perdeu seu caráter de frente política e de luta imediata responsável pelo seu potencial de mobilização de importantes contingentes de aliados. Nesse momento, os jornais alternativos também perderam seu caráter de frente jornalística, todos se voltavam para seus próprios grupos, partidos e jornais [KUCINSKI, 2003: 428]. Embora esvaziados e desarticulados nacionalmente, os CBAs mantiveram-se em funcionamento até meados da década de 1980 e tiveram importante participação na denúncia do caso Riocentro entre outros. Os CBAs colaboraram na organização do ato contra a LSN, em 1982, e do Tribunal Tiradentes, em 1983, em São Paulo, sempre ressaltando a necessidade do desmantelamento do aparelho repressivo da ditadura ${ }^{930}$.

\footnotetext{
${ }^{929}$ GreCo, Heloísa. op.cit., p.75-9 e RANCiÈRe, Jacques. “O dissenso”. In: NovaES, Adauto. A crise da razão. São Paulo, Companhia das Letras, 1996, p.372.

${ }^{930}$ GRECO, Heloísa. op.cit., p. 314-5 e TeLES, Janaina de A. Os herdeiros da memória, op.cit.
} 
Com o surgimento de novos partidos e movimentos reivindicatórios, o debate político visando aprofundar a ruptura com o legado da ditadura deixou de ocupar a centralidade que possuía até 1979. Os grupos de esquerda não priorizaram ou não conseguiram conquistar espaços públicos e definir instrumentos institucionais destinados à apuração dos crimes da ditadura, o que limitou a elaboração de propostas para o aprofundamento do projeto democrático em construção. Os olhares das esquerdas se voltaram prioritariamente para atender às lutas dos movimentos populares e sindicais e às demandas da construção dos novos partidos políticos voltados aos setores populares. O isolamento social das esquerdas - e como superá-lo - era o tema central da profunda crise de identidade por que passavam - tal sendo um tema debatido durante toda a década de 1970 e abordado repetidas vezes nas entrevistas aqui alinhavadas, como na de Jorge Eduardo Saavedra Durão:

"Eu tendo a achar que esse esvaziamento foi fruto da percepção que se tinha,
conscientemente ou não, da correlação de forças.
[...] Acho que [...] se não tivesse havido essa descontinuidade [...] da luta do Comitê
Brasileiro pela Anistia [...] poderia ter havido, vamos dizer assim, um acúmulo de forças e
ganhos em termos de [...] uma ruptura mais radical com a ditadura. [...] Mas a trajetória
das organizações de esquerda apontava um quadro de isolamento político muito grande.
[...] Significava que era uma esquerda fraca, vamos dizer assim, que carregava uma
enorme bagagem de equívocos políticos, de opções estratégicas incorretas e que
obviamente estava ansiosa para trilhar caminhos [...] de maior proximidade com a massa
do povo brasileiro. Aliás, que em boa parte tinha sido simpático aos governos militares,
os quais nunca foram tão isolados assim do ponto de vista de apoio da sociedade. Sem
falar da mídia, dos empresários, que apoiaram escancaradamente [os militares] O movimento da anistia havido sofrido os desgastes provocados pela intensidade da luta travada desde 1975 e a difícil convivência com a diversidade de grupos e propostas que a frente política exigiu a partir de 1978. Os que permaneceram no movimento entenderam que sua continuidade era tarefa de todos os partidos políticos, desde os mais atingidos pela repressão até os mais beneficiados pela própria anistia parcial, conquistada em 1979. Ademais, os traumas deixados pela experiência de tortura, prisão, clandestinidade e exílio eram muito presentes naquele momento, conforme relato de Maria Auxiliadora Arantes:

“Os CBAs, a partir [...] de 1980 se reorganizaram em outros agrupamentos, movimentos de direitos humanos, movimentos contra a carestia, em outra proposta. [...] A gente considerou que essa era uma questão que seria assumida por outras frentes, a nossa proposta de Lei da Anistia não foi alcançada, ficou uma anistia inconclusa, não resolvida. [...] A partir daí os movimentos de anistia se dissolveram, e nenhuma organização

${ }^{931}$ Entrevista concedida por Jorge Eduardo Saavedra Durão à autora. Idem, ibidem. 
nacional [...] tocou [...] essa luta para frente como uma questão própria. [...] Nós achávamos que a luta pela anistia foi uma campanha [...] com começo, meio e fim.

[...] todo o contingente da própria militância política já estava livre para se expressar. [...] Naquele momento, na nossa compreensão, [...] a liberdade de organização e de manifestação volta, inclusive, o reassentamento da vida política e eu acho que essas bandeiras deveriam ter sido assumidas por esses partidos, sobretudo os que [...] de um jeito mais genuíno se organizaram a partir da luta pela anistia. Havia toda uma gestação política como se essas lutas fossem ser encaminhadas por esses partidos, legais.

[...] A impressão que eu tenho [...] é que a luta não continuou organizada por alguns motivos, um deles é o que nós todos sabemos, nós familiares e, sobretudo, os presos: eles saíram das prisões arrebentados. Foram pessoas muito torturadas, [...] que estavam, no momento, absolutamente perplexos, com uma vida muito desorganizada politicamente, familiarmente, emocionalmente.

Além disso, as pessoas que organizaram o CBA foram retornando aos seus lugares de origem, sindicatos, associações estudantis, de professores, movimento de artistas etc. [...] O movimento de Anistia foi um movimento de frente única, ou seja, [...] as posições divergentes, de uma certa forma, eram acomodadas para se fazer uma luta comum, que era a volta dos exilados, abertura das prisões, desmontagem do aparelho de repressão, esclarecimento dos casos dos mortos e desaparecidos. [...] A gente achava que [...] essas lutas iam ser incorporadas por outros setores e segmentos políticos, organizados com toda a pompa e circunstância, o que não ocorreu. Então, os familiares acabaram ficando isolados, numa campanha que foi apoiada em muitos momentos, [...] mas sempre encarado como um trabalho muito próprio, específico ${ }^{932}$."

A questão da correlação de forças, as possibilidades de interferir ou influenciar o quadro político naquele momento, são alguns dos temas recorrentes nas entrevistas que realizamos; em vários testemunhos a própria campanha da anistia não era considerada prioritária, conforme relato de Vicente Roig:

"A Anistia foi uma luta que envolveu todo mundo, mas eu, na época, morava em Guarulhos e estava voltado para o trabalho de bairro e para fazer o jornal, a minha participação no Movimento de Anistia foi secundária [...].

No trabalho no bairro, do jornal, não se conseguia tratar da Anistia. Pelo menos, a gente não conseguiu levantar isso. Você tinha que ganhar o cara a partir dos problemas dele e, ele não tinha problemas com relação à Anistia, sequer era contra a ditadura. Falar em ditadura já era muito significativo. Esse trabalho de base no bairro e no movimento operário, que foi a opção que eu fiz, me deixou fora do movimento mais intelectualizado, que era o movimento pela Anistia.

Não fizemos uma avaliação sobre qual seria a consequência dessa luta de anistia, se continuaria ou não [...]. Não, nós da Ala [Vermelha] não chegamos a discutir isso. Pode ser um equívoco, mas não era um ponto prioritário de pauta, porque se você está voltado para a mobilização da população fica difícil. A população não se mobilizava por essas questões, naquele momento [...]. Chegamos a conversar [...], mas sem grandes aprofundamentos $[\ldots]^{933}$.”

O capital político construído durante a campanha pela anistia foi pouco acionado nos anos seguintes e a rearticulação do legado deste passado ficou reservada a alguns poucos sobreviventes. A ressignificação coletiva e plural dessas lutas e experiências não

\footnotetext{
${ }^{932}$ Entrevista concedida por Maria Auxiliadora Arantes à autora. Idem, ibidem.

${ }^{933}$ Entrevista concedida por Vicente Roig à autora. Idem, ibidem.
} 
foi tomada como uma tarefa pelo conjunto das esquerdas e da sociedade civil, o que pressupunha apurar o que aconteceu durante a repressão estatal, avaliar em profundidade a atuação das esquerdas e preservar a memória daqueles anos.

Sem esse processo, não foi possível fazer o trabalho de luto dessa história traumática articulada sob o signo do silenciamento. O caráter conservador da chamada transição política, articulada pela hierarquia das Forças Armadas, o empresariado e as lideranças dos dois partidos consentidos na ditadura, sem rupturas efetivas, é um dos fatores que concorreram para a consolidação do silenciamento, do esquecimento e da “cultura da impunidade” [GRECO, 2003: 110, 329].

As diversas entrevistas que realizamos sugerem que os militantes e agrupamentos encontraram percalços para a realização de avaliações aprofundadas de suas experiências durante o período, assim como para o estabelecimento de sínteses compreensivas sobre a repressão policial e o extermínio de seus partidos - dimensões as quais emergeriam como necessárias à elaboração coletiva destas memórias e histórias. Tal é aquilo que podemos inferir do depoimento de Laurindo Junqueira:

"Quando saí da prisão, o Régis foi a primeira pessoa que procurei, depois procurei o Eder Sader, pedindo orientação. Falei: '- Régis, como nós vamos fazer uma avaliação da prisão, do processo que a gente passou, como é que a gente pode deixar um legado disso?' Mas não senti receptividade do Régis, acho que ele não tinha força psíquica para aguentar uma discussão desse tipo. [...] No caso do Eder, [...] ele estava no jornal Em Tempo naquela época, já com vínculos estreitos com o PT, mas não quis assumir esse papel meio que de liderança do grupo, dos ex-presos políticos, mas nós o procuramos.

Eu os procurei logo depois da prisão [em 1973]. O Eder tava na França e, depois, logo que ele voltou. Eu, o Toninho, o Hélio, acho que o Stanislaw, não me lembro mais quem, nós o procuramos e pedimos orientação política. Algo assim: 'Como nós vamos remontar e nos reorganizar?' Mas o Eder não estava a fim disso, ele estava interessado em outro tipo de militância e foi muito claro: '- Não, vou escrever no jornal, etc'.

Aí não conseguimos e cada um foi para um lado. Alguns entraram no PT, eu me recusei a entrar, mas vim entrar muito mais tarde, quando fui pra Campinas ${ }^{934}$."

A despeito das dificuldades mencionadas, é importante considerar os significativos esforços com vistas à elaboração sintética das experiências vividas pelas esquerdas durante a ditadura e à avaliação de seu legado, ainda que tais esforços não tenham atingido a abrangência social necessária. Esta avaliação se aplica, por exemplo, ao grupo remanescente da ALN, que permaneceu organizado e atuante até pelo menos 1979. Este grupo elaborou um documento chamado “ALN: contribuição para um balanço

\footnotetext{
${ }^{934}$ Entrevista concedida por Laurindo Junqueira à autora. Idem, ibidem.
} 
autocrítico"935, que trata desde a formação da organização até o balanço de sua atuação após 1974. O texto foi concluído em 4 de novembro de 1979 e tinha como objetivo sistematizar a discussão dos diferentes núcleos do grupo para iniciar a elaboração de um “programa mínimo de reorganização” da ALN. Dir-se-ia que, apesar de sua importância contextual, o documento tem como objeto de interesse a avaliação da atuação da ALN no período anterior ao ano de 1971 para tentar explicar o isolamento social a que ficou reduzida a organização:

“O processo de cisão vivido em 71 representou também uma sacudida na prática da Organização, obrigando-a a preocupar-se mais seriamente com a fundamentação política dos encaminhamentos. De setembro de 71 a abril de 73 'O Guerrilheiro' será publicado com alguma regularidade, abrindo pela primeira vez um debate sistemático dentro da ALN. Os artigos de fundo que se sucedem no órgão interno refletem uma lenta evolução na autocrítica da prática desenvolvida, embora essa avaliação revele confusões e mesmo resistências quanto a uma decisão mais ousada em romper os desvios verificados.

[...] Ao invés de assumirmos a defensiva e preparmos uma retirada organizada para consolidar nossas forças, persistimos no vanguardismo, numa rotina de guerrilha urbana que se revelou inconsequente e levou a derrotas que quase raiaram o limite da extinção completa.

[...] Até fins de 73, prosseguirá em desenvolvimento esse processo autocrítico [...]. A palavra recuo já não é um fantasma inadmissível [...]. Foi uma autocrítica imposta pela dura realidade do isolamento crescente [mais] do que uma antecipação previdente, baseada na apreciação de sinais claros que apontavam perspectivas pessimistas.

Foi portanto uma autocrítica tardia e aquém do necessário. [...] não se partiu corajosamente para a implantação no seio das classes populares e não se acionou o recuo organizado que a realidade exigia, antes que fosse desagregada, em 74, a última de nossas coordenações nacionais.

[...] Em 1977 foi feito um primeiro esforço de rearticulação geral, que se propunha a cumprir etapas prévias de discussão para culminar numa recomposição orgânica. [...] E a dispersão voltou a ser a tônica, ficando os vários setores mais uma vez agindo isoladamente [Idem, ibidem].”

O grupo fez uma dura avaliação sobre o peso da dinâmica da sobrevivência na clandestinidade, que impôs o ciclo vicioso das ações armadas urbanas. Presa a essa dinâmica, predominou na organização a autonomia tática de pequenos grupos, o que inviabilizou o debate político interno e a formação dos militantes. O texto não poupou críticas às análises superficiais da conjuntura econômica, que se mostrava em ascensão e totalmente desfavorável aos dissidentes no momento em que deflagraram a luta armada.

A partir desta avaliação despontou no grupo a perspectiva de que seria importante se reaproximar do tipo de organização revolucionária de tradição leninista. Em 1979, os remanescentes da ALN preocupavam-se em combater o reformismo expresso nas

\footnotetext{
935 “ALN: contribuição para um balanço autocrítico”, 04/11/79. A pessoa que forneceu o documento prefere manter seu nome em sigilo.
} 
concepções do PCB, assim como visavam definir o tipo de organização mais adequado para aquele momento. Como a Ala Vermelha e o PCBR, entre outros grupos, a ALN não reviu sua posição quanto à importância da luta armada em determinadas circunstâncias históricas. Estas preocupações resumem-se na seguinte colocação da autocrítica do grupo:

"Como aliar nossa perspectiva de luta armada com nossa postura atual, em que corretamente não estamos lançando mão de operaçãos armadas; como comportar-se frente à questão da articulação partidária hoje em curso; em que sentido orientar a política de frente com outras organizações revolucionárias; onde concentrar esforços prioritários etc [Idem, ibidem]."

Algumas destas análises estavam em descompasso com uma série de debates político-teóricos que já apareciam na impresa alternativa da época, mas constituíram-se numa importante tentativa de avaliação que não prosseguiu e que muito teria a contribuir para a elaboração e conhecimento dessas histórias e memórias.

É digno de nota que, para além da especificidade das autocríticas realizadas, o sentimento de isolamento social durante a ditadura tornou-se generalizado entre os diversos grupos constituintes das esquerdas, revelando-se relativamente independente do modelo de combate escolhido e, em termos mais específicos, da posição assumida em relação à luta armada.

Ricardo Azevedo, entre outros, associa o isolamento social a graves erros de avaliação política cometidos por todos os grupos de esquerda nos anos 1970, isolamento que não autorizava a busca pelo confronto direto (ele não distigue, porém, partidos como o PCB de outros que, claramente, optaram pela luta armada):

“[...] acho que a experiência dos anos 70 tem dois lados. De um lado a resistência à ditadura foi fundamental e nós fomos para a resistência. Tinha que resistir, isso eu acho que é um marco na história do Brasil. De outro lado a gente errou muito politicamente e isso fez com que quase na sua totalidade a esquerda existente naquele período tenha sido dizimada. Qual foi a organização que sobreviveu, eu não vou dizer intacta, mas mantendo a maioria das suas bases, dos seus quadros? Nenhuma. Algumas foram inteiramente dizimadas, outras, parcialmente, mas todas foram muito golpeadas, primeiro, porque tinha uma ditadura militar assassina, feroz e etc.; segundo, porque nós erramos muito na política, todas [as organizações], sem exceção. Do PCB à mais esquerdista erraram na política. Nos isolamos socialmente e tentamos ir direto para um confronto com o aparelho repressivo. Só podíamos perder. Então, acho que é um grande aprendizado político, mas é um aprendizado muito duro, porque à custa de muitas perdas, de muitas mortes, mas acho que a esquerda brasileira tem algumas particularidades que não encontro em outras de outros países. Acho que é uma capacidade, primeiro, de reflexão autocrítica, e, segundo, de interação que não vejo na esquerda argentina, francesa, chilena, para citar três que conheci $^{936}$."

\footnotetext{
${ }^{936}$ Entrevista concedida por Ricardo Azevedo à autora. Idem, ibidem.
} 
Outras entrevistas sugerem, no entanto, que o processo de avaliação e de reflexão autocrítica das esquerdas brasileiras enfrentou muitas resistências internas e de diversos setores da sociedade. Destacam-se também as dificuldades inerentes àqueles que pertenciam aos grupos extintos pela repressão estatal. Desse modo, persistem as resistências em realizar uma avaliação da atuação de vários grupos guerrilheiros, assim como das circunstâncias das mortes e desaparecimentos de seus militantes, cujas histórias ainda desconhecemos. A Guerrilha do Araguaia, por exemplo, é um caso emblemático. O debate a respeito de seu isolamento em relação à população local e sobre outras questões referentes à guerrilha rural no país não se desenvolveu, em grande medida, em função do silêncio imposto pelo Estado brasileiro, mas também à persistente recusa do PCdoB em fazer uma avaliação aprofundada sobre a guerilha [RIDENTI, 1993]. De acordo com Criméia de Almeida, a análise sobre o isolamento social da guerrilha é polêmica:

"Para a população éramos simples posseiros, mas com o tempo, à medida que se estreitava o nosso relacionamento com a população e surgiam os problemas políticos, nós discutíamos com eles. [...] Apenas não falávamos que éramos do partido, nem sobre a preparação da guerrilha, por uma questão de segurança. [...]

[...] Em abril de 1972, quando as Forças Armadas chegaram à região [...], os guerrilheiros foram obrigados a se refugiar na mata para se defender e, concomitantemente, procuraram a população local, de quem desde o início obtiveram informações e alimentos.

As patrulhas de militares que nos atacaram [...] eram formadas por militares preparados, mesmo assim demoraram mais de dois anos para derrotar a guerrilha.

No início, o Exército conseguiu isolar bastante os guerrilheiros, mas mesmo assim foi possível manter um vínculo com o partido nas áreas próximas, no Maranhão e Goiás, o que nos ajudou a refazer o contato com o Comitê Central. Com a queda de grande número de dirigentes no Rio e em São Paulo, acredito que o isolamento da guerrilha foi maior ou completo [...].

Nunca participei de um debate no partido sobre o assunto, mesmo depois da anistia e da reorganização na legalidade. Acredito que houve erros não só militares, mas de avaliação política, principalmente, sobre o poder da ditadura de fazer aliados e nos isolar, inclusive entre os camponeses. Anos depois, quando voltei à região, pude perceber quantos se alinharam do lado dos militares, não só pelo poder que os militares tinham, mas porque eram "comprados". E, ainda hoje, "vendem” o seu silêncio.

[...] Em fins de 1978 [...] ainda estava sob o impacto dos acontecimentos de 1976, queria esclarecer melhor as coisas, o que esperava fazer com o retorno de João Amazonas do exílio. Fui convidada pelo Genoíno para dar entrevista ao Jornal da Tarde sobre o fim da guerrilha, mas não confiava em ninguém.

Quando voltou, o Amazonas não quis conversar [...]. Ele alegava que eu tinha lhe causado problemas, antes da queda da Lapa, quando informei aos companheiros que a pessoa com quem eu havia tido contato era ele [...].

Com a 'legalização', encontrei muitas barreiras para participar no partido, hoje acredito que isso se deveu ao fato de que os dirigentes, nessa época, eram aqueles que me afastaram em 1976.

Em 1982, eu e outros familiares de desaparecidos fizemos uma revista sobre os 10 anos da Guerrilha do Araguaia, impressa pela editora do partido, Anita Garibaldi. Toda a edição foi subsidiada por empréstimos feitos pelos familiares, não houve ajuda do partido. Quando fomos expulsos ou afastados do partido em 1987 [...], a editora ficou com a 
revista; fizeram mais duas ou três edições, alterando, inclusive, o seu conteúdo inicial $[\ldots]^{937}$."

Os partidos remanescentes tiveram de lidar com as cobranças e vicissitudes de fazer uma avaliação dos erros políticos e com as responsabilidades e posturas que acarretaram em prisões e perdas humanas, aspecto ainda mais penoso, conforme destacou Vicente Silvestre:

“[...] Fui para o [presídio] Hipódromo em meados de 76 [...], foi então que entrei em contato com a direção do partido propriamente dito. Estavam lá o Marco Antônio do Comitê Central e outros mais. Estava lá também o tesoureiro geral do partido e ele me disse: '- Para nós foi uma surpresa vocês terem caído, porque de há muito essa célula estava desativada'. Eu falei: '- Bom, mas se a célula estava desativada e a nossa contribuição mensal que entregávamos para o Renato?' Ele falou: '- Nunca entrou esse dinheiro'. Esse episódio me deixou profundamente revoltado, porque, para mim, o partido era um negócio muito sério, lá só se cuidava com pessoas honestas, direitas, idealistas e isso não podia acontecer dentro do partido. Tanto que me afastei imediatamente do Renato Motta, que era o contato da nossa célula com o C.C. [...]. Soube mais tarde que ele morreu no Rio de Janeiro, mas esse episódio me deixou muito chocado com relação ao partido.

[...] nós achamos que aquele não era o momento de levantar o problema. O Renato iria ficar numa situação difícil [...]. Nós tínhamos de enfrentar o problema do momento, com dignidade $[. .$.$] .$

Nós não discutimos dentro da prisão certas quedas, como a do Marco Antônio, que acarretou uma série de prisões, porque lá não havia só o PCB, tinha o PCdoB, tinha o pessoal da ALN. Acho que uma discussão desse tipo iria provocar choques, não era oportuno brigarmos dentro da prisão.

$[\ldots]$ Depois que acabou a ditadura, nós nunca mais voltamos a discutir isso $[\ldots]^{938}$.”

A avaliação de Frederico Pessoa indica que o balanço sobre as prisões e desaparecimentos dos militantes e dirigentes do PCB ficou inconcluso e restrito à direção do partido. Inicialmente, o fato dos dirigentes que desapareceram atuarem na clandestinidade, sem relação com um trabalho político e social legalizado, dificultou a circulação e a articulação das informações e dos movimentos de denúncia. A relativa inserção no movimento social, porém, não evitou novas prisões e desaparecimentos dos militantes do PCB. Com o agravamento da luta interna e a restrição do debate sobre o balanço da sua atuação, sua história se tornou, de certo modo, incompreensível para a militância do partido, dificultando o restabelecimento e a atualização de sua identidade política, assim como a construção e fortalecimento dos vínculos com seu passado:

"Havia dentro do partido algumas pessoas da direção que conseguiam enxergar mais longe e, naquele período, a partir das quedas do Rio de Janeiro em 1970 fizeram essa

\footnotetext{
937 Entrevista concedida por Criméia A. S. de Almeida à autora. SP, 27/07/2000, 28 e 30/11/2001, e 20/10/2004.

${ }^{938}$ Entrevista concedida por Vicente Silvestre à autora. Idem, ibidem.
} 
avaliação: a luta armada foi exterminada ou está sendo exterminada, [...] e era uma questão de tempo: a ditadura viria em cima do partido, principalmente, por conta de sua influência no movimento legal. O Golbery já sabia que a ditadura tinha seus dias contados, a tal da abertura lenta e gradual não era bondade do Geisel, era um esforço de controlar a transição. O que eles conseguiram no fundamental [...]. Significava tirar do movimento legal aqueles [...] com influência dentro do MDB, do movimento sindical, do movimento de massa [...]. Em 1970, 1972 e 1974, a repressão atingiu principalmente a organização do partido, os dirigentes, o Comitê Central e o Comitê Estadual, mas em 1975, a repressão vai em cima dos militantes que tinham atividade legal.

[...] Era uma repressão direcionada, bem demarcada, e nesse aspecto há duas constatações: a primeira, [...] é que houve infiltração [...] de uma maneira que, até hoje, ninguém tem a dimensão ao certo. A gente não sabe quem são etc. [...] A segunda, foi negligência. $\mathrm{O}$ partido, em que pese a existência dessas pessoas que enxergavam mais longe, e, a direção como um todo, subestimou essa questão e não adotou a rigor nenhuma medida para reduzir 'a pancada'. A direção continuou trabalhando com os aparelhos, com os carros, com toda a estrutura que vinha até de antes de 1964!

[...] A gente não tinha ideia da dimensão do negócio. Num primeiro momento, nós achamos que a coisa estava restrita a uma parte do Comitê Central, isto porque sabíamos do episódio anterior, quando os agentes da CIA procuraram membros do Comitê Central. Num primeiro momento, a gente achou que era uma coisa parecida, [...]: '- Já que os caras não toparam [se infiltrar], então, vamos pegá-los!’ Acho que passamos a ter noção da dimensão da coisa, quando estávamos sendo preso. Foi uma coisa muito concentrada: em dois meses, setembro e outubro, as prisões aconteceram no Brasil inteiro.

[...] o Comitê Central fez uma investigação paralela para tentar entender quem seriam os infiltrados, os agentes da CIA etc, que terminou muitos anos depois com o relatório do Hércules Correia.

[...] depois que as coisas aconteceram se vê que não foram fatos isolados, foi uma operação. Como eles chegaram a esses [...] companheiros? Até hoje, nós não sabemos, mas na medida em que as coisas foram acontecendo, não parecia uma operação articulada [...]. Pelo menos, a maior parte dos casos tinha uma explicação. E [...] com o tempo as pessoas vão relaxando, já tinham se passado dez anos desde o golpe militar. [...] conheço uma meia dúzia de militantes que nunca deu mole... Agora, uma grande parte não, vai relaxando.

[...] Sucederam-se [...] disputas internas. [...] O Prestes se afastou do partido [...]. O grupo do David Capistrano acabou ingressando no PT. [...] O que restou do partido se trasformou em PPS [em 1992] e, nesse momento, me afastei da atividade partidária.

[...] A minha frustração foi essa, eu achava que quando mudasse a correlação de forças, essa questão e da anistia seriam retomadas, [...] mas a sensação que tenho é que a maior parte das forças políticas que se pretendem de esquerda [...] não têm mais nenhum compromisso com o resgate dessa história [...]. Todo ano quando a gente faz a entrega do Prêmio Vladimir Herzog em Direitos Humanos é o mesmo discurso [...], não tem mais a tortura contra o preso político, mas precisamos acabar com [...] o desrespeito aos direitos humanos dos pobres! Como é que você vai enfrentar essa questão se não punir a tortura? Como é que o torturador da delegacia, hoje, vai se sentir intimidado de torturar, se os torturadores estão todos aí 'nadando de braçada' e até com respaldo de governo?! [...] Nenhuma entidade, categoria, central sindical tem esse compromisso com os seus mortos... 939 ",

Para alguns entrevistados, a avaliação da experiência guerrilheira é extremamente negativa. De acordo com a análise de Lúcia Murat, a partir de determinado momento, a

${ }^{939}$ Entrevista concedida por Frederico Pessoa da Silva à autora. Idem, ibidem. 
luta teria perdido sua perspectiva política e o sentimento de culpa em relação aos companheiros presos ou mortos se tornou sua motivação principal:

“[...] Imagine, todos os meus amigos tinham sido presos ou mortos. Eu tinha 21 anos de idade, era um horror, quer dizer, a minha família me mandaria para a lua se eu quisesse sair do país. Realmente, era uma coisa tão clara a derrota que hoje acho que a gente só ficava aqui por uma relação total de sentimento de culpa com quem tinha morrido, com quem estava preso. Era uma coisa tão clara que a gente já tinha sido derrotado naquele momento, a gente já tinha entrado num ciclo de sobrevivência, não conseguíamos fazer mais nada. Agora, eu estava na Bahia, um pouco longe disso. Acho que tive essa visão, quando voltei para o Rio, porque foi duro quando voltei. Em suma, acho que, do ponto de vista emocional, havia mais uma relação de culpa que nos fazia ficar do que uma análise política, porque era claro o que estava acontecendo, o grau de isolamento em que a gente estava. A essas alturas, mesmo no Rio, depois do sequestro do americano, depois que começaram as quedas, você encontrava um cara na rua que era parceiro do movimento estudantil, ele te olhava e saía correndo. Ninguém te dava mais guarida, todo mundo tinha medo! Até porque a repressão era fudida mesmo, matava todo mundo. A situação mudou inteiramente.

[...] no final, se começa a discutir a questão do ciclo de sobrevivência, que a gente tinha virado marginal, vivendo [...] naquela mecânica de assaltar para ganhar dinheiro para sobreviver, sem conseguir fazer nada, cada vez mais isolado, e o documento do Ladislau [Dowbor], o Jamil, foi importante.

[...] Sofri um baque com a perda dos meus amigos mais próximos, com a morte do Zé Roberto [Spiegner]. Foi um horror!

[...] É difícil, é difícil! A gente estava num ritmo muito acelerado. Eu era comando de organização, tinha perdido muita gente, quer dizer, não via saída a não ser continuar naquilo. Não me via de outra maneira, não via o mundo de outra maneira. Tudo estava muito denso, muito pesado, não me vi fazendo outra coisa que não fosse aquilo ${ }^{940}$."

Outros entrevistados, no entanto, caracaterizaram a experiência guerrilheira como

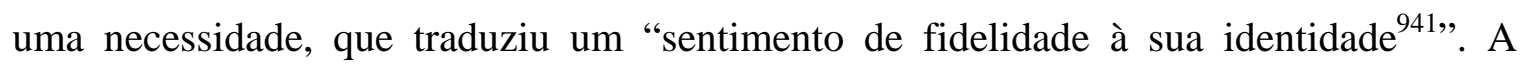
experiência guerrilheira foi parte de sua busca para encontrar caminhos para resistir à ditadura e construir um projeto revolucionário para a sociedade brasileira. De acordo com Pedro Rocha, muitos fatores contribuíram para que ele continuasse na guerrilha mesmo quando a derrota parecia evidente. Segundo sua avaliação, era necessário insistir para encontrar alternativas e o sentimento de culpa pelos que tombaram foi apenas um dos elementos que influenciaram aquela conjuntura complexa. Não predominava nessa busca um sentimento autodestrutivo. Ele sublinhou que na sua percepção havia “[...] mais a

\footnotetext{
${ }^{940}$ Entrevista concedida por Lúcia Murat à autora. Idem, ibidem. De acordo com as conclusões da CEMDP, Spiegner possuía marcas de tortura próprias do uso de pau-de-arara, recebeu vários tiros, um deles a distância, na coxa, e outro de execução, a queima roupa, na cabeça. As descrições do laudo necroscópico desmentem a versão de tiroteio, assim como a de morte "por acidente”. Ele morreu no Rio de Janeiro, quando já estava preso em dependências do Estado, em 17/02/70. V. ALMEIDA, 2009, p.179-180.

${ }^{941}$ Expressão do historiador Jean-Pierre Vernant referente à sua participação na resistência francesa contra o nazismo e na luta contra a guerra colonial na Argélia. RouDinESCO, Elizabeth. "Georges Canguilhem”. In: Filósofos na tormenta. Canguilhem, Sartre, Foucault, Althusser, Deleuze e Derrida. Rio de Janeiro, Zahar, 2007, p. 32.
} 
presença desse sentimento de culpa entre aqueles que foram para o exílio, do que entre os que ficaram ${ }^{942}$."

O processo de reconhecimento da derrota ocorreu de maneira distina para cada grupo ou indivíduo, o qual emerge marcado por vicissitudes subjetivas, mas também políticas de grupos e instituições. Não obstante, Pedro Rocha avalia essa luta de forma positiva:

“[...] algumas pessoas, mesmo depois de sair do presídio, ainda acreditavam que podiam se reorganizar, [...] reagrupar essa turma e recomeçar ou continuar [...]. Portanto, não estavam aceitando até então a derrota de uma política, embora aceitassem uma derrota tática, momentânea, em função da perda de militantes etc. Acho que hoje essa posição não existe mais. Ninguém acha que a luta armada do jeito que nós fizemos, resolva alguma coisa, agora ou mesmo daqui a pouco. Acho que o pessoal está mais numa de política de luta institucional, de movimentação de massa, ninguém mais pensa em reorganizar núcleo guerrilheiro no país no curto e médio espaço de tempo. Até 1977, quando saí da cadeia, acredito que ainda existisse essa posição.

[...] Mas, talvez, a perspectiva de realizar mudanças significativas apenas pela via institucional tenha levado a um grau maior de conciliação do que o desejável, do que o necessário.

[...] Acho que tudo que a gente fez, fez porque no momento tinha que ser feito. [...] Tudo que se faz é experiência positiva, ainda que se cometa erros. Acho que muitos erros foram cometidos, mas isso não tira o caráter de experiência. Tenho orgulho de ter vivido essa trajetória, desde menino praticamente até 1980 e pouco. Acho que eu não tinha muitas alternativas na época, infelizmente. [...] A nossa derrota, no caso da guerrilha, foi muito dolorosa. [...] Perdemos muita gente boa, muita gente de primeira linha. [...] Não quero dizer intelectualmente, [...] quero dizer gente disposta, combativa, a fim de lutar por um Brasil melhor; e isso é sempre lamentável. Esse é o custo da revolução, é o custo social da opção que foi feita. O que resta pra gente fazer é continuar coerente, [...] quem sabe conseguindo a melhoria de algumas coisas. Espero que a revisão da Lei de Anistia possibilite a condenação dos torturadores, que considero que é a grande falha dessa história [...]. Mas [...], se não houver uma mobilização [...], pode continuar desse jeito $[\ldots]^{943}$."

A autocrítica das esquerdas registrada nos testemunhos se fixou, em grande medida, nas questões relativas ao isolamento social. A partir desta perspectiva, existiu uma grande disposição dos militantes em atuar nos novos partidos políticos. A despeito do caráter positivo dos esforços empenhados neste sentido, esta disposição foi, em parte, prejudicada por dificuldades para a manutenção das identidades próprias dos grupos da esquerda revolucionária, o que por sua vez caminhou em contiguidade com sua generalizada diluição nos grandes partidos e as resistências e dificuldades em constituir movimentos sociais autônomos, conforme o relato de Vicente Roig:

\footnotetext{
942 Entrevista concedida por Pedro Rocha Filho à autora. SP, 24/02/2011.

${ }^{943}$ Entrevista concedida por Pedro Rocha Filho à autora. SP, 05/03/2010. AAPP/AEL-LEI.
} 
“[...] uma coisa muito importante que aconteceu com a gente de Ala, a partir da autocrítica, é que nós baixamos a nossa bola.

Nós estávamos [...] trabalhando lá embaixo. Quando a gente faz autocrítica, a gente chega à conclusão de que não adianta atuar na superestrutura. [...] Se você analisar qualquer revolução, vai ver que as pessoas que as fizeram tinham atrás de si um contingente significativo [...]. Nós estamos tentando criar primeiro uma consciência de classe na classe operária, essa é a nossa prioridade zero. [...] Os movimentos que a classe média vinha fazendo [como a luta pela anistia e as diretas], [...] ótimo, mas...

[...] um dos momentos mais importantes, foi o da fundação do PT. Íamos de casa em casa, convidando e recrutando gente para entrar no PT. A gente conseguiu formar o PT, participar das eleições e eleger dois vereadores. Isso, a certa altura, era uma rede. A gente fazia reuniões na sede do jornal [...], sobre o PT, sobre outros temas, com a Oposição Metalúrgica e sobre questões políticas. Tinha a Casa de Cultura que a gente ajuda a montar também.

[...] A gente começou a se acostumar com o fato de que a realidade era mais forte do que nós e nos acostumamos - eu, pelo menos - a atuar dentro da realidade. Posso me indignar, posso ser contra as atitudes que foram tomadas, mas daí a tirar uma posição... A gente era contra o colégio eleitoral, era a favor das "Diretas Já”, por suposto, mas, aí veio o colégio eleitoral, o que a gente ia fazer? [...] A esquerda, naquele momento, não atuava nesse plano do poder, nós não estávamos próximos do poder.

[...] Depois das eleições do PT de 82, fiz uma proposta, pois achava que [...] aquele tipo de partido não tinha sentido; propus que nossa organização se transformasse numa tendência dentro do movimento sindical. Continuaríamos nos reunindo, discutindo, porque era um grupo que já tinha uma discussão privilegiada, mas não mais com um 'nome de guerra', como partido do proletariado, porque isso era uma coisa que não estava no horizonte político. Então, era necessário abaixar a bola e criar uma tendência dentro do movimento operário. Fiz essa proposta - convém dizer que nesse momento eu era da direção nacional da Ala - eu era do secretariado, formado por três pessoas. O secretariado discutiu e a gente encaminhou essa posição. Havia outra posição que era a de que a gente devia se transformar numa tendência, mas se diluir no PT, não no movimento sindical. Aí a coisa ficou meio parada e, no fim, quem achou que era para ir para o movimento sindical foi e quem achou que era para ir para o PT foi. E acabou aí a minha história e a desse grupo político que esteve preso. [...] Passei a trabalhar como advogado em sindicatos ${ }^{944}$.”

Uma parcela significativa das esquerdas considerou prioritário levar adiante uma militância nos partidos políticos para se fortalecer e realizar um "trabalho de base", especialmente, no PT. Alguns decidiram aderir inteiramente ao projeto de criar os novos partidos, com destaque para o PT, extinguindo os grupos clandestinos remanescentes, conforme o relato de Ricardo Azevedo:

“Na AP [...], um setor de São Paulo começou a defender que tínhamos de ficar no PMDB, mas a grande maioria da organização, $90 \%$, era a favor de entrar no PT. [...] a questão era entrar como AP, organizadamente, mantendo a sua estrutura clandestina, ou entrar individualmente. Eu puxo a posição de entrar individualmente contra a posição do Jair [Ferreira de Sá] e da Doralina, que era a de entrar no PT e manter a AP, como diversas outras organizações fizeram. O MEP, a Ala Vermelha e outros fizeram isso [...]. Depois, todas se dissolveram. No final de 79 estava havendo esse processo de discussão [...], o Geraldinho se precipitou e declarou a sua adesão ao PT. Já havia uma maioria da AP que

${ }^{944}$ Entrevista concedida por Vicente Roig à autora. Idem, ibidem. 
ia nesse sentido, mas não tinha havido uma resolução formal. Ele foi muito pressionado como deputado estadual na Assembleia, o Airton Soares já tinha entrado e outros deputados também, então ele aderiu ${ }^{945}$.”

O relato de Artur Scavone indica uma experiência que guarda semelhanças com a trajetória descrita acima. Ele ingressou no PT e se dedicou à formação do partido, foi candidato a deputado nas eleições de 1982 e 1992 e atuou intensamente na vida partidária. Scavone saiu da prisão em 1977, pouco depois, em 1979, fez parte da dissidência do PCdoB, que resultou na criação do PRC (Partido Revolucionário Comunista) em 1984. O testemunho de Scavone e de outros aqui compilados sugerem que houve uma desradicalização ${ }^{946}$ das esquerdas nos anos 1980, quando vários adotaram uma postura de distanciamento dos projetos ideológicos gestados nos anos 1960 e encontraram muitas dificuldades para reconstituir sua identidade, levando em conta essa herança política dentro do novo cenário político:

"Era um período ainda difícil [...] achei melhor ir para Santa Catarina. Nesse período, acabei me movimentando muito para reestruturar as condições pessoais, de trabalho, de vida, para poder tocar as coisas. A minha participação dos movimentos de anistia ficaram bem lá embaixo [nas prioridades], não porque não quisesse apoiar [...], mas porque eu estava me estruturando.

Depois, [...] começo a organizar o PRC [...]. Participei do processo de construção do PT, coordenei o movimento das Diretas Já [...], regularizo-me como jornalista pela prática da profissão [...], mas sou demitido [...]. Os caras falaram declaradamente: '- Você não pode trabalhar aqui, você é ex-preso político, não dá!’ Aí saio candidato a deputado estadual pelo PT em 1982, com a Lei Falcão, em que aparecia a cara e o currículo. No meu currículo estava "ex-preso político". Tive uns 400 votos, [...] não era para eleger, era para fazer o PT acontecer.

[...] Estava, nesse tempo todo, fazendo as duas coisas: PRC e PT. Voltei para São Paulo em 1984, [...] fui trabalhar como assessor de imprensa do José Carlos Dias, que era secretário de Justiça do Franco Montoro, [...] acusado de defender direitos humanos para bandidos [...]. Logo em seguida, o jornalista Milton Parron fez uma 'denúncia' dizendo que o José Carlos Dias estava contratando um ex-terrorista [...]. Pedi demissão [para não prejudicá-lo]. A bancada do PT, recém-eleita, abrigou-me e fui trabalhar na assessoria da bancada do PT com a Teresa Lajolo, vereadora de São Paulo.

A partir do PRC, a gente faz uma disputa muito grande dentro do PT, acho que muito produtiva, muito criativa. [...] o PRC ainda era clandestino, não era uma tendência aberta, [...] o PT meio que sabia, fechava os olhos e aceitava. [...] entro na executiva municipal do PT, depois, na direção nacional, faço parte da coordenação da campanha da Luiza Erundina, eu e o Carlos Neder. A gente elege a Erundina, o que foi um feito fenomenal em São Paulo, [...] ela é uma grande figura que ainda está aí brigando com os mesmos valores e com a mesma cabeça [...]. Há o primeiro governo do PT em São Paulo com uma porção de problemas, há uma crise dentro do PT, porque o partido não queria a Erundina. O PT, enfim, nós estávamos vivendo as dores do parto de uma nova realidade. Acho que a ditadura não foi derrotada, mas saiu de cena. Inicia-se um processo de disputa política

\footnotetext{
945 Entrevista concedida por Ricardo Azevedo à autora. Idem, ibidem.

${ }^{946}$ Expressão tomada emprestada de Maria Matilde Ollier utilizada no contexto argentino dos anos 1980 . V. Ollier, Maria Matilde. De la revolución a la democracia. Câmbios privados, público y políticos de la isquierda argentina. Buenos Aires, Siglo Veintiuno Ed., 2009, p. 184-200.
} 
que, [...] fecha um ciclo com a eleição do Lula. O PT cresce, [...] o PRC vive uma crise. Temos a queda do muro em 1989, que foi profundamente demarcadora de épocas. E o PRC, em um congresso, decide pela sua própria dissolução, por entender que não tinha mais sentido existir. Aí, uma parte do PRC forma a Nova Esquerda com o Genoino, Ozeas [...] e eu participo com outros da formação da Tendência Marxista [...] dentro do PT. [...] A Nova Esquerda depois se diluiu, aproximou-se da articulação e [...] fez uma tendência mais light ${ }^{947}$."

Não obstante, nas eleições de 1982, grupos e militantes remanescentes da esquerda lançaram candidatos que reivindicavam seu passado de luta armada, sua condição de combatentes e de ex-presos políticos. Esses grupos entenderam que essa herança tinha relevância e representava um capital político e eleitoral importante. O PRC, por exemplo, lançou um candidato a deputado federal pelo PT que destacava sua participação na Guerrilha do Araguaia: José Genoíno Neto foi eleito com 58.650 mil $\operatorname{votos}^{948}$. Naquela eleição, o PT elegeu oito deputados federais no país, seis deles de São Paulo e vários ex-presos políticos ${ }^{949}$. Esta foi ma vitória bastante significativa, pois não era fácil se eleger pelo PT, que disputava pela primeira vez uma eleição.

A análise das resoluções do PT indica a transformação do partido e o distanciamento ideológico em relação ao passado revolucionário das esquerdas. Além disso, gradualmente, as questões pendentes do passado de ditadura vão perdendo destaque; esta temática aparece nos documentos do partido até $1994^{950}$.

Os militantes da Oposição Sindical Metalúrgica de São Paulo entrevistados nesta pesquisa, por outro lado, exemplificam uma experiência de atuação política mais autônoma dos trabalhadores. Depois de libertado, Stanislaw Szermeta, militante do extinto POC, passou a trabalhar em fábricas de São Paulo em 1974. Participou muitos

\footnotetext{
${ }^{947}$ Entrevista concedida por Artur Scavone à autora. Idem, ibidem.

${ }^{948}$ V. o site www.genoino.org. Acesso em: 07/05/2011.

${ }^{949}$ O Congresso Nacional era composto por 479 deputados federais. Na eleição de 1982, o PT elegeu uma ex-presa política, Bete Mendes, e um advogado de defesa, Airton Soares. Djalma Bom, o mais votado, havia sido preso com Lula, na greve dos metalúrgicos de 1980. O PMDB elegeu 2 deputados que eram militantes do PCB: Alberto Goldman (com 113.844 votos) e Marcelo Gato (54.428). O PT teve 4 guerrilheiros candidatos, que não se elegeram mas tiveram expressiva votação: José Ibrahim (34.826); Alípio Freire (21.002); Altino Dantas (20.319) e Raphael Martinelli (10.621). Juntos, eles somaram 86.768 votos. Outros candidatos de partidos clandestinos se candidataram pelo PMDB: José Aníbal (44.375); Ricardo Zaratinni (35.839); Aldo Rebelo (30.591) e Claudio Campos (24.445). V. Folha de S. Paulo, 25/11/82, p. 6.

${ }^{950}$ Na primeira plataforma política escrita antes de sua formalização, o PT reivindicava anistia para todos perseguidos políticos e a reintegração em seus cargos de todas os que foram demitidos ou aposentados por força de atos de exceção; pedia pela desativação dos órgãos repressivos; o fim da tortura, a investigação das arbitrariedades policiais e punição dos responsáveis; e o fim dos tribunais de exceção. V. Resoluções. Documentos pré-PT, 13/10/79. Em 1994, o PT passou a defender a abertura dos arquivos policiais e militares para esclarecer os casos de "desaparecidos" e assassinatos de opositores do regime militar. A Constituição de 1988 havia mantido parte do entulho autoritário e precisava ser revisada. V. Resoluções. op.cit.
} 
anos da coordenação da “Oposição” e teve uma atuação destacada nas greves metalúrgicas daquele período. A “Oposição”, contudo, também acabou aderindo ao PT e se dissolveu no partido, conforme o testemunho de Szermeta:

“A eleição [sindical] de 1981 foi uma eleição que nos tencionou barbaramente, porque já vínhamos de um processo de unificação e organização na prática, [...] e os outros que racharam conosco não tinham uma identificação, eles tinham outras formulações e, [diziam] que nós fazíamos a construção de um sindicato paralelo. Nós dizíamos que aquilo era a construção de um trabalho com autonomia, com independência, com programa, com uma coordenação, com uma linha de trabalho que tivesse um conjunto definido. Esse conjunto era definido em assembleias da Oposição, ele não era definido na coordenação. [...] O que aconteceu foi que por [...] diferenças no processo de condução da conjuntura se deram as chapas do Aurélio [Peres] e do Waldemar [Rossi]. [...] No processo da eleição ficou difícil explicar para a categoria, que tinha duas oposições, duas chapas. [...] nós fizemos a maior das forças, no segundo turno o Aurélio veio, mas já estava feito o estrago, [...] nem todos que votaram no Aurélio votaram posteriormente na Oposição. Com isso, a Oposição acabou perdendo, [havia...] oito, nove mil votos de aposentados.

[...] a Oposição começa cada vez mais a definir um bloco e os partidos começam a ter a sua autonomia de organização, de expressão e [...], a partir de 1981, o enfrentamento é cada vez mais com a pelegada e com os grupos de esquerda, que vão se juntando no sindicato, o PC, PCdoB, MR8. Esses grupos definem a estratégia de ir para dentro do sindicato.

A Oposição não entra no PT, porque a esperança do conjunto que atuava era a de formar alguma coisa em termos de um partido que tivesse uma postura mais classista, [...] que construísse um programa que apontasse para o socialismo, que apontasse [...] para o processo revolucionário e desse guarida para esse 'pé’ que sempre faltou para a Oposição. [...] chegou um momento em que alguns da Oposição foram para o PT e também começaram a participar da CUT. Em 1985, 1986 a Oposição toda entra no PT. A CUT era [...] uma das bandeiras da unificação dos trabalhadores e desde o começo a Oposição participou dela. Esse também foi um dos elementos estruturantes da continuidade da Oposição, nesse sentido ela trabalhou os opostos, [mas ...] o Lula não apoiou a Oposição, sempre teve restrições.

[...] A Oposição [...] trabalhava essa questão estratégica e avançou no processo de organização dos trabalhadores. [...] Depois de 1987 há, realmente, um enfraquecimento da Oposição, [...] que não consegue mais trabalhar com tantos elementos contra, mesmo que o trabalho de fábrica continuasse.

[...] A minha vida foi combinada entre a atividade sindical e a atividade partidária do PT, que, naquela época, tinha uma importância muito grande, que avançava no processo de moradia, da resistência popular e essa coisa toda. [...] fui do PT até $2005^{951}$.”

Outros ex-presos políticos entrevistados nesta pesquisa construíram uma trajetória de militância mais distante dos partidos. Eles ajudaram a criar ou ingressaram em movimentos sociais, tais como o MST, o Movimento Feminista e ONGs independentes e atuantes, mas que, em geral, não são voltados para as questões relacionadas ao passado de ditadura. De acordo com o testemunho de Jorge Eduardo Saavedra Durão, coordenador da FASE (Federação de Órgãos para Assistência Social e Educacional) desde 1984:

${ }^{951}$ Entrevista concedida por Stanislaw Szermeta à autora. SP, 16/12/2009. 
“[...] como indivíduo avaliei bastante sobre [...] o descompasso ou a defasagem entre as minhas opções revolucionárias dos finais dos anos 60 [...] e as minhas próprias forças. [...] acho que era uma das características mais generalizadas da esquerda naquela época, a do voluntarismo absurdo. Eu era, sou e espero morrer como uma pessoa que detesta o capitalismo. Só que a minha maneira de fazer isso mudou muito, porque acho imprescindível que a gente tenha compromisso [...] com os valores democráticos. Isso significa, por exemplo, não ter nenhuma paciência com quem faz a defesa da atual situação dos presos políticos em Cuba; o que acho uma posição detestável. Resolvi que ia continuar brigando pelas mesmas causas na sua essência, mas dentro das minhas forças. Trabalho a trinta anos numa ONG que não faz concessões, que é respeitada pela fidelidade a determinados valores e princípios. É modesto o resultado do que a gente consegue fazer, mas pelo menos é uma coisa que tem consistência ${ }^{952}$."

Militantes aqui entrevistados buscaram por meio da expressão cultural e subjetiva outras maneiras de realizar o balanço da própria história e entendê-la, como é o caso da cineasta Lúcia Murat, que realizou três filmes premiados que tratam do período ditatorial:

“[...] parti para uma coisa mais artística, me distanciei muito de qualquer análise sociológica. É muito difícil para mim diante também de todas as perdas que sofri, falar qualquer coisa sobre arrependimento, não acredito nisso. Acho que a gente vive na época em que a gente vive.

Eu buscava uma elaboração sobre a tortura e, com certeza, foi a psicanálise que [...] me ajudou muito a tentar me entender, e [...] nos filmes, me ajudou muito.

[...] fiz o Que Bom Te Ver Viva, todos os trechos da Irene, a partir [...] da psicanálise [...]: escrevia a partir de tópicos, por exemplo, texto sobre transferência para o marido da relação com o torturador, foram textos feitos em cima de experiências que eu tinha processado. E, obviamente, não escapei delas, mas com certeza o fato de eu ter conseguido trabalhar com elas, me permitiu viver muito melhor.

[...] As entrevistadas não sabiam [do texto ficcional da Irene Ravache] e eu tinha muito medo delas não gostarem. Fiquei muito feliz quando na primeira apresentação todo mundo gostou muito do filme, todo mundo teve a mesma sensação que eu tive: - Bom, agora é a nossa vez de estar falando. [...] E o terceiro medo era de não conseguir comunicação com o público, porque era um filme muito agressivo [...]. O filme trabalhava muito no limite do que não era conhecido na época. Era o medo também de como o público ia aceitar.

[...] Acho que resta muito da ditadura ainda, [...] a violência, a tortura nas cadeias, tudo e vai continuar enquanto a gente não conseguir abrir os arquivos, enquanto a gente não conseguir discutir exaustivamente o que foi a ditadura [...] e caminhar para [a defesa] dos direitos humanos e a reeducação de todo mundo [...]. Quando o passei a primeira vez em Gramado, foi muito bonito, foi muito legal a repercussão com o público ${ }^{953}$.”

A despeito da persistência de alguns grupos e militantes, as entrevistas indicam que a ressignificação coletiva e plural dessas lutas e experiências do passado recente não foi tomada como uma tarefa pelo conjunto das esquerdas e da sociedade civil.

As demandas por "verdade e justiça" continuaram presentes no horizonte dos movimentos sociais e dos partidos políticos, âmbito no qual construíram um discurso de

\footnotetext{
${ }^{952}$ Entrevista concedida por Jorge Eduardo Saavedra Durão à autora. Idem, ibidem .

${ }^{953}$ Entrevista concedida por Lúcia Murat à autora. Idem, ibidem. Murat realizou outros dois filmes sobre esta temática: Quase Dois Irmãos (2004) e Uma Longa Viagem (2011). E está preparando outro mais.
} 
memória, mas que, a despeito de seu potencial crítico, manteve-se relativamente marginal, dificultando a construção de vínculos com o passado recente e com as memórias das vítimas e seus familiares.

Com a rápida dissolução dos movimentos de anistia, os sobreviventes encontraram dificuldades para se organizar em grupos ou movimentos que contemplassem suas reivindicações específicas e que ocupassem um espaço simbólico significativo na sociedade. Muito em função destas peculiaridades, esses grupos não levaram a cabo um projeto que delineasse e aprofundasse os elos com essa história necessários para uma reflexão crítica e para avançar na perspectiva de ruptura com o legado da ditadura. 


\title{
Considerações finais:
}

\section{As lutas e disputas pelas \\ memórias sobre a ditadura}

\section{O Projeto Brasil: Nunca Mais e a construção da memória sobre a ditadura}

\subsection{A conflituosa história das memórias}

Na atualidade, a relação entre história e memória e a reflexão sobre a temporalidade, o passado e os processos de mudanças sociais tornaram-se uma preocupação central e estão presentes em diversos campos do conhecimento. Historiadores, filósofos e estudiosos em geral têm se ocupado da questão e suas implicações. Partindo da perspectiva de que o passado, sendo algo findo e determinado, não pode ser mudado, enquanto o futuro, ao contrário, é incerto, aberto e indeterminado; o que pode ser mudado é o sentido desse passado, sempre sujeito a reinterpretações ancoradas na intencionalidade, nas disputas políticas e expectativas para o futuro. Desse modo, o sentido do passado é sempre ativo, dado por agentes sociais que estão em cenários de confrontação e disputa frente a outras interpretações, contra esquecimentos e silêncios e cuja intenção é estabelecer, convencer e transmitir uma determinada narrativa. Neste sentido, Paul Ricoeur assinalou:

\begin{abstract}
“Ainda que os feitos não sejam apagáveis e não se possa desfazer o que está feito, nem fazer com que o que sucedeu não suceda mais, o sentido do que passou, pelo contrário, não está fixado de uma vez por todas. Ademais de que os acontecimentos do passado podem ser interpretados de outra maneira, a carga moral vinculada à relação de dívida com respeito ao passado pode incrementar-se ou rebaixar-se, segundo tenham primazia a acusação, que encerra o culpável no sentimento do irreversível, ou o perdão, que abre a perspectiva da isenção da dívida, que equivale a uma conversão do próprio sentido do passado. Podemos considerar este fenômeno da reinterpretação tanto no plano moral como no do simples relato, como um caso de ação retroativa da intencionalidade de futuro sobre a apreensão do passado." 954
\end{abstract}

A investigação sobre os sentidos que o passado adquire ao longo do tempo consiste em analisar como processos e atores sociais intervêm no trabalho de construção e

954 Ricoeur, Paul. La lectura del tiempo pasado: memória y olvido. Madrid: Arrecife, Universdad Autônoma de Madrid, 1999, p.49, citado em JELIN, E. Op.cit., p.39. Tradução livre da autora. 
formalização das memórias sobre feitos e eventos dotados de duração e estabilidade. Atores sociais diversos, com diferentes vínculos com o passado, os que viveram as experiências passadas e os que as herdaram, os que a estudaram e a expressaram de várias maneiras, lutam para afirmar sua legitimidade e verdade. Atores que lutam pelo poder e legitimam sua posição por meio desses vínculos com o passado, afirmando continuidades ou rupturas com o mesmo.

Nestas disputas, os agentes estatais têm papel central para estabelecer e elaborar as histórias e memórias oficiais, processo em que algumas versões e relatos se dispersam e, outros, tornam-se hegemônicos. Intentos mais ou menos conscientes de definir e reforçar sentimentos de pertença para manter a coesão social e defender fronteiras simbólicas. Versões da história que junto com símbolos, monumentos e panteões de heróis nacionais servem para construir a identidade nacional. Como toda narrativa, estes relatos oficias são seletivos. Ressaltar certos traços com sinais de heroísmo implica silenciar outros, especialmente os erros e derrotas dos que passam a ser definidos como heróis. Frente à narrativa nacional transmitida pela educação formal constroem-se também relatos e sentidos diferentes do passado mantidos pela transmissão oral ou como práticas de resistência frente ao poder, muitas vezes constituídos nos âmbitos da intimidade ou da clandestinidade [JELIN, 2002: 39-42].

Os momentos de abertura ou transições políticas habilitam uma esfera pública e nela podem se incorporar narrativas antes silenciadas e gerar também novos relatos. Momentos em que ocorrem mudanças institucionais e na relação entre Estado e sociedade. Por vezes, as memórias de quem foi oprimido e marginalizado - de quem foi afetado pela prisão, tortura, assassinatos e desaparecimentos forçados ou exílio - surgem com a pretensão de dar a versão "verdadeira” da história através do seu testemunho e exigir justiça. Nesses momentos, memória, verdade e justiça parecem confundir-se. Estas conjunturas mostram que os processos de recordar ou suprimir a memória não ocorrem de forma linear e nem correspondem diretamente ao tempo cronológico. Não se apresentam na contraposição simples entre Estado e sociedade e, tampouco, o Estado se manifesta de maneira unitária, eventualmente, ele se articula com a multiplicidade de sentidos do passado em disputa. Esses momentos representam “um novo intento fundacional” [JELIN, 2002: 43-4], onde estão em conflito novas e velhas leituras do passado.

No Brasil, o período pós-ditadura foi marcado pela publicação do relatório do Projeto Brasil: Nunca Mais, o primeiro momento em termos de construção da memória social sobre os crimes da ditadura. O relatório do projeto, conhecido por meio do livro 
Brasil: Nunca Mais, publicado em julho de 1985, possibilitou uma ampla tomada de consciência coletiva em relação à amplitude da política repressiva da ditadura. No que se refere aos marcos de memória, representou um ato de fundação na construção da memória sobre a repressão política desse período. O projeto definiu, em grande medida, o lugar dos sobreviventes, trazendo a público um exaustivo levantamento a respeito dos crimes, das vítimas e dos perpetradores fundamentado, exclusivamente, pela documentação encontrada nos arquivos da Justiça Militar. Este primeiro núcleo organizacional influenciou decisivamente a opinião publica e, ainda hoje, é uma contribuição fundamental para a formação escolar e a pesquisa acadêmica, assim como para a sistematização de denúncias dos crimes do período ditatorial. As operações de memória influenciadas por este trabalho têm se prolongado em desdobramentos, construídos lentamente ${ }^{955}$.

A abertura da vala clandestina de Perus, em setembro de 1990, a fim de recuperar os restos mortais de militantes assassinados pela repressão estatal na ditadura, e as sucessivas escavações arqueológicas realizadas desde então, tornaram-se símbolos da construção da memória do período pós-ditadura, marcada por bloqueios e mecanismos de denegação. Neste processo, a visibilidade das denúncias dos crimes cometidos pelo terrorismo de Estado não se deu nas instâncias da justiça ${ }^{956}$, nem por meio de procedimentos e instituições extrajudiciais como as Comissões de Verdade, mas, principalmente, através da divulgação de relatórios e informes, como os do Projeto Brasil: Nunca Mais ${ }^{957}$.

A memória social representa práticas com marcas e suportes. Neste sentido, no período pós-ditadura a abertura da vala de Perus figurou como o segundo momento mais importante no que se refere aos marcos de memória, adquirindo o significado de um ato de fundação na construção da memória sobre a ditadura, em especial, sobre os mortos e desaparecidos políticos e seus familiares. Este fato teve implicações políticas e deu

\footnotetext{
${ }^{955}$ Utilizei como referência para esta análise, o texto de CAPELATO, Maria Helena R. Memórias da ditadura militar argentina: um desafio para a história. São Paulo, 2007, mimeo, p.14-7.

${ }^{956}$ Tratei da importância simbólica do Tribunal Tiradentes (1983) e da abertura da Vala de Perus em TeLes, Janaina de A. Os herdeiros da memória: a luta dos familiares de mortos e desaparecidos políticos por "verdade e justiça" no Brasil. Mestrado, História/FFLCH, USP, 2005.

${ }^{957} \mathrm{O}$ relatório resumido do projeto foi divulgado em 38 edições, sendo a última de 2009. Nos dois anos subsequentes à publicação do livro, foi a obra mais comprada pelos brasileiros. V. LIMA, Samarone. Clamor. A vitória de uma conspiração brasileira. São Paulo, Objetiva, 2003. Em entrevista, o pastor Jaime Wright disse que foram vendidos mais de 300 mil exemplares. "A tortura é uma doença". Entrevista de Jaime Wright a Jorge Antonio Barros publicada no site DHNet - Rede Direitos Humanos e Cultura, sem data. Disponível em <http://www.dhnet.org.br/denunciar/tortura/textos/barros.htm>.
} 
sequência a outras operações de memória, com desdobramentos voltados para a investigação dos crimes relacionados aos mortos e desaparecidos políticos.

Em seguida, formou-se a Comissão Parlamentar de Inquérito da Vala de Perus, na Câmara Municipal de São Paulo, com o objetivo de apurar os crimes cometidos naquele contexto. Outras valas comuns foram encontradas contendo restos mortais de militantes assassinados, no Rio de Janeiro e em Pernambuco. A repercussão nacional desses fatos favoreceu também a pesquisa nos arquivos do IML de São Paulo e Rio de Janeiro; a abertura dos arquivos das polícias políticas estaduais, os DEOPS, a partir de 1992; a criação da Comissão de Direitos Humanos do Congresso Nacional, em 1995; e, principalmente, a promulgação da Lei dos Desaparecidos, em 1995.

Durante seis meses, entre 17 de setembro de 1990 e maio de 1991, a CPI investigou as irregularidades da vala de Perus, trabalhou na recuperação dos fatos e obteve informações sobre como os militares, a polícia e os médicos legistas do Instituto Médico Legal se articularam para ocultar as causas das mortes e os cadáveres de militantes assassinados. Depoimentos de torturados e alguns poucos de torturadores foram registrados. Seu relatório final exigia a devolução dos arquivos do DEOPS de São Paulo, retidos pela Polícia Federal, a reformulação do IML desvinculado da polícia estadual e a reorganização dos cemitérios. ${ }^{958}$ De fato, em fevereiro de 1992, os arquivos do DEOPS foram transferidos para o Arquivo Público do Estado de São Paulo.

Essas investigações motivaram outras e, assim, sete ossadas de militantes foram identificadas na Universidade de Campinas (UNICAMP). Os trabalhos de identificação das ossadas encontradas em Perus ficaram sob a responsabilidade da Unicamp durante dez anos e, após a constatação de negligência por parte do MPF/SP, foram assumidos pela USP, mas permanecem inconclusos. Neste período iniciou-se, também, o Inquérito Policial n. 10/90, na Seccional Oeste, presidido pelo Dr. Jair Cesário da Silva para apurar as responsabilidades sobre a vala clandestina, mas rapidamente foi arquivado. Esta situação motivou o MPF/SP a iniciar diversas ações civis em 2008 e 2009 visando responsabilizar os chefes do antigo DOI-Codi/SP entre 1970 e 1976, Carlos Alberto Brilhante Ustra e Audir Maciel, bem como o ex-prefeito Paulo Maluf, o então senador Romeu Tuma e a própria Unicamp ${ }^{959}$.

\footnotetext{
${ }^{958}$ CALigiuri Filho, Júlio César e outros. Onde estão? Relatório da Comissão Parlamentar de Inquérito que investigou a vala clandestina no Cemitério Dom Bosco, em Perus, e os desaparecidos políticos. São Paulo, Câmara Municipal de São Paulo, 1992.

959 V. "Vala de Perus", em www.desaparecidospoliticos.org.br; e "MPF processa Maluf e Tuma por ocultação de cadáveres durante a Ditadura”, em www.ultimainstancia.uol.com.br.
} 
As escavações arqueológicas e investigações realizadas com pouco apoio oficial ou por iniciativa da sociedade civil evocaram e substituíram a ausência da cena judicial. Sem apoio público constante e sem uma política de memória que possibilite o encaminhamento de uma investigação criteriosa com o uso de diversas fontes, tais como os documentos dos arquivos do antigo SNI e dos órgãos de informação militares, assim como a ausência do registro sistemático do testemunho das vítimas e dos perpetradores, foi impossibilitado um conhecimento mais profundo sobre os fatos referentes à repressão estatal durante a ditadura. Essas ausências têm dificultado a realização de um efetivo e amplo debate na sociedade e a resolução da questão.

\subsection{O marco inaugural da memória sobre a ditadura:}

\section{o Projeto "Brasil: Nunca Mais"}

O projeto de pesquisa “Brasil: Nunca Mais” inaugurou as operações de memória sobre a ditadura, no período de democratização. O projeto foi organizado com o apoio decisivo de d. Paulo Evaristo Arns, da Arquidiocese Metropolitana de São Paulo, e coordenado pelo reverendo presbiteriano Jaime Wright, entre agosto de 1979 e março de $1985^{960}$. Para sua realização foram consumidos mais de 350 mil dólares, em valores da época, fornecidos pelo Conselho Mundial de Igrejas. Nele trabalharam advogados, expresos políticos, militantes de defesa dos direitos humanos, historiadores, cientistas políticos, psicólogos, técnicos em informática e jornalistas. Com a extinção do AI-5 e a reformulação da LSN, em dezembro de $1978^{961}$, alguns advogados de presos políticos se sentiram mais à vontade para copiar os processos de seus clientes no Supremo Tribunal Militar (STM). Eles podiam solicitá-los e, assim, membros do projeto lograram copiar secretamente 707 processos completos e dezenas de outros incompletos, do período transcorrido entre 1964 e 1979, reunindo cerca de 1,2 milhão de páginas com testemunhos e documentos produzidos pelo aparato repressivo ou por ele apropriado dos grupos dissidentes.

\footnotetext{
960 Jaime Wright morreu em 1999 e era irmão de Paulo Stuart Wright, dirigente da AP-ML, desaparecido desde $1^{\circ}$ de setembro de 1973. V. Dossiê Ditadura. op.cit., p. 456-58.

${ }_{961}$ Antes do final do seu mandato, o general Ernesto Geisel extinguiu o AI-5, mas incorporou parte do seu conteúdo à Constituição. A reformulação da LSN implicou na redução das penas. V. ALVES, Maria Helena M. Op. cit.
} 
Este impressionante material foi submetido a uma metodologia de análise, que resultou na elaboração de 12 volumes com as conclusões da pesquisa, somando 6.891 páginas, o chamado "projeto A”, ${ }^{\text {„62 }}$. Em seguida, os jornalistas Ricardo Kotscho e Frei Betto escreveram a síntese do projeto, publicada no livro Brasil: Nunca Mais, conhecido como o "projeto B", constituindo-se, desde o início, num marco, dando grande visibilidade às denúncias dos crimes cometidos pela ditadura.

Parte disso foi possível porque parcela dos perseguidos políticos submetidos aos tribunais de exceção, controlados pela Justiça Militar desde 1965, fizeram declarações em juízo que continham denúncias das torturas sofridas, nas quais mencionavam os nomes dos torturadores e os métodos de sevícia empregados ${ }^{963}$. Conforme tratamos no capítulo sobre a resistência empreendida pelos presos políticos e os advogados de defesa nos julgamentos da Justiça Militar, mesmo sob ameaça de voltarem a ser torturados, vários presos revelaram as torturas e assassinatos. Diversos relatos se referem às ameaças e a existência de uma sala utilizada para torturar no porão da II Auditoria Militar, de São Paulo, por exemplo ${ }^{964}$. Assim, a ditadura acabou por documentar parte das violações aos direitos humanos que praticava e manteve esses documentos em arquivo no STM.

A obra revelou, pela primeira vez, com provas irrefutáveis, a atuação do terrorismo de Estado instaurado em 1964 e sua estratégia de repressão. O livro analisa as origens do aparelho repressivo e sua estruturação. Descreve as ilegalidades cometidas nos processos da Justiça Militar, desde o momento da constituição dos Inquéritos Policiais Militares (IPM) até os julgamentos dos réus enquadrados na LSN e o comportamento conivente das autoridades judiciais, passando pelo estudo da legislação de exceção, constantemente desrespeitada. Relata a participação de médicos tanto no auxílio à tortura quanto na falsificação de laudos necroscópicos. Nomeia e descreve diversos centros de tortura. Divulga partes dos depoimentos feitos em juízo, à época, dando voz às vítimas e adotando seu ponto de vista.

A história da concepção, organização, execução e o processo para editar a publicação do BNM ainda é parcialmente desconhecida. Passados muitos anos após o fim da ditadura, os membros do projeto têm preferido manter discrição a respeito dessa

\footnotetext{
962 O "Projeto A" foi doado ao Arquivo Edgar Leuenroth, na Unicamp, em 1987, pela Cúria Metropolitana de São Paulo. Como medida de segurança, três cópias foram enviadas para o exterior, duas para a Europa e a outra para os Estados Unidos.

${ }^{963}$ V. Brasil: Nunca Mais, op. cit., p.25. Há no "Projeto A" 2.700 páginas datilografadas de depoimentos relatando torturas.

${ }^{964}$ V., por exemplo, entrevista concedida por Lenira Machado à autora, idem, ibidem.
} 
história. Algumas iniciativas procuram reverter esta lacuna ${ }^{965}$. Os riscos e obstáculos enfrentados pelo projeto foram muitos, tendo em vista que ele foi realizado ainda durante a ditadura e iniciado no momento em que estavam em disputa vários projetos de anistia, em que o tema da tortura, dos assassinatos e desaparecimentos estava em evidência.

Em maio de 1979, após acirrada disputa, deputados “autênticos” do MDB recuperaram a proposta de formação da CPI da Tortura (ou dos Direitos Humanos) de 1975. Apesar de alguns deputados mais à esquerda do partido declararem-se contrários à formação da CPI, o MDB aprovou a proposta, mas manobras regimentais impediram que ela fosse apresentada ao Congresso Nacional. Em agosto daquele ano foi aprovada a lei de anistia com uma redação ambígua, o que favoreceu a interpretação de que ela era recíproca, contemplado torturados e torturadores ${ }^{966}$.

O período após a aprovação da anistia viu crescer o acirramento dos atentados terroristas organizados clandestinamente por agentes dos órgãos de segurança interna. Ocorreram os atentados a bomba contra bancas de jornal que vendiam periódicos da imprensa alternativa em várias cidades do país, culminando com os atentados contra a OAB, a ABI e a Câmara Municipal do Rio de Janeiro, que levaram à morte da secretária da OAB, Lyda Monteiro ${ }^{967}$. Em abril de 1981, houve ainda a tentativa de executar o que teria sido o maior atentado terrorista, durante um show realizado no Riocentro com a presença de milhares de pessoas, frustrado pela inépcia dos militares do CIE encarregados de colocar a bomba no local. Em fevereiro de 1981, a Casa da Morte de Petrópolis, utilizada pelo CIE para torturar, matar e desaparecer dissidentes, foi descoberta e denunciada, provocando uma dura reação por parte dos militares contrários a qualquer tipo de investigação do passado recente. O caso do Riocentro, que possuía muitas evidências a respeito da sua autoria, teve a investigação protelada e arquivada. Esses fatos justificavam as preocupações com os riscos decorrentes da realização do projeto. Os riscos eram bastante concretos e presentes, o que explica o sigilo criado em torno dele.

O projeto teve entre seus principais colaboradores os advogados Eny Raimundo Moreira, Luiz Eduardo Greenhalgh, Luís Carlos Sigmaringa Seixas e Mário Simas, os

\footnotetext{
${ }^{965}$ V. WESCHLER, Lawrence. Um milagre, um universo: o acerto de contas com os torturadores. São Paulo, Companhia das Letras, 1990; o site Armazém Memória apresenta entrevistas com alguns dos participantes do projeto, que contam parte da história da sua realização. Ver: $<$ http://www.dhnet.org.br/memoria/nuncamais/index.htm\#tomo1>; LIMA, Samarone. Clamor: A vitória de uma conspiração brasileira. Rio de Janeiro, Objetiva, 2003; FIGUEIREDO, Lucas. Olho por olho: os livros secretos da ditadura. Rio de Janeiro, Record, 2009.

${ }^{966}$ V. TELES, Janaina de A. Os herdeiros da memória, op.cit; e a entrevista concedida por Airton Soares à autora. Idem, ibidem.

${ }^{967}$ V. Dossiê Ditadura, op.cit.
} 
jornalistas Paulo Vannuchi, Ricardo Kotscho e Frei Betto, a historiadora Ana Maria Camargo, a socióloga Vânya Santana, entre outros ${ }^{968}$. De acordo com relato de Eny Raimundo, advogada de presos políticos, a ideia do projeto surgiu de uma preocupação do jurista Sobral Pinto, em cujo escritório trabalhava, que repetidas vezes contava a história da destruição dos documentos do Tribunal de Segurança Nacional do período do Estado Novo, provavelmente queimados ou eliminados. Durante o ano de 1978, com o impulso da luta pela anistia, Eny, então presidente do Comitê Brasileiro de Anistia do Rio de Janeiro, começou a procurar parceiros que a ajudassem, até chegar ao Conselho Mundial de Igrejas, sediado na Suíça. Os objetivos apresentados ao secretário para direitos humanos na América Latina do $\mathrm{CMI}^{969}$, pastor Charles Harper, eram preservar a documentação sobre a repressão política e produzir uma análise histórica e jurídica que contribuísse para uma melhor compreensão da ditadura brasileira, além de realizar uma história das práticas de tortura no país. Ele deu total apoio à ideia e solicitou-lhe que ela procurasse d. Paulo e o reverendo Jaime Wright.

Eny conseguiu o aval dos dois e o projeto começaria com uma equipe de advogados, predominantemente do Rio de Janeiro, mas d. Paulo pediu-lhe que fosse sediado em São Paulo, único lugar onde poderia garantir segurança à equipe e ao material copiado. Assim, a equipe foi modificada, pois a maioria não tinha disponibilidade para se deslocar para São Paulo ${ }^{970}$.

De acordo com Sigmaringa Seixas, o advogado responsável pela retirada e reprodução dos processos do STM, em Brasília, em dois anos foi possível realizar as cópias de 1.000 processos (707 completos), usando como pretexto a lei de anistia. Os advogados necessitavam consultar os processos para saber se seus clientes poderiam ser anistiados ou não. O projeto envolvia um grande volume de material, obtido por meio de trabalho intenso de cópia de centenas de milhares de páginas, mas, durante os cinco anos de sua realização, não despertou maiores suspeitas. Em cada fase do projeto eram contratados especialistas e assim foram envolvidas cerca de 30 pessoas no trabalho.

\footnotetext{
${ }^{968}$ V. depoimento de Eny Raimundo Moreira em www.dhnet.org.br/memoria/nuncamais. As entrevistas foram disponibilizadas parcialmente no referido site, que não traz informações sobre autoria, duração, data e local das mesmas. O coordenador do site é Marcelo Zelic.

${ }^{969}$ Nos anos 1970, o CMI agregava mais de 300 igrejas no planeta, alcançando 500 milhões de pessoas. V. site <www.emilianojose.com.br>.

${ }^{970}$ A equipe inicial contaria com a ajuda de Sobral Pinto e seria composta por Heleno Fragoso, Bento Rubião, Rosa Cardoso, um historiador e um cientista político, entre outros. V. depoimento de Eny Raimundo Moreira em <www.dhnet.org.br/memoria/nuncamais>.
} 
Todas as informações foram tratadas com cuidado e rigor, pois o projeto deveria ser uma denúncia, mas também um legado para as gerações futuras.

Paulo Vannuchi, ex-Secretário Nacional dos Direitos Humanos, relata que a equipe mudou-se de lugar mais de uma vez. Permaneceram cerca de um ano no prédio do Sedes Sapientiae, depois, por motivos de segurança, foram transferidos para o Seminário do Ipiranga e, em seguida, para uma igreja do Jardim Paulista.

Carlos Lichtsztejn, um militante do "grupo de fogo" da ALN preso em 1969, trabalhou no projeto durante quatro anos. Ele nos contou sobre a atmosfera de trabalho e sobre sua organização e execução do BNM:

\begin{abstract}
"Era totalmente secreto, nós estávamos na ditadura, em 1980 as pessoas tinham muito medo, para arrumar pessoas para trabalhar nisso era muito difícil. Aí conseguiu-se meia dúzia de pessoas que achavam importante esquadrinhar os crimes da ditadura com os próprios documentos da ditadura. Isso era o que tinha de original nesse projeto. Era pegar todos os documentos da própria ditadura e com eles mostrar os crimes cometidos.

No início, a gente fazia de tudo. A gente pegava processo por processo e havia um roteiro com um questionário que a gente ia preenchendo. Assim, classificávamos todas as irregularidades, todos os abusos, torturas, o que é que tinha, todos os prazos.

[...] A informática foi uma mão na roda, a gente trabalhava com computadores quase que movidos a lenha. A partir de certo momento, eu fiquei responsável por essa parte. [...] Foram horas e horas de digitação, comparado com hoje, eram condições precaríssimas, o computador era o CP 500.

[...] Chegou uma época, que havia falta de condições para acabar aquilo em um prazo viável. Então, começamos a reestruturar e decidiu-se por contratar um monte de gente para trabalhar na pesquisa dos dados, informática, história, jornalistas, entre outros ${ }^{971}$."
\end{abstract}

De acordo com Paulo Vannucchi, o que havia sido pensado como um estudo sob o enfoque jurídico foi se transformando num extenso levantamento e análise de tudo aquilo que aflorava dos mecanismos da Justiça Militar em relação aos direitos humanos ${ }^{972}$. Eny Raimundo menciona ter havido divergências sobre o enfoque da análise e a maneira de apresentar o projeto, sem esclarecer quais seriam as diferenças, declarando apenas que foi voto vencido.

Luis Eduardo Greenhalgh relata que houve muita discussão entre os participantes do projeto sobre como deveria ser o livro resultante e seu formato de divulgação:

"Nós discutimos muito e havia duas posições: tinha uma que dizia que não dava para fazer um livro extensivo sobre o que nós achamos nos processos, tínhamos que fazer um pequeno resumo, para que tivesse impacto na sociedade brasileira. E tinha outras pessoas que falavam: não dá pra fazer uma pesquisa de seis anos, clandestina, cheia de riscos, e depois fazer um resumo dela, é muito pobre isso, temos que publicar extensivamente os

\footnotetext{
${ }^{971}$ Entrevista concedida por Carlos Lichtsztejn à autora. SP, 07/05/2010. AAPP/AEL-LEI.

${ }^{972}$ V. depoimento de Paulo Vannuchi em <www.dhnet.org.br/memoria/nuncamais>.
} 
locais e os centros de tortura, as pessoas que foram torturadas, a lista dos torturadores, os laudos, pistas sobre desaparecidos, os métodos e os tipos de tortura, os locais das torturas no Brasil durante o regime militar. [...] D. Paulo era a favor de fazer o livro extensivo, divulgando ipsis literis o que nós tiramos dos processos, até porque assim não tinha como a repressão contestar. [...] Jaime Wright achava que, além disso, devíamos fazer um resumo. Aí consultamos outras pessoas, entre as quais o Ricardo Kotscho e o Frei Betto, e a maioria defendia que dava pra fazer as duas coisas."973

De fato, as duas propostas de divulgação foram encaminhadas parcialmente, a versão que se tornou conhecida da maioria das pessoas foi o livro. Não sabemos, porém, como lidaram com as divergências referentes ao conteúdo. Inicialmente, a equipe resolveu adiar a publicação do livro até depois da posse do presidente civil eleito indiretamente pelo Congresso Nacional, Tancredo Neves, marcada para 15 de março de 1985. Eles não queriam arriscar-se a provocar o cancelamento da posse e possíveis represálias provocadas por militares [WESCHLER, 1990: 75].

Segundo Vannuchi, em maio de 1985, José Sarney, já então presidente do país, deu sinais de que era possível lançar o livro. Neste momento, iniciaram-se as discussões sobre a formação do Congresso Constituinte e Sarney recebeu os dirigentes do PCB e do PCdoB para discutir a proposta de emenda constitucional que permitiria a legalização dos dois partidos. Ele ainda encaminhou ao Congresso uma proposta de alterações de alguns elementos restritivos da lei de anistia ${ }^{974}$, direcionando-a para o aspecto trabalhista, com desdobramentos relativos ao pagamento de reparações a alguns setores de sobreviventes.

Os nomes dos torturadores não foram publicados no livro, pois a equipe decidiu suspender a publicação da lista dos 444 torturadores até que a situação política pudesse afirmar-se. O BNM foi chamado pelos seus realizadores até as vésperas do lançamento de Testemunhos para a paz. Com a doença do presidente eleito Tancredo Neves, o lançamento do livro foi adiado para 15 de julho, quando efetivamente chegou às livrarias. Os organizadores do projeto esperaram até o dia 21 de novembro daquele ano para liberar a lista dos torturadores aos jornalistas, ou seja, poucos dias depois das primeiras eleições municipais realizadas sob um regime civil. ${ }^{975}$ Esta lista era uma continuidade do levantamento elaborado pelos presos políticos de São Paulo, contendo 233 nomes de torturadores, encaminhado ao presidente da OAB em 26 de outubro de 1975. Apenas em 1978 esta lista foi publicada pelo jornal Em Tempo. Paulo Vannucchi e Carlos Lichtsztejn

\footnotetext{
${ }^{973}$ V. depoimento de Luis Eduardo Greenhalgh em < www.dhnet.org.br/memoria/nuncamais >

${ }^{974}$ V. depoimento de Paulo Vannuchi em <www.dhnet.org.br/memoria/nuncamais>.

${ }^{975}$ WeSCHLER, L. Op. cit., p.75 e 82.
} 
foram alguns dos presos que ajudaram a organizar esta lista nos cárceres de São Paulo ao longo da primeira metade da década de 1970.

O BNM refletiu as ambiguidades e limites da transição política brasileira que ainda marcam a construção das memórias sobre a ditadura. Ao analisarmos os prefácios de d. Paulo Arns e de Philip Potter, da CMI, de maio e junho de 1985, e a apresentação do livro, é possível destacar alguns aspectos que chamam atenção a respeito da atmosfera, das preocupações e posicionamentos dominantes da época.

Preocupado com o clima de insegurança institucional que o início do primeiro governo civil inspirava, o prefácio de d. Paulo faz referência ao legado de Cristo, ele mesmo "perseguido, torturado e morto" e menciona sua missão de trabalhar pela "justiça, verdade, liberdade e amor”. Primeiro, relata o sofrimento das mães e parentes de desaparecidos políticos, os quais se transformam "numa sombra que ao escurecer-se vai encobrindo a última luminosidade da existência terrena”. E, por fim, descreve casos de tortura, cujos relatos ouviu diretamente das vítimas.

A apresentação do livro ressalta a função pedagógica da história e sua importância, auxiliando para que "nunca mais" se repitam os erros e crimes do passado recente. O livro é definido como uma “[...] reportagem sobre uma investigação no campo dos Direitos Humanos. É uma radiografia inédita da repressão política que se abateu sobre milhares de brasileiros considerados pelos militares como adversários do regime instaurado em abril de 1964. É também a anatomia da resistência”. ${ }^{976}$ A militância política dos sobreviventes e vítimas fatais não foi subtraída, mas somente em 1987 saiu publicado o livro Perfil dos Atingidos, o tomo III do "Projeto A", onde consta um extenso levantamento sobre os grupos da esquerda revolucionária ${ }^{977}$.

A utilização exclusiva de fontes oficiais é a característica principal assinalada pelos organizadores do projeto e o fator decisivo que garantiu à obra confiabilidade e legitimidade:

"No mundo todo, a questão da repressão política é quase sempre levantada a partir de denúncias de atingidos, ou de relatos elaborados por entidades que se dedicam à defesa dos Direitos Humanos. Emotivos ou equilibrados, são testemunhos que ajudam a revelar uma história oculta. Mas tropeçam, às vezes, na desconfiança daqueles que alegam serem depoimentos tendenciosos, por partirem de vítimas que, na sua maioria, teriam motivações políticas.

\footnotetext{
${ }^{976}$ V. Brasil: Nunca Mais, op. cit., p.21.

977 ArquidioCESE de São Paulo. Perfil dos Atingidos. Petrópolis, Vozes, 1987.
} 
A pesquisa 'BRASIL NUNCA MAIS' (BNM) conseguiu superar esse dilema, estudando a repressão exercida pelo Regime Militar a partir de documentos produzidos pelas próprias autoridades encarregadas dessa tão controvertida tarefa. [...]

Pode-se argumentar que, dispensando a tomada de depoimentos das próprias vítimas, e trabalhando com documentos produzidos pelas autoridades do regime, o Projeto estaria condenado a apurar apenas pequena parte das violências cometidas contra os Direitos Humanos no período. A fonte documental podia ser comparada a um material de onde os agentes da repressão removeram as "impressões digitais" dos crimes cometidos no ato de investigar.

Mas havia uma contrapartida compensadora: o que se produzisse como constatação de irregularidades, de atos ilegais, de medidas injustas, de denúncias sobre torturas e mortes, teria a dimensão de prova indiscutível. Definitiva ${ }^{978}$."

O risco foi calculado, segundo Vannuchi esta foi uma opção que se mostrou “historicamente acertada” ${ }^{979}$. O BNM de fato influenciou e foi fundamental para todas as iniciativas de resgate da história da ditadura, ajudando pesquisadores com informações e sustentando investigações. O caráter oficial da documentação e, principalmente, sua origem nos tribunais de exceção - instância afastada dos centros de decisão da repressão política - forneceram, no entanto, informações com determinadas características, que não levaram ao esclarecimento dos assassinatos sob tortura e dos desaparecimentos forçados, nem do funcionamento dos centros de tortura e extermínio.

Não obstante, há muita informação neste acervo, sob todos os aspectos e, principalmente, tendo em vista que são processos da Justiça Militar. O volume 4, do tomo $\mathrm{V}$, é dedicado aos mortos e contém os testemunhos, citados nos autos dos processos judiciais, de pessoas que presenciaram nos cárceres a morte de outros presos sob tortura, desmentindo as versões de que teriam ocorrido em tiroteios com agentes do governo ou em atropelamentos ${ }^{980}$. Baseado nos processos judiciais, obrigatoriamente, o BNM possui mais informações sobre os sobreviventes, conforme se pode perceber pelo espaço menor dedicado à temática dos mortos e desaparecidos, tanto no livro como no “projeto A”.

Um espírito de conciliação está presente no texto de apresentação, o qual se escora em uma interpretação do conceito de justiça no Brasil que, segundo os autores, faz-se

\footnotetext{
${ }^{978}$ Brasil: Nunca Mais, op. cit., p.22 e 24.

${ }^{979}$ V. depoimento de Paulo Vannuchi em <www.dhnet.org.br/memoria/nuncamais>.

${ }^{980}$ Foram encontrados depoimentos sobre 19 mortos e alguns laudos necroscópicos foram anexados nos processos: Chael Charles Schreier; João Lucas Alves e Severino Viana Colou; Eduardo Collen Leite; Luiz Eduardo da Rocha Merlino; Joaquim Alencar Seixas; Carlos Nicolau Danielli; Odijas Carvalho de Souza; Alexandre Vannucchi Leme; José Ferreira de Almeida; Vladimir Herzog. Sobre os desaparecidos, encontram-se registros de denúncias na Justiça Militar a respeito de Edgard Aquino Duarte, Bérgson Gurjão Farias; Armando Teixeira Frutuoso; Antônio Joaquim Machado, Carlos Alberto Soares de Freitas; Paulo Stuart Wright; José Montenegro de Lima; Rubens Beirodt Paiva. Elio Gaspari em sua pesquisa localizou 129 laudos necroscópicos espalhados nos autos dos processos judiciais do período que compreende os anos entre 1969-1973. V. GASPARI, Elio. A Ditadura Escancarada. São Paulo, Cia. das Letras, 2002, p.385.
} 
alheio ao de vingança. Para desenvolverem esta exposição de ideias, utilizam termos extraídos da retórica militar, como "revanche" e "vingança" - não havendo no texto menções diretas a conceitos classicamente associados à reflexão acerca do estado de direito, tais como "lei” e “direito". A perspectiva apontada como sendo principal é a da recuperação da “verdade” histórica:

"Não é a intenção do Projeto organizar um sistema de provas para a apresentação em qualquer Nuremberg brasileiro. Não o anima qualquer sentido de revanche. Na busca de justiça, o povo brasileiro nunca foi movido por sentimentos de vingança. [...] É a observância do preceito evangélico que nos aconselha o conhecimento da verdade como pressuposto para a libertação."981

Philip Potter, do CMI, identificou a Igreja Católica como uma instituição defensora dos direitos humanos, obviamente sem fazer referências ou criticas ao seu posicionamento favorável a golpes e ditaduras em nome do combate à ameaça comunista, no Brasil e no continente: “[...] os Católicos têm estado nas fronteiras da luta pelos direitos humanos na América Latina, sendo que muitos padres e religiosos foram torturados até a morte." ${ }^{982}$ Evocou ainda o sofrimento como remissão e o perdão aos torturadores, fortalecendo a "solução conciliadora" e a equiparação da violência dos dois lados - guerrilheiros e repressores -, confirmando a interpretação da lei de anistia como tendo sido recíproca:

"É com penitências, pois, que encaramos este livro. Ele não pretende ser meramente uma acusação, mas sim um convite para que todos nós reconheçamos nossa verdadeira identidade através das faces desfiguradas dos torturados e dos torturadores. Fazemos isso em nome de Cristo que foi torturado e crucificado para que tivéssemos vida em toda a sua plenitude. Na cruz, Jesus intercedeu pelos seus torturadores: 'Pai, perdoa-lhes, pois não sabem o que fazem., ",983

Os reflexos institucionais da publicação do livro sentiram-se lentamente. O pedido de D. Paulo, feito no prefácio, apelando ao governo brasileiro para que assinasse e ratificasse a Convenção contra a Tortura e outros Tratamentos ou Penas Cruéis, Desumanos ou Degradantes, aprovada pela Assembleia Geral da ONU, em 1984, obteve a assinatura do então presidente Sarney dois meses após seu lançamento, mas a

\footnotetext{
${ }^{981}$ Brasil: Nunca Mais, op. cit., p.26.

${ }^{982}$ Idem, Ibidem, p.17. Sigo aqui a análise de BAUER, Caroline Silveira. A produção dos relatórios Nunca Mais na Argentina e no Brasil: aspectos das transições políticas e da constituição da memória sobre a repressão. In: Revista de História Comparada, v.3, p.4, 2008. Disponível em: $<$ http://www.hcomparada.ifcs.ufrj.br/revistahc/revistahc.htm $>$, p.12.

${ }^{983}$ Brasil: Nunca Mais, op. cit., p.18-9.
} 
Convenção só foi ratificada em 15 de fevereiro de 1991. A lei tipificando o crime de tortura somente foi votada no Congresso Nacional e promulgada em 1997.

No âmbito da sociedade civil, a publicação também gerou desdobramentos significativos, tais como o surgimento dos grupos constituintes do movimento Tortura Nunca Mais, com destaque para o primeiro grupo, surgido em 1985, no Rio de Janeiro e composto por ex-presos políticos e familiares de mortos e desaparecidos políticos ${ }^{984}$.

Esses desdobramentos, no entanto, não levaram à realização de “julgamentos pela verdade” como na Argentina ou a ações penais contra os torturadores e mandantes. Este tema foi discutido pelos organizadores do BNM; refletindo sobre isto, Carlos Lichtsztejn, assim como outros entrevistados nesta pesquisa, destaca a ausência de hipóteses bem definidas para o entendimento desta falta de processos judiciais contra os torturadores:

\begin{abstract}
“A gente fez essa discussão [...]. O Jaime Wright participava um pouco dessa discussão com a equipe inicial, o d. Paulo não. [...] Era muito claro e estava correto pensar que aquilo era uma documentação valiosa para incriminar a ditadura, que seria fundamental para mostrar, condenar, criminalizar todos os torturadores e os responsáveis por isso. Não só aqueles que participaram diretamente da tortura, mas também os mandantes. Os generais que tinham toda a concepção e a metodologia desse processo de tortura, pois aquilo não era uma excentricidade, mas a base do sistema.

[...] Eu não sei porque esse trabalho nunca foi usado em ações judiciais... Para mim que participei quatro anos desse projeto, realmente, eu acho que o resultado efetivo é que, por um lado, do ponto de vista histórico foi muito importante, isso não tem discussão. Porém, eu achava que isso teria uma repercussão na sociedade no sentido de identificar e processar as pessoas que cometeram essas barbaridades. Aquilo era um instrumento, eu achava isso fundamental, porque temos o nome da pessoa, onde ela trabalhava e as testemunhas... mas, aí....

[...] Em 1984 eu me desliguei do projeto. Aconteceram as publicações e isso ficou com a Cúria, o Jaime Wright, eles são os pais do projeto. Enfim, a publicação teve a repercussão que deveria ter, naquele momento, e a consequência esperada por todos que trabalharam nele ${ }^{985}, "$
\end{abstract}

O panorama delineado pela publicação do BNM estabelece paralelos e, de certo modo, contrastes com o ambiente definido pela publicação do informe argentino Nunca Más, o qual foi precedido de 9 meses de intensos trabalhos públicos na busca de informações sobre os desaparecidos políticos. Este informe foi produzido pela Conadep e quase inteiramente sustentado por testemunhos de sobreviventes e familiares. A edição do BNM foi inspirada pelo Nunca Más (de novembro de 1984) e publicada menos de um ano depois.

\footnotetext{
${ }^{984}$ Em seguida, formaram-se outros GTNM em SP, MG e PE.

${ }^{985}$ Entrevista concedida por Carlos Lichtsztejn à autora. Idem, ibidem.
} 
Apesar das resistências iniciais dos movimentos de direitos humanos contra a formação da Conadep - em especial das Madres da Plaza de Mayo - as pessoas fizeram filas em frente à sua sede para registrar o seu depoimento a esta que tem sido considerada a primeira experiência de organização de uma Comissão de Verdade.

A reivindicação dos movimentos era pela formação de uma Comissão Parlamentar bicameral (exibindo paralelos com o movimento brasileiro para a instituição de uma CPI similar em 1975 e 1979) para apurar todos os crimes cometidos pela repressão estatal e não deixar espaço para qualquer possibilidade de realizarem-se julgamentos dos grupos guerrilheiros. Queriam uma investigação que abrangesse não apenas os desaparecimentos forçados e que fosse realizada por um órgão com poder e independência suficiente para fazer diligências e convocar militares e policiais para depor. Reivindicavam uma comissão que não fosse apenas uma intermediária entre a sociedade civil e a justiça, ao encaminhar as denúncias para o poder judiciário, mas que pudesse realizar também o julgamento político da ditadura. Esta perspectiva contrastava com a determinação de Alfonsin, que assumiu o governo no final de 1983 e no início de seu mandato determinou o processo das juntas militares e da cúpula da guerrilha ${ }^{986}$.

Estes depoimentos, registrados desde as experiências de um contingente populacional inicialmente descrente, que ao final registrou cinco mil quinhentos e oitenta denúncias, mostraram-se fundamentais para a compreensão do que se passou durante os períodos mais sombrios da ditadura argentina - em relação à qual faz-se paradigmática a transição da crença inicial da população civil de que os desaparecidos estariam vivos (por exemplo, encarcerados em manicômios e prisões secretas) para a percepção da dura realidade que de fato se abatera sobre as vítimas deste regime sangrento.

Diante da ausência de documentos oficiais, os militares supostamente teriam queimado a maioria dos documentos e registros sobre sua atuação repressiva, os relatos se tornaram cruciais. A Conadep convocou as pessoas a testemunharam por meio de chamadas no rádio e na televisão. Estabeleceu um plano para realizar visitas ao interior do país, assim filiais da Conadep foram criadas e coletaram testemunhos em Córdoba, Mar Del Plata, Bahia Blanca, Santa Fé, Tucumán e Jujuy, entre outras cidades. A Conadep organizou também viagens ao exterior para ouvir os testemunhos de sobreviventes exilados que temiam fazer declarações nas embaixadas argentinas. Os depoimentos iniciais foram catalisadores de outros e estas iniciativas acabaram por

${ }^{986}$ CRenzel, Emilio. La história política del Nunca Más. La memória de las desapariciones em la Argentina. Buenos Aires, Siglo XXI, 2008. 
conseguir recolher milhares de denúncias nunca antes registradas. Para maioria dos sobreviventes, tratava-se da primeira interpelação pública sobre suas experiências e recordações [CRENZEL, 2008: 71].

Este processo teve êxito em função do acolhimento da prerrogativa da validade intrínseca dos depoimentos, a qual estava inscrita sob a ética do testemunho e do respeito singular pela experiência. Não obstante, diversos sobreviventes deixaram de testemunhar, devido às ameaças e à atmosfera de medo, naquele momento ainda bastante presente ${ }^{987}$. A esta perspectiva cabe adicionar o papel catalisador das exumações de restos mortais de desaparecidos políticos em cemitérios públicos e outras ações efetivas, as quais tiveram grande impacto na opinião pública argentina, sobretudo em face da ampla divulgação do tema nos meios de comunicação [CRENZEL, 2008: 73-5].

As organizações de defesa dos direitos humanos continuaram reivindicando a formação de uma comissão bicameral de investigação e, paralelamente, cederam à Conadep todo o material de suas pesquisas sobre o paradeiro dos desaparecidos (a exceção das Madres da Plaza de Mayo). A Conadep, que iniciou seus trabalhos sem uma estratégia clara de investigação, decidiu então classificar esse vasto material testimonial por centros clandestinos de detenção, critério que se extendeu às crianças desaparecidas, rastreadas de acordo com o lugar de cativeiro de suas mães. Essa estratégia podia comprovar a coordenação repressiva, inclusive, aquela existente entre as ditaduras dos países sul-americanos. Estes centros clandestinos de detenção transformaram-se no eixo para reconstruir a materialidade dos desaparecimentos. Assim, a Conadep decidiu fazer inspeções nestes locais, que foram amplamente divulgadas e seus resultados expostos nos meios de comunicação [CRENZEL, 2008: 73-5].

Os testemunhos deram materialidade aos desaparecimentos forçados, permitiram a articulação das informações sobre as fases pública e clandestina da repressão estatal e incrementaram o número conhecido de responsáveis por estes crimes. Estes milhares de testemunhos expressaram um exercício público de evocação que permitiu ampliar o conhecimento sobre a história da ditadura argentina [CRENZEL, 2008: 75]. Este processo culminou com a apresentação dos resultados dos trabalhos da Conadep em um programa de televisão com uma audiência massiva. Assistido por 1.640 .000 pessoas, todas as intervenções feitas no programa apelaram à justiça, em especial, sobreviventes e

\footnotetext{
987 No início dos trabalhos, a Conadep contava apenas com 70 testemunhos de sobreviventes, ao final conseguiu reunir cerca de 1.200 depoimentos de ex-presos políticos. CRENZEL, Emilio. Op.cit., p.71.
} 
familiares reivindicaram que as responsabilidades não ficassem restritas à cúpula militar [CRENZEL, 2008: 88-9].

A condenação moral da ditadura inscrita no informe “Nunca Más” e a importância da sua enorme repercussão, de certa forma, obscureceram a ideologia conservadora expressa em seu prólogo escrito por Ernesto Sábato, no qual o terrorismo de estado foi igualado ética, política e juridicamente às ações efetuadas pelas organizações revolucionárias. Esta posição, conhecida como a "teoria dos dois demônios”, foi refutada somente em 2006, no novo prefácio escrito para a edição relativa aos 30 anos do golpe de estado de 1976.

Esta aproximação com o caso argentino pode ajudar-nos a entender a diferença definida para com a experiência brasileira, a qual manteve-se tanto mais aderida às fontes documentais. É de se ter em vista que um dos objetivos desta pesquisa é abordar o tema com base na incorporação da ética do testemunho, vindo assim a acrescentar algo de original à maneira de se refletir sobre o tema no Brasil, sobretudo dado o fato de que os depoimentos compilados pelo BNM foram produzidos em situações coercitivas cercadas por grande risco - realizados em juízo, nos tribunais militares. A outra fonte fundamental, através da qual foi possível obter dados sobre o aparato repressivo e seus crimes, foi aquela proveniente de denúncias que saíram clandestinamente dos presídios políticos, em condições bastante difíceis.

No período democrático, os testemunhos escritos encaminhados à Comissão Especial de Mortos e Desaparecidos Políticos, à Comissão de Anistia ou às Comissões de Estaduais de Reparação, foram produzidos livremente e à margem da esfera jurídica. Estes testemunhos desempenham um papel paradigmático ao esclarecer e nos aproximar dos fatos relativos à repressão política da ditadura. A perspectiva aqui exposta pretende salientar o caráter estratégico desta fonte e da importância de se fortalecer uma ética do testemunho, que além de ser capaz de trazer novas informações, contribui para a transmissão das memórias e experiências do período ditatorial e para a construção de uma cultura política que estabeleça uma ruptura com o seu legado autoritário.

As "políticas da narrativa” produzidas no contexto das Comissões de Verdade, entre outras maneiras, possibilitam a ressignificação dos conflitos do passado no presente, tornam público o que tem sido bloqueado e abrem caminho à responsabilização civil e a “uma ação política inovadora e criativa, dentro de um agir democrático ${ }^{988, " . ~}$

988 TELES, Edson de A. Brasil e África do Sul: os paradoxos da democracia, op.cit., p.90. 


\subsection{A conformação de uma história e memória oficiais ${ }^{989}$}

A transição política brasileira ocorreu sem estabelecer rupturas claras com o legado da ditadura, tendo sido pactuada entre as elites militares e civis de forma secreta. Neste momento de mudanças, alguns atores e setores sociais buscaram exibir marcas simbólicas de rompimento com aquele período histórico, explicitando um corte, o qual muitas vezes surgiu em meio a notáveis dificuldades.

A votação da lei de anistia teve lugar num Congresso cerceado por cassações, mudanças arbitrárias na legislação eleitoral e senadores biônicos. No dia da votação - sob ameaça de invasão de militares ao prédio, que chegaram a ficar na galeria por algumas horas - ocorreu um ritual de manobras regimentais que culminou com o voto das lideranças dos dois partidos, Arena e MDB, sem direito a amplo debate sobre emendas. Mesmo assim, 29 deputados fizeram sua declaração de voto, protestando contra o texto do substitutivo do partido do governo, considerado discriminatório, e recusando-se a legitimá-lo. ${ }^{990}$ A transição de 1985 consumou-se também porque foram dadas mostras aos generais de que não se remexeria o passado, preservando assim a interpretação de que a anistia fora recíproca. De acordo com Elio Gaspari, o surgimento do livro BNM “[...] foi um claro empecilho a esse acobertamento, mas não alterou fundamentalmente o espírito da política que o havia sustentado no início.”991

A mobilização popular de protesto ao final da ditadura não se arregimentava principalmente em torno do repúdio às violações aos direitos humanos, mas contra a política econômica da ditadura. Neste contexto, predominou a negociação e a atitude conciliadora e tolerante de alguns dos principais atores sociais. A contribuição das movimentações de denúncia dessas violações desempenhou importante papel mas não foi decisiva. Mesmo assim, os ecos traumáticos da ditadura forjaram um papel crucial para o desenho institucional da transição e para a questão de como se avaliar o legado da ditadura., vicissitudes que se converteram em eixos importantes nas disputas entre estratégias políticas diversas.

\footnotetext{
${ }^{989}$ Para aprofundar esta análise pretendo fazer uma comparação entre as comemorações dos 20 e dos 30 anos de anistia no Brasil.

${ }_{990}$ Ao contrário do que afirma o historiador Carlos Fico, não se efetivou na votação da lei de anistia um pacto político legítimo, pois não se baseou no amplo debate e nos termos e condições próprios do Estado de Direito. Ver CONGRESSO Nacional. Anistia, Comissão Mista sobre anistia, Brasília-DF, 1982, vol.II, p.23738; e Fico, Carlos. A negociação parlamentar da anistia de 1979 e o chamado "perdão aos torturadores". Disponível em $<$ www.ppghis.ifcs.ufrj.br $>$.

${ }^{991}$ WESCHLER, Op.cit., p.79.
} 
Os familiares de mortos e desaparecidos políticos e os Grupos Tortura Nunca Mais erigiram-se ao papel de atores políticos e gestores de memória; os militares e a direita mantiveram o papel de protagonistas, ao passo que, em sua maioria, os partidos políticos de esquerda (tradicionais e novos), adotaram posturas ambíguas sobre esta questão. $^{992}$

No intervalo entre a publicação do Brasil: Nunca Mais e a abertura da Vala de Perus ocorreu o Congresso Constituinte e a aprovação da nova Carta de 1988. A Constituição “cidadã”, como foi chamada na época, incluiu uma série de direitos progressistas em várias áreas, ao mesmo tempo em que manteve significativos elementos autoritários - especialmente no que tange à relação entre o poder político e as Forças Armadas, que manteve, neste ponto, grande similaridade com a Constituição de 1967.

Iniciados os trabalhos do Congresso constituinte em 1986, a Comissão de Organização Eleitoral Partidária e Garantia das Instituições (responsável pela nova estrutura política, pelo papel dos militares e das instituições de segurança pública) foi presidida pelo coronel Jarbas Passarinho, ex-ministro dos governos dos generais Geisel, Médici e Figueiredo e signatário de um do AI-5 ${ }^{993}$. O resultado foi o controle do Exército sobre as forças de segurança pública e a tutela das Forças Armadas sobre os poderes políticos legitimamente instituídos.

Na Constituição de 1988, seu Título V trata "Da defesa do Estado e das Instituições”, e o artigo 142 trata da ingerência militar nos assuntos civis e do poder político: “As Forças Armadas destinam-se à defesa da pátria, à garantia dos poderes constitucionais e, por iniciativa de qualquer destes, da lei e da ordem”. Em Estados de Direito os militares não podem se submeter aos “poderes constitucionais” (Executivo, Legislativo e Judiciário) e, ao mesmo tempo, garanti-los. Ao instituir as Forças Armadas como garantes da lei e da ordem, acaba-se por estabelecê-las como um dos poderes políticos da sociedade. “As Forças Armadas deixam de ser meio para se transformar, quando necessário, em fim do Estado.” Elas têm sido protagonistas na manutenção da segurança interna. ${ }^{994}$ Além disso, ainda hoje a Lei de Segurança Nacional, os Códigos Penal e Processual Militar, o Decreto estipulando que os serviços reservados das Polícias Militares façam parte do sistema de informação do Exército, o Estatuto dos Estrangeiros

\footnotetext{
992 JeLIN, E. Op.cit., p.46-7. Baseei-me na sua análise sobre as transições na Espanha e no Cone Sul.

${ }^{993}$ Ver o site < www.senado.gov.br>. Jarbas Passarinho escreveu em 2006 que não pediram perdão, pois não se arrependeram do que fizeram durante a ditadura. Ver PASSARINHO, Jarbas. "A tortura e o terrorismo". Folha de S.Paulo, 28/11/06, p.3.

${ }_{994}$ ZAVERUCHA, Jorge. FH, Forças Armadas e Polícia. Entre o autoritarismo e a democracia (1999-2002). Rio de Janeiro, Record, 2005, p.63-4, 93-5 e 122. Grifos meus.
} 
elaborados durante a ditadura, continuam em vigor [ZAVERUCHA, 2005: 15, 27, 63-4]. E somente em 2009 a Lei de Imprensa foi revogada.

Questionamentos sobre quais aspectos foram se modificando ao longo do tempo e quais permaneceram fazem-se até hoje fundamentais, desde a inerente atualidade dos efeitos das ações políticas concebidas então. Historicizar esta memória significa questionar-se sobre as mudanças nos cenários políticos, o surgimento de novos atores sociais e as alterações de sensibilidade que implicam, em geral, em transformações dos sentidos do passado [CAPELATO, 2007: 20].

Em muitos aspectos, a Anistia de 1979 teve o significado de um reencontro. Por um lado, constituiu-se num momento marcado pela alegria da conquista de uma vitória, que, embora parcial, abria possibilidades, projetando para o futuro os investimentos pessoais e políticos dos sobreviventes, mas representou também a denegação a respeito do que ocorrera aos mortos e desaparecidos políticos, dando início à constituição e posterior consolidação das "memórias e versões da conciliação", que têm suplantado tantas outras.

Apenas nos anos 1990 iniciou-se uma política de reparação às vítimas da ditadura $^{995}$. Este processo, ainda em andamento, foi possível em função de muitas lutas, que conquistaram as ampliações da lei de anistia de $1979,{ }^{996}$ a criação de leis estaduais de reparação e indenização às vítimas de tortura e a ampliação da Lei dos Desaparecidos (9.140/95), cabendo destacar a lacuna produzida pela ausencia da restituição da verdade jurídica, da recuperação dos corpos dos militantes assassinados e da punição dos responsáveis pelos crimes cometidos pela ditadura.

Os dilemas existentes em torno da avaliação do passado recente refletem-se nas leis federais e estaduais de reparação, prevalecendo a resolução da questão por meio de processos administrativos e não judiciais, cuja característica principal é o pagamento de indenizações. Ressalte-se que pouco foi feito em termos de uma reparação simbólica às vítimas e sobreviventes, sendo a mais importante o pedido de desculpas público. Os processos administrativos, embora considerados públicos, permanecem restritos às petições escritas, cujas audiências raramente aconteciam em lugares de fácil acesso e

\footnotetext{
995 A promulgação da Lei dos Desaparecidos (lei 9.140), de 04/12/95, teve grande influência nesse processo. Isso ocorreu também com o direito internacional, no início dos anos de 1990 as instâncias internacionais começaram a enfrentar o problema dos desaparecimentos políticos, avançando no campo da responsabilidade individual em relação aos crimes contra os direitos humanos.

${ }_{996}$ A Lei 6.683/79 e suas modificações ver em:<www.planalto.gov.br/CCIVIL/leis/L6683compilada.htm>.
} 
visibilidade. A partir de 2008, estas audiências começaram a ser mais divulgadas, através do programa Caravanas da Anistia, nas quais participaram cerca de 14 mil pessoas ${ }^{997}$.

Desde os anos 1990, os diversos governos que assumiram a direção do país priorizaram as políticas que promovem a reparação pecuniária, o reconhecimento de injustiças no âmbito trabalhista, mas não estabelecem a responsabilidade civil do Estado pelos crimes de lesa-humanidade praticados pelas Forças Armadas e os órgãos de segurança interna durante a ditadura. Ademais, pouco avançaram na sua recuperação factual ou no estabelecimento da justiça. Ao contrário, promoveram a inversão do ônus da prova: os sobreviventes e familiares de mortos e desaparecidos políticos devem narrar o que lhe aconteceu e apresentar as provas dos crimes de que foram vítimas ${ }^{998}$. O Estado fica desobrigado de investigar e de apresentar as provas ou dados pormenorizados a respeito das operações policiais ou manobras militares das quais resultaram estes crimes.

A política de reparação do período democrático não foi acompanhada da garantia do direito à verdade e do direito de acesso à justiça. A demanda por "Verdade e Justiça" ficou circunscrita a organizações de familiares e sobreviventes, ao setores do movimento de direitos humanos e parcelas minoritárias da sociedade,. Familiares e sobreviventes tornaram-se os herdeiros e agentes da memória, buscando comprometer a outros, provocando o debate e a atenção, tentando gerar participação. Tentando influir e mudar o sentido e o conteúdo da "história oficial” ou da história dominante, com o fim de eliminar distorções, tornar públicos e legítimos os relatos que foram silenciados, criando e elaborando rituais, comemorações e marcas simbólicas de reconhecimento e pertencimento [JELIN, 2002:50].

Estes grupos, em muitos momentos, não conseguiram romper com os limites jurídicos e políticos impostos pela transição, não conseguindo mudar as normas e os marcos interpretativos herdados desse período, conforme a decisão do STF, realizada em abril de 2010, confirmando a interpretação de que a anistia foi recíproca, dada a importância de não romper o suposto “acordo histórico” que permitiu a "transição

\footnotetext{
${ }^{997}$ V. relatório da Comissão de Anistia do ano de 2010, em portal.mj.gov.br.

998 O Habeas Data, instituído na Constituição de 1988, foi fornecido através de resumos elaborados pela ABIN, que mantém ainda hoje nos seus quadros os antigos funcionários do extinto SNI. Em diversas ocasiões, foram negados ao peticionário diversos dados a seu respeito. A partir da lei 11.111/05, começa-se a ter acesso a alguns documentos, mas o acervo foi certamente "limpo" antes da transferência dos arquivos do SNI para o Arquivo Nacional, em dezembro de 2005. Como ocorreu quando da transferência dos arquivos dos Deops, a partir de 1991.
} 
pacífica e harmônica” no país. ${ }^{999}$. Tampouco conseguiram mobilizar outros atores sociais, partidos, movimentos sociais ou organizações não governamentais para esta tarefa. Os familiares, por um lado, apesar de protagonistas dessa luta, não se tornaram a voz hegemônica das narrativas e memórias sobre a ditadura ${ }^{1000}$. Os sobreviventes, por outro lado, conquistaram maior espaço nos discursos e memórias sobre o período, em especial, os exilados.

No Estado de São Paulo e em alguns outros, foram instituídas Comissões de Reparação que têm poder de decidir sobre solicitações de indenizações de pessoas que conseguirem provar terem sido sequestradas, presas, torturadas ou exiladas durante a ditadura, ou por terem parentes assassinados por agentes do Estado. Estas indenizações são simbólicas, de valores bastante baixos, cujo pagamento tem sido feito muito lentamente, mas que determinam reparações às vítimas de crimes contra a humanidade cometidos pelo Estado ditatorial e seguem um padrão de tratamento mais equitativo ${ }^{1001}$.

A Comissão de Anistia, subordinada ao Ministério da Justiça, tem contemplado um maior número de pessoas. e despertado polêmicas sobre a legitimidade das reparações. Diante da pressão de setores conservadores e de militares, que denominam pejorativamente as indenizações de "bolsa ditadura”, o debate crítico sobre o significado dessa política de reparação tem sido bastante limitado. As reparações correspondem a reivindicações que remontam à campanha pela anistia aos perseguidos políticos, são demandas por direitos estabelecidos. Não pairam dúvidas sobre o direito às reparações de acordo com a legislação internacional. Desse modo, cerca de 62.000 pedidos de aposentadorias especiais e indenizações tramitam na comissão, seguindo determinação da lei 10.559, cujo foco são as injustiças trabalhistas cometidas pela ditadura e os pedidos de aposentadorias mencionados ${ }^{1002}$. Neste sentido, a referida comissão deveria ser

\footnotetext{
${ }^{999}$ V. Arguição de Descumprimento de Preceito Fundamental (ADPF) $n^{\circ}$ 153, apresentada ao STF pelo Conselho Federal da OAB em 2008, cuja interpretação da Lei de Anistia considera que os torturadores não foram anistiados.

${ }^{1000}$ Conhecemos cinco livros de testemunho feitos por familiares e apenas um romance. Em 30 anos surgiram apenas dois filmes que retratam sua luta, Pra Frente Brasil (1982) e Zuzu Angel (2006).

${ }^{1001}$ Em São Paulo, por exemplo, 1.850 pessoas solicitaram indenizações à Comissão instaurada pela Lei 10.726/01. Há leis de reparação nos seguintes estados: Paraná, São Paulo, Rio Grande do Sul, Pernambuco, Minas Gerais, Ceará e Rio de Janeiro.

${ }^{1002}$ Criada em agosto de 2001, a Comissão de Anistia já analisou 29.079 pedidos de anistia. Segundo o Ministério da Justiça, cerca de 62 mil pedidos de anistia ou indenizações foram apresentados à Comissão de Anistia. Desde sua criação, entre os 38 mil casos julgados, 25 mil foram deferidos. Desses, 10 mil tiveram direito a reparação econômica. Ver Comissão de Anistia em <www.mj.gov.br>. Para as críticas à Comissão de Anistia ver entrevistas concedidas a autora de Frederico Pessoa da Silva, São Paulo, em 26/08/2008, 27/08/2008 e 28/08/2008; e Paulo Martins, São Paulo, em 18/12/2009.
} 
denominada Comissão de Reparação aos Perseguidos Políticos e não Comissão de Anistia.

A legislação reitera as desigualdades sociais ao vincular as indenizações aos seus aspectos trabalhistas e não aos danos e sofrimentos vividos pelas vítimas quanto às graves violações de direitos humanos, conforme apontou Frederico Pessoa Silva, um dos entrevistados no âmbito dessa pesquisa ${ }^{1003}$. Além disso, testemunhos dão conta que na Comissão de Anistia, o princípio de isonomia não tem prevalecido na avaliação das solicitações e no tratamento dado aos requerentes.

O contraste com o direito internacional e a precariedade da política de reparação brasileira diz respeito ao conceito de reparação subjacente a ela, pois que não significa apenas o pagamento de indenizações. Seu ponto de partida é o da perspectiva da vítima, contudo, esta palavra sequer é mencionada nas leis de reparação ${ }^{1004}$. A reparação inclui programas de reabilitação que abrangem terapia e assistência médica, além de medidas simbólicas como o reconhecimento público das vítimas por meio de pedidos oficiais de desculpa e a constituição de espaços públicos de reconhecimento dedicados à memória das vítimas etc. Medidas que foram pouco adotadas no Brasil, mas que, em função de pressões de grupos de defesa dos direitos humanos e de organismos internacionais como a OEA, vêm tomando um lugar mais central nas preocupações do Estado.

Durante o segundo mandato do presidente Lula, o governo federal direcionou-se para a construção de uma política de memória, abrindo com acesso restrito o arquivo do antigo SNI e de outros órgãos da repressão política, em dezembro de 2005; lançando o relatório final da Comissão Especial de Mortos e Desaparecidos Políticos da SEDH, o livro Direito à Memória e à Verdade, sem, contudo, realizar uma ampla investigação nos arquivos do SNI visando sistematizar as informações sobre os mortos e desaparecidos políticos, a exemplo do que realizaou o estado uruguaio. Por outro lado, veiculou uma bela campanha publicitária em todos os veículos de comunicação solicitando à população informações sobre os desaparecidos

O livro Direito à Memória e à Verdade, da SEDH, resultado do trabalho de 10 anos da Comissão Especial de Mortos e Desaparecidos Políticos, constituiu-se num marco, ao reconhecer as responsabilidades do Estado sobre os crimes cometidos pela repressão política. Este reconhecimento oficial foi fundamental para que o Ministério

\footnotetext{
${ }^{1003}$ V., por exemplo, entrevista concedida por Frederico Pessoa da Silva à autora, Idem, ibidem.

1004 MezzrobBA, Glenda. "O processo de acerto de contas e a lógica do arbítrio", em O que resta da ditadura, op.cit., p.115.
} 
Público Federal de São Paulo iniciasse as ações civis mencionadas. A campanha publicitária divulgada em veículos de comunicação foi outra importante iniciativa para que esta temática chegasse à população. Seu conteúdo, porém, retira do Estado a responsabilidade e obrigação de investigar o que aconteceu, pois solicita às pessoas que doem seus arquivos pessoais ou disponibilizem as informações que tiverem sobre os crimes cometidos pelo Estado durante a ditadura.

Em 2008, o Ministério da Justiça instituiu as Caravanas da Anistia, tornando mais públicas as sessões da Comissão de Anistia. Iniciou também a construção do Memorial da Anistia em Minas Gerais. E, em 2009, lançou o projeto Memórias Reveladas, organizado pela Casa Civil da Presidência da República.

Pouco a pouco mais atores sociais têm se engajado nos trabalhos de memória, como o Fórum dos Perseguidos e Ex-Presos Políticos (SP), o MNDH, a OAB, entre outros. O governo federal, porém, desde 2003, quando da divulgação da sentença da justiça favorável aos familiares de desaparecidos da Guerrilha do Araguaia, interpôs recursos e embargos para impedir sua execução, argumentando que a decisão estabeleceu exigências que foram além do pedido da petição inicial de 1982 A sentença, transitada em julgado em 2007, considerou procedente o pedido dos familiares e determinou a quebra de sigilo das informações militares relativas a todas as operações de combate à guerrilha; determinou a obrigação da União informar onde estão sepultados os restos mortais dos guerrilheiros e proceder ao traslado dos mesmos e que sejam fornecidos os dados para serem lavrados os atestados de óbito; e apresentar todas as informações relativas à totalidade das operações militares relacionadas à guerrilha. Estabeleceu também que se proceda à rigorosa investigação no âmbito das Forças Armadas para obter um quadro preciso e detalhado das operações realizadas na Guerrilha do Araguaia ${ }^{1005}$.

O governo Lula assumiu a mesma postura com relação à petição dos familiares da Guerrilha do Araguaia na OEA, procurando postergar - no final de 2009 solicitou o arquivamento do caso - a decisão da Corte Interamericana de Direitos Humanos sobre a questão, finalmente divulgada em dezembro de 2010. Protelando decisões judiciais ou a execução das mesmas, os governos civis do período democrático pouco informaram ou investigaram sobre as circunstâncias dos crimes cometidos pela repressão estatal durante a ditadura.

${ }^{1005}$ Sentença do processo sobre a “Guerrilha do Araguaia”. Brasília-DF, 2007, p. 45-46. 
Em 2008, no lançamento do projeto Caravana da UNE, voltado à recuperação histórica do acervo e do edifício da entidade, Lula procurou afastar a sensação de continuidade quanto à postura dos governantes de bloquear o acesso ao passado recente, apresentando uma nova estratégia retórica:. "No Brasil, não costumamos contar a história dos mortos nem transformá-los em heróis. É preciso tratar um pouco melhor os nossos mortos. O martírio nunca vai acabar se não aprendermos que nossos mortos têm que ser transformados em heróis e não em vítimas”. Desde então, tem feito diversas declarações reafirmando a necessidade de tratar os mortos da ditadura como heróis ao invés de “xingar os algozes”, limitando-se à percepção simplificadora dessa história, pontuada pelo discurso "heroicizante" ou "vitimizante"

No final de 2009, a repercussão sobre a proposta de criação de uma Comissão da Verdade visando apurar os crimes cometidos pelo Estado brasileiro durante a ditadura militar suscitou reação surpreendente do presidente Lula. A proposta, inserida no Programa Nacional de Direitos Humanos, sofreu a pronta oposição das Forças Armadas e do ministro da Defesa, Nelson Jobim, sob a alegação de que uma apuração legítima teria de incluir os crimes da esquerda armada. As diretrizes 23 e 25 do Programa, referentes ao direito à memória e à verdade, foram as que receberam mais críticas. Na diretriz 23, o texto dizia: "promover a apuração e o esclarecimento público das violações de Direitos Humanos praticadas no contexto da repressão política”; na segunda, a diretriz 25, lê-se: "suprimir do ordenamento jurídico brasileiro eventuais normas remanescentes de períodos de exceção”. 1007

Após superficial, mas rumorosa, discussão pública sobre o assunto, Lula assinou, em janeiro de 2010, um novo decreto sobre o tema no qual suprimiu o termo "repressão política”. Deixando para o Congresso Nacional a tarefa de analisar e decidir sobre a proposta de projeto de lei criando a Comissão de Verdade, entregue ao legislativo. ${ }^{1008}$ Este gesto representou um retrocesso do Estado brasileiro no que diz respeito ao estabelecimento de uma ruptura explícita com o legado do passado de ditadura num texto

\footnotetext{
${ }^{1006}$ V. MENDONÇA, Alba Valéria. “'Brasil precisa lembrar de seus mortos como heróis’, diz Lula”, Portal G1, 12/08/2008; Bernardes, Monica. "Lula: 'Brasil precisa de novos heróis'”, O Estado de S. Paulo, 06/09/2008; GóIS, Antônio e SANDER, Letícia. “'País deve lembrar heróis em vez de xingar algozes’, diz Lula”, 13/08/2008, Folha de S.Paulo; RiBEIRO, Jeferson. "Lula diz que abertura de arquivos da ditadura não pode ser revanchismo". Portal G1, 13/05/2009.

1007 Teles, Edson. "Restos da ditadura. Por que as Forças Armadas de hoje temem a punição dos torturadores de ontem". O Globo, 30/01/10.

${ }^{1008}$ A respeito da lei sobre o acesso à informação (lei 11.111/05), que possibilita o "sigilo eterno" de documentos públicos, o governo procedeu da mesma maneira: criou um grupo de trabalho que apresentou proposta de projeto de lei em 2009. O projeto, apesar dos avanços apresentados, manteve um artigo com a possibilidade de "sigilo eterno".
} 
legal. Desde 1985, nenhuma medida oficial havia aceitado a equiparação das violências dos “dois lados”. O decreto retrocede, aceitando implicitamente a interpretação de que a lei de anistia foi recíproca e abrangeu os “dois lados”. Colabora, assim, para sedimentar este mito explicativo, que em nada ajuda a esclarecer o papel do aparato repressivo do Estado e nem o da sociedade e, que ao contrário, encontra nesta figura da reciprocidade a confirmação de sua “inocência e alienação”.

A memória dos anos de repressão política e da ditadura, em grande medida ainda silenciada, permanece, tanto objetivamente quanto subjetivamente, subtraída dos cálculos da razão política no período democrático. Se alguns países latino-americanos dedicam-se à criação de novos investimentos na memória, na elaboração simbólica e judicial do passado, o Brasil mantém-se como modelo de impunidade e sequer promove uma política de reconstituição factual dos crimes da ditadura, mantendo parte importante da estrutura autoritária herdada desse período.

No Brasil, as políticas de memória, iniciadas mais recentemente, aliadas às políticas de reparação precárias instituídas nos anos 1990, estão dissociadas de mecanismos de recuperação da verdade jurídica e histórica e da construção de uma esfera pública que englobe uma ética do testemunho. Desse modo, os governos do período democrático têm conseguido bloquear os conflitos e impossibilitar as “[...] reconfigurações do campo social e do ordenamento jurídico que poderiam equacionar as exigências de reconhecimento” das vítimas e setores sociais atingidos pela ditadura. Trata-se de uma "lógica astuta”, pois ao mesmo tempo em que reconhece as demandas das vítimas por reparações, as desloca o mais possível para fora do campo político e de suas reivindicações por modificações profundas na sociedade [SAFATLE, 2005: 34]. 


\section{Conclusão}

Esta pesquisa compilou 108 entrevistas de ex-presos políticos, advogados e militantes oposicionistas e defensores dos direitos humanos, revelando novos aspectos sobre a memória e as lutas de resistência nos cárceres da ditadura, sob o enfoque metodológico da História Oral. Acontecimentos históricos ainda pouco difundidos ou conhecidos, assim com a própria memória constituída a partir deste legado foram recuperados e re-significados ao longo das quatro unidades temáticas desta tese que, simultaneamente, converteu o próprio testemunho em objeto de análise.

Neste sentido, reconhecemos a necessidade de uma ética do testemunho capaz de transcender limites normativos em direção ao reconhecimento de responsabilidades civis e às obrigações para com os passados dolorosos de violência, com vias às transformações políticas e sociais do futuro tangível. Uma ética do testemunho que implique numa normatividade que não deve se sujeitar à programação e codificação rígida, nem à normalização. Uma ética que implique a construção de "políticas da narrativa” relacionada às práticas articuladoras abertas ao questionamento e à transgressão radical, que possibilitem a ressignificação dos conflitos do passado no presente, tornando público o que tem sido bloqueado e abrindo caminho à ação política inovadora e criativa, dentro de um agir democrático.

Os testemunhos compilados trouxeram à tona a efetiva importância dos presos políticos na sistematização e divulgação das denúncias dos crimes da ditadura, além de sua importância nas lutas e disputas políticas que então se desenrolavam. Paralelamente, a tese procurou mostrar que sobreviventes, familiares e militantes das novas gerações constituíram redes de solidariedade aos presos e perseguidos políticos durante os anos 1970. À despeito de terem contribuído decisivamente para o desgaste da ditadura, estas redes não alcançaram uma unidade duradoura em torno de objetivos político-estratégicos comuns.

A caracterização da experiência dos entrevistados levou-nos à necessidade de tratar dos meandros do aparelho repressivo, desde seu perfil secreto e clandestino até sua face mais visível, representada pelos presídios onde foram encarcerados os militantes oposicionistas. Por meio da descrição de diversas operações repressivas e suas respectivas dinâmicas, aprofundamos o entendimento acerca do funcionamento do próprio sistema DOI-CODI, com ênfase em seus aspectos clandestinos, representados pelos centros de tortura e extermínio. Os testemunhos compilados, em associação com a pesquisa 
complementar realizada, revelou uma interação entre os braços do sistema repressivo que era mais ampla do que se supunha até agora. Dir-se-ia que apesar das conhecidas divergências entre grupos civis e militares, a repressão permaneceu em grande medida centralizada pelo sistema DOI-CODI.

Esta abordagem contemplou novos aspectos do caráter seletivo da repressão brasileira, o que ganhou forma no direcionamento das punições mais severas aos considerados 'irrecuperáveis', cuja perfilação permitiu-nos ainda trazer à tona, o substrato traumático das experiências-limite da tortura e do encarceramento, reificadas no presente.

Descrevemos o cotidiano na prisão e as maneiras encontradas para resistir e se adaptar à dura realidade do encarceramento prolongado, assim como as estratégias de defesa político-jurídicas usadas nos tribunais militares, explicitando um contexto que implicou na formação de redes de solidariedade envolvendo familiares, advogados e militantes de direitos humanos, que por sua vez ganharam uma relativa autonomia social e exerceram importante papel na luta pela anistia aos perseguidos políticos.

Sob o mote do estabelecimento de um campo para transformações político-sociais profundas, a luta em defesa da "anistia, ampla geral e irrestrita” para os perseguidos políticos mobilizou diversos setores da sociedade civil e estabeleceu uma contra memória, rompendo com a invisibilidade e o silêncio impostos aos presos políticos e exilados, combatendo a imagem de "subversivos" e "terroristas" que lhes foi atribuída pela ditadura.

De certo modo, é possível aventar que os grupos e entidades de familiares, sobreviventes e militantes dos direitos humanos como a CJP/SP, a Comissão de Familiares e Mortos e Desaparecidos Políticos, o Centro Santo Dias de Direitos Humanos e os grupos “Tortura Nunca Mais”, entre outros, reverberaram esta luta, reivindicando justiça e o esclarecimento dos crimes cometidos pela ditadura, o desmantelamento do aparelho repressivo, a depuração do Estado, a revogação da LSN e da legalidade de exceção.

As demandas por "verdade e justiça” continuaram presentes no horizonte dos movimentos sociais e dos partidos políticos, âmbito no qual construíram um discurso de memória que, a despeito de seu potencial crítico, permaneceu relativamente marginal, dificultando a construção de vínculos com o passado recente e com as memórias das vítimas fatais e dos sobreviventes.

A exemplo do que havia acontecido em 1945 após o fim da ditadura Vargas, repetiu-se a tradição política brasileira, bastante marcada pela "conciliação pelo alto". Os 
setores políticos, tanto à direita como à esquerda, que tiveram maior protagonismo na etapa final da ditadura civil-militar levaram a um processo de transição política que não exigiu o enfrentamento do passado recente nem transformações mais profundas no país, que levassem à construção de uma democracia plena. Diante de uma correlação de forças desfavorável, as esquerdas passaram a reservar um lugar de menor importância àquelas bandeiras diretamente relacionadas à perspectiva de uma ruptura com o legado da ditadura.

Com a rápida dissolução dos movimentos de anistia, os sobreviventes encontraram dificuldades para se organizar em grupos ou movimentos que contemplassem suas reivindicações específicas e que ocupassem um espaço simbólico na sociedade. Muito em função destas peculiaridades, dir-se-ia que grupos fundamentais, como o "Tortura Nunca Mais”, não puderam levar a cabo seu projeto de delinear e aprofundar os elos com essa história necessários para uma reflexão crítica mais ampla da sociedade acerca deste passado de violência, o qual dependeria da adesão generalizada e efetiva das esquerdas e de outros setores oposicionistas.

Pensamos ter contribuído para o delineamento destes elos, recuperando o contexto de lutas e memórias dos presos políticos, na construção de uma análise crítica que antes de se propor a encerrar uma verdade, propõe-se a dar voz àqueles que mais propriedade têm para a expor. Historicizando um passado que ainda é presente. 


\section{Referências bibliográficas:}

ABRÃo, Paulo. "Brevíssimo panorama sobre a justiça de transição no Brasil”, em: Coordenação de combate à Tortura da SEDH (org.). Tortura, Brasília, SEDH, 2010.

Abramo, Zilah W. e MAuÉs, Flamarion (orgs.). Pela Democracia, contra o arbítrio. A oposição democrática, do golpe de 1964 à campanha das Diretas Já. São Paulo, Ed. Fundação Perseu Abramo, 2006.

AdES, César. "Múltipla Memória”. In: Revista Psicologia USP, Memória, vol. 4. São Paulo, Psicologia USP, 1993.

AdoRno, Theodor. "Caracterização de Walter Benjamin” In: CoHn, Gabriel (org.). Theodor Adorno. São Paulo, Ática, 1986.

Agamben, Giorgio. O que resta de Auschwitz. O arquivo e a testemunha. Homo Sacer III. São Paulo, Boitempo, 2008.

. O poder soberano e a vida nua. Belo Horizonte, UFMG, 2004.

O estado de exceção. São Paulo, Boitempo, 2004a.

Alleg, Henri. A tortura. São Paulo, Zumbi, 1959.

AlenCASTRO, Luiz Felipe. “1964: por quem os sinos dobram?”, em TELES, Janaina (org.). Mortos e desaparecidos políticos: Reparação ou impunidade? 2a . ed. São Paulo, Humanitas/FFLCH-USP, 2001, p. 39-43.

AlmeidA, Criméia A. S. de; LisbôA, Suzana K.; Teles, Janaina de A.; Teles, Maria Amélia de A. (orgs.). Dossiê Ditadura: mortos e desaparecidos políticos no Brasil (1964-1985). São Paulo, IEVE/Imprensa Oficial, 2009.

Alves, Maria Helena Moreira. Estado e oposição no Brasil (1964-1984). Petrópolis, Vozes, 1984.

. Estado e oposição no Brasil (1964-1984). Bauru (SP), Edusc, 2005.

AMÈRY, Jean. Más allá de la culpa y la expiación. Tentativas de superación de una víctima de la violencia. $2^{\mathrm{a}}$ ed., Valencia/Espanha, Pré-textos, 2004.

ANTUnes, Priscilla Carlos Brandão. SNI \& ABIN. Uma leitura dos serviços secretos brasileiros ao longo do século XX. Rio de Janeiro, FGV, 2002.

Argentina, Brasil e Chile e o desafio da reconstrução das agências nacionais civis de inteligência no contexto de democratização. Doutorado, IFCH/Unicamp, 2005.

ARANTES, Paulo Eduardo. “1964, o ano que não terminou”, em: SAFATLE, Vladimir e TELES, Edson (orgs.). O que resta da ditadura? A exceção brasileira. São Paulo, Boitempo, 2010.

AREndT, Hannah. Responsabilidade e julgamento. São Paulo, Companhia das Letras, 2004.

. Origens do totalitarismo. São Paulo, Companhia das Letras, 1989.

ARns, Dom Paulo Evaristo (org.). Brasil: nunca mais. Petrópolis: Vozes, 1985. Brasil: nunca mais. Prefácio Dom Paulo Evaristo Arns. Petrópolis, Vozes, 1985.

. Perfil dos atingidos. Petrópolis, Vozes, 1987.

Avelar, Idelber. Alegorias da derrota. A ficção pós-ditatorial e o trabalho de luto na América Latina. Belo Horizonte, UFMG, 2003.

Azevedo, Ricardo. “O plantão do Napolitano”, em Freire, Alípio; AlmadA, Izaías e Ponce, J. A. de Granville (orgs.). Tiradentes, um presídio da ditadura: memórias de presos políticos. São Paulo, Scipione, 1997.

BAstos, Lúcia Elena Arantes Ferreira. As leis de anistia face ao direito internacional: o caso brasileiro. Doutorado/USP, Direito, 2007.

Batista, Nilo. “Aspectos Jurídico-Penais da Anistia”. Revista Civilização Brasileira. Rio de Janeiro, 1980. 
BAUER, Caroline Silveira. “A produção dos relatórios Nunca Mais na Argentina e no Brasil: aspectos das transições políticas e da constituição da memória sobre a repressão”. In: Revista de História Comparada, v.3, 2008. Disponível em: $<$ http://www.hcomparada.ifcs.ufrj.br/revistahc/revistahc.htm>.

BEnEDITO, Mouzar e Rezende, José Roberto. Ousar lutar. Memórias da guerrilha que vivi. São Paulo, Viramundo, 2000.

Benevides, Maria Victoria de Mesquita. UDN e o Udenismo. Rio de Janeiro, Paz e Terra, 1981.

. Fé na luta. A Comissão Justiça e Paz de São Paulo, da ditadura à democratização. São Paulo, Lettera, 2009.

BENJAmin, Walter. "O narrador: considerações sobre a obra de Nicolai Leskov" (1936). In: Obras escolhidas: Magia e técnica, arte e política. São Paulo, Brasiliense, 1985.

Benveniste, E. Problemas de linguística geral. Vol. I, Campinas, Pontes, 2005. . Problemas de linguística geral. Vol. II. Campinas, Pontes, 1989.

. O vocabulário das Instituições Indo-europeias. Vol.II: Poder, Direito, religião. Trad. D. Bottman, Campinas, Unicamp, 1995.

BerCovicI, Gilberto. "O Direito Constitucional Passa, o Direito Administrativo Permanece: Persistência da Estrutura Administrativa de 1967”. In: SAFATLE, Vladimir e TELES, Edson (orgs.). O que resta da ditadura? A exceção brasileira. São Paulo, Boitempo, 2010.

Bettelheim, B. A fortaleza vazia. São Paulo, Martins Fontes, 1987.

. Coração informado: autonomia na era da massificação. Rio de Janeiro, Paz e Terra, 1988.

. Sobrevivência e outros estudos. Porto Alegre, Artes Médicas, 1989.

BETTO, Frei. Diário de Fernando nos cárceres da ditadura militar. São Paulo, Rocco, 2009.

. Cartas da prisão. Rio de Janeiro, Civilização Brasileira, 1977.

Das catacumbas: cartas da prisão (1969-1971). Rio de Janeiro, Civilização Brasileira, 1978.

Bierrembach, Maria Luiza Flores Cunha. Depoimento. In Merlino, Tatiana e OJedA, Igor. Direito à memória e à verdade: Luta, substantivo feminino. São Paulo, Caros Amigos, 2010.

BioccA, Ettore. Estratégias do Terror. A face oculta e repressiva do Brasil. Lisboa, Iniciativas Editoriais, 1974.

Boff, Leonardo. Prefácio. In: EloysA, Branca (org.). I Seminário do Grupo Tortura Nunca Mais. Petrópolis, Vozes, 1987.

Bonavides, Paulo. Curso de direito constitucional. 11 a ed. São Paulo, Malheiros, 2001.

BRODSKY, Marcelo (Ed.). Memoria en construcción: el debate sobre la ESMA. Buenos Aires, La marca editorial, 2005.

Buchenhorst, Ralph e Lorenzano, Sandra (eds.). Políticas de la memoria. Tensiones en la palabra y la imagen. Buenos Aires, Gorla; Mexico, Universidad del Claustro de Sor Juana, 2007.

CABral, Pedro Corrêa. Xambioá, Guerrilha do Araguaia. Rio de Janeiro, Record, 1993.

CALIGIURI FILHO, Júlio César e outros. Onde estão? Relatório da Comissão Parlamentar de Inquérito que investigou a vala clandestina no Cemitério Dom Bosco, em Perus, e os desaparecidos políticos. São Paulo, Câmara Municipal de São Paulo, 1992.

CAlveIro, Pilar. Poder y desaparición: los campos de concentración en Argentina, $1^{\mathrm{a}}$ ed., $3^{\text {a }}$ reimp. Buenos Aires, Colihue, 2006.

. Valencias políticas de memoria y testimonio, hoy. Mimeo, ago. /2009. 
. “A verdade da repressão”. In Teresina. Rio de Janeiro, Paz e Terra, 1980. (Publicado inicialmente em Opinião, $n^{\circ} 11,15-22$, I, 1972)

CAMARgo, Ana Maria de Almeida. "Os arquivos e o acesso à verdade". In: Desarquivando a ditadura. Memória e Justiça no Brasil. SANTOS, Cecília M.; Teles, Edson; TELES, Janaina de A. (orgs.).

CAMARgos, Márcia M. de R.; e SACChetTA, Vladimir. “A história do presídio Tiradentes: um mergulho na iniquidade”, FreIRE, Alípio; AlmADA, Izaías e PONCE, J. A. de Granville (orgs.). Tiradentes, um presídio da ditadura: memórias de presos políticos. São Paulo, Scipione, 1997.

CÂMDIDO, Antonio. “Os brasileiros e a literatura latino-americana”. In Novos Estudos Cebrap. São Paulo, v. 1, dez. 1981.

. "O purgatório”, em Freire, Alípio; Almada, Izaías e Ponce, J. A. de Granville (orgs.). Tiradentes, um presídio da ditadura: memórias de presos políticos. São Paulo, Scipione, 1997.

CAPElato, Maria Helena. Memórias da ditadura militar argentina: um desafio para a história. São Paulo, 2007, mimeo.

CARDOSO, Irene. “O arbítrio transfigurado em lei e a tortura política”. In: FreIRE, Alípio; AlmadA, Izaías e Ponce, J. A. de Granville (orgs.). Tiradentes, um presídio da ditadura: memórias de presos políticos. São Paulo, Scipione, 1997.

Carnovale, Vera; Lorenz, Federico e PitTaluga, Roberto (comps.). Historia, memoria y fuentes orales. Buenos Aires, CeDinCI, 2006.

CARVAlHO, Luiz Maklouf. O coronel rompe o silêncio. Rio de Janeiro, Objetiva, 2004.

CARUth, Cathy. "Modalidades do despertar traumático. (Freud, Lacan e a Ética da memória)”. In: Nestrovski, Arthur e Seligmann-Silva, Márcio (orgs.). Catástrofe e representação. São Paulo, Escuta, 2000.

CATANI, Afrânio. “Duas memórias de presos políticos: Argentina e Brasil (anos 1970)”. In: Margem Esquerda. Ensaios marxistas. São Paulo, Boitempo, 2005.

Cavalcanti, Pedro C. U.; Ramos, Jovelino (Org.). Memórias do exílio: Brasil (196419??) v. 1. São Paulo, Livramento, 1978.

Citelli, Adilson Odair. “O pequeno concerto que não virou canção”, em FreIRE, Alípio; AlmadA, Izaías e Ponce, J. A. de Granville (orgs.). Tiradentes, um presídio da ditadura: memórias de presos políticos. São Paulo, Scipione, 1997.

ChAuí, Marilena. “A tortura como impossibilidade da política”. In: ElOYSA, Branca (org.). I Seminário do Grupo Tortura Nunca Mais. Petrópolis, VozEs, 1987.

CoelHo, Maria Francisca P. José Genoino. Escolhas políticas. São Paulo, Centauro, 2007.

COMISSÃo de Familiares de mortos e desaparecidos políticos, InSTITUTO de Estudos da Violência do Estado (IEVE), GRUPo Tortura Nunca Mais - RJ e PE. Dossiê dos mortos e desaparecidos políticos a partir de 1964. Prefácio de D. Paulo Evaristo Arns, São Paulo, IMESP, 1996.

COMISSÃo de Familiares de mortos e desaparecidos políticos, INSTITUTO de Estudos da Violência do Estado (IEVE). Dossiê Ditadura - Mortos e Desaparecidos Políticos no Brasil - 1964/1985. São Paulo, IMESP, 2009.

CoMISSÃo Interamericana de Direitos Humanos - Informe anual 1973 - $1^{\mathrm{a}}$ seção, parte III Brasil; citado em RiBEIRO, Flávia Maria F.

Congresso Nacional. Anistia, Comissão Mista sobre anistia, Brasília-DF, 1982, vol.II.

Couto, Ronaldo Costa. História indiscreta da ditadura e da abertura. Brasil: 19641985. Rio de Janeiro, Record, 1998.

Dalgastagnè, Regina. O espaço da dor: O regime de 64 no romance brasileiro. Brasília, Editora UnB, 1996. 
DANIEL, Herbert. Passagem para o próximo sonho. Rio de Janeiro, Codecri, 1982.

D'ARAÚJO, M.C.; SOARES, G.A.D.; CASTRO, C. Os anos de chumbo: a memória militar sobre a repressão. Rio de Janeiro, Relume-Dumará, 1994.

. A volta aos quartéis: a memória política sobre a abertura. Rio de Janeiro, Relume-Dumará, 1995.

DERRIDA, Jacques. El siglo y el perdón seguida de Fé y saber. Buenos Aires, Ediciones de la Flor, 2003.

. Força de lei. São Paulo: Martins Fontes, 2007, p.140.

. "O direito à justiça”. In: Força de Lei. O fundamento místico da autoridade. São Paulo, Martins Fontes, 2007.

DiAs, Luzimar Nogueira (Org.). Esquerda armada: testemunhos dos presos políticos do Presídio Milton Dias Moreira no Rio de Janeiro. Vitória, Edições do Leitor, 1979.

DuHALDE, Eduardo Luis. El Estado Terrorista Argentino. Barcelona, Editorial Argos Vergara, 1983

EloYSA, Branca (org.). I Seminário do Grupo Tortura Nunca Mais. Petrópolis, Vozes, 1987.

Endo, Paulo César. A violência no coração da cidade. Um estudo psicanalítico. São Paulo, Fapesp/Escuta, 2005.

. A dor dos recomeços: a luta pelo reconhecimento e pelo dever histórico no Brasil, mimeo, 2009.

. "Elaboração onírica e representação na literatura de testemunho pós-ditadura no Brasil”, em: Coordenação de combate à Tortura da SEDH (org.). Tortura, Brasília, SEDH, 2010.

FALCON, Yara. Mergulho no passado. A ditadura que vivi. Maceió, Livro Rápido, 2007.

FARIA, Cátia. Revolucionários, Bandidos e Marginais. Presos políticos e comuns sob a ditadura militar. Mestrado, História/UFF, 2005.

FERNANDES, Fernando Augusto Henriques. A voz humana: a defesa perante os tribunais da República. Rio de Janeiro, Revan, 2004.

FICO, Carlos. Reinventando o otimismo. Rio de Janeiro, FGV, 1997. . Como eles agiam. Rio de Janeiro, Record, 2001.

. Além do golpe: versões e controvérsias sobre 1964 e a ditadura militar. Rio de Janeiro, Record, 2004.

. A negociação parlamentar da anistia de 1979 e o chamado "perdão aos torturadores". Disponível em <www.ppghis.ifcs.ufrj.br>

FigueIREDO, Lucas. Olho por olho: os livros secretos da ditadura. Rio de Janeiro, Record, 2009.

FINKIELKRAUT, Alain. A memória vã: do crime contra a humanidade. Rio de Janeiro, Paz e Terra, 1989.

FOUCAUlT, Michel. Vigiar e Punir. Vigiar e punir. História da violência nas prisões. $10^{\mathrm{a}}$ ed., Petrópolis, Vozes, 1993.

FrANCO, Renato. "Literatura e catástrofe no Brasil: anos 70". In: SeligmanN-Silva, Márcio. História, Memória, Literatura. O testemunho na Era das Catástrofes. Campinas/SP, Edunicamp, 2003.

. Itinerário político do romance pós-64: A Festa. São Paulo, Editora Unesp, 1998.

FrAGOSO, Heleno Cláudio. Advocacia da liberdade: a defesa nos processos políticos. Rio de Janeiro, Forense, 1984.

FreIRE, Alípio. “Quem pintou na cadeia”. In: Teoria e Debate, n 27dez 94/e jan/fev 1995.

- "Um acervo de imagens dos presídios políticos: o cotidiano através das artes plásticas”. In: Projeto História, São Paulo, nº 21, pp.183-203, nov. 2000. 
Freire, Alípio; AlmadA, Izaías e Ponce, J. A. de Granville (orgs.). Tiradentes, um presídio da ditadura: memórias de presos políticos. São Paulo, Scipione, 1997.

FREUD, S. “O estranho”. In: Edição Standard Brasileira das obras psicológicas completas de S. Freud, Vol. XVII. Rio de Janeiro, Imago, 1976.

. "O inconsciente”. In: Escritos sobre a psicologia do inconsciente. Vol.II, (19151920)/Sigmund Freud. Rio de janeiro, Imago, 2006.

“Além do princípio do prazer". In: Escritos sobre a psicologia do inconsciente. Vol.II, (1915-1920)/Sigmund Freud. Rio de janeiro, Imago, 2006.

. “A repressão”. In: Introdução ao narcisismo: ensaios de metapsicologia e outros textos (1914-1916)/Sigmund Freud. Trad. Paulo César de Souza. São Paulo, Companhia das Letras, 2010.

"Recordar, repetir e elaborar" (1914). Trad. Paulo César de L. Souza. Jornal de Psicanálise, São Paulo, jul.1994.

_ .Luto e melancolia” (1917). Artigos sobre Metapsicologia. Rio de Janeiro, Imago, 1999.

FRIEDLANDER, Saul. (comp.). En torno a los limites de la representación. El nazismo y la solución final. Bernal: Univ. Nacional de Quilmes, 2007.

GAGNEBIN, Jeanne Marie. “O preço de uma reconciliação extorquida”, em: TELES, Edson e SAFATLE, Vladimir (orgs.). O que resta da ditadura. A exceção brasileira. São Paulo, Boitempo, 2010.

"Esquecer o passado?", Recordando a Walter Benjamin: justicia, historia y verdad. Escrituras de la memória. III Seminário Internacional de Políticas de la Memória. Buenos Aires, outubro de 2010.

GALVÃo, Walnice Nogueira. “Um novo biografismo”. In: As musas sob assédio. Literatura e indústria cultural no Brasil. São Paulo, Senac, 2005.

GASPARI, Elio. A Ditadura Envergonhada. São Paulo, Cia. das Letras, 2002a. . A Ditadura Escancarada. São Paulo, Cia. das Letras, 2002b.

GASPAROTTO, Alessandra. "O Terror renegado." Uma reflexão sobre os episódios de retratação pública protagonizado por integrantes de organização de combate à ditadura civil-militar no Brasil (1964-1975). Mestrado, História/UFRGS, 2008.

GinzBuRG, Carlo. "Sinais. Raízes de um paradigma indiciário”, em Mitos, Emblemas e Sinais. São Paulo, Companhia das Letras, 2001.

. "Solo um testigo". In: FRIEDLANDER, Saul. (comp.). En torno a los limites de la representación. El nazismo y la solución final. Bernal: Univ. Nacional de Quilmes, 2007.

. “Prueba, memoria y olvido”. In Nuestra Memoria (Año XI · No 26 · Dic./2005), Buenos Aires, Fundación Memoria del Holocausto.

. "Unus testis - o extermínio de judeus e o princípio de realidade”, em: $O$ fio e os rastros. São Paulo, Companhia das Letras, 2007.

GINZBURG, Jaime. “Imagens da tortura: ficção e autoritarismo em Renato Tapajós”, em: KeIL, Ivete. O corpo torturado. São Paulo, Escritos, 2004.

. "Ditadura e estética do trauma: Exílio e fantasmagoria”, em: VianA, Chico. O rosto escuro de Narciso ensaios sobre literatura e melancolia. João Pessoa, Ideia, 2004. . "A ditadura militar e a literatura brasileira: tragicidade, sinistro e impasse”, em:

SANTos, Cecília MacDowell; Teles, Edson; Teles, Janaina de A. (orgs.) Desarquivando a Ditadura. Memória e Justiça no Brasil, Vol. II. São Paulo, Hucitec, 2009.

Gorender, Jacob. Combate nas trevas. São Paulo, Ática, 1998.

GoretTA, Nilda Actis e outros. Ese infierno. Buenos Aires, Altamira, 2006. 
Greco, Heloisa Amélia. Dimensões fundamentais da luta pela anistia. Doutorado, FAFICH/UFMG, 2003.

Green, James N. Apesar de Vocês. São Paulo, Companhia das Letras, 2009.

Gouveia JR., Antonio. “Teatro do Zebedeu”, em: Buzzoni, Henrique d'Aragona (org.). Arcadas no tempo da ditadura. São Paulo, Saraiva, 2003.

HobsBawn, Eric; RANGER, Terence (orgs.). A invenção das tradições. Rio de Janeiro: Paz e Terra, 1984.

HuYsSEn, Andreas. Seduzidos pela memória: arquitetura, monumentos, mídia. Rio de Janeiro, Aeroplano, 2000.

"En busca del futuro perdido", em: En busca del futuro perdido. Cultura y memoria en tiempos de globalización. Buenos Aires, FCE/Goethe-Institut, 2002.

IOKOI, Zilda M. Grícoli. "A longa tradição de conciliação ou estigma da cordialidade: democracia descontínua e de baixa intensidade”, em: SANTOS, Cecília MacDowell; Teles, Edson; Teles, Janaina de A. (orgs.) Desarquivando a Ditadura. Memória e Justiça no Brasil, Vol. II. São Paulo, Hucitec, 2009.

JELIN, Elisabeth. Los trabalhos de la memoria. Madrid, Siglo XXI, 2002.

JimenEz, Tenente José . Bacaba: memórias de um guerreiro de selva da Guerrilha do Araguaia. Campo Grande (MS), Editora do Autor, 2007.

JOFFILY, Mariana. "Quando o ataque é a melhor defesa: interrogatórios políticos da Oban e do DOI-CODI”. In: Antíteses, Ahead of Print do vol.2, n 4, jul.-dez. de 2009. Disponível em: <http://www.uel.br/revistas/uel/index.php/antiteses>.

. No centro da engrenagem. Os interrogatórios na Operação Bandeirante e no DOI de São Paulo (1969-1975). Doutorado, História/USP, 2008.

José, Emiliano. As asas invisíveis do Padre Renzo. São Paulo, Casa Amarela, 2000.

José, E.; MiRAndA, O. Lamarca, o capitão da guerrilha. 16a. ed., São Paulo, Global.

KeHL, Maria Rita. O ressentimento. São Paulo, Casa do Psicólogo, 2004.

. “Tortura e sintoma social”. In: SAFATLE, Vladimir e TELES, Edson (orgs.). O que resta da ditadura? São Paulo, Boitempo, 2010.

KORDON, Diana e EDELMAN, Lucila. Efectos psicológicos multigeneracionales de la represión de la dictadura. Disponível em: www.psi.uba.ar/biblioteca/bvs/aappg/revistas_digitalizadas. Acesso em 02/05/2010.

KoutzII, Flávio. Pedaços de morte no coração. Um depoimento de um brasileiro que passou quatro anos no inferno das prisões políticas da Argentina. Porto Alegre, LPM, 1984.

KUCINSKI, Bernardo. Abertura, a história de uma crise. São Paulo, Brasil Debates, 1982.

Kushnir, Beatriz. Cães de Guarda: Jornalistas e Censores, do AI-5 à Constituição de 1988. Doutorado, História/Unicamp, 2001.

LACAPRA, Dominick. Historia em tránsito. Experiencia, identidad, teoría crítica. Buenos Aires, Fondo de Cultura Econômica, 2006. . Escribir la historia, escribir el trauma. Buenos Aires, Nueva Visión, 2005.

LEVI, Primo. Os afogados e os sobreviventes. São Paulo, Paz e Terra, 1990. . É isto um homem? Rio de Janeiro, Rocco, 1988.

LIMA, Haroldo. Itinerário. Salvador, Comitê Brasileiro pela Anistia - Núcleo Bahia, 1979.

LiMA, Ruth Ribeiro de. Nunca é tarde para saber: histórias de vida, histórias da guerrilha. Doutorado, História/USP, 1998.

LIMA, Samarone. Clamor. A vitória de uma conspiração brasileira. São Paulo, Objetiva, 2003.

Lins E Silva, Técio. O que é ser advogado. Rio de Janeiro, Record, 2005.

LoBo, Amilcar. A hora do lobo, a hora do carneiro. Petrópolis, Vozes, 1989. 
Lowenthal, David. “Como conhecemos o passado”. In Projeto História, São Paulo, nov./1998.

LöWY, Michael. Walter Benjamin: aviso de incêndio. Uma leitura das teses "Sobre o conceito de história”. São Paulo, Boitempo, 2005.

LUCA, Derlei Catarina de. No corpo e na alma. Criciúma, Ed. do autor, 2002.

LYOTARD, Jean-François. La diferencia. Barcelona, Gedisa, 1988.

MACHADO, Luiz Raul. "Recordação da casa dos vivos", em Freire, Alípio; AlmadA, Izaías e Ponce, J. A. de Granville (orgs.). Tiradentes, um presídio da ditadura: memórias de presos políticos. São Paulo, Scipione, 1997.

MAIA, Maurício. Henfil e a censura: o papel dos jornalistas. Mestrado, Jornalismo/ECAUSP, 1999.

MARTINS Filho, João Roberto. A guerra da memória: a ditadura militar nos depoimentos de militantes e militares. Congresso LASA, Texas/EUA, mar. 2003, mimeo.

. “A ditadura revisitada: unidade ou desunião?” In UFRJ, UFF, CPDOC e APERJ. 1964-2004. 40 anos do golpe. Ditadura militar e resistência no Brasil. Rio de Janeiro, 7 letras, 2004.

. "Tortura e ideologia: os militares brasileiros e a doutrina da guerre révolutionnaire (1954-1979)”. In: SANTOS, Cecília MacDowell; TELES, Edson; TELES, Janaina de A. (orgs.). Desarquivando a Ditadura: Memória e Justiça no Brasil. Vol. I, São Paulo, Hucitec, 2009.

MARTINS, Roberto Ribeiro. Liberdade para os brasileiros: anistia ontem e hoje. Rio de Janeiro, Civilização Brasileira, 1978.

MATTOS, Marco Aurélio Vannucchi Leme de. Em nome da segurança nacional: os processos da justiça militar contra a Ação Libertadora Nacional (ALN), 1969-1979. Mestrado, História/USP, 2002.

MAUÉs, Eloísa Aragão. Em câmera lenta, de Renato Tapajós: a história do livro, experiência histórica da repressão e narrativa literária. Mestrado, História/USP, 2008.

MAUÉs, Flamarion. Editoras de oposição no período da abertura (1974-1985): negócio e política. Mestrado/História, USP, 2005.

“"Ter simplesmente este livro nas mãos é já um desafio’: livros de oposição no regime militar, um estudo de caso.” Em Questão, Porto Alegre, v. 11, n 2, jul./dez. 2005.

Meiny, José Carlos Sebe Bom. Manual de História Oral. $3^{\text {a }}$ ed., São Paulo, Loyola, 2000. . "Definindo história oral e memória”. In: Cadernos CERU, n 5, série 2, São Paulo, 1994.

Meloni, Catarina. 1968 - O tempo das escolhas. São Paulo, Nova Alexandria, 2010.

MEZArobBA, Glenda. Um acerto de contas com o futuro. A Anistia e suas consequências - Um estudo do caso brasileiro. Mestrado, Ciência Política/USP, 2003.

. O Preço do Esquecimento: as reparações pagas às vítimas do regime militar (uma comparação entre Brasil, Argentina e Chile). Doutorado, Ciência Política/USP, 2008.

“O processo de acerto de contas e a lógica do arbítrio”, em TELES, Edson e SAfATLE, Vladimir (orgs.). O que resta da ditadura. A exceção brasileira. São Paulo, Boitempo, 2010.

Morais, Taís; Silva, Eumano. Operação Araguaia. Os arquivos secretos da guerrilha. São Paulo, Geração Editorial, 2005.

MoreIRA, Fernanda Machado. "Modesto da Silveira: um soldado humano”. In: SÁ, Fernando; MunteAL, Osvaldo e MARTins, Paulo Emílio. Os advogados e a ditadura de 1964. A defesa dos perseguidos políticos no Brasil. Rio de Janeiro, Vozes, 2010.

MourA, Mariluce. A Revolta das Vísceras. São Paulo, Codecri, 1982. 
NAPOLITANO, Marcos. “O 'tesouro perdido': a resistência no campo da cultura (Brasil 1969/1976)”. In: DuARTE, André; Lopreato, Christina; MagalHÃEs, Marion Brepohl de (Org.s). A banalização da violência: a atualidade do pensamento de Hannah Arendt. Rio de Janeiro, Relume-Dumará, 2004.

Nestrovski, Arthur e Seligmann-Silva, Márcio (orgs.). Catástrofe e representação. São Paulo, Escuta, 2000.

OBERTI, Alejandra. "Memorias y testigos, uma discusión actual". In: Memoria(s) y política. Experiencia, poéticas y construcciones de nación. Buenos Aires, Prometeo Libros, 2009.

. "El valor del testimonio: usos, accesos y saberes". Texto apresentado no Seminário Internacional 30 Anos de Anistia no Brasil: o direito à memória, à verdade e à justiça. Fadusp, São Paulo, 26/08/2009a.

Ollier, María Matilde. La creencia y la pasión. Privado, público y político en la izquierda revolucionária. Buenos Aires, Ariel, 1998.

. De la revolución a la democracia. Câmbios privados, público y políticos de la isquierda argentina. Buenos Aires, Siglo Veintiuno Ed., 2009.

PADROS, Enrique Serra. Como el Uruguay no hay... TERROR DE ESTADO E SEGURANÇA NACIONAL. Uruguai (1968-1985): do Pachecato à Ditadura CivilMilitar. Doutorado/História, UFRGS, Tomo I e II, 2005.

PALmAR, Aluízio. Onde vocês enterraram nossos mortos? Foz do Iguaçu, Travessa dos Editores, 2005.

Pellegrini, Tânia. Gavetas vazias: ficção e política nos anos 70. São Carlos/SP, Eduscar/Mercado de Letras, 1996.

Pellegrino, Helio. "O tesouro encontrado”. In: Polari, A. Em busca do tesouro Perdido. Rio de Janeiro, Codecri, 1982.

Perazzo, Priscila Ferreira. Prisioneiros de guerra. Os "súditos do eixo" nos campos de concentração brasileiros (1942-1945). São Paulo, Humanitas-Imesp, 2009.

PereirA, Anthony W. Ditadura e Repressão. O autoritarismo e o estado de direito no Brasil, no Chile e na Argentina. Rio de Janeiro, Paz e Terra, 2010.

PereirA, Anthony W. "Sistemas judiciais e repressão política no Brasil, Chile e Argentina”. In: SAnTos, Cecília MacDowell; Teles, Edson; Teles, Janaina de A. (orgs.). Desarquivando a Ditadura: Memória e Justiça no Brasil. Vol. II, São Paulo, Hucitec, 2009.

PÉRIÈS, Gabriel. "La doctrina militar contrainsurgente como fuente normativa de um poder de facto exterminador basado sobre la excepcionalidad”. In: FEIERSTEIN, Daniel (org.). Terrorismo de Estado y genocídio em América Latina. Bs. As./Argentina, Prometeu, 2009.

Pietrocolla, Luci Gati. Anos 60/70: O viver entre parênteses - A perseguição política aos revolucionários e suas famílias. Doutorado, Sociologia/FFLCH-USP, 1995.

PinheIro, Paulo Sérgio. Estratégias da ilusão: a revolução mundial e o Brasil (19221935). São Paulo, Companhia das Letras, 1991.

PivetTA, Idibal de Almeida. "Habeas Data de Idibal Matho Gomes de Almeida Pivetta”. In: VIEIRA, César. Em busca de um teatro popular. 4a ed. São Paulo, Funarte, 2007.

PolARI, Alex. Em Busca do Tesouro Perdido. Rio de Janeiro, Codecri, 1982.

Politi, Maurice. Resistência atrás das grades. São Paulo, Plena Editorial, 2009.

POMAR, Wladimir. Araguaia, o partido e a guerrilha. São Paulo, Brasil Debates, 1980.

Prado Junior, Antonio de Pádua. "A massa quer sangue, então terá...”, em Freire, Alípio; AlmadA, Izaías e Ponce, J. A. de Granville (orgs.). Tiradentes, um presídio da ditadura: memórias de presos políticos. São Paulo, Scipione, 1997.

RAMOs, Graciliano. Memórias do cárcere, Rio de Janeiro, Record, 2008. 
ReIS FILHo, Daniel Aarão. Ditadura militar, esquerdas e sociedade. Rio de Janeiro, Zahar, 2000.

Ricoeur, Paul. A crítica e a conviç̧ão. Lisboa, Edições 70, 1997. . A memória, a história, o esquecimento. Campinas, Unicamp, 2007. ."Dever de memória, dever de justiça”. In: A crítica da convicção. Lisboa/Portugal, Edições 70, 1997.

RiDENTI, Marcelo. O fantasma da revolução. São Paulo, Ed. Unesp, 1993.

Em busca do povo brasileiro, Rio de Janeiro, Record, 1999.

“O romantismo revolucionário nos anos 60”. In: FREIRE, Alípio; AlmADA, Izaías e Ponce, J. A. de Granville (orgs.). Tiradentes, um presídio da ditadura: memórias de presos políticos. São Paulo, Scipione, 1997.

. "Resistência e mistificação da resistência armada contra a ditadura”. In: REIS FILHO, Daniel Aarão; RIDENTI, Marcelo; MotTA, Rodrigo Patto Sá (orgs.). O golpe e a ditadura militar: quarenta anos depois (1964-2004). Bauru/SP, Edusc, 2004.

Fantasmas da Revolução Brasileira. $2^{\text {a }}$ ed., São Paulo, Ed. UNESP, 2010.

Brasilidade Revolucionária. São Paulo, Ed. UNESP, 2010.

RochA, Jorge Luís. "Heleno Cláudio Fragoso: um mestre nos tribunais de exceção". In:

SÁ, Fernando; Munteal, Osvaldo e Martins, Paulo Emílio. Os advogados e a ditadura de 1964. A defesa dos perseguidos políticos no Brasil. Rio de Janeiro, Vozes, 2010.

RoIG, Vicente. "Encontro e reencontro com o amor e a vida", em FrEIRE, Alípio; AlmadA, Izaías e Ponce, J. A. de Granville (orgs.). Tiradentes, um presídio da ditadura: memórias de presos políticos. São Paulo, Scipione, 1997.

ROLLEMBERG, Denise. Entre raízes e radares. Rio de Janeiro, Record, 1999.

. "Esquerdas revolucionárias e luta armada". In: FERREIRA, Jorge e DELGADO, Lucília de Almeida Neves (orgs.). O Brasil Republicano. O tempo da ditadura. Regime militar e movimentos sociais em fins do século $X X$. Rio de Janeiro, Civilização Brasileira, 2003.

RosA, Susel Oliveira da. Estado de Exceção e vida nua: violência policial em Porto Alegre entre os anos de 1960 e 1990. Doutorado, História/Unicamp, 2007.

RoudinESCO, Elizabeth. “Georges Canguilhem”. In: Filósofos na tormenta. Canguilhem, Sartre, Foucault, Althusser, Deleuze e Derrida. Rio de Janeiro, Zahar, 2007.

Rousso, Henry. "La trayectoria de un historiador del tiempo presente, 1975-2000" In PÉrotin-Dumon, Anne (dir.). Historizar el pasado vivo en América Latina, 2007. Disponível em http://etica.uahurtado.cl/historizarelpasadovivo/es_contenido.php, acesso em 15/12/2010.

SÁ, Fernando; Munteal, Osvaldo e MARTins, Paulo Emílio. Os advogados e a ditadura de 1964. A defesa dos perseguidos políticos no Brasil. Rio de Janeiro, Vozes, 2010.

SAFATLE, Vladimir. "Do direito ao uso da violência contra o estado ilegal”, em: SAFATLE, Vladimir e TELES, Edson (orgs.). O que resta da ditadura? A exceção brasileira. São Paulo, Boitempo, 2010.

"Encontro marcado". Reportagem, n ${ }^{\circ}$ 65, fev.2005.

SARlo, Beatriz. Tempo Passado. Cultura da memória e guinada subjetiva. São Paulo, Companhia das Letras/UFMG, 2007.

Sanna Pinto, Fernando. Depoimento apresentado à Comissão de Anistia. Montpellier (França), 26/05/2005.

SANTOS JR., Belisário dos. "O advogado, o bêbado e a equilibrista (um tempo necessitado de anistia)”. In: Anistia 20 anos. Revista Cultural, ano I, nº 5, 1999.

SANTos, Cecília MacDowell; Teles, Edson; Teles, Janaina de A. (orgs.) Desarquivando a Ditadura. Memória e Justiça no Brasil, Vol. I e II. São Paulo, Hucitec, 2009. 
SCHILLING, Flávia. Estudos sobre resistência. Mestrado, Educação/Unicamp, 1991.

SeCRETARIA Especial de Direitos Humanos da Presidência da República; CoMISsão Especial de Mortos e Desaparecidos Políticos. Direito à Memória e à Verdade. Brasília (DF), 2007.

SeCRETARIA Especial de Direitos Humanos da Presidência da República; ComISSÃo Especial de Mortos e Desaparecidos Políticos. Habeas Corpus - que se apresente o corpo. Brasília (DF), 2010.

Seligmann-Silva, Márcio (org.). História, Memória, Literatura. O testemunho na Era das Catástrofes. Campinas, Ed. Unicamp, 2003 . Adorno. São Paulo, PubliFolha, 2003.

. "Testemunho e a política da memória: o tempo depois das catástrofes”. Projeto História, São Paulo, 30, jun.2005.

. (org.). Palavra e imagem: memória e escritura. Chapecó, Argos, 2006.

- Adorno, a paisagem catastrófica do século XX e a estética após o “desencadeamento do elementar”. Prolegômenos para o pós-estético. São Paulo, 2006, mimeo.

"Deletar arquivos, apagar o passado: ars oblivionalis, entre a necessidade e a resistência”. In: Cadernos AEL, Anistia e direitos humanos. Campinas, Unicamp/IFCH/AEL, v. 13, n 24/25, 2008.

. O caso brasileiro ou o não-lugar do testemunho. Mimeo, ago./2009.

"Anistia e (in) justiça no Brasil: o dever de justiça e a impunidade” em: SANTOS, Cecília MacDowell; Teles, Edson; Teles, Janaina de A. (orgs.) Desarquivando a Ditadura. Memória e Justiça no Brasil, Vol. II. São Paulo, Hucitec, 2009.

SERBIN, Kenneth P. Diálogos na Sombra. Bispos e Militares, tortura e justiça social na ditadura. São Paulo, Companhia das Letras, 2001.

SiLVA, Mário Augusto Medeiros da. Os escritores da guerrilha urbana. São Paulo, Annablume, 2008.

Silverman, Malcom. Protesto e o novo romance brasileiro. $2^{\mathrm{a}}$ ed. revista. Rio de Janeiro, Civilização Brasileira, 2000.

SiPAHI, Rita. "Em nome da rosa”, em Freire, Alípio; AlmadA, Izaías e PonCE, J. A. de Granville (orgs.). Tiradentes, um presídio da ditadura: memórias de presos políticos. São Paulo, Scipione, 1997.

SkIDMORE, Thomas. Brasil: de Castelo a Tancredo. Rio de Janeiro, Paz e Terra, 1995.

SimAs, Mário. Gritos de justiça: Brasil (1963-1979). São Paulo, FTD, 1986.

SouZA, Percival. Autópsia do medo. São Paulo, Globo, 2000.

StUdART, Hugo. A Lei da Selva. Estratégias, imaginário e discurso dos militares sobre a Guerrilha do Araguaia. São Paulo, Geração Editorial, 2006.

SüsseKInd, F. Literatura e vida literária: Polêmicas, diários \& retratos. Rio de Janeiro, Jorge Zahar, 1985.

Swensson JR., Lauro Joppert. Anistia Penal. Problemas de Validade da Lei de Anistia Brasileira (Lei 6.683/79). Curitiba, Juruá, 2007.

SWENSSON JR., Walter Cruz. Os limites da liberdade. A atuação do STF no julgamento de crimes políticos durante o regime militar (1964-1979). Doutorado/História-USP, 2006.

TAPAJós, Renato. “A floresta de panos”, em Freire, A.; AlmadA, I. e PONCE, J. A. de G. (orgs.). Tiradentes, um presídio da ditadura: memórias de presos políticos. São Paulo, Scipione, 1997.

TAVARES, F. Memórias do esquecimento. Rio de Janeiro, Editora Globo, 1999.

Tavares, Marco Antônio. Herança de um sonho. As memórias de um comunista. Rio de Janeiro, Record, 2000. 
TeIXeIRA, Iberê Athaide. Nuvens de Chumbo sobre o Cambaí - a Queda de João Goulart, um Campo de Prisioneiros em Itaqui. Porto Alegre, Martins Livreiro, 2009.

TELes, Edson Luís de Almeida. Brasil e África do Sul: os paradoxos da democracia. Memória política em democracias com herança autoritária. Doutorado/Filosofia, USP, 2007.

TEles, Edson e SAfATle, Vladimir (orgs.). O que resta da ditadura. A exceção brasileira. São Paulo, Boitempo, 2010.

TELES, Janaína (org.). Mortos e desaparecidos políticos: Reparação ou Impunidade? 2a ed., Humanitas/FFLCH-USP, 2001.

Os herdeiros da memória: a luta dos familiares de mortos e desaparecidos políticos por "verdade e justiça” no Brasil. Mestrado, História/FFLCH, USP, 2005.

. "Os familiares de mortos e desaparecidos políticos e a luta por "verdade e justiça" no Brasil”. In: SAFAtle, Vladimir e Teles, Edson (orgs.). O que resta da ditadura? A exceção brasileira. São Paulo, Boitempo, 2010.

TELES, Janaina de A.; RIDENTI, Marcelo; IOKOI, Zilda M. Grícoli (orgs.). Intolerância e Resistência: Testemunhos da repressão política no Brasil (1964-1985). São Paulo, FFLCH/USP, 2010.

Teles, Maria Amélia de A. "Lembranças de um tempo sem sol...”, em PedRo, Joana Maria; Wolff, Cristina Scheibe (orgs). Gênero, Feminismo e Ditaduras no Cone Sul. Ilha de Santa Catarina, Editora Mulheres, 2010.

THIESEN, Icleia (org.). Imagens da clausura na ditadura de 1964. Informação, Memória e História. Rio de Janeiro, 7 Letras, 2011.

Thompson, Paulo. A voz do passado - História Oral. Rio de Janeiro, Paz e Terra, 1992.

Todorov, Tzvetan. Los abusos de la memoria. Barcelona/Espanha, Paidós/Asterisco, 2000.

Traverso, Enzo. “História y memória. Notas sobre um debate”. In: Franco, Marina y LeVIn, F. (comps.). Historia reciente. Perspectivas y desafios de un campo en construcción. Buenos Aires, Paidós, 2007. 2007 a.

. El pasado, instruciones de uso. Historia, memoria, política. Madrid, Marcial Pons,

TroncA, Ítalo Arnaldo. “Trinta anos de Brasil: História, ficção e violência a propósito da violência em Hannah Arendt”. In: DuARTE, André; LOPREATO, Christina; MAGALHÃEs, Marion Brepohl de (Orgs.). A banalização da violência: a atualidade do pensamento de Hannah Arendt. Rio de Janeiro, Relume-Dumará, 2004.

VAldeZ, Patrícia. Tiempo óptimo para la memoria (2000). Disponível em: $<$ www.memoriaabierta.org.ar>.

VenturA, Toni. "Hércules 56 e os cacos do espelho estilhaçado". In: Teoria e Debate, no 71, ano 20, mai./jun. 2007.

VERBITSKY, Horacio. O Vôo. A história da operação militar de extermínio que abalou a Argentina. São Paulo, Globo, 1995.

VezzetTi, Hugo. Sobre la violencia revolucionaria. Memórias y olvidos. Buenos Aires, Siglo XXI, 2009.

VIANNA, Gilney Amorim. 131-D. Linhares: Memorial da prisão política. Contagem, Editora História/Comitê Brasileiro pela Anistia/ Movimento Feminino pela Anistia, 1979.

VIÑAR, Maren e Marcelo. Exílio e tortura. São Paulo, Escuta, 1992.

WEINRICH, Harald. Lete: A arte e crítica do esquecimento. Rio de Janeiro, Civilização Brasileira, 2001.

WESCHLER, Lawrence. Um milagre, um universo: o acerto de contas com os torturadores. São Paulo, Companhia das Letras, 1990. 
WiNTER, Jay. “A geração da memória: as reflexões sobre ‘boom da memória’ nos estudos contemporâneos de história” In: SEligmanN-Silva, Márcio (org.). Palavra e imagem: memória e escritura. Chapecó, Argos, 2006.

ZAVERUCHA, Jorge. FH, Forças Armadas e Polícia. Entre o autoritarismo e a democracia (1999-2002). Rio de Janeiro, Record, 2005.

\section{Documentos e Periódicos}

Ação Judicial dos familiares dos desaparecidos da Guerrilha do Araguaia iniciado em 1982, transitado e julgado em 2007, pela $1^{\text {a }}$ Vara da Justiça Federal/DF.

AlenCAR, Kennedy e Cruz, Valdo. "Caso Herzog abre crise entre Lula e Defesa”. Folha de S. Paulo, 19/10/2004.

“Anistia para sempre” (Editorial). Folha de S. Paulo, 16/12/06.

Almeida, Criméia A. S. Habeas-data. Brasília/DF, Presidência da República - Secretaria de Assuntos Estratégicos, 10/07/1991.

Habeas-data. Brasília/DF, Presidência da República - Casa Militar, Subsecretaria de Inteligência, 20/02/1998.

ARGUIÇÃo de Descumprimento de Preceito Fundamental (ADPF) $n^{0} 153$, apresentada ao STF pelo Conselho Federal da OAB em 2008.

“Arquivos violados?” Metro News, 19/03/92.

ATO Institucional no 1, de 09/04/64, em <www.senado.gov.br/legislação>.

ATO Institucional n ${ }^{\circ}$ 5, de 13/12/68, em < www.senado.gov.br/legislação>.

“Autopsia da Sombra”. Veja, 18/11/92.

Bernardes, Monica. "Lula: 'Brasil precisa de novos heróis’”, O Estado de São Paulo, 06/09/2008.

"Breve histórico das divergências com o PC da China”. A Classe Operária, dez.1978. In: GASPARI, E. A Ditadura Escancarada. São Paulo, Cia. das Letras, 2002.

CALIGIURI Filho, Júlio César e outros. Onde estão? (Relatório da CPI da Vala de Perus) São Paulo, Câmara Municipal, 1992.

CARTA de Manoel Henrique dirigida à D. Paulo E. Arns. Presídio Político, Rio de Janeiro, 1976. Arquivo pessoal de Marcelo Mário de Melo.

CANTANHÊDE, Eliane e DANTAS, Iuri. "Para general Félix, arquivos vão expor vítimas do regime”, Folha de S.Paulo, 14/11/04.

ChAVES, Marival do Canto. Depoimento concedido pelo ex-agente do DOI-Codi/SP e do CIE à Comissão de Familiares de Mortos e Desaparecidos Políticos. São Paulo, CJP-SP, 20/06/92.

“Comemoração dos 20 anos da lei começa hoje com ato em SP”. Folha de S. Paulo, 23/08/99.

ConVENÇÃo Interamericana sobre Desaparecimento Forçado de Pessoas. Adotada pela OEA, expedida na cidade de Belém, Brasil, em 09/06/94.

"Convenção Internacional para Proteção de Todas as Pessoas contra Desaparecimentos Forçados”, Organização das Nações Unidas (ONU), 23/2010.

CORTE Interamericana de Direitos Humanos. Caso Gomes Lund e Outros ("Guerrilha do Araguaia”) Vs. Brasil. Sentença de 24 de Novembro de 2010 (Exceções Preliminares, Mérito, Reparações e Custas), p. 73 e 106, item 292. Disponível em: $<$ http://www.corteidh.or.cr/docs/casos/articulos/seriec_219_por.pdf>.

D’ÁvilA, Sérgio. "Senado dá a Bush poder de definir tortura”. Folha de S. Paulo, 29/09/06. 
Depoimento escrito de Artur Machado Scavone lido por ele na $2^{\text {a }}$ Auditoria Militar de São Paulo em 28/09/73.

DeSAGRAVo a Idibal Pivetta, OAB/SP, 26/10/76.

GAMA, Rinaldo. "Eu vi os corpos queimados”. Veja, 13/10/93.

GóIS, Antônio e SANDER, Letícia. “'País deve lembrar heróis em vez de xingar algozes', diz Lula”, 13/08/2008, Folha de São Paulo.

HARDMAN, Francisco Foot. "Vozes que não se deixam morrer”. O Estado de São Paulo, 28/02/10

LOYOLA, Leandro. “O filho do caçador”. Época, 10/11/03.

MACIEL, Lício Augusto Ribeiro. Depoimento em juízo, em 04/03/2010. Processo das famílias de desaparecidos da Guerrilha do Araguaia iniciado em 1982, $\mathrm{n}^{0}$ 2003.01.00.041033-5/DF.

MAgalhães, Mário. "Papéis da ditadura somem dos arquivos”. Folha de S. Paulo, 04/02/2007.

. "Ex-presos dizem que Ustra chefiou ação com tortura na BA”. Folha de São Paulo, 10/02/09.

“Ação de Anselmo é pré-64, diz policial”. Folha de S. Paulo, 31/08/09.

Mattarollo, Rodolfo. "Argentina, 25 anos contra a impunidade”. Le Monde Diplomatique Brasil, fev.2010.

“Memorial da Resistência rebatiza celas do antigo Dops”. Agência Estado, 02/05/2008.

MENDOnÇA, Alba Valéria. “'Brasil precisa lembrar de seus mortos como heróis', diz Lula”, Portal G1, 12/08/2008.

“Museu do Imaginário só fica pronto no fim do ano”. O Estado de São Paulo, 03/07/2002.

NossA, Leonencio. "Curió abre arquivo e revela que Exército executou 41 no Araguaia”.

O Estado de São Paulo, 21/06/09.

"Não se corta erva daninha pelo caule”. O Estado de São Paulo, 22/06/09.

NossA, Leonencio; MADUEÑo, Denise. "Aumenta a pressão pela abertura de todos os arquivos sobre a Guerrilha do Araguaia”. O Estado de São Paulo, 22/06/09.

OPERAÇÃo Mesopotâmia, Ordem de operações nº 01-SPC/71.

“Pai acha filho 'roubado’ na ditadura argentina”. O Estado de São Paulo, 24/02/10.

PASSARINHO, Jarbas. “A tortura e o terrorismo”. Folha de S. Paulo, 28/11/06.

"Primeiras fotos das vítimas da ditadura militar no Brasil”; "Somem pastas do Araguaia” e "Material comprova mortes”. Diário Popular, 19/03/92

PinHeIRo, Coronel Álvaro de Souza. "Guerrilha na Amazônia: uma experiência no passado, o presente e o futuro”. Edição brasileira da Military Review, jan.-mar./1995.

"Por uma revisão da estratégia de guerra revolucionária”, "Questões de organização e programa para o movimento operário", "Sobre a construção do partido leninista de combate", "O que é o PCB" e "Teses sobre o ABC" no site www.ovpsp.org/hist_poc.htm

"Razões Finais orais do advogado Idibal Almeida Pivetta (César Vieira)” no proc. 23/73 da $2^{\text {a }}$ Auditoria da 2a . CM- S. Paulo”, 1974. Arquivo Pessoal de Idibal Pivetta.

RELATÓRIo Parcial da Investigação sobre a Guerrilha do Araguaia. MPF, jan. /2002.

"Relatório da Paquera". Declarações de José Anselmo dos Santos, o Cabo Anselmo, no arquivo do Dops/SP, de 04/06/71.

RElATÓRIO “Operação Pajussara”, 1971, Ministério do Exército/VI Exército/6ª Região Militar/Quartel General-2 seção. Protocolado no SD/SAF em 6/03/75, sob n 249.

“Relatório Inês. Dossiê da tortura.” Pasquim, nº 607, Rio de Janeiro, 12 a 18/01/81.

RIBEIRO JR., Amaury. "Mesopotâmia: uma operação militar desconhecida”. O Globo, 05/04/1998.

“A ordem é matar” e “Os matadores”. IstoÉ, São Paulo, 24/03/04. 
RIBEIRO, Jeferson. "Lula diz que abertura de arquivos da ditadura não pode ser revanchismo". Portal G1, 13/05/2009.

RI-Reservado $n^{\circ} 10$, de 16/09/71, do BPEB.

SELIGMAN, Felipe; CruZ, Valdo. "Comissão de Anistia declara Lamarca coronel do Exército”. Folha de São Paulo, 14/6/2007.

TELES, Edson. "Restos da ditadura. Por que as Forças Armadas de hoje temem a punição dos torturadores de ontem”. O Globo, 30/01/10.

“Terroristas enganam os próprios companheiros”. Correio do Povo, 19/10/71.

VALENTE, Rubens. "Ordens no Araguaia eram dadas por quatro generais". Folha de São Paulo, 28/06/09.

"Vítima de Fuzilamento”. Istoé, 29/04/87.

\section{Filmes e Documentários:}

BARreto, Bruno. Que é isso, Companheiro? Brasil, 1997.

Linha Direta Justiça sobre Zuzu Angel, exibido em 27/11/03, pela TV Globo.

Linha Direita Justiça sobre Cabo Anselmo, exibido em 05/07/2007, pela TV Globo.

LITEWSKI, Chaim. Cidadão Boilesen, Brasil, 2009.

Anos Rebeldes. Minissérie brasileira produzida e transmitida pela Rede Globo, entre 14 de julho e 14 de agosto de 1992.

MURAT, Lúcia. Que bom te ver viva. Brasil, documentário, 1989.

. Quase dois irmãos. 2004.

. Uma Longa Viagem, 2011.

NEHRING, Marta e OliveIRA, Maria. 15 Filhos. Brasil, documentário, 1996.

PonteCorvo, Gillo . Batalha de Argel. Argélia/Itália, longa metragem, 1965.

RatTon, Helvécio. Batismo de Sangue. Brasil, 2006.

REZENDE, Sérgio. Zuzu Angel (2006).

RoBin, Marie-Monique. "Escuela Francesa - Escuadrones de la muerte” (Escadrons De

La Mort: L'Ecole Française). Documentário, França, 2003.

FARIAS, Roberto. Pra Frente, Brasil. Brasil, 1982.

\section{Sítios na internet:}

www.oab.org.br

www.stf.jus.br.

www.oamigoescolar.com.br

www.cels.org.ar

www.mj.gov.br

www.memoriaabierta.org.ar.

www.abuelasplazademayo.org.ar.

www.cptnac.com.br.

www.fpa.org.br

www.dhnet.org.br

www.desaparecidospoliticos.org.br

www.ultimainstancia.uol.com.br.

www.senado.gov.br

www.planalto.gov.br 
Entrevistas realizadas:

\section{1 - Acervo Audiovisual sobre ex-Presos Políticos/AEL-LEI ${ }^{1009}$ :}

\begin{tabular}{|c|c|c|c|c|}
\hline Nome & Partido & Sexo & Ocupação & Local \\
\hline Alberto Becker ${ }^{1010 *}$ & PRT & M & Secundarista & SP \\
\hline Alberto Negri & PCB & $\mathrm{M}$ & Metalúrgico & SP \\
\hline Alípio Freire & Ala Vermelha & $\mathrm{M}$ & \begin{tabular}{|l|} 
Estudante \\
\end{tabular} & SP \\
\hline André Ota & Molipo & $\mathrm{M}$ & Estudante & SP \\
\hline Anivaldo Padilha & AP & $\mathrm{M}$ & Religioso & SP \\
\hline Antônio Duarte & Marinheiros/RJ & $\mathrm{M}$ & Marinheiro & RJ \\
\hline Antonio Funari Filho & AP & $\mathrm{M}$ & Advogado & SP \\
\hline Antonio Roberto Espinosa & VPR & $\mathrm{M}$ & Operário & SP \\
\hline Ariston Oliveira Lucena & VPR & $\mathrm{M}$ & Secundarista & SP \\
\hline Arthur de Paula & AP/PCdoB & $\mathrm{M}$ & Bancário & BA \\
\hline Artur M. Scavone & Molipo & $\mathrm{M}$ & Estudante & SP \\
\hline Aytan Miranda Sipahi & PCBR & $\mathrm{M}$ & Médico & SP \\
\hline Beatriz Bargieri** & AP & $\mathrm{F}$ & \begin{tabular}{|l|} 
Estudante \\
\end{tabular} & SP \\
\hline Carlos A. Lobão Cunha & ALN & $\mathrm{M}$ & Estudante & SP \\
\hline Carlos Alberto Soares & PCBR & $\mathrm{M}$ & Estudante & $\mathrm{PE}$ \\
\hline Carlos Fayal & ALN/RJ & $\mathrm{M}$ & Estudante & RJ \\
\hline Carlos Gilberto Pereira & AP & $\mathrm{M}$ & Metalúrgico & SP \\
\hline Carlos Lichsztejn & ALN & $\mathrm{M}$ & Estudante & SP \\
\hline Celso Brambilla & Conv. Socialista & $\mathrm{M}$ & operário & SP \\
\hline César Augusto Teles* & PCdoB & $\mathrm{M}$ & Sindicalista & SP \\
\hline Cloves de Castro & ALN & $\mathrm{M}$ & Func. Pub. & SP \\
\hline Criméia A. S. de Almeida & PCdoB/Araguaia & $\mathrm{F}$ & \begin{tabular}{|l|} 
Estudante \\
\end{tabular} & SP/PA \\
\hline Daniel Bonfim & PCB & $\mathrm{M}$ & sindicalista & SP \\
\hline Danilo Carneiro & PCdoB/Araguaia & $\mathrm{M}$ & Estudante & $\mathrm{RJ} / \mathrm{MG}$ \\
\hline Derly José de Carvalho & Ala-Vermelha & $\mathrm{M}$ & Operário & SP \\
\hline Dulce Maia de Souza & VPR & $\mathrm{F}$ & Prod. Cult. & SP \\
\hline Dulce Muniz & PORT & $\mathrm{F}$ & Atriz & SP \\
\hline Edward Ferreira & PCB & $\mathrm{M}$ & PM & SP \\
\hline Elza Lobo & AP/independente & $\mathrm{F}$ & Estudante & SP \\
\hline Eunício P. Cavalcante & Sargentos/RJ & $\mathrm{M}$ & Sargento & RJ \\
\hline Frederico Pessoa da Silva ${ }^{1011} * *$ & PCB & $\mathrm{M}$ & Jornalista & SP \\
\hline Iara Areias Prado & VAR-Palmares & $\mathrm{M}$ & Estudante & SP \\
\hline Idibal de Almeida Pivetta & Advogado & $\mathrm{M}$ & Advogado & SP \\
\hline Iran Jacome Rodrigues & PORt & $\mathrm{M}$ & Estudante & SP \\
\hline Jano Ribeiro & PCB & $\mathrm{M}$ & Sindicalista & SP \\
\hline Jesus Paredes Sotto & MR-8 & $\mathrm{M}$ & Operário & RJ \\
\hline Joaquim dos Santos & VPR & $\mathrm{M}$ & Operário & SP \\
\hline Jorge Eduardo S. Durão & Var-Palmares & $\mathrm{M}$ & \begin{tabular}{|l|} 
Estudante \\
\end{tabular} & RJ \\
\hline Jôse Bacariça & VAR-Palmares & $\mathrm{F}$ & & SP \\
\hline José Olavo Ribeiro & VAR-Palmares & $\mathrm{M}$ & Estudante & SP \\
\hline
\end{tabular}

1009 Todas as entrevistas foram gravadas em mini-DV por Júlio Ramos de Toledo, com exceção das entrevistas de Frederico Pessoa Silva e Idibal Pivetta que foram gravadas por Assad Abdala Ghazal.

* Entrevistas realizadas conjuntamente com Zilda M. G. Iokoi e Claudio Kahns.

** Entrevistas realizadas conjuntamente com Marcelo Ridenti. 


\begin{tabular}{|c|c|c|c|c|}
\hline José Raimundo da Silva & PCB & $\mathrm{M}$ & Sindicalista & RJ \\
\hline Laurindo Junqueira & POC & $\mathrm{M}$ & Operário & SP \\
\hline Leane de Almeida & POC & $\mathrm{F}$ & \begin{tabular}{|l|} 
Estudante \\
\end{tabular} & SP \\
\hline Lenira Machado & PRT & $\mathrm{F}$ & Estudante & SP \\
\hline Lúcia Murat & MR-8 & $\mathrm{F}$ & Estudante & RJ \\
\hline Manoel Cyrillo Netto & ALN & $\mathrm{M}$ & Publicitário & SP \\
\hline Marcelo Mário de Melo & PCBR & $\mathrm{M}$ & Estudante & $\mathrm{PE}$ \\
\hline Márcia Basseto Paes & Conv. Socialista & $\mathrm{F}$ & Estudante & SP \\
\hline Márcia Mafra & ALN & $\mathrm{F}$ & Estudante & SP \\
\hline Maria Auxiliadora Arantes & AP & $\mathrm{F}$ & Estudante & SP \\
\hline Maria Luiza Garcia Rosa & MR-8 & $\mathrm{F}$ & Estudante & RJ \\
\hline Mario Miranda Albuquerque & PCBR/NE & $\mathrm{M}$ & Secundarista & $\mathrm{CE} / \mathrm{PE}$ \\
\hline Maurice Politi & ALN & $\mathrm{M}$ & Estudante & SP \\
\hline Murilo Melo* & PCB & $\mathrm{M}$ & Func. Pub. & SP \\
\hline Nair Yumiko Kobashy & PCdoB & $\mathrm{F}$ & Estudante & SP \\
\hline Nelson Rodrigues Filho & MR-8 & $\mathrm{M}$ & Estudante & RJ \\
\hline Nelson Vicente da Silva & PCB & $\mathrm{M}$ & PM & SP \\
\hline Paulo Enrique Lins & ALN/RJ & $\mathrm{M}$ & Estudante & RJ \\
\hline Paulo Ribeiro Martins & Ala & $\mathrm{M}$ & Estudante & RJ/BA \\
\hline Pedro Rocha Filho & Molipo & $\mathrm{M}$ & Estudante & SP \\
\hline Raimundo de Oliveira & AP & $\mathrm{M}$ & operário & SP \\
\hline Raphael Martinelli* & ALN & $\mathrm{M}$ & Sindicalista & SP \\
\hline Raul de Carvalho & PCBR & $\mathrm{M}$ & Estudante & SP \\
\hline Reinaldo Morano Filho & ALN & $\mathrm{M}$ & Estudante & SP \\
\hline Ricardo de Azevedo & AP & $\mathrm{M}$ & Estudante & SP \\
\hline Roberto Ribeiro Martins & PCdoB & $\mathrm{M}$ & Estudante & SP \\
\hline Rômulo Noronha & ALN & $\mathrm{M}$ & Estudante & RJ \\
\hline Rosalina de O. Santa Cruz & VAR-Palmares & $\mathrm{F}$ & Estudante & $\mathrm{RJ} / \mathrm{SP}$ \\
\hline Sara Becker* & PCB & $\mathrm{F}$ & Func. Pub. & SP \\
\hline Sebastião Velasco Cruz & AP & $\mathrm{M}$ & Estudante & SP \\
\hline Sérgio Gomes & PCB & $\mathrm{M}$ & Jornalista & SP \\
\hline Sérgio Sister & PCBR & $\mathrm{M}$ & \begin{tabular}{|l|} 
Estudante \\
\end{tabular} & SP \\
\hline Stanislaw Szermeta & PORt & $\mathrm{M}$ & Operário & SP \\
\hline Tullo Vigevani & PORt & $\mathrm{M}$ & Prof. univ. & SP \\
\hline Vicente Roig & Ala & $\mathrm{M}$ & Estudante & SP \\
\hline Vicente Silvestre & PCB & $\mathrm{M}$ & PM & SP \\
\hline Waldemar Rossi & Pastoral Operária & $\mathrm{M}$ & Metalúrgico & SP \\
\hline Wilson Nascimento Barbosa & PCB & $\mathrm{M}$ & Estudante & SP \\
\hline Wilson Skorupski & AP & $\mathrm{M}$ & Estudante & SP \\
\hline
\end{tabular}




\section{Outras entrevistas:}

Criméia Alice Schmidt de Almeida. São Paulo, 27/07/2000, 28 e 30/11/2001, e 20/10/2004.

Maria Amélia de Almeida Teles. São Paulo, 04/11/2001.

Flávio Augusto Neves Leão Salles. Rio de Janeiro, 23/01/2002.

Ana Müller. Rio de Janeiro, 06/04/2004

Modesto da Silveira. Rio de Janeiro, 09/04/2004.

Ozeas Duarte. São Paulo, 04/11/2004.

Theodomiro Romeiro dos Santos. Recife (PE), 19/03/2010.

Mauricio Frejman. San José da Costa Rica, 27/05/2010.

Carlos Alberto Lobão da Cunha. São Paulo, 10/10/2010.

Virgílio Egydio Lopes Enei. São Paulo, 29/01/2011.

Maria Luiza Flores Bierrenbach. São Paulo, 19/02/2011.

Rosa Maria Cardoso da Cunha. Rio de Janeiro, 25 e 28/03/11.

Idibal de Almeida Pivetta. São Paulo, 06/02/2011.

Belisário dos Santos Jr. São Paulo, 19/02/2011.

Airton José Esteves Soares. São Paulo, 27/02/2011.

Darci Miyaki. São Paulo, 10/03/2011.

Gilney Amorim Viana. São Paulo, 05/03/2011.

Alberto Henrique Becker. São Paulo, 11/03/2011.

Reinaldo Morano Filho. São Paulo, 14/03/2011.

Pedro Rocha Filho. São Paulo, 24/02/2011.

Manoel Cyrillo de Oliveira Netto. São Paulo, 20/03/2011.

José Luiz Del Roio. São Paulo, 08/01 e 13/02/2002, 08/01/2003 e 20/03/2010.

Ana Maria de Almeida Camargo. São Paulo, 14/04/2011.

Sinézio Martins Ribeiro à autora. Xambioá (TO), 18/07/2001.

Suzana K. Lisbôa. Rio de Janeiro/RJ. 10 e 11/02/03, 05/01/04 e São Paulo/SP, 17 e 21/02/05.

Sérgio Ferreira. Rio de Janeiro, 25/03/2011. 
Tabelas e Gráficos:

1. Tabela de porcentagens de presos processados por filiação partidária:

\begin{tabular}{|l|c|c|}
\hline Partido & Quantidade/ Processo & Quantidade/Porcentagem \\
\hline PCB & 603 & $16 \%$ \\
\hline ALN & 458 & $12,3 \%$ \\
\hline AP & 409 & $11 \%$ \\
\hline VAR-Palmares & 241 & $6,5 \%$ \\
\hline PCdoB & 233 & $6,3 \%$ \\
\hline PCBR & 207 & $5,6 \%$ \\
\hline MR-8 & 150 & $4 \%$ \\
\hline PORT & 141 & $3,8 \%$ \\
\hline POC & 123 & $3,3 \%$ \\
\hline VPR & 122 & $3,3 \%$ \\
\hline Ala Vermelha & 114 & $3 \%$ \\
\hline Grupo-11 & 94 & $2,5 \%$ \\
\hline POLOP & 80 & $2,1 \%$ \\
\hline Corrente & 74 & $2 \%$ \\
\hline Colina & 51 & $1,4 \%$ \\
\hline Vários grupos & 285 & $7,7 \%$ \\
\hline Outros & 319 & $8,6 \%$ \\
\hline TOTAL & 3.698 & $100 \%$ \\
\hline
\end{tabular}

Fonte: RidENTI, Marcelo. O fantasma da revolução brasileira. São Paulo, Ed. UNESP, 1993, p.70.

Dados retirados do BNM, referentes ao total de processados por vinculação com organizações políticas clandestinas. Foram contabilizados os que têm ocupação conhecida e excluídos os nomes repetidos. V. Arquidiocese de São Paulo. Brasil: Nunca Mais. Petrópolis/RJ, Vozes, 1985. 


\section{Gráficos sobre a literatura de testemunho:}

\section{Gráfico 1}

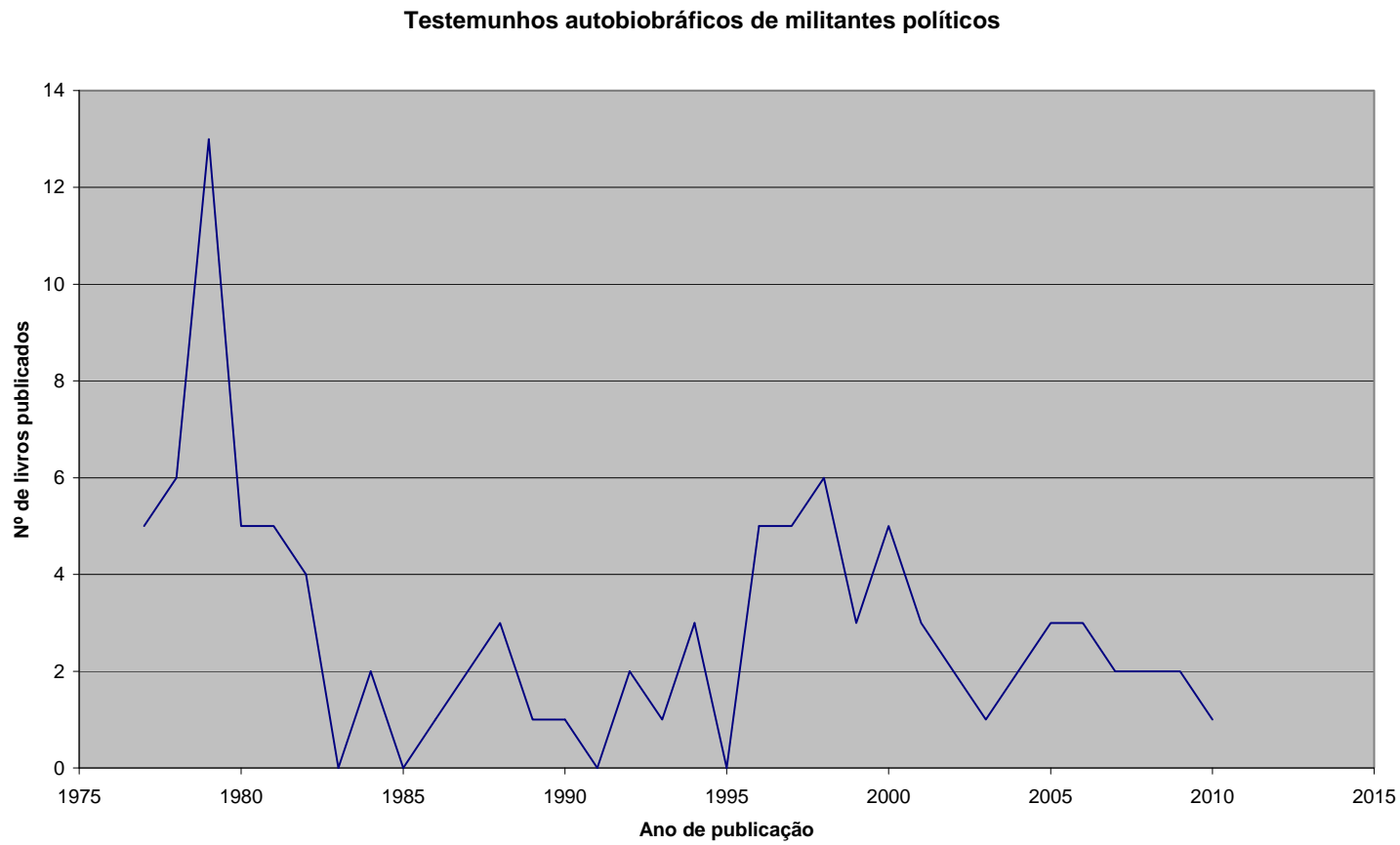

\section{Gráfico 2}

Livros editados com depoimentos de militantes

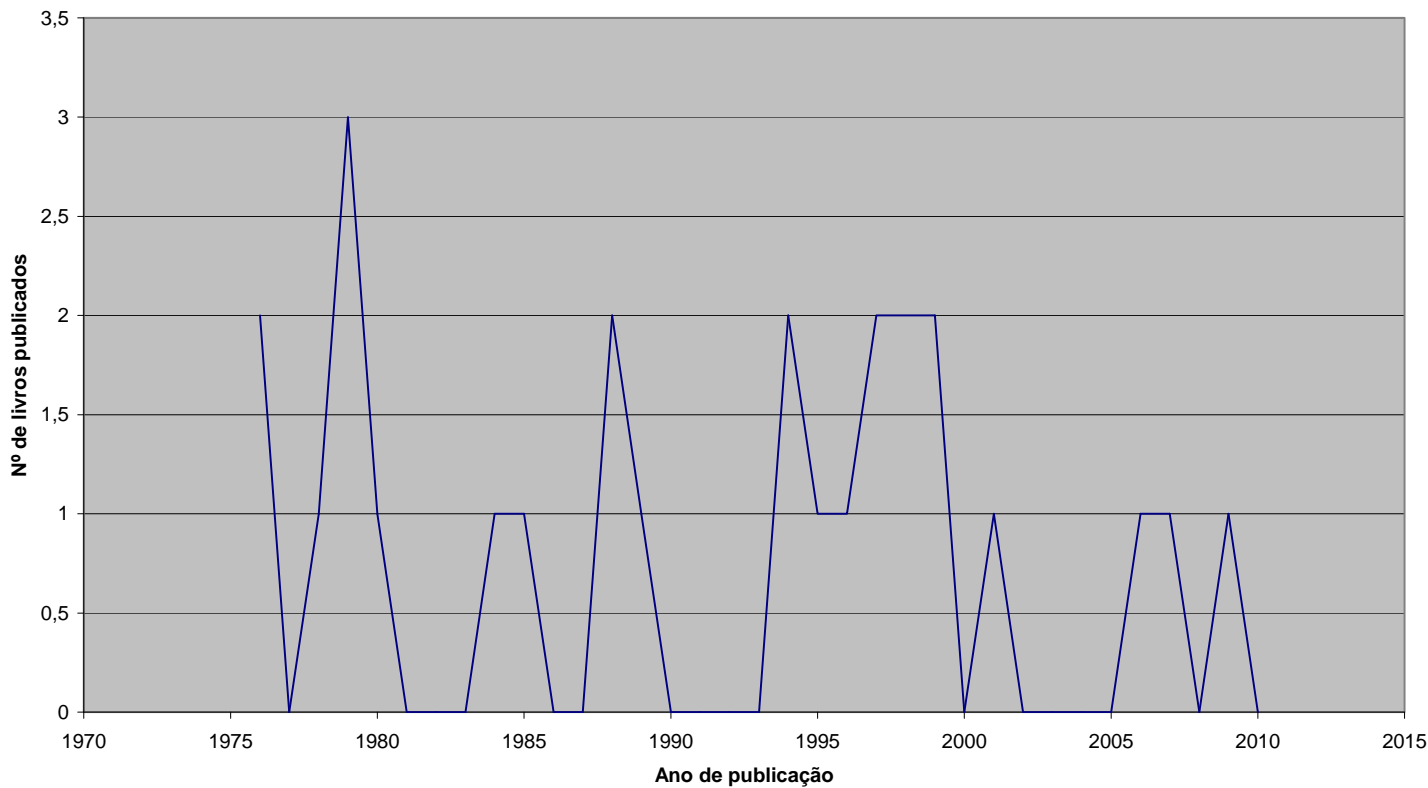


Gráfico 3

Biografias

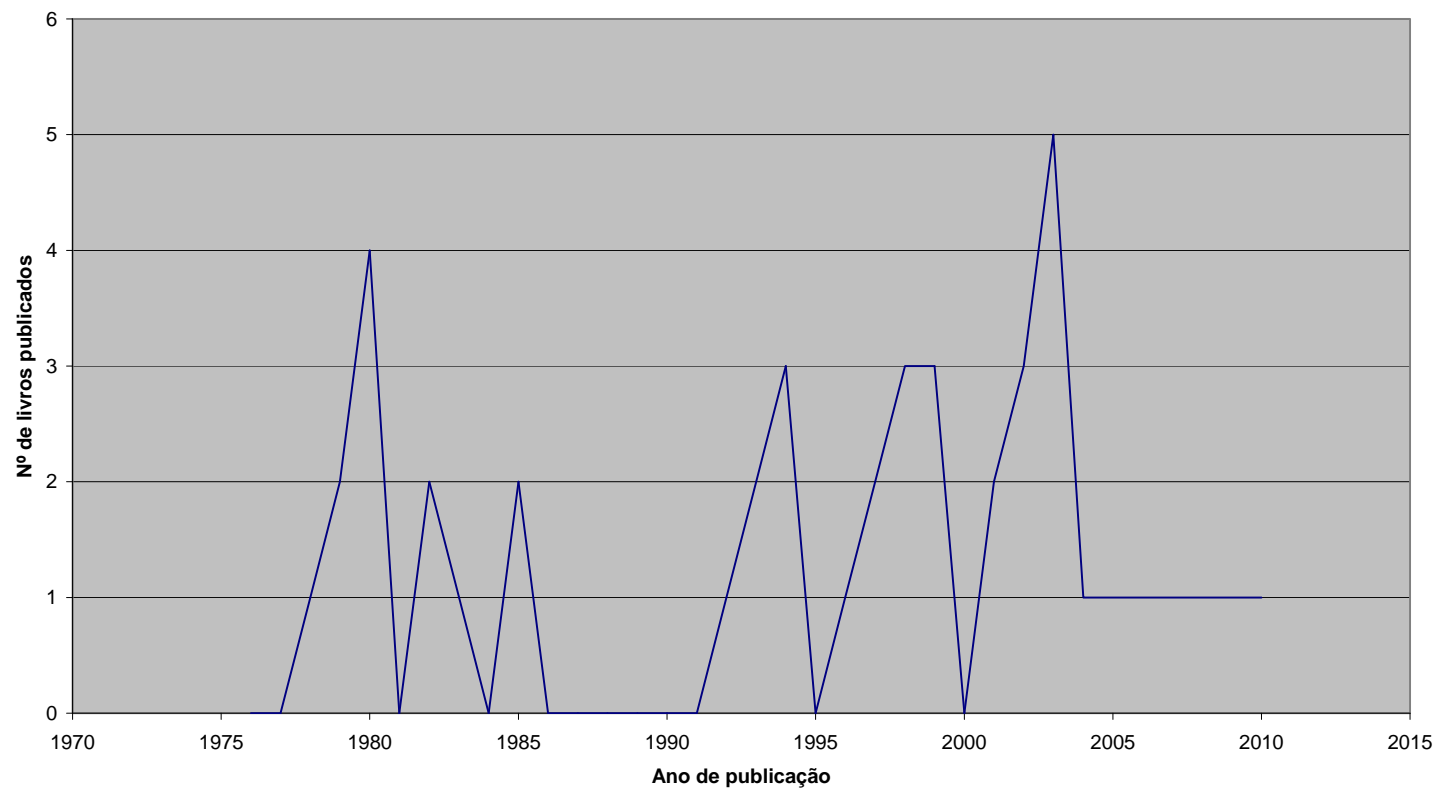


Bibliografia de literatura de testemunho ${ }^{1012}$ :

\section{Testemunhos autobiográficos de militantes políticos ${ }^{1013}$ :}

TAPAJós, Renato. Em Câmara Lenta. São Paulo, Editora Alfa-Omega, 1977.

BetTo, Frei. Cartas da prisão. Rio de Janeiro, Civilização Brasileira, 1977.

Konder, Rodolfo. Cadeia para os mortos. São Paulo, Alfa-Omega, 1977.

BRITO, Frei Fernando de; LESBAUPIN, Frei Ivo; BETTO, Frei. O canto na fogueira:

Cartas de três dominicanos quando em cárcere político. Petrópolis, Vozes, 1977.

LAGO, Mário. Bagaço de beira-estrada. Rio de Janeiro, Civilização Brasileira,1977.

Cavalcanti, Paulo. O caso eu conto como o caso foi. São Paulo, Alfa-Ômega, 1978.

BetTo, Frei. Das catacumbas: cartas da prisão (1969-1971). Rio de Janeiro, Civilização Brasileira, 1978.

Polari, Alex. Em busca do tesouro. Rio de Janeiro, Codecri, 1982. Anistia-RJ/Teatro Ruth Escolar, 1978.

MARCELO, Antonio. Ensaio geral. São Paulo, Alfa-Omega, 1978.

POLARI, Alex. Inventário das cicatrizes. 1978.

KonDER, Rodolfo. Tempo de ameaça: autobiografia de um exilado. São Paulo, AlfaOmega, 1978.

BoAL, Augusto. Milagre no Brasil. Rio de Janeiro, Civilização Brasileira, 1979.

GABEIRA, Fernando. O que é isso, companheiro? Rio de Janeiro, Codecri, 1979.

GABEIRA, Fernando. Carta sobre a anistia: a entrevista do Pasquim. Rio de Janeiro, Codecri, 1979.

LiMA, Haroldo. Itinerário. Salvador, Comitê Brasileiro pela Anistia - Núcleo Bahia, 1979.

Tierra, Pedro. Poemas do povo da noite. São Paulo, Livramento, 1979.

PolARI, Alex. Camarim de prisioneiro. São Paulo, Global, 1980.

NunEs, Adão Pereira. Do Planalto à Cordilheira: memórias de um médico cassado. Rio de Janeiro, Civilização Brasileira. 1979.

\footnotetext{
1012 Esta seleção inclui romances, poesia, autobiografias, memórias, reunião de cartas, diários ou outros escritos editados a partir dos anos 1970. As obras selecionadas são aquelas escritas por militantes ou exmilitantes políticos de grupos de esquerda e que dizem respeito à sua experiência pessoal e à sua atuação política durante a ditadura. Neste sentido, este levantamento é mais amplo do que o realizado por Marcelo Ridenti no seu posfácio à nova edição do livro O fantasma da revolução brasileira (Ed. Unesp, 2010), cujo objetivo é analisar a esquerda armada urbana. Ridenti considera que "ao menos 30 pessoas escreveram livros sobre a própria militância na esquerda armada urbana”. Nosso balanço inclui os militantes vinculados à Guerrilha do Araguaia e também os do PCB e de outros grupos de esquerda que não optaram pela luta armada.

${ }^{1013}$ Nesta lista não estão incluídos relatos autobiográficos de pessoas que embora tenham contribuído para a luta de resistência à ditadura não podem ser classificadas como militantes de esquerda revolucionária, tais como os advogados de presos políticos: Fragoso, Heleno Cláudio. Advocacia da liberdade: a defesa nos processos políticos. Rio de Janeiro, Forense, 1984; SIMAs, Mário. Gritos de Justiça. Brasil 1963-1979. São Paulo, FTD, 1986; Sobral PinTo, Heráclito Fontoura. Lições de liberdade. Belo Horizonte, Ed. Comunicação/Universidade Católica de Minas, 1997; Lins E SiLVA, Evandro. O salão dos passos perdidos. Rio de Janeiro, Nova Fronteira, 1997; Lins E SiLva, Técio. O que é ser advogado. Rio de Janeiro, Record, 2005. Assim como os relatos autobiográficos de bispos e arcebispos tais como: CASALDÁligA, D. Pedro. Creio na justiça e na esperança. Rio de Janeiro, Civilização Brasileira, 1978; CÂMARA, D. Hélder. Mil razões para viver. Rio de Janeiro, Civilização Brasileira, 1979; ARNS, D. Paulo Evaristo. Da esperança à utopia: testemunho de uma vida. Rio de Janeiro, Sextante, 2001; PADIM, Dom Cândido. Dom Cândido Padim, OSB: Itinerário de uma vida. Bauru, Edusc, 2002.
} 
Arroyo, Ângelo. Diário da guerrilha do Araguaia. $2^{\mathrm{a}}$ ed. São Paulo, Alfa-Ômega, 1979. MourA, Clóvis. (Apresentação).

BEZERRA, Gregório. Memórias: segunda parte (1946-1969). Rio de Janeiro, Civilização Brasileira, 1979. v. 2.

VIANA, Gilney Amorim. 131-D. Linhares: Memorial da prisão política. Contagem, Editora História/Comitê Brasileiro pela Anistia/ Movimento Feminino pela Anistia, 1979.

Detrez, C. O jardim do nada. Rio de Janeiro, Civilização Brasileira, 1979.

CONVERSAÇÕES com Arraes: depoimento a Cristina Tavares e Fernando Mendonça. Belo Horizonte, Vega, 1979.

SAlles, Pinheiro. Confesso que peguei em armas. Belo Horizonte, Editora Vega, 1979.

GABEIRA, Fernando. O crepúsculo do macho. Rio de Janeiro, Codecri, 1980.

SIRKS, Alfredo. Os carbonários: memórias da guerrilha perdida. São Paulo, Global, 1980.

SIMÕES, Reinaldo Guarany. Os fornos quentes. São Paulo, Alfa-Omega, 1980.

CONCEIÇÃO DOS SANTOS, Manuel. Essa terra é nossa: depoimento sobre a vida e as lutas de camponeses no Estado do Maranhão. Entrevista e edição: Ana Maria Galano. Petrópolis, Vozes, 1980.

MATA-MACHADO, Edgar da. Memorial de ideias políticas. Belo Horizonte, Vega, 1980.

FREITAS, Alípio de. Resistir é preciso. $2^{\mathrm{a}}$ ed. Rio de Janeiro, Ed.Record, 1981.

Costa, Alcir Henrique da. Barão de Mesquita, 425: a fábrica do medo. São Paulo, Brasil Debates, 1981.

GABEIRA, Fernando. Entradas e bandeiras. Rio de Janeiro, Codecri, 1981.

VARGAS, Índio. Guerra é guerra, dizia o torturador. $3^{\mathrm{a}}$ ed. Rio de Janeiro, Codecri, 1981.

CALDAS, Álvaro. Tirando o capuz. Rio de Janeiro, Codecri, 1981.

Moraes, D. e Viana, F. Prestes: Lutas e autocríticas. Petrópolis, Vozes, 1982.

BETTO, Frei. Batismo de sangue. Rio de Janeiro, Civilização Brasileira, 1982.

SIRKS, Alfredo. Roleta chilena. $3^{\mathrm{a}}$ ed. Rio de Janeiro, Record, 1982.

Moura, Mariluce. A revolta das vísceras. Rio de Janeiro, Codecri, 1982.

SANTOS, Paulo de Tarso. 64 e outros anos. Depoimentos a Oswaldo Coimbra. São Paulo, Cortez, 1984.

SiMÕES, Reinaldo Guarany. A fuga. São Paulo, Brasiliense, 1984.

PaIVA, Maurício. O sonho exilado. Rio de Janeiro, Achiamé, 1986.

VAlli, Vírgínia. Eu, Zuzu Angel, procuro meu filho, A verdadeira história de um assassinato político. Rio de Janeiro, Record, $2^{\mathrm{a}}$ ed., 1987.

SiLVA, José Wilson da. O tenente vermelho: assessor militar de Brizola conta como Fidel Castro entregou um milhão de dólares para os exilados brasileiros no Uruguai (Brizola, Jango e Darcy Ribeiro) financiarem movimentos de guerrilha no Brasil. Porto Alegre, Tchê, 1987.

SAlinas Fortes, L. R. Retrato calado. São Paulo, Marco Zero, 1988.

AfFOnso, Almino. Raízes do golpe: da crise da legalidade ao parlamentarismo. São Paulo, Marco Zero, 1988.

Momesso, Luiz. José Duarte. Um maquinista da história. São Paulo, Oito de Março, 1988.

Garcia, J.C. Bona; Posenato, Júlio. Verás que um filho teu não foge à luta. $2^{\mathrm{a}}$ ed. Porto Alegre/RS, Posenato Arte \& Cultura, 1989.

SÁ, Glênio de. Araguaia, relato de um guerrilheiro. São Paulo, Anita Garibaldi, 1990.

AlmAdA, Izaías. A metade arrancada de mim. São Paulo, Estação Liberdade, 1992.

VianA, Gilney A. e Cipriano, Perly. Fome de liberdade. Vitória, Fund. Ceciliano Abel de Almeida, 1992. 
CALDAS, Álvaro. Balé da utopia. Rio de Janeiro, Objetiva, 1993.

CAldeVilla, Vinícius. Vitral do tempo. São Paulo, Xamã, 1994.

CORRÊA, Hércules. Memórias de um stalinista. Rio de Janeiro, Opera Nostra, 1994.

SODRÉ, Nelson Werneck . A fúria de Calibã: memórias do golpe de 64. Rio de Janeiro, Bertrand Brasil, 1994.

PAZ, Carlos Eugênio Sarmento da. Viagem à luta armada. Rio de Janeiro, Civilização Brasileira, 1996.

Perrone, Fernando. 68 - Relato de guerras: Praga, São Paulo, Paris. São Paulo, Busca Vida, 1996.

Prestes, Maria. Meu companheiro. 40 anos ao lado de Luis Carlos Prestes. $2^{\mathrm{a}}$ ed. Rio de Janeiro, 1993.

Betinho [Herbert José de Souza]. Revoluções da minha geração: depoimento a François Bougon. Tradução Lourdes Grzybowski. São Paulo, Moderna, 1996.

Betinho [Herbert José de Souza]. No fio da navalha. Rio de Janeiro, Revan, 1996. (Coleção Quem é?).

PAZ, Carlos Eugênio Sarmento da. Nas Trilhas da ALN: memórias romanceadas. Rio de Janeiro, Bertrand Brasil, 1997.

Abramo, Bia (org.). Um trabalhador da notícia: textos de Perseu Abramo. São Paulo, Ed. Fundação Perseu Abramo, 1997.

Abramo, Lélia. Vida e arte: memórias de Lélia Abramo. São Paulo/Campinas, Ed. Fundação Perseu Abramo/Unicamp, 1997.

CAPITANI, Avelino Biden. A rebelião dos marinheiros. Porto Alegre, Artes e Ofícios, 1997 (2 $2^{a}$ Ed., São Paulo, Expressão Popular, 2005).

CARVAlHo, Apolônio de. Vale a pena sonhar. Rio de Janeiro, Rocco, 1997.

Dirceu, José e PAlmeira, Vladimir. Abaixo a ditadura: o movimento de 68 contado por seus líderes. Rio de Janeiro, Garamond e Espaço \& Tempo, 1998.

PAUlino, Leopoldo. Tempo de resistência. Ribeirão Preto, Editora COC, 1998.

VIEIRA, Ildeu Manso. Memórias torturadas (e alegres) de um preso político. Maringá, EUDEM, 1998.

Gomes, Dias. Apenas um subversivo. Rio de Janeiro, Bertrand Brasil, 1998.

Gullar, Ferreira. Rabo de foguete: os anos de exílio. Rio de Janeiro, Revan, 1998.

BoITEuX, B. D. A guerrilha de Caparaó e outros relatos. Rio de Janeiro, Inverta, 1998.

TAVARES, Flávio. Memórias do esquecimento. São Paulo, Globo, 1999.

Hohlfeldt, Antônio (org.). Condições ideais para o amor. Poemas, manifestos e correspondência de um poeta-guerrilheiro: Luiz Eurico Tejera Lisboa. Porto Alegre-RS, Sulina, 1999.

Gutierrez, Cláudio Antônio Weyne. A guerrilha brancaleone. Porto Alegre/RS, Proletra, 1999.

Rezende, J. R. Ousar lutar: memórias da guerrilha que vivi. [entrevista a Mouzar Benedito]. São Paulo, Viramundo, 2000.

Coelho, Marco Antônio Tavares. Herança de um sonho: as memórias de um comunista. Rio de Janeiro, Record, 2000.

José, Emiliano. Galeria F: lembranças do mar cinzento. São Paulo, Casa Amarela, 2000.

EsPINOSA, Roberto. Abraços que sufocam. São Paulo, Viramundo, 2000.

SANTOS, Joel Rufino dos. Quando eu voltei, tive uma surpresa (cartas para Nelson). Rio de Janeiro, Rocco, 2000.

LAGO, Mário. Reminiscências do sol quadrado. São Paulo, Cosac \& Naify, 2001.

Rabelo, José Maria; Rabelo, Thereza. Diáspora: os longos caminhos do exílio. São Paulo, Geração Editorial, 2001.

LiMA, Carlito. Confissões de um capitão: memórias. Rio de Janeiro, Garamond, 2001. 
CIPRIANO, Perly. Pequenas histórias da cadeia. Vitória-ES, s.n., 2002.

DE LuCA, Derlei Catarina. No corpo e na alma. Criciúma, Ed.da Autora, 2002.

Cannabrava Filho, Paulo. No olho do furacão: América Latina nos anos 60/70. São Paulo, Cortez, 2003.

FERNANDES JÚNIOR, Ottoni. O baú do guerrilheiro. Memórias da luta armada urbana no Brasil. Rio de Janeiro, Record, 2004.

VIEGAS, Pedro. Trajetória rebelde. São Paulo, Cortez, 2004.

LungARETTI, Celso. Náufrago da utopia: vencer ou morrer na guerrilha aos 18 anos. São Paulo, Geração Editorial, 2005.

SANTOS, A. Duarte dos. A luta dos marinheiros. Rio de Janeiro, Ed. Inverta, 2005.

LourenÇO, Osvaldo. Companheiros de viagem. São Paulo, Maturidade, 2005.

MARTINELli, Renato. Um grito de coragem. Memórias da luta armada. São Paulo, Comarte, 2006.

Coelho, Teixeira. História natural da ditadura. São Paulo, Iluminuras, 2006.

SORIANO, Francisco. A grande partida: anos de chumbo. Rio de Janeiro, Or Editores, 2006.

FALCON, Yara. Mergulho no passado: a ditadura que vivi. Maceió, Livro Rápido, 2007.

SÁ, Aybirê Ferreira de. Das ligas camponesas à anistia. Memórias de um militante trotskista. Recife, Fund. de Cultura Cidade de Recife, 2007.

Branco, T. Confidências de um guerrilheiro. Caxias do Sul, Maneco, 2008.

VIEIRA, Liszt. A busca - memórias da resistência. São Paulo, Hucitec, 2008.

BeTto, Frei. Diário de Fernando. Nos cárceres da ditadura militar brasileira. Rio de Janeiro, Rocco, 2009.

Politi, Maurice. Resistência atrás das grades. São Paulo, Plena Editorial, 2009.

AzEVEDO, Ricardo de. Por um triz: memórias de um militante da AP. São Paulo, Plena Editorial, 2010.

\section{Livros editados com depoimentos de militantes ${ }^{1014}$ :}

Documentos dos presos políticos brasileiros. Acerca da repressão fascista no Brasil. Lisboa, Edições Maria da Fonte, 1976.

CAso, Antônio. A esquerda armada no Brasil (1967-1971). Lisboa, Moraes, 1976.

Cavalcanti, Pedro C. U.; Ramos, Jovelino (Org.). Memórias do exílio: Brasil (196419??). São Paulo, Livramento, 1978. v. 1.

CABRAL, Reinaldo, LAPA, Ronaldo (orgs.). Desaparecidos políticos: prisões, sequestros, assassinatos. Rio de Janeiro, Opção, Comitê Brasileiro pela Anistia, v. II, 1979.

MACHADO, Cristina Pinheiro. Os exilados: 5 mil brasileiros à espera, da anistia. São Paulo, Alfa-Ômega, 1979.

DiAs, Luzimar Nogueira (Org.). Esquerda armada: testemunhos dos presos políticos do Presídio Milton Dias Moreira no Rio de Janeiro. Vitória, Edições do Leitor, 1979.

Costa, Albertina Oliveira; Moraes, Maria Teresa Porciúncula de; Marzola, Norma e LIMA, Valentina da Rocha (orgs.). Memórias das mulheres do exílio. Rio de Janeiro, Paz e Terra, 1980.

\footnotetext{
${ }^{1014}$ Os livros incluídos aqui são coletâneas de entrevistas ou depoimentos de militantes de grupos de esquerda que se opuseram à ditadura e sua experiência. Há também livros que reúnem os históricos sobre a morte e desaparecimento de militantes decorrentes da repressão política, muitos deles baseados no testemunho de presos políticos sobreviventes.
} 
Comité Brasileiro de Anistia/seção RS e Assembleia Legislativa do RS. Dossiê dos Mortos e Desaparecidos Políticos. Porto Alegre, Imprensa da Assembleia Legislativa RS, 1984.

ARQUIDIOCESE de São Paulo. Brasil: nunca mais. Prefácio Dom Paulo Evaristo Arns. Petrópolis, Vozes, 1985.

SANTOS, Maria Cecília Loschiavo dos, SIMÃO, Azis (orgs.). Maria Antônia: uma rua na contramão. São Paulo, Nobel, 1988.

ReIS FILHO, Daniel Aarão; MORAES, Pedro de (Org.). 1968: a paixão de uma utopia. Fotos de Pedro de Moraes. Rio de Janeiro, Espaço e Tempo, 1988.

MoraEs, Denis de. A esquerda e o golpe de 64: vinte e cinco anos depois, as forças populares repensam seus mitos, sonhos e ilusões. Posfácio de René Dreifuss. Rio de Janeiro, Espaço e Tempo, 1989.

Rodrigues, H. B. C. et alli. Rua Viva - homenagem aos mortos e desaparecidos políticos mineiros. Câmara e Prefeitura Municipal de Belo Horizonte, 1994.

Comissão de Familiares de Mortos e Desaparecidos Políticos; InstituTo de Estudos da Violência do Estado; Grupo Tortura Nunca Mais. Dossiê dos mortos e desaparecidos políticos a partir de 1964. Recife, Ed. de Pernambuco, 1995.

Comissão de Familiares de mortos e desaparecidos políticos, InSTITUTO de Estudos da Violência do Estado (IEVE), GRUPo Tortura Nunca Mais - RJ e PE. Dossiê dos mortos e desaparecidos políticos a partir de 1964. Prefácio de D. Paulo Evaristo Arns. São Paulo, Imesp, 1996.

AzEvedo, Ricardo de e MAUÉs, Flamarion (orgs.). Rememória - Entrevistas sobre o Brasil do século XX. São Paulo, Editora Fundação Perseu Abramo, 1997.

Freire, Alípio; AlmadA, Izaias; Ponce, J. A. de Granville (Org.). Tiradentes, um presídio da ditadura: memórias de presos políticos. São Paulo, Scipione, 1997.

CARVAlHO, Luiz Maklouf. Mulheres que foram à luta armada. São Paulo, Globo, 1998.

NADER, Ana Beatriz. Autênticos do MDB: Semeadores da Democracia. História oral de vida política. São Paulo, Paz e Terra, 1998.

SouZA, Daniel e CHAVEs, Gilmar (orgs.). Nossa paixão era inventar um novo sonho. Rio de Janeiro, Rosa dos Tempos, 1999.

MirandA, Nilmário e Tibúrcio, Carlos. Dos filhos deste solo - Mortos e desaparecidos políticos durante a ditadura militar: a responsabilidade do Estado, São Paulo, Fundação Perseu Abramo/Boitempo, 1999.

FErreira, Marieta de M.; RochA, Dora; Freire, Américo (org.). Vozes da oposição: depoimentos. Rio de Janeiro, Grafine Artes Gráficas, 2001.

MAUÉs, Flamarion e ABRAMO, Zilah Wendel. Pela democracia, contra o arbítrio - A oposição democrática, do golpe de 1964 à campanha das Diretas Já. São Paulo, Perseu Abramo, 2006.

Comissão Especial dos Mortos e Desaparecidos Políticos. Direito à memória e à verdade. Brasília, Secretaria Especial dos Direitos Humanos, 2007.

Teles, J. A. et al. Dossiê Ditadura: mortos e desaparecidos políticos no Brasil (19641985). $2^{a}$ ed., revista, ampliada e atualizada. São Paulo, Imprensa Oficial do Estado de São Paulo, 2009. 


\section{Biografias ${ }^{1015}$ :}

AlmeIDA Filho, Hamilton. A sangue quente: A morte do jornalista Vladimir Herzog. São Paulo, Alfa-Omega, 1978.

Braga, Teodomiro e Barbosa, Paulo. Meu filho Alexandre Vannucchi. Depoimentos de Egle e José Vannucchi. São Paulo, Edição S.A., 1979.

JoRDÃo, Fernando Pacheco. Dossiê Herzog: prisão, tortura e morte no Brasil. São Paulo, Global, 1979.

José, Emiliano e MiRANDA, Oldack. Lamarca, o capitão da guerrilha. São Paulo, Global, 1980.

LUPPI, Carlos Alberto. Manoel Fiel Filho: Quem vai pagar por este crime? São Paulo, Escrita,1980.

Nosella, Paolo. Porque mataram Santo Dias: quando os braços se unem à mente. São Paulo, Cortez, 1980.

EsCARIZ, Fernando. Por que Theodomiro fugiu. São Paulo, Global, 1980.

Benjamin, Iramaya. Ofício de Mãe. Rio de Janeiro, Marco Zero, 1982.

Figueiredo, Carlos Eduardo de Senna. Mario Pedrosa, retrato do exílio. Antares, 1982.

OliveirA, Ana Maria Rodrigues de. Helena Greco eu te batizo: Anistia. Belo Horizonte, s/ed., 1983.

Assis, Chico de et alii. Onde está meu filho? A história de um desaparecido político. Rio de Janeiro, Paz e Terra, 1985.

MARKun, Paulo (Org.). Vlado: retrato da morte de um homem e de uma época. $2^{\mathrm{a}}$ ed. São Paulo, Brasiliense, 1985.

PATARRA, Judith L. Iara: reportagem biográfica. $2^{\mathrm{a}}$ ed. Rio de Janeiro, Rosa dos Tempos, 1992.

Wright, Delora Jan. O coronel tem um segredo: Paulo Wright não está em Cuba. Petrópolis, Vozes, 1993.

FALCÃo, João. Giocondo Dias: a vida de um revolucionário. Rio de Janeiro, Agir, 1993.

MorAes, João Luiz e AhMed, Aziz. O calvário de Sônia Angel. Uma história de terror nos porões da ditadura. Rio de Janeiro, Gráfica MEC, 1994.

Alves, Valdir. João Rocco: o último guerrilheiro. Florianópolis, Paralelo 27, 1994.

Carvalho, Luís Maklouf. Contido à bala: a vida e a morte de Paulo Fonteles. Advogado de posseiros do sul do Pará. Belém, Cejup, 1994.

Paiva, Maurício. Companheira Carmela: a história da luta de Carmela Pezzuti e seus dois filhos na resistência ao regime militar e no exílio. Rio de Janeiro, Mauad, 1996.

José, Emiliano. Carlos Marighella: o inimigo número um da ditadura militar. São Paulo, Sol e Chuva, 1997.

Oliveira, Frederico Mendonça de. O Crime contra Tenório. Saga e martírio de um gênio do piano brasileiro. Belo Horizonte, Atenas Editorial, 1997.

Araújo, José Pessoa de. Lamarca, Herzog e outros heróis. São Paulo, Scortecci Editora, 1998.

LeOne, Matilde. Sombras da repressão - o outono de Maurina Borges. Petrópolis, Vozes, 1998.

\footnotetext{
${ }^{1015}$ Este levantamento inclui biografias de militantes de esquerda em geral. Marcelo Ridenti apurou a existência de "18 biografias e outros textos sobre ex-militantes da chamada 'esquerda revolucionária”". Ao mapear as esquerdas em geral, porém, não podemos deixar de mencionar religiosos como D. Waldyr Calheiros, entre outros. V. COSTA, Célia e PANDOFI, Dulce. Dom Waldyr Calheiros: o bispo de Volta Redonda. Rio de Janeiro, FGV, 2001.
} 
LiMA, Samarone. Zé: José Carlos Novais da Mata Machado, uma reportagem. Belo Horizonte, Maza, 1998.

Goes, Maria Conceição Pinto de. A aposta de Luiz Ignácio Maranhão Filho: cristãos e comunistas na construção da utopia. Rio de Janeiro, Revan/UFRJ, 1999.

Nova, Cristiane; NovoA, Jorge (Org.). Marighella: o homem por trás do mito. São Paulo, Ed. Unesp, 1999.

CAMARgos, Márcia; MARingoni, Gilbeto e SACChetTA, Wladimir. A imagem e o gesto. Fotobiografia de Carlos Marighella. São Paulo, Editora Fundação Perseu Abramo, 1999.

Bertol, Sônia. Tarso de Castro, editor de "O Pasquim”. Passo Fundo, Editora UPF, 2001.

SANTIAGO, Vandeck. Francisco Julião: luta, paixão e morte de um agitador. Recife, Assembleia Legislativa do Estado, 2001.

Bercht, Verônica. Coração Vermelho. A vida de Elza Monnerat. São Paulo, Anita Garibaldi, 2002.

José, Emiliano. As asas invisíveis do padre Renzo. Uma história singela de amor e dor nos tempos da ditadura brasileira. São Paulo, Casa Amarela, 2002.

Kushnir, B. (Org.). Perfis cruzados: trajetórias e militância política no Brasil. Rio de Janeiro, Imago, 2002.

Pomar, Wladimir. Pedro Pomar. Uma vida em vermelho. São Paulo, Xamã, 2003.

CostA, Caio Túlio. Cale-se: a saga de Vannucchi Leme. A USP como aldeia gaulesa. O show proibido de Gilberto Gil. São Paulo, A Girafa, 2003.

Pedroso JR., A. Márcio, o Guerrilheiro. Rio de Janeiro, Papel Virtual, 2003.

ViannA, Martha. Uma tempestade como a sua memória. A história de Lia, Maria do Carmo Brito. Rio de Janeiro, Record, 2003.

MolicA, F. O homem que morreu três vezes - uma reportagem sobre o "Chacal brasileiro". $2^{\mathrm{a}}$ ed. Rio de Janeiro, Record, 2003.

Bertolino, O. Maurício Grabois, uma vida de combate - da batalha de ideias ao comando da guerrilha do Araguaia. São Paulo: Anita Garibaldi: 2004.

Palmar, A. Onde foi que vocês enterraram nossos mortos? São Paulo, Travessa dos editores, 2005.

Del Roio, José Luiz. Zarattini. A paixão revolucionária. São Paulo, Ícone, 2006.

FARIAS, A. Além das armas: guerrilheiros de Esquerda no Ceará durante a Ditadura Militar (1968-1972). Fortaleza, Edições Livro Técnico, 2007.

LESSER, J. Uma diáspora descontente: os nipo-brasileiros e o significado da militância étnica (1960-1980). Paz e Terra, 2008.

Mota, Urariano. Soledad no Recife. São Paulo, Boitempo, 2009.

Laque, João Roberto. Pedro e os lobos: Os Anos de Chumbo na trajetória de um guerrilheiro urbano. São Paulo, Ava, 2010. 